
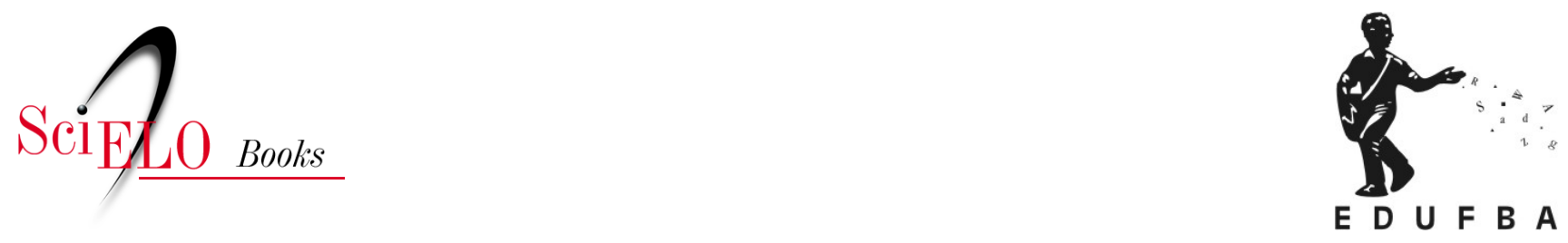

\title{
A luz na gênese do espetáculo
}

\author{
Eduardo Tudella
}

TUDELLA, E. A luz na gênese do espetáculo [online]. Salvador: EDUFBA, 2017, 614 p. ISBN: 97885-232-1858-4. https://doi.org/10.7476/9788523218584.

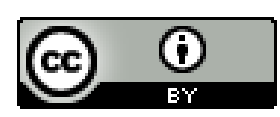

All the contents of this work, except where otherwise noted, is licensed under a Creative Commons Attribution $\underline{4.0 \text { International license. }}$

Todo o conteúdo deste trabalho, exceto quando houver ressalva, é publicado sob a licença Creative Commons Atribição 4.0.

Todo el contenido de esta obra, excepto donde se indique lo contrario, está bajo licencia de la licencia Creative Commons Reconocimento 4.0. 


\section{a luZ na gênese do espetáculo}


UNIVERSIDADE FEDERAL DA BAHIA

REITOR

João Carlos Salles Pires da Silva

VICE-REITOR

Paulo Cesar Miguez de Oliveira

ASSESSOR DO REITOR

Paulo Costa Lima

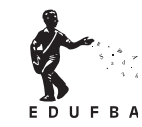

EDITORA DA UNIVERSIDADE FEDERAL DA BAHIA

DIRETORA

Flávia Goulart Mota Garcia Rosa

CONSELHO EDITORIAL

Alberto Brum Novaes

Angelo Szaniecki Perret Serpa

Caiuby Alves da Costa

Charbel Ninõ El-Hani

Cleise Furtado Mendes

Evelina de Carvalho Sá Hoisel

José Teixeira Cavalcante Filho

Maria do Carmo Soares de Freitas

Maria Vidal de Negreiros Camargo 
EDUARDO TUDELLA

\section{A luz na gênese do espetáculo}

Salvador | EDUFBA | 2017 
2017, Eduardo Tudella.

Feito o depósito legal.

Direitos para esta edição cedidos à Edufba.

Grafia atualizada conforme o Acordo Ortográfico da Língua Portuguesa de 1990, em vigor no Brasil desde 2009.

PROJETO GRÁFICO E EDITORAÇÃO

Lucia Valeska Sokolowicz

REVISÃO

Lucas Pacheco e Paulo Bruno Ferreira da Silva

NORMALIZAÇÃO

Sandra Batista

IMAGEM DO SOL NA CAPA

NASA

FOTOGRAFIA DO AUTOR NA CAPA

Andressa Graciotto

Sistema de Biblioteca - UFBA

T899 Tudella, Eduardo.

A luz na gênese do espetáculo./ Eduardo Tudella. Salvador: EDUFBA, 2017.

614p. il.

ISBN 978-85-232-1581-1

1. Teatro. 2. Produção teatral. 3. Técnica.

I.Título.

CDD 792.028

CDU 792.02

Editora filiada à
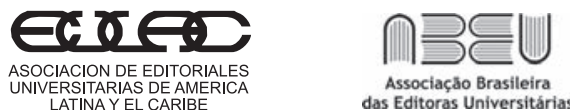

$\mathrm{CBaL}$

EDITORA DA UNIVERSIDADE FEDERAL DA BAHIA

Rua Barão de Jeremoabo s/n

Campus de Ondina - 40.170-115

Salvador - Bahia - Brasil

Telefax: 0055 (71) 3283-616o/6164

edufba@ufba.br -www.edufba.ufba.br 
Aos meus filhos Beatriz, Douglas e Gabriel. 
AGRADECIMENTOS

A todos os professores cuja orientação me abriu caminhos para o desejo de conhecer.

Em especial a Ewald Hackler, pelo enorme apoio na elaboração deste livro. 
Quando me refiro à luz, é evidente, quero dizer, a atividade luminosa, e não usá-la apenas para enxergar.

(Adolphe Appia, 1896, p. 77) 


\section{SUMÁRIO}

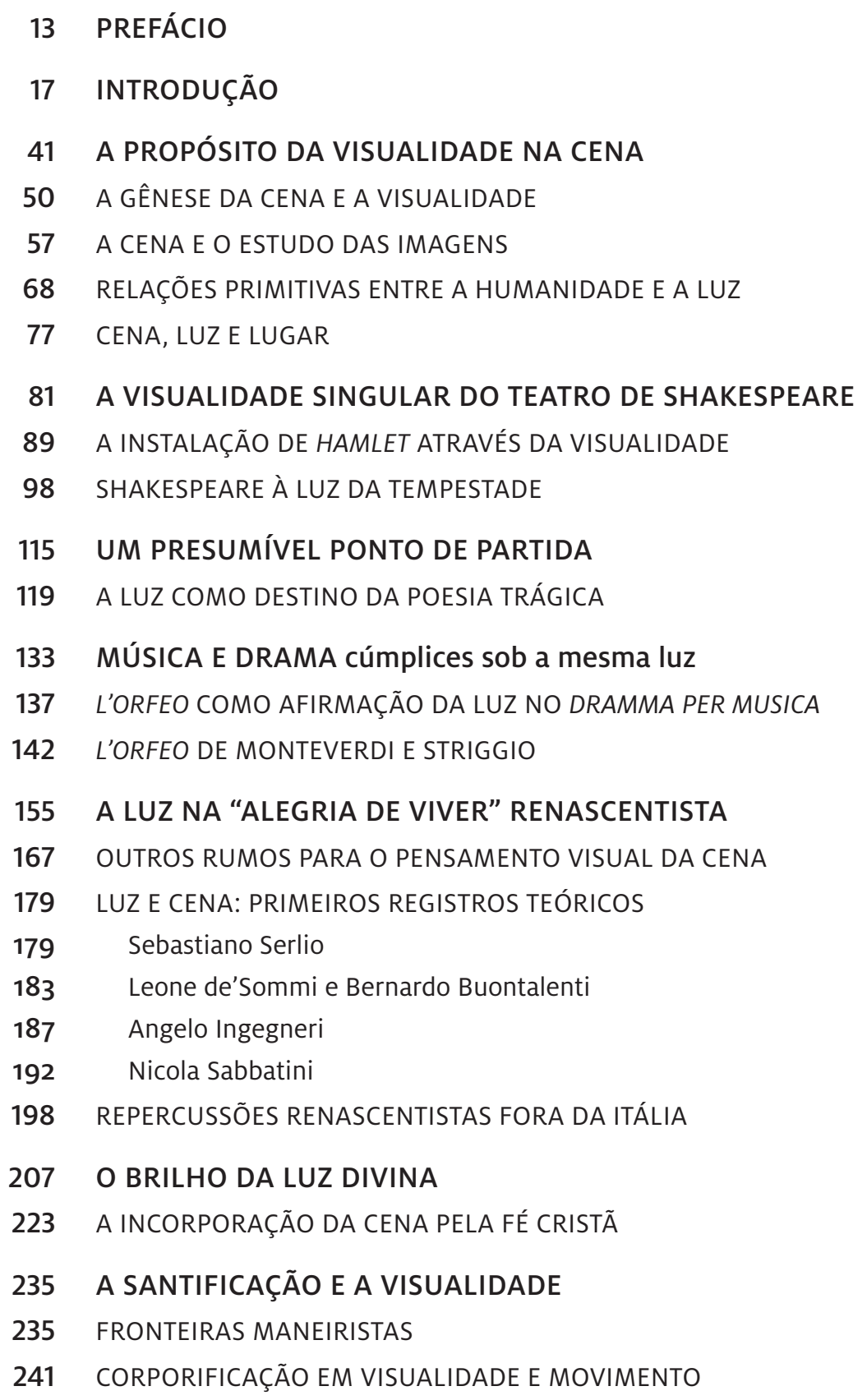




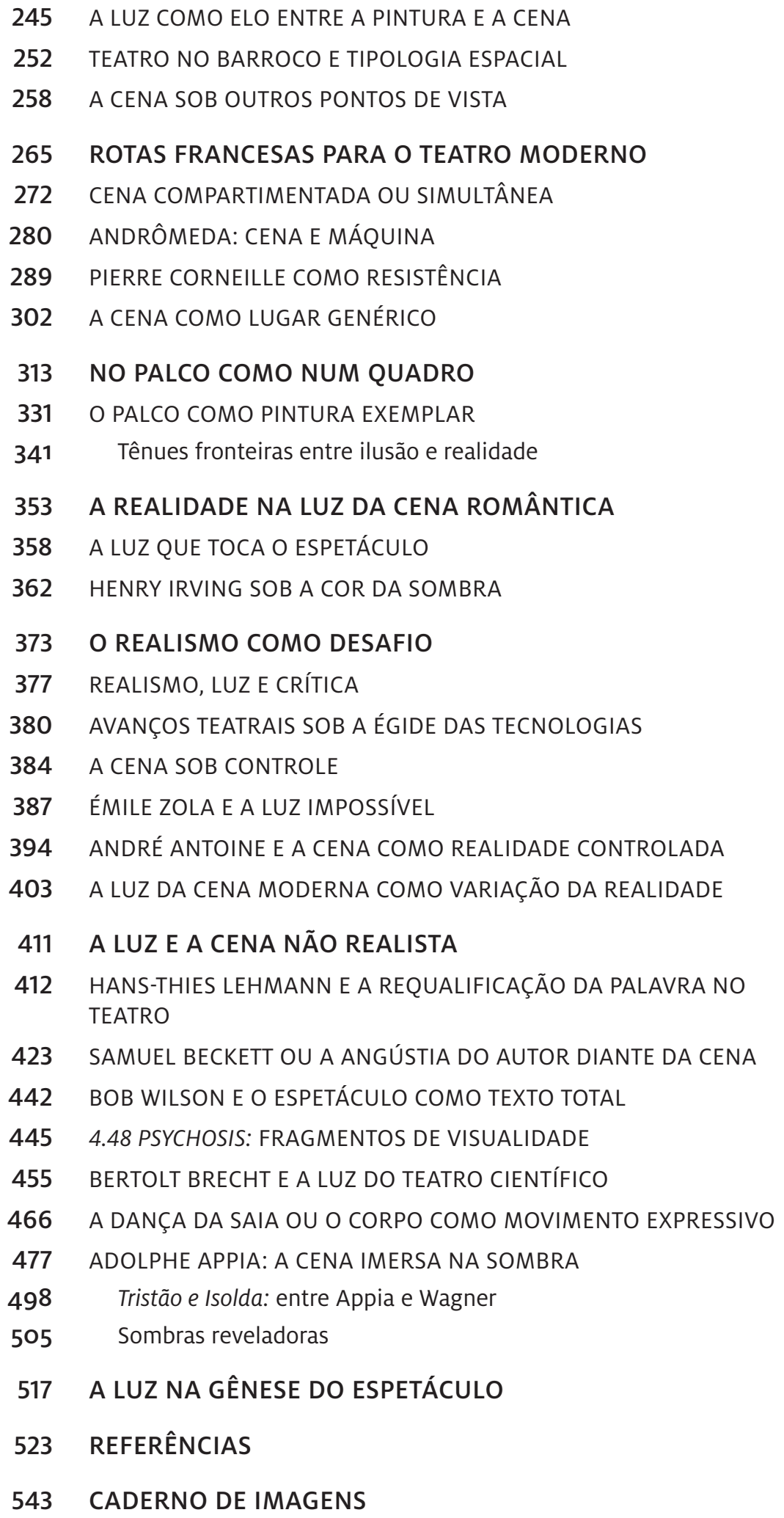




\section{PREFÁCIO}

Existem muitas maneiras de se fazer um estudo sobre a iluminação teatral - e numerosas e variadas são as obras em que teóricos, pesquisadores, artistas e técnicos se detiveram sobre o tema. Desta vez, no entanto, Eduardo Tudella conta a história da iluminação em uma obra que talvez seja a mais completa sobre o assunto já publicada no país.

De modo articulado, Eduardo nos oferece a possibilidade de transitar como se fôssemos um daqueles personagens da história da iluminação, com nomes, datas, momentos marcantes, escolas, biografias e citações. Utilizando a linguagem teatral de caráter próprio com desenvoltura, o autor nos leva ao encontro do real processo criativo, sempre respeitando rigor histórico e técnico.

Esse estudo apresenta significação viva e empolgante porque vem de alguém que respira teatro. Revela ainda uma extraordinária capacidade de abrir novos caminhos e apresenta desafios críticos com solidez teórica. São características que fazem deste trabalho um estudo singular, que fala, em última instância, da luz na gênese do espetáculo. A obra é, ainda, atualíssima em sua 
penetração aos mais fundamentais problemas da arte teatral e, por isso, abre caminhos e presenteia o leitor com o que há de melhor.

Eduardo Tudella é uma das figuras mais importantes do teatro baiano. Lutador pela cultura teatral, sempre esteve à frente de seu tempo, seja no teatro ou na academia, onde formou, como professor, grande parte dos profissionais do estado.

O seu amor pelo teatro começa ainda na adolescência. Descobriu a potência da cenografia e soube, com humildade e sabedoria, iniciar a construção de uma grande obra. É um professor personalíssimo porque traz em si a força criadora de uma grande capacidade de sentir e de analisar a vida. E é com o equilíbrio de duas qualidades - sentimento e vontade - que ele oferta uma nova visão da iluminação teatral, escrevendo com dedicação e amor.

Eduardo Tudella foi meu aluno na Universidade Federal do Estado do Rio de Janeiro, oriundo da Universidade Federal da Bahia, para o bacharelado em Cenografia. Desde cedo, então, pude perceber sua sede de conhecimento, paixão pelo teatro, amor pela história da iluminação teatral, seriedade e, mais tarde, sua perseverança como professor universitário, iluminador, cenógrafo, pesquisador e estudioso da técnica teatral.

Por tudo isso, a obra de Eduardo Tudella é de tirar o fôlego devido ao tamanho e a relevância do trabalho historiográfico. Transita na história da arte, da civilização e dos gregos até a atualidade. Fala ainda de pintura, cena, luz, sombra e do contraste na arte pictórica, tendo um grande impacto sobre o discurso visual e sublinhando sempre a importância de sua qualidade na práxis cênica.

A interação entre estudos teóricos e a reprodução de toda a história do espetáculo deixam o leitor perplexo com tanta informação e lhe permite experimentar um extremo aprendizado de vários séculos. Se não bastasse, Eduardo Tudella encara a nossa arte em sua verdadeira expressão cultural e social, reconhecendo no teatro uma importante ferramenta educativa de civilização.

No Brasil, têm crescido as publicações que abordam os aspectos de interpretação ou direção teatral. Muito se fala também das inúmeras possibilidades da iluminação - às vezes de forma poética -, e temos acompanhado um grande crescimento das técnicas e dos equipamentos de iluminação, assim como o desenvolvimento, nas últimas décadas, de especialistas em iluminação teatral. No campo das técnicas, entretanto, a carência é muito grande. Não há tradição de preservação e memória da cenografia, cenotécnica, iluminação ou figurinos e outras técnicas necessárias ao fazer artístico.

Esta obra, portanto, vem no momento certo e compreende o espetáculo teatral como obra composta, cuja efetivação congrega o trabalho de muitos artistas. 
A abordagem inclui um conjunto de documentos, desde o teatro grego clássico, até a contemporaneidade, e descarta um ordenamento cronológico, pois leva em conta específicas relações entre os textos e a problematização que orienta a obra.

A lacuna que existe no mercado editorial em língua portuguesa nos impulsiona, sem dúvida, a encarar o trabalho de Eduardo de forma auspiciosa. Certamente, terá uma bela acolhida da classe artística brasileira e de países de língua espanhola porque, reforço, trata-se da mais completa obra sobre o assunto já publicada no Brasil.

Um velho ditado inglês diz que cada pessoa de teatro deveria ser "maestro em algo e aprendiz em tudo". O livro de Eduardo Tudella nos ajuda a pôr isso em prática a partir do momento em que nos impulsiona ao aprendizado de valor.

E se o abrir das cortinas e as luzes dos refletores dão vida aos atores, textos, reflexões e histórias de personagens materializados em nossos palcos, Eduardo Tudella põe ainda mais luz no palco e nos ajuda a iluminar tema tão importante à classe teatral. O corpo técnico, os estudiosos e os profissionais de teatro de uma maneira geral são aqui valorizados e ganham um presente para ser lido e guardado.

Boa leitura!

José Dias

Mestre e doutor pela Universidade de São Paulo

Professor titular da Universidade Federal do Estado do Rio de Janeiro

Professor associado da Universidade Federal do Rio de Janeiro

Cenógrafo e diretor de Arte de Cinema, Teatro e Televisão

Membro da Academia Brasileira de Educação 


\section{INTRODUÇÃO}

Este livro trata de aspectos específicos das relações entre a luz e a cena, acentuando a necessidade da sua discussão, no Brasil. A observação da luz como um aspecto que integra organicamente o espetáculo ${ }^{1}$ estabeleceu o ipso facto a necessidade de nele incluir elementos de outros campos do conhecimento, especialmente da história, da filosofia e da ciência. Algumas reações dos leitores a essa orientação e conteúdo são previsíveis. Para uns e outros, certas informações e/ou opiniões podem ser consideradas excessivas ou até mesmo desnecessárias. A reação dos leitores estará ligada ao interesse, à vinculação a determinado campo do conhecimento, o que gera expectativas diferenciadas. Certamente cada um deles escreveria este livro de modo, o que implicaria em outra abordagem.

Há um risco calculado quando se decide encarar a luz como um aspecto que contribui amplamente para o espetáculo, e não como uma exclusiva questão técnica, mecânica, superficial ou até externa. De todo modo, do leitor é solicitada alguma flexibili-

1 O termo espetáculo tem sua origem latina em spectare, que se refere a: olhar para, ver, assistir. 
dade: quando a informação sobre um autor ou período histórico lhe parecer desnecessária, sugere-se que seja levado em conta o reduzido público interessado num texto cujo tema é a atuação da luz na cena, podendo incluir uma clientela não familiarizada com sua abordagem teórico-histórica. Ou seja, o leitor nem sempre será um especialista, um crítico ou um estudioso da teoria. Por outro lado, a diversificada ramificação do conhecimento com a qual a atuação da luz na cena se relaciona pode sugerir a inclusão de um ou outro nome que aqui não aparece.

Esclareça-se que a seleção de autores e artistas, assim como a abordagem específica de certas obras, pretende empreender uma trajetória teórica e analítica particularmente articulada para interagir com o tema. Pede-se que seja levado em consideração que o presente livro já pode ser considerado de demasiada extensão para os padrões vigentes, o que orientou a exclusão e/ou que fossem evitadas outras possíveis discussões, análises, autores e artistas.

Há certa demanda para a apresentação de um novo método para "fazer a luz" no teatro, assim como para a descrição de processos do trabalho particular de um iluminador. Tais caminhos foram deliberadamente desconsiderados. Pode-se dizer que o primeiro poderia resultar na legitimação de uma "cartilha" obsoleta já ao final de sua redação devido às frequentes mudanças nas características dos instrumentos, acessórios e sistemas de controle utilizados pelo iluminador em seu ofício; o segundo caminho envolveria demasiada ênfase no trabalho de determinado artista. As duas opções pareciam muito atreladas ao "como fazer", enquanto o interesse aqui está em "por quê?". Essa compreensão indica discussões acerca da contribuição estética da luz na práxis² cênica, com o objetivo de problematizar seu papel na realização de um espetáculo.

Deve-se ressalvar: parte substancial das questões que originaram tal compreensão está intrinsecamente vinculada às atividades do cenógrafo e do iluminador. A problematização da atividade de "iluminar" espetáculos promoveu o contato com um extenso volume de textos que, além da dramaturgia, incluíam vários outros documentos de igual importância. Desse processo resultou o estimulante desafio de selecionar um corpo significativo de textos que contribuíssem na presente argumentação.

Ao participar de um espetáculo no qual deve "fazer a luz", uma demanda presente em vários processos pode incomodar o iluminador. Mesmo que lhe

2 O termo praxis ( $\pi \rho \tilde{\alpha} \xi 1 \varsigma$ ), que pode ser relacionado com prattein - literalmente - "fazendo". Em sua origem grega, referia-se a uma atividade da qual participavam homens livres. Aqui se considera o termo com a abrangência de um processo, da efetivação de uma proposição que incorpora o conhecimento e as problematizações apresentadas pela cultura. 
ocorram ideias apropriadas, a tarefa de "fazer a luz" pode estar, em muitos casos, comprometida com uma espécie de "urgência" da qual resultaria uma qualidade apenas sofrível, de cunho essencialmente técnico, inferior àquela que se poderia alcançar caso fosse incluída a experimentação exigida por um trabalho artístico. E não somente os prazos, mas também limitações técnicas e artísticas presentes em certos processos podem redundar em qualidade apenas satisfatória quando se considera a excelência esperada de uma obra artística. Fica uma impressão: ou o teatro é uma atividade que aceita o tratamento negligente de um dos seus aspectos essenciais, ou a luz é encarada como elemento sem importância no contexto do espetáculo, sendo considerada parcialmente, até mesmo desconsiderada, ou há alguma ignorância no que se refere à sua contribuição para o trato visual do espetáculo.

Essas questões integram a motivação para este livro, orientando uma inquietação específica: mesmo que o iluminador seja autorizado a desenvolver seu trabalho um, dois, ou, quem sabe, três dias antes da estreia de um espetáculo, a cena em si pode incorporar relações visuais que se iniciam antes mesmo dos momentos concedidos para que se "monte" a luz. Ou seja, a luz parece ingressar no processo do espetáculo em situações que antecedem àquelas nas quais o profissional é autorizado a adentrar o espaço físico de um teatro, para "fazer a luz". Ficaria, então, a questão: onde e quando o trabalho do iluminador deve ser iniciado?

Observando ensaios que antecedem a "montagem da luz", ainda que sua presença seja facultativa em alguns estágios, o iluminador pode ser estimulado por diversos eventos desses estágios, como a ação delineada por cada ator, pelas relações entre atores que buscam um "lugar" no espaço da cena. Mesmo sem um cenário já construído e na ausência de um palco - ou local definido para o espetáculo -, os atores edificam virtualmente o lugar artificial da cena, deslocando-se nas salas de ensaio. Isso indica a presença e a necessidade de uma luz que interaja com aquelas experimentações espaciais. Afinal, se há um lugar cênico a ser percebido visualmente, deve haver luz. Ou seja: ainda que o iluminador não esteja nos ensaios para "fazer a luz", ela já está lá, de certa maneira.

Outro aspecto da questão ficou sublinhado: essa "luz" que antecede a presença do iluminador se evidencia também em muitas "falas" - nas palavras - proferidas pelos atores. Torna-se flagrante na obra de muitos dramaturgos a intenção de compartilhar com o fruidor, não somente o lugar e o tempo da ação, mas também a atmosfera de cada espetáculo, ou cena. Mais do que a necessidade de iluminar onde e quando a ação ocorre, podem ser sugeridas qualidades visuais simbólicas para o possível tratamento de cada ação, lugar, tempo, ou atmosfera (que só 
podem ser compreendidos separadamente nesse nível discursivo, já que interagem na efetivação do acontecimento espetacular) experimentados pelos atores, até mesmo antes dos ensaios, já nas "leituras de mesa". Por conseguinte, além de apenas mostrar o deslocamento mecânico no espaço, a luz também se relaciona com as causas e consequências do movimento, participando do processo argumentativo da ação dramática. Há algo que provoca o movimento da personagem, levando-a a interagir com o mundo. O dramaturgo expressa sua opinião sobre tal processo, no modo como o trata em sua obra. Observando traços artísticos deixados por tais relações, o iluminador elabora sua própria interpretação visual de uma peça.

Seguindo a trilha dos ensaios, estudando alguns dos textos de espetáculos nos quais ele "fez a luz", o iluminador pode constatar a observação inicial: tanto em indicações de ordem mecânica dos movimentos, ou seja, o deslocamento das personagens no espaço da cena, quanto em questões de natureza simbólica relacionadas aos aspectos ontológicos do movimento, ao movimento como devir, a luz já se faz presente nos textos das peças. Para revelar compromissos com a luz, portanto, a dramaturgia dispensa a elaboração cênica de um diretor, dos atores, do cenógrafo, do figurinista, do maquiador, do aderecista, do músico, ou de qualquer outro artista envolvido em um espetáculo.

A luz que pode ser identificada em momentos anteriores à estreia de um espetáculo, também se manifesta antes que a ideia de cena alcance as salas de ensaio. Ela já está presente nos traços do espetáculo que pulsam no trabalho do dramaturgo, caracterizando uma espécie de estado "pré-cênico", um processo vivo, constituído por todas as atividades que ocorrem desde as primeiras ideias que levam à realização espetacular. Transformando-se sucessivamente, o estado pré-cênico transfigura-se quando o acontecimento teatral ocorre, no ato de compartilhar com o público. O que parece óbvio, mas não equivale a dizer que o diretor esteja obrigado a usar o texto como um livro de receitas rígidas.

Até esse momento, contudo, a observação do problema se referiu ao trabalho do iluminador, produzindo outra inquietação: trata-se de uma característica da práxis cênica atual ou, ainda, do restrito universo da atividade do iluminador, o que poderia ser interpretado como uma idiossincrasia? No intuito de compreender tal problematização e testar a abrangência desse ponto de vista foram incorporados determinados documentos, ampliando a observação para estabelecer um espectro capaz de construir a argumentação. Tal espectro pode abranger um amplo contexto cultural ao qual se incorpora a obra de arte, incluindo a dramaturgia de 
um modo geral, assim como outras obras teóricas e/ou artísticas com as quais ela opera correspondências.

Cada aspecto da arte teatral só cumpre integralmente sua função quando o acontecimento se inicia, incluindo o texto teatral aqui compreendido como um passo em direção à cena, provocação para um espetáculo e um aspecto do estado que denominei aqui "pré-cênico". Caberia testar a convicção de que a luz toma parte dos primeiros estágios do processo teatral e já se inscreve na gestação do espetáculo, desde as suas primeiras ideias, alcançando a qualidade de elemento unificador do corpo da cena.

A presença da luz, então, pode estar investida de certo grau de simplicidade que deve ser diferenciado, entretanto, do tratamento simplório ao qual a cena pode ser submetida, quando apenas se decide "fazer a luz" ou iluminar, de modo genérico, seguindo regras oriundas de práticas observadas corriqueiramente, pelas quais os efeitos passam, de espetáculo a espetáculo, gerando uma espécie de tautologia visual. Isso ocorre quando a ideia que sustenta o estatuto visual dos espetáculos está ligada ao objetivo de criar efeitos, tratando os eventos como mera reprodução extemporânea de festividades que abusam dos fogos de artifício. Como se todo espetáculo fosse uma variação do réveillon.

Se a presença da luz pode ser identificada desde a elaboração poética do dramaturgo, ela alcança a qualidade de um elemento estético-poético da práxis cênica, originando estímulos que desobrigam o iluminador a abusar dos efeitos para demonstrar sua presença. Mesmo que um autor não se dê conta, sua relação com a abordagem visual já se efetiva quando ele cria imagens mentais ${ }^{3}$ relacionadas ao contexto de sua obra. A investigação de tais imagens estabelece provocações para todo artista que encara a cena como um problema estético-visual.

Tal abordagem tenciona confrontar a possibilidade da presença da luz na gênese da cena com a diversificada informação encontrada no trabalho de artistas, estudiosos e críticos, orientando tal confronto por um problema simples: em que momento a cena exige a presença da luz? Identificar esse momento leva a duas questões: em primeiro lugar, por que a luz ingressa na práxis cênica num dado momento, e que luz a cena exige para se qualificar como manifestação artística? Por outro lado, isso pode levar a questões acerca do aparecimento histórico da luz no teatro.

A cena é aqui compreendida como um acontecimento no qual o artista opera conceitos e ações estético-poéticas para a criação de uma obra cuja ocorrência se

3 Diferentes das imagens visuais elaboradas em um espetáculo. 
dá em lugares escolhidos para abrigar seu encontro-confronto com o público, sem o qual ela não se efetiva. Isso propõe a articulação entre as partes de um todo, compreendida como regulação através de acordos que dirigem a determinado fim os aspectos de um processo, no caso, a práxis cênica. Tal articulação está ligada à observação da cena como um acontecimento que também expressa, comunica e sensibiliza visualmente.

Vale lembrar a abordagem de Vilém Flusser (1999, p. 18) quando ele discute a etimologia do termo design ${ }^{4}$ e apresenta uma interpretação do termo latino articulum, que se relaciona com articulus, ${ }^{5}$ ganhando relevância no propósito deste livro: a "capacidade de transformar algo em benefício próprio". ${ }^{6}$ Nesse caminho, será aqui observada a compreensão da práxis cênica - ou do acontecimento espetacular - como um locus ${ }^{7}$ no qual a visualidade pode ser avaliada como articulação capaz de cumprir expressividade, comunicação e experimentações sensoriais particulares.

Uma decisão importante na redação do presente texto foi evitar o uso de analogias, de metáforas e expressões que fazem menções à luz e/ou à visão para substituir ou significar conhecimento, esclarecimento, razão, sabedoria, revelação, entre outros. Tais soluções foram descartadas para acentuar que qualquer autor - independente do seu interesse, seja um artista, um crítico, um interessado exclusivamente nos estudos teóricos, um cientista - aplica tal categoria de expressões como resposta involuntária à relevância da luz na construção da cultura, ou seja, na efetivação da presença humana. De todo modo, expressões como "dar luz a", "pôr em foco", "à luz de", "iluminar", "trazer à luz", entre outras, nos sentidos acima indicados, serão aqui raramente aplicadas.

Termos como "teatro", “espetáculo", “espetacularidade”, “cena”, além de expressões como "acontecimento espetacular", "evento cênico", evento espetacular, são aplicados como referência, tanto ao teatro quanto à dança, assim como ao balé, à ópera, ou a qualquer manifestação da atual performatividade. Tais eventos integram o conjunto que nesse livro será denominado "práxis cênica", considerando-se a dilatação que vem sendo associada ao termo espetáculo, hoje motivo de muitas discussões, que incluem até mesmo intenções de novas "teatralidades", a ausência de personagens e, portanto, de drama (conflito).

\footnotetext{
4 Muitos estudos, em diferentes áreas do conhecimento, vêm sendo apresentados; o design, de modo geral, é descrito como "o arranjo geral das partes de um objeto". (TUDELLA, 2012)

5 Ou um ponto de conexão [entre várias partes de um corpo].

6 "ability to turn something to one 's advantage."

7 Ou o exato lugar onde algo acontece ou que se considera o centro de alguma coisa.
} 
A dramaturgia está aqui relacionada (exceções serão comentadas) à acepção

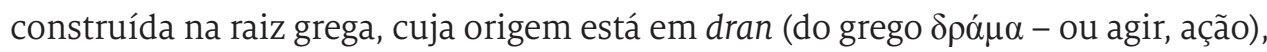
de onde teria se originado o termo drama, como elaboração poética de construção dialógica que trata esteticamente conflitos humanos. ${ }^{8}$ Dramaturgia, portanto, remete aqui ao trânsito do vocábulo "drama", no teatro ocidental, e trata da produção de um texto escrito com o olhar voltado para a ação cênica, motivada por objetivos e/ou desejos que impulsionam o ser humano e movem a personagem. Ou seja, trata-se da práxis cênica efetivada numa relação entre personagens, que se expressa através de uma ação integrada por conflitos motivadores, mesmo sem a exigência de um diálogo verbalizado, premissa que dispensa a palavra falada.

Iniciativas artísticas do século XX que clamam por modelos revolucionários ou pela desconsideração de modelos - recebem aqui o mesmo tratamento dispensado ao drama de câmara, ou ao balé, como exemplos. A práxis cênica, então, é aqui abordada como manifestação artística que incorpora organicamente qualidades visuais. Um evento espetacular, que prescinde de conflitos, de ação cênica e até de personagens, será, portanto, integrado ao universo da práxis cênica, contexto que reúne uma diversidade de acontecimentos espetaculares efetivados em relações imediatas artista-público.

Como exemplo, foram levadas em consideração as iniciativas incluídas no teatro denominado pós-dramático, justificando tal decisão na exegese apresentada pelo teórico alemão Hans-Thies Lehmann (2006, p. 81, grifo e tradução nossos): "[...] o conceito de ação desaparece em favor de ocorrências em metamorfose contínua, o espaço da ação aparece como uma paisagem continuamente modificada por diferentes estados de luz, com figuras que aparecem e desaparecem". ${ }^{9}$ Vale mencionar, ainda, a provocação de outra assertiva do mesmo Lehmann (2006, p. 98, grifo e tradução nossos): "No teatro, então - que é um lugar do olhar - tornou-se possível realizar um princípio extremo de 'dramaturgia visual'. [...] a 'concreta' realização de estruturas visuais formais da cena". ${ }^{\circ}$ Ficam estabelecidas, portanto, substanciais associações entre a luz e a cena, como a qualificação visual do termo dramaturgia.

Num certo sentido, toda práxis cênica incorpora um modo visual de pensar, promovido pela interação de seus pressupostos estéticos com os processos

8 O monólogo se impondo como um limite flexível.

9 " "...] the concept of action dissolves in favour of occurrences, of continual metamorphosis, the space of action appears as a landscape continually changed by different states of light, appearing and disappearing objects and figures."

10 "Thus, in theatre - which is a place of the gaze - it became possible to realize an extreme of the principle of 'visual dramaturgy'. [...] the 'concrete' realization of formal visual structures of the scene." 
culturais nos quais os artistas que a concebem e realizam estão envolvidos. O movimento da segunda metade do século XX, que aponta para uma "dramaturgia visual" e propõe autonomia para a luz, representa a resposta do artista ao contexto cultural no qual ele está inserido.

Até mesmo respostas como a proposição da "morte da personagem", discutida por Elinor Fuchs, ${ }^{11}$ na qual a representação teatral formulada através de conflitos originados por desejos da personagem dá lugar à apresentação do corpo do ator, à sua presença, aos seus gestos, mantém a luz, ainda, como aliada. Seria prudente, nesse contexto, incorporar a compreensão do corpo como aspecto deflagrador na performance, presente no discurso de Richard Schechner. ${ }^{12}$ A cena, por conseguinte, é aqui tratada na sua condição de corpo transitório, dinâmico, até inacabado, mas indissociavelmente impregnado de articulações orientadas por processos visuais.

Até mesmo a cena que pretende negar o "espectador-passivo [sic]" e procura parceria com um corpo sensivel abrangente, com novas funções participativas de fruidor-criador, poderá incluir a capacidade desse novo parceiro de perceber visualmente, mantendo, assim, compromissos com a luz. Finalmente, a menos que se pretenda reduzir deliberadamente o alcance de uma obra que incorpora, representa ou apresenta alguma ação, impedindo que nela se envolva a capacidade perceptiva visual, a luz será imprescindível.

Com reservas, os termos iluminação e iluminador serão aqui aplicados para propor referências às ações de conceber e planejar a qualidade visual de um espetáculo, através da aplicação da luz. Vale dizer, portanto, que associar o uso de tais termos ao objetivo de "fazer luz" para a cena pode resultar em fragilidade na abordagem das contribuições da luz para os acontecimentos espetaculares. Atividades simplórias com os objetivos de "iluminar" e "fazer luz" podem reduzir a função do iluminador à ação quase mecânica de lançar luz sobre a cena, sem o aprofundamento de qualquer aspecto estético-poético norteador. E ainda, por vezes o iluminador pode parecer mais interessado na atividade de "inventor", do ponto de vista científico, do que na sua função de artista.

Tal contexto oferece espaço para que se estabeleçam diferenciações entre a visibilidade e a visualidade, nos termos que serão aplicados ao longo deste texto. Ou seja: a adição de luz pode tornar a cena "visível", como se fosse possível acionar a visão apenas como uma operação físico-química, sem que a visualidade resul-

11 Professora de Dramaturgia e Crítica da Universidade de Yale, EUA, autora de A morte da personagem: perspectivas acerca do Teatro depois do Modernismo [The death of character: perspectives on Theater after Modernism] (1963).

12 Professor da New York University, fundador dos Performance Studies, na Tisch School of the Arts/NYU. 
tante - a afirmação visual - de tal visibilidade atenda a quaisquer critérios artísticos. A visualidade, como abordada no presente livro, está relacionada à atitude crítica que orienta o iluminador e confere postura estético-poética à sua contribuição para a práxis cênica. Desse modo, projetar luz sobre a cena promoverá visibilidade. A análise de aspectos técnicos, estéticos e poéticos de tal ação, identifica a visualidade de um espetáculo, ou a qualidade das imagens (cênicas) que estabelecem a articulação do seu discurso artístico-visual.

A presente abordagem assume duas outras compreensões básicas, relacionadas à presença da luz como uma exigência da cena: em primeiro lugar, a práxis cênica é considerada aqui como uma arte compósita, cujos aspectos constitutivos - desde a dramaturgia, passando pelo ator, pela cenografia, até a luz - se relacionam de modo transversal para propor relações entre os acontecimentos espetaculares e o público. Os diversos aspectos da cena interagem em movimentos irregulares, transversalmente articulados, entrelaçando-se ao longo do processo de criação de um espetáculo, e não em camadas lineares superpostas sucessivamente. Ou seja: quando se "faz a luz" de um espetáculo, costumeiramente como etapa final do processo, acentua-se uma estratégia, de natureza operacional e/ou um simples hábito sem, necessariamente, ligação com o desígnio espetacular do teatro.

É até possível dizer que a decisão de convocar o "iluminador", quando o espetáculo está "pronto", pode estar vinculada à presunção de que só nesse momento ele terá o que "iluminar". Ora, pode-se conjecturar: uma vez que estão criados os ambientes e as ações da peça, fica definida a hora de convocar a luz para "complementar", ou "ajudar". o presente trabalho presume que a cena em si não impõe tal processo e a luz tem função mais contundente e abrangente do que essas atividades podem cumprir. As atitudes de ajudar e complementar (quando desempenhadas pela luz na cena), então, somente interessam à presente abordagem como objeto de análise crítica.

A segunda compreensão refere-se aos movimentos transversais a ocorrer entre um estado pré-cênico e a cena propriamente dita, tornando possível encontrar indicações de diversificados elementos do espetáculo (cenografia, luz, entre outros), desde seu ponto de partida objetivo (ou material), que pode ser o texto de uma peça, um roteiro, uma composição musical, ou até um estímulo para improvisações, e assim por diante. As relações entre a luz e os demais agentes do espetáculo promovem as instâncias visuais presentes já na ideia primeira de cena; mesmo quando não há um texto dramático na origem do estágio denominado pré-cênico, já se encontra ali uma visualidade latente, que interage com questões 
culturais, incluindo particularidades históricas, além das decisões estético-poéticas de cada autor.

Isso não implica que a qualidade visual presente no estado pré-cênico deve ser, ou será atendida - ou representada - na cena. Cada diretor tomará decisões estéticas particulares, considerando a proposição de espetáculo que intenta elaborar, em parceria com outros tantos artistas. Suas escolhas podem até negar - ou desarticular - a qualidade visual, a visualidade de certa obra da dramaturgia. Entretanto, se considerarmos as extensas implicações visuais da cena, o artista que reconhecer ou identificar a visualidade do material provocador do seu trabalho, seja uma obra da dramaturgia ou uma dentre as outras possibilidades já mencionadas, terá ampliadas suas chances de compreendê-lo, aguçando seu poder crítico e ampliando sua própria capacidade de criar caminhos.

Grande parte das traduções de originais, em inglês e francês, usadas no trabalho em curso, foram efetivadas pelo próprio autor do livro. Elas se referem a trechos de peças, de textos teóricos e poéticos, incluindo obras antológicas. Fica descartada, contudo, a intenção de apresentar novas ou revolucionárias traduções da teoria e/ou da poesia; elas funcionam aqui como indicativas de uma compreensão particular dos textos comentados.

Este livro resulta da abordagem da práxis cênica como um problema artístico-visual, cuja origem se encontra, não apenas nas primeiras teorizações do teatro da Grécia Clássica, mas também nos estágios iniciais do drama clássico, uma vez que ambas as abordagens observam e analisam a posição da luz no contexto do espetáculo teatral. Isso sublinha a posição da luz na práxis cênica que, ao incorporar esteticamente a visualidade, indica o seu reconhecimento como um dos aspectos artísticos do contexto.

O objetivo particular é identificar a presença da luz na gênese do espetáculo, através do estudo de documentos relevantes para a história da práxis cênica, aqui reunidos. Tal identificação permite observar variáveis estéticas, apontando a abordagem da luz como um problema cuja investigação é decisiva para a realização do acontecimento espetacular, evitando superficialidade em seu tratamento.

Destaquem-se duas instâncias que geram tal superficialidade na compreensão dos papéis da luz na cena. A primeira advém de certo desconhecimento das mencionadas questões estéticas envolvidas, seguida do acesso indiscriminado e pouco consequente a informações de natureza técnica, incluindo documentos encontrados na rede mundial de computadores. Como parece óbvio, a combinação das duas variáveis pode ampliar o saldo negativo dos resultados. Daí, a ausência da consideração dos papéis artístico-expressivos da luz ou seu tratamento como 
um mero produto da genialidade de profissionais envolvidos na área, favorecendo uma discutível hegemonia tecnológica e determinando o equívoco de considerar a habilidade de operar hardware e/ou software (equipamentos e programas de computador), o principal contributo do iluminador.

A expectativa de literatura especializada na área corre o risco de limitar-se numa discutível orientação para a operação de aparatos (instrumentos, acessórios e sistemas de controle). Considerando-se que a cada momento novos aparatos são colocados à disposição dos iluminadores, tal literatura parece condenada a uma infindável lista de "manuais".

Na verdade, o conjunto de habilidades e competências técnicas, imprescindível como requisito parcial na elaboração da luz para a práxis cênica, torna-se discutível quando transformado em objetivo final da formação e atuação do profissional/ artista. Vale registrar que, ao assumir a responsabilidade de conceber e planejar a luz para um espetáculo, o artista se obriga, não somente a dominar os aparatos tecnológicos, mas também a apresentar uma proposição estético-poética. Em The magic of light (1972), escrito por Jean Rosenthal com a contribuição de Lael Wertenbaker (integrando a habilidade para escrever que ela declarou não dominar) é revelada uma provocadora compreensão do tema: "Lighting design, a incorporação de qualidade ao ar pouco visível, através do qual se veem objetos e pessoas, começa com o ato de pensar sobre tal ação" ${ }^{13}$ (ROSENTHAL; WERTENBAKER, 1972, p. 3, grifo e tradução nossos)

Encaminhar tais discussões, sublinhando reflexões acerca da qualidade visual da práxis cênica, questiona a compreensão de que a luz é incorporada aos espetáculos com o objetivo de "ajudar" e/ou "complementar". Ao contrário disso, o presente trabalho procura compreender a presença da luz na cena como aspecto indissociável de sua constituição. Abordando o espetáculo como uma elaboração visual, o estudo aqui desenvolvido incorpora diversas categorias espetaculares, sejam atuais, ou localizadas em momentos particulares da história.

Foi observada uma seleção de artistas e autores cujo trabalho pudesse contribuir para a elaboração de um pensamento organizado acerca dos papéis desempenhados pela luz no evento cênico, oferecendo alicerces que suportassem uma postura crítica sobre a constituição visual da cena. Tornou-se, então, oportuna, a inclusão de documentos visuais e textos antigos, que exigiram introduções sucintas sobre autores, manifestações e/ou obras, para familiarizar o leitor com

13 "Lighting design, the imposing of quality on the scarcely visible air through which objects and people are seen, begins with thinking about it." 
um material raramente mencionado em trabalhos acadêmicos brasileiros acerca do tema em questão.

Documentos antes observados sob outros ângulos ou abordagens teóricas, agora consultados sob a consideração da presença da luz na gênese do espetáculo, apresentaram novas contribuições. A busca de instâncias anteriores a cada processo observado incluiu referências históricas que indicam traços visuais de cada momento estudado, o que tornou evidente a interação entre a cena e a luz em diversos contextos históricos. Esse procedimento permitiu compreender melhor tais relações nos processos atuais. No que se refere à pintura, foram evitadas menções aprofundadas de análises apresentadas por teóricos ou filósofos, uma vez que isso ampliaria, em muito, o volume deste livro. Associe-se, portanto, a abordagem de tais obras à natureza do tema, ou seja, problematizações acerca das relações entre visualidade e luz, na cena.

Por outro lado, a inclusão de certos autores ou questões pode parecer desvio ou excesso para o leitor que pretenda isolar a luz considerando-a, de modo superficial, uma instância técnica. Nesse caso, certos documentos, manifestações ou processos teóricos, podem ser considerados dispensáveis, por um ou outro leitor. A documentação e os eventos discutidos foram selecionados com a convicção de sua relevância para a argumentação aqui elaborada. Aliás, muitos textos e documentos foram consultados em leitura exploratória e dispensados, inclusive para limitar a extensão final do texto.

Considere-se, portanto, duas vertentes da questão: a primeira refere-se à relevância da luz para a presença humana no universo, levando-se em conta a complexidade das relações entre a luz e a vida no nosso planeta; a segunda está ligada à própria natureza da práxis cênica que, como obra de arte compósita, dá voz a cada um dos elementos que a constituem, respeitando a função de todos os outros, estabelecendo trocas e elegendo instâncias particulares para suas atuações. O processo em questão incorpora sutileza e complexidade à cena que, buscando uma só manifestação, faz interagir organicamente contribuições de diversos artistas e meios. Isso indica, por outro lado, relações produtivas entre autonomia e parceria, procurando avaliar o comportamento da luz nesse contexto.

Para apreender a cena na sua condição de evento que incorpora a luz, foi indispensável o contato com a história do teatro, sem a intenção de escrever mais uma História da luz teatral. O leitor atento perceberá que, mesmo sendo a presente abordagem indicativa de um trato histórico, ela se distancia da superficialidade de descrições cronologicamente lineares e generalizantes. A observação de contri- 
buições da luz, em momentos e iniciativas muito particulares, provocou contatos com a filosofia, a arte e a ciência, identificando o que levou alguns artistas a construírem respostas para atitudes que precederam sua contemporaneidade, apontando diferentes caminhos para seu próprio ideário artístico. A ausência de acento na cronologia pode suscitar o desejo de determinado leitor do deslocamento de um ou outro trecho do livro, reposicionando-o. Isso não somente é compreensível, como demonstra que outros trabalhos sobre o tema podem, ou devem, ser escritos.

Abordagens da história estão incluídas - nollens, volens - como tangências ao presente trabalho. Uma investigação com abordagem estritamente histórica, entretanto, exigiria pesquisa capaz de ampliar o alcance de estudos importantes, por exemplo, como aquele do historiador Gösta Mauritz Bergman4 (1905-1975), o que se afasta dos objetivos deste trabalho. Fica dispensada, portanto, a descrição sistemática de aparatos - instrumentos, acessórios e sistemas de controle usados nos espetáculos ao longo da história -, ainda que seja oportuno registrar o valor de estudos que abordem a questão.

A visualidade aparece aquí como índice ou sintoma da natureza estética do espetáculo, evitando a visibilidade que expõe a dimensão material dos corpos presentes na cena, nem sempre de modo competente e/ou eficiente, uma vez que isso já exige do iluminador formação e/ou prática positivamente qualificada. Além disso, a visibilidade superficialmente tratada pode desconsiderar proposições estéticas consistentes. Por outro lado, é importante salientar que no contexto da presente abordagem, toda obra - drama ou cena - apresenta sua própria assertiva visual. Ou seja, a visualidade não se manifesta apenas no "bom" espetáculo, no acontecimento espetacular aprovado pela teoria/crítica, ou pelo público, mas em qualquer manifestação. Então, o modo como um iluminador trata ou considera a visibilidade no espetáculo, como ele constrói sua narrativa visual, determina a identidade artística de sua proposição.

Em um espetáculo, por conseguinte, visibilidade e visualidade só podem ser desconectadas em processos de estudo, de análise crítica específica e todo espetáculo oferecerá ao público determinada visibilidade que promoverá visualidade ou assertiva visual. Se o iluminador deixou de lado pressupostos estético-poéticos, acentuando o ato mecânico de iluminar, ou considerou exclusivamente a visibi-

14 Gösta Mauritz Bergman (1905-1975), estudioso sueco. Var 1934-57 den første sjef for det svenske Riksteatern, virket også som teaterkritiker, og ble dosent i teat erhistorie ved Stockholms universitet 1947, professor 1958-1971. Trabalhou como crítico de teatro e foi professor de história do teatro na Universidade de Estocolmo, de 1958-1971. Bergman publicou vários livros, incluindo Lighting in the theatre (1977). 
lidade mecânica, aquilo que ocorre no espaço cênico-teatral findará - provavelmente - numa visualidade inconsequente, inconsistente. Isso equivale a dizer que quanto mais o "iluminador" se afasta da mera "iluminação", mais ele se aproxima da elaboração de um discurso poético-visual consistente e capaz de provocar a percepção, assim como as instâncias sensoriais.

Com efeito, uma vez que a natureza humana é compreendida neste livro como um complexo perceptivo do qual a visão representa um dos aspectos, fica afastada qualquer pretensão de defender qualquer hegemonia espetacular da visão, assim como da crença em uma absoluta - ou exclusiva - relação de visibilidade entre o espectador e o espetáculo.

É preciso compreender, portanto, que a luz não depende do seu tratamento hegemônico na cena para se tornar importante. Por outro lado, importa ponderar que a luz não pode ser desconsiderada ou substituída, já que nenhum outro aspecto da práxis cênica pode desempenhar suas funções. Desse modo, fica esclarecido seu papel de índice constitutivo, construtivo e fundante da cena. É preciso, portanto, assumir a responsabilidade de tratá-la como tal, observando tanto suas possibilidades artísticas, quanto as reflexões teóricas que contribuem para esse processo.

Há, então, um mérito parcial nas "experimentações" que tratam os efeitos como o objetivo final da contribuição da luz, ou naquelas que exigem a invenção de um novo aparato a cada espetáculo, para que ela alcance importância. Tal decisão corre o risco de tratá-la como um apêndice que se refere apenas à percepção da natureza tridimensional, material, da práxis cênica, desconsiderando os diversos traços estéticos do espetáculo concentrando-se em mostrar o que está fisicamente visível, tornando a cena atrativa, "agradável".

Se o iluminador levar em consideração a relativa educação visual de parte do seu público, compreenderá que produzir algo "atrativo" ou "agradável" para esse público, nem sempre representará um tratamento artístico consistente.

Ainda que a natureza tridimensional seja inerente às construções espetaculares procura-se uma ruptura produtiva com vinculações exclusivas a essa qualidade tridimensional da cena, e leva-se em conta implicações filosóficas e artísticas que, em parceria, questionam a mera visibilidade dos efeitos como fim ou objetivo.

Este livro se relaciona com iniciativas teóricas que compreendem a imagem como objeto de uma disciplina, em particular com a corrente identificada como Cultura Visual à qual se encontram ligados os Estudos Visuais. São estabelecidas, ainda, relações com o enfoque germânico, denominado Bildwissenchaft, ou Ciência da Imagem. Num certo sentido, a natureza da cena pode estranhar procedimentos 
de registro e/ou gravação, a menos que se almeje fazê-la passar a outra categoria de expressão. Ela estaria transfigurada em fotografia, vídeo ou cinema. Vale a tautologia para ponderar que, fotografada, mesmo por um fotógrafo capacitado para registrar e mostrar uma imagem que revele grande semelhança com aquilo que se vê no espetáculo, a cena se tornaria fotografia, instante fixado, imagem material ou arbitrária, gravada e reproduzida. Algo similar ocorre no registro fílmico da práxis cênica, que sugere movimento da imagem gravada em quadros inanimados, registrados numa película através de reações físico-químicas, distanciando-se do teatro, cujas imagens se dissipam a cada instante do acontecimento propriamente dito. Pode-se ainda citar a imagem digital, em sua diversificada abordagem. Por conseguinte, considerando os estudos da imagem que remetem à imagem gravada e reproduzida, pode parecer tarefa difícil relacionar a contribuição da luz teatral à Ciência da Imagem.

Este livro, no entanto, incorpora a abrangência de um dos problemas centrais dessa Ciência das Imagens, por considerar que ela indica possibilidades teóricas, apontando uma vertente ainda pouco discutida nos ambientes teatrais brasileiros, e que até poderia provocar futuras pesquisas. Aqui se inclui o estudo das relações entre o "projeto de luz para a cena", na abordagem que se inicia por volta da década de 1930, nos EUA, e as imagens criadas no espetáculo. Para ser qualificado como um projeto que trata a luz para a cena, dentro do modelo mencionado, ele precisa apresentar um determinado conjunto de documentos que registrem (grafem ou gravem), precisamente, todos os procedimentos referentes à contribuição da luz para o espetáculo. Nele devem ser incluídos: uma apresentação sucinta da concepção estético-poética do iluminador - um texto curto de aproximadamente uma lauda - a distribuição gráfica de instrumentos e acessórios, o planejamento do seu uso, incluindo sketches, ${ }^{15}$ roteiro de operação, planilhas e desenhos técnicos, em escala.

Vale dizer que, sob o olhar de especialistas, tal conjunto poderia ser mais eficaz como documento referente às imagens que serão criadas, ou que foram criadas na cena, do que uma fotografia, vídeo ou filme, uma vez que tais registros podem ser submetidos a diversificados processos de manipulação da imagem. Um projeto de luz para a cena, no entanto, como instrumento técnico de registro e comunicação deve conter informações que promovam o acesso de qualquer profissional qualificado às proposições do designer que o concebeu.

15 Desenhos em perspectiva, aplicando-se a mesma escala da planta de luz e do(s) corte(s). 
Aqui se observa um modo diferenciado de compreender a imagem, relacionando-a a um conjunto de representações gráficas e planilhas concebidas por um iluminador, ${ }^{16}$ que documentam com grande eficiência a imagem cênica. Desafortunadamente, o incipiente estágio de sistematização daquilo que se conhece, no Brasil, como "mapa de luz", ${ }^{17}$ até o momento da redação do presente texto, torna difícil a identificação, a codificação e a documentação daquilo que o iluminador pretende, ou pretendeu, em um "mapa" de luz.

Interagindo com o tratamento da luz no acontecimento teatral, questiona-se a demanda do senso comum que, mesmo de boa fé, invade o ambiente do teatro, esperando do iluminador uma sucessão de "efeitos espetaculosos". Não confundir com espetaculares, pois o termo "espetaculoso" aqui se refere àqueles efeitos que abrem mão do direito de interagir positivamente na cena, permanecendo na operação mecânica de projetar sobre o espetáculo uma luz "bonita". No entanto, diante de crítica fundamentada, eles são lavados como um cosmético banal que age na mera superficialidade. Talvez seja possível evitar uma "luz" que pode ser reduzida a uma operação aritmética: o total de instrumentos (inclusive aqueles automatizados) é dividido por dois, distribuído simetricamente e posto a pulsar em padrões gráficos já vistos em muitos outros eventos. Parece valer a pena subverter tal demanda quando se compreende que a mesma pode construir clausuras para a luz, desconsiderando sua condição de aspecto construtivo na estética da cena.

Aliás, a crítica às imagens cênicas deve produzir mais do que elogios à mencionada luz "bonita", ou a condenação de um operador de mesa de controle de luz, que se revela ineficiente e comete erros óbvios, facilmente identificáveis, pois repercutem grosseiramente em um espetáculo. Melhor seria observar que a tal luz "bonita" pode ser apenas um efeito sem fundamentação estética e que o erro do operador, além de resultar da ausência de habilidade e competência profissional, pode estar aliado à falta de experimentação e do amadurecimento da repetition,

16 No caso, talvez fosse melhor seria aplicar a expressão lighting designer, considerando o interesse em projetar a luz de um acontecimento cênico, de acordo com pressupostos sistematizados, reconhecidos.

17 O ambiente da "iluminação cênica" no Brasil incorporou o termo mapa, e criou a expressão "mapa de luz". É notável o esforço dos interessados no tema para desenhar "mapas de luz". Não se pode, contudo, reconhecer sistematização nos desenhos, assim como não há trabalhos acadêmicos ou profissionais que funcionem como proposta de padrão para os mesmos. Se um especialista em cartografia, em Moscou, deve ser capaz de ler, precisamente, um mapa do Brasil, executado na França, um "mapa de luz", desenhado em um bairro de Salvador, só poderá ser executado em outro local da mesma cidade, se for aplicada a improvisação, a invenção, a dedução generalizada, pois cada um desenha seu "mapa” aplicando o esforço próprio para organizar seu trabalho, atendendo a normas próprias, descaracterizando o papel - de organizar, registrar e comunicar universalmente - característico de um desenho técnico. 
isto é, ensaio, como, sabiamente se diz em francês. Aliás, ensaio, em inglês, escreve-se rehearsal, ${ }^{18}$ provavelmente relacionado com o termo anglo-francês rehercier, com origens que podem remeter ao século XIV, no qual o prefixo "re", incluído no nosso verbo repetir, está originalmente ligado a "dizer de novo, do início ao fim".

Parece confortável apontar os erros de um operador que deixa o artista às escuras, em um momento - dois segundos, talvez - no qual a presença da luz parece óbvia. A práxis cênica, no entanto, precisa de críticos que tenham incluído em sua formação a educação visual que os autorizaria a avaliar de maneira consistente a contribuição da luz para um evento cênico.

Pouco se escreveu sobre a interação entre a luz e a cena, no Brasil, e são raros os estudos que abordam o espetáculo como um locus específico de imagens. No entanto, o estudioso francês Jean-Jacques Roubine, doutor em Letras, professor de teatro na Universidade de Paris VII, abre uma porta convidativa e oportuna, no seu livro Théâtre ${ }^{19}$ et mise en scène I880-I980 (1998) ${ }^{20}$ quando, ao tratar das relações entre a imagem e a cena, mesmo que em breve comentário, se refere ao espetáculo como um conjunto de imagens em movimento. Ainda que fortuita, tal referência apresenta grande potencial para quem deseja adentrar o ambiente das investigações acerca do trato da luz na cena. Além disso, em A arte do ator (L'art du comédien, 1982), o mesmo Roubine emprega inúmeras vezes o termo imagem, assim como a palavra composta corpo-imagem, estabelecendo provocações pertinentes para o interesse da categoria investigativa em questão. Tratando-se de um teórico festejado no Brasil, é oportuno citar essas observações. Consideradas suas elaborações sobre a arte do ator, pode-se ponderar que, no teatro, todo corpo é, simultaneamente, imagem, e vice-versa.

Tratando a corporificação aqui mencionada vale citar Patrice Pavis, em Análise dos espetáculos, quando este autor se refere à cena como um corpo constituído pela interação espaço-tempo-ação. Incorporou-se aqui, também, as reflexões de Hans Belting - autor alemão, pesquisador da História da Arte e da Antropologia da Imagem -, o seu interesse pelo seu estudo das interações entre corpo e imagem. Dialogando com a abordagem apresentada por William John Thomas [Tom] Mitchell (1986), ${ }^{21}$

18 Disponível em: 〈http://www.etymonline.com/index.php?term=rehearse\&allowed_in_frame=0〉. Acesso em: 25 nov. 2012.

19 A linguagem sa Encenação teatral título em português.

20 Usar o termo encenação para traduzir mise en scène parece uma decisão discutível, pois incorporar ao termo "encenador" um pressuposto hierárquico do ponto de vista estético-poético em relação ao "diretor" ainda é um procedimento a ser avaliado. Usa-se com parcimônia o termo encenação e aplicar-se-á sempre a palavra diretor, compreendendo as diferenças de abordagem da função ao longo da história.

21 Professor de Inglês e História da Arte, na Universidade de Chicago, editor do periódico Critical inquiry e autor de Iconologia: imagem, texto, ideologia (Iconology: image, text, ideology, 1986), entre outros. 
Belting propõe uma nova tríade, imagem-meio-corpo (image-medium-body). Ainda que ele não esteja tratando especificamente da cena, os elementos da tríade indicada por Hans Belting sugerem estímulos para o enfoque norteador do trabalho em curso. Belting é mais reconhecido no Brasil pelo seu trabalho $O$ fim da história da arte, cuja publicação em língua portuguesa se deu em 2006. Ele estabelece subsídios para a abordagem da imagem cênica quando questiona discursos institucionalizados pela crítica literária e pela história da arte.

A investigação da práxis cênica como um conjunto de imagens, também visuais, ${ }^{22}$ de qualidade muito particular devido à sua interação imediata com o espectador, tornou indispensável considerar a cena um discurso poético-visual.

Italo Calvino (1923-1985), principalmente em Seis propostas para o próximo milênio: lições americanas (Lezioni americane: Sei proposte per il prossimo millennio), indica caminhos para a compreensão das imagens como provocadoras da sua obra literária. Tal contexto é intrigante, em particular, pela identificação de rotas transversais nas quais transitam, chocam-se e transfiguram-se palavras e imagens. Há, ainda, tangências possíveis com os escritos póstumos de Nietzsche, diante da sua abordagem das relações entre imagem e conceito. O discurso efetivado através da imagem encaminha para a apreensão da visualidade particular de um espetáculo. Deve-se mencionar, também, o trabalho de Adauto Novaes, no projeto do qual resultou a publicação de Muito além do espetáculo (2005), um conjunto de artigos assinados por diferentes autores, que inclui o estudo da imagem. Desde a apresentação, de autoria do próprio Novaes, os textos representam leitura obrigatória para todo interessado ou envolvido nas questões visuais da cena. O livro organizado por Edélcio Mostaço, Para uma história cultural do teatro (2010), é de grande relevância para a compreensão de conexões entre a teatralidade e a imagem, em particular o seu artigo Teatralidade, a espessura do olhar (2010).

A natureza particular da práxis cênica inclui a ideia do seu próprio corpo-imagem. Os eventos cênicos construídos por desejos humanos implodem os limites da qualidade física, tridimensional do corpo, racionalmente reconhecida na cena. O público é aspecto chave da corporificação da cena, caracterizada como uma manifestação cuja natureza transdisciplinar exige trocas e negociações estéticas que incluem a presença da imagem. Se as relações entre teatro e imagem são milenares, até primitivas, cabe investigar a posição da luz, no contexto de tais relações.

As investigações que originaram o presente livro levaram em conta o papel do contraste na percepção visual - observando as transições entre o visível e o

22 Não somente imagens mentais, sonoras, e assim por diante, tratamento que aparece no trabalho de Mitchell. 
"não visível" - como aspecto importante na elaboração de imagens. Tal enfoque se volta para o questionamento da mencionada compreensão da luz como meio para iluminar, adornar e até "ajudar" ou "complementar", como se o espetáculo já existisse sem a sua presença. Ainda que tornar uma cena visível seja considerado um dos objetivos gerais de um projeto de luz, sua função tem maior amplitude e particularidade. Esse tipo de projeto deve apontar para a construção de ambientes, atmosferas, imagens impregnadas de traços estilísticos inerentes ao pensamento espetacular que norteia cada acontecimento, e desconstrói, assim, a chamada tirania - hegemonia - da imagem visual, pictórica, impressa, gravada e/ou projetada.

Tal reflexão indica uma presença produtiva e nem sempre analisada quando se trata da imagem teatral, a sombra. As transições entre luz e sombra são aqui consideradas instâncias decisivas para a construção do espaço da cena, para a composição da cena em si, na sua condição de processo visual dinâmico. Fica introduzida, então, a contribuição da sombra para a construção das imagens cênicas, categorias particulares no contexto em questão.

A sombra é aqui observada como um aspecto relevante, não somente na efetivação física da visibilidade, mas também na expansão do conceito de visualidade. A mera exposição da qualidade tridimensional, visível, do corpo-imagem em trânsito na cena e, portanto, do corpo-cena em si, apequena a contribuição da luz e, inevitavelmente, da sombra. A visualidade ganha espaço, quando o projeto de luz integra as proposições estético-poéticas de um evento cênico e, mais do que expor, ela alcança níveis expressivos e sensoriais de uma obra de arte. Sombra, como tema aqui proposto, difere daquela especificamente vinculada ao chamado "teatro de sombras", sobre o qual podem ser encontrados inúmeros trabalhos.

Há uma espécie de compreensão tácita que indica - ou aceita - as atividades teatrais da Idade Média, tanto as eclesiásticas quanto aquelas que integravam festividades realizadas no interior de castelos, como os primeiros momentos na história da luz teatral. Quando muito, se considera que os artistas do teatro fechado - coberto -, da Renascença italiana do século XVII, "inventaram" a luz para a cena. Ainda que tal compreensão pareça justificada, se considerarmos a aplicação de luz artificial para promover visibilidade em eventos espetaculares que ocorriam em espaços fechados, estaremos diante de uma verdade parcial que pode ser questionada.

Trata-se de um raciocínio óbvio: uma vez que os teatros passaram à categoria de edificações cobertas, havendo a necessidade de luz artificial, ali começou a "história" da luz teatral. É possível, contudo, conjecturar que a luz ingressou na arte teatral num momento anterior a um ponto qualquer da Idade Média, ou da Renascença. 
Mais que isso, as relações entre a luz e a cena não estão atreladas a datas, movimentos, escolas ou edifícios. A luz atua como uma problematização inerente ao teatro, mesmo antes do advento de espaços fechados - que introduziram a exigência de luz artificial, principalmente no Renascimento - como um aspecto constitutivo do pensamento teatral, um problema que integra a gênese da cena.

Investe-se, então, na busca de uma possível parceria artística, observando as mencionadas trocas e negociações estéticas entre a luz e os demais aspectos da práxis cênica. Tal abordagem é sustentada pela convicção de que o espetáculo somente se efetiva através da propriedade reveladora das imagens, incorporando luz à sua natureza, desde os primeiros traços de uma ideia poética que origina um espetáculo. Ou seja, ela já se encontra no interior da ideia, não sendo possível conceber cena, sem luz.

Deve ser registrado que a presente abordagem evita fixar a atenção num determinado momento histórico, e/ou vincular sua intervenção a determinada qualidade espetacular. De todo modo, este trabalho está organizado em 13 capítulos, os quais são relacionados a seguir.

Em "A propósito da visualidade na cena", são apresentados elementos introdutórios de determinadas inserções culturais da luz, buscando aproximar o leitor dos termos gerais do livro, assim como de uma proposição particular do conceito de visualidade, compreendida aqui como o conjunto de aspectos que delineiam a qualidade visual de um espetáculo. A visualidade singular do teatro de Shakespeare trata da visualidade latente na obra de William Shakespeare (1564-1616), observando, em particular, duas de suas peças, A tempestade e Rei Lear. A obra de Shakespeare tem o valor de profundo sintoma para o teor das observações aqui encaminhadas, uma vez que, quando se procura estudar a história da luz na cena, a preferência recai sobre o Renascimento italiano, momento no qual - como já disse - apareceram os primeiros teatros cobertos da Europa. O uso obrigatório da luz artificial naqueles teatros pode sugerir que, quando se trata da luz para a cena, deve-se começar pelo teatro renascentista da Itália. A abordagem em curso articula outra compreensão da questão, que empresta à obra de Shakespeare um papel exemplar.

Um presumível ponto de partida delineia relações entre Ésquilo e Shakespeare, utilizando como critério a natureza do teatro para o qual eles escreviam seus textos e observando a dramaturgia de ambos que, escrita com o olhar sobre a cena, incorpora a luz como aspecto indissociável. O texto efetiva-se como provocador de imagens, de ambientes e atmosferas. A ausência da luz artificial, como fator de visibilidade no teatro, representa um traço de união entre Ésquilo e Shakespeare. 
Música e Drama: cúmplices sob a mesma luz, na sequência, aborda a repercussão da tragédia grega na cena, desde o século XVI, e observa a ópera, sublinhando os elos entre drama e música, encaminhados pela luz. A principal obra estudada é Orfeu (L'Orfeo) de Claudio Monteverdi (1567-1643), com libreto de Alessandro Striggio (ca. 1573-1630), publicada em 1609, tendo estreado provavelmente em 1606. Observa-se a obra artística que pretende inscrever-se como presença da tragédia grega na arte do século XVII, e resulta numa práxis cênica diferente daquilo que se conhecia, mantendo, contudo, fortes raízes teatrais na sua relação com a luz.

O capítulo seguinte, "A luz na 'alegria de viver' renascentista", sublinha o contraste entre o rigor da cena renascentista e as convenções operísticas, acentuando a hegemonia da visão calculada, praticada no Renascimento italiano, que privilegiou a visão artificializada através da perspectiva, resultando numa observação monocular do mundo, que se transformaria em ponto de partida para as críticas ao tratamento oculocêntrico - ou ocularcêntrico - do modelo moderno. (JAY, 1988) "O brilho da luz divina" revela a outra face da moeda, abordando o mundo e, consequentemente, a cena, como um lugar disposto sob a luz divina, originada na fé cristã. "Deus é luz" tornou-se a epígrafe do texto humano na Idade Média e repercutiu decisivamente na práxis cênica.

A "santificação e a visualidade" concentra-se na arte barroca, sublinhando interações entre a pintura e a cena, norteadas por uma compreensão particular da representação de imagens religiosas, que trazem na fisicalização da santidade uma corporeidade exemplar, resultando num espetáculo de características muito particulares. Almejando o movimento e a aproximação com o observador, a visualidade no Barroco criou referências diretas à teatralidade, fazendo da luz um índice de unidade entre as artes plásticas e a práxis cênica. Em "Rotas francesas para o teatro moderno" a atenção volta-se para a diversidade das variadas abordagens da organização cênica no teatro francês do século XVII, para identificar relações com a luz. Seja na cena concebida em compartimentos simultâneos, ou no espetáculo da assimilação de máquinas pelo dispositivo cenográfico, a luz afirma-se como aspecto latente e definidor. A interpretação particular da tragédia grega faz aparecer necessidades de uma luz que seja capaz de interagir com os pressupostos da tragédia denominada "regular", submetida a rígidos controles da função do dramaturgo, gerando conflitos observados neste capítulo.

A incorporação do sentido de quadro (tableau), ou pintura, à cena, provocou a discussão em "No palco como num quadro". A teatralidade francesa que se estendeu para o século XVIII, radicalizou a compreensão do teatro como um lugar de imagens, fornecendo valioso tema para a discussão das suas interações 
com a luz. A arte teatral reafirmou suas qualidades de arte concebida para os olhos, confiando numa representação visual capaz de convencer o observador da verdade incorporada à imagem criada na cena. "A realidade na luz da cena romântica" aborda a visualidade inscrita no teatro do século XIX para combater o que se entendeu como a racionalidade veiculada pelo neoclássico francês. A idealização da presença humana gerou a busca de volumes acentuados pelas sombras, cuja relevância começa a ser citada, destacando-a como aspecto a ser tratado na cena. A práxis cênica instala-se como um empreendimento artístico, cuja natureza visual é determinante. O teatro de Henry Irving (1838-1905) é abordado como exemplo desse movimento.

"O realismo como desafio" trata da particular "artificialização" da qual se impregnou a cena para o atendimento das convenções realistas. A decisão de representar a realidade exigiu uma elaboração convincente da "realidade cênica", designando para a luz uma qualidade diferenciada, muito particular. O intuito de compartilhar com o observador a verdade realista da cena determinou a exigência de uma luz "naturalmente" presente, propondo grandes desafios ao artista. "A luz e a cena não realista" volta-se para iniciativas assim denominadas para incorporar variadas reações ao modelo discutido no capítulo anterior. A práxis cênica não realista confirma contornos profundamente comprometidos com a visualidade, manifestando demandas radicais ao iluminador, encaminhando desafios no emprego de tecnologia para interagir com as diversificadas proposições cênicas, que se instalaram desde o início do século XX, sendo rapidamente suplantadas - ou substituídas - por revoluções que se sucedem, mantendo uma aliada comum, a luz.

Vale dizer, por fim: a definitiva contribuição da luz para a criação do ser humano provoca o pensamento visualmente articulado. Ecoando nas diversas culturas, a articulação visual associa à luz ideias de revelação, clareza, esclarecimento, entre outros termos aplicados, com significados muito similares, quase como sinônimos. O pensamento visualmente articulado repercute, também, na práxis cênica. Isso sugere que o iluminador pode questionar a mera função de "iluminar", com o intuito de tornar visível, levando-o a reconhecer a presença da luz no conjunto das interferências humanas, tanto na natureza, quanto na sociedade. Ou seja: aí estão incluídas a arte, a filosofia, a religião e a ciência, considerando-se a dilatação das fronteiras entre cada um dos campos citados. Procurei, então, aprofundar a compreensão das relações entre a luz e a cena, acentuando os aspectos artísticos da primeira, através da interação com diversos momentos da cultura, compreendida, aqui, como o conjunto das diversificadas manifestações 
da presença humana. O presente processo investigativo problematiza as demandas da cena atual à visualidade e, por conseguinte, à luz.

A atuação da luz sugere um modo visual de pensar a práxis cênica, propondo tangências teóricas ainda por emergir. Urge observar que o estudo da atuação da luz na práxis humana pode indicar mais do que a descrição de aparatos e procedimentos mecânicos e/ou tecnológicos, mais do que um tratamento que apenas transite na superficialidade da aplicação de fórmulas que incluem riscos de destruir possibilidades estético-poéticas. Afaste-se a compreensão da luz na cena como o exclusivo, ou o acentuado manuseio de ferramentas, instrumentos e acessórios, e, por outro lado, fica descartada a defesa de hegemonias da luz na constituição da cena. Apesar disso, pode-se dizer que a luz se encontra nos acontecimentos espetaculares em momentos muito anteriores ao ponto histórico no qual ela é geralmente localizada.

Finalmente, vale torcer para que este livro seja lido por um jovem ou uma jovem que dele se aproxime com postura crítica e disposição para avaliar a tentativa de observar os caminhos poético-teóricos das discussões orientadas pela contribuição da luz para espetáculos, questionando fórmulas, repetições de efeitos fáceis e abordagens superficiais. 


\section{A PROPÓSITO DA VISUALIDADE NA CENA}

A presente investigação inclui uma abordagem particular de dois termos muito similares, visibilidade e visualidade. Hall Foster, crítico de arte e historiador, membro da Academia Norte-Americana de Artes e Ciências, oferece, no prefácio de Vision and visuality, um caminho que pode contribuir para o tema:

Embora o termo visão sugira o ato de ver como uma operação física, e visualidade como um fato social, os dois não se opõem, como aspectos da natureza, à cultura: a visão é social e também histórica, e a visualidade envolve o corpo e a mente ${ }^{1}$ (FOSTER, 1988, p. IX, tradução nossa)

\footnotetext{
1 "Although vision suggests sight as a physical operation, and visuality sight as a social fact, the two are not opposed as nature to culture: vision is social and historical too, and visuality involves the body and the psyche."
} 
Ele pondera que, além de não serem idênticos, esses conceitos assinalam uma tensão positiva no interior do processo visual, ou seja: uma tensão que faz interagir o mecanismo da visão, suas técnicas históricas, os dados da visão e suas determinações discursivas, com muitas diferenças entre como podemos ver, como somos capazes, permitidos, ou levados a ver, como compreendemos esse ver, ou como encaramos seu interno invisível.

O termo visibilidade será aqui aplicado para referência esquemática à sensibilização do aparelho óptico humano, como resultado da incidência de luz sobre um objeto. Ou seja, quando um autor descreve ou sugere na sua peça uma fonte de luz, ele está incluindo - mesmo que intuitivamente - aspectos técnicos relacionados ao aparato e estabelecendo graus de visibilidade, numa relação direta com a capacidade humana de ver. Tais aspectos técnicos têm função ativa na compreensão da qualidade visual proposta pela dramaturgia. Essa qualidade visual incorpora também aspectos estéticos e poéticos que, presentes já na dramaturgia e interagindo com a visibilidade, promovem a visualidade.

Nos termos que serão aqui aplicados, fica estabelecido um espaço teórico-prático para que se reconheçam diferenças entre os termos visibilidade e visualidade. Ou seja: ainda que o acionamento da visão, através da adição de luz, torne a cena "visível", tal operação "física" resultará na visualidade do espetáculo, mesmo que essa visualidade não atenda a quaisquer critérios artísticos. A visualidade, como abordada no presente trabalho, portanto, está relacionada à postura crítica que orienta o iluminador e confere qualidade estética à sua contribuição para a práxis cênica.

Desse modo, projetar luz sobre a cena promoverá visibilidade. A avaliação de cada um dos aspectos técnicos, estéticos e poéticos de tal ação, identifica a visualidade de um espetáculo, ou a qualidade das imagens (cênicas) que suscitam a articulação do seu discurso poético-visual.

Assim, na práxis cênica, os aspectos constitutivos da visibilidade (as fontes de luz e os corpos sobre os quais elas incidem, nas condições específicas do ambiente) contribuem para a qualidade visual, ou visualidade, já indicada pela dramaturgia (ou por outro ponto de partida qualquer que origine um espetáculo), sendo perpassada por variáveis estéticas e poéticas. Tais variáveis incluem os traços de períodos, de estilos, do ideário que provoca e constitui a poética de cada artista.

O termo dramaturgia foi usado acima como referência às diversas possibilidades de estímulos que geram um evento espetacular. Também se poderia dizer que qualquer evento provocador, qualquer manifestação que leve o artista a conceber um espetáculo, já incorpora aspectos da visibilidade e da visualidade. 
Lendo um texto ou roteiro de um espetáculo, o artista já pode apreender sua qualidade visual, sem a necessidade da operação física de qualquer mecanismo de iluminação que promova visibilidade, mas compreendendo a natureza da abordagem de cada autor, das relações entre fontes de luz sugeridas ou descritas, e o ambiente da ação. Não será necessária a presença efetiva da luz do sol; nem mesmo uma lâmpada ou, sequer, uma vela. A ideia de espetáculo (uma espécie de estado pré-cênico) pode estar sendo narrada por alguém que a mantém na memória, e a narrativa, em si, já incorpora qualidades visuais. O iluminador pode apreender tais qualidades, ampliando sua abordagem da visualidade na práxis cênica. No escopo da imagem cênica, esse estado pré-cênico é encontrado em qualquer indício da ideia de um espetáculo. Ele pode se referir a uma tragédia grega ou a uma sutil elaboração mental engendrada na imaginação de um performer da nossa atualidade, no preciso momento em que ele decide responder a qualquer que seja o estímulo, nos termos da performatividade.

No espetáculo, contudo, a visibilidade incorpora objetivamente fontes de luz especificamente definidas pelo iluminador. Isso exige a análise de instâncias tecnológicas que incluem as características de cada instrumento, de cada acessório e do sistema de controle incluído no projeto, permitindo ao iluminador discutir a visualidade presente nas primeiras indicações da dramaturgia, como estratégia para definir aquela mais tarde efetivamente incorporada à cena propriamente dita.

Por outro lado, é importante salientar, na presente abordagem, que, ao apresentar visibilidade própria, toda práxis cênica estabelece um nível de visualidade, ou seja: a visualidade não representa um privilégio do "bom" espetáculo. Então, o modo como um iluminador aplica a visibilidade para construir a narrativa visual do espetáculo, que constitui o seu discurso visual, determinará a qualidade da proposição artística. Esclarecendo: mesmo um acontecimento cênico no qual proliferaram os efeitos especiais, sem aparente disciplina, no qual a luz recebeu um tratamento superficial e "espetaculoso", oferece ao seu público uma visualidade particular, ainda que inconsistente de um ponto de vista artístico-poético.

Essa abordagem incorpora à aplicação da luz na obra artística a compreensão de componentes intravisíveis. A interação entre visibilidade e visualidade revela uma categoria intravisivel presente nos pressupostos estético-poéticos alocados no interior de uma obra, por exemplo, o acontecimento espetacular, e que permaneceriam desconhecidos (in-visíveís) numa hipotética exclusiva aplicação de visibilidade.

Como já foi dito, a resposta do iluminador às atmosferas presentes na ideia primeva de cena inclui aspectos artísticos, exigindo a aplicação de conceitos ligados 
ao discurso visual, como cor, textura, forma, intensidade, ritmo, movimento, equilíbrio, força, entre outros.

Tais procedimentos podem libertar o artista do acaso, da cópia, dos efeitos mirabolantes injustificados, criando sua própria abordagem crítica do espetáculo, na contribuição do seu design para a cena, sem se tornar um inventor, a cada espetáculo. A ciência necessita dos inventores, mas o teatro não pode depender da invenção de um novo aparato a cada espetáculo. Sua opinião sobre a visibilidade e a visualidade que interagem na cena pode dar ao iluminador a autonomia necessária para posicioná-lo como um artista, cujo trabalho tem um papel decisivo no contexto. A consequência disso deve ser uma elaboração cênico-crítica da visualidade inscrita na ideia que originou um espetáculo, incluindo a proposição do diretor, assim como dos demais artistas que elaboram a práxis cênica. Tal elaboração cênico-crítica é promovida pela consulta a fontes primárias (dramaturgia, roteiros) e secundárias, que podem inserir na pesquisa uma extensa ramificação provocada pelas questões culturais indicadas nas fontes primárias, sugerindo contatos com a ciência, a filosofia e as artes. O iluminador pode, portanto, compreender que seu trabalho inclui a natureza de uma pesquisa especializada, permitindo registro e avaliação.

Quando uma ideia é corporificada na cena pela iniciativa de um diretor ao serem estabelecidas relações específicas entre ele e o iluminador, novas variáveis ingressam no processo. O iluminador deve incorporar flexibilidade à compreensão das dificuldades apresentadas por um ou outro artista, no que se refere às especificidades do discurso visual. Com tudo isso, fica compreendido que a interpretação particular de cada iluminador da visualidade proposta pelo elemento provocador do espetáculo, pela ideia inicial da qual ele se origina, determina a assertiva visual que será compartilhada com o espectador ou, a visualidade da práxis cênica. Por conseguinte, visibilidade e visualidade estão indicadas desde o momento no qual um autor começa a elaborar suas ideias, mas só se efetivam na cena através da contribuição da luz.

Os compromissos da cena com a visualidade há muito despertaram o interesse de artistas e teóricos importantes. Escrever sobre tais compromissos, portanto, é seguir uma trilha já iniciada por Sebastiano Serlio (1475-1554), Nicola Sabbattini (1574-1654) e Joseph Furttenbach (1591-1667) e compilada por Hewitt (1958). Como se pode constatar, trata-se de um antigo interesse demonstrado por autores motivados pela raiz científica do olhar que gerou a Renascença italiana.

Depois da Renascença, o mais importante passo da ciência para as relações do homem com a luz pode ser creditado à introdução da luz elétrica, em finais do 
século XIX. Já no início do século seguinte, o trabalho de Louis Hartmann² permite observar a repercussão de tal avanço, no teatro. Ele publicou, em 1930, Iluminação para o teatro: um manual do sistema de controle de luz para o palco (Theatre lighting: a manual of the stage switchboard). Hartmann trabalhou como eletricista-chefe (ou expert em luz) nos espetáculos produzidos e/ou dirigidos por David Belasco ${ }^{3}$ (18531931), nas primeiras décadas do século XX, nos EUA, e inaugurou a trilha da literatura técnica moderna acerca da luz para a cena.

Hartmann integra, então, o extenso conjunto de pesquisadores do século XX que abordaram questões de natureza tecnológica referentes à aplicação da luz no teatro, e o seu livro resulta de exaustiva pesquisa voltada para os espetáculos de Belasco. Tal legado tem repercussão pouco significativa no ambiente acadêmico brasileiro. Em geral, a literatura técnica sobre a luz teatral tem seu valor relativizado cada vez mais rapidamente devido ao furor na busca por novos efeitos e, por conseguinte, o aparecimento frequente de "novidades".

A hegemonia dos efeitos pode priorizar o aparato, repetindo sucessivamente resultados que se transformam em fórmulas. Se no processo de redação do presente trabalho os moving lights ${ }^{4}$ e os painéis de LED ${ }^{5}$ são os nomes em voga, um novo instrumento ou técnica logo se tornará o sonho de consumo. A incessante busca pelo efeito que "está se usando muito" vem lançando certos instrumentos, acessórios e sistemas de controle reconhecidos oportunamente como grande e novíssima solução, no campo do obsoleto.

Louis Hartmann deixou contribuições que sobrevivem até hoje, como a primeira gelatina criada especificamente para um designer. Ele solicitou a produção da gelatina Bastard Amber (Roscogel \#O2), desenvolvida pela Rosco, depois de um achado casual. O próprio nome da cor nasceu de um comentário de David Belasco. ${ }^{6}$ Ainda que a sutileza cromática do filtro bastard-amber não seja vista com frequência em projetos corriqueiros, ele ainda se encontra à disposição e pode ser muito importante, quando não se procura a saturação acentuadamente óbvia. Depois de vinte e oito anos trabalhando juntos, Belasco escreveu no prefácio do

2 Dados biográficos de Hartmann não foram encontrados, constando aqui os registros da sua relação profissional com David Belasco.

3 Diretor e produtor norte-americano que trabalhou no teatro entre os anos de 1884 e 1930.

4 Os moving lights são instrumentos automatizados, que atendem a comandos de um programa de computador, com flexibilidade para mudanças de cor, texturas e movimento. Em muitas situações são chamados de "múvi".

5 Ou: light-emiting diode (diodo que emite luz). O diodo é um componente eletrônico que permite um fluxo elétrico em apenas uma direção.

6 Ver em: <http://www.rosco.com/spectrum/index.php/2012/o1/spectrum-wavelengths-designer-series-louis-hartmann/>. Acesso em: 15 maio 2012. 
livro de Hartmann: "O Sr. Hartmann é um expert em luz, em fazer sombras e colorir, um artista que pinta com fachos de luz e brilhos difusos ao invés de pigmentos e pincéis".7 (BELASCO, 1970, p. V, grifo e tradução nossos)

É importante assinalar que o próprio David Belasco publicou um livro sobre sua experiência teatral. ${ }^{8}$ A primeira edição ocorreu em 1919 e sublinha sua preocupação com a luz. A parceria desenvolvida por três décadas entre ele e Hartmann promoveu etapas importantes nas reflexões em torno do binômio luz-cena. Isso faz do trabalho de Hartmann um documento relevante, não apenas para a compreensão do teatro dos EUA, mas também fornece uma dentre as primeiras teorizações modernas da montagem teatral, incluindo a luz como um dos seus aspectos determinantes. O depoimento posterior de Belasco, no seu próprio livro, delineia a relevância da parceria:

Chega o momento de considerar aquele que é o mais importante fator de uma montagem, a luz das cenas. Discuto a peça detalhadamente com meu eletricista, usando o mesmo método que segui para trabalhar com o cenógrafo. ${ }^{9}$ (BELASCO, 1919, p. 55, tradução nossa)

O seu processo incluía exaustiva pesquisa referente à dramaturgia, à cenografia e à luz:

As luzes estão para o drama como as palavras para uma canção. Nenhum outro fator de uma montagem é tão eficiente para comunicar seus climas e sentimentos. Elas são tão essenciais para a arte dramática como o sangue para a vida. Atribuo a maior parte do meu sucesso no teatro ao meu sentimento para as cores, traduzido em efeitos de luz. ${ }^{10}$ (BELASCO, 1919, p. 55, tradução nossa)

O termo "efeito" deve ser destacado. Sua questionável compreensão proliferou durante todo o século XX e ainda parece presente, mesmo depois de Jean

7 "Mr. Hartmann is an expert in lights, shading and coloring, an artist who paints with light-beams and diffused glows instead of pigments and brushes."

8 Livro The theatre through its stage door, de 1919.

9 "It is time now to begin to consider what to me is the all-important factor in a dramatic production - the lighting of the scenes. With my electrician I again go over the play in detail, very much according to the method I have previously followed with my scenic artist."

10 "Lights are to drama what music is to the lyrics of a song. No other factor that enters into the production of a play is so effective in conveying its moods and feeling. They are as essential to every work of dramatic art as blood is to life. The greatest part of my success in the theatre I attribute to my feeling for colors, translated into effects of light." 
Rosenthal haver chamado a atenção para sua aplicação, já na década de setenta do mesmo século:

\begin{abstract}
A luz afeta tudo o que toca: o modo como vemos, o que vemos, como nos sentimos sobre isso, e como ouvimos aquilo que estamos escutando. | 'Afeta' [affect] é a palavra chave. Mude o 'a' para um 'e' [effect], e você terá efeitos de iluminação. Os efeitos devem ser tratados com todo o cuidado e usados com a raridade de fogos de artifício. $O$ trabalho mais bem-sucedido e brilhante de um lighting designer é usualmente, o menos notado. ${ }^{11}$ (ROSENTHAL; WERTENBAKER, 1972, p. 3, grifo e tradução nossos)
\end{abstract}

O uso dos efeitos tem grande relevância no discurso visual de um espetáculo. A cena é o momento do processo onde eles são efetivamente testados e aplicados. Somente observando seu resultado na relação com o público pode-se avaliar sua eficiência. Contudo, é possível localizar o equívoco de alguém que desconsidera a sutileza e transforma a luz para a cena numa sucessão descontrolada de efeitos. Conceber um projeto de luz para a cena pode incluir a radicalidade de imagens visuais nas quais a mencionada sutileza é índice determinante. Num movimento contrário à assertiva de Rosenthal, pode haver espetáculos nos quais todas as providências são tomadas para que a luz seja sempre um destaque, um efeito. É compreensível que isso aconteça, se o iluminador mantiver sua "luz" no domínio do senso comum, transformando a cena em um desmedido vai e vem de cores e padrões gráficos. Daí, a fumaça (ou neblina, a umidificação do ar) transforma-se em componente primeiro da luz "espetaculosa".

Louis Hartmann teve como incentivador o professor na Universidade de Yale, Stanley McCandless (1897-1967), que escreveria em 1932 um livro aclamado por estudiosos norte-americanos, Um método para a luz no palco (A method of lighting the stage). Importante dizer que McCandless foi professor de Jean Rosenthal, já citada, na Universidade de Yale, nos anos de 1930.

Antes do aparecimento do trabalho de Hartmann, na década de 1930, a transição entre os séculos XIX e XX trouxe dois artistas investigadores responsáveis por provocações decisivas para o teatro, a partir de então. Trata-se dos já citados Adolphe Appia, cenógrafo e autor suíço e Gordon Craig, cenógrafo inglês, cujas

\footnotetext{
11 "The lighting of it affects everything light falls upon: how we see what we see, how we feel about it, and how you hear what you are hearing. | "Affect" is the key word. Change the "a" to an "e" and you get lighting effects. Effects should be handled with all care and used with the rarity of fireworks. The most successful and brilliant work of a lighting designer does it usually least noticeable."
} 
reflexões e elaborações sobre a contribuição da luz para o espetáculo determinaram passos importantes para o pensamento sistematizado acerca da luz na cena. Os trabalhos de Appia, como exemplo, devem ser observados nas suas devidas proporções, pois não se pode dizer que o teatro estava morto, antes da publicação do seu livro A obra de arte viva (L'ouevre d'art vivant), em $1921 .^{12}$

Deve-se reconhecer o papel de visionários desempenhado por ambos, Appia e Craig, sem perder de vista uma geração de artistas, como os exemplos de Belasco e Hartmann, que alcançaram relevância no seu próprio tempo, sistematizando a montagem teatral de sua época, e contribuindo para a qualidade técnica e artística do teatro profissional moderno.

É importante destacar aqui a importância da interação entre a práxis cênica e a tecnologia e levar em conta o acolhimento de processos tecnológicos, inclusive aqueles oriundos de outras áreas do conhecimento que assumem função determinante na montagem teatral de cada período. No entanto, motivado pelo interesse na mencionada qualidade artística, o presente trabalho evita concentrar-se na descrição dos aparatos, assim como das suas possibilidades técnicas, ou ainda na suposta orientação de uso dos mesmos. Quaisquer compêndios cujo objetivo seja a apresentação de aparatos, de tecnologia, devem ser produzidos com a clareza da sua função de registro histórico. Caso contrário, podem redundar cartilhas obsoletas mesmo antes de serem concluídas, pois não se pode esquecer a progressiva rapidez dos avanços tecnológicos.

Além disso, a sustentação de fórmulas destinadas à elaboração da luz na cena pode resultar numa consideração parcial que acabará por acentuar a "visibilidade", submetendo a luz dos espetáculos às características técnicas dos espaços (teatros), dos instrumentos, acessórios e sistemas de controle. Isso promoverá terreno para a hegemonia dos efeitos que acabam por se repetir, passando de um evento a outro. Talvez fosse melhor identificar tais características e avaliar sua aplicação em cada contexto ou espetáculo, considerando-se as questões estéticas em jogo.

Por outro lado, pesquisadores interessados nas questões de natureza estética não devem interpretar a documentação técnica como um desprestígio às contribuições artísticas da luz para a cena. O exagerado receio pode originar preconceito no que se refere a tal categoria de trabalhos, considerando-os ameaça ou aspecto negativo para a cultura da luz no teatro. Afinal, ainda que seja recomendada cautela na leitura de trabalhos de tal natureza, considerando o momento no qual foram escritos, a precisão e até as discutíveis traduções, cabe lembrar que a docu-

12 Sua obra será abordada adiante, no capítulo "A luz e a cena não realista". 
mentação técnica tem papel importante como registro de etapas e processos. Em qualquer atividade humana, há a possibilidade do uso da técnica, para fundamentação, controle e eficiência. O artista pode aplicar, em muitos casos, procedimentos técnicos, incluindo o planejamento. Mesmo que pareça óbvio, deve-se lembrar que a preocupação com pressupostos estéticos de uma obra não exclui o uso de informação técnica e tecnológica. Afinal, quando se trata de contribuições da luz, há um grande elenco de possibilidades ligadas a um conhecimento já produzido, que pode indicar soluções.

É importante sublinhar a dificuldade em se traduzir documentos da literatura técnica, principalmente manuais de equipamentos. Documentos em língua estrangeira que tratam das relações entre a luz e a cena geralmente se referem a um ambiente muito específico. A atividade de traduzir exige familiaridade com o universo no qual os textos se originaram, para evitar resultados superficiais e/ ou suposições equivocadas que podem comprometer a seriedade das iniciativas, reduzindo seu valor como fontes de estudo. Por outro lado, incorporar de modo indiscriminado expressões em língua estrangeira pode gerar muitos equívocos.

O estudo das habilidades e competências que devem ser incorporadas pelo designer no desenvolvimento de uma carreira no campo do conhecimento artístico aqui abordado pode apresentar certos riscos. Deixar a confiança exclusiva em procedimentos de natureza prática, por vezes em práticas equivocadas e/ou em uma acentuação desmedida da intuição "genial", nortear desse modo uma atividade que incorpora instâncias diversificadas do conhecimento, desde a física até os estudos das artes visuais, assim como da filosofia, da dramaturgia e da história pode resultar em superficialidade de tratamento ou qualidade alcançada ao acaso.

Precisam ser destacados autores que, trabalhando no campo da História do Teatro, trataram as relações entre a luz e o espetáculo na sua condição de aspecto importante para a compreensão das artes cênicas. Dentre eles, destacam-se: Alois Maria Nagler (1907-1993), cuja pesquisa da história do teatro foi decisiva para o estudo aqui empreendido, principalmente quando ele menciona diversificados documentos referentes à atuação da luz, Phyllis Hartnoll (1906-1997), John Ramsay Allardyce Nicoll (1894-1976) e Gösta Mauritz Bergman (1905-1975), cujo trabalho aborda particularmente a atuação da luz na cena.

Deve ser afastada a expectativa de encontrar no trabalho em curso mais uma História da Luz Teatral. Sublinhando a relevância de pesquisas operadas nesse caminho deve-se considerar que escrever agora uma abordagem histórica do tema exigiria um estudo capaz de questionar ou ampliar o alcance do trabalho de especialistas, por exemplo, Gösta Mauritz Bergman (1977). Fica também descartada a 
redação de uma listagem de aparatos - instrumentos, acessórios e sistemas de controle - usados nos espetáculos ao longo da história.

\section{A GÊNESE DA CENA E A VISUALIDADE}

Sem a atenção que o problema exige, pareceria óbvio escrever um trabalho acadêmico acerca da necessidade da luz para o teatro. Afinal, como se repetiu incontáveis vezes, a palavra teatro deriva do verbo théa - ver, em grego, relacionado ao substantivo theatron [ $\theta \dot{\varepsilon} \alpha \tau \rho o v]$, ou lugar de onde se vê ou para ver. Ainda se pode considerar o termo theaomai [ $\theta \varepsilon \alpha ́$ o $\mu \alpha 1]$, ver/observar. Num processo associativo, pode-se compreender que o termo theatron se refere ao lugar no qual os espectadores se acomodavam; é justamente onde eles se posicionavam para assistir a rituais, tragédias, comédias, fazendo do teatro um tempo/templo da visão.

Se o objetivo é tornar a cena visível, deve-se, portanto, projetar luz sobre ela. Devem ser evitados obstáculos entre a fonte de luz e a cena, assim como entre a cena e o observador. Já se encontram aqui algumas variáveis. A mais importante exige que a luz apresente brilho capaz de alcançar a cena, para refletir em direção ao observador. Seria possível observar inúmeras variáveis envolvidas na relação entre luz e cena, discutindo as características dos instrumentos, acessórios e sistemas de controle, associando-os à capacidade reflexiva dos materiais aplicados na cena, incluindo o dispositivo cenográfico, os figurinos, a maquilagem, a densidade do ar, entre outros.

As relações entre diversas variáveis oferecem ao designer um amplo espectro de escolhas, permitindo a definição de imagens que serão criadas na cena e estabelecendo diferenças entre tornar visível e construir visualidade através de imagens cênicas. A visualidade pode ser avaliada em seus aspectos técnicos e estéticos, que são associados às imagens cênicas através do trabalho de um designer.

Ao tratar de problemas referentes à direção e à edição de textos de Samuel Beckett (1906-1989), Stanley E. Gontarski (1995, p. 10, grifo e tradução nossos) relata: "Tendo trabalhado em estreita colaboração com Anthony Page no Royal Court Theatre de 1973 na produção de Not I e tendo dirigido-o em 1975 no Teatro d'Orsay, Beckett permaneceu em silêncio ambivalente sobre a imagem visual final da peça."'13

\footnotetext{
13 "Having worked closely with Anthony Page on the 1973 Royal Court Theatre production of Not I and having directed it himself in 1975 at the Theatre d'Orsay, Beckett still remained ambivalent about the final visual image of the play."
} 
A ambivalência de Beckett, no que se refere à imagem visual final da peça, tratando da personagem Auditor, designa a qualidade de "problema visual" para o posicionamento (da personagem) em cena. Ele mesmo descartou o Auditor em montagens que dirigiu, sem nunca haver incluído no corpo do próprio texto tal solução, mas sugeriu tal caminho em correspondência com diretores. Há no pequeno trecho citado um detalhe que merece atenção, quando Gontarski (1995) menciona a "imagem visual" que, aparecendo no final do texto, deixa de ser criada no espaço espetacular. Isso reforça a abordagem da dramaturgia como um problema visual, pré-cênico, e aponta para um estudo específico da cena, recortado por tal viés. Ou seja, qual o papel das imagens visuais, materiais e arbitrárias na cena? Parece óbvio que não há resposta exclusiva para tal questão. No entanto, reconhecendo a visualidade já presente no estado pré-cênico, ${ }^{14}$ o designer pode definir a visibilidade para alcançar a assertiva visual que projeta para a cena.

A expressão visual da práxis cênica inclui cada imagem elaborada, assim como a sucessão de imagens que instalam visualmente a espetacularidade. Pode ser arriscado tomar decisões nesse caminho contando puramente com o acaso ou com a "genialidade" de um diretor ou iluminador. Cada uma das imagens que constituem a cena pode ser encarada como um problema a ser estudado. É possível reconhecer que há critérios para tal procedimento. Quando se identifica a visualidade inscrita na dramaturgia, ${ }^{15}$ cria-se um ponto de vista, permitindo que seja avaliada sua repercussão na cena. Beckett deixou uma brecha no texto, quando se trata do Auditor, e cada diretor tomará sua própria decisão.

A percepção visual atua como um aspecto determinante da relação entre o observador e o espetáculo, envolvendo níveis estéticos e poéticos. Desde metáforas que apareçam no texto até o conjunto de tudo aquilo que é percebido visualmente, na cena, pode ser objeto de estudo do iluminador.

Em Seis propostas para próximo milênio: lições americanas (Lezioni americane: sei proposte per il prossimo millennio), Italo Calvino (1923-1985) expressa uma produtiva relação entre imagens e texto. O livro resultou de um conjunto de cinco conferências, escritas a partir de um convite da Harvard University, em 1984; o evento nunca ocorreu, devido ao falecimento do autor antes da sua realização, até mesmo sem que ele concluísse a sexta e última conferência do projeto. Na quarta conferência, Visibilidade, Calvino indica caminhos para a compreen-

\footnotetext{
14 Todo procedimento que ocorre antes do espetáculo propriamente dito, o texto em si, um ensaio, e assim por diante.

15 Como exemplo; lembre-se que o material do qual se parte para construir a práxis cênica pode ser muito diversificado.
} 
são das imagens como provocadoras da sua própria obra, processo no qual pode ser identificada significativa familiaridade com a abordagem em andamento. É importante, contudo, ressaltar que Calvino (1998) aplica o termo visibilidade de modo diferenciado daquele que a presente abordagem propõe, ou seja: sem a diferenciação estratégica aqui incorporada ao termo visualidade. De todo modo, é relevante observar que Calvino (1998, p. 104) estabelece a importância das imagens para a construção poética: "Quando comecei a escrever histórias fantásticas, ainda não me colocava problemas teóricos; a única coisa de que eu estava seguro era que na origem de um de meus contos havia uma imagem visual".

Ele considerava muito importante a relação com as imagens, não somente para o artista, mas também para o ser humano.

[...] estamos correndo o perigo de perder a faculdade humana fundamental: a capacidade de pôr em foco visões de olhos fechados, de fazer brotar cores e formas de um alinhamento de caracteres alfabéticos negros sobre uma página branca, de pensar por imagens. (CALVINO, 1998, p. 107-108, grifo do autor)

Seu interesse pelas imagens em muito transcendem a mera visibilidade física, remetendo o leitor a um intrigante ambiente no qual as imagens atuam como agentes provocadores da sua narrativa. Elas constituem um pensamento visual que a alimenta e move:

[...] o poeta deve imaginar visualmente tanto o que seu personagem vê quanto aquilo que acredita ver [...] assim como deve imaginar o conteúdo visual das metáforas de que se serve precisamente para facilitar essa evocação visiva. O que Dante está procurando definir será, portanto, o papel da imaginação na Divina Comédia, e mais precisamente a parte visual de sua fantasia, que precede ou acompanha a imaginação verbal. (CALVINO, 1998, p. 99)

Referindo-se a Dante, Calvino (1998) demonstra como a poesia permite interações com imagens mentais, que repercutem e acompanham as imagens verbais na elaboração do texto propriamente dito. Incorporar imagens é um desafio para aquele que elabora a dramaturgia ou outro elemento provocador da práxis cênica. O iluminador, esse não tem escolha: sua função o obriga a criar imagens, mesmo que elas não precisem representar uma invenção "absoluta”, saída de lugar nenhum. É possível estabelecer contatos com o mencionado elemento "provocador". Calvino (1998) distingue dois processos imaginativos, tanto o que parte da 
palavra para chegar à imagem "visiva", quanto o que parte da imagem para chegar à palavra. Quando lê um romance ou uma narração jornalística, o leitor parte da palavra para ver a cena acontecendo diante dos seus olhos, mesmo em fragmentos ou detalhes.

Calvino (1998) acentua a relação entre a capacidade do texto de provocar as imagens e a do leitor de criar imagens mentais, cuja força pode lembrar uma projeção cinematográfica. As imagens cênicas são corporificadas pela presença dos agentes - animados ou inanimados - que compõem a imagem elaborada ou provocada desde a primeira ideia de cena. Ainda que isso não represente, necessariamente, uma novidade, deve-se acentuar que a imagem cênica somente se revelará com a contribuição da luz, estabelecendo relações com processos imaginativos engendrados pelo observador.

A cena pode, então, se configurar como um discurso poético-visual que incorpora a flexibilidade na sua relação com o observador. O termo discurso é aqui compreendido como sistematização de ideias, práticas e pensamentos - no caso, visuais - desvinculando-se das abordagens já exaustivamente aplicadas e questionadas de leitura da imagem. Devem ser evitadas ligações com tentativas, surgidas na segunda metade do século passado, de reduzir a relação do ser humano com as imagens, enclausurando o processo em diferentes molduras do pensamento de cada período. Reduzir a imagem a algo que deve ser "lido" inclui a imposição de limites oriundos da normalização textual, que considera um texto o resultado da organização de pensamentos em palavras, regulada pela gramática e por ideologias.

Cabe lembrar Roland Barthes (2004), quando, no seu texto Aula, ${ }^{16}$ se refere à linguagem como um lugar fechado e à língua como uma relação de servidão e poder. Barthes (2004) aponta como saída a trapaça salutar com a língua, combatendo tal servidão através da possibilidade de jogar, que ele absorve do teatro. Indicando representação e interpretação, o ato teatral de jogar (jouer) propõe uma subversão da língua, cujo poder normativo pode encarcerar o discurso. O jogo teatral inclui no seu discurso instâncias poético-visuais que abrem possibilidades multirreferenciais para questionar as limitações dos papéis do espectador, considerando aquele com quem se compartilha a cena um cocriador de imagens. Na cena, a imagem pode atuar como provocação, afastando-se de qualquer enquadramento que pretenda tornar "legíveis" seus elementos constitutivos. A referência a conceitos, como forma, textura e cor, assim como a derivações que incluem

16 Aula inaugural no Colégio de França, proferida em 7 jan. 1977. 
elementos da natureza própria da imagem, por exemplo, equilíbrio e força, objetiva acentuar a apreensão de tais elementos como componentes da provocação dirigida ao observador que, instigado pela visualidade da cena, assume o papel de criador de imagens (suas próprias imagens).

Ao incorporar a visão como aspecto intrínseco da sua efetivação, o teatro grego já investia na elaboração de imagens em movimento, de natureza muito semelhante àquelas que Jean-Jacques Roubine (2003, p. 29, grifo nosso) menciona: "Ora, na ótica de Aristóteles, sua finalidade [a do teatro] é, como vimos, a catarse, que só pode operar se o espectador acaba por confundir a imagem e seu modelo". o "modelo" em questão refere-se ao amplo conceito de "natureza", como objeto a ser mimetizado pela imagem criada na cena. Roubine já identifica em Aristóteles a imagem como um inexorável aspecto da cena. Diferente daquela que ele identifica como o corpo-imagem do cinema:

No cinema, o corpo estabelece uma forma completamente diferente [daquela que se dá no teatro] de relação com o espectador. Sendo uma imagem, ele está fisicamente 'ausente', por mais forte que possa ser a sua presença na tela. Engano, ilusão... Pois este corpo, se é ausente, irreal, é ao mesmo tempo valorizado, exaltado, pelos efeitos de filmagem e edição. Paradoxo da 'presença-ausência', aqui levado à sua máxima tensão. (ROUBINE, 1982a, p. 39)

Antes, o mesmo autor já havia reconhecido: “[...] o corpo não é por natureza, teatral. Ele precisa aprender a se movimentar, e mesmo a 'estar', no espaço artificial que é o palco". (ROUBINE, 1982a, p. 32) Importante observar que o termo artificial não apresenta qualificação negativa e, sim, reconhecimento da natureza do teatro. Isso equivale a dizer que, mesmo algo posto em cena para "parecer natural”, só alcançará tal objetivo, se artificializado de modo preciso. Portanto, a imagem criada no contexto espetacular, qualquer que seja o modelo ou o estilo, será sempre um produto artificialmente criado por um artista, ou grupo de artistas. Todo elemento constitutivo da imagem deve ser submetido a um tratamento artificial, especialmente elaborado para cada proposição. Nesse conjunto está incluída a luz, pelo menos enquanto a cena mantiver sua raiz grega e oferecer algo para que o espectador perceba visualmente, uma imagem, ou sucessão de imagens, em movimento.

Ainda Roubine (1982b, p. 32):

[...] aquilo que o espaço cênico nos faz ver é uma imagem. [...] em três dimensões, organizada, animada... Descobre-se que 
essa imagem pode ser composta com a mesma arte que um quadro, [...] a organização das cores, o jogo das áreas cheias e vazias, das sombras e luzes, etc.

Ele faz tais considerações, ao tratar do simbolismo no teatro. Tal observação deixa, no entanto, uma questão: em que situação a cena abandona a condição de imagem, desconsiderando a organização das cores, o estudo de área e massa e da interação entre sombra e luz? A cena nunca alcançou tal direito. Enquanto mantiver a condição de objeto artístico, "artificial", não importam estilos ou revoluções, ela ainda será "grega", no sentido de oferecer ao público uma imagem, como diz Roubine (1982b), tridimensional, mas segundo um ordenamento particular, um discurso em movimento; inserida, portanto, no tempo.

Observando o teatro de Gordon Craig, Roubine (1982b, p. 57) afirma:

O 'regente' deve organizar seus cheios e vazios, animá-los, modificá-los pelo recurso à luz. Se o teatro persegue o sonho de ser uma arte sagrada, então a imagem cênica deve ser composta com tanto cuidado quanto um quadro. Mas o teatro é também movimento e mudança, uma vez que a representação não é apenas inscrição em um espaço, [...].

Ainda que concentrado no estudo de um artista, estilo e período, Roubine (1982b) revela nuanças indissociáveis presentes em qualquer manifestação teatral, à parte as qualidades do sagrado. Mesmo um teatro cruamente profano estará submetido e exige a criação da "imagem cênica", de composições em movimento, não apenas uma, mas uma sucessão finita, elaborada para cada espetáculo, em parceria com a luz. Incorpora-se neste trabalho o objetivo de identificar tal processo, em diversos momentos representativos da práxis cênica, na expectativa de reconhecer o papel da luz como problema que demanda estudos particulares, numa relação direta com o discurso visual provocador de cada um dos momentos da cultura teatral.

Tal imagem cênica difere da abordagem moderna de imagem, exaustivamente discutida como uma imagem elaborada pela tecnologia que possibilitou o seu registro, sua manipulação e reprodução. Se a imagem material, plástica, pode ser remontada à arte rupestre, datada do Paleolítico Superior (40.00o a.c.), e alcançou a sofisticação pré-capitalista da pintura a óleo, transformando-se em objeto portável e negociável, na imagem cênica é possível reconhecer a ingenuidade crua daquelas inscritas no contexto de quatro dimensões (incluindo sua efetivação temporal) dos rituais testemunhados pelo mesmo artista do período 
rupestre. Ela ainda pode ser efetivada pela presença de um ser humano (artista), que busca a fisicalização artificial de um objeto (ou modelo) ausente.

O artista que pintou as imagens das cavernas em Lascaux, na França, há mais de 15 mil anos, poderia estar próximo da ordem antropológica das imagens performativas. Ele selecionava um conjunto de materiais e instrumentos para trabalhar no suporte escolhido, as paredes das cavernas. Podem ter sido necessários andaimes e luz artificial. Considerando a instabilidade da luz produzida pela suscetibilidade das fontes às correntes de ar, pode-se imaginar a mobilidade das imagens, mesmo enquanto eram pintadas. O pintor deveria selecionar as intervenções (traços, linhas) que materializariam a imagem que lhe vinha à mente. Se o pintor estava acompanhado por alguém que assumia o papel de observador da sua habilidade e competência para gravar a imagem, sua atividade ganhava uma qualidade quasi-espetacular, podendo contemplar aspirações das mais recentes revoluções performáticas, incluindo a novíssima arte da ação, sem "personagem", derivada das artes visuais.

Na caverna citada, portanto, alguém (artista, performer) era contemplado por outro (um espectador/observador) enquanto efetivava uma ação, sob luz artificial, especificamente instalada para tal fim. Tratava-se de uma espécie de fronteira entre a visibilidade promovida pela fonte de luz artificial aplicada para permitir o trabalho do pintor e a visualidade daquele momento de elaboração da imagem que ganha, então, características de performance (visual). A sombra do pintor não deveria incidir sobre a imagem plástica, pictórica, enquanto a mesma estava sendo elaborada, exigindo determinado posicionamento das fontes de luz artificial. O corpo do pintor, em si, era uma imagem que criava a segunda imagem, profundamente enraizada na cultura (suas observações, seus desejos ou sonhos), da qual ele retirou seu modelo. A imagem visual (cênica?) do corpo do pintor desvanesceu-se no tempo, e a imagem plástica, gravada, sobreviveu. A imagem plástica de um animal ainda hoje presente, afirma a efemeridade da outra imagem (cênica, teatral, performática) ausente. Mas isso não deve impedir o estudo desta última, da sua recriação crítica.

Quaisquer quebras de paradigmas espetaculares, por mais revolucionários que sejam, quando põem em cena um ser humano, estão elaborando imagens que contam com a presença de um corpo fisicalizador do desejo de presentar-se (ou "presentificar-se") em cena. Afirma-se, portanto, a práxis cênica, como interação de imagens: verbais, sonoras, olfativas, mentais, e, também, visuais. A cena como meio que efetiva a imagem total do evento espetacular e, simultaneamente, como fisicalização artificializada do corpo que cria e projeta imagens, desde, e em si mesmo. A qualificação da totalidade das imagens não pressupõe, necessaria- 
mente, unidade. Em tempos nos quais ainda se fala de pós-modernidade, pareceria ingenuidade impor à cena, a unidade das chamadas "grandes narrativas".

\title{
A CENA E O ESTUDO DAS IMAGENS
}

\section{A discussão iconológica empreendida pelo estudioso alemão Hans Belting (2005) pode contribuir para a abordagem da imagem que norteia esta investigação:}

\begin{abstract}
Os papéis que têm sido destinados à imagem, aos meios e ao corpo variam frequentemente, mas sua estreita interação continua ativa até hoje. O medium, a despeito do seu caráter polissêmico e aplicação polivalente, oferece a mais facilitada identificação e, por essa razão, é favorecido pelas teorias contemporâneas. O corpo apresenta-se em seguida, mas é frequentemente e de modo excessivamente purista, impelido contra as atuais tecnologias e considerado seu observador. Impõe-se, portanto, uma nova ênfase aos corpos, como meios vivos, capazes de perceber, lembrar e projetar imagens. O corpo como proprietário e destinatário de imagens, meio administrado como extensões das suas próprias capacidades visuais. Corpos que recebem imagens, percebendo-as, e na condição de media as transmitem para corpos. Com a ajuda de máscaras, tatuagens, roupas e performance, corpos também produzem imagens de si mesmos ou, no caso de atores, imagens que representam outros, caso em que atuam como media no sentido mais pleno e original. Seu monopólio inicial na mediação de imagens nos permite falar de corpo como o arquétipo de todas as media visuais. ${ }^{17}$ (BELTING, 2005, p. 315, tradução nossa)
\end{abstract}

Em diversificadas instâncias, a assertiva de Belting tangencia o foco do presente trabalho. Importa, contudo, acentuar sua menção ao ator como lugar da tríade por ele cunhada, imagem-meio-corpo. E mesmo que esse ator seja banido

\footnotetext{
17 "The roles that have been assigned to image, medium, and body constantly varied, but their tight interaction continues up to the present day. The medium, despite its polysemantic character and polyvalent use, offers the easiest identification and is for this reason favored by contemporary theories. The body comes next, but it is all too often and all too neatly played out against current technologies and considered as their obverse. It therefore needs a new emphasis on bodies as living media, able to perceive, to remember, and to project images. The body, as owner and addressee of images, administered media as extensions of its own visual capacities. Bodies receive images by perceiving them, while media transmit them to bodies. With the help of masks, tattooing, clothing, and performance, bodies also produce images of themselves or, in the case of actors, images representing others - in which case they act as media in the fullest and most original sense. Their initial monopoly on mediating images allows us to speak of bodies as the archetype of all visual media."
} 
para dar lugar ao agente do teatro performativo, o acontecimento espetacular ainda se efetivará no âmbito desse trinômio. Sua abordagem da iconologia interage com os estudos de William John Thomas Mitchell, comentando aquilo que Mitchell apresenta como imagem, texto, ideologia. Ambos estão em conexão com vários outros que dedicaram, e vêm dedicando esforço na investigação da imagem.

Belting tem sido mencionado como referência para o estudo antropológico da imagem e do termo alemão Bildwissenchaft, cuja tradução já apresenta um problema, podendo-se compreendê-la como "ciência da imagem". O contexto pode incluir vários estudiosos, desde Erwin Panofsky (1892-1968), considerando-se suas proposições acerca da Iconologia. Uma importante introdução ao estudo do mencionado contexto foi oferecida por Paulo Knauss, no seu abrangente artigo, publicado em dezembro de 2008, "Aproximações disciplinares: história, arte, imagem". As discussões e ramificações norte-americanas, inglesas e também alemãs, contemplam um significativo campo de estudos que inclui propostas de investigação da imagem, não apenas como um aspecto a ser abordado pela história da arte, mas também como campo específico de estudo.

No contexto do presente trabalho, a imagem corporifica na cena o desejo do artista de conectar-se com o outro que recria as imagens a ele oferecidas. Se há um corpo, incluem-se visão e mente. Um artista - que pode ser um dramaturgo - ausente do ponto de vista físico, elaborou um construto que transitou desde a condição de imagem mental elaborada pelo autor, até a corporificação ou, a imagem visual presente na cena. Na sua mais direta e operacional configuração, a cena propõe um jogo que exige a presença do corpo do ator, meio principal de elaboração da imagem cênica, e o corpo do observador, que a reelabora. Meios vivos, ativos.

O trinômio proposto por Belting liberta a práxis cênica da clausura de determinadas teorias "revolucionárias" que, como tal, vêm acompanhadas de prazo de validade, sendo desconstruídas na próxima revolução. Um novíssimo performer que executa uma "ação" (desprovida da adjetivação "cênica") para alguém que aceitou o papel do fruidor "não performer", estará se efetivando como imagem-meio-corpo, assim como esteve um ator ou atriz do mais rigoroso realismo, do melodrama, da farsa medieval, da tragédia grega, e assim por diante. A menos que se invente uma "ação" ou categoria de performatividade que remova deliberadamente a expressão-comunicação-percepção visual, o comentado trinômio estará sempre presente.

Ainda que tal processo possa configurar um intricado contexto epistêmico, observando-o cuidadosamente pode-se, por outro lado, apreender sua simplicidade. Uma situação que se instale na interação do ator com o outro, o espectador 
ou o "não ator" da situação, pode ser efetivada, literalmente, com a presença de apenas um representante de cada categoria, numa relação direta. O corpo de um ator que interage com o corpo do "não ator" pode prescindir de qualquer elemento físico externo, à parte o ar que os manterá vivos, e a luz. O corpo nu do ator, sob a luz natural, sem a intervenção de quaisquer mecanismos de controle ou proteção, disposto num espaço preexistente, também sem nenhuma interferência ou artificialização, é perfeitamente capaz de criar presença artística no mencionado acontecimento - para não dizer espetáculo - ou sucessão de imagens.

E o sujeito "A" do acontecimento, o ator - ou performer - pode até prescindir de um modelo, de uma personagem, e configurar a si mesmo como estímulo e meio. Assim, ele estará projetando sua própria imagem em um novo nível de expressão, na medida em que ela estará incorporada a um acontecimento de qualidade artificial - ou artística (para evitar, nesse momento, termos como teatro e cena). Ou seja: mesmo com a ausência de personagens, conflito ou cena, mesmo que a única vontade presente no acontecimento seja a do ator - ou do performer que o nega ao desejar ele mesmo estar diante de alguém, o outro que aceitou o papel de sujeito "B", um observador-espectador-"criador"-fruidor, "não ator", cuja função é compartilhar com "A" o acontecimento, ali se efetivará o trinômio imagem-meio-corpo.

Além disso, pode-se até especular acerca da visualidade relacionada à ausência material do corpo do dramaturgo, ou outro criador responsável pela gênese do processo provocador da cena, e mencionar a corporificação da imaginação desse artista, um locus de impossível acesso material e imediato para o observador-espectador-criador-fruidor, "não ator".

A cena se rebelará contra qualquer tentativa de apontar uma autoria isolada ou exclusiva, já que sua natureza compósita impõe interação, equilíbrio - por vezes, ou com frequência - assimétrico, ou seja: os aspectos da cena interagem de modo dinâmico, transversal, ainda que não se perceba racionalmente, até mesmo numa aparente negação provisória, ou momentânea, de um ou mais aspectos, resultando na acentuação pontual de outro(s).

Como exemplo, o corpo nu do ator, mencionado acima, pode não ser considerado, necessariamente, uma simplória exclusão do figurino. Quando se define a ausência de indumentária, elementos externos ou estranhos ao corpo do ator, uma espécie de "não roupa" passa a configurar a escolha deliberada, eleita para transformar a pele do ator em figurino único e indispensável, primevo, para aquela entidade, na imagem-cena (ou cena-imagem).

A imagem já foi considerada anulação do corpo em interpretações de Narciso e dos estudos de Platão, pois pensada como representação, um segundo que devasta 
a potencialidade do primeiro que o origina, "descorporificando-o". Como uma sombra que esconde, mente e deforma, tornando bidimensional, "chapando", destruindo a profundidade da experiência, o conhecimento. Ainda que se possa

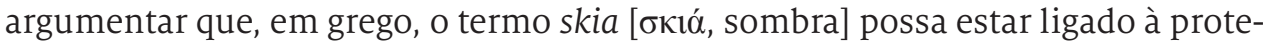
ção, ao abrigo. Além disso, não seria surpresa testemunhar a desqualificação da imagem, ou a demonização da visão, considerando-as aliadas do cientificismo da modernidade a partir do cartesianismo perspectivista que narra um mundo pensado. Um mundo fitado através da visão monocular calculada, já investigada por Filippo Brunelleschi (1377-1446) e difundida por Leon Baptista Alberti (14041472). Desde o século XV, portanto, lançavam-se bases do pensamento mais tarde incorporado pela filosofia.

O ideal renascentista de permitir ao ser humano a investigação da vida, buscando a compreensão sistemática daquilo que ocorria diante de si e a capacidade de dividir com o outro aquilo que ele pensava ver, representando-o cientificamente, rompia as barreiras do olhar divino medieval. Por outro lado, tal processo parece ter resultado num tiro que saiu pela culatra e gerou a criticada hegemonia da visão cientificista moderna. Num determinado momento, acreditou-se que o cientificismo exacerbado, duro, da modernidade engendrada pelo cogito ergo sum cartesiano tinha a visão como cúmplice maior. Consequentemente, as imagens produzidas pelo ocularcentrismo moderno, de raiz renascentista, eram vistas como provas do crime.

O teatro, no entanto, sempre pode ser desatrelado de tais comprometimentos, quando recupera diariamente (ou a cada noite) a imagem cênica que, como já foi dito, esteve presente desde rituais do Paleolítico. Ao recuperar uma imagem que pode ser simplesmente corporificada no ator, independentemente de qualquer artificio visual, a cena desmembra e multiplica o ator, permitindo-lhe assumir virtualmente o triplo papel sugerido por Belting, imagem, meio e corpo, operando em um complexo artificial de quatro dimensões (considerando a tridimensionalidade espacial e o tempo). Ele é imagem, meio e corpo vivos, simultaneamente, no nível temporal da cena. Ou seja, a imagem cênica que alcança o observador, provocando e interagindo com seu imaginário, tem como meio o corpo do ator. Além disso, mesmo sendo uma categoria de imagem que precede e transcende os limites da técnica moderna, sua flexibilidade permite interações com as imagens tecnológicas, quaisquer que sejam os estágios da tecnologia. E a imagem cênica elaborada no corpo do ator subverte a imagem tecnológica, emprestando-lhe funções diferentes daquelas designadas no seu meio original, novas funções que resultam da interação com o corpo vivo. 
Observando as famílias de imagens propostas por William J. Thomas Mitchell (1986), estudioso norte-americano já mencionado, cujo trabalho é referência para a Cultura Visual, pode-se considerar que a cena se configura como um amálgama de ramificações das "famílias" de imagens, no qual imagens gráficas, ópticas, perceptivas, mentais, verbais, sonoras, juntam-se para criar as semelhanças e dessemelhanças propostas por um espetáculo. Mitchell procura estabelecer um terreno no qual possam transitar as mencionadas famílias de imagens. Ele associa ideia (idein, em grego: forma, padrão) ao verbo ver e acentua que o termo está ligado à imagem visual (eidolon), de uso corrente na óptica antiga e na teoria da percepção. Mitchell (1986) reconhece a prudência da estratégia platônica que distinguia eidos - a realidade suprassensível, constituída de formas, ideias e espécies - de eidolon - a impressão sensível que provê o simulacro - eikon - ou o termo latino phantasma (que se origina no grego phantazo, phantazein, ou tornar visível, e ainda phaeinein, mostrar), ilusão do eidos.

No entanto, ele propõe uma abordagem de maior risco:

Isso envolve a atenção para a maneira como as imagens (e ideias) assumem umas os lugares das outras: a maneira como descrevemos o ato de retratar, imaginamos a atividade imaginação, figuramos a prática da figuração. Esses quadros, imagens e figuras duplicadas [ ] são estratégias para, tanto ceder, quanto resistir à tentação de ver ideias como imagens. ${ }^{18}$ (MITCHELL, 1986, p. 5-6, tradução nossa)

O teatro se refaz sucessivamente na construção intermitente da imagem cênica corporificada no ator. Parece óbvio, mas vale repetir: o gérmen da imagem já estava latente na primeira imagem mental, ou ideia (lembre-se sua origem em idein: forma, padrão, imagem) experimentada pelo dramaturgo. Daí, a noção de pré-cênico. Ainda que determinado momento da história da práxis cênica possa incluir a hegemonia de um ou outro aspecto de sua constituição, negando textos, modos e modelos que o tenham antecedido - incluindo a figura do dramaturgo o acontecimento em si ainda pode estar comprometido com uma primeira ideia (ou imagem mental) que o originou.

Tal processo inclui a articulação de visualidade que gera e está presente na cena. De tal articulação podem tomar parte ilustrações, figuras, estátuas, projeções óticas, aparências, dados sensoriais, sonhos, memórias, ideias, metáforas, narra-

18 "This involves attention to the way in which images (and ideas) double themselves: the way we depict the act of picturing, imagine the activity of imagination, figure the practice of figuration. These doubled pictures, images, and figures [...] are strategies for both giving into and resisting the temptation to see ideas as images." 
ções, descrições, entre outras manifestações da imagem. O que inclui a imagem superfície invocada por Flusser (1985), que pode ser confundida com limitação bidimensional. Elas podem juntar-se, chocar-se, interagindo com o ator e, consequentemente, com o observador. Isso pode envolver diversificados campos de conhecimento, como a psicologia, a epistemologia, a física, a história da arte, a fisiologia, a neurologia, a filosofia e até a crítica, literária e teatral. Tudo isso, como resultado da criação de uma imagem em movimento, radical, a imagem cênica, que não permite - ou resiste - à gravação mecânica, analógica ou digital.

A despeito das críticas que ligam o trabalho de Rudolf Arnheim ao formalismo, vale lembrar sua abordagem da imagem que, engendrada no interior de uma obra, se relaciona, inevitavelmente, tanto com a imprevisibilidade e a flexibilidade do objeto artístico, quanto com a objetividade do contexto no qual está inserida. Discutindo a pintura de Johannes Vermeer (1632-1675), Mulher segurando uma balança (Vrouw met weegschaal, de 1665) Arnheim pondera que as conclusões às quais alguns comentadores podem chegar, relacionando a mulher com a pintura que se vê atrás dela, ${ }^{19}$ levando em conta sua ação de pesar a riqueza, dependem de interações com o entendimento intelectual que relaciona os dois temas (Figura 1).

Arnheim (1994) destaca as elaborações visuais construídas por Vermeer: em primeiro lugar, o artista dispõe a cabeça da mulher imediatamente abaixo da figura do Cristo, indicando familiaridades na cor, na forma ovalada e na proximidade; depois, ele desloca a mulher do centro e ali insere um elemento contundente na organização visual, a moldura da pintura ao fundo, que além do comentado posicionamento, do contraste entre os valores da parede altamente iluminada e da sua própria cor escura, estabelece um ângulo de noventa graus com o limite horizontal da própria moldura, em frente do qual Vermeer colocou, precisamente, a mão da mulher que, como uma extremidade do corpo tem relevante papel visual.

Considere-se o importante papel das extremidades do ser humano, como elementos visuais que promovem a alteridade. Afinal, ainda que se possa criticar a media pela imposição do apelo à imagem elaborada superficialmente em pressupostos sexuais, ao longo da história moderna, não se pode negar a importância visual da genitália, como uma das extremidades do corpo humano, assim como os olhos, os pés e as mãos, elementos de referência para o contato com o outro e com o mundo. A estratégia elaborada por Vermeer corrobora seu interesse em discutir visualmente o contexto intelectual no qual sua pintura transita.

19 Em O juízo final, cuja autoria não se sabe ao certo, Vermeer pode ter usado elementos de várias obras. 
Vale lembrar, quando nos escritos póstumos, Friedrich Nietzsche (2005, p. 16), diz: "Ao conceito corresponde primeiro a imagem, as imagens são pensamentos originais, [...]". No teatro, conceber a imagem como modo primevo de pensar, sugere a aproximação entre as imagens mentais e os artefatos físicos que as corporificam, definindo o corpo do ator como referência para as imagens criadas na cena. o que é a imagem e qual o seu papel, ainda será motivo de disputa entre vários campos do conhecimento, como observa Belting (2005, p. 304, tradução nossa):

A semiologia, para dar um exemplo, não permite que as imagens existam para além do território controlável de símbolos, sinais e comunicação. A teoria da arte teria outras reservas, mas igualmente fortes, sobre qualquer teoria da imagem que ameace o antigo monopólio da arte e seu assunto exclusivo. As ciências, em particular a neurobiologia, examinam a atividade perceptiva do cérebro como um fenômeno de 'representação interna', enquanto a percepção de artefatos geralmente recebe pouca atenção neste contexto. ${ }^{20}$

Seria inconsequência arbitrar tais querelas, pois, a julgar pela dinâmica participação na cultura, as diversas "imagens" parecem se tornar cada vez mais sintomas e traços sociais agudos. Vale encarar sim, provocações, para buscar a compreensão daquilo que a luz pode incorporar ao contexto do espetáculo, na sua condição de conjunto dinâmico de imagens cênicas - em movimento.

E aqui pode ser introduzido um conceito que exige leitura cuidadosa. Trata-se de um processo empreendido pelo iluminador, quando ele cria uma imagem deflagradora para a cena, uma espécie de concentração latente das imagens cênicas, uma imagem-gênese, que precede a cena de modo perene. Como o leitmotiv ${ }^{21}$ na música, ela estará sempre presente no espetáculo, através dos elementos que a constituem. Mesmo que pareça invisível, a imagem-gênese soará constante nas

20 "Semiology, to give one example, does not allow images to exist beyond the controllable territory of signs, signals, and communication. Art theory would have other but equally strong reservations about any image theory that threatens the old monopoly of art and its exclusive subject matter. The sciences - in particular, neurobiology - examine the perception activity of the brain as a phenomenon of 'internal representation', while the perception of artifacts usually receives little attention in this context."

21 Termo alemão. Pode ser compreendido como tema dominante, recorrente ou condutor. Estratégia reconhecida desde o período inicial da ópera, o termo foi cunhado por Friedrich Wilhelm Jähns (1809-1888), em 1871, referindo-se à obra de Carl Maria Friedrich Ernst von Weber (1786-1826), importante compositor de ópera romântica e é mais frequentemente associado a Wagner, a despeito da severa crítica de Adorno (Theodor Ludwig Adorno Wiesengrund, 1870-1941) no seu trabalho Versuch über Wagner (Em busca de Wagner), publicado nos anos cinquenta, do século passado e que aparece nas referências através da tradução inglesa (In search of Wagner, 2005). Vale acentuar que desde o século XX, o leitmotiv é também relacionado à literatura, ao cinema, e ao teatro, manifestando-se também em imagens dominantes que transitam nas obras. 
cores, texturas e formas inscritas na cena. Na qualidade de imagem deflagradora, transitará de modo intermitente na visualidade do espetáculo, sucessivamente corporificada em notas, acordes e harmonia visual, o que não afasta a possibilidade de uma imagem atonal, ${ }^{22}$ como exemplo.

Ou ainda, num exercício desafiador, qual seria a imagem deflagradora da peça Parade, do compositor francês Erik Satie (Éric Alfred Leslie Satie, 1866-1925), considerando-se o choque causado pela obra, no espetáculo realizado no ano de 1917, em Paris? É importante a busca da imagem que agiria como provocação para o pensamento visual daquele espetáculo. Daí, cumplicidade e familiaridade com a obra musical são imperativas. Isso não significa que o iluminador tenha prévio domínio dos diversos aspectos da questão e, sim, que ele reconheça a necessidade de estudos que o qualifiquem para tomar decisões pertinentes.

Ficaria, portanto, questionado o ato simplório de projetar alguma luz sobre o espaço cênico para que o público veja o espetáculo. À pretensa operação físico-química-mecânica de projetar luz sobre o que se deseja mostrar - caracterizada aqui como promoção de visibilidade - impõem-se as ações deliberadas de um artista em busca do ambiente visual de sua obra, ou da criação de sua visualidade. Antes do interesse em expor algo para que o público veja o que está em cena como um contemplador passivo, efetiva-se a criação de imagens que provoquem o observador, levando-o a elaborar visualidades.

Mesmo os resultados mais "brilhantes, coloridos e repletos de movimentação" podem permanecer nos limites da visibilidade estéril no que se refere à natureza estético-poética da práxis cênica, permanecendo aquém de uma proposição artística. Aqui se configura uma armadilha na qual o iluminador pode cair, diante da facilidade em aprender que o público, em geral, deixa-se impressionar pela esterilidade visível na qual podem mergulhar os espetáculos, mesmo aqueles coloridos, brilhantes, repletos de fumaça e graficamente "nervosos". Vale ponderar que a criação da visualidade de um espetáculo incorpora o risco agudo da obra de arte, uma vez que o espectador sempre estará interagindo com o que vê, em trânsito dinâmico com o seu imaginário.

De todo modo, é dado ao iluminador, o direito de confrontar a postura que considera o espectador como alguém que diz impunemente: "estou apenas olhando", com a compreensão do espectador-corpo que, na práxis cênica, compartilha espaço

22 Levem-se em conta as críticas ao conceito de atonalidade, desde a opinião do próprio Albert Schoenberg (18741951), no seu livro Harmonia (Harmonielehre, 1911), que aparece nas referências através da tradução inglesa, Theory of harmony (1978). 
e tempo com o outro corpo, o ator. Tal processo incorpora o amplo leque de aspectos culturais que constituem a visualidade.

Na práxis cênica tal processamento inclui a luz como aspecto determinante da interação com o quadro de referências que repercute as contribuições da luz para a construção da cultura. E a visualidade instalada na cena, através da interação entre os elementos que a constituem, expõe e questiona a visibilidade artisticamente estéril. Afinal, se os procedimentos responsáveis pela produção das "autonomias" que "destruiriam" a unidade de tratamento não forem cuidadosamente investigados, essa unidade pode ser alcançada ao acaso. Isso poderia resultar na negação de uma proposta revolucionária, que findaria atrelada ao antigo desejo de unidade, execrado pelos seus promotores. Ou seja, ainda que o objetivo seja a "desunidade", o acaso e/ou a genialidade podem não ser a solução.

O que se caracteriza aqui como visualidade indica a fisicalização das ideias de um artista ou grupo de artistas, ou seja, o caráter visual de uma obra. Vale comentar o termo caráter, do verbo grego kharakessein, ou gravar; daí deriva kharakter (caráter), que se refere a uma "marca gravada". Suspeita-se, então, que o iluminador tem a liberdade de propor uma marca poética na visualidade de cada acontecimento cênico.

Fica encaminhada uma problematização que observa a natureza estética da práxis cênica, considerando relações com a luz em uma abordagem mais abrangente, ou seja, que sublinha o caráter visual do espetáculo.

Tal abordagem já aparece anunciada por Adolphe Appia, em 1898. Inicialmente, ele faz uma constatação que parece óbvia: “[...] a visibilidade é um importante aspecto de uma montagem: se o público deve assistir à peça, a face do ator deve estar claramente visível." ${ }^{3}$ (APPIA, 1962, p. 20, tradução nossa) Adiante, ele completa:

Agora, o que, se não a luz, dá essa maravilhosa unidade ao espetáculo que contemplamos cada dia, permitindo-nos viver através de nossos olhos? | Sem essa unidade, seremos capazes de distinguir apenas vagamente o significado das coisas, e nunca a sua expressividade, pois, para que as coisas sejam expressivas, elas devem ter forma, e forma sem luz, só se comunica com o nosso sentido do tato. (APPIA, 1962, p. 46, tradução nossa) ${ }^{24}$

23 "[...] visibility is a major consideration in production; if the audience is to experience the play, the faces of the actors must be clearly seen."

24 "Now what is it if not light that gives that wonderful unity to the spectacle we contemplate each day, allowing us to live through our eyes? Lacking this unity, we should be able to distinguish only dimly the meaning of things, 
Em uma nota de rodapé, Appia esclarece seu enfoque e abre uma trilha que ainda hoje parece pouco discutida, mas que promoveu o suporte para o encaminhamento da compreensão do papel da luz na cena, discutido no presente traba1ho. Ele alerta: "Quando me refiro à luz, é evidente, quero dizer, a atividade luminosa, e não, de usá-la apenas para enxergar." ${ }^{25}$ (APPIA, 1962, p. 46, tradução nossa)

Levando-se em consideração um estágio que se expande para além da simplória visibilidade mencionada por Appia, para além das meras operações mecânicas usadas no intuito de tornar a cena fisicamente visível, fica identificada a função do iluminador como alguém que contribui para a visualidade da qual a cena está, ou deve ser impregnada. Ao questionar a mera visibilidade, Appia parecia considerar o caráter e a função da luz como uma atitude esteticamente ativa e capaz de construir visualmente uma obra teatral. A busca por tal qualidade representa, no núcleo da presente abordagem, tarefa fundamental e pode, de acordo com as razões mencionadas, indicar diversificadas ramificações estético-filosóficas, de acordo a cada obra e/ou contexto.

Num certo sentido, tanto a decisão mecânica de tornar visível projetando luz, quanto aquela de esconder na escuridão teriam o mesmo resultado destruidor. Além disso, fica uma indagação: uma vez que a presença de um responsável, em particular, pelo comportamento da luz artificial na cena seja muito recente, ${ }^{26}$ como ela era tratada no teatro, até o aparecimento do responsável pela sua incorporação? Já na década de 1970, ainda eram testemunhados processos nos quais a luz ficava a cargo de um eletricista encarregado de fazer "gerais" coloridas, focos e efeitos; era uma espécie de fórmula, que se repetia sem indícios de qualquer preocupação com um possível universo visual ao qual os espetáculos se relacionassem ou aos quais se referissem.

Deve-se sublinhar a honrosa tentativa de Jean-Jacques Roubine de se aproximar do estudo da luz, esboçando a intenção de sistematizá-lo. Ele concentra sua abordagem em diretores e/ou teóricos, tais como André Antoine (1858-1943), Constantin Stanislavski (1863-1938), Antonin Artaud (1896-1948), Adolphe Appia (1862-1928), Gordon Craig (1872-1966), Jean Villar (1912-1971), Bertolt Brecht (18981956), Jerzy Grotowski (1933-1999), Giorgio Strehler (1921-1997), Patrice Chéreau e Peter Brook. Da abordagem de Roubine pode-se extrair uma tentativa de classificar

\footnotetext{
and never their expressiveness; for in order that things be expressive, they must have form, and form without light communicates only to our sense of touch."

25 "By light, I mean the activity of light, not simply 'visibility'."

26 A identificação de um especialista responsável exclusivamente pela luz, em um espetáculo, só aparece na transição entre os séculos XIX e XX.
} 
ou identificar caminhos seguidos pela luz, principalmente depois da luz elétrica. Ele cita ao menos três qualificações: a iluminação atmosférica (do realismo), a "iluminação-cenografia" (como em Appia e Craig), a não figurativa e a simbólica (desde Artaud).

Suas observações podem ser absorvidas como uma provocação positiva, tanto no que se refere à extensa discussão possível em torno de cada um dos mencionados termos ou expressões, quanto pela ausência de menção específica a qualquer iluminador, em suas considerações. A luz é considerada pelo viés da dramaturgia e/ou da direção.

Outra assertiva de Roubine (1982b, p. 31) pode ser destacada. Tratando daquilo que caracteriza como simplicidade, ele afirma: "[...] a iluminação que se assume como puro instrumento da representação, nada mais é do que um meio de tornar um espetáculo visível e legível [...]". Classificações de tal natureza aparecem quando se analisa a luz realista como tentativa exclusiva de tornar a cena visível, iniciativa que Roubine qualifica como "atmosférica". Para tornar um evento visível, no entanto, não há necessidade de qualquer compromisso com a representação ou com qualquer atmosfera. Ao contrário, um reduzido grau de conhecimento técnico da aplicação da luz na cena já é suficiente, e basta contar com a ajuda de um técnico para instalar à frente do acontecimento espetacular tantos instrumentos (mais conhecidos como refletores) quanto necessários para iluminar (até que a cena se torne visível), e contar com o fornecimento contínuo de eletricidade até o final do espetáculo.

Até seria possível dizer que a promoção de visibilidade define a visualidade do teatro épico ou científico de Bertolt Brecht, já que a cena deveria ser exposta, banindo a representação realista do espaço, excluindo atmosferas, cores, ângulos e/ou texturas, usadas por outros diretores como solução para configurar o espaço realista ou simbólico da ação representada. Ou seja, o que torna a luz um aspecto consequente, em um espetáculo, não é o desejo de um crítico ou teórico. Importa, sim, a natureza do espetáculo em si. Bertolt Brecht afastaria do seu teatro, tanto a luz aplicada por Stanislavski, quanto aquela criada para um espetáculo de Robert (Bob) Wilson ou de Adolphe Appia. O discurso visual presente na obra de cada um dos artistas citados rejeitaria os caminhos considerados de excelência por outros. Aqui se identifica, por conseguinte, uma importante característica da luz efetivada na espetacularidade, ou seja, ela desempenha papel decisivo na elaboração do pensamento visual subjacente à cena ao interagir com as particularidades de cada espetáculo, construindo a natureza estético-poética - de uma montagem em 
si ou do conjunto da obra de determinado autor. Como explicitado no sumário a obra de Brecht será brevemente abordada no capítulo "A luz e a cena não realista."

\section{RELAÇÕES PRIMITIVAS ENTRE A HUMANIDADE E A LUZ}

O presente capítulo incorpora uma obra da dramaturgia, Nossa cidade (Our town), de Thornton Wilder (1897-1975), escrita em 1937, para introduzir a profundidade das primitivas relações entre a humanidade e a luz. A ação se passa nas duas primeiras décadas do século XX. Sem interesse na análise crítica da peça em si, será destacado o final do primeiro ato para considerar as relações entre o ser humano e a luz. ${ }^{27}$

É noite na cidade de Grover's Corners em New Hampshire, ao norte dos EUA; casa da família Gibbs; os irmãos Rebecca e George conversam ao final do dia, numa atmosfera de reflexão. Pode-se imaginar o quarto banhado por uma espécie da luz externa da noite, que entra pela janela. Logo, ambos se dirigirão às suas camas e, depois de uma noite de sono, como usualmente, recomeçarão a rotina de mais um típico dia da cidadezinha do interior. Rebecca comenta uma carta recebida por uma moradora local. De acordo com o remetente, a correspondência deveria ser entregue a Jane Crofut, cujo endereço seria: Fazenda Crofut, Cidade de Grover's Corners, Condado de Sutton, Estado de New Hampshire, Estados Unidos da América, Continente Norte-Americano, Hemisfério Ocidental, Planeta Terra, Sistema Solar, Universo, Mente de Deus.

Algum carteiro com maior pretensão científica poderia alegar que o endereço está incompleto, pois omitiu a Via Láctea. E até dispensaria o último detalhe, a Mente de Deus. Tal atitude poderia causar efeito traumático e conflito envolvendo carteiros cristãos. Ou até iluministas, que convocariam o seu deus, a razão. Isso, contudo, é tema de outro trabalho, que poderia ganhar tratamento particular de cada artista interessado em dramaturgia. Importa observar que, diante da diversidade de opiniões, se o endereço de Jane Crofut finaliza ou não em Deus - em meio às certezas da fé, ou, às dúvidas e especulações científicas - um detalhe não muda: ainda que more numa pequena cidade, de um dos menores Estados da América do Norte, ela está necessariamente ligada a um planeta que integra o Sistema Solar, cujo centro é apenas uma estrela, entre os prováveis quatrocentos milhões de estrelas da Via Láctea, o Sol. Ao fim e ao cabo, portanto, tudo se refere

27 Note-se que o termo dramaturgia ganhou aplicações diversificadas ao longo do século XX, aplicações essas cuja discussão será evitada aqui. 
a estrelas. Daí, a importância do texto de Wilder: tanto numa abordagem mística, quanto numa outra apoiada na experimentação científica, o endereço final - e primevo - de Jane Crofut, e do ser humano, é a luz.

Escritos religiosos, como as narrativas que originaram o cristianismo, há mais de uma dezena de séculos antes da era cristã, a tradição judaica, a civilização egípcia da Antiguidade, incorporaram e interpretaram a luz, sugerindo poder, fascinação e magia. As relações entre o ser humano e a luz percorrem a história da espécie há muito, despertando progressivo interesse. Na atualidade, quando os pesquisadores continuam a destituir fronteiras, o intuito de compreender a ação da luz sobre a presença humana no planeta, pode soar pretensiosa, bem como a intenção de refletir sobre as relações entre a luz e a práxis cênica, como um problema a ser investigado. Por outro lado, a busca por compreensão parece apontar a necessidade da discussão de tais relações, já que o conhecimento indica o enfrentamento de barreiras.

Pode-se resumir dizendo: iluminador é aquele que "faz a luz de uma peça". Tal assertiva, contudo, provoca questionamentos. Ao concluir a sentença, já se encontram razões para uma investigação, quando se leva em consideração que a luz artificialmente produzida pelo ser humano está ligada ao seu desejo de ampliar as relações com o ambiente, buscando substitutos para o sol e interferindo, inclusive, no conceito de tempo; são ampliadas as operações produtivas, assim como de lazer, entre outras, com a extensão (da luz) do dia. O ser humano emprega substitutos que, atuando de maneira relativa e parcial, buscam cumprir uma ou outra função da estrela.

Com o propósito de introduzir reflexões especificamente voltadas para a contribuição da luz à práxis cênica, vale antes sublinhar que ela é responsável pela construção de traços decisivos da natureza humana. Ao refletir acerca do seu próprio aparecimento e permanência no planeta, o ser humano depara-se, inevitavelmente, com o sol. Diante de tal constatação, o leitor pode presumir a amplitude do tema e compreender que o presente trabalho não pretende tratá-lo em profundidade. Ainda assim, dada sua importância ele não pode ser simplesmente ignorado, ou melhor, deve ser mencionado e, mesmo brevemente, comentado. Tais comentários podem ser considerados uma digressão, caso o leitor siga a tendência de observar superficialmente a luz aplicada à cena, considerando-a distante da investigação como procedimento sistemático.

O texto que se segue pode causar estranheza caso essa tendência seja mantida, encarando-se a luz como se ela representasse somente um apêndice necessário, sem conexões com o conhecimento, com a cultura. 
De todo modo, evitando detalhamentos que exigiriam o domínio de um especialista, é imprescindível registrar a presença do sol, da luz, na organização do sistema integrado pelo ser humano. É necessário, então, lembrar: a maior parte da energia que alimenta a Terra origina-se da fusão nuclear produzida no Sol, caracterizando sua interferência no conceito de humano. A humanidade estabeleceu-se no planeta de maior massa, dentre aqueles rochosos, o corpo celeste de maior densidade do seu sistema solar. Um corpo de tal dimensão depende de enorme equilíbrio para se manter vivo, funcionando. Da relação com seu único satélite natural - a lua - dependem muitos movimentos, inclusive a estabilidade de inclinação do seu eixo. A complexidade de tal relação só se amplia, quando o centro do sistema, o Sol, é levado em consideração.

Ainda que o total de dígitos necessários para quantificar a Terra seja enorme se comparado à escala humana, quando se envolve o Sol, nos termos aqui discutidos, toma-se consciência da dimensão relativa do ser humano. Desde Galileu (1564-1642), já se reconheceu que a humanidade não está no centro do sistema, posição ocupada por uma gigantesca esfera gasosa e brilhante. Não seria possível fazer qualquer ponderação acerca da luz, sem pontuar o núcleo da questão e/ou, sem sublinhar que a Terra se formou a partir de uma nuvem de poeira solar, agregando massa progressivamente, na forma granular de minérios atraídos pela força gravitacional.

Levem-se em consideração as cento e nove Terras que seriam necessárias para completar a circunferência do Sol, com um diâmetro de 1.392.00o km, e, em seu interior, caberiam 1,3 milhões de Terras. Trata-se, então, de uma estrela mais de uma centena de vezes maior que a Terra, constituída inteiramente de gás, cuja parte visível, do ponto de vista do nosso planeta, apresenta uma temperatura de 5.500 graus centígrados. Ativo há aproximadamente 4,5 bilhões de anos, o sol deve continuar brilhando por outros tantos bilhões de anos, quando, no fim de sua vida, começará a fundir o hélio em elementos mais pesados e se expandirá, finalmente, a uma proporção que engolirá a Terra, atraída para o seu interior. O que somente ocorrerá num ponto muito distante no futuro, dando algum tempo para que o ser humano reflita sobre a importância dessa estrela. A abordagem aqui encaminhada presume que, se alguém quer "fazer luz", deve considerar o mencionado contexto, o que já exige considerável esforço de pesquisa.

De modo simplificado, pode-se dizer que reações termonucleares ocorrem quando, no Sol, o hidrogênio, de que ele é basicamente constituído, é submetido a uma enorme pressão no interior da estrela e tem o seu núcleo fundido em temperaturas de até 15 milhões de graus Celsius, transformando-se em hélio. Parte 
da massa resultante é convertida pela fusão em energia, e, lançada no sistema solar, alcança a Terra, depois de filtrada pela própria atmosfera do planeta. Em tal processo, origina-se a principal fonte da energia que alimenta o planeta e permite o seu funcionamento, na condição de elemento constitutivo de um extenso sistema. A energia, na forma de luz solar, leva em torno de oito minutos e 18 segundos para percorrer a distância entre o Sol e a Terra, cerca de 150 milhões de quilômetros, onde é armazenada pelos seres vivos que, de variadas maneiras, dela dependem para sobreviver, inclusive no que se refere à manutenção da água em seu estado líquido. É importante dizer que, mesmo apresentando natureza diversificada, em diferenciadas extensões de ondas eletromagnéticas, a mais ampla manifestação da energia é a luz visível. A vida no planeta mantém, portanto, profundo compromisso com a visão.

Vale ponderar: aquilo que alguns chamam de realidade, o mundo visivelmente percebido, é fato do passado se considerarmos que o deslocamento da luz é mensurável no tempo. Isso determina que as imagens visuais percebidas pelo ser humano já ocorreram, quando ele registra sua presença. O que se considera presente, real, é sempre um acontecimento que se efetivou em um momento do passado, quando a luz incidiu sobre algo. A percepção humana só ocorre em alguma ocorrência temporal no futuro.

Cabe acentuar que tais observações não passam de um breve e superficial comentário e que os interessados na pesquisa acerca das relações entre a luz e a cena devem se debruçar sobre autores que discutem tais questões, estudando a temperatura termodinâmica, a radiação eletromagnética, o sistema Kelvin de mensuração, assim como diversificadas ramificações em determinadas áreas do conhecimento. Para o objetivo do trabalho que se segue, basta que se leve em conta a importância definitiva do Sol para a vida na Terra, alertando quem quer que se interesse pela luz a observá-lo com atenção.

Pode, então, parecer óbvio dizer que o ser humano interage com o Sol. O que interessa aqui, contudo, é sublinhar a íntima relação entre a humanidade e a maior estrela do sistema. É possível tratar das relações entre a luz e o pensamento, iniciando-se com o estudo dos gregos antigos, pesquisando sua exegese da visão, para investigar a construção humana do conhecimento ocidental.

Torna-se indispensável, entretanto, mencionar ações da humanidade que, anteriores a tal momento, provocam a abordagem do envolvimento do ser humano com a luz. De tais ações tomam parte antigas edificações, tão antigas a ponto de apresentarem dificuldade em sua datação ou até em sua função e autoria: as construções megalíticas. Nomeadas, aliás, a partir dos gregos: mega (grande, em grego) 
e lithó, pedra. Entre os megálitos mais famosos encontram-se a Grande Pirâmide de Khufu e o objeto da presente reflexão, Stonehenge (Figura 2).

Um complexo de pedras localizado na planície de Salisbury, no sul da Inglaterra, cuja construção é apontada por estudiosos em uma dilatada datação, entre 2.950 a.c. e 1.600 a.c., Stonehenge tem despertado grande interesse da ciência, envolvendo o trabalho de físicos, arqueólogos, astrônomos, arqueoastrônomos e estudiosos da história da arte. Impressiona quando se especula que tal complexo foi progressivamente modificado durante um período de quase 14 séculos, comprovando-se o interesse de sucessivos e diferentes momentos da humanidade pela edificação. Já se produziu grande diversidade de estudos acerca de Stonehenge - ou pedras suspensas, também chamadas trílitos - com interpretações que ligam o complexo a práticas religiosas, à observação astronômica e à tecnologia da construção.

Há grandes mistérios, no que se refere aos procedimentos aplicados para transportar e elevar blocos de pedras de 45 toneladas a 5 metros de altura, suscitando muitas questões. Em 1963, o arqueoastrônomo inglês e professor da Boston University, Gerald Hawkins (1928-2003), defendeu uma ideia que causou surpresa no ambiente científico. Ele afirmou, com base em pesquisa na qual já usou um computador transistorizado de segunda geração, o IBM 1970, usando recursos de pesquisa da Harvard University e do Smithsonian Institute, que a estrutura de pedras funcionou como observatório astronômico, como um dispositivo que interage com corpos celestes, permitindo, inclusive, a previsão de eclipses da Lua. Dois anos depois, Hawkins provocou reações muito adversas, quando comparou a estrutura a um sistema computacional, considerando-a uma espécie de computador neolítico, justificando suas conclusões na grande quantidade de cálculos que, segundo ele, podem ser efetivados usando-se as relações entre seus elementos arquitetônicos, o Sol e a Lua (Figura 3). Richard Atkinson (1920-1994), arqueólogo inglês, com pesquisas e escavações no sítio arqueológico de Stonehenge, desde a década de 1940, discordou veementemente de Hawkins.

Em 1966, Atkinson afirmou que os alinhamentos entre os elementos arquitetônicos da estrutura e o Sol, apontados por Hawkins, eram ilusórios, julgando imprecisas suas conclusões. É importante registrar que o interesse científico pelo lugar, contudo, já aparece desde o século XVIII, sempre se referindo à sua relação com a luz natural.

Interessa à presente abordagem sublinhar Stonehenge como presença na história humana, mesmo antes que qualquer pensamento sobre a intervenção da luz na Terra fosse registrado em um texto, ganhando cada vez mais atenção, ao longo 
dos últimos três séculos. Tendo despertado interesse de pesquisadores, vem sendo mencionado como complexo arquitetônico, obra importante da engenharia, observatório astronômico, monumento artístico e templo. Abordagens inevitavelmente relacionadas à luz, fazendo dele um dos mais antigos documentos-imagem acerca das relações entre o ser humano e a luz.

Na reconhecida trilha que inicia a construção do pensamento ocidental, as raízes gregas apontam a luz (phos) como o princípio de tudo (arché panton). Desde Zoé, a vida; nous, o pensamento; téchne, a arte; pólis, a cidade; episteme, o estudo da ciência ou da filosofia; poíesis, o fazer produtivo; pracsein, o agir; chrestai, o prestar. (LEÃO, 2010) Sua relevância para o homem grego pode ser assim expressa: “[...] luz é sempre energia irradiante em todo ser e não ser de tudo que é e está sendo, de tudo que não é nem está sendo. Energia de pura irradiação, a luz concentra em si a força poética do raio de Zeus, que rege e acata todas as coisas [...]". (DIELS apud LEÃO, 2010, p. 90)

Aqui interessa lembrar que a força de Zeus, no entanto, foi desafiada por Prometeu (dotado da antevisão), filho de Jápeto e Clímene, segundo Hesíodo; e de Têmis, segundo Ésquilo. Tinha três irmãos: Menécio, Atlas e Epitemeu (o que pensa depois).

Prometeu, o mais sábio entre eles, teria moldado o ser humano de argila e água (ou talvez com as suas lágrimas, numa versão poética, romântica). O homem moldado em barro recebeu vida dos ventos insuflados por Atena (Palas Atena). Durante o reinado de Cronos, homens e deuses eram igualmente tratados. Quando os deuses olímpicos tomaram o poder, Zeus os reuniu com representantes da humanidade para determinar que partes das vítimas dos sacrifícios deveriam ser entregues às divindades. Prometeu recebeu a incumbência de fazer a partilha de um boi entre deuses e humanos. De um lado, ele colocou carne e vísceras, do outro, ossos cobertos com toucinho reluzente e convidou Zeus para escolher. Preferindo o brilho da segunda opção e, descobrindo depois o truque, Zeus decidiu vingar-se. O brilho pode ser enganador; o opaco, a penumbra, por vezes, tem grande valor.

Em vários momentos da sua vida, Prometeu usou a astúcia para ajudar a humanidade, e teria roubado o fogo das rodas do carro do sol, para doá-lo ao ser humano. Prometeu estava presente quando Atena nasceu da cabeça de Zeus. Dela, ele recebeu ensinamentos de arquitetura, astronomia, matemática, navegação, medicina, metalurgia, entre outras artes, conhecimento que compartilhou com o ser humano.

Isso teria dado crescente poder e talento à humanidade, mas alimentou a raiva em Zeus, que decidiu aniquilar a raça humana, enviando Pandora (aquela que recebeu todos os dons), uma virgem de beleza única, moldada em barro, que recebeu 
de cada divindade um dom especial, incluindo a perfídia e os discursos enganadores, doados por Hermes. Pandora trazia consigo uma caixa, que se dizia conter maravilhas. Curiosa, abriu a caixa e espalhou males horrorosos sobre a Terra, mantendo apenas a esperança no seu interior. A ira de Zeus ainda não estava amainada e ele enviou o dilúvio para inundar a Terra. Deucalião, rei da Tessália e filho de Prometeu, aconselhado pelo pai, construiu uma embarcação e nela se protegeu acompanhado da mulher, Pirra.

A intervenção de Deucalião fez reinar a paz entre os homens e os deuses, mas Zeus não perdoou Prometeu, determinando uma dolorosa punição: ele ordenou que Hefesto, Crato e Bias acorrentassem Prometeu ao monte Cáucaso. Para completar o castigo, que durou 30 mil anos, uma águia devoraria seu fígado durante o dia que, crescendo durante a noite, seria comido no dia seguinte, destruindo de modo intermitente seu orgulho e revolta. Zeus finda por conceder perdão a Prometeu, que mais tarde seria imortalizado. Sua insurreição, contudo, já havia permitido ao ser humano a sabedoria originada no fogo (na luz).

Afinal, no dizer de Heráclito (ca. 535 a.c. - 475 a.c., o obscuro ou enigmático), o fogo, a luz, tem relações diretas com a vida. Por mais dessemelhanças que apresentem as inúmeras traduções e/ou comentários dos fragmentos de sua obra que, aliás, são fragmentos. Na versão de Heráclito para o inglês, Patrick (1889, p. 90, tradução nossa) escreveu: "O homem acende uma luz para si durante a noite, quando ele está morto e vivo. Aquele que dorme, cuja visão foi retirada, ilumina de entre os mortos; ele, que está desperto ilumina desde o que dorme". ${ }^{28}$ Diante de inúmeras opções que se referem a acender, tocar, apagar, cuja discussão deixa ser objetivo da abordagem em curso, interessa a presença da luz nas referências à vida, à morte, à consciência, à vigília e ao sono (portanto, ao sonho).

Investigando as relações entre a luz (fogo) e a sabedoria, encontra-se também uma provocação significativa em uma imagem construída pelo texto bíblico, no Primeiro livro de Moisés, também chamado Gênesis: antes de tudo, Deus criou os céus e a terra. Até tal ponto, somente se toma conhecimento dos feitos do Senhor através da narrativa do evangelista mencionado; não há menções à luz, não se sentia sua falta; não era acentuada e, aparentemente, não existia. Tudo não passava de uma imagem mental?

A decisão divina parece fundamentar-se na precaução de refrear o envolvimento prematuro com a luz, tendo o cuidado de preservar os estágios preliminares do processo criativo, afastando problemas tão específicos, como aqueles

28 "Man kindles a light for himself in the night-time, when he has died but is alive. The sleeper, whose vision has been put out, lights up from the dead; he that is awake lights up from the sleeping." 
oriundos da intervenção contundente da luz. Daí, após a criação de terras, céus e águas - quando as trevas pairavam sobre a face do abismo - alcança-se o instante mágico de revelação da obra divina. Aquele ponto no qual um traço de união revelará, de modo substancial, o seu feito.

Um passo crucial, um momento para o qual tudo foi previamente preparado, exigindo procedimentos de excelência; Moisés, então, põe a si mesmo de lado e traz à cena o sujeito, dada a relevância do ato, deixando ao próprio Deus as palavras, aliás, suas primeiras palavras: "Fiat lux" (Gênesis, Capítulo 1, vers. 1/3). Da narrativa épica, passou-se ao drama, transformando a natureza do sujeito; agora há uma primeira pessoa que fala, não mais um narrador e, sim, a personagem que vivencia um conflito.

É importante mencionar Jó 1.6: "Num dia em que os filhos de Deus vieram apresentar-se perante o senhor, veio também Satanás entre eles" (BÍBLIA, 1999, p. 579), e destacar a nota teológica:

Seu nome significa 'adversário' [o que faz oposição a Deus e ao seu povo], e o Antigo Testamento o apresenta como tal (1 Cr 21.1; Jó 1-2; Zc 3.1-2]. [...] A esperteza enganadora de Satanás é realçada pela afirmação de Paulo, quando nos diz que Satanás transforma-se em anjo de luz, apresentando o mal como bem (2 Co 11.14) [...]. (BÍBLIA, 1999, p. 579)

Victor Hugo (1802-1885), por seu turno, aproxima-se da antiga cena, com a assertiva: "Jó começa o drama. E isso há quarenta séculos, pondo frente à frente Jeová e Satã; o mal desafia o bem e assim começa a ação; a terra é o palco, e o homem é o campo de batalha; os flagelos são as personagens". (HUGO, 2000, p. 41) ${ }^{29}$ Criação, drama e luz, portanto, há muito se tocam, se chocam e se transfiguram.

Considerando a Bíblia, tal interação é construída de modo robusto. Na sua Primeira Epístola, diz João: "Ora, a mensagem que, da parte dele temos ouvido, e vos anunciamos é esta: que Deus é luz, e não há nele trevas nenhumas". (BÍBLIA, 1999, 1 João 1:5) Como observa Evgen Bavcar, a luz tornou-se a primeira imagem, a primeira imagem de Deus e a primeira presença no mundo. A revelação da natureza divina, entretanto, criou a primeira ausência, pois, como observa Bavcar (2005, p. 147), "[...] a face oculta do Eterno é tão luminosa que nos impede de ver claramente". Na verdade, a luz divina, ontológica, completa e integral, como descreve João, é um artifício de Deus para se tornar mistério: iluminando-se total e virtu-

29 "Job commence le drame, et il y a quarante siècles de cela, par la mise en présence de Jéhovah et de Satan; le mal défie le bien, et voilà Faction engagée. La terre est le lieu de la scène, et l'homme est le champ de bataille; les fléaux sont les personnages." 
almente, eliminando qualquer contraste estabelecido pelas sombras (trevas), ele torna-se invisível. Por outro lado, Deus cria o primeiro espetáculo, o mundo, habitado pela sua imagem e semelhança, e lança o pensamento oculicêntrico - ou ocularcêntrico -, mais tarde tão combatido como raiz do racionalismo, o primeiro "pecado" original divino.

Ainda que se possa discutir o que o termo luz significa, ao longo das inúmeras citações da Bíblia, ele aparece como sinal de dádiva, favores, justiça e sabedoria. Desde o Antigo Testamento, Salmo 4:6, lê-se: "Senhor, levanta sobre nós a luz do teu rosto". (BÍBLIA, 1999, p. 617) Trata-se de um rosto de luz, luz absoluta que se basta. Para difundir e confirmar a figura de Deus como fonte do conhecimento, santo Agostinho refere-se ao Salmo 36:9: "Na tua luz, veremos a luz". (BÍBLIA, 1999, p. 638) Tal conhecimento é dilatado para alcançar as hostes do contato com o sagrado, que acaba por indicar salvação.

Salvação que reside no Deus onisciente, com total domínio de sua semelhança, por ele mesmo projetada e inscrita na humanidade. O que é o Deus que não vejo, senão luz? Como não vejo, se é luz? Caso tivesse que se representar em imagem, Deus provavelmente projetar-se-ia como um sólido regular e desprovido de arestas. No limite da percepção visual humana, ele talvez fosse uma esfera, obviamente, também em semelhança ao "mundo". A esfera, no entanto, deveria ser concebida para evitar o sistema óptico do qual a humanidade foi provida. Deus, então, construiria a si mesmo como uma esfera, monocromática, opaca, (ou de polidez e brilho absolutos), iluminada virtualmente em cada um dos pontos visíveis, e colocar-se-ia num ambiente com o mesmo tratamento. Figura e fundo idênticos gerariam invisibilidade, ausência de referência corpórea ou material. Deus, somente e totalmente luz, tornou-se, portanto, invisível, uma ausência, uma instância de magia e crença.

No ato próprio de Deus, ao proferir a ordem que João acredita narrada por ele, expressa seu desejo através da palavra (Fiat lux!), fazendo nascer a imagem visual do mundo. Poder-se-ia afirmar que, também Deus, pensou visualmente, que ele construiu um discurso visual, ao criar sua ausência, desconstruindo a própria imagem, mas permitindo o equilíbrio na presença terrena do seu filho, respondendo à necessidade humana da visão. Na práxis cênica, nem mesmo as mais agudas revoluções propuseram a exclusão da imagem, o que pode provocar reflexões sobre a importância da mencionada "imagem visual", da imagem cênica e da visualidade como índices de sua natureza. A abordagem aqui encaminhada procura identificar como a natureza visual da práxis cênica propõe incorporações 
da luz ao pensamento que a provoca e cria, assim como à sua realização propriamente dita.

Mesmo que tais conexões causem estranheza, é importante acentuá-las, no presente estudo, para questionar a abordagem da luz como uma presença isolada, apenas funcional e inevitável, já que necessária para tornar a cena visível e atraente.

\section{CENA, LUZ E LUGAR}

A cena é irresistível; quando um romancista decide transgredir o espaço-tempo diegético do romance inserindo diálogos diretos - aqueles nos quais as personagens têm voz como discurso e proferem suas próprias palavras -, ele pode estar sendo atraído pelo teatro, como se desejasse ver sua obra em cena. Parece óbvio que, ao descrever ou narrar uma situação, o autor de um romance possa também estar abrindo portas para permitir à sua obra acesso ao palco, se esta for a vontade de um diretor, um coreógrafo, ou outro artista que decida levá-la à cena.

No texto dramático, contudo, as palavras constituem um estágio do processo rumo à cena, elemento indissociável de uma ação incorporada pela busca da realização de um desejo. Por esta razão, certas vertentes da crítica literária exclamam, ao falar de Racine, afirmando que sua poesia prescinde do palco. O termo exclamar é usado aqui para denotar a força da reação diante da possibilidade de um diálogo que se basta e desconsidera o palco. A cena latente na dramaturgia será impregnada de cores, formas e texturas, revelando na práxis cênica visões brotadas da leitura de um diretor que, por sua vez, empregará sua capacidade de provocar a equipe de um espetáculo para subverter caracteres alfabéticos impressos numa página, elaborando o conjunto de imagens que delinearão um pensamento visual para a cena.

Depois de tentar, por duas vezes, retirar os sapatos, como num jogo, Estragon diz: "Nada a fazer", ${ }^{\circ}$ primeira fala de Esperando Godot (En attendant Godot), de Samuel Beckett, estreada em 1953. Considerando que Beckett escreveu para o teatro e, mesmo levando em conta a força sonora das palavras, pode-se buscar a ação da qual a fala é apenas um dos aspectos. Uma assertiva de tal natureza pode sugerir, numa leitura superficial, que Estragon propõe a imobilidade: não há nada que se possa fazer. Ou seja, estaria abolida a ação e, consequentemente, o teatro, o acontecimento espetacular. Na constatação de Estragon, no entanto, reside uma ação contundente, uma deliberação vigorosa. Leia-se: eu preciso aniquilar o silêncio! 
Beckett escolheu de modo competente uma expressão muito dura para caracterizar a impotência que se instalará no seu drama, diante da espera sem perspectivas. Como uma situação de grave crise, a impotência opera aqui no nível dramático para, mesmo diante da iminência de estagnação, da paralisia, provocar a ação. Para Estragon, o contato com o outro é vital; ele, então, provoca Vladimir, caracterizando um desejo - e a ação que decorre de um desejo - e, portanto, um lugar onde a ação ocorre. O desejo faz de um espaço um lugar tocado por almas. A elaboração cênica de tal acontecimento resulta e se efetiva em imagens. Inclusive materiais. No contexto teatral, cênico, sem luz o processo não se completa, o objeto artístico deixa de existir.

Diante disso, manter a luz fora da sua obra transformar-se-ia numa tarefa hercúlea para um dramaturgo; a menos que ele exclua a ação, o ser humano, seus desejos e reações. Inclusive o seu próprio, o desejo de revelar sua obra corporificada no espaço teatral. Portanto, ao gerar na imaginação as primeiras ideias (idein, em grego, forma, padrão), as primeiras personagens da sua trama - cujos desejos serão selecionados para garantir a eficiência - o autor teatral estará incorporando luz ao seu trabalho. Mesmo que o faça intuitivamente. Será chocante para um antagonista de tal assertiva observar que ela é imune aos limites dos estilos, das escolas, das poéticas, das estéticas, das vanguardas, do "anti" e do "pós", qualquer que seja o modelo questionado. Enquanto tratar-se de práxis cênica, lá estará a luz. Assim como a sombra. E vale lembrar as iniciativas que investem na iluminação em si, como objeto da provocação espetacular.

No contexto do estudo da luz como elemento da espetacularidade se inclui, desde um dramaturgo com décadas de experiência que esteja escrevendo uma peça encomendada para ser levada ao público em um chamado "palco italiano", configurando-se no mais tradicional espetáculo, até um jovem artista (não mais denominado ator e conhecido talvez como performer), movido pelo desejo de realizar uma ação diante de, pelo menos, uma pessoa - espectador, fruidor, ou outra denominação variante das diversificadas tendências estéticas -, em qualquer que seja o espaço, que pode ser uma via pública ou um shopping mall, como exemplos, - sem qualquer compromisso com o drama, ou até com a palavra. Se alguém comparecer ao local determinado pelo artista para compartilhar com ele o evento e, durante a performance, tiver a chance de ver o acontecimento, mesmo que seja por uma pequena fração de tempo, estará efetivada a presença da luz. Mesmo que o autor do acontecimento exclua deliberadamente o adjetivo cênico, a personagem, o conflito, ainda assim, ele não será capaz de excluir o seu desejo 
de se constituir como um corpo transfigurado em imagem visual. Para realizar tal desejo, ele necessitará da luz.

O interesse da presente discussão indica uma consideração: mesmo que se trate de um pequeno instante de luz, ele terá grande relevância, até mesmo porque a redução e/ou o isolamento acentuará sua presença na composição visual da cena. Para explicitar: um evento em total escuridão que inclua um fragmento de luz, o tornará um momento único. E mais, em geral, num evento cênico, a incorporação da luz pode ser tão contundente a ponto de fazer o espectador considerar os momentos de black-out (na cena, escuridão esteticamente deliberada, definida pela retirada de toda luz artificial) como uma ausência momentânea de luz e não a presença da escuridão. Isso pode parecer vantagem. A longa permanência da luz na cena pode, contudo, transformar-se em armadilha, ou seja: ela pode ser aplicada de modo generalizado, atendendo a fórmulas fáceis e/ou efeitos superficiais.

A luz lembra uma praga. Negligenciada, poderá se instalar e agir como uma maldição milenar. O iluminador tem a oportunidade, alguns diriam o dever, de tratar cuidadosamente de cada detalhe do seu trabalho e, mesmo num pequeno momento da cena, todos os artistas envolvidos reúnem-se em uma única pessoa, o performer, lidando inevitavelmente com a luz. Daí, cada pequeno instante exigirá grande atenção daquele artista que respeita integralmente a obra, que não aceita superficialidades sem função estética. Mesmo que se imponha um instrumento de corte, como a cortina ou o black-out, isso exige enorme atenção e precisão na elaboração da luz.

Recebendo atenção e sendo aplicada com discernimento, a luz pode passar de praga à dádiva, uma vez que coloca à disposição do artista um conjunto de instrumentos, acessórios e procedimentos, capazes de contribuir positivamente na realização do seu espetáculo. Alcançando tal ponto, seria bom interagir com uma teoria e uma crítica fundamentadas que reconheçam as diferenças.

Estudando as fontes mais antigas que tratam da luz teatral pode-se encontrar, surpreendentemente, já nas atividades consideradas mais incipientes do teatro, uma série de considerações teóricas, críticas e artísticas, que antecipam questões encontradas também em textos da atualidade. Muitos textos antigos estão relacionados a uma abordagem utópica da cena, projetando uma categoria de espetáculo apenas imaginada ou desejada.

Os próximos capítulos destacam e comentam importantes documentos do mencionado corpo teórico, crítico e artístico consultado, sob o ângulo das relações entre a luz e a práxis cênica. 


\section{A VISUALIDADE SINGULAR DO TEATRO DE SHAKESPEARE}

Em procedimento comum, e até certo ponto esperado, os estudos da luz na cena são iniciados com discussões acerca da atividade teatral renascentista na Itália ou, quando muito, contemplando o teatro eclesiástico que a antecede. Aí devem ser incluídos espetáculos religiosos dos quais se tem notícia em relatos que datam do século X, de acordo com Alois M. Nagler (1952), eventos que ocorreram durante a Idade Média, em países da Europa.

A decisão de iniciar os mencionados estudos da luz pelo Renascimento italiano pode ser justificada em evidências que indicam a presença das primeiras ocorrências da aplicação de luz artificial - com o objetivo de promover visibilidade para a cena - em igrejas, catedrais, e, posteriormente, em teatros dos períodos citados. Podia-se até encontrar espetáculos nos quais o uso de luz artificial sugeria noite e/ou escuridão. Textos que apresentam tal característica sugerem uma convenção simples, mas sofisticada, indicando que a observação atenta de sinais 
deixados pela dramaturgia, por vezes muito sutis, pode revelar a interação da práxis cênica com a visualidade. Tais sinais podem estar contidos em circunstâncias que parecem óbvias, correndo o risco de serem desconsiderados.

A abordagem de aspectos particulares da obra de William Shakespeare (1564-1616), no momento inicial da presente discussão, é justificada por uma compreensão particular da sua dramaturgia, ou seja, trata-se de textos teatrais que já trazem inúmeros indícios da presença da luz na sua própria constituição. Portanto, a obra de Shakespeare ganha relevância para o presente trabalho, à medida que, ocorrendo já no século XVI - quando o teatro italiano havia instituído o uso da luz artificial na cena -, ele constrói a visualidade do seu espetáculo em consistente parceria com a dramaturgia, dispensando compromissos evidentes com aparatos de luz artificial.

Ao elaborar uma introdução ao contexto no qual Shakespeare escreveu, o presente trabalho considera desnecessário produzir um texto mais extenso sobre detalhes circunstanciais da sua obra e sublinha estrategicamente elementos pertinentes e relevantes para a abordagem em curso. Serão comentadas, especialmente, Hamlet (The tragedy of Hamlet-prince of Denmarke), A tempestade (The tempest) e Rei Lear (The tragedy of King Lear), ${ }^{1}$ na versão do Primeiro Fólio (First folio, 1623), com algumas passagens pelo Quarto I, ${ }^{2}$ para problematizar indícios de presenças da luz desde a ideia inicial de um espetáculo.

A citação de trechos das peças torna-se indispensável para alicerçar os argumentos aqui elaborados. As traduções para as obras de Shakespeare que aqui aparecem são de Bárbara Heliodora, exceto para o caso de Hamlet, cuja tradução é de Anna Amélia Carneiro de Mendonça.

Anne Surgers (2005b, p. 93, tradução nossa) define aquilo que se conhece como Teatro Elisabetano: "O traço explícito da complexa correlação entre teatro e poder". ${ }^{3}$ A autora inclui em tal assertiva aspectos do amparo provido pelos nobres e pela própria rainha aos atores e autores, oficialmente acordado em 1574. Alguns comentadores registram o acesso da Rainha Elisabeth ao poder (1558), como o início do período. Surgers (2005b, p. 94, tradução nossa), entretanto, pondera:

\footnotetext{
1 Hamlet e Rei Lear, respectivamente, em português.

2 O termo quarto, do latim, refere-se originalmente à dimensão do papel; uma folha dobrada para se alcançar duas partes iguais era conhecida como fólio. Ao ser novamente dobrada, resulta quatro folhas com, em geral, 10'x6'" [254 cm x $203 \mathrm{~cm}$ ]. Quando se trata de Shakespeare o termo quarto pode indicar, por vezes, cópias incompletas ou revisadas. O Primeiro Fólio, publicado em 1623, é reconhecido como importante documento para o estudo da dramaturgia de Shakespeare.

3 "[...] la trace explicite de la corrélation complexe entre théâtre et pouvoir [...]."
} 
Com efeito, em 1572, um decreto do Parlamento, a Lei para a punição de Vagabundos, exigia que cada companhia de atores estivesse sob a proteção de um nobre ou dignitário da justiça. Sem tal proteção, que os concedia o direito ao trabalho, os atores eram tratados como vagabundos, e, como tal, sujeitos a pena de prisão ou até mesmo ao pelourinho. Em 1572, James Burbage obteve a proteção do Conde de Leicester para sua companhia, e dois anos depois, a da própria rainha. ${ }^{4}$

Por outro lado, da oposição puritana à monarquia derivava - ou incluía - grave desaprovação ao teatro, culminando com uma ação definitiva do Parlamento que aprovou, em 2 de setembro de 1642, a interdição de qualquer representação teatral. Era o fim oficial do período teatral no qual Shakespeare elaborou sua obra.

Ele teria se transferido para Londres, no final da década de 1580, período no qual a atividade teatral londrina se intensificava. James Burbage (ca.1531-1597) pai de Richard Burbage (1568-1619), que seria o principal ator nos espetáculos de Shakespeare - já havia construído, em 1576, numa sociedade com o seu cunhado John Brayne, a casa de espetáculos que batizou como O Teatro (The Theatre). Na opinião de Surgers, considerando que a expressão mais usada àquela época na Inglaterra seria "casa de espetáculos" (playhouse), Burbage teve motivos particulares para escolher a denominação:

Quando ele denomina Teatro o seu lugar de representação, Burbage escolhe uma referência erudita e humanista, expressando assim o desejo de emprestar 'títulos de nobreza' ao seu trabalho, à sua companhia, aos seus autores e ao seu público; também na Inglaterra a Antiguidade greco-romana atuava como referência. ${ }^{5}$ (SURGERS, 2005b, p. 96, tradução nossa)

Alois M. Nagler (1952, p. VII, tradução nossa) acentua aspectos importantes para a abordagem aqui aplicada: "[...] Shakespeare era não apenas um poeta ou dramaturgo, ele era também ator e produtor. Ele montava suas próprias peças, atuava nelas, e, como acionista, dividia lucros e prejuízos em dois teatros. [...] O estudante

\footnotetext{
4 “En effet, em 1572, une ordennance du Parlement, l'Act for the punishment of Vagabonds, exigeait que chaque troupe de comédiens fût sous la protection d'un noble ou de dignitaires de la justice. Faute de cette protection, qui valeur l'autorisation leur métier, lês comédiens étaient assimiles à dês vagabonds, et comme tels, passibles de prison, ou même du pilori. Em 1572, James Burbage obtint pour sa compagnie la protection du Comte de Leicester, et, deux ans plus tard, celle de la reine elle même."

5 "Quand il appelle Theatre son lieu de représentation, Burbage choisit une référence erudite et humaniste, exprimant par là un desir de donner 'letters de noblesse' à son métier, à sa troupe, à sés auteurs et à son public; en Anglaterre aussi l'Antiquité greco-romaine servait de référence."
} 
do teatro elisabetano não pode ignorar o palco". ${ }^{6}$ Tal assertiva é significativa para a perspectiva do presente trabalho, considerando-se o interesse pelas rotas transversais de ligação entre a dramaturgia e a cena. Aqui, em especial, aquelas que ligam a poesia dramática de William Shakespeare e o palco elisabetano, buscando a credibilidade necessária em documentação que favoreça a presente abordagem, evitando repousar em conjeturas, ou abstrações que originam obscuridade, incerteza, imprecisão, quando se trata de informações sobre sua vida.

Nagler (1964, p. 1, tradução nossa) acentua a dificuldade para apontar o modo como Shakespeare teria começado suas atividades no teatro:

Não sabemos o que levou Shakespeare ao teatro. [...] A história de que ele se juntou a uma companhia itinerante é pura lenda. [...] A lenda diz que um jovem de Stratford tomava conta dos cavalos dos nobres na parte externa de um teatro ou que ele começou sua carreira como um assistente de um diretor de cena [...]. ${ }^{7}$

Como se pode apreender nas considerações de Nagler, muito do que se lê a respeito da vida de Shakespeare parece se aproximar dos ares de lenda, sem evidências ou registros efetivos. Nagler (1964) aponta como primeiro documento da sua presença na condição de dramaturgo, um trecho do trabalho de Thomas Nashe, Pierce pennilesse, em 1592, que remete ao primeiro Henrique IV de Shakespeare. A peça teria sido encenada no Rose Playhouse, de Philip Henslowe que, inclusive, manteve recibos em seu Diário.

Como Nagler (1964) também aponta, no mesmo ano de 1592, no seu testamento literário, Groats-worth of Witte, bought with a million of repentance, Robert Greene menciona o sucesso de Shakespeare. De acordo com Nagler (1964), em dezembro de 1594, uma conta da Corte aponta Shakespeare, juntamente com William Kempe e Richard Burbage, como membros da companhia e servos do Lord Chamberlain. ${ }^{8}$ Ele completa: "Em fins de 1594, Shakespeare atuou diante da Rainha em Greenwich como membro da Companhia do Lord Chamberlain, que se

6 "[...] Shakespeare was not only a poet or a dramatist, he was also an actor and a producer. He staged his own plays, appeared in them, and, as stockholder, shared in the profit and loss of two theatres. [...] The student of Elizabethan drama cannot ignore the stage."

7 "We do not know what brought Shakespeare to the theatre. [...] the story that he joined a troupe of strolling players is pure legend. [...] Legend says that the young man from Stratford guarded the gentry's horses outside one of the theatre or that he started his career as assistant to a stage manager [...]."

8 Menos um mecenas e mais um protetor no sentido de dar segurança aos atores para o desenvolvimento das suas funções. 
compunha de remanescentes de antigas companhias". ${ }^{9}$ (NAGLER, 1964, p. 3, grifo e tradução nossos) Fontes raras e valiosas, que contribuem para um esboço de rotas confiáveis na construção da estatura histórica de William Shakespeare.

O ambiente teatral por ele encontrado ainda guardava traços da práxis cênica medieval e, na Inglaterra, a tradição dos pageants não havia simplesmente desaparecido (Figura 4). O próprio Shakespeare parece, por um lado, manter laços com o pensamento medieval e, por outro, lançar-se numa aventura mais barroca que renascentista. Segundo Nagler (1964), ao chegar a Londres, Shakespeare deve ter encontrado em funcionamento duas casas de espetáculos, o Curtain Playhouse e o Theatre. Um mercador da cidade de Ulm, Samuel Kiechel, em visita a Londres em 1585, escreveu:

E se representam comédias todos os dias; é particularmente interessante assistir os Homens da Rainha (uma companhia mantida pela Rainha) [...] há algumas casas estranhas com três galerias, uma sobre as outras, de modo que uma grande multidão venha sempre assistir esse tipo de entretenimento. ${ }^{10}$ (KIECHEL apud NAGLER, 1952, p. 4-5, tradução nossa)

Determinadas considerações de Victor Hugo (1802-1885), no seu livro William Shakespeare (1864), encaminham reflexões importantes em torno de Shakespeare. Duas delas aparecem já na primeira parte:

Cada peça de Shakespeare, escrita para as necessidades de sua trupe, era, ao que tudo indica, apreendida e ensaiada às pressas pelos atores, no original mesmo, pois não se perdia tempo fazendo cópias; [...] [Há] pouco ou nenhum registro sobre esses teatros quase ambulantes. [...] isso faz compreender porque se encontra tanta obscuridade sobre as épocas em que Shakespeare escreveu suas peças e porque é difícil determinar as datas com precisão.." (HUGO, 1864, p. 33, tradução nossa)

Se Hugo corrobora a opinião de outros estudiosos, no que se refere à imprecisão dos dados biográficos de Shakespeare, ele dá, por outro lado, um testemu-

9 "At the end of 1594 Shakespeare was playing before the Queen in Greenwich as a member of the Lord Chamberlain's troupe, which has been formed from remnants of older troupes."

10 “And comedies are given every day; it is particularly amusing to look on when the Queen's Men [a troupe under protection of the Queen] play, [...] there are some odd houses with three galleries one on top of other so that a large crowd of people always come to watch this kind of entertainment."

11 “Chaque drame de Shakespeare, composé pour les besoins de sa troupe, était, selon toute apparence, appris et répété à la hâte par les acteurs sur l’original même, qu’on ne prenait pas le temps de copier; [...] Peu ou point de registres dans ces théâtres presque forains; [...] ceci fait comprende pourquoi il est resté tant d'obscurité sur les epoques où Shakespeare composa ses drames, et pourquoi il est difficile d'en fixer les dates avec precision." 
nho relevante sobre a qualidade da sua poesia dramática, quando acentua a sua relação com as necessidades da companhia que iria encená-la. Destaca-se o olhar de Shakespeare, voltado para o espetáculo e, inevitavelmente, para as convenções visuais do teatro, do teatro que ele fazia. Tal olhar ficava evidente, não apenas na cena que ele oferecia ao seu público, mas sobreviveu no texto em si. Não se pode escrever dramaturgia impunemente. Ela é uma poesia fértil, repleta de sementes; como um vulcão, pode estar prestes a entrar em erupção. Quem a faz, se efetivamente escreve para a cena, envolve-se ou, melhor, mergulha no seu universo visual.

Mesmo que não registre racionalmente a cumplicidade e, em momentos decisivos, a luz subverta o logos e tome rédeas. Para considerar em Shakespeare a inconfidência imposta ao poeta, pela luz, volto ainda às palavras de Victor Hugo (1864, p. 109-110, tradução nossa):

Homero, Jó, Isaías, Ezequiel, Lucrécio, Juvenal, São João, São Paulo, Tácito, Dante, Rabelais, Cervantes, Shakespeare. | Essa é avenida dos gigantes imóveis do espírito humano. | [...] Cada um deles representa toda a soma do absoluto que o ser humano pode realizar. | [...] Talvez, a extremo rigor, e ainda todas as reclamações seriam legítimas, pudéssemos | designar como os mais altos cimos entre esses, Homero, Ésquilo, Jó, Isaías, Dante e Shakespeare. | Entenda-se que falamos aqui do ponto de vista da Arte, e, na Arte, do ponto de vista literário. | Dois homens nesse grupo, Ésquilo e Shakespeare, representam especialmente o drama. ${ }^{12}$

Tratando particularmente de Ésquilo, Hugo (1864, p. 65, tradução nossa) diz:

[...] Uma espécie de terror preenche Ésquilo, de uma extremidade à outra. Uma profunda medusa move-se vagamente atrás das figuras que se movem na luz. [...]

Ésquilo é o mistério antigo feito homem; algo como um profeta pagão. Sua obra, se a tivéssemos toda, seria uma espécie de Bíblia grega. ${ }^{13}$

\footnotetext{
12 “Homère, Job, Eschyle, Isaïe, Ézéchiel, Lucrèce, Juvénal, saint Jean, saint Paul, Tacite, | Dante, Rabelais, Cervantes, Shakespeare. | [...] Ceci est l'avenue des immobiles géants de l'esprit humain. [...] | Chacun d'eux représente toute la somme d'absolu réalisable à l'homme. | [...] Peut-être à l'extrême rigueur, et encore | toutes les réclamations seraient légitimes, pour | rait-on désigner comme les plus hautes cimes | parmi ces cimes Homère, Eschyle, Job, Isaïe, Dante et Shakespeare. | II est entendu que nous ne parlons ici qu'au point de vue de l'Art, et, dans l'Art, au point de vue litteraire. Deux hommes dans ce groupe, Eschyle | et Shakespeare, representent spécialement le drame."

13 “Une sorte d'épouvante emplit Eschyle d'un bout a l'autre; une méduse profonde s'y dessine vaguement derrière les figures qui se meuvent dans la lumiere. [...] Eschyle est le mystère antique fait homme; quelque chose comme un prophete paien. Son oeuvre, si nons l'avions toute, serait une sorte de Bible grecque."
} 
Deve ser acentuada a contundência da luz na narrativa de Jó, assim como a presença definitiva do fogo em Prometeu acorrentado, de Ésquilo, apesar das alegações de autoria duvidosa. Para introduzir Shakespeare, Hugo (1864, p. 105, tradução nossa) continua: “[...] Shakespeare, é o quê? Poderíamos quase responder: é a Terra"14 Ele ainda afirma que se deve um lugar de destaque para Ésquilo, tecendo muitas relações entre ambos, sublinhando sempre o drama como o núcleo de tais relações: "A epopeia só pode ser grande, o drama é forçado a ser imenso. Essa imensidão é todo Ésquilo e todo Shakespeare". ${ }^{15}$ (HUGO, 1864, p. 166, tradução nossa)

Sem a moldura emocional, Jaeger (1995, p. 291-292) afirma:

Infelizmente não temos qualquer ideia precisa das mais antigas formas da tragédia, e, portanto, só podemos julgar as formas superiores da sua evolução. Na forma acabada que vemos em Ésquilo, aparece como o renascimento do mito na nova concepção do mundo e do homem ático a partir de Sólon, cujos problemas morais e religiosos atingem em Ésquilo o seu mais alto grau de desenvolvimento.

Voltando para Hugo, a admiração devotada pelo autor francês àqueles que ele relaciona como gênios, e o destaque para a relação entre Ésquilo e Shakespeare fornecem apoio para o trabalho em andamento, alcançando uma assertiva fundamental: "Shakespeare, o Antigo, é Ésquilo". ${ }^{16}$ (HUGO, 1864, p. 163, tradução nossa) Uma semelhança, em particular, une efetivamente os dois artistas: o modo como trabalhavam para o teatro. Ou melhor, a familiaridade que detinham com a cena do seu próprio tempo; ambos escreviam com o olhar voltado ou impregnado pela práxis cênica.

Sobre a vida de Shakespeare, é possível encontrar inúmeras especulações. Além dos documentos que o localizam na segunda metade do século XVI, membro da Companhia do Lord Chamberlain, sobreviveu até nossos dias aquilo que pode ser um registro muito próximo da sua poesia trágica, o Primeiro Fólio. É um conjunto de trinta e seis das suas obras, publicado em 1623 por William Jaggard, juntamente com seu filho Isaac, e Ed Blount. A contribuição de dois companheiros de Shakespeare, atores da Companhia John Hemminge e Henry Condell, juntando as peças, foi decisiva.

\footnotetext{
14 "Shakespeare, qu'est-ce? On pourrait presque répondre: c'est la Terre."

15 “L'epopée peut n'être que grande, le drame est forcé d'être immense. | Cette immensité, c'est tout Eschyle et c'est tout Shakespeare."

16 Do original: "Shakespeare l'Ancien, c'est Eschyle".
} 
Desafortunadamente, nenhum manuscrito original foi encontrado. Considerando-se que os Foul Papers, ${ }^{17}$ e até os Prompt Books, ${ }^{18}$ poderiam conter indicações e anotações relativas à cena em si, é uma gigantesca lacuna. Hemminge e Condell usaram provavelmente cópias das peças para a organização do Primeiro Fólio, tendo Ralph Crane como escriba na versão que foi impressa. O manuscrito cuidadosamente redigido é até considerado de maior credibilidade, uma vez que os Quartos apresentam, por vezes, certas diferenças em relação ao Primeiro Fólio, o que leva à interpretação de revisão - incluindo cortes - não necessariamente feita pelo autor. Tantas incertezas, que incluem ausência de informações sobre sua vida escolar, deram lugar a longas e acirradas discussões.

A educação formal de William Shakespeare pode ter incluído a leitura de autores da Antiguidade, como Plauto, Ovídio, Horácio, Sêneca; ele pode ter participado de espetáculos comemorativos na escola. Ler latim, traduzir latim-inglês e vice-versa pode ter sido atividade escolar obrigatória. Teria Shakespeare lido Ésquilo? Agamêmnon era uma tragédia que a ele interessava especialmente? Tais indagações contribuem para a abordagem em curso e qualquer que seja a resposta há algo que pode ser mais importante do que autores ou peças: a manifestação teatral em si. ${ }^{19}$ De todo modo, de acordo com Hugo, lendo ou não Ésquilo

17 Os dramaturgos elisabetanos forneciam aos atores manuscritos/fragmentos dos textos, conhecidos como foul papers.

18 Principal cópia de uma peça - e hoje do roteiro de um filme - contendo todas as deixas, movimentos dos atores, assim como da técnica. No teatro norte-americano, fica sob a responsabilidade do Stage-Manager, profissional responsável pelo controle da performance, com formação específica possível, no nível superior. (Pode-se dizer que, no Brasil, há certa correspondência no Diretor de Cena, ainda que este seja confundido com o contrarregra, profissional com outra função, muito importante e supervisionada pelo stage-manager). Também denominado o "livro", Prompt Copy ou Prompt Script. O Stage-Manager, ou o membro da sua equipe responsável por orientar o espetáculo, deve estar muito familiarizado, deve conhecer, deve dominar o Prompt Book e, consequentemente, o espetáculo. Ele deve estar "On the Book". Este documento contém informações detalhadas sobre a casa de espetáculos - ou qualquer que seja o lugar escolhido para a performance -, relatórios dos espetáculos realizados, procedimentos de segurança, emergência, assim como toda informação necessária para a realização de cada performance. É conhecido como a "bíblia" da montagem. Há termos relacionados e conhecidos no Brasil como "ponto", no teatro - artifício usado para dar suporte de texto ao ator em cena, e telepronto, na televisão - expressão provavelmente originada no inglês tele-prompter, dispositivo acoplado ao sistema de vídeo através do qual se fornece (em tempo real) o texto de um programa, ao profissional diante das câmeras. Além do ponto eletrônico, um dispositivo auricular sem fio, que fornece informações ao profissional em cena, ao apresentador de um programa, um repórter, e assim por diante.

19 A familiaridade com o idioma grego na Inglaterra, àquele período, não era comum. A rainha Jane Grey (1536/1537-1554), casada com Lord John Guilford Dudley (1536-1554), reinou por apenas nove dias e nunca coroada, é citada como uma jovem de formação muito abrangente, provavelmente falava grego e pode ser considerada uma exceção: ela devia contar no seu castelo com um daqueles raros especialistas com quem aprendeu este idioma. Lady Jane Grey foi levada ao trono pelo desejo do jovem rei morto Edward VI, que assim determinou em seu testamento, desconsiderando suas irmãs Mary e Elizabeth, na linha sucessória. Lady Jane foi executada na Torre de Londres, sob ordens de Mary I, em 12 de fevereiro de 1554. No mesmo dia, o seu marido foi também executado. 
e, em particular, Agamêmnon, a obra de Shakespeare aponta semelhanças entre ambos, que se referem ao teatro que eles faziam, como o próprio Hugo (1864, p. 168, tradução nossa) descreve: "Atenas, ao sentir que vinha Ésquilo, Sófocles e Eurípedes, deu-se os teatros de pedra. Sem teto, o céu por cobertura, a luz do dia como iluminação." ${ }^{20}$

A interpretação de Hugo (1864) sublinha traços que aproximam os dois poetas e indica a semelhança da práxis na qual sua dramaturgia deveria operar, como estado pré-cênico, uma dramaturgia projetada para completar-se numa tipologia espacial que incluía a exposição à luz do sol, confiando à poesia funções importantes na criação dos lugares e atmosferas.

\title{
A INSTALAÇÃO DE HAMLET ATRAVÉS DA VISUALIDADE
}

A provocação originada na assertiva acima leva a um fragmento da peça The tragedy of Hamlet, prince of Denmarke (Hamlet), ora usando o Primeiro Fólio (Figura 5), ora citando versões modernas, que incluem outras fontes na sua composição, como os Quartos. Dada a inexistência de datas específicas para cada peça, na publicação mencionada, há especulações na tentativa de localizá-las cronologicamente. De qualquer modo, a abertura da obra demonstra a relação de Shakespeare com a cena para a qual ele escrevia:

\author{
ATO I CENA I \\ (Elsinore. Uma plataforma do castelo. Francisco \\ em seu posto. Entra Bernardo) \\ Bernardo Quem está lá? \\ Francisco Responde tu: pra trás e diz quem és! \\ Bernardo Viva o Rei! \\ Francisco É Bernardo? \\ Bernardo É ele mesmo. \\ Francisco Chegaste exatamente em tua hora. \\ Bernardo Acaba de soar a meia noite. \\ Vai tu pra cama; vai dormir, Francisco. \\ Francisco Muito obrigado porque assim me rendes.
}

20 "Athènes, sentant venir Eschyle, Sophocle et Euripide, s'est donné des théâtres de pierre. Pas de toit, le ciel pour plafond, le jour pour éclairage." 
'Stá frio e o coração trago oprimido

Bernardo Foi calma a guarda?

Francisco Não se ouviu um rato.

Bernardo Muito bem. Boa noite. Se encontrares

o Horácio e o Marcelo, companheiros

Desta noite, eu te peço que os apresse.

(Entram Horácio e Marcelo).

(SHAKESPEARE, 1995, p. 29)

Quaisquer que sejam as interpretações, qualquer que seja o teórico eleito para orientar a compreensão da obra, Shakespeare fez muito bem a sua parte. A rubrica de abertura exige um compromisso, no espetáculo; caso alguém se pergunte: para onde entram Bernardo e Francisco? Shakespeare responde com o seu texto: não interessa, agora. Um leitor, que pode ser o diretor, pergunta-se ainda: entram, sim; mas, de onde vêm? De acordo com a primeira fala de Bernardo, ele parece encontrar dificuldade para identificar Francisco. O que pode indicar uma grande distância entre eles.

Por outro lado, a distância relativiza-se com a resposta de Francisco. Ele recusa-se a responder e exige que o outro se identifique. A saudação ao Rei, proferida por Bernardo e sua provável aproximação, deixa pistas para que Francisco o reconheça, a começar pela voz. Bernardo confirma e agora já está próximo o suficiente para que o outro registre: "Chegas exatamente em tua hora". ${ }^{21}$ Bernardo, então, traz uma informação decisiva: são doze horas, hora de ir para a cama. Shakespeare continua construindo atmosfera sem revelar, contudo, o ambiente. Para alguém que tem a função de Sentinela, ir para a cama às doze horas não significa necessariamente que seja noite. Pode ser meio-dia. De qualquer modo, Francisco teve um turno muito tranquilo, apesar do frio que dói no coração, resultante de uma temperatura muito baixa. Bernardo despede-se do companheiro que está deixando o posto, desejando boa noite.

Fica esclarecido, é noite; meia-noite. E não de uma noite qualquer, mas muito fria e escura. Provavelmente com neblina, considerando a dificuldade para se enxergar, mesmo a curta distância, como se pode observar na entrada de Horácio e Marcelo, que se segue: Francisco pensa que pode ouvi-los chegando, mesmo que não possa vê-los perfeitamente. Shakespeare precisou de apenas um minuto para abrir as portas da tragédia, delineando a atmosfera que considera indicada

21 "You come most carefully upon your hour." 
para guiar o espectador por um caminho repleto de atalhos e encruzilhadas. Mas ainda sem revelar o ambiente. Para ele, a atmosfera pode se instalar em muitos ambientes; por isso, ela é mais importante, deve ser construída antes mesmo que se defina um lugar para a ação.

Há, contudo, certas particularidades: versões publicadas após o First Folio informam que Francisco está no seu posto e só depois Bernardo aparece. Levando-se em conta a lógica de uma ação dramática com pressupostos realistas, isso parece plausível. O que Shakespeare tinha em mente, então, quando diz que entram sentinelas, Bernardo e Francisco? A pulsação do seu palco, do seu teatro.

Pode ser diferente num espetáculo moderno, onde se aplicam diversificados instrumentos de corte ou transição realidade-ficção, como luz ou cortina, entre outros. Ele, no entanto, tinha uma cena aberta, e mais, à luz do dia, numa tipologia espacial do teatro que recebeu, em inglês, uma expressão moderna sugestiva: thrust-stage. ${ }^{22} \mathrm{O}$ ator, responsável por Francisco, estaria já em cena desde a entrada do público, aguardando que o outro surgisse, encaminhando a ação? Parece pouco provável. Shakespeare não diz que eles entram simultaneamente, isso é verdade. Pode-se, entretanto, imaginar tudo pronto para começar o espetáculo, entram Bernardo e Francisco, por lados opostos, extremos. Bernardo aproxima-se. Francisco, alerta, percebe o movimento sem identificar visualmente; pode ser qualquer pessoa ou coisa. A ação propriamente dita pode ser iniciada já na atitude de Francisco, que revela o frio, e logo saberemos por que: durante grande parte da cena a atmosfera escura, fria e densa torna-se progressivamente presente, palpável.

O autor encarrega-se de guiar o público apresentando-o à curiosidade incrédula de Horácio, ao introduzir o motivo da sua presença no posto da Sentinela, àquela adiantada hora. Um evento particular vem acontecendo e despertou a atenção dos dois jovens - ele está acompanhado de Marcelo - já que Bernardo é o responsável por assumir o posto, após a saída de Francisco. Logo, precisamente ao soar o sino que anuncia a primeira hora do dia que se inicia - como já acontecera na última madrugada -, surge um espectro. Até o incrédulo Horácio confessa seu pavor e espanto, concordando que o fantasma se assemelha muito ao rei morto, no seu paramento de guerra.

22 "O verbo to thrust, avançar, é aqui revelador. Uma vez que o palco avança em direção ao observador, deslocando-o para as laterais e oferece novos campos visuais, expondo duas outras faces [ou ângulos] da cena. Agora o espectador não somente tem acesso visual à frente do palco, mas ingressa com o seu complexo perceptivo nas faces direita e esquerda, também." 
A curiosidade de Horácio lhe fornece uma espécie de antídoto para seu próprio medo, permitindo-o realizar a bravata de ordenar ao espectro que fale. As especulações parecem indicar que a aparição é um aviso sobre eventos que ameaçam desnudar a aparente tranquilidade. Sua oscilação entre a descrença e o temor revela nuanças da sua personalidade. Bernardo parece convencido de que as aparições fantasmagóricas se relacionam com a notícia da tentativa de retaliação do jovem nobre norueguês Fortimbrás - cujo pai desafiou o rei Hamlet e por ele foi morto em combate - quando o fantasma reaparece, como que lançando dúvidas, alertando para algum outro evento. Diante do seu silêncio, a situação se agrava e alcança o limite do bom senso, quando Marcelo pergunta: "Devo tocá-lo a golpes de alabarda?". ${ }^{23}$ Ainda que a partisan seja uma espécie característica de alabarda de haste longa, continua sendo uma arma branca, que exige certa proximidade do alvo. (Figura 6). E o alvo é um fantasma que, como resposta, desvanece num ponto para imediatamente surgir em outro.

Numa noite fria, na qual uma espessa neblina torna difícil enxergar alguém que se encontra a alguns metros, o espectro parece tornar-se visível - como se tivesse uma luz própria, especial! Tudo isso ocorrendo na área de atuação propriamente dita, num tempo efetivo aproximado de 10 a 12 minutos, numa ação dramática que, contudo, sugere horas; e, segundo Bernardo: "Ia falar, quando cantou o galo". ${ }^{24} \mathrm{O}$ canto do galo já anuncia o amanhecer e, no minuto que se segue, Horácio chama a atenção:

Mas olha, a aurora, com seu manto róseo,

Já pisa o orvalho nos distantes montes:

Terminemos a guarda: e, a meu conselho,

Contemos o que vimos esta noite

Ao jovem Hamlet; pois, por minha vida,

Este espírito, mudo para nós, só quer falar com ele. ${ }^{25}$

(SHAKESPEARE, 1995, p. 35)

Shakespeare investe na cumplicidade entre as imagens construídas na sua poesia e o imaginário do espectador, norteado pela experiência humana com a luz. Em pouco mais de 13 minutos, talvez 15, transita-se por uma noite lúgubre,

\footnotetext{
23 "Shall I strike it with my Partizan?"

24 "It was about to speake when the Cocke crew."

25 “[...] But looke, the Morne in Russet mantle clad, | Walkes o're the dew of yon high Easterne Hill, | Breake | we our Watch vp, and by my aduice | Let vs impart what we haue seene to night | Vnto yong Hamlet. For vpon my life, | This Spirit dumbe to vs, will speake to him."
} 
densa, fantástica, alcançando uma madrugada repleta de metamorfoses cromáticas, impregnadas de vermelho, com a luz do dia apontando o esclarecimento, a decisão clara. E tudo isso ocorrendo objetivamente, numa tarde do verão ou outono londrino, numa cena aberta e num teatro sem cobertura, com o espetáculo ocorrendo, portanto, sob a luz do sol.

Sem acentuar efetivamente questões relativas à luz, Nagler (1964, p. 34, tradução nossa) afirma: “[...] O palco elisabetano público conhecia trevas apenas por descrição. Os versos do poeta precisavam construir a atmosfera, [...]". A dramaturgia de Shakespeare representa valioso material para o entendimento das parcerias entre a luz e o teatro do seu tempo, numa poesia dramática construída como passo inicial no caminho para a realização teatral, por um artista que, com ambas, mantinha especial familiaridade. Pode parecer um contrassenso sublinhar positivamente a atitude de Nagler, quando ele prioriza os documentos e, por outro lado, acentuar o interesse em discutir a visualidade, uma vez que a escassez de evidência visual, no que se refere aos espetáculos de Shakespeare, é quase absoluta. Até mesmo as imagens, gravuras, pinturas e esculturas, que pretendem retratá-lo são severamente criticadas; desde sua acuidade técnico-estética, incluindo a análise de sua proporção, questionando a credibilidade como documento histórico-social. Não poderia ser diferente, já que se trata de uma personalidade que despertou tanta atenção, sendo visitada pelo tratamento de outro artista, impregnado pela visualidade de seu tempo.

Mesmo considerando textos importantes, como o de Morton Paterson (1961), que estuda o Office of the revels na época da Rainha Elizabeth, abordando diversos aspectos das festas e dos espetáculos elisabetanos, incluindo a luz, assim como o trabalho de Irwin Smith (1956), que busca uma reconstrução moderna minuciosa do Globe da época de Shakespeare, efetivando uma pesquisa rigorosa, há poucos documentos iconográficos sobre o edifício teatral, produzidos à época. Além dos documentos já mencionados, o interessado na pesquisa sobre a luz no teatro da época de Shakespeare encontrará bom material de estudo no trabalho de Robert B. Graves (1999).

Por outro lado, não fosse encontrado - e publicado por K. T. Gaedertz - a cópia de um desenho que objetiva representar o interior do Swam, na Utrecht University Library da menor província dos Países Baixos do mesmo nome, em 1988, os estudos estariam limitados a descrições, inventários e indicações contidas nas peças. (NAGLER, 1964, p. 9) A ilustração original teria sido desenhada por um estudante ou estudioso alemão que visitava Londres, Johannes De Witt, presumidamente, em 1596, e de localização hoje ignorada. O que se conhece, e foi encontrada por 
Gaedertz, é uma cópia que teria sido feita por Arend van Buchel, amigo de De Witt, e originou inúmeras interpretações e discussões (Figura 7).

Sobre a imagem, Chambers (1923, p. 527, tradução nossa) afirma: “[...] o desenho é a base inevitável para qualquer relato abrangente dos principais aspectos estruturais de uma casa de espetáculos [do período em questão]". ${ }^{26}$ Nagler (1964) acredita que o desenho revela a ocorrência de um ensaio, embora questionado por comentadores, que indicam a bandeira hasteada como sinal de espetáculo. A bandeira pode indicar que haveria sessão naquele dia, mesmo estando o elenco ensaiando no momento da visita. Cada um dos elementos físicos das instalações que aparecem no desenho foi revolvido por debates importantes, desde seu aparecimento, com tentativas de relacionar a poesia dramática de Shakespeare e aquela orientação espacial.

Além de uma tendência a reconhecer o seu valor como documento único, a discussão aponta, também, dúvidas em torno da habilidade de quem executou o desenho e, portanto, sua validade como documento daquilo que De Witt pretendia mostrar. Podem ainda ser consideradas certas convenções - como a superposição de informações no mesmo desenho - e até uma relação direta com a arquitetura teatral romana; os textos em latim, identificando as partes do teatro [orchestra (espaço da plateia reservado para convidados especiais), sedilia (assentos), porticus (galeria coberta)], apontam em tal direção, representando interesse particular de De Witt e van Buchel, ambos envolvidos com a atividade de antiquário. Uma informação parece não sugerir controvérsias: os espetáculos ocorriam durante o dia, sob a luz do sol, uma vez que parte da plateia era descoberta, como mostra o desenho.

Menciona-se ainda outra imagem, uma gravura de Claes Jan Visscher, elaborada por volta de 20 anos depois da viagem de De Witt, mostrando uma vista panorâmica de Londres, provavelmente de 1616. De acordo com Bryson (2009, p. 97, tradução nossa), a confiabilidade da gravura pode ser questionada:

[...] Em 1948 um estudioso chamado I. A. Shapiro demonstrou de maneira bastante conclusiva que Visscher havia baseado seu desenho numa gravura já existente, de 1572, antes que qualquer teatro por ele retratado fosse efetivamente construído. Na verdade, parece que Visscher nunca esteve em Londres não sendo, portanto, a mais confiável das testemunhas. ${ }^{27}$

26 " $[. .$.$] the drawing is the inevitable basis of any comprehensive account of the main structural features of a$ [Elizabethan] playhouse."

27 "[...] in 1948 a scholar named I. A. Shapiro showed pretty conclusively that Visscher had based his drawing on an earlier engraving, from 1572, before any of the theatres he depicted had actually been built. In fact it appears that Visscher had never actually been to London, and so was hardly the most reliable of witnesses." 
Bryson (2009) cita também uma gravura de Wenceslas Hollar, executada entre finais da década de 1630 e início da seguinte, na qual se vê uma construção identificada como Bere baiting. Muitos acreditam tratar-se do Teatro Globo. Outras interpretações conjecturam que a mencionada edificação acomodava lutas entre animais, incluindo ursos, de grande apelo, especialmente no que se refere a sua força e agressividade.

Do ponto de vista do espetáculo em si, outras abordagens têm envolvido historiadores e/ou críticos. Nagler apresenta considerações acerca da natureza dos cenários, ponderando que as especulações em torno das decisões dos dramaturgos elisabetanos que, segundo comentadores, tendiam a substituir os aspectos ilusionistas da cenografia por descrições mais ou menos poéticas no texto, não passam de mitos. Contradizendo aqueles que fundamentam tal crença nas intervenções do Coro, em Henry V, ele aponta como principal fonte para sua argumentação o inventário executado pelo proprietário do Rose Playhouse, Philip Henslowe, em 10 de março de 1598. (NAGLER, 1964) Nagler (1964, p. 35, grifo e tradução nossos) acentua: "O teatro elisabetano - nesse caso, o Rose Playhouse em 1598 - não era, de modo algum, um deserto; pelo contrário, determinadas ações eram definitivamente pontuadas por elementos cênicos que se autossustentavam". ${ }^{28}$ Os itens descritos no inventário e destacados por Nagler (1964) incluem: uma rocha, três túmulos, uma "Boca do Inferno", uma jaula (ou cela), duas escadas, dois campanários, um farol, "a cidade de Roma", um loureiro, uma "árvore de maçãs douradas", dentre outros elementos.

Ele parece considerar tais elementos indicadores do espaço da cena e até estruturas cênicas capazes de suportar ou abrigar um ator, ou atores, como um banco, uma árvore, uma tenda. Considerando-se que tais itens representam parte da convenção daquele teatro, o argumento de Nagler parece plausível. Uma vez que a introdução de um inteiro regimento ou uma floresta em cena seria pouco provável, três soldados ou uma árvore poderiam contribuir para construção do ambiente e das relações exigidas pela cena, na moldura de uma convenção específica. O dramaturgo investe numa tentativa de cumplicidade com o espectador, no intuito de aproximá-lo do seu espetáculo. Anne Surgers (2005b) trata do mesmo tema, observando o teatro elisabetano como uma "retórica do visível". (Já no seu primeiro exemplo, para introduzir tal abordagem, pode ser vislumbrada uma relação com o presente enfoque, ainda que seu objetivo seja diferenciado:

28 "The Elizabethan Stage - in this case, the Rose Playhouse in the year 1598 - was by no means a desert, rather that certain actions were definitely pin-pointed by mean of free-standing scenic elements." 
Para ajudar a entender a natureza dessa correlação elisabetana entre o dito e o mostrado, analisarei em primeiro lugar dois exemplos escolhidos na obra de Shakespeare, que tratam o céu. Em O Mercador de Veneza, Lorenzo diz a Jessica: Olha, o piso do céu está todo incrustado com brilhantes discos de ouro (O Mercador de Veneza, a V-1, v. 58-59) [...] A mesma imagem é encontrada na confidência de Hamlet a Rosencrantz e Guildenstern: [...] Vede! O firmamento, esse dossel esplêndido, este teto majestoso trastejado com chamas de ouro (Hamlet, II-2 v. 311 e ssq.). ${ }^{29}$ (SURGERS, 2005b, p. 110, tradução nossa)

Tanto a última imagem, parte da confidência de Hamlet a Rosencrantz e Guildenstern, quanto a fala anterior, de Lorenzo, ambas tratam inequivocamente da luz. A correlação apontada pela autora refere-se a um estado da natureza que, para Shakespeare, como realizador, era imprescindível e só possível na poesia. Mais que uma descrição do lugar ou de eventos, ele mergulha a ação dramática numa atmosfera de nobreza, sob um céu imaginário que resplandece em ouro.

Para concluir o capítulo no qual discute a questão, Surgers (2005b, p. 113, tradução nossa) afirma:

[...] para o teatro elisabetano, a imagem não é da ordem do visível, mas do imaginário. É uma imagem mental, interior, espiritual, que o expectador constrói tanto através do texto falado, respirado e encarnado, quanto através da arquitetura e da cenografia. ${ }^{30}$

Na versão do Primeiro Fólio, em Henry VI, part one, encontra-se: "Entra Purcel na parte superior, empunhando uma tocha acesa". ${ }^{31}$ (SHAKESPEARE, 1623, p. 107, tradução nossa) A prática de usar tal artefato em cena poderia, como se observa nessas didascálias, até indicar escuridão ou noite, num espaço teatral que recebia luz do sol, configurando um traço muito particular para a cena. Parece óbvio que não se trata de uma discussão esgotada e que outros autores podem encontrar

\footnotetext{
29 "Pour aider a comprendre de quelle nature est cette corrélation elisabethaine entre le dit et le montrer, j'analysareait em premier lieu deux examples choisis dans Shakespeare, a propôs du ciel. | Dans Le Marchant de Venise, Lorenzo dit à Jessica: | Regard, le parquet du ciel est tout incrusté de disques d'or étincelants (Le Marchant de Venise, V-1, v. 58-59) [...] | On retrouve La même image dans la confidence de Hamlet à Rosencrantz e Guildenstern:[...] voyer! Le firmament, ce dais splendide, ce toit majesteux fretté de flammes d'ór" (Hamlet, II-2 v. 311 e ssq.).

30 “[...] pour le théâtre élisabéthain, l'image n'est pas de l'ordre du visible mais de l'imaginaire. C'est une image mentale, interieure, spirituelle, que le spectateur se construit tant par l'intermédiaire du text proféré, respiré et incarné que par l'intermédiaire de l'architecure et de la scenographie."

31 "Enter Purcel on the top, thrusting out a Torch burning."
} 
novas justificativas para os textos que, em Shakespeare, descrevem ou sugerem os ambientes; não apenas as incontáveis interpretações, que não cessam de surgir, mas também a possibilidade da descoberta de alguma fonte legítima que fundamente novas abordagens.

Por outro lado, deve-se registrar outra importante relação entre o teatro de Shakespeare e a luz artificial, sua passagem pelo Blackfriars. Tratava-se de um antigo monastério dominicano que foi usado como teatro privado, inicialmente por Richard Farrant, abrigando em princípio o coro de rapazes da Windsor Chapel e, eventualmente, apresentando espetáculos para entretenimento da rainha, a partir de 1576. Vinte anos mais tarde, James Burbage comprou o antigo refeitório do monastério e fez alterações que parecem ter resultado em muita dificuldade e alto custo. Em seguida, Burbage cedeu o espaço para uma companhia de crianças, dirigida por Nathanael Giles e Henry Evans. Um registro no diário de Friedrich Gerschow, viajante alemão que assistiu um dos espetáculos da companhia, diz: "[...] Esses rapazes têm seus instrutores especiais em todas as artes, [...] de modo que eles podem aprender boas maneiras da corte, e são obrigados a apresentar uma comédia toda semana [...] tudo isso com luz [artificial] muito impressionante". (NAGLER, 1964, p. 94, tradução nossa)

Em 1608, de novembro a março de 1609, a companhia King's Men, de Burbage - da qual Shakespeare era integrante, ocupou o Blackfriars, em lugar dos jovens comediantes de Evans. Algumas dentre as últimas peças de Shakespeare teriam sido escritas para o Blackfriars. Desafortunadamente, não há qualquer registro de procedimentos específicos para a incorporação da luz artificial à cena shakespeariana. Pode-se argumentar que a solidificação da sua prática teatral, realizada a céu aberto, o tenha levado a desconsiderar a possibilidade de incorporação da luz, como um movimento estético, que produzisse resultados particulares em sua dramaturgia. Levando-se em conta o que diz Nagler, ao mencionar Gerald Eades Bentley (1901-1994), The Tempest está entre as peças certamente escritas para serem originalmente montadas no Blackfriars.

É difícil, contudo, discutir com segurança a relação do espetáculo com a luz artificial, devido à inexistência de qualquer documentação, como já se ponderou, exceto o próprio texto. Além da peça citada, também Cymbeline e The Winter's Tale, como textos do último período da obra de Shakespeare, teriam sido escritos para serem montados no Blackfriars. A ausência de fontes - como os prompt books, que seriam valiosíssimos - deixa enorme dificuldade para os interessados na visualidade. É inevitável lembrar que a Inglaterra passava por um grave momento polí- 
tico, com a sucessão da Rainha Elizabeth e a ascensão de James I ao trono. Gary Schmidgall (1981) comenta a tendência literária que se afigura na transição de poder, acentuando a necessidade de atenção para o movimento:

Se tivéssemos que entender o dilema que Shakespeare encarou à medida que o estilo teatral jacobino mudava: em poucos anos, ele teve que decidir se aplicava seu talento ao [teatro] público ou ao [teatro] da corte - ou através de alguma alquimia dramática, em ambos. ${ }^{32}$ (SCHMIDGALL, 1981, p. 27, tradução nossa)

\section{SHAKESPEARE À LUZ DA TEMPESTADE}

Outro momento na obra de Shakespeare de grande relevância para a presente abordagem é sua peça, já citada, A tempestade (The tempest). A rubrica de abertura dessa obra, no Primeiro Fólio, alarga a fundamentação para a presente argumentação: "Ato I, Cena I |A bordo de um navio no mar: ouve-se ruído de tempestade, | trovões e raios. | (Entram um Mestre e um Contra-Mestre)". (SHAKESPEARE, 1999, p. 13) Ao ruído que traz a atenção da plateia, logo se junta o desenrolar da ação, provocando o imaginário na direção de imagens da tempestade. Uma múltipla tempestade que se relaciona com a experiência de cada um e a disponibilidade de atuar como cúmplice, criando sua própria visualidade da tormenta. Mais uma vez, como em Hamlet, entram duas personagens. Ao dirigir-se ao segundo, o Capitão lançará a primeira pincelada no quadro imaginário, como num cinema mental:

MESTRE. Contra-mestre!

CONTRAMESTRE. Olá, Mestre: tudo em ordem?

MESTRE. Tudo. Diga aos marinheiros que se não trabalharem rápido, encalhamos: mexam-se, mexam-se!

(SHAKESPEARE, 1999, p. 13)

E, adiante, o Contramestre menciona pela primeira vez a tormenta ou tempestade [storme]. Shakespeare investe decisivamente nas imagens sonoras, quando relaciona a impaciência do mar e os rugidos da natureza, na fala do Contramestre, linha 24.

32 "If we are to are to understand the dilemma Shakespeare faced as Jacobean theatrical fashion diverged: in a few years he would have to decide whether to employ his talent in public or in private, courtly service - or by some special dramatic alchemy, in both." 
GONZALO. Não, meu amigo; tenha paciência.

CONTRAMESTRE. Quando o mar tiver. Fora! O que é um rei para essas ondas? Pros camarotes! Silêncio! Não nos atrapalhem.

GONZALO. Muito bem; mas lembrem-se de quem têm a bordo. CONTRAMESTRE. Ninguém de quem eu goste mais do que de mim mesmo. O senhor é conselheiro; se puder calar os elementos e trazer paz ao presente, nós não tocamos mais numa só corda; use a sua autoridade. Mas se não puder, dê graças por ainda estar vivo e vá se preparar no camarote para os riscos do que pode acontecer numa hora dessas. Ânimo, meus corações! Já falei, saiam do caminho (Sai). ${ }^{33}$

(SHAKESPEARE, 1999, p. 14)

Observe-se que o termo "ondas" que aparece na tradução ao final da linha 24, originalmente é escrito roa-rers, por Shakespeare, que se refere a rugidos. Note-se que ele aposta nas imagens sonoras, já elaboradas na abertura do espetáculo, enquanto a tradução parece sentir a necessidade da imagem mental do mar. Deve-se registrar que o autor já deu uma reserva para a memória do público, iniciando a ação cênica com ruídos assustadores de tempestade, sugerindo instrumentos para efeitos especiais, de uso provavelmente comum. Shakespeare investe na imagem mental de um mar "impaciente". (SHAKESPEARE, 1999, p. 14) Nem mesmo a presença de um Rei pode acalmar os elementos. A ação da qual as falas tomam parte impele o espectador a se misturar com a atmosfera de ameaça e perigo.

Num momento assim, nem mesmo as mediações do conselheiro de um soberano têm qualquer poder. Mais vale a voz e o comando do Contramestre e a perícia dos marinheiros diante da necessidade de combater os ruidosos elementos. Do espetáculo oferecido pela King's Men no Blackfriars, sob uma luz artificial, cujas características e detalhes técnicos são desconhecidos, restariam apenas especulações sobre o que se conhece da tecnologia daquele momento, levando a imaginar a aplicação de velas (lustres), lamparinas a óleo e tochas; incluindo-se como ingredientes a fumaça e o odor desagradável. A tempestade também é construída na atitude das personagens e consequentes conflitos, interagindo com tais condições.

33 "Gonz. Nay, good be patient. | Botes.When the Sea is: hence, what cares these roa-rers | for the name of King? to Cabine; silence: trouble | vs not. | Gon. Good, yet remember whom thou hast aboord. | Botes. None that I more | loue then my selfe. You are | a Counsellor, if you can command these Elements to silence, | and worke the peace of the present, wee will not | hand a rope more, vse your authoritie: If you cannot, | giue thankes you haue liu'd so long, and make your | selfe readie in your Cabine for the mischance of the | houre, if it so hap. Cheerely good hearts: out of our | way I say." 
A cena seguinte traz uma revelação contundente: se uma tempestade já representa todas as ameaças e riscos, como a que se presenciou na cena de abertura, fazendo sucumbir uma embarcação, determinando o destino dos seus ocupantes, trata-se de uma tempestade particular, construída deliberadamente pelo Rei Próspero, numa atitude de vingança. É uma tempestade controlada por alguém com poderes especiais e, portanto, repleta dos traços da magia. Shakespeare instala um universo fantástico para a ação, que inclui um homem invisível e danças de espíritos. Aquele que pretenda, portanto, construir tais imagens na cena, tem o privilégio de contar com significativas provocações.

Mencionar a tempestade na obra de Shakespeare aponta, no caso particular da abordagem em curso, para Rei Lear (The tragedy of king Lear). Tratando daquilo que define como o estilo em um projeto de luz para a cena, Linda Essig invoca o mesmo texto, asseverando:

[...] se alguém está projetando Rei Lear, a iluminação não precisa instalar uma tempestade numa charneca com aparência de real. A linguagem de Shakespeare define a realidade de uma tempestade naquele contexto, dando liberdade à luz para criar uma tempestade metafórica, uma tempestade com qualidade teatral, ao invés de buscar a realidade. ${ }^{34}$ (ESSIG, 1997, p. 6, tradução nossa)

Para o designer que atua, hoje, num espaço teatral instalado no interior de uma edificação coberta, com bloqueio para a luz natural e acesso à diversificada e sempre renovada tecnologia, pode ser um desafio construir um projeto, considerando a observação de Essig; tais condições permitem alcançar grande abrangência de resultados, até mesmo a atmosfera realista, mesmo que não seja exatamente uma tarefa fácil criá-la em cena; na contemporaneidade, afinal, o designer pode correr o risco de afogar a ação cênica num volume exacerbado de "efeitos", atendendo ao apelo do senso comum instalado, inclusive, em certos ambientes teatrais.

Em Rei Lear, Shakespeare procura garantir que a atmosfera de uma tempestade particular, como afirma em outros termos Linda Essig, esteja presente - ou seja, construída - no jogo entre o drama e o imaginário do público. Pode-se apreender tal expectativa como uma mixagem de risco, compreensão e confiança nas convenções do teatro de seu tempo. Quantos já testemunharam uma tempestade de tal magnitude e sobreviveram para reativá-la na memória? Shakespeare alia

34 "[...] if one is designing King Lear, the lighting need not necessarily set up a real-looking storm on a heath. Shakespeare's language defines the reality of a storm contextually, freeing the lighting to function to create a metaphorical storm, a storm that functions dramatically rather than realistically." 
às instâncias cognitivas da linguagem, os traços estéticos da sua poesia e do seu teatro, apostando na capacidade perceptiva e imaginativa do ser humano para engendrar uma parceria na construção de atmosferas.

A cena III do Ato 3 é sempre trazida à discussão, já que ali se desenvolve a tempestade enfrentada por Lear. É indispensável, contudo, voltar a momentos anteriores, do Ato 1, onde Shakespeare inicia a construção progressiva da atmosfera que a ele interessa. O desequilíbrio que provocará a ira dos elementos naturais manifestada no Ato 3 começa a ser delineado já na tormenta metafórica, que se instala na mente de algumas personagens, com ênfase em Lear. A incapacidade de julgamento é revelada pelo Rei que aceita o discurso superficial das filhas mais velhas, como em Goneril: "[...] Senhor, pro meu amor faltam palavras; [...]" (SHAKESPEARE, 1998, p. 16), 35 e em Regan: “[...] Pois minha única felicidade | Reside em vosso amor" (SHAKESPEARE, 1998, p. 17), ${ }^{36}$ desconsidera a franqueza expressa por Cordelia: "Infeliz, não sou capaz de botar | Na boca o coração. A vós eu amo | Nem mais nem menos do que é meu dever". ${ }^{37}$ (SHAKESPEARE, 1998, p. 17-18) Tal incapacidade culminará com reações e sentimentos tempestuosos do soberano. Começando, por deserdar a filha mais jovem, momento no qual Shakespeare invoca, de modo contundente, as relações com a natureza:

Que seja! E co'a verdade pra seu dote!

Pois pelo brilho sagrado do sol,

Os mistérios de Hecate e da noite.

Pelo curso dos astros aos quais nós

Devemos o existir e a finitude,

Aqui renego o cuidado paterno,

Todo o poder da consanguinidade,

E como estranha a mim e ao meu amor

A tenho sempre [...]. ${ }^{38}$

(SHAKESPEARE, 1998, p. 18-19)

35 "Sir, I loue you more than word can weild y matter; [...]."

36 "And finde I am alone felicitate In your deere Highnesse loue."

37 "Vnhappie that I am, I cannot heaue | My heart into my mouth: I loue your Maiesty | According to my bond, no more nor lesse."

38 "Let it be so, thy truth then be thy dowre: | For by the sacred radience of the Sunne, | The misteries of Heccat and the night: | By all the operation of the Orbes, | From whom we do exist, and cease to be | Heere I disclaime all my Paternall care, | Propinquity and property of blood, | And as a stranger to my heart and me, | Hold thee from this for euer. [...]." 
Clamando pelo Sol e envolvendo as propriedades misteriosas da noite personificada por Hecate ${ }^{39}$ - Lear invoca todo o universo para deserdar e destituir Cordelia da qualidade de filha. Na sua mais grave crise, Lear escala o mais alto dos cumes, em busca da mais poderosa luz, o Sol, e se lança no mais profundo abismo para encontrar as trevas, a noite. Shakespeare confiava em tal relação para expressar a natureza humana. E mais importante: para além do julgamento superficial e ocioso que se recosta na adjetivação de maniqueísta, ele provoca a percepção das incontáveis relações luz-sombra-penumbra, não necessariamente em tal ordenamento. No espaço entre o brilho reluzente de Apollo ${ }^{40}$ e na tenebrosa profundidade de Hecate, estão corporificados os desejos humanos que podem gerar múltiplos acentos, intervalos, espessuras, traços, temas, manchas.

Vale lembrar que a figura de Hecate aparece também em Sonho de uma noite de verão (A midsummer night's dream): "Nós, duendes, que corremos | Com o trio da maldição, | E o que do Sol esquecemos | No sonho da escuridão, | Vamos brincar". ${ }^{41}$ (SHAKESPEARE, 1995, p. 192) A tradução apresentada intenta aproximar o leitor, ao substituir a deusa (como aparece no original) por "maldição", facilitando a apreensão, exigindo menor esforço. Para o iluminador de um espetáculo que aceite o texto como provocação, no entanto, o direito de ignorar a presença de Hecate na escrita original pode ser bastante relativo: ele pode empreender trocas entre traços particulares da dramaturgia e o seu imaginário, considerando a natureza da divindade, abrindo portas para o espetáculo.

A sua presença pode favorecer múltiplas apreensões, uma vez que ela tem o privilégio de diversificados domínios, nos quais se incluem o dom da eloquência nas assembleias, a vitória nas batalhas, a prosperidade material, a abundância, a magia, os encantamentos e o mundo das sombras.

Destaque-se em seguida a fala de Goneril, quando ela relaciona ação cênica e tempo: "Irmã, não é pouco o que tenho a dizer, que afeta a nós | ambas. Creio que nosso pai parte hoje daqui". (SHAKESPEARE, 1998, p. 27) ${ }^{42}$ Por outro lado, o poeta investe também numa cumplicidade com os elementos da natureza, para construir a metafórica atmosfera da tempestade. As relações humanidade-natureza, invocadas por Lear na cena 1 do Ato 1, avolumam-se na cena seguinte, aparecendo

\footnotetext{
39 Hekátē, do grego Eká $\eta$, divindade da luz e das trevas da magia noturna.

40 Em grego A $\pi$ ó $\lambda \lambda \omega v$ (Apóllōn) ou A $\pi \varepsilon ́ \lambda \lambda \omega v$ (Apellōn). Não somente Deus da Poesia, mas também chamado Phoebus Apollo ou Apolo, o brilho reluzente.

41 "[...] And we Fairies, that do runne, | By the triple Hecates teame, | From the presence of the Sunne, | Following darkenesse like a dreame, | Now are frollicke."

42 "Sister, it is not little I haue to say, | of what most neerely appertaines to vs both, | I thinke our Father will hence to night."
} 
já na abertura, com Edmund: "Tu, Natureza, és minha deusa”. (SHAKESPEARE, 1998, p. 28) ${ }^{43}$ Adiante, Gloucester - pai de Edmundo - exclama:

Esses recentes eclipses do Sol e da Lua não nos prenunciam nada de bom. Embora o conhecimento da natureza possa dar estas ou aquelas causas racionais, mesmo assim a natureza se vê açoitada pelas consequências: o amo(r) esfria, os amigos brigam, os irmãos se separam. Nas cidades, os motins; nos países, discórdias; nos palácios, traições; e quebradas as ligações entre o filho e o pai. Esse meu vilão se enquadra nessas previsões: é um filho contra o pai; o Rei se afasta do caminho da natureza: é um pai contra a filha. Já vivemos o melhor do nosso tempo [...]. ${ }^{44}$ (SHAKESPEARE, 1998, p. 33)

A natureza lança maus presságios sobre a condição humana e, simultaneamente, é atingida pelos eventos produzidos pela humanidade. Edmund, o filho bastardo de Gloucester, parece discordar de seu pai, ao criticar a atitude de responsabilizar os elementos naturais pelas desventuras e feitos negativos do ser humano, numa postura renascentista, que desconstrói crenças difundidas pelo pensamento medieval:

[...] quando vai mal nossa fortuna - muitas vezes como resultado de nosso próprio comportamento - culpamos pelos nossos desastres o Sol, a Lua e as estrelas, como se fôssemos vilões por necessidade, tolos por compulsão celeste, safados ladrões e traidores por predominância das esferas, bêbados, mentirosos e adúlteros por obediência forçada a influências planetárias. ${ }^{45}$ (SHAKESPEARE, 1998, p. 34)

Ainda que Shakespeare aponte questionamentos para tal crença, o encaminhamento dos fatos, a ação dramática por ele construída revela no pai Lear, traído pelas próprias filhas, uma ira que sugere insanidade - quando menos temporária - como uma manifestação da natureza. Se ao final da tragédia, a conjuntura

43 "Thou Nature, art my Goddesse."

44 "These late Eclipses in the Sun and Moone por- | tend no good to vs: though the wisedome of Nature can | reason it thus, and thus, yet Nature finds it selfe scourg'd | by the sequent effects. Loue cooles, friendship falls off, | Brothers diuide. In Cities, mutinies; in Countries, dis- | cord; in Pallaces, Treason; and the Bond crack'd, 'twixt | Sonne and Father. This villaine of mine comes vnder the | prediction; there's Son against Father, the King fals from | byas of Nature, there's Father against Childe. We haue | seene the best of our time [...]."

45 "[...] when we are sicke in fortune, often the surfets of our own | behauiour, we make guilty of our disasters, the Sun, the | Moone, and Starres, as if we were villaines on necessitie, | Fooles by heauenly compulsion, Knaues, Theeues, and | Treachers by Sphericall predominance. Drunkards, Ly- | ars, and Adulterers by an inforc'd obedience of Planatary | influence." 
política alcança sua mais grave crise, culminando no combate inglês contra forças francesas, o poeta revela momentos contundentes, já no ato três, cena três, nos quais a interação entre o ser humano e os elementos naturais revela a tempestade, invocada na poesia. Mesmo que se possa sublinhar a sequência final, onde se precipitam os eventos decisivos para o conflito - as mortes dos principais envolvidos na ação cênica -, o Ato 3 revela um momento no qual humanidade e natureza se unem numa simbiose que alcança ápice importante na presente abordagem. Para chegar a tal ponto, Shakespeare pontua estrategicamente, como um compositor que desenvolve variações sobre um mesmo tema.

Se a tormenta será materializada pelas intempéries, ela já parece presente na alma das personagens. Acentue-se o agravante das relações entre uma cena exposta à luz natural e o desejo do poeta de descortinar uma tormenta devastadora, na qual os elementos naturais interagem, provocando um desequilíbrio descomunal. Já nos primeiros momentos da cena I do Ato 2, os eventos revelam sentimentos tempestuosos entranhados nas almas, como eco e reflexo da ira instalada no coração do Rei Lear. Shakespeare já introduz, na primeira cena do Ato 2, a construção de um ambiente que abriga as nefastas ações de Edmund, ao acusar seu meio-irmão Edgar de traição a Gloucester, pai de ambos.

E o ambiente é mergulhado na atmosfera noturna: "E o Senhor também! Estive com seu pai e dei-lhe a | notícia de que o Duque de Cornwal e Regan, sua du- | quesa, estarão esta noite aqui com ele". ${ }^{66}$ (SHAKESPEARE, 1998, p. 6o)

Pode-se até argumentar que seria difícil precisar certos intervalos temporais entre uma e outra cena. A atmosfera, contudo, é perseguida de modo quasi-musical. O próprio filho bastardo menciona a noite, em três momentos da primeira parte da ação, na linha 943, além das linhas 952 e 954, no Primeiro Fólio:

Meu pai vela. Senhor, fuja daqui.

Um espião já disse onde se esconde;

A vantagem de agora é ser de noite.

Acaso andou falando de Cornwall?

Trazendo Regan. Não andou falando

A favor dele contra o Duque de Albany?

Pense bem. ${ }^{47}$ (SHAKESPEARE, 1998, p. 61)

46 "Cur. And your Sir, I haue bin | With your Father, and giuen him notice | That the Duke of Cornwall, and Regan his Duchesse | Will be here with him this night."

47 "My Father watches: O Sir, fly this place, | Intelligence is giuen where you are hid; | You haue now the good aduantage of the night, | Haue you not spoken 'gainst the Duke of Cornewall? | Hee's comming hither, now i'th' night, i'th' haste, | And Regan with him, haue you nothing said." 
À noite é associada a qualidade de refúgio, na qual o negativo se afirma, sob a proteção das trevas. Retirando do outro o poder da visão, ele o mergulha na incapacidade perceptiva, na ignorância. Após simular um combate com o irmão, ouvindo o pai que se aproxima acompanhado de servos, Edmund constrói tal qualidade, exclamando:

Estou ouvindo o meu pai vir. Perdão,

Mas tenho de fingir que tiro a espada.

Vamos, defenda-te! Lute direito!

Alto! Entregue-se a meu pai! Socorro! Luzes!

(à parte) Fuja irmão! Alto Tochas! Tochas!

(à parte) Boa viagem! ${ }^{48}$

(SHAKESPEARE, 1998, p. 61-62)

Depois de sugerir ao irmão que fuja protegido pela escuridão, ele usa as trevas para ferir a si mesmo, simulando uma ação fratricida e, exige urgência aos servos, que se aproximam transportando tochas. Que iluminem a trilha da fuga de Edgar! Sua descrição do embate é um movimento eficiente para indicar o ambiente, a atmosfera, assim como traços do seu caráter:

(Entram Gloucester e criados, com tochas.)

Gloucester - Onde está o vilão?

Edmund - Estava aqui no escuro, a espada em punho.

Com invocações do mal, chamava a Lua

Para apoiá-lo.

Gloucester - Mas onde está ele?

Edmund - Veja, eu sangro.

Gloucester - Onde está o vilão, Edmund?

Edmund - fugiu por cá, quando não conseguiu...

Gloucester - Atrás dele! (Saem alguns criados). ${ }^{49}$

(SHAKESPEARE, 1998, p. 62)

48 "I heare my Father comming, pardon me: | In cunning, I must draw my Sword vpon you: | Draw, seeme to defend your selfe, | Now quit you well. | Yeeld, come before my Father, light hoa, here, | Fly Brother, Torches, Torches, so farewell."

49 "Enter Gloster, and Seruants with Torches. | Glo. Now Edmund, where's the villaine? | Bast. Here | stood he in the dark, his sharpe Sword out, | Mumbling of wicked charmes, coniuring the Moone | To stand auspicious Mistris. Glo. But where is he? | Bast. Looke Sir, I bleed. | Glo. Where is the villaine, Edmund? | Bast. Fled this way Sir, when by no meanes he could. | Glo. Pursue him, ho: go after." 
Com a saída dos servos, levando consigo as tochas e mergulhando a ação em profunda penumbra, Edmund, o filho bastardo, concretiza seu plano de transformar Edgar num vilão; ele insinua atos de bruxaria que invocam a lua na escuridão, além de inventar um suposto plano de Edgar para assassinar o próprio pai. O mesmo Edmund, racional e descrente das influências da natureza nas ações humanas, confessa haver usado o poder divino como argumento para dissuadir seu irmão, fazendo-o abandonar a ideia de assassinato do próprio pai:

$$
\begin{aligned}
& \text { Eu lhe disse que os deuses da vingança } \\
& \text { Vibram seus trovões nos parricidas; } \\
& \text { Lembrei-lhe os laços fortes e variados } \\
& \text { Que ligam pai e filho [...]. } .^{50} \\
& \text { (SHAKESPEARE, 1998, p. 63) }
\end{aligned}
$$

E Shakespeare conclui, reafirmando a noite no diálogo entre Cornwall, Regan e Gloucester, cena 1, Ato 2: “Cornwall - Não sabe por que viemos visitá-lo... | Regan - Fora de hora, em meio à noite escura [...]".51 (SHAKESPEARE, 1998, p. 66)

Depois da cordial recepção de Gloucester, Cornwall e Regan saem acompanhados do anfitrião. É uma nova ação para a qual o autor estabelece um ataque preciso. A primeira fala de Steward, na cena que se segue, é decisiva para a imagem mental criada em cada um que ocupa a plateia: "Bom dia, amigo. És aqui da casa?". ${ }^{2}$ (SHAKESPEARE, 1998, p. 67) Pode-se dizer que a transição noite-dia é instalada, ainda que ao final do encontro Kent lance a estranha ameaça: "Puxa a espada, calhorda! Pois mesmo | que seja noite, a Lua está brilhando. Vou fazer uma papa | de ti, ao luar, seu filho".53 (SHAKESPEARE, 1998, p. 69)

Ainda que a noite persista por alguns momentos, portanto, mesmo sem quaisquer menções a artefatos de luz artificial, Kent - mensageiro de Lear - encarrega-se de esclarecer que é perfeitamente possível atacar seu oponente, já que iluminado pela luz da Lua. Trata-se de um luar observado de modo muito especial, distanciado do lugar-comum romântico. Um luar frio, agressivo, que perpassa a práxis cênica em momentos muito especiais, quando tal qualidade atmosférica é exigida pela ação.

\footnotetext{
50 "But that I told him the reuenging Gods, |'Gainst Paricides did all the thunder bend, | Spoke with how manifold, and strong aBond | The Child was bound to'th' Father."

51 "Cor. You know not why we came to visit you? | Reg. Thus out of season, thredding darke ey'd night."

52 "Good dawning to thee Friend, art of this house?"

53 "Draw you rogue, | for though it be night, yet the Moone shines, Ile make a | sop oth' Moonshine of you [...]."
} 
Essa estratégia atua como um instrumento eficaz aplicado pelo autor para instalar a ação. Kent logo será punido pelas suas atitudes. Os nobres de Cornwall encarregam-se de proferir a sentença: "Cornwall - Tragam o tronco! Pela minha honra | Ficará nele até o meio-dia. | Regan - Meio-dia? Até a noite e a noite toda". ${ }^{54}$ (SHAKESPEARE, 1998, p. 74)

A atmosfera noturna permanece como um abrigo para a cena até o último momento, quando Kent, preso ao artefato de tortura, diz: “[...] Fortuna, boa noite; sorri e gira tua roda!". ${ }^{5}$ (SHAKESPEARE, 1998, p. 76) Por outro lado, o momento seguinte parece prescindir de tempo objetivo: Edgar, transformado no mendigo "lunático" Tom, para escapar da caçada na qual desempenha o papel do animal encurralado, prepara-se para enfrentar as intempéries corporificadas no texto: "[...] Os ventos e perseguições do céu". ${ }^{6}$ (SHAKESPEARE, 1998) Não bastasse o infortúnio de ser considerado traidor pelo próprio pai, ele está ameaçado do castigo imposto pela natureza. E, mais importante do que o tempo objetivo, do que dia e hora, é que sua vida será invadida pelos ventos e pela ira dos céus; o que pode transformar um dia de sol brilhante numa noite sem fundo, como um eclipse. Ainda que o Globo pudesse apresentar um relativo conforto no outono londrino - se comparado ao rigor do inverno - Shakespeare acentuará a atmosfera da ação dramática na qual a dureza fria e afiada dos eventos não parece perto de se extinguir.

A tempestade de ira que habita o Lear traído pelas filhas revela seus traços no caráter de Edmund e também no seu pai Gloucester, que ordena a perseguição do seu filho legítimo. Até alcançar o Ato 3, o espectador terá sua imaginação sucessivamente provocada, aproximando-o da tempestade. Na cena 4 do ato 2 - se o monólogo de Edgar for considerado como cena 3, como em versões modernas - o Bobo reflete: "O inverno ainda não acabou se os gansos selvagens | Voam nessa direção”. (SHAKESPEARE, 1998) E na mesma cena aparece pela primeira vez o verbo chover, seguido do vocábulo tempestade (storme), quando o Bobo diz:

\footnotetext{
54 "Corn. Fetch forth the Stocks; | As I haue life and Honour, there shall he sit till Noone. | Reg. Till noone? till night my Lord, and all night too."

55 Do original: “[...] Fortune goodnight, | Smile once more, turne thy wheele”. Preferi, neste caso particular, apresentar outra possibilidade de tradução, para acentuar a imagem da roda da fortuna, já conhecida desde a Idade Média, comum àquela época e incluída pelo próprio Shakespeare em outros textos como As you like It (1.2.30) e Henry V (3.3.27), para dar dois exemplos.

56 "The Windes, and persecutions of the skie."
} 
[...] Quem não serve mas explora,

Ou só serve pra constar,

Quando chove vai-se embora;

Tempestade, nem falar [...]. ${ }^{57}$

(SHAKESPEARE, 1998, p. 81)

Além da chuva e dos ventos que já foram lançados por Shakespeare em momentos anteriores, aparecem também raios, relâmpagos e trovões - como na mencionada fala de Edmund (SHAKESPEARE, 1998, p. 63) -, antecipando a tempestade que se instalará no Ato 3. Lear, por seu turno, depois de ter o seu pedido de abrigo para os seus seguidores negado pelas filhas, vocifera para Goneril:

Eu peço, filha, que não me enlouqueça:

Não hei de importuná-la, filha; adeus,

Separados, não mais nós nos veremos;

Porém és minha carne, sangue, filha,

Ou és doença que eu tenho na carne

E devo dizer minha: uma bolha

Uma chaga de peste, ou um furúnculo

Do meu sangue corrupto. Não, não falo:

Eu não chamo a vergonha que virá,

Eu não invoco quem manda o trovão,

Nem a entrego ao tribunal de Júpiter..$^{58}$

(SHAKESPEARE, 1998, p. 88)

Lear envolve o julgamento de Júpiter, anunciando a reação dos céus. Os termos storme e tempest - voltarão a aparecer apenas na sequência final da cena 4 do segundo ato e, importante, pela primeira vez numa rubrica. O autor não apenas usa o segundo termo, de origem latina, e que se refere a uma atuação violenta dos ventos, mas também inclui o primeiro, cuja raiz germânica indica: "Um violento distúrbio climático com ventos fortes e frequentemente chuva, trovão, raios ou neve". ${ }^{59}$ (OXFORD ADVANCED LEARNER'S DICTIONARY, 2010, tradução nossa)

57 "That Sir, which serues and seekes for gaine, | And followes but for forme; | Will packe, when it begins to raine, | And leaue thee in the storme, [...]."

58 "I prythee Daughter do not make me mad, | I will not trouble thee my Child; farewell: | Wee'I no more meete, no more see one another. | But yet thou art my flesh, my blood, my Daughter, | Or rather a disease that's in my flesh, | Which I must needs call mine. Thou art a Byle, | A plague sore, or imbossed Carbuncle | In my corrupted blood. But Ile not chide thee, | Let shame come when it will, I do not call it, | I do not bid the Thunder-bearer shoote, | Nor tell tales of thee to high-iudging loue, [...]."

59 Storm 1. very bad weather with strong winds and rain, and often thunder and lightning. 
Tal indicação é crucial para a compreensão da qualidade do texto de Shakespeare, como estágio do processo de elaboração da cena, independente do Promptbook. Considerando a importância do som no teatro elisabetano, pode-se inferir que a tempestade, a tormenta, cai de modo estrondoso sobre o público.

O poeta ataca a questão de frente. A imagem da tempestade se alarga, desde o pensamento de personagens enfurecidas, em particular o Rei, até os elementos da natureza. Toda a ira de Lear leva-o a praguejar desmedidamente:

$$
\begin{aligned}
& {[\ldots . .] \text { Que do céu caiam todas as vinganças }} \\
& \text { Sobre essa ingrata! Atinjam seus ossos, } \\
& \text { Ventos vis, pros aleijarem! }{ }^{60} \\
& {[\ldots . .} \\
& \text { Ágeis raios, lancem chamas que ceguem } \\
& \text { O desdém de seus olhos. Gases pútridos } \\
& \text { Contaminem ao Sol sua beleza [...]. } .^{61} \\
& \text { (SHAKESPEARE, 1998, p. 85-86) }
\end{aligned}
$$

Confirma-se a devastação da tempestade, já na alma do Rei ofendido pelas filhas e, ao contrário do que ele pede, logo os céus cairão sobre sua própria cabeça. Uma primeira vez, Cornwall é o mensageiro que se comunica com o espectador, para apontar a ameaça no horizonte: "Vamos entrar. Vai haver tempestade". ${ }^{62}$ (SHAKESPEARE, 1998, p. 91) Na mesma cena, Gloucester, que havia saído, seguindo Lear, retorna e informa: "O Rei está furioso". ${ }^{63}$ (SHAKESPEARE, 1998, p. 92) E, mais uma vez, agora na sua última intervenção do Ato 2, como um arauto que anuncia, como o coro que antecipa e prepara, como um narrador que introduz, Cornwall lança definitivamente a tempestade sobre o espectador, alertando Gloucester: "Tranque as portas; a noite 'stá violenta. | Regan diz bem: saiamos da tormenta". 64 (SHAKESPEARE, 1998, p. 93)

No Ato 3, fica estabelecido o estado de tormenta que se impõe sobre o ambiente, desde o início da ação. A primeira rubrica do ato define: "Uma charneca. Tempestade, com raios e trovões. Entram Kent e um Cavalheiro, que se

\footnotetext{
60 "All the stor'd Vengeances of Heauen, fall | On her ingratefull top: strike her yong bones | You taking Ayres, with Lamenesse."

61 "You nimble Lightnings, dart your blinding flames | Into her scornfull eyes: Infect her Beauty, | You Fen-suck'd Fogges, drawne by the powrfull Sunne, [...]."

62 "Let vs withdraw, 'twill be a Storme [...]."

63 "The King is in high rage."

64 "Shut vp your doores my Lord, 'tis a wil'd night, | My Regan counsels well: come out oth' storme."
} 
encontram". 65 (SHAKESPEARE, 1998, p. 94) Tal informação deve chegar ao espectador através de artefatos introduzidos na cena, principalmente efeitos sonoros, contribuindo para a apreensão da violência da tempestade. O diálogo se encarrega de desenvolver a espessura, a dimensão, a profundidade da imagem, já nas duas primeiras falas, dada a importância a ela conferida por Shakespeare. Tal imagem pode levar, ao espectador, a luz que habitou a imaginação do autor, nos momentos de criação da sua poesia:

Kent - Quem está aí, além do mau tempo?

Cavalheiro - Um que se vê inquieto como o tempo.

Kent - Eu o conheço. Aonde está o Rei?

Cavalheiro - Lutando com os inquietos elementos,

Pede ao vento que o mar afogue a terra,

Ou que subam as águas para os montes,

que tudo cesse ou mude. ${ }^{66}$

(SHAKESPEARE, 1998, p. 94)

As linhas citadas a seguir aparecem na continuação da réplica do Cavalheiro - no Primeiro quarto, de 1608, assim como nas versões modernas do Primeiro Fólio e mergulham a ação numa tormenta particular: além do frio, da chuva, dos ventos e trovões. O Cavalheiro tem aí função específica, contribuindo para instalar a tempestade e, além disso, não bastassem os rigores da intempérie, ele amplia a gravidade:

E as lufadas do vento, cego em fúria,

Pegam no ar as cãs que não respeitam.

Quer que o humano derrote a tempestade,

A ventania e a chuva que se batem.

Nesta noite, em que o urso esconde a prole. ${ }^{67}$

(SHAKESPEARE, 1998, p. 94-95)

Shakespeare radicaliza e revela uma terra coberta pelo véu das trevas noturnas e, antes do final da cena, Kent ainda exclama: "Maldita tormenta!"

\footnotetext{
65 "Storme still. Enter Kent, and a Gentleman, seuerally."

66 "Kent. Who's there besides foule weather? | Gen. One minded like the weather, most vnquietly. | Kent. I know you: Where's the King? | Gent. Contending with the fretfull Elements; | Bids the winde blow the Earth |into the Sea, | Or swell the curled Waters 'boue the Maine, | That things might change, or cease."

67 "[...] Which the impetuous blasts with eyles rage | Catch in their furie, and make nothing of, | Striues in his little world of man to outscorne, | The too and fro conflicting wind and raine, | This night wherin the cub-drawne Beare would couch."
}

68 "Fye on this Storme, [...]." 
(SHAKESPEARE, 1998, p. 96), confirmando-se a manifestação da tempestade, já na primeira rubrica da cena seguinte: "Continua a tempestade". ${ }^{9}$ (SHAKESPEARE, 1998, p. 97) Além de definir a presença da tempestade em seis momentos particulares da didascália - entre as linhas 1614 e 1615, 1655 e 1656, 1780 e 1781, 1843 e 1844, 1880 e 1881, 1942 e 1943 - já no início da cena 2, ela é sublinhada quando Lear esbraveja:

Soprai ventos; rasgai a face em fúria!

Vós, cataratas e tufões jorrai

E afogai campanário e catavento!

Fogos de enxofre, que sois arautos

Dos raios que bifurcam os carvalhos,

Queimai minha cabeça branca. E vós,

Trovão que tudo treme, golpeai

A espessura rotunda deste mundo!

Quebrai a forma e ora espalhai os germes

Da natureza que faz o homem ingrato! ${ }^{70}$

(SHAKESPEARE, 1998, p. 97)

Diante do perigo imposto pela tormenta, o Bobo reconhece e aconselha: "[...] esta noite não tem dó de sábio nem de bobo". ${ }^{71}$ (SHAKESPEARE, 1998, p. 97) E Lear continua:

Ribomba o ventre! Cospe fogo e chuva!

Não tenho filha vento, fogo ou chuva:

Não vos chamo de ingratos, elementos;

Não vos dei reinos nem chamei-vos filhas.

Não me deveis lealdade; jorrai, pois,

Vosso horrível prazer; pois sou vosso escravo,

Um velho pobre, fraco e desprezado. ${ }^{72}$

(SHAKESPEARE, 1998, p. 97)

\footnotetext{
69 D "Storme still."

70 "Blow windes, \& crack your cheeks; Rage, blow | You Cataracts, and Hyrricano's spout, | Till you haue drench'd our Steeples, drown the Cockes. | You Sulph'rous and Thought-executing Fires, | Vaunt-curriors of Oake-cleauing Thunder-bolts, | Sindge my white head. And thou all-shaking Thunder, | Strike flat the thicke Rotundity o'th' world, | Cracke Natures moulds, all germaines spill at once | That makes ingratefull Man."

71 "[...] heere's a night pitties | neither Wisemen, nor Fooles."

72 "Rumble thy belly full: spit Fire, spowt Raine: | Nor Raine, Winde, Thunder, Fire are my Daughters; | I taxe not you, you Elements with vnkindnesse. | I neuer gaue you Kingdome, call'd you Children; | You owe me no subscription. Then let fall | Your horrible pleasure. Heere I stand your Slaue, | A poore, infirme, weake, and dispis'd old man: [...]."
} 
Adiante, Kent apresenta a união da escuridão da noite com a dureza do clima hostil:

[...] Mesmo quem ama a noite,

Não ama as como esta: os céus irados

Assustam os que erram pelo escuro

E os prendem na toca. Em toda a vida,

Lençóis de fogo, roncos de trovão,

Gemidos e vento e chuva como estes

Não me lembro de ouvir; e é mais que o homem

Aguenta em medo e susto. ${ }^{73}$

(SHAKESPEARE, 1998, p. 98-99)

A literatura, e principalmente o cinema, aprendeu em fontes dessa qualidade a possibilidade de unir tais características. São incontáveis os filmes - o que até desgastou tal estratégia, transformando-a em rotina - nos quais a insanidade, a morte, o perigo e o temor são vinculados às trevas, à noite, assim como às tormentas.

Shakespeare insiste em traços da atmosfera no diálogo - com diversas menções específicas à chuva, ao vento, à tempestade, à tormenta e ao trovão, ao longo do Ato 3. Na cena 4, ainda Kent: "A tirania da noite é ruim demais para a natureza arcar. (Continua a tempestade)". (SHAKESPEARE, 1998, p. 110)

O Rei Lear, dada sua relevância para a fábula, sublinha reiteradas vezes a agressividade do clima e da atmosfera, como nos exemplos a seguir:

[...] Em noite assim

Trancar-me fora? À chuva eu resisto,

Em noite assim? [...]. (3.4.1797-1799) ${ }^{74}$

[...] Não consigo pensar nessa tormenta,

Nas coisas que mais me doem [...]. (3.4.1805-1806) $)^{75}$

[...] Desgraçados sem roupa, onde estiverem,

Enfrentando o açoite da tormenta,

Como podem assim, com flancos magros,

73 "[...] Things that loue night, | Loue not such nights as these: The wrathfull Skies | Gallow the very wanderers of the darke | And make them keepe their Caues: Since I was man, | such sheets of Fire, such bursts of horrid Thunder, | Such groanes of roaring Winde, and Raine, I neuer | Remember to haue heard. Mans Nature cannot carry | Th' affliction, nor the feare."

74 "[...] in such a night, | To shut me out? Poure on, I will endure: | In such a night as this? O Regan, Gonerill, [...]."

75 "[..] This tempest will not giue me leaue to ponder | On things would hurt me more, [...]." 
Os seus trapos rasgados defendê-los

De tempo assim? [...]. ${ }^{76}$

(SHAKESPEARE, 1998, p. 103-104)

No papel do louco Tom, Edgar confessa: "Deus abençoe seus cinco sentidos! Tom | está com frio! O do de, do, de, do, de. Deus o livre de | pés de vento, estrelas que explodem e mau olhado!".77 (SHAKESPEARE, 1998, p. 105)

Diante da tempestade que não cede, o Bobo resume a impotência do ser humano sob a ofensiva da natureza: "Essa noite fria está nos transformando todos em bobos e loucos”. (SHAKESPEARE, 1998, p. 106) ${ }^{78}$ Como um eco definitivo de tal assertiva, logo Lear arrancará as próprias roupas. E, no momento seguinte, surge Gloucester trazendo consigo uma tocha. Além de objetivamente materializar a noite, com a introdução do artefato, Shakespeare o faz no instante que deseja revelar na cena a sensatez corporificada em Gloucester, a racionalidade, a iluminação, anunciada pelo Bobo:

Por favor, Vovô, se acomode; a noite está muito ruim Para se nadar. Um foguinho assim nesse campo todo é como coração de devasso velho: uma fagulhazinha à toa, e todo o resto do corpo gelado. Olhem só: lá vem um foguinho que anda. ${ }^{79}$ (SHAKESPEARE, 1998, p. 107)

A lealdade e a razão são como que trazidas por Gloucester que - diante do próprio filho que perseguiu e abandonou - entra sustentando uma tocha e revela a contradição de parecer cego, incapaz de julgar a verdade e, simultaneamente, de manter sua devoção ao Rei:

$$
\begin{aligned}
& \text { Gloucester - O quê? Não tem sua Graça companhia melhor? } \\
& \text { Edgar - O Príncipe das Trevas é um cavalheiro; é chamado de } \\
& \text { Modo e Mahu. } \\
& \text { Gloucester - Nossa carne, senhor, ficou tão vil, }
\end{aligned}
$$

\footnotetext{
76 "[...] Poore naked wretches, where so ere you are | That bide the pelting of this pittilesse storme, | How shall your House-lesse heads, and vnfed sides, | Your lop'd, and window'd raggednesse defend you | From seasons such as these? [...]."

77 "[...] Blisse thy fiue Wits, Toms a cold. O do, de, do, de, do, de, | blisse thee from Whirle-Windes, Starre blasting, and ta- $\mid$ king, do poore Tom some charitie, whom the foule Fiend | vexes."

78 "This cold night will turne vs all to Fooles, and | Madmen."

79 "Enter Gloucester, with a Torch. | Prythee Nunckle be contented, 'tis a naughtie | night to swimme in. Now a little fire in a wilde Field, | were like an old Letchers heart, a small spark, all the rest | on's body, cold: Looke, heere comes a walking fire."
} 
Que odeia o que a gerou.

Edgar - O Pobre Tom está com frio.

Gloucester - Venha comigo. Meu dever não pode

Aceitar o que mandam suas filhas;

Embora ordenem que eu tranque as portas,

Mesmo assim eu ousei vir procurá-1o

E levá-lo onde há fogo e alimento [...]. ${ }^{80}$

(SHAKESPEARE, 1998, p. 109)

Encaminhando o final da cena 4, ele mesmo diz: "[...] pra falar a verdade, | a dor me ensandeceu. Que noite é esta [...]". ${ }^{81}$ (SHAKESPEARE, 1998, p. 110) Essa, então, é a tempestade com a qual a luz há que lidar na construção espetacular: uma tormenta que leva o homem à loucura. Ainda que determinado leitor possa transitar impunemente por tais momentos, ou que, para outro, eles não pareçam relevantes, sua presença é definitiva para a construção da visualidade da cena. A atmosfera é consistentemente sustentada, durante todo o ato, através de tais inserções, que asseguram sua efetivação no ambiente da ação.

Shakespeare, portanto, cultivava interesse menor pelo leitor "absoluto", quero dizer: aquele que se restringe aos caracteres impressos numa página. Seu esforço voltava-se para o público, na sua condição de agente integrante da práxis cênica, sendo por ela provocado, compartilhando com seu imaginário a corporificação da realidade teatral.

Ao concluir o presente capítulo, é importante registrar a particularidade que une Victor Hugo e Shakespeare, precisamente no que se refere à tempestade. Hugo era também pintor e incluiu as tormentas como tema de sua obra. Ainda que tal particularidade não seja objeto da abordagem em curso, vale o seu registro (Figura 8). Há, inclusive, propostas de conexões do surrealismo com sua pintura, o que indica atenção para a vertente plástica de sua produção artística. A obra de Hugo pode, portanto, ser associada às conexões entre a literatura e as artes visuais.

80 "Glou. What, hath your Grace no better company? | Edg. The Prince of Darkenesse is a Gentleman. Modo | he's call'd, and Mahu. | Glou. Our flesh and blood, my Lord, is growne so | vilde, that it doth hate what gets it. | Edg. Poore Tom's a cold. | Glou. Go in with me; my duty cannot suffer | T'obey in all your daughters hard commands: | Though their Iniunction be to barre my doores, | And let this Tyrannous night take hold vpon you, | Yet haue I ventured to come seeke you out, | And bring you where both fire, and food is ready. | Lear. First let me talke with this Philosopher, | What is the cause of Thunder?"

81 "[...] true to tell thee, | The greefe hath craz'd my wits. What a night's this?" 


\section{UM PRESUMÍVEL PONTO DE PARTIDA}

O capítulo que se inicia tentará estabelecer uma ligação entre Ésquilo e Shakespeare, observando o trato político e a familiaridade com o palco que os levava a escrever com o olhar projetado para a cena, encarada aqui como poderosa tentação para um dramaturgo. Assume-se, portanto, que a presença de tais feições no teatro de ambos indica certo grau de parentesco dramatúrgico entre eles.

A hipótese em questão leva à observação do teatro da Antiguidade, particularmente no século $V$ a.c., uma vez que lá podem ser identificados contatos particulares entre a luz e a práxis cênica. Torna-se necessário, então, refletir sobre as articulações operadas na cena, com o intuito de compreender sua qualidade visual, o que efetiva uma ação decisiva da luz, mesmo diante da 
situação limite na qual estava instalada a obra teatral da Antiguidade, ao produzir o seu espetáculo sob a luz do sol, reduzindo-se drasticamente as possibilidades de controle.

A investigação volta-se, então, para textos que provoquem discussões a respeito das mencionadas feições da luz nos espetáculos, observando a articulação de um raciocínio organizado acerca de suas contribuições. O primeiro documento destacado é a compilação de Ioulios Poludeukes ou Iullius Pollux (século II d.C.), Onomastikon, sem ignorar possíveis controvérsias, incluindo o questionamento da integridade ou validade do texto.

É preciso registrar que tais dúvidas e controvérsias devem ser estendidas a outras obras, sobre as quais existem incertezas, inclusive sobre sua autoria, seu estado incompleto e/ou fragmentado. Ainda assim, algumas dentre elas podem representar fontes únicas e valiosas para a pesquisa, em muitas áreas do conhecimento. No caso do texto de Pollux, há, segundo Nagler, claros indicadores de que ele trata do edifício teatral helenístico. Nagler (1952, p. 8, tradução nossa) salienta: "Não temos certeza se ele fala do teatro Helenístico ou daquele da era de Péricles, ainda que sua referência ao palco elevado indique, sem dúvida, que ele está discutindo as características do Teatro Helenístico".

De qualquer modo, mesmo considerando-se tal questionamento, é indispensável registrar a escassez de textos daquele momento e subsequentes, que discutam o edifício teatral grego, entre os anos 500 a.c. e o segundo século na presente era, momento no qual Pollux produziu seu trabalho, o que define sua importância para a pesquisa que apoia o presente trabalho. Mesmo que se possa questioná-lo, parece prudente observar sua consulta a relatos de estudiosos interessados no assunto, incluindo, segundo Nagler (1952), a Theatrical History escrita pelo Rei Juba II (52 a.c. - 23 d.C.). O Rei Juba II, da Numídia, escreveu diversos estudos, como corrobora Smith (1866, p. 636, tradução nossa):

Mas é por sua produção literária que Jubá [II] alcança mais importante reputação. Ele parece ter mantido, enquanto ocupava o trono, seus hábitos de estudo adquiridos desde jovem; o número e a variedade dos seus escritos podem ser comparados àqueles de muitos gramáticos reconhecidos. Seus trabalhos são frequentemente citados por Plínio (História Natural V. VIII. X. XII. XIII. \& C. passim), que lhe confere a mais alta deferência. [...] Ele parece ter trabalhado, sem dúvida, em quase todos

1 "We are not always sure whether he speaks of the theater of the Hellenistic or Periclean era, though his reference to the raised stage would indeed indicate that he is discussing the features of Hellenistic Theatre." 
os ramos da literatura: alguns dos seus trabalhos eram puramente voltados para a gramática ou para o estudo da antiguidade, enquanto que outros alcançam um vasto campo da história, geografia, história natural, e as belas artes. ${ }^{2}$

Smith (1866) menciona ainda um tratado do Rei Jubá II com, provavelmente, perto de duas dezenas de libri [capítulos], que tratam de todas as questões referentes ao teatro. Certos aspectos da descrição apresentada por Pollux constituem elementos importantes para o pensamento que se procura desenvolver no presente estágio deste trabalho. Em nenhum momento, o autor romano menciona a aplicação de luz artificial para promover visibilidade. A tradução inglesa, tendo como referência Nagler, traz apenas duas indicações de luz, em expressões muito particulares. A primeira delas é a expressão light-house ou farol, cujo posicionamento, função e aparência, não são explicitados e, mais tarde, encontra-se lightning-tower, "torre de relâmpago", descrita como um periaktos (elemento do dispositivo cenográfico usado no teatro grego antigo, de base triangular) com elevada dimensão vertical (Figura 9). Ambas as expressões trazem vestígios de ligações com a luz sem, contudo, considerar questões de iluminância (fluxo luminoso ou quantidade de luz que alcança ou chega a determinado ponto/objeto) do objeto descrito, pois o que se aplica à cena é uma representação pictórica, convencional, de um objeto encontrado no cotidiano, fora do espetáculo. Exclui-se, portanto, a expectativa da projeção de luz artificial sobre a cena, com a função específica de iluminar, de tornar visível. Por outro lado, os mencionados elementos da arquitetura cênica revelam, para o público, uma espécie de luz metafórica, simbólica, contribuindo para a visualidade do espetáculo.

Tal procedimento pode ser reconhecido como um aspecto muito particular que integrava as sofisticadas convenções do teatro na Grécia clássica, caracterizando as singularidades daquela práxis cênica. Nela se estabeleceu uma estreita relação entre a ação e o seu espaço, estimulando progressivas mudanças, ao longo dos séculos V e IV a.c., para efetivar um diálogo entre a poesia trágica e a cena para a qual ela foi concebida. Estava criado na civilização do Ocidente o termo teatro, assim como suas derivações, nomeando a atividade de natureza cênica. O entendimento moderno de teatro origina-se na palavra theatron ( $\theta \dot{\varepsilon} \alpha \tau \rho o v)$, do grego antigo.

\footnotetext{
2 "But it is to his literary works that Juba is indebted for his chief reputation. He appears to have retained on the throne the habits of study which he had acquired in early life; and in the number and variety of his writings he might vie with many professed grammarians. His works are continually cited by Pliny (H. N. v. viii. x. xii. xiii. e passim), who regards his authority with the utmost deference [...]. He appears indeed to have laboured in almost every branch of literature; some of his works being purely grammatical or antiquarian, while others comprise a wide field of history, geography, natural history, and the fine arts."
} 
Thea $(\theta \dot{\varepsilon} \mathrm{o} \mu \alpha 1)$, indicando ver, assistir, enquanto que theatron refere-se ao "lugar de onde se vê" ou "o que se vê", relacionando-se tanto ao espaço que acomodava os espectadores, quanto ao público em si, o conjunto de espectadores presentes ao evento. Theatron ( $\theta \dot{\varepsilon} \alpha \tau \rho o v)$ é um substantivo derivado da ação de ver, olhar, contemplar, observar $(\theta \dot{\varepsilon}$ o $\mu \alpha)$ ). A arte teatral, portanto, encontra-se visceralmente enraizada num contexto visual, repercutindo a energia que alimenta o planeta, incluindo a luz visível originada pelo Sol.

Do theatron grego, o espectador poderia vislumbrar tanto a orchestra (ou lugar onde se dança), como espaço de atuação do coro, assim como a skéné, cuja utilização revelava a hierarquia social apresentada na tragédia. A porta central estava reservada para o trânsito das personagens de maior distinção nas relações sociais instituídas, e era acompanhada de duas portas menores, uma a cada lado. Tratava-se de uma configuração presente em um estágio avançado, no espaço do teatro da Grécia da Antiguidade, e, para citar um exemplo, basta destacar a mudança radical da orchestra, na arquitetura teatral romana, em relação à sua forma no período grego (Figuras 10 e 11). No período em questão, aliás, foram acrescentadas mais duas portas, dispostas nas paredes laterais da skéné que, mantidas na Roma Antiga, reapareceriam no Teatro Olímpico, em Vicenza, no século XVI.

Acentue-se, por outro lado, o valioso trabalho de Marcus Vitruvius Pollio, arquiteto/engenheiro romano, autor de De Architectura (ca. 80/70 a.c. - 15 a.c., 90-20 a.c.), que trata da arquitetura teatral romana do século I, e repercutiria no Renascimento, para depois influenciar todo o teatro moderno.

Quando se usa o termo audiência, compreende-se a relação com auditorium, do latim audire (ouvir), numa alusão ao resgate da arquitetura romana antiga, provavelmente a partir dos estudos de Vitruvius. Em De Architectura Libri X, ele diz:

2. Como resultado desta planta com três centros os gregos têm uma orchestra mais espaçosa e uma 'scaena' disposta mais ao fundo, assim como um palco de menor profundidade. Eles o denominam o $\lambda$ oysiov [logeum, em grego; pulpitum, em latim] porque os atores trágicos e cômicos ocupavam o palco enquanto que outros artistas desempenhavam suas funções por toda a orchestra; a partir de então, eles receberam, em grego, os nomes distintos 'Cênicos' e 'Thimélicos'. O pé-direito do 'logeum' não deveria ser menor do que três metros nem maior do que três metros e sessenta centímetros. ${ }^{3}$ (VITRUVIUS, 1914, p. 151, tradução nossa)

3 'As a result of this plan with three centers, the Greeks have a roomier orchestra, and a 'scaena' set further back, as well as a stage of less depth. They call this the $\lambda$ orsiov for the reason that there the tragic and comic actors 
Isso demonstra como o teatro grego daquele tempo se instalou em um contexto no qual a percepção visual representava aspecto de grande relevância. Uma vez que a função do coro grego, como elemento essencial na convenção da poesia trágica desaparece no teatro romano, a orchestra se modifica para atender às suas novas proposições.

\section{A LUZ COMO DESTINO DA POESIA TRÁGICA}

Se o espetáculo era apresentado sob a luz do Sol e as imagens da cena exigiam atmosfera diversificada daquela expressa no tempo e no lugar onde o evento efetivamente ocorria, o artista criava soluções, para construir a visualidade que tornaria a cena possível. o Oxford companion to the theatre, organizado por Phillys Hartnoll, avança numa direção crucial, quando diz:

Para lidar com a história da luz para a cena é necessário distinguir entre a iluminação artificial do teatro e o uso de luzes no palco. [...] Em todos os períodos, velas, tochas, lamparinas e lampiões foram usados como adereços de cenografia para indicar noite ou escuridão. ${ }^{4}$ (HARTNOLL, 1957, p. 461)

Ele chama a atenção para a inexistência da necessidade de luz artificial, com o objetivo de garantir visibilidade à cena, tanto na Grécia quanto em Roma; até mesmo nos palcos móveis, ao ar livre, do teatro religioso medieval, assim como na cena elisabetana e jacobina, com os seus teatros sem cobertura. Como já foi dito antes, na referência a Shakespeare, é possível especular acerca da necessidade de luz artificial para corrigir a reduzida visibilidade num fim de tarde, durante o outono londrino. Ao trabalho em curso, contudo, importa retornar ao teatro grego clássico, com o intuito de observar suas prováveis relações com a luz, desde sua gênese na dramaturgia. Para tanto, vale introduzir a definição de Aristóteles (384 a.c. - 322 a.c.), para a tragédia. Diz ele: “A tragédia, então, é um processo de

perform on the stage, while other artists give their performances in the entire orchestra; hence, from this fact they are given in Greek the distinct names 'Scenic' and 'Thymelic'. The height of this 'logeum' ought to be not less than ten feet nor more than twelve."

4 "In dealing with the story of stage lighting, it is necessary to distinguish between the artificial illumination of the theatre and the use of lights on the stage. [...] In all periods candles, torches, lamps, and lanterns have been used as stage properties to indicate night and darkness." 
imitação [mimese] de uma ação [não de homens] [...]; encenada efetivamente por pessoas e não apresentada através de narração". 5 (ARISTÓTELES, 1983, p. 25)

Sublinhe-se a mimese de ações para apresentar uma compreensão da dramaturgia grega como obra concebida para se efetivar no espetáculo (opsis). A ponderação de Aristóteles delineia a contribuição da ação cênica, para a efetivação da tragédia: "Agora, antes de tudo, uma vez que eles elaboram a imitação através da ação, a ornamentação da sua aparência visual constitui alguma parte da tragédia; assim como a música e a expressão verbal, pois esses são os meios através dos quais eles efetivam a tragédia6 (ARISTÓTELES, 1983, p. 26)

Problematizando, pode-se considerar que, desde Aristóteles, a presença do espetáculo para a completude da tragédia, na sua condição de forma artística, sugere discussões. É possível argumentar que, para Aristóteles, a poesia trágica, a palavra, apresenta hegemonia em relação ao opsis, autossuficiência como obra de arte, capaz de efetivar a função catártica, dispensando a práxis cênica e concentrando o propósito de expressar as ideias na palavra em si, no processo da elocução. Na última citação acima, entretanto, cabe observar a particularidade do pensamento teatral ao qual Aristóteles se refere.

No século XXI, o espetáculo cênico (opsis), pode ser encarado de maneiras diversificadas, inclusive como um conjunto de fragmentos sem compromisso com a unidade. Naquilo que os gregos clássicos denominaram teatro, contudo, a poesia era elaborada para ser representada numa cena norteada pelos princípios da unidade, ela era gerada para se completar como forma artística na realização cênica, no espetáculo. No que se refere ao espetáculo trágico, portanto, também a música e a elocução representavam procedimentos pensados pelo poeta, e planejados para o momento da corporificação no espetáculo. A abordagem da cena, na sua condição de "corpo", aparece no trabalho de Patrice Pavis (2005, p. 139):

Poderia se esperar que o espaço, a ação e o tempo sejam os elementos mais tangíveis do espetáculo, mas a dificuldade consiste não em descrevê-los separadamente, mas em observar sua interação. Um não existe sem os outros dois, pois o espaço/tempo dramatúrgico, o trinômio espaço-tempo-ação, forma um só corpo atraindo para si, como que por imantação, o resto da representação. Ele se situa, além dis-

\footnotetext{
5 "Tragedy, then, is a process of imitating an action [...]; enacted by the persons themselves and not presented through narrative."

6 "Now first of all, since they perform the imitation through action (by acting it) the adornment of their visual appearance will perforce constitute some part of the making of tragedy; and song-composition and verbal expression also, for those are the media in which they perform the imitation."
} 
so, na intersecção do mundo concreto da cena (como materialidade) e da ficção imaginada como mundo possível. Constitui um mundo concreto e um mundo possível no qual se misturam todos os elementos visuais, sonoros e textuais da cena.

É importante esclarecer que a expressão cena-corpo é aqui compreendida de modo diferenciado daquela usada por Pavis (2005), quando ele menciona o trinômio espaço-tempo-ação. Os elementos que ele chama de "resto" da representação são compreendidos, no presente trabalho, como elementos constitutivos do corpo denominado acontecimento espetacular. Não há, portanto, um resto da representação que é por ela atraído, pensamento do qual Pavis se aproxima quando, mais tarde, no mesmo texto, aplica a expressão "os outros elementos materiais da representação". (PAVIS, 2005, p. 168-184) Qualquer aspecto da práxis cênica é parte orgânica de um corpo constituído de espaço-tempo-ação. Cada um desses aspectos tem funções diferenciadas, mas cada um deles se encontra organicamente incorporado à constituição da cena. Isso é característica fundamental do espetáculo: o mundo concreto da cena, o ambiente no qual ela se revela e se manifesta como corpo, não aceita a imposição de elementos que constituiriam o tal "resto" da representação. Ou seja, qualquer aspecto da cena estará inserido em uma das categorias mencionadas por Pavis - visual, sonora ou textual - tendo, portanto, função particular no organismo, na fisicalização do corpo cênico, identificado por Pavis pelo trinômio espaço-tempo-ação.

Por outro lado, pode-se considerar que cada instância particular do espetáculo - cenografia, dramaturgia, luz, música, figurinos, direção, maquiagem, interpretação - conduz um discurso autônomo e, simultaneamente, conectado a uma ideia catalisadora que provoca a práxis cênica, mesmo que se esteja tratando de proposições espetaculares que desprezam a definição de um sentido prévio e invistam no processo - ou relação - entre o acontecimento espetacular e o fruidor. Daí, o alto grau de dificuldade encontrado na realização de um espetáculo, ou seja, a interação de múltiplos discursos autônomos num só objeto artístico. Note-se a proposição do teatro performativo, observando-se a ponderação de Josette Féral (2008, p. 209, grifo nosso): ${ }^{7}$

Uma das principais características desse teatro é que ele coloca em jogo o processo sendo feito, processo esse que tem maior importância do que a produção final. Mesmo que essa seja meticu-

7 Professora da Universidade do Quebéc. 
losamente programada e ritmada, assim como na performance, o desenrolar da ação e a experiência que ela traz por parte do espectador são bem mais importantes do que o resultado final obtido.

Essa produção final, que na tragédia grega era também programada e ritmada para atender a objetivos específicos, o terror e a piedade, constituía o opsis. Ambos os exemplos investiram na excelência da visualidade, cada um no seu tempo e norteado por desejos particulares. No caso do teatro performativo, espera-se uma intervenção da luz meticulosamente concebida.

A cena grega será aqui retomada com a Medeia de Eurípedes, abordando a elocução particular da qual a poesia dramática estava impregnada. Quando o Mensageiro sai do interior da skéné e descreve o envenenamento da jovem Glauce, o espectador devia ser surpreendido através de uma métrica precisamente definida, que expressa o horror da visão. Uma acentuação equivocada na poesia poderia distanciar o espetáculo dos propósitos definidos pela dramaturgia de Eurípedes. É preciso imaginar o momento, a primeira fala, antes de quaisquer detalhes fornecidos pelo servo de Jasão, para construir o quadro de pavor testemunhado no interior do palácio.

Entra o Mensageiro, vindo do palácio real - | MENSAGEIRO | [...] Ela, então, levantou-se de seu | assento e caminhou | até o outro lado do aposento, movendo-se delicadamente | sobre seus pés pálidos, encantada com os presentes | inspecionando cuidadosamente $\mid$ a justeza do vestido nas suas pernas | Mas então aconteceu - uma horrível visão. | [...] Ela mudou de cor, cambaleou para trás e para os lados, | tremendo e, em seguida, jogou-se em sua cadeira, | quase caindo no chão. | [...] uma espuma branca lhe saia da boca, seus olhos | estavam inchados em suas órbitas, e sua pele pálida | completamente sem sangue. | [...] Ela sofria uma dupla agonia - o diadema de ouro em torno de sua cabeça | derramava incríveis fluxos de fogo derretido | queimando tudo e o rico manto | presente dos seus filhos consumia a carne da pobre jovem. | Ela pulou da cadeira e correu para longe, | fogo por todo o corpo, sacudindo a cabeça, os cabelos, | tentando livrar-se da sua coroa dourada - mas ela estava presa e, | quando a jovem sacudia os cabelos, o fogo ardia | duas vezes mais. Em seguida, ela caiu no chão, | abatida pela desgraça. Ninguém a reconheceria, exceto seu pai. | Seus olhos perderam sua límpida expressão, | sua face transformou-se. E havia sangue | sobre sua cabeça, escorrendo, misturado ao fogo. | Sua pele saía dos ossos, carcomida | Pelas mandíbulas 
secretas do veneno, [...] | Uma visão pavorosa! ${ }^{8}$ (EURÍPEDES, 2008, p. 1368-1414, tradução nossa)

Ainda que diante do texto cada leitor possa alcançar experiências diversificadas na relação direta entre o seu próprio imaginário e leitura, o estudo da métrica na tragédia clássica grega representa uma disciplina. No caso particular da poesia de Eurípedes, quando um ator, treinado segundo aquelas convenções, partilhava com um diretor as singularidades da obra, a cena podia efetivar a métrica planejada pelo poeta, para encaminhar determinadas emoções, de acordo com os desejos e conflitos que geraram a ação.

Não é difícil imaginar o grau de dificuldade que o espectador mais afastado da skéné enfrentaria, ao buscar detalhes de visibilidade naqueles espetáculos realizados em teatros com capacidade para abrigar milhares de pessoas, por vezes mais de uma dezena de milhares, como é o caso de Epidaurus. Parece, portanto, que do ator grego da Antiguidade eram esperados gestos muito largos, aliados à elocução competente. Os homens precisavam falar bem e, principalmente, deveriam ser capazes de executar a métrica particular de cada momento. O poeta incluía qualidade musical - ritmo, andamento e melodia - na ação trágica, uma melopeia que se efetivava em parceria com uma abordagem visual particular. O ator, cuja esta-

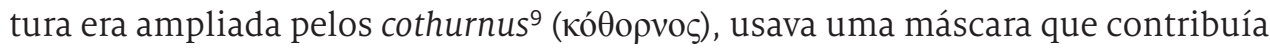
para uma caracterização estritamente ligada a convenções muito específicas, que impulsionavam aquela poesia para a cena, cena na sua condição de corpo transitório, dinâmico, sempre inacabado, mas não por isso destituído de planejamento (Figura 12).

8 " [...] Then she stood up from her seat and strolled | across the room, moving delicately $\mid$ on her pale feet, delighted with the gifts, | with a great many glances to inspect | the straightness of the dress against her legs. | But then it happened - a horrific sight. | [...] She changed colour, staggered back and sideways, | trembling, then fell into her chair again, | almost collapsing on the floor. | [...] the white spit foaming in her mouth, her eyes | bulging from their sockets, and her pale skin | quite drained of blood. | [...] She was suffering a double agony - | around her head the golden diadem | shot out amazing molten streams of fire | burning everything, and the fine woven robe, | your children's gift, consumed the poor girl's flesh. | She jumped up from the chair and ran away, | all of her on fire, tossing her head, her hair, | this way and that, trying to shake off | her golden crown - but it was fixed in place, | and when she shook her hair, the fire blazed | twice as high. Then she fell down on the ground, | overcome by the disaster. No one | could recognize her, except her father. | Her eyes had lost their clear expression, | her face had changed. And there was blood | on top her head, dripping down, mixed with fire. | The flesh was peeling from her bones, chewed off | by the poison's secret jaws, [...]. | An appalling sight!"

9 Uma bota. Sua distinção essencial era a sua altura, alcançando o meio da perna, de modo a envolver a panturrilha, às vezes chegando até os joelhos. Foi usada principalmente pelos cavaleiros, caçadores, e por homens de posição e autoridade. Os atores da tragédia ateniense assumiram o uso de um coturno com solas muito espessas, como um dos métodos adotados para ampliar sua figura. (VIRGÍLILO; HORÁCIO apud SMITH, 1870, p. 336) 
Na atualidade brasileira, quando se entende "encenação" como forma artística autônoma que toma quaisquer parâmetros que a antecedam como provocações e até desconsidera qualquer indício de poesia dramática, observações de tal natureza podem indicar o obsoleto. O que é aqui acentuado, contudo, é a opção disponível para um diretor familiarizado com tais aspectos. O que deve ser necessariamente mencionado é a consciência que o artista grego tinha da importância das imagens visuais para a cena, como se pode observar na decisão de evitar ocorrências violentas na cena propriamente dita, precisamente porque essa qualidade de visões incorporaria ao espetáculo imagens que - na compreensão daqueles artistas - eram consideradas inapropriadas.

Ao espectador era revelado um resultado visual de ações, o que gerou um elemento determinante para a convenção dramatúrgico-cênica. É possível supor que a cena grega enfrentava a criação das atmosferas propostas pela poesia trágica num espetáculo cruamente exposto pela luz do sol, como um problema do teatro. Caminhar ou não, na direção proposta pela poesia, é uma escolha que pode ser definida pela compreensão de suas potencialidades. Construir uma cena que desconsidere as premissas propostas por uma dramaturgia de tal natureza, que tem na sua gênese a cena como destino, é uma séria decisão exigindo fundamentação consistente.

Aquele que se interessa pela imagem cênica pode projetar na mente a qualidade do espetáculo grego, construído com unidades visuais impregnadas de movimentos muito particularmente concebidos, segundo convenções amadurecidas através da experimentação, incluindo contexto sonoro específico. É possível, portanto, inferir que aqueles artistas desenvolveram habilidade para incorporar as condições de visualidade oferecidas pela luz solar. Retornando ao contexto de Medeia, ainda que se possa dizer que o espectador de Eurípedes detinha familiaridade com a narrativa de Argos, cuja popularidade só era menor que a da saga de Troia, o espetáculo grego se constituía da expressão de uma narrativa poética na qual o termo ação é aqui compreendido como uma relação exemplar: uma parceria entre a ação dramática inscrita na poesia e uma atividade cênica - voz, gestos e movimentos do ator na cena propriamente dita - impregnada de determinadas convenções, inclusive espaciais, resultando em espetacularidade particular.

As possibilidades de interpretação da Poética aristotélica passam, então, na presente abordagem, pelo entendimento de uma poesia cujo destino é a cena. Na abertura do capítulo XIV dessa obra, lê-se:

É possível provocar o terror e a piedade através da aparição dos atores, mas é também possível que eles sejam provocados pela 
estruturação dos acontecimentos, e esta é a marca do melhor poeta. Ou seja, a fábula deve ser tão estruturada que, mesmo sem o uso de qualquer efeito visual aquele que estiver ouvindo o relato dos eventos estremeça e se apiede, pois é o que acontece com aquele que ouve a fábula de Édipo. Procurar o alcance dessas emoções através do uso de máscaras e figurinos é menos artístico e requer suporte técnico no espetáculo, [...]..$^{10}$ (ARISTÓTELES, 1983, p. 40, tradução nossa)

O que está em discussão é o jogo de hegemonias; as máscaras e os figurinos, assim como a técnica exigida para sua eficácia em cena, parecem assustar Aristóteles. Parece claro que promover a relação entre tais elementos, no contexto da poesia trágica, é conditio sine qua non para o poeta que escreve vendo a cena como estágio do processo. Atingir os objetivos da tragédia por meio do acontecimento cênico, entretanto, é a primeira possibilidade por ele mencionada, apontando-a como outra instância expressiva da manifestação trágica, que atraía milhares de membros da comunidade para a única experiência estética imediata, presencial, que a humanidade pôde realizar até hoje, ou seja: discutir, experimentar emoções, contemplar e avaliar sua própria condição e relações, numa realização que congregava artista e público, nas condições mencionadas acima, a práxis cênica. O comentário a seguir, apresentado por Fernando M. Gazoni (2006, p. 28, grifo nosso), acentua as relações entre opsis e mimesis:

A melodia é classificada como um hedusma, palavra traduzida como 'ornamento', mas que tem a mesma raiz de 'prazer' e seria vertida mais propriamente como 'tempero'. A ela cabe, na Poética, um destino similar ao do espetáculo. O prazer que ela proporciona, assim como o prazer ligado a efeitos cênicos, deve dar lugar ao prazer próprio da tragédia, aquele que provoca o medo e a piedade por meio da mimese, e que deve estar ligado às ações.

Tratando do medo e da piedade gerados pela mimesis de uma ação completa, acentuando a ação, pode-se considerar que a poesia é suficiente para, e capaz de cumprir a função trágica, prescindindo de hedusmas, no sentido de ornamentos.

\footnotetext{
10 "Now it is possible for the fearful or pathetic effect to come from the actors' appearance, but it is also possible for it to arise from the very structure of the events, and this is closer to the mark and characteristic of a better poet. Namely, the plot must be so structured, even without benefit of any visual effect, that the one that the one / who is hearing the events unroll shudders with fear and feels pity at what happens: which is what one would experience on hearing the plot of the Oedipus. To set out to achieve this by the means of the masks and costumes is less artistic, and requires technical support in the staging."
} 
O opsis poderia ser considerado um ornamento e, portanto, desnecessário. Ele estaria sendo equiparado a "efeitos" como aqueles mencionados por Pollux (apud NAGLER, 1952, p. 9, tradução nossa): "A torre de relâmpago e trovão eram, respectivamente, um periaktos de grande dimensão vertical, e sacos cheios de seixos colocados atrás da skéné, que eram despejados em vasos de bronze"."11 E ainda poderiam ser listados separadamente, como itens isolados, a melodia, o opsis, assim como outros "efeitos". Estariam sendo questionados aspectos considerados dispensáveis, exageros em "ornamentação", e não a cena, não a mimesis em si, da ação humana, já que ela seria indispensável para que se efetivasse a representação trágica, para a comunidade.

É possível inferir que, no entendimento de Aristóteles, tal "tempero" era menos importante que a ação humana em busca da felicidade e, assim, a tragédia cumpriria sua função, já na poesia, na palavra lida e/ou também, ouvida. Por outro lado, o crítico Aristóteles poderia estar desaprovando excessos "espetaculosos" e, portanto, desnecessários. Tais considerações podem sugerir uma articulação da cena, anunciando aquilo que no teatro brasileiro do século XX se denominaria "encenação".

Um enfoque atual pode suscitar comentários acerca da hegemonia da palavra usando o rótulo de visão texto-centrista; e ainda, o interessado no reconhecimento do espetáculo como obra autônoma, discordaria em muitos pontos, afirmando mesmo que a melopeia, como exemplo, não pode ser considerada mero "tempero" ou ornamento. Até mesmo certos "efeitos" - como o ruído dos trovões, mencionado acima - se forem levadas em conta as características do espaço teatral em que era realizada a cena da Grécia Antiga, podem ser considerados aspectos inerentes e perfeitamente incorporados a determinado espetáculo. Cabe lembrar que mesmo na compreensão brasileira da função de "encenador", ele provoca, sugere caminhos para a realização do espetáculo e precisa contar com a conjunção resultante das realizações de diversos artistas que articulam a corporificação da cena. Desde os atores, podendo-se incluir um dramaturgo, um músico, além dos autores da proposição visual, seja um cenógrafo, um figurinista, e até um iluminador, membro mais recente no grupo de artistas envolvidos, entre outros. Um espetáculo sugere, portanto, uma espécie de conjunção que integra certa diversidade de práticas, com o intuito de "fisicalizar"12 ideias num corpo expressivo.

11 "The lightning-tower and thunder were, the former a high periaktos, and the other backwards under the skené, bags full of pebble-stones poured into a brazen vessel."

12 Sem ligação com o fisicalismo de Rudolf Carnap (1891-1970), e sua incursão no positivismo lógico, “[...] teoria segundo a qual os diversos campos do conhecimento, inclusive as chamadas ciências humanas, devem elevar a 
Valho-me da poesia de Ésquilo (ca. 525/524 a.c.-456/455 a.c.), uma vez que ela oferece elementos determinantes para as reflexões sobre o trinômio texto-visuali-

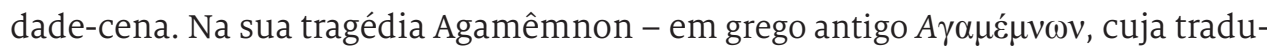
ção pode até aproximar-se de impulsivo - que abre a trilogia Oréstia (cuja primeira representação se deu em 458 a.c., em Atenas), o arranjo dos fatos elaborado pelo autor abre a instalação da fábula, com a intervenção de uma única personagem na skéné. Mesmo levando-se em conta a proximidade do público com o mythos, cabe indagar por que o poeta começaria sua tragédia com uma personagem considerada secundária na escala social abordada em sua trilogia, cujo tema revela conflitos que envolvem reis e rainhas. Parta-se de uma abordagem que aceita Ésquilo como artista profundamente envolvido na cena, tendo transitado desde o papel de autor da poesia trágica até aquele de ator em cena, assumindo também a posição de responsável pela organização do espetáculo.

Além disso, ainda que se considere o corifeu um ator, mesmo enquanto ele toma parte do coro, como líder, pode-se dizer que Ésquilo criou também a figura do ator, na sua posição de artista e profissional. Melhor dizendo: quando ele introduziu um ator, além do corifeu, o segundo ator que dividiria os papéis com o primeiro ator - também autor e até diretor - Ésquilo estaria inventando a figura própria do ator, como aquele cuja função é interpretar papéis. Ele não é o corifeu que lidera um grupo e assume falas mais importantes, tampouco é um autor que faz os papéis por razões diversas - por exemplo, porque são os mais importantes ou porque são os mais difíceis e ele os conhece bem, uma vez que os elaborou. Ésquilo introduziu o específico profissional cuja função especializada é interpretar papéis.

Em Agamêmnon, a ação se inicia quando uma Sentinela postada na cobertura do Palácio dos Atridas, casa de Agamêmnon, relata a espera por um sinal de fogo que se originará numa distante montanha, revelando a queda de Troia, e o consequente retorno do herói. Após longa e dolorosa espera, a Sentinela anuncia, cantando e dançando para o povo de Argos, a vitória do seu rei, configurando-se uma espécie de "rotina vazia". É preciso dizer que as trevas noturnas, já descritas na poesia de Ésquilo, serão reinventadas na imaginação do espectador, no momento mesmo de cada espetáculo.

física à condição de um paradigma científico universal, supondo que todos os aspectos da realidade, inclusive estados mentais e afetivos, somente adquirem plena compreensibilidade e concretude se analisados como realidades físicas". (HOUAISS, 2009) 
De modo simples e engenhoso, o poeta propõe (na introdução monológica do prólogo) um diálogo com o imaginário do espectador, compartilhando com ele o ambiente sombrio da prolongada espera noturna.

Deve-se observar a gravidade da situação política da qual trata o mito, reconhecido pelo espectador de Ésquilo. O tão esperado anúncio luminoso foi arquitetado por Clitemnestra, que planejou se preparar para a chegada do marido. Lembre-se que, em algumas versões do mito, Agamêmnon havia sacrificado a própria filha Ifigênia, para apaziguar ira da deusa Artemísia, e, por conseguinte, ter vento para velejar em direção à batalha. Quando, anos depois, Agamêmnon parte para a guerra de Troia, deixando sua mulher Clitemnestra, que se torna amante de Egisto - assassino de Atreu, pai do seu marido, e de quem Egisto era sobrinho - com o argumento da garantia de equilíbrio político e de paz. O retorno de Agamêmnon representa, portanto, uma ameaça de conflito político, e aponta para uma guerra civil. Numa história de profundos traumas, deve-se acentuar que, mesmo antes do episódio da guerra de Troia, o pai de Agamêmnon, Atreu, assassinou os filhos do seu irmão gêmeo Tiestes e serviu em banquete a carne de ambos para o próprio pai. A tragédia era levada à cena para um público familiarizado com a narrativa mítica.

No que se refere à atmosfera criada por Ésquilo, a personagem deixa de ser uma mera "sentinela", deixa de ser mais uma figura em cena. Não se trata de alguém com baixa posição na pirâmide representativa do modelo social vigente, mas um aspecto determinante da poesia dramática e da instalação do opsis. A Sentinela anuncia:

Aqui no alto do palácio dos Atridas | aos deuses todos peço há muitos, longos anos que me liberem da vigília cansativa. | Firmado em meu braço dobrado, sempre atento, | igual ao cão fiel, de tanto olhar o céu | noite após noite agora sei reconhecer | a multidão inumerável das estrelas, | senhoras lúcidas do firmamento etéreo, | indicadoras dos invernos e verões | em seu giro constante pela imensidão. | Espreito a todo instante o fogo sinaleiro | que nos dará notícia da queda de Tróia; | são ordens da mulher de ânimo viril, | rainha nossa, persistente na esperança. (ÉSQUILO, 1990, p. 19, grifo nosso)

Os grifos incluídos na tradução delineiam o cerne da discussão: a noite, elaborada em um espetáculo realizado em plena luz do dia - como ocorria naquele período - através da contundência da dramaturgia de Ésquilo, acentua a confiança do poeta na força da palavra. A poesia incorpora relações vitais do ser humano 
com a luz, relações capazes de projetar uma parceria vigorosa, que promoveria, na imaginação do público, uma expressiva efetivação da ação trágica mergulhada numa densa atmosfera noturna. Parece quase óbvia a afirmação visual do ambiente da ação, imerso numa interminável e angustiante espera que torna difícil imaginar a Sentinela sob um luar romântico, confortável. A imagem instalada por Ésquilo indica frieza, dureza, aspereza, desconforto. A atmosfera já se encontra na poesia, e aquele que se deixa provocar pela obra, aventurando-se no empreendimento de fisicalizá-la como corpo-cena, terá uma tarefa hercúlea: decidir entre propor em cena a mencionada atmosfera ou construir argumentos para negar sua validade como índice relevante para a discussão encaminhada pelo autor, trilhando outros caminhos.

Gösta M. Bergman (1977, p. 28), observando o momento no qual a tragédia antiga foi representada, comenta que os edifícios teatrais onde ocorriam os espetáculos da Grécia Clássica eram espaços sem cobertura, o que poderia expor muitos dos eventos ao escaldante calor da luz do sol, considerando que a apresentação de uma tetralogia (três tragédias e um drama satírico do mesmo autor) ou, mais tarde, uma tragédia de cada autor envolvido no festival, mais uma comédia, era programada para ocorrer ao longo do dia, gerando um acontecimento teatral que se estendia, provavelmente, até o crepúsculo.

Daí, é possível inferir que as diferenças de luminosidade apresentadas em um dia inteiro de atividades devem ter sido incorporadas pelos responsáveis pela cena, aplicando elaborações estéticas, buscando construir atmosferas.

Pode-se questionar a apresentação de uma trilogia em um único dia, argumentando que seriam necessárias mais de seis horas, e que a apresentação de uma tragédia e uma comédia coloca bem a moldura do tempo disponível em uma tarde. E ainda se pode questionar a possibilidade do próprio Ésquilo, como ator de várias "máscaras", atuar em três tragédias no mesmo dia. Sendo apresentada uma tragédia a cada dia, qual seria a ordem de apresentação? Observando que a tragédia como o momento mais importante do evento, ela seria encenada depois da comédia? Ou ao contrário, a comédia serviria como uma espécie de alívio para o público?

Considere-se que a atmosfera encaminhada na abertura da tragédia exige efetivação cênica contundente, capaz de abrir as portas do espetáculo para um público de milhares de espectadores. Em Agamêmnon, a noite representa para a Sentinela dolorosa vigília e as trevas noturnas são imprescindíveis para a revelação do sinal emitido ao longe: uma chama que se insinuará no escuro véu, povoado por incontáveis corpos celestes distantes, e até mortos, anunciando 
a vitória e, consequentemente, o fim da longa espera. Mais adiante, na mesma fala, e após uma pausa mencionada em publicações modernas (provocada pela dramaturgia que, quando apresenta a qualidade da poesia em questão, pode indicar aquilo que não se escutará, indicando silêncio vocal), ouve-se sua exclamação de júbilo:

É o sinal! É o sinal! Meus próprios olhos veem!| Eis a noturna luz que mudará decerto $\mid$ a treva $[\ldots]$.

[...] e a mensagem da chama vista de tão longe | é o lance mais feliz de toda a minha vida! (ÉSQUILO, 1990, p. 20, grifo nosso)

A longa espera transforma-se em dúbia alegria, ou talvez fosse melhor dizer que os sinais de fogo produzem grande alívio, pois a mensagem de luz que revela o fim da guerra e o consequente retorno do rei proverá aos líderes tempo para que reflitam com o intuito de avaliar tensões políticas. A celebração que ocorre depois do anúncio da Sentinela, incluindo o desfile de archotes, as luzes dos altares, fortalece o traço de união entre a luz, os desejos e a situação dramática em curso.

Num certo sentido, bom seria tomar conhecimento da morte de Agamêmnon, uma vez que tal notícia já resolveria parte do problema. Clitemnestra, agora no poder, soberana, mãe e amante, tem diante de si a função de articular e conter a crise política que poderá se abater sobre o país. Se assassinando o próprio marido, Clitemnestra não evita e até precipita os fatos que se desenrolarão num novo anoitecer, a dramaturgia de Ésquilo mergulha em sombras profundas um mundo que se vê tomado pelas trevas. A poesia, então, constrói um ambiente particularmente diversificado do momento físico no qual o opsis ocorre, ou seja, durante o dia.

Se, em muitos casos, a noite é temida como um momento de trevas e terror, ao responder aos anseios do Corifeu, que se apresenta pronto a ouvir seu pronunciamento, Clitemnestra atende, dizendo: "Desejo que do seio maternal da noite | Desponte cheio de venturas este dia”. (ÉSQUILO, 1990, p. 28, grifo nosso) Ésquilo, então, nos dá uma visão positiva da escuridão, uma qualidade que remete ao conforto do enlace materno. Ou, como adiante declara o Coro, a noite é amiga, aliada, pois acoberta a ação violenta, no ataque à Troia. Importa, finalmente, salientar: qualquer que tenha sido a configuração do festival no qual Ésquilo tomou parte com Agamêmnon, o espetáculo começou sob a luz do sol, o que reforça a abordagem das relações entre poesia trágica, luz e atmosfera.

Além das qualidades da sua obra, da introdução de um segundo ator, Mynniscus de Chalci - depois de já haver trazido Cleander - o vigor da poesia de Ésquilo estabeleceu poder a uma estrutura simples, concentrada na grandeza e 
elevação heroica das personagens, criando mudanças no modelo trágico e introduzindo aspectos visuais importantes: elementos cenográficos que incluíam pinturas, altares, cenotécnica, com grande contribuição para aquela espetacularidade, o que reitera sua postura de artista familiarizado com a cena.

É importante lembrar que Ésquilo desconhecia a necessidade de luz artificial para promover visibilidade efetiva ao seu espetáculo. Ela poderia sugerir ou indicar trevas que poderiam ser, naquele momento, apenas imaginadas. Tal assertiva alcança relevância no presente estudo uma vez que o provável uso de tochas, lanternas, ou até mesmo o farol mencionado por Pollux não atenderia à função de iluminar um espaço cênico profusamente invadido pela luz do sol.

Pode-se apreender que, ao escrever com o olhar na cena, pensando em uma práxis que ocorreria durante o dia, Ésquilo operou o texto, de modo a provocar no espectador relações com a atmosfera da cena propriamente dita, o ambiente da ação a ser mimetizada e construída através da interação com o seu imaginário. Se, por um lado, o papel da luz artificial no contexto era bastante limitado, por outro, podia alcançar grande força simbólica. Profundamente envolvido com o teatro do seu tempo, Ésquilo investiu em tais possibilidades.

Contemplando a imensidão do Teatro Dionisus, em Atenas, pode-se avaliar a ousadia e o risco de uma dramaturgia exemplar, que buscava efetivar luz através da palavra, numa relação de troca, cumplicidade e compreensão do alcance das relações entre as imagens arbitrárias tanto aquelas mentais, quanto as imagens visuais. Ésquilo inaugurou, então, uma trilha seguida por outros dramaturgos, que por isso mesmo representam elevado interesse para a presente investigação.

As assertivas visuais inscritas na poesia trágica indicam a presença de feições da luz na sua constituição, estabelecendo uma provocação que revelará a cena, notadamente quando o autor considera as particularidades do opsis. Como já foi acentuado, antes de propor "textocentrismo", tal relação leva em consideração as parcerias que caracterizam a práxis cênica. Uma vez que a corporificação da cena se efetiva no espaço teatral, o dramaturgo tem a liberdade de construir sua obra em estreita cumplicidade com a luz. Aristóteles (1951, p. 124), no capítulo XXVI da Poética, concluindo suas considerações, afirma: "Mas a tragédia é superior porque contém todos os elementos da epopeia (chega até a servir-se do metro épico) e, demais, que não é pouco, a música e o espetáculo cênico [opsis], que lhe acrescem a intensidade dos prazeres que lhe são próprios."

A despeito de questionamentos acerca dessa tradução interessa aqui assinalar a possibilidade vislumbrada pelo tradutor em questão, acentuando a compreensão aristotélica da relevância da música e do opsis, considerando que Aristóteles 
tenha indicado uma distinção entre eles. Ainda que Aristóteles tenha elaborado essas considerações a certa distância temporal, uma vez que sua obra foi produzida no século IV a.c., de um ponto de vista teórico e como observador externo, a Poética alcançou status de documento chave para as reflexões acerca do teatro grego.

Ademais, vale repetir o interesse da presente abordagem na parceria entre os diversos aspectos da cena, excluindo-se quaisquer hegemonias. Reafirma-se, portanto, a poesia dramática como gênese e poderosa provocação para a corporificação cênica, como um conjunto de contribuições indissociáveis, desempenhadas por diversos artistas, questionando a inclusão de hedusmas - se eles forem compreendidos como ornamentos inconsequentes ou exagero. Por fim, a classificação de "ornamento" pode ser discutida, uma vez que todo elemento incorporado organicamente à cena torna-se teor intrínseco da sua constituição.

Quando Gazoni (2006) apresenta a possibilidade da tradução de hedusma como "tempero", ele abre um caminho promissor porque tal tempero pode se tornar item indispensável, ao contribuir para a sugestão de aromas, texturas, temperaturas, criando a atmosfera exigida pela cena. Tudo isso leva a uma premissa que indica posição particular para a luz no conjunto de contribuições como um elemento de grande fluidez e, simultaneamente, capaz de promover intervenções de grande contundência: imprescindível em certos aspectos e insubstituível em outros. Apesar da sua impalpabilidade, ela desempenha papel decisivo e único na corporificação da cena, mesmo quando pareceria não ser necessária, como na cena aberta da trilogia de Ésquilo. A poesia trágica, assim como o drama, cumpre seu destino na cena.

Como foi dito na abertura deste capítulo, além do trato político presente, tanto no teatro de Shakespeare quanto no de Ésquilo, a familiaridade com o teatro de seu tempo os levava a escrever com o olhar na cena, o que exercia uma tentação definitiva para seus impulsos poéticos. Em ambos os casos, pode-se presumir o uso de luz artificial, inclusive para sugerir noite e/ou escuridão, como um passo estratégico e orgânico da dinâmica dramatúrgica. 


\section{MÚSICA E DRAMA cúmplices sob a mesma luz}

Muitos séculos depois do seu apogeu na Antiguidade, a tragédia grega repercutiria significativamente entre os artistas do século XVI. Certas manifestações do período apontam para um movimento mais agudo da atividade teatral sistematizada, que eclodiria no início do Renascimento, como aquelas que eram efetivadas em instalações provisórias patrocinadas pela Academia Olímpica, fundada em 1556, seguindo a tradição da Academia Platônica, reinventada pelo pensamento humanista do século XVI, na Itália. ${ }^{1}$ Como ressonância da tragédia grega, surgiria na Itália uma manifestação cênica assim definida pelo Oxford Companion to the Theatre: "Uma composição dramática

1 As academias renascentistas seguiam uma tradição que se iniciou na Grécia, provavelmente a partir da atividade de Platão, quando ele reunia discípulos, seguidores, para a apresentação dos seus princípios filosóficos, nos arredores de Atenas, no jardim público, denominado Academia, cujo nome pode ter sido originado de Hecademus ou Academus, que teria doado o jardim aos cidadãos para a prática da ginástica. 
concebida para ser representada no palco, na qual a música vocal e instrumental desempenha função especial".' (HARTNOLL, 1957, p. 585, tradução nossa)

Considerando outra opinião, encontramos uma definição semelhante, em Burton D. Fischer ${ }^{3}$ (2005, p. 14, tradução nossa): "A ópera ${ }^{4}$ é um modo formal do teatro que expressa sua essência dramática integrando palavras e ações com música. Como drama, a ópera incorpora todo o espectro dos elementos teatrais: diálogo, interpretação, figurinos, cenário e ação, [...]".5 Artistas italianos do período em questão acreditavam estar refazendo a tragédia, como uma manifestação cênica em grande parte cantada e parcialmente dançada; produzindo a interação de música e dramaturgia, eles incorporaram condições técnicas da época - tochas, velas, lamparinas a óleo e tratamento cenográfico, com repercussões renascentistas. O estudo da ópera, por conseguinte, há de contribuir para a observação das relações entre a luz e a práxis cênica.

Para compreender o contexto no qual a ópera se insere, vale a pena mencionar as relações de poder estabelecidas pela presença da Igreja Católica na Itália. Acentue-se que, assim como o teatro permaneceu durante muito tempo uma atividade proscrita - desde o século V d.C. -, só reaparecendo como forma expressiva oficialmente reconhecida, a partir da sua reelaboração no interior dos templos católicos, também a música secular alcançou o status de expressão artística condenada pela Igreja. Por outro lado, no ambiente religioso, o canto gregoriano de princípio monofônico - em uma única linha melódica - com ou sem acompanhamento instrumental, era largamente usado. A música executada fora da Igreja Católica era execrada e, simultaneamente, a vida monástica estava repleta de salmos e hinos que constituíam parte importante das orações durante a missa. Mais uma vez caía por terra a intenção de sufocar uma expressão artística. A diversidade de vozes que se instalou progressivamente nas composições, já fortalecia os caminhos do interesse pela polifonia, ${ }^{6}$ ainda que a pluralidade de vozes não

\footnotetext{
2 "A dramatic composition, intended to be represented on the stage, in which vocal and instrumental music plays an essential part."

3 Maestro que estudou na Julliard School, em Nova York, autor de mais de uma centena de livros sobre a ópera.

4 Opera, plural de opus, em latim, significa obras.

5 "Opera is a formal theatrical medium that express its dramatic essence by integrating its words and action with music. Like drama, opera embraces the entire spectrum of theatrical elements: dialogue, acting costumes, scenery, and action, [...]."

6 Do termo grego polyphōnos: poly, muitos e phōnē, voz. Uma textura musical caracterizada pela presença de diversas vozes melódicas, ao contrário da monofonia - música com apenas uma voz - ou homofonia - música com uma voz dominante acompanhada por cordas. O termo é usado para referir-se inicialmente a mudanças que começam a aparecer na música do final da Idade Média.
} 
incluísse, inicialmente, uma intenção de contraponto ${ }^{7}$ e preservasse a importância, o valor de cada linha melódica.

Os encaminhamentos de tais conflitos contribuíram, entre outras coisas, para o aparecimento de duas formas musicais que são apontadas como precursoras da ópera moderna. O madrigal e a pastoral combinavam dramas poéticos e acompanhamento instrumental, com uma diferença importante no contexto: o primeiro lidava com temas da liturgia, com temas bíblicos, era ligado às atividades sacras, aos rituais, às moralidades e aos milagres; a segunda incorporava motivos seculares à simplicidade da vida rural, sua contraposição ao luxo e à corrupção das cidades e da corte, envolvendo, nos contrastes, a alegria, a traição, a presença de entidades mágicas, assim como a de heróis. Estudiosos acreditam que nelas pulsavam os germens da expressão artística que integraria poesia dramática e música, construindo progressivamente a ópera.

Deve-se enfatizar que a Igreja proibiria os madrigais, precisamente porque o grau de contraponto do qual eles foram impregnados representavam impasses à apreensão do texto da missa, interferindo na liturgia, dilapidando a função de catequese, de afirmação da fé, e subvertendo a estrutura dos serviços religiosos.

O madrigal tornou-se a forma vocal dominante e era praticado com maestria pelos compositores italianos. A Reforma Protestante originou a Contrarreforma Católica, que culminou no Concílio de Trento $^{8}$ e impôs estritas limitações à polifonia vocal, que favorecia o estilo de Palestrina, ${ }^{9}$ o qual permitia que o texto fosse claramente apreendido [...]. ${ }^{10}$ (GREENBERG, 1998b, p. 23, tradução nossa)

7 Contraponto, ou a habilidade particular da música, de acordo com o The Concise Oxford Dictionary of Music, de dizer duas coisas ao mesmo tempo, de modo compreensível. Interessados no estudo do contraponto podem pesquisar as possibilidades musicais da adição de uma "parte" ou uma "voz" a outra, ou a combinação simultânea de vozes; cada uma delas com sua significação e característica em si mesma. Em música, isso pode resultar numa textura íntegra, com uma especial ordem interna. Para aprofundar esse caso, é recomendável o estudo da polifonia.

8 Entre 13 de dezembro de 1545 e 4 de dezembro de 1563 ocorreu em Trento, na Itália, o décimo nono conselho ecumênico da Igreja Católica, numa resposta à Reforma Protestante, o que incluiria uma revisão do comportamento no interior da Igreja, eliminando o que ela considerava inadequado. Devem ser destacados os 18 anos de duração do Concílio de Trento, necessários para as demoradas discussões das questões teológicas, políticas, das regras do teatro neoclássico, de questões jurídicas - direito canônico e direito geral. Tratava-se de uma reformulação dos aspectos éticos, artísticos, morais e teológicos, que interferiram politicamente no mundo ocidental. Foi o mais longo concílio da história da Igreja Católica.

9 Considerado o maior entre os compositores da música litúrgica, Giovanni Pierluigi ficou conhecido pelo nome da sua cidade natal, Palestrina. Nasceu entre 1514 e 1526 e morreu em 1594, na cidade de Roma.

10 "The madrigal became the dominant Renaissance vocal form, and it was mastered by the Italian composers. In reaction to the Protestant reformation, the Catholic Counter-Reformation culminated in the Council of Trent, which 
A $22^{\mathrm{a}}$ seção do Concílio de Trento, realizada em 17 de setembro de 1562, presidida pelo papa Pio IV, lista o que deveria ser atendido e aquilo que deveria ser evitado na missa: "[...] banir das igrejas todo o tipo de música na qual, executada através do órgão ou cantada, se mistura qualquer lascívia ou impureza"."11 (THE COUNCIL..., 1848, p. 161, tradução nossa) Se não lasciva, ao menos impura seria toda música que impedisse o fiel de assimilar a palavra da Igreja.

Ainda sob o impacto do Concílio trentino, na transição entre os séculos XVI e XVII, as primeiras iniciativas de "invenção" da ópera eram tomadas em Florença, no centro da Itália. Já em janeiro de 1593, na casa do conde Giovanni Bardi, um grupo de poetas e músicos reunia-se em torno de um pensamento norteador, que criticava a música de seu tempo, tomando o nome de Camerata ${ }^{12}$ de Bardi, também conhecida como Camerata florentina. Voltando-se para traduções de textos antigos, eles acreditavam - como muitos pensadores da época - que o caminho para a reedificação da arte musical estava no retorno às raízes gregas. A influência de Girolamo Mei (1519-1594), estudioso da cultura grega antiga, ganhou força na discussão do teatro grego. Em longas discussões, o círculo de músicos e literatos, que incluía advogados, médicos, farmacêuticos e outros profissionais, tentava reconstruir sua práxis.

A Camerata defendia a aproximação da música de sua época de tais raízes clássicas - um refazer da tragédia grega - como um caminho para a excelência. É importante destacar que os estudiosos tentavam traduzir as versões latinas, como as de Sêneca, no intuito de compreender como as tragédias eram montadas. Com sólidos conhecimentos dos originais da tragédia grega e perfeita leitura do grego clássico, Sêneca adaptou com perícia em suas numerosas versões para o latim de sua época, a arte da métrica dos originais, especialmente os dramas de Eurípedes.

O círculo da Camerata de Bardi, provavelmente impressionado pela força teatral da obra de Sêneca, imaginou que as tragédias da Grécia Clássica eram cantadas, devido à organização musical dos versos, nas adaptações e versões elaboradas por Sêneca. Não há informações claras sobre as técnicas dos atores gregos, restando imprecisões sobre seu canto e sua dança. Os amigos do Conde Bardi, entretanto, pareciam convencidos: os textos da tragédia clássica eram cantados e,

\footnotetext{
put strict limitations on vocal polyphony, and it favored the smooth style of Palestrina, which allowed the text to be heard clearly."

11 "[...] banish from churches all those kinds of music, in which, whether by the organ, or in the singing, there is mixed up anything lascivious or impure."

12 Literalmente, aqueles que se reúnem numa câmara.
} 
assim, reformularam a Tragédia Grega Clássica como uma representação cantada, apontando para a Ópera.

As pesquisas levaram ao primeiro exercício efetivo no palco, tomando como tema o mito de Apolo e Daphne, apresentado em 1597. O libretto ${ }^{13}$ de Daphne foi assinado por Ottavio Rinuccini (1562-1621), e a música composta por Jacopo Peri (1561-1633). Caracterizada por Peri como "dramma per musica", a obra, infelizmente, se perdeu. A empreitada seguinte, escrita pelos mesmos autores [Eurídice, (1600)], também sob a influência da mitologia grega, adaptada da obra de Ovídio (Publius Ovidius Naso 43 a.c. -17/18 d.C.) [Metamorfosi]. Isso pode indicar uma diversidade de fontes, de provocações para quem se interessa pela ópera, podendo incluir um regente, um diretor e também um iluminador, dentre outros artistas.

A rota proposta pela Camerata Florentina de Bardi indica peças que procuravam instalar um tratamento capaz de reagir à polifonia renascentista, buscando a apresentação integral de um drama, numa estrutura relacionada pelos eruditos à qualidade monódica, ${ }^{14}$ e investindo no diálogo entre uma voz solo que usava linha melódica ornamentada por acompanhamento instrumental. Sem o aprofundamento na análise musical que exigiria maior domínio da questão, observe-se a convicção dos artistas daquele período acerca do poder daquele tipo de obra "cênico-musical", para suscitar profundas emoções e acentuado efeito moral. Ora, combinando tais aspectos e destacando o tema usado por Rinuccini na construção do seu libreto, é possível vislumbrar as possibilidades cênicas do espetáculo que pode ser elaborado a partir das fontes mencionadas, compreendidas como partes vivas da práxis cênica e representando elemento importante para a abordagem aqui encaminhada, quando se as confronta com o desejo expresso pelos artistas que propunham a ópera.

\section{L'ORFEO COMO AFIRMAÇÃO DA LUZ NO DRAMMA PER MUSICA}

Na transição entre os séculos XVI e XVII, os artistas romperam os limites da estética musical do mundo aristocrático, traçando novos caminhos e caracterizando a vida através de uma mentalidade emergente da poderosa burguesia que ascendia na Europa, num processo que envolvia o crescimento das cidades e o desenvolvi-

13 Libretto, diminutivo de libro, em italiano. O libretto traz todo o texto de uma ópera, as rubricas e eventualmente observações da montagem. Em muitos casos, os libretti ficam disponíveis (ou são vendidos) no foyer, o que permite que o público acompanhe o texto cantado. A tradição, que exige dos cantores alta expressividade musical, pode, por outro lado, comprometer a articulação e com isso a compreensão do texto cantado.

14 No sentido musical de melodia - canto - em uníssono. 
mento econômico das Cidades-Estado. Tal atividade se relacionava a um comércio cada vez mais globalizado e o fomento da produção de bens manufaturados.

A burguesia ascendente e enriquecida investiu não apenas no poder políticomilitar, mas também numa educação abrangente e sofisticada para seus filhos, até superando a aristocracia. Pode-se dizer que os aficionados pela música eram amadores no sentido positivo da palavra, na sua maioria, tratando-se de profissionais liberais, advogados, juízes, médicos, entre outros, que tinham no aprendizado musical uma atividade regular de sua formação, estudando disciplinas como harmonia e contraponto, dentre outras, prática já comum na aristocracia e que se estabeleceu na burguesia emergente nas Cidades-Estado da Itália.

Claudio Giovanni Antonio Monteverdi (1567-1643), em particular a sua ópera L'Orfeo, [em parceria com o libreto de Alessandro Striggio (ca. 1573-1630), ${ }^{15}$ publicada na cidade de Mântua em 1607], pode ser mencionada como representante do primeiro estágio de organização da ópera. A escolha de Orfeu como figura central da ópera de Monteverdi/Striggio foi uma decisão emblemática. Na mitologia grega e também na sua acepção romana, ele tinha especial talento musical, com poderes mágicos, era instrumentista virtuose com a lira, inventor da cítara e cantor. Além disso, Orfeu era um semideus, uma personagem próxima do homem que lutava para se impor na ascensão burguesa, e não uma figura mítica isolada na instância divina.

Há versões que o apresentam como filho de Calíope e Oeagrus, um rei da Trácia; no Symposium, Platão afirma que ele é filho de Apollo. Ora, mesmo aceitando a última versão, não se pode esquecer que, ainda assim, Orfeu é o filho da mais importante entre as nove irmãs Musas - filhas de Zeus e pertencentes ao cortejo de Apolo, deus da música; vale lembrar que as Musas se transfiguraram em deusas da inspiração poética. O Dicionário eletrônico Houaiss da língua portuguesa (indica a raiz etimológica do termo música: "[...] mousikós, ê, ón (dórico mousiká) 'que diz respeito às Musas, à poesia, às artes, esp. à música". ${ }^{16}$ Ruth Guimarães (1995, p. 239) acentua, referindo-se a Orfeu: "Suas cantigas eram tão suaves que as feras o seguiam, inclinavam-se as árvores para ouvi-lo e os homens mais coléricos sentiam-se penetrados de doçura e bondade". E acrescenta que ele fez parte da jornada dos Argonautas, ${ }^{17}$ sendo o responsável por estabelecer a cadência dos remadores.

\footnotetext{
15 Filho do compositor de mesmo nome.

16 o Concise Oxford English Dictionary explica: [...] mousiké (tekhné) "(arte) das Musas", de mousa, "muse".

17 O termo deriva de Argo, nome da embarcação de 50 remos, construída por Argus, sob o comando de Jasão, para viajar à Cólquida, em busca do Velocino de Ouro. Acompanhado de uma tripulação composta de mais de quatro dezenas de jovens heróis, depois de uma saga que envolve traição, ganância, bravura e magia, Jasão retorna com o Velocino, entregando-o a Pelias. (GRAVES, 1957)
} 
Na ópera, a saga de Orfeu inicia-se quando sua esposa Eurídice é picada por uma serpente, enquanto foge da perseguição de Aristeu, que em alguns relatos aparece com um sátiro. Diante do corpo sem vida da amada, o herói entoa canções de profundo lamento, fazendo chorar as Ninfas. O imenso amor a ela devotado e o sofrimento originado na perda impelem Orfeu numa jornada ao Hades (do termo grego Haidés, um nome de Plutone, o deus dos mortos), com o intuito de trazê-la de volta à vida.

Uma pesquisa originada pela intenção de aproximar L'Orfeo de Monteverdi e Striggio da práxis cênica, leva a Ovídio e suas Metamorfosi. Mesmo tendo sido acusado de imoral no seu tempo e exilado por ordens do imperador Augusto, a importância de Ovídio para a poesia do Renascimento foi decisiva e L'Orfeo é considerada um relevante modelo para o período. Tratando-se de um clássico, em língua estrangeira, o considerável volume de estudos que incorporam a obra de Ovídio pode sugerir pesquisa exaustiva, mas gratificante, para alcançar abrangência. Destaque-se a abordagem de Italo Calvino (2009, p. 37, grifo nosso), que assim se refere às Metamorfosi:

As metamorfoses são o poema da rapidez, tudo deve seguir-se em ritmo acelerado, impor-se à imaginação, cada imagem deve sobrepor-se a outra imagem, adquirir evidência, dissolver-se. É o princípio do cinematógrafo: cada verso como fotograma deve ser pleno de estímulos visuais em movimento.

Considere-se o interesse de Calvino pela imagem, assimilando a contribuição da imagem para o seu pensamento. A simbiose que faz interagir poesia, imagem e movimento, apresenta um terreno muito fecundo para as reflexões do presente contexto.

O poema de Ovídio é constituído por episódios cuja narrativa elabora uma tessitura de imagens que tomam como provocação a origem do universo, sugerindo investigações acerca de rotas transversais ligadas às ideias provocadoras de um espetáculo:

Antes do mar, da terra e céu que tudo cobre, | Não tinha mais que um rosto a Natureza: | Este era o Caos, massa indigesta, rude, | E, consistente só num peso inerte. | Das coisas não bem juntas as discordes, | Priscas sementes em montão jaziam | O Sol não dava claridade ao mundo, | Nem crescendo outra vez se reparavam | As pontas de marfim da nova Lua [...]. (OVÍDIO, 2006, p. 1, grifo nosso) 
Num constante fluxo que desliza vigorosamente constitui-se a desordem imposta no conflito instaurado pela ausência da luz. Na tradução do poeta português Manuel Maria de Barbosa l'Hedois du Bocage (1765-1805), o sol aparece em lugar do Titã, e Febe ${ }^{18}$ assume a figura da lua crescente, com suas extremidades pontiagudas; trata-se de uma configuração de natureza poética, já que o autor introduz a lua sem que ela existisse, pois suas fases dependem da relação direta com o sol, que ainda não iluminava o mundo.

Ar, e pélago e terra estavam mistos:

As águas eram, pois inavegáveis.

Os ares negros, movediça a Terra,

Forma nenhuma em nenhum corpo havia,

E neles uma coisa a outra obstava,

Quem em cada qual dos embriões enormes

Pugnavam frio, e quente, úmido, e seco,

Mole, e duro, o que é leve e o que é pesado.

(OVÍDIO, 2006, p. 15-16)

Na condição de verbos ativos, obstar e pugnar indicam a tensão presente na "[in] existência" composta de ares negros, que precedem a introdução da luz, e indica a energia que instalará a vida no planeta. No Livro I, Ovídio (2006, p. 16) trata da transformação do caos em organismo de nova ordem: "[...] Para que a Terra | não fosse desigual em parte alguma, | Por todas a compôs na forma de orbe”. ${ }^{19}$ Ele insere a fábula de Orfeu no Libro (ou capítulo) X da Metamorfosi, que se apresenta como um poema sequenciado num total de 15 libri. Assim como na abertura do mito da criação, o poema se inicia nas trevas:

De rutilantes vestes adornado

Himeneu rompe o ar, à Trácia voa

Lá donde o chama Orfeu, porém debalde.

O deus sim presidiu do vate às núpcias

Mas não levara ali solenes vozes,

Nem presságio feliz, nem ledo rosto.

Sentiu-se apenas crepitar-lhe o facho,

E em vez de viva luz soltar um fumo

18 Ou Phoebe, o termo pode ser compreendido como "brilhante", referindo-se a primeira deusa da Lua na mitologia grega.

19 Orbe, em latim orbis, ou qualquer figura esférica ou circular. 
Tentou co [sic] movimento erguer-lhe a chama.

O efeito foi pior que o mesmo agouro.

(OVÍDIO, 2006, p. 77, grifo nosso)

Convidado por Orfeu para a celebração de sua união com Eurídice, o deus Himeneu $^{20}$ vê sua tocha fracassar e não prover a luz que o júbilo da ocasião demanda, mergulhando em fumaça o ambiente. Uma poderosa imagem anunciadora dos eventos e, portanto, da atmosfera que se aproxima. Na versão usada por Striggio, a heroína morre depois de picada por uma serpente, enquanto passeava acompanhada das ninfas. Após chorar a dor da sua enorme perda, o semideus decide confrontar as sombras das profundezas e trilha os rumos negros do rei das trevas. ${ }^{21}$ (OVÍDIO, 2006) Entoando versos e tocando a lira, faz da música sua força e do seu amor o suporte da resignação, para até mesmo permanecer no Hades, se ali estiver a solução para continuar perto de sua mulher: melhor prisioneiro das trevas do que retornar sem a amada.

O poder da música comove Proserpine (nome de Perséfone, entre os romanos), que intercede a seu favor e convence o marido Plutone (Hades); Orfeu tem de volta a esposa, ganhando o direito de levá-la num triunfal retorno à vida, sob uma condição: “[...] Recebe o trácio Orfeu sua bela esposa | Lei de que para trás não volte os olhos | Enquanto for trilhando o feio abismo, | Se nula quiser a graça extrema". (OVÍDIO, 2006, p. 79) Ora, é uma grave imposição: ter bem próxima de si a mulher amada, suplantando tamanho infortúnio e alcançando imensurável vitória, sem poder vê-la. Orfeu dirige-se para longe das trevas, seguido de Eurídice; a tentação e o desejo de contemplá-la, de confirmar sua presença com a visão, entretanto, levam-no a - já nas fronteiras entre o tártaro e a luz - olhar para trás:

Temendo o amante aqui perder-se a amada,

Cobiçoso de a ver, lhe volve os olhos:

De repente lha roubam. Corre, estende

As mãos, quer abraçar, ser abraçado,

E o mísero somente o vento abraça.

$[\ldots]$

E recai a infeliz na sombra eterna.

(OVÍDIO, 2006, p. 79, grifo nosso)

\footnotetext{
20 Hymeneos, na sua forma grega, era o deus do casamento. Também conhecido como Hymenaeus ou Hymenaios em latim; filho de Apolo e Afrodite.

21 Nota da tradução de Bocage esclarece: “Orco, que corresponde ao grego Hades”. (OVÍDIO, 2006, p. 78)
} 
Orfeu sucumbe à tentação da visão, da luz, e paga por isso, pois, mesmo alcançando a vida, mergulha nas trevas da sua perda. Desrespeitando o acordo, ele vê o objeto da sua paixão pela última vez: Eurídice desvanece, transformando-se numa sombra e sumindo para sempre. Retornando sozinho à superfície, ele mantém inabalável a fidelidade e o amor por Eurídice, alimentando o ciúme e a ira das bacantes, que o matam. Como em grande parte dos temas da mitologia, há versões e interpretações diferenciadas e ambíguas.

\section{L'ORFEO DE MONTEVERDI E STRIGGIO}

Monteverdi e Striggio aceitaram a provocação do mito de Orfeu e Eurídice para criar L'Orfeo. Familiarizado com as imagens fantásticas que permeiam a poesia de Ovídio, o leitor pode elaborar seu próprio ponto de vista sobre a mesma, incorporando os benefícios de tal familiaridade. Aproximar-se da ópera pode contribuir para as trocas que o contato com uma obra de arte promove. Ainda que tal estágio possa incluir flexibilidade para se misturar ao universo particularmente criado pelos autores do libreto e da música, o trânsito pelas Metamorfosi pode contribuir para uma compreensão diferenciada. Tal compreensão pode atuar como alicerce, chama, tempero, como hedusma na construção das imagens na cena. O mito agora funde-se à música e vice-versa: linha melódica, narrativa, diálogo verbal, acento, andamento, registro, volume, som e palavra, todos estes elementos coabitam o mesmo ambiente.

O texto de Striggio, assim como a música de Monteverdi, na condição de respostas estéticas às provocações ovidianas, constituem outro possível caminho. A investigação das relações entre texto e música pode estimular a imaginação de qualquer artista envolvido na construção da cena. Se ele for o iluminador, as imagens passarão por um toque seu, particular, único. A aproximação com a visualidade, já presente na narrativa de Ovídio, pode ser de grande ajuda em seu trabalho.

Parece óbvio que a variedade de fontes disponíveis, além da obra de Monteverdi, propriamente dita, abre diversas vias de interpretação musical da dramaturgia.

O Orfeo de Monteverdi tornou-se uma síntese de formas musicais do Renascimento, tendo o compositor adaptado e estendido madrigais e pastorais para responder às necessidades do seu drama musical, dotando-o de intensa expressividade. [...] | Monteverdi tornou-se também um pioneiro da instrumentação dramática: ele ampliou os recursos da orquestra, percebeu o seu 
incomparável espectro, poder e timbres variados, e reconheceu o seu poder de reforçar a representação dramática. Ele afirmava que teria inventado o tremolo nas cordas e o pizzicato. | o Orfeo de Monteverdi foi a primeira ópera de sucesso; ela representava uma síntese dos elementos teatrais conhecidos como cenografia, dança e balé, canções e baladas, coros nos estilos do madrigal e da pastoral, e recitativos; todos estes elementos foram integrados em uma ópera, uma integração singular de todos os elementos teatrais. ${ }^{22}$ (FISCHER, 2005, p. 20, tradução nossa)

Uma discussão da natureza compósita da arte teatral, sua manifestação como Gesamtkunstwerk, termo alemão para obra de arte integrada ou obra de arte total, deve se iniciar com o estudo do L'Orfeu, música de Monteverdi e libreto de Striggio. Antes do prólogo, o compositor insere uma tocatta, atendendo provavelmente a convenções do período, que demandavam, na corte de Mântua, uma saudação ao duque, fazendo impregnar os metais - trompetes - de uma qualidade marcial, encaminhando para a introdução do prólogo, numa atmosfera mais suave, rotunda. Uma análise mais aprofundada de questões específicas de natureza musical, assim como o estudo das diversas fontes que discutem uma obra de tamanha complexidade, abriria uma digressão no presente trabalho, além de exigir alto grau de familiaridade com questões específicas do campo musical.

Por outro lado, considerando que, dentre as diversas provocações às quais Monteverdi responde para escrever a peça, está incluído o libreto de Striggio, interessa a importância que a dramaturgia ganha, logo no início da história da ópera, em que a apreensão da fábula é condição imprescindível. Assim como a emoção inscrita na peça de Monteverdi, o trabalho de Striggio pode ser sublinhado para dialogar com a crença de que ele, assumindo o papel de dramaturgo, já incorpora a luz, ao elaborar sua obra. O compositor recebeu, então, contundentes provocações originadas pelo texto e respondeu com sua música.

Trata-se de uma ópera, cuja primeira personagem a intervir é a própria Música. Como uma entidade investida de poderes especiais, ela abre possibilidades para a imaginação, provocando os artistas envolvidos na construção da cena:

\footnotetext{
22 "Monteverdi's Orfeo became a synthesis of extant Renaissance musical forms, the composer adapting and expanding madrigals and pastorals to suit the needs of his music drama, and endowing them with an intense expressiveness. [...] | Monteverdi also became a pioneer in dramatic instrumentation: he extended the resources of the orchestra, realized its unrivalled range, power, and varied tone colors, and recognized its power to enhance the dramatic representation; he claimed that the string tremolo and the pizzicato were his own discoveries. | Monteverdi's Orfeo was the first successful opera; it represented a synthesis of existing theatrical elements, such as stage scenic design, dance and ballet episodes, songs and ballads, madrigal-style and pastoral-style choruses, and recitative; all of these parts were integrated into an opera, a singular integration of all theatrical elements."
} 
Eu sou a Música, que com doces acentos

sei tranquilizar os corações exaltados,

e com nobre ira ou com amor

posso inflamar as mentes mais frias

[...]

Com a minha cítara de ouro eu sei

lisonjear e encantar o ouvido dos mortais

e da mesma forma, com a harmonia sonora

da lira do céu, ainda mais envolvo as almas. ${ }^{23}$

(STRIGGIO, 2011, p. 23)

Merece especial atenção a ousadia de Monteverdi, ao escrever uma composição que deseja expressar os poderes profundos e mágicos da própria música. Cabe sublinhar o tema escrito para a Música, repetido em momentos chaves de L'Orfeo, desde aquele que antecede sua entrada propriamente dita, sugerindo aquilo que se conhece hoje como o leitmotiv, que repercutiria em toda a história da ópera, e, de modo decisivo, na obra de Richard Wagner (1813-1883), séculos depois. Burton D. Fischer (2005, p. 20, grifo nosso), cuja obra já foi mencionada, acentua: “L'Orfeo de Monteverdi utiliza muitas tradições que ainda hoje aparecem na ópera: recitativo, arioso, dueto, interlúdios corais e de dança, caracterização musical e continuidade através do leitmotiv". ${ }^{24}$

Donald Jay Grout e Hermine Weigel Williams, autores de A Short History of Opera, comentam e exemplificam:

[...] O prólogo que precede a entrada de Orfeo abre com um ritornello ${ }^{25}$ que é repetido quatro vezes numa versão reduzida depois de cada stanza ${ }^{26}$ e executada integralmente uma vez no final do prólogo. Além disso, Monteverdi traz o mesmo ritornello no fim do Ato IV, conclusão de significante ação dramática - construindo assim um tipo de leitmotiv, sim-

\footnotetext{
23 "Io la Musica son, ch'ai dolci accenti | so far tranquillo ogni turbato core, | et or di nobil ira et or d'amore | poss'infiammar le più gelate menti. [...] lo su cetera d'or cantando soglio | mortal orecchio lusingar talora; | e in questa guisa all'armonia sonora | de la lira del ciel più l'alme invoglio."

24 "Monteverdi's Orfeo utilizes many traditions that still dominate opera today: recitative, arioso, duet, choral and dance interludes, musical characterization, and continuity through leitmotiv."

25 Uma espécie de refrão musical que se repete em uma obra musical de natureza vocal.

26 Versos ou linhas em um poema; um conjunto de linhas que constroem uma unidade métrica básica e recorrente em um poema. Um grupo de quatro linhas em certos exemplos da métrica antiga, na poesia grega e também latina.
} 
bolizando o 'poder da música', a ideia central da ópera [...]. ${ }^{27}$ (GROUT; WILLIAMS, 2003, p. 53, grifo e tradução nossos)

Tal menção ao leitmotiv importa aqui como estratégia para a observação da atmosfera pretendida por Monteverdi. Não somente no que se refere às características musicais do ritornello em si, mas também na decisão do compositor, repetindo-o, nos finais dos atos II e IV, e elaborando uma pulsação de qualidade particular (Figura 13).

No prólogo escrito por Striggio, a Música deixa um alerta do seu poder, cujo eco se manifestará na obra como um todo:
Agora, ao entoar meus cantos
alegres ou tristes,
não se mova uma avezinha entre os ramos,
nem se ouça uma onda nesses regatos
e toda brisa se detenha no seu movimento. ${ }^{28}$
(STRIGGIO, 2011, p. 23, tradução nossa)

No início da ópera, pulsa uma luz cuja qualidade é principalmente subjetiva, que se entrelaça e propõe trocas com as instâncias metafóricas de um arquétipo de tamanha dimensão. Cabe acentuar a ousadia de ambos, ao escreverem texto e música para personagem de tamanha relevância na história da cultura, lembrando que a relação de Orfeu com a música começa quando o próprio Apolo o presenteia com uma lira e, em seguida, as Musas o ensinam a tocar. (GRAVES, 1957)

O texto dramático é construído por Striggio em cinco atos, com diferentes ambientes para a ação - primeiro, segundo e quinto, em lugares na Trácia; terceiro e quarto, nos caminhos e nas profundezas do Hades - oferecendo ao iluminador a possibilidade de elaborar diversificação visual, desde o prólogo, já na transição para o primeiro ato. Todo o libretto, afinal, encontra-se impregnado de visualidade específica, despertando a atenção daquele que se interessa por tal abordagem. Já na abertura do Ato 1, um pastor revela: "Neste dia alegre e afortunado [...]". ${ }^{29}$ (STRIGGIO, 2011, p. 24, tradução nossa) Ficam indicados tempo e atmosfera, o que

\footnotetext{
27 " [...] the prologue to Orfeo opens with a ritornello what is repeated four times in a shortened form after each stanza and once in its original form at the end of the prologue. Moreover, Monteverdi brings in the same ritornello at the end of Act IV, the close of the significant dramatic action - thus making it a kind of leitmotiv symbolizing the 'power of music', the central idea of the opera [...]."

28 "Or mentre i canti alterno, | or lieti or mesti, | non si mova augellin fra queste piante, | Ne s'oda in queste rive onda sonante, | Et ogni auretta in suo cammin s'arresti."

29 "In questo lieto e fortunato giorno [...]."
} 
introduz nova qualidade, trazendo certos índices do ambiente corporificado: é dia, e se trata de um dia específico, um dia de bem-aventurança, num sítio rodeado de bosques, como se pode ler: "[...] Hoje Orfeu tornou-se feliz | nos braços da dela, por quem tanto | nestes bosques ele suspirou e soluçou [...]". ${ }^{\circ}$ (STRIGGIO, 2011, p. 24)

Assim como nas diversas indicações do ambiente, a abertura indica o caminho repleto de imagens que povoam a poesia de Striggio (2011, p. 24, grifo e tradução nossos): "Deixai os montes, | deixai as fontes, | ninfas belas e alegres | nestes prados | com as danças costumeiras | oferecei gracioso vosso belo pé [...]". ${ }^{31}$ Imagens que, além de projetarem a elaboração do ambiente, deixam uma pista significativa para as mudanças na atmosfera, como neste último trecho, quando o poeta provoca: exponham vossos belos pés. Parece possível ligar tal momento à morte de Eurídice. Em seguida, o Coro de Ninfas e Pastores pede a intervenção de Himeneu, invocando um contraste do qual a cultura ocidental se encontra impregnada:

Vem, Himeneu, oh, vem, | Que o teu rosto radiante | Seja qua-
se um sol nascente, | E traga a estes amantes os dias serenos,
|e para longe afaste sempre | os anseios, a dor, os horrores e a
sombra. | [...] Que o sol contemple | Vossas rodas, | Bastante mais
graciosas | Do que aquelas que em redor da lua | Na noite escura,
| As estrelas dançam no céu. ${ }^{32}$ (STRIGGIO, 2011, p. 24-25, grifo e
tradução nossos)

A crença no Sol, na luz como afirmação positiva capaz de vencer a sombra, caracterizada como força negativa, ecoa também na obra de Striggio. Revela-se, portanto, substancial parceria com a visualidade, expressa tanto na música quanto no texto dramático, assim como na estreita relação que qualifica cada um dos aspectos mencionados como agentes decisivos na elaboração da ação, do seu ambiente e da atmosfera. Desde o primeiro ato, que pode ser compreendido como uma celebração do amor entre Orfeu e Eurídice - presentes em cena, numa corporificação do amor - até o ato final, quando ele perde sua amada para as profundezas e para sua incerteza. Evitando o excesso de detalhes, no que se refere às inúmeras provocações deixadas, tanto por Striggio quanto por Monteverdi, podem ser citados alguns trechos, além daqueles já mencionados.

\footnotetext{
30 "[...] Oggi fatto é felice | Orfeo nel sen di lei, per cui giá tanto | per queste selve ha sospirato e pianto. [...]."

31 "Lasciate i monti, | Lasciate i fonti, | Ninfe vezzose e liete. | E in questi prati | Ai balli usati | Vago il bel piè rendete."

32 "Vieni, Imeneo, deh, vieni, | e la tua face ardente | sia quasi un sol nascente | ch'apporti a questi amanti i dì sereni | e lunge omai disgombre | degli affanni e del duol gli orrori e l'ombre. [...] qui miri il sole | vostre carole, | più vaghe assai di quelle | ond'alla luna, | la notte bruna, | danzano in ciel le stelle."
} 
Diversas vezes o poeta traz as relações entre o sol, a lua, as estrelas e suas implicações em luz e sombra, elaboradas como presença nas emoções; o trabalho de qualquer interessado nas questões que envolvem visualidade e cena pode exigir atenção na busca da contribuição das mencionadas relações para o espetáculo, não somente na sua condição de práxis, mas também de pensamento visual.

O primeiro ato revela o contraste entre o infortúnio ao qual Orfeu esteve submetido e a felicidade trazida pela presença de Eurídice. Definindo o sol como rosa do céu e vida do mundo, o semideus pergunta: "[...] ó Sol que tudo envolves e tudo contemplas | no teu movimento sideral, | diz-me, terás visto alguma vez | um amante mais feliz e afortunado | do que eu?"33 (STRIGGIO, 2011, p. 25, grifo e tradução nossos) A resposta para tal pergunta tem grande relevância, pois, segundo Orfeu, o sol é aquele que tudo vê, está munido de absoluta onisciência, tem poderes divinos. Momentos antes do fim do primeiro ato, o coro de ninfas e pastores corporifica a atmosfera na qual a ação cênica se encontra mergulhada: "[...] Pois após as nuvens de chumbo | que trazem no ventre | a furiosa tempestade, que o mundo espanta | vem o Sol e lança mais claros | seus raios luminosos. [...]". ${ }^{34}$ (STRIGGIO apud MONTEVERDI, 2011, p. 26, tradução nossa) Em seguida, um dueto de pastores canta, assentando o ambiente: "E depois do áspero e despido gelo do inverno, | a primavera veste os campos de flores. [...]".35 (STRIGGIO, 2011, p. 26, grifo e tradução nossos)

É notável, portanto, o empenho do libretista em elaborar relações entre ambiente, atmosfera e desejos. O Ato 2 é iniciado num alicerce semelhante, já na sinfonia escrita por Monteverdi, irradiando-se pelo texto e pela música, confirmando a atmosfera de júbilo que emana da felicidade do amante e amado Orfeu. Em toda intervenção, de qualquer que seja a personagem presente na mencionada parte inicial do Ato 2, tais relações são acentuadas de modo consistente. Os bosques, as montanhas, os prados, as árvores, os campos gramados, as águas, as flores, os pomares, as rochas, tudo agora está abençoado e envolto pela bem-aventurança que se origina nos fulgurosos raios de Phoebus. ${ }^{36}$

As emoções que pairam no ambiente são a felicidade, o amor e a fortuna, que sobrepujaram o tormento, a tristeza, a aflição, a pena e o lamento. Mais uma vez,

\footnotetext{
33 "Sol, che'l tutto circondi e'l tutto miri, | dagli stellanti giri, | dimmi, vedestu mai | i me più lieto e fortunato amante?"

34 "Che, poiché nembo rio gravido il seno | d'atra tempesta inorridito ha il mondo, | dispiega il sol più chiaro i rai lucenti."

35 "E dopo l'aspro gel del verno ignudo | veste de fior la primevera e campi."

36 Phoebus Apollo ou Apolo, o brilho reluzente.
} 
Orfeo expressa seu amor por Eurídice e a atmosfera interage com tal sentimento. Um dos pastores sublinha: "Olha, pois, Orfeu, como sorriem | em redor os bosques e os prados! | Prossegue, pois, com tua inspiração dourada | e suaviza o ar neste dia bem-aventurado". ${ }^{37}$ (STRIGGIO, 2011, p. 28, tradução nossa) Em um dia abençoado, poesia e música preenchem o ar de um doce tom, desde o horizonte; repentina e abruptamente irrompe a Mensageira, em um recitativo ${ }^{38}$ no qual Monteverdi apresenta uma contribuição importante, ampliando a função de explicitar o texto, qualificando-o como elemento decisivo para a proposição do dramma per música, incorporando acentuada qualidade expressiva: "Ai, amarga desgraça! Ai, destino ímpio e cruel! | Ai, estrelas injuriosas! | Ai, céu ruim!".39 (STRIGGIO, 2011, p. 28, tradução nossa) Para ela, a existência tornou-se amarga e cruel como resultado da ação de entidades celestes: "A tua amada esposa morreu". ${ }^{\circ 0}$ (STRIGGIO, 2011, p. 29, tradução nossa)

Daí em diante, por todo o ato, a primeira intervenção da Mensageira é repetida por um pastor e pelo coro, que com ela encerram esse momento da ação no qual se toma conhecimento que Orfeo descerá às profundezas, com o intuito de trazer sua amada de volta à vida. Temos, então, uma espécie de divisão do ato, em duas partes, que podem ser compreendidas - cada uma delas - como um crescendo particular, em diferentes direções: a felicidade da primeira metade e o luto da segunda. Na verdade, a primeira atmosfera funciona como uma preparação para o contraste que se estabelecerá na elaboração da segunda parte, numa estratégia definida pela poesia e pela música:

De acordo com a cor sonora dos instrumentos, o universo de Orfeo é dividido em duas partes: uma luminosa e transparente, tendo como base os violinos e as flautas, que evoca o mundo pastoril e da felicidade, e a outra, sinistra e ameaçadora, com instrumentos de sopro graves, sobretudo os metais, invocando o mundo dos mortos. (FRAGA; MATAMORO, 2011, p. 15)

Assumindo tal estratégia, o autor do libreto anuncia, já nas primeiras palavras de Orfeu no ato seguinte, em diálogo com a Speranza: "Escoltado por ti, ó deusa

\footnotetext{
37 "Mira, deh mira, Orfeo, che d'ogni intorno | Ride il bosco e ride il prato. | Segui pur col plettro aurato | D'addolcir l'aria in sì beato giorno."

38 "Parte declamada da ópera, responsável por narrar o desenvolvimento da ação, em complemento às árias, dedicadas à reflexão que contém geralmente uma somatória de sentimentos. Normalmente escrito para uma única voz, o recitativo desenvolve-se para atender mais aos ritmos e acentos do texto do que à riqueza melódica. Se a ária pode ser apreendida como lugar dos sentimentos, no recitativo, a razão e a disputa aparecem."

39 "Ahi caso acerbo, ahi fat'empio e crudele. | Ahi stelle ingiuriose, ahi ciel avaro."

40 "La tua dilleta sposa è morta."
} 
| Esperança, único consolo | dos mortais aflitos, | chegamos à fronteira | destes reinos tristes e tenebrosos, onde jamais um raio de sol penetra [...]". ${ }^{41}$ (STRIGGIO, 2011, p. 32, grifo e tradução nossos) O texto impõe-se como uma obra exemplar: invocando o contraste entre o brilho dos dias afortunados que antecedem a morte de Eurídice e as trevas, as sombras nas quais proliferam choro e tristeza, durante a viagem de Orfeu ao vale dos mortos, põe-se em destaque a presença da luz na construção da ação cênica. Pode-se dizer que o tema central da ópera é a oposição entre luz e sombra. Uma comparação entre a fala de Orfeu, mencionada acima, e a que será mencionada a seguir, demonstra os compromissos que Striggio mantinha com a luz. Na abertura do Ato 2, diz o semideus: "Eis-me aqui, que a vós retorno | caros bosques e rios amados, | vós que sois benditos por este sol, | que as minhas noites transforma em dias [...]".42 (STRIGGIO, 2011, p. 27, tradução nossa)

Ainda que o compositor tenha incluído um baixo entre os quatro níveis de vozes, no coro de pastores já no primeiro ato, a aparição de Caronte ${ }^{43}$ - ele sim, um baixo com destaque solístico - no terceiro ato, corporifica a atmosfera anunciada por Orfeu e já presente na transição entre o segundo e o terceiro atos. Impedido pelo obstinado barqueiro de cruzar as águas escuras de lama e lodo do Estige e do Aqueronte, em direção ao vale dos mortos, o herói emprega o poder da música, toca sua lira e canta a ária que é considerada por muitos o ponto alto musical da ópera em questão:

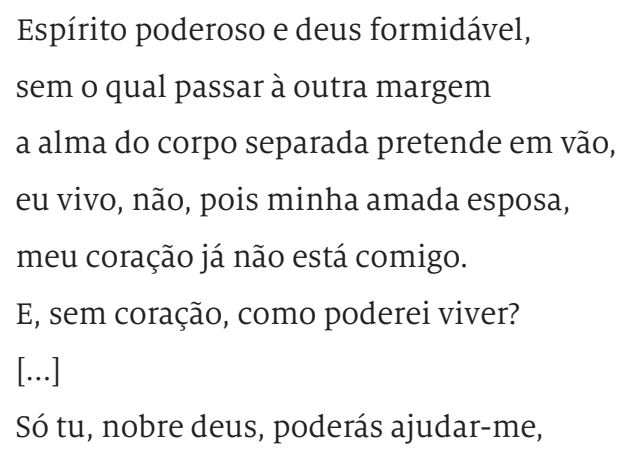

\footnotetext{
41 "Scorto da te, mio Nume | Speranza, unico bene | degli afflitti mortali, omai son giunto | a questi mesti e tenebrosi regni | ove raggio di sol giammai non giunse."

42 "Ecco pur ch'a voi ritorno, | care selve e piaggie amate, | da quel sol fatte beate | per cui sol mie notti han giorno."

43 Em grego, Xápœv - o brilho é um Gênio velho e barqueiro do rio Aqueronte, nas fronteiras do inferno; filho de Érebo e da Noite, tem como função transportar as sombras dos mortos na sua barca escura, atravessando o pantanoso rio e garantindo que os mortos cheguem ao seu destino, o Hades. Caso contrário podem permanecer no rio por muitos anos. Os gregos temiam que eles, então, retornassem à luz. Por isso o barqueiro é recompensado pelos vivos que põem duas moedas na boca - ou uma em cada olho - dos seus mortos, assegurando a travessia. (GUIMARÃES, 1995, p. 98)
} 
E temer não deves, que apenas

De uma cítara de outro

De suaves cordas venho armado,

Contra a qual em vão se insurge a dura alma. ${ }^{44}$

(STRIGGIO, 2011, p. 33, tradução nossa)

Caronte, por sua vez, sucumbe à força do amor e da música:

Muito me agrada, pois,

E me encanta o coração

ó cantor desconsolado,

teu pranto e teu canto [...]. ${ }^{45}$

(STRIGGIO, 2011, p. 34, tradução nossa)

Agora Orfeu tem aberto o seu caminho para a mais profunda região do Hades. E, diante do triunfo da música sobre a vigilância de Caronte, fica cada vez mais configurada a atmosfera de fantasia anunciada desde que o herói decide mergulhar nos abismos para trazer de volta a esposa morta. Alcançando o profundo e escuro vale da morte, ele recebe o apoio de Proserpine, mulher de Plutone, logrando assim a autorização para resgatar Eurídice. Em um momento de tensão e suspense, a fala da dama dos infernos ganha importância especial. Ela diz: "Senhor, esse infeliz | que por estes campos da morte | vem chamando Eurídice [...]”. ${ }^{66}$ (STRIGGIO, 2011, p. 34, tradução nossa)

Qualquer que fosse a personagem incumbida de falar agora, ela diria algo muito parecido com a frase escrita para Proserpine, pois estaria cumprindo a função de elaborar o ambiente e a atmosfera da ação. Como se os autores estivessem respondendo a algo maior que eles, já presente na natureza da práxis cênica, as personagens assumem sucessivamente a função de indicar os ambientes e as atmosferas.

Espíritos no coro do Hades usam expressões como "sombra eterna" e "horríveis cavernas"47 (STRIGGIO, 2011), estabelecendo contrastes com a ação, acentuando o amor que une os senhores do Hades. Proserpine diz: "[...] Bendito seja o dia em

\footnotetext{
44 "Possente spirito, e formidabil nume, | senza cui far passaggio a l'altra riva | alma da corpo sciolta invan presume, | (Ritornello) non viv'io, no, | che poi di vita è priva | mia cara sposa, il cor non è più meco, | E senza cor com'esser può ch'io viva? (Ritornello) [...] sol tu, nobile Dio, puoi darmi aita, | né temer dei, | ché sopra un'aurea cetra | Sol di corde soavi armo le dita | Contra cui rigid'alma in van s'impetra."

45 "Ben mi lusinga alquanto | Dilettandomi il core, | Sconsolato cantore, | II tuo pianto e 'I tuo canto."

46 "Signor, quell'infelice | Che per queste di morte ampie campagne | Va chiamando Euridice, [...].

47 "l'ombre eterne e quest'oribili caverne."
} 
que te agradei, | [...] pois, para minha grande ventura, | pude ganhar a ti, perdendo o sol". ${ }^{48}$ (STRIGGIO, 2011, p. 37, grifo e tradução nossos) Nada pode ser mais grave do que perder o sol, a luz, a visão e o esclarecimento. É como submergir sem forças, afogando-se na alienação em nome do sentimento pelo outro. Somente um amor de dimensão e qualidades incomuns pode justificar tal perda.

Para a mulher apaixonada, dizer ao amado que ele toma o lugar do sol na sua vida é a mais intensa maneira de expressar seu amor. A ação parece descrever curvas que ascendem e descendem, grafadas na música e na dramaturgia. Seguido pela amada no caminho de volta aos prados da Trácia, perseguido pela dúvida, Orfeu tem sua atenção despertada pela música - um som ecoa ao longe - olha para trás e, no mesmo momento, o prazer transforma-se em dor: "Oh, dulcíssimas luzes, posso enfim olhar-vos! | Posso | Mas que eclipse é este, ai de mim, que vos | escurece?". ${ }^{49}$ (STRIGGIO, 2011, p. 38, tradução nossa) O prazer de contemplar os olhos de Eurídice converte-se em eclipse, em escuridão, em "não ver" e, portanto, em dor.

O quinto ato revela o retorno de Orfeu à superfície; agora, contudo, a desgraça está definitivamente instalada e ele descreve a natureza abatida pelo seu infortúnio: “[...] Vós gemestes, ó montes, e chorastes | e vós, rochedos, pela partida do nosso sol, | e eu convosco chorarei para sempre [...]". ${ }^{\circ}$ (STRIGGIO, 2011, p. 40, tradução nossa)

Nos seus passos iniciais, a ópera deixou-se provocar pela tragédia da Grécia Antiga - cuja música não sobreviveu - e, nos casos de Monteverdi e Striggio, trilhou caminhos indicados pela Camerata de' Bardi. Trata-se de uma obra exemplar, no que se refere à função e à presença da luz. Inúmeras ocorrências de expressões e termos como raio, luz, sol, inferno, treva, sombra, eclipse, estrela, céu, escuridão, propõem estreita relação com a imaginação do espectador, provocando-o a vivenciar relações entre a cena, a vida e a luz.

Considerando que a ópera foi escrita numa espécie de fusão do Renascimento com o Barroco, levando em conta a premissa que indica a ópera Eurídice, de Peri, datada de 1600, como traço inicial da música barroca, fica enfatizada a permanência da luz na condição de suporte e motriz para a efetivação da práxis cênica, no momento da afirmação do Dramma per Musica. A abordagem renascentista, motivada pela subversão da cosmogonia medieval, indica um deslocamento do ponto

\footnotetext{
48 "Sai benedeto el di che prai ti piacqui | [..] poi Che per mia ventura | fece aquisto di te, perdendo il sole."

49 "O dolcissimi lumi, io pur vi veggio! | lo pur... | Ma qual eclissi, ohimé, | v'oscura?"

50 "[...] Vuoi vi doleste, o monti, e lagrimaste | voi sassi, al dipartir del nostro sole, | ed io com voi lagrimeró mai sempre, [...]."
} 
de vista de observação da luz, reposicionando o ser humano naquela realidade cuja orientação depende do horizonte artificialmente calculado e projetado na perspectiva, da qual trata o capítulo que se segue. O Barroco católico, por sua vez, prima pela unicidade, como conjunto da forte expressividade das emoções, pela afirmação do sentimento religioso. A relevância da luz para a cena, no entanto, mantém-se firme.

Antes de concluir a abordagem de L'Orfeo, é necessário apontar um importante detalhe: ao final do quinto ato, quando resgatado por Apolo - a quem chama de pai - Orfeu pergunta, no texto originalmente atribuído a Striggio (2011, p. 40, grifo e tradução nossos): "E não verei nunca mais | da amada Eurídice os doces raios de luz?". ${ }^{51}$ A simples presença do termo 'raio' impele a tradução a incluir a luz, numa contundente afirmação da sua presença no imaginário que envolve a obra. Apollo responde: "No sol e nas estrelas | reconhecerás seu belo semblante". (STRIGGIO, 2011, p. 40, tradução nossa) ${ }^{52}$ A tradução pode ter se rendido à relevância da luz ou pode ter acrescentado o termo para garantir maior expressão e empatia. Em ambos os casos, isso se deve à reconhecida importância da luz, uma vez que, sem ela, ambiente e atmosfera seriam inexistentes na práxis cênica.

Configura-se, então, mais um exemplo de acontecimento artístico no qual a ação humana é representada, discutida e/ou interpretada em cena. Elabora-se um ambiente que abriga embates provocados por desejos humanos, estabelecendo uma manifestação artística cujo processo incorpora a luz desde os primeiros passos. O que se modifica é a natureza de cada obra, o pensamento que a suporta ou provoca. A compreensão da práxis cênica grega da Antiguidade, como uma manifestação permeada pela expressão musical, apontou para uma representação encarada como drama, no qual a palavra é cantada e até pontuada com diálogos e narrativa. Com Orfeu, A Camerata florentina de' Bardi inaugura, então, um tratamento espacial da cena, que resulta numa visualidade específica.

Do ponto de vista da música, o tempo de Monteverdi está localizado na primeira década do século XVII, na transição entre o pensamento renascentista e as emoções, a incorporação de grandeza e o movimento, do Barroco. Se alguns estudiosos registram o ano 1600 - com a ópera Eurídice, de Jacopo Peri - como o início do Barroco na música, sabe-se que a expressão artística, cuja denominação se origina no termo português que se refere a uma pérola deformada, ganhou abrangência, incorporando outras formas de arte. As artes visuais, a arquitetura, a

\footnotetext{
51 "Sì non vedrò più mai | de l'amata Euridice i dolci rai?"

52 "Nel sole e nelle stelle | vagheggerai le sue sembianze belle."
} 
pintura, a escultura e as artes cênicas incorporaram tal mentalidade, que se originou na Itália e logo avançou por toda a Europa.

A ópera barroca configurou-se sob o fascínio da simbiose de todas as artes numa única obra. Era uma fantasia utópica, contida no legado do Renascimento que o Barroco levou ao que se acreditava uma concretização triunfal. 


\section{A LUZ NA "ALEGRIA DE VIVER" RENASCENTISTA}

\footnotetext{
A discussão das diferenças entre a tragédia grega e a tentativa italiana de recriá-la pode resultar nas mais diferenciadas abordagens. No presente contexto, deve ser sublinhado um traço principal que distingue a tragédia grega da ópera italiana: esta última foi concebida para ser levada a público em um espaço fechado, que exigia a aplicação de luz artificial, incluindo suas possibilidades de manuseio, e excluindo a luz do sol, enquanto a primeira se servia do sol, como única e ininterrupta fonte de luz, acontecendo a céu aberto, durante o dia.

Na sua condição de práxis cênica, a ópera indicava, portanto, a expectativa de contribuição da luz artificial para o espetáculo. Indícios de tal expectativa já aparecem mais de um século antes da obra de Monteverdi. A investigação de outros documentos, além da dramaturgia e da música, revela, em vários momentos do presente trabalho, não somente relações entre a luz e a cena, mas também questões amplas da cultura, remetendo a fontes com outras origens.
} 
É importante mencionar os relatos do Bispo Abraham, da cidade russa de Ssusdal, sobre eventos cênicos que ele teria assistido em igrejas na Itália, na primeira metade do século XV. Foram preservados por monges russos alguns fragmentos dos seus efusivos comentários sobre a representação da Anunciação ocorrida em 25 de março de 1439, na Igreja Annunziata, e também da Ascensão, em Santa Maria del Carmine, no dia 14 de maio desse mesmo ano, e publicados numa tradução alemã (1877), no periódico Russische Revue. Nagler (1952, p. 41, tradução nossa) comenta:

[...] era apresentada em um andaime [tablado] na nave, e a plateia aglomerava-se ao redor para extasiar-se diante das centenas de luzes que circundavam o trono de Deus, enquanto crianças, paramentadas como anjos, tocavam a música da esfera em pratos, flautas e harpas. Um mecanismo especial controlava a descida do Arcanjo Gabriel. ${ }^{1}$

Giorgio Vasari (1511-1574) publicou em 1550 um conjunto de biografias de artistas italianos, desde Cimabue (ca. 1240-1302?), pintor de Florença - também conhecido como Ceni de Pepi - até Titian de Cadore, o pintor (ca.1487/90-1576), de quem se declarou grande amigo. Trata-se de $A$ vida dos mais talentosos pintores, escultores $e$ arquitetos (Le vite dé piu eccelenti pittori, scultori ed architeti) ou, simplesmente, Vida (Vite). Vasari incluiu a biografia de Filippo di Ser Brunelleschi (1377-1446) e descreveu um espetáculo realizado durante a festa da Anunciação, que teria suplantado em grandeza e beleza a sacra rappresentazione comentada no parágrafo acima, representando uma grande contribuição para o estudo da luz no teatro:

Diz-se que Filippo inventou também o dispositivo para o Paraíso de San Felice na Praça (localizada na mesma cidade) para encenar o mistério, ou mais, a festa da Anunciação, como era costume antigamente em Florença. O dispositivo era verdadeiramente maravilhoso e demonstrava o talento e a habilidade do homem que o criou, pois no alto podia-se ver um Céu cheio de figuras vivas, em movimento, assim como incontáveis luzes, raios que acendiam e apagavam. [...] Filippo instalou um meio globo, como no formato de uma tigela ou bacia de barbeiro virada de cabeça para baixo entre duas das vigas que suportam o telhado da igreja. [...] Na parte interna da base desse meio globo, algumas estruturas de madeira foram colocadas, com dimensão

\footnotetext{
1 "[...] was presented on a scaffold in the nave, and the audience crowded round to marvel at the hundreds of lights which circled the throne of God, while children, garbed as angels produced the music of the sphere on cymbals, flutes and harps. A special contrivance controlled the descent of the Archangel Gabriel."
} 
suficiente para suportar uma pessoa de pé e, também na parte de dentro, mas na altura de um braço, havia barras de ferro. Em cada uma das estruturas [apoio construído com madeira] ficava uma criança, de pé, de aproximadamente doze anos de idade, protegida por uma barra [gancho] de ferro na altura de um braço e meio, de modo que ele [ela] não cairia, mesmo que tentasse. ${ }^{2}$ (VASARI, 1998, p. 141-142, tradução nossa)

O próprio Vasari menciona discussões acerca da autoria do aparato descrito, e não é possível garantir que Brunelleschi o tenha inventado, uma vez que não se tem conhecimento de qualquer desenho (ou projeto) de tal engenho. É importante registrar, entretanto, o papel desempenhado pelo relato de Vasari nos estudos que o sucederam. Se hoje a fragmentação é um princípio importante na elaboração da cena, o texto de Vasari indica uma unidade na qual se pode observar a contribuição da luz, que interage com outros aspectos do evento, em busca de sua totalidade, apontando na direção do modelo das grandes narrativas que encaminhavam sua consolidação naquele momento. A luz configura-se como um elemento decisivo, apresentando respostas às proposições da cena. Fica configurada uma troca ou parceria: a cena exige tratamento visual e a luz responde em contribuições que somente ela pode apresentar.

De acordo com Bergman (1977), os relatos do Bispo Abraham de Ssusdal parecem referir-se a acontecimentos cênicos ainda mais elaborados, apresentando uma visualidade mais espetacular do que aquela concebida por Brunelleschi, usando toda a extensão da nave da igreja, tanto no sentido vertical quanto horizontal. Mil lamparinas, efeitos com fogo, figuras que se deslocam no alto sobre as cabeças dos fiéis/espectadores resultavam num fantástico evento que integrava ação, música e luz em movimento, remetendo ao brilho e ao poder de Deus.

Mais uma vez, é preciso lembrar a quantidade e qualidade da luz com a qual a sociedade daquele período tinha contato cotidiano e imaginar o impacto que tal tratamento visual produzia no público. Para o espectador do período, era um evento muito mais grandioso do que seria para uma plateia da atualidade,

2 "It is also said that Filippo invented the machinery for the Paradise of San Felice in Piazza (located in the same city) in order to stage the mystery play or, rather, the feast of the Annunciation as was customary in the old days at the place in Florence. The machinery was truly marvelous and demonstrated the talent and skill of the man who invented it, for on high a Heaven full of living and moving figures could be seen, as well as countless lights, flashing on and off lightning. [...] Filippo had placed a half-globe shaped like an empty bowl or a barber basin turned upside-down between two of the beams which supported the roof of the church. [...] At its base on the inside edge, certain wooden brackets were placed, just large enough for a person to stand upon, and also inside but at the height of an armslength, there were iron claps. On each of the brackets stood a child of about twelve years of age, secured win an iron clasp one-and-one-half armslengths high in such way that he could not be fallen even if he tried." 
que traz um aprendizado de mais de um século de luz elétrica. Vale lembrar que desde a Exposição Universal, em 1900, em Paris, o Palácio das Luzes (Grandpalais des Champs Elysées) anunciou uma nova era, a era da luz artificial, da luz elétrica. A história trouxe a experiência do cinema, dos artefatos eletrônicos, do processamento digital da imagem, da tecnologia 3D, do LED, e assim por diante. O princípio, entretanto, persiste: a imagem cênica, em movimento.

Outro nome relacionado aos eventos compostos de cena e luz é Francesco d'Angelo (1446-1488) ou Il Cecca, como era também conhecido, citado como escultor, carpinteiro e engenheiro de Florença. Referindo-se a Il Cecca, Nagler (1952, p. 44, tradução nossa) diz: “[...] [a ele] deve ser dado o crédito pelo desenvolvimento técnico do padrão fundamental estabelecido por Brunelleschi [...]". ${ }^{3}$ O relato do Bispo Abraham inclui outro evento assistido no mesmo ano cuja exuberância teria suplantado o resultado do primeiro. Cabe considerar que textos de tal natureza constituem documentação relevante para a avaliação da força que as relações entre a luz e o espetáculo ganham no período em questão.

Incentivado pelo seu grande amigo Donato de Niccolo Bardi (Donatello, 1386-1466), com quem compartilhava o interesse pela arquitetura e pelas artes da Antiguidade, Brunelleschi viajou para Roma com o intuito de pesquisar métodos de engenharia e construção nas edificações e ruínas da Roma Antiga. Quem se interessar pela história do design pode descobrir que o mesmo Filippo Brunelleschi aplicou na construção da cúpula da Igreja Santa Maria Del Fiore (1420-1434) soluções que já apontam para a compreensão moderna de design, elaborando um processo que partiu de um conceito particular para conceber e planejar detalhadamente a cúpula. Assim, ele pode ter criado um processo hoje aplicado como prática comum na atividade dos arquitetos e designers, de um modo geral.

O Quattrocento na Itália não resistiu e incorporou a cena ao seu universo, interagindo com a postura renascentista, desde mesmo o rigor "monocular" perspectivista, proposto por Brunelleschi, em pesquisas desenvolvidas já na primeira década do século XV e aplicadas também no teatro. Tal rigor se efetivava na aplicação do ponto de fuga disposto no eixo da imagem, no equilíbrio simétrico regulador, assim como na disciplina do contexto cromático. Desse modo era construída uma imagem constante, absolutamente calculada e controlada, pensada.

Tais procedimentos podem ser observados no trabalho de artistas como Masaccio [Tommaso di ser Giovanni di Mone Cassai (1401-1428)], principalmente no monumental afresco A trindade [La trinità (317 X $617 \mathrm{~cm})$ ], elaborado entre 1425 e 1428,

3 "[...] must go the credit for a number of technical improvements on the fundamental pattern that Brunelleschi established [...]." 
na igreja Santa Maria Novella, em Florença. O equilíbrio simétrico instala a composição, na qual as personagens representam valores visuais precisamente calculados. Os conceitos de área e massa, aliados a proporção, matiz e volume, são aplicados para promover a simetria desejada, e constituem inovações importantes. Deve ser observada, ainda, a ênfase da triangularidade na composição (Figura 14). Apesar da relativa escassez de informação sobre o homem Tommaso di ser Giovanni, ${ }^{4}$ a despeito da vida muito breve e de uma obra construída em apenas onze ou doze anos, nela se reconhece um marco do discurso visual perspectivista. ${ }^{5}$

Os conhecidos laços de amizade que Masaccio mantinha com Brunelleschi podem ter causado influência em seus primeiros estudos da perspectiva. Em O pagamento do tributo [Il pagamento del tributo $(599 \times 260 \mathrm{~cm})$ ], um afresco que integra o políptico ${ }^{6}$ da Capela Brancacci, na igreja Santa Maria del Carmine, em Florença, elaborado entre 1425 e 1426 (Figura 15), registra-se uma referência importante para o estudo da luz como um problema central da cena. Quando comparada à simetria de La Trinità, mencionada acima, o afresco $O$ pagamento do tributo demonstra a atitude renascentista. Masaccio retrata o evangelista Mateus de modo revolucionário para sua época, enfatizando a complexidade e a contradição do seu caráter: antes de se tornar apóstolo, ele teria atuado como coletor de impostos. o pagamento do tributo aparece como um dos primeiros exemplos da representação da personagem complexa, mais tarde tratada por Victor Hugo (1988), no prefácio de Cromwell, quando se refere à personagem como um ser heterogêneo, múltiplo, e composto de todos os contrários.

A pintura de Masaccio é provocada pela seguinte passagem bíblica:

${ }^{24}$ Tendo eles chegado a Cafarnaum, dirigiram-se a Pedro os que cobravam o imposto de duas dracmas e perguntaram: Não paga o vosso Mestre as duas dracmas? ${ }^{25} \mathrm{Sim}$, respondeu ele. Ao entrar Pedro em casa, Jesus se lhe antecipou dizendo: Simão, que te parece? De quem cobram os reis da terra impostos ou tributos: dos seus filhos ou dos estranhos? ${ }^{26}$ Respondendo, Pedro: Dos estranhos, Jesus lhe disse: logo, estão isentos os filhos. ${ }^{27}$ Mas, para que não os escandalizemos, vai ao mar, lança o anzol,

\footnotetext{
4 O apelido Masaccio pode ter sua origem na aparência do jovem pintor, já que o sufixo accio pode se referir ao sentido de feio, ou grande.

5 Esse pensamento, encaminhado desde Agatharcus de Samos (século V a.c.) - cujo tratado sobre perspectiva não sobreviveu, mas é mencionado por Vitruvius - reapareceu em Roma, repercutiu em Giotto (1266-1337), tornou-se objeto de estudo em Brunelleschi, figurou como item importante na obra Della Pittura, de Leon Batista Alberti (1404-1472), e acompanha a expressão da visualidade até hoje.

6 Do grego polýs - "numeroso" + ptýx "dobra; prega". O políptico é um retábulo que integra quatro ou mais painéis fixos ou móveis, formando um conjunto de imagens com o mesmo tema ou assunto.
} 
e o primeiro peixe que fisgar, tira-o; e, abrindo-lhe a boca, acharás um estáter. Toma-o e entrega-lhes por mim e por ti. (BÍBLIA, 1999, p. 1126)

Trata-se, portanto, da efetivação de mais um milagre de Jesus Cristo, um momento de grande apelo místico. Masaccio surpreende, no entanto, já no seu modo inovador de compreender (e representar) a figura humana e, como Vasari acentua: "[...] no seu trabalho Masaccio buscava frequentemente criar figuras vivas, indicando movimentos convincentes e similaridade com o real".7 (VASARI, 1998, p. 103, tradução nossa) A busca pela materialização das personagens, impregnando-as de vida e conexão com a realidade, pode ser observada no gesto de Cristo, assim como no Pedro claramente desaprovador do constrangimento imposto ao seu mestre, com pequenos detalhes que diferenciam o seu gesto daquele de Jesus. As expressões de cada um dos 12 apóstolos demonstram, também, um tratamento que procura revelar as figuras retratadas como personalidades reconhecíveis. Daí, observando o movimento de Masaccio na busca de materializar as personagens diante daquele(a) com quem compartilha, na obra impressiona o interesse pela anatomia revelado no(s) cobrador(es) de impostos, os quais, usando trajes curtos, expõem os membros inferiores que recebem muita atenção do pintor e alcançam eficácia na representação da musculatura e na indicação de postura e/ ou movimento.

O mesmo caminho será particularmente percorrido em $O$ batismo dos neófitos (Battesimo dei neofiti), situado à direita ainda na Capela Brancacci, cujas imagens - principalmente do jovem sendo batizado e daquele à espera do sacramento revelam compromisso com a personificação das figuras, tornando-as críveis na condição de seres humanos (Figura 16).

Ademais, Masaccio aplica em $O$ pagamento do tributo o rigor renascentista mencionado, contando a história anunciada no seu título, de modo peculiar, com predominância radical da horizontalidade e acentuando a qualidade épica, narrativa. Em primeira instância, apreende-se a firmeza da distribuição das personagens como uma massa composta por elementos verticais precisamente calculados. O olhar de cada uma das figuras coincide ou está tão próximo da linha do horizonte, a ponto de não ser possível notar o pequeno deslocamento vertical, senão através de uma observação minuciosa, dado o compromisso visual que o reduzido deslocamento impõe. Uma exceção é acentuada por Masaccio, ao revelar para o observador um homem à esquerda, numa postura casual, à beira d'água,

7 "And in his work Masaccio constantly tried to create the most life like figures with a fine animation and similarity to the real." 
depois de deixar de lado sua toga: é o "primeiro" simão, que recolhe do peixe a moeda a ser destinada ao tributo, como orientara Jesus.

Se a história a ser contada refere-se ao mencionado pagamento de uma taxa, o pintor concentra esforços em tal direção. Pedro, que recebe a tarefa de atender a exigência dos cobradores de impostos, reaparece ao lado de Jesus, no grupo disposto no centro relativo da imagem, onde se observa a presença do coletor. O braço direito estendido de Jesus Cristo indica o gesto na direção de Pedro e da ação da pesca. A narrativa é concluída com o cumprimento da obrigação cívica pelo apóstolo, à direita, reproduzindo graficamente o seu primeiro gesto, ao recolher as moedas do peixe, com uma diferença: para remeter ao triângulo configurado pelos seus braços na introdução, Masaccio usa o braço do coletor que recebe a taxa.

Cristo encontra-se curiosamente fora do centro, deslocado para a esquerda do observador numa decisão que parece desconstruir a hierarquia comum nas representações de temas religiosos à época. Isso revela, no entanto, uma solução formal que qualifica o centro visual da imagem, não meramente geométrico, estabelecendo um contraponto com as duas figuras à direita. Observando a imagem com atenção percebe-se que as leis da perspectiva decidem o impasse uma vez que o filho de Deus atrai o ponto de fuga, como se para ele tudo se encaminhasse e nele se originasse.

Ainda assim, em outras instâncias, a obra demonstra o enfoque apontado por Vasari (1998) e mencionado acima, quando o pintor parece emprestar uma atmosfera de casualidade ao evento, criando uma relação área/massa na qual o primeiro Simão - à beira do lago - constitui-se como o flash-forward.$^{8}$ O grupo constituído por Cristo, pelos apóstolos, aos quais se junta o cobrador, de costas, desenvolve a história, ainda que narrando o passado. Repetindo-se, como uma personagem desdobrada, o derradeiro Simão surge diante do coletor de tributos, à direita, concluindo a narrativa. À frente dos dois últimos, numa indicação sutil de contraplano à direita, Masaccio dispõe uma estrutura vertical que praticamente aponta, dirigindo o olhar. Tratam-se, portanto, de três instâncias temporais abordadas com o intuito de trazer o observador para a trama que sustenta a obra, com um tratamento que pode ser relacionado à estrutura do tríptico. ${ }^{9}$

8 Um artifício ou estratégia literária ou cinematográfica, no qual a sequência cronológica de eventos é interrompida para introduzir um evento futuro.

9 Obra de pintura, desenho ou escultura, composta de três painéis: um, central e fixo, e os outros dois, laterais e móveis, ligados ao primeiro por dobradiças ou gonzos. As partes laterais podem dobrar-se sobre a parte central. (HOUAISS, 2009) 
O gesto do pagamento, à direita, remete geometricamente ao vértice do triângulo, também revelado nos braços do Pedro às margens do lago, e o tratamento cromático revela também grande controle do artista: túnicas e togas em púrpuras, azuis e amarelos, representam massas distribuídas com maestria, para atuar no equilíbrio assimétrico que regula o desejo de tornar a cena "real", humana, a despeito das auréolas identificadoras das santidades representadas. Pode-se compreender o último apóstolo à esquerda, com sua toga num verde de grande luminosidade, como uma força visual a interagir com o cobrador, de costas, cuja túnica curta, na família dos vermelhos, expõe os membros inferiores e constitui um acento visual.

Fica estabelecido um limite para aquela unidade narrativa, cujo centro é Jesus Cristo. Aliás, o traje de Cristo atua como uma moldura particular, quando se observam as áreas definidas pelas relações entre a toga azul e a túnica púrpura; a visualidade da cena em si é determinada, afinal, pela luz que revela a cena, projetada da direita. Ela estabelece compromissos entre aqueles corpos e seu ambiente através de sombras persistentes, sempre dispostas na mesma direção, à esquerda dos obstáculos (dos corpos), definindo o lugar de cada um naquele universo fisicamente instituído.

O pintor procede como um lighting designer que elabora a composição revelada em cena. Obviamente o artista não pinta, por assim dizer, um único quadro de um filme imaginário, sua obra não se refere a um momento estático, congelado. A imagem aparentemente imóvel está organicamente ligada ao acontecimento que a antecede e, simultaneamente, invade o espaço daquilo que ainda não aconteceu.

A relação entre as personagens e o ambiente é uma marca inovadora, uma vez que texturas, abordagem tridimensional das figuras, assim como múltipla narrativa já aparecem no gótico, numa extensão relativa, em certas obras. É necessário lembrar, contudo, as personagens destituídas de peso físico, libertadas da gravidade, flutuantes, alongadas, luminosas e transcendentes, que povoam as artes visuais, desde a pintura medieval até o gótico que se propaga pela Europa no Quatrocento. Quando aplicam a tridimensionalidade, o movimento e a superposição ou entrelaçamento de tramas, operando não somente o flash-back, ${ }^{10}$ mas também o flash-forward, tanto a práxis cênica quanto o cinema estão aplicando princípios já presentes em obras como Il pagamento del tributo - exemplo dentre muitas outras.

10 Um artifício ou estratégia literária ou cinematográfica, no qual a sequência cronológica de eventos é interrompida para introduzir um evento do passado. 
Há outro aspecto fundamental para a aproximação com o discurso poético-visual da obra, que interage com a instância cultural na qual se instala: por um lado, as auréolas revelam figuras que ocupam um estágio diferenciado na crença católica, figuras acima da objetividade do real; por outro, o artista representa as mesmas figuras com o claro desejo de torná-las críveis, repletas de materialidade. O que pode parecer uma contradição sugere uma tensão dinâmica e exemplar que entrelaça a convicção humanista do Renascimento e a espiritualidade religiosa da narrativa.

Essa religiosidade permeia também a visualidade da cena até o terço final do século XVI, principalmente durante os festivais da cidade de Florença. Bergman descreve o tratamento da "visão celestial" que se tornou grande apelo para o público - uma mixagem de temas que impregnavam as tramas de um intrincado brilho peculiar -, incorporando decisivamente a luz artificial na sua configuração, e afirma: "[...] no teatro italiano dos principados e das academias humanistas do século XVI foram efetivados experimentos avançados na luz para a cena, que se constituíram na base para todo o seu desenvolvimento futuro"."1 (BERGMAN, 1977, p. 40, tradução nossa)

O espetáculo Il paradiso, realizado em 1490, como homenagem do Duque de Mântua à sua esposa Isabela de Nápoles, aconteceu em um estupendo dispositivo cênico elaborado por Leonardo da Vinci (1452-1519). Assim como da Vinci, também outros artistas integraram tecnologia e inventividade na elaboração de eventos que seguem as tendências traçadas por Brunelleschi. Nota-se, contudo, uma diferença: a cena desloca-se da Igreja e dos seus temas, integrando-se ao ambiente dos palácios, deslocando o esplendor da glória de Deus para um plano secundário e prestando homenagens seculares, para entreter a nobreza italiana. Bergman salienta:

A visão celestial tornou-se uma tradição viva nascida durante o século XVI, tanto no teatro eclesiástico quanto naquele secular realizado na corte. Nas novas peças escritas naquele período inspiradas em temas da mitologia, os humanistas letrados fizeram o Olimpo da Antiguidade invadir o Paraíso Cristão, fizeram Júpiter, como no Il Paradiso de Leonardo da Vinci, substituir Deus Pai em um Céu profusamente iluminado, fizeram cupidos e divindades flutuar em suas bigas, ao invés de Jesus Cristo. ${ }^{12}$ (BERGMAN, 1977, p. 40, tradução nossa)

11 "[...] in the 16th century Italian theatre at the princely courts and in the humanistic academies, advanced experiments were made in stage lighting which were to form the basis of the entire future development."

12 "The celestial vision became a living tradition borne during the 16th century both by the ecclesiastical and the secular theatre attached to courts. In newly written plays with mythological motifs, the learned humanists made 
O poeta Bernardo Bellincioni (1452-1492), no prefácio escrito para o poema dramático Il Paradiso, diz que o evento teria recebido tal título devido à engenhosidade e espetacularidade das soluções de Leonardo, incluindo os sete planetas que giravam durante o espetáculo. De acordo com uma carta anônima: “[...] o Paraíso tinha a forma da metade de um ovo cujo interior era inteiramente coberto com ouro e [...] onde havia uma grande quantidade de velas cintilando como estrelas". ${ }^{3}$ (ANÔNIMO apud BERGMAN, 1977, p. 39, tradução nossa) Leonardo projetou um paraíso que incorporava os sete planetas, assim como os signos do zodíaco, que resplandeciam. Tratava-se de adereços translúcidos aplicados à cenografia, atrás dos quais eram dispostas velas que revelavam fantásticos efeitos, demonstrando não apenas o uso de fontes visíveis de luz artificial - como as estrelas que brilhavam e refletiam na superfície brilhante da cúpula - mas também a luz dos signos do zodíaco, que eram planejados de modo a incorporarem o brilho das velas.

A presença de Leonardo da Vinci na discussão, considerando seu espírito investigativo e pioneiro, caracteriza o século XVI como um momento novo e crucial para a compreensão da luz na sua condição de aspecto determinante para o espetáculo. Bergman (1977, p. 39, tradução nossa) chama a atenção para um provável engano em relação a certos desenhos de Da Vinci: "Alguns desenhos de Leonardo são ligados a essa performance; pesquisas mais recentes comprovaram que, muito provavelmente, esses esboços se referem a uma performance do poema dramático de Poliziano, Orfeo". ${ }^{44}$ Angelo Ambrogini, ou Poliziano (1454-1494), foi um poeta de Florença que reviveu o latim, na Renascença, e escreveu estudos sobre Virgílio (ca. 70 a.c. - 19 a.c.). Ainda que seja importante para o pesquisador estabelecer a relação entre os desenhos e um ou outro evento, deve ser sublinhada a contribuição de Leonardo da Vinci que, como se pode especular, dado o seu interesse pela óptica, pelos princípios visuais, ele certamente efetivou uma aplicação exemplar da luz.

Num certo sentido, tratava-se da mesma abordagem da luz encaminhada por Brunelleschi, com técnica semelhante, incluindo a aplicação da mecânica. Ainda que as fontes visuais e gráficas, referentes a manifestações cênicas do século XVI

\footnotetext{
the Olympus of Antiquity invade the Christian Paradise, made Jupiter as in Leonardo da Vinci's II Paradiso, replace God the Father in a brilliantly lit Heaven, made cupids or deities float on their chariots instead of Jesus Christ."

13 "[...] the Paradise was shaped like half of an egg, the inside of which was entirely covered with gold, and in its interior there was a large number of candles twinkling like stars."

14 Esses desenhos aparecem no Codex Arundel c. $1490-c .1518$ (um conjunto de manuscritos ilustrados sobre diversificados assuntos, como arquitetura, geometria e incluindo o célebre mecanismo para respiração subaquática). Tradução: "Some sketches by Leonardo were supposed to be connected with this performance, but later research has proved that, in all probability, these sketches refer to a performance of Poliziano's dramatic poem Orfeo."
} 
sejam muito raras, certos documentos apontam para um profundo interesse nos mais diversos aspectos da luz, naquela época. Não apenas em eventos da nobreza, incluindo casamentos e jubileus, mas também nos intermezzi apresentados entre os atos de espetáculos (em sua maioria eram compostos de material da dramaturgia romana antiga), assim como entre os discursos e pratos principais de banquetes. Há relatos de interferências que mencionam danças nas quais o uso virtuoso de tochas e velas deslumbrava o público. O fascínio pelo brilho do fogo, da luz, seja no texto de Ésquilo, na práxis cênica eclesiástica ou já no Renascimento, determinava a assertiva visual - a visualidade - dos espetáculos.

Os eventos cênicos renascentistas mergulharam profundamente em tal tendência, multiplicando os efeitos e os fogos de artifício popularizados a partir de então, desde o crescente intercâmbio com a China e o Japão. Bergman (1977, p. 46, tradução nossa) menciona o festival ocorrido em Florença, em 1579: "O que foi talvez o mais brilhante festival de luz da Renascença [...] de acordo com o relato das núpcias do jovem Francesco dei Medici com a estonteantemente bela jovem veneziana, Bianca Capelo". De acordo com relatos produzidos por Gualterotti (Raffaello Gualterotti, de Florença, 1543-1639), em livro publicado em 1579, com gravuras de Accursio Baldi e Bastiano Marsilli, as festividades apresentaram efeitos com "uma luz miraculosa" (Figuras 17 e 18). Bergman (1977, p. 47-48, tradução nossa) comenta os relatos:

Tanto a luz direta de todas as fontes em diferentes níveis, quanto a luz refletida do material de seda e joias brilhantes dos trajes deram o testemunho dessa intensa sensação de luz, do sentimento de alegria e bem-aventurança. O pátio do palácio foi transformado em um salão de festas preparado para receber concursos os quais, na sua concepção teatral com várias contribuições de luz, dotava a iluminação de vivacidade e mobilidade. As gravuras que ilustram os relatos de Gualterotti sobre a festa dão apenas uma distante ideia da sua pompa. Eles são, como as xilogravuras de Serlio, um esplêndido exemplo para mostrar que as imagens precisam ser 'iluminadas' pela nossa imaginação visual. ${ }^{15}$

Para compreender a busca pelo esplendor, alguns estudiosos acentuam a limitada oferta de luz artificial, àquele período, em um cotidiano no qual a vida mergu-

15 "It was both the direct light from all the sources at different levels and the reflected light of the silk material and brilliant jewels of the costumes that gave the eyewitness this intense sense of light and joyous feeling of bliss. The palace courtyard had been converted into a festival hall prepared to receive pageants which, in their theatrical design with numerous contributions of light endowed the lighting with dynamic life and mobility. The engravings that adorn Gualterotti's feast account do give a faint echo of the pageantry. They are, like Serlio woodcuts, a splendid example that goes to show that the pictures need to be 'illuminated' in our visual imagination." 
lhava em profunda escuridão, tão logo anoitecia. Contava-se apenas com velas e, quando se tinham recursos, com lamparinas a óleo e tochas, para prover luz nos ambientes fechados. Deslocar-se na espessa treva da noite era uma aventura que exigia de cada ser humano uma fonte de luz artificial, portável, individual. Nobres levavam consigo um ou mais servos para o desempenho da função.

Há relevantes correspondências que podem ser abordadas para sublinhar a abrangência perceptiva humana. No que se refere à audição, para lembrar a sensível diferença entre o nível de ruído experimentado pelo homem renascentista e aquele que hoje se experimenta no cotidiano, pode-se traçar uma analogia com a música. É possível conjecturar acerca das diferenças entre o ser humano (pós) moderno, (em contato com novos ruídos e com o incremento do volume dos aparelhos eletroeletrônicos que progressivamente "ensurdecem" boa parte das pessoas, e com a especificidade dos instrumentos musicais, hoje em dia), e os renascentistas-barrocos. Transportado ao século XI, um espectador da atualidade estranharia um evento musical. Mesmo um expert em música ouviria algo bem diferente daquilo que outro, vivendo naquele século, perceberia. O ser humano moderno acostumado à Escala Temperada, com ajustes de pouco mais de uma dezena de semitons no espaço de oitava, habituado a intervalos radicalmente regulares - ou seja, o intervalo entre o C e C\# é igual àquele entre C\# e o D - estranharia uma afinação naturalmente mais flexível com a qual o ouvido do ser humano da Idade Média estaria familiarizado.

O grau de visibilidade dos espetáculos representava uma permanente preocupação, para assegurar o interesse do espectador, acomodado em uma plateia também iluminada, remetendo aos espetáculos diurnos em praça pública. Enquanto o público permanecia de pé na orchestra, durante todo o espetáculo, e o centro era reservado para as autoridades que tinham o privilégio de contemplar o cenário do ponto de vista ideal: o centro que permitia a relação geometricamente calculada pela perspectiva.

Pode-se, então, levar em conta a importância da elaboração de espetáculos capazes de seduzir e surpreender seus espectadores, o que impulsionava os artistas na elaboração de uma espetacularidade que celebrasse a vitória da luz sobre as trevas, a materialização do brilho da glória de Deus já acentuada por Tertuliano e, no Renascimento, assim qualificada por Gösta M. Bergman (1977, p. 44, tradução nossa): “[...] luz não apenas como símbolo da onipenetrante claridade de Deus, 
mas do ampliado senso de vida da Renascença em si. Essa alegria de viver era refletida no esplendor dos reluzentes festivais culturais dos principados". ${ }^{16}$

A discussão desse momento na história da contribuição da luz para a cena torna relevante sublinhar: no período que liga Brunelleschi a Leonardo devem ser levadas em conta não somente as festividades, na corte e na igreja, mas também as pesquisas realizadas pelas academias renascentistas a respeito do espaço clássico e helenístico do teatro.

Cada um dos períodos comentados deixou legados que, observados com alguma atenção, revelam a gradativa transfiguração dos espetáculos, em crescente interação com a luz.

\section{OUTROS RUMOS PARA O PENSAMENTO VISUAL DA CENA}

Alguns relatos acerca da atividade teatral na Itália no final da segunda metade do século XV indicam o acentuado interesse pela Antiguidade, o que repercutiu em numerosos estudos nas mais variadas áreas das artes cênicas. De acordo com Allardyce Nicoll, ${ }^{17}$ principalmente as cidades de Roma, Florença e Ferrara produziram espetáculos que reforçaram a tendência. Nicoll informa que a Academia Romana produziu espetáculos com tragédias de Sêneca e, pelo menos, uma comédia de Plauto, organizados por Julius Pomponius Laetus (1425-1498). Ele acrescenta que os espetáculos apresentavam muitas experimentações, inclusive no que se refere à luz, como ocorreu em Amphituo (1487), no qual foi usado um paraíso com muitas estrelas, entre outros artefatos.

Espaços teatrais improvisados apresentavam palcos de dimensões variadas, com o público acomodado numa espécie de cávea, ${ }^{18}$ sobre a qual se estendiam coberturas, como um toldo ou lona de circo, similar ao velum ${ }^{19}$ da Roma antiga. Isso pode ter acontecido em praças e também no interior de palácios, como também menciona Allardyce Nicoll, no mesmo texto e página. No seu entendimento, tais eventos revelam as bases da cena renascentista, o que faz deles fontes importantes.

\footnotetext{
16 "[...] - light not as a symbol of all-pervading clarity of God, but of the enhanced sense of life of the Renassaince itself. This joy of living was reflected in the splendour of the sparkling festival culture of the princely courts [...]."

17 Estudioso inglês e professor da Universidade de Yale.

18 Ou theatron, em grego: local destinado ao público.

19 Uma espécie de cobertura, em tecido.
} 
A pesquisa da informação visual sobre o momento é uma aventura em busca de algo inexistente ou raríssimo, devido à escassez de documentação. Num esforço para reduzir tal lacuna, pode-se usar como importante referência a edição francesa da dramaturgia de Terêncio (Publius Terentius Afer, 195/185-159 a.c.), publicada em Lyon, na França, em 1493, por Johann Trechsel, e em Veneza, em 1497. Nicoll acentua que as descrições de espetáculos do período devem ser estudadas com atenção, uma vez que em tais documentos podem ser encontradas as bases do teatro renascentista. A publicação da obra de Terêncio traz, em sua opinião, evidências relevantes:

[...] cada peça é ilustrada por uma série de xilogravuras mostrando vários episódios da trama. [...] o estudo cuidadoso revela que elas devem ter sido tiradas diretamente de produções das peças. A indicação principal deste fato está no próprio agrupamento das xilogravuras. Uma referência à Fig. 72 mostrará que o cenário é constante em toda a comédia ilustrada. Ele se constitui de uma parede de fundo composta por cinco pilares simples que apoiam quatro arcos circulares, sendo os espaços entre as colunas fechados por cortinas que podem ser abertas, como se pode ver na segunda xilogravura na Fig. 72, e atrás das quais se encontram pequenos espaços com janelas ao fundo (primeiras xilogravuras na Fig. 72). Cada compartimento indica um lugar independente, ou, para ser mais exato, denota a casa (domus ou mansion) de uma das personagens da peça [...] identificada abaixo de cada um dos quatro arcos [Figuras 19, 20 e 21]. ${ }^{20}$ (NICOLL, 1927, p. 82-83, tradução nossa)

A publicação da obra de Terêncio, com 159 gravuras, juntamente com a edição de Johann Grüninger, publicada em latim, no ano de 1496, e em alemão, em 1499, representam um empreendimento notável, de acordo com Füssel:

As comédias de Terêncio [...] circularam na Alemanha depois de 1470, com o apoio de Johann Mentelin. Johann Grüninger (14551533) trouxe uma edição latina em 1496 e em 1499, um Terêncio em alemão ricamente ilustrado (15431 e 15434). Este último foi

\footnotetext{
20 " [...] each play is adorned with a series of woodcuts showing various episodes in the plot. [...] careful study reveals the fact that they must have been taken directly from actual productions of the plays. The chief indication of this fact lies in the grouping of the woodcuts themselves. A reference to Fig. 72 will show that throughout the particular comedy there illustrated the setting is constant. This setting consist of a back wall composed of five simple columns supporting four round arches, the spaces between the columns being closed by curtains, which can be drawn as is shown in the second woodcut in Fig. 72, and behind which are tiny rooms with rear windows (firstwood cuts in the Fig. 72). Each compartment denotes a separate locality, or, to be more exact, denotes the house (domus or mansion) of one of the characters in the play [...] being written below the four arches."
} 
precedido por outro com 159 xilogravuras impressas em Lyon em 1493, por Johann Treschel (ca. 1498), que representa um feito notável na arte francesa do livro (5424). A edição de Grüninger é de grande importância não só pelo seu texto crítico, mas também para a história da imprensa, assim como para a história do figurino teatral e do teatro em si. A xilogravura na primeira página (ver prancha 28) mostra, pela primeira vez, um 'palco contemporâneo para a obra Terêncio', e as ilustrações dos cenários em toda a sua extensão antes de cada peça retratam personagens da literatura dramática, pela primeira vez na história da ilustração de livros. ${ }^{21}$ (FÜSSEL, 2003, p. 77-78, tradução nossa)

A busca pela acuidade na representação gráfica da cenografia revela significativos indícios da relação entre o pensamento ocidental moderno que começava a ser delineado e o novo discurso visual que o integrava. Isso aponta para uma atitude efetivada algumas décadas mais tarde, já no século XVI: o progressivo incremento de experimentos técnicos nos espetáculos, que já haviam aparecido na práxis cênica patrocinada pela Igreja Católica, expandiu-se no último quarto do século e alcançou a espetacularidade produzida fora da Igreja.

As dinâmicas relações entre a luz artificial e a cena apresentavam, então, um novo estágio e incorporavam influências decisivas. Cabe acentuar: obras da antiguidade - como os trabalhos de Vitruvius e Aristóteles -, as dramaturgias grega e romana, além da difusão recente da perspectiva linear aplicada em conjunto com o surgimento das convenções do espaço cênico implantado em uma edificação coberta e fechada, impondo a luz artificial e sendo conhecida mais tarde como cena italiana ou palco italiano. Parece óbvio que diversificados comportamentos espetaculares, realizados antes do momento em questão, haviam aplicado a luz artificial, como já foi dito. O Renascimento, contudo, introduz possibilidades técnicas vinculadas à luz artificial que contribuem para proposições estéticas, inclusive teatrais. Assim como Leonardo Da Vinci, outros artistas da visualidade do período trabalharam nos espetáculos, por exemplo, Andrea Mantegna (1431-1506). De acordo com Nicoll, podem ser citados os espetáculos apresentados

\footnotetext{
21 "The comedies of Terence [...] were circulated in Germany after 1470 through Johann Mentelin. Johann Grüninger (1455-1533) brought out a Latin edition in 1496 and in 1499 a richly-illustrated German Terence (15431 and 15434). This last was preceded by a Terence with 159 woodcuts printed in Lyons in 1493 by Johann Treschel (d. 1498), which is notable achievement in French book art (15424). Grüninger's edition is of great importance not only for its critical text and in the history of printing, but also in the field of theatrical and costume history. The woodcut on the title page (see plate 28) shows for the first time a contemporary 'Terence stage', and the full-width stage settings at the head of each comedy depict dramatic characters for the first time in the history of book illustration."
} 
em fevereiro de 1501, na cidade de Mântua, segundo a descrição de Sigismondo Cantelino:

Havia no cenário tecidos de ouro e alguns arbustos, como solicitado pelas cenas; um dos lados estava decorado com seis pinturas do triunfo real, feitas pelas mãos do famoso Mantegna. [...] No cenário, ao pé do frontispício, apareciam os Triunfos de Petrarca, pintados também pela mão de Mantegna. ${ }^{22}$ (CANTELINO apud NICOLL, 1927, p. 86, tradução nossa)

Apresentações com tal proposição visual parecem ter impulsionado o interesse pelas funções da luz na visualidade, na elaboração de atmosferas nos espetáculos. No início do século XVI, a atividade teatral na Itália ainda estava significativamente vinculada às numerosas festividades promovidas na corte: nascimentos, casamentos, aniversários, jubileus, visitas ilustres, geravam extensa programação festiva na qual se incluía, com frequência, apresentações teatrais realizadas em palcos temporários erguidos nos palácios. O evento cênico renascentista começava a revelar o mencionado grande interesse e influência da perspectiva, uma artificialidade capaz de afirmar a concretude proposta pela cena, através da sugestão de tridimensionalidade. Já em 1513, depois da representação de La Calandria, comédia do Cardeal Bernardo Bibiena (1470-1520), Baldassarre Castiglione (autor e diplomata, 1478-1529), um dos responsáveis pela realização do evento, enviou uma carta ao amigo Ludovico Canossa (1475-1532) [então bispo da diocese de Tricarito], comentando o cenário projetado por Girolano Genga (1476-1551):

O palco representava uma cidade muito bonita, com ruas, palácios, igrejas e torres. As ruas pareciam reais, tudo foi feito em relevo e era ainda mais marcante graças à arte da pintura e da bem concebida perspectiva. Havia dois pequenos altares em cada lado do cavalo, cada um deles como um vaso dentro do qual ardia uma chama brilhante durante toda a performance. ${ }^{23}$ (CASTIGLIONE apud NAGLER, 1952, p. 71, grifo e tradução nossos)

Um ano depois, a mesma comédia foi encenada como parte do entretenimento oferecido ao Papa Leão X, que visitava o Duque de Mântua, sendo o cenário assi-

22 "Within the scene were cloths of gold and some shrubs, as the scenes required; one of the sides was decorated with six pictures of the royal triumph from the hand of the famous Mantegna. [...] Within the scene at the foot of the frontispiece appeared Petrarch's Triumphs, painted also by the hand of Mantegna."

23 "The stage represented a very beautiful city, with streets, palaces, churches and towers. The streets looked as if they were real, and everything was done in relief, and made even more striking through the art of painting and well-conceived perspective. [...] On either side of the horse were two small altars, each of which showed a vessel wherein a bright flame was burning throughout the entire performance." 
nado por Baldassare Perucci (1481-1537). A julgar pelo comentário de Vasari o espetáculo parece haver indicado uma atuação diferenciada da luz. Além de considerar "maravilhosos" os cenários em perspectiva, construídos em um palco estreito e remetendo àquilo que pretendiam representar, ele acrescentou: "[Perucci] também dispôs as luzes no interiror das perspectivas [...]".24 (VASARI apud NAGLER, 1952, p. 72, tradução nossa)

Trata-se de um detalhe inovador, pois aponta para proposições realistas aplicadas à luz teatral até hoje. As "luzes no interior das perspectivas" podem se referir a velas, lamparinas a óleo e/ou tochas colocadas atrás dos elementos cenográficos para sugerir iluminação dentro das edificações, cujas fachadas estavam voltadas para os espectadores. Quando se dispõe uma lamparina atrás de uma janela, isso pode indicar uma noção particular de tempo, pode sugerir noite, revelar a presença de uma ou mais personagens no interior, até mesmo através de sombra(s) projetada(s) no material transparente ou translúcido das janelas. Candelabros dispostos acima da área da cena, com o intuito de promover visibilidade para as fachadas propriamente ditas, tinham, então, outra função. Ou seja, se naquele momento o objetivo começava a se deslocar, pois o ambiente retratado na cena precisava ser visto para alcançar credibilidade, também era possível incorporar objetivamente o tempo (hora do dia, ou da noite). Isso é muito diferente de usar uma tocha para sugerir noite ou escuridão, em espetáculos realizados a céu aberto, durante o dia. Tratava-se de aplicar um efeito que ganhava a qualidade de movimento de luz na cena, caracterizado pela disposição do aparato em contraluz, pelo uso da transparência e da cor, para indicar tempo e atmosfera. Registra-se, então, o uso do aparato produtor de luz artificial não somente para permitir visibilidade, mas, também, para elaborar a visualidade da cena.

Outro exemplo do mesmo enfoque é também apontado por Vasari (apud NAGLER, 1952), ao descrever a montagem da comédia em cinco atos Il commodo, de Antonio Landi (1506?), realizada como parte das celebrações do casamento do Duque Cosimo de Medici, com Eleonora de Toledo, em junho de 1539. Sebastiano, também chamado Aristotile de San Gallo (1482-1551), um dos arquitetos da Corte de Medici e responsável pela cenografia de vários eventos, no segundo quarto do século XVI, construiu um palco temporário, assim como um dispositivo cenográfico no pátio do palácio. Na mesma tendência, a perspectiva continuava a extasiar os espectadores e, no caso do espetáculo em questão, o ambiente construído em cena representava a cidade de Pisa. Na assertiva de Vasari, arquiteto-assistente na

24 "He also arranged the lights inside for the perspective [...]." 
Corte daquele período, um detalhe acerca da luz desperta a atenção no trabalho de San Gallo:

Em seguida, ele concebeu uma engenhosa lanterna, como um arco de madeira atrás dos edifícios, e um sol de um braccio [cerca de 60 centímetros] de altura, feito com uma bola de cristal cheia de água destilada, com duas tochas acesas atrás, iluminando o céu e a perspectiva, de modo que parecia um sol verdadeiro. ${ }^{25}$ (VASARI apud NAGLER, 1952, p. 73, tradução nossa)

Como se pode apreender, os esforços visuais para evocar os princípios do divino que "desmaterializava" a vida na arte medieval cediam espaços para a vontade de construir um discurso visual-cênico que revelasse a presença e a intervenção do ser humano no mundo "real". As características técnicas das fontes de luz disponíveis no período, por si só transformavam a cena, apesar dos limites no que se refere ao seu controle. Os artistas, no entanto, trabalharam incessantemente para incrementar a luz da cena. Nas noites de espetáculo, o público era progressivamente surpreendido no teatro através de novas experiências visuais.

Na descrição de Vasari encontra-se mais um princípio que ganharia desde aquele momento um lugar importante na construção da visualidade da cena. Refiro-me à aplicação de filtros coloridos, que conhecemos hoje como gelatina, devido ao seu processo de manufatura e aplicação no teatro. A gelatina animal, produzida através do cozimento de diversos componentes orgânicos, tais como tendões, ossos e/ou tecidos de animais, e depois transformada em lâminas pigmentadas foi aplicada como filtro para colorir a luz usada nos espetáculos. A tecnologia hoje disponível permite até mesmo processos eletrônicos, digitais, para a produção de cor na luz artificial aplicada à cena, fortalecendo os princípios da construção de atmosferas, da sugestão de tempo e/ou da construção de movimentos da luz na cena. Tais operações ou estratégias dependem da familiaridade do iluminador com as questões de natureza técnico-estética envolvidas.

Gustav Mauritz Bergman (1977, p. 53, tradução nossa) apresenta considerações sobre a luz produzida àquele momento, nos teatros: "As velas de cera e de sebo, mas também as lamparinas a óleo criavam uma atmosfera de poeira dourada, suavemente saturada, brilhante, em sintonia com as imagens do cenário mostrado

25 "He next devised an ingenious wooden lantern like an arch behind the buildings, and a sun a braccio (ca. 2 feet) high made of a crystal ball filled with distilled water, with two lighted torches behind, illuminating the sky of the scenery and the perspective, so that it looked like a veritable sun." 
na perspectiva". ${ }^{26}$ Os espectadores do teatro renascentista viam a cena, portanto, através de um filtro dinâmico, produzido por uma luz cintilante e variável emitida por velas, tochas e lamparinas, que cortavam o ar denso e característico de um espaço iluminado por uma enorme quantidade de fontes de luz artificial. Bergman cita ainda os argumentos de Battista Guarino ou Guarini (1638-1612), para defender o uso da luz artificial, questionado pelo nobre que patrocinava a apresentação da pastoral Pastor Fido, por volta de 1580. Interessado na redução de custos, como qualquer responsável pela produção de um espetáculo, pretendia realizá-lo durante o dia. Guarini, que além de autor era também arquiteto, discordou, e defendeu a necessidade de convencer o Príncipe da exigência de luz artificial:

Temos que fazê-lo saber que sem iluminação artificial a cena será privada de sua beleza, em especial os intermezzi, que parecerão muito pobres sob a luz do sol, embora sejam os mais belos e ricos do mundo. Além disso, os gastos serão reduzidos, se for usada a iluminação artificial, pois a beleza, que é criada diante de nossos olhos através dela, somente poderá ser alcançada [se aplicada a luz natural] através de enormes gastos em adornos. ${ }^{27}$ (GUARINI apud BERGMAN, 1977, p. 53, grifo do autor, tradução nossa)

O conceito de beleza incorporado pelo espetáculo renascentista pode e deve ser discutido, pois a exigência de beleza sugere questionamentos, quando se invoca a atualidade. Todo o esforço era efetivado para responder aos princípios estéticos imaginados por artistas, alguns deles propondo soluções diferenciadas de padrões já implantados, rompendo regras rígidas. Assim, a subversão de valores estabelecidos apontou novos caminhos, não sem reações adversas. O que Guarini defendia era a capacidade da luz artificial de produzir um apelo especial, emprestando uma atraente qualidade visual à cena. A discussão da beleza produzida pela luz pode passar pela avaliação da visualidade, numa relação direta com o contexto cultural no qual toda práxis cênica está integrada. Efeitos mirabolantes, aplicando toda a tecnologia disponível e até rara, em certos casos, já é um objetivo plenamente alcançado, desde a Idade Média. Se o iluminador transforma, hoje em dia, essa natureza de efeitos no objetivo final da sua intervenção em um espetá-

26 "The wax and tallow candles, but also oil lamps created an atmosphere of gold-dust, softly saturated, glittering, which was in keeping with and the prerequisite of the imagery of the perspective scene."

27 "We have to let him know that, without artificial lighting the scene will be deprived of its beauty, in particular the intermezzi which appear very poor in sunshine even though they are the most beautiful and richest in the world. Besides, expenses would be reduced if stage lighting were used, for the beauty that is created before our eyes through artificial light can be made up for only by great expenses in adorning devices." 
culo, seu trabalho pode não passar de "intervenção", no sentido de uma imposição estranha à cena.

George Riley Kernodle (1907-1988) ${ }^{28}$ considera que o espetáculo renascentista do século XVI, invadido pela perspectiva, dava passos inovadores: "Pela primeira vez, desde o teatro clássico, um grande palco foi projetado para representar um único lugar. Pela primeira vez no teatro europeu a cena foi concebida para criar uma ilusão completa [...]". ${ }^{29}$ (KERNODLE apud HEWITT, 1958, p. 9, tradução nossa) É importante sublinhar nessa assertiva o espaço para reflexões acerca da luz como aspecto determinante na realização teatral, desde o teatro grego da Antiguidade, passando pelo esplendor das manifestações cênicas da Idade Média e alcançando a cena renascentista, na qual se instalou o olhar artificializado pela perspectiva, apontando para o discurso visual norteador da cena moderna. Em todas as instâncias mencionadas, a visualidade desempenha papel de particular relevância, desde as rígidas convenções formais da Grécia antiga, que criava noite em pleno dia, até a ilusão de real, na modernidade, alcançando a fragmentação na performatividade.

A atitude renascentista introduziu inúmeras contribuições às atividades artísticas, e a visualidade da cena, por seu turno, recebeu proposições exemplares. Algumas, dentre as contribuições, podem ser encontradas nos trabalhos de teóricos como Sebastiano Serlio (1475-1554), Leone de'Somi (ca. 1525-1590), Angelo Ingegneri (ca. 1550-1613), Nicola Sabbattini (1574-1654) e Josef Furtenbach (15911667). Eles escreveram os primeiros textos que discutiram e sistematizaram as relações entre a luz e o espetáculo, incorporando importante influência de autores antigos. Ou seja, os estudos dos traços espetaculares da luz já alcançam mais de cinco séculos.

Além da dramaturgia grega e romana que se tornaria progressivamente disponível naquele momento, o trabalho de Vitruvius, Da arquitetura (De architectura, uma abordagem da arquitetura romana da Antiguidade, escrito por volta de 40 a.c. e já mencionado), seria decisivo para o teatro, a partir do Renascimento. Inúmeras pesquisas abordam sua repercussão contundente na construção do espaço renascentista, numa interação significativamente produtiva com as pesquisas voltadas para a perspectiva linear. Em 1414, Poggio Bracciolini (13801459) descobriu um manuscrito do tratado de Vitruvius, cuja publicação origi-

28 Ph.D. na Yale University em 1937, autor, professor em algumas universidades norte-americanas, como a State University of lowa.

29 Do original: "For the first time, since the classic theatre a large stage was design to represent a single unified place. For the first time in the European theatre the scene was designed to create a complete illusion [...]". 
nou grande interesse por parte dos estudiosos da época. Seguiram-se traduções em italiano, alemão e francês, ampliando a difusão dos princípios discutidos por Vitruvius, e provocando artistas e arquitetos do período. A efervescência do século XVI demonstrava ligações notáveis com a tradição grega e romana, já no trabalho do mencionado Filippo Brunelleschi, cujas experimentações com a perspectiva introduziram um modo inovador de conceber e representar a espacialidade. Desde o século IX, o texto de Vitruvius foi consultado por vários interessados, ainda na corte de Charlemagne (Carlos Magno, 742-814), que exerceu o poder na Europa Central, entre os séculos VIII e IX, permanecendo como Imperador Romano do Ocidente desde 800 até sua morte.

A leitura do trabalho de Vitruvius apresentava grande dificuldade, como destacou Alberti, característica mais tarde reiterada por Júlio Roberto Katinsky (1999, p. 24) - que menciona Da arquitetura, juntamente com o Satyricon, como exemplos de latim vulgar. Além disso, o desaparecimento de parte substancial das 10 ilustrações originais da obra de Vitruvius agrava a dificuldade citada. Ele foi amplamente mencionado no compêndio enciclopédico Speculum maius (Grande espelho), do final da primeira metade do século XIII, enciclopédia considerada por muitos especialistas um dos textos mais consultados durante a Idade Média, cujo autor é o frade dominicano francês Vincent de Beauvais (ca. 1190-1264).

Mesmo antes da primeira edição de Vitruvius na Itália, em 1486, Leon Battista Alberti já publicaria sua obra Sobre a arte de construir ou Io livros (capítulos) de arquitetura (De re aedificatoria), seguindo o exemplo do autor romano. No século seguinte, o arquiteto Andrea Palladio (1508-1580) toma a obra de Alberti como guia, pesquisando e elaborando desenhos, além de incluir ilustrações para a tradução em italiano, de Daniele Barbaro. Palladio publicaria seu próprio trabalho, Os quatro livros da arquitetura (I quattro libri dell'architecttura), em Veneza, 1570. Estudioso da tradição arquitetônica romana, ele se tornaria um dos principais arquitetos renascentistas, tendo concebido uma edificação de importância vital para o estudo em curso, o Teatro Olímpico, em Vicenza.

O Olímpico resultou do empreendimento da Academia Olímpica, uma associação de burgueses, profissionais liberais, como médicos, advogados, além de comerciantes, entre outros, fundada em 1556. As academias renascentistas seguiam uma tradição que se iniciou na Grécia, provavelmente a partir da atividade de Platão, quando ele reunia discípulos, seguidores, para a apresentação dos seus princípios filosóficos, nos arredores de Atenas, no jardim público, denominado Academia, cujo nome pode ter sido originado de Hecademus ou Academus, que teria doado o jardim aos cidadãos, para a prática da ginástica. Em 1579, a Academia Olímpica 
recebeu permissão para construir um teatro permanente, comissionando Andrea Palladio, um de seus fundadores, para conceber o projeto. Cabe dizer que Palladio já havia provavelmente trabalhado na construção de teatros temporários em Vicenza, como aqueles no principal salão da Basílica Palladiana, para espetáculos patrocinados pela mesma Academia Olímpica. Com o falecimento de Palladio, em 1580, alguns meses depois de iniciada a obra, a construção do Teatro Olímpico foi encaminhada por Vicenzo Scamozzi (1548-1616). Importante evidenciar que o Olímpico não é uma edificação originalmente construída para abrigar espetáculos, como os teatros gregos e romanos da Antiguidade e, sim, o resultado de uma adaptação de Palladio, usando o Castelo del Territorio, um antigo palácio e fortaleza que se encontrava em desuso, depois de funcionar como prisão. De qualquer modo, ele é hoje um marco da arquitetura teatral.

Observando as características da edificação original, Palladio tomou decisões importantes: em primeiro lugar, estendeu lateralmente o espaço destinado aos espectadores - a cávea romana - criando uma plateia menos circular e mais relacionada com a forma elíptica. Por outro lado, mais do que transformar de modo generalizado o velho Castelo, em uma casa de espetáculos permanente, Palladio procurou garantir a realização de dispositivos cenográficos, de acordo com as normas técnicas da perspectiva. Ele, então, estendeu o centro da parede situada ao fundo do palco, criando uma distância apropriada para a implantação do ponto de fuga dos cenários, promovendo o espaço exigido pelo seu cálculo, em uma linha do horizonte convincente para o espectador disposto na posição do observador ideal renascentista. Tratava-se de um elemento arquitetônico encontrado nas igrejas, a apse ou apsis. ${ }^{30}$ Isso implicou na demolição de parte de uma espessa parede, transformando uma edificação para atender às proposições de um cenógrafo, de um espetáculo, e particularmente do primeiro cenário do Olímpico, solidamente construído e até hoje preservado. Note-se a parede ao fundo, comentada acima (Figuras 22 e 23).

Até mesmo hoje em dia, tal demanda pode causar reações negativas. Afinal, não é difícil encontrar "teatros" que, mesmo tendo sido integralmente projetados desde a ideia inicial, apresentam impropriedades tão sérias a ponto de, numa análise justa, nem sequer alcançarem o direito de serem assim denominados. Isso significa dizer que ensinamentos discutidos há mais de 500 anos, ou são ignorados ou desconsiderados, repetindo-se certos equívocos, como se os erros conti- 
dos em uma obra fossem copiados em outro projeto que o sucede. O tema, aliás, aponta para uma pesquisa com recorte específico.

O Teatro Olímpico, em Vicenza, configurava-se como o primeiro projeto concebido no Ocidente para responder às proposições espaciais da cena, numa edificação permanente, uma reprodução reduzida de um teatro da Roma antiga. Instaurava-se a tipologia da espetacularidade ocidental moderna, para a qual o Olímpico representa um marco significativo.

Ele foi usado pela primeira vez como espaço cênico na montagem de Édipo Rei, de Sófocles, na ocasião do carnevale em Vicenza, no ano de 1585. Uma carta, escrita por Filippo Pigafetta para um aristocrata não identificado, revela: "Angelo Ingegneri, capaz de tais coisas, dirigiu o empreendimento trágico". ${ }^{31}$ (PIGAFETTA apud NAGLER, 1952, p. 84, tradução nossa) Os cenários foram projetados por Vicenzo Scamozzi (1548-1616), concebidos para representar a cidade de Tebas, e contam com cinco "portas", sendo que a Porta Régia ou Central dá acesso a três ruas construídas com madeira e gesso, cada uma das restantes, em número de quatro, mostram uma rua, e afirmam a influência da perspectiva linear.

Aliás, mais que isso, o dispositivo cenográfico projetado por Scamozzi demonstra, de maneira exemplar, a aplicação de perspectiva linear forçada, na cena. Ou seja, para criar uma ilusão de profundidade muito maior do que aquela efetivamente disponível no palco, ele intervém na aparência espacial objetiva, usando uma importante solução técnica. Construído em aclive, o piso atrás das portas da fachada da cena resulta numa aceleração na redução das dimensões dos prédios em cada uma das ruas. Uma casa ao fundo chega a ter uma dimensão vertical total, de apenas 1,80m. Significa que um ator, ao "caminhar" por uma daquelas ruas, poderia parecer maior que os prédios (Figura 24).

A carta de Pigafetta revela, ainda, que o espetáculo (noturno) começou às sete e meia, permanecendo até às $11 \mathrm{~h}$, atestando a necessidade da iluminação artificial, pois, além de acontecerem em um espaço fechado, os espetáculos eram, ou podiam ser realizados à noite.

Estava registrado um dado importante para a mudança de comportamento de parte da comunidade. O teatro, agora, passava a ser uma opção, um motivo para atravessar o buraco negro das ruas e se dirigir a outro lugar que não sua própria casa, mudando a experiência dia-noite. Um espectador muito diferente daquele mencionado por Aristóteles, que participava de um ato cívico que ocorria durante parte do dia.

31 "Angelo Ingegneri, capable of such things, has directed this tragic business." 
Scamozzi deixou ainda outra obra de grande relevância, ao construir em Sabbioneta, pequena cidade do nordeste da Itália, entre Parma e Mântua, de 1588 a 1590, o Teatro all'Antica, uma pequena casa de espetáculos com uma plateia que acomoda em torno de 250 espectadores, ainda com inspiração na Roma antiga e seguindo pressupostos renascentistas de uso da perspectiva. Trata-se, provavelmente, da primeira edificação concebida, projetada e construída originalmente como teatro, depois dos grandes espaços da Antiguidade. Mais uma vez o arquiteto usou a perspectiva forçada ${ }^{32}$ na cenografia, aplicando a solução técnica do aclive no palco, mas acrescentou uma particularidade: excluir as portas que eram vistas no Olímpico, abrindo toda a extensão do palco à visão do espectador e apontando para a nova tipologia espacial da cena, que se instalaria a partir de então. Tais características fazem do Teatro all'Antica, em Sabbioneta, um passo importante nas relações entre o público e o espetáculo, quando estabelece a possibilidade de deslocamento do ator para um ponto mais distante da plateia, ao fundo do palco, usando toda a extensão da sua tridimensionalidade visível (Figuras 25 e 26).

Um mergulho na profundidade do ambiente da cena aponta para uma dramaturgia que logo se firmará, como o Rei Lear, de Shakespeare. Cada vez que o drama se adensa, construindo perfis psicológicos de maior complexidade, mais interagirá com a profundidade física da tridimensionalidade do espaço cênico, criando, inclusive, a possibilidade do contraste com a horizontalidade narrativa épica. Pode-se observar, desde o século passado, a obsessão produtiva do cinema, e agora do vídeo, na busca para romper o limite da horizontalidade, investindo nos efeitos de 3D, ou terceira dimensão. Scamozzi já promoveu tal caminho seguindo a trilha mencionada, cujas origens podem ser traçadas desde a horizontalidade parcial dos espetáculos de Ésquilo até a ilusão de profundidade, em $A$ trindade de Masaccio.

No ambiente renascentista, surgem os primeiros documentos, além da dramaturgia propriamente dita, que abordam as relações entre a luz e a cena. Em 1543 , Giraldi (Giambattista Giraldi Cinzio 1504-1573), apontado como um dos principais tragediógrafos do período, publicou o Discurso acerca da composição da comédia e da tragédia (Discorso intorno al comporre delle commedie e delle tragedie), um tratado

\footnotetext{
32 A perspectiva forçada é um recurso visual aplicado para sugerir maior profundidade do que aquela que a extensão objetiva do ambiente efetivamente apresenta. Pode ser observada na arquitetura antiga, já no início do século IV d.C., na Basílica de Constatino [Konstantinbasilika], construída na Alemanha, em Trier, pelo imperador Constatino (306-337 a.D.), que the deu o nome. Na vista lateral externa, pode-se observar a menor dimensão das janelas dispostas na extremidade circular. Essas mesmas janelas sugerem uma ilusão de mesma dimensão na vista interna, devido à perspectiva forçada. O teatro, o cinema e muitos outros meios que pretendem interferir na percepção da tridimensionalidade aplicam esse recurso. Um clássico exemplo encontra-se no Teatro Olímpico, em Vicenza, na Itália, no cenário projetado por Vicenzo Scamozzi (1548-1616) para o espetáculo de inauguração em 1585, Édipo Rei, dirigido por Angelo Ingegneri (1560-1613).
} 
teórico de dramaturgia sob a influência de Aristóteles. No mesmo ano, ele publicou Orbecche, uma tragédia que pretendia seguir de modo estrito a Poética de Aristóteles, e é mencionada como exemplo da tragédia "regolare" (regular, padrão) na literatura italiana do período. O trabalho de Giraldi é um dos exemplos do diversificado legado de textos especificamente voltados para a arte teatral, produzidos na Itália renascentista. Provocados pela redescoberta da civilização greco-romana, alguns autores empreenderam estudos da poesia dramática e da arquitetura, incluindo as atividades espetaculares que podem ter se originado naquela cultura.

\section{LUZ E CENA: PRIMEIROS REGISTROS TEÓRICOS}

A grande ebulição que caracterizou o século XVI revelou artistas inquietos na cena, afirmando um movimento que se fortaleceu desde o Renascimento, quando a práxis cênica produziu vasto conhecimento, incorporando nomes como os de Da Vinci e Michelangelo, que interagiram em diversificadas atividades na corte, inclusive na engenharia bélica e de fortificações.

\section{Sebastiano Serlio}

A já mencionada influência greco-romana deu origem a muitos trabalhos teóricos que incorporavam o interesse no estudo do teatro. Ao publicar o Regole generali di architettura, em 1537, Sebastiano Serlio começa uma carreira de autor pioneiro na atividade teatral. Ao longo dos oito anos que se seguiram, ele escreveu um dos mais importantes tratados sobre arquitetura, exercendo enorme influência na tradição arquitetônica da Europa, continuando a tradição das obras de Vitruvius e Alberti. Em 1545, foi publicado o Livro II do seu compêndio, em italiano e francês, uma vez que Serlio encontrava-se em Paris, a convite de Francis I, aliado político de Veneza e entusiasta da arquitetura e da arte italianas.

Sendo o Livro II um tratado de geometria e perspectiva é importante lembrar que o arquiteto da corte naquele período era, de modo geral, um artista envolvido com o teatro, elaborando projetos de casas de espetáculo, assim como de cenários. O teatro era considerado, então, um problema especial no estudo da perspectiva, devido à necessidade de tratar o espaço do palco de modo a permitir a execução dos projetos cenográficos que exigiam muita precisão para o efeito de trompe l'oeil (ou ilusão óptica). Ainda que Serlio tenha declarado sua insatisfação com o que escreveu sobre esse tema, por entender que ele exigia um estudo mais deta- 
lhado, sua breve abordagem repercutiu significativamente no estudo da história das artes cênicas. Ele sublinhou a aplicação das leis da perspectiva linear como parâmetro indispensável à concepção de teatros e cenários, discutindo questões particulares da sua contribuição para a cena. Certas preocupações parecem muito específicas, como o posicionamento do ponto de fuga e, consequentemente, da linha do horizonte. Serlio chama a atenção para a dificuldade de demonstrar na cena a disposição dos elementos da perspectiva, afirmando que o seu tratamento obedecia a regras diferentes de todas as outras por ele mencionadas.

Ao tratar especificamente do palco, impregnado pela paixão que caracteriza o artista, ele diz:

Entre todas as coisas feitas pela mão do homem, poucas, em minha opinião, trazem maior contentamento aos olhos e satisfação para o espírito do que o desvelar de um cenário, no teatro. [...] todo enriquecido por inúmeras luzes (grandes, médias e pequenas, de acordo com sua posição), por vezes tão habilmente colocadas que parecem joias faiscantes - diamantes, rubis, safiras, esmeraldas e outras pedras preciosas. ${ }^{33}$ (SERLIO apud NICOLL, 1958, p. 24, tradução nossa)

A consideração de Serlio apontava para as contribuições específicas da luz. Mais do que apenas instalar determinada quantidade de instrumentos produtores de luz artificial, sua distribuição deve ser subordinada às características de cada um deles, exigindo atenção para as relações entre suas particularidades técnicas e suas funções na cena.

É indispensável, portanto, acentuar a relevância da experiência visual no teatro por ele abordado. As gravuras que ilustram o Livro II, já bastante conhecidas, seguem a classificação apresentada em Vitruvius e se constituem em importante documento visual do pensamento teatral daquele período. (Figuras 27 a 29). Tais imagens contribuem para a apreensão da efervescência que tomava conta da práxis cênica e do papel que os artistas da renascença na Itália desempenharam na elaboração do espetáculo moderno. Nesse mesmo volume, Serlio deixou muitos subsídios para o presente trabalho ao abordar, pela primeira vez no nível teórico, a aplicação da luz artificial à cena. Isso, a partir do ponto de vista da investigação em andamento, relativiza sua própria opinião quando ele considerou superficial sua

33 "Among all things made by hand of man few in my opinion bring greater contentment to the eye and satisfaction to the spirit than the unveiling to our view of a stage setting. [...] all enriched by innumerable lights (large, medium and smalls, according to their position) at times so skillfully placed that they seem like so many sparking jewels - diamonds, rubies, sapphires, emeralds and other gems." 
própria abordagem, ao concluir que deveria escrever de modo mais extenso sobre os problemas visuais do teatro.

Na verdade, o que se deve registrar aqui é que ele voltou sua atenção para a luz, separando os objetivos de iluminar, prover efeitos e até sugerir atmosferas, de acordo com pressupostos muito particulares. Sebastiano Serlio devotou atenção a problemas técnicos e acentuou o uso da cor na luz, descrevendo variados efeitos e discutindo o uso das lentes e refletores: "Para todas essas cores você deve ter recipientes [bozze] feitos de vidro, em formato especial, com um lado plano e outro arredondado, para reter a água". ${ }^{34}$ (SERLIO apud NICOLL, 1958, p. 34, grifo e tradução nossos) (Figura 30)

Serlio descreve, portanto, o princípio de um acessório usado na cena ainda hoje, o filtro ou gelatina, antes mencionado. Ele se refere a um recipiente que, apresentando uma face convexa e outra plana (pode ser encontrado também com acabamento côncavo), funcionava como uma lente/filtro, permitindo projetar cor na cena, quando preenchido com líquidos coloridos, como vinho ou água pigmentada, e colocado diante de uma fonte de luz. A seguir, ele introduziu mais um importante elemento técnico, que contribuiu para a criação de um instrumento crucial para a luz na cena, conhecido no Brasil como refletor: "Quando você precisar de uma luz especialmente forte ponha uma tocha por trás de um vidro e, por trás da tocha, uma bacia de barbeiro, bem polida. Ela refletirá um esplendor como os raios do Sol". (SERLIO apud NICOLL, 1958, p. 34, tradução nossa) ${ }^{35}$ A bacia já é um exemplo do uso de uma superfície refletora como solução técnica para ampliar o brilho da cena e que, também como princípio, já define o rebatedor que será aplicado na fotografia, no cinema e no vídeo. E ainda, quando projetamos luz de uma poderosa fonte como um instrumento fresnel, que incorpora uma lâmpada de 2.00oW no teatro, até 10.00oW ou mais, no cinema, estamos buscando aquilo cujo princípio Serlio discutiu no século XVI.

Considerando a acuidade visual humana àquela época, acostumada a uma quantificação de iluminação muito reduzida se comparada aos padrões que hoje são oferecidos, pode-se projetar o apelo visual que os espetáculos produziam para seus espectadores. Os princípios da luz aplicada ao teatro, que parecem muito próprios do teatro moderno, já estavam presentes, portanto, nos teatros renascentistas.

\footnotetext{
34 "For all these colors you must have containers[bozze] made of glass, of special shapes with flat and rounded side to hold the water."

35 "When you need a especially strong light you put a torch behind a glass and behind the torch a barber's basin well burnished. This will reflected a splendor like the rays of the Sun."
} 
Assinale-se ainda a atitude do autor, quando ele separou os efeitos, as possibilidades da elaboração de imagens particulares e a luz usada para tornar a cena visível:

Mas nenhuma dessas luzes foi disposta para fazer a iluminação da cena. Para cumprir essa função, um grande número de velas foi colocado na frente da cena. Também acima da cena foram pendurados candelabros e acima desses, um vaso com água e um pedaço flutuante de cânfora que, aquecida, produzirá uma luz muito bonita e agradável odor. ${ }^{36}$ (SERLIO apud NICOLL, 1958, p. 34-35, tradução nossa)

Ele parecia sugerir uma diferença entre "iluminação", compreendida como o ato de projetar luz para permitir visibilidade, e a construção de imagens na cena.

Retomando o uso de líquidos pigmentados, que funcionavam como um elemento da proposição estética cabe lembrar que tal decisão aponta também para a preocupação com o conforto do espectador: usava-se a cânfora para criar um aroma agradável para a plateia, ainda que as reações olfativas sejam muito particulares e o que parece agradável para alguns pode ser muito desconfortável para outros. No entendimento de Serlio, assim como de seus contemporâneos, o aroma da cânfora seria menos agressivo ao olfato do espectador, operando uma espécie de correção no odor da gordura animal usada como combustível. Do ponto de vista da distribuição dos instrumentos, Hewitt acrescenta uma nota importante:

A frase 'pendente davantti alla Scena' é geralmente entendida como 'pendurada na frente da cena'. O uso de 'também acima da cena' na frase seguinte nos leva a pensar que Serlio está falando de algum tipo de ribalta semelhante, talvez, à 'luz inclinada', descrita por Furttenbach. Se esse for o caso, essa é uma importante e uma dentre as primeiras referências à ribalta. ${ }^{37}$ (SERLIO apud NICOLL, 1958, p. 34, tradução nossa)

Apreendendo tal referência como indicação da luz de ribalta aí se registra mais um relevante indício da qualidade visual daqueles espetáculos. Por outro lado, o verbo to hang, indicando pendurar/suspender, parece apontar mais apro-

36 "But none of these lights have anything to do with the illumination of the scene. For this a large number of candles are placed leaning at the front of the scene. Also above the scene are hung chandeliers, and above these chandeliers a vase of water in which a floating piece of camphor burns will give a very beautiful light and odor."

37 "The phrase 'pendente davanti alla Scena' is usually taken to mean 'hanging in front of the scene'. The use of 'also above the scene' in the following sentence leads us to think that Serlio is speaking of some kind of footlight perhaps similar to the 'leaning light' described by Furttenbach. If so this is an important early reference to footlights. 
priadamente para um dispositivo colocado à frente e acima do palco. Mesmo se configurando como uma abordagem introdutória, o texto de Serlio é vital para a compreensão do espetáculo renascentista uma vez que documenta a gênese da relação moderna entre a luz e o espetáculo, sendo Sebastiano Serlio seu primeiro teórico conhecido.

\section{Leone de'Sommi e Bernardo Buontalenti}

Tal relação ganharia outra incursão na obra de Judah Leone, ben Isaac Somo ou Leone de'Sommi. ${ }^{38}$ Para tratar os elementos da cena, ele escreveu em forma dialógica na qual destacou a contribuição da luz, elaborando uma ação que ocorre quando a personagem Veridico (de'Sommi) recebe no seu atelier a visita de dois cortesãos, Massimiano e Santino. Em uma conversa sobre a dramaturgia e a cena, eles discutem interpretação, figurinos, a montagem de pastorais e a luz:

Santino. Qual é o uso e qual é a origem dessas luzes sobre os telhados das casas no palco? Não me parece que elas ajudem a perspectiva, e para efeitos de iluminação, há tochas o suficiente. | Veridico. Acho que tenho dito e repetido que comédias são apresentadas com o propósito de divertir e aliviar os pensamentos sombrios, e por isso eu disse e repito que o ator deve ser convidado a dizer suas falas de modo alegre e brilhante. Então, se o autor nos apresenta uma trama charmosa e agradável, se o ator interpreta com um espírito alegre, é certamente necessário que o arquiteto, por seu turno, represente felicidade e alegria, uma vez que tanto no costume moderno e quanto no antigo, fogueiras e tochas têm sido ateadas nas ruas, nos telhados e nas torres, como sinal de alegria, pois essa é a origem das convenções - imitar tais celebrações de felicidade. | Santino. Essas luzes, então, poderiam ser usadas na tragédia? | Veridico. Talvez elas não estejam tão fora de lugar na tragédia, pois geralmente tragédias começam com a felicidade [assim] então não seria inconveniente despertar a mente, tanto quanto possível, para essa

38 Nascido em Mântua, descendente de aristocratas, com formação, tanto no pensamento renascentista, quanto na tradição hebraica, poeta e homem de teatro, foi responsável e supervisor de espetáculos na Corte de Mântua, que era frequentada por muitas autoridades europeias. Escrevendo não somente em italiano, mas também em hebraico, a ele se credita a autoria da primeira peça nessa última língua, datada de 1550. Sua carreira é diversificada e mostra um artista versátil: sendo autor de textos, cenários e direção de espetáculos, gozava de grande reputação na Europa. Sua obra contém 13 peças, poemas, sátiras, canções, pastorais e o Dialoghi in matéria di rappresentazioni sceniche [Diálogos sobre a representação cênica], provavelmente escrito depois de 1550, submetido a Cesare Gonzaga, patrono da escola literária Accademia degl'Invaghiti. 
felicidade. [...] Uma vez eu produzi [...] uma tragédia. O palco foi brilhantemente iluminado por toda a extensão da ação na qual os acontecimentos eram felizes: assim que o primeiro incidente infeliz ocorreu - a morte inesperada de uma rainha - enquanto o coro exclamava que o Sol poderia sofrer ao ver tanta miséria, eu decidi [...] que, naquele instante, a maioria das luzes do palco não utilizadas para a perspectiva seria escurecidas ou apagadas [...]. ${ }^{39}$ (DE’SOMI apud NICOLL, 1927, p. 213, tradução nossa)

Os Dialoghi representam os primeiros textos com abordagem crítica do espetáculo, conservados desde aquele período, que tratam da parceria entre o teatro e a luz. Discutindo a cena, Leone de'Sommi voltou-se para o estudo da incorporação da luz artificial pelo espetáculo, como um índice fundamental no teatro, definindo parâmetros para a discussão de tal incorporação. Já na primeira resposta de Veridico, surgem indicações da importância da luz na interação entre a poesia dramática e a cena, atribuindo parte da responsabilidade da mediação ao arquiteto.

O arquiteto é aqui compreendido, então, como um artista profundamente envolvido no teatro, cujo exercício produzia ensinamentos que se projetavam para outras áreas da sua atuação. É importante lembrar que o interesse abrangente do arquiteto renascentista pode explicar a facilidade com a qual de'Sommi fez experimentações envolvendo luz e óptica, no teatro. O arquiteto do Renascimento podia ser também, pintor, escultor, cenógrafo, figurinista, designer e engenheiro (trabalhando inclusive na produção bélica e em fortificações). Leonardo da Vinci ficou conhecido como pintor, escultor, arquiteto, responsável pela parte visual de festividades, exibições, espetáculos, desfiles e procissões, dentre outros.

A indumentária da Guarda Suíça do Vaticano, por ele projetada, encontra-se em uso até hoje (Figura 31). Trata-se de um típico exemplo do arquiteto renascen-

39 "Santino. What is the use and the origin of those lights on the rooftops of the houses on the stage? They do not seem to me to aid the perspective, and for purposes of illumination there are torches enough. | Veridico. I think I have said and repeated the fact that comedies are presented for the purpose of enjoyment and the alleviating gloomy thoughts; for that reason I said to you, and I repeat it again, that the actor must be bidden to speak his lines in a happy and bright manner. Now, granted that the author gives us a pleasant, charming plot and that the actor interprets it in a joyous spirit, surely it is necessarily that the architect on his part should represent gladness and joy, and since both modern and ancient custom is and has been to light fires and torches in the streets, on housetops, and on towers as a sign of gladness, therefore this is the origin of the conventions - to imitate such glad celebrations. | Santino.

These lights, then, could not be used in tragedy? | Veridico. Perhaps they would not be so out of place there, since generally tragedies open in happiness [and so] it will not be unfitting to arouse the mind as much as possible to this happiness. [...] Once I had to produce [...] a tragedy. The stage was brightly illuminated through all the part of the action in which the episodes were happy: as soon as the first unhappy incident occurred - the unexpected death of a queen - while the chorus was an exclamation that the sun could suffer to see such misery, I contrived [...] that at that very instant most of the stage lights not used for the perspective were darkened or extinguished [...]." 
tista, e não uma exceção. Ainda que Alberti tenha demonstrado resistência ao termo, é bom lembrar que em grego, a palavra arquitetura se constitui de arche (início) e tectura, que se origina em tekhné (técnica/arte). Incorporando tamanha abrangência a arquitetura seria, na visão dos gregos, não somente a primeira arte-habilidade exercida pelo ser humano, mas também a primeira, numa ordem hierárquica.

Como já dito ao tratar da montagem de Édipo Rei, no Teatro Olímpico, havia um responsável pelo conjunto do evento, que aqui será chamado de diretor, numa referência ao artista que mais tarde se firmaria na atividade teatral. Pelo que se pode deduzir do texto de Leone de'Sommi cabia a um arquiteto a elaboração do contexto visual da cena, naquele caso específico, incluindo a luz. Pode-se considerar tanto a formação humanista, quanto as habilidades específicas de um artista do Renascimento, para refletir sobre a visualidade daqueles espetáculos. Aliam-se a isso comentários e ilustrações, alguns já citados, para contribuir em tal compreensão. Importa menos aqui estabelecer críticas ao espetáculo que se produzia naquele momento, e, sim, apreender a possibilidade de uma proposição particular para a atuação da luz na práxis cênica, vislumbrada por de’Sommi.

Trabalhos como o de Leone de'Sommi não apenas operam como indicadores da contribuição da luz para a cena de determinado período, mas podem sublinhar reflexões acerca da luz, na sua condição de problema inerente e profundamente enraizado no espetáculo, sugerindo sua abordagem como um elemento que integra a natureza estética do espetáculo.

Gösta M. Bergman (1977) diz que, de acordo com Appia, de'Sommi fundamenta a presença de uma luz criativa no palco. Ele reduz a intensidade depois da peripateia um momento crítico na ação das tragédias, no qual uma radical mudança na situação do herói trágico transforma sua aparente segurança em vulnerabilidade - e cria um efeito de Tenebrae. ${ }^{40}$ Segundo Bergman (1977, p. 68, tradução nossa): "A luz do mundo não foi negada às pessoas, mas o destino e a infelicidade lançaram suas sombras, escurecendo a imagem, uma luz expressiva". ${ }^{41}$ Tal observação assinala o pioneirismo de Leone de'Sommi, que sublinhou uma posição estética na cena, para a luz.

Há outro artista que, mesmo sem publicar textos, parece haver deixado contribuição efetiva no teatro do período. Conta-se com relatos e documentos escritos por membros de equipes de trabalho, além de alguns desenhos, para observar o trabalho de Bernardo Buontalenti (1536-1608) na Corte de Uffizi, principalmente

40 Cf. a subseção "Outros Rumos para o Pensamento Visual da Cena" desse livro.

41 "It is not the light of the world that had been withdraw from people, but fate and misfortune cast their shadows darkening the picture, an expressive light." 
em 1589. Ainda que o responsável pelas decisões técnicas tenha sido o engenheiro de fortificações da Corte de Florença, Girolamo Ser Jacobi, Bergman (1977, p. 70, tradução nossa) afirma: "As anotações preservadas sobre o trabalho técnico preliminar realizado nas peças mostram claramente o cuidado que era tomado com a iluminação, de acordo com as orientações de Buontalenti". ${ }^{42}$

Segundo Bergman (1977), os relatos acerca dos festivais esclarecem que os salões de festas eram espaços ainda usados para os espetáculos, sendo Buontalenti apontado como um artista muito interessado pela iluminação e preocupado em esconder as fontes de luz. Num sistema cenográfico de muita experimentação e com decisiva influência na dinâmica da cena, tanto no que se refere aos elementos aéreos, quanto àqueles ao nível do palco, operados em intensos deslocamentos, pode-se imaginar que ele exigia muita disciplina nas diversas operações relacionadas ao acionamento, assim como à manutenção das velas e lamparinas. O diário técnico de 18 de abril de 1589 recomenda: "O céu deve ser muito fortemente iluminado, mas deve-se tomar cuidado para que as luzes não sejam vistas, mas refletidas, na medida do possível, entre os deuses". ${ }^{43}$ (BERGMAN, 1977, p. 71, tradução nossa) (Figuras 32 e 33)

Os elementos aéreos do cenário, figuras alegóricas que pendiam sobre o palco (como a Harmonia), deveriam estar banhados de luz, cujas fontes seriam também posicionadas fora do alcance visual da plateia, iluminando as nuvens mais próximas, dispostas em um céu cheio de névoa. Céu, aliás, que apresentava perfurações com duas funções distintas: promover ventilação e permitir que a luz brilhasse através delas. O espectador deveria contemplar o ambiente sem identificar de onde a luz partia. Os efeitos descritos para o mesmo evento incluíam uma mudança na atmosfera da cena, com uma penumbra que caía de modo surpreendente, escurecendo a perspectiva da cidade de Florença e revelando um céu repleto de nuvens. Comentários da época descrevem efeitos nunca antes vistos, enquanto Bergman aponta os desenhos que reproduzem os cenários para os intermezzi de 1589, concebidos por Buontalenti, como exemplo das visões extraordinárias de luz e sombra que ele criou.

O trecho de um diário técnico escrito em 13 de fevereiro do mesmo ano traz um entre os primeiros registros de luzes na ribalta: "Em primeiro lugar, balaustra-

\footnotetext{
42 "The preserved notes on the preliminary technical work on the plays show clearly what care was taken with lighting in conformity with Buontalenti's directions."

43 "The sky should be very strongly illuminated but see to it that the lights are not seen but are reflected, as far as possible, among the gods."
} 
das e pilares no praticável elevado para serem colocadas velas". ${ }^{44}$ (BERGMAN, 1977, p. 71, tradução nossa)

Isso sugere uma imagem muito diferenciada daquilo que se via até então, devido ao novo ângulo de projeção da luz, possibilitando maior brilho e estabelecendo um sentido ascendente, o que propunha uma nova qualidade visual. E adiante: "[...] é muito claro, a partir de relatos sobre o festival, que Buontalenti usou a luz para o palco de uma nova maneira. Vez por outra se menciona que as fontes de luz foram protegidas para impedir que espectadores as enxergassem". 45 (BERGMAN, 1977, p. 71, tradução nossa)

O público de Buontalenti assistia a um milagre, testemunhando um momento no qual o teatro "superava" o sol: a ribalta criava um ângulo incomum para a luz, estabelecendo uma visão somente possível se um homem estivesse no topo de uma montanha, ao nascer ou pôr do Sol, e outro estivesse logo abaixo contemplando a imagem. Como se fossem dois alpinistas: um deles, apenas um, poderia ver aquilo que Buontalenti ofereceu ao seu espectador (Figura 34).

É preciso registrar que a decisão de esconder os instrumentos (fontes, refletores, projetores) inaugura um princípio que vem sendo aplicado durante os últimos quatro séculos. Somente nos anos 1920, Brecht rompeu a tradição e decidiu revelar os instrumentos, o aparato destinado a produzir visibilidade e construir as imagens da cena, numa clara intenção de sublinhar a natureza teatral ao expor a técnica usada no palco. Uma atitude tão significativa que contribuiu para o princípio de desconstrução da ilusão de real no teatro, uma prática privilegiada até hoje, em muitas montagens, como marca registrada da modernidade.

\section{Angelo Ingegneri}

Algumas décadas depois da publicação dos Diálogos (Dialoghi) de Leone de'Sommi e nove anos depois das aventuras de Buontalenti, surge no ambiente teatral outro artista italiano, cuja obra marcou o espetáculo, o acadêmico Angelo Ingegneri. Ele escreveu $O$ discurso da poesia representativa (Il discorso della poesia rappresentativa) e Do modo de representar a fábula cênica (Del modo di rapppresentare le favole sceniche), publicados em 1598 por V. Baldini Ferrara - nos quais se pode encontrar valiosa informação acerca do espetáculo de inauguração do Teatro Olímpico de Vicenza, a tragédia de Sófocles, Édipo Rei, em 1594/1595, sob sua responsabilidade.

44 "First of all, balustrades and pillars at the raised platform to put candles in."

45 "[...] it is quite clear from the festival accounts that Buontalenti used the light on the stage in a new way. Time and again we are told that sources of light were concealed from the eyes of the spectators." 
Humanista filiado à Academia Olímpica, também em Vicenza, homem do espetáculo, Ingegneri foi o responsável pela organização de festividades em vários principados, escreveu também vários poemas, uma pastoral e uma tragédia. Nascido em 1550, tem suas atividades teatrais mencionadas na corte de Ferrara, desde que completou 28 anos de idade; depois disso, ele reaparece em Parma, no ano 1584, e sucessivamente: em Roma, 1592 e em Urbino, 1598. E, finalmente, no ano 1602, em Turim, onde permaneceu até falecer, em 1613.

A dramaturgia e suas questões constituem a primeira parte da obra, enquanto que a segunda aborda o apparato. Por apparato, ele entende a organização do espaço do público, os cenários, figurinos e a luz. De acordo com Bergman (1977, p. 66, tradução nossa), Ingegneri devotou grande atenção à luz:

[...] Ingegneri defende calorosamente uma iluminação da cena na qual as fontes de luz são escondidas do olhar do espectador. Se as fontes de luz são colocadas de modo que o público vê apenas a luz, mas não a sua origem, isso aumentará o encanto do espetáculo. [...] o encanto do espetáculo é acentuado, em particular, se as luzes são dispostas de modo que possam iluminar o rosto dos atores. ${ }^{46}$

No trato da luz Ingegneri, então, foi enfático ao dizer que não deveria ser permitido ao espectador ver suas fontes. Bergman lembra que, pela primeira vez se colocava uma discussão sobre a necessidade de iluminar o rosto do ator. Deve-se considerar, por conseguinte, que há mais de quatro séculos um artista percebeu um problema para o qual até hoje podem ser encontradas soluções insatisfatórias. As discussões sobre a luz colocada em um ângulo de 45 graus, acima do rosto do ator, com intuito de corrigir sombras nas cavidades oculares parecem esquecidas em projetos de teatro nos quais se torna quase impossível resolver tal problema devido à instalação equivocada de varas de luz fixas, cuja relação com o palco desconsidera ou desconhece totalmente o problema. Se uma situação de tal natureza impõe sombras ou ilumina excessivamente o olho do ator, o espetáculo estará perdendo a importante possibilidade de revelar ou até antecipar, se for o caso, expressões ou emoções que o ator procura criar.

Ingegneri inclui, também, indicações de segurança e conforto sugerindo que toda fonte de luz deveria ser disposta de modo a prevenir incêndios, fumaça

46 " $[. .$.$] Ingegneri speaks warmly in favour of stage lighting with sources of light concealed from the eyes of the$ spectator. If the sources of light are placed so that the audience sees only the light but not its origin, it will enhance the charm of the performance. [...] the charm of the performance is heightened in particular if the lights are place so that they can illuminate the face of the actors." 
exagerada e maus odores. Além disso, os candelabros sobre a plateia deveriam evitar respingos que pudessem danificar as roupas dos espectadores.

Mesmo enfrentando enormes dificuldades técnicas, Ingegneri antecipou princípios do espetáculo moderno. Propor luz específica para a boca de cena, que seria acentuada ao se retirar a luz que iluminava o público, era uma decisão crucial para a nova visualidade do espetáculo, movimento que até hoje é aplicado: retirando-se ou reduzindo-se a luz da plateia e acentuando a boca de cena ou a cortina, estabelece-se uma transição realidade/ficção. Tal movimento, que pode parecer banal e óbvio, sob o olhar do século XXI, estabeleceu importante passo para a visualidade da cena moderna, como uma transição planejada no início de um espetáculo.

No que se refere à luz, palco e plateia constituíam espaço único, sem divisão conceitual. Se um evento se estendesse até as primeiras horas da noite, as tochas iluminariam tanto o público quanto a cena. Assim era o pensamento visual instalado no teatro, onde a tradição ordenava: As luzes são acesas - para a cena e para o público - e a peça pode começar. Leone de'Sommi propôs a redução e Ingegneri radicalizou, indicando a retirada total da luz da plateia e subvertendo as convenções do seu tempo.

Ingegneri foi adiante, fazendo importantes considerações acerca da boca de cena, discutindo o seu papel na arquitetura teatral. Ele ampliou suas funções, pensando-a, não apenas como moldura decorativa, que operava a transição entre a realidade da plateia e a ficção do palco:

Ele imagina a iluminação vinda de cima, de uma ponte de iluminação instalada atrás da borda superior da boca de cena, de onde a luz é dirigida para a ação cênica na parte frontal do palco. [...] O topo da boca de cena foi adornado com o brasão de armas do príncipe, festões, frutas e cupidos. Sua função não era apenas criar - em conjunto com as partes laterais - uma moldura festiva, decorativa, circundando a cena, mas também esconder a crescente mecânica do palco, cada vez mais complexa e necessária a um mundo dinâmico, imaginário, com mudanças de cenário, nuvens suspensas e bigas. ${ }^{47}$ (BERGMAN, 1977, p. 66-67, tradução nossa)

Sua imersão na luz, como um problema a ser tratado pela cena, vai adiante:

\footnotetext{
47 "He imagines lighting from above, from a lighting bridge behind the upper edge of the proscenium arch, from where the light is directed towards the scenic action on the front part of the stage. [...] The top of the proscenium was adorned with the prince's coat-of-arms, festoons, fruits, and cupids. Its function was not only to give - together with the side pieces - a festive, decorative frame round the picture but also to conceal the increasingly complex stage machinery needed for a dynamic, imaginary world with changeable scenery, mobile clouds and chariots."
} 
Ingegneri imagina, então, uma fileira de luzes com material reflexivo, colocadas na parte de trás da boca de cena. Era um elemento separado das peças laterais e poderia ser baixado antes da apresentação para o acendimento das lamparinas. Assim, a boca de cena recebeu uma terceira função: a de ser, no interior, uma base para uma ponte de iluminação. Ingegneri, entretanto, usou essas luzes também como dispositivos para adornar, fazendo-os iluminar por trás o topo transparente do brasão de armas do príncipe, assim como outros adornos que, para o público, pareciam luminosos em si. ${ }^{48}$ (BERGMAN, 1977, p. 67, tradução nossa)

Desperta a atenção, portanto, o princípio do back-light - estrutura de material translúcido atrás da qual são colocadas lâmpadas para que a luz, atingindo a superfície translúcida, sugira que o elemento é, de per si, uma fonte de luz. O back-light pode ser encontrado, ainda hoje, na cena, no entretenimento em geral, na publicidade e nos projetos de interiores, como exemplos.

E mais, quando o palco se adiantou em direção à plateia, estendendo sua profundidade e ampliando o proscênio, a "ponte" interna acima mencionada influenciou engenheiros e arquitetos, que conceberam o mesmo tipo de pontes, para serem instaladas sobre o público, com o objetivo de projetar luz no proscênio e/ou no interior da caixa cênica. Mesmo que, na condição de elementos técnicos, tais posições já sejam itens importantes, as decisões que a elas se referem interessam de modo particular quando se apresentam como resposta para o discurso visual da cena. Sem a função desempenhada pela citada "ponte"; sem os suportes para instrumentos dispostos sobre a plateia, o teatro realista não se efetivaria uma vez que a inexistência dos ângulos superiores por ela proporcionados impossibilitaria a criação da imagem, na cena realista, em muitos casos.

Para apontar um exemplo: elaborar imagens cênicas para $O$ inimigo do povo (1882) [En folkenfiende, Henrik Ibsen (1828-1906)], com luz de ribalta, será uma tarefa de extrema dificuldade se for levada em conta sua proposição realista. Observando-se a rubrica de abertura registram-se duas fontes de luz artificial visíveis: uma sobre a pequena mesa, na sala de estar, outra sobre a grande mesa, ao

\footnotetext{
48 "So Ingegneri imagines a row of lamps with reflective material placed on the backside of the proscenium arch. This was a separate element detached from the side pieces and could be lowered before the performance for the lighting of the lamps. So the proscenium arch had been given its third function: that of being, on the inside, a base for a lighting bridge. But Ingegneri used these lights as adorning devices too, by making them illuminate from behind the transparent top of the prince's coat-of-arms and other adornments which to the audience, seemed luminous."
} 
fundo, na sala de refeições. As portas que dão acesso a outros ambientes, quando abertas, podem contribuir para a luz do ambiente principal, sem mencionar o espelho.

Tudo isso, e cada um dos detalhes, apresentando aspectos decisivos como temperatura de cor, definição dos limites entre a luz e a sombra (o que implica na extensão da penumbra), intensidade, ângulos de incidência, reflexão/rebatimento, além do movimento proposto pela ação cênica. Contudo, se a ilusão realista for ignorada, tais detalhes podem ser desconsiderados e, em certos casos, a ribalta resolveria.

O caso particular de $O$ inimigo do povo, considerando a convenção realista compreendida como um sofisticado conjunto de artificialidades cujo objetivo é elaborar uma ilusão de real e não uma cópia simplória da realidade - isso poderia representar uma armadilha. Como aplicar elementos de sustentação, as varas ou pontes dispostas acima da cena, uma vez que elas produziriam um ângulo descendente que, se definido como high-light (o resultado da maior intensidade de luz a incidir sobre a cena) mentiria sobre os ângulos decorrentes do posicionamento das principais fontes de luz disponíveis nos ambientes da cena propriamente dita, ambas à altura do tronco das personagens? É recomendável desenvolver experimentação e familiaridade com o equipamento, acessórios e sistemas de controle, para propor soluções, uma vez que os elementos de sustentação acima da área de atuação e da plateia são, comumente, mais numerosos.

É importante sublinhar que cada espetáculo, levando-se em conta as variáveis estéticas, poéticas e seus traços estilísticos particulares exige determinado discurso visual. Tal convicção já pode ser identificada no trabalho deixado por Angelo Ingegneri, como se pode apreender no texto de Bergman, acerca das suas visões cênicas:

As aparições fantasmagóricas, diz Ingegneri, devem ocorrer na parte de trás, bem ao fundo da perspectiva, uma vez que ali os atores parecerão desproporcionais, quando comparados aos edifícios circundantes, e isso já produzirá um efeito assustador. Mas há também outra razão: naquele ponto, o espaço entre as tapadeiras é menor e pode ser coberto com um véu preto. Através do véu se pode ver tudo o que acontece por trás, de um modo misterioso, e o monstro infernal, que 'deve se expandir em trevas, assim como as figuras de santos bilham em luz', transmitindo ao espectador uma ilusão. O véu deve ser esticado no palco, distante o suficiente do pano de fundo, para permitir que o fantasma possa se mover por trás dele [ou entre ele e o telão 
de fundo]. O monstro infernal deve estar vestindo preto criando 'uma figura disforme', sem definir as pernas ou os braços. Ele não deve caminhar, mas deslizar sobre pequenas rodas, sua voz deve ser aguda, estridente, e mantida sempre na mesma altura. Enquanto fala, ele deve estar em constante movimento e, então, desaparecer de repente. Ao mesmo tempo, o véu negro deve ser queimado, em um efeito preparado com antecedência para que o fogo não cause nenhum acidente. $O$ fogo aumenta o medo do espectador e o ofusca. ${ }^{49}$ (BERGMAN, 1977, p. 68, tradução nossa)

Na opinião de Bergman, Ingegneri deixa uma imagem assustadora e expressiva, que acentua a virtuosidade do seu espetáculo. No relato acima, cada decisão se voltava para a assertiva visual da cena, tornando o efeito, em si, secundário. Tal abordagem ganhou importância para a luz da cena da atualidade: o iluminador pode ampliar a qualidade expressiva do seu projeto, da sua contribuição para o espetáculo, se ele compreender que o efeito não necessariamente é um fim em si, e que uma sucessão de efeitos pode não ser suficiente para construir o discurso poético-visual de um acontecimento espetacular. Ou seja, cada efeito deve ser projetado como um movimento orgânico e indispensável, concebido para elaborar cada visualidade em particular.

\section{Nicola Sabbatini}

Em meados da primeira década, no século XVII, através do trabalho de Nicola Sabbatini, o Renascimento antecipa outra importante compreensão da luz como aspecto decisivo para o espetáculo moderno. Na introdução escrita para os textos de Sabbatini, John H. McDowell (1958, p. 37, tradução nossa) diz: "Detalhes biográficos sobre Sabbatini são imprecisos. Thieme-Becker apresenta-o como um arquiteto, um construtor e um cenógrafo, nascido em Pesaro, por volta de 1574, onde

\footnotetext{
49 "The ghostly apparitions, says Ingegneri, have to take place at the very back of the perspective scene, for here they seem out of proportion to the surrounding buildings, and this alone produces a frightening effect. But there is also another reason: there the breadth between the screens is smaller and could be covered with a black veil. Through the veil one sees everything that happens behind it in a mysterious and the hellish monster, which 'must spread around it darkness just as the holy figures shed light', conveys to the spectator an illusion. The veil should be stretched across the stage so far from the back-drop that the ghost can move behind it. He should be dressed in black and form 'a shapeless figure' by not letting legs or arms show. He should not move by steps but glide on small wheels, his voice should be high-pitched, shrill and all the time be kept at the same pitch. While speaking, he should be in continuous motion and then vanish suddenly. At the same time, the black veil should begin to burn, prepared in advance so that the fire could do no harm. The fire increases the spectator's fright and dazzles him.
} 
também faleceu, em 12 de dezembro de $1654 .{ }^{50}$ No início da primeira metade do século XX, cresce fora da Itália o interesse por sua obra, aparecendo traduções em alemão (1926) e uma tradução completa do texto, em francês (1942). A versão aqui citada é a tradução inglesa, de 1958, publicada por Barnard Hewitt.

Sabbatini trabalhou como arquiteto na corte de Urbino e Foglia entre 1598 e 1614. Ele teria construído e/ou equipado o Teatro del Sole, em Pesaro, em 1637, inaugurado com a tragédia L'Asmondo - escrita por um nobre da mesma cidade -, cujos intermezzi despertaram grande ou maior interesse do que a peça principal devido a sua extraordinária espetacularidade. Ainda segundo McDowell (1958), no mesmo ano, Sabattini teve publicado o primeiro livro do seu trabalho Prática de fabricar cenário e máquinas nos teatros (Pratica di fabricar scene e machine ne' Teatri), e, no ano seguinte, edita o segundo, em Ravena. Seus textos ficaram conhecidos como o primeiro manual para técnicos, maquinistas e outros envolvidos com efeitos especiais, com a cenografia e com a luz teatral, já que representam uma compilação da técnica cênica daquele período. O próprio Sabattini (apud MCDOWELL, 1958, p 38, tradução nossa) diz:

[...] os mecanismos descritos em ambos os livros foram, em sua maioria, utilizados em nobres espetáculos recentemente apresentados no Teatro del Sole em Pesaro, e eles funcionaram de forma tão satisfatória que receberam admiração especial e deram prazer aos espectadores. ${ }^{51}$

Ao descrever máquinas e arranjos aplicados em efeitos especiais, incluindo procedimentos do seu próprio trabalho, ele apresentou segredos dos bastidores do teatro renascentista italiano. Estudiosos que se voltaram para o texto de Sabbatini acentuam que ele não deve ser considerado um inventor, precursor dos mecanismos da técnica cenográfica, ou visionário, pois os aparatos e processos por ele apresentados, os "segredos" técnicos descritos já seriam conhecidos entre os especialistas há algum tempo, antes da publicação da sua obra. Alguns desses procedimentos e máquinas poderiam ser até obsoletos, quando se considera a práxis teatral da segunda metade do século XVI. Por outro lado, vale a pena considerar a relevância do seu trabalho como o principal registro de um grande número de métodos então conhecidos.

50 "Biographical details about Sabbatini are lacking in precision. Thieme-Becker lists him as an architect, a constructor and a painter of scenery, who was born at Pesaro about 1574 and who died there on December 12, 1654."

51 "[...] the machines described in both these books have been to a great extent used in the very noble spectacles which recently were presented in the Teatro del Sole at Pesaro, and they worked so satisfactorily that they received particular admiration and gave pleasure to the spectators." 
A perspectiva que funcionava como a disciplina que ligava arquitetura, pintura e cenografia, encontrou na cena renascentista o lugar onde esses modos expressivos interagiam de forma exemplar. Um lugar no qual se compartilhavam conhecimentos e onde a interação era constantemente ampliada. Efetivamente no teatro, depois da definição da boca de cena como abertura para um espaço teatral de maior profundidade, já no século XVI, surgiram demandas - incluindo as mudanças de cenários - para a configuração da cena perspectivista nos teatros da nobreza italiana. É precisamente no que se refere a mecanismos para o movimento do dispositivo cenográfico que aparece uma das mais contundentes críticas ao texto de Sabattini, uma vez que ele deixou de mencionar o sistema de tapadeiras operadas em movimentos laterais, que teriam sido introduzidas em 1606 - uma década depois da estreia de Édipo Rei, no Olímpico - por Giovanni Battista Aleotti (1546-1636) no Teatro degl'Intrepidi, em Ferrara.

No que se refere à ilusão promovida pelo cenário em perspectiva elaborado no Renascimento, Aleotti deve ser lembrado como responsável pelo mais antigo projeto de um teatro que suscitou definições para as fronteiras entre a realidade da plateia e a ficção do espaço do palco.

Trata-se do Teatro Farnese, na cidade de Parma, Itália. Iniciado em 1618, foi inaugurado 10 anos depois, com o espetáculo Mercúrio e Marte, cuja música foi composta por Claudio Monteverdi (1567-1643), já mencionado no capítulo anterior. O "Farnese" apresenta uma inovação decisiva para a visualidade da arte teatral, sendo o primeiro teatro construído na Europa que apresenta uma boca de cena permanente. Estava inaugurado, assim, um discurso visual que dominaria o espaço teatral, nos quatro séculos que se sucederam, constituindo bases estéticas para a ilusão teatral que fortaleceu a ficção emoldurada fisicamente pela boca de cena.

Aleotti, entretanto, não desejou se afastar, ou não poderia ter se afastado completamente do espetáculo do seu tempo, que incorporava influências da arquitetura romana, mas estava muito próximo das festividades renascentistas e até medievais. O seu projeto teatral revelou um curioso conflito sobre o qual se deve refletir com atenção, pois apresenta sutilezas inerentes às questões visuais do espetáculo, pouco aprofundadas e até recebidas com estranheza.

O Teatro Farnese deixou um exemplo de tais sutilezas. Ele conta com um enorme palco e apresenta uma importante particularidade, no que se refere à plateia, uma espécie de cávea que pode acomodar mais de quatro mil espectadores. Diante da cávea e à frente do palco encontra-se uma imensa orchestra projetada como um perfil em U, lembrando a configuração das praças públicas onde 
aconteciam os espetáculos medievais. A orchestra poderia até abrigar torneios, nos quais eram envolvidos vários cavaleiros, e até batalhas. ${ }^{52}$ Isso pode explicar a relação entre a plateia (cávea) e a "orchestra-arena": a grande maioria dos espectadores sentados na cávea estava voltada diretamente para a orchestra. Por outro lado, os espectadores acomodados nos pontos centrais da cávea, que tinham uma visão frontal do palco, estavam no ponto mais distante dele, tendo uma imensa orchestra diante de si (Figura 35).

A ação representada no palco mostrava deuses e deusas envolvidos em uma performance de grande apelo visual durante a qual algumas personagens pairavam em nuvem e até voavam, num ambiente que se transformava sucessivamente através da complexa movimentação mecânica dos cenários. A ação emoldurada no palco pela boca de cena era oferecida ao espectador acomodado no centro da cávea - no sentido da visão frontal perspectivista - mas, simultaneamente, afastada dele pela distância que o olhar deveria percorrer e que correspondia à área da enorme orchestra. É preciso dizer que os outros espectadores, aqueles que ocupavam as laterais da cávea, observavam frontalmente a orchestra e, para contemplar o palco, deveriam forçar o olhar lateralmente. Lembre-se que, na observação do cenário em perspectiva do período, o ponto central da plateia é o local de excelência para a colocação do observador. Tal "contradição visual” é importante para registrar, tanto a presença histórica da primeira boca de cena permanente da qual se tem conhecimento, quanto a tensão estética inerente ao momento de transição no qual a visualidade do Renascimento interagia com o contexto que a antecedeu, principalmente a práxis cênica medieval, e preparava terreno para o teatro do Barroco.

A tecnologia que sustentava a espetacularidade de Mercúrio e Marte estava provavelmente incluída na compilação de Sabbatini, ainda que ele tenha insistido na descrição dos periaktoi, já citados, quando as tapadeiras planas com deslocamento lateral já faziam parte da técnica cenográfica. Deve-se acentuar que, quando se trata do estudo da iluminação, a abordagem do seu trabalho geralmente provoca a expectativa de uma listagem de artefatos e efeitos relacionados à luz artificial para a cena, encontrados em alguns poucos capítulos da sua obra, no Livro 1 (capítulos 38, 39 e 41) e também no Livro 2 (capítulos 11, 12, 52 e 55).

52 Como ocorreu durante o espetáculo de inauguração, no qual foi apresentado um torneio de que tomaram parte quarenta cavaleiros. Na parte final do espetáculo, a orchestra foi preenchida com água, para mostrar uma espetacular batalha naval, que incluiu disputas entre seis contendores montados em golfinhos. 
É importante, no entanto, mencionar a preocupação de Sabbatini com as imagens que constituem visualmente a cena, preocupação identificada já no capítulo 2, do Livro 1:

Na construção do palco deve-se tomar cuidado com o espaço usado, caso contrário uma ou duas inconveniências aparecerão: (I) devido à limitação no espaço, o cenário não mostrará distância suficiente para a perspectiva e, consequentemente, não resultará agradável ao olhar. Além disso, as restrições de espaço, por vezes criarão grande confusão [...] e (II), se for usado espaço demasiado, a capacidade de acomodar espectadores será reduzida, o que é ruim. ${ }^{53}$ (SABATTINI apud MCDOWELL, 1958, p. 44, tradução nossa)

Pode-se ver como Sabbatini seguiu a tendência renascentista e mergulhou nas questões visuais, incluindo a perspectiva e incorporando experiências anteriores como as lições deixadas por Palladio e Scamozzi na adaptação do antigo Castelo Del Território. O observador atento compreenderá que a citação acima denota compromissos com a luz, com o olhar e, portanto, com a visualidade.

Como já foi dito, os capítulos 38, 39 e 41, (Livro 1) são sempre mencionados quando se trata do estudo da luz, uma vez que neles Sabbatini indica a distribuição das lamparinas, tochas ou velas na plateia, e também no palco. Ele chama a atenção para a melhor qualidade das lamparinas a óleo, tecendo considerações sobre odores desagradáveis e respingos de cera e/ou óleo nos espectadores, orientando a distribuição das lamparinas ou velas nos candelabros, e mencionando possibilidades decorativas para esses aparatos. A necessidade de esconder as fontes de luz exigia soluções técnicas específicas. Sabbatini recomendou:

Outras lamparinas a óleo, ou melhor, tochas, devem ser distribuídas sobre o palco. Isso será mais bem realizado, se alguns pedaços de madeira de tamanho apropriado forem utilizados, cobrindo-se a distância entre o piso do salão e a parte inferior [do cenário] de cada casa, na rua que será iluminada. Eles devem ser firmemente fixados no piso, com gesso, por meio de orifícios suficientemente largos para que os pedaços de madeira não toquem o palco, em nenhum ponto. Em seguida, as suas extremidades devem ser bem fixadas na parede, por

\footnotetext{
53 "In building the stage you must watch not to take up too much or too little space, otherwise one or two inconveniences will result: (I) because the limitation in space the scenery will not show sufficient perspective distance and consequently will not prove so pleasing to the eye. Besides which the restrictions of space will at times create great confusion [...] and (II) because by too much space the number of spectators will be curtailed, which is bad."
} 
meio de travas [madeira], ficando as lamparinas bem protegidas, [...]. Desse modo elas permanecerão firmes e estáveis, mesmo quando o palco balança durante a dança e os saltos. ${ }^{54}$ (SABATTINI apud MCDOWELL, 1958, p. 95, tradução nossa)

As exigências dos dispositivos cenográficos encaminhavam inúmeras decisões técnicas e mecânicas, com o objetivo de realizar as proposições estéticas da cena. No capítulo 3, Livro 1, ele apresenta detalhes sobre a construção de um palco, que incluem uma espécie de parapeito no limite do proscênio, com dupla função: como proteção para elementos da cenotécnica instalados sob o piso, assim como suporte para as luzes da ribalta. Mais adiante, no capítulo 39 do mesmo livro, ele discute a ribalta propriamente dita, apresentando sérias restrições a tal posição. A primeira delas refere-se a uma questão técnica, uma vez que os aparatos instalados devem ser de grande porte, com o intuito de prover intensidade suficiente para iluminar a parte frontal do proscênio e do palco, gerando uma enorme quantidade de fumaça muito densa, com prejuízo para a visibilidade, além de gerar odor mais desagradável, devido à proximidade das luminárias em relação à plateia. Sabbatini aponta ainda outra grande desvantagem: "É verdade, pode-se ver melhor o figurino do ator e os dançarinos, mas também é verdade que os seus rostos se tornam tão pálidos e abatidos, que eles parecem ter sido acometidos por uma grave febre". ${ }^{55}$ (SABATTINI apud MCDOWELL, 1958, p. 96, tradução nossa)

Além disso, o brilho excessivo desses aparatos gerava incômodos para os olhos dos atores e dançarinos. Tal ponderação revela que, mesmo mencionado como obsoleto, Sabbatini apontou para uma preocupação que se tornou presente na maneira de pensar a contribuição da luz para o teatro, quando observou a diferença entre tornar visível e elaborar uma imagem eficiente para a espetacularidade do evento. Atores bem expostos pela intensidade da luz, mas pálidos como se portadores de alguma enfermidade, rostos chapados, criando imagens distanciadas dos objetivos da cena, representavam - na opinião de Sabbatini - um equívoco.

Trata-se de uma antecipação da observação da assertiva visual (visualidade) da cena, como um compromisso com a ideia que a originou. Se, por um lado, a crítica

\footnotetext{
54 "Other oil lamps, or better, torches must be distributed over the stage. This will be best accomplished if some suitable sized pieces of wood are used, as long as the distance from the floor of the hall to the lowest part of each house on the street which is to be illuminated. These should be firmly fixed with plaster to the floor by means of holes sufficiently large that the pieces of wood do not touch the stage at any point. Then their ends are well fixed by means of braces to the wall, and lamps well secured, [...]. By this means they are firmly and steady even when the stage shakes from the dancing and tumbling."

55 "True, one can see better the costumes of the actor and the dancers, but is also true that their faces seem so pale and wan that they look as though they just a had a bad fever."
} 
de Sabbatini indicava obediência a um padrão superficial de beleza comprometido em mostrar de modo "agradável" o ator em cena, por outro, sua abordagem aproximava-se da intenção de construir a visualidade exigida por cada espetáculo em particular, considerando-a mais importante do que apenas tornar visível a ação (o ator e o ambiente) no palco.

Na compreensão de Sabbatini, se não havia razões para que os atores estivessem pálidos, tal imagem deveria ser descartada. Do mesmo modo que, ainda hoje, um rosto rosado e agradavelmente iluminado não deve ser mostrado em cena, se o espetáculo precisa do contrário. Pode-se observar aí determinada tensão estética: ainda que o acontecimento espetacular intente seduzir o espectador através do discurso visual, transformar o espetáculo em mero prazer ou entretenimento é uma decisão que recebe severa crítica. Tal observação qualifica as funções do iluminador, exigindo dele muita atenção àquilo que cada diretor (ou espetáculo) propõe.

No capítulo 12 do Livro 2, Sabbatini apresentou uma das ilustrações mais comentadas do seu trabalho. Tratava-se de um sistema concebido para bloquear as velas e escurecer o palco, através de um aparato metálico e cilíndrico que, deslocando-se no sentido vertical na direção das velas, impedia que a luz chegasse ao palco (Figuras 36 e 37). Considerar a retirada de toda a luz da cena era, naquele tempo, uma atitude revolucionária e inatingível do ponto de vista operacional. O aparato, entretanto, deve ser sublinhado como a primeira versão do dimmer moderno e do caminho para o black-out, definindo esses princípios como contribuições já presentes no espetáculo, há cinco séculos.

\section{REPERCUSSÕES RENASCENTISTAS FORA DA ITÁLIA}

As proposições do teatro renascentista na Itália romperam fronteiras, não somente pelas viagens de artistas italianos para outros países, mas também em decorrência da passagem por lá de artistas de outras regiões. Entre eles, destaca-se o alemão Joseph Furttenbach, o velho (1591-1652), que chegou à Itália em 1610 e retornou ao seu país 10 anos depois, onde se estabeleceu como engenheiro e arquiteto sediado na cidade de Ulm, interessado em muitas áreas da construção incluindo a militar, assim como a naval. Lendo seu texto Novas viagens à Itália (Newes Itinerarium Italiae), conjunto de relatos publicados em 1627 acerca da sua passagem pela Itália, pode-se observar seu interesse pelos estudos da arquitetura, incluindo a construção naval, assim como seu entusiasmo pelos espetáculos. 
Em Florença, Furttenbach provavelmente acompanhou, ou foi orientado, por Giulio Parigi (1571-1635), de quem recebeu grande incentivo e a quem se refere como mestre. Parigi foi responsável pela montagem de diversos espetáculos, incluindo a cenografia e a luz, sendo também arquiteto e engenheiro a serviço do Duque da Toscana. Ao descrever com entusiasmo um espetáculo religioso apresentado por ocasião da sexta-feira santa, Joseph Furttenbach acentuou a beleza da perspectiva projetada por Parigi, e comentou o tratamento do grande salão onde se deu o evento:

\begin{abstract}
A impressão de grande distância e largura foi criada pelo bom uso da perspectiva. Numa direção, através de uma floresta, era vista a cidade de Jerusalém. No lado direito, estava o castrum doloris [ou castelo da dor, aparato criado para ser colocado o esquife durante velórios], ou sepulchrum Dominicum [sepulcro divino]. Com oito palmos de comprimento e cerca de seis de altura, decorado como um caixão bem construído, completamente coberto de veludo negro, e sobre o qual se encontrava uma grande quantidade de caros e indescritíveis diamantes [...]. Um grande espetáculo de riquezas era criado pelo brilho das luzes escondidas no céu. Os diamantes faiscavam como estrelas quando brilham no céu. ${ }^{56}$ (FURTTENBACH apud KERNODLE, 1958b, p. 180, grifo e tradução nossos)
\end{abstract}

Tal relato amplia a compreensão da cena daquele momento como um evento fortemente impregnado pela visualidade. A relação entre a perspectiva e a luz no espetáculo renascentista deixaria marcas profundas no jovem artista alemão que escreveu ainda vários tratados e entre esses, três textos que abordam a atividade teatral. Em Architectura civilis (1628) Furttenbach, incluiu na parte final, estudos introdutórios acerca do palco e da cenografia, além do projeto de um pequeno teatro inserido no complexo de uma mansão. Ainda que se possa argumentar que ele representava apenas um aspecto decorativo da edificação, pode-se antever uma tendência do barroco segundo a qual os nobres incluíam teatros nos projetos de muitos castelos, já que tais edificações funcionavam como unidades mais ou menos autônomas, que deveriam atender as demandas essenciais da comunidade que abrigava.

\footnotetext{
56 "The impression of great distance and width was created by good use of perspective. In one direction, through a forest was seen the city of Jerusalem. At the right side was the castrum doloris, or sepulchrum Dominicum. It was eight spans long and about six spans high, decorated like a well-formed coffin completely covered with black velvet on which was a large quantity of expensive diamonds that cannot be described. [...] A great spectacle of riches was created by the glow from standing lights put in hidden places within the heavens. The diamonds sparkled as though stars in heaven where shining."
} 
Na sua descrição desse teatro ele acentuou a aplicação da luz. Ao descrever a cenografia para a comédia ele diz:

No palco, deve ser instalado um grande número de lamparinas a óleo, [...] colocadas dentro da cena, acima, entre as nuvens, em ambos os lados, e nos fossos, à frente e ao fundo; todas, é claro, completamente ocultas. Elas produzirão um brilho tão esplêndido que parecerá o dia rompendo através das nuvens. ${ }^{57}$ (FURTTENBACH apud KERNODLE, 1958b, p. 192, tradução nossa)

Furttenbach acreditava que o seu espectador estaria interessado em um brilho que aproximasse a experiência visual presente na cena, do brilho da luz do sol. Em 1640, ao escrever Arquitetura do entretenimento (Architectura recreationis), Furttenbach ampliou o tratamento dispensado à cenografia e ao palco, além de inserir desenhos e projetos de espetáculos nos quais trabalhou. O seu escrito teórico serve, então, como importante fonte para o estudo da enorme influência e atenção que a práxis teatral italiana provocou na Alemanha no século XVII.

Começava a tomar corpo a ocultação dos instrumentos, assim como acessórios da mecânica teatral exaustivamente aplicada como caminho decisivo para o realismo. Também na compreensão de Furttenbach os instrumentos deveriam permanecer fora do alcance visual do espectador. Mais uma vez aparece a necessidade da ilusão, o princípio de ilusão de real.

Furttenbach publica ainda Nobre espelho da arte (Mannhafter kunstspiegel, 1663), um conjunto de dezesseis textos que incluem geometria, mecânica e perspectiva cenográfica, tratando não somente de obras realizadas, mas também transitando por especulações voltadas para projetos que ele poderia ou desejaria formalizar. Em tais textos está incluída a proposta de um grande salão com quatro palcos dispostos sobre um anel giratório, em torno de uma mesa de banquete. De acordo com George R. Kernodle (1958b), ao introduzir sua tradução do trabalho de Furttenbach, os relatos que aparecem em Nobre espelho da arte tratam de dois espetáculos que podem ter sido os mais ousados da carreira do artista alemão, realizados em 1640 e 1650 . Kernodle (1958b) menciona ainda comentários de Furttenbach sobre limitações no orçamento das produções nas quais participou, cujos resultados ficaram aquém daqueles que ele pretendia, se comparados às montagens italianas.

57 Da tradução inglesa: "On the stage, there should be a large number of oil lamps, [...] placed within the scene, above between the clouds, at both sides, and in the front and rear pits, all of course completely concealed. These will give out such a splendid glow that will seem as if daylight were breaking through the clouds." 
Ainda que seus espetáculos impressionassem o público burguês, na Alemanha, ele usava como critério para julgamento, o padrão italiano, que conhecia bem. Se, por um lado, baseando-se excessivamente nos periaktoi Furttenbach faz sua discussão do tratamento cenográfico parecer ultrapassada, Kernodle (1958b), aponta três principais razões para a grande relevância das suas plantas e descrições:

Elas nos falam mais sobre a prática italiana do que podemos apreender em qualquer outra fonte, e mostram como essa prática foi adaptada em um país longe de Itália. Em segundo lugar, elas nos dão a mais ampla informação que encontramos sobre a forma e o uso do inner stage [no teatro elisabetano, a parte ao fundo do palco, geralmente sob a estrutura construída no segundo nível, para cenas como a do balcão, em Romeu e Julieta]. A utilização do inner stage como uma parte comum do palco nem sempre foi reconhecida no teatro [da Europa] continental e sua importância como um paralelo ao palco inglês ainda não foi totalmente investigada. Terceiro, mostram Furttenbach como um pensador avançado na prática de iluminação. ${ }^{58}$ (KERNODLE, 1958b, p. 184, grifo e tradução nossos)

No que se refere à aplicação da luz ao seu trabalho ele revela progressos que o colocam muito à frente da prática italiana de aplicação de luz na cena. O trabalho de Furttenbach tem grande relevância para a introdução de novas possibilidades de contribuição da luz para a cena, já que ela interage com os demais aspectos do processo criativo. Ele revela ainda uma face inesperada das suas preocupações, quando enfatiza a importância da atividade teatral na formação dos jovens:

A montagem de espetáculos é o mais agradável e útil treinamento para os jovens em crescimento, [...]. Atuar em um teatro bem equipado dará aos jovens [meninos] uma aparência agradável, um modo de falar confiante, e um espírito heroico, que vai prepará-los para mais tarde se expressarem, tanto em ocasiões espirituais [religiosas] quanto seculares. Há, portanto, uma razão especial para que os cidadãos construam esses benéficos teatros para salvar a sua juventude dos pecados, das vergonhas e dos vícios. ${ }^{59}$ (FURTTENBACH apud KERNODLE, 1958b, p. 203, tradução nossa)

58 "They tell us much about Italian practice that we can learn from no other source, and show how that practice was adapted in a country far from Italy. Second, they give us the most extensive information we have about the form and use of the inner stage. The use of the inner stage as a regular part of the continental theatre has not always been recognized, and its importance as a parallel to the English stage has not been fully explored. Third, they show Furttenbach as an advanced thinker in lighting practice."

59 "The putting of plays is a most delightful and useful training for growing youth, [...]. Acting in a well-equipped theatre will give boys a pleasing appearance, a confident speech, and a heroic spirit that will prepare them well 
Furttenbach defende a implantação de teatros "bem equipados", sublinhando sua preocupação com a justeza desses espaços para atender às proposições dos artistas e cumprir uma função educacional. Do ponto de vista específico do aprendizado teatral durante sua passagem pela Itália, ele detalhou inúmeros instrumentos, acessórios e efeitos especiais. Seus comentários acerca do uso de dimmers, descritos por Sabbatini, no Livro 2, capítulo 12, mostram o potencial desses acessórios, num trecho que ele intitula "como transformar o dia em noite". Exemplificando uma solução para o espetáculo Moisés, que teria sido montado sob os auspícios do seu patrono Herr Merchius, ele indicou o uso desses dimmers no momento em que o profeta faz a noite cair sobre o Egito:

Durante uma tempestade a luz do dia deve ser reduzida e, gradualmente, tornar-se escura como a noite. Pode-se fazer um planejamento para que as lamparinas a óleo e as luzes por trás do cenário sejam apagadas e acesas novamente. Mas isso exigiria tempo e as lamparinas de óleo, ao serem apagadas, produzem mau cheiro. Assim, temos pequenas caixas ou coberturas, feitas especialmente de metal preto que, por meio de cordas são abaixadas na frente das lamparinas a óleo que se encontram escondidas atrás das pernas e também na frente das lamparinas dispostas atrás da boca de cena. Elas podem desbloquear todas as lamparinas simultâneamente, ou apenas parte delas. Elas boqueiam as lamparinas, mantendo-as acesas, de modo que parece noite, no palco. O cabo de cada lamparina é esticado para a parte superior do palco [urdimento], juntando-se depois em um único acionamento para todos os cabos. Quando esse acionamento eleva os bloqueadores, as luzes brilham como um dia claro, mas quando cada bloqueador é abaixado, cobrindo a lamparina correspondente, nenhum raio de luz é visto. Isso foi feito para escurecer e criar o trovão e o relâmpago, na cena em que o Faraó se torna inflexível e, através do ato de Moisés, cai a noite, naquele momento, sobre o Egito. Tal efeito, em ocasiões dessa natureza, dá grande prazer a quem o contempla. ${ }^{60}$ (FURTTENBACH apud KERNODLE, 1958b, p. 230-231, tradução nossa)

\footnotetext{
for later discourses on both spiritual and secular occasions. Therefore there is a special need for private citizens of cities to build such beneficial theatres to save the growing your from sins, shames and vices."

60 "During such a storm the daylight should get dimmer and gradually become dark like night. It could be arranged that the oil lamps and lights behind the scene be put out and later relighted. But it would require time, and extinguished oil lamps produce a bad smell. Hence we have little boxes or covers, specially made of black metal that by cords are drawn over and then away from the oil lamps on the floor behind masking screen, as well as over and away from the oil lamps behind the proscenium. They can be drawn over all of the oil lamps at a time, or only part. They cover the lamps but still permit them to burn, so that it seems night on the stage. The cord from each
} 
É possível imaginar variadas oportunidades para o uso do mesmo sistema de controle, como em momentos generalizados de transição entre a luz de um dia claramente iluminado pelo sol e uma situação de tempestade, para usar um exemplo citado por Furttenbach. Importante aqui é lembrar que o resultado alcançado, caracterizando movimentos de transição entre luz e sombra, dia e noite, claro e escuro, já está presente no teatro desde o Renascimento. E ainda que se tenham modificado os meios, a tecnologia e as convenções, os princípios se mantiveram.

Tais momentos de redução da intensidade de luz, que repercutiam também na retirada de luz da plateia, representam uma preocupação com a visualidade da cena, não somente na Itália e na Alemanha, mas também na França e na Inglaterra. Para tratar da questão, Furttenbach sublinhou a localização das janelas em um teatro, indicando planejamento cuidadoso antes da construção, a partir mesmo dos projetos, para evitar o constrangimento e a inconveniência de intervenções nos edifícios depois de finalizada a obra. Ele sublinha problemas particulares de ventilação e iluminação, como aspectos decisivos na distribuição das janelas, tanto nos bastidores quanto no palco e na plateia, sugerindo que a distribuição seja planejada previamente. Trata-se de uma atitude originada no seu próprio trabalho no teatro, levando-o a decisões fundamentadas no estudo e na experiência adquirida com a cena propriamente dita. Isso pode servir como exemplo, ainda hoje, para um arquiteto que projeta uma casa de espetáculos sem identificar as funções desempenhadas em cada uma das suas áreas ou partes. Ele foi incisivo:

É imprescindível que as janelas sejam planejadas nos lugares corretos para iluminação adequada e circulação de ar. Muita gente aglomerada no mesmo espaço faz com que o ar se torne muito quente e úmido, e o arquiteto seria considerado um simplório se, após a construção, tiver que incluir mais janelas, obrigando-o a cortar as paredes, ou danificar o piso superior com grandes aberturas para o ar. ${ }^{61}$ (FURTTENBACH apud KERNODLE, 1958b, p. 206, tradução nossa)

\footnotetext{
lamp is led up above the stage and thence to a single handle for all the cords. When this handle is forward, the lights shine as for a bright day, but when the handle is drawn back when each cap covers its oil lamp so that not a ray is seen. Thus it was made to grow dark with the thunder and lightning in the scene where the Pharaoh grew obdurate, and through the act of Moses it became night for a time in Egypt. This effect for such occasions gives great delight to those who see it."

61 "It is very important that the windows be planned at the right places for proper lighting and plenty of air. So many people so close together cause the air to become very warm and damp, and the architect would be held a simpleton if, after the building has been finished, more windows had to be cut into the walls, or the upper flooring spoilt by cutting large vents for the air."
} 
Furttenbach não somente demonstra a necessidade de planejamento da ventilação que evitasse o desconforto causado pela insalubridade do ar em um espaço fechado e planejado para acomodar grande número de pessoas, com o agravante da fumaça produzida por velas e lamparinas a óleo, ou até tochas, mas também chama a atenção para aspectos estéticos. Depois de indicar a exigência de janelas nas laterais do palco para que, durante o dia, a entrada da luz do sol dispense o uso de lamparinas a óleo, ele completa:

Nenhuma janela deve ser colocada nas laterais do fosso à frente do palco. As paredes devem ficar intactas para que o espectador não seja ofuscado [pela luz do exterior], e permanecendo sentado na escuridão tenha grande deleite com a luz do dia banhando as ruas entre as casas, assim como a luz da manhã vinda de entre as nuvens. ${ }^{62}$ (FURTTENBACH apud KERNODLE, 1958b, p. 206, tradução nossa)

Dispensando atenção especial às janelas da plateia, recomenda:

O melhor seria não colocar nenhuma janela nas laterais da plateia de modo que os espectadores deixados na escuridão, como na noite, dirijam sua atenção para a luz do dia, no palco. E seria melhor ainda se tivéssemos um par de janelas a cada dez fileiras de assentos [bancos], para permitir a circulação do ar até o início do espetáculo. Ao som da trombeta e dos tambores, antes que a cortina caia, as janelas da plateia podem ser bloqueadas por persianas ou preenchidas com folhas verdes trançadas de modo a que o ar possa circular e a plateia continue escurecida. ${ }^{63}$ (FURTTENBACH apud KERNODLE, 1958b, p. 206, tradução nossa)

Para apreender os limites da mencionada "escuridão", é indispensável lembrar que a luz do sol estaria entrando pelas janelas incluídas nas coxias, produzindo certo grau de luminosidade na plateia. Importa, contudo, aproximar-se da intenção do artista alemão na busca da distinção palco-plateia, ator-espectador, e observar sua determinação ao defender a convenção. Furttenbach antecipa aqui

\footnotetext{
62 "No windows are placed at the sides of the front pit. The walls there are left unbroken so that the spectator will not be blinded, but will sit in darkness and have the greater wonder at the daylight falling in at the streets between the houses as well as at light of the morning coming from between the clouds."

63 "It were better if no windows are put at the side of the audience, so that the spectators, left in darkness like night would turn their attention to the daylight on stage. But it is still better to have a pair of windows at the every tenth bench to let in air before the play begins. Then, at the sound of trumpet and drums, before the curtain is let down, the windows of the audience can be closed by shutters, or filed with green leafwork so that the air can come in and the room still be darkened."
} 
a solução técnica aplicada pela fotografia e pelo cinema, quando se construíram estúdios que integravam dispositivos para permitir a entrada da luz do sol, com o intuito de alcançar a luminosidade necessária aos trabalhos. Em suas memórias Thomas Edison (1847-1931) escreveu:

Nosso estúdio era quase tão impressionante quanto os filmes que ali fazíamos. [...] O edifício tinha cerca de 25 por 30 pés $[7,5 \mathrm{~m} \mathrm{x} \mathrm{9,0} \mathrm{m],} \mathrm{e} \mathrm{demos} \mathrm{um} \mathrm{efeito} \mathrm{grotesco} \mathrm{ao} \mathrm{telhado,}$ elevando-o no centro e acrescentando uma saliência provida de venezianas que podiam ser abertas ou fechadas, por meio de uma roldana, de modo a permitir-nos aproveitar ao máximo a luz. (EDISON apud MANNONI, 2003, p. 389)

Edison refere-se ao Photographic building, construído nas dependências dos seus laboratórios, em West Orange, Essex, New Jersey/USA, em 1893. Seu estúdio ficou conhecido como Black Maria devido a sua semelhança com os furgões da polícia local, que tinham o mesmo nome (Figuras 38 e 39). Além de contar com dispositivos que elevavam a cobertura para possibilitar a entrada de luz, em todo o edifício - construído em madeira - ele estava instalado sobre um dispositivo giratório circular, permitindo que fosse movimentado a partir do próprio eixo para receber a luz do sol no ângulo indicado às filmagens. Os historiadores ponderam que o Black Maria não pode ser considerado o primeiro estúdio cinematográfico, uma vez que em 1890 Étienne-Jules Marey (1830-1904) já trabalhava no seu estúdio do Bois de Boulogne, em Paris. Marey, médico e inventor, é considerado um pioneiro, com pesquisas e inventos importantes para as artes da fotografia e do cinema. Há, contudo, uma relevante diferença entre o trabalho de Edison e o seu, se considerarmos que o trabalho de Marey partia de abordagem substancialmente científica, enquanto que Edison projetava a comercialização dos seus filmes. É importante dizer que, em 1889, Edison foi até a França, onde se encontrou com Marey.

Retomando Furttenbach, vale lembrar que também ele operou com a ideia do que denominamos, no Brasil, refletor, trabalhando no projeto de um instrumento, cujo princípio já havia sido descrito por Serlio. Ele propôs a implantação de uma superfície refletora diante da fonte de luz artificial e apresentou o que pode ser considerado um avanço, ao indicar o uso da mica (expressão provavelmente originada no latim micare ou brilho), ou seja: algum dentre os diversos minerais brilhantes e muito resistentes, até hoje usados como isolantes, e/ou em lugar do vidro, em situações de agressividade das altas temperaturas. Caracteriza-se, então, um progresso relacionado tanto à eficiência nas relações de iluminância (fluxo luminoso ou quantidade de luz que alcança ou chega a determinado ponto/ 
objeto), quanto à sua preocupação com a segurança, quando ele chamou a atenção para a propriedade isolante da mica, que evitaria incêndios (Figura 40).

Considerando o risco de incêndios, Furttenbach (apud KERNODLE, 1958b, p. 236, tradução nossa) acentuou uma grande vantagem no uso do mencionado acessório: "A experiência mostra como se produz um forte esplendor usando-se lamparinas equipadas com refletores desse tipo, parafusadas nos céus e dispostas sobre toda a cena". ${ }^{4}$ As preocupações de Furttenbach tornam-se compreensíveis quando se considera a frequente ameaça de incêndios em teatros iluminados por velas, tochas e lamparinas a óleo, já que ele fala como alguém efetivamente envolvido na aplicação desses aparatos nos eventos.

Ao apresentar seus quatro diferentes métodos para iluminar a cena, Furttenbach demonstra como os aparatos deveriam ser distribuídos por todo o palco e, também, fixados no dispositivo cenográfico, sempre atento às exigências de segurança. Isso também pode ser tomado como ensinamento, hoje em dia, quando - apesar da sofisticação de muitos sistemas - ainda se podem encontrar inúmeras situações de risco.

Furttenbach comentou o deleite produzido por momentos como o descrito acima, para quem os contempla, devido ao brilho ampliado pela reflexão. Ainda que o julgamento do século XXI apresente críticas ao desmedido apelo à "beleza" produzida por efeitos, uma vez que isso pode gerar superficialidade, desequilíbrio na cena, visibilidade desprovida de relações efetivas com a visualidade do espetáculo, é preciso considerar que, mesmo no início do século em curso, ainda se pode encontrar demasiada e progressiva acentuação de efeitos, como já foi dito na introdução deste livro. É possível identificar na proposição de Furttenbach a intenção de tratar a atmosfera indicada pela ação, instigando o jovem designer que hoje se aventura no estudo da luz para a cena. O trabalho de Joseph Furttenbach representa um documento relevante sobre o teatro renascentista italiano e mostra que as práticas originadas na Itália foram difundidas na Europa Continental.

64 Da tradução inglesa: "Experience shows how strong a splendor will be cast by lamps fitted with such reflectors and screwed in the heavens and about the entire scene." 


\section{O BRILHO DA LUZ DIVINA}

Como já foi dito, o desejo renascentista de ver o mundo através do olhar calculado pelo ser humano representa um importante registro da presença abrangente da luz na cultura. Há, entretanto, indicações bem anteriores ao Renascimento italiano que permitem refletir sobre a relevância da luz no teatro, incorporando passos importantes das relações entre a cena e a luz, determinando a abrangência do estudo da visualidade na práxis cênica, assim como sua interação com os processos culturais.

Marcus Vitruvius Pollio (ca. 8o/70 a.c. - 15 a.c.), engenheiro romano, em Da arquitetura, livro X (De architectura, libri X), adverte:

2. Nós devemos estar também cientes de que não há exposição ao sol. Quando o sol brilha intensamente sobre a sua [do teatro] parte circular, ficando o ar preso na estrutura e sendo impedido de circular, permanece lá dentro, aquecendo-se; tornando-se brilhante e quente, queima, resseca e deteriora os fluídos humanos. Por essas razões, os locais com tal insalubridade devem ser evita- 
dos, dando-se preferência àqueles saudáveis. ' (VITRUVIUS, 1914, p. 138, tradução nossa)

Na arquitetura atual, tal comentário poderia remeter às interações entre iluminação e conforto. Em se tratando do teatro romano, a preocupação com o conforto estaria referendada pelo seu caráter de entretenimento, que incluía o máximo de bem-estar para aquela parte do sofisticado público, formada por autoridades. Aquilo que Vitruvius chamou de "parte circular", pode incorporar a orchestra e a cávea, já mencionadas, estabelecendo compromissos com o bem-estar do público, incluindo no planejamento da arquitetura teatral da Roma antiga a possibilidade, ou o privilégio, de ver bem.

As relações entre a visibilidade na cena e o conforto determinavam a distribuição dos espectadores no espaço da cávea. Tal distribuição representava a organização social romana, exigindo que o público fosse acomodado nos diversos níveis da plateia (cavea), de acordo com sua posição na escala hierárquica da sociedade. Então, ao acomodar na cávea inferior (ima cavea) as classes superiores, para lhes dar facilidade de acesso, atendendo à mencionada escala hierárquica, ${ }^{2}$ seguindo sucessivamente e passando pela media (media cávea) até chegar à cávea superior (summa cavea), onde se localizavam as classes consideradas inferiores, ficava também determinada a qualidade do acesso visual ao espetáculo. Ou seja, enxergar bem, ver de perto os acontecimentos apresentados na orchestra e no proscenium (ou espaço diante da scaenae frons ${ }^{3}$ ), determinava um privilégio no teatro romano daquela época. Cabe ao iluminador avaliar tais associações e relacioná-las à compreensão humana da visão, o que pode contribuir para apreensão da relevância do seu trabalho.

Pode-se vislumbrar nas observações de Vitruvius (1914) uma parceria que, desde o teatro grego do século V a.c., já se havia manifestado no mechané. ${ }^{4}$ Trata-se de uma interação da práxis cênica com a tecnologia, resultando em mudanças periódicas na configuração arquitetônica do teatro e na tipificação espacial da cena. Tais mudanças estão estreitamente ligadas à capacidade do teatro de intera-

\footnotetext{
$1 \quad$ 2. "We must also beware that it has not a southern exposure. When the sun shines full upon the rounded part of it, the air, being shut up in the curved enclosure and unable to circulate, stays there and becomes heated; and getting glowing hot it burns up, dries out, and impairs the fluids of the human body. For these reasons, sites which are unwholesome in such respects are to be avoided, and healthy sites selected."

2 Deve-se lembrar que não havia elevadores.

3 A elaborada construção, ao fundo do palco, onde aparecia a Porta Régia, ao centro, e ainda presente no Farnese. Progressivamente a Porta Régia se expande até originar a boca de cena moderna.

4 Mecanismo (guindaste de palco) que permitia elevar e descer atores e/ou objetos.
} 
gir com os processos tecnológicos de cada período, mesmo os mais inovadores, e até fazer surgir novas tecnologias, gerando um discurso visual próprio.

Por outro lado, ainda que não se tenha registro de especificidades referentes ao papel da luz nos espetáculos da época de Vitruvius, a contemplação da arquitetura, em si, traz indícios do prazer visual experimentado por quem assistia a um espetáculo. Cerca de três décadas antes da publicação da sua obra, certas edificações teatrais - algumas ainda temporárias - já agradavam e surpreendiam os cidadãos romanos. Sob a responsabilidade do edil (administrador público) M. Aemilius Scaurus, em 58 a.c., um teatro provisório, construído para funcionar por alguns poucos dias, provocou comentários entusiasmados. Registre-se a opinião de Gaius Plinius Secundus - Plínio, o Velho (23-79):

Durante sua administração e apenas para uso temporário, de alguns dias, Scaurus erigiu o maior trabalho desempenhado por mãos humanas, mesmo considerando-se aqueles construídos como permanentes: refiro-me ao seu teatro. O edifício tinha três pavimentos, sustentados por trezentos e sessenta pilares, e isso numa cidade onde não se concedia permissão aos seus mais proeminentes cidadãos para construir seis pilares de mármore do Monte Hymettus, sem alguma crítica. [...] os pilares mais baixos [...] tinham doze metros de altura e, entre eles [...] havia três mil estátuas de bronze. ${ }^{5}$ (PLÍNIO apud NAGLER, 1952, p. 21, tradução nossa)

Acomodando perto de 80 mil pessoas, a edificação suplantava até mesmo o Teatro di Pompeo, o primeiro empreendimento teatral permanente e que seria construído em Roma por volta de 55 a.c. Outros aspectos a distinguiam, incluindo a aplicação de vidro, iniciativa completamente inovadora e considerada uma extravagância pelo mesmo Plínio. Para exemplificar a ousadia dos projetos da arquitetura teatral romana, Nagler (1952) menciona ainda a História Natural de Plínio:

C. Curio construiu, próximos um do outro, dois grandes teatros de madeira; muito bem posicionados, sobre um sistema de pivôs. Antes do meio-dia, um espetáculo de jogos era apresentado em cada um deles, com os teatros encostados um no outro, pela parte traseira, de modo que o ruído em cada um deles não inter-

5 "During his aedileship, and just for the temporary use of a few days, Scaurus wrought the greatest work ever achieved by the hands of man, even when intended for permanence: I refer to his theatre. The building had three stores, supported on three hundred and sixty columns, and is also in a city which had not given one of its leading citizens permission to erect six pillars of Hymettian marble without some criticism. [...] the lowest columns [...] were thirty eight feet high, and place between them [...] were three thousands bronze statues." 
ferisse na performance apresentada no outro. Então, de repente, mais tarde - no mesmo dia - os dois teatros giravam para ficar frente a frente, as laterais se conectavam e, com as molduras externas removidas, eles formavam um anfiteatro no qual eram apresentados combates de gladiadores. ${ }^{6}$ (PLÍNIO apud NAGLER, 1952, p. 21, grifo e tradução nossos)

A arte teatral incorporou à sua arquitetura as tecnologias disponíveis, surpreendendo com inovações a cada complexo construído. Exemplos de casas de espetáculo espalharam-se pelo Império Romano, desde os primeiros séculos da Era Cristã, e ainda podem ser encontrados na Europa, Ásia e África, como os exemplos de Aspendos, na Ásia, assim como em Sabratha, na África (Figuras 41 e 42). A repercussão dos traços da perspectiva, já aplicados por Agatharcus de Samos, ${ }^{7}$ pode ser confirmada em obras como o afresco de Boscoreale (43-30 a.c.) (Figura 43), e até o uso da cortina revelam possíveis características do espetáculo daquele período. A interação cena/tecnologia mudaria a face do espaço cênico, numa relação direta com os eventos em si, acentuando a parceria dinâmica entre as instâncias da cena. O acessório conhecido como velum ou velarium pode ter gerado contribuição determinante para o teatro provisório, construído na administração de M. Aemilius Scaurus, como relatam Adkins e Adkins:

Em frente ao palco havia uma vala ou fosso para a cortina (auleum), que era depositada nessa vala no início do espetáculo e levantada no final. Havia também cortinas menores (siparia), para esconder partes frontais do palco [scaenae frons], se necessário. A orchestra, o espaço plano entre o palco e a plateia, era usada para os assentos destinados aos senadores, sacerdotes e militares. Sobre o palco havia uma cobertura de madeira que também funcionava como dispositivo acústico. Os espectadores eram protegidos do sol e da chuva por um toldo (velum ou velarium), fixado por cordas em mastros posicionados na par-

6 "C. Curio had two large wooden theatres built close together; each was nicely poised, turning on a pivot. Before noon, a spectacle of games was performed in each, with the theaters back to back so that the noise in each would not interfere with the other's performance. Then, suddenly, toward the latter part of the day, the two theatres would swing around to face each other with their corners interlocking, and, with their outer frames removed, they would form an amphitheater in which gladiatorial combats were presented."

7 Pintor grego que viveu no século V a.c. e teria trabalhado com Ésquilo, de acordo com Vitruvius (1914, p. 161). Ainda que Aristóteles (1951, p. 73) tenha afirmado que Sófocles teria introduzido a cenografia, Vitruvius menciona a contribuição de Agatharcus para o espetáculo de Ésquilo, comentando adicionalmente que isso provocou Demócrito e Anaxágoras, levando-os a escrever acerca do tema, seguindo os passos dos comentários anteriormente elaborado por Agatharcus, cujos termos incluem o que se pode inferir como princípios do desenho perspectivista. Vitruvius, ao mínimo, inicia a discussão da perspectiva, já no século I d.C. 
te superior da plateia. Em alguns teatros foram construídos pórticos, como parte da plateia ou atrás da scaenae frons, para proteger os espectadores nos intervalos entre os espetáculos. ${ }^{8}$ (ADKINS, L.; ADKINS, R., 2004, p. 149-150, tradução nossa)

É importante registrar que a espécie de toldo instalado sobre a plateia (cavea) tinha a função primeira de proteger o público do sol e da chuva, proporcionando conforto. Além disso, no entanto, ele determinava a qualidade visual de um ambiente preenchido pela luz natural, mas filtrada através da espessura e textura do velum: isso promovia uma atmosfera visualmente "macia", suavizada pela atenuação das sombras diluídas sob a luz difusa. Mais tarde, o cinema usaria um acessório similar para filtrar e atenuar a luz natural, em externas filmadas à luz do dia.

Essa assertiva visual estava mixada aos altos padrões de luxo da Roma Imperial, assim como à exacerbada violência que incluía a morte em cena, em espetáculos sem "personagens", sem compromissos com a ficção, uma vez que a pessoa a ser executada, e/ou devorada representava a si mesma, desafiando até hoje muitas iniciativas espetaculares consideradas revolucionárias ao incorporarem na práxis cênica a efetiva morte em cena.

Deve-se registrar o tabu e a desconfiança em relação aos snuff films, ${ }^{9}$ nos quais se presume que as pessoas agredidas ou assassinadas nas cenas são efetivamente agredidas ou assassinadas, não se tratando de truque ou efeito. Pode-se imaginar as reações se, na práxis cênica, considerando-se qualquer acontecimento espetacular, alguém for realmente assassinado diante do olhar do público.

Mesmo o decorum romano, como conjunto de normas para a conduta do cidadão, ganhou nuanças que desafiam as mais radicais "revoluções espetaculares", mesmo as mais modernas ou atuais. Certas performances romanas, por conseguinte, romperam limites dos quais as mais radicais revoluções performativas que se sucederam ainda não conseguiram se libertar.

o Oxford companion to the theatre questiona outra face daquela práxis espetacular romana: "Nesses vastos, esplêndidos e luxuosos teatros eram apresentados

8 "In front of the stage was a trough or trench for the curtain (aulaeum), which was lowered into the trough at the beginning of the performance and raised at the end. There were also smaller curtains (siparia) to screen off parts of the scaenae frons as required. The orchestra, the flat space between the stage and the auditorium, was used for seating for senators, priests and officials. Above the stage was a wooden roof that also acted as a sounding board. The audience was protected from sun and rain by an awning (velum or velarium) rigged on ropes from masts on the top of the auditorium. In some theatres, covered porticos were built as part of the auditorium or behind the scaenae frons to provide shelter for the audience between performances."

9 O termo snuff - ou rapé, na gíria, pode significar morte em vários contextos. Pode ser aplicado como substantativo ou como verbo composto (two words verb), i. e., snuff it, snuff sth out. 
shows triviais da Roma Imperial, os quais, entretanto, ainda que magnificamente confortáveis, deve-se confessar, para um gosto público de baixa qualidade."10 (HARTNOLL, 1957, p. 676, tradução nossa)

Importa sublinhar a atenção dispensada pelos produtores desses eventos às questões visuais, mesmo que implícita e/ou intuitivamente assumidas. Por outro lado, enquanto o espetáculo romano dos primeiros séculos da história cristã ampliava seu requinte e desenvolvia alta tecnologia em eventos que incluíam corridas, combates diversos entre animais ferozes, entre gladiadores, entre animais e gladiadores, tentando superar uns aos outros no apelo ao cidadão comum, também ocorriam as representações de tragédias clássicas ao gosto da plateia composta pela elite sofisticada.

O emergente pensamento cristão, no entanto, desenvolvia grande desaprovação a tais práticas espetaculares. Não somente as corridas e a luta entre gladiadores, mas também os espetáculos teatrais originados na cena grega, apresentados à sofisticada plateia romana, eram atacados. A mais contundente e documentada crítica ao entretenimento apareceria no final do século II, na obra de Tertuliano [Quintus Septimius Florens Tertulianus (ca. 155/160-222)]. ${ }^{11}$ Em Dos espetáculos (De Spetaculis), obra escrita entre 197 e 201, ele rejeita e condena os espetáculos de qualquer natureza, conclamando os cristãos a se afastarem de tais atividades, uma vez que elas eram originadas na tradição grega pagã. Sublinhando a origem dos espetáculos nos cultos aos deuses gregos, Tertuliano menciona, entre outros, Circe e Dionisus, que suscitavam o fortalecimento das diversas celebrações e eventos espetaculares da Roma Imperial, desde o circo até o teatro. Ele seguiu, em sua análise, um rumo contrário àquele escolhido por estudiosos que hoje negam a teoria responsável por localizar a origem do teatro grego na religião da Grécia arcaica.

De acordo com o julgamento de Tertuliano, a superficialidade da idolatria que fundamentava os eventos espetaculares afastaria os cristãos do original e seu único Deus. Aqui se pode observar uma importante base para o modo como a cultura ocidental formulou sua abordagem do mundo, orientada pela fé cristã, transformando-se numa importante instigação para a compreensão do Renascimento, já discutida.

10 "In these vast, splendid, and luxurious theatres were staged trivial shows of Imperial Rome, which, however, magnificent catered, it must be confessed, for a debased public taste."

11 Advogado nascido em Cartago, filho de pais pagãos, Tertuliano converteu-se ao Cristianismo, por volta do ano 193, emprestando sua erudição - que incluía desde o conhecimento jurídico, a retórica, até grande familiaridade com o idioma grego - ao fervor da fé cristã. Considerado por muitos o mais original e importante autor eclesiástico latino até Agostinho [Aurelius Augustinus (354-430)]. 
Tertuliano (1842) afirmou que os lugares nos quais cristãos foram executados e devorados para a diversão e prazer dos romanos, deviam ser execrados, uma vez que caracterizavam um elo entre o espetáculo pagão e o prazer. Além disso, ele relacionou espetáculo e distúrbio do espírito, uma vez que o prazer impõe a parcialidade para que se atinja o deleite, incluindo o deleite produzido pelo ato teatral. Sua opinião era incisiva, ao julgar a rivalidade (conflito) presente nos espetáculos, concluindo que nela se instala a insanidade, a ira, o ódio e todo o tipo de sentimentos que desrespeitam os princípios da fé cristã:

Que condição de fé, que argumento de verdade, que regra de disciplina, evita, entre outros erros do mundo, também os prazeres dos espetáculos públicos, ouçam vocês, servos de Deus, que estão muito perto de Deus; [...]. De qualquer modo, para alguns, talvez tenham algum encanto as opiniões desses pagãos, os quais estão acostumados a argumentar contra nós desse modo: estes grandes deleites para os olhos ou para os ouvidos não são impedimentos para a religião, na mente e na consciência; e que não há ofensa a Deus nessas satisfações do homem, pois não há pecado em desfrutá-las, nos momentos e locais, apropriados, guardando-se sempre honra a Deus. Mas é isso que estamos especialmente preparados para provar, como essas coisas não estão de acordo com a verdadeira religião e com o ato de servir ao verdadeiro Deus. Há aqueles que pensam que os cristãos, um povo sempre pronto para a morte, são treinados para essa obstinação, pela renúncia aos prazeres. ${ }^{12}$ (TERTULIANO, 1842, p. 188, tradução nossa)

Aqui se veem princípios que, muito próximos das teses do puritanismo inglês do século XVII, conduziram à proibição de qualquer atividade teatral. É importante sublinhar que o poder da visualidade presente nos "deleites para os olhos", era atentamente observado, uma vez que ele podia mudar ou construir opinião.

Em 435, a atividade teatral foi inicialmente proibida aos domingos, pelo Código de Theodosius, e, finalmente, no século VI, todos os teatros europeus foram fechados,

12 "What state of faith, what argument of truth, what rule of discipline, barreth among other errors of the world, the pleasures also of the public shows, hear, ye servants of God, who are coming very nigh unto God; [...] In either case to some, perchance, the opinions of those heathens have still a charm, who, on this question, have been accustomed to argue against us thus: that these great refreshments of the eyes or the ears from without are no hindrance to religion in the mind and in the conscience; and that God is not offended by such gratification of a man as there is no $\sin$ in his enjoying at its proper time and in its proper place, saving always the fear and the honour due unto God. But this is what we are prepared especially to prove, how it is that these things do not accord with true religion, and with the true service of the true God. There are who think that the Christians, a people ever ready for death, are trained up to this obstinacy, by the renouncement of pleasures." 
fazendo com que os atores procurassem o benefício de mecenas interessados em produzir espetáculos para a nobreza e para o alto clero. Os atores se tornaram artistas itinerantes e trabalhavam longe dos centros urbanos. Muitos dentre eles mantinham os temas bíblicos, como principal origem da sua dramaturgia. É importante destacar Constantinopla, onde a própria imperatriz Teodora (500-548) - mencionada como atriz - provavelmente influenciou no relaxamento da repressão aos espetáculos públicos e até no fornecimento de provisões para atores.

Definhando como entretenimento organizado, sob a ameaça das invasões dos sarracenos no Oriente, nos séculos VII e VIII, além do desprezo bárbaro (como os romanos denominavam os povos que viviam do outro lado de suas fronteiras), o teatro resiste, em grande parte, graças à produção dramatúrgica que incentivava os interessados no espetáculo. Três séculos antes, o interesse pela dramaturgia já havia recebido um comentário muito importante para as discussões traçadas no presente trabalho.

Santo Agostinho sublinhou a importância do drama, inclusive como meio de educar:

Entre essas peças, as menos inofensivas são as comédias e as tragédias, quer dizer, aqueles dramas que os poetas escrevem para os palcos e os quais, mesmo lidando frequentemente com temas impuros, ainda assim o fazem sem a obscenidade na linguagem que caracteriza tantos outros espetáculos. E são esses dramas que os mais jovens são levados pelos mais velhos a ler e aprender, como parte daquilo que é chamada uma educação liberal e distinta. ${ }^{13}$ (AGOSTINHO, 1887, tradução nossa)

Deve-se observar que Agostinho, o antes dissoluto professor de Retórica era, então, fervoroso cristão e Bispo da cidade de Hipona. Em meio aos debates sobre as razões da queda de Roma, sob o rei visigodo Alarico, em 410, ele procura descaracterizar a crença que interpretava tal queda como uma vingança dos deuses pagãos, numa resposta à prática cristã da fé em um único Deus. Agostinho começou a escrever A Cidade de Deus (De Civitate Dei, 416] em que pôs, frente a frente, a cidade do título e outra, do demônio. A julgar pela sua avaliação há certa qualidade de espetáculos que podem, ou devem receber autorização para adentrar a cidade

13 "Of these plays, the most inoffensive are comedies and tragedies, that is to say, the dramas which poets write for the stage, and which, though they often handle impure subjects, yet do so without the filthiness of language which characterizes many other performances; and it is these dramas which boys are obliged by their seniors to read and learn as a part of what is called a liberal and gentlemanly education." Essa citação resulta de pesquisa em um site da rede mundial de computadores que não inclui número de páginas (Livro II, Capítulo 8). Disponível em: 〈http://www.newadvent.org/fathers/1201.htm〉. Acesso em: 25 set. 2008. 
de Deus. A opinião de uma celebridade com a reputação de Agostinho, reconhecido como importante pensador da Patrística (como se denominou o conjunto dos escritos da antiga literatura católica), por certo influenciou a Igreja na inclusão de manifestações teatrais em suas festividades e na decisão de apoiar atividades cênicas que aconteciam nos seus arredores. Por outro lado, os mimos, menestréis e outras companhias itinerantes que aplicavam derivações de textos bíblicos em seus espetáculos, contribuíram grandemente para manter o entusiasmo pelo teatro.

Retorne-se a Tertuliano para citar a conclusão do seu estudo crítico e tratado de execração categórica dos espetáculos. Ele deixou uma questão instigante, que antecipou um movimento deflagrado séculos depois do seu tempo:

Mas que tipo de espetáculo está bem próximo? A Vinda do Senhor, agora reconhecido, glorioso, triunfante. O que é essa alegria dos Anjos? A glória dos santos que ascendem? O reino dos justos que segue? A Nova Jerusalém? E ainda restam outros espetáculos: o último e eterno Dia do Juízo Final, o inesperado, o desprezado das Nações, quando todas as antigas coisas do mundo, e todos os que estão nascendo, devem ser consumidos pelo fogo? Qual será então a extensão do espetáculo? ${ }^{14}$ (TERTULIANO, 1842, p. 217-218, tradução nossa)

Tertuliano não poderia prever que seria mais tarde atendido, mas respondeu às suas próprias exigências, impelindo o cristão a substituir o prazer do espetáculo pelas relações com Deus, nos cultos em si.

A espetacularidade dos ritos católicos ganhou força no teatro eclesiástico, que seria mais tarde difundido na Europa, durante a Idade Média, influenciando a liturgia da Igreja nos séculos subsequentes. Tertuliano teria, então, antecipado a espetacularização da liturgia católica, ao afirmar que nada poderia haver de mais espetacular, mais repleto de glória e triunfo, do que o retorno de Deus. Ele dedica todo o extenso parágrafo (ou capítulo) final, à demonstração da verdadeira espetacularidade, aquela da qual será impregnado o retorno do seu Senhor. Vale acentuar que não se pode dar ao convertido cristão cartaginês o crédito exclusivo pela qualidade teatral da qual se investiu a mencionada liturgia, corporificando expressiva

\footnotetext{
14 "But what sort of show is that near at hand? The Coming of the Lord, now confessed, now glorious, now triumphant. What is that joy of the Angels? What the glory of the rising saints? What the kingdom of the righteous which followeth? What the city of the New Jerusalem? And yet there remain other shows: that last and eternal Day of Judgment, the unlooked for, the scorned of the Nations, when all the ancient things of the world, and all that are rising into life, shall be consumed in one fire? What shall then be the expanse of the show?"
} 
espetacularidade. Afinal, ao incorporaram determinado "mysterium fascinosum"15 os ritos católicos propriamente ditos já manifestam, num certo sentido, sua natureza espetacular.

O seu discurso, no entanto, prevê o amálgama entre a provocação dos textos bíblicos, a face histriônica da humanidade e o poder educativo da literatura dramática, já presente na gênese do teatro, na Grécia, e acentuado por Agostinho. Tertuliano aponta, então, involuntariamente, para uma cena cristã imersa no fascínio da luz, do fogo. Entre Tertuliano e Agostinho há o caminho que desenvolve a Patrística e depois a Escolástica. ${ }^{16}$

A espetacularidade mencionada por Tertuliano como componente essencial do retorno de Deus representa apenas um pequeno fragmento das diversificadas aparições da luz, tanto no antigo, quanto no Novo Testamento. Deve-se também levar em conta o papel de artistas ligados à Igreja da Idade Média que interpretaram as narrativas bíblicas e suas imagens, representando-as na cena e constituindo, assim, a visualidade do teatro eclesiástico. No método delineado para o presente trabalho, que inclui atenção às mais diversificadas abordagens da luz, a referência ao teatro medieval indica a inclusão nas discussões da sua principal fonte, a Bíblia, em cujas narrativas é imensa a inserção da luz e da sombra. Acentue-se, portanto, a afinidade entre o pensamento ocidental, o Deus cristão, a luz e a sombra. Bill Williams, em seu endereço na rede mundial de computadores afirma:

Há mais de 200 referências à palavra 'luz' na Bíblia. Por volta de 75 delas estão no Novo Testamento. O livro de Jó contém a maioria (mais de 25) e o Livro dos Salmos tem por volta de 25 referências à luz. No Novo Testamento. O Evangelho de João tem maioria (em torno de 16). ${ }^{17}$ (WILLIAMS, 2005, tradução nossa)

Alguns até dizem que a luz teria sido a primeira criação divina, mesmo que no primeiro livro da Bíblia - Gênesis, 1.1 - tome-se conhecimento que, no princípio, Deus criou os céus e a terra. Ainda em Gênesis, versículo 2, constata-se que,

15 Uma qualidade de mistério comum às práticas religiosas, que se refere aos temores e castigos resultantes das relações entre a humanidade e as divindades, mediadas pelas limitações do ser humano, que é exposto a variadas manifestações de mistérios inexplicáveis.

16 Aqui mencionada como o conjunto de ensinamentos do Cristianismo, praticados durante a Idade Média, difundindo a filosofia cristã. A Escolástica ganha corpo desde o fim da Patrística, no século V, e permanece sendo aplicada até o início da Era Moderna, na segunda metade do século XV.

17 "There are more than 200 references to the word "light" in the Bible. About 75 of these occur in the New Testament. The Book of Job contains the most references (over 25) and the book of Psalms has about 25 references to light. In the New Testament, the Gospel of John has the most references (about 16)." 
mesmo disforme e vazia, como um abismo sob trevas, havia a Terra; e o espírito de Deus pairava sobre as águas. Somente depois de tal constatação, sabe-se que Deus determinou: haja luz! (Fiat lux!)

De acordo com a versão bíblica, mesmo amorfa, pois mergulhada nas trevas, a Terra estava em algum lugar, ainda que não pudesse ser vista, já que não havia luz. Deus, por conseguinte, enfrentava um problema, as trevas. Ele resolveu introduzindo a luz, e comparando, concluiu: a luz é boa. Fazendo com que ela revelasse faces camufladas e construísse conhecimento, Deus elaborou a primeira imagem visual, a Terra. Trata-se de uma mitologia impregnada pela visão, pela imagem.

Ao criar a luz, contudo, Deus lançou no extremo antagônico as trevas que a antecederam. Houve, então, o dia. Com o surgimento desse primeiro dia, estabeleceu-se, portanto, para um espaço preexistente, o tempo, revelando a complexidade da transição manhã, tarde, noite (ou trevas), numa proliferação de formas, texturas, cores, atmosferas. Sem as trevas a Terra não teria alcançado o segundo dia; sem elas o tempo seria inconcebível; haveria somente o dia absoluto, uno e eterno, interminável, tornando a existência imutável, fixa, estática. O equilíbrio dinâmico espaço-tempo foi, portanto, criado pela ausência de luz, pela sua interação com as trevas (ou sombra) que aponta para o retorno da primeira.

Estava criado o contraste, estabelecendo-se a abrangência perceptiva. Inclusive e, principalmente, no contexto visual. Desde então, ao homem foi dado o direito à visão. Interessa ao contexto desta abordagem a narrativa bíblica na sua condição de pensamento fundado em relações com a luz, compreendendo que sua leitura pode interagir com a subjetividade e questionando interpretações fechadas.

Ainda que a obra de Agostinho de Hipona justifique inúmeras outras citações, serão mencionadas aqui suas considerações acerca do que ele denomina a luz interior de verdade. De acordo com o pensamento cristão, aquele que desconsidera a importância da verdade mergulha nas trevas, nas sombras. O fragmento a seguir, selecionado no texto De Magistro, de Agostinho, lança a seguinte ideia:

[...] trata-se das coisas que percebemos pela mente, isto é, através do intelecto e da razão, estamos falando ainda em coisas que vemos presentes naquela luz interior de verdade, pela qual é iluminado e de onde flui o homem interior [...]. (AGOSTINHO, 198ob, p. 397)

Aquele que lida com sua luz interior, baseada na verdade, segue o mesmo caminho do outro, como Tertuliano, que vê na mente a espetacularidade do retorno do seu Deus. 
As reflexões de Agostinho já foram estudadas exaustivamente e se tornaram obras importantes para os estudos do Cristianismo. Ele apresenta uma notável resposta à narrativa bíblica, no que se refere à relevância da luz na formação do pensamento cristão, considerando-a determinante para a existência da humanidade, uma vez que a natureza do saber - como conhecimento da verdade - encontra-se na própria natureza de Deus. Ele (Deus), afinal, é a luz absoluta, onipotente, integral, que retirou de si mesmo, estrategicamente, as trevas, arremessando-as para fora, criando o outro antagônico. Em sua obra Confissões (Confessionum), Agostinho dedicou seis capítulos à luz, discutindo, sob seu prisma, os fundamentos do pensamento cristão, relacionando-a ao conhecimento, à sabedoria, à revelação, dentre outros, citando a Bíblia para construir sua Doutrina da Iluminação Divina:

Nem parece justo aos vossos olhos que o ser mutável e por Vós iluminado conheça a luz imutável como ela se conhece a si própria. Por isso, 'a minha alma é, aos vossos olhos, como terra ressequida sem água', porque, assim como ela se não pode iluminar por si mesma, assim também, por virtude própria, se não pode saciar. 'Em Vós jorra a fonte da vida, e na vossa Luz veremos a luz'. (AGOSTINHO, 1980a, p. 319)

E, antes, ele já se perguntara:

Que nome darei a esta matéria, como sugerir sua ideia às inteligências mais curtas, senão usando um termo de uso corrente? O que se pode encontrar no mundo que seja mais parecido com essa ausência total de forma, que a terra e o abismo? Colocados no mais baixo grau da criação, eles não têm a beleza dos corpos que no alto brilham de luz fulgurante. (AGOSTINHO, 1980a, p. 278)

Agostinho trata de uma luz divina, fulgurante, que paira numa instância diversa daquela na qual a "outra luz", física, material, se instala. A primeira revela o belo dos corpos ou transforma em belos, os corpos. A outra pode revelar traços inquietantes dos corpos, o desequilíbrio. Interessa aqui destacar aquela primeira luz imutável, absoluta fonte de beleza e sabedoria, reveladora espetacular da fé cristã, presente no centro da dramaturgia da época e, por conseguinte, do teatro eclesiástico que dela se originou.

Encontra-se aqui um elo com a luz que pode ser incorporada à cena até hoje, aquela que propõe uma interação entre a luz física, material - reveladora e/ou transformadora do visível no mundo, promotora de visibilidade - e aquela outra, que atua não necessariamente como uma manifestação exclusiva do divino, mas 
que habita o imaginário do espectador fascinado pela fé, de modo abrangente, criando arrebatamento, estupor, fantasia e conhecimento, aproximando-se da visualidade. Agostinho podia antever tais relações, ou seja, a capacidade humana de operar conexões transcendentes. Trata-se da dimensão plural que percorre o pensamento proposto pela luz na sua relação com a cena. A cada artista que assume a responsabilidade de elaborar a atuação da luz num acontecimento espetacular é dado o direito de discutir tais relações. Ele só precisa incorporar sensibilidade, aliada a determinado elenco de habilidades e competências.

Ao escrever sobre o que ele chama de luz nas peças litúrgicas, Bergman (1977) aponta ligações entre a cena e a metafísica da luz, já presente na filosofia de Platão, tratada na Alegoria ou Mito da Caverna, no pensamento cristão preliminarmente delineado no Neoplatonismo e na Escolástica dos séculos XII e XIII. O pensamento central da fé cristã "Deus é luz" foi, então, incorporado ao palco da Igreja medieval.

O conceito de "palco da Igreja medieval" deve ser abrangente para incluir eventos espetaculares efetivados no exterior dos templos. Assim, a ideia cristã do divino produziu uma práxis cênica que, diversamente tipificada de acordo com o local da representação - exterior ou interior -, se repetiu inúmeras vezes durante a Idade Média em várias regiões da Europa. Nos acontecimentos teatrais aplicava-se a tecnologia disponível, a mecânica, o fogo e a fumaça de pólvora, para sugerir luz e trevas nos espetáculos ao ar livre, como nas Bocas do Inferno, nos Mistérios representados em praças públicas ou nos espetáculos das companhias (troupes) itinerantes.

A luz que se havia instalado no teatro grego da Antiguidade repercute no medievo, eclode na Renascença e reaparece durante toda a atividade teatral que se segue, provocando o entendimento do teatro como uma manifestação artística que se realiza numa relação direta e vital com o fogo e, portanto, com a luz. Não apenas do ponto de vista físico, mas também alcançando profundas instâncias simbólicas, como se pode ver na ilustração da Paixão de Valenciennes, na Bélgica, em 1547 (Figura 44). As convenções narrativas já estão definidas na distribuição dos lugares onde a ação se passa, assim como na abordagem visual do pecado e da consequente condenação expressa nos mistérios, construída cenicamente com grande singularidade nas Bocas do Inferno, nas quais o pecador é consumido pelo fogo. Outro fogo diferente daquele que, originado no sol, promove a vida no planeta (Figuras 45 e 46).

Em face disso, o imaginário é provocado e dialoga com o pensamento que reconhece a luz ou a "iluminação divina" e a importância do drama para a educa- 
ção, como disse Agostinho. Quando se projeta a concepção agostiniana do teatro, como um meio para educar, espera-se uma categoria de espetáculos medievais incentivados pela ideia de uma luz que é também a verdade para a fé cristã; uma verdade gloriosa, brilhante e nobre, uma luz que pressupõe revelação em níveis diversificados. Afinal, Deus houvera criado não apenas a luz que opera no mundo sensível; ele também determinou um lugar na ordem divina para outra categoria de luz, com alto grau de nobreza e pairando num nível que transcende as instâncias materiais. Aquela luz que, no texto bíblico, precede a criação dos céus e da Terra revelando-se a qualquer momento, sob a ordem divina, com grande alcance e complexidade.

A provável ação física da luz, indispensável na realidade material, sua interação com moléculas de carbono, hidrogênio e oxigênio, que estabelece a vida material na Terra, a fusão nuclear a ocorrer no ambiente solar, todo esse contexto é alojado numa instância de interesse menor, pois já ocorreu: céus e Terra já foram criados. Aqui fica sugerida uma abordagem especulativa da luz. Mais uma vez, Bergman (1977) contribui para a discussão, quando trata do poder divino vinculado ao Cristianismo e a sua orientação do sentido de organização do universo:

Deus criou a luz que se manifesta nos anjos, na Graça divina e, finalmente, na luz óptica - formas de revelação, portanto, em diferentes níveis. O conceito especulativo de luz está sempre ligado à luz sensível, quanto mais uma coisa do mundo material estiver impregnada de luz, tanto maior será o seu grau de nobilitas [nobreza]. [...] A ordem de precedência dos quatro elementos está determinada pelo seu grau de luminosidade: fogo, ar, água e terra. ${ }^{18}$ (BERGMAN, 1977, p. 29, grifo e tradução nossos)

Dentro de cada elemento, o mesmo ordenamento pode ser observado, por exemplo: no mar, as águas superiores, mais luminosas, são as mais nobres. Ora, as narrativas fundadoras do pensamento cristão, presentes há mais de uma dezena de séculos antes do nascimento de Cristo, representaram a principal provocação para o renascimento do teatro antes banido pela própria Igreja, e determinaram a qualidade das artes visuais, durante todo o medievo. Mesmo sem profunda familiaridade com fundamentos teológicos, a arte medieval produziu inúmeras obras que refletem tal metafísica da luz.

18 "God created the light that is manifested in the angels, in the divine Grace and, finally in optical light - thus forms of revelation at different levels. The speculative concept of light is always linked to the sensuous light, and the more a thing of the material world is permeated with light, the greater is its degree of nobilitas. [...] The order of precedence of the four elements is determined by their degree of luminosity: fire, air, water and earth." 
Naquele momento da história ocidental, as artes visuais ainda perseguiam a estética da "des-corporificação", na qual as qualidades físicas, materiais, da vida no planeta foram deslocadas para uma instância inferior ou representavam um estágio no caminho para a transcendência religiosa (espiritual, do ponto de vista cristão). Caracteriza-se um relativo desinteresse pela tridimensionalidade, assim como pela gravidade, e se exacerba o valor da luz corporificada pelo fogo. Vale lembrar que Bergman (1977) destaca Adolphe Appia - cujas proposições serão mencionadas adiante, ao discutir o papel desempenhado pela luz, na cena:

Quando, em A música e o espetáculo [Die Musik und die Inszenierung], Adolphe Appia fala poeticamente do papel da luz na cena, ele nos lembra de que Apolo é, não apenas o Deus da Poesia, mas também da luz. Seu antigo nome é Phoebus Apollo, Apolo o brilho reluzente. A adoração da luz e do fogo é recorrente na história de todos os povos e é expressa em ritos simbólicos, que testemunhamos até hoje, e. g. nas fogueiras ateadas na Noite das Walpurgas, para saudar o advento da primavera. ${ }^{19}$ (BERGMAN, 1977, p. 28, grifo e tradução nossos)

A tradição mantém viva a adoração ao fogo quando, durante as comemorações do nascimento de São João, dia 24 de junho, são ateadas fogueiras em torno das quais as pessoas se reúnem para celebrar, cantando, dançando, bebendo, banhando-se nos lagos. Fazendo parte do calendário católico, a manifestação incorpora atividades pagãs, permitindo compreender a capacidade da luz de destituir fronteiras do pensamento, apreendendo-a como um aspecto determinante da cultura. O elo é a força simbólica do fogo, que se impõe, revelada em eventos semelhantes, como aqueles da cultura germânica, nos quais enormes rodas eram confeccionadas no topo de montanhas e embaladas com feno e materiais combustíveis, adicionando-se breu e enxofre.

Depois de atear fogo nesses artefatos, os participantes dos eventos as arremessavam montanha abaixo, como gigantescas rodas de fogo que, fazendo trajetória acidentada, giravam, pulavam e aumentavam progressivamente sua velocidade. A manifestação ocorria numa noite do outono, e representava um pedido para que o sol retornasse na primavera. É possível imaginar o fascínio de enormes caudas de faíscas flamejantes no céu noturno, rolando em direção a um vale

19 "When, in Die Musik und die Inszenierung, Adolph Appia speaks poetically of the role light plays on the stage, he reminds us that Apollo was not only the God of Poetry but also of light. His ancient name was Phoebus Apollo, Apollo the brightly shining. The worship of light and fire recurs in the history of all peoples and is expressed in symbolical rites which we still witness today, e. g. in the Walpurgis Night bonfires lighted to greet the advent of spring." 
e se misturando ao temor de que o sol não voltasse. Detalhe muito importante é que tais circunferências tinham a forma do símbolo da roda do sol, comum entre os povos germânicos do período nômade, ou da cruz do sol, dos nórdicos, sendo o símbolo para a "luz" na escrita runa-germânica, podendo ser encontrado em arranjos ornamentais na Índia, na Grécia e Roma antigas, assim como em diversas regiões da Europa pré-cristã. Pode-se notar a semelhança com a suástica, usada como emblema do III Reich, que apresentava uma diferença, estando os braços voltados para a direita (Figura 47 a, b e c).

O teatro que se origina em tal apreensão do mundo representa os primeiros movimentos na direção de uma atividade cênica ocidental, institucionalizada, a ocorrer num recinto fechado, exigindo a aplicação do fogo, única fonte de luz artificial disponível àquele momento. Configurando-se, portanto, como um evento diverso daqueles empreendimentos espetaculares itinerantes, incluindo os mistérios - provavelmente apresentados em praças, locais de grande aglomeração significativa da comunidade, em uma aldeia - para os quais a luz natural era aspecto indispensável. Vale lembrar que, para responder à necessidade de luz em momentos nos quais o sol não estava disponível, o uso do fogo já era uma prática comum na Antiguidade: pedaços de madeira embebidos em material combustível produziam chamas mais duradouras, de acordo com Rosenthal e Wertenbaker (1972). As tochas desempenharam, durante muito tempo, o papel de principal fonte de luz artificial, aplicadas como arandelas e/ou candelabros; nos espetáculos, poderiam ser fixadas em pilares, como na Roma de Tibério (Tiberius Claudius Nero Cæsar, 42 a.c. - 37 d.C. - imperador romano de 14 a 37 d.C.). Segundo Rosenthal e Wertenbaker (1972, p. 45, tradução nossa): "Quinhentos escravos portando tochas conduziam os espectadores para casa, depois de um espetáculo, e, em ocasiões festivas, as grandes festas e encontros romanos, iluminação fixa era fornecida por grande quantidade de tochas instaladas para esse fim."2o

o Oxford Companion to the Theatre menciona, especificamente:

Com esse propósito, aparentemente, eram usadas tochas. A definição de Cotgrave do termo francês falot no seu dicionário de 1611 é luz de tochas (como aquelas usadas nos teatros), feitas com cordas, enroladas, untadas com resinas e colocadas dentro de recipientes de ferro pequenos e abertos [Figuras 48 e 49]. ${ }^{21}$ (HARTNOLL, 1957, p. 461, grifo e tradução nosso)

\footnotetext{
20 "[...] five hundreds slaves bearing torches conducted the audience home after a spectacle, and for festive occasions, the great Roman feasts and gathering, stationary light was provided by enormous numbers of fixed torches." 21 "For this purpose, apparently, cressets were used. Cotgrave's definition of the French falot in his 1611 Dictionaire is cresset light (such as they use in playhouse) made of ropes, wreath, pitched and put into small and open cages of iron."
} 
A versão romana desse artefato foi largamente difundida no Império, aparecendo depois por toda a Europa medieval. Deve-se acentuar que os espetáculos medievais ocorriam durante o dia, podendo se estender até depois do anoitecer. A aplicação da luz artificial, no entanto, tinha também a função de denotar ausência da luz do sol no lugar onde a ação dramática ocorria, como na Grécia antiga. Pode-se inferir, portanto, que a cena incorporou o fogo desde os seus primórdios; não apenas para cumprir uma função de "substituir" o sol, permitindo visibilidade objetiva da natureza tridimensional da cena, mas também alcançando categorias simbólicas, até mesmo configurando a escuridão, as trevas, naquelas performances a ocorrer durante o dia. Alguns podem até argumentar que o fogo de natureza simbólica, presente no teatro da cena aberta, que ocorreu desde a Antiguidade, ganhou outra função, de natureza material, objetiva, quando o teatro foi enclausurado em recintos fechados.

\section{A INCORPORAÇÃO DA CENA PELA FÉ CRISTÃ}

Segundo Dunbar Ogden (2002) ${ }^{22}$ a mais antiga representação teatral ocorrida na Idade Média de que se tem notícia aconteceu em Winchester, principal cidade da Inglaterra, em finais do século X. Ogden informa que um conselho especial foi convocado neste local, entre 965 e 975, com o objetivo de escrever um código que suplementaria a Regra de São Bento (Rule of Saint Benedict), originalmente escrita por Bento de Núrsia (ca. 480-543) no século VI.

Tratava-se de um momento no qual a vida cristã estava orientada por normas diversificadas. Desde o século VIII esse documento teve grande aceitação como ordenador da conduta, transformando-se num guia baseado em três conceitos: pax, ora e labora (viver em paz, rezar e trabalhar) que representavam os pontos de partida básicos para a comunidade cristã, originando, inclusive, a Ordem de São Bento - séculos mais tarde. O objetivo era escrever uma versão anglo-saxã da Regula Benedicti, conjunto de normas concebidas para regular o cotidiano de uma comunidade monástica cristã, administrada por um abade. O movimento era liderado pelo Arcebispo de Canterbury, o hoje São Dunstan, padroeiro dos Ourives (ca. 909-988), acompanhado pelo seu mais próximo amigo, Æthelwold ou Ethelwold (ca. 912-984), Bispo de Winchester, de 963 a 984. Sob a provável influência e inspiração de Dunstan, Ethelwold escreveu o texto que representa

22 Autor e Professor emérito da Universidade da Califórnia/Berkeley. Orientou a tese de doutorado do professor Ewald Hackler - nos anos de 1980, na mesma Universidade de Berkeley -, orientador da presente tese. 
um marco de grande relevância para discussões acerca do ressurgimento do teatro na Europa.

Como Ogden (2002) também acentuou, Ethelwold incluiu no quinto capítulo orientações para uma performance cerimonial, a ser efetivada ao amanhecer do domingo de Páscoa, nos monastérios beneditinos. Ele descreveu passos para uma representação inserida na missa festiva, firmando padrões reconhecíveis de teatralização da celebração pascal. Ethelwold escreveu:

Enquanto se lê a terceira lição, quatro dos irmãos [religiosos] devem aparecer, um deles vestindo uma alba, como se fosse para um diferente propósito, entra e vai cuidadosamente para o lugar do 'sepulcro' e senta-se em silêncio, segurando uma folha de palmeira na mão. Então, enquanto o terceiro responsório está sendo cantado, os outros três irmãos, usando capas e segurando turíbulos, entram a seu tempo, dirigindo-se para [em frente, diante] o lugar do sepulcro, devagar, como se procurassem alguma coisa. Ora, estas coisas são feitas à imitação do anjo sentado sobre [no, em] o túmulo [no monumento], e das mulheres que vêm com perfumes para ungir o corpo de Jesus. Quando, portanto, aquele que está sentado vê os três que se aproximam, vagueando como se buscando alguma coisa, começa a cantar baixinho e docemente o Quem quaeritis [quem buscais]. Assim que ele conclui, os três devem responder em conjunto Ihesum Narazarenum [Jesus de Nazareth]. Então, aquele que está sentado dirá [cantará] Non est hic. Surrexit sicut praedixerat. Ite, nuntiate quia Surrexit a mortuis. [Ele não está aqui. Ele ressuscitou como previu. Ide e anunciai que Ele ressuscitou dos mortos.] Neste comando, os três devem voltar-se para o coro dizendo: [cantando] Alleleuia. Ressurexit Dominus. [Aleluia. O Senhor ressuscitou] Quando isso tiver sido cantado, aquele que está sentado, como se os chamando de volta, dirá [cantará], a antífona Venit et videte locum [Venham ver o local], e, então, levantando-se e elevando o véu, ele deve mostrar-lhes vazio o lugar da Cruz, com apenas o tecido com o qual a cruz tinha sido envolvida. Vendo isso, os três deixarão os turíbulos no mesmo sepulcro e, tomando o linho, sustentando-o diante dos clérigos e, como se mostrando que o Senhor ressuscitou, e não está mais envolto no tecido, eles cantam a antífona: Surrexit Dominus de Sepulchro [O Senhor ressuscitou do Sepulcro]. Em seguida, colocam o tecido no altar. | Quando a antífona é concluída, aquele que falava anteriormente, regozijando-se no triunfo do nosso Rei, no qual Ele venceu a morte e ressuscitou, deve cantar o 
hino Te Deum Laudamus [Nós Te louvamos, ó Deus], e então todos os sinos devem ressoar. ${ }^{23}$ (ETHELWOLD apud OGDEN, 2002, p. 19, tradução nossa)

Esse é um importante documento do ponto de vista estilístico, do ponto de vista da convenção literária. Aquelas que seriam as rubricas de um texto teatral ganham força, não apenas pela extensão, mas, principalmente, pela importância das questões que tratam, pelo detalhamento da cena. É como uma radicalização da rubrica, que se vê entrecortada ocasionalmente pelo diálogo, representando um exemplo importante da natureza pré-cênica do drama. Vale ressaltar que, na representação teatral de base realista, mesmo sendo o diálogo aspecto fundamental na apreensão do extenso universo da cena, ele é parte da ação, integrando o conjunto de atitudes da personagem na busca da realização de objetivos (ou desejos). Diante disso, para compreender a ação realista e elaborar seu ponto de vista, o iluminador precisava familiarizar-se com o texto.

Ainda que, durante milênios, falar bem tenha sido requisito para o ator, no contexto do realismo a compreensão da palavra como fim podia representar um equívoco. O ator que se dirigia à cena para - exclusiva e/ou isoladamente - falar, estava reduzindo o alcance do seu trabalho ao abrir mão do direito de construir uma ação da qual a fala é uma das múltiplas faces. No antigo universo realista cada atitude, incluindo a fala, era provocada por um desejo profundamente enraizado na vida da personagem. Pode-se dizer que o texto de Ethelwold já trazia tal princípio, ao incorporar a relevância da ação.

23 "While the third lesson is being read, four of the brethren shall vest, one of whom wearing an alb as though for some different purpose, shall enter and go stealhly to the place of the 'sepulchre' and sit there quietly, holding a palm in his hand. Then while the third respond is being sung, the other three brethren, vested in copes and holding thuribles in their hands, shall enter in their turn and go to [before, ante] the place of the 'sepulchre', step by step, as though searching for something. Now these things are done in imitation of the angel seated on [in, at] the tomb [in monumento] and of the women coming with perfumes to anoint the body of Jesus. When, therefore, he that is seated shall see these three draw nigh, wandering about as it were and seeking something, he shall begin to sing softly and sweetly, Quem quaeritis [whom seek ye]. As soon as this has been sung right through, the three shall answer together. Ihesum Narazarenum [Jesus of Nazareth]. Then he that is seated shall say [sing] Non est hic. Surrexit sicut praedixerat. Ite, nuntiate quia surrexit a mortuis. [He is not here. He is risen as he foretold. Go and announce that $\mathrm{He}$ is risen from the dead.] At this command the three shall turn to the choir saying [singing] Alleleuia. Ressurexit Dominus. [Aleluia. The Lord is risen] When this has been sung he that is seated, as though calling them back, shall say [sing] the antiphon Venit et videte locum [Come and see the place], and them, rising and lifting up the veil, he shall show them the place void of the Cross with only the linen in which the Cross had been wrapped. Seen this, the three shall lay down the thuribles in that same 'sepulchre' and, taken the linen, shall hold it up before the clergy; and, as though showing that the Lord was risen and was ho longer wrapped in it, they shall sing the antiphon: Surrexit Dominus de sepulchro [The lord is risen from the Sepulcre]. They shall then lay the linen on the altar. | When the antiphon is finished the prior, rejoincing in the triumph of our King in that He had conquered death and was risen, shall give out the hymn Te Deum laudamus [We praise Thee, o God], and thereupon all the bells shal peal." 
Além da Visitatio sepulchro (Visita ao sepulcro) que acontecia na Páscoa, aqui mencionada como exemplo da teatralização presente em tais cerimônias, é importante registrar que Ethelwold incluiu outras manifestações cênicas na Regularis corcordia.

Ao estabelecer um roteiro cuidadoso para a representação teatral, ele configurou uma atitude que pode ser vista como uma antevisão do papel de um dramaturgo/diretor teatral. Ogden (2002, p. 20, tradução nossa) sublinha um importante aspecto: "Não foi por acaso que o novo nascimento do drama ocorreu precisamente no mais importante momento do calendário da igreja". 24 Trata-se de uma dentre as mais antigas manifestações da dramaturgia na Igreja medieval, como também afirma Ogden (2002, p. 19), originada provavelmente nos tropes, como eram conhecidos os cantos introduzidos em momentos particulares da missa.

Incorporando ao roteiro da representação denominada Visitatio sepulchro uma referência à visita das três Marias (a Virgem, Madalena e Maria, irmã de Lázaro) ao sepulcro onde deveria estar o corpo de Jesus, a Regularis concordia traz um diálogo que ficaria conhecido com o Quem quaeritis (in sepulchro) -, largamente comentado por estudiosos e interessados. Nele aparece um breve diálogo musicado que ocorria entre as Marias e o guardião do túmulo, extraído da descrição acima, na qual Ethelwod descreve os passos da performance que ocorreria na cerimonia:

- A quem buscais no sepulcro, ò cristãs.

- Jesus de Nazareth crucificado.

- Ele ressuscitou como previra.

Vão e anunciem que Ele ressuscitou!

- Aleluia! Aleluia! Jesus ressuscitou!

(ETHELWOLD apud OGDEN, 2002, p. 19, tradução nossa)

Como se pode observar no roteiro elaborado por Ethelwold, essa representação integrava o rito. Resta, porém, indagar onde se encontram as bases por ele utilizadas para escrever a mencionada inserção no evento. Ainda de acordo com Ogden (2002), as prováveis fontes vieram da Europa continental. Sabe-se que Dunstan esteve em Ghent, na Bélgica, por, aproximadamente, um ano, e que Ethelwold enviou um dos seus monges para estudar em Fleury, na França, cidade onde foram preservados manuscritos de finais do século XII, dos quais consta uma coleção de peças montadas nas igrejas.

24 "It was no accident that the new birth of drama occurred right at the fulcrum of the whole church year." 
Aí se pode identificar uma pista para as representações eclesiásticas na cidade, ao tempo de Ethelwold, sendo que ele propõe uma manifestação cênica derivada de uma liturgia efetivada há aproximadamente um milênio, relacionando o texto com uma melodia conhecida pelo seu público, propondo um trato espetacular. É imprescindível notar como as rubricas indicam a qualidade cênica, quando o guardião mostrava às mulheres o interior do sepulcro, encoberto por um grande véu, no altar-mor.

Lá elas encontravam apenas o tecido que envolvia a cruz, provando a ressurreição de Cristo. As mulheres, então, retiravam o tecido e o mostravam cerimoniosamente ao clérigo, e provavelmente, para a congregação que representava, naquele momento, os apóstolos. Ficava acentuada a contundente teatralidade na atitude de revelar, de modo cerimonial, o invólucro da morte. A cena apodera-se da intimidade de Jesus, dos seus últimos momentos.

Na condição de fonte primária, a Bíblia traz momentos que tratam do milagre da ressurreição de Cristo: no Novo Testamento, O Evangelho de Mateus, capítulo 28, versículos 1-10; Marcos, capítulo 16, versículos 1-10, assim como Lucas, capítulo 24, versículos 1-7. Ao entrarem no túmulo, cuja pedra que bloqueava a entrada já havia sido retirada, as três Marias encontram "[...] dois varões com vestes resplandecentes" (BÍBLIA, 1999, p. 1222); Marcos relata a presença de "[...] um jovem assentado ao lado direito, vestido de branco" (BÍBLIA, 1999, p. 1177); e, em Mateus, toma-se conhecimento de um grande terremoto: "[...] porque um anjo do Senhor desceu do céu, chegou-se e removeu a pedra e assentou-se sobre ela. O seu aspecto era de um relâmpago. E a sua veste alva como a neve". (BÍBLIA, 1999, p. 1142) Os grifos indicam a implícita relação com a luz: vestes brancas, resplandecência, relâmpagos, tudo isso sugerindo provocação contundente para imagens: mentais criadas pelo leitor, ou imagens visuais, determinantes na fisicalização desses eventos ou corpos cênicos expressivos.

Ainda que Ethelwold não tenha deixado registro de um tratamento particular da luz, as descrições da representação, os detalhes de figurinos e adereços, demonstram preocupação com a qualidade visual do evento. E como já foi dito, a narrativa bíblica por si só é um poderoso universo de conflitos e imagens, provocando espetacularidade particular ao longo da história.

As peças litúrgicas efetivaram-se como um seguimento desses modos de pensar cúmplices da luz e a incorporaram cada vez mais intencionalmente. Bergman pondera: 
A missa católica, em si, encontra-se repleta do simbolismo da luz, o que era, e talvez ainda seja, expresso de modo mais tangível na cerimônia, assim chamada Tenebrae, que ocorria na semana da Páscoa. As velas nas diversas hastes dos candelabros eram apagadas, uma a uma, como um símbolo da morte de Cristo, deixando acesa apenas aquela da parte superior central. O Bispo Ethelwold, no seu Concordia Regularis (965-975) conta-nos como os milagres da Ressurreição são encarnados em luz. ${ }^{25}$ (BERGMAN, 1977, p. 30, grifo e tradução nossos)

É notável a natureza espetacular da retirada das velas que constrói a atmosfera lúgubre do mergulho na penumbra. Documentou-se, então, pela primeira vez, uma desconstrução progressiva da imagem visual, que será aplicada ao cinema, séculos depois, sendo denominada fade-out.

O Bispo Ethelwold, no Regularis concordia, expressa ainda mais o compromisso simbólico do espetáculo católico com a luz, quando descreve a igreja completamente iluminada que estabelece uma atmosfera de grande brilho para a apresentação do símbolo da Ressurreição, o Vernicle, seguindo-se o Te deum, ou cantos de júbilo. Chilvers (2004) comenta a definição do verbete Vernicle, que aparece no Oxford dicionary of art:

Vernicle, (ou sudarium) 'O tecido ou lenço usado na cabeça, que teria pertencido a Santa Verônica e com o qual, segundo a lenda, ela enxugou o rosto de Cristo enquanto ele caminhava para o Calvário e sobre o qual seus traços ficaram miraculosamente impressos' [...], ou por extensão, qualquer estampa do rosto de Cristo impressa em um tecido ou véu, como alusão à história. Uma relíquia que pretende ser o sudário original está na Catedral de São Pedro, em Roma, desde o fim do século VIII; outros lugares também afirmam possuir o original. De acordo com o que se dizia na Idade Média, o nome Verônica deriva de vera icon ('imagem verdadeira'), e é provável que a santa seja meramente fictícia e que foi criada para explicar a relíquia. O nome alternativo, sudarium, é a grafia em latim para lenço de cabeça ou toalha. Na história da arte, o vernicle foi um tema muito usado, desde o século XV até o século XVII. É frequentemente levado por Santa Verônica, ainda que Zurbarán, por exemplo, tenha

\footnotetext{
25 "The Catholic Mass itself was filled with a light symbolism which was, and perhaps still is, most tangibly expressed in the so called Tenebrae ceremony in Easter week. The candles in the many branched candelabrum are put out, one by one, as a symbol of the death of Christ but the one at the top is left burning. Bishop Aethelwold, in his Concordia Regularis (965-975) tells us how the miracles of Resurrection are embodied in light."
} 
feito várias pinturas mostrando o tecido em si; Claude Mellan, do mesmo modo, retratou o tecido, separadamente, na sua célebre gravura sobre o tema. ${ }^{26}$ (CHILVERS, 2004, p. 734, grifo e tradução nossos)

Trata-se de uma das mais emblemáticas imagens do Cristianismo, aparecendo aqui como um adereço, no sentido teatral, cenográfico, de grande relevância espetacular. Muitos pintores, como Francisco de Zurbarán (1598-1664) e El Greco (15411614) produziram obras a partir do mesmo tema (Figuras 50 e 51).

O nascimento de Cristo, assim como sua ressurreição, é representado, afinal, como uma vitória da luz sobre as trevas: da Tenebrae para o mundo (a igreja) pleno de luz. Ainda que pareça óbvio, deve se ter cuidado para evitar uma interpretação simplória da relação, apoiando-se em rótulos superficiais, como maniqueísmo. Alguma flexibilidade pode ser aplicada para que se estenda a observação, apreendendo o embate dinâmico entre a luz e a sombra, como manifestação de intenso conflito que pode apresentar incontáveis nuanças.

É possível considerar uma interação entre as manifestações que ocorriam dentro das igrejas e aquelas outras realizadas fora do ambiente religioso. A cena religiosa deslocou-se para fora do espaço físico das igrejas, acompanhando o crescente número de espectadores e de atores que, em princípio, eram apenas sacerdotes; integraram-se depois representantes laicos até que os primeiros tornaram-se raros ou desapareceram, estabelecendo-se, no teatro europeu, uma relação direta entre o teatro que ocorria no interior da celebração católica e as demais atividades espetaculares.

Um importante exemplo de manifestações cênicas que deixaram o interior das igrejas, das quais se têm registros, ocorreu na França do século XII, e era denominada Jeu d'Adam, uma representação do Mistério de Adão e Eva, cujo texto em versos octossilábicos deve ter sido escrito por um padre que também teria participado como ator no espetáculo. O mistério contém três momentos justapostos: a queda de Adão e Eva, a morte de Abel e uma procissão de profetas que

26 "vernicle (or sudarium). 'The cloth or kerchief, alleged to have belonged to St Veronica, with which, according to legend, she wiped the face of Christ on his way to Calvary, and upon which his features were miraculously impressed' [...], or, by extension, any picture of Christ's face shown on a cloth or veil in allusion to the story. A relic that purports to be the original vernicle has been in St Peter's, Rome, since the late 8th century; other places have also claimed possession of the original. The name Veronica was said in the Middle Ages to derive from vera icon ('true image'), and it is likely that the saint is purely fictitious and was invented to explain the relic. The alternative name, sudarium, is Latin for handkerchief or towel. In art, the vernicle was a popular subject from the 15th to the 17th century. Usually it is shown as being carried by St Veronica, although Zurbarán for example, painted several pictures showing the cloth by itself; Claude Mellan likewise depicted the cloth alone in his celebrated engraving of the subject." 
anunciam a vinda do Messias. As rubricas dão conta da profusão de detalhes e do cuidado com cores, texturas e formas presentes na cena, revelando grande interesse pela sua expressão visual.

Considere-se que o espetáculo ocorria, agora, já no adro da igreja, à luz do dia, diante de uma aglomeração de espectadores. As indicações de figurinos, de adereços, do dispositivo cenográfico, de posturas, denotam preocupação com a proposição visual do evento como um todo, entendendo tais aspectos como também responsáveis pela construção da narrativa do Mistério. De acordo com Nagler (1952), as rubricas incluíam indicações visuais importantes, como a localização do paraíso, a instalação de cortinas para criar um modo particular de visibilidade daqueles que estão no seu interior, além das vestes de Jesus Cristo. O texto esclarece, por exemplo, que Adão deve usar uma túnica vermelha, enquanto Eva exibe uma veste feminina branca, com véu de seda, também branco.

Depois da queda no pecado, o casal enfrentará a Boca do Inferno: “[...] outros demônios apontam, um após o outro, enquanto eles se aproximam; e os empurram para o Inferno; assim que eles entram, surge muita fumaça, e todos [os demônios] gritam, no inferno, em grande júbilo". ${ }^{27}$ (NAGLER, 1952, p. 46, tradução nossa) A profusão de detalhes atesta o interesse na natureza visualmente espetacular das ocorrências impregnadas do divino cristão, como Tertuliano afirmara muitos séculos antes. Mesmo que se possa argumentar que os artistas tomavam tais decisões intuitivamente, cabe dizer que ao trabalharem em tais condições para efetivar um espetáculo sob a luz do sol, eles traziam a experiência adquirida na observação cotidiana da luz solar e a aplicavam na construção visual da cena.

Como acontecia no teatro grego, a relação com a qualidade da luz no espetáculo determinava sua construção como uma interação operada através de imagens visuais, vivas e carnais, acentuando-se a presença do performer na cena. Outros exemplos poderiam ser mencionados, como O Martírio de Santo Apolinário [Le martire de Sainte Apolline, (ca. 1460)], e o Castelo da perseverança (Castle of perseverance), cujo manuscrito data de, aproximadamente, 1440, editado em fac-símile (1908), por John S. Farmer, e ainda o Mistério da paixão (Mystére de la passion), representado em Valenciennes [1547 (Cf. Figuras 57 a 59)]. Tratava-se de uma tipologia cênica que se manteria viva - e em mudança - durante o Renascimento, interagindo com a cena do

27 "[...] other devils shall, one after another, point to them as they come; and they shall take them up and thrust them into Hell; and there upon they shall cause a great smoke to arouse, and shall shout one another into Hell, greatly rejoicing." 
período. Na Inglaterra do período no qual está inserido o teatro de Shakespeare, tais manifestações eram prática teatral comum.

O mundo como lugar do "reluzente" instalou-se em outra obra, que atuou como influência e referência para a arte do seu tempo, assim como de momentos subsequentes, a Comédia (Commedia), de Dante Alighieri (1265-1321):

Prata, alvaiade, grão, ouro fulgente

Índico, linho límpido e lustroso,

Pura esmeralda, ao lapidar luzente, [...].

(ALIGHIERI, 2003, p. 278)

O autor refere-se à determinada face de um universo destituído de materialidade, no qual a atenção se transfere para a existência do espírito, para uma vida transcendente, posterior. É uma obra exemplar, pois representa a arte que faz interagir a luz e a crença. Originalmente intitulada Comédia, em 1321, a qualificação Divina apareceria numa edição de 1555, muito depois da morte do autor. As informações sobre Dante Alighieri são contraditórias, impedindo um traçado biográfico preciso. Ele teria nascido em Florença, em 1265, sabendo-se pouco acerca de sua educação. Alguns afirmam que ele teria estudado, como autodidata, poesia e Escolástica. Certos indícios sugerem que Dante teve contato e interesse pela Escola Poética Siciliana (Scuola Poetica Siciliana), movimento cultural que, como diz o nome, se originou na Sicília e foi difundido, naquele momento, para a região da Toscana.

Por conseguinte, ele teria se familiarizado com a poesia latina, desde os clássicos. Horácio, Ovídio, Cícero e, provavelmente Tito Lívio, Sêneca e Plínio, além de Aristóteles, proveram companhia em seus estudos. Dante vivia em um momento no qual o que conhecemos hoje como Itália era um Império dividido, onde diversificadas regiões se comportavam como Estados autônomos. Tais regiões abrigavam corporações rivais que, motivadas por razões diferenciadas, buscavam hegemonia; ele participou da atividade política, inclusive lutando na batalha de Campaldino, saindo vencedor, quando o exército guelfo retomou Florença, então sob o domínio de Pisa e Arezo.

Em 1300, Dante foi eleito um dos priores (algo como a maior autoridade local, mas subordinada a Roma) da cidade. Depois de constantes atritos com a Igreja, representada pela administração em Roma, foi acusado de comportamento corrupto, de oposição ao papa e condenado ao pagamento de uma multa de alto valor, além de ser banido de Florença, por dois anos. No exílio, passando por várias cidades, produziu obras como A nova vida (La vita nuova), Da eloquência 
vulgar (De vulgare eloquentia) e a Comédia, à qual devotou 14 anos de sua vida, concluindo-a em 1321 - pouco antes de morrer, sem retornar à sua cidade natal.

O universo circular e imutável criado pelo poema de Dante, de influência ptolomaica, no que concerne à sua face material, é perpassado pela luz desde o inferno, aparecendo também no purgatório e, inevitavelmente, no paraíso. O limite do universo criado por Deus está na mais absoluta e pura luz, no mais alto dos céus. Sua presença definitiva até influenciou uma tradução, que se deixou impressionar e impôs o vocábulo "luz", mesmo onde ele não se apresentava no original italiano. Já no Canto I do Inferno, tercetos 16 a 18, lê-se: "Guardai in alto e vidi le sue spalle | vestite già de' raggi del pianeta | che mena dritto altrui per ogne calle". ALIGHIERI, 1966, p. 1, grifo nosso) O grifo destaca "os raios do planeta" mantidos numa tradução anglo-americana: "Upward I looked, and I beheld its shoulders | Vested already with that planet's rays | Which leadeth others right by every road". (ALIGHIERI, 1997, grifo nosso) Em português, o mesmo trecho recebe outro tratamento. Observe-se o termo luz: "Ao alto olhei, e já, de luz banhando, | Vi-lhe estar às espaldas o planeta, | Que, certo, em toda parte vai guiando." (ALIGHIERI, 2003, p. 18, grifo nosso)

Verifique-se a influência contundente que a experiência com a luz opera sobre o pensamento. Resta mencionar que Dante, ele mesmo, já inundou o seu poema de luz, mencionando-a diversas vezes, desde o Inferno, deixando marcas para a arte cristã que lhe sucedeu imediatamente, assimiladas e ampliadas por diversos artistas, inclusive nas artes cênicas. Bergman assinala:

Esse conceito de esferas é completamente incorporado pelas peças litúrgicas florentinas do século XV, as representações sacras, peças que representam o clímax do desenvolvimento do lighting design na Igreja Católica. ${ }^{28}$ (BERGMAN, 1977, p. 30, grifo e tradução nossos)

Tais representações sacras, respostas espetaculares da hermenêutica cristã ao divino, revelam uma expressividade que parece lembrar as descrições das casas de espetáculos da Roma antiga, do requinte e da grandiosidade elaborada pelos artistas romanos. Há, contudo, um agravante: para abrigar sua glória, o Deus cristão medieval "construiu" artesanalmente igrejas que são monumentais complexos arquitetônicos, com um detalhe vital: são também edificações cobertas. As gigantescas obras de arquitetura, planejadas para interagir com a luz

28 "This concept of the spheres is directly embodied in the Florentine liturgical plays of the 15 th century, the sacre rappresentazione, these plays are the climax of the development of lighting design in the Catholic Church." 
natural, foram oportunamente incorporadas como espaços para representações nas quais a aplicação da luz artificial era decisiva. Se o teatro da Antiguidade greco-romana, mesmo tendo relações particulares com a luz não necessitava da sua produção artificial para se efetivar, as performances que se originaram no pensamento cristão aliaram a grandeza e o brilho da dramaturgia ao uso da luz artificial, trazendo contribuição nova, vigorosa, que vem se modificando ao longo dos séculos. 


\section{A SANTIFICAÇÃO E A VISUALIDADE}

O universo criado pela literatura, pela música e pelas artes visuais repercutiu na práxis cênica, produzindo trocas entre as mais diversas expressões artísticas e abrindo intercâmbios de "mão dupla" que resultaram em uma profunda interação estética. Tal universo apresenta variáveis que interagem com a conjuntura político-religiosa, preponderante na economia e na construção da história moderna. O presente capítulo trata de proposições do Barroco para observar seu impacto visual na modernidade.

\section{FRONTEIRAS MANEIRISTAS}

A ópera, como exemplo, provocou contexto visual particular ao espetáculo, produzindo ecos e extensões que se instalaram progressivamente, desde as primeiras décadas do século XVI. Certas reações radicais de artistas do período estenderam-se até a segunda década do século XVI, caracterizando-se como um 
momento na história da arte, principalmente das artes visuais, conhecido progressivamente como Maneirismo e definido assim por Hugh Honour e John Fleming (1984, p. 379, tradução nossa).: "[...] [O maneirismo] foi construído como uma reação ou extensão dos ideais da Alta Renascença, como uma expressão da crise espiritual desse momento, [...]".

Também se pode compreender a atitude maneirista como estilização estética rigorosa, o que abriria espaços até mesmo para que se apreenda na implantação da práxis cênica em um espaço formalmente definido e construído para esse fim, um princípio de natureza maneirista, por vezes interpretado como atitude de confinamento/aprisionamento do acontecimento espetacular. A sistematização do palco e dos bastidores, como espaços definidos e constantes - incluindo a tecnologia que permite a realização de espetáculos - redundou numa rigorosa estilização estética da cena, que buscou sucessivo "refinamento". Certos exageros tecnológicos podem ser compreendidos também como "maneirismo", numa crítica que os considera nocivos para a abordagem artística.

Os comentadores concordam que a obra de Giorgio Vasari contribuiu para a disseminação do termo Maneirismo, como caracterização da obra de artistas do período. A palavra italiana maniera aparece inúmeras vezes nos seus escritos, sendo traduzida como maneira, modo, jeito e até como estilo. Em qualquer desses casos, relacionando-a ao modo particular e até peculiar de cada artista. Já na introdução de sua obra, Vasari aplicou diversas vezes a palavra maniera de forma destacada. (VASARI, 1993) Referindo-se à pintura a óleo, ele aplicou o termo para sugerir excelência e modo particular de aplicação de técnicas:

Este modo de colorir revela mais as cores, além disso, exige diligência e cuidado, porque o óleo em si deixa o colorido mais suave, mais doce, mais delicado, e torna a mixagem e o esfumado mais fácil do que nos outros casos, e quanto mais continuadamente [sem permitir que a tinta seque] você trabalha, mais facilmente elas se misturam e se fundem umas às outras. E, em suma, os artistas produzem assim, graciosidade, vivacidade, galhardeza nas suas figuras, de tal modo que muitas vezes nos fazem parecer em relevo as suas figuras, e principamente quando elas são contornadas com bom desenho, com invenção e bela maneira. ${ }^{2}$ (VASARI, 1993, p. 81)

\footnotetext{
1 "It has been construed as either a reaction against or an extension of the ideals of the High Renascence, as an expression of the spiritual crises of the time [...]."

2 "Questa maniera di colorire accende più i colori, né altro bisogna che diligenza et amore, perché l’olio in sé si reca il colorito più morbido, più dolce e delicato e di unione e sfumata maniera più facile che li altri, e mentre che fresco si lavora, i colori si mescolano e si uniscono l'uno con l'altro più facilmente. Et insomma li artefici danno
} 
Segundo alguns comentadores o maneirismo está ligado, nas artes visuais, à iniciativa de um grupo de pintores que reagiam aos pressupostos renascentistas, pesquisando a visualidade da Roma antiga, incluindo a escultura e a pintura de grandes mestres do passado. A adjetivação do trato específico de um artista forja a expressão bella maniera para indicar o atendimento a determinado conjunto de procedimentos que caracterizariam o modelo de suavidade, identificado em Leonardo da Vinci ou Rafael, ambos mencionados como exemplos para indicar a qualidade esperada e difundida na Alta Renascença. A bella maniera encontraria oposição já no tratamento elaborado por artistas do século XVI, listados pelos estudiosos como maneiristas. Alguns deles afirmam que o termo maneirismo foi utilizado pela primeira vez em um texto de Luigi Lanzi [(1732-1810) historiador, pesquisador da arte clássica e italiana da Renascença], como no exemplo a seguir:

[...] massas de pleno e de vazio, de luzes e sombras, não são equilibradas de acordo com a vontade, como fazem os maneiristas, mas, na imitação da seleção natural [da natureza]: tudo é arte, mas tudo é facilidade e ocultação da arte. A Escola de Atenas, [pintada] no Vaticano, neste gênero é, talvez, o empreendimento mais notável que há no mundo [Figura 52].3 (LANZI, 1972, p. 222, grifo nosso)

Em A Escola de Atenas (Scuola di Atene), de Rafael [Rafaello Sanzio (1493-1520)], pintada entre 1506 e 1510, podem ser encontrados cânones da mais alta expressão da visualidade do Renascimento. O empenho no atendimento à proporção e à perspectiva, na humanização das figuras, na fidelidade às narrativas usadas como ponto de partida e argumento, alcançavam extremos de representatividade, de acordo com alguns críticos. Por outro lado, cabe registrar a moldura que envolve a cena instalada na obra e anuncia um tratamento visual que só apareceria como forma permanente no teatro, um século depois - a boca de cena - com a construção do Teatro Farnese, em 1618, projeto de Giovanni Batista Aleotti.

Rafael indica uma trilha visual que passaria a interessar às artes cênicas e se consolidaria como um modelo que permanece em prática até hoje - mesmo sendo incessantemente combatido -, no qual a ação teatral é inscrita dentro da caixa

in questo modo bellissima grazia e vivacità e gagliardezza alle figure loro, talmente che spesso ci fanno parere di rilievo, e che elle eschino de la tavola, e massimamente quando elle sono continovate di buono disegno, con invenzione e bella maniera." (A tradução para a língua portuguesa é de Ana Maria Santanchè)

3 ' “...] masse de' pieni e de' vuoti, de' lumi e delle ombre sono equilibrate non a norma del volere, come ne' manieristi, ma ad imitazione della scelta natura: tutto è arte, ma tutto è disinvoltura e nascondimento dell'arte. La scuola di Atene in Vaticano è forse in questo genere la più ragguardevole cosa che abbia il mondo." (A tradução para a língua portuguesa é de Ana Maria Santanchè). 
cênica. A mencionada moldura indica uma espécie de ampliação da Porta Central (ou Porta Régia) localizada na skéné do teatro grego da Antiguidade, antecipando a quarta parede, difundida do século XIX como aspecto determinante para o teatro do Realismo.

A Escola de Atenas traz ainda curiosas provocações. Uma delas origina-se na atitude de algumas personagens representadas por Rafael, cujas posturas sugerem movimentos artificializados, deslocados do cotidiano. As posturas apresentadas por essas personagens podem indicar trilhas que seriam seguidas pelos maneiristas, cuja marca incluiria a radicalização de tal abordagem, desinteressando-se pelo argumento explicitado no texto mítico ou bíblico, optando por pesquisar na arte romana antiga e encaminhando sua própria apreensão das fontes. Rafael parecia estabelecer contato direto com o observador através das personagens que fitam quem contempla a obra, rompendo - de certa maneira - as fronteiras da ficção. Tais decisões podem servir como alerta para críticos, comentadores, historiadores e demais interessados na abordagem da obra e das suas relações com supostas fronteiras ou modelos rígidos.

Nos seus aconselhamentos técnicos para o alcance de melhores resultados, Vasari (1993) sugere índices de caráter estilístico, como orgulho, projeto, força, vitalidade, beleza e bella maniera. Artistas que teriam pintado com tal maestria, como Michelangelo e Rafael, são também citados como influência ou ponto de partida para os pintores listados entre os maneiristas. Como especulam Honour e Fleming (1984, p. 378-379), tal classificação derivava dos escritos acerca do comportamento social e da arte do século XVI, quando os especialistas pretendiam caracterizar mais que literalmente estilo ou modo de fazer, e sugeriam virtuosismo, fluência e refinamento, como nos mencionados Rafael e Michelangelo, além de Leonardo. O termo Maneirismo viria a ser aplicado até num sentido pejorativo, para se referir a artistas da segunda metade do século XVI, entre eles Correggio [Antonio Aleggri, (ca. 1489-1534)] e Parmigianino [Francesco Mazzola (1503-1540)]. Aponta-se em Correggio o perigo de um erotismo vulgar, que estabeleceria contradições no tratamento de temas religiosos.

Por outro lado, e isso é importante, ele é tido como o responsável por um novo modelo de ilusionismo na pintura, onde se deve incluir grande habilidade técnica para representar a pele humana, assim como figuras vistas de baixo, e nos movimentos demonstrados pela excelência na representação dos corpos. Comparando a Assunção (da Virgem) em Titian [Tizian, Tiziano Vecelli ou Tiziano Vecellio (ca. 1488/9o-1576)] e em Correggio [Antonio Allegri da Correggio (1489 - 1534)] (Figuras 53 e 54), Honour e Fleming (1984, p. 379, tradução nossa) observam: 
[...] um novo tipo de pintura de teto que rompe completamente os limites da arquitetura para abrir uma visão de figuras girando no céu e, por assim dizer, rodopiando com elas, o espectador. Ao invés de testemunhar a cena como se estivesse diante de uma boca de cena (como na Assunção, de Titian), o espectador toma parte nela. ${ }^{4}$

O "espectador" ideal, compreendido em algumas abordagens estético-poéticas como um fruidor, deveria ser partícipe dessa assertiva visual que parece haver permanecido em repouso durante séculos no teatro efetivamente emoldurado pela boca de cena. Quando a diversificada ruptura com o realismo deseja desconstruir o limite palco-plateia, pode indicar um gérmen criado por um artista como Corregio, séculos atrás.

O mencionado tratamento maneirista dos corpos apresenta a deformação provocada pelo alongamento e/ou pela torção inesperada como outro aspecto que merece atenção. Ficam sugeridos corpos e movimentos artificializados, derivados de uma "ideia" particular de corpo, mais uma abstração do que uma representação que toma a natureza como modelo. A tendência ganhou intrigante expressão em El Greco [como assinava Doménikos Theotokópoulos (1541-1614)], em cuja obra a crítica encontrou características do Maneirismo. A Adoração dos pastores revela personagens míticas impregnadas por uma luz divina, enormes figuras que desconstroem a gravidade. A figura do Cristo criança recebeu um tratamento singular ao incorporar uma intrigante luz própria. Configura-se um mundo de brilhos derivados de pedras preciosas, no qual reinam as qualidades cromáticas do ouro, da prata, e do fogo (Figura 55).

Também segundo Honour e Fleming (1984, p. 387), quando Michelangelo teve seu Juízo final (1534-1541) condenado pelo pensamento da Contrarreforma, El Greco afirmou ser capaz de criar obras com maior decência e virtude, capazes de provocar fervor religioso e colocar o espírito dos fiéis acima da realidade sensível do cotidiano. Em A ressurreição [La resurrección (ca. 1597-160o)] pode-se esboçar alguma aproximação entre sua pintura e o Maneirismo, observando o alongamento que já aparece verticalizando artificialmente as personagens; além disso, as imposições narrativas originadas nos escritos bíblicos parecem se dissipar. Note-se que a tumba não é sequer representada, as relações espaciais são artificializadas e a luz

4 "[...] a new type of ceiling painting which breaks completely through the architecture to open a vision of figures swirling into the heavens and, as it were, whirling the spectator into the vortex with them. Instead of witnessing the scene as if through a proscenium arch (as in Titian's Assumption) the spectator is made part of it." 
não inclui parâmetros da natureza. Tais características dão à sua obra grande relevância no estudo da visualidade como aspecto do pensamento daquele período.

Outros artistas podem ser lembrados quando se acentua a contribuição do objeto artístico para o pensamento em questão. Parmigianino [Girolamo Francesco Maria Mazzola (1503-1540), também conhecido como Parmigiano] empenha-se para que sua obra que retrata a mãe de Cristo com o filho desperte a atenção do observador já no título: Madona com longo pescoço [Madonna dal collo lungo (ca. 1535)] (Figura 56). Não somente o pescoço da mãe de Cristo parece estranhamente alongado, mas também a figura do próprio filho de Deus em seu colo. É uma imagem com tratamento inesperado das proporções convencionais. E ainda é difícil apreender a presença da minúscula figura, na extremidade inferior direita do quadro, o que acentua a estranheza da obra. Destaque-se também, o seu Autorretrato em espelho convexo [Autoritratto entro uno specchio convesso, (1623-1624)], como exemplo de tal dissonância (Figura 57).

Apontado como um momento da história da arte cuja compreensão apresenta desencontros nas interpretações, o período deixou traços importantes para sua aproximação com o Barroco, movimento de grande representatividade na práxis cênica. O combate renascentista à teocracia que havia imperado desde o século VII até o século XV incorporou um renovado trato artístico dos temas religiosos, ainda que representando-os como algo distante do público, para ser contemplado "de fora", acentuando-se o papel do observador. As figuras representadas nos quadros eram arquétipos de uma beleza ideal, calculada. Na cena, o uso da perspectiva e o advento da boca de cena que a emoldurava contribuíram para efetivar tal relação. Os eventos sociopolíticos, as ameaças ao poder da Igreja católica, indicam os caminhos mencionados acima, reconhecendo a força do ofício do artista. A Contrarreforma católica demanda uma expressão artística que aproxime as entidades religiosas do homem comum, do fiel; as personagens devem parecer familiares, indicando vida, movimento. O Maneirismo já parece incorporar tais características, antecipando a explosão setecentista. O caráter de grande tensão e movimento que se observa em Assunção da Virgem [Assunzione della Vergine (1526-1530] de Correggio, revelando corpos que parecem girar, expressando deslocamento, é um bom exemplo. Os mesmos Honour e Fleming (1984, p. 379, tradução nossa), citados acima, dizem: "A habilidade de Correggio para representar figuras vistas de baixo (sotto-in-sùs), mostrando membros superiores e inferiores muito convin-

5 Traduzido como "visto de baixo" ou "de baixo para cima", a técnica foi aplicada por Mantegna em afrescos pintados na Camera degli Sposi no palácio ducal em Mântua, em 1473. A técnica inclui a representação em escorço, que sugere um ponto de vista extremo e cria uma espécie de deformação do objeto representado. 
centes enquanto giram no espaço, estabelecem um novo modelo de ilusionismo". ${ }^{6}$ Tal consideração demonstra os estreitos laços do Maneirismo, tanto com a Alta Renascença, de onde teria se originado, quanto com o Barroco, para o qual aponta.

\section{CORPORIFICAÇÃO EM VISUALIDADE E MOVIMENTO}

Quando se observa o século XVII cabe atenção às grandes reviravoltas que incluíam o deslocamento de um poder que perdurara por aproximadamente 400 anos, entre 600 d.C. e 1000 d.C., com a teocracia estabelecida sob a autoridade do Sagrado Império Romano, cuja unificação teve como decisivo ingrediente o catolicismo, na condição de religião oficial. A reforma alemã em ascensão, a Guerra dos 30 Anos (1618-1648), o declínio espanhol, que enfrentou rebeliões nos Países Baixos, a presença do parlamentarismo na Inglaterra, o pensamento francês em Descartes, resultaram em mudanças significativas na Europa. Certos eventos produziram grande eco ou representaram estágios do processo de construção de modos de pensar, tanto nas artes visuais, quanto na música, e também nas artes cênicas.

$\mathrm{O}$ interesse renascentista em selecionar, calcular e representar matematicamente o mundo, como resultado do posicionamento rigidamente definido por regras geométricas que submetiam a vida ao olhar humano, provocaria reações radicais. O reconhecimento da visualidade como aspecto relevante para a aproximação com Deus e com os santos, como instrumento na construção e na manutenção da fé revela uma Igreja católica que assume, não somente a eficiência da imagem, mas também o desejo do fiel de ver o objeto de sua veneração e adoração. É relevante no presente momento da discussão sublinhar o reconhecimento do apelo que uma imagem pode produzir, mencionando exemplos efetivos dos compromissos estabelecidos pela Igreja, entre o catolicismo e a arte.

As repercussões de tal reconhecimento deram ao teatro do Barroco uma característica importante: nunca antes foram aplicados tantos recursos financeiros no teatro; a compreensão barroca da importância da imagem levava alguns aristocratas a investirem mais no teatro que no exército, a ponto de se aproximarem da ruína econômica, provocada também pelos altos gastos de um teatro exuberante (ágil nas trocas de cenários) e, portanto, fascinante. Isso permitia e suscitava cons-

6 “Correggio's skill in depicting figures seen from below - sotto-in-sù is the technical term - displaying wellturned limbs as they gyrate in space, set a new space for illusionism." 
tantes mudanças, por vezes a cada década, para garantir e ampliar a eficiência do discurso visual; tais mudanças foram rapidamente difundidas por toda a Europa.

Aqui deve ser destacado o fator de regulamentação para a produção artística que responde aos pressupostos do Barroco, as decisões do Concílio de Trento, em particular aquelas que aparecem no documento produzido na $24^{\mathrm{a}}$ sessão, realizada nos dias 3 e 4 de dezembro de 1603. Parte das decisões já estava indicada no subtítulo Sobre a invocação, veneração, relíquias e santos, e sobre imagens sagradas (On the invocation, veneration, and relics, of saints, and on sacred images):

O santo Sínodo ordena a todos os bispos e outros que mantêm o ofício e a responsabilidade de ensinar de acordo com a prática da Igreja Católica Apostólica [...] que eles especialmente instruam os fiéis sobre a diligente intercessão e invocação dos santos, a honra devida às relíquias e o legítimo uso de imagens [...].

[...] pois a honra que a eles é devotada refere-se aos protótipos representados por tais imagens; desse modo, através das imagens, que beijamos e diante das quais descobrimos a cabeça e nos prostramos, nós adoramos Cristo e veneramos os santos, a cuja semelhança elas são feitas: assim, atendendo aos decretos dos Conselhos, e especialmente do segundo Sínodo de Niceia, ficou deliberada (ação) contra os que se opõem às imagens [...].

[...] E os bispos devem cuidadosamente ensinar que, por meio das histórias dos mistérios da nossa Redenção, retratados através de pinturas ou outras representações, o povo é instruído, confirmando (no hábito de) lembrar, e revolvendo de modo contínuo na mente os artigos de fé; assim também, esse grande proveito é derivado de todas as imagens sagradas, não só porque as pessoas são, desse modo, alertadas acerca dos benefícios e dons a eles concedidos por Cristo, mas também porque os milagres que Deus realizou por meio dos santos, e seus exemplos salutares, são apresentados diante dos olhos dos fiéis [...]. ${ }^{7}$ (THE COUNCIL..., 1848, p. 233-235, grifo e tradução nossos)

\footnotetext{
7 "The holy Synod enjoins on all bishops, and others who sustain the office and charge of teaching, that, agreeably to the usage of the Catholic and Apostolic Church, [...] they especially instruct the faithful diligently concerning the intercession and invocation of saints; the honour (paid) to relics; and the legitimate use of images [...] because the honour which is shown them is referred to the prototypes which those images represent; in such wise that by the images which we kiss, and before which we uncover the head, and prostrate ourselves, we adore Christ; and we venerate the saints, whose similitude they bear: as, by the decrees of Councils, and especially of the second Synod of Nicaea, has been defined against the opponents of images. [...] And the bishops shall carefully teach this, - that, by means of the histories of the mysteries of our Redemption, portrayed by paintings or other representa-
} 
Dois aspectos devem ser destacados, uma vez que exercem impacto sobre o discurso visual: a confiança no movimento e na proximidade com a natureza dos corpos. Esse desejo de movimento e de irromper nos domínios daquilo que se acreditava real, buscava a representação dos corpos à semelhança daqueles encontrados no cotidiano. A despeito do tema sendo pintado, do grau de fantasia da história sendo contada, da acentuada saturação e fortes traços estilísticos, o tratamento da musculatura e da pele [sublinhado pelos críticos como um recurso que as aproximava da aparência humana]. O movimento e a similaridade visual com o real se fez presente no Barroco - num sentido específico - quando os artistas incorporaram o desejo de aproximar o espectador da obra que contemplava.

Incorporando à discussão a necessidade barroca de movimento e de expressão da natureza humana, aqui será incluída a obra de Michelangelo Merisi da Caravaggio (1571-1610). Na sua pintura Ceia em Emaús [Cena in Emmaus (1601)] encontram-se aspectos que sublinham as relações entre a visualidade - na qual se incluem entrelaçamentos entre visibilidade e cultura - e a cena (Figura 58). Os principais registros com os quais Caravaggio contava na elaboração desta obra estão no Novo Testamento, em particular nos evangelhos de Marcos e Lucas:

13 Nesse mesmo dia, dois deles estavam de caminho para uma aldeia chamada Emaús, que distava de Jerusalém sessenta estádios; ${ }^{14} \mathrm{E}$ iam conversando a respeito de todas as coisas sucedidas. ${ }^{15}$ Aconteceu que, enquanto conversavam e discutiam, o próprio Jesus se aproximou e ia com eles, ${ }^{16}$ Os olhos deles estavam como que impedidos de o reconhecer. ${ }^{17}$ Então lhes perguntou Jesus: Que é isso que vos preocupa, e de que ides tratando à medida que caminhais? E eles pararam entristecidos. ${ }^{18} \mathrm{Um}$, porém, chamado Cleopas, respondeu dizendo: És o único porventura, que, tendo estado em Jerusalém, ignora as ocorrências destes últimos dias? ${ }^{19}$ Ele lhes perguntou: Quais? E explicaram: O que aconteceu a Jesus, o Nazareno, que era varão profeta, poderoso em obras e palavras diante de Deus e de todo o povo. ${ }^{20}$ e como os principais sacerdotes e as nossas autoridades e entregaram para ser condenado à morte, e o crucificaram. ${ }^{21}$ Ora, nós esperávamos que fosse ele quem havia de redimir a Israel; mas depois de tudo isso, é já este o terceiro dia desde que tais coisas sucederam. ${ }^{22}$ É verdade tam-

tions, the people is instructed, and confirmed in (the habit of) remembering, and continually revolving in mind the articles of faith; as also that great profit is derived from all sacred images, not only because the people are thereby admonished of the benefits and gifts bestowed upon them by Christ, but also because the miracles which God has performed by means of the saints, and their salutary examples, are set before the eyes of the faithful; [...]." 
bém, que algumas mulheres, das que conosco estavam nos surpreenderam, tendo ido de madrugada ao túmulo ${ }^{23}$ e, não achando o corpo de Jesus, voltaram dizendo terem visto uma visão de anjos, os quais afirmam que ele vive. ${ }^{24}$ De fato, alguns dos nossos foram ao sepulcro e verificaram a exatidão do que disseram as mulheres; a ele, mas não o viram. ${ }^{25}$ Então, lhes disse Jesus: ó néscios, e tardos de coração para crer em tudo o que os profetas disseram! ${ }^{26}$ Porventura, não convinha que o Cristo padecesse e entrasse na sua glória? ${ }^{27} \mathrm{E}$, começando por Moisés, discorrendo por todos os Profetas, expunha-lhes o que a seu respeito constava em todas as Escrituras. ${ }^{28}$ Quando ele fez menção de passar adiante. ${ }^{29}$ Mas eles o constrangeram, dizendo: Fica conosco; porque é tarde, e o dia já declina. E entrou para ficar com eles. ${ }^{30} \mathrm{E}$ aconteceu que, quando estavam à mesa, tomando ele o pão e o abençoou-o e, tendo-o partindo, lhes deu. ${ }^{31}$ então, se lhes abriram os olhos, e o reconheceram; mas ele desapareceu da presença deles [...]. ${ }^{8}$ (BÍBLIA, 1999, p. 1223-1224)

Marcos, em 16-12, relatou: "[...] [Jesus] manifestou-se em outra forma a dois deles que estavam de caminho para o campo". (BÍBLIA, 1999) Caravaggio construiu sua versão fazendo assertivas visuais contundentes. É notável o seu desejo de revelar naqueles apóstolos a semelhança com pessoas que se podia efetivamente encontrar numa estalagem, sentados à mesa comendo frutas, uma ave e pão. Se o homem de pé, à esquerda de Cristo, parece imobilizado, isso reflete o apelo que o último exerce. Outros reagem às palavras e atos de Jesus, como a uma força que os arrebatou.

Há um grau explícito de tensão, como se fosse possível reter efetivamente na pintura um fragmento do ocorrido. Num certo sentido, o observador pode ser surpreendido a qualquer momento e testemunhar aqueles homens "saindo" do quadro, projetando-se, escapando e continuando a ação fora do plano da obra artística. A bandeja, à direita, em primeiro plano, pode cair a qualquer instante. Tal conjunto de aspectos produziria uma aproximação com a pessoa que contemplasse a imagem, levando-a a interagir com todo o seu corpo. Caso estivesse muito perto da imagem ela talvez precisasse prover espaço para permitir que os homens envolvidos na ação se deslocassem e até, talvez, fosse surpreendida por um movimento brusco sendo tocada por uma daquelas figuras.

8 Os números em sobrescrito que aparecem nessa citação não se referem a notas específicas desta tese, mas representam a subdivisão dos capítulos no texto de Lucas. 
Alguns comentadores consideram que o Cristo pintado por Caravaggio parece muito jovem, se comparado com o homem de longas barbas que as artes visuais difundiram ao longo da história da pintura religiosa. Outros veem traços femininos na composição da personagem. Observando o texto bíblico, podemos notar já no apóstolo Lucas que os homens não o podem reconhecer. No breve texto de Marcos, tomamos conhecimento que Cristo "[...] manifestou-se em outra forma [...]". (BÍBLIA, 1999, p. 1178) Aí, tanto em Lucas quanto em Marcos, Caravaggio se deixa provocar e reage como um artista próximo da Alta Renascença que arremessa adiante sua poética.

\section{A LUZ COMO ELO ENTRE A PINTURA E A CENA}

Caravaggio trabalhou com uma arte religiosa na qual a representação da divindade e dos santos incorporava concretude e semelhança humana. Além disso, ele introduziu um tratamento exemplar do ambiente onde cada evento ocorria. A retórica maneirista elaborada através de "figuras de arte" artificializadas e distanciadas cede espaço à necessidade de contato com o observador. Caravaggio propôs um modo inovador de incluir as relações entre luz, penumbra e sombra na arte pictórica. Se as suas figuras míticas assemelham-se a outras que poderiam ser encontradas no dia a dia, por outro lado, ele as mergulhava num mar de trevas, criando intrigantes contrastes que revelavam a força expressiva de cada uma das personagens e, por conseguinte, da ação inscrita na imagem.

Não é raro encontrar comentários que classificam sua pintura como exemplo de aplicação "dramática" da luz, referindo-se ao apelo emocional da imagem, além de uma assertiva visual que impulsiona sua obra na direção da cena, considerando-se que suas pinturas sugerem fragmentos-chave de espetáculos, fragmentos cuidadosamente selecionados como núcleo visual de uma ação cênica que contém movimentos passados e que se projeta no futuro. Para o iluminador, a obra de Caravaggio pode indicar relevantes objetos de pesquisa, investigando-se o rigor aplicado por ele na busca de excelência para suas imagens. Independente de estilos, poéticas e revoluções, rigor e excelência na criação da imagem integram (ou deveriam integrar) a práxis cênica.

Waldemar Januszczac ${ }^{9}$ afirma que durante a Contrarreforma a pintura se esforçou por atender à indicação ou exigência da Igreja Católica, para a qual o objeto artístico deveria ganhar a atenção do católico e convencer os infiéis. Ele acrescenta:

9 Crítico de arte inglês, nascido em 1954, escreve no Guardian e no Sunday Times. 
"[...] um truque muito eficiente é usar dramaticamente a escuridão e transformar a pintura em teatro". ${ }^{\circ}$ (BAROQUE..., 2009, tradução nossa) O termo "truque" pode dar lugar a interpretações negativas e/ou pejorativas e talvez fosse preferível dizer estratégia ou procedimento, notando-se em Caravaggio caminhos que estabelecem uma visualidade repleta de atmosferas, mergulhando a ação nas sombras, alcançando níveis de precisão com altíssimo grau de dificuldade para sua efetivação no teatro, seja considerando o estágio técnico da luz aplicada àquele tempo, na cena, ou a escassez de treinamento específico, hoje em dia. O grau de controle da intensidade, da cor, da distribuição dos aparatos que determina os ângulos e da dimensão do foco apresentado pela sua pintura só seria alcançado séculos mais tarde, com o advento da luz elétrica. Foi necessário o aparecimento de outra qualidade tecnológica dos instrumentos aplicados na produção de luz artificial, assim como dos sistemas de controle e dos acessórios, para que se pudessem alcançar na cena resultados próximos daqueles já vislumbrados por Caravaggio, séculos antes da aplicação da eletricidade como recurso para a luz artificial.

Depois de ter visto obras com tal proporção, o olhar moderno ganhou a oportunidade de aproximar-se de imagens com qualidade semelhante também na cena, desde os finais do século XIX, e pode ter assumido que elas sempre lá estiveram. A observação atenta e a reflexão cuidadosa provam o contrário, o que torna a obra de Caravaggio objeto relevante de estudo, apontando possibilidades de contato entre a abordagem cênica da luz e as artes visuais, principalmente a pintura.

O contato com Caravaggio leva a abordagens que se originaram no Barroco, ligadas ao fervor de um pensamento religioso que busca aproximar a narrativa das artes visuais de cada fiel, de cada um que contempla uma obra. A incorporação da "verdade", no sentido de semelhança com o real observado no cotidiano e da sugestão de movimento, que sugere a presença do corpo vivo, é um dos aspectos mais determinantes do Barroco. Tudo isso, por outro lado, de acordo com a elaboração particular de cada artista pode sugerir resultados completamente diversificados. Para exemplificar tal possibilidade, cabe observar a obra de outro artista do período, Annibale Carracci (1560-1609), como uma possível transição entre os cânones da Alta Renascença - passando por influências de Michelangelo e Rafael - e o Barroco. Interessa destacar aqui os afrescos pintados pelos Carracci, Annibale e seus irmãos, em 1595, no Palácio Farnese, em Roma, entre os quais O triunfo de Baco e Ariadne [Il trionfo di Bacco e Arianna, imagem central no teto

10 "[...] one very effective trick is to make dramatic use of the dark and turn painting into theatre. A citação foi retirada de um vídeo e, portanto, não possibilita a inclusão de número de página." 
da Galeria (Figuras 59 e 60)]. O conjunto pictórico da Galeria Farnese é conhecido como Os amores dos deuses.

O primeiro biógrafo de Carracci, Giovanni Pietro Bellori (ca. 1615-1696), já aponta a natureza barroca da sua obra e acentua os traços maneiristas, sem o enfoque pejorativo mais tarde associado ao termo. De acordo com Honour e Fleming (1984), essas pinturas apresentam uma espécie de racionalização de Michelangelo, tomando como fonte de inspiração a Capela Sistina. Buscando alcançar o grau de ilusionismo desejado para definir os diferentes níveis de realidade aplicados, a obra de Caracci alcança o grau de ilusionismo desejado, para definir os níveis de realidade envolvidos, e estabelece uma estrutura decorativa, composta da simulação de relevos de gesso e medalhões de bronze, além de estátuas que funcionam como moldura para as pinturas. Importante notar a visualidade diferenciada, quando são comparados os relevos e medalhões, que reagem à luz do ambiente da Galeria, em constante mudança, com a luz fixada nos afrescos.

Além da estratégia do sotto-in-sù já conhecida na Itália àquele tempo, aplicada desde Andrea Mantegna (Figura 61), a técnica da quadratura ${ }^{11}$ foi aplicada por Caracci, incorporando referências à perspectiva, como elo entre pintura e arquitetura, elaborando o convencimento daquele que contempla a obra. Uma policromia particular determina a assertiva visual, estabelecendo o contraste para a identificação dos casos de amor entre os deuses, narrados no interior das molduras. As estátuas mantêm um aspecto de pedra polida, enquanto querubins povoam toda a obra, aparecendo não somente fora das cenas pintadas, como também ingressando no espaço de algumas unidades narrativas. Cada uma das soluções tem relação direta com a aplicação diferenciada da luz e da sua potencialidade cênica moderna, ou seja, o enquadramento da ação pela boca de cena. Tais soluções apresentariam no teatro um elevado grau de dificuldade, devido a limitações de natureza técnica, especialmente na luz. Vale, portanto, incluir a obra de Carraci como mais uma e relevante fonte de pesquisa para a compreensão da luz na cena da modernidade. A afirmação de Honour e Fleming (1984, p. 427-428, tradução nossa) pode contribuir para alargar o horizonte dos estudos do tema:

11 De acordo com Oxford Dictionary of Art, o termo quadratura, originalmente ligado aos três problemas da geometria grega, foi usado no Barroco para caracterizar a técnica ilusionista na pintura, principalmente nos afrescos pintados em tetos de edificações, aplicando a perspectiva. Usado desde a pintura romana antiga, esse procedimento ganha expressão particular no Barroco, provocando ilusão da extensão dos limites arquitetônicos de uma edificação, sugerindo tridimensionalidade inexistente. A técnica da quadratura bolonhesa foi aplicada na pintura de superfícies abobadadas, como os tetos das igrejas ou dos palácios. (CHILVERS, 2004, p. 571, tradução nossa) 
Annibale Carraci não era um teórico, mas seu trabalho viria a ser exaltado como um exemplo de uma versão racionalizada da teoria estética do século XVI, substituindo a 'Ideia' metafísica neoplatônica, um ideal derivado puramente da arte em si mesma. Por mais de dois séculos, ela proveria a base de toda a prática acadêmica. ${ }^{12}$

Trata-se de um caminho que indica outros exemplos de conexão com a cena. Vale destacar O êxtase de Santa Teresa (L'estasi di Santa Teresa), conjunto escultórico inspirado pela narrativa apresentada pela própria Santa Teresa D'Ávila (1515-1582), concebido por Bernini [GianLorenzo Bernini (1598-1680)] a pedido do Cardeal Federico Cornaro (1579-1673), e construído entre 1647 e 1652, na Capela Cornaro - Igreja Santa Maria della Vittoria - em Roma, considerado depois um marco da expressão do Barroco (Figura 62).

No capítulo XXIX de sua autobiografia, Teresa D'Ávila relata uma experiência na qual um belo e pequeno anjo vem ao seu encontro. Sua descrição indica uma aparência em brasa, relacionando o divino à luz e ao fogo. Ele traz um dardo ou seta dourada, cuja ponta parecia em chamas. Penetrada no coração, com as entranhas ferventes e extrema dor espiritual, que repercutia profundamente no corpo, ela teve a alma abrasada pelo amor de Deus.

O que resulta na obra de Bernini é um conjunto de esculturas que representa um teatro dentro da Capela, incluindo uma espécie de palco ao centro, e até camarotes. Em um deles, à direita, aparece o próprio Cardeal Cornaro, acompanhado de membros da sua família, que assistem a um espetáculo. Os membros da plateia (nesses camarotes) guardam traços que configuram um elo com o cotidiano, quando menos destacando expressões de um grupo de espectadores que reagem à ação revelada no "palco", o nicho central. O artista apoia a santa sobre uma nuvem que transcende a gravidade, revelando ao espectador um momento particular de profundo êxtase da jovem Teresa, que paira no céu, penetrada pelo amor divino.

Em uma decisão de natureza significativamente espetacular, Bernini materializa os raios do brilho de Deus com fachos dourados de luz, que se projetam do centro superior, como que inundando o ambiente.

Em muitos espetáculos da atualidade podem ser identificadas semelhantes tentativas de corporificação da luz. De modo primitivo, instrumentos (refletores) posicionados atrás da cena, como se pode ver em circos e ringues de boxe, criam a

12 "Annibale Carraci was no theorist, but his work soon came to be extolled as the exemplar of a rationalized version of sixteenth-century aesthetic theory, substituting for the Neoplatonic metaphysical 'Idea', an ideal derived from art itself. For more than two centuries it was to provide the basis of all academic teaching." 
luz "materializada", "pulverizada" ou "fragmentada", como resultado dos raios que incidem em partículas presentes no ar. Bertolt Brecht (1898-1956) buscou incorporar em suas montagens momentos com tal qualidade.

A tecnologia aplicada à cena, desde o século passado, introduziu equipamentos e acessórios diversos, do tipo máquina de fumaça ou de neblina que umidificam o ar e produzindo a exposição dos fachos de luz oriundos dos instrumentos, pigmentando a fumaça ou neblina de acordo com a cor dos filtros. Em certas "estéticas", o efeito comentado tornou-se uma espécie de norma, sendo seu uso largamente difundido, o que até estabelece o lugar comum de certas regras impostas a uma forma de arte. Num certo sentido, pode-se compreender a tendência como mera repetição ou como "maneirismo vulgar".

O mencionado corpo escultórico, ao centro do conjunto concebido por Bernini, num branco muito brilhante, revela a força da luz que se projeta simbolicamente em sua direção. Se Bernini parece diluir as fronteiras entre escultura e arquitetura, como se pode verificar no baldaquino (baldacchino),$^{13}$ construído na catedral de São Pedro, na cidade de Roma [(1624-1633, Figura 63)], em O êxtase de santa Teresa, ele elabora imagem provocada pela inexorável parceria que envolve o teatro e a luz. Por conseguinte, pode-se dizer que Bernini indica trilhas dinâmicas, entre as artes visuais e o espetáculo, que serão visitadas por muitos outros artistas, sublinhando a assertiva visual da práxis cênica, assim como a potencialidade cênica das artes visuais.

Afastando o objetivo de um estudo aprofundado do Barroco é importante apresentar aqui uma breve observação do seu extenso e diversificado caráter. Desse modo, buscando acentuar a qualidade atmosférica incorporada pela sua visualidade, o presente capítulo inclui a obra de Andrea Pozzo (1642-1709), pintor, arquiteto e teórico nascido em Trento. O início da sua carreira inclui pinturas cujo tratamento indica relação direta com a estética já sublinhada em Caravaggio. Jodi O'Toole, em dissertação apresentada como requerimento parcial para o título de mestre na McGill University, no Canadá, oferece em breve descrição elementos para tal assertiva: "Essas telas, na sua maioria, decoravam igrejas jesuítas no nordeste e na região central da Itália. O tema de cada tela exigia cenas imersas na escuridão e

13 Numa igreja, uma estrutura ornamental em forma de dossel, apoiada em quatro pilares, usualmente construída para abrigar um altar, e incluindo geralmente estátuas e relevos decorativos. (THE OXFORD..., 2004, p. 47, tradução nossa) 
iluminadas por luz controlada, frequentemente através do uso de velas ou tochas"m4 (O’TOOLE, 1999, p. 9, tradução nossa) (Figura 64).

Andrea Pozzo segue caminho semelhante àquele escolhido por Caravaggio e pode-se verificar a antecipação empreendida por ambos, quando eles se debruçam sobre a expressão da visualidade controlada e deixam uma provocação para as artes cênicas, uma vez que, como já foi dito, tal controle da luz permanecerá um desafio técnico só efetivamente atingido através da aplicação da luz elétrica. O teatro foi obrigado, portanto, a esperar alguns séculos até que nele se pudesse elaborar - no seu modo tridimensional - a afirmação visual já observada em artistas como Pozzo e Caravaggio, além de outros que se seguirão, alguns deles aqui mencionados. Vale verificar, então, que a práxis cênica pode ter experimentado um extenso aprendizado por centenas de anos.

Pozzo, que trabalhou na elaboração de eventos para a ordem dos jesuítas, como arquiteto e cenógrafo, incluiu na sua obra o trabalho teórico Perspectiva para a pintura e para a arquitetura (Perspectiva pictorum et architectorum), em dois volumes ilustrados, publicados, respectivamente em 1693 e 1698, como instrução para artistas que trabalhavam com a arquitetura e também com a cenografia. Esses livros estão entre os primeiros manuais de perspectiva que se conhece, na trilha do trabalho de Leon Batista Alberti, já citado, e foram traduzidos para vários idiomas, inclusive o chinês. Note-se que o trabalho teórico de Pozzo inclui plantas, elevações, cortes e perspectivas de um teatro, apresentando a organização espacial do palco barroco, ainda que a plateia pareça mais ligada a princípios originados no teatro romano, e já aplicados no início do Renascimento por Andrea Palladio no projeto do Teatro Olímpico, em Vicenza, citado e comentado no capítulo anterior do presente texto. Tal característica do espaço destinado ao público pode justificar a ponderação de Allardyce Nicoll (1927, p. 138), quando diz que, apesar de publicados em 1692, os desenhos foram realizados muitos antes do período em discussão (Figura 65)

De um ângulo que pode ser considerado extremo na obra de Andrea Pozzo, quando comparado a suas telas contempladas acima, que mergulhavam nas trevas, deve ser destacado o afresco realizado no teto da igreja jesuíta de Santo Inácio, ${ }^{15}$ em Roma, entre 1685 e 1694. Quando começou a execução da obra em questão,

\footnotetext{
14 "For the most part, these canvases decorated Jesuit churches throughout northern and central Italy. The subject matter of each canvas demanded scenes immersed in darkness with controlled lighting. Often by candle light or torch."

15 A Igreja de Santo Inácio foi construída entre 1626 e 1650, para celebrar a canonização de Inácio de Loyola, em 1626, fundador da Companhia de Jesus, com projeto de Orazio Grassi (1583-1654).
} 
Pozzo já pertencia à ordem jesuíta há vinte anos, na qual havia ingressado em 1665. Denominado Apoteose de Santo Inácio, o afresco é destacado como sua obra-prima, e um dos principais exemplos de ilusão perspectivista até sua época, além de ser considerado importante demonstração de movimento impregnado de grandiosidade, traço determinante no Barroco. O observador deve posicionar-se sobre um disco de bronze, disposto no piso da nave da igreja, para mergulhar na ilusão de tridimensionalidade, experimentando assim o "desaparecimento" da superfície plana do teto que parece se abrir numa multiplicidade de acontecimentos, celebrando os feitos missionários dos jesuítas (Figura 66).

Pozzo teria declarado que a narrativa por ele criada se derivava do evangelho de Lucas, 12:49: "Eu vim para lançar fogo sobre a terra e bem quisera já estivesse a arder". (BAROQUE, 2009) No afresco, a luz emana de Deus Pai, em direção ao Cristo, que a lança para Santo Inácio. Esse, por sua vez, projeta a luz divina para todos os cantos da Terra, representados pelos quatro continentes, numa alusão à ideologia jesuíta. Do ponto de vista filosófico, a obra empregou a compreensão da luz como instrumento para difundir a fé católica, como fonte de conhecimento. A aparente complexidade cênico-visual da imagem criada por Andrea Pozzo, apresentando imensa profundidade numa superfície plana, encontra unidade na contribuição da luz, elaborando visualmente o pensamento político-religioso que fundamenta a narrativa.

Aqui também a pintura deixou impulsos para a visualidade da cena, não somente no teatro, mas também, posteriormente, no cinema. O manual escrito por Pozzo deixou exemplos de procedimentos largamente utilizados por cenógrafos e mestres em efeitos especiais, desde aquele momento até os nossos dias. Waldemar Januszczak, já citado, tece um comentário onde dá conta que Cecil B. de Mille (1881-1959) teria consultado a obra de Andrea Pozzo durante a elaboração dos seus filmes bíblicos. (BAROQUE, 2009)

A interação entre estudos teóricos, a pintura, a arquitetura, a ilusão e a cena, alcança em Pozzo um ponto que se reproduziria por toda a história do espetáculo e, já no Barroco, provocava exclamações de espanto dos espectadores e o interesse de especialistas. Em meio a tal efervescência visual, a cena barroca incorporou ensinamentos da técnica renascentista, como registrado por Sabbattini e Furttenbach. Certos aspectos, no entanto, merecem destaque na sua condição de elementos introduzidos pelo teatro do século XVII. Em primeiro lugar, a nova tipologia espacial do teatro exige modos diferentes de elaboração e ocupação do espaço cênico. A disposição preponderantemente horizontal do modelo renascentista modifica-se, ao ganhar o incremento da profundidade do palco, apontando inclusive para uma 
nova atitude do ator (ou do performer). Além disso, o tratamento desse novo espaço de acentuada profundidade encaminha uma nova estética cenográfica, em parceria com a perspectiva e, inevitavelmente, com a luz.

\section{TEATRO NO BARROCO E TIPOLOGIA ESPACIAL}

De acordo com Gösta M. Bergman (1977), o modelo do espaço teatral barroco apresentava casas de espetáculo nas quais a profundidade da caixa cênica chegava a representar uma dimensão três vezes maior que a sua largura, incluindo os bastidores. Ele compara o teatro italiano do período com aquele que se praticava na França, e comenta a atitude francesa na qual os eventos teatrais funcionavam também como um meio de relações sociais, incluindo conversas e sedução. O espectador ia ao teatro não somente para ver, mas também para ser visto. Tanto a Opéra, em Paris, quanto a Comédie Française serviam como um grande salão para abrigar festividades nas quais os membros da plateia se comunicavam efusivamente, inclusive em camarotes abertos. Segundo Bergman (1977, p. 89, tradução nossa), foi estabelecido na Itália um comportamento diferenciado:

Aqui se encontrava a vitória de um novo princípio óptico com uma nova espécie de edifício teatral: a imensa plateia com suas fileiras uniformes de camarotes, uma sobre a outra, imersa numa misteriosa escuridão ou semiescuridão, sendo a luz concentrada no palco. Essa diferença da luz era a marca de excelência dos teatros italianos, durante os séculos XVIII e XIX. ${ }^{16}$

Na França, desde o final do século XVI, a corte realizava deslumbrantes espetáculos de balé, no Petit Palais Bourbon. A tecnologia vista na Renascença italiana podia ser também encontrada em Paris, no mesmo período. O grande salão que recebeu o Ballet comique de la reine, em 1581, foi inteiramente iluminado para revelar o brilho dos cenários e figurinos e celebrar o rei em toda a sua glória e poder.

Desafortunadamente, os documentos que se referem aos espetáculos de balé na corte francesa não contêm detalhes sobre os arranjos da luz. Em espaços usados para festividades, o padrão era estabelecido na necessidade de iluminar todo o ambiente. Sabe-se que na grande Salle du Louvre, durante o Ballet du duc Vendome,

16 "Here is to be found the victory of the optical principle with a new type of theatre building, the box and circle theatre: the huge auditorium with its huge tiers of boxes, one above other, lay in a mysterious darkness or semi-darkness, the light being concentrated exclusively on stage. This differentiation of the light was to be the hallmark of the public Italian theatres during the 18th and 19th centuries too." 
em 1610, 1600 candelabros e tochas transformaram o espaço teatral numa orgia de luz. Tal aplicação da luz diverge da proposição cênica que a antecede na Itália.

O correspondente do Mercure galant,${ }^{17}$ Chassebras de Cramailles (dados biográficos não identificados), destacou o Teatro San Giovanni Grisostomo como o maior e o mais belo de Veneza naquele momento e comentou que uma hora antes do início do espetáculo uma pintura de Vênus era deslocada no teto (plafond), e, por uma grande abertura, descia um candelabro que media aproximadamente quatro metros de altura, iluminando a plateia e sendo levantado momentos antes do início da performance.

A cena era construída em perspectiva num espaço seletivamente iluminado que alcançava desde 30 e 40 quarenta metros de profundidade. Bergman (1977, p. 99, tradução nossa) pondera: "O sistema normalizado de luz, com aparatos dispostos acima do espaço cênico e nas laterais, codificados por Sabbattini e Furttenbach, pode muito bem ter sido adaptado para o palco barroco, cada vez mais profundo". ${ }^{18}$ A mobilidade promovida pelos sistemas instalados sob o palco para as mudanças de cenários, assim como os intricados elementos aéreos como nuvens repletas de personagens, um céu que se abria e fechava - representavam uma convenção na qual a luz desempenhava papel decisivo. Tal apelo ao movimento sugere parceria com a luz, acentuando-se a aplicação de brilhos e transparências.

Contando com ilustrações relativas ao trabalho de Giacomo Torelli (16081678) e projetando a repercussão de trabalhos como os de Serlio, Sabbattinni e Furttenbach, pode-se imaginar a provocação exercida pelas proposições visuais do Barroco sobre artistas responsáveis pela visualidade da práxis cênica. Bergman (1977) afirma que a grandiosidade presente na obra de Torelli, considerando como exemplo Bellerofonte (Veneza, 1642), será até suplantada, como se pode observar em A Idade do ouro (L'etá dell-oro), balé apresentado em Parma (1690), no Palácio da Virtude: "[...] [um palácio] construído em gigantescas dimensões flutuava sobre a cidade preenchendo grande parte do cenário". ${ }^{19}$ (BERGMAN, 1977, p. 101, tradução nossa)

Enfrentando limites importantes para a produção de luz artificial originada na combustão, através de velas, tochas e lamparinas, os arquitetos e artistas plásticos

\footnotetext{
17 Periódico francês, fundado em 1672 por Donneau de Visé. Inicialmente publicado em intervalos regulares, passou a edições mensais, em 1678.

18 "The normalized lighting system with advanced overhead, under and side light, which had been codified by Furttenbach could very well be adapted to the more and more deepened baroque stage."

19 "[...] built on a gigantic scale, floated above the town filling the greater part of the set."
} 
que se aventuravam na empreitada de revelar a cena lidavam com a dificuldade de controle sobre tais fontes. De todo modo, os artistas procuravam tirar o maior partido possível das características das fontes de luz artificial e sua relação com os aspectos arquitetônicos dos espaços teatrais, apresentando soluções que impressionavam o público da época. Parece óbvio que definir a dimensão do facho, assim como o direcionamento da luz eram tarefas quase impossíveis, naquela época, quando se compara à tecnologia aplicada aos instrumentos disponíveis, depois do advento da luz a gás e, principalmente, da luz elétrica, dado o enorme progresso tecnológico que resultou em controle e grande precisão.

O teatro do Barroco entendeu visualmente tal limitação e deu respostas diversificadas, acentuando o modelo espetacular de movimento mecânico aplicado à cenografia, incorporando a luz produzida por fontes dispostas longe do alcance do olhar do espectador, adotando o bloqueio da luz através de aparatos cujo princípio já estava presente no dimmer de Serlio, adicionando cor - prática também desenvolvida no Renascimento -, e aplicando a fantasia proporcionada pelos fogos de artifício, já largamente usados nas festividades medievais. Pode-se presumir que variada estratégia foi aplicada para interagir com as técnicas da produção de luz artificial mencionada, cujos avanços significativos tardaram a aparecer.

Ainda assim, as tapadeiras que se moviam, não somente em sentido paralelo à boca de cena, mas também em movimentos diagonais, assim como a aplicação maciça de grandiosos elementos aéreos, representaram mudanças importantes para a visualidade no teatro do século XVII. Incorporavam-se, também, provocações decorrentes das festividades medievais que se encontraram com o desejo de grandeza do pensamento barroco, juntando-se a isso uma incessante busca pelo movimento.

O principal nome mencionado, quando se trata dos passos desbravadores das tendências do barroco, é o de Giacomo Torelli. Pouco se conhece da vida de Torelli, antes da sua notoriedade no teatro. Nascido em Fano, de origem nobre, recebeu provavelmente educação inerente a sua posição social, ainda que não haja registro referente à sua formação no teatro. O jovem Torelli mostrou talento natural para a arquitetura, a pintura e a cenografia, e alguns comentadores até especulam que ele teria sido orientado por Niccola Sabbattini, o que seria plausível, uma vez que a distância entre Fano e Pesaro é de quarenta quilômetros. Em 1637, Torelli projetou cenários para as performances apresentadas entre os atos (intermezzi) da Pastoralle, de Ridolfo Campeggi, onde demonstrou sua habilidade para os projetos de cenotécnica que possibilitaram grande eficiência na mecânica aplicada às mudanças da cena. 
Graças à reputação alcançada na sua cidade natal, Torelli mudou-se para Veneza, aos 33 anos, convidado pela Accademia degli incogniti, uma sociedade de muito prestígio, na qual encontrou seu primo Vincenzo Nolfi. Lá, ele recebeu da academia a incumbência de construir um teatro. Em 27 de janeiro de 1641, Torelli inaugurou o Teatro Novíssimo e assinou a cenografia de A falsa louca (La finta pazza), com música de Francesco Sacrati (1605-1650) e libreto do acadêmico Giulio Strozzi (1583-1652) (Figura 67). Torelli desenvolveu um sistema de mudança de cenários baseado no uso de contrapesos, o que contribuiria para torná-lo famoso em toda a Europa. O Teatro Novíssimo trazia essa inovação: o palco apresentava cortes laterais no piso, em cada coxia, que funcionavam como trilhos ou guias, para tapadeiras que eram movidas lateralmente, revelando novos ambientes, de acordo com cada momento.

As tapadeiras planas foram provavelmente introduzidas por Giovanni Battista Aleotti (1546-1636), como elemento cenográfico no qual se pintavam partes do cenário de um espetáculo e, dispondo de várias tapadeiras, uma atrás da outra, estabelecia-se a possibilidade de mudanças rápidas e diversificadas na cenografia. Tal solução se transformaria num passo decisivo para a operação dos cenários simétricos, aplicando a perspectiva com um ponto de fuga ao centro da imagem, modelo aplicado naquele período, ainda que apresentasse a desvantagem de exigir um maquinista para cada unidade do sistema a ser operada. Desafortunadamente, para a história do teatro, o Novíssimo foi atingido pelos resultados econômicos da guerra turca, e nunca mais reaberto depois de 1647.

Apesar do breve período de operação, contudo, ele ficou reconhecido como o único teatro de Veneza, na época, que incorporava paralelos com as salas de Bolonha e Florença. Além disso, sua iniciativa de entretenimento principesco, sem a exigência de resultados financeiros, em primeiro plano certamente contribuiu para a experimentação desenvolvida por Giacomo Torelli, suscitando novos padrões de magnificência para a ópera. As soluções técnicas implantadas por Torelli permitiam movimentação simultânea de conjuntos de tapadeiras, operando a mudança total no cenário, de modo rápido e sincronizado (Figura 68). O sistema espalhou-se pelos teatros de toda a Europa, fazendo Torelli ficar conhecido como "mago da cena". (KIMBLE, 1995, p. 115) É plausível reconhecer o importante papel desempenhado pela luz para revelar essa qualidade mágica.

Alguns especulavam que ele havia acordado um pacto com o demônio. A documentação acerca de sua obra, incluindo a iconografia por ele produzida, não revela de modo específico as relações com a luz. No entanto, considerando as características do novo palco barroco, às quais estava associada a grandiosidade dos cená- 
rios de Torelli, é possível indicar um significativo grau de relações dessa natureza. Algumas gravuras do período retratam espetáculos como Bellerofonte (1642), libreto de Vincenzo Nolfi; La venere gelosa (1643), libreto de Niccolo Enea Bartolini, Deidamia, de Scipione Herrico, no Teatro SS, Giovanni e Paolo, além de Ulisse errante, de Giacomo Badoaro, em (1644). Ainda que as gravuras não representem exatamente a maneira como as cenas aconteceram, principalmente do ponto de vista das cores, elas sugerem parcialmente o tratamento visual dos espetáculos citados. O projeto de Torelli para o Teatro della Fortuna, inaugurado na sua cidade natal, em 1667, mostra esquematicamente a disposição simétrica das tapadeiras (Figura 69).

Outro documento do século XVII, que tem papel relevante para a compreensão técnica dos espetáculos da época, é o diário de viagens escrito por Nicodemus Tessin, o jovem (1654-1728). ${ }^{20}$ Elaborado entre 1687 e 1688 , o texto inclui no segundo volume relatos acompanhados de desenhos acerca do aparato cênico que Tessin teria encontrado em Veneza, registrando impressões de espetáculos e teatros característicos do Barroco. Ainda que tardio, uma vez que se refere ao último terço do século XVII, o seu diário é um raro registro de aspectos da luz aplicada naqueles teatros, devido à raridade das informações sobre o assunto.

A mais recente publicação dos mencionados diários foi editada por Merit Lane e Börge Magnusson, em 2002, sob a responsabilidade do National Museum de Estocolmo; Trata-se de um livro raro que deveria estar à disposição em instituições que, interessadas efetivamente na práxis cênica, incluam a compreensão da sua natureza visual como objeto da pesquisa teatral qualificada. As observações sobre os diários de Tessin, aqui apresentadas, baseiam-se nos comentários e citações do estudioso Gösta Mauritz Bergman (1977). É possível identificar nos relatos de Tessin a aplicação de padrões já demonstrados por Sabbattini e Furttenbach. Ele indica, contudo, novos elementos incorporados à contribuição da luz para cena.

Além dessas anotações, Tessin deixou 31 desenhos, que se referem às óperas Germanico sul Reno e Adone, espetáculos que ele assistiu em 1676, no Teatro di San Luca ou di San Salvador. Seu texto inclui observações acerca do maior teatro de Veneza no período, o San Giovanni Grisostomo. ${ }^{21}$ que inaugurado em 1678, apre-

\footnotetext{
20 Nicodemus Tessin, o jovem - homônimo do seu pai, Nicodemus Tessin, o velho (1615-1681) - era um arquiteto sueco que estudou em Roma e Paris, na segunda metade do século XVII. Nesse período ele visitou Veneza e registrou observações em diários de viagens. Tessin, o filho, ocupou o lugar de seu pai, como arquiteto da cidade de Estocolmo. O principal projeto a ele atribuído é a reconstrução do Palácio Real da capital sueca, destruído pelo fogo em 1697.

21 O espaço destinado à cena media 32,5 metros de profundidade, incluindo um proscênio, cuja extensão, desde a ribalta até a cortina, tinha 4,2 metros, configurando o até hoje reconhecido "palco italiano", com um proscênio projetado entre a plateia e a caixa cênica.
} 
sentava importante tratamento, não somente da cenotécnica, mas também dos instrumentos, suportes e acessórios aplicados à luz para a cena.

Os comentários de Bergman (1977) dão conta de três principais aspectos nos sistemas encontrados por Tessin:

I. varas verticais cilíndricas de madeira, afixadas no fosso, que apresentavam suportes para luzes em diferentes distâncias do piso do palco e podiam girar no próprio eixo, permitindo que o palco fosse iluminado ou escurecido; esses suportes eram constituídos de elementos com três lados, provavelmente aplicando algum processo de reflexão, permitindo emissão da luz na direção desejada e bloqueio na face que se desejava escurecer;

2. uma espécie de vara horizontal, disposta atrás de elementos cenográficos aéreos, na qual podiam ser instaladas espécies de arandelas cujo mecanismo permitia que elas fossem giradas para também prover controle para a luz emitida emdireção ao palco. Nota-se que as luzes dispostas acima do palco eram limitadas, o que Tessin sublinha como medida de segurança contra o alto risco de incêndio, uma vez que, devido aos mencionados elementos aéreos da cenografia, a região acima do palco já era substancialmente ocupada, exigindo muito cuidado;

3. outro importante dado a ser levado em consideração é a aplicação da transparência para efeitos como o sol, a lua, estrelas e janelas, com um papel sobre o qual se aplicava algum tipo de óleo. Tais efeitos incluíam o uso do vidro, cujo brilho fascinava o espectador da época.

Um depoimento do próprio Nicodemus Tessin, a respeito de uma mudança de ambiente e atmosfera, que ele testemunhou no Teatro di San Giovanni Grisostomo, demonstra o papel da luz na práxis teatral do Barroco: "[...] como uma sala completamente iluminada e sedutora se converteu numa medonha caverna, o que foi completamente maravilhoso devido à extrema diferença entre os dois cenários". ${ }^{22}$ (TESSIN apud BERGMAN, 1977, p. 97, tradução nossa) Vale sublinhar que tais movimentos no ambiente e na atmosfera eram realizados à vista do público, ou seja, com a cortina levantada.

Tal momento reafirma a compreensão que o artista envolvido com a cena desenvolveu, com um agudo sentido de interação entre a cena e a luz. Os movimentos executados dentro do espaço de um espetáculo, à vista do espectador,

22 "[...] how the quite illuminated enchanted room was converted into a terrible cave, which was quite wonderful because of the the extremes of the two such different sets." 
assim como a organização do libreto, incorporavam inúmeras possibilidades de interação com a luz artificial. No teatro do Barroco, portanto, a assertiva visual residia também no fascínio produzido pelas mudanças espetaculares que ocorriam diante do olhar do espectador.

\section{A CENA SOB OUTROS PONTOS DE VISTA}

Já em 1687, em Piacenza, quando Tessin começa a escrever seus diários sobre o teatro veneziano, apareceu uma mudança muito importante na abordagem visual do teatro. A gravura que representa a cenografia elaborada por Ferdinando (Bibiena) Galli (1657-1743), para a ópera Didio Giuliano (1687), de Bernardo Sabadini (ou Sabatini) na qual ele introduziu uma maneira inovadora de conceber a cena, através de uma mudança relativamente simples, o novo posicionamento do ponto de fuga (Figura 70). Agora deslocados do centro e localizados fora da imagem mostrada no palco, os novos pontos de fuga estabeleciam ângulos que revelavam a cena numa disposição dinâmica, por vezes assimétrica, conjugando-se ao princípio barroco de movimento. Tal tratamento da perspectiva seria denominado de "cena em ângulo" (scena per angolo), pelo próprio Ferdinando Bibiena, nos seus livros, A Arquitetura preparada com o uso da geometria e reduzida em perspectiva (L'Architettura civile preparata su la geometria e ridotta alle prospettive), publicado em 1711, e Orientações para os jovens (Direzioni ai Giovani), em 1731 (Figura 71). A história da ópera registra o apelo dessa inovação, resultando em grande atenção para os cenários. Os ensinamentos deixados por Brunelleschi, Alberti, Torelli e Pozzo, como exemplos, produziram frutos no trabalho da família Galli, inaugurando em Ferdinando uma trajetória que duraria aproximadamente um século, entre 1687 e 1780 .

A jornada inicia-se quando Giovanni Maria Galli [(1625-1665), pai de Ferdinando] demonstra talento e vontade de se tornar pintor, sendo enviado pelo seu pai - então governante da fortaleza toscana de Bibiena -, para estudar no atelier do pintor Francesco Albani (1578-1660), em Bologna. Ainda que sua família fosse de origem florentina, ao começar suas atividades com Albani e constatar que havia outro aprendiz com o nome idêntico ao seu, ele atendeu a um costume italiano e incorporou Bibiena como sobrenome, provavelmente respondendo à notoriedade que sua família lá alcançou. Outros estudiosos aceitam que ele tenha passado a ser conhecido assim, simplesmente por que Bibiena era o local do seu nascimento. 
Ao morrer, em 1664, Giovanni deixa o filho Ferdinando com sete anos de idade, que seria criado por um pupilo seu, Carlo Cignani (1628-1719), considerado depois o último grande pintor bolonhês. Ferdinando estudou arquitetura com a geração que sucedeu grandes construtores do Barroco. Além disso, trabalhou em colaboração com o famoso cenotécnico Ercole Rivani (?-1689), alcançando depois grande notoriedade na arquitetura teatral e na cenografia. Em 1708, em Barcelona, após supervisionar as festividades do casamento de Carlos III da Espanha ele se tornou o principal arquiteto e pintor, trabalhando sob os auspícios do rei. Quando Carlos III transferiu-se para Viena, em 1711, onde foi coroado Carlos VI rei da Boemia, convidou Ferdinando Bibiena que, aceitando, juntou-se ao irmão Francesco, já estabelecido na corte vienense. No ano 1702, Francesco Bibiena concebeu e supervisionou as festividades da recepção de Felipe V da Espanha, como rei das Duas Sicílias e de Maria Theresa de Hapsburg, como sua rainha. Chamado a Viena, pelo imperador germânico Leopold I, Francesco projetou o Teatro Nuovo, em 1704. Ele teria projetado ainda outros teatros, em Nancy, Roma e Verona que, infelizmente, desapareceram.

Ferdinando levou mais tarde para Viena seus filhos, Alessandro, de 24 anos de idade, e Giuseppe (1696-1756), nove anos mais jovem. Juntos criaram inúmeros dispositivos cenográficos provisórios para as celebrações da nobreza, durante toda uma geração, e essa associação gerou um enorme conjunto de aproximadamente duas centenas de desenhos, ainda que a maioria tenha sido perdida. Muitos dentre os projetos, desenhos e esboços - assinados por Ferdinando ou pelo seu filho Giuseppe - foram reproduzidos no período, em água forte e gravura. As atividades da família Bibiena geraram uma empresa que recebia encomendas para teatros em diversas cortes europeias, assim como cenários e decoração de festividades. Era um empreendimento multinacional; há documentos que registram a presença dos Bibiena em capitais como Berlim, Hamburgo, Paris, Madri, São Petersburgo e Viena, dentre outras (Figura 72).

O trabalho dos Bibiena pode ser comparado com o da empresa dos irmãos Brückner, Max e Gotthold, que trabalharam com a Companhia de Georg II, o Duque de Sax-Meiningen, no século XIX, também fornecendo planejamento e execução de cenários por toda a Europa. A empresa dos Brückner trabalhou inclusive para Richard Wagner (1813-1883), no Teatro Bayreuth, projetando e executando os cenários que Adolphe Appia consideraria esteticamente obsoletos. Os cenários dos Brückner são periodicamente expostos e revelam a qualidade, sem precedentes, do estilo romântico de bases realistas. 
Na maneira de tratar visualmente a cena, introduzida por Ferdinando Bibiena, é importante sublinhar o citado deslocamento dos pontos de fuga do centro da imagem e as consequentes diagonais, acentuando a obliquidade do ambiente, o que incorporou virtual expansão ao espaço da cena, que se projetava para "fora do palco". O ambiente da ação parecia romper as fronteiras da boca de cena e dos bastidores, provocando o espectador a imaginar uma dimensão dilatada. A busca de uma síntese eloquente que buscava mixar o espaço da natureza com a materialidade geométrica do espaço construído pelo homem (as construções arquitetônicas), radicalizava-se através de uma intervenção na ordem inicial renascentista que impunha uma espécie de centralidade imutável associada à simetria promovida pelo ponto de fuga único.

Pode-se, até certo ponto, considerar uma espécie de antiepifania perspectivista: o espaço da cena já não se oferece integralmente ao espectador, que apreende sua provável extensão através de um fragmento irregular, assimétrico, implantado na cena. Por outro lado, esse grau de desconhecimento do todo é, por assim dizer, relativizado: assimilando o padrão arquitetônico em questão ele pode operar associações, interpretando a composição e construindo em imagens mentais uma sucessiva busca da totalidade. Os vários pontos de fuga introduzidos pela scena per angolo através de perspectivas múltiplas elaboravam uma disposição que parecia "sugar" o espectador, colocando-o no interior de um espaço cênico com nova dinâmica uma vez que seus limites eram projetados para fora dos limites do palco.

É possível apreender um discurso visual em operação; a proposição de Brunelleschi ainda sobrevivia, pois, na contemplação do espaço de Deus agora geometrizado numa entidade pensada e quantificada pelo artista-cientista-filósofo, o observador aceitava instalar-se numa relação matemática que o dispunha em um lugar ideal precisamente calculado, integrando ponto de fuga e linha do horizonte para efetivar a representação bidimensional da realidade (tridimensional). Trata-se de uma equação visual impregnada pelo pensamento filosófico em ebulição. Na proposição da scena per angolo, ao implodir limites físicos do edifício teatral sobrepujando a moldura da boca de cena, o espaço artificializado abraça o ser humano representado pelo observador e o integra em um todo inacabado, "infinito".

Pouco se pode dizer da práxis cênica propriamente dita, no que se refere à aplicação objetiva dos desenhos dos Bibiena no espetáculo do Barroco e, consequentemente das relações com a luz. É possível, contudo, inferir que os procedimentos disseminados pela Itália, e descritos por Tessin, tenham sido aplicados pela família Bibiena. A incorporação da luz aos eventos podia parecer um movimento 
esperado, a ponto de ser dispensável sua abordagem teórica, mesmo no campo da descrição. Havia o flagrante interesse pela crescente parceria entre a arquitetura, inclusive como componente do real construído pelo ser humano, e o teatro que, por sua vez, se interessava em ampliar a compreensão da vida questionando sua representação limitada pelo interior de um espaço arquitetônico fechado que a enclausurava.

Um cenógrafo-arquiteto-pintor do Barroco poderia ser capaz de projetar um espaço cênico capaz de se estender e abraçar o espectador, integrando-o ao ambiente e, portanto, até destruindo os limites da realidade objetivamente construída pelo ser humano. A incapacidade da luz de convencer o espectador de que o revelado no palco representa a realidade, ou é uma extensão da realidade objetiva que ele constrói no cotidiano, instala, contudo, certas crises nessa relação.

Em correspondência efetivada durante os anos 1738-1739, o francês Charles de Brosses, ${ }^{23}$ (1709-1777) compara os teatros da Itália com aqueles que via no seu país, considerando a eficácia italiana. Tal julgamento parece conter certo exagero, tanto quanto o daqueles que rotulam a scena per angolo apenas como um desejo de virtuosismo dos arquitetos e tentativa de incorporar certa variação nos seus projetos, uma vez que se tratava de estéticas com origens e objetivos diferenciados. Aliás, pareceria equívoco qualificar negativamente a proposta de variar a abordagem visual num projeto para a cena. Charles de Brosses dá testemunho da resposta que essa espécie de cenografia provocava no público:

É realmente uma sacada, uma floresta, um lugar no campo, uma choupana, um calabouço etc. Ao invés de dispor os elementos cenográficos de modo uniforme em duas ranhuras na coxia, como fazemos [na França], eles os distribuem por todo o palco, sejam pilares ou sacadas, eles os colocam de modo oblíquo, em várias diagonais, o que amplia o efeito de perspectiva. [...]: se deve ser um pequeno ambiente eles reduzem o palco e bloqueiam tão bem todas as laterais que se pode dizer que estamos numa caverna, numa tenda, ou sob uma abóboda. ${ }^{24}$ (DE BROSSES apud BERGMAN, 1977, p. 113, tradução nossa)

23 Charles-Nicolas Cochin, o Jovem, conde de Tournai e de Montfalcon, autor, cuja obra mais reconhecida é Cartas familiares sobre a Itália (Lettres familières sur l'Italie), publicada postumamente em 1799, depois de larga circulação em manuscrito.

24 "It is really a gallery, a forest, a camp, a shed, a room, a dungeon, etc. Instead of placing uniformally, as we do, the décor-elements in the two wing alleys, they distribute them all over the stage, whether they are colonnades or galleries, they place them obliquely on several diagonal lines, which increase the effect of perspective [...] if there should be a small room, they limit the stage and close it so well from all sides that one may say that one is in a cavern, in a tent or under a vault." 
O interessado na visualidade da práxis cênica deve usar de cautela na observação de depoimentos dessa natureza. O espectador, e até mesmo o artista envolvido com a cena tende a reagir efusivamente aos "efeitos,", a tudo o que especialmente surpreende sua visão, como algo que o projeta para fora de experiências cotidianas, no sentido de impulsionar a fantasia. O iluminador da atualidade pode evitar render-se ao senso comum ou pode transformar seus projetos em sucessões de efeitos que reduziriam a proposição estética de um espetáculo à superficialidade que até mesmo certos artistas parecem desejar quando clamam pelo movimento sem justificativa, pela cor sem propósito, e assim por diante.

No depoimento de Charles de Brosses, a perspectiva é destacada como responsável por estabelecer uma visão daquilo que pretende o cenógrafo, um efeito capaz de convencer o espectador de que ele está diante de um fragmento do seu próprio cotidiano. O seu relato deixou, contudo, um dado muito importante para a apreensão da estética buscada na scena per angolo. Quando dizia que os elementos cenográficos eram distribuídos em sentido oblíquo no palco ele poderia estar questionando a proposição cenográfica que considerava apenas a disposição de telões paralelos à boca de cena, nos quais a obliquidade era exclusivamente pintada.

Deve-se considerar a dificuldade em definir soluções técnicas que não apresentem desvantagens. No caso específico do modo elaborado pelos Bibiena, de acordo com depoimentos da época, a mudança de cenários durante os espetáculos era operada com visível dificuldade, gerando certa confusão no palco. Bergman (1977) menciona os comentários, no diário do arquiteto sueco Erik Palmstedt, referindo-se a observações sobre o teatro, em viagens à Itália:

Não há nenhuma máquina em nenhum desses teatros, de modo que as tapadeiras são movidas manualmente, uma a uma, e a mudança é executada enquanto a cena acontece. Não é agradável ver os maquinistas carregando peças de cenários e velas no palco, enquanto os atores estão representando. ${ }^{25}$ (PALMSTEDT apud BERGMAN, 1977, p. 116, tradução nossa)

Pode-se considerar aí um conflito entre a técnica cenográfica e a práxis barroca, na qual mudanças no dispositivo cenográfico eram processadas sob o olhar extasiado do espectador. Ainda que se possa desconfiar da total ausência de sistemas mecânicos para a mudança de cenários, naquele momento, na Itália, cabe considerar o testemunho de Palmstead, no que se refere à estranheza causada

25 "There are no machines at any of these theatres, so the wings are pulled out manually, one by one, and the change is going on all through that scene. It is not agreeable to see the stage hands carrying candles and pieces of decorations across the stage while the actors are engaged in reciting." 
por essas mudanças, que competiam com a performance, om os atores. Acentue-se o trânsito dos maquinistas, portando velas e cruzando o palco: aos olhos daqueles que se acostumaram às entradas e saídas de tapadeiras e elementos aéreos, como num passe de mágica - com a luz fora do alcance da visão - isso deveria gerar um enorme ruído. A necessidade de velas para iluminar o trajeto dos técnicos, revelando a mecânica das mudanças e sublinhando o palco, em detrimento do lugar da ação, podia gerar, como no caso em questão, reação negativa do público.

Bergman destacou as ilustrações do período para afirmar que a luz nelas representada não tem, necessariamente, relação com a luz da cena. Segundo ele, o brilho que se via ao nível do palco e a sua relação com as sombras pintadas, dificilmente corresponderia ao que era mostrado em cena, uma vez que, para isso, seria exigida uma disposição radicalmente assimétrica dos instrumentos de luz aplicados. Por outro lado, Bergman (1977) pondera que os teatros não contavam com um conjunto de superfícies refletoras capazes de produzir tal resultado. As casas de espetáculo do período, de acordo com a documentação disponível, contavam com sistemas conhecidos, ou seja: ribalta, luzes nas coxias, possíveis varas e alguns elementos móveis.

Os desenhos que sobreviveram não documentam particularmente a organização da luz. Em setembro de 1764, durante os trabalhos para a ópera Temístocles (Temistocle), em Stuttgart, o pintor de cenários Colomba revelou dificuldade para realizar seu trabalho, em carta destinada ao gerente Jacob Bühler: "[...] não fiz um desenho para a primeira cena por que preciso antes descobrir como as varas de luz podem ser alteradas de maneira que eu possa fazer um conjunto cenográfico inteiramente com peças irregulares".. ${ }^{26}$ (COLOMBA apud BERGMAN, 1977, p. 116, tradução nossa)

Ainda que elementos cenográficos irregulares oferecessem muitas possibilidades, eles exigiam soluções inventivas e flexíveis: antes de definir um detalhe cenográfico, seria necessário planejar a atuação da luz já que, sem tal planejamento, o espaço da cena seria invisível. Isso vale para qualquer que seja a práxis cênica. Importante notar que as variáveis de um espetáculo que interagem com a luz são diversificadas. Por vezes, ao se tratar da cenografia, do figurino, da maquiagem, da dramaturgia, do ator, desconsidera-se ingenuamente a luz, como se fosse possível discutir a presença na cena de qualquer um dos seus aspectos (a imagem cênica) sem a contribuição da luz.

26 "[...] have not made a sketch for the first scene since I want to find out first whether light rods [varas] can be altered so that I can make an entirely irregular set of scenery." 
Seria proveitoso, portanto, ampliar os horizontes da crítica e trabalhar com a compreensão da cena como um conjunto de aspectos conectados transversalmente, o que inclui (ou tem como traço de união) a luz. Pode ser difícil para o neófito perceber que qualquer mudança em um dos mencionados aspectos com a intenção de propor caminhos diferenciados para a práxis cênica, interage organicamente com a luz. E até mesmo quando um teórico se refere a qualquer um dos elementos da cena - ou grupo de elementos - ele estará assumindo a presença da luz, a imagem. Mesmo que não se dê conta. 


\title{
ROTAS FRANCESAS PARA O TEATRO MODERNO
}

\begin{abstract}
Alguns comentários parecem assumir que o fim do Renascimento resultou em uma espécie de esgotamento da vitalidade do teatro italiano, acreditando que a influência da Itália em questões teatrais se estendeu, quando muito, até o Barroco. É importante, no entanto, enfatizar que o legado da arte italiana gerou enormes impulsos para o teatro de toda a Europa, mesmo além dos limites cronológicos do Barroco. A práxis cênica europeia foi sucessivamente impactada por ideias originadas na Itália, e os ecos de tal impacto no conhecimento teatral podem ser observados na influência demonstrada, mais tarde, pelo teatro da França, que será abordado no presente capítulo.

Determinados aspectos configuram tal influência e devem ser listados: o desenvolvimento renascentista da perspectiva, representando mais que um aspecto técnico e, sim, o estabelecimento de uma nova maneira de ver o cotidiano, sublinhando suas verdadeiras proporções através da interpretação geométrica. Ficava comprovado: o rei tinha estatura humana, a
\end{abstract}


majestade era imposta e instalada na imaginação do súdito. A perspectiva provocou uma abordagem revolucionária do mundo, subvertendo o sistema filosófico da época. A visão perspectivista questionava a filosofia do poder, cujo exercício não era mais outorgado por Deus e, sim, uma manipulação política. A sociologia e a ciência política do poder começavam a ser instituídas, como se pôde ver no espelho negativo do príncipe interpretado por Maquiavel. O palco tornou-se um espaço calculável e o teatro passou a caracterizar-se como um domínio da física, da matemática e da mecânica, na dinâmica dos mecanismos do palco, das suas partes e elementos, na sistematização e consequente eficiência da tecnologia teatral. O processo foi documentado no trabalho de Sabbatini, já comentado.

Por outro lado, na França absolutista de Louis XIV, ator, dançarino e Rei-Sol, o lugar privilegiado do monarca como figura central para quem o espetáculo é dirigido, teve repercussão importante. Do teatro frances da época, desde o final do século XVI até o final do século XVII, derivou um conjunto de traços teórico-estéticos que contribuíram em grande escala para o teatro moderno, de fundamento realista. O processo gerou uma espécie de virada na contribuição da luz para a cena incorporando também compromissos entre a cena e a visualidade, delineados no Barroco. Desenvolve-se nessa época a institucionalização das viagens pela Itália, como parte da educação de artesãos e artistas. Alguns nomes, como Albert Dürer (1471-1528) e Hans Holbein (ca. 1497-1543), podem ser citados como pioneiros nesse contexto. Agigantando seu acervo de pintura, escultura e arquitetura a Itália funcionou como um museu didático para gerações da inteligência europeia. As viagens dos artistas da época geraram enorme troca de experiências com grande repercussão na visualidade da arte francesa e, por conseguinte, na cultura da França, como um todo.

A inclusão do teatro francês nas presentes argumentações é motivada pelo desafio de compreender a assertiva visual do período particularmente estudado, uma vez que sua primeira parte, nos séculos XVI e XVII, apresenta visualidades particulares e diversificadas, mas com excassa documentação acerca da contribuição da luz. Entretanto, os raros documentos citados atestarão que, com olhar atento, é possível observar a presença de tal contribuição.

A rainha Catarina de Médici, mãe de Henri III de Valois, desejando ver também na França o brilho do entretenimento que havia conhecido da Itália decidiu, entre outras atitudes, levar para seu país o artista italiano Baldassare de Belgiojoso [que ficou conhecido como Balthasar de Beaujoyeulx (também grafado Beaujoyeulx, ca. 1535-1587)], violinista, compositor e coreógrafo. Trabalhando em Paris na função de principal músico da corte, Beaujoyeulx foi o responsável pelo arranjo 
cênico das festividades de casamento do Duque de Joyeuse, com Margueritte de Vaudemont, em 1581. Ele fez um espetáculo que alguns chamam de extravaganza, ${ }^{1}$ em um evento de mais de cinco horas, o Balé da rainha (Ballet comique de la reine) apresentado na Grande salle du Petit Bourbon, no Louvre, num encaminhamento francês de uma expressão artística que já havia mostrado suas feições também na Itália (Figura 73).

Bergman menciona a organização cênica do espetáculo, destacando a luminosidade distribuída pelos cenários simultâneos que instalavam diversos ambientes em um mesmo espaço cênico repleto de brilhos e transparências: o interior de um palácio, cujo trono cintilava recoberto com pedras preciosas; um bosque onde as árvores eram constituídas por muitas lamparinas a óleo; uma caverna escura parcialmente escondida, pois diante dela era disposto um tecido transparente através do qual brilhavam diamantes. Por toda a cena proliferavam o dourado, o prateado e a policromia, indicando a imperativa presença da luz na revelação de magia e grandiosidade. (BERGMAN, 1977) Ele cita o próprio Beaujoyeulx, para descrever os jardins de Circe:

[...] e o mais belo na abóboda, é que ela estava cheia de orifícios redondos com vidros de todas as cores: atrás desses vidros, brilhavam lamparinas a óleo lançando sobre o jardim centenas de milhares de cores, através da transparência do vidro. ${ }^{2}$ (BEAUJOYEULX apud BERGMAN, 1977, p. 398, tradução nossa)

A repercussão foi tamanha que suplantou outros balés antes apresentados na corte francesa - como A defesa do Paraíso (La defense du paradis), em 1572 e o Balé dos poloneses (Ballet des polonais), no ano seguinte - sendo frequentemente mencionado como o marco inicial na história do Balé. O teatro francês dos séculos XVI e XVII apresentou organizações da cena que podem atuar como índices importantes para o estudioso das suas relações com a imagem e provocam reflexões acerca da presença da luz na origem dos espetáculos. A escassez de documentos relevantes sobre o tema, no teatro francês do período, transforma textos como o de Beaujoyeulx em fontes raras e estimuladoras da imaginação. Aquele momento

1 De acordo com a Enciclopédia Britânica on-line, a extravaganza é uma forma literária ou musical fundada em extrema liberdade de estilo, ostentando uma estrutura flexível, que tende a mixar elementos burlescos ou da paródia. Pode também se referir a um evento cênico, de elaborada espetacularidade, e relacionado ao Teatro de Variedades do século XVIII. (EXTRAVAGANZA, [201-])

2 “[...] et le plus beau de cette voulte paroissoit en ce qu'elle estóis tout percee de trous rond, boucher de vers de toutes sortes de couleurs: derriere ces verres reluisoyent autant les lampes à huile, lesquelles representoyent ou ce jardin cent mille couleurs, par la transparence du verre." 
da cena francesa apresentou particularidades e mudanças que identificavam a natureza do seu discurso visual.

Em primeiro lugar, quando se leva em conta a aplicação da luz, o teatro da corte francesa do período desconsidera qualquer divisão entre o lugar da ação cênica e o espaço destinado ao espectador. O público ia ao teatro para também se colocar no centro da atenção e devia ser visto durante os espetáculos. Não se pode esquecer que, mesmo ocorrendo em locais não concebidos originariamente como teatros, a maioria desses acontecimentos teatrais apresentavam semelhanças nos procedimentos de produção e aplicação da luz artificial.

Ainda assim, nem a relativa uniformidade do uso de velas e lamparinas a óleo, difundido no continente europeu, resultou numa padronização técnico-estética, em decorrência das características tecnológicas dos instrumentos utilizados na iluminação dos ambientes. O trabalho de Anne Surgers fornece sólidos subsídios para essa discussão quando ela comenta os arranjos sistemáticos da práxis cênica francesa - desde as últimas décadas do século XVI -, destacando certas proposições espetaculares. Sua abordagem dos diferentes modos de conceber a cenografia revela possibilidades diferenciadas de espetáculos, e sugere uma incorporação importante da luz. Tal observação deve ser sublinhada para afirmar que toda referência ao espetáculo inclui aspectos relevantes da presença da luz, mesmo que artistas e/ou teóricos a desconsiderem, ou decidam omitir suas funções. Para que se registre a contribuição da luz é indispensável observar indícios deixados nos mais variados documentos.

De acordo com Surgers (2005b), o fim do século XVI indica mudanças importantes no teatro francês, cujos temas já não estão atrelados exclusivamente a instâncias religiosas ou, nas suas próprias palavras: “[A arte] não é mais, portanto, a manifestação do Verbo [que se fez carne], como na Idade Média, e torna-se a representação de uma ficção mais ou menos relacionada, ou que se refere ao real, ou à verdade [...]".3 (SURGERS, 2005b, p. 115, grifo do autor e tradução nossa) Se for considerada a extravaganza levada à cena por Beaujoyeulx no Grande salle du Petit Bourbon do Louvre, pode-se ainda observar um arranjo cênico constituído de múltiplos espaços que se manterá no teatro francês, registrando certa ressonância tardia do teatro medieval. Muitos espetáculos exigiam visualidade particular que abrigasse na cena a ficção que tem como referente o real, como diz Surgers (2005b).

Um dos principais trabalhos teóricos daquele momento, editado sob orientação oficial francesa, foi escrito por François Hédelin (1604-1676), abade de Mainac

3 "Il ne sert plus dès lors à la manifestation du Verbe comme au Moyen Âge, et devient la représentation d'une fiction en rapport de conformité ou de ressemblance plus ou moins directes avec le réel, ou le vrai, [...]." 
e Aubignac - razão que o tornou conhecido como L'Abeé D'Aubignac -, dramaturgo e teórico. É possível destacar nessa obra elementos que podem coadjuvar na compreensão do caráter visual do teatro da época. D’Aubignac (1715) faz comentários abrangentes, inclusive sobre os atores, dos quais exige formação apropriada, tanto estudando, quanto praticando com artistas de reputação positiva comprovada, discutindo também o papel dos cenógrafos, o comportamento do público e até a arquitetura teatral:

Acrescente-se que [nos teatros da Antiguidade, Grécia e Roma] os assentos dos espectadores eram bem organizados, de modo que ninguém poderia causar desordem mudando de lugar. Hoje, as galerias e a plateia são muito incômodas e a maioria dos camarotes está muito distante [do palco] e malsituada, e a plateia não apresenta nenhuma elevação e nenhum assento [...]. ${ }^{4}$ (D’AUBIGNAC, 1715, p. 353, tradução nossa)

Aqui se observa o registro de aspectos importantes para as condições de visibilidade nos teatros do período, derivados de espaços retangulares, ou seja: a plateia encontrava-se ao nível do solo, sem assentos ou qualquer inclinação que favorecesse a visibilidade da cena; a disposição dos camarotes, instalados nas laterais e acima da plateia, estabelecia progressiva dificuldade para que os espectadores localizados nos camarotes laterais tivessem efetivo acesso visual ao espetáculo. Ali acomodados, eles teriam diante de si, precisamente, outros espectadores dispostos nos camarotes do lado oposto. Trata-se de um dado relevante para a compreensão da convicção que se tinha do apelo visual exercido pelo espetáculo e da importância da visualidade para a cena. O arranjo arquitetônico assumia, mesmo de modo ingênuo, uma força visual do espetáculo que o tornava capaz de atrair o olhar do espectador. Vale lembrar que, já no início do século XIX, André Antoine critica (1890) de modo veemente essa organização espacial do teatro, apontando-a como o caminho a ser evitado para criar o que ele denominou de teatro "modelo":

Todos os teatros atuais se compõem de uma plateia ao nível do solo [...] e de uma variável quantidade de estágios superiores. A forma circular, geralmente adotada, condena as duas fileiras de espectadores desses planos superiores a, literalmente e sem nenhum exagero, ser colocados uns diante dos outros. Eles não

\footnotetext{
4 "Ajoutez que les sièges des spectateurs étoient autresfois si bien ordonnez, que chacun étoit placé commodément \& que l'on ne pouvoit faire aucun désordre pour changer de place; au lieu que maintenant les Galléries, \& le Parterre sont très-incommodes, la plupart des loges étant trop éloignées \& mal situées, \& le Parterre n’ayant aucune élévation, ni aucun siège."
} 
podem acompanhar a ação dramática, a menos que girem dolorosamente a cabeça na direção do palco. Se, a rigor, todas as pessoas colocadas na primeira fileira dos balcões podem apreciar os espetáculos sob uma tortura suportável, os ocupantes das três ou quatro fileiras ao fundo são obrigados a ficar de pé, a inclinar-se no vazio para ver uma pequena parte do palco. Podemos mesmo afirmar que, em todos os teatros atuais, nos últimos níveis dos balcões, há toda uma série de lugares de onde não se vê absolutamente nada. ${ }^{5}$ (ANTOINE, 189o, p. 44-45, grifo e tradução nossos)

Ainda hoje é possível encontrar espaços teatrais nos quais a visibilidade é prejudicada e parte do público precisa se esforçar para ver o espetáculo; ainda se assiste a espetáculos destratados visualmente, onde parece que o mais importante é mostrar "alguma coisa" no palco, do que criar um discurso visualmente expressivo. Parece que se cometem erros, já sublinhados no século XVII e condenados no século XIX. A menos que se pretenda intencionalmente desconstruir uma das mais importantes relações entre um espetáculo e o público, excluindo dessas relações a percepção visual, na qual a própria origem do termo teatro se fundamenta, ou que se pretenda fundamentar o projeto visual da práxis cênica na improvisação absoluta, divinizando o acaso.

Para voltar ao teatro francês do século XVII, vale citar Anne Surgers (2005b), quando ela acentua a introdução de certo laicismo na cena francesa do período, assim como a ausência de um lugar convencionado para a sua ocorrência, restando como exceção a ópera de influência italiana. Ainda que se possa identificar na dramaturgia e na cenografia a presença de traços estilísticos oriundos da Itália, a prática teatral francesa apresentava-se de modo diversificado do espetáculo italiano, inclusive pela diferença no uso da luz. Surgers (2005b) aponta como razão importante para tanto, a transformação de diversos espaços em teatro, entre eles grandes salões e pátios de castelos e hotéis, espaços abertos de jardins e quadras de jogos precursores do tênis.

\footnotetext{
5 “Toutes les salles actuelles se composent d'un rez-de-chaussée [...] et d'un nombre variable d'étages. La forme circulaire, adoptée généralement, condamne les deux tiers des spectateurs de ces étages supérieurs à être placés littéralement et sans exagération aucune les uns em face des autres. L'action dramatique ne peut être suivie par eux sur la scène, qu'en tournant péniblement la tête. Si à la rigueur, toutes les personnes placées au premier rang d'un étage peuvent jouir du spectacle au prix d'une torture supportable, les occupants des trois ou quatre rangs placés en arrière sont obliges de se tenir debout, de s'arc-bouter, de se pencher dans le vide pour apercevoir une très petite partie du théâtre. On peut même afirmer que dans tous les théâtres actuels, il existe, aux deux derniers étages, toute une série de places d'où l'on ne voit absolument rien."
} 
A configuração espacial dessas quadras repercute na construção da primeira edificação pública francesa destinada à cena, o teatro L'Hôtel de Bourgogne (1548), que receberia os espetáculos da Confraria da Paixão (Confrérie de la Passion) nos momentos que antecedem a era moderna (Figuras 74 e 75). A casa de espetáculos foi assim denominada por haver sido construída no mesmo terreno antes ocupado pela residência parisiense da família Burgundy. Inicialmente destinado ao teatro religioso, sob a responsabilidade da Confraria, a atividade foi interrompida no mesmo ano, pelo rei Henry II (1519-1559), que proibiu a montagem dos "mistérios". O teatro passou então a ser ocupado por companhias que passavam por Paris, ou até mesmo por espetáculos locais, que recebiam autorização especial.

A tipologia espacial e os espetáculos realizados no Hôtel de Bourgogne denotaram relevantes características das soluções encontradas pelos artistas da época, na elaboração da visualidade particular do teatro daquele período. Um dos mais importantes documentos acerca dos espetáculos realizados no Hôtel du Burgogne apareceria na segunda metade do século XVII, Memória de inúmeros cenários que serviram às peças contidas no presente livro, começada por Laurent Mahelot e concluída por Michel Laurent no ano de I673 [Mémoire de plusieurs décorations qui serve aux pièce contenus en ce présent livre, commance par Laurent Mahelot et continué par Michel Laurent en l'année I673 (ou 1678, como se pode ler na capa do manuscrito)]. A edição de 1920, publicada por Henry Carrington Lancaster - professor de literatura francesa da Universidade John Hopkins - lista relatos que teriam sido escritos desde 1633, por Mahelot, e depois de 1643 até 1686, por Michel Laurent e/ou outro autor não identificado.

Ainda que seja frequentemente atribuído a Mahelot, o Mémoire - como ficou mais conhecido - inclui o decorateur (raízes do atual cenógrafo) Michel Laurent, como coautor, e até se especula a participação de um terceiro colaborador, desconhecido. O documento traz relatos acerca das montagens no Hôtel de Bourgogne e, como o próprio título indica, refere-se a uma série de cenários de peças ali postas em cena durante o século XVII. Os relatos incluem desenhos que registram os arranjos espaciais de quase cinco dezenas de espetáculos, entre os mais de duzentos e cinquenta, cujos títulos são mencionados, indicando as atividades desenvolvidas por esses artistas, entre eles predominantemente Mahelot, como maquinista e/ou cenógrafo. Mesmo que algum comentador considere as descrições incompletas e/ou imprecisas em certos relatos, os manuscritos representam a mais valiosa fonte que registra a organização espacial, assim como procedimentos ali aplicados. 


\section{CENA COMPARTIMENTADA OU SIMULTÂNEA}

Lancaster (1920, p. 34) salienta que algumas das peças montadas no Hôtel de Bourgogne pareciam apresentar uma abordagem moderna em termos cenográficos, representando "casas e ruas" ou uma floresta, como exemplos. ${ }^{6}$ Ele diz que, em muitos casos, era assumida uma convenção na qual o lugar objetivo onde a ação da peça se passa é maior do que aquele disponível no palco. Por outro lado, ainda que essa mesma convenção permitisse a disposição dos elementos de cada dispositivo cenográfico em posições de relativa distância entre os mesmos, para o espectador todo o quadro consistia em um único lugar iluminado de modo mais ou menos uniforme, caracterizando a visualidade proposta que instalava uma exposição integral do palco.

Outra observação do mesmo autor apresenta a configuração mais usada, definindo as características dos espetáculos:

Mas os cenários descritos na maioria das anotações são geralmente organizados como na Idade Média, em dimensão reduzida, para serem acomodados no palco do Hôtel [de Bourgogne]. A cena era dividida em compartimentos [cenários simultâneos], ainda que cada um representasse um lugar completo [autônomo]. A ação da peça passa de um compartimento a outro, e o espectador tem a tarefa de perceber um de cada vez. ${ }^{7}$ (LANCASTER, 1920, p. 34, grifo e tradução nossos)

O espaço teatral compartimentado propunha a estética de uma montagem flexível e eficiente, na qual certos aspectos merecem destaque. Muitas especulações podem ser feitas, uma vez que não há documentação substancial sobre a aplicação da luz no Hôtel. Num palco de, no máximo, oito metros de largura por sete metros de profundidade o cenógrafo distribuía indícios de vários ambientes, usando os espaços laterais e o centro alto. Numa convenção simples e sofisticada a ação era iniciada nas proximidades do lugar que virtualmente a abrigaria e deslocava-se progressivamente para o espaço livre ao centro do palco.

6 O cenário de Édipo Rei, montado em 1545 no Teatro Olímpico em Vicenza, como exemplo, mostra uma interpretação ingênua de Tebas, considerada na Antiguidade uma grande cidade, pois tinha sete ruas e uma praça: o cenário reproduz, com certo pedantismo, exatamente esse número. Sete ruas e uma praça, ou "casas e ruas" implica uma soma que daria a impressão de cidade. Nesse mesmo raciocínio ou método, várias árvores criariam essa ideia de floresta.

7 "Mais les décors décrits dans la plupart des notices, sont plutôt disposés comme au Moyen Âge, quoique rapetisses pour la salle de l'Hôtel. La scène se divise en compartiments, dont chacun fait un tableau complet. L'action de la pièce passe d'un compartiment à un autre et le spectateur obligeant tâche de n'en voir qu'un seul à la fois." 
Os cenários indicavam muito mais uma alusão ao lugar da ação do que o desejo ilusionista do modelo renascentista italiano. Um ou outro elemento cenográfico poderia ser usado para contribuir na corporificação da cena, como uma cadeira ou um telão ao fundo. Tal organização revela forte influência da estética do medievo, com uma diferença principal, considerando-se que a cena simultânea medieval ocorria em espaços abertos, em praças públicas, ou era distribuída no interior de igrejas. No Hôtel de Bourgogne a cena estava contida num pequeno palco coberto e confinado numa edificação.

No mesmo ano da inauguração do Hôtel de Bourgogne, ocorreu na cidade belga de Valenciennes a montagem do Mistério da Paixão (Mystère de La Passion), um espetáculo realizado num espaço público aberto, contando com efeitos especiais e centenas de atores. Essa organização espetacular repercutirá na tipologia espacial que orientou a proposição cênica francesa, mais tarde conhecida como cenários compartimentados e simultâneos (décor a compartiments). É também justo ponderar que o modelo perspectivista podia ser encontrado nos cenários citados, mesmo sem o rigor de Alleoti, Torelli ou dos Bibiena. No contexto do Hôtel de Bourgogne, cabia ao espectador a tarefa de selecionar o que devia ser "visto", já que os cenários estavam dispostos simultaneamente e somente um por vez deveria ser o objeto ou tema da cena. A mencionada conjuntura técnica impedia que a luz cumprisse efetivamente tal função. O espectador era incumbido de selecionar, isolando mentalmente o local da ação para que o espetáculo ocorresse do modo como foi concebido. Essa é uma visualidade muito particular, que se reflete na escrita do dramaturgo, dando-lhe liberdade na elaboração da mecânica ou na distribuição das cenas.

Os meios tecnológicos hoje disponíveis permitiriam de modo eficiente aos olhos do espectador atual o isolamento de cada ambiente, elaborando uma visualidade muito diferenciada daquela que um artista da época em questão poderia vislumbrar. Portanto, diante da conjuntura técnica então vigente, tal isolamento deixava de integrar aquela convenção. Pode-se até imaginar que um dramaturgo francês do século XVII, ao escrever seu texto, projetava na imaginação a acentuação de cada ambiente, através da ocupação do espaço do palco, sem vinculação com tratos detalhados da luz, o que dava ao espetáculo por ele imaginado um ritmo visual muito particular.

Ou seja, se o teatro efetiva uma simbiose dinâmica com a visualidade desde sua origem na cena grega, a imaginação de um autor que escreve hoje em dia, aliando sua experiência de espectador que "conhece" a flexibilidade e a precisão que a luz alcançou através dos procedimentos eletroeletrônicos, amplia suas 
opções dramatúrgicas. A luz interfere na sua escrita, e, consequentemente, em toda a ramificação visual do espetáculo. Isso determina o modus espetacular que o público efetivamente experimenta. A conjuntura técnica na qual a luz está inserida define, portanto, a assertiva visual que instala a cena.

Mesmo sem encontrar textos que tratem separadamente suas questões técnicas, é possível elaborar certa conjectura no intuito de compreender as relações entre os espetáculos mostrados no Hôtel de Bourgogne e a luz artificial então disponível. Os desenhos incluídos no Mémoires não contemplam especificamente aspectos da luz, e não se documentou qualquer interesse, do ponto de vista de uma possível estética da iluminação, em destacar ou acentuar o espaço no qual se origina a cena. Encontrando um ou outro exemplo da presença de instrumentos destinados à luz, como no caso da descrição do cenário para Argénis (peça publicada em 1631) ou Argénis et Poliarque $(1630),{ }^{8}$ de Pierre du Ryer (1606-1658), registram-se momentos nos quais os autores têm seus textos como que invadidos pela visualidade: "É necessário que tenhamos, no meio do palco, um rico altar-mor, duas tochas e luzes, um fogão e incenso. Em um dos lados do palco, fogos de artifício escondidos no mar. Do outro lado, uma gruta [...]" (Figura 76). ${ }^{9}$ (MAHELOT apud LANCASTER, 1920, p. 79, tradução nossa)

Observando o desenho incluído no Mémoires, define-se a presença de duas fontes de luz (tochas), no centro, ao fundo. É possível presumir que a luz fornecida por essas fontes, dispostas sobre o altar, não seriam suficientes para iluminar integralmente a cena; então, ao acrescentar o termo "luzes" (não contempladas no desenho), o autor designa para as mesmas a função particular de promover a visibilidade exigida pela cena, tornando-as imprescindíveis à criação das imagens que ele vê mentalmente ao elaborar a dramaturgia, determinando a necessidade de instrumentos "complementares" (não presentes na iluminação do ambiente "real ou verdadeiro" representado em cena).

Não há indícios de qualquer procedimento técnico que orientasse a realização técnica da imagem cênica projetada, tanto no desenho, quanto na descrição; além disso, o limitado controle de instrumentos e acessórios disponíveis naquela época resultava num altíssimo grau de dificuldade para o planejamento dessas imagens, numa cena de tamanha complexidade visual. É possível, portanto,

8 O texto editado por de Lancaster (1920, p. 78) se refere à peça de 1630, enquanto o desenho que o ilustra é identificado como cenário para Argénis. Em qualquer caso o documento mantém seu papel de suporte para a presente discussão.

9 "Il faut, au milieu du théâtre, un autel fort riche, deux flambeaux et des lumières, un rechaut, de l'encens. A un des costez du théâtre, un feu d'artifice dans une mer et caché. De l'autre costé, une grotte." 
especular que o iluminador encontrava limites e os incorporava às soluções aplicadas aos espetáculos, de acordo com a conjuntura tecnológica em que ele estava inserido. Tais variáveis definiam o modo de pensar visualmente a cena, assim como o espetáculo que se poderia assistir.

Então, quando um aparato de luz artificial (no caso, as tochas sobre o altar) é introduzido no espetáculo, como responsável pela iluminação do ambiente teatralizado - e tal decisão já pode ter sido tomada pelo cenógrafo ou mesmo haver sido indicada pelo dramaturgo -, fica estabelecido mais um problema a ser resolvido pela cena propriamente dita. Se o espetáculo estiver ligado a compromissos com o real, como se pode observar na tragédia francesa do período, certas nuanças técnico-estéticas indicarão caminhos para o planejamento da luz.

A literatura especializada do século XX, em inglês, introduziu a expressão "luz motivada" (motivated light), para caracterizar o resultado de uma fonte de luz dessa natureza, efetivamente presente na cena; o verbo motivar refere-se aqui ao resultado produzido em um ambiente por diversificadas fontes de luz, como uma lâmpada, uma fogueira, o sol, a lua, e assim por diante, incluídas na cena. O glossário escrito por Norman C. Boulanger e Warren C. Lounsbury, traz o seguinte comentário:

Espetáculos realistas devem apresentar fontes de luz realistas; quer dizer, uma cena noturna deve parecer iluminada por uma lâmpada, um aparato aéreo, uma lareira, ou pela luz da lua que entra por uma janela. A aparente fonte de luz pode ser a key light ${ }^{10}$ como a forte luz do sol através da janela ou pode ser parte da atmosfera, como uma fonte sugerida por uma veneziana projetada na parede." (BOULANGER; LOUNSBURY, 1992, p. 102, grifo e tradução nossos)

10 De acordo com Boulanger e Lounsbury (1992), key light é uma expressão originada na linguagem do vídeo e usada no teatro. No cinema, há a expressão "ataque", com função similar. Refere-se à luz de maior brilho na cena, mais concentrada, aquela que modela as figuras. Há certas nuanças no uso das expressões "key light" e "high light"; a expressão "high light", em certos casos, refere-se à luz de maior iluminância, ou brilho, incidindo sobre a cena. A formação do interessado na luz para a práxis cênica deve considerar a discussão desses conceitos, inclusive no que se refere à atmosfera, incluída no texto de Boulanger e Lounsbury (1992). Por vezes, construir a atmosfera realista é um desafio com alto grau de dificuldade técnica, exige habilidade artística e apresenta sofisticada simplicidade visual, que não resulta em vantagem para o "iluminador”, uma vez que sua interferência não será evidenciada para o público que busca a obviedade grosseira e banalizada.

11 "Realistic plays should have realistic light sources: thus an interior night scene may appear to be lighted from a lamp, overhead fixture, fireplace, or moonlight through a window. The apparent source may be the key light such as a strong sunlight a window, or it may be part of the atmosphere such a source suggested by a projected venetian blind on the wall." 
Se o espetáculo está orientado por alguma convenção de cunho realista e o cenógrafo incluiu, no seu projeto, um lustre sobre uma mesa de refeições, a geografia da cena pode parecer perfeita, sem a interferência da luz artificialmente concebida para um espetáculo. Pode-se dizer que, numa proposta realista, a luz da cena deveria ser simples como o ambiente sugere: ao menos uma lâmpada no lustre sobre o centro da mesa distribui a luz para todo o ambiente, num padrão concêntrico. Se a luz da cena for concebida seguindo essa provocação, ela, praticamente, não "aparecerá", ou seja, a luz não será - ou não deveria ser - "notada".

Caso a luz projetada por uma lâmpada instalada no lustre seja considerada insuficiente, como assumiu Mahelot no texto já mencionado, e forem acrescentadas "luzes" (hoje instrumentos - refletores - de diversos tipos) para promover a visibilidade desejada ou necessária, o lustre terá influência direta na luz projetada sobre a ação e originada em outras fontes aplicadas pelo iluminador. Tal influência derivará da projeção de sombras na cena, uma vez que o lustre representará um obstáculo (entre as "luzes" e a cena), destruindo a ilusão pretendida pelo espetáculo: em se tratando de um lustre cuja função é iluminar o ambiente, numa compreensão realista ele não teria sua própria sombra projetada sobre o ambiente que está iluminando, o aconteceria como resultado de outra fonte de luz imposta, no teatro. Caso a sombra seja revelada isso poderá provocar a desconstrução do pensamento visual (realista) que norteia essa categoria espetacular (Figura 77).

Evitando usar como parâmetro o olhar desaprovador que se apoia no aprendizado do século XX para qualificar a estética realista, interessa aqui a identificação de problemas espetaculares criados pela relação direta entre essa convenção e a luz. Apesar de ser hoje considerada um retrocesso, a simplicidade visual pode oferecer soluções para muitos problemas cênicos, nesse caso, implicitamente criados pela cenografia da peça citada, Argénis, que incorpora alto grau de dificuldade na sua elaboração e execução, mesmo com a tecnologia do século XXI.

Até se poderia considerar um bom exercício para um jovem em formação a tarefa de produzir uma luz integrada ao ambiente de uma ação realista de modo que os instrumentos, os acessórios e o sistema de controle não sejam os elementos centrais do discurso visual a operar na cena, no sentido que não devem ser notados. Nessa categoria de evento, portanto, as fontes de luz inseridas no dispositivo cenográfico, porque estariam produzindo a efetiva iluminação do ambiente "real" ou "verdadeiro" (motivated light) representado em cena, elaboravam um problema cênico de considerável desafio para o iluminador.

O objetivo seria buscar uma luz que não causasse qualquer estranheza e, de acordo com o propósito realista, não desse ao espectador chances de levan- 
tar questões que o afastassem do espetáculo e destruíssem a empatia: vendo a imagem criada, o público não devia ter dúvidas acerca do ambiente da ação, o que inclui a luz que o ilumina.

As variáveis técnico-estéticas que podem interagir numa situação dessa natureza exigiriam abordagem particular que indica uma pesquisa específica. Por essa razão, retornando às convenções teatrais do século XVII, na França, reafirme-se que a luz realista pode se configurar como um excelente tema de pesquisa para o designer (theatre lighting) em formação.

Na condição de dramaturgo, Du Ryer [autor de L'Argénis, versão francesa da obra neolatina, descrita como ficção heroico-galante, de John Barclay (15821621)] contava com alto grau de liberdade para elaborar ambientes e imagens das quais o cenógrafo, assim como o figurinista, o maquiador e o aderecista se aproximavam, elaborando formas, cores e texturas sem, necessariamente, a divisão estrita de funções. A luz, contudo, era obrigada a subverter a limitada conjuntura tecnológica, para tentar compartilhar com o público as imagens concebidas pelo dramaturgo, pelo cenógrafo, pela presença dos atores, pela música, e assim por diante. A criação da imagem cênica estará sempre perpassada pela compreensão do iluminador, envolvendo questões culturais, como a tecnologia, a estética, a práxis de cada artista, dentre outras. A revelação da visualidade presente na dramaturgia ocorrerá ou não, na cena, através de "trans-ações" com inúmeros agentes culturais. De todo modo, mesmo que a dramaturgia aponte possibilidades muito diversificadas, como no teatro francês em questão, ainda assim não se pode excluir a luz da realização cênica.

Se considerarmos a França do período agora em pauta, quando se concebia um espaço teatral integralmente iluminado sem interesse na separação entre o palco - théâtre - e a plateia, o locus da ação cênica era inscrito no espaço teatral por uma relação entre a dramaturgia, a geografia particular da cena e a presença dos atores. Ainda assim, quando são avaliados os instrumentos que efetivavam a luz artificial então aplicada - tochas, candelabros e lamparinas -, assim como os procedimentos conhecidos naquele momento, é possível aproximar o teatro francês do legado italiano mesmo na ausência de registros sistemáticos da aplicação cênica da luz. Ou seja, acentuações, destaques, isolamentos de lugares e/ ou personagens, elaboração de atmosferas, entre outros. Eram desafios com alto grau de dificuldade. Por outro lado, mesmo que sejam reconhecidas autonomias e/ou hegemonias periódicas da dramaturgia, da cenografia e do ator, a fundamentação e/ou confirmação das estéticas que delas derivaram não caracterizam maior ou menor importância da visualidade. 
As descrições do dispositivo cenográfico que pode ser ligado à cena compartimentada ou simultânea (décor à compartiments), escritas por Mahelot, já incluem solicitações intuitivas à luz. Seus comentários acerca da tragicomédia O hipocondríaco [L'hipocondre - L'hypocondriaque ou le mort amoureux (Figura 78)], de Jean Rotrou (1609-1650), levada à cena em 1628, indicam feições de imagens visuais/ materiais:

No centro do palco temos uma câmara fúnebre e três túmulos, com luzes que ardem, sendo que a mencionada câmara se abre e se fecha, quando necessário. Em um lado do palco, uma bela casa com duas cadeiras onde se pode sentar e no mesmo lado, no quarto ato, uma árvore [...]. Do outro lado do palco, uma madeira [tronco], uma toca, uma fonte e uma relva, onde se senta ou se agacha uma dama, do mesmo lado do tronco. ${ }^{12}$ (MAHELOT apud LANCASTER, 1920, p. 82, tradução nossa)

Ainda que se considere tal intervenção apenas uma breve sugestão de luz, ela representa um impulso irrefreável para os artistas que definem o caráter visual do teatro. A opinião de Lancaster, já mencionado acima, sobre as atividades desempenhadas por Mahelot durante os espetáculos caracteriza a ligação do decorateur com a luz. Dentre suas atribuições estava incluída a elaboração de mecanismos para as mudanças de cenários, efeitos sonoros e efeitos especiais de modo geral; além de pedras caindo e ruídos de animais, ele acrescentaria raios, trovões, fogo e também o anoitecer.

E o anoitecer ganha importância aqui, pois, de acordo com Lancaster, Mahelot não aplicava os efeitos noturnos com a frequência necessária (de acordo com a solicitação dos textos!); Mesmo que a dramaturgia indicasse tais efeitos os autores nem sempre pareciam atendidos: "Mahelot talvez não estivesse familiarizado com o referido sistema, o que explica a omissão da noite nos relatos que se referem às peças dos jovens autores como Du Ryer e Rotrou". ${ }^{3}$ (LANCASTER, 1920, p. 39, tradução nossa)

\footnotetext{
12 "Il faut, au milleu du theatre a chambre funebre et trois tombeaux avec quantité de lumières ardantes, et que ladicte chambre s'ouvre et ferme quand il en est besoing. D'un des costez du théâtre, forme d'une maison assez belle avec deux chaires ou l'on s'assied dedans, et, du mesme costé, au quatriesme acte, un arbre [...]. De l'autre costé du théâtre, un bois, un antre, forme de fontaine, et du gazon ou tapit ou se repose une dame du mesme costé du bois."

13 “Mahelot n'était pas, peut-être, tout à fait accoutumé à ce système, ce qui explique l'omission de la nuit de quelques notices qui appartiennent à des pièces de jeunes auteurs comme Du Ryer et Rotrou. Mahelot talvez não estivesse familiarizado com este sistema, o que explica a omissão da noite nos relatos que se referem às peças dos jovens autores como Du Ryer et Rotrou."
} 
Lancaster (1920) até aponta a escassez de relatos sobre a luz, e justifica com uma possibilidade que merece destaque:

Em Bajazet, a representação da cor local se reduz a um 'salão turco'. Não se fala de máquinas, exceto nos relatos sobre o Amphitryon, uma vez que Le Mémoire não cita mais do que o título de Andromède, peça notabilizada pelas suas máquinas [mecanismos para mudanças de cenários]. Já não se fala da noite, como fez tantas vezes Mahelot, exceto para a descrição de Davineresse [Feiticeira], onde aparece a iluminação. Provavelmente, a obrigação de produzir a noite já não era atribuição dos cenógrafos. ${ }^{14}$ (LANCASTER, 1920, p. 44, grifo e tradução nossos)

A noite parece representar um tema importante para a discussão daquele teatro. Se a sua criação não era mais atribuição dos cenógrafos, alguém deveria responsabilizar-se por isso. Cabe lembrar que Lancaster estava escrevendo sua introdução para Le Mémoire, na segunda década do século XX, um momento no qual a luz elétrica ganhou espaço no teatro e começavam a aparecer profissionais especializados em sua aplicação. É possível, por conseguinte, que o aparente desmembramento da equipe que criava o espetáculo, no século XVII, sugerindo um responsável pela luz, não passasse duma conjectura de Lancaster. Por outro lado, independentemente de quem a exercia, a atividade era imprescindível. Além disso, ele já aponta um aspecto de grande relevância ao mencionar a demanda apresentada pelos autores, quando solicitavam a noite nos seus textos. Como essa função não parece ter sido documentada fica uma lacuna que pode ser preenchida pela experiência teatral. É possível especular que alguém, ou uma equipe, tenha sido envolvida nas resoluções de um problema tão particular. Mesmo que fosse o cenógrafo, o diretor, ou qualquer outro membro da companhia, ele estaria contribuindo para a visualidade inscrita pela cena.

Para Lancaster (1920), o trabalho de Du Ryer e Rotrou mostra que a noite já estava incorporada à dramaturgia tornando a luz indispensável para que a cena imaginada pelo dramaturgo acontecesse diante do espectador. Afinal, pensar drama, cena, ou acontecimento espetacular é estar sendo inevitavelmente provocado, mesmo num movimento intuitivo, pela luz. Como se presumiu em diversos momentos, quando se trata de elaborar a práxis cênica, desde suas primeiras imagens mentais um convite é enviado à luz; nem sempre, no entanto, como já foi dito, ele aparece de

14 "La représentation de la couleur locale se borne à um "salon à la turque" pour Bajazet. On ne parle de machines que dans la notice d'Amphitryon, car le Mémoire ne donne que le titre $A^{\prime}$ Andromède, pièce fameuse pour ses machines. On ne parle plus de la nuit, comme faisait si souvent Mahelot, sauf dans la notice de la Devineresse, où il s'agit d'illuminations. Probablement l'obligation de faire venir la nuit n'appartient plus aux décorateurs." 
modo explícito. O teatro, então, exigiu progressivamente a presença de um responsável pela luz cujo desempenho de natureza técnico-estética depende de alguma habilidade e competência para o trato dessas questões. Isso inclui, tanto a apreensão de feições da luz nas ideias provocadoras de um espetáculo - texto, roteiro, movimento, música, descrição verbal, improvisação -, quanto a resolução cênica do problema.

A noite solicitada por um autor ganha muita importância, pois implica na necessidade de controle: pode não bastar a redução da luz disponível, criando uma penumbra generalizada, uma vez que o espetáculo pode exigir atmosfera específica, implicando uma relação entre intensidade, distribuição, cor e movimento, particulares. Atreladas às condições técnicas de cada período tais implicações apresentam-se ao iluminador como problemas cênicos: que resposta visual seria indicada para a noite proposta por determinada dramaturgia?

Uma montagem atual poderia dar ao artista grande liberdade para criar tal condição ou qualidade, em consonância com a convenção escolhida pelo diretor, pela geografia da cena, na ocupação da geografia pela personagem, o que pode incluir uma solução que desconsidere qualquer indício realista da noite. Em um texto de Shakespeare, como já se sabe, um artefato de luz artificial, por exemplo uma tocha, pode indicar noite ou escuridão, mesmo num espetáculo apresentado em pleno dia. Um sistema de contraluz que preencha todo o palco de azul, geralmente azuis aquecidos, avioletados pela incorporação de uma sutil alma de vermelho, pode indicar uma atmosfera noturna romântica. Inúmeras possibilidades se apresentam, hoje em dia, alguns séculos depois que Mahelot escreveu seu trabalho.

Por outro lado, pode-se discutir o equívoco do uso de fórmulas como a aplicação redundante da mesma "família" de azuis, em contraluz, para indicar noite. Será que basta fazer incidir sobre o palco certo matiz projetado de uma vara ao fundo para enviar ao espectador um mar de azul através da reflexão, e teremos sempre uma noite? Usar essa ou outra saída qualquer como fórmula que se repete e repete, pode afastar os projetos da simplicidade e afundar a visualidade no terreno do simplório, do senso comum.

\section{ANDRÔMEDA: CENA E MÁQUINA}

Lancaster sublinhou outra instância do comportamento da cena na França do mesmo período referindo-se ao emprego de máquinas nos espetáculos. Essa atitude configurava a acentuada influência do teatro italiano. Não somente nas festividades 
da realeza e na ópera inscreveu-se a presença italiana, mas também numa práxis cênica cuja denominação pièces à machines, (literalmente, espetáculos feitos com máquinas) revelava a incorporação de tal influência. Surgers (2005b, p. 124, grifo e tradução nossos) define, assim, essa manifestação: "[...] todas as peças nas quais a ação necessita de mudanças dos lugares espetaculares; as tragicomédias pré-clássicas, o balé, as óperas, ou ainda as tragédias ou comédias à machine [...]". ${ }^{15}$

Como se pode registrar, trata-se de um espectro de relativa amplitude cujo traço de união é o dispositivo cenográfico, que se modifica e/ou se transforma. Cabe destacar que essa mudança se refere à tecnologia da cena reinventada no Renascimento, e que respondeu no Barroco a pressupostos de grandeza e movimento, já mencionados. Assim, as manifestações que incorporavam a estética italiana, fortemente fundada na abordagem perspectivista e na "mudança frequente e surpreendente de cenários", difundida por Torelli e Vigarani, ${ }^{16}$ produziram direta contribuição para as piéces à machine.

Uma, dentre as mais documentadas expressões das peças realizadas com máquinas, é Andrômeda (Andromède), montada em 1651, libreto de Corneille e música de Charles Coypeau (1605-1677), também conhecido como Dassoucy. O espetáculo teve cenários de Giacomo Torelli, que havia se transferido para a França, em 1645, indicado pelo Duque de Parma, onde alcançou sucesso com a A falsa louca (La finta pazza), música de Francesco Sacrati e libreto de Giulio Strozzi, montada no Salão Petit Bourbon do Louvre, quatro anos depois da estreia em Veneza, em 1641. Em 1647, entretanto, sua montagem da tradução de Corneille para Orfeu (L'Orfeo), no Palais Royal, recebeu grande resistência, em meio à crise social francesa. Parte do público agitou-se contra o que entendia como desperdício, as despesas dos caríssimos espetáculos "estrangeiros".

Tal reação negativa repercutiu na parceria entre Corneille e Torelli, originando um novo espetáculo denominado Andromède (1650), com texto original do dramaturgo francês que tomou como provocação o mito de Perseu e Andrômeda. Torelli reutilizou na montagem os cenários do combatido L'Orfeo, citado como marco da influência italiana na piéce à machine. Nagler diz que Corneille teria levado em consideração os cenários já existentes para escrever o libreto. (NAGLER, 1952, p. 168)

\footnotetext{
15 "tous les pièces dont l'action necéssite des changement de lieux spetaculaires: les tragi-comédies pré-classiques, les comédie-ballets, les óperas, ou encore les tragedies ou les comédies à machine, [...]."

16 Gaspare Vigarani (1588-1663), renomado arquiteto e cenógrafo italiano, que esteve em Paris a convite de Mazarin, em 1659, para trabalhar na Salle de Machines das Tulherias. Depois do reduzido sucesso da sua cenografia para o balé de inauguração desta casa de espetáculos, em 1662, hostilizado por artistas franceses retornou para a Itália. (SURGERS, 2005, p. 175, tradução nossa)
} 
Aceitando essa premissa, estaremos diante de um exemplo explícito de cumplicidade radical entre a visualidade e a cena.

Usar como tema o amor entre Perseu e Andrômeda já pode representar a possibilidade de fazer repercutir no espetáculo eventos fantásticos que integram a ação relatada no mito, envolvendo divindades e monstros. O ambiente originalmente descrito pelo dramaturgo, logo abaixo da relação de personagens, parece de extrema simplicidade, localizando a ação na capital do Reino de Cephée, Etiópia. (CORNEILLE, 1862)

Os cenários dos cinco atos, cada um deles em ambiente diverso do outro, estão ilustrados nas gravuras de François Chauveau (1613-1676), já artista proeminente, que seria nomeado conselheiro da Academia Real de Pintura e de Escultura (Académie royale de peinture et de sculpture), em 1663 (Figuras 79 a 84). As gravuras mostram a busca pelo rigor perspectivista e configuração esquemática, apresentando uma visão generalizada de cada ambiente, sem preocupações com a luz ou a atmosfera particular de cada momento. A julgar pela esquematização observada principalmente nas sombras das personagens, Chauveau define para o prólogo uma luminosidade abrangente que banha uniformemente o lugar, a partir de uma fonte natural única, ligeiramente deslocada para a esquerda. Nos dois primeiros atos há indícios de uma luz principal ao fundo, no centro-alto, como se originada pelo sol ou pela luminosidade do céu. No terceiro e quarto atos, ele estabelece uma variação e sugere a fonte de luz principal vinda da esquerda.

Os desenhos para a cenografia, por vezes, mais sugerem a exposição da topografia da cena do que evocam a atmosfera do momento. Uma tarefa muito bem colocada para um interessado nas relações entre a luz e a cena seria incluir nos seus projetos representações pictóricas das cenas, expressando as condições climáticas, as atmosferas, assim como os índices simbólicos da visualidade proposta, repercutindo sua compreensão dessa visualidade. Isso pode contribuir para o amadurecimento do pensamento visual que sustenta seu projeto.

A conjectura de Bergman, na qual ele suspeita que Corneille tenha escrito Andromède prevendo um espetáculo que usaria cenários já existentes e projetados para o L'Orfeo, pode representar elemento decisivo no caminho para a interação do espetáculo com a visualidade. Além disso, Bergman ainda destaca uma provável afirmação do dramaturgo, que teria apontado a aplicação dos décors à machine na sua montagem de Andromède, como mais do que simplesmente um sistema mecânico interferindo no espetáculo e, sim, como um elemento da poética, integrado organicamente no corpo da cena: ele acentua certas definições referentes à cenografia quando, depois de apresentar o argumento da peça discute questões 
particulares do espaço cênico. Corneille pondera que, a despeito da diversidade de lugares necessários para a ação, teria sido supérfluo especificar (os cenários) nos versos, uma vez que eles são apresentados aos olhos do espectador. ${ }^{17}$ Ele ainda diz que o único lugar apresentado rigorosamente pela fábula é o mar (com os rochedos, na praia onde a heroína é deixada como dádiva ao monstro), no terceiro ato.

Corneille (1862) afirma que os outros espaços da ação eram produtos de sua própria invenção, que ela não exige cenários tão específicos e poderia ocorrer em outro lugar, ou lugares. Corneille até usa o primeiro ato como exemplo, e argumenta que a ação de tirar a sorte para a indicação da próxima vítima do monstro ocorre numa praça pública, o que não é imperativo, e explica: "[...] tudo que aí se diz, poderia ser dito também em um palácio ou um jardim [...]". 18 (CORNEILLE apud MARTY-LAVEAUX, 1862, p. 306, tradução nossa) Para ele, há dois conceitos determinantes - o provável e o necessário -, remetendo a uma das características da ação dramática moderna de natureza realista, a lógica. Vale lembrar que no seu texto sobre o argumento de Andromède, e incluído antes da peça propriamente dita, ele comenta e justifica mudanças operadas na narrativa do mito, quando estabelece um número de cinco filhas para Cefeu e Cassiopeia, ao invés de apenas uma, Andrômeda.

Em se tratando de uma dramaturgia mergulhada em temas míticos, incluindo o trânsito de deuses, semideuses, heróis e efeitos extraordinários ocasionais, o estabelecimento da lógica é cuidadosamente acentuado para que o contraste entre a indicação de real e de extraordinário apresente impacto, também, e no caso, visual. Vale lembrar que Andromède não é a primeira peça francesa a incorporar música e o sistema décors à machine, pois, como afirma Guizot (1852), Alexander Hardy (1570/1572-1632) já havia usado o coro em suas tragédias, assim como máquinas nas pastorais. Ele especula, ainda: “[...] parece que todos os acessórios foram combinados em 'Casamento de Orfeu e Eurídice, ou a grande jornada das máquinas', montada em 1640 [...]". ${ }^{19}$ (GUIZOT, 1852, p. 178, grifo e tradução nossos) Dando conta de um relato do período, ele mencionou a entrada de Vênus numa enorme estrela que ilumina todo o palco.

Dessa época, há peças cujos programas traziam uma inscrição muito importante para o contexto, informando ao espectador que ele veria cinco mudanças de

\footnotetext{
17 Parece remeter ao teatro grego e às substanciais referências a tempo e lugar, na poesia dramática da Antiguidade, assim como ao teatro de Shakespeare, por motivo semelhante.

18 "Tout se qui s'y dit se dirait aussi bien dans cette palace qu'en ce jardin ou dans ce palais."

19 "[...] it appears that all these accessories were combined in the "Marriage d'Orphée et Euridice ou la grande Journée des Machines", performed in 1640, [...]."
} 
cenários. Tal estratégia pressupõe uma incorporação particular da luz para interagir nesses eventos. Era uma promessa de fusões mecânicas espetaculares de cenários, entre um e outro ambiente, o que remete ao sistema fade in/fade out, ${ }^{20}$ introduzi- $^{2}$ dos mais tarde no cinema, sem mencionar a própria elaboração do cross-fade ${ }^{21}$ muito aplicado na luz para a cena, hoje em dia. O apelo visual desse teatro até suscita uma discussão que sublinha certa radicalização: em Androméde, o dramaturgo teria integrado a música para, também e estrategicamente, camuflar o ruído dos mecanismos que movimentavam elementos do dispositivo cenográfico. Ou seja, o som introduzido como artifício para emprestar excelência à visualidade. O próprio Corneille pode ter provocado tal discussão, quando escreveu no Examen, disposto entre o argumento e o texto da peça:

[...] eu apliquei [a música] para, nada mais do que o entretenimento dos ouvidos dos espectadores, enquanto seus olhos observam uma máquina que sobe ou desce, ou estão presos a alguma coisa que os impeça de prestar atenção àquilo que os atores possam estar dizendo, como no combate entre Perseu e o monstro. ${ }^{22}$ (CORNEILLE apud MARTY-LAVEAUX, 1862, p. 304, tradução nossa)

Alguns comentadores questionam tal papel mecânico e superficial da música, apontando funções mais organicamente ligadas à dramaturgia que a fazem assumir papéis determinantes como aquele de dar poder a Perseu para derrotar o monstro (POWELL, [200-]) No interesse da presente abordagem, importa mencionar as dinâmicas relações que põem em jogo os diversos aspectos da práxis cênica, incluindo a visualidade.

A despeito da escassez de relatos e documentos que tratem especificamente das soluções técnicas referentes à contribuição da luz, assim como dos resultados produzidos nos espetáculos do período, enfatizem-se os movimentos do dramaturgo, que deixam pistas do seu interesse pela cena na sua condição de objeto da percepção visual. Nicodemus Tessin, já mencionado aqui, mesmo sem apresentar avanços significativos, do ponto de vista puramente técnico, fornece indicações do tratamento da luz no teatro francês do século XVII.

\footnotetext{
20 Expressões da linguagem cinematográfica que se referem ao aparecimento e desaparecimento gradual da imagem.

21 Fade in e fade out (aparecer-desaparecer) simultâneos e com tempos próprios, em um movimento de luz para um espetáculo.

22 “[...] que je n’ai employée qu'à satisfaire les oreille des spectateurs, tandis que leurs yeux sont arrêtés à voir descendre ou remonter une machine, ou s'attachent à quelque chose qui les empêche de prêter attention à ce que pourraient dire les acteurs, comme fait le combat de Persée contre le monstre."
} 
Bergman (1977) enfatiza que, enquanto se podem verificar referências a uma ribalta móvel brilhando desde o início do espetáculo, embutida no limite anterior do palco, não há no Palais Royal, como exemplo, indicações de varas (elementos de sustentação dispostos horizontalmente acima do espaço destinado à representação). Antes de simplesmente sublinhar tal ausência como mera deficiência, deve-se lembrar, no entanto, que Bergman também menciona relatos de viajantes franceses em visita à Itália, nos quais são comentados o que os autores chamam de cenários mal iluminados. Um julgamento que poderia ser justificado, pela sua assertiva: "Os italianos tornaram a luz um componente mais ativo da criação pictórica (na cena). Isso já era possível com o escurecimento da plateia e pelas mudanças mais rápidas de cenários, com luz intensa ou reduzida”. ${ }^{23}$ (BERGMAN, 1977, p. 126-127, tradução nossa)

Na mencionada introdução para Andromède, edição de 1651, Corneille deixa um documento valioso para a pesquisa que levou ao presente trabalho. Tal valor já se justificaria no discurso que anuncia a estratégia aplicada pela dramaturgia, que incorporava a visualidade do espetáculo. Considerando tratar-se de um texto escrito em um momento decisivo para a construção da espetacularidade moderna, essa introdução torna-se um documento provocador para as elaborações aqui propostas. Mesmo reconhecendo as regras estabelecidas no século XVII, período no qual o teatro francês apresenta uma compreensão peculiar da tragédia antiga e da Poética de Aristóteles, cabe sublinhar o legado deixado por Corneille.

Discutindo e esclarecendo a construção da intriga que movimenta os conflitos do seu drama, justificando escolhas que determinam sua elaboração particular e/ou apontando a origem dos argumentos que provocam suas obras - como Ovídio, no caso da peça em questão, ele produziu um relevante documento para a compreensão da cena. Nos textos chamados Examen, que introduzem ou acompanham sua obra dramática, ele construiu trilhas para a compreensão das profundas relações entre o seu teatro e a visualidade.

Aqui será evitada a discussão de abordagens que pretendem sublinhar uma categorização para Andromède, em que se sugere que o texto de Corneille deve ser compreendido como um libreto, ou seja, elemento de um espetáculo cujo caráter é notadamente musical; importa pouco também se a vinculação aos pressupostos da piéce à machine deva ser reconhecida como sua característica mais determinante. Nenhuma das abordagens invalidaria o principal interesse da discussão em andamento, qual seja o de sublinhar os traços da visualidade já presentes na

23 "The Italians made light a more active part of the pictorial creation. This had already been made possible by the darkened auditorium and by the more rapid rhythm of changing décor, illuminated and in dimmed light." 
dramaturgia, para um espetáculo que a tome como provocação. Por outro lado, a antecipação da cena pelo dramaturgo que escreve com o olhar voltado para o palco é um aspecto determinante.

Para definir as bases do espetáculo desde a introdução do prólogo, Corneille dá as mãos aos pressupostos da visualidade. Sua primeira providência é assegurar que se ofereça ao espectador a visão frontal de uma vasta montanha de picos irregulares, que se elevam até as nuvens. Na base dessa montanha, há uma gruta através da qual se vê o mar, ao longe. Diante da montanha, em cada lado do palco, muitas árvores entrelaçadas. A primeira ação revela o grau de fantasia do tema. Ovídio mais uma vez é a fonte, nos livros quarto e quinto da já mencionada Metamorfosis: "Sobre um dos picos da montanha aparece Melpômene, a musa da tragédia; e no lado oposto, no céu, o Sol que avança num carro todo iluminado, conduzido pelos quatro cavalos, como relata Ovídio". ${ }^{24}$ (CORNEILLE apud MARTY-LAVEAUX, 1862, p. 258 , tradução nossa)

Assim como em outras obras, a abertura de Andromède oferece pistas da grandiosidade pretendida: a primeira personagem é Melpômene, uma das nove musas de acordo com a Teogonia de Hesíodo (11.75-103) - que apesar do seu canto de júbilo ficou conhecida como Musa da Tragédia - portando uma máscara na mão direita. O primeiro diálogo envolve Melpômene e o próprio Sol, com a maiúscula inicial que se refere à sua presença na lista de personagens da trama (dramatis-personae). Na edição de 1651, a relação das personagens apresenta uma divisão, introduzindo em primeiro lugar os deuses - que aparecerão à machines - e somente depois as personagens humanas, declarando a diferença de tratamento de tais categorias opostas, e deixando pistas para a luz. Trata-se de um importante indício das trilhas que guiarão um espetáculo originado em Andromède e destaca a compreensão da visualidade nela instalada, até para que se possa negar ou desconsiderar as indicações que Corneille oferece. A primeira fala da musa define a composição que o dramaturgo imagina para a cena:

Retenha um pouco sua impetuosa corrida | Meu palco, oh Sol, bem merece teus olhos | Jamais vistes nestes lugares | Pompa tão majestosa:| Reuni para ser admirado | O que há de mais belo na França e na Itália, | Adornado pelas artes das minhas irmãs:

\footnotetext{
24 "Sur un des sommets de montagne parait Melpomène, la muse de la tragédie; et, a l'opposite dans le ciel, on
} voi le Soleil s'avancer dans un char tout lumineux tire par les quatre chevaux qu'Ovide lui donne." 
| Empresta-me teus raios, para melhor iluminar. ${ }^{25}$ (CORNEILLE apud MARTY-LAVEAUX, 1862, p. 1, tradução nossa)

São inúmeros os elementos de provocação para qualquer abordagem dessa obra, o que sugere estreitas relações com a percepção visual. O autor convida o espectador e promete maravilhar "os olhos" do próprio Sol, anunciando o milagre que está por vir, o vigoroso brilho da atmosfera que ele mesmo via na espetacularidade da sua dramaturgia. As oito irmãs de Melpômene, musas como ela - Clio, Euterpe, Tália, Terpsícore, Érato, Polímnia, Urânia e Calíope -, trazem, não somente a inspiração poética, mas também, simbolicamente, todas as formas de pensamento, incluindo a eloquência, a sabedoria, a persuasão, a história, a matemática e a astronomia.

Por outro lado, o autor expressa o poder do Sol, ou da luz, cujos raios são indispensáveis para revelar a beleza concebida pelos artistas, pelos filósofos e pelos homens da ciência: "Empresta-me teus raios, para melhor iluminar". ${ }^{26}$ (CORNEILLE apud MARTY-LAVEAUX, 1862, p. 316, tradução nossa) No final do prólogo, o Sol afirma haver retardado o curso do tempo para contemplar o príncipe, e decide voar rapidamente, levando Melpômene em seu carro reluzente, determinando mais uma vez o tempo sobre a Terra. Qualquer referência futura ao controle do tempo/espaço nas artes cênicas e no cinema não parece mera coincidência.

Em seguida, a prometida mágica dos cenários em movimento é apresentada por Corneille, na transição para o primeiro ato. A grande montanha se eleva progressivamente, em blocos de rochas e, simultaneamente, também em um movimento progressivo, a cidade é revelada, instalando-se a praça na qual ocorre toda a ação do ato. Ele descreve o cenário: “[...] Nos dois lados do palco e ao fundo há magníficos palácios, diferentes na aparência, mas guardando admiravelmente o equilíbrio e a precisão da perspectiva [...]". ${ }^{27}$ (CORNEILLE apud MARTY-LAVEAUX, 1862, p. 320, tradução nossa)

Essa é a conjuntura das relações estético-poéticas presentes na Andromède de Corneille. Em cada mudança de cenários, o olhar do espectador deve ser maravilhado; para o segundo ato, a praça pública desvanece, enquanto surge, simultaneamente, um "delicioso" jardim, de acordo com adjetivação do próprio Corneille;

\footnotetext{
25 "Arrête un peu ta course impétueuse; | Mon théâtre, Soleil, mérite bien tes yeux; | Tu n’en vis jamais en ces lieux | La pompe plus majestueuse; | J'ai réuni par la faire admirer, | Tous ce qu'ont de plus beau la France et l'Italie; | De tous leurs arts mes souers l'ont embellie: | Prête-moi tes rayons pour la meieux éclairer."

26 "Prête-moi tes rayons pour la mieux éclairez."

27 "[...] Les deux cotés et le fond du théâtre sont des palais magnifiques, tous différents de structure, mais que gardent admirablement l'égalité et le justesse de la perspective."
} 
introduzindo o terceiro ato, ele indica uma estranha metamorfose para a entrada de Perseu, com a monstruosa cabeça da Medusa em seu escudo: o jardim se transforma na imagem de um horrível espetáculo, originado no suplício de Andrômeda, causado pela presença do funesto dispositivo da injustiça dos deuses. O mar, rodeado de rochedos gigantescos agita, sob um vento perturbador, enormes ondas entre as quais aparecerá o monstro enviado por Júpiter Ammon.

Aí ocorrerá a luta entre Perseu e a monstruosa criatura. Voando com a ajuda de Pégaso, portando a cabeça da Medusa, o herói desposará a jovem, após vencer a batalha, configurando-se o milagre anunciado por Corneille no início do ato, quando Timante diz: "Se o céu não é injusto, dar-se-á um milagre". ${ }^{8}$ (CORNEILLE apud MARTY-LAVEAUX, 1862, p. 353, tradução nossa) Segundo Corneille (apud MARTY-LAVEAUX, 1862), o quarto ato pode se passar tanto em um vestíbulo quanto numa grande sala, onde se dará o casamento de Perseu e Andrômeda. Pilares de cada lado, estátuas de mármore branco, tudo obedecendo à justeza da arquitetura. Para que tal ambiente seja instalado, no entanto, as ondas devem "afundar no palco"; ainda que indique no cenário para o quinto ato pilares semelhantes aos do Ato 4 - com pequenas modificações - o dramaturgo revela a influência de Torelli, e sugere um ambiente que pode se parecer com aquele que o antecede, mas deve incorporar a grandiosidade da morada dos Deuses:

Veem-se ainda duas fileiras de pilares como no outro [cenário], mas com uma ordem diferente, como nunca se ouviu relato. Estes são de pórfiro e todas as bases e acabamentos são de bronze, com gravuras que representam muitos deuses e deusas. A reflexão da luz sobre o bronze produzirá um dia extraordinário. $^{29}$ (CORNEILLE apud MARTY-LAVEAUX, 1862, p. 380, tradução nossa)

Além de especificar a natureza plástica dos elementos que constituem o dispositivo cenográfico, Corneille conclui enfatizando o papel da luz como fator determinante na efetivação do seu teatro, fazendo ecoar a já comentada repercussão do teatro renascentista e do teatro barroco na cena francesa.

\footnotetext{
28 "Si le ciel n'est injuste, il lui doit un miracle."

29 “On voit encore en celle-ci deus rangs de colonnes comme en l'autre, mais d'un ordre si différent, qu'on n'y remarque aucun rapport. Celles-ci sont de porphyre, et tous les accompagnements qui les soutiennent et qui les finissent, de bronze ciselé, dont la gravure représente quantité de dieux et déesses. La réflexion du lumière sur ce bronze en fait sortir um jour tout extraordinaire."
} 


\section{PIERRE CORNEILLE COMO RESISTÊNCIA}

Uma dentre as mais reconhecidas obras de Corneille, Le Cid - inicialmente classificada por ele como uma tragicomédia -, alcançou, simultaneamente, grande aceitação do público e desaprovação de teóricos e críticos. Tal reação negativa rendeu significativo volume de documentos, originando o episódio denominado a "Querela do Cid", nos anos 1637 e 1638, que a tornou importante, tanto para a dramaturgia quanto para a teoria, assim como para a crítica teatral. Além disso, esses episódios ganham relevância quando remetem à práxis cênica, ao tratamento do espaço teatral. Corneille escreveu Le Cid depois de desligar-se da sociedade chamada "Os Cinco Autores" (Les cinq auteurs), criada pelo Cardeal Richelieu, ${ }^{30}$ para congregar poetas capazes de divulgar suas ideias, em obras que atendessem a certo ordenamento gerado por um conjunto de costumes considerados importantes para o engrandecimento moral. Deviam ser seguidos pressupostos de excelência da língua francesa - em acordo com os postulados da Academia Francesa (Academie Française) - em uma dramaturgia que acompanhasse os cânones originados na interpretação da estética grega da Antiguidade, seguindo um movimento de quase um século de esforços da mesma natureza.

Tratava-se da aceitação do "modelo clássico", em detrimento do teatro praticado desde o medievo, de apelo popular na França e efetivado numa diversidade teatral significativa que incluía milagres, mistérios, moralidades, farsas e sotties. ${ }^{31}$ É possível observar essa tendência de atender ao mencionado "modelo clássico" já na obra de Étienne Jodelle (1532-1573) que procurava seguir estritamente as supostas regras da dramaturgia da Antiguidade. A sua tragédia Cleópatra [Cléopâtre (1552)] é considerada a primeira tragédie régulière, ${ }^{32}$ no caminho da tragédia neoclássica francesa que representou parte do empenho em busca de uniformidade e precisão, para combater aquilo que se entendia como a desordem na linguagem e na poesia, fortemente manifestada até as primeiras décadas do século XVII.

\footnotetext{
30 Ou Armand Jean du Plessis (1585-1642), primeiro-ministro e articulador do poder na corte francesa, desde 1628 até sua morte.

31 Espetáculo farsesco, de conteúdo politicamente agressivo, muito cultivado no século XV.

32 Cf. verbetes régulière e réglé, nas referências. No século XVI, na França, a tragédia que atendia naturalmente às regras; no caso, a convenção das três unidades [ação, tempo e lugar], derivadas de interpretações da Poética de Aristóteles. O substantivo regularité, assim como o adjetivo regulier[ière] tornaram-se fortemente ligados à tragédia; o Dictionnaire de l'Académie Française asssocia ambos ao verbete tragédia (consulta à sexta edição, de 1835). Regularidade refere-se, nesse contexto, a um padrão que se considera normal, esperado, sem extrapolações: O Dictionnaire universel des synonymes de la langue française inclue nos verbete réglé e régulière associações à tragédia. (GUIZOT, 1861, p. 628)
} 
Mitchell Greenberg (1986) se refere ao Classicismo francês como o protótipo de uma nova estética capaz de dar cunhos de "perfeição" à obra de arte, aplicando regras de harmonia e simetria, assim como outras propriedades similares em torno das quais o teatro que se fazia, então, apenas tateava. Ainda segundo Greenberg (1986), o novo modo de representação que os contemporâneos de Corneille identificavam como tragédie régulière, estabelecia relações tanto com a estética quando com o ethos. ${ }^{33}$

Em um primeiro sentido 'régulière' designa uma obra que segue as regras: regras de unidade, de imitação e verossimilhança que foram primeiramente articuladas (ou assim se acreditava) por Aristóteles. A tragédia regular obedece à lei. Reproduzida como espetáculo essa obediência serve continuamente como uma nova produção da origem da Lei, o ato que funda a organização social. Em segundo lugar, 'régulière' define os parâmetros estéticos de uma representação. Seguindo as regras do Classicismo ela alcança uma totalidade, uma integridade na qual as várias partes da obra são aglutinadas em um sistema unificado, em uma estrutura totalizada. ${ }^{34}$ (GREENBERG, 1986, p. 66)

A opinião delineada por Kastner e Atkins (1907) ao analisarem os estudos teóricos de Boileau (1838) [Nicolas Boileau-Despréaux (1636-1711)], indica o rumo que se procurava: "[...] a imitação dos antigos, não porque são antigos, mas porque ninguém [como eles] imitou a natureza com a mesma fidelidade [...]".35 (KASTNER; ATKINS, 1907, p. 128-129, tradução nossa)

Tal imitação da natureza encaminhava a necessidade de referência ao comentado real e/ou verdadeiro e começava a ganhar destaque com a repercussão de textos da Antiguidade clássica, principalmente a Poética, de Aristóteles, cuja interpretação foi incorporada à práxis cênica do Renascimento italiano e recebeu interpretação particular na França.

Pode-se dizer que a manifestação artística inclui uma aspiração latente de reconhecer princípios do real, se o considerarmos uma compreensão dinâmica

\footnotetext{
33 Ethos, como um conjunto de ideias e atitudes relacionadas a uma organização social em particular. 34 "In a first sense 'régulière' designates a work which follows the rules: those rules of unity, of imitation and verisimilitude that were first articulated (or so it was thought) by Aristotle. A regular tragedy obeys the Law. This obedience, reproduced as spectacle, continually serves as a new production of the Law's origin, the founding act of society. Secondly, 'régulière' defines the esthetic parameters of such a representation, by following the rules Classicism achieves a wholeness, an integrity of being in which the various part of the work are subsumed in a unified, total structure."

35 " [...] the imitation of the ancients not because they are the ancients, but because no one since has imitated nature with the same fidelity [...]."
} 
que guarda relação direta com sua contemporaneidade. Os artistas e filósofos do Renascimento na Itália são os primeiros que tratam do real de maneira sistemática, assim como da sua própria representação, provocados pelos escritos de Aristóteles e de Horácio. A indicação da aparência de real é uma aspiração já presente na mentalidade humanista de vincular o ser humano, seu ambiente e seus desejos, à literatura. Tal mentalidade ganha força na Itália, desde o século XV com a introdução da tradução latina da Poética de Aristóteles, considerando sua abordagem literária, diversa da obra de Horácio, Arte poética, já conhecida desde o século I antes de Cristo.

A divulgação do trabalho de Aristóteles através das traduções italianas, e principalmente os comentários de Ludovico Castelvetro (1501-1571), publicados em 1570, suscitaram muitos debates na França do século XVII. As interpretações francesas culminariam com a mencionada proposição radical que ficou conhecida como "regra das três unidades" (ação, tempo e lugar).

Mesmo levando em consideração as especulações acerca da autoria da Poética de Aristóteles enfatize-se que uma leitura atenta de suas considerações sobre esses pontos revela, com alguma clareza, que ele não estabeleceu essas três regras e, tampouco exige seu cumprimento na constituição da tragédia. Vale, por conseguinte, lembrar texto da Poética:

A tragédia é, então, um processo de imitação de uma ação que tem implicações sérias | é completa e tem magnitude; construída com uma linguagem sensivelmente atrativa, com cada um dos seus elementos distribuídos em partes; realizada efetivamente por pessoas e não por meio de narração; através de uma jornada de piedade e terror se dá a purificação dos atos trágicos, os quais têm essas características emocionais. ${ }^{36}$ (ARISTÓTELES, 1983, p. 25, tradução nossa)

Aristóteles considerava que a ação deve ser completa, apresentada por atores numa linguagem cuidadosamente elaborada com determinado ordenamento, tornando-a capaz de purificar profundos sentimentos relativos aos atos trágicos, através do terror e da piedade que os mesmos provocam, e não por alguém que narra. Certas argumentações teóricas em torno das interpretações dessa obra concorreram para a expectativa de determinados caminhos do espetáculo, com

36 "Tragedy, then, is a process of imitating an action which has serious implications, | is complete, and possesses magnitude; by means of language which has been made sensuously attractive, with each of its varieties found separately in the parts; enacted by the persons themselves and not presented through narrative; through a course of pity and fear completing the purification of tragic acts which have those emotional characteristics." 
especulações sobre as relações entre o tempo e o espaço que geraram demandas particulares à luz. A resposta dos artistas a tal demanda, de acordo com as regras aplicadas dentro das condições técnicas da luz em cada período, é questão importante para a presente abordagem.

As unidades de tempo e lugar já haviam aparecido em comentários anteriores. Castelvetro, contudo, mencionou pela primeira vez as três unidades como um conjunto regulador. Ainda que a unidade de ação apareça no seu trabalho mais como derivação do tempo e do lugar, o conjunto de regras se estabeleceu progressivamente como norma crítico-literária. É importante lembrar, no entanto, que ao comentar a Poética de Aristóteles ele aborda a dramaturgia como manifestação prática ligada ao palco, garantindo alcance diferenciado para seu trabalho, e oferecendo trilhas para conexões com a abordagem em curso. Confrontando a compreensão aristotélica, que lhe parece conferir um plano inferior para o espetáculo, ele diz: "[...] a opinião de Aristóteles que garante maior prazer na leitura de uma tragédia do que numa representação no palco, é falsa". ${ }^{37}$ (CASTELVETRO apud CHARLTON, 1913, p. 83, tradução nossa)

Para ler seu trabalho, portanto, pode-se considerar a assertiva que se segue: "[...] o palco é necessário para a sua [da dramaturgia] perfeição". ${ }^{8}$ (CASTELVETRO apud CHARLTON, 1913, p. 83, tradução nossa) Quando se considera o original italiano, transcrito em nota de rodapé, notamos que Castelvetro inclui a percepção visual, como aspecto importante na efetivação da tragédia, o que Charlton interpreta como sua realização no palco.

Tal abordagem ganha aqui importância, pois, como já deve estar evidente, uma manifestação cênica que não incorpora a luz pode ser considerada extrema, um evento para deficientes visuais, ou exceção radical. Perfeição, no contexto, refere-se tanto ao ideal de instrução que o teatro deve assumir, quanto à sua capacidade de persuadir o espectador do verdadeiro, do real, e, principalmente, da verossimilhança presente na cena. Se a abordagem da verossimilhança parecer dispensável em uma discussão da visualidade, vale ponderar: como uma estratégia da dramaturgia, o princípio da verossimilhança é concebido para repercutir na cena; sua efetivação visual, portanto, é inexorável. E Castelvetro elabora sua teoria observando certas relações entre as condições materiais do espetáculo e a verossimilhança, desinteressando-se por uma abordagem exclusivamente

37 Da tradução inglesa: "[...] the opinion of Aristotle that as much delight can be had from a mere reading of tragedy as from a performance of it on the stage, is false".

38 "[...] the stage is a necessity for its perfection, para o original italiano: [...] la vista essendovi necessaria, se la tragedia deve havere la sua perfettione, la quale ella ha, quando e recitata in atto con la vista convenevole." 
literária. Ele compara poesia épica e drama, partindo da sua compreensão de representação:

Na poesia, há dois possíveis modos de representar a ação, ou seja, através de palavras e coisas, ou usando somente palavras; um desses modos mais se assemelha à coisa representada, o outro menos; palavras e coisas constituem o modo mais semelhante, palavras sozinhas, o menos; portanto, no primeiro modo, palavras são representadas por palavras e coisas são representadas por coisas. ${ }^{39}$ (CASTELVETRO apud CHARLTON, 1913, p. 83-84, tradução nossa)

Para Castelvetro, a cena tem o poder de, assemelhando-se à coisa representada (a ação), convencer o espectador. Daí, o lugar deve atender a uma exigência particular: "[...] que o lugar da ação seja consistente, não apenas restrito a uma cidade ou a uma casa, mas a um único lugar, cuja extensão seja visível para uma pessoa". ${ }^{40}$ (CASTELVETRO apud CHARLTON, 1913, p. 84, tradução nossa) Destaque-se nessa assertiva a relação entre lugar e visão para o alcance da verossimilhança, ou seja, o espectador será convencido de que está diante de um lugar verdadeiro, ele acredita que está vendo (ou que pode ver) todo o lugar representado. A unidade de tempo está ligada, também, a presumíveis capacidades humanas de permanecer num mesmo lugar, consideradas as necessidades básicas, como beber e comer. Ele compreende, portanto, que sob a mesma premissa da verossimilhança, o limite temporal da ação pode contribuir: "[...] o tempo da representação e o tempo da ação devem coincidir exatamente". ${ }^{41}$ (CASTELVETRO apud CHARLTON, 1913, p. 84, tradução nossa)

Castelvetro propõe normas peculiares para a representação teatral, numa abordagem simples da verossimilhança, com o intuito de fazer a ação no palco alcançar aparência de verdade, ou de real:

[...] a tragédia deve ter como objeto uma ação que aconteceu em um lugar de extensão limitada e numa extensão temporal muito limitada, ou seja, no lugar e tempo nos quais e para os quais os atores que representam a ação se mantêm ocupados

\footnotetext{
39 "In poetry there are possible two modes of representing action, viz., either by words and things, or by words alone; one of these modes is more similar to the thing represented, the other less; words and things together are the more similar mode, words alone the less; for in the former words are represented by words and things by things, whilst in the latter both words and things are represented by words alone."

40 "[...] that the scene of the action must be constant, being not merely restricted to one city or house, but indeed to that one place alone which could be visible to one person".

41 "[...] the time of the representation and that of the action represented must be exactly coincident."
} 
na representação; e em nenhum outro espaço e em nenhum outro tempo. ${ }^{42}$ (CASTELVETRO apud CHARLTON, 1913. p. 84, tradução nossa)

Desses pressupostos para a elaboração precisa de um espetáculo, derivarão normas literárias da mentalidade neoclássica, solidificando a exigência das três unidades na dramaturgia. Na compreensão de Charlton, a especificidade do drama é assim sublinhada, na obra de Castelvetro:

O teatro representa coisas através de coisas e palavras através de palavras: a poesia épica representa coisas e palavras apenas através de palavras. O modo de Castelvetro julgar a questão determina um presságio do rigor sob o qual a verossimilhança será atrelada ao drama. ${ }^{43}$ (CHARLTON, 1913, p. 84, tradução nossa)

A incorporação desses axiomas aponta para um movimento teórico na França do século XVII, de grande relevância para este estudo, considerando-se a comentada inclusão da luz, mesmo involuntária, nas indicações de novos caminhos para a cena, sejam iniciativas de um teórico ou de um artista. Mesmo que o estudioso não se dê conta disso, ou o faça intuitivamente, como ocorre frequentemente até hoje. Ora, sem a luz a abordagem da verossimilhança seria obrigada a descartar a percepção visual. Por essa razão, é importante citar determinados autores, para enfatizar o papel da luz em estudos que abordem a visualidade particular da práxis cênica.

Na França, a divulgação do texto de Aristóteles através da tradução italiana, em 1549, gerou trabalhos de vários comentadores, elaborando-se uma interpretação norteada por compreensão particular da verossimilhança. Oscar Gross Brockett (1923-2010) afirmou:

Na doutrina neoclássica [derivada de interpretações da Poética de Aristóteles], a principal demanda era a busca pela verossimilhança, ou aparência de verdade. A verossimilhança é um conceito complexo, que pode ser dividido em três objetivos secundários: realidade, moralidade e generalidade. No que concerne à realidade os críticos alertavam os dramaturgos para que limitassem seus assuntos e tratassem de eventos que pudessem

\footnotetext{
42 "[...] tragedy ought to have for subject an action which happened in a very limited extent of place and in a very limited extent of time, that is, in that place and in that time, in which and for which the actors representing the action remain occupied in acting; and in no other place and in no other time."

43 "Drama represents things by things, and words by words: the epic represents things and words by words alone. Castelvetro's way of stating the case is a foreboding of the rigor with which verisimilitude is to be screwed on the drama. The result is the unities."
} 
ocorrer na vida 'real'. Em consequência disso, a fantasia e o sobrenatural eram comumente evitados, a menos que representassem elementos dos mitos, da história, da Bíblia, e, mesmo nestes casos, eles eram minimizados tanto quanto possível. Além disso, artifícios como o coro e o solilóquio eram desaconselhados, pois se acreditava que não é natural uma personagem falar em voz alta quando está sozinha, ou que ela mencione questões pessoais na presença de um grupo tão grande quanto o coro. Esses mecanismos dramatúrgicos foram abolidos, introduzindo-se outros, como o mais típico de todos, o[a] confidente, que acompanhava as personagens centrais da trama: deste modo, elas poderiam revelar seus segredos mais íntimos. ${ }^{44}$ (BROCKETT, 1995, p. 126, grifo e tradução nossos)

As correspondências entre verossímil e verdadeiro provocaram inúmeras discussões e abordagens teóricas. O uso da verossimilhança ou a aparência de verdade como guia gerou uma linha limítrofe que pode se revelar tênue, apresentando como referência o juízo de quem determina o que é verdadeiro, incluindo-se aspectos da técnica dramatúrgica, e até por trás deles, questões de natureza política. Surgers (2005b) menciona a relação entre realidade e verdade, deixando provocações para a observação da verdade neoclássica, que inclui, segundo Brockett, três objetivos que a sustentavam: a realidade, a moralidade e a generalidade.

A verdade e o real estavam submetidos a certa generalização das relações humanas, do comportamento, que descartava particularidades. Criava-se, então, um complexo universo que se constituía de um conjunto de normas aplicadas a um comportamento típico generalizado, ideal, tanto da humanidade quanto da "natureza", passível de ser observado sistematicamente e difundido, inclusive pelo teatro. Brockett (1995, p. 127, tradução nossa) traz a seguinte ponderação:

Ainda que o ideal didático tenha sido frequentemente afirmado no teatro clássico, ele não recebeu ênfase até que os humanistas do Renascimento compreenderam que tal ideal era necessário

\footnotetext{
44 "In neoclassical doctrine the fundamental demand was for verisimilitude, or the appearance of truth. A complex concept, verisimilitude may be divided into three subsidiary goals - reality, morality, and generality. In relation to reality critics urged dramatists to confine their subjects to events which could happen in real life. Consequently, in practice, fantasy and supernatural events were usually avoided unless they were integral parts of some received story from, myth, history, or the Bible, and even in these instances they were minimized as much as possible. Furthermore, such devices on the grounds that it is unnatural for characters to speak aloud while alone or to discuss private matters in the presence of a group so large as the chorus. These devices were replaced by others, of which the most typical was the inclusion of a confidant (or trusted companion) for each of the main characters, so that he might believably reveal his inmost secrets."
} 
para justificar o estudo e a produção literária, numa época em que o aprendizado estava se afastando dos conceitos puramente teológicos. ${ }^{45}$

Brockett compreende que a necessidade de estabelecer o teatro como ferramenta útil para a sociedade fez com que os estudiosos afirmassem sua capacidade de instruir, pondo, num plano inferior, a práxis literária. Na França do século XVII, tratava-se de instalar, através do teatro, um modelo de realidade baseado no decorum $^{46}$ vigente, que determinava sucesso para os que cumpriam as regras e punição para quem delas se desviasse.

Pierre Corneille alcançou sucesso, desde suas primeiras iniciativas, e ganhando grande prestígio público com Le Cid (1637) desencadeou uma ruidosa controvérsia, provocando ciúme nos concorrentes, incluindo, segundo alguns autores, o próprio Richelieu, que se considerava poeta. Em primeiro lugar, deve-se sublinhar a desaprovação de Richelieu ao uso de temas espanhóis como o duelo e a pompa, devido ao confronto político entre as duas nações. Além disso, a obra de Corneille recebeu severas críticas baseadas na regra das três unidades. Entre aqueles que polemizaram contra Corneille, estavam Jean Mairet (1604-1686), Georges de Scudéry (1601-1657), Calveret, Charles Faucon des Ris (1612-1693) e Pierre Scarron (1541-1603). Scudery escreveu Observações sobre o Cid [Observations sur le Cid (1637)], enquanto Jean Chapelain (1595-1674) produziu uma compilação encomendada por Richelieu e denominada Os Sentimentos da Academia sobre o Cid [Les sentiments de l'academie sur le Cid (1638)], atacando duramente Corneille, acusando-o de desobedecer às normas, o que contribuiu para a mencionada controvérsia sobre sua obra.

A situação levou Corneille a deixar a sociedade (Les cinq auteurs) no vencimento do contrato, pensando até em encerrar sua carreira como dramaturgo. No entanto, além de responder com Desculpe, Ariste [Excuse à Ariste (1637)], Corneille escreve mais tarde, não apenas tragédias, mas também textos teóricos em sua própria defesa, como os Três discursos sobre a poesia dramática [Trois discours sur le poème dramatique (1660)], cujo tema central é a sua interpretação do modelo grego. O estudioso francês Jean-Jacques Roubine menciona o próprio Corneille, dando abrangência para a presente discussão. Na compreensão de Roubine, o mais importante para Corneille era o prazer do espectador; partindo dessa premissa, mais que perseguir o verossímil e o verdadeiro, o caminho seria buscar o necessário. Corneille teria acreditado que o prazer

45 "Although the didactic ideal had often been stated in classical times, it was not given primary emphasis until the Humanists of the Renaissance found it necessary to justify the study and writing of literature at a time when learning was moving from purely theological concerns."

46 Ou normas de conduta baseadas na moralidade. 
do público justificaria um grande efeito, pondera Roubine, acentuando sua intenção de se afastar dos modelos aprisionados ao verossímil, quando ele diz: "[a verossimilhança é um] privilégio que Aristóteles nos dá, e não uma servidão que ele impõe”. (CORNEILLE apud ROUBINE, 2003, p. 36)

Roubine define as dificuldades que a postura de Corneille lhe renderam:

A contestação cornelliana visa claramente salvaguardar uma liberdade de invenção constantemente questionada desde a Querela do Cid, mas talvez também preservar para o dramaturgo a possibilidade de explorar essa mina que é a História e servir-se teatralmente de acontecimentos inacreditáveis, mas incontestáveis. De todo modo, a argumentação de Corneille não derrubará a convicção dos aristotélicos de estrita obediência. Por mais prestigiado que fosse o autor de Rodogune se verá isolado e sob suspeita de heresia. (ROUBINE, 2003, p. 36, grifo nosso)

Os estudos de Corneille, assim como sua poesia dramática, contudo, não representam um movimento isolado, sendo precedidos pelo trabalho de outros dramaturgos e teóricos, que refletem uma provável concordância com a dramaturgia clássica, e com seus reflexos na obra de Aristóteles. Deve-se mencionar Jean Mairet (1604-1686) que em 1631 dá um passo importante, ao concluir a tragicomédia Silvanire ou A morta-viva (La Sylvanire ou La morte-vive). No texto teórico que aparece antes da peça, denominado Prefácio em forma de discurso poético (Preface en forme de discours poétique), ele apresenta seu postulado sobre a poesia, incluindo uma discussão das regras da poesia dramática. Segundo Hartnoll (1957), na sua tragédia Sofonisba [La Sophonisbe (1634)], Mairet aplica a regra (das três unidades), produzindo o primeiro grande espetáculo francês que, atendendo a essa teoria, é representado num palco público, introduzindo o modelo clássico no teatro francês de sua época.

O debate que acirraria as críticas a Le Cid começou a se delinear desde o fim da primeira metade do século XVI. Em 1549, a Pléiade ${ }^{47}$ incorpora o que considera princípios aristotélicos na poesia dramática, pondo de lado a teoria de Fabri e Sibilet. ${ }^{48}$ Autores, como Julius Caesar Scaliger (1484-1555), Jacques Grévin (1538-1570), Jean De la Taille (ca. 1540-1607) e Pierre Ronsard (1524-1585), apresentaram contribuições em

47 Associação francesa do século XVI, composta de sete autores, entre eles Étienne Jodelle, liderados por Pierre de Ronsard (1524-1585). Foi assim denominada numa referência à Pléiade, grupo também de sete autores, atuantes no reinado de Ptolemy II Philadelphus (285-246 a.c.).

48 Obras como Le grand et vrai art de pleine réthorique (1544), de Piérre Fabri, e Art poétique (1548), de Thomas Sibillet, perdem espaço para interpretações da Poética de Aristóteles. 
favor das três unidades, enquanto Jean de Beaubreuil, ${ }^{49}$ Pierre de Laudun Daigaliers (1575-1629) e François Ogier (1597-1670) assumem posições contrárias a tais ideias. Como já foi dito, a Academia Francesa incorporou oficialmente, em 1635, sob a orientação de Richelieu, a regra das três unidades como premissa para a produção da tragédia, na França. A questão já não era mais o que Aristóteles escreveu e, sim, uma censura imposta pelo pensamento "oficial". Na mesma conjuntura, subsistia o espetáculo cômico, farsesco, de natureza popular e espaço cênico multifacetado, assim como a pièce à machine, com cenários sucessivos operados por intricados mecanismos.

Interpretações diferenciadas da verossimilhança ao longo da história, orientadas pela compreensão particular das suas referências baseiam-se, por sua vez, nas necessidades humanas. De acordo com Aristóteles, a dramaturgia parece impregnada de flexibilidade, fazendo o poeta interessar-se menos por aquilo que aconteceu na história (da humanidade) e mais pelo que poderia haver ocorrido, no campo do provável, assim como pelas possibilidades de natureza simbólica. Tal flexibilidade pode estar relacionada às diversificadas abordagens do conceito de realidade e de verdade, assim como das suas referências. A verossimilhança, portanto, pode se instituir tanto no interior da obra, levando-se em conta os elementos constitutivos de cada manifestação poética, quanto do ponto de vista externo, ao se considerar o papel que uma obra desempenha na cultura, incluindo as imposições políticas. O discurso da obra de arte interage de modo dinâmico, portanto, com outros discursos ativos na sociedade.

As normas que orientam esses discursos atuam como referência, o conhecimento do qual o espectador se apropriou contribui para sua relação com a obra e atua na sua interpretação do conceito de realidade. A unidade de ação devia ser efetivada num jogo entre o possível e o necessário, instalando-se de modo particular em cada obra. A mimesis aristotélica refere-se às inúmeras variáveis do comportamento humano, libertando o drama da noção de imitação vinculada a um padrão fundado na imutabilidade ou na cópia simplista. Como condição para a efetivação do discurso dramático, portanto, o verdadeiro e real podem representar um espectro de grande amplitude; importa, sim, a coesão interna que regula os elementos da narrativa. No interesse da investigação em andamento, a visualidade da cena pode exercer o direito de interagir com esses pressupostos.

49 Não foi possível encontrar informação segura sobre sua data de nascimento e/ou óbito; é, no entanto, conhecida, a sua obra Régulus, de 1582, em cujo prefácio ele questiona a regra das três unidades, que classifica de supersticiosas. Bernard Weinberg publicou uma compilação de estudos críticos, escritos no século XVI, que inclui o mencionado trabalho de Beaubreuil. A compilação foi intitulada Critical prefaces of French Renaissance, publicada em 1950, pela Northwestern Universit Press de Illinois, EUA. 
A reação dos artistas franceses (principalmente a partir do século XVI) ao modelo multifacetado e simultâneo da práxis cênica popular derivada do padrão católico medieval estabeleceu a necessidade de uma ação que parecesse verdadeira e natural, como regulação para o jogo dramático. Daí, sua relação com o espaço e o tempo deveria também parecer verdadeira e natural. Como diz Mairet, no prefácio da sua tragicomédia pastoral La Silvanire ou La morte-vive: "A segunda condição (para a constituição da poesia dramática) é a unidade de ação, ou seja, deve haver uma ação mestra e principal à qual todas as outras se referem como as linhas em uma circunferência convergem para o centro".50 (MAIRET, 1631, p. 27, tradução nossa $)^{51}$ Vale destacar em Mairet a metáfora visual quando ele se refere à circunferência, indicando uma figura geométrica definida pelo equilíbrio. Sublinhe-se essa analogia, destacando sua intimidade como a visualidade; na verdade, a ação cênica reguladora poderia ser compreendida como uma esfera, numa relação direta com a qualidade tridimensional do espetáculo.

No que se refere ao tempo, Gazoni (2006, p. 49) cita Aristóteles: "E ainda, pela extensão: enquanto a tragédia se esforça, o mais possível, para dar-se dentro de um único período solar, ou pouco se distinguir disso, a epopeia é indefinida quanto ao tempo e por isto difere". Efetivando suas observações, Gazoni (2006, p. 49, grifo do autor) apresenta a nota a seguir:

${ }^{111}$ Não se pode defender, contra toda argumentação, que a frase tenha o caráter prescritivo rígido que quis ver nela o Renascimento. Vários comentadores (Halliwell, Dupont-Roc e Lallot, Gernez) chamam a atenção para este fato. Deve-se dizer, entretanto, a favor da leitura renascentista, que a presença do 'mais possível' (hotimalista) e do 'se esforça' (peiratai) pode induzir a tal interpretação.

Como se sabe, o século XVII na França exemplifica certo radicalismo na leitura do "mais possível" assim como do "esforço", presentes no texto aristotélico, e inclui limites para o tempo da ação, como aparece em Chapelain (apud ARNAUD, 1888, p. 343, tradução nossa): “[...] Porque a ação termina, geralmente, entre dois sóis, isto um pouco mais ou menos que a metade de vinte e quatro horas [...]"..$^{2}$ Do ponto de vista da luz, a verossimilhança permitiria, ou exigiria,

50 “La séconde condition est l'únité d'action, c'est à dire qu'il doit avoir une maitresse e principal action à laquelle toutes les autres se rapportent comme les lignes de la circonference au centre."

51 A edição usada na citação não apresenta numeração de páginas no prefácio. Incluí uma numeração arbitrária, na cópia com a qual trabalhei, para orientar a pesquisa e permitir o acesso posterior de interessados.

52 "[...] car d'ordinaire l'action se termine entre deux Soleils, c'est à dire un peu plus ou un peu moins que la moitié des vingt-quatre heures, [...]." 
um tratamento muito particular, de acordo com a ação e o seu ambiente. Dois sóis, ou seja, a transição dia-noite-dia sugere ângulos, intensidades, cores, tudo em mudança constante. Hoje em dia, tal sugestão permitiria a elaboração de um projeto de luz com grande sofisticação e alto grau de dificuldade.

Para resistir a uma crítica efetivamente qualificada, seria recomendável a presença de um especialista na realização de tarefa tão específica. Parece claro que, atualmente, a elaboração de um projeto de luz para um espetáculo ligado à estética realista, suscitaria a aplicação de muitas variáveis. Certas fórmulas cristalizadas, portanto, podem ser impotentes para criar os diversos momentos, pois cada novo espaço apresenta traços particulares que indicam relações dinâmicas com as fontes de luz atuando no ambiente, o que exigiria o tratamento muito particular e um olhar capacitado.

Ainda através de Arnaud pode-se tomar conhecimento de que, provavelmente entre 1570 e 1572, já aparece num prefácio Da arte da tragédia (De l'arte de la tragédie), na obra Saul o furioso (Saul le furieux), de Jean de la Taille a presença da unidade de lugar na dramaturgia do período em questão: "A história ou o jogo devem ser sempre representados em um mesmo tempo e em um mesmo lugar". ${ }^{53}$ (DE LA TAILLE apud ARNAUD, 1888, p. 117, tradução nossa) Sem identificar na Poética de Aristóteles, ou mesmo em Horácio, suporte para essa regra, alguns autores, como Kastner e Atkins (1907), a classificam de "pura invenção". Ainda assim, não se pode desconsiderar a veemência de Nicolas Boileau-Despréaux, ao escrever sua Art poétique (1674): "Que o lugar da cena seja fixo e demarcado [...] Que em um lugar, um dia, um fato único seja consumado [...]".54 (BOILEAU-DESPRÉAUX, 1838, p. 29-30, tradução nossa)

Aqui se vislumbra o passo seguinte na construção da visualidade dessa derradeira fase da tragédia regular (tragédie regulière) francesa do século XVII. Ao discutir a interpretação francesa de Aristóteles interessa a provável atuação da luz naquele contexto. A exigência de um único lugar fixo e demarcado pode ter sido uma prática comum, em Molière e Racine, como exemplos; parece prudente, entretanto, considerar especulações que dão conta de particularidades apresentadas ou exigidas por certos dramaturgos para a configuração da visualidade nos seus espetáculos, como os últimos citados, que teriam solicitado a instalação de telões de fundo especialmente concebidos para espetáculos montados a partir de sua dramaturgia. Ou seja, o lugar único ganharia um telão de fundo originalmente escolhido - ou pintado -

\footnotetext{
53 "Il faut toujours représenter I'histoire ou le jeu en un mesme temps, et en un mesme lieu."

54 "Que le lieu de la scène y soit fixe et marquée. [...] Qu'en un lieu, qu'en un jour, un seul fait accompli [...]."
} 
para cada espetáculo, ou ato, como uma mudança ou particularidade excepcionalmente permitida.

Em 1640 D’Aubignac escreveu A prática teatral (La pratique du théâtre) para atender ao Cardeal Richelieu, que demandava esclarecimentos sobre a Poética de Aristóteles. D’Aubignac assumiu a responsabilidade, uma vez que Jean Chapelain não aceitou a incumbência e Hippolyte-Jules Pilet de la Mesnardière (1610-1663) deixou inacabado seu trabalho depois da morte de Richelieu (1642). D'Aubignac publicou seu texto em 1657, estabelecendo regras para os dramaturgos franceses na direção da tragédie regulière ou classique. Isto parece sugerir uma reação de D’Aubignac às proposições espaciais da simultaneidade dos décors à compartiments, assim como ao exagero de mudanças mecânicas nas pièces de théâtre à machine (peças representadas com a ajuda de máquinas).

Reservando a parte final do último livro (capítulo) do seu estudo a uma proposição teórica do espetáculo e até da cenografia, ele louva a destreza dos gregos da Antiguidade. Ao elaborar sua teoria dos Spectacles (cenografia e efeitos) ele apresenta três categorias: coisas, ações e a simultaneidade de coisas e ações. Para coisa, D’Aubignac (1715) usa como exemplo o céu, o mar e um grande palácio; para ação, alguém que se atira do alto de uma torre ou de uma rocha e cai no mar; para coisas e ações, um combate naval (que reúne embarcações e homens). Sua proposição teórica ainda considera que tanto coisas quanto ações podem ser Miraculosas uma divindade que desce dos céus; Naturais - um belo deserto ou uma montanha em chamas; e Artificiais - as grandes obras de arte, como um templo. Por outro lado, ele adverte seus contemporâneos: "Mas agora, ainda que a Corte não os considere inconvenientes e que o público se aglomere para contemplar qualquer coisa desta natureza, eu não aconselharia nossos poetas a empregarem esforços nessas Peças Representadas com a Ajuda de Máquinas [...]". ${ }^{5}$ (D’AUBIGNAC, 1715, p. 323, tradução nossa)

Como encaminhamento para uma teoria do espetáculo, ele declara: "Restam os cenários permanentes, qualquer que seja a sua natureza; nesse sentido sugiro que sejam reduzidos tanto quanto possível". ${ }^{6}$ (D'AUBIGNAC, 1715, p. 323, tradução nossa) Ficam sublinhados, ainda, cuidados específicos: "Primeiramente, eles devem ser indispensáveis, de modo que a peça não possa ocorrer sem esse orna-

55 "Mais maintenant, bien que la Cour ne les ait pas desagréables, \& que le peuple fasse foule a toutes les occasions de voir quelque chose de semblable, je ne conseillerois pas a nos poètes de s'occuper souvent à faire de ces Piéces de Théâtre à Machines [...]."

56 “Il reste donc les Décorations permanentes, de quelques nature qu'élles soient; a quoi mon avis seroit de se restraindre autant qui seroit possible." 
mento [...]. Em segundo lugar, eles devem ser agradáveis para a visão, pois é este charme que atrai as pessoas". ${ }^{57}$ (D’AUBIGNAC, 1715, p. 323, tradução nossa)

D’Aubignac já anuncia, portanto, a práxis cênica como um organismo em funcionamento equilibrado, pela interação dos seus elementos. Ainda que use termos como ornamento e charme para se referir ao cenário, e esses termos possam indicar uma apreensão superficial da cenografia, ele também diz que o espetáculo não se efetivará sem o mencionado "ornamento", ampliando a sua compreensão para considerar o dispositivo cenográfico como aspecto indispensável à constituição da práxis cênica. Recupere-se o vocábulo hedusma, usado por Aristóteles e já mencionado no capítulo "Um presumível ponto de partida". Trata-se da noção de "tempero" que alcança a abrangência de traços particulares dos quais a ação cênica é impregnada, sugerindo temperaturas, aromas, sabores, texturas, formas e cores, com os quais o espectador estará interagindo através das imagens de natureza diversificada que atuam na cena.

\section{A CENA COMO LUGAR GENÉRICO}

As preocupações de D’Aubignac ainda incluem a boa execução dos cenários, de modo que mesmo algo abominável, monstruoso e horrível, se comparado com a natureza, fosse bem realizado e visualmente agradável; devia ser atendido o decoro, ou seja, respeitadas as regras de conduta, do gosto e da moralidade, da justeza; o dispositivo cenográfico devia ser de fácil execução e os mecanismos deviam permitir agilidade às mudanças de cenário, evitando torná-las enfadonhas para o espectador; devia ser observada a verossimilhança da imagem em cena, pois não parece razoável - como exemplo - colocar uma prisão diante da sala de um castelo, ou do quarto de uma princesa. Ele diz ainda:

Também não podemos fazer cenários contrários à Unidade de Lugar, como o quarto de um príncipe no proscênio, do qual se pode entrar numa floresta colocada no mesmo nível [sem qualquer elevação no piso], pois toda essa ficção, por mais bela que seja para os olhos, parece deformada à Razão, que a reconhece como falsa, ridícula, e impossível..$^{8}$ (D’AUBIGNAC, 1715, p. 325, tradução nossa)

\footnotetext{
57 “Premierement, il faut qu'elles soient necessaires et que la piéce ne puisse être joüée sans cet ornement; [...] Secondement, ils devoient être agréables à voir, car c'est ce charme que le peuple s'y laisse attirrer."

58 “Il ne faut aussit faire des Décorations qui soient contraires à l'Unité du Lieu, comme de supposer l'Avant-Scéne pour la chambre d'un Prince, de l'aquelle on entreroit de plain-pied das une forêt; car toutes ces fictions, qoui que belles à l'oeil paroeint difforme à la Raison, qui les connoît fausses, impossibles e ridicules."
} 
D’Aubignac (1975) sublinha ainda a atenção com o planejamento das mudanças, evitando-se o burburinho das exclamações dos espectadores, que os impediria de ouvir o texto. Os cenários, portanto, deveriam mudar no início e no fim de cada ato. O teatro sofisticado, nobre e de elevação moral, atendendo aos princípios do provável e do possível deveria, de acordo com o pensamento da Academia, fazer a ação se passar em um lugar único. Aí se originou outra proposição espacial para a cena, fundamentada na unidade de lugar mencionada por D’Aubignac, e que ficou conhecida como palais à volonté. Tratava-se de um lugar fictício, genérico, mas capaz de abrigar quaisquer categorias de ação cênica. Tal configuração espacial não se poderia efetivar sem a elaboração de um modo visual de pensar, o que demandava qualidade específica para a luz, repercutindo na visualidade de cada acontecimento cênico-espetacular.

Diante da dramaturgia do período podem-se compreender certos ajustes procedidos pelos autores para o atendimento da verossimilhança, originando uma ação cênica capaz de interagir com a visibilidade, sem comprometer aquilo que se considerava razoável e verdadeiro. A cena, por seu turno, também pode ter recorrido à mesma categoria de ajustes, incluindo certas mudanças, mas procurando reforçar, como princípio, uma reação às tipologias cênicas praticadas na simultaneidade do décor à compartiments e na feérica movimentação da piéce à machines, consideradas exagero ou desvio dos propósitos da verossimilhança, do provável e necessário.

Durante a primeira metade do século XVII, no reinado de Louis XIII, os espetáculos começavam nas primeiras horas da tarde permitindo que se tirasse vantagem da luz natural e possibilitando, inclusive, o seu uso, com janelas laterais dos teatros abertas durante alguns períodos no ano. Pode-se considerar, também, que se tratava de uma medida para evitar tumultos noturnos em locais fechados, além da necessidade de reduzir o alto custo da luz produzida artificialmente. Um decreto de Louis XIV, seu filho, autorizou que os teatros funcionassem a partir das quatro ou cinco horas, à tarde, o que tornou imprescindível a aplicação de luz artificial para prover visibilidade, desde o escurecer. Por outro lado, qualquer que fosse a fonte ou fontes - a cena precisaria contar com a luz, para se efetivar. No entanto, seria difícil assegurar o compromisso com a verossimilhança e com o verdadeiro nas pièces à machine ou no espetáculo que usava o décor à compartiments.

Roubine (2003) discute a "Querela do Cid" e sua relação com tais convenções, no interesse da verossimilhança: 
É com a Querela do Cid que a regra de um lugar único vai se impor e que a tradição barroca será condenada. Quer a ação se desenrole em vários lugares figurados simultaneamente (cenário simultâneo) ou sucessivamente (mudança de cenários durante os entreatos), tais opções são denunciadas como inverossímeis. Pois, como um mesmo lugar real poderia representar vários? E, além disso, a multiplicação dos lugares é fonte de confusão para o espectador. É D’Aubignac quem fará a exposição mais clara e mais sistemática da nova regra. Em primeiro lugar, baseia-a no princípio de verossimilhança. Um único espaço, o do palco, não seria capaz, desse ponto de vista, de representar dois, 'por exemplo a França e a Dinamarca, a galeria do Palácio e as Tulherias'. Não admite portanto nem mesmo a extensão do espaço da ação à área geográfica que um indivíduo pode percorrer em um dia. (ROUBINE, 2003, p. 47-48)

A maioria dos autores redigia normas que se referiam originalmente à dramaturgia e levavam em conta a flexibilidade com a qual contaria o dramaturgo. $\mathrm{Na}$ abordagem da verossimilhança formulada por D'Aubignac, portanto, seria impossível convencer o espectador que um lugar pudesse conter ou se transformar em tantos outros, como num passe de mágica. Afinal, a interpretação aristotélica francesa baseava-se em princípios da racionalidade dirigida contra o que consideravam obscurantismo do passado. Para criar na cena, com alguma credibilidade, as intenções do dramaturgo, o espetáculo deveria incorporar diversos aspectos técnicos que integravam o que Roubine (2003) chama de componentes da representação, listando: figurinos, gestual e dicção dos atores.

Ainda que devam ser consideradas as características técnicas daquele momento, Roubine, assim como muitos críticos e teóricos, exclui a luz, reduzindo sua condição de importante componente da representação. Elaborar cada ambiente e transformar suas mudanças em momentos de magia e atração, nos espetáculos do Barroco, isolar ambientes nos cenários simultâneos (décor à compartiments) e, ainda assim, revelar de modo convincente cada quadro, eram tarefas difíceis, mas essenciais para o espetáculo.

Essa questão inclui, portanto, um aspecto importante e pouco discutido. Os espetáculos teatrais da época, que resultavam ou que adotavam as normas neoclássicas das três das unidades - apresentando ação, tempo e lugar como obrigatoriamente únicos - sugerem uma abordagem específica da luz, justificada pela economia de movimentos e/ou interferências, exigida por um espetáculo com tais características. Pressupõe-se que, no caso, as cores, os ângulos, as texturas, 
os efeitos, inclusive na luz, deveriam ser criteriosamente planejados, muitíssimo calculados e executados com parcimônia. Se a ação cênica deveria ocorrer em um único lugar, numa extensão de tempo muito limitada, aplicando a narrativa linear, qualquer movimento ou efeito injustificado poderia perturbar essa noção de "unidade", elemento decisivo da visualidade pretendida. Mais importante que impor uma "presença visível" da luz é compreender a qualidade da luz proposta pelo espetáculo, ou seja, sua visualidade. Essa postura permite avaliar cada interferência que se pretenda incluir, exigindo decisões autônomas do iluminador, mas necessárias à natureza compósita da práxis cênica.

É importante contemplar nessa conjectura a dramaturgia de Jean Racine (16391699), poeta, ministro de Estado, diretor teatral e fundador da Comédie Française. Ele escreve suas peças em um momento no qual o apelo popular pela exacerbação de imagens feéricas da Opéra já enfrentava resistência. A influência do teatro italiano resultava numa elaborada ornamentação e exuberância visual ligada a muitos movimentos nos dispositivos cenográficos, associados ao ilusionismo e à teatralidade particular do Barroco, o que gerava críticas contundentes. Para exemplificar o contexto no qual Racine se insere, Karl Vossler (1872-1949), ${ }^{59}$ menciona o trabalho do seu antecessor, Corneille, para lembrar como ele procurou superar a interferência dos produtores e cenógrafos:

[...] ele [Corneille] varreu do seu teatro todo o encantamento do brilho secular e refinado, todas as transformações e surpresas no cenário, todas as maravilhas e metamorfoses; ele os transferiu para as mentes e para as almas dos seus heróis e para o poder dos seus discursos. ${ }^{60}$ (VOSSLER, 1972, p. 116, tradução nossa)

Corneille procurava combater aquilo que, em sua opinião, era uma rápida sucessão de cenas com multiplicidade vaga e confusa, cores em excesso, exagero ilusionista que resultava em desordem, e decidiu acentuar a personagem que fala, transformando os outros componentes do espetáculo naquilo que Vossler (1972) qualifica como uniformidade cinza.

O ambiente no qual se encontrava mergulhada parte do teatro, no momento da entrada de Racine no universo da dramaturgia, é assim descrito por Vossler (VOSSLER, 1972, p. 115): "Uma cena austera, sem cor, e personagens infladas por

59 Linguista alemão, foi professor de literatura românica na Universidade de Munique, e também trabalhou na Universidade de Heidelberg.

60 "[...] he swept from his theater all the enchanting brilliance of a secular and courtly nature, all the transformations and surprises in décor, all the wonders and metamorphoses; he transferred them to the mind and souls of his heroes and to the power of their speech." 
grandes decisões, conscientes da sua responsabilidade moral, proferindo palavras que retumbavam [...]". Tais comentários despertam de modo próprio a atenção quando ele, mais uma vez, compara Corneille e Racine; na compreensão de Vossler, Corneille define suas personagens como silhuetas traçadas com linhas precisas e duras, enquanto Racine permite que o espírito da personagem se expanda, fazendo-a desaparecer, confundindo-se na atmosfera, para emergir de novo maravilhosamente viva. Seu tratamento desfavorece o detalhe naturalista, pondo na voz do ator as cores e os sons, tornando a dramaturgia responsável por instalar tons, meios-tons, ambiguidades, luz e sombra.

A obra de Racine revela a consistência peculiar da sua formação jansenista, movimento espiritual de cunho puritano que desaprovava a Contrarreforma. Órfão desde os três anos, ele passou a viver sob a supervisão dos avós, morando em Port Royal, centro do rigor cristão de cunho ortodoxo, cuja severidade monástica sob a autoridade dos sacerdotes incluía, além dos estudos teológicos, a filosofia. O aprendizado da língua grega lhe permitiu ler no original e traduzir os três grandes dramaturgos do teatro grego, Ésquilo, Sófocles e Eurípedes, aproximando-o do teatro clássico, da natureza do trágico em si.

Em 1666, Racine inicia um conjunto de peças consideradas até hoje, principalmente na França, obras primas do teatro. Vossler observa como postura chave de Racine o rigor no princípio da unidade de lugar no seu teatro, cujas peças se completam em um espaço ou lugar cênico concebido de forma rigorosa e econômica, em parceria com a força do discurso, do som, da palavra falada, sublime e solene, de qualidade musical. Vossler (1972, p. 117) enfatiza o ponto, quando afirma: "O teatro de Racine não necessita ser representado para ser completamente efetivo". ${ }^{61}$ A verdade, contudo, é que suas peças foram encenadas. Para ele, o espetáculo era tão importante que o fez romper relações com o já reconhecido Molière, em 1665, para montar suas peças no Teatro Hôtel de Bourgogne. Acredita-se que uma das razões, senão a principal, para tal mudança, teria sido a experiência da companhia do Hôtel de Bourgogne na montagem de tragédias. A documentação acerca do tratamento visual dispensado à sua dramaturgia nos espetáculos ali montados é escassa. A leitura atenta das suas peças, contudo, oferece pistas da natureza cênica que ele almejava para o seu texto.

Tome-se como primeira fonte Ifigênia [Iphigénie (1674)], apresentada pela primeira vez no mesmo ano durante as festividades dedicadas a Louis XIV, no Teatro de Versailles. Ainda que um estudioso, teórico ou diretor possa perscru-

61 "Racine's drama does not need to be performed in order to be completely effective." 
tar no diálogo pistas para instalar a ação da peça em outro, ou em outros lugares, Racine afirma, na edição publicada em 1675, depois de listar as personagens envolvidas: "A ação se passa em Áulida, na Tenda de Agamêmnon"; 62 e não faz qualquer menção a eventuais mudanças de lugar, durante a peça. Já na abertura do diálogo, entretanto, ele procura assegurar que o espectador - não tendo lido a rubrica - seja introduzido na atmosfera da cena, e dá a Arcas, servo do Rei, tal função: "É o Senhor, sem dúvida! Que importante motivo | Vos faz adiantar-se tanto à Aurora? | Uma tênue luz, apenas, me guia e te ilumina | Vossos olhos e os meus são os únicos abertos em Áulida | Ouviste no ar algum rumor? | Teriam os ventos nos respondido esta noite". ${ }^{63}$ (RACINE, 1675, p. 1, tradução nossa) Essa tradução descarta qualquer interesse em alcançar o mérito poético do texto em questão, e apenas procura interpretar o desejo do autor em revelar o ambiente e a atmosfera na qual instala seu drama: o sol ainda está por nascer, e o ambiente se encontra envolto em penumbra.

Racine (1675) apresenta a situação através da réplica de Arcas investindo-o do papel de arauto da atmosfera da ação. Essa é uma estratégia historicamente conhecida e eficaz para o drama, sendo aplicada por Shakespeare e Ésquilo de modo exemplar. Mas em Racine abre-se uma nova via: seus espetáculos ocorriam em locais fechados, como o Hôtel de Bourgogne, o que sugere a possibilidade do emprego de luz artificial para criar as atmosferas desejadas. Em Ifigênia, a ação se refere a um Rei que decide sacrificar a própria filha para obter a vitória na guerra e, toda a peça ocorre em um mesmo ambiente, tornando necessária a narração de partes importantes dos acontecimentos. Ou seja, o espectador não está obrigado a comprimir o tempo e o espaço para localizar no palco os eventos; ele é provocado a ver, na sua imaginação, as longas viagens, as complexas ações da campanha, e tudo aquilo que ocorre fora do espaço "único" destinado à cena.

Compreendendo o espetáculo como espaço para experimentação, não seria surpresa se na cena seis do terceiro ato um diretor decidisse gravar e amplificar a voz de Aquille e começar a ação com a personagem "congelada", imóvel, diante do espectador, que ouviria a gravação: "Madame, estou e permanecerei imóvel e em silêncio. | Sabes que dizes tais palavras para mim, | Aquille?". ${ }^{44}$ (RACINE, 1675, p. 39, tradução nossa)

\footnotetext{
62 "La Scene est en Aulide, dans la Tente d'Agamemnon."

63 "C'est vous mesme Seigneur! Quel important besoin | Vous a fait devancer l'Aurore de si loin? | A peine um foible jour vous éclaire \& me guide, | Vos yeux seuls \& les miens sont ouverts dans Aulide. | Avez-vous dans les airs entendu quel bruit? | Les Vents nous auroient-ils exaucer cette nuit?"
}

64 “Madame, je me tais \& demeure immobile. | Est-ce à moi que l'on parle, \& connoit-on | Achille? " 
A imaginação que promove instigantes caminhos na elaboração cênica de um texto poderia motivar um cenógrafo a fazer transcorrer toda ação de Ifigênia sob algum tipo de tecido espesso, que permitisse a experimentação de uma luz difusa, durante, praticamente, quase todo o espetáculo, como se estivesse filtrada pela "tenda" de Agamêmnon. Tal opção apresentaria uma visualidade muito próxima daquela vislumbrada por Racine, dramaturgo e diretor. Essa ausência-presença dos instrumentos usados para tornar visível a cena implantaria uma qualidade muito difusa, macia, para a luz, com sombras ambíguas, em interferência mútua. Pode ser sublinhada, por conseguinte, a cena cinco do terceiro ato quando Arcas revela a intenção de Agamêmnon, que planeja sacrificar a própria filha, em troca de favores dos deuses, para alcançar Troia e vencer os inimigos. "Ele a espera no altar, para sacrificá-la”. 65 (RACINE, 1675, p. 39, tradução nossa) Sob a luz difusa mencionada, uma luz "invisível", estaria elaborada a intenção de acentuar as funções desejadas pelo dramaturgo para a palavra, assim como para o som.

Por outro lado, aí se pode identificar enorme provocação para diretores e iluminadores. Repousar no apelo fácil dos efeitos pode dar inúmeras razões para "ilustrar" as emoções presentes na cena, com tantos artifícios quanto seu orçamento e familiaridade com os truques permitissem. Ainda que tal solução possa se afastar do logos visual indicado por Racine, inundando sua tragédia com movimentos e cores, o propósito deste livro afasta a necessidade de avaliar uma ou outra abordagem. O objetivo é apreender, no texto, a visualidade inscrita por Racine na obra em questão. Isso até pode trazer, à tona, brechas por ele deixadas - traído pela obra e pela própria natureza do teatro - para a compreensão da luz presente na dramaturgia.

Considerando a mencionada cena de abertura do primeiro ato, pode-se até identificar possibilidades para a desconstrução da uniformidade sugerida no parágrafo anterior, permitindo movimentos da luz, provocados pelo nascer do sol e criando uma intensa invasão de matizes na cena. No mesmo caminho, a sequência final da tragédia, última fala de Ulysses, encontra-se impregnada de densa atmosfera: "[...] Deste espetáculo pavoroso que chocou sua filha". 66 (RACINE, 1675, p. 71, tradução nossa) Ele se refere à batalha travada por Achille contra os soldados do rei, em defesa de Ifigênia, e já anunciada por Arcas na cena anterior: "O fatal sacrifício ainda não aconteceu. | [...] o ar geme, o ferro brilha". ${ }^{67}$ (RACINE, 1675, p. 69, tradução nossa) Na acirrada disputa, o céu geme com o movimento das setas que

\footnotetext{
65 "Il l'attend à l'autel pour la sacrifier."

66 “De ce spectacle affreux votre fille allarmée | [...]'.

67 "Le fatal sacrifice est encore suspendu. | [...] l'air gémit, le fer brille."
} 
cortam o ar, formando uma nuvem de ferro sobre o campo de batalha, momento assim descrito por Ulysses: "Traços [as setas] no ar criaram uma nuvem. | Na carnificina o sangue coloria a terra”. ${ }^{6}$ (RACINE, 1675, p. 71, tradução nossa)

O sacrifício, contudo, toma outro rumo, quando se sabe que Eriphile, também filha de Agamêmnon, será sacrificada para atender a demanda de Diane. No momento em que deveria ser consumada a imolação, Eriphile nega-se a morrer pelas mãos de estranhos e desfere, no próprio peito, um golpe fatal, com o punhal sagrado. Ulysses, relata:

Logo seu sangue escorreu e tornou rubra a terra; | Do altar, os Deuses fizeram ouvir o trovão, | Os ventos agitaram efusivamente o ar, | E o Mar os respondeu com seu rugido. | Ao longe, a Costa gemeu branqueada pelas ondas. | A chama da pira, sozinha se acendeu | O Céu brilhou em relâmpagos, e entreaberto | lançou sobre nós um santo horror que nos tranquilizou. | Maravilhado, o soldado contou que numa nuvem | Diane desceu sobre a pira, | E acredita que ela se elevou no seu próprio fogo [...]. ${ }^{69}$ (RACINE, 1675, p. 72, tradução nossa)

Como se pode ler, a luz e a atmosfera são criadas pela voz do ator. Se for considerada a compreensão de Racine, aceitando-se a força que pulsa nessas palavras, pode-se manter aquela luz filtrada pela "tenda" e deixar a cargo da sua poesia a criação do ambiente. O que significa dizer: a luz da qual o autor faz impregnar sua dramaturgia abre espaços para a visualidade da qual se impregnará um espetáculo.

Tanta intensidade poética pode, no entanto, sugerir diversificados movimentos na luz. E a expressão "movimentos na luz" explicitamente abre espaços para, além do movimento em si, a presença de cores, texturas, ângulos e intensidades, que poderiam gerar inclusive muitas formas e sombras radicalmente definidas na cena. Ifigênia pode, portanto, provocar diversificados tratamentos. Identificando a visualidade proposta pelo autor, cada um pode elaborar um ponto de vista sobre ela e seguir os caminhos pretendidos para exercer sua própria abordagem.

Rigoroso no que se refere à regra das três unidades, Racine criou um momento diferenciado que deve ser destacado como único da sua categoria, em sua obra. Se em peças como Ifigênia e Fedra (Phèdre), toda a ação se passa no mesmo ambiente,

68 “Déja des traits en l'air s'eslevoit un nuage. | Déja couloit le sang prémices du carnage."

69 "A peine son sang coule e fait rougir la terre; | [...] Les Dieux son sur l'autel entendre le tonerre, Les Vents agitent l'air d'heureux frémisemens, | Et la Mer leur répond par ses mugissements. | la Rive au loin gémit blanchissante d'ecume. La flame du Bucher d'elle meme s'allume. | Le Ciel brille d'éclairs, s'entrouve, \& parmy nous | Jette une sainte horreur, qui nous assure tous. | Le soldat etonné dit que dans une nue | jusques sur le bucher Diane est descendue, | Et croit que s'élevant à travers de ses feux, [...]." 
a tragédia Atália (Athalie), originada em um tema bíblico [assim como Esther (1689)], e publicada em 1691, apresenta um traço que a diferencia. ${ }^{70}$ (BIBLIA, 1999, p. 441-442)

Atália foi regente de Judá no século IX a.c., depois do assassinato do seu filho Ochosias por Jeú, e é chamada usurpadora do Reino de Judá, nos escritos bíblicos. Ela era filha de Achab, Rei de Israel, e de Jézabel. Com o objetivo de por fim a conflitos políticos, fez-se seu casamento com Joram, rei de Judá. Athalie foi, no entanto, repudiada pelo povo e pelos sacerdotes, devido a sua adoração a Baal, para o qual construiu um templo em Jerusalém. Tomando conhecimento da morte do seu filho Ochosias, a regente ordena a morte de todos os membros da casa Real de David, inclusive seus próprios netos. Em meio a tão trágicos incidentes, Josabet, meio-irmã de Ochosias e esposa do sumo sacerdote, salva Joas juntamente com sua ama, que são mantidos em segurança e protegidos da ira de Athalie, por sete anos. Ao final desse período, encontra-se o "momento zero" da peça de Racine.

Ele divide a ação em cinco atos. Agora, viúva do Rei Joram, Athalie deixou a religião da família e segue em adoração a Baal - considerado um falso deus - acreditando haver dizimado toda a família real de David. Abner, oficial do exército, declara, com júbilo, ao sumo sacerdote Joad, que reconheceria um sobrevivente da família real como seu verdadeiro e único soberano. Revelando à sua mulher, Josabet, o apoio de Abner, Joad decide anunciar a identidade do herdeiro, para retirar Athalie do trono e restaurar sua religião e o verdadeiro reinado.

Athalie dirige-se ao templo onde encontra uma criança que já lhe havia aparecido em sonho. Desconhecendo tratar-se, na verdade, de Joas que escapou da morte por ela ordenada, convida-o a morar no palácio real. A regente teme um complô, enquanto Joad prepara o anúncio da identidade do herdeiro. Joas é declarado descendente e sucessor dos reis de Judá. Os sacerdotes preparam-se para defender o templo, e recebem dura reação de Athalie, que decide tomar a criança, quando finalmente fica sabendo que se trata do seu concorrente no direito ao trono. Os soldados de Athalie entram em pânico e a abandonam. Sua execução é ordenada por Joad, destino que deve ser estendido a qualquer um que a apoie.

Ainda que a fábula tenha sido aqui muito resumida, o relato deixa ver a gravidade dos acontecimentos. E tal gravidade torna-se evidente já na primeira rubrica do texto: "A cena se passa no Templo de Jerusalém, no vestíbulo dos aposentos do sumo-sacerdote". ${ }^{71}$ Ou seja: tudo ocorrerá em um único ambiente e grande parte

\footnotetext{
702 Reis 11: 1-21.

71 "La scène est dans le temple de Jérusalem, dans un vestibule de l'appartement du grand-prêtre."
} 
dos acontecimentos implicitamente incluídos na ação da tragédia será narrada. A convicção de Racine da substância poética do seu texto inclui a confiança numa espécie de espetacularidade rítmico-sonora do discurso, como em um movimento menos barroco católico, e mais - num certo sentido - protestante, musical. Na antepenúltima cena da peça, contudo, Racine introduz uma exceção, numa rubrica: "A cortina se abre"72 (Ato 5, cena 5, entre as linhas 1717 e 1718). (RACINE, 1892, p. 72, tradução nossa) Trata-se da única mudança explícita no ambiente, levando-se em conta a maioria das suas peças e se refere à cortina no fundo da cena, através da qual Joas é revelado. Aproxima-se o final da tragédia; no momento seguinte, mais uma surpresa, e agora, radical: "Aqui o fundo do palco se abre: vê-se o interior do templo, e os levitas entram de todos os lados para a cena"73 (Ato 5, cena 5, rubrica que se segue à linha 1730). (RACINE, 1892, p. 73, tradução nossa)

Mesmo que os defensores da ação, numa possível contenda contra a palavra, possam acentuar o momento como uma rendição de Racine ao poder cênico do acontecimento efetivo, em detrimento da palavra que narra, tal abordagem deixa de ser importante, pois interessa a aproximação com o pensamento visual elaborado pelo dramaturgo. Ele solicita uma sensível cumplicidade da luz, cujas mudanças significativas no ambiente devem ser aplicadas parcimoniosamente com o intuito de preservar o impacto do momento final, a invasão dos levitas, preparada pela abertura da cortina que revela Joas. Um momento de exceção que representa uma confirmação da regra aplicada em outras obras. Aproximando-se do espetáculo vislumbrado por Jean-Baptiste Racine, na sua dramaturgia, pode-se concordar, ou apontar outras possibilidades.

\footnotetext{
72 "Le rideau se tire."

73 "Ici le fond du théâtre s'ouvre: on voit le dedans du temple, et les lévites armés sortent de tous côtés sur la scène."
} 


\title{
NO PALCO COMO NUM QUADRO
}

\begin{abstract}
A flagrante visualidade da práxis cênica interage com o pensamento do século XVIII que define o espetáculo como uma imagem, ou melhor, como uma sucessão de imagens vivas. Tratando da unidade de ação, já aqui discutida, D’Aubignac (1715, p. 72, tradução nossa) diz: "O Palco, certamente, nada mais é que uma imagem [...]". Sua abordagem teórica da representação teatral do século XVII projeta a cena como uma manifestação visual e estabelece relações de simbiose entre imagem e cena, assegurando para os aspectos visuais papéis determinantes no espetáculo. Ainda que ele tenha deixado brechas para a desqualificação parcial da sua abordagem ao defender com veemência as unidades de ação e de lugar, seu trabalho é relevante para a exemplificação da atitude de artistas e teóricos que aplicam a visualidade como instrumento, caminho e/ou estratégia para fundamentar suas convicções teatrais.
\end{abstract}

1 "Il est certain que le Théâtre n'est rien qu'une Image [...]." 
O estudioso francês Jean-Jacques Roubine traz o texto de Jean Chapelain (1585-1674), escrito em 1630, para demonstrar o realismo ali anunciado: "Coloco como fundamento que a imitação em qualquer poema deve ser tão perfeita que nenhuma diferença transpareça entre a coisa imitada e a que imita". (CHAPELAIN apud ROUBINE, 2003, p. 29) Num determinado momento do século XVIII, a práxis cênica tornou-se um encontro que fazia interagir a dramaturgia e o desejo de imitação da realidade expresso pela imagem. Denis Diderot (1713-1784) usa a pintura como referência, mas alerta o responsável pela cena para que ele se afaste dos equívocos cometidos pelos pintores:

Se, ao invés de permanecer entre as personagens e deixar ao espectador suas próprias escolhas, o poeta sair da ação e descer para a plateia, ele interferirá no seu plano. Ele imitará os pintores que, em vez de se concentrarem na rigorosa representação da natureza, a perdem de vista, para se ocuparem dos recursos da arte, e pensam, não em mostrar a natureza como ela é, e como eles a veem, mas em subordinar sua representação aos meios técnicos e comuns. ${ }^{2}$ (DIDEROT, 1875, p. 373-374, tradução nossa)

Para comentar tal vertente, é preciso trazer à discussão trabalhos de outros estudiosos, dada a relevância de determinadas reflexões teóricas para a discussão da luz na sua condição de componente da cena. O século XVIII incorpora o fortalecimento da abordagem científica que, já vislumbrada na Renascença, ganhou abrangência na investigação praticada no século XVII. A arte interage com o movimento em direção ao trato científico da experimentação do mundo, que pode ser representado pelo legado de alguns estudiosos, como a publicação de Isaac Newton (1642-1727), Princípios matemáticos da filosofia natural (Philosophiae naturalis principia mathemática, 1686), obra considerada de grande importância para o estudo dos princípios da ciência. O progresso científico encaminhado pelo pensamento iluminista interagiu com mudanças no contexto político-social, o que encetou discussões no caminho do pensamento democrático moderno e provocou como movimento decisivo a Revolução Francesa (1789-1799).

A trajetória que se instala desde o empirismo de Francis Bacon (1561-1626), o racionalismo moderno da abordagem de René Descartes (1596-1650), passando

2 "Si, au lieu de se renfermer entre les personnages et de laisser le spectateur devenir ce qu'il voudra, le poëte sort de l'action et descend dans le parterre, il son plan. Il imitera les peintres, qui, au lieu de s'attacher à la représentation rigoureuse de la nature, la perdent de vue pour s'occuper des ressources de l'art, et songent, non pas à me la montrer comme elle est et comme ils la voient, mais à en disposer relativement à des moyens techniques et comuns." 
por Isaac Newton e John Locke (1632-1704), demonstra a contribuição das reflexões de pensadores ingleses e franceses ao conjunto de ações que tornaram o século XVIII conhecido como o Siècle des lumières, na França. O idioma inglês refere-se a Enlightenment e, em alemão, aparece no célebre texto de Immanuel Kant (1724-1804) Was ist aufklärung? (1784). Então, já no último quarto do século, Kant usa uma expressão mais abrangente que pode ser compreendida como esclarecimento. É importante registrar que, tanto em francês quanto em inglês, e até no vocábulo português "Iluminismo" é notável o modo otimista - já bastante estudado pelos mais diversos campos do conhecimento - de se colocar diante da vida, ligando a luz aos pressupostos do progresso científico, social, filosófico e artístico.

Se a excelência da luz esteve ligada a instâncias divinas, instaladas além do alcance humano, iluminando-o de modo absoluto, ideal, desde então, a humanidade passou a entender-se capaz de também iluminar suas próprias relações, através do esclarecimento, da dedução racional e da indução empirista, da luz da razão. A instância material que daí decorre indica uma busca que se refere a pressupostos negados pelo chamado Ancien régime (Antigo regime), nos moldes da Escolástica, criticada pelos iluministas por representar o caminho para um conhecimento dependente de dogmas religiosos e sem a sustentação da racionalidade natural.

Sem intentar aprofundamentos particulares, serão destacados aqui aspectos que podem contribuir para a presente investigação, principalmente quando se considera o movimento teórico orientado pelos estudos da retórica, que estabeleceram elos não apenas entre a oratória e a estética, mas também entre oratória e música, repercutindo nas artes visuais. Tal proposição acabou por se expandir e alcançar o ofício do ator, cuja excelência apontava para o gesto inspirado na pintura e na escultura. É importante mencionar certas iniciativas, inscritas tanto em investigações teóricas, quanto na poética de alguns artistas do século em questão, uma vez que são determinantes para a visualidade da cena.

O presente capítulo observa, por conseguinte, documentos que constituem bases para a compreensão da interação dinâmica entre a visualidade e a práxis cênica, reconhecendo a necessidade de pontuar traços que resultam de tal interação e podem ser observados nas atividades de artistas, comentadores e críticos, em momentos particulares do período denominado Iluminismo. Considere-se a possibilidade de estudar a luz como um componente do espetáculo, cuja atuação efetiva seu discurso poético-visual, fazendo cair por terra a abordagem limitada que estabelece vínculos exclusivamente técnicos-operacionais para a luz 
na práxis cênica e/ou trata de maneira apenas superficial a trajetória estética da imagem cênica.

Desde o teatro da Grécia clássica, a cena esteve comprometida com a expressão visual. O espaço dos teatros gregos interagia de modo inevitável com a luz natural, com a aproximação do pôr do sol, elaborando o discurso visual através da recriação da majestosa arquitetura em gigantescas sombras projetadas sobre a cena e até sobre os espectadores, criando uma visualidade grandiosa. Pode-se dizer que se algum elemento do teatro grego se mantinha em movimento constante, somente a sombra, projetada sobre o espaço cênico em relação direta com o movimento do sol, tinha tal privilégio. As assertivas visuais na espetacularidade medieval não pouparam esforços para incorporar a luz divina à cena. E a celebração renascentista da centralização no humano confiava na eficiência do controle visual do mundo, afirmada na sua observação e representação monocular controlada e calculada.

Na França dos séculos XVII e XVIII, os artistas tiveram a companhia de teóricos, ou se apresentaram também como teóricos, registrando suas preocupações com a natureza visual da práxis cênica. Ao final da primeira metade do século XVIII, depois de várias décadas de experiências apresentadas pelo empreendimento teatral francês, ao escrever a introdução da sua tragédia Semiramis (1748), Jean-François Arouet ${ }^{3}$ (1694-1778) critica severamente a configuração espacial e a qualidade visual do teatro francês do seu período:

Um teatro construído de acordo com as regras [artísticas] deve ser um amplo edifício; nele deve ser possível representar uma praça pública, o peristilo de um palácio, a entrada de um templo. Ele deve permitir que uma personagem vista pelo público possa estar supostamente invisível para outras personagens em cena, de acordo com as necessidades de uma peça. Ele deve agradar aos olhos, em primeiro lugar. Deve ser capaz de apresentar a mais majestosa pompa. Todos os espectadores devem ouvir e ver igualmente bem, de qualquer lugar da plateia. Como se pode esperar tudo isso de um teatro estreito, em meio a tantos jovens [sentados nas laterais do palco], o que deixa tão pouco espaço para os atores desempenharem seus papéis. Devido a isso, a maioria das peças não representa mais do que extensas

3 Nome de registro de Voltaire. Algumas prováveis razões são apresentadas por estudiosos para que ele tenha assumido o nome: uma delas indica a inspiração numa propriedade da sua família, um castelo chamado Airvaut. Outros pensam que ele pode ter usado um anagrama da latinização do seu sobrenome que geraria Arovet Li. Acredita-se também que ele decide tomar o nome Voltaire, depois de ser preso na Bastilha, e cortar relações com seu passado, o que estabelece uma separação formal da família. 
conversas: toda a ação dramática é frequentemente perdida ou representada de modo ridículo. Esse abuso ainda subsiste porque foi estabelecido antes e, pelo mesmo motivo que as pessoas não derrubam suas casas, ainda sabendo que elas foram mal construídas. O abuso público raramente é corrigido até que se alcancem extremas proporções. De resto, quando falo de uma ação teatral, me refiro a um dispositivo, a uma cerimônia, a um conjunto; a um acontecimento necessário à peça; e não a esses espetáculos vazios, com mais imaturidade que pompa, recursos dos cenógrafos que solucionam [escamoteiam] a esterilidade do poeta e que divertem aos olhos, sem falar aos ouvidos ou à alma. ${ }^{4}$ (AROUET, 1761, p. 152, tradução nossa)

Voltaire clamava pela unidade de um espetáculo no qual os diversos aspectos interajam, num conjunto (assemblée) de contribuições artísticas, jogando positivamente para criar uma única obra. Por outro lado, no prefácio da sua tragédia Les scythes (ou saces), ${ }^{5}$ representada em março de 1767, ele diz: "É nessa grande arte de falar aos olhos que brilha o maior ator que a Inglaterra já teve, Mr. Garrick, que assombrou e tocou a todos nós, mesmo aqueles que não sabiam sua língua”. 6 (AROUET, 1835, p. 50, tradução nossa) Ele se refere a David Garrick (1717-1779), ator inglês, cuja parceria com o cenógrafo Phillipe de Loutherburg (1746-1812) deixou significativo legado para a história da visualidade do teatro. Não se pode dizer, de modo simplório, que a declaração de Voltaire represente uma contradição, pois a grande arte de falar aos olhos está intimamente ligada àquela que "fala à alma", uma vez que não se trata de isolar um sentido, mas de reconhecer a relevância da visualidade no teatro.

4 “Un théâtre construit selon les règles tout être très vaste; il doit représenter une partie d'une place publique, le péristyle d'un palais, l'entrée d'un temple. II doit être fait de sorte qu'un personnage vie par les spectateurs, puisse ne l'être point par les autres personnages selon le besoin. Il doit en imposer aux yeux qu'il faut toujours séduire les premiers. Il doit être susceptible de la pompe la plus majestueuse. Tous les spectateurs doivent voir \& entendre également, en quelque endroit qu'ils soient placés. Comment cela peut-il s'exécuter sur une scène étroite au milieu d'un foule de jeunes gens qui laissent à peine dix pieds de place aux acteurs? De là vient que la plupart des pièces ne sont que de longues conversations; tout action théâtrale est souvent manquée \& ridicule. Cet abus subsiste comme tant d'autres, par la raison qu'il est établi, \& parce qu'on jette rarement sa maison par terre quoi qu'on sache qu'elle est mal tournée. Un abus public n'est jamais corrigé qu'à la dernière extrémité. Au reste, quand je parle d'une action théâtrale, je parle d'un appareil, d'une cérémonie, d'une assemblée, d'un événement nécessaire à la pièce ; \& non pas de ces vains spectacles plus puériles que pompeux, de ces ressources du décorateur qui suppléent à la stérilité du poète, \& qui amusent les yeux, quand on ne fait pas parler aux oreilles \& à l'âme."

5 Em grego antigo $\Sigma \kappa v ̉ \theta \alpha$, Skútha; um grupo de povos nômades de origem indo-europeia, que ocupou regiões como as estepes eurasianas até por volta do século III.

6 “C'est dans ce grand art de parler aux yeux qu'excelle le plus grand acteur qu'ait jamais en Anglaterre, $M$. Garrick qui a effrayé et attendri parmi nous ceux même qui ne savaient pas sa langue." 
Em 1781, Antoine Lavoisier (1743-1794) abre seu Relato sobre a iluminação de casas de espetáculo (La Mémoire sur manière d'eclairer les salles de spectacle), cujo título já desperta interesse, uma vez que ele destaca a iluminação dos teatros e também dos espetáculos no século XVIII como objetos de estudo. Lavoisier criticou severamente o espaço teatral da sua época, na França. Em sua opinião, de vários pontos da plateia, o público não podia ver, tampouco ouvir de modo correto, o que acontecia no palco. Segundo ele, tanto em Paris quanto nas principais cidades francesas, as casas de espetáculo eram construídas em espaços alongados como quadras de jogos, um tipo de edifício inadequado que nem sequer podia ser denominado teatro.

Consultando-se os desenhos que representam a Salle de machines, como era denominado o teatro instalado nas Tulherias, é possível considerar equivocadas proporções de largura e profundidade, repercutindo nos ângulos de visão do espectador (Figura 85). No que se refere à luz, Lavoisier (1781, p. 409, tradução nossa) resume: "O modo como se ilumina o espetáculo e os espectadores corresponde a essa espécie de estado de barbárie".7

A observação do termo barbárie é importante para a compreensão do seu ponto de vista. Ele critica duramente o incômodo causado aos espectadores durante o processo de reparo das velas, assim como aquele gerado pelos candelabros, cujo posicionamento impedia que o público acomodado nos balcões superiores tivesse pleno acesso visual ao espetáculo. Lavoisier aponta mudanças importantes ocorridas no período, como a substituição das velas de sebo por outras de cera e por lamparinas, que representaram menor desconforto, quando comparadas ao mau odor produzido pelas primeiras velas citadas.

A unificação da luz da plateia em um único candelabro tornou a iluminação mais suave, ou seja, corrigindo a ofuscação dos espectadores. Lavoisier (1781) aponta, contudo, graves problemas, tais como a impossibilidade de iluminar satisfatoriamente a plateia com um candelabro, tornando impossível reconhecer pessoas sentadas à média distância. O candelabro também não permitia a leitura de libretos para acompanhar os atores, atividade que Lavoisier considerava muito importante para o desenvolvimento do gosto e da educação literária dos jovens; além disso, a luz de ribalta era demasiado intensa, a ponto de prejudicar a visão dos espectadores sentados mais próximos do limite do palco.

Apoiado no seu próprio trabalho sobre a iluminação das ruas, ele apresenta indicações para o teatro:

7 "La manière d'éclairer le spectacle et les spectateurs répondait à cette espèce d'état de barbarie." 
Três objetivos devem ser efetivados quando se pretende iluminar um teatro: iluminar o palco e os cenários, iluminar o ator e iluminar o espectador. | O modo de iluminar o palco e os cenários por meio de lampiões adaptados aos elementos cenográficos [tapadeiras], de modo que a luz instalada numa tapadeira ilumine aquela que está imediatamente atrás dessa primeira, e assim sucessivamente até o fundo do palco, não está sujeito a qualquer objeção; acredito que poderíamos fazer uma considerável economia de combustível, adaptando a esses lampiões, como já se tentou fazer, refletores [réverbères] $]^{8}$ móveis e bem executados, de modo que se possa direcionar a luz refletida para onde for necessário; isso resultaria numa recuperação de grande parte da luz que se perde no modo como hoje se opera. ${ }^{9}$ (LAVOISIER, 1781, p. 411, tradução nossa)

Lavoisier comenta várias questões ainda hoje inerentes aos espetáculos, deixando um testemunho vivo da relevância dos processos que envolvem a aplicação da luz na práxis cênica, desde aspectos de natureza econômica até aqueles que se referem a pressupostos estéticos. Ele aponta, entre outras coisas, soluções para iluminar os telões de fundo, buscando corrigir um defeito que parecia recorrente no tratamento desses elementos e que considerava decisivo para a constituição do espaço da cena: a parte central dos telões de fundo apresentava deficiência na sua visibilidade durante os espetáculos, uma vez que o sistema de luzes laterais não a iluminava corretamente. Lavoisier, então, indicou a aplicação de lanternas, luminárias ou lampiões que, instalados numa vara acima do palco e incluindo refletores móveis permitiriam dirigir a luz para o ponto desejado, alcançando o brilho que ele exigia para a cena:

Essa parte do palco [do cenário], sempre vista de frente e que representa as perspectivas e as distâncias, é uma das mais importantes no que se refere à ilusão que se deve produzir no espectador: é necessário, portanto, que se possa iluminá-la com maior

8 Como são conhecidos os postes aplicados na iluminação pública, cuja denominação pode ter derivado da função de reflexão da luz, possibilitada por esses artefatos, também adaptados aos instrumentos da luz teatral.

9 "Trois objets sont à remplir pour éclairer une salle de spectacle: éclairer le théâtre et les décorations, éclairer l'acteur, éclairer le spectateur. La manière d'éclairer le théâtre et les décorations par le moyen de lampions adaptés aux feuilles des décorations, de façon que celle de devant éclaire celle qui est immédiatement derrière elle, et ainsi successivement jusqu'au fond du théâtre, n'est susceptible d'aucun inconvénient; je crois seulement qu'on pourrait faire une économie assez considérable de combustible, en adaptant à ces lampions, comme on a déjà essayé de le faire, des réverbères bien faits et mobiles, de manière qu'on pût diriger la lumière réfléchie dans les parties où on la jugerait nécessaire; on profiterait ainsi d'une portion considérable de lumière qui se perd dans l'état actuel." 
ou menor intensidade, tanto quanto se queira, e não há outra maneira para representar com verdade os diversos momentos do dia, o calor do sol, a luz sombria de uma tormenta ou de uma tempestade, um nascer ou um pôr do sol, uma noite, um clarão da lua [...]..$^{10}$ (LAVOISIER, 1781, p. 413, tradução nossa)

Considerações dessa natureza podem contribuir para a compreensão da expectativa de contribuição da luz nos espetáculos, que inclui, na abordagem de Lavoisier, a ilusão e o controle, incorporando aí duas vertentes, a técnica e a estética.

Além disso, sua demonstração da necessidade de iluminar a plateia pode ser equivocadamente apreendida, como se representasse uma desvantagem para a função da luz no espetáculo. Vale ressaltar suas assertivas, pois elas confirmam a importância da luz para o contexto por ele descrito e reiteram a contundência das marcas dessa mesma luz na estética em questão. Ele tratava, por um lado, de níveis particulares da contribuição social do teatro, ao considerar imprescindível a boa iluminação da plateia, tanto para o contato entre os espectadores quanto para a formação dos jovens. Por outro, Lavoisier fez incursões de natureza técnica ao estabelecer relações diretas com a proposição estética do teatro. Se o cenário deve ser iluminado de modo a expressar determinada atmosfera, incluindo a aplicação de cores, ao ator deveria ser dispensada maior atenção, de acordo com suas justificativas: "é ele [o ator] que anima a cena, é através dele que o sentimento alcança a alma do espectador; o menor movimento, a menor alteração nas suas expressões, tudo deve ser sentido, nada deve ser evitado [...]".11 (LAVOISIER, 1781, p. 413, tradução nossa)

Do ponto de vista da estética que apoia o espetáculo vislumbrado por Lavoisier, a ilusão de realidade é imprescindível. E, sem a aplicação precisa da luz, o objetivo estético não seria alcançado. Os diversos aspectos da cena - a dramaturgia, a cenografia, a interpretação e a luz - deveriam interagir na sua realização.

Outro autor cujo pensamento alcança grande relevância no debate acerca do teatro francês do século XVIII é Denis Diderot, já citado anteriormente. Ele propõe uma abordagem visual do espetáculo, solicitando do dramaturgo olhar constante

\footnotetext{
10 "Cette partie du théâtre qui est toujours vue de face, et qui représente des perspectives et des lointains, est une des plus importantes, relativement à l'illusion qu'elle doit produire sur les spectateurs ; il est donc nécessaire qu'on puisse l'éclairer plus ou moins à volonté, et ce ne sera que par ce moyen qu'on pourra rendre avec vérité les divers instants du jour, l'ardeur du soleil, la lumière sombre d'un orage ou d'une tempête, un lever ou un coucher du soleil, une nuit, un clair de lune, [...]."

11 "cést lui qui anime la scène, c'est par lui que le sentiment passe dans I'âme du spectateur: le moindre mouvement, la moindre altération dans ces traits, tout doit être sènti, rien ne doit échapper [...]."
} 
e atento à cena, o que resultaria em um modo particular de escrita teatral. Diderot reage a um teatro ocupado pela imitação empoada da Antiguidade e/ou interessado por lugares distantes e exóticos, resultando numa ficção deslocada da experiência cotidiana.

Refletindo sobre essa escrita para o teatro, assim como nas suas relações com a práxis cênica, ele escreveu Discussão sobre o Filho natural [Entretiens sur Le fils naturel (1757)] e Da poesia dramática [De la poésie dramatique (1758)], além das peças O filho natural (Le fils naturel) e O pai de família (Le père de famille). Diderot se insurge, importunado pelo teatro do seu tempo que, de modo negativo, impregnaria a rima, os versos alexandrinos, ${ }^{12}$ e critica as convenções cenográficas generalizantes do palais à volonté, e das múltiplas mudanças de cenários (scene à machine); a cena era povoada por atores que se expressavam através de gestos exagerados usando uma indumentária negativamente estilizada:

O que mais mostra, contudo, como ainda estamos longe do bom gosto e da verdade é a pobreza e a falsidade dos cenários, além do luxo dos figurinos. | Vocês exigem que os dramaturgos se ajustem à unidade de lugar, e abandonam a cena à ignorância de maus cenógrafos. ${ }^{13}$ (DIDEROT, 1875, p. 373-374, tradução nossa)

Ele fundamenta suas convicções enfatizando a necessidade de uma compreensão particular da natureza do teatro:

Na sociedade, os eventos não duram mais do que um conjunto de pequenos incidentes, o que daria verdade a um romance, mas que removeria todo o interesse da obra dramática: nossa atenção é capaz de atender a uma infinidade de diferentes objetos: mas, no teatro, onde não se representa mais que instantes particulares da vida real, faz-se necessário que nos concentremos inteiramente na mesma coisa. ${ }^{14}$ (DIDEROT, 1875, p. 88, tradução nossa)

\footnotetext{
12 Maurice Grammont (1913) assim definiu: o alexandrino era originalmente um verso silábico composto por dois membros iguais ou hemistíquios separados por uma cesura [pausa]. Cada hemistíquio contava seis sílabas, cuja última era obrigatoriamente acentuada; mas cada uma era susceptível de conter uma sétima sílaba, tendo por vogal um e inacentuado e terminando a palavra que fornecia a sexta sílaba. Essa sétima sílaba não contava no metro e sua pronúncia encontrava lugar na pausa que separava um verso do próximo ou naquele que comportava a cesura. Nenhuma dessas duas pausas poderia ser puramente artificial: a sintaxe as devia exigir ou pelo menos as permitir. 13 “Mais, ce qui montre surtout combien nous sommes encore loin du bon goût et de la vérité, c'est la pauvreté et la fausseté des décorations, et le luxe des habits. | Vous exigez de votre poëte qu'il s'assujettisse à l'unité de lieu; et vous abandonnez la scène à l'ignorance d'un mauvais décorateur."

14 "Dans la société, les affaires ne durent que pas de petits incidents, qui donnerait la verité à um roman, mais qui òteraient tout l'intérêt à un ouvrage dramatique: notre attention s'y partage sur une infinité d'objets différents: mais au théâtre, où l'on ne représente que des instants particuliers de la vie réelle, il faut que nousw soyons tout entiers à la même chose."
} 
Diderot (1875) acreditava em um teatro que deveria eleger seletivamente eventos para se referir à natureza humana. E defendia a unidade de lugar, considerando que a multiplicidade de ocorrências, inclusive mudanças sucessivas de cenários, dificultava a concentração do espectador, julgando difícil - mas importante - a aplicação das três unidades. No núcleo do seu raciocínio teatral estava a crítica a uma convenção dramatúrgica que dava ao autor e ao responsável pelo espetáculo a possibilidade e o direito de "resolver a cena" com procedimentos que ele considerava um artifício teatralmente falso. Em Da poesia dramática, Diderot (1771, p. 147, grifo e tradução nossos) define o procedimento:

\begin{abstract}
O segundo ato da peça começa com um tableau e é concluído com um coup de théâtre. [...] Um incidente inesperado que ocorre na ação e, de repente, muda o estado das personagens, é um coup de théâtre [uma saída brusca, sem justificativa aparente]. Qualquer disposição dessas personagens no palco, se natural e verdadeira, como fielmente representada numa tela por um pintor, me deleitaria; isso é um tableau [quadro]. ${ }^{15}$
\end{abstract}

O confronto entre tableau e coup de théâtre contribuiu para a teoria do espetáculo encaminhada por Diderot; ao invés de resolver uma cena através de um mecanismo dramatúrgico sem justificativa na ação e denominado coup de théâtre, ele defendia a aplicação do tableau, ou seja, a criação, o desenrolar e a conclusão do espetáculo, através de imagens capazes de compartilhar com o espectador o natural e o verdadeiro. Ele julgava necessária a estreita intimidade dessas imagens com a palavra, na sua condição de componente que contribui para a criação da cena. Na verdade, a escolha do termo tableau - como ele mesmo declarava - ligava drama e pintura, portanto, palavra, ação e imagem. Essa eloquência da imagem, que "fala" de modo eficiente, sugere tangências com a retórica e fornece pistas para localizar provocações que ele teria aceitado, ao construir sua teoria.

Nos estudos de Diderot, o conceito de tableau pode ser vinculado à discutida tipificação espacial originada no teatro italiano da Renascença. E a organização frontal caixa cênica/boca de cena/plateia - que aponta para a convenção da quarta parede (invisível) já disposta na boca de cena, determinando o limite virtual entre realidade e ficção: "Esteja você escrevendo ou representando, pense no espectador, como se ele não existisse. Imagine, na frente da boca de cena, uma grande parede

\footnotetext{
15 “Le second acte de la piéce s'ouvre par un tableau, \& finit par un coup de theatre. [...] Un incident imprévu qui se passe en action \& qui change subitement 1'etat des personnages, est un coup de théâtre. Une disposition de ces personnages sur la scène, si naturelle \& si vraie, que rendue fidelement par un peintre, elle me plairoit sur la toile, est un tableau."
} 
que o separa da plateia; represente como se a cortina não estivesse erguida". ${ }^{16}$ (DIDEROT, 1875, p. 345, tradução nossa) Tal configuração espalhou-se por todo o mundo e foi, por outro lado, exaustivamente criticada como mecanismo ilusionista que tratava o espectador como um membro passivo do jogo teatral, encarcerado numa poltrona, mero voyeur do quadro instalado no interior da caixa-cênica: uma espécie de repercussão da alegoria da caverna de Platão, uma ilusão do real e distância imposta da ideia e da verdade.

Para lidar com a expressão quadro/pintura cênica (tableau dramatique), vale buscar a compreensão do seu uso na obra de Diderot. Romira Worvill'17 (2010) observa a aplicação do termo tableau pela crítica francesa numa relação com o termo grego hypotyposis, que, no ambiente da retórica, é assim definida por M. Fabius Quintilianus (35 d.c. - 95 d.c.):

[...] aquilo que pinta as coisas sobre as quais falamos e as coloca diante dos nossos olhos, e isto acontece quando, ao invés de simplesmente relatar um evento, vemos como ele ocorreu, não em generalizações, mas em cada uma das suas circunstâncias particulares. No último livro, tratei desse tema, quando falei da evidência [evidentiae], nome dado a esta figura por Celsus. Ela é denominada por outros hypotyposis e definida por eles como uma representação de coisas em palavras, expressas de tal modo que mais parece uma questão de ver que de ouvir. ${ }^{18}$ (QUINTILIAN, 1774, p. 115, tradução nossa)

Desde abordagens modernas, a hypotyposis ganha maior abrangência, referindo-se à qualidade visual e à vividez da descrição de um evento ou objeto, estabelecendo-se relações com outro termo, agora da retórica grega - a ekphrasis - que define, de modo geral, a estratégia aplicada por um orador para criar a ilusão de realidade; ele alcança tal resultado, empreendendo uma descrição tão vívida que faz o ouvinte se sentir diante da cena, estimulado pela imagem mentalmente elaborada. Criar hypotyposis é fazer ver; ela traz uma contaminação mimética, quando o autor da narração ou descrição torna real (ou cria a ilusão de tornar real)

16 "Soit donc que vous composiez, soit que vous jouiez, ne pensez non plus au spectateur que s'il n'existait pas. Imaginez, sur le bord du théâtre, un grand mur qui vous sépare du parterre; jouez comme si la toile ne se levait pas." 17 Worvill é docente da Acadia University, na Nova Scotia, Canadá.

18 "[...] which paints the things we speak of, and places them, as Cicero says, before our eyes, it happens whenever instead of relating simply a fact, we rather shew how it passed, not in a general way, but in all its particular circumstances. This article in the last book I placed under evidence, the name which Celsus has given to that figure. By others is called hypotyposis and defined by them a representation of things so expressed by words, as to seem rather to be seen, than heard." 
o objeto/evento do processo narrativo ou descritivo. Tais abordagens tanto têm, por um lado, dado lugar a vastos debates quanto, por outro, até se discute a ilusão de real, sem sequer mencionar esses termos. O trabalho em curso, no entanto, incorpora o interesse por esses ângulos muito particulares da questão.

Mencione-se a especulação de Worvill, acentuando que mesmo diante do traço comum entre hypotyposis e ekphrasis, quando ambas se referem ao desejo de fazer o leitor (ou o ouvinte) visualizar na mente o objeto abordado, pode-se observar uma importante diferença: enquanto a primeira buscaria reduzir ou aniquilar a distância entre o leitor e a representação, a segunda introduziria certa rivalidade, ao buscar a autonomia radical da palavra, como que sublinhando uma virtuosidade verbal, exercitando o domínio da palavra que se basta como meio expressivo e de comunicação. Tal diferença importa, uma vez que a presente abordagem investe em parcerias, trocas e negociações, processos nos quais a visualidade se apresenta como aspecto instalador e articulador da manifestação cênica (que ainda hoje pode incluir a manifestação verbal). Daí importa a flexibilidade que reconhece a capacidade da palavra para contribuir na eficiência visual da cena. O movimento inverso torna-se também verdadeiro, uma vez que a visualidade busca interações com a palavra, ou com a ideia que promove o espetáculo.

Tal eficiência já havia sido destacada por Aristóteles, quando ele escreveu:

É necessário arranjar o enredo e completá-lo por meio da elocução, colocando o mais possível, a cena diante dos olhos (pois assim, vendo as coisas o mais possível concretizadas como se estivesse junto aos próprios incidentes, o poeta encontraria o que é adequado e escapar-lhe-ia minimamente o que há de contraditório [...]. (ARISTÓTELES apud GAZONI, 2006, p. 99-100)

A tradução de Gazoni evidencia, para a tarefa do poeta, a importância de ver - com os olhos da mente - a ação acerca da qual se dispõe a escrever; o impacto da palavra no leitor, ou no espectador, era considerado uma qualificação importante para o sucesso da poesia dramática. Observe-se a seguir a tradução inglesa de Gerald F. Else ${ }^{19}$ do mesmo trecho, para destacar o termo vividly, cuja compreensão é muito relevante para a discussão do assunto:

[... ] na construção do mito e na sua apresentação em linguagem verbal, o autor deve por a trama diante do olhar, tanto quanto possível. Dessa forma, vendo mais vívidamente, como

19 Gerald Frank Else (1908-1982), estudioso da Antiguidade clássica, foi professor de latim e grego nas universidades de Michigan e lowa. 
se estivesse realmente perto dos eventos $\mid$ como eles estivessem acontecendo, o poeta pode conceber a adequada 'estratégia', e as discrepâncias estarão menos propensas a escapar de sua observação. ${ }^{20}$ (ARISTÓTELES, 1983, p. 47, tradução nossa)

Tanto Else quanto Gazoni, portanto, corroboram a importância do "ver diante dos olhos", para o ofício do poeta. As traduções do trecho que se segue, "[...] indicam que o autor deve colocar a trama diante dos seus próprios olhos [...]". ${ }^{21}$ Tal capacidade e/ou estratégia garantiria, de acordo com a tradução de Else, maior vividez (seing most vividly), como se o autor estivesse diante daquilo que é descrito e garantindo que suas palavras fossem também capazes de provocar vívidas imagens mentais, emprestando, portanto, eficiência à sua poesia dramática. A particularidade dessa tradução inglesa é a presença do termo "vividamente", derivado da pala-

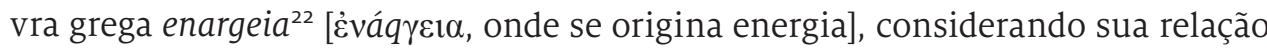
com a visualidade. A compreensão de Aristóteles, assim como de outros estudiosos da poesia e da retórica antigas, incorpora à palavra a capacidade de afirmar-se visualmente. Também para Diderot, a visão imaginativa do dramaturgo é decisiva:

Essas imagens, criadas de acordo com as personagens, afetarão também os discursos e o movimento da cena, sobretudo se o poeta as evoca, as vê, as projeta diante de si mesmo e observa suas mudanças. | [...] não concebo como o dramaturgo pode começar [a escrever] uma cena sem imaginar a ação e o movimento da personagem que ele introduz. ${ }^{23}$ (DIDEROT, 1875, p. 360, tradução nossa)

No seu artigo sobre a crítica poética da Antiguidade, Graham Zanker ${ }^{24}$ apresenta comentários de Dionysius de Halicarnassus (ca. 60 a.c. - 7 a.c.), acerca da obra de Lysias (ca. 445 a.c. - 380 a.c.) e, ainda que muitos estudiosos concordem que enargeia é uma palavra de difícil tradução, Zanker compreende que é possí-

\footnotetext{
20 [...] in constructing one's plot and working them out in language, one should put them directly before one's eye as much as possible. That way, seeing most vividly, as if he were actually betting close to the events $\mid$ as they happen, the poet can devise the appropriate 'business', and discrepancies are least likely to escape his notice.

21 "[...] put them directly before one's eye [...]."

22 De acordo com o Oxford Advanced Learner's Dictionary a raiz etmológica do substantivo energia, sendo em (dentro), no interior e ergon (trabalho), atividade. Estudiosos concordam que enargeia é uma palavra de difícil tradução.

23 “Ces images, formées d'après les caractères, influeront aussi sur les discours et sur le mouvement de la scène; surtout si le poëte les évoque, les voit, les arrête devant lui, et en remarque les changements. | [...] je ne conçois pas comment le poëte peut commence une scène, s'il n'imagine pas l'action et le mouvement du personage qu'il introduit."
}

24 Graham Zanker é professor da University of Canterbury, especialista em literatura grega. 
vel identificar nos comentários de Dionysius uma definição importante do termo. Aplicando a abordagem particular da crítica literária, Dionysius diz que enargeia se refere a um efeito estilístico no qual a qualidade de uma descrição apresenta forte apelo aos sentidos; além disso, as circunstâncias que acompanham o evento são descritas de modo a gerar forte impacto no leitor ou na audiência, tornando aquele que lê ou ouve a leitura de uma obra, testemunha ocular da coisa descrita. Para Dionysius, portanto, a visão é sentido decisivo para a excelência, no contexto. (ZANKER, 1981, p. 297)

Autores como Homero, Platão e Virgílio têm fragmentos dos seus textos mencionados como exemplos da aplicação ou da presença da enargeia. Já foi mencionada a força do drama de Ésquilo, quando se abordou Agamêmnon. Na tragédia grega, ao relatar horríveis fatos e ações que testemunhou, um mensageiro traz o impacto de um acontecimento, mesmo sem ter tomado parte na ação com a plenitude da dramatis personæ. Ele apenas estava presente, ele viu o ocorrido. Na Medeia, de Eurípedes - comentada em Um presumível ponto de partida, o relato do mensageiro constrói a imagem de horror que decorre do envenenamento de Glauce e é um exemplo de excelência na aplicação da enargeia. Vale acentuar que nem mesmo o distanciamento de alguém que estava "fora" da ação enfraquece a função da cena na tragédia como um todo, graças à maestria de Eurípedes no trato da enargeia. Aliás, é precisamente a sua aplicação que dá força ao encaminhamento da ação dramática.

De acordo com estudiosos, essa qualidade da boa poesia pode estar presente também na retórica, qualificando o trabalho do orador. A abordagem teórica em torno do poder de comunicar e exprimir, do qual a palavra pode ser impregnada, produziu uma vastidão de textos: desde os gregos antigos, repercutindo na cultura latina e alcançando Diderot, depois de deixar profundos traços no século XVII. A particularização inerente a diversas áreas do conhecimento determinou variações do conceito de enargeia, e incorporou termos como ekphrasis e hypotyposis. Em certos casos, os termos parecem estar sendo usados como sinônimos ou, quando menos, como manifestações muito próximas, quase sem limites explícitos.

Toda a enorme quantidade de expressões que derivaram do conceito de enargeia, incluindo os correspondentes latinos - que são identificados desde o século I da nossa era, entre eles, descriptio ${ }^{25}$ - guardam um traço comum: os elos entre a palavra e a imagem mental produzida no interlocutor, ouvinte ou leitor, como

25 Zanker (1981 p. 301) cita a definição de descriptio que aparece no Tratado ad Herenium e se refere a uma exposição vívida das consequências de uma ação que provoca indignação e piedade. 
resultado do mencionado impacto que os coloca diante daquilo que é descrito ou narrado, como pondera Ruth Webb: ${ }^{26}$

Enfatizar a natureza retórica da ekphrasis é também dirigir atenção para os vestígios de oralidade do fenômeno, para o modo como as discussões tanto acerca da ekphrasis quanto da enargeia, assumem interações vivas entre aquele que fala e a plateia, com a linguagem passando como uma carga elétrica entre eles. ${ }^{27}$ (WEBB, 2009, p. 129, tradução nossa)

Mesmo que se possa observar uma acentuação utópica, com certo tom romântico ou ideal na observação de Webb, ela pode tocar o ator ou o artista que se aventura na cena acreditando nessa "carga elétrica", fazendo um movimento diverso daquele que se interessa pelo exclusivo tratamento especulativo teórico.

Retorno a Aristóteles (1983, p. 17) para relembrar a compreensão da tragédia como uma manifestação artística que trata de seres humanos que agem ou, na tradução de Else: "[...] men in action". Aqui podem ser encontradas tangentes entre enargeia, ekphrasis, hypotyposis, e vários outros termos como euidentia, demonstratio, illustratio, repraesentatio e descriptio, todos eles ancorados no apelo visual que se pode emprestar à palavra, e alguns deles relacionados à compreensão aristotélica de tragédia, ou seja: "homens que agem".

Dada a abordagem diferenciada da ação nos diferentes momentos da história da espetacularidade a incorporação da palavra pode ser exercida com maior ou menor contundência; a visualidade, contudo, é conditio sine qua non para a práxis cênica. Por um lado, Diderot testemunhava ainda um teatro no qual a palavra parecia reclamar para si uma espécie de hegemonia. (WORVILL, 2010, p. 15) Por outro, impregnado pela apreensão da palavra como uma manifestação repleta de enargeia, Diderot pode ter experimentado certa angústia, não vendo na cena aquilo que a palavra é capaz de provocar no espectador.

A tragédia grega e a Poética de Aristóteles exerceram grande influência naqueles interessados no teatro durante muitos séculos. A repercussão, em Diderot, de pensadores que o antecederam já pode ser observada quando se leem autores como Bernard Lamy (1640-1715) e de Jean-Baptiste Dubos (1670-1742). Lamy (1679, p. 74, tradução nossa) teria assim comentado o trato retórico: "Os tropos

26 Professora e pesquisadora emérita do Departamento de História, Clássico e Arqueologia da Universidade de Londres/Birkbeck; professora associada do Departamento de Grego da Universidade de Paris X, Nanterre.

27 "To emphasize the rhetorical nature of ekphrasis is also to draw attention to the vestigial orality of the phenomenon, the way in which the discussions of both ekphrasis and enargeia assume live interactions between speaker and audience, with language passing like an electrical charge between them." 
são uma pintura sensível da coisa sobre a qual se fala". ${ }^{28}$ Da obra de Dubos vale destacar Reflexões críticas sobre a poesia e pintura, 1719 (Réflexions critiques sur la poésie et la peinture), na qual se podem observar aspectos que teriam influenciado certas proposições teatrais de Diderot. Dubos manifestou sua cumplicidade com Horácio, ao apresentar a expressão horaciana ut pictura poesis (na pintura como na poesia), anunciando seu interesse pelas relações entre a palavra e a visualidade. Seu modo de acentuar a excelência da poesia de Horácio reafirma a crença na intimidade entre essas duas formas de expressão: “[...] as palavras aplicadas pelo poeta para fazer sua pintura nos revelam as ideias, e essas ideias constroem o quadro, na nossa imaginação [...]".29 (DUBOS, 1733, p. 392, tradução nossa)

Fascinava Dubos a habilidade do poeta que aplica signos artificiais, arbitrários - como ele compreendia as palavras -, para pintar na imaginação do público as ideias que lhe vinham à mente, processo cujo resultado ele denominou quadro (tableau), como uma tela executada por um pintor. Worvill invoca uma transparência do signo, que se poderia notar numa pintura na qual a pincelada se desloca para um plano de relativa invisibilidade, acentuando o objeto, o tema da pintura. (WORVILL, 2010) Somente um observador particularmente interessado na intervenção do pincel, registraria a pincelada. Cabe lembrar a pintura que sensibilizava Dubos àquele tempo, obras daqueles que ele chamou grandes mestres, como Peter Paul Rubens (1577-1640) e Nicolas Poussin (1595-1665), destacando em Poussin a paixão com a qual ele impregnou obras como Os pastores de Arcádia (Et in Arcadia Ego), (Figuras 86 e 87), inspirado pelo trabalho de Virgílio (Publius Vergilius Maro, 70 a.c. - 19 a.c.) em Éclogas (ou Bucólicas), cujo tema já aparece em Hesíodo que aponta Arcádia como a cidade de Pan, o deus com chifres e membros inferiores de bode.

Dubos acreditava que na obra de Poussin, o coup de pinceau (golpe ou toque do pincel, a pincelada) é suplantado pelas paixões que movem a pintura. Abordando a expressão ut pictura poesis - na pintura como na poesia - Dubos discute a excelência de uma poesia na qual a palavra alcance transparência, pintando um quadro (tableau) na tela da imaginação do leitor/observador. Em sua opinião, mais que uma pintura, a poesia é capaz de pintar inúmeros quadros que se sucedem, na extensão de uma única obra, tornando-se mais poderosa na expressão e na comunicação.

\footnotetext{
28 "Les tropes son une peinture sensible de la chose dont on se parle."

29 “les mots dont le poëte se sert pour faire sa peinture réveillent en nous les idées, et ces idées forment ensuite dans notre imagination le tableau [...]."
} 
A argumentação de Dubos pode ser sublinhada em relevantes assertivas: "Pode-se dizer, metaforicamente falando, que o olho está mais perto da alma que o ouvido". A mentalidade que suporta afirmações dessa natureza deixou traços importantes em Diderot.

Dubos confiava na eficiência da pintura como meio de estabelecer empatia com o observador, e acreditava que a poesia teria menor poder de alcance no ser humano, pois a pintura se insinua através da visão. Com isso, ele reafirmava sua crença no poder superior da imagem visual construída materialmente com os instrumentos, materiais e suportes próprios da pintura. Ele até apresenta sua defesa, antecipando algum contestador que argumente em favor da poesia, usando o exemplo de uma tragédia, cuja leitura pode suscitar emoções no ouvinte ou leitor. Mesmo que não discordasse radicalmente, ele pondera que, ao lermos uma tragédia, principalmente se nunca a vimos encenada, não experimentaremos a profundidade das emoções que nos alcançam quando temos sua representação no palco.

Dubos (1733, p. 402, tradução nossa) declara-se, portanto, completamente favorável à montagem como necessária para que o trabalho do dramaturgo se completasse, pois, como ele afirma: "[...] uma tragédia contém um infinito número de tableaux [quadros, imagens]. O pintor que faz uma obra sobre o sacrifício de Ifigênia não nos apresenta na tela mais que um instante da ação". ${ }^{\circ}$ Ele parece estar tratando da Ifigênia (Iphigénie), de Racine, e acrescenta que o dramaturgo põe diante dos nossos olhos diversos momentos da ação. Na compreensão de Dubos (1733), enquanto uma pintura lança um único "ataque" à alma do leitor, o poeta tem a seu favor a apresentação sucessiva e planejada de inúmeros quadros, preparando e desenvolvendo visualmente a trama. E conclui essa parte da sua obra salientando que a tecnologia (l'industrie des hommes) havia municiado o pintor com muitas possibilidades, muitos aspectos que poderiam contribuir para a maior eficiência da sua obra, destacando os vernizes e a tela emoldurada que concentra a atenção; ainda assim, contando com o simples ato de recitar - aquele recitar que é acompanhado de gestos, da declamação, e/ou do canto - a poesia guarda a mencionada capacidade de criar inúmeros e sucessivos quadros em uma obra. (DUBOS, 1733) Vale dizer que a mesma pintura figurativa evocada nessas abordagens também serviu de modelo para outros autores, como François Fénelon [ou François de Salignac de La Mothe-Fénelon (1651-1715)].

30 “[...] une tragédie renferme une infinité de tableaux. Le peintre qui fait un tableau du sacrifice d’Iphigenie, ne nous represente sur la toile qu'un instant de l'action." 
Fénelon (1740) parece haver influenciado Diderot de modo muito significativo, quando tratou a eloquência na poesia e criticou a excessiva ornamentação a ela aplicada, compreendo que isso afastava a obra poética da linguagem encontrada na fala cotidiana. Fénelon, na compreensão de Worvill, buscava uma poesia que se rebelasse contra ornamentos que acentuavam o virtuosismo do poeta ou daquele que fala; ou seja, a verdadeira retórica torna invisível o orador e comunica a verdade: "O poeta desaparece; não se vê mais do que aquilo que ele nos faz ver, não se ouve mais do que ele fala. Esse é o poder da imitação e da pintura". ${ }^{31}$ (FÉNELON, 1740, p. 96, tradução nossa) Ele considerava a possibilidade de um "pintar com palavras", que a elas daria a equivalência da ilusão artística alcançada pela pintura, quebrando os limites da descrição, para fazer ver o objeto descrito.

Vale lembrar que a obra de Fénelon interage com uma importante discussão acerca da pintura na França. Enquanto uns defendiam aspectos técnicos, como o uso da cor, a técnica empregada pelo artista (como os chamados coloristas), outros se interessavam pelos temas tratados. Tal debate punha em evidência a intenção de conceder à pintura o status de arte liberal, em contraposição a uma limitada posição de "ofício". Incluindo nas suas obras temas de reconhecida significação histórica, para evidenciar nos seus quadros o alcance dos assuntos abordados, o pintor demonstraria sua posição de artista, de pensador. Fénelon, contudo, não parece tomar partido, o que sugere seu interesse tanto pela qualidade técnica figurativa, que era defendida pelos coloristas ligados a Peter-Paul Rubens (15771640), quanto pelo contexto representado na obra, cujo exemplo está relacionado a Nicolas Poussin (1594-1665).

Pode-se presumir que obras como a de Fénelon tenham deixado marcas importantes em Diderot, atuando em conjunto com sua observação do teatro e com seu desejo de vislumbrar na cena uma discussão da vida que pusesse em foco a sociedade francesa em transformação. Tudo isso gerou um impulso na direção da sua teoria para o espetáculo. Se o coup de théâtre lhe parecia uma estratégia grosseira e simplória, como uma pincelada que ao se tornar evidente descaracterizaria o trabalho do pintor, o caminho estava aberto para pôr do mesmo lado a enargeia da palavra e aquela da imagem. A incorporação dos tableaux à cena dispensaria a falsidade e aniquilaria a deficiência do coup de théâtre que afastava o espetáculo do público, destituindo-o da sua capacidade de incorporar os signos naturalmente representados. O espetáculo contaria com uma contribuição exemplarmente visual, construindo quadros, no palco. A elaboração desses quadros

31 "Le Poète disparoît; on ne voit plus que ce qu'il fait voir, on n'entend plus que ceux qu'il fait parler. Voilà la force de l'imitation \& de la peinture." 
emprestaria qualidades pictóricas à práxis cênica, propondo nova compreensão da ilusão teatral e, também, novas estratégias dramatúrgicas. Worvil classifica tal decisão como uma aplicação literal da ut pictura poesis.

É possível que a aplicação das proposições de Diderot na cena propriamente dita pode ter sido limitada por duas condições presentes no teatro francês do século XVIII: a primeira delas refere-se à sua organização espacial, que permitia a presença de público em regiões laterais do palco, incluindo os espectadores nos tableaux criados na cena. ${ }^{32}$ (Figura 88) E, ainda, as condições técnicas da luz artificial aplicada em cena naquele tempo, que, aos olhos da luz teatral atual, limitariam os resultados. Pode-se conjecturar que o público seria convocado a atender a uma espécie de acordo tácito, apreendendo o esforço do artista para criar na cena imagens que repercutissem a exigência visual da dramaturgia. É possível, portanto, compreender o desejo de Diderot de aproximar o espetáculo do espectador, incluindo temas e linguagem que por si só revelassem feições da própria vida de quem ia ao teatro.

\section{O PALCO COMO PINTURA EXEMPLAR}

Desde o autor até qualquer outro artista ou teórico que reflete sobre a natureza do espetáculo, todos estão ligados a elaborações da visualidade, ainda que intuitivamente ou mesmo, inadvertidamente. Por essa razão, os teóricos, assim como os artistas, têm como opção dedicar algum cuidado às relações entre a luz e o acontecimento cênico. Reconhecer efetivamente a importância de tais relações pode ser um caminho para evitar tratamentos exclusivamente mecânicos, superficiais ou, como já foi dito, cosméticos. Diderot parecia discordar de um dramaturgo que, acreditando na hegemonia da palavra, desconsiderasse a visualidade. Aqui se incorpora uma abordagem transversal da cena que indica conexões entre a dramaturgia e o acontecimento cênico, validadas por interações visuais que questionam o tratamento do espetáculo como um punhado de camadas superpostas das quais a luz é a derradeira.

Na opinião de alguns comentadores, o período em discussão denota uma incipiente relação do teatro francês com as questões visuais. Destaque-se a resistência francesa em assimilar diferenças de tratamento entre plateia e palco já praticadas na Itália, onde se retirava a luz da plateia para tornar o palco mais visível, estabe-

32 Essa prática, que só seria afastada no último quarto do século XVIII, era muito criticada, não somente por Diderot, mas também por outros estudiosos, como Voltaire. 
lecendo o contraste que dava a ilusão de maior brilho. A resistência francesa teve grande importância para o trabalho de Jean-Nicolas Servan [ou Giovanni Niccolò Servando e, ainda, Servandoni (1695-1766)]; nascido na cidade de Florença, ele estudou em Roma e trabalhou como cenógrafo em Portugal, para depois encaminhar sua carreira na França. Com Servandoni, o teatro francês recebeu a incorporação da radicalização italiana, escurecendo a plateia para acentuar o palco.

As pinturas deixadas por Servandoni demonstram seu grande interesse por uma imagem cenográfica com alto grau de excelência na ilusão de tridimensionalidade, como no capriccio ${ }^{33}$ romano pintado por volta de 1731 (Figura 89). Mesmo que poucos cenários propriamente ditos, de sua autoria, sejam hoje conhecidos, sabe-se que a primeira metade do século XVIII na França foi surpreendida pelos empreendimentos espetaculares de Servandoni. Gösta Mauritz Bergman (1977) cita os relatos detalhados que aparecem no Mercure de France sobre seus espetáculos, dando conta da exuberância que resultava da aplicação da luz. Servandoni teria aplicado com maestria a transparência, o brilho e a capacidade reflexiva de diversos materiais, para criar resultados que causavam exclamações e muitos elogios, inclusive do próprio Diderot: "Este Servandoni é um homem que todo o ouro do Peru não enriquecerá. [...] Grande cenotécnico, grande arquiteto, bom pintor, sublime cenógrafo, não há nenhum desses talentos que ele não detenha". ${ }^{4}$ (DIDEROT, 1796, p. 186, tradução nossa)

Servandoni, no entanto, teria ido mais longe ao elaborar espetáculos nos quais nenhuma ação humana ocorria efetivamente e o ser humano aparecia com uma função diferenciada: pintadas no dispositivo cenográfico, as "personagens" funcionavam como referência para a apreensão da proporção (espacial) proposta pelas imagens. A proposição era colocar o espectador diante de uma experiência visual, dispensando o apelo a quaisquer outros sentidos. Estava abolida a música, o ator e, com ele, a palavra.

O primeiro espetáculo da série, cujo tema era a Basílica de São Pedro, em Roma, mostrava o interior da igreja exatamente como se veria no local propriamente dito,

33 Este termo se refere a imagens criadas pelos pintores, comumente inseridas na categoria paisagem, nas quais se observava um grau de fantasia já que não se referiam a um lugar idenficável na experiência cotidiana. Inicialmente, no século XVII, os capriccios incluíam elementos arquitetônicos e o pintor Marco Ricci (1676-1730) é mencionado como o responsável pelo aprimoramento desse tipo de pintura, no qual os seres humanos e animais retratados não representam o objeto principal da imagem [como em Poussin e Claude Lorain (1630-1682)], sendo que a livre elaboração arquitetônica e/ou a paisagem representam o tema central. Depois de Ricci, Giovanni Paolo Paninni (1691-1765) produziu uma série de obras célebres nesse caminho, seguido de outros como Canaletto [Giovanni Antonio Canal (1697-1768)] e Piranesi [Giovanni Battista Piranesi (1720-1778)].

34 "Ce Servadoni est un homme que tout l'or du Perou n'enrichiroit pas. [...] Grand machiniste, grand architecte, bon peintre, sublime decorateur, il n'y a aucun de ces talents qui ne lui ait valu des sommes." 
e desconsiderava até mesmo a narrativa linear da representação teatral da época. (PELLETIER, 2006, p. 280) Era uma busca pela emoção que poderia ser provocada através da apresentação sucessiva de espaços tratados de modo próprio, pela luz. Na compreensão do artista, a visão se bastava como sentido último na relação com o público, resultando naqueles, assim denominados, espetáculos ou jogos de óptica (spéctacles ou jeu d'optique). Traduzir essas expressões como "teatro óptico" sugeriria certa estranheza na tautologia, uma vez que, como já foi reiterado aqui, não se pode compreender amplamente o termo teatro, sem considerar suas implicações visuais, desde o teatro grego da Antiguidade.

Dentre os espetáculos, Quatremère de Quincy ${ }^{35}$ destacou a peça Pandora (Pandore), que descreve com entusiasmo:

A abertura da peça representava o caos e sua elucidação de acordo com as ideias dos poetas. A imagem da natureza, tal qual descrita na idade do ouro, sucedia à confusão, e essas diversas mudanças serviam como prólogo para a história de Pandora. Sua ascensão ao céu, levada por Mercúrio, sua estadia no Olimpo, onde recebeu os presentes dos deuses, a doação da famosa caixa e seu retorno para a terra, formam um conjunto de cenas surpreendentes e brilhantes. Não havia nenhuma figura viva na ação. [...] Essa grande representação, que durou mais que uma hora, terminava com a abertura da caixa fatal e com a imagem dos males que ela espalhou sobre a terra. ${ }^{36}$ (QUINCY, 1830, p. 289, tradução nossa)

Servandoni usava personagens pintadas em imagens sucessivas, sugerindo um movimento continuado. Esses espetáculos, segundo Quincy, lhe valeram a reputação de pintor e poeta, cuja poesia se inscrevia exclusivamente em estímulos visuais. Pode-se avaliar a reação a tal tendência, na declaração de Quincy, escrita no início do século XIX:

Considerando o emprego que deles se faz no teatro, os cenários geralmente não representam mais que um acessório do espetáculo, um meio de mostrar para o olhar os lugares da ação dramática,

35 Antoine-Chrysostome Quatremère de Quincy, (1755-1849) arqueólogo, filósofo, crítico de arte e político francês 36 "L'ouverture de la pièce représentait le chaos et son débrouillement selon les idées des poètes. L'image de la nature, telle qu'ils la décrivent sous l'âge d'or, succédait à la confusion, et ces différents changements servaient de prologue à l'histoire de Pandore. Son enlèvement au ciel par Mercure, son séjour dans l'Olympe, où elle recevait les présents des dieux; le don de la fameuse boîte et son retour sur la terre, formaient une suite de scènes aussi nouvelles qui brillantes. Aucune figure vivante ne se mêlait à l'action. [...] Cette grande représentation, qui durait plus d'une heure, se terminait par l'ouverture de la boîte fatale et par l'image des maux qu'elle répandit sur la terre." 
os países onde se espera que ela aconteça. Coube a Servandoni dar àquilo [ao cenário] que não é mais que um acompanhamento do drama, a integridade de uma espécie de drama sem palavra, e de criar no espírito o interesse por uma ação cênica dirigida exclusivamente aos olhos. ${ }^{37}$ (QUINCY, 1830, p. 288, tradução nossa)

Sabe-se que na continuação desse ousado projeto espetacular ele adicionaria música e, eventualmente, atores. As mudanças, contudo, não devem ser compreendidas como enfraquecimento da visualidade no seu espetáculo, como será destacado a seguir. Para o propósito do trabalho em curso, aliás, basta o registro da tendência inicial de um artista que sonhava com a espetacularidade de uma cena fundamentada na ação da luz, promovendo hegemonia do discurso visual. Por outro lado, como já foi dito, uma hegemonia de tal natureza seria transitória no empreendimento teatral, como se pode observar no trabalho do próprio Servandoni. Seu retorno ao espetáculo, que se constituía da interação entre espaço, tempo e ação - presença humana, portanto -, reafirma a contribuição vigorosa da visualidade.

Tal exclusividade da visão é, quando menos uma utopia, considerando que o espectador não teria capacidade de anular outros sentidos, a menos que se aplique algum tipo de artefato ou tecnologia ainda desconhecida. Mesmo permanecendo sentado na sua poltrona durante todo um espetáculo, ele experimenta imagens mentais que o sensibilizam integralmente, provocando visões, aromas, texturas, temperaturas, sons, e assim por diante. Parece razoável reconhecer que o fascínio de Servandoni por imagens materialmente criadas no palco não the concedia o acesso exclusivo à visão do espectador, cujo imaginário interage com a cena e provoca as mais diversas sensações, impedindo uma abordagem simplória e/ ou exclusivista da experiência visual. Entretanto, essa espécie de "drama visual", assim como a especulação acerca de uma ação cênica dirigida "exclusivamente" aos olhos, revela a força e o apelo da visão.

Servandoni chegou à França em 1724 e, quatro anos depois, se tornou PintorCenógrafo da Academia Real de Música (Académie Royale de Musique), isto é, a Opéra de Paris, mantendo-se na posição por quase duas décadas, e trabalhando em mais de sessenta projetos cenográficos. Em 1737, ele obteve os direitos para uso

37 “Les décorations scéniques, considérées dans l'emploi qu'on en fait au théâtre, ne son ordinairement qu'un accessoire du spectacle, un moyen de mettre, pour les yeux, l'effet de l'action dramatique d'accord avec les lieux, les pays où elle est censée se passer. Il appartint à Servadoni de pouvoir donner a ce qui n'est l'accompagnement du drame, la valeur entière d'une sorte de drame sens parole, et d'intéresser l'esprit à une action scénique par le seul secours des yeux." 
da casa de espetáculos Sala das Máquinas (Salle des Machines), nas Tuilleries, em Paris, cuja denominação decorria das elaboradas possibilidades mecânicas instaladas pelo arquiteto Gaspari Vigarani (1586-1663), que o construiu para o rei Louis XIV, adaptando uma edificação já existente, sob a demanda de Mazarin. ${ }^{38}$ As características arquitetônicas da Salle des Machines, de profundidade muito superior à sua reduzida dimensão horizontal, abrigaram o teatro ótico inicialmente criado por Servandoni.

Sua estratégia era a aplicação do discurso visual no diálogo com o público. Para tanto, a scena per angolo trazia grande contribuição: a combinação dos múltiplos pontos de fuga, dispostos fora do alcance visual do espectador, com enormes elementos cenográficos implantados no primeiro plano da caixa-cênica, produzia um espaço cênico cujos limites se projetavam, virtualmente, para "fora do palco". Cenários que contavam com pilares de grandes dimensões dispostos logo depois do proscênio, e se estendendo para cima, atrás da bambolina régia (ou mestra), sugeriam uma dimensão vertical inesperada, no interior de um palco.

Durante os dezoito anos nos quais esteve à frente da Salle des Machines, maravilhando o público com inúmeros espetáculos, Servandoni aplicou temas históricos e mitológicos. Quincy comentou seu espetáculo, cujo tema era uma jornada ao inferno, chamando a atenção para o tratamento visual que resultou em grande apelo para o público: "Ele favorecia, no mais alto nível, passagens súbitas das sombras à luz, do terrível ao gracioso". ${ }^{9}$ (QUINCY, 1830, p. 290, tradução nossa) Pode-se registrar tanto a repercussão no espectador, quanto o empenho e a capacidade do artista de alcançar tal resultado, reiterando a contribuição da luz, mesmo levando-se em conta as condições técnicas das quais ele dispunha. Num momento em que o teatro francês incorporava a presença de público no palco propriamente dito, propor a interação entre o dispositivo cenográfico e a luz, como o principal meio de contar as histórias e provocar sensações e emoções, era um ato de ousadia.

O surpreendente empreendimento teatral ganharia abrangência, a ponto de influenciar o arquiteto Le Camus de Mézières (1721-1789), repercutindo na sua teoria da arquitetura. Já na maturidade, em 1780, ele escreveu O gênio da arquitetura (Le genie d'architecture), onde evocou a cenografia e o teatro como fonte de inspiração e orientação:

38 Jules Mazarin, ou Giulio Raimondo Mazzarino (1602-1661). Cardeal, diplomata e político, sucedeu Richelieu.

39 "Il favorisait au plus haut point les passages subits des ténèbres à la lumière, du terrible au gracieux." 
Respeitemos [ou asseguremos] a magia da óptica; assim o artista deve desenvolver seus talentos e dar a conhecer a envergadura do seu trabalho. [...] Ele pode aquecer suas ideias estudando pinturas e gravuras, como aquelas que se veem nos cenários dos nossos teatros. ${ }^{40}$ (MÉZIÈRES, 1780, p. 142, tradução nossa)

Se por muito tempo, desde a Renascença, seria difícil encontrar um cenógrafo que não fosse também arquiteto ou pintor - mesmo tendo Servandoni recebido formação em arquitetura -, vemos em Mézières o trabalho do cenógrafo repercutindo na obra do arquiteto. Na segunda metade do século XVIII, outros arquitetos como Claude-Nicolas Ledoux (1736-1806) e Étienne-Louis Boullée [(1728-1799), também conhecido como Arquiteto das Luzes], discutem a arquitetura como linguagem, criticando a obediência aos cânones clássicos, cujo modelo estava na aplicação das ordens arquitetônicas: jônica, dórica, coríntia e até a versão romana compósita. Na compreensão dos estudiosos, a arquitetura poderia criar um discurso silencioso através de imagens capazes de provocar os sentidos, levando a sensações análogas ao uso para o qual a edificação foi concebida, e até alcançar o status de "poema silencioso".

A parceria indicada por Le Camus de Mézières, entre o espaço cênico e a arquitetura, na busca de estados emocionais, deixou um legado do tratamento atmosférico aplicado à cena. Observando com atenção, pode-se notar como tal tratamento está intimamente ligado à luz. A identificação de atmosferas é notável e pode atuar, até hoje, como aprendizado para jovens artistas que se aventurem no teatro, em particular, diretores e designers.

No comentário a seguir, ele trata de um espetáculo denominado Representação com máquinas (Représentation en machines), que teve lugar no Théâtre des Tuilleries (ou Salle des machines) Paris, em 1741:

Quem pode resistir, então, a essa tripla magia [juntas, a pintura, a arquitetura e a escultura] que faz a alma experimentar quase todos os afetos e sentimentos conhecidos por nós? [...] Queremos julgar com certeza e satisfação? Voltemos nossos olhos para os cenários dos nossos palcos, onde a simples imitação das obras engendradas pela arquitetura determina nossas condições [emocionais]. Aqui está o palácio encantado de Armida, tudo é belo e voluptuoso, pensamos que foi erguido pelas instâncias do amor. Uma nova tela aparece; é a morada de Plutão, que leva

\footnotetext{
40 “Ménageons toute la magie de l'optique; c'est dans ce cas où l'Artiste doit développer ses talents, \& faire connaître l'étendue de son Art. [...] Il peut échauffer ses idées par l'étude des tableaux \& des estampes, par celles de nos décorations de théâtre."
} 
o horror e o terror às almas. Vemos o Templo do Sol? Ele produz admiração. A aparência de uma prisão dá lugar à tristeza; edifícios destinados a uma festa, rodeados por jardins, fontes e flores, preparam para a alegria e o prazer. Ao ver a floresta de Dodone, a alma se modifica; torna-se impressionada pelo horror sagrado da árvore. | O famoso Servandoni, cuja genialidade e conhecimento dos segredos da sua arte, nos surpreendeu e encantou na cena, [...] em um espetáculo silencioso, nos fez sentir o efeito do calor escaldante do Sol. Vimos o acampamento de Godefroy sob o fogo de Canícula, quase sem sombra, céu vermelho, uma terra seca, um efeito de luz que invoca um ar em chamas; tudo produz uma ilusão da qual nenhum expectador pode se afastar, todos pensavam sofrer; fomos submetidos ao poder da arte, ele nos fez, sem dúvida e com sucesso, sentir na alma a ideia de um frio intenso, como se nos tivesse apresentado a imagem do clima, onde algumas bétulas nuas são as únicas plantas que se erguem das rochas cobertas de neve eterna; um ar sombrio, um céu pálido e uniforme anunciava geadas prontas para se precipitar. Rios congelados e imóveis, [...] ele não apresentava mais que uma natureza privada da vida e de movimento. Esse espetáculo nos fez arrepiar. Como nos sentimos diante do contraste entre as trevas mais espessas e o dia mais puro, entre os encantos da calmaria e os distúrbios da tempestade e dos ventos? As nuanças, as gradações, nos afetam. | Portanto, as disposições da forma, seu caráter, juntos, eles se tornam a fonte inesgotável das ilusões. É desse princípio que devemos partir, quando desejamos produzir estados afetivos através da arquitetura, quando queremos falar ao espírito, tocar a alma, e não apenas nos contentarmos, através da construção, em colocar pedras sobre pedras, e imitar arranjos aleatórios e ornamentos acordados ou tomados como empréstimo, sem profunda avaliação. ${ }^{41}$ (MÉZIÈRES, 1780, p. 4-7, tradução nossa)

41 “Quelles sont les causes de ces différents effets? Démelons -les, s'il est possible, l'existence n'en est pas douteuse; combien se montrera-t-elle plus sensible, si l'on réunit à l'Architecture, la Peinture \& la Sculpture? (p. 5) Qui peut résister alors à cette triple magie dont les prestiges sont éprouver à l'âme presque toutes les affections et sensations qui nous sont connues? Voulons-nous en juger avec certitude \& satisfaction? Jettons les yeux sur les décorations de nos Théâtres, où la simple imitation des ouvrages enfantés par l'Architecture détermine nos affections. Ici, c'est le Palais enchanté d'Armide; tout y est à la foi magnifique \& voluptueux; on devine qu'il futélevé par les ordres de l'Amour. La toile change; c'est le séjour de Pluton qui porte l'horreur \& l'effroi dans les âmes. Voyonsnous le Temple du Soleil? II produit l'admiration. L'aspect d'une Prison fait naître la tristesse; des Appartements déstinés à une fête, entourés de jardins, de fontaines \& de fleurs, excitent la gaieté \& préparent aux plaisirs. A la vue de la forêt de Dodone, l'ame est émue; on est saisi de l'horreur sacrée des bois. | Le fameux Servandoni y dont le génie sécond \& la connoissance des secrets de son Art nous ont surpris \& charmes sur la scêne, a sçu, dans un 
Sua apreensão das mais diferentes atmosferas que progressivamente se instalavam no espetáculo, é exemplar. Não se tratava simplesmente de mostrar um ou mais lugares, e sim, da intensa busca pelo estabelecimento de contrastes que determinavam variações na melodia visual silenciosa, no tom, no tema; o carvalho sagrado (ou o fagus sylvatica, ou ainda faia) na floresta do santuário de Dodone fazia emudecer a alma. Observando uma imagem dessa imensa árvore (Figura 90), pode-se construir uma opinião acerca da visão testemunhada pelos soldados da Cruzada cristã, comandada pelo cavaleiro franco Godefroy de Bouillon (ca. 10601100), na campanha que resultou na tomada de Jerusalém, em combate contra os sarracenos. Voluptuosidade, terror, alegria, prazer, integram as robustas imagens invocadas por Le Camus, incluindo o calor relacionado à Canicule, termo que se refere às altas temperaturas causadas por condições climáticas particulares, cuja origem é a palavra italiana canicula (pequena cadela), que se refere aos "dias de cão", ou ao excesso de calor no verão europeu, sendo também o outro nome da estrela Sirius.

Profundamente tocado pelo espetáculo, o arquiteto revela a contribuição decisiva da luz para a criação de cada uma das imagens comentadas. Amplia-se, então, a apreensão da cena, quando ela provoca imagens mentais originadas na visibilidade, mas prenhes de aromas, cores, formas, texturas e ruídos, que qualificam cenicamente o ambiente, criando uma visualidade particular.

Qualquer que seja a época, o estilo, a escola, esteja o artista ligado ao denominado ilusionismo, ou busque sua desconstrução, a práxis cênica demonstra o interesse por atmosferas a cada momento da sua história. Importa, no trabalho de Le Camus, o destaque para a função da cena de compartilhar com o espectador as mais diversificadas atmosferas, e para a contribuição da luz para a realização de tal

\footnotetext{
Spectacle muet y faire éprouver l'effet de l'ardeur brûlante du Soleil. On y voyoit le Camp de Godefroy en proie aux feux de la Canicule; presqu'aucune ombre, un ciel rougeâtre, une terre aride, un effet de lumière qui rappelloit celui d'un air enflammé; tout y produisoit une illusion dont aucun Spectateur n'étoit à l'abri; on croyoit souffrir, on étoit soumis à la puissance de l'Art, ïl eût sans doute, avec autant de succès fait passer dans nos âmes l'idée d'un froid cuisant, s'il nous eût présenté l'image de ces climats où quelques bouleaux dépouillés sont les seuls végétaux qui s'élèvent sur des rochers couverts de neiges éternelles; un air sombre, un ciel pâle \& uniforme auroit annoncé de nouveaux frimats prêts à se répandre. Des fleuves glacés \& immobiles, des sources surprises \& comme arrêtées dans leur suite n'auroient présenté (p. 7) qu'une nature privée de vie \& de mouvement. Ce spectacle nous eût fait frissonner. Que n'éprouvons-nous pas dans les oppositions des ténèbres les plus épaisses, \& du jour le plus pur, dans les agréments du calme \& les désordres de la tempête \& des vents? Les nuances, les gradations nous affectent. | Ce sont donc les dispositions des formes, leur caractère, leur ensemble qui deviennent le sond inépuisable des illusions. C'est de ce principe qu'il faut partir, lorsqu'on prétend dans l'Architecture produire des affections, lorsqu'on veut parler à l'esprit, émouvoir l'âme, \& ne pas se contenter, en bâtissant, de placer pierres fur pierres, \& d'imiter au hasard des dispositions, des ornements convenus ou empruntés sans méditation. L'intention motivée dans l'ensemble, les proportions \& l'accord des différentes parties produisent les effets \& les sensations."
} 
desejo. Sabemos que sua proposição recebeu críticas que consideraram exagero aplicar tais pressupostos em projetos dos edifícios. Seu testemunho, por outro lado, atestava o valor das atmosferas para a criação da práxis cênica.

A relevância da obra de Servandoni, para a presente abordagem, reafirma-se no artigo de Jérôme de la Gorce, no qual ele comenta um documento encontrado no Museu de artes decorativas (Musée des arts decoratifs), em Lyon. Trata-se de uma perspectiva relacionada ao dispositivo cenográfico para o espetáculo O triunfo da harmonia (Le triomphe de l'harmonie), classificado como Balé Heroico (Ballet heroique), pelo autor do libreto, Jean-Jacques Lefranc Pompignan (1709-1784), e cuja estreia se deu em 9 de maio de 1737, com música de FrançoisLupien Grenet (ca. 1700-1753) (Figura 91). ${ }^{42}$ Ainda que a citada ópera não tenha hoje grande repercussão, a inscrição que aparece na parte inferior da mesma folha de papel onde se vê a perspectiva, contribui para definir sua importância: "Aparência da cenografia da cidade de Tebas, criada e pintada pelo Sr. Servandoni para o $3^{0}$ ato do Le triomphe de l'harmonie". ${ }^{43}$ (DE LA GORCE, 2009, p. 578 , grifo e tradução nossos)

O trabalho de Servadoni como cenógrafo tem sido estudado a partir da observação de plantas, cortes, descrições e relatos encontrados na publicação da época Mercure de France, dada a escassez de imagens originais da época. O citado desenho em perspectiva ganha importância precisamente porque sugere tridimensionalidade, revelando parte substancial do projeto, do tratamento desejado pelo cenógrafo. Le triomphe de l'harmonie é o último espetáculo para o qual Servandoni contribuiu, na sua passagem pela Opéra, já comentada, antes de assumir a Salle des machines.

No libreto de Pompignan (1737), a divisão hoje classificada em atos é identificada como entrées, sendo o texto composto de um prólogo e três entrées. Cada uma dessas partes apresenta ação dramática independente, dispensando ligação entre elas. A primeira cena do Prólogo revela a Paz, descendo do céu, ao som de tímbales e trompetes, enquanto o Coro exclama: "A Paz vem realizar nossos desejos, | Que felicidade! Que glória! Ela traz [de novo] os prazeres | sobre as asas da vitória". ${ }^{44}$ (POMPIGNAN, 1737, p. 4, tradução nossa) Podem-se observar pistas para a atmos-

\footnotetext{
42 Este foi provavelmente o último projeto de Servandoni no Palays Royal, antes da sua empreitada na Salle des Machines, com o teatro óptico.

43 "Aspect de la décoration de la Ville de Thèbes, inventé e peint par le Sieur Servandoni pour le зe acte du Triomphe de L'Harmonie."

44 "La Paix vient combler nos désirs, | Quel bonheur pour nous! Quelle gloire! | Elle rameine les plaisir | sur les aîles de la Victoire."
} 
fera na qual o autor abriria o espetáculo, fosse ele o diretor. Com a identificação da perspectiva já citada, o terceiro ato ganha maior importância para a presente abordagem: no texto manuscrito, abaixo da ilustração, pode-se ler: "A parte do papel que se eleva, mostra um segundo cenário que sai do porão, quando Amphion ergue novas muralhas para a cidade, com o poder da sua voz".45 (SERVANDONI apud DE LA GORCE, 2009, p. 583, tradução nossa)

O terceiro ato tem como tema o mito de Amphion, um dos filhos de Zeus e Antíope, e considerado criador da música, juntamente com seu irmão Zethos; ele seria também o fundador de Tebas, diante da qual se passa a ação. Cabe destacar o ambiente descrito pelo autor:

O palco mostra florestas, cavernas e rochedos; um acampamento de selvagens instalado diante da cidade de Tebas, que aparece ao fundo semidestruída. A Cena se passa no fim da noite. ${ }^{46}$ (POMPIGNAN, 1737, p. 35, tradução nossa e grifo do autor)

Um dos aspectos abordados por De La Gorce (2009) é a comparação entre a perspectiva localizada em Lyon e uma planta-baixa já conhecida e mantida pelo National museum, em Estocolmo (Figura 92). O que pode sugerir desencontro entre os dois, talvez possa apontar possibilidades para algum esclarecimento: observa-se na planta-baixa uma série de elementos (tapadeiras ou trainéis), que não parecem estar presentes na perspectiva de Servandoni. Sem acesso ao texto manuscrito, incluído no desenho técnico mantido pelo Museu Nacional da Suécia, é possível presumir que alguma modificação possa ter ocorrido, levando cada um deles a incluir informação diferenciada, de acordo com as datas de execução e/ou proposição do desenho em si. Por outro lado, vale considerar que a perspectiva esteja intencionalmente incompleta, no que se refere ao ambiente da cena, uma vez que Servandoni tenha particularmente nela representado a "cidade de Tebas, que aparece ao fundo semidestruída", incluindo as muralhas, à esquerda-alta, para indicar o tratamento planejado para o momento específico da mencionada intervenção de Amphion.

O que parece ausente, ao menos, é uma representação dos rochedos, das cavernas, das florestas, e daquilo que ele chama "campo de selvagens". A rubrica, no entanto, traz ainda em destaque a indicação da atmosfera que o dramaturgo considera imprescindível à ação, para a intriga que ele propõe: "a cena se passa no fim

45 "La Partie Du Papier que se réleve [souléve] forme une seconde Décoration, qui sort de dessous le théâtre, Iorsqu'Amphion élève de nouveaux murs à la ville, par le charme de sa voix."

46 "Le Théâtre représente des Forêts, des Cavernes, des Rochers; | un Camp de Sauvages y est formé devant la Ville de Thebes, qui paroit dans le fond à demie ruiné. | La Scène se passe sur la fin de la nuit." 
da noite". Originalmente destacada em itálico, essa observação soa quase como um alerta, como se ele estivesse dizendo: "Essa é a luz, a atmosfera que tenho em mente, ao conceber a cena!" E isso se amplia no solo de Niobe, filha do Rei Tantale e esposa de Amphion: "Amor do Universo, chama brilhante e pura, Aurora, que teus fogos abrandem meu temor! Os horrores da noite desvanecem diante de ti; Teus raios [benevolentes] confortam a natureza [...]". ${ }^{47}$ (POMPIGNAN, 1737, p. 35, tradução nossa e grifo do autor).

Note-se que logo depois da rubrica de abertura que anuncia o "fim da noite", Niobe anuncia as cores, o tom, o brilho, a pureza e o conforto que acompanham o dia especial. Isso, o desenho de Servandoni não revela e, mesmo que ele tivesse deixado uma pintura, com sua impressão da atmosfera, sua efetivação na cena estaria ligada à conjuntura técnica (incluindo instrumentos e acessórios disponíveis àquele tempo), além de procedimentos decorrentes dessa mesma conjuntura.

\section{Tênues fronteiras entre ilusão e realidade}

Mesmo meio século depois da iniciativa de Servandoni ainda podem ser encontradas críticas à falta de controle da luz nos teatros franceses, como em Boullée (apud Rosenau, 1976, p. 96, grifo e tradução nossos):

Há outro aspecto que tem recebido ainda menor atenção: um grande volume de observações sobre isto me torna capaz de lidar com o problema. Refiro-me aos métodos de iluminar uma plateia, de acordo com o modo como a peça deve tocar o espectador. Se o título de uma peça induziu pensamentos sombrios, ninguém que esteja acomodado em uma plateia muito iluminada, deixa de ter dificuldade para afastar-se das sensações induzidas pelo brilho dessa luz, quando a cortina for levantada, revelando uma cena sombria. O esforço ao qual se é obrigado, para colocar-se na atmosfera apropriada, destrói a ilusão; a [totalidade do] efeito destrutivo na performance é desconhecido. ${ }^{48}$

\footnotetext{
47 "Amour de l'Univers, flamme brillante et pure, | Aurore, que tes feux redoublent mon effroi! | Les horreurs de la nuit s'effacent [effacent] devant toi; | Tes rayons bienfaisons consolent la nature, | [...]."

48 "There is another aspect that has received even less attention; a mass of observations about it have enabled me to deal with it. It concerns methods of lighting an auditorium according to the effect the work should have presented on the audience. If the title of a play has induced gloomy thoughts, no one seated in a brightly lit auditorium, will not experience some difficulty in tearing himself away from the sensations induced by the brightness of the lighting when the curtains rises and suddenly reveals a sombre scene. The effort he is obliged to make to put himself in the right mood destroys the illusion; the destructive effect on the performance is unknown."
} 
Demonstrando amplo espectro de preocupações com a atividade - incluindo a segurança, a excelência na operação técnica e no trabalho do responsável pelo espetáculo - referendadas pela larga experiência como observador, por ele mesmo atestada, Boullée não apresentava queixas referentes aos espetáculos, do ponto de vista daquilo que se contemplava nos palcos. Em sua opinião, os responsáveis pela cena alcançariam importantes resultados caso fosse corrigida a presença indevida de luz na plateia, durante a performance. O que vale dizer: quando um autor propunha determinada atmosfera, como faz Pompignan através de Niobe, ele sabia o que esperar. O dramaturgo atento era capaz de imaginar as diferenças entre a atmosfera presente na sua dramaturgia e o resultado provável, no momento de um espetáculo.

A organização dos sistemas de iluminação de teatros na França do século XVIII apresentava, com certa variação, um padrão que se constituía na aplicação de velas de sebo, ou de cera animal em candelabros sobre o proscênio, lamparinas na ribalta, assim como sistemas de velas no interior da caixa cênica. Essa organização sugeria um tratamento previsível, simétrico e, provavelmente, repetitivo. Progressivamente, a introdução de ribaltas móveis associada à redução de candelabros na plateia, e a implantação de luminárias Argand, tratadas adiante, estabeleceu uma acentuação visual da ação no palco. A incorporação de superfícies refletoras (réverbères), já implantadas na iluminação pública, teria incrementado a luz projetada sobre o centro da caixa cênica, e também nos telões de fundo.

Mesmo considerando um provável padrão no tratamento da luz para a cena nesse período, que proporcionava a regularidade já mencionada, há registros da preocupação com certas diferenças entre os espetáculos, como Gösta M. Bergman (1977) especula. Em 1757, Atália [Athalie, (abril)] e Ifigênia em Taurida [Iphigénie en Tauride (junho)], ambas de Racine, parecem ter merecido especial atenção, como observa Bergman (1977), citando o inventário de instrumentos usados na iluminação. Mesmo caso de Órfãos da China (Orphelin de la Chine), de Voltaire, levada ao público na temporada 1759-176o, com cenários de Paolo Antonio Brunetti (1726-1783), pintor e cenógrafo muito ativo no período, tendo elaborado também cenários para Semiramis, também de Voltaire, escrita em 1749. Aliado à comentada possibilidade de ampliação dos instrumentos de iluminação, o interesse pelo tratamento diferenciado de certas peças começa a indicar um novo princípio acerca da aplicação da luz na cena a partir da segunda metade do século XVIII.

Certas mudanças ocorridas nesse momento indicavam rotas para o robustecimento da modernidade na práxis cênica. A reforma realizada em 1759 no teatro Comédie Française, em Paris, delineia as principais tendências dessas rotas. 
Bergman sublinha traços do ilusionismo romântico que ingressaria na arte do século XIX e arregimentaria esforços de artistas envolvidos nos espetáculos. Na trilha desse tom romântico, o teatro francês anunciava a necessidade de diferenças no tratamento da luz empregada na cena. No dizer de Bergman, em novas imagens que se insinuavam lentamente como que apontando para uma nova função da luz.

A ilusão indispensável para a abordagem romântica, na qual lugar e atmosfera eram imprescindíveis, começou a tomar corpo nos espetáculos da Comédie Française quando, na mencionada reforma, foram retirados os bancos nos quais espectadores eram acomodados nas laterais do palco. No entendimento dos responsáveis pela reforma esses espectadores produziam graves limitações aos espetáculos. Além de impedirem flexibilidade no trânsito das personagens e destruírem a ilusão, eles ocupavam um espaço que poderia ser usado pelas personagens e pelo dispositivo cenográfico propriamente dito. Por outro lado, quando são consideradas as diversas tendências não ilusionistas difundidas desde o início do século XX, ao colocar espectadores no palco essa organização do espaço cênico era muito revolucionária: o público estava dentro da cena, tomava parte dela.

Depois da reforma, o palco livre foi parcialmente retomado pela ação. Apesar disso, o espaço da cena era agora domínio apenas relativo da personagem, pois o espectador era ainda acomodado em camarotes ao lado do palco (Figura 93). Os figurinos ainda pareciam sujeitos à estilização exagerada, se não forem observados com a atenção que permite identificar tentativas de aproximação histórica com a ação e com as personagens envolvidas em cada trama. A qualidade romântica ainda necessitava da contribuição da luz para incorporar atmosfera ao ambiente da ação. Os sistemas de tapadeiras ou traineis laterais permitiam, ou sugeriam, a adição de bambolinas, que integradas como elementos aéreos do dispositivo cenográfico, estabeleciam os limites verticais do ambiente ou criavam ilusão de um espaço com amplitude muito maior do que o palco em si poderia acomodar.

Por outro lado, as bambolinas permitiam a inclusão de varas (de luz) horizontais, paralelas e acima do palco. Nessas varas - dispostas atrás das bambolinas eram instaladas velas de cera então consideradas mais seguras e eficientes, pois forneciam maior brilho com menor risco de incêndio. A atmosfera romântica exigia, ainda, um tratamento cromático da luz que apresentasse correspondência com a emoção veiculada em cena. Cada um desses passos apontava na direção do teatro realista, que provocaria desde o início do século XX a grande revolta da cena contra a ilusão, rendendo grandes mudanças na contribuição da luz.

O trabalho teórico do arquiteto francês Pierre Patte (1723-1814) ganha importância no trabalho de Surgers, quando ela comenta proposições realistas no 
teatro. Em seu Ensaio sobre a arquitetura teatral (Essai sur l'architecture théâtral, 1782), Patte aponta a impotência da cena pintada quando confrontada com a realidade. Na sua compreensão, comparada à multiplicidade de interações visuais entre o ser humano e o objeto real, à questão dos volumes e seus reflexos, a perspectiva mostra-se enfraquecida, revelando limitações, quando impõe ao observador a rigidez expressa nas relações entre o ponto de vista e o ponto de fuga. Surgers (2005b) amplia sua abordagem, mencionando inquietações que podem ser encontradas em Adolphe Appia. Mais de um século depois, Appia acentuou o conflito entre um ambiente pintado sob as regras da perspectiva e o corpo do ator, chamando a atenção para uma contradição implantada pelo teatro italiano, já no século XVI. A sugestão de volume na perspectiva era uma flagrante limitação denunciada pelas sombras pintadas em superfícies bidimensionais, na busca de "ilusão" tridimensional. (SURGERS, 2005b)

Na compreensão de Appia, um cenário composto de elementos bidimensionais pintados para criar a ilusão de tridimensionalidade torna-se alienado e falso, ao ser confrontado com o corpo vivo do ator. Numa relação de tal natureza, não somente o volume pintado, mas também o corpo do ator perde sentido e função, se o ambiente da cena pretende demonstrar unidade de tratamento. Juntamente com o ator, o ambiente da ação deveria apresentar também a tridimensionalidade; desse modo ficaria estabelecida uma relação "verdadeira". Apresentando volumes verdadeiros, "reais", objetivos, o ambiente não permitiria ao espectador dúvidas sobre a verdade espacial da cena, ele seria coagido pela "realidade absoluta" da qual o espetáculo estaria investido. Em tal contexto, portanto, a "verdade" não mantém nenhuma relação com o tratamento realista. Um dispositivo cenográfico tridimensional e abstrato ganha status de verdadeiro no diálogo formal, visual, espacial com o corpo do ator. Importante registrar que, sem a contribuição congruente da luz, tal qualidade não será revelada.

Desconsiderando tal contexto, a cena francesa do século XVIII "tratava" o ator, então, como uma superfície plana, chapada, sempre vista de frente: num certo sentido, se toda pintura é um produto artificial, o corpo do ator passava a ser artificializado para atender a convenção cenográfica. Tratava-se, por assim dizer, de uma convenção extrema, se consideramos que a cena, na sua condição de "corpo-espaço teatral", incorpora o corpo do ator como sua primeira célula tridimensional.

Tal abordagem compreende a cena como um acontecimento no qual o corpo do ator representa o primeiro corpo-espaço da ação. Por outro lado, o ator interage no teatro com diversificadas instâncias perceptivas e emocionais, resultando numa dilatação das funções da cena, em níveis que ampliam e também diversifi- 
cam seu caráter dimensional. Ou seja: a relação do espectador com o ator liberta-se da instância exclusivamente física, material, tridimensional. Transformando-se a cada gesto ou movimento, o corpo do ator gera inúmeras equações visuais "transdimensionais" em diretas relações com o ambiente.

A contradição principal apontada por Patte não parecia aproximar-se de qualquer solução, senão pela convenção já mencionada, que resolvia o problema tratando o ator como uma face plana, bidimensional. Surgers (2005b, p. 145, tradução nossa) destaca a questão:

A superioridade do volume 'natural' sobre o volume artificial da pintura ou do cenário de teatro está aqui aplicada em nome da semelhança com o 'natural'. Mas o argumento de Patte não poderia ter sucesso, pois o imitante (o volume), e o imitado (o natural ou a natureza), não passam de um só e mesmo fim [termo]. Patte chega a um impasse que só será resolvido um século mais tarde, graças às grandes revoluções da representação: na pintura, com o cubismo e o nascimento da arte abstrata e, no teatro, com Craig e Appia, e a invenção da. mise em scène. ${ }^{49}$

Como Surgers (2005b) acentua, o trabalho de Appia sugere uma direta relação entre a cenografia "ideal" - na qual o volume seja aspecto concreto - e a ilusão de realidade. Na segunda metade do século XVIII, a semelhança entre o real e aquilo que se vê tornou-se objetivo da representação teatral. A reforma do teatro Comédie Française representou importante passo dessa tendência.

Já foi mencionada aqui a crítica de Voltaire à ordem espacial do teatro francês do seu tempo. Surgers aponta o ataque de Voltaire à dramaturgia de Shakespeare, no qual ele usou adjetivos como monstruosa, qualificando negativamente a evocação de magia, a introdução de aparições, do sobrenatural, que deveriam ser banidos do teatro. Também os trabalhos de Diderot e Lavoisier, discutem tanto o real quanto o verdadeiro sob o prisma das imagens criadas em cena. Lavoisier mais particularmente interessado na aplicação da luz ao teatro. Voltando-se à sua contribuição pode-se destacar o interesse na exclusão da (luz de) ribalta que seria substituída por fontes de luz dispostas sobre o proscênio, e também nas suas laterais. Diz Lavoisier (1784, p. 96, tradução nossa): "[...] uma [luz do] dia que atinge o corpo de baixo para

49 “La supériorité du volume 'naturel' sur le volume fictif de la peinture ou de décor de théâtre est ici affirmée au nom de la ressemblance au 'naturel'. Mais le raisonnement de Patte ne pouvait aboutir, pluis que l'imitant (le volume) et l'imitér (le naturel ou la nature) n'y son qu'un seul et même terme. Patte arrivait donc à une impasse, qui s'est ouverte environ un siècle plus tard, grâce aux grandes revolutions de la reprèsentation: en peinture avec le cubisme e la naisssance de l'art abstrait et, pour le théâtre avec Craig et Appia et l'invention de la mise en scène." 
cima não é a mais natural, uma vez que ela reverte a ordem das sombras e da luz, uma vez que ela distorce, até certo ponto, a fisionomia dos atores". ${ }^{\circ}$

Apesar da sua opinião sobre as impropriedades da ribalta, Lavoisier (1784) afirma que a luz disponível àquele momento nos teatros, fossem lamparinas a óleo ou velas, seria insuficiente para iluminar os atores, se dispostas nas laterais ou acima do proscênio: a luz lateral produzia luminosidade deficiente no centro do proscênio; instrumentos localizados acima, em relação perpendicular com essa área de atuação, projetavam sombras próprias indesejadas no corpo do ator, nos olhos, sobre a parte baixa do rosto e faziam aparecer as menores rugas e imperfeições da pele. A perpendicularidade das fontes de luz instaladas acima da cabeça transformaria o ator em obstáculos, cujas sombras se projetariam sobre seu próprio corpo. Nos momentos mais trágicos (importantes) essas sombras o fariam "escapar visualmente", por assim dizer, aos espectadores. Na opinião de Lavoisier (1784, p. 96, tradução nossa), ${ }^{51}$ tal conjunto de resultados representaria, "[...] o mais desagradável de todos os efeitos [...]". ${ }^{22}$

Note-se a importância da qualidade "natural" (ou real) que começava a se impor manifestando-se em diversas instâncias da atividade teatral. Surgers (2005b) acentua Beaumarchais, [Pierre-Augustin Caron de Beaumarchais (1732-1799)], comentando a rubrica de abertura de "Le mariage de Figaro", citada a seguir:

O palco representa uma sala semidesmobiliada, uma grande cadeira para doentes [uma poltrona de dimensões especiais] ao centro. Fígaro, com uma toesa [antigo instrumento francês para medir], mede o piso. Suzanne está diante de um espelho e põe à cabeça um pequeno buquê de flores de laranjeira, chamado chapéu de noiva. ${ }^{53}$ (BEAUMARCHAIS, 1934, p. 48, tradução nossa)

\footnotetext{
50 “[...] un jour qui frappe le corps de bas en haut n'est pas le plus naturel, qu'il renverse l'ordre des ombres et des clairs, qu'il démonte même, si l'on veut, jusqu'à un certain point la physionomie des acteurs; [...]

51 No trabalho de Lavoisier podem ser encontradas indicações técnicas que ele considerava solução de parte destes problemas, como se observa na sua proposição para que adicione superfícies refletoras (réverbères) às fontes de luz, o que resultaria em duas grandes vantagens: ampliação do brilho projetado sobre a cena e controle da direção da luz, quando planejada em conjunto com a disposição das "varas" fora do palco [próximas ao proscênio] Aqueles interessados na aplicação da ótica aos instrumentos concebidos para produzir luz na cena, podem encontrar neste trabalho de Lavoisier material importante para estudo, incluindo a avalição das superfícies refletoras de natureza esferoide-elíptica neste contexto.

52 "les plus désegréable de tous les effets, [...]."

53 "Le théâtre représente une chambre à demi démeublée; un grand fauteuil de malade est au milieu. Figaro, avec une toise, mesure le plancher. Suzanne attache à sa tête, devant une glace, le petit bouquet de fleurs d'orange, appelé chapeau de la mariée. [O móvel ao centro é a poltrona na qual o Cherubino se esconderá no curso da ação]."
} 
De acordo com Surgers (2005b) essa rubrica é a primeira na instalação da dramaturgia denominada burguesa; é importante notar a descrição de um único ambiente no interior de um edifício, assim como a ação "natural", incluindo a localização das personagens. Trata-se de um exemplo que demonstra o caminho da dramaturgia em direção ao realismo que se fortaleceria mais tarde. Para experimentar emoções profundas, o público precisava reconhecer o ser humano em cena, assim como o seu ambiente. Tomando parte no contexto, estudiosos do espaço teatral avaliaram a contribuição da luz para o movimento em curso.

A segunda metade do século XVIII trouxe outros estudos ligados à visualidade da cena, a despeito de diferentes abordagens. Destaque-se, no interesse da investigação em andamento, Ensaio sobre a ópera (Essai sur l'opéra), 1755, de Francesco Algarotti (1712-1764); Cartas sobre a dança (Lettres sur la dance), 1760, de Jean-Georges Noverre (1727-1810); O projeto de uma sala de espetáculos (Le project d'une salle de spetacles), 1765, de Charles-Nicholas Cochin (1715-179o); Tratado da construção de teatros e máquinas teatrais (Traité de la construction des théâtres et des machines théâtrales), (1777), de André-Jacob Roubo (1739-1791); Observações sobre a construção de uma sala de espetáculos (Observations sur le construction d'une salle de spetacles), 1781, também de Noverre. Ainda que, de "lugares" diferentes, cada um deles se refere à luz, estabelecendo uma possibilidade de reflexão sobre o espetáculo motivada pelas suas manifestações visuais.

A obra de Noverre interessa, antes de tudo, ao artista envolvido com a práxis cênica em si, e não exclusivamente aos pesquisadores da dança. Um jovem diretor em formação encontrará nesses escritos vigorosas provocações que levaram o "Compositeur" ou "Mâitre de Ballet" (como ele chama o responsável pelos espetáculos de dança), a discutir novos princípios para a dança, incluindo aspectos da sua teatralidade e do seu caráter visual.

Já no início da primeira carta, Noverre (1760, p. 1, tradução nossa) dispõe uma assertiva que integra a orientação de suas proposições acerca da dança: "A Poesia, a Pintura e a Dança não são, Senhor, ou não devem ser, mais que uma cópia fiel da bela natureza; é pela verdade dessa imitação que as obras de artistas como Racine e Raphael passarão à posteridade [...]".54

Ele aplicará, em outros momentos, os termos cópia e imitação, como sinônimos, aliando características que, em sua opinião, seriam imprescindíveis aos novos caminhos da dança, que ele chama danse en action ou ballet en action. Tal ligação da dança com a "ação" se daria pela alocação dos sentimentos, ou seja, pela inclu-

54 "La poésie, la peinture et la danse ne son, Monsieur, ou ne doivent être qu'une copie fidelle de la belle nature: c'est par la verité de cette imitation que les Ouvrages de Racine, de Raphaël ont passé à la posterité; [...]." 
são de personagens e, portanto, de desejos humanos, incorporando e mesclando a natureza e elementos do drama. Noverre reconhece o alto grau de dificuldade então enfrentado por um Maître de Ballet ou Compositeur, uma vez que, na elaboração estética, visual, desses espetáculos, o artista não tem à sua disposição instrumentos (como pincéis ou espátulas), ou materiais, como tintas. Ele deve produzir através da arte dos gestos e da pantomima quadros diversificados que durarão apenas alguns instantes, sucedendo-se uns aos outros. Trata-se de um novo caminho para a dança, espetáculos que buscam ligações com a história, com a poesia e com a pintura, para alcançar mais que a possibilidade de agradar aos olhos. Uma pintura que só se pode alcançar na cena, capaz de revelar imagens - quadros, pinturas - em movimento, que se sucedem até o final do espetáculo.

Ele acreditava que, incorporando elementos do teatro, a dança podia cativar o espectador através do encantamento da mais perfeita ilusão, falando-lhe à alma. Criticando a dança do seu tempo, Noverre (1760, p. 6, grifo e tradução nossos) aponta novos rumos: "[...] a maioria dos compositeurs sacrificam a beleza da Dança e abandonam a graça ingênua do sentimento [...]".55 Ao mencionar o sentimento, a emoção, ele se refere (positivamente) aos traços teatrais que deseja ver incorporados à dança.

Compreendendo a práxis cênica como um empreendimento visual, ele comentou:

Seria necessário que os Maîtres de Ballets consultassem os quadros dos grandes pintores: este exame os aproximaria, sem dúvida, da natureza; eles evitariam então, tanto quanto fosse possível, a simetria nas figuras que, pela repetição do objeto, oferece, na mesma tela, dois quadros semelhantes. ${ }^{56}$ (NOVERRE, 1760, p. 7, grifo e tradução nossos)

Noverre procurava aliar o inesperado que se encontra tanto na natureza quanto na obra de grandes pintores (e que deve resultar na retirada de arranjos simétricos do palco), com elementos do drama, como paixões e emoções, para incorporar à dança qualidades que ele compreendia como inerentes à ação cênica. A simetria tornava-se um grande perigo para a danse en action ou o ballet em action. O uso exagerado das disposições simétricas tinha, para Noverre, o resultado nocivo de afastar a dança da vida. Aliás, em sua opinião, o abuso recorrente - mesmo dos melhores elementos -

55 "[...] les plus grand nombre des Compositeurs sacrifient les beautés de la Danse, \& abandonnent les graces naîves du sentiment, [...]."

56 "Il faudroit que les Maîtres de Ballets consultassent les Tableux des grands Peintres: cet examen les rapprocheroit sans doute de la nature; ils éviteroitent alors, le plus souvent qu'íl leur seroit possible, cette symmétrie dans les figures qui, faisant répétition d'bjet, offre sur la même toile deux Tableaux semblables." 
seria sempre nocivo. Ou seja: a repetição artificializaria (num sentido negativo), estabelecendo fórmulas. Para ele, um artista sem inteligência e sem (bom) gosto trata mecanicamente sua dança, privando-a do efeito (natural), distanciando-a do espírito; Noverre, então, indica o que se deve buscar:

Uma Scène d'action, na qual a Dança deve falar com calor, com energia: onde as figuras simétricas e afetadas não podem ser empregadas sem alterar a verdade, sem entrar em choque com a verossimilhança, sem enfraquecer a ação e afastar o interesse. ${ }^{57}$ (NOVERRE, 1760, p. 9-10, grifo e tradução nossos)

Para nomear a categoria de espetáculo que procurava, ele aplica expressões como scène d'action, danse em action ou ainda ballet en action, com a intenção de aproximar sua dança do drama e da pintura, responsáveis pelo que ele considera belo, verdadeiro, voltando-se para o gesto que ele classifica natural, acentuando a qualidade visual dessa manifestação artística:

O Balé bem composto é uma Pintura viva das paixões, do comportamento, do uso, das cerimônias e dos costumes de todos os povos da terra: consequentemente, ele deverá incluir todos os gêneros da Pantomima e falar à alma, pelo olhar. ${ }^{58}$ (NOVERRE, 1760, p. 18, tradução nossa)

Para falar à alma, a dança deveria incorporar as paixões do drama e, para criar características "reais" e ou "verdadeiras", a simetria deveria ser banida. A aparência de verdade que resultaria do tratamento assimétrico do espaço emprestaria aos espetáculos a qualidade de ação cênica. O olhar treinado de um designer vislumbraria um projeto de luz que respondesse às exigências de proposições dessa natureza, cujas indicações de ângulos, cores e texturas são muito particulares. Ele desaprovaria a estratégia mecânica que ainda hoje se repete em muitos espetáculos nos quais o palco é dividido ao meio e o projeto de luz resume-se à distribuição simétrica dos instrumentos (refletores). Quanto maior o orçamento, mais "combinações" gráficas, geralmente simétricas. Isso pode ser facilmente compreendido quando se observa a simetria como uma zona de conforto: se o orçamento do espetáculo só comporta 50 instrumentos, basta decidir que cada um dos lados do

57 “[...] une Scène d'action, où la Danse doit parler avec feu, avec energie: où les figures symmétriques \& compassées ne peuvent être employées sans altérer la verité, sans choquer la vraisemblance, sans assoiblir l'action \& refroidir l'interêt."

58 "Le Ballet bien composé est une Peinture vivante des passions, des mouers, des usages, des ceremonies, \& du costume de tous les Peuples de la terre; conséquemment, il doit être Pantomime dans tous les genres, \& parler à l'ame par les yeux." 
palco contará com 25. Se, no entanto, o número total for elevado para 500, os 25 transformam-se em 250.

Difícil errar numa operação meramente aritmética e tão simples. O trabalho de um designer, no entanto, pode alcançar outras esferas visuais. A crítica à simetria já aponta para uma disposição dos instrumentos não encontrada nos teatros franceses do período. O tratamento da visualidade, presente na ideia de espetáculo que Noverre (1760) defende, aponta para uma qualidade cromática específica. A nova dança exigia uma imagem viva.

O pensamento da cena francesa em direção aos pressupostos do realismo, também aqui podem ser aliados à ideia da cena como um "quadro vivo" (tableau vivant), ou uma sucessão de quadros vivos, revelando a verdade, o real, e reconhecendo no artista responsável pela cena, um pintor. Sua cumplicidade com a luz parece, então, inevitável. Mais uma vez pode-se citar Diderot e lembrar sua correspondência com Mme. Riccoboni. ${ }^{59}$ Ela envia uma carta a Diderot, provavelmente em 1758, na qual questiona sua teoria do espetáculo, baseando os comentários no texto teórico que acompanha Le pére de famille, escrito por Diderot no mesmo ano.

Na sua carta, Mme. Riccoboni defendeu com veemência o trabalho do ator e enfatizou o valor da experiência no palco, para a compreensão da cena. A abordagem teórica de Diderot estava fundamentada no seu próprio exercício literário, assim como no seu interesse e curiosidade sobre o funcionamento do espetáculo. Interesse, aliás, também manifestado pela correspondente. No particular, despertava a atenção do leitor para a importância da visualidade, tanto numa abordagem, quanto noutra. Defendendo, de modo veemente, seu ponto de vista, ela criticou Diderot: "O teatro é uma imagem, concordo. Mas uma imagem em movimento, da qual não temos tempo para examinar os detalhes". 60 (RICCOBONI apud DIDEROT, 1875, p. 396, tradução nossa)

Ao retrucar, numa carta enviada no mesmo ano, Diderot (1875) acentuou as relações entre a dramaturgia e a visualidade da cena, apontando a importância estratégica de certos momentos para as afirmações visuais de um espetáculo. Ele argumentou: "Não [teremos dificuldade em observar os detalhes visuais] no primeiro momento [do espetáculo], quando se levanta a cortina. Então, se há

59 Marie Laboras Mézières (1714-1792), mais tarde conhecida como Mme. Riccoboni, depois do seu casamento, em 1734, com Antonio Francesco Riccoboni, filho de Luigi Riccoboni, importante ator da Comédie Italienne e autor de Da arte da representação [Dell'arte rappresentativa (1728)] e Pensamentos sobre a declamação [Pensées sur la déclamation (1738)]. Ingressando numa família de renomados artistas, ela mesma estreia como atriz um mês depois de casar-se. Ela permanece na profissão por quase trinta anos quando, em 1631, decide dedicar-se à carreira literária. 60 "Le théâtre est un tableau, d'accord; mais c'est un tableau mouvant dont on n'a pas le temps d'examiner les details." 
silêncio entre as personagens, meu olhar se detém sobre seus movimentos e não perderei nada". ${ }^{61}$ (DIDEROT, 1875, p. 398-399, tradução nossa)

Diderot (1875) incluiu uma crítica ao posicionamento dos atores em cena, sempre de frente, dispostos num semicírculo em relação ao proscênio e à luz de ribalta. Baseando-se na sua compreensão de atriz, sua correspondente invocou o papel da percepção visual para a relação com o público, na qual, um pequeno gesto ou expressão teria função importante, argumentando: “[...] a três pés da ribalta um ator fica sem rosto". 62 (RICCOBONI apud DIDEROT, 1875, p. 396, tradução nossa) E, no que se refere à verossimilhança, Mme. Riccoboni revelou sua compreensão da cena como uma convenção, um processo seletivo de artificialização que permitia alcançar a ilusão desejada na cena: "A natureza é bela, mas é preciso que a vejamos por ângulos capazes de torna-la útil e agradável [...] A cena não pode jamais ser tão simples como um quarto [de dormir]; e, para que algo seja verdadeiro no teatro, deve ser um pouco mais que natural [real]". ${ }^{3}$ (RICCOBONI apud DIDEROT, 1875, p. 397, tradução nossa)

As assertivas de Mme. Riccoboni são relevantes para a compreensão do tratamento realista que se desenvolverá no teatro, no século seguinte. Ou seja, resumir, de modo simplório, que essa estética não passa de cópia da realidade, de ilusionismo, pode resultar numa compreensão do realismo como algo fácil, sem fundamentação ou função, um tratamento generalizado, e até preguiçoso, do espaço da cena. A atriz e autora Mme. Riccoboni enfatiza as características de convenção, que exigem atenção e muito trabalho do artista.

No quesito ilusão, à medida que novas tecnologias foram incorporadas à práxis cênica, mais se tornou possível efetivar o realismo na cena. Simultaneamente, a exigência dirigida ao artista que pretendia apresentar um tratamento realista do espetáculo era ampliada. Isso se justifica, pois, tendo à sua disposição instrumentos, acessórios, sistemas de controle, literatura, e a experiência de espectador, ele terá a obrigação de levar à cena resultados convincentes. Resultados que apontem mais para as relações entre a tecnologia disponível e a convenção realista propriamente dita, do que para a expectativa do senso comum. Além disso, não se pode esperar da crítica e do público conhecimento e vontade para avaliar métodos e/

\footnotetext{
61 "Ce n'est pas dans un premier mornent, au lever de la toile. Alors, s'il règne du silence entre les personnages, mes regards se répandront sur leurs mouvements et je n'en perdrai rien."

62 "[...] qu'à trois pieds des lampes un acteur n'a plus de visage."

63 "La nature est belle, mais il faut la montrer par les côtés qui peuvent la rendre utile et agréable. [...] La scène ne peut jamais devenir aussi simple que la chambre; et, pour être vrai au théâtre, il faut passer un peu le naturel."
} 
ou procedimentos específicos, quando até mesmo os resultados não são corretamente avaliados.

É possível observar na breve correspondência entre Mme. Riccoboni e Diderot o flagrante interesse pelas implicações visuais do espetáculo, mesmo em dois artistas com enfoques diversificados. Bom seria encontrarmos ainda hoje autores, diretores e dramaturgos seriamente interessados na discussão. 


\section{A REALIDADE NA LUZ DA CENA ROMÂNTICA}

As implicações visuais que apareceram na cena do século XIX ainda mostravam uma face poeticamente idealizada da arte, como se pode observar em $A$ arte poética [L'art poétique], de Boileau (1838, p. 28, tradução nossa): "Não há serpente ou monstro odioso | Que pela arte imitado não agrade aos olhos | De um pincel delicado a | habilidade graciosa | Do mais terrível objeto fará um objeto admirável". 64

Os versos de Boileau ganham força particular na metáfora que nomeia "pincel" o instrumento do artista, qualquer que seja a natureza do seu trabalho. É possível estender o alcance dessa imagem, apreendendo-a com flexibilidade: o poeta se refere tanto aos princípios da visualidade, aqui discutidos, quanto ao contexto integral de uma obra artística. Não somente o pintor, mas o escultor, o poeta, o ator, todo artista "empunha

64 “II n'est point de serpent, ni de monstre odieux, | Qui, par l'art imité, ne puisse plaire aux yeux: | D'un pinceau délicat l'artifice agréable | Du plus affreux objet fait un objet aimable." 
um pincel". Na práxis cênica, por conseguinte, o palco/espaço que a abriga ganha a função de suporte e a obra é criada com um "pincel" que se constitui de instrumentos e materiais muito particulares, sendo a luz indispensável para a revelação da pintura, da imagem - ou agrupamento de imagens em movimento - que chamamos cena, espetáculo, teatro, performance art, acontecimento espetacular, entre outras denominações.

Em um momento no qual o espetáculo teatral se originava tradicionalmente no texto, o trabalho do dramaturgo é assim resumido por Diderot (1875, p. 363, tradução nossa): "Pintar de acordo com a paixão e o interesse, eis o seu talento". ${ }^{65}$ No contexto da presente abordagem a compreensão do "dramaturgo que pinta" é ampliada para incluir qualquer artista envolvido na elaboração da práxis cênica. Então, mais do que um texto contendo diálogos representados por caracteres impressos sobre uma página vê-se uma "espécie de pintura cênica", ou seja, a articulação de imagens que constituem a cena. Pode-se dizer, num certo sentido, que a luz também assume o lugar de "pincel". E, para Diderot (1875, p. 374, tradução nossa), a qualidade dessas imagens deve apresentar um traço principal: "Se a natureza e a verdade forem uma vez introduzidas nos vossos palcos, na mais leve circunstância, logo se sentirá o ridículo e o desgosto em tudo que com elas contraste". ${ }^{6} 6$

Por natureza e verdade considere-se aqui uma representação figurativa da realidade, observando uma elaboração constituída de escolhas dos artistas, de artificialidades (positivas, artísticas, arbitrárias). Aquele que "pintava a cena", portanto, deveria atender a pressupostos muito particulares, aliando às imagens verdade e rigor:

Que vosso dramaturgo, tão logo julgue que vossa peça está digna de vos ser apresentada, traga o cenógrafo. Que ele a leia. Que o lugar da cena seja bem conhecido por ele, seja representado tal como é, e que ele entenda que a pintura teatral deve ser mais rigorosa e mais verdadeira que todos os outros gêneros de pintura. ${ }^{67}$ (DIDEROT, 1875, p. 374, grifo e tradução nossos)

Àquele tempo, essa pintura teatral não contava com a contribuição em separado de um responsável pelo pincel, ou seja, a luz. Essa incumbência poderia ser

\footnotetext{
65 "Peindre d'après la passion et l'intérêt, voilà son talent."

66 "Si la nature et la vérité s'introduisent une fois sur vos théâtres dans la circonstance la plus légère, bientôt vous sentirez le ridicule et le dégoût se répandre sur tout ce qui fera contraste avec elles."

67 "Que votre poëte, lorsque vous aurez jugé son ouvrage digne de vous être représenté, envoie chercher le décorateur. Qu'il lui lise son drame. Que le Heu de la scène, bien connu de celuici, il le rende tel qu'il est, et qu'il songe surtout que la peinture théâtrale doit être plus rigoureuse et plus vraie que tout autre genre de peinture."
} 
assumida pelo cenógrafo/pintor ou, quem sabe, pelo diretor. Consultando desenhos e pinturas que integravam os projetos ou foram executados por terceiros, para registrar imagens dos espetáculos, é possível imaginar o que era desejado por esses artistas.

Lendo a advertência de Diderot acerca dos cuidados com a indumentária encontra-se uma preocupação com a superficialidade usada para deslumbrar o público e alimentar a vaidade do ator, desconsiderando aquilo que o espetáculo pretenderia discutir ou provocar: "A pompa estraga tudo. [...] ela pode fascinar os olhos, mas não toca a alma". 68 (DIDEROT, 1875, p. 375, tradução nossa) "Tocar a alma" parece querer indicar a necessidade de um figurino que seja parte determinante na caracterização "verdadeira" (ou real) da personagem, incluindo tal caracterização na unidade lógica do espetáculo: “Onde está a verossimilhança, se no momento de uma ação tumultuosa os homens têm tempo de se paramentar, como num dia de representação ou de festa?". 69 (DIDEROT, 1875, p. 375, tradução nossa)

Um ator que decide se paramentar num momento de crise pode impor desrespeito à lógica da ação (realista). É importante lembrar que mais tarde, em poéticas revolucionárias assentadas na negação de quaisquer recorrências à representação figurativa da realidade para efetivar sua revolução através da imagem criada na cena, o modo como o performer "se vestia" - ou ainda se veste - também recebeu, ou recebe, atenção especial.

Diderot solicitava uma imagem fundamentada na ação e, por conseguinte, no ambiente da peça, assim como nas nuanças de cada personagem, nas relações entre as personagens. Isso pode incluir a lógica do comportamento e a atmosfera pretendida, caracterizando a visualidade inerente ao espetáculo por ele projetado.

Diderot (1875, p. 376, grifo e tradução nossos) usa sua própria dramaturgia para exemplificar a expectativa de um autor:

Se o Pai de Família for encenado, eu creio que essa personagem [o pai] não poderá se vestir de maneira muito modesta. E não se pode negar a Cécile o traje de uma filha que vive com opulência. Eu concordarei se for dado ao Comendador um galão de ouro, uma bengala com bico de corvo. Se ele mudar de roupa entre o primeiro e o segundo ato, não me surpreenderá, pois se trata de um homem muito caprichoso. ${ }^{70}$

68 "Le faste gâte tout [...] elle peut éblouir l'oeil, mais non toucher l'âme".

69 "Quelle vraisemblance, qu'au moment d'une action tumultueuse, des hommes aient eu le temps de se parer comme dans un jour de représentation ou de fête?"

70 “S'il venait jamais en fantaisie d'essayer le Père de Famille au théâtre, je crois que ce personnage ne pourrait être vêtu trop simplement. II ne faudrait à Cécile que le déshabillé d'une fille opulente. J'accorderais, si l'on veut, 
Exigindo precisão no figurino para garantir a caracterização da personagem, Diderot (1875) sublinhou a verossimilhança instalada na sua obra. Isso pode ter produzido argumento para os comentários que o atrelam exclusivamente à mencionada representação figurativa da realidade. O estudo da visualidade da cena, no entanto, prefere buscar a compreensão da conjuntura de cada convenção e identificar os problemas que ela apresenta ao designer.

A verossimilhança da imagem já estava intimamente ligada à cena concebida por Diderot, assim como por outros artistas e estudiosos do século XVIII, mesmo antes do positivismo relacionado a Auguste Comte (1798-1857), apontado por muitos como aspecto substancial do pensamento que provoca e apoia o realismo. Ainda assim, não se pode negar o fortalecimento da busca pela representação da realidade na cena do século XIX, momento no qual a história localiza o aparecimento do movimento realista no teatro. Os passos iniciais da abordagem realista devem ser acentuados, mesmo que se leve conta as diferentes compreensões de "ilusionismo" na cena, assim como dos muitos "realismos" desenvolvidos a partir do século XX.

A defesa do tratamento realista não caracteriza, num certo sentido, exclusividade do pensamento teatral do século XIX uma vez que diversificadas manifestações teatrais foram ligadas a certo grau de realismo ao longo da sua confirmação como tendência da cena. Mesmo o melodrama que aplicava inúmeros efeitos especiais e culminava em um final feliz ocasionado pelas instâncias metafísicas que o permeavam poderia ser incluído no universo do realismo, já que também tratava do cotidiano de pessoas comuns.

O drama histórico em verso, ainda que não incluísse a ação e/ou o diálogo realista no modo como se veria mais tarde, pode ser ligado à proposição realista ao incorporar cenários e figurinos que buscavam acuidade histórica.

Desse modo, é possível compreender o espanto do público diante da "naturalidade" do desempenho virtuoso de David Garrick (1717-1779), cuja interpretação hoje poderia ser reconhecida como um passo na criação da fé cênica, que mais tarde derivaria da obra de Constantin Stanislavski (1863-1938). E mesmo se for tomado como exemplo o melodrama de Pixérécourt, ${ }^{71}$ cuja descrição apresentada por Bergman o relaciona à estética romântica que incorpora um mundo fantás-

au Commandeur, un galon d'or uni, avec la canne à bec de corbin. S'il changeait d'habit, entre le premier acte et le second, je n'en serais pas fort étonné de la part d'un homme aussi capricieux."

71 René Charles Guilbert de Pixérécourt (1773-1844), dramaturgo francês, reconhecido como expoente do melodrama moderno, e apontado como precursor na função de diretor teatral, quando, montando suas peças no Théâtre de la Gaités, em Paris, cuidava de diversos aspectos do espetáculo, observando a justeza dos figurinos, cenários e a representação dos atores, para o atendimento daquilo que, em sua opinião, era o melhor caminho para a peça. 
tico, repleto de cavernas, ruínas, castelos, eremitérios, em diversificados lugares e períodos históricos, podemos encontrar traços que apontam para a abordagem realista. Em O Peregrino branco ou Os órfãos da aldeia [Le pèlerin blanc ou Les orphelins du hameau (1801)], na rubrica que segue a apresentação das personagens, o leitor encontra a seguinte indicação: "A ação acontece na aldeia de Olival, em Provence, ano de 1645". ${ }^{72}$ (PIXÉRÉCOURT, 1841, p. 82, tradução nossa)

Adiante, na primeira rubrica, do primeiro ato, encontra-se: "O palco representa o interior da aldeia de Olival; à direita, encontra-se a casa de Gervais; defronte dessa, a casa de Marceline. São seis horas da manhã, no verão".73 (PIXÉRÉCOURT, 1841, p. 83) Mesmo em uma cena povoada de luz (cores) e trevas, caracterizando o discurso visual romântico e incluindo espaços fantásticos, é possível identificar alusão explícita à realidade: fica indicada uma luz especificamente ligada ao ambiente no qual a cena se passa, apontando para um tratamento mais tarde vinculado à vertente científica, proposta pelo realismo do século XIX.

Como se pode notar, há compromissos com um tempo e um lugar objetivamente definidos. Diante da reduzida informação acerca da luz teatral incorporada ao melodrama, as ilustrações disponíveis podem dar pistas da grandiosidade pretendida pela abordagem romântica da natureza. Observando as imagens mentais criadas por Pixérécourt pode-se imaginar aquilo que o teatro buscava fisicalizar àquele momento, sugerindo, inclusive, a aplicação de cor na luz para criar atmosferas. Além disso, a cenografia tridimensional já figurava no interesse de artistas como Joseph-François-Louis Grobert, ${ }^{74}$ que questionou a exclusiva aplicação de tapadeiras laterais móveis pintadas para sugerir profundidade no palco.

A conjuntura técnico-artística que sustentava o teatro do romantismo já incluía importantes aspectos da aplicação da luz à cena, como a necessidade de criar incisivos contrastes de luz e sombra, assim como atmosferas suavemente implantadas em ambientes convincentes. Isso levou cenógrafos e técnicos a desenvolverem um intrincado controle mecânico para os instrumentos e acessórios, produzindo ilusão através de movimento, cor e transparência. Tal sistema, em grande parte protegido do olhar do espectador - e isso é muito importante para que se compreenda a busca pela ilusão realista - preenchia a cena de magia, tornando a luz elemento decisivo naquela estética.

\footnotetext{
72 "La scène est au hameau d'Olival, em Provence, l'an 1645."

73 "Le théâtre represente l'interieur du hameau d'Olival; à droite est la Maison de Gervais; vis-à-vis est celle de Marceline. Il est six heures du matin en été."

74 Autor do livro Da execução dramática... (De l'exécution dramatique...) publicado em Paris, em 1809.
} 
Diversificados elementos de suporte para instrumentos de iluminação cênica podiam ser encontrados, tais como a ribalta, as varas acima do palco, suportes móveis implantados diretamente nos dispositivos cenográficos, torres laterais dispostas entre as pernas, difusores, refletores, véus e telas de tafetá colorido que poderiam filtrar um ou mais instrumentos, provavelmente lamparinas a óleo. A combinação de tais elementos podia produzir variadas composições ou imagens - projetadas para cada momento, configurando a busca pela ilusão romântica de realidade. Da luz dependia substancialmente a efetivação dessas imagens.

\section{A LUZ QUE TOCA O ESPETÁCULO}

Ao tratar da luz no romantismo, Gösta M. Bergman faz uma incursão na documentação do Real Teatro de Estocolmo, na década de 1820, para exemplificar o conjunto de aparatos para iluminação aplicado com o objetivo de alcançar propósitos estéticos do teatro romântico. Ele comenta anotações acerca da representação de Gustaf Lagerbjelke (1777-1837), para o melodrama em versos Odin em Svithjod [Oden i Svithjod], ${ }^{75}$ música de J. F. Berwald e G. A. Brakel, em 1826, cujo tema é retirado da mitologia sueca e integra a literatura romântica do início do século XIX. Bergman (1977) cita a cenografia e as combinações de luz que aparecem nas anotações da montagem dirigida por Lagerbjelke, nas quais se pode apreender o interesse do diretor na luz do espetáculo. ${ }^{76}$ Além daquilo que está implicitamente indicado na dramaturgia, encontram-se nessas anotações aspectos importantes da contribuição da luz, incluindo cor, ritmo visual, intensidade e ângulos, dentre outros.

Juntando-se a isso os diários técnicos do teatro podem-se imaginar os movimentos de Odin. No início do primeiro ato, ao som do trovão, ele entra e ocupa o centro de uma organização simétrica de pedras nas quais os deuses estão sentados, próximos às tendas da tripulação que com ele viajou para tomar posse de Svithjod. Detalhes como filtros azuis, telas transparentes, varas de luz, nuvens que acompanham o trovão e os relâmpagos, além de observações sobre intensidade e tempo configuram indícios de um "roteiro de operação"77 para a luz do espetáculo. Um sistema de luzes que iluminava telões recortados era disposto em um dos

\footnotetext{
75 Odin é o herói e Svithjod, o antigo nome da Suécia, ou mais especificamente de um antigo território hoje denominado Svealand.

76 Essas anotações incluíam detalhes dirigidos ao professor $\mathrm{Hjelm}$ que, ao que parece, tinha particular responsabilidade nas questões referentes à luz e, na compreensão de Bergman, tinha a última palavra em muitos momentos.

77 Um documento do qual constam orientações para a operação do sistema de controle da luz usada no espetáculo.
} 
lados, o que já estabelecia decisiva assimetria com a luz. Tratava-se de um detalhe muito importante, pois é possível identificar a intenção de produzir uma qualidade "natural", através da desconstrução da simetria que imperava na convenção da luz para a cena naquele momento.

Um conjunto de nuvens era levantado em um tempo cronometrado de oito minutos, enquanto um grande véu azul era retirado através de um mecanismo elaborado para estabelecer movimentos sincronizados que representavam o nascer do dia e preparavam a atmosfera para Odin, que dizia: "Que a paz esteja com o povo, que a paz esteja com a nação".78 (LAGERBJELKE apud BERGMAN, 1977, p. 246, tradução nossa) Durante o desenvolvimento do primeiro ato, eram adicionados outros elementos do sistema de luz, como suportes atrás das pernas, determinando a visualidade que permaneceria durante todo o resto do ato e estabelecendo uma "estabilidade convencional" para a luz do dia. Depois que o sol se "erguia", a convenção definida para o espetáculo determinava, através da luminosidade instalada, que a ação ocorria durante o dia e dispensava outros movimentos da luz.

Segundo Bergman, o diretor fez um alerta importante sobre o nascer do sol chamando a atenção para que não fossem usados filtros vermelhos, uma vez que essa cor seria decisiva na elaboração das imagens para o quinto ato. Se a luz deveria ser fixa, "estática", no decorrer do ato em discussão, ela ganharia grande complexidade no próximo, cuja ação ocorria num salão do castelo de Gylfe em cujo centro ardia uma fogueira. Se isso, à primeira vista, não chamou a atenção do leitor, é importante que seja registrado: há uma fogueira no meio do espaço da cena!

$\mathrm{O}$ interior do castelo estendia-se até a profundidade da segunda perna ${ }^{79} \mathrm{e}$, ao fundo, através de uma porta, eram vistos galhos que pendiam, indicando as árvores, lá fora. Mais ao fundo, através do portão de um muro distante, contemplava-se uma paisagem marinha. A descrição do ambiente remete ao pensamento visual do teatro romântico, quando, na mesma imagem elementos arquitetônicos "se abrem" para visões da natureza, como se pode ver no esboço de Fabrizio Galliari para o cenário da ópera Enea nel lazio, música de Tommaso Traetta e libreto de V. A. Santi, cuja estreia se deu em Turim (1760). Fabrizzio e seu irmão Bernardino

\footnotetext{
78 "Peace to be As people, peace to be As land."

79 Denominação do elemento da configuração de um teatro italiano que tem as funções de definir os planos e proteger os bastidores do alcance visual do espectador. Geralmente confeccionado em tecido de cor preta, pode ser incorporado à cenografia, recebendo tratamento que o integre ao ambiente criado, e denominado tapadeira ou trainel.
} 
eram cenógrafos do Teatro Real de Turim, sendo mencionados nos documentos do período como os irmãos Galliari (Figura 94).

Mesmo sem acesso à documentação visual desses cenários pode-se presumir que os artistas levaram à tridimensionalidade do palco um aprendizado que se desenvolveu desde a Renascença, passou pelo Barroco e alcançou a abordagem romântica da pintura. Assim, eles puderam incorporar, ou reagiram às propostas de outros artistas, tais como a arquitetura de Canaletto (1697-1768), as atmosferas de Georges de la Tour (1593-1652), as personagens de Jacques-Louis David (1748-1825), todos os casos invadidos pela luz, assim como as paisagens luminosas de John Constable (1776-1837) e de Louis Jacques Mandé Daguerre (1787-1851) (Figuras 95 a 99).

Voltando a Odin em Svithjod. Bergman (1977, p. 248, tradução nossa) descreve o terceiro ato em um pequeno parágrafo sem registrar mudanças de luz em toda a sua extensão, e abre dizendo: "A luz do terceiro ato é desinteressante". ${ }^{80}$ O comentário final de Lagerbjelke, contudo, pode explicar a escolha por uma luz que, isoladamente, pode parecer "desinteressante". Considerando tratar-se de um momento no qual a indicação se refere a um ambiente sob a amplitude da luz do dia, vale a pena observar a solução técnica encontrada: "[...] há suportes padrão instalados em todas as pernas de madeira [que representam a floresta]". ${ }^{81}$ (LAGERBJELKE apud BERGMAN, 1977, p. 248, tradução nossa)

É importante observar que, partindo de um segundo ato no qual o ambiente dado pela dramaturgia já indica imagens de significativa complexidade, pode ter sido intenção, ou intuição do autor, criar simplicidade visual no terceiro, com o intuito de estabelecer equilíbrio para a totalidade do espetáculo, através do contraste. Afinal, a ação ocorre numa floresta de pinheiros e bétulas, vendo-se ao fundo o Castelo de Gylfe, à luz do dia. Isso pode ter levado à decisão de elaborar uma atmosfera visualmente uniforme para o dia, justificada nas relações entre a ação e o ambiente. Assim, o diretor e seus associados não encontraram razão para propor movimentos na luz que poderiam, inclusive, parecer gratuitos, sem propósito, caracterizando mera imposição visual. Isso pode chamar a atenção do iluminador: mesmo em proposições atuais que defendem a chamada "dramaturgia da luz", é possível questionar o uso feérico de sucessivos efeitos de luz, apenas para afirmar sua "presença".

No quarto ato, a ação também se passa à luz do dia, mas o ambiente da cena apresenta uma composição diferente, provocando outro tratamento e interação

\footnotetext{
80 "The lighting in the third act is uninteresting."

81 "It is full day light: 'ordinary lamp bords on all the wood wings'."
} 
com a visualidade sem a necessidade de impor ou "inventar" efeitos. Baseando-se nos escritos de Lagerbjelke Bergman menciona uma parede que cruza a extensão do palco e tem como referência a quarta perna; atrás dela se vê o templo de Gylfes, situado em um bosque. No proscênio, um altar com noventa centímetros de altura. Suportes padronizados para a luz eram instalados atrás das pernas que incorporavam as árvores do bosque. Na frente da mencionada parede, havia um telão verde e, entre eles, luzes nas pernas; além disso, suportes adicionais estavam instalados no alto, provendo luz para o telão de fundo e, entre os telões duplos, luz, como a do sol. A mesma luz do dia que construiu a atmosfera do terceiro ato interagia agora com um novo ambiente, estabelecendo composições diferenciadas e sutileza na assertiva visual.

O quinto e último ato comprovava tal assertiva trazendo uma característica peculiar: a luz mantinha qualidade semelhante àquela do quarto ato durante quase toda a ação. Na parte final da peça, no entanto, a crise se precipitava e, numa reviravolta, o templo era incendiado e desabava, assim como a parede à sua frente. Vitorioso, Odin aproxima-se do altar, enquanto o crepúsculo avança. O diretor escreveu:

No início dessa [cena], os suportes de luz são gradualmente removidos das pernas, tanto no interior, quanto na parte interna da parede. Mas os suportes com lamparinas postos entre a parede e o telão devem permanecer até que o templo desabe; mas devem estar preparados para serem retirados imediatamente depois da queda. ${ }^{82}$ (LAGERBJELKE apud BERGMAN, 1977, p. 248, tradução nossa)

Havia um efeito especial para a queda do templo, assim como para o incêndio. Bergman completa informando que quando Odin chegava ao altar, o sol começava a se pôr e continuava imperceptivelmente o processo durante o longo monólogo. No momento que Odin fere a si mesmo com a própria espada, o sol já se pôs completamente, instalando-se a escuridão. Isso era alcançado posicionando-se filtros vermelhos instalados em tripés, em frente às luzes que iluminavam os telões. Além disso, uma vara era acionada atrás da boca de cena, com lamparinas nas quais se acrescentou o mesmo tipo de filtro que, vindo de baixo e de cima, preenchia a cena de vermelho. A ribalta era parcialmente retirada (baixada), e os filtros vermelhos eram adicionados a todo o sistema de luz que iluminava a cena.

82 "At the very beginning of this (scene) the lamp boards are gradually removed from all the wings, both inside and outside the wall. But the lamps standards between the wall and the backdrop mask are left until the the temple has collapsed; but are loosened to be removed immediately after the collapse." 
É possível, portanto, avaliar a imprescindível função que a luz cumpria no mencionado contexto, implantando as atmosferas da cena. (BERGMAN, 1977) Pode-se imaginar a quantidade de pessoas envolvidas no processo e o alto risco de incêndio para alcançar um resultado que hoje pode ser usado como um efeito banal, aplicando de alguns instrumentos e controle digital.

As sugestões e indicações encontradas na dramaturgia apontavam para a luz que o autor desejava vislumbrar na cena propriamente dita, instigando o diretor e seus colaboradores na tarefa de elaborar a visualidade do espetáculo. Ainda que algumas indicações pareçam demasiado simples, um artista criterioso encontraria ali significativa provocação para conceber um elaborado projeto de luz, como o que foi descrito acima, estabelecendo, portanto, uma relevante contribuição para a cena.

Em tal categoria de projeto, grande parte dos instrumentos propriamente ditos deveria permanecer fora do alcance visual dos espectadores, tornando a cena surpreendente e convincente naquele contexto estético-poético. A estratégia configurava-se como um importante estágio em direção ao realismo teatral, no qual o público teria acesso apenas aos resultados da luz projetada sobre a cena sem identificar a conjuntura tecnológica que produzia a ilusão.

\section{HENRY IRVING SOB A COR DA SOMBRA}

Na segunda metade do século XIX, um artista inglês introduziu contribuições importantes para a compreensão do espetáculo como um empreendimento visual. Rosenthal e Wertenbaker, já mencionados no presente trabalho, comentaram o trabalho do ator, diretor e produtor teatral Henry Irving (ou John Brodribb, 1838-1905). ${ }^{83}$ Segundo eles, a crítica da época mencionou o tratamento melodramático que as montagens de Irving impunham a qualquer que fosse o texto, em busca de intenso lirismo e do apelo de efeitos na cena. Os espetáculos ganhavam uma espécie de realismo impregnado de romantismo. Rosenthal e Wertenbaker descreveram a montagem de Macbeth:

A Lady Macbeth da montagem de Henry Irving tinha seu cabelo ruivo fumegante sob a luz de tochas, e Macbeth, na cena final, retirava uma tocha detrás de um pilar e atirava-a, em chamas,

83 Henry Irving administrou o Lyceum Theatre, em Londres, por 20 anos, desde 1878. Nesse período, ele combinava as funções administrativas com seu trabalho no palco; além de ator e diretor, supervisionava sistematicamente o tratamento visual dos seus espetáculos, discutindo com pintores, engenheiros responsáveis pelo sistema de gás, aderecistas e operadores de lâmpadas oxídricas (limelight). E, finalmente, com os engenheiros encarregados da luz elétrica, desde 1891, quando começou a experimentar essa tecnologia no teatro. 
no solo. Sir Herbert Beerbohm-Tree, como Nero, era transportado pelo palco em uma biga conduzida por cavalos treinados, e incendiava Roma, destruindo casas, atingindo templos e ateando fogo. Apresentando seu Macbeth, Beerbohm-Tree era acompanhado de um chocalhar de granizo e dos clarões ofuscantes de relâmpagos e, quando Macbeth aparecia na charneca, tendo atrás de si um fundo deslumbrante de céus tempestuosos, o público explodia em aplausos. ${ }^{84}$ (ROSENTHAL; WERTENBAKER, 1972, p. 53, tradução nossa)

Mesmo sem ter conhecimento do texto efetivamente usado no espetáculo comentado, é possível especular que a dramaturgia de Shakespeare servia como provocação, o que pode ter originado uma deliberada intervenção na obra. Irving propunha um tratamento particular da tragédia shakespeariana reinterpretando sua visualidade para atender aos traços estético-poéticos já citados. Ainda que processos dessa natureza nos quais a dramaturgia cede espaço para certa hegemonia da representação tenham acontecido antes, o exemplo de Irving demonstra que, assim como o dramaturgo, também o diretor confia na visualidade para criar sua poética, na qual a luz exerce papel decisivo.

O espetáculo de Irving parece ter desenvolvido um discurso visual muito próprio, como se pode apreender dos comentários do amigo e admirador, Bram [Abraham] Stoker (1847-1912), escritor, crítico de teatro e administrador financeiro da companhia de Henry Irving no Lyceum Theatre. Segundo Stoker, depois de assistir a um ensaio parcial de Fausto, em 1885, ele não acreditou no sucesso que todos previam para a montagem. Tratava-se de um espetáculo que envolvia grande elenco, muitos bailarinos e, no ensaio, a maioria deles já usava seus figurinos, criando uma cena com grupos visuais no palco, luz e ação, como descreve Stoker (1907, p. 94, tradução nossa): “[...] toda a correria, vertigem e cataclismo triunfante de uma possessão demoníaca irrestrita". ${ }^{5}$ O ensaio, no entanto, mostrava uma cena - em sua opinião - fria e irreal, o que o levou a procurar Irving no camarim ao final da sessão de trabalho para argumentar que aquele espetáculo não alcançaria

\footnotetext{
84 "Henry Irving had Lady Macbeth carried out with her red hair steaming in torchlight, and Macbeth, in the final scene, took a torch from behind a pillar and hurled it blazing to the ground. Sir Herbert Beerbohm-Tree as Nero was drawn across the stage in a chariot by live, stage-trained horses, and he burned Rome with crumpling houses, crashing temples and shooting flames. Introducing his Macbeth, Beerbohm-Tree had such a roar of wind, rattle of hail and blinding flashes of lightning that when Macbeth appeared on the heath against a dazzling background of stormy skies, the audience burst into applause."

85 "[...] and all the rush and whirl and triumphant cataclysm of unfettered demoniacal possession."
} 
o público no nível projetado pelo grande ator. Convencido da honestidade do seu julgamento, Stoker ouviu a resposta de Irving:

Isso é verdade; contudo, neste caso, não tenho dúvidas. Sei que a peça vai funcionar. Penso que você não foi capaz de julgar com precisão, no ensaio, hoje à noite. Você criou uma opinião, em grande parte, influenciada pelo efeito da cena do Brocken. Considerando esse ensaio, você tem razão; mas, você não viu minha indumentária. Eu não quero usá-la até que todo o resto esteja pronto. Então você verá. Vou manter cuidadosamente todo o projeto de cor relacionado com aquele cinza-esverdeado. Quando minha roupa escarlate flamejante aparecer junto com esse tom e, lembre-se que a cor será intensificada precisamente pela luz, que criará toda a imagem, de uma maneira que você nem pode sonhar. Na verdade, eu mesmo mal consigo perceber agora, embora saiba que vai funcionar. Você verá também como o vestido branco de Ellen Terry e, até mesmo aquela cicatriz vermelha em sua garganta, se destacará no meio daquele turbilhão de relâmpagos! [Figura 100]. ${ }^{86}$ (IRVING apud STOKER, 1907, p. 94-95, tradução nossa)

Irving demonstrara sua capacidade de "pré-ver" as imagens visuais que constituiriam a cena, assim como sua confiança na luz e no poder do discurso poético-visual de promover a eficiência do espetáculo: "Ele viu na sua própria mente e com sua vasta e efetiva imaginação todas essas imagens e eventos, desde o início [antes que acontecessem]. ${ }^{87}$ (STOKER, 1907, p. 95, tradução nossa) Ficava clara a aplicação de um contraste cromático complementar sofisticado e simples, nas relações entre os cinzas frios esverdeados e o tom de púrpura provavelmente ligado à qualidade do alizarin-crimson. ${ }^{88}$

86 "That is all true; but in this case I have no doubt. I know the play will do. To-night I think you have not been able to judge accurately. You are forming an opinion largely from the effect of the Brocken. As far as to-night goes you are quite right; but you have not seen my dress. I do not want to wear it till. I get all the rest correct. Then you will see. I have studiously kept as yet all the colour scheme to that grey-green. When my dress of flaming scarlet appears amongst it and remember that the colour will be intensified by that very light it will bring the whole picture together in a way you cannot dream of. Indeed I can hardly realize it myself yet, though I know it will be right. You shall see too how Ellen Terry's white dress, and even that red scar across her throat, will stand out in the midst of that turmoil of lightning!"

87 "He had seen in his own inner mind and with his vast effective imagination all these pictures and these happenings from the very first."

88 Tons de vermelho que tendem a se aproximar do púrpura e a se afastar dos tons de laranja, no círculo cromático, alcançando densidade particular. Uma dessas cores, hoje colocadas à disposição pela indústria chama-se vermelho demônio. A alizarina é um corante e pigmento vermelho derivado originalmente da raiz da garança. O crimson, ou carmesim, é a cor do corante produzido por um inseto - kermes vermilio, um tom de vermelho forte, brilhante e pro- 
Em uma crítica publicada em 1887, antes do livro de Stoker, Joseph e Elizabeth R. Pennell já delineavam o contexto visual das montagens de Irving. Os autores comentavam a grande atenção dedicada às propriedades intelectuais da montagem e à dramaturgia propriamente dita, afinadas com a beleza da cenografia e a perfeição dos detalhes. Em uma breve assertiva, eles resumiram: "Você pode, sem dúvida, denominar a peça uma composição em vermelho, pois em todas as cenas a cor é concebida de modo que tudo se dirige para suas vestes de demônio". ${ }^{89}$ (PENNELL, J.; PENNELL, E., 1887, p. 310, tradução nossa) Observando os argumentos da crítica, outros aspectos importantes podem ser destacados, o que torna sua leitura integral de grande contribuição para pesquisadores interessados no discurso visual do espetáculo. Os autores comentaram a natureza das imagens criadas por Irving, destacando não apenas a beleza em si, mas sua contribuição para a harmonia da montagem, cumprindo o objetivo de fazer o espetador perceber, diante de si, a realidade das cenas e o tratamento da cor, ainda que ele mesmo sugira no simbolismo uma espécie de ameaça à tridimensionalidade do teatro, reduzindo-a ao que chamou de "pictorialismo" da cena. (ROUBINE, 1982b)

Considerando a fábula em questão, seu tema de origem religiosa, medieval, com alto grau de fantasia, o comentário citado abaixo apresentava uma reserva à caracterização desenvolvida por Irving para Mefistófeles, apontando um equívoco visual:

Fausto é uma lenda da Idade Média e como a personagem medieval foi preservada, não havia necessidade de exata datação. Os brocados e armaduras usados pelos cidadãos de Nuremberg [onde Irving decidiu localizar a ação], se não cópias das peças históricas, são sugeridos por imagens antigas. Mas, no caso do seu próprio figurino, o Sr. Irving conscientemente usou um casaco escarlate, uma grande pena de galo e a longa e afiada espada que Goethe tomou emprestada do Mefistófeles da peça de bonecos. O bigode pontudo e curto, assim como a barba de duas pontas do demônio criado pela ópera, não autorizados por Goethe, ele descartou, de modo imprudente, pensamos, pois ele parecia mais um Dante caído, como disse o Sr. Hatton, do que um Mefistófeles ridicularizador. Respeitando a roupa tradicional, mas desconsiderando o rosto tradicional, ele não nos

fundo; combinado com azul, resulta um certo grau de púrpura. Pode-se também encontrar essa denominação para descrever cores ligeiramente azul-avermelhadas que, em geral, estejam entre o vermelho e os róseos.

89 "You might, indeed, call the whole play an arrangement in red, for in all the scenes the color is toned so that it may lead up to his demon dress." 
deu nem o velho nem um novo Mefistófeles. ${ }^{90}$ (PENNELL, J.; PENNELL, E., 1887, p. 310, tradução nossa)

Em seguida, eles encontraram razões para qualificar positivamente o trabalho de Irving: "O principal mérito das imagens criadas pelo Sr. Irving não está nos materiais, disponíveis para todos os gestores [de companhias ou teatros], mas no uso artístico que ele faz. As mais belas cenas, de um ponto de vista pictórico são, naturalmente, as ruas, os jardins e o Brocken [uma montanha da Saxônia]". 91 (PENNELL, J.; PENNELL, E., 1887, p. 309, tradução nossa) É verdade que eles parecem influenciados pela ilusão perspectivista, capaz de fazer o palco transformar-se em ambientes muito mais grandiosos do que parece possível. Por outro lado, a qualidade pictórica destacada levou os Pennell à observação de relações entre as cenas criadas por Irving e obras importantes da história da pintura. Tal observação sublinhava não somente a capacidade do diretor de ver na mente as imagens provocadas pela dramaturgia, mas, também, de fazer conexões com a visualidade presente na história das imagens, das artes visuais. Essas conexões fazem três referências à obra de Rembrandt (1634-1693), cuja influência pareceu decisiva para a visualidade do Fausto, de Goethe-Irving.

Segundo os autores, o local escolhido por Irving para o encontro de Margaret com Fausto, a Praça de São Lourenço em Nuremberg, tinha a precisa atmosfera para a ação cênica. Eles descrevem a vividez do ambiente e das personagens, destacando as meninas, que, usando vestidos escuros de lã, lembram aquelas que aparecem na pintura Cristo abençoando as crianças (1652-1653), que acreditavam da autoria de Rembrandt. ${ }^{92}$ A menção a outras obras, essas sim confirmadas como pintadas por Rembrandt sugere, na compreensão dos Pennell, a pesquisa efetivada na representação de Henry Irving, em busca de excelência visual:

90 As for time, Faust is a legend of the Middle Ages, and so long as the medieval character was preserved there was no necessity for exact dates. The brocades and armor worn by the citizens of Nuremberg, if not copied from, are suggested by, old pictures; but for his own dress Mr. Irving conscientiously wears the scarlet coat, the tall cock's feather, and the long, sharp sword which Goethe borrowed from the Mephistopheles of the puppet play. The pointed mustache and short, forked beard of the operatic demon, not being authorized by Goethe, he has discarded, unwisely we think, since he looks much more like a fallen Dante, as Mr. Hatton says, than like a mocking Mephistopheles. By respecting the traditional dress and disregarding the traditional face, he has given us neither the old Mephistopheles nor a new one.

91 The chief merit of Mr. Irving's pictures is not in his materials, those being at the disposal of all managers, but in the artistic way in which he uses them. The finest scenes from the pictorial standpoint are naturally the streets, the gardens, and the Brocken."

92 Durante algum tempo creditada a Rembrandt, e negociada em 1866 como obra sua, hoje os estudiosos concordam que o seu autor é o artista, também holandês, Nicholas Maes (1643-1693), que estudou pintura com Rembrandt, provavelmente entre 1648 e 1653 . 
A segunda cena de rua, o duelo [ou a morte de Valentines], que ocorre mais tarde na peça, no terceiro ato, é não menos realista e bonita. Quando a cortina sobe, ainda há uma cor suave no céu, ao final da longa e tortuosa rua, à esquerda, que rapidamente desvanece. A igreja é evidenciada, uma grande massa escura acima do palco, e se vê somente os pesados contrafortes e uma grande janela. O resto está na sombra, exceto em um canto onde há uma lamparina acesa diante de um santuário. Da escuridão e ao som de tambores distantes, os soldados retornam para casa depois das guerras - esposas, filhos e namoradas pendurados em seus braços, as alabardas coroadas com verdes, tochas e cressets levados bem no alto. Cada grupo era um estudo [visual] em si mesmo. Mas a melhor imagem veio depois que Mefistófeles cantou sua canção-demoníaca e atirou seu bandolim para longe, Valentine é ferido, e todo o povo da cidade corre pela longa rua e entra por todos os lados, Margaret e Martha saem da casa em frente à igreja. Na marcha dos soldados que retornavam havia a atmosfera de $A$ Ronda noturna (1640-42) [Figura 101], de Rembrandt. Neste último grupo, o sentimento não é de uma única imagem, mas de todas as grandes imagens deste tipo, que já foram pintadas. O próprio Sr. Irving disse, que para sua composição tinha muitas delas, com frequência, em mente; e quando se analisa a imagem, considera-se que ela é magistral. O homem que carrega a tocha concentra toda sua luz no rosto de Valentine, a massa de rostos atrás dela espreita dentro uma misteriosa meia-luz, enquanto Margaret, com seu crime tipificado pela densa e negra sombra que cai sobre ela, encolhe-se no primeiro plano. [...] Essa cena lembra A Ressurreição de Lázaro, de Rembrandt [Figura 102], no seu arranjo de luz e sombra. Mas a imagem criada pelo Sr. Irving não é, de nenhum modo uma cópia: ao contrário, ela é o trabalho de um grande mestre da composição. ${ }^{93}$ (PENNELL, J.; PENNELL, E., 1887, p. 310, grifo e tradução nossos)

93 "The second street scene, which of Valentines death or duel, occurring much later in the play, in the third act, is no less realistic and beautiful. When the curtain goes up, there is still a faint color in the sky at the end of the long, twisting street to the left, but it quickly fades. The church rises, a great dark mass away above the stage, and you only see the heavy buttresses and one large window. The rest is in shadow, save in one corner where a lamp burns before a shrine. From out the gathering gloom and to the sound of distant drumming come the soldiers home from the wars, - wives, children, and sweethearts hanging to their arms, the halberds wreathed with green, and torches and cressets borne aloft. Each separate group is a study in itself. But the finest picture comes after Mephistopheles has sung his demon-song and flung away his mandolin, and Valentine is wounded, and all the towns - people hurry hack through the long street and from every side, and Margaret and Martha come out from the house opposite the church. In the soldiers marching home there was the feeling of Rembrandt's Night watch. In this last group the 
Tais comentários denotam a observação da cena como imagem (ou um conjunto de imagens em movimento), acentuando a contribuição do binômio luz-sombra para o teatro de Irving. Postos no contexto da segunda metade do século XIX, os relatos de Stoker indicam o trabalho de Irving como atitude que abria novos caminhos para a compreeensão da visualidade do espetáculo:

Com Irving tudo era diferente. Aquela marcha 'suave' dos soldados de Macbeth que retornavam fatigados após a batalha vitoriosa, vistos contra o sol que caía atrás da vasta charneca cravejada com manchas de luz brilhando sobre a água, a interminável fileira de soldados separados, um a um, individualmente, e em grupos de dois ou três, preenchia o palco para a celebração de uma infindável variedade, transmitindo uma ideia de força e poder que impressionou o espectador com uma sinceridade de valor inestimável. Irving sempre ajudava seu público a pensar. $^{94}$ (STOKER, 1907, p. 15, tradução nossa)

Irving introduziu meios para controlar os conjuntos de bico de gás, elaborando combinações de cor e intensidade, baseando-se em efetiva experimentação. Ele pondera: "[...] a natureza raramente mostra grandes efeitos regulares de luz". (IRVING apud BERGMAN, 1977, p. 302, tradução nossa) Seu argumento refere-se às dinâmicas relações entre a luz natural e o ambiente, determinadas por diversos fatores, como a densidade atmosférica, além de outros obstáculos e/ou suportes. A interpretação cênica desses eventos sugere inúmeras composições de luz e sombra. Já aplicando a eletricidade ele elaborou diversificadas possibilidades de construção de imagens, pesquisando novos caminhos para a produção de cor e brilho na luz como a aplicação de lacas nas lentes das lâmpadas oxídricas [limelight] ${ }^{95}$ (Figura 103), e também nos próprios bulbos das lâmpadas elétricas.

feeling is not of a single picture, but of all the greatest pictures of this kind that have ever been painted. Mr. Irving himself has said that in its composition he had many of them constantly in his mind; and when you analyze his picture, you find that it is masterly. All the light from the torch held by the man who supports him is concentrated on the face of Valentine. The mass of faces behind peer out from a mysterious half-light, while Margaret her crime typified by the dense black shadow falling on her, cowers in the foreground. [...] One etching that suggests itself to us just now, Rembrandts Raising of Lazarus, is somewhat like this scene in the arrangement of light and shade. But Mr. Irving's picture is in no sense a copy: it is rather the work of a great master of composition."

94 "With Irving all was different. That 'easy' progress of Macbeth's soldiers returning tired after victorious battle, seen against the low dropping sun across the vast heather studded with patches of light glinting on water; the endless procession of soldiers straggling, singly, and by twos and threes, filling the stage to the conclusion of an endless array, conveyed an idea of force and power which impressed the spectator with an invaluable sincerity. In fact, Irving always helped his audience to think."

95 Luz oxídrica ou luz de Drummond [Thomas Drummond (1797-1840)] é um artefato aplicado à iluminação teatral, a partir da primeira metade do século XIX. Ele produz uma iluminação intensa, pela combinação de uma 
Bram Stoker destaca a atenção dedicada por Irving aos ensaios de luz, precedidos e/ou acompanhados de discussões sobre a natureza dos espetáculos, envolvendo cenógrafos e técnicos. Reconhecendo que sua função não o obrigava a frequentar ensaios, Stoker revela que os assistia frequentemente, pelo prazer de testemunhar aquele processo, presumindo que ali estavam sendo criadas novas abordagens do espetáculo teatral. Intuitivamente ou não, de acordo com Bram Stoker (1907), Irving trabalhou o potencial expressivo da sombra, até hoje pouco discutido e/ou aplicado ao teatro. A sombra é frequentemente associada ao "teatro de sombras", um gênero diferenciado que conta com sua própria abordagem teórica. Interessa aqui, a interação dinâmica entre a sombra e a luz, determinando que uma não seja percebida sem a presença da outra, isto é, mesmo que não esteja obviamente presente numa imagem, a sombra estará atuando. Ela exige, desse modo, muita atenção do artista pesquisador interessado na expressão visual do acontecimento espetacular, devendo ser tratada, artisticamente, como aspecto inalienável da imagem.

Irving e Stoker referem-se ao papel da sombra na constituição visual da imagem cênica em si. Deixar de pesquisar essa possibilidade, portanto, é abrir mão de um relevante elemento constitutivo da visualidade. Irving interessava-se por uma sombra que fosse capaz de tocar o público, construindo o que ele chamava de: “[...] verdadeiro realismo que todos deviam buscar". ${ }^{66}$ (IRVING apud BERGMAN, 1977, p. 259, tradução nossa)

Ao afirmar que Irving pintava as imagens no palco com várias combinações de luz (que, obviamente, inclui cor), Bergman toma emprestado de Stoker o verbo pintar. E Stoker até cita o próprio Irving quando esse sugere que pintor e ator devem se debruçar, um sobre a atividade do outro, já que, sendo os meios de produção das suas obras tão diferentes, esse estudo ampliará a capacidade artística de ambos. E justifica:

O pintor trabalha com materiais moldáveis, inanimados, não sensíveis, mas que se rendem ao mais suave toque. Sua criação é a incorporação do fantasma da sua imaginação, pois em arte o objetivo é glorificar e não meramente reproduzir. Ele usa formas e fatos da natureza que não pode desviar das suas leis. Mas os fatos naturais que ele assimila são reproduzidos no seu trabalho,

chama de oxi-hidrogénio dirigida contra um cilindro de cal viva (CaO/óxido de cálcio), que resiste a uma temperatura de $2.572{ }^{\circ} \mathrm{C}$, antes de entrar em fusão. A luz é produzida através da combinação de incandescência e candoluminescência (luz produzida pela excitação térmica dos íons, ou um átomo ou molécula, cujo número de eletrons é diferente daquele de prótons). Disponível em: <http://www.compulite.com/stagelight/html/history-4/ limelight-spot.html>. Acesso em: 16 maio 2009.

96 "[...] the true realism towards which all should aim." 
deificados pela força da sua própria imaginação. Os atores, por outro lado, devem trabalhar com materiais naturais e não plásticos, mas sensíveis e com algo da força e da fraqueza da carne e do sangue. $\mathrm{O}$ ator deve primeiro receber na própria mente através das palavras do dramaturgo a imagem fantasmal que ele reproduz o melhor que pode, com o material impreciso que a natureza lhe deu. ${ }^{97}$ (IRVING apud STOKER, 1907, p. 259, tradução nossa)

Parece claro que Irving se refere a um ator preocupado com as circunstâncias visuais do seu trabalho, interessado em criar imagens na sua própria imaginação e "pintá-las" na cena. E Irving estende essas relações com a visualidade ao trabalho do dramaturgo:

[...] o pintor e o poeta partem de diferentes pontos da gama de possibilidades naturais. O primeiro começa da natureza para alcançar a imaginação; o outro, da imaginação para chegar à realidade. E se os meios não forem inadequados e o esforço for honesto, ambos podem alcançar aquele verdadeiro solo no qual realidade e imaginação se unem. ${ }^{98}$ (IRVING apud STOKER, 1907, p. 259, tradução nossa)

A interação poesia-visualidade (ou vice-versa) que mais tarde seria abordada por Italo Calvino (1998) para refletir sobre o papel da imagem no seu trabalho literário provocou em Irving uma imersão na pintura, na qual ele buscava provocação para as imagens nos seus espetáculos. Tal mergulho visual produziu aquilo que Bergman compreende como sua principal contribuição e que ainda hoje carece de discussão: "Mas Irving pintou o palco, não apenas com diferentes combinações de luz colorida, mas também com sombras [...]. E essa pode ter sido, na verdade, sua maior contribuição, antecipando o teatro moderno". ${ }^{99}$ (BERGMAN, 1977, p. 302 , tradução nossa)

97 "Your painter works in moldable materials, inanimate, not sensitive but yielding to the lightest touch. His criation is the embodiment of the phantasm of his imagination, for in art the purpose is to glorify and not merely to reproduce. He uses forms and facts of nature that he may not err against nature's laws. But such natural facts as he assimilates are reproduced in his work, deified by the strength of his own imagination. Actors, on the other hand, have to work with materials which are all natural, and not all plastic, but are all sensitive with some of the strength and all the weakness of flesh and blood. The actor has first to receive in his own mind the phantasmal image which is conveyed to him by the words of the poet; and this he has to reproduce as well as he can with the faulty material which nature has given to him."

98 " $[. .$.$] the painter and the poet begin from different ends of the gamut of natural possibilities the one starts from$ nature to reach imagination the other from imagination to reach at reality. And if the means be not inadequate, and if the effort be sincere, both can reach that veritable ground where reality and imagination join."

99 "But Irving painted the stage not only with different combinations of coloured light but also with shadows, [...]. And that may actually have been the greatest contribution, anticipating as he did, the whole modern theatre." 
Stoker já havia posto uma observação que caracterizava a compreensão de Irving, identificando o papel da sombra, na visualidade da cena: "De fato, descobriu-se que a escuridão, quando controlada, é um importante fator da luz [na cena]". ${ }^{100}$ (STOKER apud BERGMAN, 1977, p. 259, tradução nossa)

Intuitivamente, ou não, de acordo com as palavras de Stoker Henry Irving investigou a capacidade expressiva da sombra, até hoje pouco compreendida e pouco aplicada por artistas responsáveis pela visualidade do espetáculo (Figura 104). Quando se menciona a sombra no teatro é muito comum que se façam ligações com o mencionado teatro de sombras, outra vertente da questão, com espaço próprio de discussão.

É importante acrescentar que, quando se trata da sombra na cena, o termo realismo ganha contornos ainda por serem discutidos, incluindo as noções de verdade. Qualquer que seja a discussão da noção de verdade, em cena, ela somente será teatralizada, fisicalizada, com a aplicação de sombras (planejadas, calculadas), procedimentos que exigem mais do que o acaso ou sua combinação com ideias "geniais". Tais procedimentos integram o trabalho do theatre lighting designer, já comentado aqui, e que está por exigir um estudo aprofundado no Brasil.

Outro importante aspecto acentuado pelos Pennell revela um momento no qual Irving já investia na aplicação da luz elétrica e inclui a expectativa de uma representação de traços realistas: "É evidente que o efeito é ampliado pela luz elétrica, mas ela é aplicada com tanta habilidade que não se percebe sua presença [a presença, dos instrumentos]". 101 (PENNELL, J.; PENNELL, E., p. 310, tradução nossa)

Por outro lado, um dos mais importantes antagonistas do realismo, Gordon Craig (1872-1966), ${ }^{102}$ tendo trabalhado como ator na companhia do Lyceum Theatre, sob a direção do seu padrasto (o próprio Irving), escreveu um livro cujo título é Henry Irving (1930), no qual revela que dele herdou sua vocação para o claro-escuro no palco. Entre Irving e Craig, o teatro fortaleceu a proposição realista já anunciada pelo primeiro e por tantos outros, cada um com seus interesses e abordagem particular.

100 "In fact, darkness was found to be, when under control, as important a factor in light [...]." 101 "Of course the effect is heightened by the electric light, but so skillfully that you are not made aware of it." 102 Enteado de Irving - companheiro de sua mãe, a atriz Ellen Terry (1847-1928). 



\section{O REALISMO COMO DESAFIO}

Ao se referir às manifestações teatrais reconhecidas como realistas na segunda metade do século XIX, o historiador Oscar Gross Brockett (1995, p. 383, tradução nossa) acentua uma abordagem referendada por muitos outros: "[...] montagens que procuravam representar ações observadas cientificamente, em espaços físicos que demonstravam a interdependência entre personagem e ambiente [...]". ' Considerando tal assertiva é possível ponderar que a aplicação da luz em um espetáculo realista deveria representar alto grau de dificuldade técnica, uma vez que envolvia a abordagem científica das relações entre o ser humano e seu espaço. Do artista que desejasse alcançar com a luz a artificialização capaz de levar o espectador a acreditar na realidade da cena seria exigida grande familiaridade com a convenção realista, que deveria implicar no domínio dos aspectos científicos do problema. Ainda assim, a luz para o realismo é, por vezes, interpretada de modo generalizado e superficial, resultando em

1 "[...] productions that sought to represent scientifically observed actions in physical spaces which demonstrated the interdependence of character and environment [...]." 
opiniões que parecem emergir de uma intuição inconsequente que podem gerar distorções quando se põe em jogo a exegese teórica desse teatro "realista".

Buscando um "retrato" da realidade cotidiana a proposição do realismo dela se afasta, uma vez que depende de certa artificialidade (aquela artificialidade inerente a uma convenção artística) para criar a ilusão. Ao falar em cena, um ator tanto pode aplicar técnicas reconhecidas que lhe permitam alcançar o público com sua elocução, seus gestos, movimentos e emoções, quanto pode perseguir o cumprimento do mesmo objetivo através de soluções encontradas ao acaso. De todo modo, ambos os processos se referem a uma flagrante busca da artificialização imprescindível para construir a cena "realista".

Um cenógrafo que se interessava pelo realismo podia aplicar a perspectiva para convencer o olhar do espectador de uma profundidade com a qual o palco efetivamente não contava. Como se pode ver, o teatro realista defendia sua convenção criando uma ilusão de real, com o "falso". Um falso positivamente justificado - no caso - pela necessidade de gerar verossimilhança, ilusão de realidade.

Se o dramaturgo desejava criar uma fiel representação da realidade, ele já tomava - ou deveria ter tomado - uma série de decisões no que se refere ao ambiente onde a ação ocorria, para promover relações com a verossimilhança. A escolha recaía, em muitos casos, sobre acontecimentos do cotidiano, cujos lugares permitissem sua elaboração cenográfica num palco que atendesse ao modelo da tradição "italiana", observando questões de visibilidade e acústica, por exemplo, os comentários de André Antoine (1858-1943), que serão abordados ainda no capítulo em curso. O público deveria estar acomodado numa relação frontal com o palco, usufruindo de visão total do espaço da ação, que deveria estar alocada no interior da caixa cênica. Respeitado o limite da quarta parede, o espectador encontrava-se diante de uma espécie de "espelho" virtual da realidade, transparente para evitar a reflexão objetiva da plateia. O que se queria ver na cena era a projeção dos desejos do espectador mixados aos desejos das personagens, revelados em eventos e lugares do cotidiano.

Pensava-se que o drama instalado em ambientes fechados e envolvendo acontecimentos de natureza cotidiana, realizados dentro dos princípios da ilusão, permitiria ao espectador acreditar que, diante dele, encontrava-se efetivamente um recorte da "realidade" transplantado para a cena. A convenção alcançava, portanto, alto grau de sofisticação, quando solicitava que o público aceitasse como única interferência dos artistas do teatro realista a anulação de uma das paredes do ambiente - a "quarta" parede, vista em Diderot. Isso redundaria na exposição pura e simples de acontecimentos que ocorriam como se o espectador testemunhasse cenas do dia a dia das personagens. E o teatro precisava 
contar com a parceria do espectador que, comparecendo em data e hora marcadas, concordaria em permanecer acomodado em uma poltrona por determinado período. Ele também aceitava as convenções da fala, do gesto e do movimento tecnicamente (artificialmente) elaborados para firmar a ilusão de realidade numa configuração teatral de ação, tempo e espaço.

Isso não significa, necessariamente, que a dramaturgia realista excluiu ambientes externos e de grande amplitude. Ao contrário, há exemplos de peças cuja ação se passa em lugares que representavam grande desafio para essa estética de interiores. De todo modo, a práxis cênica realista afastava-se da realidade cotidiana à medida que aplicava métodos sofisticados de artificialização, apresentando radicais "simulacros" do real. E para que tais objetivos fossem alcançados numa manifestação de natureza visual contundente, a luz deveria assumir amplas responsabilidades. Do ponto de vista técnico, na base do combate ao realismo havia mais do que uma guerra contra a imitação da natureza. Na disputa também estavam em jogo os procedimentos de artificialização que criavam a ilusão.

O ator realista expressava desejos revelando objetivos da personagem, a quem conferia credibilidade através de excelência técnica, capaz de resistir à avaliação da crítica e do público. A criação do espaço da cena, por sua vez, exigia um tratamento visual particular, já que todo ambiente reage integral e dinamicamente à luz, mesmo que se trate de um ambiente fechado, uma pequena e simples sala de estar em qualquer classe social, localização geográfica, estação do ano, momento do dia - ou da noite. No mesmo contexto, um ambiente ao ar livre, quando relacionado a qualquer uma das variáveis mencionadas, desenvolvia reações objetivas, físico-químicas, geométricas, tridimensionais, com a luz. Isso transforma a alegada reprodução "fotográfica" de um ambiente em um problema cênico-visual com particularidades que exigiam grande domínio técnico. E a quarta-parede ocupava um lugar importante no contexto.

Sendo uma parede "falsa, imaginária e inexistente" na cena, ela deixava uma lacuna física importante e estabelecia uma grave ausência para a interação da luz com o ambiente a ser representado, já que no lugar dessa "quarta" parede faltava efetivamente um corpo, um anteparo ou obstáculo material para que tal interação se completasse, objetivamente. Daí, o resultado visual na cena deveria ser artificialmente criado, configurando-se uma "não verdade", uma resposta técnica que fisicalizaria a convenção. Tome-se como exemplo o "espaço" mencionado a seguir: cômodo único numa noite sem luar, inverno (janela e porta opacas, fechadas para evitar o incômodo causado pelas baixas temperaturas), com uma simples lâmpada incandescente pendurada no centro do ambiente, a dois metros e 
cinquenta centímetros do piso. Ao construir tal ambiente no teatro, sob a convenção da quarta-parede, o iluminador não contava com as condições do lugar real que teria provocado o dramaturgo e, mais tarde, o cenógrafo. Ele encarava, então, um problema-chave: convencer o público da "realidade" da luz criada para a cena; ou seja, para atender à convenção, o iluminador precisava construir com a luz um corpo inexistente fazendo crer que havia uma, ou mais paredes, no "lugar" da falsa quarta-parede (Figura 77).

A solução poderia envolver procedimentos e terminologia particulares, como as variáveis de luminância e iluminância. ${ }^{2}$ Termos como esses deveriam, no entanto, integrar o vocabulário de quem precisava criar luz para a cena realista. Simplificando, em uma cena de tal natureza, o designer deveria "pré-ver" e calcular o iluminamento produzido pela fonte em questão (no caso da cena, uma simples lâmpada que pende do teto). Ele deveria considerar também a luminância produzida na sua dinâmica relação com os obstáculos. Isso poderia incluir não apenas a quarta-parede, mas superfícies diversas como o piso, outras paredes, móveis, objetos e até seres vivos. Incidindo sobre eles a luz retornaria para o ambiente, modificada pelo processo, emprestando qualidade visual aos volumes, interagindo com suas formas, texturas e cores.

As bases científicas do tratamento realista poderiam, num determinado sentido, limitar "criatividades" exacerbadas e, portanto, criar resultados menos "artísticos", se comparados às mudanças mecanicamente feéricas, de uso regular, hoje em dia. No que se refere ao propósito da presente abordagem, contudo, reitere-se a intenção de compreender, tanto no realismo quanto em qualquer outra abordagem da cena, modos específicos de construção visual, aplicados para revelar, discutir, e/ou provocar no público a apreensão do ambiente concebido para sua realização.

Por um lado, a elaboração realista da luz de um espetáculo poderia ser encarada como vantagem ou facilidade, uma vez que o artista teria modelos para estabelecer analogias diretas com o cotidiano. Por outro, certas circunstâncias poderiam representar graves limitações para o alcance desses resultados: desde tempo reduzido, orçamento insuficiente para a aquisição ou locação de instrumentos, acessórios e sistemas de controle, e até condições inapropriadas de casas de espetáculo, se elas fossem projetadas, construídas e/ou equipadas por profissionais

\footnotetext{
2 A luminância pode ser definida como a intensidade luminosa que emana [reflete] de uma superfície sobre a qual incidiu um fluxo luminoso. A luminância atua em direta relação com a iluminância, ou o fluxo luminoso irradiado por uma fonte [lâmpada], cuja relacão com a superfície sobre a qual incide define uma grandeza luminotécnica, também conhecida como iluminamento ou nível de iluminação.
} 
sem qualificação para conceber e projetar um teatro, inclusive no que se refere a aspectos específicos da luz. Além disso, o iluminador que aceitasse compreensões equivocadas do realismo poderia afundar seu trabalho na banalidade da indefinição.

Se um espetáculo procurasse recuperar, atualmente, a estética realista, um dos principais aspectos favoráveis a essa recuperação se apoiaria na precisão possibilitada pelos instrumentos, acessórios e sistemas de controle hoje disponíveis, aliada à flexibilidade de uma casa de espetáculos qualificada para ser reconhecida como um teatro. Vale lembrar que não é difícil encontrar um espaço que recebeu tal denominação, mesmo sem apresentar condições técnicas para abrigar um espetáculo. E ainda, para efetivar a abordagem realista, a equipe precisaria contar com artistas treinados. Tais variáveis resultariam em enormes diferenças e dificuldades, se comparássemos, como exemplo, com aquilo que André Antoine encontrava no seu teatro, naquela fase inicial de aplicação da luz elétrica às montagens. As diferenças de natureza tecnológica entre o que está hoje disponível e o que ele encontrava àquele momento nos levam a imaginar as dificuldades, assim como os resultados que se poderia alcançar, na segunda metade do século XIX.

\section{REALISMO, LUZ E CRÍTICA}

Essa conjectura sugere a aproximação do pesquisador com aquilo que geralmente se compreende como realismo na luz teatral daquele período, e que, na compreensão de Jean-Jacques Roubine (1982b, p. 22), é assim apresentado: “[...] uma definição atmosférica do espaço. [...] um nevoeiro do crepúsculo ou um luar sentimental". Ele estava comparando o realismo em uso na luz teatral do final do século XIX ao tratamento que apareceu no trabalho de Loie Fuller (1862-1928), quando ela começou a desenvolver o que ficou conhecido como Dança da saia (Skirt dance), originando a performance denominada Serpentina [Serpentine (1891)]. (Figura 105) O grafismo, a abordagem do corpo como forma abstrata em parceria com o uso da cor, estranhos à proposição realista, lhe renderam notoriedade. Seu trabalho será comentado na abordagem da práxis cênica aqui denominada "não realista", levando-se em conta diversas reações ao "realismo" ocorridas no século XIX.

Roubine pensa que Loie Fuller teria transformado a luz num parceiro autêntico ao incorporar cor e fluidez, indo além da "definição atmosférica" realista ao efetivar interferências no corpo do performer. Isso pode sugerir que para aceitar ou considerar a presença (ou a atuação) da luz, tanto a teoria, quanto a crítica e 
o público parecem entrar em acordo: essa presença somente se efetiva em "efeitos", na "exibição". Fica a impressão que se quer ver, sempre, truques de prestidigitação. O termo "parceiro", no entanto, parecerá aplicado com parcialidade às ligações entre a luz elétrica e às iniciativas não realistas se intentar sugerir que somente essas iniciativas incorporaram a luz como parceira. Ao contrário disso, talvez seja possível ponderar que a cena realista somente se poderia efetivar se tivesse a luz como parceira. Ou seja, para realizar a mencionada "definição atmosférica", o iluminador envolvido em uma montagem realista precisava conceder à luz o status de parceira do discurso visual que sustentava o realismo. Pode não ser fácil de compreender. Ressalte-se, então: se a luz não atuasse como parceira do iluminador na definição da atmosfera realista, a luz - realista - não teria existido para ser questionada pela crítica.

Afinal, mesmo que não tenha sido identificada como "parceira" pela crítica que abominou as atmosferas por ela criadas, e apontadas como a mácula realista, a luz precisou atuar como parceira do artista responsável por projetar essas mesmas atmosferas que geraram a desaprovação dos críticos e teóricos. É recomendável, por conseguinte, cuidado, ao se considerar atitudes teórico-críticas que apontam - por vezes localizadas na distância que resulta do desconhecimento - equívocos no trabalho de um artista.

E ainda, ao mencionar a atmosfera "sentimental" de um espetáculo realista, Roubine pode deixar escapar ligações com a abordagem romântica que antecedeu as iniciativas realistas que combateram esse "sentimentalismo". Talvez fosse bom dizer que se pode falar de um realismo romântico no qual a mencionada atmosfera sentimental podia ser aplicada. Aliás, pode-se até mesmo relacionar o tratamento sentimental da cena ao tom emocional do espetáculo simbolista que confrontou a imagem realista com proposições oníricas. Vale lembrar que, em muitos casos, a abordagem realista pode exigir recortes, composições de natureza gráfica, que deixariam extasiado um defensor da distorção expressionista. Ou seja, se, por um lado, é fácil compreender certas interpretações superficiais operadas pelo senso comum, por outro, determinadas nuanças do tratamento visual do espetáculo, notadamente no que se refere à luz, exigem da teoria e da crítica alguma atenção e cautela.

O texto a seguir inclui o tema do presente capítulo numa abordagem semiótica do espetáculo:

A encenação no Teatro Realista/Naturalista deve servir como um espelho da realidade, processo semelhante ao que ocorre com as outras manifestações artísticas e literárias do naturalis- 
mo. [...] A iluminação também deve ser fiel à realidade. Se é noite, escura; se é dia, clara. Se há um abajur, foco sobre ele quando estiver aceso. A luz do sol deve entrar pela janela descortinada. Além disso, a iluminação serve também para dar o clima ao Teatro Psicológico, fazendo com que os sentimentos das personagens possam ser perfeitamente compreendidos pela plateia. (FERNANDES, 2006, p. 6)

Ainda que seja perfeitamente possível compreender a boa intenção, afirmações dessa natureza podem dar lugar a questionamentos. Ao contrário do que propõe o texto, uma cena noturna pode exigir muito mais brilho - ou intensos fluxos luminosos projetados sobre o ambiente - e ainda contar com a interação luminância-iluminância, para que a luz artificial "substitua" a luz natural, tornando "claro" o ambiente, permitindo a visibilidade. E, se for feita uma escolha realista para um espetáculo cuja ação ocorra durante o dia, a iluminação (artificial) poderia ser dispensada, em muitos casos, já que o ambiente estaria "claro" o suficiente para que se enxergassem as pessoas, os objetos e o lugar. E mais, na abordagem realista, é possível indagar: por que projetar luz sobre um abajur, se ele é a fonte de luz? Pode-se argumentar, como já foi dito, que as sombras do abajur, tanto a sombra própria - aquela que incide sobre o próprio objeto - assim como a sombra projetada no ambiente, denunciariam a aplicação de um instrumento externo (um "refletor" teatral), destruindo a ilusão realista, devido às falsas sombras apresentadas na imagem. ${ }^{3}$

Como já foi dito, a sombra de um objeto define sua tridimensionalidade e, por conseguinte, sua presentificação no ambiente. Ora, no teatro, uma sombra que resultasse da incidência do fluxo luminoso de um "refletor" projetado sobre o mencionado abajur definiria uma intervenção "falsa" - no sentido realista - pois, se a lâmpada dentro do abajur não projetava tal sombra, como ela poderia estar visualmente presente? Mesmo que o iluminador não estivesse ciente disso, ele estaria criando um sutil estranhamento visual, atacando a "ilusão", sublinhando para o espectador sua presença em um teatro, assistindo a um espetáculo. Nesse sentido, a decisão de projetar a luz de um refletor sobre um abajur aceso, no palco, talvez seja a mais indicada para as inúmeras manifestações cênicas que combatem ou negam o realismo, e não para caracterizá-lo.

Abordagens teóricas superficiais podem, então, levar à desconsideração de aspectos determinantes nos espetáculos propriamente ditos. É necessário dizer

3 Cf. capítulo Rotas francesas para o teatro moderno, Figura 90 e comentário correspondente, quando se tratou da cena compartimentada, no século XII, na França. 
que o advento da luz elétrica ganhou importância nas iniciativas teatrais que combatiam o realismo desde o final do século XIX devido às possibilidades de efeitos que o controle fornecido pela eletricidade gradativamente permitiu. Aqui se encontra, no entanto, uma questão de maior amplitude, nem sempre identificada. $\mathrm{Na}$ verdade, muitos esquecem que o realismo no teatro pode ter tirado grande proveito da eletricidade. E é compreensível que isso não seja devidamente notado, pois, no espetáculo realista, ou em momentos realistas de espetáculos, a luz poderia atuar de modo tão sutil que, para olhos desavisados, pareceria difícil reconhecer sua presença. Um ambiente realista poderia solicitar um tratamento visual que tornaria a luz "invisível", o que poderia deixar indignado o espectador/crítico que só se interessa pela obviedade e, até, pela superficialidade visual dos efeitos.

\section{AVANÇOS TEATRAIS SOB A ÉGIDE DAS TECNOLOGIAS}

Uma possível hegemonia dos efeitos está certamente ligada a transições tecnológicas que ocorreram a partir do século XVIII e fizeram surgir novos aparatos, acessórios e sistemas de controle, cuja aplicação resultou em mudanças progressivas nos espetáculos.

Patenteada em 1780, a lâmpada Argand ${ }^{4}$ pode ser citada como um desses passos na mudança da visualidade na cena. A acomodação de um pavio cilíndrico num receptáculo (uma chaminé de vidro em forma tubular) que controlava o fluxo de ar, fazendo-o circular em torno do pavio e produzindo maior brilho da luz com mais estabilidade para a chama. A diferença pode ser sutil e parecer pouco ao olhar de hoje, acostumado a tanta diversidade. É possível, entretanto, imaginar uma luz menos "nervosa" e mais "brilhante" se comparada àquela resultante da oscilação das velas, assim como de outras luminárias a óleo. Ficava efetivada, assim, uma maneira diferente de ver a cena.

A lâmpada Argand exigiu esforços do pesquisador em busca de aperfeiçoamentos: a inovação do pavio acionado mecanicamente permitia controle da chama e, consequentemente, da intensidade da luz através de ajustes no seu movimento vertical. Na França, foi chamada de Quinquet depois de comercializada e, segundo alguns, aperfeiçoada pelo farmacêutico Antoine Quinquet (1745-1803). Sabe-se que o artefato passou por mudanças para contornar desvantagens como a agressivi-

\footnotetext{
4 Um aparato usado para produzir luz artificial, usando óleo como combustível, e cuja denominação se originou do nome de seu inventor, o cientista suíço Aimé Argand (1750-1803), estudioso da física e da química. Produzia brilho equivalente ao resultado alcançado pelo uso de várias velas - entre 6 e 10.
} 
dade da chama que podia danificar a chaminé de vidro; além disso, a dimensão do recipiente de óleo, que gerava uma importante área de sombra, impunha modificações. Ainda que a informação acerca da luz aplicada à cena, no início do século XIX na França, seja escassa, Bergman presume que o problema específico deve ter suscitado modificações da lâmpada Argand para implantar seu uso no teatro. É, então, presumível que pode ter sido instalada uma superfície refletora (réverbère) entre a chaminé e o depósito de óleo, desenvolvendo o princípio aplicado na Renascença italiana.

Outro passo importante da tecnologia foi alcançado com a luz a gás, repercutindo decisivamente no espetáculo teatral. (BERGMAN, 1977) Desde o final do século XVIII, um técnico da área da produção industrial de máquinas a vapor, William Murdoch (1754-1839), trabalhava em pesquisas, e iluminou a própria casa aplicando luz a gás, já em 1792.

O próprio Murdoch publicou no Nicholson's Journal, volume XXI (1808), relatos dos seus experimentos, comentando a produção de gases com a aplicação de diversas substâncias minerais e vegetais. Ele conduziu observações com a queima de carvão, usando também turfa, madeira, assim como outras substâncias inflamáveis. O depoimento de William Richards atesta a veracidade desses relatos:

Esse é o modesto e claro relato redigido pelo Sr. Murdoch sobre a origem e o progresso das primeiras tentativas acerca da luz a gás, cujas afirmações foram depois confirmadas pelo Dr. William Henry, de Manchester, e vários outros, também pelo Sr. James Watt Jr., mencionado adiante, o que não deixa possibilidade de dúvidas sobre a fidelidade da narrativa [...]. ${ }^{5}$ (RICHARDS, 1877, p. 11, tradução nossa)

Esse momento registrou a presença de outros interessados na mesma questão: na França, Phillipe Le Bon [ou Lebon] (1767-1804), na Suécia, C. Reuterona (?), e Fredrick Albert Wintzler ${ }^{6}$ (1763-1830), na Morávia. Com sucesso diferenciado, cada um deles buscou caminhos próprios, pesquisando, escrevendo e/ou divulgando alternativas para a aplicação da nova tecnologia, com particularidades em cada processo, mantendo o princípio da produção de aquecimento e/ou luz através do uso do gás. Richards (1877) assinala a presença da thermolampe (1801), um arte-

5 "Such is the modest and clear account given by Mr. Murdoch of the origin and the progress of the first attempt at gas lighting, which statements were further confirmed by Dr. William Henry, of Manchester, and various others, also by Mr. James Watt, jun., hereafter mentioned, thus leaving no possibility of doubting the accuracy of the above narrative."

6 Também grafado Winsor. 
fato desenvolvido por Le Bon, com o qual ele não alcançaria sucesso ao buscar sua produção em escala industrial e comercialização.

Depois de adquirir o monopólio da invenção de Lebon, C. Reuterona publicou um panfleto denominado Uma descrição da thermo lamp [A description of thermo lamp (1804)], mas recebeu grande resistência da Academia Real de Ciências de Estocolmo, que considerou a produção do invento muito cara e prejudicial à saúde. Fredrick Albert Wintzler estudou a invenção de Le Bon e, em 1803, proferiu uma palestra seguida de exibição, denominada Luz a gás (Gaslight), no Lyceum Theatre em Londres, mantendo sigilo sobre o processo de purificação do gás e sublinhando vantagens como a ausência de faíscas e de fumaça, além da intensidade e estabilidade da chama.

Na segunda década do século XIX, o invento creditado a Murdoch e a Wintzler foi progressivamente usado em ruas, hotéis e outras instalações, em Londres, originando uma rede de tubulação de gás. Vários artigos sobre o assunto já apareciam em revistas quando Fredrick Accum (1769-1838), que trabalhava na área da química publicou um texto detalhado acerca do tema, Um tratado prático sobre a luz a gás [A practical treatise on gas-light (1815)]. Seu trabalho inclui ilustrações sobre lâmpadas de diversos tipos e tamanhos (Figura 106), além de gasômetros [instalações para produzir e distribuir luz a gás, em média escala, para estabelecimentos comerciais e industriais]. A regularização do seu uso originou diferentes opiniões, e dentre as vantagens na comparação com a luz a óleo apareceram o maior brilho (cerca de 10 vezes mais) e mais estabilidade da chama, o que gerava uma luz suave e difusa, além da ausência (ou redução) de odor e fuligem.

Há controvérsias sobre autoria e datas nos relatos e documentos que tratam das primeiras incursões na pesquisa com luz a gás. Os nomes de Lebon e Wintzler parecem por vezes grafados como Winsor e Le Bon, sem qualquer advertência. A tradução para a língua portuguesa de parte do capítulo quatro, A história da iluminação (The history of illumination), do livro de Jean Rosenthal e Lael Wertenbaker, A magia da luz (The magic of light), publicada na revista Cadernos de teatro n. 102, de 1984, informa que a primeira aplicação do gás no teatro se deu em 1806, sob a responsabilidade de F. A. Wintzler, a quem a tradução se refere como iluminador, enquanto os autores dizem apenas se tratar de um "alemão". (ROSENTHAL; WERTENBAKER, 1972)

Parece pouco recomendável aplicar o título de iluminador para caracterizar a função de um profissional específico, naquele momento do teatro. Além disso, é 
possível questionar a correção dessa data, 1806. Outras fontes, como Bill Williams, ${ }^{7}$ indicam 1816 como o ano no qual se registra a instalação no Chestnut Theatre, na Filadélfia, do primeiro sistema de luz a gás no teatro. Bergman (1977), por sua vez, consultando os jornais londrinos The Examiner e The Times de setembro de 1817 diz que em agosto do mesmo ano o palco do Lyceum Theatre recebeu luz a gás em 1817 e, um mês depois, o Theatre Drury Lane, também em Londres, já operava com o mesmo tipo de sistema. De qualquer maneira, parece consenso que ao final da segunda década do século XIX a luz a gás já havia introduzido significativas mudanças nos espetáculos.

A despeito do confirmado risco de incêndio como a maior desvantagem da luz a gás, sua aplicação repercutiu de modo crescente no teatro, sendo documentada em textos como a criteriosa descrição publicada no Theater-Lexicon, de Leipzig, em 1841 e escrita por Ph. J. Dürringer e H. Barthels, que inclui ponderações importantes:

De modo geral, a luz a gás na sua forma mais pura produz uma luz branca, algo amarelo-avermelhada (quanto mais puro o gás, mais branca a luz) que, comparada à luz de uma boa lâmpada Argand difere em brilho e cor, assim como essa lâmpada é diferente [apresenta melhor resultado] de uma vela de boa qualidade, [...]..$^{8}$ (DÜRRINGER; BARTHELS apud BERGMAN, 1977, p. 259, tradução nossa)

Ficava evidente um incremento na temperatura de cor, que mais tarde seria progressivamente ampliado com a luz elétrica, pela aplicação da fluorescência e, recentemente, do LED. Outra vantagem relacionada ao uso do gás refere-se à geração da chama propriamente dita que dispensava o cuidado com resíduos, como no caso das velas; além disso, a comparação com a lâmpada a óleo mostrava grande diferença, pois, nesta última a carbonização do pavio provocava mais odor e fumaça.

No teatro, o uso de sistemas mecânicos para transportar o fluxo de gás pelo emaranhado de tubos até os bicos queimadores [de formas e tamanhos diversos] definia a qualidade da chama, permitindo controle da intensidade, mudanças suaves e maior precisão. Isso incluía cores aplicadas a diferentes áreas da cena, através de uma central de operações [que Bergman chama gas-table ou, mesa de gás].

7 Disponível em: 〈http://www.mts.net/ william5/history/hol.htm〉. Acesso em: 12 jun. 2009.

8 "On the whole, gaslight in its purest form has a white, some what yellowish red light (the purer the gas, the writer the light) which, compared with the light of a good Argand lamp is different from it in brightness and colour just as this lamp is different from a good candle, [...]." 
Tais aspectos, em conjunto com novas estruturas de sustentação para instrumentos de luz como varas acima do palco, determinaram o surgimento dos novos sistemas para aplicação da luz no teatro, cuja flexibilidade contribuiu para o amadurecimento das relações técnico-estéticas.

\section{A CENA SOB CONTROLE}

De acordo com Bergman (1977), Richard Wagner (1813-1883) teria comentado um incidente que se transformaria num importante aspecto da sua obra: na abertura do Festspielhaus de 1876, no Bayreuth (Alemanha), por falta de revisão final do ajuste definido para o sistema de iluminação a gás, a plateia ficou praticamente às escuras do início do espetáculo, chocando os espectadores. Ainda segundo Bergman, Wagner corrigiu o equívoco, nos espetáculos seguintes, mas fez o público mergulhar numa considerável penumbra; o evento teria contribuído para a difusão dessa prática na maioria dos teatros da Alemanha, e deixado um importante legado que deveria servir como aprendizado, ainda hoje. Constatou-se que, mesmo com o avanço tecnológico, o iluminador não é uma de entidade infalível; se os envolvidos em um espetáculo dependem de muita experimentação e ensaios parece incongruência solicitar que o "iluminador" chegue alguns dias antes da estreia - por vezes, nem tanto - e resolva a luz, como num passe de mágica ou ato místico: faça-se a luz!

Mesmo com rumores acerca dos espetáculos do ator inglês Charles Kean (1811-1868), no Princess Theatre, em Londres, nos quais a plateia teria permanecido praticamente às escuras durante os espetáculos, muitos dizem que Wagner teria encaminhado o controle deliberado da luz na plateia. Era impossível, no entanto, mesmo na era do gás, extinguir completamente a luz - na plateia ou no palco uma vez que seria necessário voltar a acionar os instrumentos de iluminação, fossem velas, lamparinas a óleo ou bico de gás. Aí residiria o principal avanço surgido no final do século XIX, quando vários pesquisadores estudaram a produção da luz elétrica.

Na verdade, experimentos com a eletricidade têm sua história documentada desde a Antiguidade, quando os gregos, provavelmente na cidade de Magnésia, ${ }^{9}$ no século VI a.C., tiveram sua curiosidade despertada por uma pedra que atraía pedaços de ferro, denominando-a magneto. Tales de Mileto (624/625-556/558 a.C.), sábio considerado pioneiro da filosofia ocidental, teria desenvolvido experimen-

9 Localizada na região da Tessália, ou um dos vários lugares denominados Heraclea. 
tos com outras substâncias, entre elas o âmbar - ou elektron, em grego; electrum, em latim - uma substância vítrea, que teria originado o termo eletricidade e suas derivações.

No seu diálogo Ion, entre Sócrates e o rapsodo cujo nome originou o título da obra, Platão menciona o magneto para tratar da inspiração poética:

SÓCRATES: Compreendo, Ion: e explicarei o que imagino seja a razão para isso. Essa habilidade que você detém de falar tão bem, sobre Homero, não é uma arte, mas, como eu disse, uma inspiração; há uma divindade que te move, como aquela contida na pedra que Eurípedes chama magneto, mas que é conhecida como pedra de Heraclea. Ela não apenas atrai anéis de ferro, mas, também, dá a eles um poder similar de atrair outros anéis; e, às vezes, você pode ver vários pedaços de ferro, suspensos sobre outros, de modo que formam uma longa corrente: e todos eles têm seu poder de suspensão derivado da pedra original. ${ }^{10}$ (PLATO, 2008, p. 9, tradução nossa)

A despeito dos inúmeros comentários acerca dessa relação entre as capacidades magnéticas das substâncias e a inspiração que provoca os poetas, localizada além da instância das habilidades, impressiona em Platão a qualidade visual da exegese. Ele estabelece uma analogia entre a mencionada inspiração poética e uma corrente de anéis unidos por algum tipo de energia que se desloca entre eles. O termo eletricidade só apareceu muito mais tarde, quando, no século XVII, William Gilbert (1540-1603), físico inglês e médico da Rainha Elisabeth I, chamou "elétricas" todas as substâncias que atraíam outras, depois de submetidas à fricção. Diversas outras experiências relacionam a história da humanidade à propriedade elétrica das substâncias.

Várias pesquisas foram empreendidas nos séculos que se seguiram, estudando-se as cargas elétricas, as possibilidades de carregar corpos com eletricidade e de conduzir o fluido elétrico. Os estudos levaram os pesquisadores a concluir que todo corpo tem certa quantidade do fluido elétrico, mas nem todo corpo se comporta como condutor, e não atrai, portanto, nenhum outro. No processo de fricção de um corpo, determinada quantidade de fluido elétrico é perdida,

\footnotetext{
10 "I perceive, Ion; and I will proceed to explain to you what I imagine to be the reason of this. The gift which you possess of speaking excellently about Homer is not an art, but, as I was just saying, an inspiration; there is a divinity moving you, like that contained in the stone which Euripides calls a magnet, but which is commonly known as the stone of Heraclea. This stone not only attracts iron rings, but also imparts to them a similar power of attracting other rings; and sometimes you may see a number of pieces of iron and rings suspended from one another so as to form quite a long chain: and all of them derive their power of suspension from the original stone."
} 
ou passa por ele, resultando numa quantidade maior ou menor do que aquela presente no corpo "em repouso", produzindo carga positiva ou negativa. Objetos com carga positiva tendem a se repelir, assim como aqueles que têm carga negativa repelem os da mesma natureza.

No século XIX, entretanto, as investigações alcançaram um ponto que introduziria resultados inovadores no teatro. Em 1809, o químico inglês Humphry Davy (1778-1829) apresentou aquele que ficou conhecido como o primeiro artefato concebido para produzir luz artificialmente com a aplicação da eletricidade, conectando dois fios em uma bateria e ligando uma tira de carvão vegetal entre as outras extremidades dos fios. Como resultado da carga, o carvão brilhava, originando a primeira lâmpada de arco elétrico. Desde o surgimento desse aparato muitas outras pesquisas foram encaminhadas em busca de uma "lâmpada elétrica", o que torna difícil mencionar isoladamente um inventor.

A lâmpada incandescente que se afirmaria no fim do século XIX como fonte de luz artificial, de eficiência sem concorrente naquele momento, foi incrementada em um artefato constituído de filamento, bulbo de vidro, base de contato, gás e lacre (Figura 107). Vários pesquisadores contribuíram para o desenvolvimento de cada um desses componentes, o que originou demandas variadas pela exclusividade ou autoria da invenção. Nos Estados Unidos da América, nomes como os de Moses Gerrish Farmer (1820-1893), William Sawyer (?), Albon Man (?) e Hiram Stevens Maxim (1840-1916), assim como o de George Lane-Fox (?) na Inglaterra, estiveram ligados a iniciativas que buscavam uma lâmpada incandescente de filamento durável, o que gerou muitas disputas. Uma das mais notáveis controvérsias envolveu Thomas Edison (1847-1931) e Joseph Wilson Swan (1828-1914), (1828-1914), que depois se associaram fundindo suas empresas na Edison and Swan United Electric Light Company Limited, em 1883.

Já no final do século XIX a eficiência e o controle da luz elétrica, quando comparados às tecnologias que os antecederam, promoveriam importantes mudanças no teatro. A segunda metade do século XIX representou um momento de grande efervescência no ambiente teatral. Relações diretas entre tecnologia e pensamento repercutiram na práxis cênica, trazendo possibilidades nunca vistas antes. Em 1881, foi instalado no Savoy Theatre, de Londres, o primeiro sistema de luz elétrica numa casa de espetáculos. Era um total de 824 lâmpadas de 16 watts para o palco e 334 para a plateia. No ano seguinte, o Bijou Theatre da cidade norte-americana de Boston recebeu sua primeira iluminação elétrica, que tomaria o lugar da luz a gás na grande maioria dos teatros a partir de então. Em 1903, a Metropolitan 
Opera House de Nova Iorque recebeu um sistema que controlava um conjunto de 116 dimmers, ${ }^{11}$ incluindo a luz de plateia, instalado pela empresa Kliegl Brothers. ${ }^{12}$

O uso da luz elétrica no teatro é até apontado pelo estudioso francês JeanJacques Roubine como importante fator para o que ele denomina o nascimento do teatro moderno. Roubine considera decisivo o contato que se estabelece entre certos artistas europeus, cujas viagens a países estrangeiros promoveram grande intercâmbio de conhecimento. A isso ele alia a difusão de pesquisas teóricas e práticas, fazendo circular ideias que resultam de inquietações do pensamento emergente de base científica, cujo interesse na hereditariedade e no ambiente como determinantes para a construção da natureza humana encaminhou novas abordagens da obra de arte. Para Roubine, a contribuição da luz elétrica forneceu ferramentas indispensáveis à revolução que se implantou no teatro da transição entre os séculos XIX e XX.

\section{ÉMILE ZOLA E A LUZ IMPOSSÍVEL}

O interesse pela influência direta do ambiente na formação do ser humano repercutiu de modo decisivo no teatro francês, incluindo o trabalho teórico de Émile Zola (1840-1902), quando ele fundamenta seu teatro naturalista, que considera "o movimento da inteligência do século [XIX]"33 (ZOLA, 1881, p. 42, tradução nossa), declarando a influência direta da crise social derivada da Revolução Francesa. De modo sintomático, Zola dedica à dramaturgia grande parte dos seus escritos acerca do naturalismo no teatro, deixando uma pista clara sobre a relevância do texto na estética teatral em discussão. Dentre as várias definições do movimento, ele declara: “[...] [o naturalismo] consiste, simplesmente, na aplicação do método experimental ao estudo da natureza e do homem". ${ }^{4}$ (ZOLA, 1881, p. 43, tradução nossa) Sua teoria parece ligada à necessidade de introduzir a observação e o experimento à literatura, configurando um procedimento científico moderno.

Segundo Zola (1881), no teatro naturalista a linguagem deveria banir o lirismo romântico impregnado de certa confusão, de certo desequilíbrio, para prover

\footnotetext{
11 Artefato destinado ao controle da intensidade de luz no palco, cuja tecnologia vem se modificando, desde o final do século XIX.

12 John H. Kliegl (1869-1959) e Anton Tiberian Kliegl (1872-1927), inventores e fundadores da Universal Electric Stage Lighting Company, de Nova York, que permaneceu ativa desde 1896 até 1990.

13 "[...] le mouvement de l'intelligence du siècle."

14 “[...] qu'il consistait simplement dans l'application de la methode expérimental à l'étude de la nature et de I'homme."
} 
um estilo cujos alicerces estavam na lógica e na clareza, cuja construção é científica e natural, lidando com a palavra fundamentada na verdade. Um legado da linhagem cujas bases já haviam sido lançadas na França por Diderot. Considerada pelos seus críticos contemporâneos uma manifestação próxima da obscenidade, a linguagem naturalista pretendia confrontar a fala idealista baseada na retórica e na sublime "loucura lírica".

Desse modo, Zola acreditava que o naturalismo encontrou no romance sua mais importante forma de expressão, até porque o teatro guarda circunstâncias muito específicas nas suas convenções que podem criar limites para uma proposta tão radical, desenvolvida da fórmula deixada por Honoré de Balzac (1799-1850) e Stendhal (Henri-Marie Beyle, 1783-1824). Zola viu essa reação ao romantismo na obra de Gustave Flaubert (1821-1880) que teria amadurecido e completado a forma naturalista revelando-se, em sua opinião, um artista perfeito. O debate sobre as diferenças entre o romance e a dramaturgia já vinha sendo travado pela crítica que apontava divergências justificadas pelas diferentes possibilidades de cada uma dessas formas expressivas da literatura, já que o romancista desfrutava de um grau de liberdade com o qual o dramaturgo não podia contar.

Émile Zola não poupou esforços, e até parece redundante na sua intenção de esclarecer os pressupostos naturalistas, nos quais o autor está proibido de emitir julgamentos e apenas relata. Suas assertivas são contundentes: "Não há mais lugar para a imaginação, o enredo tem pequeno valor para o romancista, que não se envolve com o desenvolvimento, o mistério ou o desfecho; quer dizer, ele não intervém para subtrair [da realidade] ou adicionar à realidade, [...]".15 (ZOLA, 1881, p. 124, tradução nossa) Ainda tratando da construção dramática, ele menciona o palco, e aponta o que deve ser posto em cena:

Em lugar de imaginar uma aventura, de complicá-la, de fazer um arranjo de efeitos de palco cuja sucessão de cenas levará a uma conclusão, toma-se, simplesmente, o estudo da vida de uma pessoa ou grupo de pessoas, cujas ações são retratadas fielmente. A obra torna-se um relatório, nada mais. ${ }^{16}$ (ZOLA, 1881, p. 124, tradução nossa)

\footnotetext{
15 “L'imagination n'a plus d'emploi, l'intrigue importe peu au romancier, qui ne s'inquiète ni de l'exposition ni du noeud, ni du dénouement; j'entends qu'il n'intervient pas pour retrancher ou ajouter à la réalité, [...]."

16 "Instead of imagining an adventure, of complicating it, of arranging stage effects, which scene by scene will lead to a final conclusion, you simply take the life study of a person or a group of persons, whose actions you faithfully depict. The work becomes a report, nothing more."
} 
A dramaturgia que se encaminhava ao naturalismo era, para Zola, representada por autores acerca dos quais ele tinha opiniões diversificadas: no trabalho de Victorien Sardou (1831-1908), Zola criticava a observação da vida, que lhe parecia superficial; da obra de Alexandre Dumas, filho (1824-1895), ele destacava a disposição de sacrificar a exigência cênica, em nome da realidade; o texto de Émile Augier (1820-1889), na opinião de Zola, acentuava a capacidade que a prosa demonstrava de retratar a sociedade. Aquilo que Zola denominava teatro naturalista era caracterizado, até então, pelo trabalho de autores, de dramaturgos, o que pode servir como diagnóstico para que se compreenda a imposição de um papel hierárquico da dramaturgia no contexto teatral. Tal constatação se evidencia na sua referência ao espetáculo propriamente dito: "O palco sempre foi a última cidadela da convenção [...]". ${ }^{17}$ (ZOLA, 1881, p. 141, tradução nossa) Com isso, ele pretendia identificar as dificuldades e apontar caminhos para a implantação da fórmula naturalista no espetáculo. Afinal, incorporando rebeldia radical, o palco impõe tempo e espaço próprios que representariam enormes entraves para a exposição da observação do ser humano e da natureza tal qual aquela permitida no romance. Por outro lado, Zola desafiava o teatro e até deixou uma firme assertiva:

[...] a fórmula naturalista, ainda que completa e definida no romance está muito longe de ocupar o teatro, e eu concluo que isso se concretizará, que ele assumirá, cedo ou tarde, o rigor científico; caso contrário, o teatro se achatará, tornando-se, mais e mais, inferior. ${ }^{18}$ (ZOLA, 1881, p. 141, tradução nossa)

Sua forte convicção da necessidade de tratamento científico da cena aplicando a fórmula já vitoriosa no romance impunha que se levasse ao palco, sem as "mentiras idealistas" do romantismo, um homem de carne e osso observado cientificamente na realidade. Tal convicção esbarrava em aspectos práticos, na natureza teatral mesma, e em questões técnicas das convenções contemporâneas do seu teatro: "Em uma palavra, o palco é o domínio da convenção, tudo permanece convencional, desde o cenário, desde a ribalta que ilumina os atores de baixo para cima, até as personagens que são movimentadas por um cordão."199 (ZOLA, 1881, p. 144, tradução nossa)

\footnotetext{
17 "Le théâtre a toujours été la dernière citadelle de la convention, [...]."

18 “[...] la formule naturaliste, désormais complète et fixée dans le roman, est très loin de l'être au théâtre, et j'en conclus qu'elle devra se compléter, qu'elle y prendra tôt ou tard sa rigueur scientifique; sinon le théâtre s'aplatira, deviendra de plus en plus inférieur."

19 "En un mot, le théâtre est le domaine de la convention, tout y reste conventionnel, depuis le décors, depuis la rampe qui éclaire les acteurs par en bas, jusqu'aux personnages qu'on y promène au bout un fil."
} 
Além de qualificar como marionetes os atores que apenas "passavam pela cena", com o objetivo de declamar textos que lhe eram designados, essa é uma, dentre as raras menções que Zola (1912, p. 89, tradução nossa) faz à luz, reprovando a ribalta. Ele disse, também:

Seria um absurdo crer que se poderá transportar a natureza, tal qual ela é para os palcos, plantar árvores verdadeiras, ter [no palco] casas verdadeiras, iluminadas por verdadeiros sóis. As convenções são, portanto, necessárias, temos que aceitar as ilusões mais ou menos perfeitas, em lugar das realidades. ${ }^{20}$

Zola (1881, p. 89, tradução nossa) sublinhou, ainda, um problema de enorme importância, sem, no entanto, vislumbrar objetivamente soluções, dados os limites que a tecnologia impunha:

A questão dos cenários e dos acessórios é um excelente terreno, circunscrito e claramente delimitado para trazer o estudo das convenções no palco. Resumindo, as convenções representam grande questão. Alguns me dizem que as convenções são eternas, que a ribalta jamais será suprimida, que sempre haverá tapadeiras pintadas, que, na cena, as horas serão contadas como minutos, que as salas onde as peças se passam não terão mais que três paredes. ${ }^{21}$

Zola insistiu em sublinhar o incômodo que a luz da ribalta lhe provocava, mas não parecia ter soluções para bani-la. Portanto, lhe parecia mostrar os experimentos (espetáculos) com a estranha luz em ângulo ascendente nela originada e assumir a visualidade equivocada:

O infortúnio, eu disse, é que queremos colocar o teatro de lado considerando-o uma essência absolutamente diferente. Há, sem dúvida, sua óptica. Mas não o vimos todo o tempo obedecer ao movimento da época? Nesse momento, o cenário exato é uma consequência da necessidade de realidade que nos atormenta. É inevitável que o teatro ceda a esse impulso, quando o romance não é mais que uma investigação universal, [...].

\footnotetext{
20 "Il serait absurde de croire qu'on pourra transporter la nature telle quelle sur les planches, planter de vrais arbres, avoir de vraies maisons, éclairées par de vrais soleils. Dès lors, les conventions s'imposent, il faut accepter des illusions plus ou moins parfaites, à la place des réalités."

21 "La question des décors et des accessoires est un excellent terrain, circonscrit et nettement délimité, pour y porter l'étude des conventions au théâtre. En somme, les conventions sont la grosse affaire. On me dit que les conventions sont éternelles, qu'on ne supprimera jamais la rampe, qu'il y aura toujours des coulisses peintes, que les heures à la scène seront comptées commes des minutes, que les salons où se passent les pièces n'auront que trois murs."
} 
Nossas personagens modernas, individualizadas, que agem sob o império de influências do ambiente, que vivem nossa vida na cena, ficariam completamente ridículas em cenários do século XVII. Elas sentam, e precisam cadeiras; elas escrevem, e precisam mesas; elas se deitam, elas se vestem, elas comem, elas se aquecem, e precisam de um mobiliário completo. Por outro lado, nós estudamos todos os mundos, nossas peças caminham por todos os lugares imagináveis, [mas] os mais variados quadros devem forçosamente desfilar diante da ribalta. Essa é uma necessidade da nossa fórmula dramática [do teatro] atual. ${ }^{22}$ (ZOLA, 1881, p. 84-85, tradução nossa)

Afinal, o naturalismo necessitava da força do teatro, capaz de alcançar de uma só vez, num período de três horas, centenas e até milhares de espectadores, enquanto que o romance limitava-se a um solitário leitor. É possível compreender tal concessão, no caso de Zola, quando se leva em consideração os mencionados limites tecnológicos. Mas não é incomum encontrar, ainda hoje, espetáculos cujo tratamento visual parece aquém do que se poderia prever, mais de um século depois que ele escreveu suas inquietações. Os motivos atuais são outros, dentre eles, a limitação dos orçamentos. Mesmo assim, certos espetáculos parecem incluir no elenco das razões para uma visibilidade apenas sofrível, o desconhecimento - gerado pelo difícil acesso à formação específica - e o descaso, também muito grave. Fica uma impressão: o objetivo é, por vezes, reduzido a apenas mostrar algo no espaço cênico pouco importando o cuidado que deve inserir na práxis cênica o grau de excelência visual exigido pela sua natureza artística.

Mas Zola parecia convencido que o teatro acabaria por acompanhar a "evolução" alcançada pelo naturalismo. Mesmo com as limitações que enfrentava, ele acentuava a necessidade do estabelecimento de um ambiente no qual se pudesse acreditar, como condição para que se apresentasse em cena o ser humano "real e verdadeiro", que ele considerava o tema por excelência do teatro. Nesse ponto, Zola era tão honesto, sério e revolucionário quanto um jovem performer do século

22 “Le malheur, ai-je dit; est qu'on veut mettre le théâtre à part, le considérer comme d'essence absolument différente. Sans doute, il a son optique. Mais ne le voit-on pas de tout temps obéir au mouvement de l'époque? A cette heure, le décor exact est une consequence du besoin de réalité qui nous tourmente. Il est fatal que le théâtre cède à cette impulsion, lorsque le roman n'est plus lui-même qu'une enquête universelle, [...]. Nos personnages modernes, individualisés, agissant sous l'empire des influences environnantes, vivant notre vie sur la scène, seraient parfaitement ridicules dans le décor du dix-septième siècle. Ils s'asseoient, et il leur faut des fauteuils; ils écrivent, et il leur faut des tables; ils se couchent, ils s'habillent, ils mangent, ils se chauffent, et il leur faut un mobilier complet. D'autre part, nous étudions tous les mondes, nos pièces nous promènent dans tous les lieux imaginables, les tableaux les plus varies doivent forcément défiler devant la rampe. C'est là une nécessité de notre formule dramatique actuelle." 
XXI, que nega as grandes narrativas responsáveis por confirmar a presença da realidade funcional no palco, da construção psicológica, do conflito (drama), e até, da personagem. Ambos querem provocar o ser humano, com a discussão da sua natureza mesma, cada um acreditando no seu próprio caminho, como clama Zola (1881, p. 142-143, tradução nossa):

Espero que sejam postos de pé no teatro homens de carne e osso retirados da realidade e analisados cientificamente, sem uma mentira. Espero que nos desembaracemos das personagens fictícias, desses símbolos convencionais da virtude e do vício, sem qualquer valor como documentos humanos. Espero que o meio determine as personagens e que as personagens ajam de acordo com a lógica do seu próprio temperamento. [...] Espero, enfim, que a evolução que ocorreu no romance alcance o teatro, fazendo-o voltar-se para a ciência e para a arte moderna, para o estudo da natureza, da anatomia do ser humano, da pintura da vida, [...] o mais original e poderoso, como ninguém ousou antes arriscar sobre o palco. ${ }^{23}$

A experimentação teatral de um homem de carne e osso exigia que o ambiente no qual ele agisse fosse apresentado de modo fiel e convincente. Diferentemente do argumento usado pela crítica e apontado por Zola, o conflito não pode estar somente no ator, desconsiderando o tratamento espacial específico. Mesmo que se use Shakespeare e Molière como justificativa, Zola rebate, afirmando que ele tratava de outro tempo e de um novo entendimento do ser humano para o qual o ambiente é determinante.

Um cenário que não tem valor dramático, que é como uma curiosidade à parte, posto lá para deslumbrar o público, degrada uma obra, pondo-a em um nível inferior de magia [...]. Em uma palavra, o cenário pelo cenário, mesmo rico e curioso, é apenas uma especulação e nada mais faz do que estragar uma obra literária. ${ }^{24}$ (ZOLA, 1912, p. 96, tradução nossa)

\footnotetext{
23 “J'attends qu'on plante debout au théâtre des hommes en chair et en os, pris dans la réalité et analysés scientifiquement, sans un mensonge. J'attends qu'on nous débarrasse des personnages fictifs, de ces symboles convenus de la vertu et du vice qui n'ont aucune valeur comme documents humains, J'attends que les milieux déterminent les personnages et que le personnages agissent d'après la logique de leur prope temperament. [...] J'attends enfin que l'evolution faite dans le roman s'achève au théâtre, que l'on y revienne à la source même de la science et de l'art modernes, à l'étude de la nature, à l'anatomie de l'homme, à la peinture de la vie, dans un procès-verbal exact, d'autant plus original et puissant, que personne encore n'a osé le risquer sur les planches."

24 "Un décor qui n’a pas d'utilité dramatique, qui est comme une curiosité à part, mise là pour éblouir le public, ravale un ouvrage au rang inférieur de la féerie et du mélodrame à spectacle. En un mot, le décor pour le décor, si riche et si curieux soit-il, n'est qu'une spéculation et ne peut que gâter une oeuvre littéraire."
} 
Zola reconhecia a necessidade da artificialização na execução dos cenários, e apontava a capacidade dos artistas [pintores cenógrafos, como ele chamava] de criar resultados convincentes com papel, tecido e madeira. Além disso, ele já vislumbrava tendências pioneiras na técnica cenográfica, que criavam caminhos para a elaboração do cenário naturalista, no qual todos os móveis e acessórios deviam estar presentes. Tal necessidade era justificada na surpresa que deve tomar conta do espectador, incapaz de prever o desenvolvimento da ação já que não saberá que elementos cenográficos serão usados, a cada ocorrência da ação. Por outro lado, tais exigências com a cenografia, aliadas à impotência para superar a falta de recursos técnicos na criação da luz para a elaboração de ambientes "verdadeiros", determinavam um inevitável grau de desconhecimento, de ignorância, tornando a cena naturalista uma incompletude estética, uma contradição insolúvel, àquele momento.

Ainda que se possa dizer muito mais sobre as proposições teóricas de Émile Zola, à presente abordagem basta sublinhar essa sintomática contradição. Afinal, se o ambiente é fator conclusivo na elaboração do ser humano, vale lembrar que a luz é aspecto decisivo na construção do ambiente, do lugar, no modo como o ser humano percebe e age no ambiente, assim como na sua apreensão do outro e na interação particular com o ambiente que ambos ocupam. Diante dos enormes limites tecnológicos, portanto, atender aos pressupostos naturalistas no que se refere aos resultados precisos da observação e experimentação científicas da luz natural e/ou artificial - representava enormes desafios.

Considerem-se as demandas da visualidade: diante de uma luz de ribalta, da impossibilidade tecnológica de criar ângulos, cores e texturas que retratassem o que se podia observar no ambiente construído e/ou ocupado pelo ser humano, a experimentação naturalista da luz parecia limitada a permanecer encarcerada no romance e na teoria de Zola. No entanto, a ousadia de outro artista francês, André Antoine (1858-1943), validou o desejo de levar à cena as iniciativas radicais dessa estética fundada em pressupostos científicos ou, nas palavras do próprio Zola (1881, p. 128, tradução nossa): "Não somos mais que estudiosos que analisam, que pesquisam a anatomia, [...] e nossas obras são a certeza, a solidez e as aplicações práticas das obras da ciência".25

25 "Nous ne sommes que des savants, des analystes, des anatomistes, [...] et nos ouevres sont la certitude, la solidité et les applications pratiques des ouvrages de science." 


\section{ANDRÉ ANTOINE E A CENA COMO REALIDADE CONTROLADA}

Indignado com o sistema implantado no teatro francês da sua época André Antoine repudiava àquilo que via nos palcos, incluindo o que ele considerava o monopólio da "trindade", composta por Émile Augier (1820-1889), Alexandre Dumas, filho (1824-1895), e Victorien Sardou (1831-19o8), que recebia o reforço de Eugène Scribe (1791-1861), cuja fórmula da peça bem-feita ${ }^{26}$ (pièce bien faite) era incorporada por grande parte dos dramaturgos. Antoine acreditava que a saída estava na busca de novos autores, cujas obras estivessem livres de vínculos com o teatro comercial, que impunha o desejo dos produtores. Isso o aproximou de Émile Zola cuja teoria do teatro naturalista repercutiria nos seus espetáculos. Assim como Zola, outros novos autores foram encenados por Antoine, entre eles Edmond de Goncourt (1822-1896), além de dramaturgos de outros países: Henrik Ibsen (1828-1906), Léon Tolstoi (1828-1910), Ivan Tourguéneff [ou Ivan Sergeyevich Turgenev, (1818-1883)]. Para Antoine, os espetáculos franceses eram montados em torno da figura centralizada de uma estrela com altos salários e rodeada por atores ruins recrutados aleatoriamente. Ele resume o resultado:

Dessa interpretação heterogênea resulta uma deformação absoluta da obra [texto dramático], causa de uma nova e irremediável repulsa do público inteligente. | Em resumo, o teatro atual oferece ao espectador peças desinteressantes, em teatros pessimamente administrados, a preços exorbitantes, interpretadas por companhias sem coesão. ${ }^{27}$ (ANTOINE, 189o, p. 26-27, tradução nossa)

Ainda criança, Antoine acostumou-se a frequentar o Ba-ta-clan, ${ }^{28}$ onde assistia comédias e operetas, levado pela mãe. Mais tarde, influenciado por um amigo, interessou-se pelo movimento artístico, frequentando livrarias, teatros, a Escola de Belas Artes, os museus e, segundo seu próprio depoimento, decorava as falas

\footnotetext{
26 A fórmula da peça bem-feita é atribuída à Eugene Scribe, que a teria desenvolvido a partir de 1825, seguindo pressupostos técnicos muito claros, que determinavam uma estrutura constituída de enredo artificialmente elaborado, um clímax no qual os conflitos eram resolvidos e um final feliz.

27 “De cette interprétation hétéroclite résulte une absolute déformation de l’oeuvre, d’où nouvelle et irrémédiable cause de répulsion pour le public intelligent. | En résumé, le théâtre actuel offre au spectateur des pièces sans intérêt, dans des salles déplorablement agencées, à des prix exorbitants, avec des troupes sans cohésion."

28 Um café-concerto localizado nos arredores de Paris, cujo programa incluía vaudevilles de Eugène Scribe, Jean-François Alfred Bayard (1796-1853), Anne-Honoré-Joseph Duveyrier Mélesville (1787-1865) e Théophile Marion Dumersan (1780-1849). Antoine declara, nas suas Memórias sobre o teatro livre, que as mais importantes impressões em sua mente de criança foram deixadas por representaçõeos de Beaumarchais (Pierre-Augustin Caron de Beaumarchais, 1732 -1799). (ANTOINE, 1921, p. 9-10)
} 
das principais estrelas da Comédie Française, enquanto seu gosto pela carreira de ator se desenvolvia. Ele frequentou um curso de dicção no qual estabeleceu contato com os grandes clássicos tentando depois, sem sucesso, ingressar no Conservatório de Paris onde se estudava música, dança e o teatro francês de bases então tradicionais. Convocado para o exército, permaneceu na Tunísia entre 1878 e 1883. Três anos depois do seu retorno, ingressou no Cercle Gaulois, uma associação de atores amadores comum àquela época em Paris que apresentava modestos espetáculos mensais destinados a parentes e amigos.

Antoine sentia-se incomodado pelo aparente sucesso de uma associação vizinha, concorrente e com muito mais recursos financeiros, a Cercle Pigalle. Ele acreditava que o caminho para o teatro que lhe interessava partia da descoberta de novos autores. Um amigo, Arthur Byl, lhe indicou contatos que findaram por promover encontros com um grupo de autores, denominado Les soirées de Médan, cujo nome originou-se no lugar, Médan, perto de Paris, onde ficava a casa de Émile Zola. Lá se reuniam seis autores, o que acabou por originar a publicação, em 1880, de uma coletânea de seis contos, cujos temas se referiam à guerra franco-prussiana, um de cada membro do grupo. Émile Zola, Guy [Henry-René-Albert-] de Maupassant (1850-1893), Joris-Karl Huysmans (1848-1907), Henry Céard (18511924), Léon Henrique (1850-1935) e Paul Alexis (1847-1901).

Daí derivou uma indicação de Henrique, que enviou para Antoine o manuscrito de uma adaptação (ou uma versão dramática) do romance de Zola, Jacques Damour, cuja proposta de montagem havia sido recusada pelo Odéon. O entusiasmo de Antoine pelo novo texto não contagiou a totalidade dos membros do Cercle Gaulois levando-o a assumir toda a responsabilidade, inclusive financeira, de representação da peça, mesmo sem ter um centavo para investir. Esses eventos deram origem ao Théâtre Libre (cujo título final foi uma sugestão de Arthur Byl, depois de uma indicação de Antoine, cuja busca se dirigia mais para uma epígrafe do que para um título, cunhando "Le Théâtre en liberté", emprestado de Victor Hugo, segundo ele mesmo declara). Byl teria exclamado em um brinde: "Alors, le Théâtre Libre!” (ANTOINE, 1921, p. 23) originando a denominação que hoje se conhece. Sobre esses momentos, Antoine (1921, p. 18, tradução nossa) confessa: "Eu, por minha conta, não tinha o menor desejo de me tornar um ator ou diretor profissional e teriam me feito rir se tivessem antecipado que nós iríamos revolucionar a arte dramática". 29

29 "Pour mon compte, je n'avais pas le moindre dessein de devenir un acteur ou directeur professionnel et l'on m'eût bien fait rire si l'on m'avait prédit que nous allions révolutionner l'art dramatique." 
Antoine (1921, p. 9) estava convencido da importância do naturalismo para um novo modo de pensar a cena, como ele pondera: "A batalha, já vencida no romance pelos naturalistas, na pintura pelos impresssionistas, na música pelos wagnerianos, será transportada para o teatro". ${ }^{30}$ E essa nova maneira de pensar incluía a abordagem visual que apareceria em seus textos, como nas Memórias, aqui mencionadas. Refletindo sobre a publicação do crítico Francisque Sarcey (18271899), no folhetim Temps, ele cita impressões sobre Wagner e sobre os Meininger, ${ }^{31}$ cuja menção aparece em muitos comentadores que se seguiram:

Eu não sei nada sobre música, mas me disseram que Wagner tinha, em algumas óperas, coros em múltiplas partes e que cada série de cantores personificava um elemento distinto na multidão, transformando-se em um conjunto perfeito. Por que, no teatro falado, nós não fazemos isso? O Sr. Émile Zola queria a mesma coisa no Germinal e não o fez por que os administradores alegaram limitações de orçamento. Seu objetivo era repetir os grandes grupos, liderados por figurantes. Esse era o procedimento dos Meininger. | Note-se que eu não estou encantado por eles, como se costuma dizer. ${ }^{32}$ (ANTOINE, 1921, p. 94-95, tradução nossa)

É importante observar que Antoine havia passado duas semanas em Bruxelas, acompanhando o trabalho da companhia alemã, e que os comentários de Sarcey se baseiam no espetáculo da mesma tournée que ele acompanhou, também na capital da Bélgica. Depois de manifestar suas críticas à cenografia dos espetáculos dos Meininger, cuja pintura não lhe parecia alcançar o nível dos cenários franceses, Antoine (1921, p. 95, tradução nossa) fez observações sobre a luz, que originaram inúmeras citações e referências futuras:

\footnotetext{
30 "La bataille, déjà gagnée dans le roman par les naturalistes, dans la peinture par les impressionnistes, dans la musique par les wagnériens, allait se transporter au théâtre."

31 Meininger Hoftheatertruppe, uma companhia de Teatro dirigida e financiada por Georg II (1866-1914), duque de Saxe-Meiningen, e pela sua mulher, a atriz Ellen Franz, começou as atividades em 1866. A companhia dos Meininger foi uma dentre as primeiras que deram destaque à posição do diretor e influenciou outros artistas, pela sua busca por uma montagem teatral que unificasse os diversos elementos do espetáculo.

“Leurs effets de lumière, très réussis, sont le plus souvent réglés avec une naïveté épique. Ainsi, un fort beau rayon de soleil couchant, venant éclairer une très belle tête de vieillard mort dans son fauteuil, passait tout à coup au travers d'un vitrail, sans gradations, au moment précis où le bonhomme venait d'expirer, uniquement pour faire tableau.| Ainsi encore, après une pluie torrentielle extraordinaire, obtenue par des projections électriques, j'ai eu le chagrin de voir l'eau s'arrêter brusquement, sans transition."

32 "Je ne connais rien en musique; mais on m'a dit que Wagner avait, dans certains opéras, des choeurs à multiplex parties et que chaque série de choristes personnifiait un élément distinct de la foule, se fondait dans um ensemble parfait. Pourquoi, dans le théâtre parlé, ne ferions-nous pas ça? M. Émile Zola le voulait pour Germinal et ne l'a pas pu pour des motifs budgétaires que faisaient valoir les directeurs. Son dessein était de faire répéter longtemps les ensembles sous la conduite de comédiens figurants. Vous voyez, c'était le procédé des Meininger. | Notez que je ne suis pas du tout emballé, comme on dit, par eux."
} 
Seus efeitos de luz, muito bem-sucedidos, são, em grande parte, resolvidos com uma ingenuidade épica. Assim, um belo raio de sol que se põe ilumina a graciosa cabeça de um velho morto, em sua cadeira, passando bruscamente através de um vitral, sem gradações, no momento preciso em que o homem expira, unicamente para criar um quadro [uma imagem particular]. | E ainda, depois de uma chuva torrencial, criada por projeções através da eletricidade, tive a tristeza de ver a água parar de repente, sem transição. ${ }^{33}$

Antoine sublinha questões de tempo/ritmo, e a sua aplicação de certos termos - como é o caso da denominação de "efeito" para os movimentos de luz - é bastante compreensível considerando-se aquele momento no qual esses movimentos ainda incorporavam a novidade e a surpresa que os caracterizava como algo fora do comum. Mais de um século depois, desafortunadamente, continuamos encontrando a abordagem que leva muitos comentadores e artistas a desconsiderarem diferenças entre efeito (especial) e movimento de luz, buscando efeitos em qualquer intervenção da luz, impondo à sua contribuição papéis superficiais, vagos. Como se ela estivesse obrigada a apresentar os tais efeitos mirabolantes, infinitamente. Ou seja, cabe repetir: um efeito que envolve a aplicação da luz é, originariamente, mais um entre outros movimentos (de luz) que constituem a visualidade do espetáculo. A natureza do efeito, por sua vez, pode incluir particularidades de tratamento estético-poético, o que sugere cuidados na sua aplicação.

Ainda se referindo à mencionada publicação de Sarcey, Antoine (1890, p. 103-104, tradução nossa) continua:

Nós ainda ficamos diante de ridículas pinturas de fundo, sem ar, sem profundidade, permitindo, com o risco de perturbar a ação, a preparação ruidosa dos quadros seguintes, abrigados por uma coisa vaga, sobre a qual não se tem medo de pintar escadas, a três metros da ribalta, sob uma luz dura, o que não deixa qualquer dúvida sobre [desmascarando] o truque. [...] Nossos Administradores, para ganhar tempo, ainda pintam móveis sobre os cenários. ${ }^{34}$

\footnotetext{
33 "Leurs effets de lumière, très réussis, sont le plus souvent réglés avec une naïveté épique. Ainsi, un fort beau rayon de soleil couchant, venant éclairer une très belle tête de vieillard mort dans son fauteuil, passait tout à coup au travers d'un vitrail, sans gradations, au moment précis où le bonhomme venait d'expirer, uniquement pour faire tableau.| Ainsi encore, après une pluie torrentielle extraordinaire, obtenue par des projections électriques, j'ai eu le chagrin de voir l'eau s'arrêter brusquement, sans transition."

34 "Nous en sommes encore à de ridicules toiles de fond, sans air, sans profondeur, qui permettent, au risque de troubler l'action, de préparer bruyamment les tableaux suivants, à l'abri d'une chose vague, sur laquelle on ne
} 
Aí está uma mostra explícita da sua desaprovação ao tratamento visual do teatro francês, em curso no seu tempo. Ele desejava introduzir elementos que observara em espetáculos de outros países, em busca de credibilidade para o seu trabalho: a iluminação dos cenários (que ele chama "projeções luminosas") assim como as variações na cenografia aplicadas pelos alemães; dos ingleses, os movimentos sutis da cenografia, os objetos em relevo e o aspecto natural. Além disso, na opinião de Antoine, as características dos teatros estavam muito aquém da qualidade indicada para atender às necessidades do novo espetáculo.

Ele clamava pela construção de uma nova sala de espetáculos, não sem antes afirmar que diante da quantidade de teatros em Paris, só se justificaria tal empreendimento se fosse construído o que ele denominou um teatro "modelo". O capítulo que trata desse teatro modelo, na sua publicação Le théâtre libre (1890), deveria ser leitura obrigatória, ainda hoje, para arquitetos envolvidos em projetos de casas de espetáculo. Antoine questionava a salubridade, a segurança, o valor dos ingressos, a acústica e, entre outros pontos, inicia o capítulo abordando a visibilidade. Resumindo a composição de um teatro em três partes principais, orquestra, plateia (de forma circular) e um número variável de balcões, ele emite uma opinião contundente sobre essa disposição dos espectadores: "A forma circular de um teatro é, portanto, ilógica, contrária a uma representação teatral racional". ${ }^{5}$ (ANTOINE, 189o, p. 46, tradução nossa)

Ainda que o adjetivo "racional" possa abrir espaços para críticos de ocasião geralmente rápidos e superficiais que, simploriamente, atacariam as relações com a racionalidade, vale a pena algum esforço e/ou atenção para identificar as demandas de André Antoine, considerando sua contemporaneidade. Ele diz:

O espectador, que nos últimos vinte anos viu seu cotidiano se transformar consideravelmente no que refere ao conforto, quando vai ao teatro, se vê diante de condições absolutamente inferiores àquelas que encontra na sua própria casa, nas ruas, ou em seu trabalho. ${ }^{36}$ (ANTOINE, 1921, p. 48, tradução nossa)

Antoine assume, num certo sentido, uma postura de empresário que procura se alinhar com a história e trazer o público para o seu lado. Nem mesmo a mais

\footnotetext{
craint pas de peindre des escaliers à trois mètres de la rampe, dans une lumière crue, ne laissant aucun doute sur la tricherie. | Nos Directeurs em sont encore, pour gagner du temps, à peindre des meubles sur les décors."

35 "La forme circulaire d'une salle de théâtre est donc illogique, contraire à une représentation rationnelle."

36 "Le spectateur qui, depuis vingt ans, a vu sa vie journalière se transformer considérablement au point de vue du confortable, se retrouve, dès qu'il veut aller au théâtre, dans des conditions absolument inférieures à celles dont il jouit chez lui, ou dans la rue, ou à son travail."
} 
importante casa de espetáculos da época, a Comédie Française, escapou dos erros de arquitetos que repetiam a fórmula reconhecida no teatro italiano, perpetuando os equívocos. Antoine comentou a acústica da Comédie acentuando que para o público acomodado no último balcão os sons eram confusos e abafados. A noção de conforto, no entanto, mostra a amplitude de sua compreensão do teatro, definindo uma busca abrangente por respostas às demandas que uma sala de espetáculos efetivamente nova deveria atender:

Uma tentativa nesse sentido será, portanto, absoluta, completa, satisfatória, se já partir, inexoravelmente, desse princípio: um teatro deve ser construído para o espectador que ocupe a pior localização na plateia. Precisamos pensar no milésimo espectador. E não podemos simplesmente dar-lhe uma cadeira onde ele possa sentar-se, num ponto onde é possível chegar sem quebrar os joelhos, mas é preciso que coloquemos o espetáculo que ele veio assistir, diante dele, e não à sua direita ou à sua esquerda. | Se mantivermos as galerias [os balcões] na forma atual, isto é, se colocarmos o espectador acima da imagem que ele paga para ver, ele não verá, mesmo sentado à sua frente, mais que o piso do palco ou, se ele estiver nos dois balcões superiores, a cabeça e uma distorção dos atores. ${ }^{37}$ (ANTOINE, 1921, p. 48, tradução nossa)

Considerando o espaço erigido para abrigar uma manifestação artística visceralmente entranhada em relações visuais com o seu público, as instalações teatrais encontradas em Paris eram, em sua opinião, equivocadas. Elas sonegavam um importante direito de quem vai ao teatro, qual seja aquele de ver o espetáculo, e se revelavam incompetentes na realização de um dos mais relevantes aspectos do palco chamado "italiano" que, aliás, serviu como apoio generalizado para os críticos, ou seja: emoldurar uma ação que se tornava visível através de uma parede falsa ou inexistente. Afinal, o modelo teatral reproduzido dos italianos, com sua plateia circular, nem sequer "merecia" a crítica que lhe era dirigida, pois oferecia uma visibilidade apenas sofrível na qual a maioria das pessoas acomodadas nas laterais dos balcões tinha diante de si em lugar do espetáculo, literalmente,

37 “Une tentative dans cet ordre d'idées ne sera donc absolue, complète, satisfaisante, qu'en partant tout de suite et inexorablement de ce principe: édifier une salle de théâtre pour le spectateur le plus mal placé de cette salle. C'est ce millième auditeur qui doit nous occuper. Et non seulement nous devons lui donner un fauteuil où il puisse s'asseoir, où il lui soit possible d'arriver sans se briser les rotules, mais il faut que nous placions le spectacle qu'il vient voir, en face de lui, et non à sa droite ou à sa gauche. | Si nous maintenons les galeries dans la forme actuelle, c'est-à-dire si nous plaçons l'auditeur au-dessus du tableau qu'il paie pour voir, il ne pourra, même placé de face, que contempler le plancher du théâtre ou, s'il est aux deux derniers étages, le crâne et le raccourci des acteurs." 
outros espectadores, como afirma Antoine. Tal situação resultava em negligência no que se refere à visibilidade do espetáculo. Ele até disse que em todos os teatros de Paris, naquela época, havia lugares nos últimos balcões de onde não se via nada daquilo que acontecia no palco.

Aí falava também o artista, deixando um ensinamento óbvio, mas nem por isso hoje identificado e praticado. Se emprestarmos algum valor às preocupações de Antoine constataremos que, ainda hoje, teatros famosos nos quais se investiu enorme soma de recursos continuam repetindo essa categoria de erro. Copiados sucessivamente, transformam em regra impropriedades técnicas que acabam por se afirmar como verdade, de tal modo que, questionar parece uma atitude absurda.

Antoine, por outro lado, revelou admiração pelo teatro de Bayreuth (Festspielhaus), inaugurado em 1876, para o festival onde foram montadas as óperas de Wagner, inovando em aspectos importantes quando excluía as galerias de balcões e apresentava uma plateia na forma de "leque", em declive no sentido do palco. Há duas principais indicações para a origem das características particulares desse teatro. Segundo o Oxford companion to the theatre (HARTNOLL, 1957), o projeto aplicado na construção orientada pelo arquiteto da cidade de Bayreuth, foi originalmente concebido por Gottfried Semper (1803-1879) para um teatro em Munique e empregado pela primeira vez por Edward Shepherd (?-1747), em 1733. Parece compreensível a predileção de Antoine pelas características do Bayreuth já que ele compartilhava com Wagner o desejo de uma plateia na qual todos os espectadores tivessem a liberdade de ver, integralmente, o espetáculo.

Essa é uma importante nuança da questão, pois revela diferenças entre o discurso sobre a visualidade e sua efetivação. É também verdade que, observando em detalhe o Festspielhaus podem-se identificar progressos - no que se refere à visibilidade - em comparação com o design italiano que se instalou nas casas de espetáculo desde a renascença, como se pode ver no Teatro Farnese, já mencionado (Figura 35). É possível identificar no Farnese o objeto da crítica de Antoine sobre a impropriedade da acomodação dos espectadores, dispostos em grande parte uns em frente a outros enquanto o espetáculo ocorria no palco, à sua direita ou à esquerda (ainda que, no Farnese - o que parece mais apropriado, do ponto de vista da visibilidade - possa ter ocorrido espetáculos diversos como disputas de cavaleiros e até combates navais, no espaço entre um e outro lado da plateia). Portanto, se forem consideradas as inovações do Bayreuth, os ataques ao teatro italiano deveriam mudar de direção e concentrar forças numa crítica ao teatro alemão ou, melhor, na direção das iniciativas de Wagner, defensor de uma tipologia do espaço teatral que privilegiava a disposição frontal da plateia. 
Por outro lado, comparando hoje as aspirações de Antoine com as características do Bayreuth (Figura 108), determinados aspectos ou detalhes técnicos podem ser observados, sugerindo discussões. De acordo com suas proposições é indispensável que se coloque o espectador, visualmente, diante do espetáculo; no teatro que abrigou a obra de Wagner, no entanto, isso não acontece integralmente. Consultando-se a planta-baixa do Bayreuth (Figura 109) é possível traçar algumas ponderações: à primeira vista parece comprovada a firme relação frontal entre a plateia (1) e o palco (4), intermediados - ou separados - pela orquestra (2) e pela boca de cena (3). A plateia em nível único, cuja planta-baixa lembra a mencionada forma de "leque", deixa, contudo, espaços para questionamentos, precisamente pela localização dos espectadores acomodados nos limites laterais desse leque. Observe-se na Figura 109 que parte do palco é visualmente inacessível aos espectadores localizados em (1a) e (1b) originando, para aqueles sentados nos pontos extremos uma visão muito limitada, representada pelo triângulo isósceles (2a).

Parece óbvio que, para atender ao rigor desejado por Antoine, concentrando a plateia no retângulo (1) da Figura 109, parte substancial dos assentos seria perdida, o que sempre representa um terror para produtores e artistas. Afinal, é compreensível que um investidor ou um artista queira sempre uma plateia com a maior quantidade possível de espectadores; isso representa uma demanda passível de ser entendida e facilmente atendida. No caso do Festspielhaus, poder-se-ia apresentar uma solução, mantendo, e até ampliando o total de espectadores na plateia. Para isso bastaria demolir os elementos 3 e 4 , deslocando horizontalmente os limites da boca de cena, ampliando coxias e bastidores, assim como os acessos laterais para o público, entre as linhas tracejadas em azul e a plateia.

Os entraves principais para a realização de tal incremento residiriam em duas limitações: orçamento e reconhecimento da contribuição da visualidade para a práxis cênica. Seria possível também conceber uma edificação como aquela que resultou da parceria entre Adolphe Appia e Emile Jacques-Dalcroze (1865-1960) no projeto do Teatro de Hellerau (Hellerau Festspielhaus) construído em Dresden, na Alemanha, no ano de 1911. Influenciado pelo teatro grego, Appia propôs um espaço - ainda que coberto - totalmente aberto, tanto na dimensão vertical quanto horizontalmente, indicando algo efetivamente novo se forem consideradas as convenções que se impuseram desde o Renascimento..$^{38} \mathrm{O}$ trabalho de Adolphe Appia será abordado adiante, no capítulo final deste livro, "A luz e a cena não realista".

38 De acordo com Brockett (1995, p. 444), Appia contribuiu para o projeto desse que foi o primeiro teatro moderno sem boca de cena e um palco completamente aberto. 
Pode soar como excesso aplicar tal rigor à visualidade da cena. No entanto, o grau de exigência é o mesmo usado em inúmeras instâncias da atividade humana nas quais se domina um contexto e se definem normas. Como quando se revisa um projeto, um artigo, ou outro texto acadêmico, e se aponta uma vírgula posicionada de modo indevido, para atender a regras gramaticais e estilísticas definidas por alguma norma. No caso de um projeto orientado pela excelência da proposição de Antoine, o estudioso seria obrigado a mudar de posição - ou excluir - não apenas uma vírgula, mas, em inúmeros casos, um enorme volume de alvenaria, concreto, ferro, madeira, e assim por diante. Talvez fosse possível analisar os projetos de teatros com o rigor técnico originado na orientação de um consultor especializado em arquitetura teatral acompanhado de um cenógrafo com experiência na definição prioridades visuais. Não se trata de exclusiva aplicação da "sensibilidade" e significa muito mais do que a escolha de materiais sofisticados para o acabamento ou para uma "volumetria" interessante. Afinal, estaria Antoine equivocado quando desejava que em um edifício cujo planejamento e denominação foram originados na capacidade visual do ser humano, um teatro, fosse respeitado o direito à visibilidade?

Assim como outras edificações, um teatro é um espaço cujo uso apresenta particularidades. É indispensável, portanto, o apoio a estudantes de arquitetura interessados em projetos de casas de espetáculo, incluindo na sua orientação crítica a projetos já construídos, identificando equívocos para se evitar que o desconhecimento origine a reprodução dos tantos equívocos. Teatros construídos sem excelência na previsão do seu uso por artistas e técnicos resultam em problemas, graves e complexos. Por outro lado, a enorme carência da comunidade teatral inclui a escassez de espaços para a realização dos seus espetáculos fazendo com que os artistas aceitem edificações cujos projetos deveriam ter sido reprovados na prancheta, ou na tela do monitor, mesmo aqueles desenhados em programas de computador, famosos e caros.

De acordo com os pressupostos definidos pelos seus textos, se fosse possível encontrar um teatro construído por Antoine, apresentando uma plateia com perfeita visibilidade frontal, os comentadores seriam obrigados a mudar ou, ao menos, deveriam deslocar a crítica dirigida ao chamado "palco italiano" para encaminhá-la ao "teatro francês" ou "antoineano". De todo modo, quaisquer que tenham sido os aspectos positivos do projeto de Antoine, eles parecem ter sido sufocados pela sua ligação com o naturalismo, combatido já no seu próprio tempo. Tal ligação parecia fortalecida na dramaturgia e na teoria de sua época, como se pode registrar na citação que se segue, originada num evento ocorrido em 13 de janeiro de 1893: 
"Strindberg, para sua tragédia Senhorita Júlia, que vamos representar, escreveu um longo prefácio repleto de coisas curiosas; pareceu-me necessário imprimir e distribuir aos espectadores." 39 (ANTOINE, 1921, p. 286, tradução nossa)

No prefácio, que será abordado a seguir, August Strindberg (1849-1912) deixou importantes elementos para a discussão encaminhada no trabalho em curso, ao tratar das possíveis relações entre a luz e a cenografia no teatro realista.

No programa da montagem de Senhoria Júlia, em 2002, Ewald Hackler diz que o pequeno Théâtre Libre em Paris, fundado em 1887, tornou-se mundialmente famoso pelas montagens de peças naturalistas, em um ato, inspirando-se em Strindberg, que escreveu entre 1888 e 1892 onzes peças do gênero, dentre elas A mais forte e Senhorita Júlia. ${ }^{40}$

\section{A LUZ DA CENA MODERNA COMO VARIAÇÃO DA REALIDADE}

O título acima deriva do mencionado prefácio de Senhorita Júlia, de Strindberg, ambos escritos em 1888. É importante sublinhar: a peça representa uma fase específica na obra de Strindberg, que sempre procurou novas maneiras de responder às suas inquietações de artista. Desde o início da sua carreira, em 1870, ele viu montado seu primeiro texto, I Rom (Em Roma), ainda sob a influência das tradições românticas voltadas para temas históricos, sagas e fantasias.

No prefácio de Senhorita Júlia, ele revelou ligações com a abordagem clássica do teatro e apontou para a caracterização da dramaturgia moderna:

Quando escolhi o tema [tirado de uma história real] que me contaram há alguns anos e que deixou em mim profunda impressão, vi nele o argumento de uma tragédia, pois é trágico, sem dúvida, ver uma pessoa favorecida pela sorte sucumbir e, mais trágico ainda, assistir ao extinguir-se de uma família. (STRINDBERG, 1970, p. 2)

Strindberg deixou margem para críticas políticas ao se referir à posição social da personagem central como se sua posição social resultasse de favorecimento da sorte, em lugar de questionar os aspectos abrangentes da construção de riqueza. Além disso, sua relação com a instituição familiar também pode provocar excla-

39 "Strindberg, pour sa tragédie de Mademoiselle Julie que nous allons jouer, avait écrit une assez longue préface pleine de choses curieuses; il m'a paru utile de la faire imprimer et distribuer à nos spectateurs."

40 Senhorita Júlia estreou com direção de Ewald Hackler, e cenografia de Maurício Pedrosa, em 2002, na Sala 5 do Teatro Martim Gonçalves, Salvador/Bahia. No elenco: Jussilene Santana, Júlia; Agnaldo Lopes, Jean; Lika Ferraro, Cristina; Oswaldo Baraúna Neto, lia as rubricas durante o espetáculo. 
mações. Aqui, entretanto, será destacado um aspecto da declaração: ele afirmou que o tema foi retirado de uma história "real". Tratava-se de um momento do seu teatro no qual Strindberg acentua o vínculo com histórias reais, o que pode sugerir a necessidade de ilusão para convencer o público da verdade na cena. Dessa necessidade derivaram aspectos decisivos para sua estratégia de dramaturgo. Ele elaborou sua Júlia como resultado de um emaranhado de razões entranhadas no contexto social, em meio a densos comprometimentos psicológicos originados no contexto familiar da personagem e, portanto, em sua formação para a qual o ambiente tem importante papel. Strindberg fez tais escolhas, provocado pela sua noção de complexidade das causas que geram a ação humana, buscando a revelação de personagens diferentes dos tipos fixados pelo teatro burguês que, segundo o próprio Strindberg, aparecem até mesmo em Molière.

Numa atitude que lembra Corneille, ele defendeu o monólogo, privilegiando o verossímil em detrimento de regras impostas à conduta teatral. Ficava justificado o caráter irregular dos pensamentos e dos diálogos, pois assim se dá, "na realidade" (STRINDBERG, 1970, p. 10), enfatizando uma curiosidade "quasi-científica":

[...] não nos satisfaz ver que alguma coisa acontece, se não nos mostram como ela acontece. Queremos enxergar os fios, o mecanismo, examinar o fundo duplo, apalpar o aro mágico, para descobrir o ponto de junção, inspecionar as cartas para ver de que modo estão marcadas. (STRINDBERG, 1970, p. 10)

O revolver investigativo requer grande domínio do dramaturgo sobre suas ferramentas e suportes, para prover unidade com assimetria, irregularidade e economia, criando uma convenção sofisticada e eficiente. Strindberg parece se referir à performance de um mágico na qual ele fazia parte daquele público que só se interessa pelo resultado de um truque se lhe for dado conhecimento dos mecanismos que o tornaram possível. O desejo do espectador, revelado por Strindberg, inclui a sensação táctil, que atua como uma metáfora da agudez do seu olhar, um olhar que quase "toca" o ator em cena. Isso exige do artista, portanto, extremo cuidado na elaboração visual do espetáculo.

Revelando interesse pela pintura impressionista, ele escrevia com o olhar já lançado no palco buscando um dispositivo cenográfico que levasse o público a apreender o espaço cênico como uma rigorosa seleção extraída da totalidade do seu próprio ambiente. No teatro naturalista de Strindberg, a cena fazia parte de algo maior, nunca dado integralmente, a realidade. Essa abordagem já seria motivo suficiente para incluir seu trabalho na discussão dos compromissos entre cena e visualidade. No teatro que abrigava a personagem por ele denominada moderna, 
era importante fortalecer os elos entre o verossímil e a ilusão. Chegava o momento de afastar-se da herança romântica que ele mesmo havia compartilhado; urgia a supressão de Deus e da culpa ainda que fossem mantidas as consequências das ações do homem, nele mesmo e nas suas relações sociais que impõem o julgamento e a punição institucional.

Em decorrência dessa abordagem, Strindberg (1970) propôs experimentações que incluíam a exclusão da divisão em atos, aliada à redução da duração de uma peça. Isso resultaria, em sua opinião, na garantia de uma ação ininterrupta e eficiente, capaz de manter a ilusão, sempre seriamente ameaçada pelos intervalos entre um e outro ato. E preveniria que um espetáculo longo cansasse o público, ainda segundo o próprio Strindberg, infelizmente deseducado para assistir uma peça de ato único, com longa duração, ou, como ele mesmo diz: "[...] o tempo de um espetáculo inteiro". (STRINDBERG, 1970, p. 11)

Demonstrando sua perspicácia técnica, Strindberg criticou a má execução dos cenários cuja construção apresentava estruturas de madeira revestidas de tecido e impedindo a movimentação natural dos atores sob o risco de balançar todo o cenário, denunciando sua fragilidade material que resultava no afastamento da "verdade". Ele também condenou o exagero, assim como a aplicação da pintura para sugerir a tridimensionalidade, já criticada por outros. Essa é uma questão importante para o contexto da ilusão buscada por Strindberg (1970, p. 13):

[...] recorri a um cenário único, seja para fazer as personagens fundirem-se com o ambiente, seja para pôr um paradeiro ao hábito do luxo nas montagens. Quando se tem somente um cenário, pode-se exigir que ele seja verossímil. [...] Mesmo que as paredes continuem sendo de pano, é tempo de se acabar com as prateleiras e os utensílios de cozinha nelas pintados. Já há tantas coisas convencionais, no palco, que precisamos aceitar que deveriam nos poupar o esforço de acreditar em panelas pintadas.

Na última parte do prefácio, ele incluiu a luz encaminhando importantes definições para o seu teatro. Quando se considera o lugar comum da compreensão do tratamento visual realista que é atrelado à criação simplista de atmosferas, observamos na proposição de Strindberg uma clara oposição a tal julgamento, privilegiando as funções que a luz deveria cumprir no seu teatro, que ele denominou drama psicológico moderno: “[...] os mais sutis movimentos da alma devem refletir-se no rosto, mais do que em gestos e gritos". (STRINDBERG, 1970, p. 15) Para que a luz apresentasse uma resposta visual para tal premissa, ele pondera: "[...], 
o mais indicado me parece trabalhar com um palco pequeno, utilizando-se uma forte iluminação lateral e com atores renunciando à maquilagem ou usando-a com sobriedade". (STRINDBERG, 1970, p. 15)

Essa limitação da extensão do palco, principalmente no sentido horizontal, tinha como primeiro objetivo garantir a iluminação de ambos os lados do rosto do ator sem o prejuízo causado pela redução de luminosidade no centro de um palco excessivamente largo. A ideia era permitir um razoável grau de visibilidade em toda a extensão da cena e, ainda, possibilitar ângulos de projeção para a luz que interagissem com os volumes do rosto do ator criando uma visualidade capaz de revelar, principalmente, a fisionomia e a expressividade do seu olhar. Nesse sentido, ele desprezava qualquer maquilagem imposta ao rosto como uma máscara limitadora, mesmo aquela cujo objetivo fosse prover beleza.

Para aquele Strindberg que escreveu Senhorita Júlia, ser "natural" no teatro era mais importante do que ser "bonito". Ele também propôs a exclusão das luzes da ribalta, uma vez que sua posição eliminava detalhes do rosto, deformando e projetando sombras sobre a região dos olhos. ${ }^{41}$

A preocupação de Strindberg (1970, p. 15) com as relações visuais entre o público e o seu espetáculo o levaram a solicitar que a orquestra se tornasse invisível, apontando sérias justificativas: "[...] suas luzes incômodas e suas caras voltadas para o público, [...]".42 É possível imaginá-lo indignado ao pensar que durante seu espetáculo, concentrado num espaço cênico reduzido e tratado visualmente para revelar a expressão do rosto das personagens, o público visse as luzes da orquestra e, mais grave, o rosto de cada um dos músicos, numa concorrência absurda com os atores. Importante observar o legado de Wagner, através do Festspielhaus, ao manter a orquestra fora do alcance visual do espectador.

Ele listou ainda outras decisões importantes para o novo teatro: a retirada de camarotes do proscênio nos quais os ocupantes mais se interessavam pelo que comeriam, do que pelo espetáculo em si. A plateia - mantida em completa escuridão durante a representação - deveria ser projetada em aclive desde a primeira

\footnotetext{
41 Muitas décadas mais tarde, já no século XX, Jean Rosenthal (1912-1969) apostaria nas torres laterais, em projetos de luz para a dança, vistos com frequência na sua parceria com Martha Graham (1984-1991). Vale ressaltar a busca pela sistematização, em um desenho de 1948, e avaliar sua função no desenho técnico para a luz aplicada à cena, assim como em qualquer outra área do conhecimento. O desenho apresenta particularidades da área, mas continua sendo a representação técnica de um projeto. Para o(a) lighting designer é possível observar na representação das torres laterais o importante papel que desempenhavam nos espetáculos (Figura 129).

42 É importante lembrar que Richard Wagner colocou a orquestra sob o piso do palco. Não se viam mais os músicos, e, regendo sentado, o maestro só era visto quando ele ficava de pé ou, ocasionalmente, se podia ver-Ihe as mãos. É evidente que Strindberg comentava o atraso dos teatros da Suécia, que não acompanhavam essa tendência.
} 
fileira de assentos, para dar total visibilidade à cena, incluindo o piso do palco de dimensões reduzidas, como já foi dito. Ficava registrado, desse modo, o extremo compromisso entre o teatro que busca o natural como índice de verdade e a visualidade.

Strindberg propôs uma convenção muito particular para a luz do seu teatro, propondo a aplicação de fontes laterais, determinando um grau de realidade muito reduzido ou específico, mesmo que se possa encontrar justificativa para o ângulo de incidência nas arandelas. ${ }^{43}$ Parece, nesse caso, que ele não estava interessado em justificativas realistas, sendo a proposição técnica da distribuição lateral das fontes de luz determinada pelo resultado visual que, em sua opinião, favoreceria a expressão do rosto do ator.

O modo como essa visão sobre o teatro se efetivou na sua dramaturgia pode ser observado desde a rubrica de abertura:

A ação ocorre na noite de São João, o festival de meados do verão que sobrevive dos tempos pagãos. | [CENA - Uma grande cozinha. O teto e as paredes são parcialmente cobertos por cortinas e verdes. No lado esquerdo da cena, a parede do fundo se inclina para cima. Nessa parede do fundo, à esquerda, duas prateleiras cheias de panelas, chaleiras de cobre, caçarolas de ferro e panelas de estanho. As prateleiras são acabadas com um extravagante papel recortado. À direita [do meio] uma grande entrada em arco, com portas de vidro através do qual se vê uma fonte com uma estátua do Cupido, arbustos de lilás em flor e álamos altos. No canto esquerdo da cena, um grande fogão, com capa decorada em ramos de bétula. À direita, a mesa de jantar dos empregados, de pinho branco, e algumas cadeiras. Sobre a mesa há um pote japonês cheio de flores de álamo. O chão está repleto de ramos de zimbro.] | Próximo ao fogão, uma geladeira, uma pia e mesa de pratos. Um grande sino antigo pendurado acima da porta, à esquerda da porta de um tubo de comunicação. | [Kristin, de pé em posição de cegonha, cozinha. Ela usa um vestido leve de algodão e um avental. Chega Jean, usando uma farda e carregando uma bota de montaria com esporas, que põe no chão]. ${ }^{44}$ (STRINDBERG, 2009, p. 69, tradução nossa)

\footnotetext{
43 Luminárias fixadas lateralmente às paredes de uma edificação.

44 "The action takes place on Saint John's night, the mid-summer festival surviving from pagan times. [SCENE A large kitchen. The ceiling and walls are partially covered by draperies and greens. The back wall slants upward from left side of scene. On back wall, left, are two shelves filled with copper kettles, iron casseroles and tin pans. The shelves are trimmed with fancy scalloped paper. To right of middle a large arched entrance with glass doors through which one sees a fountain with a statue of Cupid, syringa bushes in bloom and tall poplars. To left corner
} 
A descrição particular do dispositivo cenográfico revela a importância dos detalhes na construção do ambiente, assim como o uso efetivo dos elementos que constituem a cenografia. A definição de tempo e lugar, incluindo estação do ano e hora, determinava o grau de conforto térmico e contribuía para a atitude corporal das personagens. Escrevendo em um momento no qual se consolidava o conceito da quarta-parede, Strindberg explicitou sua compreensão dos limites dessa convenção. Mesmo reconhecendo os obstáculos para que seja alcançado tamanho grau de naturalidade, ele confessou o desejo de ver um ator de costas para o público, durante a representação. Mas, preocupado com a composição visual do ambiente em si, ele questiona o resultado de uma abordagem superficialmente radical da teoria da quarta-parede que dispusesse móveis na frente do palco e de costas para o público. Ele parecia compreender que a instalação de convenções deve estar subordinada à comunicação visual com o espectador.

Além disso, a rubrica que se refere às influências do ambiente sobre o estado de Júlia, combinada com o trecho a seguir, extraído do prefácio, revela-se de grande valia para o estudo de um iluminador:

[...] a atmosfera da noite de São João, a ausência do pai, a sua própria condição física, o seu lidar com os animais, a excitação provocada pela dança, o fascínio do prolongado crepúsculo da noite de verão, a influência afrodisíaca das flores, [...]. (STRINDBERG, 1970, p. 4)

Numa montagem da peça esse pequeno trecho trará indicações inestimáveis para o tratamento visual da cena. Podem-se estabelecer relações provocadoras entre o ambiente - uma cozinha - e a atmosfera, um longo crepúsculo que antecede uma noite quente de verão numa região que apresenta baixíssimas temperaturas no inverno. Tais elementos podem representar valioso material de estudo, não apenas para essa peça, mas para a abordagem dos traços estético-filosóficos da dramaturgia.

Strindberg poderia ter escrito um artigo científico sobre a questão, poderia haver escrito artigos sobre a interação entre os aspectos sociais e os desejos de uma jovem abastada. Tendo escrito uma peça ele provoca a imaginação do seu público, discutindo limites que pareceriam intransponíveis na vida daquela jovem em particular, se a encontrássemos na "regularidade" do seu cotidiano, nos cômodos "nobres" da sua propriedade. E Strindberg foi incisivo:

of scene a large stove with hood decorated with birch branches. To right, servants' dining table of white pine and a few chairs. On the cud of table stands a Japanese jar filled with syringa blossoms. The floor is strewn with juniper branches]. 
Motivei o destino trágico da Senhorita Júlia com uma abundância de circunstâncias: os básicos 'maus' instintos da sua mãe; a educação imprópria recebida do pai; sua própria natureza e a influência que o noivo exerceu sobre sua mente fraca e degenerada; mas também, e mais imediatamente: a festiva atmosfera do Solstício de Verão; a ausência do pai; sua menstruação; sua ligação com os animais; o intoxicante efeito da dança; o crepúsculo de verão; a poderosa influência afrodisíaca das flores; e, finalmente, a oportunidade de tê-los num ambiente fechado, mais a ousadia do homem excitado. ${ }^{45}$ (STRINDBERG apud TÖRNQUIST; STEENE, 2007, p. 64, tradução nossa)

Ele reforçou sua estratégia, demonstrando a decisão de eleger momentos de grave crise na vida da personagem, prenhes dos densos conflitos que alimentam a ação dramática. As personagens são encontradas em um dos limites da casa, sob a influência de um longo crepúsculo, cujos tons laranjas, azuis aquecidos e violetas, pairam sobre o ambiente. Os ângulos de incidência sugerem texturas, formas e cores, definindo a qualidade visual. A atmosfera está impregnada pelo aroma contundente do lilás. A noite de São João é também conhecida como noite da fogueira, enormes fogueiras; a tradição mandava que fossem acesas ao anoitecer, sendo veneradas até o dia seguinte. A disposição em círculo evidenciava traços ritualísticos; as cinzas abençoariam as plantações e todos os seres vivos. Inimigos seriam sacrificados ao fogo e demônios exorcizados.

Disso resultam importantes indagações para o iluminador, capazes de originar provocações para um artista atento. De tais indagações derivam problemas instigantes para o tratamento da cena: por que o autor definiu aquele lugar e aquela hora para a ação da sua peça? Um dramaturgo cuidadoso já revela nessas definições ou escolhas sua compreensão da natureza humana, das relações entre as personagens, deixando sua opinião sobre tais relações. Um iluminador pode revelar seu ponto de vista sobre essas questões no tratamento que propõe para cada montagem. O fogo pode ser eleito como o deflagrador visual de um acontecimento espetacular, um estimulador dos desejos e/ou dilacerador de corpos.

\footnotetext{
45 "I have motivated Miss Julie's tragic fate with an abundance of circumstances: her mother's "bad" basic instincts; her father's improper raising of the girl; her own nature and the influence her fiancé's suggestions had on her weak, degenerate brain; but also, and more immediately: the festive atmosphere of Midsummer Eve; her father's absence; her period; her preoccupation with animals; the intoxicating effect of the dance; the summer twilight; the powerful aphrodisiac influence of the flowers; and finally chance that drives the two together in a secluded room, plus the boldness of the aroused man."
} 
Vale lembrar que mais adiante em sua carreira, Strindberg descaracterizaria a busca particular do naturalismo investindo em instâncias mais voltadas para o que ele encarava como forças interiores da natureza humana, responsáveis pela revelação de uma realidade mais ampla e profunda. Pondere-se que as iniciativas "não realistas" na práxis cênica já estavam sendo encaminhadas por vários artistas, abrindo caminhos para os questionamentos que serão ampliados no século XX. É possível observar que cada modo particular de construir a cena vem incorporando compromissos com a visualidade e, portanto, com a luz. Resta investigar se o pensamento teatral que se estabelece no século XX apresentou o desejo de desconsiderar ou questionar tais compromissos. Para tanto, serão abordadas a seguir iniciativas aqui denominadas "não realistas", abrigando nessa expressão a diversidade de manifestações que pretendem combater a modernidade. Aliás, por vezes, os autores dessas iniciativas parecem demasiadamente atrelados à modernidade ou até, ao realismo, já na própria nomenclatura.

Ainda está por aparecer uma manifestação que efetivamente destrua os compromissos com a arte teatral que ainda resistiu em Strindberg, Ibsen, Tchekhov, Stanislavski, Jorge Andrade, Eugenio Kusnet, entre muitos outros, e apresente uma conceituação que exclua totalmente os elos com a práxis cênica derivada do projeto da Antiguidade grega, denominada teatro por razões já apresentadas aqui, profundamente imersa nas relações visuais com o público. Espera-se ainda testemunhar uma práxis que assuma a postura do radicalmente novo e desconsidere quaisquer referências às convenções teatrais, banindo a percepção visual. Afinal, os gregos investiram numa manifestação de convenções muito particulares que gerou o conceito moderno de "teatro". 


\section{A LUZ E A CENA \\ NÃO REALISTA}

A expressão "não realista" (que pode ser relacionada ao teatro "não mais dramático", mencionado abaixo) é aqui aplicada com o intuito de ampliar o espectro das escolhas para este último capítulo cujo princípio orientador está nas referências à visualidade, presentes em manifestações cênicas que começaram a aparecer no final do século XIX, continuaram no século XX, e se mantêm ativas até hoje. Os artistas e/ou teóricos aqui mencionados ocupam tal espaço devido às suas relações com a natureza visual do acontecimento espetacular. Durante os estudos que antecederam essas escolhas foi significativa a provocação de determinados autores, pensadores e/ou artistas, listados a seguir: Hans-Thies Lehmann, O teatro pós-dramático (Postdramatisches theater); Sarah Kane (1971-1999), 4:48 Psicose (4.48 - psychosis); Berthold Brecht (1898-1956), o poema A iluminação (Die beleuchtung); Louie Fuller (1862-1928); Samuel Beckett (1906-1989), a peça Comédia (Play); e Adolphe Appia, A música e $a$ arte do teatro (Music and the art of the theatre). 


\section{HANS-THIES LEHMANN E A REQUALIFICAÇÃO DA PALAVRA NO TEATRO}

Desde sua publicação original em 1999, O Teatro pós-dramático de Lehmann causou muita discussão no nível internacional, sendo traduzido para vários idiomas, desde francês e japonês, em 2002, seguindo-se esloveno (2003), persa (2005), repercutindo ruidosamente na universidade e na práxis cênica brasileira desde sua publicação em português, em 2007. Parecia haver surgido um manifesto, um documento definitivo de apoio - ou uma oportuna poética de programação e provocação, incorporada rapidamente por artistas e teóricos.

O reconhecimento da desconstrução da personagem dramática havia se tornado realidade. Abrindo a tradução inglesa, Karen Jürs-Munby (2006, p. 1, tradução nossa) resume a questão:

O estudo de Hans-Thies Lehmann obviamente respondeu à vital necessidade de uma acessível e compreensível teoria articuladora das relações entre as formas de teatro 'não mais dramáticas' que emergiram desde os anos de 1970. ${ }^{1}$

Essa tradução, que mereceu elogios do próprio autor, foi usada no trabalho em curso. A primeira observação de Lehmann que desperta a atenção aparece logo no prefácio dessa edição anglo-americana. Ressaltando que seu interesse não está no texto e, sim, nos meios da realização teatral, ele mencionou a tensão entre o teatro dramático e o que ele denominava novo teatro, ou pós-dramático, citando a obra 4.48 psychosis, da autora inglesa Sarah Kane, cuja estreia se deu em 23 de junho de 2000, pouco mais de um ano depois de sua morte, em fevereiro de 1999. A declarada intenção de Lehmann privilegia na sua teoria a atenção ao acontecimento cênico em detrimento do texto que o antecede, e, por outro lado, reconhece a importância de Sarah Kane como autora que, de acordo com seu próprio juízo, produziu um dos mais importantes textos relacionados ao teatro pós-dramático. Suas observações geraram um consistente material para o presente trabalho, uma vez que permitiram uma espécie de elo entre teoria, dramaturgia e práxis cênica.

As inquietações sobre o papel do texto na cena pós-dramática e a desconstrução da palavra falada como um dos elementos da ação (de uma personagem) fortalecem a necessidade de algo que, na cena, seja visto (do já repetido verbo grego théa). Isso aponta para uma interpretação radical dos gregos antigos no que se refere à acentuação da natureza visual do teatro, já na sua própria denominação,

\footnotetext{
1 “Hans-Thies Lehmann's study has obviously answered a vital need for a comprehensive and accessible theory articulating the relationship between drama and the 'no longer dramatic' forms of theatre that have emerged since the 1970s."
} 
como já se repetiu exaustivamente. A mais notável abordagem do teatro grego, que apareceria no trabalho de Aristóteles, repercutiu de tal modo entre os estudiosos ao longo da modernidade, a ponto de tornar a tragédia grega academicamente conhecida como "aristotélica". No entanto, a fala poética incluída na manifestação denominada "teatro" pelos gregos, a importância das palavras ouvidas na tragédia "greco-aristotélica", nos diálogos construídos sob o prisma de conflitos originados em desejos profundos das personagens - tema determinante na compreensão de Aristóteles para a tragédia - finalmente havia desaparecido sob o teatro pós-dramático.

De todo modo, o grau de heterogeneidade no espectro do pensamento pós-dramático e das manifestações por ele validadas leva a uma derivação estética, comentada na tradução norte-americana: “[...] a noção de teatro pós-dramático e sua valorização da dimensão da performance, não implica que textos escritos para o teatro deixem de ser relevantes ou não possam ser considerados nesse contexto".' (JÜRS-MUNBY, 2006, p. 6, grifo e traducão nossos) Tal assertiva pode parecer mero atrelamento a uma tradição condenada pelas "vanguardas" do século XX; no entanto, ela pode também incluir certa sagacidade estratégica da estética em questão. Afinal, a práxis cênica questionou, modificou e subverteu o texto dramático ao longo da história sem, no entanto, desconsiderar seu papel decisivo em importantes momentos do teatro.

Por outro lado, o anseio pelo questionamento do modelo "aristotélico" dá lugar a iniciativas como aquela mencionada por Tim Etchells, diretor da companhia britânica Entretenimento forçado (Forced entertainment): "A peça trata da ação física e da construção do cenário como modos de escrita, [a peça] fala das palavras escritas que serão vistas e lidas no palco, ao contrário de serem faladas [...]".3 (ETCHELLS apud JÜRS-MUNBY, 2006, p. 9) A resposta a tal anseio, o desejo de desconstruir o diálogo originado na iniciativa grega, incorpora profundamente, então, a visibilidade, no diversificado modelo pós-dramático que assume uma espécie de interpretação radical da ideia grega de cena. Quero dizer, desconsiderando o diálogo falado, resta no pós-dramático - como legado do teatro concebido pelo pensamento grego - o que está latente no substantivo nomeador do próprio teatro, ou seja, a acentuação da cena como algo que se vê. As considerações preliminares da tradução, das quais aspectos chave serão mencionados a seguir, representam excelente esforço para introduzir o leitor no novo teatro vislumbrado por Lehmann.

2 "the notion of postdramatic theatre and its valorization of the performance dimension does not imply that texts written for the theatre are no longer relevant or cannot be considered in this context."

3 "The piece talks about physical action and set construction as forms of writing, it talks about writing words to be seen and read on-stage rather than spoken, [...]." 
No teatro pós-dramático o texto devia apresentar uma "teatralidade" latente, que o afastasse da representação dramática de um cosmos ficcional fechado e da mimética de uma fábula. Separado do drama na segunda metade do século XX o novo teatro trouxe a imposição da materialidade da cena e a destruição da hegemonia do texto (dramático). A linguagem buscada pelo que Lehmann denominou novo teatro e também teatro pós-dramático exigia nova postura que incorporasse diversificados instrumentos, acessórios e controle, com o objetivo de promover excelência visual. Portanto, mesmo no enfrentamento entre o novo teatro e o drama, restava ainda um traço que os unia, o binômio visualidade-visibilidade.

O texto deveria ser transformado em mais um elemento da scenography (grafia da cena/escrita cênica/escritura cênica), mostrado por vezes em imagens reproduzidas através de diversificados media de áudio e vídeo. O espectador era chamado a atuar como cocriador do texto (espetáculo), o que implica numa transtextualidade, num processo de reciclar, reusar e refazer, livre de normas, analogamente ligado por Jürs-Munby, ao palimpsesto. ${ }^{4}$ É importante ressaltar o ataque à noção aristotélica de equilíbrio e totalidade do drama que apresenta extensão e duração apropriadas para sua apreensão lógica, administrável, como espelho de um mundo passível de ser apreendido integralmente.

Comentadores do teatro pós-dramático consideram que ele se relacionava com a descrença no controle, fundamentando-se no que caracterizava como seu escorregadio cotidiano contemporâneo revolvido por entranhas tecnológicas. Segundo Jürs-Munby (2006, p. 12), o mundo deixara de ser a totalidade ficcional enclausurada pela quarta-parede como acreditavam Antoine e Strindberg. O performer não representava uma personagem, ele estava lá. Não se tratava de ficção; uma ação acontecia, naquele instante e lugar definidos para a performance, como numa celebração. Talvez seja possível dizer que o desejo da ação pós-dramática era ser a ação verdadeira, viva, presente, ou "real" (?!). Outro "naturalismo" ou o naturalismo elevado a uma instância radical. Tivesse vivido nos tempos pós-dramáticos Zola aplaudiria: tratava-se de incorporar pressupostos artísticos à investigação do ser humano. Arte e ciência compartilhando espaço e tempo, sugerindo um ritual.

Ao traçar um panorama de sua abordagem da cena na segunda metade do século $\mathrm{XX}$, na qual ele encontrou o pós-dramático, o próprio Lehmann voltou à noção de totalidade. É importante dizer que, compreendida como totalidade teatral e não prioritariamente dramática, caracterizando a cena como uma espécie de "texto total". Isso, ainda segundo ele, reduz o valor do texto dramático, levando-o a assumir o papel de mais um aspecto da cena, em companhia dos aspectos visuais e sonoros;

4 Papiro ou pergaminho, cujo texto primitivo foi raspado, para dar lugar a outro. (HOUAISS, 2009) 
quiçá tácteis e olfativos. Eliminando-se a célebre hegemonia (do drama) abriu-se espaço para uma parceria que exigia flexibilidade do texto, uma vez que ele deixava de representar a fala de personagens - se é que ainda se poderia encontrá-las - assumindo uma "teatralidade" autônoma.

Essa nova função da palavra destruía as figuras (personagens) de pretensa profundidade que, no antigo teatro "dramático", falavam. Mergulhado no universo da visão, Lehmann (2006, p. 18, tradução nossa) fez uma declaração prenhe de pistas dos profundos compromissos do seu novo teatro: “[...] ao invés da ilusão de um espaço tridimensional, 'leva-se ao palco' uma imagem sem planos, sua realidade bidimensional e a realidade da cor como uma qualidade autônoma [...]". ${ }^{5}$ Ao confrontar a ilusão de tridimensionalidade com essa nova cena bidimensional, ele indica relações entre cena e pintura, mergulhando na visualidade.

Via-se uma manifestação que incorporava a multiplicidade de camadas produzidas por um conjunto de artistas, incluindo a tecnologia dos media (eletro-eletrônico-digitais), mas, que mantinha um momento e lugar de encontro no qual a vida "real" tocava a vida poética e esteticamente organizada. Então, para Lehmann, o que ele descrevia como teatro pós-dramático era um novo tipo "multiformal" de discurso teatral, provocado pela divulgação e pela onipresença dos media no cotidiano. Sendo, também, meditação autorreflexiva que incorporava ritmo, tom e silêncio - acentuando sua qualidade musical - o teatro efetivava gestualidade e formas grotescas, por vezes, em espaços “vazios”. Encontrar-se-ia, portanto, nessas considerações, uma profunda radicalização da práxis cênica pós-dramática como assertiva visual.

Em abordagens de questões mais especificamente ligadas ao tratamento do espaço, Lehmann deixou para o leitor ou estudioso do seu (novo) teatro uma vigorosa articulação visual. Uma das suas mais importantes indicações encontra-se no prólogo, quando ele diz:

Ainda que possamos discutir o grau, e de que maneira as plateias dos séculos que nos antecederam foram sensibilizadas pelas 'ilusões' criadas pelos truques de palco, pela luz ardilosa, fundo musical, figurinos e cenários, pode-se afirmar que o teatro dramático era a ordem da ilusão. ${ }^{6}$ (LEHMANN, 2006, p. 22, tradução nossa)

5 "instead of the illusion of three-dimensional space, what is being 'staged' is the picture's plane-ness, its two-dimensional reality, and the reality of colour as an autonomous quality."

6 "Although it remains debatable to what degree and in what way the audiences of former centuries were taken in by the 'illusions' offered by stage tricks, artful lighting, musical background, costumes and set, it can be stated that dramatic theatre was the formation of illusion." 
Seguindo o raciocínio que constrói essa afirmação é possível sublinhar a decisiva função da imagem visual na ilusão à qual ele se refere, uma vez que o teatro precisava - e dependia - da luz para mostrar todo o aparato criado no palco e, desse modo, "iludir" visualmente o espectador. O que não mudou, completamente, até hoje. E mais que isso, a luz fica cada vez mais ardilosa através da incorporação de tecnologias podendo até incorporar outras possíveis traduções do termo artful (que aparece na tradução de Jürs-Munby mencionada neste livro) e revelar-se "esperta", "astuciosa" e, quem sabe até, com mais uma possibilidade radical de tradução: um truque velhaco. Portanto, quando se levam em conta os compromissos visuais que o teatro pós-dramático assumiu toda a cautela será bem-vinda ao trabalho do iluminador que ainda hoje se interesse pelas propostas de Lehmann. Sem cautela o iluminador acabará repetindo as trapaças que ele parecia condenar.

Mesmo os compromissos mais primitivos com a luz estão registrados na linguagem usada por Lehman (2006, p. 26, tradução nossa) no seu texto:

Em relação aos novos textos teatrais, os estudiosos têm falado sobre 'textos teatrais não mais dramáticos', como já mencionei, mas, o que ainda está por se fazer é uma tentativa de investigar o novo teatro e a diversidade dos seus meios teatrais mais detalhadamente sob a luz da estética pós-dramática. ${ }^{7}$

Como se pode ver no exemplo acima, ele aplica o termo "luz" para se referir ao ideário do teatro pós-dramático. Além disso, Lehmann comprova e estreita sua confiança na contribuição da luz, em momentos particulares, ainda que, ao discutir a Poética de Aristóteles, ele faça uma importante ressalva:

[...] Aristóteles volta-se para o filosófico, na tragédia. Ele vê a mimesis como uma espécie de 'mathesis', um aprendizado que se torna mais agradável através da alegria do reconhecimento dos objetos da mimesis - um prazer necessário apenas para as massas, não realmente para o filósofo [...]. ${ }^{8}$

Como o público não é composto exclusivamente por filósofos, o teatro decidiu incorporar a importância da imagem (o reconhecimento dos objetos), tornando-a indispensável em sua constituição. Citando o próprio Aristóteles, Lehmann

\footnotetext{
7 'With respect to newer theatre texts, scholars have talked about 'no longe dramatic theatre texts', as already mentioned, but what is still missing is an attempt to survey the new theatre and the diversity of its theatrical means in more detail in the light of postdramatic aesthetics."

8 '[...] Aristotle is concerned with the philosophical in tragedy. He regards mimesis as a kind of 'mathesis', a learning that becomes more pleasurable through the enjoyment of recognizing the object of mimesis - a pleasure only needed by the masses, not actually by the philosopher."
} 
(2006) apresenta o que pode ser considerado um importante argumento para a definição de critérios de aplicação da luz à práxis cênica:

Compreender é extremamente agradável, não apenas para filósofos, mas, do mesmo modo, também para outros, apesar da sua capacidade limitada para isso. Essa é a razão porque as pessoas têm prazer em ver imagens; o que acontece é que, vendo as imagens elas passam a entender e descobrem o que cada coisa é [...]. ${ }^{9}$ (ARISTÓTELES apud LEHMANN, 2006, p. 40, tradução nossa)

Ao fim e ao cabo, Aristóteles parecia ter razão. Se não é possível avaliar precisamente a relação dos homens daquele seu tempo com a imagem, hoje, ao menos, testemunha-se o papel dessa mesma imagem na construção da cultura, registrado pelo próprio Lehmann (2006) ao longo do seu livro. No discurso em torno das primeiras manifestações históricas das vanguardas modernas, ele cita Michael Kirby, descrevendo, sucintamente, o teatro dos simbolistas:

A estética simbolista demonstra um voltar-se para dentro, longe do mundo burguês e dos seus padrões, para um mundo mais privado, pessoal, e extraordinário. O espetáculo simbolista ocorria em pequenos teatros. Era deslocado, distante e estático, envolvendo reduzida energia física. A iluminação era frequentemente de reduzida intensidade. Os atores trabalharam, muitas vezes, por trás de telas... A arte era autossuficiente, isolada, completa em si mesma. Podemos chamar este o modelo 'hermético' de espetáculo da vanguarda. ${ }^{10}$ (KIRBY apud LEHMANN, 2006, p. 57, tradução nossa)

Uma imaginação treinada e familiarizada com as iconografias teatrais do século XIX vislumbraria a qualidade visual inscrita, ou, desejada pelo teatro pós-dramático, e registraria ainda que o uso da tela e da penumbra não seriam, necessariamente, novidades simbolistas. Desde suas primeiras incursões, portanto, as chamadas vanguardas que eclodiram no século XIX tratavam a luz como um aspecto integrado e de contribuição indispensável. Apresentando marcas radicais

9 "[U]nderstanding is extremely pleasant, not just for philosophers but for others too in the same way, despite their limited capacity for it. This is the reason why people take delight in seeing images; what happens is that as they view them they come to understand and work out what each thing is."

10 "Symbolist aesthetics demonstrate a turning inward, away from the bourgeois world and its standards, to a more personal private, and extraordinary world. Symbolist performance was done in small theatres. It was detached, distant, and static, involving little physical energy. The lighting was often dim. The actors often worked behind scrims... The art was self-contained, isolated, complete in itself. We can call this the 'hermetic' model of avant-garde performance." 
daquilo que Lehmann compreende como pré-história das vanguardas, o simbolismo trazia em sua proposição estética, aprofundamentos de compromissos particulares com a visualidade:

Com isso, a dissolução da tradicional amálgama de texto e palco tornou-se possível, além da possibilidade de uma nova maneira de reconectá-los. Olhando o texto teatral com uma dimensão poética independente e, simultaneamente, considerando a 'poesia' do palco, desacoplada do texto, como uma poesia atmosférica de espaço e luz, uma nova disposição teatral se tornou possível. ${ }^{11}$ (LEHMANN, 2006, p. 59, tradução nossa)

Num certo sentido, ao assinalar a contribuição da luz para as novas realidades cênicas dessa "poesia atmosférica de espaço e luz", Lehmann questionou a crítica que relacionava a atmosfera à luz realista. O pós-dramático afirmava-se pela elaboração independente da poética do espaço teatral exigindo contribuições estéticas muito particulares da imagem visual.

Vale comentar aqui o simbolismo de Maurice Maëterlinck (1862-1949), assim como seu "teatro estático" (drame statique) que apontam numa direção muito relevante para o presente estudo, indicando o tratamento da práxis cênica como corporificação da imagem. Aquela imagem que se projeta numa instância diversa do contexto dos media eletro-eletrônico-digitais da atualidade aproximando-se das imagens primevas, presentes na ancestralidade espetacular que antecede o teatro.

Pode-se dizer que Maëterlinck foi um autor atípico, incomum, tendo recebido o Prêmio Nobel de Literatura, em 1911, cuja justificativa oficial declara:

[...] como reconhecimento das suas multifacetadas atividades literárias, e especialmente de suas obras dramáticas, que se distinguem por uma riqueza de imaginação e por uma fantasia poética que revelam, por vezes, sob a aparência de um conto de fadas, uma inspiração profunda, e de uma maneira misteriosa elas apelam para os próprios sentimentos dos leitores e estimulam sua imaginação. ${ }^{12}$ (THE NOBEL..., 2012)

\footnotetext{
11 "With that, the dissolution of the traditional amalgamation of text and stage has become thinkable, but also the possibility of their reconnection in a new way. By regarding the theatre text as an independent poetic dimension and simultaneously considering the 'poetry' of the stage uncoupled from the text as an independent atmospheric poetry of space and light, a new theatrical disposition becomes possible."

12 "[...] in appreciation of his many-sided literary activities, and especially of his dramatic works, which are distinguished by a wealth of imagination and by a poetic fancy, which reveals, sometimes in the guise of a fairy tale, a deep inspiration, while in a mysterious way they appeal to the readers' own feelings and stimulate their imaginations."
} 
O tratamento da cena oferecido por Maëterlinck impressionou Peter Szondi (1983) que o considerou responsável por um novo rumo do drama. Szondi menciona a rubrica de abertura de Os cegos [Les aveugles, (1890)] na qual o dramaturgo "pinta" aquela que pode ser considerada a imagem "zero" da obra, uma espécie de suspensão imagética onde se introduz a visualidade inscrita numa peça. A extensão da imagem criada por Maëterlinck, da qual Szondi menciona fragmentos, está repleta de provocações que se referem à luz:

Uma floresta do norte, muito antiga, de aparência eterna, sob um céu brilhantemente estrelado. No centro, e diante do mais profundo da noite está sentado um padre muito velho, envolto em um grande manto preto. Seu dorso e cabeça, ligeiramente voltados para cima e mortalmente imóveis apoiam-se sobre o tronco de um enorme e cavernoso carvalho. O rosto é de uma lividez imutável de cera, onde se entreabrem lábios roxos. Olhos mudos e fixos não olham mais o lado visível da eternidade e parecem ensanguentados sob um grande volume de dores antigas e lágrimas. Os cabelos, de uma grave brancura, caem em duras e raras mechas no rosto mais iluminado e mais cansado do que qualquer coisa em torno dele, no silêncio atento da mesma floresta. As mãos finas estão rigidamente ligadas às coxas. À direita, seis velhos cegos estão sentados em pedras, cepas e folhas mortas. À esquerda, e separadas destes por uma árvore arrancada e pedaços de rocha, seis mulheres, também cegas, estão sentadas em frente aos velhos. Três delas oram e se lamentam, numa voz surda e interrupta. Outra é muito ve1ha. A quinta, numa atitude de demência muda, tem, sobre os joelhos, uma criança adormecida. A sexta é uma jovem luminosa, cujos cabelos inundam todo o seu ser. Elas, assim como os velhos, usam vestes amplas, escuras e uniformes. A maioria espera, cotovelos sobre os joelhos, rosto entre as mãos; e todos parecem ter perdido o hábito do gesto inútil e não dirigem mais a cabeça para os rumores abafados da ilha. Grandes árvores sepulcrais, teixos, salgueiros, ciprestes, os cobrem com suas sombras fiéis. Um tufo de longos asfódelos doentes floresce perto do sacerdote, na noite. Há uma escuridão profunda, apesar do brilho da lua, que aqui e ali, tenta afastar, por um momento, as trevas, das folhagens. ${ }^{13}$ (MAËTERLINCK, 1892, p. 75-76, tradução nossa)

13 "Une très ancienne forêt septentrionale, d’aspect étemel sous un ciel profondément étoile. Au milieu, et vers le fond de la nuit, est assis un très vieux prêtre enveloppé d'un large manteau noir. Le buste et la tête, 
No seu artigo, que trata de correspondências entre Maëterlinck e Samuel Beckett (1906-1989), Ewald Hackler (1983) acentua a qualidade dramatúrgica particular da qual está impregnada a peça Os cegos. Segundo Hackler (1983, p. 25), não há um "enredo" na peça: "[...] o guia de um bando de cegos, um padre, morrera numa excursão pela floresta; os cegos encontram-se sentados em volta do padre morto e aguardam sua volta" Hackler (1983) estabelece uma primeira comparação entre Maëterlinck e Beckett apontando similaridade entre Esperando Godot (Waiting for Godot, 1948/1949) e Os cegos: “[...] a categoria de ação, no drama, é substituída pela categoria de situação, a descrição da condição". (HACKLER, 1983, p. 25) E complementa a observação: "O drama como tradicional espaço da ação perdeu sua função original. Les aveugles não é mais drama, no sentido grego de dran (se é verdade que o verbo grego para ação é realmente a origem do substantivo)". (HACKLER, 1983, p. 25)

Szondi, por sua vez, comenta de falas que se deslocam paralelamente ou até em direção oposta em um "diálogo" que descaracteriza a reconhecida natureza do drama, como se pode ler no trecho abaixo:

$$
\begin{aligned}
& \text { Terceiro Cego - Está na hora de voltar ao asilo. } \\
& \text { Primeiro Cego - Precisamos saber onde estamos. } \\
& \text { Segundo Cego - Esfriou desde sua partida. }{ }^{14} \\
& \text { (MAËTERLINCK, 1892, p. 77) }
\end{aligned}
$$

Maëterlinck (1892) elaborou no seu texto compromissos entre uma imagem precisa e um diálogo fragmentado, entrecortado pelos sons da ilha. Há uma espécie de presença-ausência corporificada na imobilidade, pois o único que poderia ver e guiar o grupo é agora um cadáver. E mesmo os cegos que estão juntos há

\footnotetext{
légèrement renversés et mortellement immobiles, s'appuient contre le tronc d'un chêne énorme et caverneux. La face est d'une immuable lividité de cire où s'entr'ouvrent les lèvres violettes. Les yeux muets et fixes ne regardent plus du côté visible de l'éternité et semblent ensanglantés sous un grand nombre de douleurs immémoriales et de larmes. Les cheveux, d'une blancheur très grave, retombent en mèches roides et rares, sur le visage plus éclairé et plus las que tout ce qui l'entoure dans le silence attentif de la môme forêt. Les mains amaigries sont rigidement jointes sur les cuisses. - A droite, six vieillards aveugles sont assis sur des pierres, des souches et des feuilles mortes. À gauche, et séparées d'eux par un arbre déraciné et des quartiers de roc, six femmes, également aveugles, sont assises en face des vieillards. Trois d'entre elles prient et se lamentent d'une voix sourde et sans interruption. Une autre est très vieille. La cinquième, en une attitude de muette démence, porte, sur les genoux, un petit enfant endormi. La sixième est d'une jeu-nesse éclatante et sa chevelure inonde tout son être. Elles ont, ainsi que les vieillards, d'amples vêtements, sombres et uniformes. La plupart attendent, les coudes sur les genoux et le visage entre les mains; et tous semblent avoir perdu l'habitude du geste inutile et ne détournent plus la tête aux rumeurs étouffées et inquiètes de l'île. De grands arbres funéraires, des ifs, des saules pleureurs, des cyprès, les couvrent de leurs ombres fidèles. Une touffe de longs asphodèles maladifs fleurit, non loin du prêtre, dans la nuit. Il fait extraordinairement sombre, malgré le clair de lune qui, ça et là, s'efforce d'écarter un moment les ténèbres des feuillages."

14 "Troisième Aveugle-né. II serait temps de rentrer à l'hospice. | Premier Aveugle-né. II faudrait savoir oú nous sommes!| Deuxièmes Aveugle-né. | II fait froit depuis son depart."
} 
anos, não se conhecem. Resta esperar por alguém que permanecerá ausente, pois apesar de estar bem próximo e no centro da situação, encontra-se mergulhado no silêncio e na imobilidade da morte.

O lamento expresso na oração das três mulheres cegas estabelece a atmosfera sonora que se mostrará elemento essencial da situação, instalada na escuridão de uma floresta de árvores sepulcrais, situada em uma ilha. O corpo de um velho morto, no entanto, expressa a força visual da imobilidade que avança para a intriga "invisível" do diálogo. As posturas podem ser observadas como racionamento de movimento e a profundidade do som "mudo" e "surdo" é ampliada na morte, que se projeta dos lábios roxos de um rosto inerte, numa espécie de ritual ou cerimônia.

Szondi (1983, p. 221) afirma: "Tudo isso, finalmente, diz que as personagens estão longe de serem agentes causais ou sujeitos de uma ação. Eles são, simplesmente, objetos de uma ação". ${ }^{5}$

A categorização de "teatro estático" começa a ser justificada e a situação criada por Maëterlinck não parece conter ou encaminhar uma ação dramática. Segundo Hackler (1983, p. 25), como em outras obras da fase inicial da sua dramaturgia, Maëterlinck (1892) concebe uma peça cujo caráter musical parece sobreposto ao propósito visual. Trata-se de uma espécie de paradoxo, quando se concebe o teatro como arte do ver. Na sua primeira tentativa de romper o limite imposto pela ausência de visão, o Primeiro Cego não faz mais do que levantar e tatear. E logo depois, quando tenta dar um passo, ele tropeça, cai e diz: "Há alguma coisa entre nós [...]". ${ }^{16}$ (MAËTERLINCK, 1892, p. 78, tradução nossa)

Entre ele e seu "interlocutor" solidifica-se uma imensurável barreira, construída pela cegueira que limita a extensão do mundo ao limite do gesto, no corpo imóvel. A peça inscreve-se visualmente através de acontecimentos nos quais a incapacidade de ver define o extremo da situação.

Hackler cita também a análise de Max Dvořák ${ }^{17}$ (1874-1921) da pintura A queda do cego (Der blindensturz, 1568), de Pieter Breughel, o Velho (1525-1569):

[...] A natureza é indiferente... Em algum lugar alguns pobres cegos foram vítimas de um acidente... Ninguém vai dar atenção... Mas o que podia parecer um acaso, um acontecimento único, temporal e espacialmente limitado, incorpora o desti-

\footnotetext{
15 "All this finally says that the dramatis personae are far from being causal agents or subjects of an action. They are, quite simply, objects of an action."

16 "Il y a quelque chose entre nous [...]"

17 Historiador austríaco, nascido tcheco, um dos nomes mais importantes da Escola de Viena, da História da Arte.
} 
no do qual ninguém consegue escapar e ao qual a humanidade inteira é cegamente submissa [Figura 110]. (DVOŘÁK apud HACKLER, 1983, p. 29)

Brueghel inspirou-se na parábola da contaminação escrita pelo evangelista Mateus (15,1-20), na qual ele reprova a atitude de cegos que, sendo guiados por outros cegos correm o risco de cair no abismo. Na versão apresentada pela pintura de Brueghel, o Primeiro Cego que estava guiando seus companheiros de jornada acabou de cair e, inevitavelmente, levará consigo os demais. A paisagem inclui uma igreja, ao fundo: nem mesmo a proximidade com Deus impedirá a queda do ser humano que não enxerga seu próprio caminho e se deixa levar por "guias".

Maëterlinck, por seu turno, enclausura os cegos no isolamento de uma ilha de cegueira e faz entrar em cena um cão que, podendo enxergar, escolhe seu lugar no mundo. O ser humano, no entanto, está preso à impotência e à ignorância.

Hackler (1983) sugere correspondências entre o teatro simbolista e o teatro do absurdo ou, melhor, entre Maëterlinck e Beckett, sublinhando o que denomina o "princípio artístico da contração", caracterizado pela exclusão de tudo aquilo que não é essencial à situação. Ele acentua ainda a passividade e destaca a "dialética estratégica" de Maëterlinck, que pinta a humanidade mergulhada no isolamento mortal de um infinito vácuo, cujo destino é a morte.

Como define Hackler (1983), trata-se de um retrato pavoroso e exato daquilo que se tornou o ser humano moderno, como se vê em Esperando Godot, onde não se reconhece uma pessoa e, se há dois nomes como Estragron e Vladimir, também está presente a variação tragicômica de Pozzo em Bozzo. A humanidade, por conseguinte, é a expressão do isolamento, da passividade e da ignorância, a caminho da morte.

Cada um pode "iluminar" a situação do modo que lhe aprouver. No entanto, investigando a dramaturgia como problematização visual, cabe uma pergunta: que luz constrói a imagem elaborada por Maëterlinck?

Por um lado, vale "inventar a própria luz" desprezando tal indagação, aceitando o risco de elaborar algo que já se encontra na dramaturgia, "inventando" o que já existe. Por outro, mesmo que o iluminador analise cuidadosamente a imagem criada por Maëterlinck, no momento da elaboração da cena, cada artista deveria ser capaz de incluir sua própria "marca" - ou kharakter (caráter), como já foi dito no capítulo A propósito da visualidade na cena, do presente trabalho - estabelecendo sua convicção visual. Essa marca será efetivada caso o iluminador, ao menos, leve em consideração uma variável relevante: ainda que se trate de uma situação extrema que ocorre no mais profundo da noite, numa floresta, na qual 
estão envolvidos cegos dependentes de um cadáver para continuarem vivos, há alguém que está presente porque deseja e precisa ver os acontecimentos: o espectador. A práxis cênica inscreve-se pela contundência visual de uma situação na qual, sendo o único que pode ver, o espectador ganha enorme poder. E tal poder só será efetivado através da luz, da imagem.

\section{SAMUEL BECKETT OU A ANGÚSTIA DO AUTOR DIANTE DA CENA}

A obra teatral de Samuel Beckett (1906-1989) poderia ter aparecido desde o primeiro capítulo do presente trabalho dada sua relevância para a história do teatro, da dramaturgia e, principalmente, para a abordagem da imagem visual teatral aqui desenvolvida. Beckett ganha espaço particular através do seu enfrentamento da angústia de um dramaturgo que vê na cena o destino da sua obra.

A observação da sua dramaturgia foi aqui incluída para acentuar que mesmo diante de uma obra com tamanha dimensão, quando se discute a realização teatral as funções da imagem visual são imediatamente sublinhadas. Afinal, ainda que o autor tenha inserido significativas indicações de luz em suas peças, sem um projeto (lighting design) apropriado, suas ideias não se efetivarão na cena. Serão comentados aqui aspectos muito específicos da sua obra, contemplando discussões particulares da investigação em curso.

Beckett fez mais que escrever peças. Ele deixou "partituras" cênicas e dirigiu espetáculos nos quais foram aplicados seus próprios textos. O termo partitura refere-se tanto à codificação presente na sua dramaturgia quanto ao controle que ele procurou exercer sobre o teatro do qual o texto dramático é um estágio da mencionada condição pré-cênica. De modo abrangente, o termo partitura é assim definido: "[...] notações impressas ou manuscritas, que mostram a totalidade das partes de uma composição [...]". (PARTITURA, 2009) Configura-se, então, uma maneira de escrever com o olhar voltado para o palco, na qual o dramaturgo busca incorporar a totalidade das funções de diretor, de cenógrafo e de iluminador, apresentando grande tendência musical.

As partituras escritas por Beckett incluem didascálias que definem o espetáculo e não podem ser lidas como adendos ao texto. O artista que as descarta estará efetivamente elaborando outra obra. A abordagem de tal assertiva evita acentuar a contenda entre o texto e a liberdade de cada diretor, interessando-se pela natureza da mudança que se processa quando se ignoram as didascálias de uma peça como Play, que será comentada adiante. Importa considerar que ignorar tais circunstân- 
cias com o intuito de propor um acontecimento espetacular autônomo não invalida a dramaturgia de Beckett em si, como um passo consciente em direção à cena.

A inclusão da obra de Beckett neste trabalho está justificada, também, quando se leva em conta que ele dirigiu espetáculos baseados nos seus próprios textos, estreitando os elos entre a dramaturgia e a cena. Reiterando o reconhecimento da imagem visual como aspecto intrínseco da atividade teatral desde as primeiras articulações de ideias da cena, ele contribui para a argumentação do presente trabalho. Beckett tem lugar aqui, afinal, devido ao rigor visual do seu teatro.

As relações entre o teatro de Beckett e a visualidade têm sido tema de diversos estudos que observam seu interesse pelas artes visuais, por ele mesmo registrado nos chamados Diários alemães (German diaries) nos quais aparecem anotações sobre suas visitas a museus, denotando um olhar atento voltado para a pintura. Várias dentre suas peças, entre elas Dias felizes [Happy days (1961)], Não eu [Not I (1972)], Passadas [Footfalls (1975)], e Monólogo [A piece of monologue (1977)] poderiam ser destacadas no contexto. Além disso, o estudo biográfico Condenado à fama: a vida de Samuel Beckett (Damned to fame: the life of Samuel Beckett), escrito por James Knowlson em 1996, fornece instigações para mais do que uma abordagem das relações entre sua obra e as artes visuais, mas também para o estudo da interação entre as artes visuais e a práxis cênica em si, de modo abrangente.

Outro elemento importante no contexto é a opinião de Lois Oppenheim (2000, 125, p. 125, tradução nossa): ${ }^{18}$ "[Beckett] dirigiu sua própria obra para assegurar a realização mais fiel de sua visão". ${ }^{19}$ Tal assertiva revela estreita ligação com um dos principais argumentos da presente investigação quando se sublinha o trabalho do dramaturgo como um estágio em direção à cena. O legítimo desejo de ver sua obra no palco está quase sempre presente na mente de um autor desde as mais incipientes ideias que levarão a um texto teatral até, de modo geral, na mais elaborada obra de dramaturgia.

Vale lembrar que escrever com o olhar na cena é uma tendência já estabelecida pelo teatro grego clássico, com Ésquilo, Sofócles e Eurípedes. Cada um deles escrevia o texto, trabalhava como ator, diretor e produtor dos seus espetáculos, elaborando uma simbiose triunfal na reunião das várias atividades da natureza compósita do teatro. Repercutindo a tendência, dramaturgos como Eduardo de Filippo (1900-1984), Samuel Beckett (1906-1989), Bertholt Brecht (1898-1956) e Dario Fó (1926-), depois de muitos outros, como William Shakespeare (1564-1616), Molière (1622-1673) e Johann Nestroye (1801-1862) escreveram com o olhar clara-

18 Pesquisadora, autora de alguns livros que abordam a obra de Beckett, professora da Montclair State University. 19 "[...] directed his own work to ensure the most faithful realization of his vision." 
mente voltado para o palco, incluindo decisões de natureza visual, nas quais cada aspecto incorporado à cena exige rigor de tratamento.

Ainda na opinião de Oppenheim (2000, p. 125, tradução nossa) pode ser observada outra nuança da questão: “[...], Beckett assumiu também a função de pintor, no palco. Seus atores comumente atestam isso". Billie Whitelaw ${ }^{20}$ assim escreveu sobre seu trabalho com Beckett, na montagem de Passadas (Footfalls):

[...] como se ele fosse um escultor e eu, uma peça de barro. Em outros momentos, eu poderia ser um pedaço de mármore que ele precisava desbastar. Ele movia insistentemente meus braços e minha cabeça, de certo modo, para chegar o mais perto da imagem precisa que tinha na mente. [...] Às vezes eu me senti como se eu fosse o modelo para um pintor [...] por vezes eu senti que estava sendo pintada com luz. ${ }^{21}$ (WHITELAW apud OPPENHEIM, 2000, p. 125, tradução nossa)

A montagem de Passadas à qual Whitelaw se refere estreou em 1976 no Royal Court Theatre, em Londres, juntamente com Play (cuja tradução para Comédia soa estranha e, por isso, aqui é mantido o título original) ${ }^{22}$ e (Nessa altura) That time, como parte do Festival Samuel Beckett. Para compreender as observações da atriz devem ser levadas em conta as diretas relações de Becket com as artes visuais. De acordo com Knowlson (1996, p. 57), ele visitou a Galeria Nacional de Dublin em 1926 e expandiu seu interesse através de contatos com "Boss" Sinclair, seu tio, envolvido em negócios com obras de arte. Beckett documentou inúmeras visitas a museus, durante vários anos, na Alemanha, na Irlanda, na Inglaterra e na França, demonstrando interesse diversificado, desde a escultura e a arquitetura, desde os grandes mestres da pintura italiana até a alemã moderna, além da predileção pela pintura holandesa e flamenga. Ele citou e comentou trabalhos de Johannes [Jan] Vermeer (1632-1675), Hieronimus Bosch (ca.1450-1516), Andrea Mantegna (14311506), Masaccio [Tommaso di San Giovanni di Mone (1401-1428)], Albrecht Durer (1471-1528), entre outros.

Lois Oppenheim (2000) menciona, dos Diários alemães (German diaries, fevereiro de 1937), os comentários de Beckett acerca da pintura San Sebastiano (1476-

\footnotetext{
20 Atriz inglesa, nascida em 1932, trabalhou com Beckett durante 25 anos, e é considerada uma das suas mais importantes intérpretes.

21 " $[. .$.$] as if he were a sculptor and I a piece of clay. At other times I might be a piece of marble that he needed to$ chip away at. He would endlessly move my arms and my head in a certain way, to get closer to the precise image in his mind.[...] sometimes I felt as if I were modeling for a painter [...] I felt I was being painted with light."

22 O título desse texto tem sido traduzido como Comédia, o que não parece boa solução. Peça, simplesmente, serve aos propósitos do presente trabalho.
} 
1477), de Antonello da Messina (ca. 1430-1479), nos quais ele parece tocado pela distribuição das personagens na composição, sublinhando o contraste entre o homem executado no primeiro plano da imagem e a atmosfera cotidiana das ações que elaboram a composição (Figura 111). Beckett (apud NIXON, 2011, p. 147) constatou: "[...] É bom estar vivo". Revela-se a intenção de aproximar-se da obra mais do que numa simplória visita turística a um museu. Essa atitude deixa marcas que aparecerão 11 anos depois, numa carta escrita para Georges Duthuit, em primeiro de fevereiro de 1948:

Puro espaço sob a força da matemática... e a lápide [sic] expõe, dando-se à admiração de cortesãos que respiram o ar dominical na varanda, tudo invadido, consumido pelo humano. Diante de uma obra como essa, diante de tal vitória sobre a realidade da desordem, na pequenez do coração e do espírito, quase nos enforcamos. ${ }^{23}$ (BECKETT apud NIXON, 2011, p. 147, tradução nossa)

A imagem deixou fortes impressões originadas no rigor perspectivista e na idealização da representação pictórica. E ainda que se possa considerar o interesse de Beckett pelas artes visuais como uma característica de um autor cuja obra que transita na fronteira entre a dramaturgia e outras linguagens, é importante observar que tal curiosidade visual parece haver se configurado como estudo com alguma sistematização, repercutindo de modo contundente, não somente na sua dramaturgia, mas também nos seus espetáculos.

Tomando como exemplo o mencionado texto, Passadas, vê-se que as imagens estão submetidas ao mesmo rigor que um pintor, um escultor, ou qualquer outro artista seriamente interessado na assertiva visual impõe à sua obra. Beckett elabora uma contradição radical na relação entre o desequilíbrio da figura esfarrapada de May e seu deslocamento no espaço rigorosamente, teatralmente controlado.

O que se deve ver em cena na abertura do espetáculo, segundo as palavras de Beckett (1984a, p. 237, tradução nossa), é: "May (M), cabelo grisalho despenteado, pés escondidos por desgastados invólucros cinza, arrasta-se". ${ }^{24}$ Uma imagem precisamente definida, concreta, descrita graficamente por Beckett. Cada aspecto foi selecionado para que May seja identificada como um ser em estado deplorável, que deve ser reconhecido pelo observador através de uma descrição "realista", fugurativa, poder-se-ia dizer.

23 “Espace pur a force de mathematique... et le lapide [sic] expose, s'exposant a l'admiration des courtisans prenant l'air dominical au balcon, tout ça envahi, mangé par l'humain. Devant une telle oeuvre, une telle victoire sur la realite du désordre, sur la petitesse du coeur et de l'esprit, on manque se pendre."

24 "May (M), dishevelled grey hair, worn grey wrap hiding feet, trailing." 
Ainda que a disposição gráfica do espaço e da ação possa levar a uma leitura que indica abstração, Beckett concebeu visualmente de modo objetivo essa figura desgastada que pode indicar descuido, imprecisão. Para dizer de maneira simples e explícita: ele cria um intenso contraste entre um espaço cênico de aguda precisão geométrica e uma personagem cuja aparência indica o descontrole e o desequilíbrio de uma figura maltrapilha. Sintomaticamente, a desgrenhada May desloca-se em movimentos rigorosamente ordenados, gerando, já no discurso visual, um choque. Tal rigor fica explícito desde a primeira página do texto que até inclui orientação gráfica da movimentação.

Como uma figura que sugere desequilíbrio ou instabilidade desloca-se de modo tão regular e preciso? É uma visão perturbadora, teatral, artificialmente planejada que, apresentando índices figurativos importantes na construção da personagem e da situação, estabelece o choque mencionado. Revela-se uma pessoa atacada por circunstâncias que criam uma imagem de deterioração, mas que caminha de maneira uniforme, definida, regular. Simples, uma ação simples, vigorosa.

O depoimento da atriz revela a natureza multirreferencial da montagem e determina a importância que o autor diretor emprestava à sua visualidade:

Em Passadas, me senti como uma pintura musical de Edvard Munch em movimento [...] e, de fato, quando Beckett estava dirigindo Passadas, ele não estava apenas me usando para tocar notas, mas eu quase senti que ele empunhava um pincel e estava pintando e, é claro que o que ele sempre tinha no outro bolso era uma borracha, pois tão rápido quanto desenhava uma linha ele passava a enorme borracha, apagando-a, até que mal se podia vê-la. ${ }^{25}{ }^{26}$ (JOURNAL OF BECKETT STUDIES, 1978, p. 89, grifo nosso)

Dispensados os julgamentos da direção de Samuel Beckett, do seu processo de fazer e apagar, o que importa aqui são suas decisões como autor. Considere-se, no entanto, a abordagem de um hipotético Samuel Beckett, diretor, que decide atender as indicações do autor. Destaque-se a luz para ponderar que mesmo com o rigoroso controle por ele proposto, certos detalhes podem se insinuar como

25 "In Footfalls, I felt like a moving musical Edvard Munch painting [...] and in fact when Beckett was directing Footfalls, he was not only using me to play notes, but I almost felt that he did have the paintbrush out and was painting, and, of course that he always has in the other pocket is rubber, because as fast as he draws a line in, he get out that enormous India-rubber and rubs it out until it is only faintly there."

26 Trecho de uma entrevista espontânea com Billie Whitelaw, por James Knowlson, uma gravação para a televisão, efetuada em 1 fev. de 1977. 
objetos de discussão. Antes de tudo, temos um locus cênico concebido como um espaço sem luz no qual é destacada uma faixa iluminada no piso, à frente, com um metro de largura e extensão horizontal suficiente para comportar nove passos de May cuja cabeça deve estar na penumbra, ampliando a intensidade da luz à medida que o observador dirige sua atenção aos pés. A quantidade de passos, as pausas entre as falas, e os momentos de imobilidade são rubricas indispensáveis para a compreensão do texto e da sua repercussão no espetáculo. Há, no entanto, questões referentes à imagem visual que tornam importante a presença de um iluminador, uma vez que Beckett (1984a, p. 237, tradução nossa) não deixou um projeto. Ele escreveu: "Luz: em resistência [penumbra], maior intensidade no piso, menor no corpo, ainda menor na cabeça". ${ }^{27}$

Visualmente simples: acentuação nos pés, progressivamente reduzindo a intensidade, elaborando virtualmente a personagem em uma gradação que trata os pés, o corpo e a cabeça numa transição sem fronteiras visuais bruscas entre uma e outra parte da figura.

Um projeto eficiente com especial atenção para a escolha, distribuição e manipulação dos instrumentos e acessórios indicados resolveria parte dos problemas da luz, no espetáculo. Ainda há, contudo, indagações referentes à cor, especificamente à cor da luz, uma vez que a penumbra indicada pelo texto pode resultar em armadilha, pois não basta apenas reduzir a intensidade duma lâmpada, ou das lâmpadas, estabelecendo uma penumbra genérica. O próprio texto de Beckett (1984a, p. 240, tradução nossa) indica uma aparente solução, quando May diz, depois de uma pausa: "Esfarrapada [Pausa] Um emaranhado de farrapos. [Pausa] Observa-a, a ela que passa diante do candelabro, como suas chamas, sua luz [...] como a lua passando através da grade". ${ }^{28}$

A inclusão do candelabro pode estabelecer uma contradição do ponto de vista cromático, uma vez que ele pode sugerir uma luz amarelada alcançando provavelmente os alaranjados da incandescência influenciada pelos vermelhos, o que resultaria num tratamento visualmente suave, confortável, até romântico. Por outro lado, há uma referência à lua. Entretanto, de que lua May (ou Beckett) está falando? Ou de que lua a cena precisa? De um tom levemente alaranjado, como se poderia ver numa lua que nasce refletindo a família cromática do pôr do sol; ou uma (falsa) lua romântica que emitiria, talvez, azuis repletos de vermelho, mas com o indispensável cuidado de permanecer entre os violetas, evitando a artifi-

\footnotetext{
27 "Lighting: dim, strongest at floor level, less on body, least on head."

28 "Tattered. [Pause] A tangle of tatters. [...] Watch her pass before the candelabrum, how its flames, their light... like moon through passing rack."
} 
cialidade dos magentas, ausentes na luz natural? Como já se pode notar, o encaminhamento de tal discussão envolveria detalhes técnico-estéticos somente acessíves, ou do interesse, de um leitor muito familiarizado com o contexto. Algumas questões são, contudo, muito estimulantes para o iluminador e serão brevemente mencionadas.

Observando a peça com atenção, pode-se diagnosticar que Beckett (1984a, p. 240, tradução nossa) indicou respostas para as indagações sobre cor, já no momento anterior da fala mencionada acima: "A semelhança. Em resistência [penumbra], nunca invisível, sob certa luz [Pausa]. Dada a luz correta. [Pausa] Cinza, ao invés de branco, um tom pálido de cinza". ${ }^{29}$ Mesmo que não tenha explicitado tecnicamente a cor do filtro (ou gelatina), ele deixa portas abertas para discussões sobre o problema, ficando ao diretor considerar essa fala, eleger outra saída qualquer, ou deixar ao acaso. Mas, o cinza pálido, de baixa intensidade, visualmente frio, contudo, incorpora uma provocação visual intrigante.

Qual seria a melhor opção para essa peça, considerando a atmosfera descrita pelo autor? Como exemplos, uma atmosfera romântica, macia, suave, ou um ambiente frio, cortante, como a lua na ópera Don Giovani de Mozart, quando o dissimulado Giovani faz a "apaixonada" serenata para Elvira, uma nobre que ele seduziu e abandonou?

Como já foi dito, seria exaustivo e enfadonho para o leitor em geral a transformação da presente abordagem em um seminário técnico-estético sobre a luz em Passadas. Ao interesse da discussão basta a compreensão da visualidade proposta por Beckett como projeto relativamente simples, mesmo registrando que as imagens por ele indicadas estão relacionadas à aplicação de acessórios específicos e ainda pouco usados em algumas comunidades, como os filtros de densidade neutra (ND) cuja aplicação em conjunto com determinados filtros azuis operam na temperatura de cor das lâmpadas - incandescentes, com filamentos de tungstênio e gás halogênio no interior do bulbo, responsáveis pela família cromática dos amarelos alaranjados - poderiam promover o encaminhamento da atmosfera cinzenta de frieza e desconforto. Como se pode imaginar, bem diferente de um ambiente iluminado por um candelabro, que poderia resultar numa atmosfera acolhedora. Decisões simples, mas acompanhadas da precisão e do detalhamento técnico indispensável ao theatre lighting design.

Discussões semelhantes poderiam contribuir de modo positivo em ambientes nos quais a visualidade da cena representa investigação específica. A qualidade

29 "The semblance. Faint, though by no means invisible, in a certain light. [Pause] Given the right light. [Pause] Grey rather than white, a pale shade of grey." 
das imagens cênicas está relacionada a um conjunto de variáveis que incluem ângulo, intensidade, textura, movimento, e assim por diante. Tal abordagem pode desagradar quem busca fórmulas para seguir um "como se faz", pois tais variáveis interagem com outras tantas, como o espaço de cada espetáculo em questão, assim como cada composição em si, o que desafia a mera cópia de resultados ou aplicação de receitas.

Tal enfoque pode parecer insuficiente e/ou desagradar quem espera uma minuciosa análise da dramaturgia. O presente momento do texto, contudo, exige que determinadas especificidades do trabalho do iluminador sejam acentuadas, sublinhando que mesmo as rigorosas "partituras" escritas por Samuel Beckett acabam por se configurar como provocações que exigirão criteriosa seleção de atitudes, envolvendo aspectos técnico-estético-poéticos capazes de apontar respostas cênicas para a dramaturgia.

E nem se mencionou que, em Passadas, a luz da lua se projeta através de grades - incluídas no texto de Beckett. Isso poderia possibilitar a revelação das "grades" sobre o espaço cênico. Causaria surpresa confirmar que não se tenha buscado tal possibilidade, até hoje. Ou seja, mais do que "inventar" uma mirabolante saída "criativa", pode-se também optar pela pesquisa em laboratório de luz, como opção de investigação visual: quais seriam os resultados das imagens cênicas em Passadas, numa montagem que incorporasse a luz emitida pela lua, passando através de grades?

Entre outras obras de Beckett que permitem observar as relações entre o dramaturgo e a cena pode-se destacar o texto Play, escrito em inglês nos anos de 1962/1963 e publicado pela primeira vez numa tradução alemã de Erika e Elmar Tophoven com o título Spiel, na revista Theater heute, em julho de 1963. O primeiro espetáculo da versão alemã estreou no Teatro Ulmer, Ulm-Donau, em 14 de junho de 1963. Publicada pela primeira vez na língua inglesa em 1964, a peça estreou na Grã-Bretanha com a Companhia Nacional de Teatro, no Teatro Old Vic, em Londres, no dia 7 de abril de 1964.

Seis anos mais tarde, foi produzida uma versão cinematográfica francesa, denominada Comédie que, parece óbvio, trata-se de outra obra; menos no que se refere à tradução da dramaturgia e mais, se considerarmos a condição de imagem gravada e reproduzida em movimento diante do público, sem a presença dos atores e, tampouco, do operador de mesa de controle de luz.

A importância do ator como presença viva no teatro já confirmou seu espaço na discussão da práxis cênica; Beckett, no entanto, sublinha a função categórica do operador da mesa de controle de luz. Ao longo da história da dramaturgia, 
encontramos textos nos quais os autores procuram fornecer um grande volume de indicações para o diretor, o que pode levar a julgamentos apressados que consideram menor o trabalho do diretor, pois ele apenas seguiria tais indicações.

Problematizando a angústia do dramaturgo diante da incompletude do drama e, por conseguinte, da sua própria impotência diante da cena, será aqui observado um texto realista que por sua natureza representativa, presume-se, deva apresentar uma extensa descrição daquilo que deve ocorrer no acontecimento cênico, sonegando de diretores e atores o direito de "criar". Assumindo também a função de diretor, o autor seria capaz de completar os lapsos de ação, tempo e espaço, "deixados" pela dramaturgia.

Para discutir tais lapsos será brevemente comentada a peça em um ato $O$ Canto do cisne, de Anton Tchékhov (1860-1904), escrita em 1888. A importância da escolha de Tchékhov fica evidente quando se leva em conta que se trata de um dos mais reconhecidos e, portanto, mais atacados representantes do teatro realista.

Em O canto do cisne, Tchékhov (2001) expõe, ou desnuda em cena, o homem por trás do ator Svetlovídov, personagem central da trama. Não é o seu talento artístico que está em discussão, mas sua dor. Sua alma é revolvida diante do espectador que, na verdade, vê muito além da peça na qual ele tomou parte, como alguém que adentra um palácio requintado pelos aposentos dos serviçais, pela cozinha, pela lavanderia. O glamour do teatro perde relevância nesse contexto, tornando-se referência para a crueza de um palco sem "espetáculo".

A rubrica inicial indica a imagem cênica vislumbrada por Tchékhov (2001, p. 25):

A ação transcorre no palco de um teatro de província, à noite, depois do espetáculo. Um palco despojado de um teatro provinciano de segunda categoria. À direita, uma fileira de portas sem pintura e malpregadas, que levam aos camarins; o plano esquerdo e o fundo do palco estão atulhados de cacarecos. No centro do palco, um banco caído. Noite. Escuridão.

A descrição do ambiente é empreendida com grande rigor, configurando uma das muitas razões para críticas ao realismo, integrando a demanda por um novo teatro no século XX. A qualificação de despojamento usada mais tarde como sinônimo do avanço estético das vanguardas é aplicada pela tradução para sublinhar negativamente o espaço onde ocorre a ação e para representar o resultado de limitações econômicas, além do mau gosto, do descaso e/ou da ignorância, como em tantos espaços que um artista do teatro da primeira metade do século XXI pode ainda encontrar. Tchékhov vai adiante e completa o que se poderia chamar cenografia, incluindo portas à direita, que além de malpregadas não foram sequer 
pintadas, denotando desleixo e/ou falta de recursos. Vale destacar: essas portas levam aos camarins que, portanto, são expostos ao público; não se trata de portas construídas como elementos de um dispositivo cenográfico, mas da própria arquitetura do teatro. Presentes em cena durante a representação, contudo, elas constituirão o dispositivo cenográfico, uma imagem que inclui "cacarecos" amontoados à esquerda e ao fundo (em relação ao ponto de vista do espectador). Há um banco, caído, ao centro.

Sem contar com a informação visual de desenhos, o leitor cria imagens mentais como resposta a tais provocações. Para o espectador, quando o cenógrafo, o aderecista, o iluminador e o diretor, o músico, dentre outros, assumem a posição de leitores, eles ganham elevada importância, pois assumirão a função de elaborar em parceria as imagens que efetivamente serão criadas na cena. Tratando-se do teatro realista essas leituras devem atender a compromissos com a lógica e com o estudo da imagem no intuito de elaborar um espaço que responda às proposições do autor, norteando-se pela unidade e pela precisão. Cumprida essa fase, conta-se com a capacidade do diretor e do ator para fisicalizar a cena provocada pelo texto, cuja ação ocorre em um ambiente fechado, na escuridão da noite. Abre-se a cortina de boca. Tchékhov (2001) não dá qualquer indicação de uma fonte de luz artificial que possa promover a visibilidade do ambiente. O que se vê? Noite, escuridão. Num ambiente externo, à luz da lua ou de eventuais fontes de luz artificial seria possível distinguir visualmente o lugar, mesmo em traços suaves e/ou disformes. Mas o autor é categórico: escuridão. Portanto, nada se enxerga; o palco é um buraco negro. Fica a impressão de que não há ninguém naquele lugar; ativo ou acordado; se alguém dorme está distante, em um espaço fechado, ou em completa escuridão. O autor descreve a ação: "Svetlovídov, ${ }^{30}$ (em trajes de Calchas, ${ }^{31}$ com uma vela na mão, sai de um camarim rindo às gargalhadas)". (TCHÉKHOV, 2001, p. 25)

A rubrica sugere ponderações. Em primeiro lugar, há mais de uma porta: de onde ele sairá? Antes de sair, no entanto, ele procura uma vela e, depois de acendê-la, abre a porta. Ou a porta escolhida já se encontrava aberta? Cada diretor deve decidir, inaugurando uma parceria com o dramaturgo, incorporando um cenógrafo, um ator, um figurinista, um maquiador e um aderecista, quando menos. Mesmo que alguém assuma todas essas funções, ou que uma ou mais dentre elas seja desempenhada por um artista, as funções estarão presentes.

\footnotetext{
$30 \mathrm{Na}$ nota do tradutor, o sobrenome Svetlovídov é formado pelas palavras sviétli (iluminado, luminoso) e vid (aspecto, aparência, semblante).

31 Personagem da tragédia de Shakespeare, Troilus e Cressida, Calchas é o pai de Cressida.
} 
Se o diretor toma a decisão de manter como única fonte de luz na cena a vela trazida pelo "iluminado" Svetlovídov fica dispensada a contribuição de um iluminador. Será a vela, no entanto, suficiente para que o espectador apreenda o ambiente descrito pelo autor? Aqui se identifica uma abordagem provocadora para um interessado em pesquisar a luz aplicada ao espetáculo: elaborar a cena sem acrescentar nenhuma fonte de luz além da vela descrita por Tchékhov, investigando a percepção visual dos espectadores e o efetivo resultado que uma vela produziria nessas condições, prevendo variáveis, como as dimensões de cada espaço onde a peça venha a ocorrer, a duração da cena, associadas à visão escotópica e eventualidades, como uma vela que se apaga durante a ação dramática, para mencionar exemplos.

Do ponto de vista da ação propriamente dita, o autor informa que Svetlovídov sai do camarim vindo de uma porta, uma entre as mais próximas (do espectador). Já se tratou da questão acima. Sabe-se que, durante a sua primeira longa fala ele levanta o banco caído ao centro e se senta. Mas como ele chegou lá? As respostas são simples, pois se encontram no reconhecimento demonstrado pelo dramaturgo das limitações da sua contribuição. Ele espera que diretor e ator preencham essas lacunas. Isso, aliás, ao invés de traço negativo pode representar a afirmação da flexibilidade e da natureza compósita da arte teatral. Adiante, nessa mesma fala, Tchékhov (2001, p. 26) inclui outra rubrica intrigante: "[Svetlovídov] Vira a cabeça de um lado para outro". Como assim? E o que ele fez até agora? Permaneceu imóvel, congelado?

Uma didascália dessa natureza demonstra, por um lado, o esforço do autor para alcançar a maior aproximação possível com o leitor. Ou seja, ele reconhece sua limitação; por outro, o que foi acima denominado lapso só pode ser compreendido no próprio devir da dramaturgia, que inclui relações dinâmicas com a ação cênica. Tais lapsos, no entanto, não são feições exclusivas do realismo, podendo também ser encontrados nas mais revolucionárias versões das "antiteatralidades" ou novas teatralidades. Mas eles podem ocorrer, também, num evento originado em um roteiro considerado incompleto, sem precisão, com ausência de rigor, insuficientemente descritivo. Pondere-se, então: se um diretor apenas obedece aquilo que o dramaturgo prescreve, raramente um texto promoverá um espetáculo.

Em sua peça Play, Beckett tomou decisões radicais, nos moldes da partitura já mencionada, indicando soluções para tal natureza de problemas. Sem a intenção de fazer uma análise alongada do texto serão destacados pontos importantes para sua abordagem, e mesmo que a peça já tenha sido exaustivamente comentada é preciso registrar que ela trata do chamado "Eterno Triângulo" como imagem que representa uma situação de adultério. A denominação das personagens (se é permitido usar 
tal termo, no caso) como W1, W2 e M, que parecem indicar Mulher 1, Mulher 2 e Homem, demonstra a estratégia dramatúrgica que, por sua vez, pode provocar as escolhas efetivadas na definição do seu tratamento visual.

A didascália inicial de Play pode assustar aqueles mais conservadores e, talvez, mergulhar em um poço sem fundo os mais afoitos, de leitura superficial, que podem alegar ditadura do texto, ou da palavra:

A partir do centro, três urnas cinza de aproximadamente noventa centímetros, tocam-se. | De cada uma delas projeta-se uma cabeça com o pescoço mantido firme na extremidade. Essas cabeças estão, do ponto de vista da plateia, da direita para a esquerda $\mathrm{m} 2$, h e m1. Todos olham para a frente, na direção do público, durante toda a ação. Os rostos têm uma aparência indefinida na idade e no aspecto, como se fizessem parte das urnas. Mas não usam máscaras. | As falas são provocadas por uma luz projetada apenas nas faces... | A mudança de luz de uma face para a outra é imediata. | Não há black-outs, i. e., não se retornará para a quase completa escuridão do início, exceto onde existe uma indicação [do texto]. |A resposta à luz é imediata. | As faces permanecem impassíveis. As vozes não apresentam nenhuma entonação, exceto quando uma expressão é | indicada [pelo texto]. | Tempo [andamento] rápido durante todo o espetáculo. | A cortina sobe mostrando um palco em quase completa escuridão. | Mal se distinguem as urnas. Cinco segundos. | Focos suaves, simultaneamente, nas três faces. Três segundos. Voz fraca, em grande parte | ininteligível. ${ }^{32}$ (BECKETT, 1984b, p. 145, grifo e tradução nossos)

Uma rubrica que por si só justifica a presença de Beckett na discussão em curso. Em primeiro lugar, cabe problematizar o que ele chama de palco: "[...] um palco quase em completa escuridão. As urnas quase não são identificadas"33 (BECKETT, 1984b, p. 145, tradução nossa). Na verdade, o "palco" ou "espaço ideal", como ele mesmo

\footnotetext{
32 "Front center touching one another, three identical grey urns about one yard high. | From each a head protrudes, the neck held fast in the urn's mouth. The heads are | those, from left to right as seen from auditorium, of w2, $\mathrm{m}$ and w1. They face | undeviatingly front throughout the play. Faces so lost to age and aspect as to seem | almost part of urns. But no masks. | Their speech is provoked by a spotlight projected on faces alone. | The transfer of light from one face to another is immediate. | No blackout, i.e. return to almost complete darkness of opening, except where | indicated. | The response to light is immediate. | Faces impassive throughout. Voices toneless except where an expression is| indicated. | Rapid tempo throughout. | The curtain rises on a stage in almost complete darkness. | Urns just discernible. Five seconds. | Faint spots simultaneously on three faces. Three seconds. Voice faint, largely | unintelligible."

33 "[...] a stage almost in complete darkness. Urns just discernible."
} 
denomina, não passa de uma região na penumbra, determinando qualidade visual específica para o ambiente proposto pelo dramaturgo. Ao escrever palco, ele descaracteriza ligações com lugares do cotidiano: "palco", no contexto, indica qualquer que seja o espaço no qual a situação esteja efetivamente ocorrendo, abolindo referências aos ambientes do chamado "mundo real".

Ainda assim, é relevante lembrar que Beckett incluiu uma cortina. Ele afirmou que faces e urnas parecem um só corpo, como se fossem feitos do mesmo material: a descrição parece aproximar a situação na qual Play está instalada, o refúgio-prisão no qual se encontrava o ser humano moderno, atado aos hábitos e ao seu lugar banal. Uma borboleta que faz uma transmutação inversa, aprisionando-se numa crisálida de valores e normas, findando por rastejar.

O autor exige: não podem ser usadas máscaras. Se, como exemplo, for aplicado um acessório de maquiagem que, com a interferência da luz e a consequente projeção de sombras próprias no corpo do ator denuncie o acessório implantado, como algo imposto ao seu corpo, será destruída a ilusão exigida por Beckett. Esses corpos desenvolveram certa simbiose com uma espécie de urna-situação-lugar, levando à mixagem das suas texturas e cores, tornando-se difícil apreender diferenças definitivas e/ou limites entre um e outro.

Depois do primeiro dueto envolvendo W1 e W2, o autor reitera o papel que a luz pode desempenhar, identificando seus limites: "[Spots apagados. Black-out. Cinco segundos. Poderosos spots simultaneamente nas três faces. Três segundos. Vozes com força normal.]". 34 (BECKETT, 1984b, p. 145, grifos e tradução nosso) Cada um e todos os aspectos do trecho citado, exceto as "vozes com força normal", somente podem ser criados, registrados e controlados, pela luz.

Como se pode constatar, há questões que nem sempre estão diretamente subordinadas ao dramaturgo e ao diretor, mas que precisam contar com algum responsável pelas imagens visuais, o iluminador, para reconhecê-las e encaminhá-las como problematização visual na cena.

Quando Beckett (1984b) descreve o posicionamento das urnas levando em conta a visão de quem está na plateia, ele faz uma abordagem do espaço cênico que difere da convenção aplicada na dramaturgia de língua inglesa na qual se escreve do ponto de vista de quem está em cena. Beckett (1984b), ao contrário, reafirma a posição de alguém que vê a cena de fora, vê como um diretor, um cenógrafo, um iluminador e, entre outros, o espectador.

34 "[Spots off. Black-out. Five seconds. Strong spots simultaneously on three faces.Three seconds. Voices normal strength.]." 
E é preciso citar a orientação para a luz que Beckett (1984b, p. 159, tradução nossa) escreveu ao final do texto:

A fonte de luz é simples e não deve estar situada fora do espaço ideal [palco] ocupado por suas vítimas. A melhor posição para o refletor é o centro da ribalta, iluminando as faces de perto e de baixo. Quando, excepcionalmente, três refletores [instrumentos] forem necessários para iluminar as três faces ao mesmo tempo, eles devem funcionar como um instrumento desmembrado em três. Fora esses momentos, um refletor móvel deve ser usado, deslocando-se rapidamente de uma face a outra, conforme necessário. O método que consiste em atribuir para cada face um refletor fixo e separado é insatisfatório, uma vez que ele expressa menos a figura de um inquisidor, do que um só refletor que se desloca em direção às personagens. ${ }^{35}$

Podem ser vislumbradas imagens que ele desejava criar. Leve-se em conta que suas detalhadas orientações podem estar sujeitas a muitas variáveis técnicas envolvendo, entre outros aspectos, desde a distância entre as urnas e os spotlights (refletores, instrumentos), o tipo de instrumento, localização do técnico que fará a manipulação do mesmo, além das sombras projetadas pelas cabeças. Se tais sombras forem vistas pela plateia, o espaço da "situação" será bastante alargado prolongando sua extensão até o ponto no qual elas estejam projetadas, deslocando o centro de atenção.

Outro aspecto da questão é a precisão exigida do técnico que executará os movimentos, incluindo o tempo calculado em segundos, assim como a concentração de luz exclusiva em uma ou mais faces. Deve-se enfatizar que, tanto uma indicação que pareça muito generalizada quanto as específicas descrições apresentadas por Beckett, exigem um elevado grau de atenção do iluminador.

Beckett, bem se poderia dizer, além de assumir a posição de dramaturgo-diretor, aventura-se também no papel de designer, pois, além de escrever a mencionada partitura dramático-cênica e dirigir o espetáculo ele também parece impelido a conceber o projeto de luz. E, se o fizesse, estaria garantindo a precisão das imagens cênicas da sua dramaturgia.

\footnotetext{
35 "The source of light is single and must not be situated outside the ideal space (stage) occupied by its victims. The optimum position for the spot is at the centre of the footlights, the faces being thus lit at close quarters and from below. When exceptionally three spots are required to light the three faces simultaneously, they should be as single spot branching into three. Apart from these moments a single mobile spot should be used, swivelling at maximum speed from one face to another as required. The method consisting in assigning to each face a separate fixed spot is unsatisfactory in that it is less expressive of a unique inquisitor than the single mobile spot."
} 
Por outro lado, tal detalhamento pode ser interpretado como a mencionada angústia de um autor que precisaria ocupar as posições de diretor, de cenógrafo, de maquiador e de iluminador, dentre outras, para - e somente dessa maneira - garantir que as imagens cênicas presentes na sua dramaturgia fossem elaboradas no palco.

Registrando a inexorável atuação da luz na sua ideia de espetáculo, Beckett faz de Play um manifesto em favor da presente abordagem. Enquanto escrevia a peça, ele concebia sua dramaturgia como devir, caracterizando um movimento de natureza ontológica que projeta entre a dramaturgia e a práxis cênica uma trajetória não linear, transversal, na qual interagem vários aspectos. Play, como toda peça, é uma exclamação da dramaturgia arremessando-se em direção ao espaço cênico.

No teatro realista, as personagens falam impulsionadas por fortes desejos, uma vez que as palavras - as falas - são, entre vários outros, aspectos de uma ação. Uma das principais características do texto dramático - aquele no qual se faz presente o conflito - é, precisamente, as provocações às quais uma personagem é submetida. Tais provocações são geradas, inclusive, pelos seus próprios desejos. Ou seja, uma personagem ganha lugar no drama porque as provocações às quais ela é exposta resultam em ações que transformam sua vida em material que desperta o interesse do teatro.

$\mathrm{O}$ ato de provocar merece especial atenção em Play, uma vez que as cabeças reagem a provocações da luz. Poder-se-ia até dizer que tais reações não passam de reflexão - ou seja: a resposta física de um corpo à incidência de luz sobre sua superfície. Beckett (1984b, p. 147, grifo e tradução nossos) introduz a luz como provocação, segundo suas próprias palavras, e até remete a um inquisidor postado diante de um suspeito: "Suas falas são provocadas por um spotlight ${ }^{36}$ projetado somente nas faces. | A transferência de luz de um rosto para o outro é imediata". ${ }^{37}$ Mesmo sem nunca tratar de cor, que deve ser sempre uma preocupação preponderante, Beckett (1984b, p. 147, grifo e tradução nossos) define o tempo e, mais tarde, exige intensidade reduzida e focos suaves: "Urnas ligeiramente visíveis. Cinco segundos. Spots em resistência [baixa intensidade] nas três faces". ${ }^{8}$

\footnotetext{
36 No Brasil, pode-se traduzir como refletor, o que me parece um termo incompleto, de reduzida precisão técnica, mais apropriado para o senso comum. Quando não há necessidade de especificar a fonte de luz usada na situação, prefiro chamar de instrumento (aplicado para a produção de luz artifical na cena), o que pode se referir tanto ao mais recentemente cobiçado aparato, dotado da mais avançada tecnologia, quanto a uma simples vela de parafina. Na cena, um ou outro será o instrumento aplicado, de acordo com a excelência da imagem pretendida.

37 "Their speech is provoked by a spotlight projected on faces alone. | The transfer of light from one face to another is immediate."

38 "Urns just discernible. Five seconds. Faint spots simultaneously on three faces. Three seconds."
} 
Ao mencionar um spotlight - ou spot - no entanto, ele estabelece uma generalização que, na abordagem de um designer, seria avaliada com rigor. A disponiblidade de spotlights na época em que ele escreveu a peça se transformou hoje em uma multiplicidade que exige precisa especificação do equipamento a ser usado, mesmo que seja apenas um spotlight. Mais uma vez, o leitor não familiarizado será poupado, pois tratar tecnicamente da questão exigiria um texto muito específico e longo. No entanto, deve ficar um alerta: sem um projeto que defina precisamente o mencionado spotlight, os resultados podem ser inesperados e de difícil controle.

Em Play, a luz atua como uma espécie de regente que define a qualidade visual-musical do espetáculo, contribuindo para o tema: o andamento, o ritmo e a melodia propostos por Beckett, numa ação que alcança em certos momentos qualidade operística nos quais os duetos e trios funcionam tanto como palavra, quanto como som.

Depois da primeira fala, pronunciada simultaneamente pelas três figuras, há dois movimentos na imagem. Primeiro, as cabeças ficam sem luz e, em seguida, há um black-out. Após exatos cinco segundos as três cabeças são atingidas por uma luz de grande intensidade e "saltam" em direção ao espectador. Após mais uma fala dita ainda por todas as figuras, os movimentos na imagem se repetem: as cabeças ficam sem luz e, mais uma vez, um black-out; Exatos cinco segundos mais tarde, as três cabeças devem receber um golpe da luz. Beckett não faz qualquer observação sobre a intensidade. Levando em conta o padrão estabelecido na peça, uma vez que ele sempre registra diferenças necessárias pode-se presumir que as cabeças recebem o mesmo "ataque", ou a mesma qualidade de luz que antecedeu ao black-out.

Durante toda a peça, a luz comanda as ações. Os comentadores parecem unânimes em dizer que se deve desistir de encontrar personagens - dramáticas - uma vez que o autor trata as figuras como estereótipos. Tal observação pode representar importante indicação para o iluminador, uma vez que ele tem instrumental técnico para dar um caráter bidimensional ou, como se diz no teatro, para "chapar" as figuras, ainda que posicionar o spotlight ao centro para iluminar as três cabeças não seja a melhor decisão, no que se refere ao resultado proposto, pois, ao atingir, no sentido ascendente e principalmente de modo predominante, um dos lados do rosto, a luz pode acentuar volumes.

Nos diversos comentários acerca da luz em Play, o spotlight já foi considerado um inquisidor, o próprio Deus, ou até o demônio. Uma vez que a atuação da luz é determinada pelo dramaturgo e integrada a relações explícitas com as figuras que falam, sua participação pode tornar-se óbvia. A função de inquisidor pode ser ligada ao dramaturgo que a definiu e até identificada com o espectador (LAWLEY, 
1983), dado o lugar que este último ocupa como destinatário final das palavras proferidas pelas cabeças imóveis. A luz, então, ganha notoriedade em Play. Por outro lado, pode-se argumentar que Beckett cometeu um grave crime levando a circunstâncias extremas o "textocentrismo" já mencionado aqui. Ou seja, ele impôs que mesmo depois da sua morte, as imagens de uma montagem obedeçam a ordens explicitamente registradas no texto.

No entanto, há outro aspecto da questão que pode provocar um iluminador atento: mais do que uma rubrica reguladora, a primeira fala - proferida simultaneamente por todas as figuras em cena - faz sucessivas referências à escuridão, ou trevas, e à sombra. Tratando-se de uma peça onde a luz é integrada de modo tão direto à situação a ponto de ter se transformado em alvo de inúmeros comentários é importante registrar que a sombra é invocada, desde o seu início:

Sim, estranho, o melhor é a escuridão, quanto mais escuro pior, então tudo bem, | agora, mas virá, virá o tempo, a coisa está lá, você | verá, sai, mantenha-se longe de mim, tudo escuro, tudo parado, por toda parte, eliminado - | Sim, talvez, uma sombra se foi, eu suponho, alguns podem dizer, coitada, uma | sombra se foi, apenas uma sombra, na cabeça - [risada selvagem fraca] apenas uma sombra, | mas eu duvido, eu duvido, não realmente, eu estou bem, ainda bem, faço | o melhor, tudo o que posso - | Sim, a paz, um assumiu, tudo, toda a dor, toda como se... nunca foi, | ele virá - [Soluço.] - perdão, não há sentido nisso, oh eu sei... não | obstante, a paz, alguém assumiu... Quero dizer... não apenas tudo, mas como | se... nunca foi. ${ }^{39}$ (BECKETT, 1984b, p. 146, tradução nossa)

Beckett usa termos como dark, darker e darkness - escuro, mais escuro e escuridão, de reconhecida ligação com a ideia de sombra. Há, pelo menos, dois termos em inglês - shade e shadow - que podem ser destacados aqui como referência à sombra, e uma vez que Beckett usa somente o primeiro na fala inicial é até possível que um especialista no estudo da língua possa apresentar observações mais específicas, pois o termo shade é por vezes relacionado ao "estado de sombra", ou a uma área não banhada pela luz, numa abordagem simbólica e diversa daquela que

39 "Yes, strange, darkness best, and the darker the worse, then all well, for | the time, but it will come, the time will come, the thing is there, you'll | see it, get off me, keep off me, all dark, all still, all over, wiped out - |Yes, perhaps, a shade gone, I suppose, some might say, poor thing, a| shade gone, just a shade, in the head - [Faint wild laugh] - just a shade, | but I doubt it, I doubt it, not really, I'm all right, still all right, do my | best, all I can- | Yes, peace, one assumed, all out, all the pain, all as if... never been, | it will come - [Hiccup.] - pardon, no sense in this, oh I know ... none | the less, one assumed, peace ... I mean ... not merely all over, but as if... never been." 
se refere a uma forma objetiva, como a sombra - shadow - de uma árvore, graficamente definida no ambiente.

Finalizada a primeira fala da primeira parte que ele mesmo denominou Narração (Narration), a luz é arremessada exclusivamente sobre as cabeças, fazendo tudo o mais permanecer mergulhado nas trevas. Desde então, as figuras dentro das urnas reagem à luz, que se mantém em intensidade constante, iluminando uma ou outra cabeça durante toda a primeira parte da peça, executando precisamente aquilo que o autor determinou. Observando suas indicações, pode-se presumir que a forte intensidade dos spotlights lançados na segunda fala, simultaneamente sobre as três cabeças, será mantida durante toda a Narração na qual as três figuras revelam em fatos do passado que construiu a tortura sob crua exposição à luz, culminando com a seguinte declaração de W2: "Eu fiz um pacote das coisas dele e queimei. Era novembro e a fogueira estava ardendo. Durante toda a noite, senti o odor fumegante". ${ }^{\circ 0}$ (BECKETT, 1984a, p. 158, tradução nossa)

Nada mais radical, no que se refere à exposição à luz, do que arder numa fogueira. E ateada em novembro, já muito distante das fogueiras da última noite de abril (ou primeiro dia de maio), quando o fogo celebra a bem-aventurança da primavera queimando as bruxas - na noite das Walpurgas, já comentada aqui. Meses depois, já em novembro, tardiamente, W2 decide queimar seus demônios.

Depois da queimação de demônios e fantasmas ocorre uma mudança, como se poderia presumir. Na segunda parte da peça, a Meditação (Meditation), depois do intervalo de cinco segundos que segue um black-out as figuras se dirigem à luz e emitem opiniões sobre ela, assim como sobre a situação. Já na primeira fala da Meditação, todos mencionam em uníssono o verbo mudar: "[...] Quando isso mudou". ${ }^{41}$ (BECKETT, 1984b, p. 152, tradução nossa) Uma mudança efetiva ocorreu e deve ser reconhecida pelo espectador. Como Beckett (1984b, p. 157, tradução nossa) sublinha, ao abrir a segunda parte: "[Spot apaga em W2. Black out. Cinco segundos. Spots em metade da intensidade anterior simultaneamente nas três faces. Vozes proporcionalmente em menor volume]". ${ }^{42}$

Trata-se da mais importante mudança no espetáculo. E o dramaturgo-iluminador propõe um movimento que, considerada a simplicidade, ganha qualidade radical. É a principal mudança. Mas nem por isso são evocados os costumeiros efeitos especiais, tampouco fogos de artifício, como se fosse um feriado nacio-

\footnotetext{
40 "I made a bundle of his things and burnt them. It was November and the bonfire was going. All night I smelt them smouldering."

41 "When this first change."

42 "[Spot off W2. Blackout. Five seconds. Spots half previous strength | simultaneously on three faces. Three seconds. Voices proportionately lower.]."
} 
nal. A intensidade dos instrumentos é, simplesmente, reduzida à metade. Tal simplicidade, contudo, exige do iluminador um cuidado muito especial. Não se trata de programar mecanicamente - ou acionar - os três instrumentos, usando uma redução numérica 50\% menor do que aquela anteriormente usada. Ou seja, ele precisa experimentar, julgar, controlar e decidir que intensidade demonstra visualmente uma redução de 50\%.

Mesmo que ele parta de uma decisão numérica, e registre no comando enviado à mesa de controle um numeral que expresse a metade daquele usado na primeira parte, a construção da cena deve ser o resultado do seu controle visual. E deve levar em consideração as relações entre a redução de intensidade e a temperatura de cor, uma vez que o resultado alaranjado do âmbar que pode ser produzido com tal redução é muito relevante para a imagem cênica estabelecida.

Essas variáveis devem interagir com a diferença entre as duas partes da peça. Na Meditação as cabeças fazem referências a "algo melhor", "repousante", além de relações entre trevas e paz, como na fala de M: "Para baixo, tudo para baixo, para a escuridão, a paz está chegando, eu pensei que, afinal, enfim, eu estava certo, afinal, graças a Deus, quando isso mudou". ${ }^{33}$ (BECKETT, 1984b, p. 158, tradução nossa)

A associação entre paz e escuridão pode ser importante para a leitura do iluminador. A luz intensa e dura da primeira parte foi agora reduzida e a tortura de estar exposto à luz do conhecimento que revela os demônios de cada um parece haver acabado, parece haver sido extinta na fogueira. W1, no entanto, logo em seguida exclama: "Meia-luz infernal". ${ }^{44}$ (BECKETT, 1984b, p. 152, tradução nossa) Ou seja: as figuras, agora, continuam reagindo à luz, mas comentam sua intervenção; ela passa, também, a ser objeto da situação. A intensidade reduzida não lhe subtrai, portanto, o poder de promover conhecimento. O jogo muda, mas a tortura continua.

Estaria W1 negociando: "Como eu não falo a verdade, é isso, algum dia, de alguma forma, eu posso dizer a verdade, finalmente, e então não haverá mais luz, finalmente, em nome da verdade?". ${ }^{45}$ (BECKETT, 1984b, p. 153, tradução nossa) A luz que gera a ameaça de expor provoca uma confissão que libertaria da exposição intermitente. Mesmo que as figuras pareçam ter alcançado o direito de fazer comentários sobre a luz, ela estará presente, retornando inexoravelmente, perpetuando a luta

43 "Down, all going down, into the dark, peace is coming, I thought, after all, at last, I was right, after all, thank God, when first this change."

44 "Hellish half-light."

45 "Is it that I do not tell the truth, is that it, that some day somehow I may tell the truth at last and then no more light at last, for the truth?" 
para sobreviver diante de tal condenação e confirmando as cabeças como vítimas da luz, da exposição, da revelação. À luz é dada uma força brutal e violenta: "Saia de mim. Saia de mim". ${ }^{46}$ (BECKETT, 1984b, p. 153, tradução nossa)

A sucessão de imagens cênicas em Play resulta da reação das figuras à luz, numa pulsação precisamente concebida e projetada pela dramaturgia. O que difere muito de uma situação na qual alguém tenciona elogiar o iluminador e exclama que "sua luz", em determinada peça é uma "personagem", como se isso conferisse ao seu trabalho uma posição de destaque dentro da hierarquia teatral. Tal elogio parece, no entanto, dispensável uma vez que a luz não precisa ser reconhecida como personagem para ganhar importância. Na verdade, seu papel se cumpre quando somente ela torna teatralmente plausível e possível uma personagem na sua condição de corpo, quando ela estabelece os ambientes povoados por esse corpo, quando define as atmosferas originadas nos desejos do trinômio corpo-mente-alma e instala as imagens cênicas.

Elaborar um projeto que contemple tais exigências é uma tarefa que exige precisão. Se o iluminador acompanhar o rigor exigido por Beckett, cada didascália indica muitas decisões referentes a ângulo, posição, distância, cor, intensidade, lente, lâmpada, dentre muitas outras, que devem ser registradas em planilhas e desenhos técnicos, cuja aparência já assustaria qualquer neófito. Um projeto, contudo, responderia à expectativa do autor, no que se refere ao controle e à precisão.

Pode-se dizer que Beckett foi o responsável por estabelecer a maior comoção e o maior reconhecimento da luz como aspecto ativo na cena desde que se constatou a importância da eletricidade na luz teatral ao final do século XIX. Foi necessário, portanto, que um dramaturgo a ela emprestasse uma função mecanicamente objetiva em seu teatro para que teoria e/ou crítica notassem sua presença, como se ela estivesse ausente do teatro até então, ou fosse acessório sem motivo para menção. Grave engano, como venho tentando comentar aqui.

\section{BOB WILSON E O ESPETÁCULO COMO TEXTO TOTAL}

Mais tarde, ainda no século XX, outro artista trataria a luz com destaque, ao elaborar espetáculos apontados por comentadores como acontecimentos repletos de qualidades cerimoniais. Trata-se de Robert (Bob) Wilson, celebrado artista norte-americano nascido em 1941, reconhecido como diretor, coreógrafo, escul-

46 "Get off me. Get off me." 
tor, pintor, dramaturgo e lighting designer, em atividade desde o final da década de 1960. Suas montagens foram destacadas como importantes manifestações no ambiente do teatro pós-dramático e qualificadas pelas primeiras críticas como "cultos realizados por estranhas pessoas". O próprio Hans-Thies Lehmann (2006, p. 69, tradução nossa) define a natureza cerimonial do teatro pós-dramático, aproximando-se de Wilson:

O que se denomina cerimônia, como um momento do teatro pós-dramático é, portanto, todo o espectro de movimentos e processos que não têm referentes, mas que são apresentados com precisão aguda; eventos de 'comunalidade' [compartilhamento] peculiarmente formalizada, construções ritmomusicais ou construtos de desenvolvimento visual-arquitetônico; formas para-rituais, bem como a cerimônia (muitas vezes profundamente obscura) do corpo e da presença; a enfaticamente ou monumentalmente acentuada ostentação da apresentação. $^{47}$

Como se pode constatar, ele se refere a um espectro muito amplo que tem na visualidade uma linha mestra transversal. As competências e habilidades dos responsáveis por essas manifestações ocupam campos do conhecimento que ganhavam espaço, ampliavam e até descartavam certos pressupostos do então chamado antigo teatro dramático.

Aristóteles podia, afinal, descansar em paz levando consigo o mythos e seus pares - a fábula, o enredo, a ação, os desejos humanos, a interpretação, a mimesis figurativa - e assim por diante. Por outro lado, o artista envolvido com essa mencionada "dinâmica cênica" necessitava incorporar uma elaborada educação visual ou estaria apenas especulando na cena ao fazer uma aplicação radicalmente exclusiva da intuição, produzindo seu novo teatro através do acaso. As instituições de ensino envolvidas com o novo teatro obrigar-se-iam a incluir no seu trato acadêmico-pedagógico a efetivação da práxis visual (elaboração, planejamento e efetivação de objetos visualmente - esteticamente - competentes) para evitar que, mesmo com todo o conhecimento filosófico-científico com o qual o artista em processo de aprendizado era obrigado a se familiarizar, ele fosse levado a resolver

47 "What is meant by ceremony as a moment of postdramatic theatre is thus the whole spectrum of movements and processes that have no referent but are presented with heightened precision; events of peculiarly formalized communality; musical-rhythmic or visualarchitectonic constructs of development; para-ritual forms, as well as the (often deeply black) ceremony of the body and of presence; the emphatically or monumentally accentuated ostentation of the presentation." 
seus problemas visuais com a genialidade e/ou, na sua ausência, com a mencionada intuição.

Quando se trata daquele momento pós-dramático, penso que caberia refletir sobre as demandas apresentadas ao ator de um teatro sem personagem; ao diretor, que lidaria com "situações" nas quais os desejos das personagens não estariam em discussão, através da ação; ao cenógrafo, que criaria arranjos cênicos sem o compromisso com a antiga noção de ambiente da chamada "dinâmica dramática"; ao figurinista, cujos objetos podiam ter mais valor para o arranjo cênico do que aquele ser humano que o portaria, antigamente denominado ator; ao lighting designer, que cumpriria sua função criando momentos visuais autônomos, sem, necessariamente, qualquer relação com qualquer ambiente humano, concentrando-se apenas no lugar e momento onde o evento ocorreria. Logo a noção de evento ou acontecimento incorporaria hierarquicamente o termo "movimento" para questionar a antiga compreensão de ação, dramática, que exigia uma personagem. Tratava-se de um novo artista.

Bob Wilson, cuja formação se iniciou na administração de negócios (Universidade do Texas, de 1959 a 1962), passou depois pela arquitetura (no Instituto Pratt, em Nova York, 1965) e pela pintura, tendo estudado com George J. McNeil. Reconhecido por Lehmann como um dos mais importantes nomes do novo teatro, ele iniciou seu trabalho por volta de 1968 quando fundou a companhia experimental School of Byrds Byrd Hoffman, cujo nome era uma homenagem à dançarina Byrd Hoffman com a qual ele teve contato ainda adolescente e o marcou de modo significativo, até ajudando-o na solução de problemas da fala.

Na opinião de Lehmann (2006), as experimentações de Wilson investem na "desierarquização" dos meios teatrais ligados a figuras psicologicamente elaboradas ou mesmo aquelas individualmente locadas em um contexto coerente. Suas figuras são apresentadas como emblemas incompreensíveis e a ostentação da aparência determina seu significado, dispensando interrogações e, consequentemente, a busca de respostas. Os atores que dividem o palco raramente (ou nunca) ingressam em qualquer contexto de interação e a luz é aplicada para criar descontinuidade ou eliminar a homogeneidade do espaço. A cena se constitui de citações do armazenamento humano de imagens que são apresentadas como danças de imagens com qualidade neomítica, incorporando os mitos - o imaginário mítico - como imagens nas quais a ação aparece apenas como fantasias virtuais. Como define o próprio Lehmann (2006, p. 79, tradução nossa): “[...] no teatro de Robert Wilson, o espaço é dividido 'em tiras' paralelas ao proscênio, de modo que as ações 
acontecem em diferentes profundidades do palco e podem ser sintetizadas pelo espectador ou podem ser lidas como 'paralelogramos', por assim dizer". ${ }^{48}$

Lehmann (2006) diz, ainda, que o teatro de Bob Wilson cria um tempo do olhar e, numa das inúmeras explicações e definições, ele usa a expressão - já aplicada desde Louis Hartmann e John Alton, "pintar com luz" -, além de indicar uma importante interpretação do novo teatro ao afirmar que os seres humanos são transformados em esculturas gestuais. Na verdade, essa observação deveria ser um alerta para todo iluminador: uma das mais importantes funções do lighting design, na sua condição de aspecto definidor da visualidade da cena é tratar o ator - mesmo naquilo que Lehmann compreende como o antigo, ou velho teatro dramático - como um corpo, obstáculo ou suporte, com o qual a luz interage. Caso contrário, o iluminador estará abrindo mão de compreendê-lo como uma decisiva presença tridimensional em cena. Ou seja, mesmo uma grande estrela representando Hedda Gabler em uma montagem realista, deve ser compreendida, também, como um corpo em cena.

A acentuação da imagem corporificada em cena é determinante no teatro de Lehmann e exige do iluminador enorme competência no estabelecimento de respostas visuais para tais demandas. Uma vez que os resultados são cuidadosamente concebidos e exaustivamente planejados, tanto a familiaridade com instrumentos, acessórios e sistemas de controle, quanto o aprofundado conhecimento das artes visuais, da estética, será indispensável para essa extrema e radical elaboração do espaço teatral. Independentemente da opinião de um ou outro crítico - contra ou a favor - interessa uma indagação: teríamos a obra de Wilson para discutir, se a ele fossem disponibilizados o equipamento e os prazos de que dispõe a maioria dos iluminadores brasileiros?

\subsection{PSYCHOSIS: FRAGMENTOS DE VISUALIDADE}

Na compreensão do próprio Lehmann, a dinâmica cênica radical do teatro pós-dramático pode incorporar textos que interajam com tais proposições, Como foi esclarecido no início do presente capítulo, a abordagem em curso segue a própria indicação do texto 4.48 psychosis, de Sarah Kane, ${ }^{49}$ com o objetivo de identificar

48 "[...] Wilson's space is divided 'into stripes' parallel to the apron of the stage, so that actions taking place in different depths of the stage can either be synthesized by the spectator or be read as 'parallelograms', so to speak."

49 Sarah Kane suicidou-se poucos meses depois de concluir esse texto, mencionado por alguns comentadores como uma provável nota de suicídio. 
seus traços visuais-imagéticos. Afaste-se o interesse de classificar, enquadrar ou julgar o texto de Kane a partir de abordagens da possível enfermidade mental, que pode ter contribuído para sua elaboração, posto que tal enfoque exigiria autoridade particular. O texto foi lido como desafio para uma proposição de visualidade na cena sem a pretensão de aprofundamento da análise, no trabalho em curso, uma vez que isso tornaria esta seção muito extensa. Serão mencionadas provocações visuais latentes buscando aproximação com a hipótese que se refere à presença da visualidade na gênese do pensamento cênico. Pode-se até argumentar que a construção 4.48 psychosis não determina a intenção explícita de produzir um texto teatral, que não há uma construção convencional de diálogo ou identificação de personagens que falam; nada impede que ele seja compreendido como um monólogo; nada o conecta à estrutura dramático-realista reconhecida, na qual se espera a elaboração lógica de um ambiente onde ocorre a ação.

Por outro lado, mesmo de modo intuitivo e sem qualquer fundamentação de natureza científico-médica apreende-se no texto um modo de falar controlado por um autor para comunicar e expressar certo desarranjo interno no discurso: como se a aparência de caos fosse sustentada por um ordenamento interno da obra que o procura expressar e comunicar. Deixa de interessar ao estudo em curso o ponto no qual se encontram as fronteiras entre uma possível enfermidade mental de Kane e suas escolhas de artista que definiram a elaboração do texto. Ainda que, quando se considera a fala que ela põe em cena - a voz de alguém em desequilíbrio, em sofrimento, sentindo culpa, alimentando relações com a morte e fazendo pedidos de socorro - é possível observar uma organização do discurso que demonstra interesse na verossimilhança. Aqui são apresentadas considerações de um leitor movido por uma compreensão visual do texto, sem a profundidade de um teórico, crítico ou diretor, e muito menos de um psicanalista ou psiquiatra. Sarah Kane (2001, p. 206-207, tradução nossa) escreveu:

Eu estou triste | Eu sinto que o futuro é sem esperança e que as coisas não podem melhorar | Eu estou de saco cheio e insatisfeito(a) com tudo | Eu sou um completo fracasso como pessoa | Eu sou culpado(a), estou sendo punido(a) | Eu gostaria de me matar | Eu costumava conseguir chorar, mas agora estou além das lágrimas | Eu perdi o interesse em outras pessoas | Eu não consigo tomar decisões | Eu não consigo comer | Eu não consigo dormir | Eu não consigo pensar | Eu não consigo derrotar minha solidão, meu medo, meu desgosto | Eu estou gorda | Eu não consigo escrever | Eu não consigo amar | Meu irmão está morrendo, meu amor está morrendo, estou matando os dois | Eu avanço em direção à minha morte | Eu estou aterrorizado(a) 
com a medicação | Eu não consigo fazer amor | Eu não consigo foder | Eu não consigo ficar sozinho(a) | Eu não consigo ficar com outras pessoas | Meus quadris são muito grandes | Eu não gosto da minha genitália [.....$^{50}$

Um conjunto de falas, ou fala única, que pode resumir a apresentação que, no drama realista, é distribuída na didascália de abertura e/ou no decorrer da ação, mesmo que uma personagem do realismo não se declare de modo tão explícito.

Ela pode estar triste, pode estar avançando para a sua própria morte, e não pode se revelar através da própria escrita; mas Sarah Kane, a autora, foi capaz de escrever o texto, apresentando uma situação teatral que pode representar um considerável desafio e se transformar numa armadilha para o iluminador, ou seja: a figura em cena pode remeter a uma pessoa que pede socorro encontrando-se, portanto, em algum lugar e tempo. Na intenção de distanciar a obra do contexto "dramático-realista", o lugar e o tempo devem ser aqueles nos quais a ação acontece, na hora em que o evento acontece, onde e quando um artista (ou grupo de artistas) decide trabalhar com o texto de Sarah Kane. O trecho acima citado parece indicar uma exposição crua da pessoa que descreve a si mesma. Efeitos espetaculares podem mascarar ou teatralizar negativamente, destruindo essa espécie de amostragem que se revela um pedido de socorro: "Eu não quero morrer [...] Eu não quero viver". ${ }^{1}$ (KANE, 2001, p. 207, tradução nossa)

Já no título, o termo "psicose" é acompanhado pelo número "4.48". Sabe-se que a autora acordava a essa hora toda madrugada e que via, nesse instante de trevas, grandes lampejos de claridade que afastavam os confusos sentimentos da psicose. Ainda assim, cabe perguntar por que ela escolheu tal título para a obra. O termo "psicose" ganha destaque no texto propriamente dito (sem a interferência de outras interpretações, inclusive daquelas voltadas para abordagens não cênicas da questão), através do isolamento, já que não se repete, explicitamente, em nenhum outro momento. No que se refere à visualidade, o isolamento e o posicionamento são indícios importantes para a composição, para a imagem. Por outro lado, a compreensão do termo

\footnotetext{
50 "I am sad | I feel that the future is hopeless and that things cannot improve | I am bored and dissatisfied with everything | I am a complete failure as a person | I am guilty, I am being punished | I would like to kill myself | I used to be able to cry but now I am beyond tears | I have lost interest in other people | I can't make decisions | I can't eat | I can't sleep | I can't think | I cannot overcome my loneliness, my fear, my disgust | I am fat | I cannot write | I cannot love | My brother is dying, my lover is dying, I am killing them both | I am charging towards my death | I am terrified of medication I cannot make love | I cannot fuck | I cannot be alone | I cannot be with others | My hips are too big | I dislike my genitals [...]."

51 "I do not want to die [...] I do not want to die."
} 
psicose - ainda que rasa e não científica - pode se referir a uma condição geral que revela alto grau de desajuste ao cotidiano, estabelecido na ação.

O texto-imagem "4.48" aparece logo depois da apresentação citada acima: "Às 4.48 | quando o desespero visita | eu deverei me enforcar | ao som da respiração do meu [da minha] amante [...]. ${ }^{52}$ (KANE, 2001, p. 207, tradução nossa) Simule-se um exercício no qual serão lidas essas palavras logo depois do título, considerando-se um tempo (e um lugar) no qual a ação foi instalada, um momento que antecede aquele das $4 \mathrm{~h} 48$, antes da visita do desespero, diante da presença do (a) amante. Ou, quem sabe, a ação esteja se iniciando precisamente às 4 h48. Por que 4 h 48 e por que 4 h 48 reaparece? O texto traz: "Depois das 4 h 48 eu não devo mais falar [...]"53 (KANE, 2001, p. 213, tradução nossa); "Às 4 h48 quando a sanidade visita por uma hora e doze minutos eu tenho controle da minha mente." (KANE, 2001, p. 229, tradução nossa); e ainda: "Às 4 h48 / Eu dormirei [...]". ${ }^{44}$ (KANE, 2001, p. 233, tradução nossa)

Então, o tempo flui ou permanece... congelado? O controle da mente relacionado ao preciso momento, 4h48, levará ao silêncio, ao sono, à morte? Kane pode haver sugerido na evocação do título e ao longo do texto, uma provocação temporal que pode ser incorporada ao tratamento cênico. Não necessariamente no sentido de tempo linear ou traços realistas. Ou seja, podem estar sugeridos movimentos na luz que construam visualmente esses momentos nos quais se considera o tempo e suas variações de andamento, de ritmo e de pulsação, no sentido musical. Sem incluir compromissos com a representação figurativa, mas com extrema atenção e acentuação da pessoa que fala, como corpo e como imagem. Corpo que atua como meio na construção da imagem. Os ângulos referentes ao posicionamento das fontes de luz podem gerar sombras que determinem visualmente relações da pessoa que "fala" (age) com o ambiente. Como uma sombra que projete firmemente a cabeça da pessoa que fala (age), sugerindo atenção no ponto onde ela (a sombra) toca. Ou todo o corpo pode ter sua sombra diluída, sugerindo destituição de limites lógicos, desvanecendo-se.

Esses são alguns aspectos da abordagem visual que podem promover consistência artística ao tratamento concebido por um lighting designer. As observações do parágrafo acima referem-se apenas a um instrumento (refletor). E se outros forem adicionados, multiplicando as sombras? No que se refere a cores e texturas, que relações podem ser estabelecidas? Não se pretende aqui esgotar possibilida-

\footnotetext{
52 "At 4.48 | when depression visits | I shall hang myself | to the sound of my lover's breathing [...]."

53 "After 4.48 I shall not speak again."

54 "At 4.48 I shall sleep."
} 
des, pois não parece possível, tampouco necessária, a enumeração completa de caminhos prováveis de abordagem visual de qualquer que seja a obra. No entanto, é recomendável visitar outros momentos para o fortalecimento da presente argumentação.

O texto é iniciado com uma referência temporal, de duração, presença e permanência. Já na abertura, a autora indica:

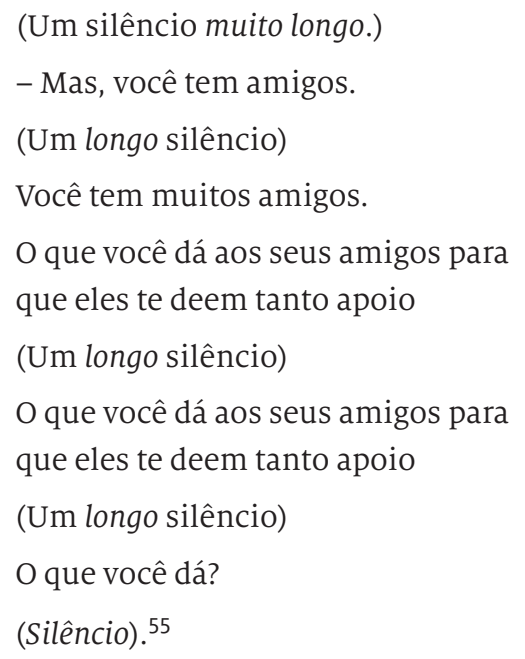

(KANE, 2001, p. 205, grifo e tradução nossos)

Ela opera com extrema generosidade, uma vez que o leitor tem absoluta liberdade para determinar a duração referente a qualidades como silêncio "longo" ou "muito longo". Que extensão está sugerida, ou determinada, pelo termo "silêncio"? E mais: é possível compreender essa indicação como um silêncio vocal, mas não, necessariamente, silêncio gestual e/ou de movimento (corporal). Se o iluminador estiver trabalhando com um diretor que estudou Lehmann ou assistiu Bob Wilson, haverá grande possibilidade de surgir, no intercâmbio de opiniões, o que Lehmann (2006, p. 164, tradução nossa) diz sobre o problema:

Ele [o corpo] não pode ser reduzido a um mero efeito visual externo. Quando o movimento físico é executado muito lentamente, de tal forma que o tempo do seu desenvolvimento em si parece ser ampliado, como através de uma lente de aumento, o próprio corpo é, inevitavelmente, exposto na sua concreção. Ele está sendo ampliado, como através da lente de um observador

55 "(A very long silence.) | - But you have friends. | (A long silence.) | You have a lot of friends. | What do you offer your friends to make them so supportive? | (A long silence.) | What do you offer your friends to make them so supportive? | (A long silence.) | What do you offer? | (Silence.)" 
e é, simultaneamente, um 'recorte' do espaço-tempo contínuo, como um objeto de arte. Ao mesmo tempo, o aparelho motor é alienado: cada ação (a pé, de pé, levantando-se e sentando-se) permanece reconhecível, mas é alterada, como nunca se viu. ${ }^{56}$

O corpo tornado radicalmente concreto pode revelar mais do que a mera aparência visível externa da pessoa em cena. Ele pode expor a dilaceração interna do ser. E a luz tem um papel em tal contexto que só a ela pertence: é o seu domínio. O momento mencionado da cena, de duração inicialmente desconhecida, pode representar excelente tema de pesquisa para o designer. Uma pesquisa diferente daquela que se processa em busca de respostas para problemas teóricos. Uma investigação em busca da imagem, da sucessão de imagens inscritas dinamicamente no tempo ficcional-cênico. Um problema específico de design. Não há "coelhos a serem retirados de cartolas". Os truques com fumaça podem não ter qualquer valor na cena. Gobos ${ }^{57}$ digitais que pululam, circulam ou esperneiam podem não contribuir. As cores que estão "sendo muito usadas" podem até continuar sendo usadas, mas, em outras instâncias. Ou seja: não há respostas prontas.

O acontecimento cênico, para evitar o termo espetáculo, projeta-se para além do seu momento inicial. Pode-se apreender, na situação criada por Kane (2001), duas presenças: uma que pergunta e outra, que não responde, além do bystander (aquele que observa), que pode ser compreendido como testemunha, alguém presente (um terceiro), ou um espectador. E se o momento de abertura for tratado como um diálogo - mesmo somente com um ator -, pergunte-se onde e quando ele se passa. Um leitor regular do antigo teatro, ao qual esse novo teatro se opunha, perguntaria: onde se passa tal "diálogo"? Seguindo adiante no texto, observa-se que a autora tomou uma decisão importante, uma decisão visual, gráfica, tratando seu texto como uma imagem, também: depois do diálogo inicial, ela marca a página com um sinal, uma linha, um traço que parece indicar fim de um fragmento e início de outro, o que pode sugerir diversidade de lugares e tempos.

Em que lugar se encontra a pessoa que, na abertura, permanece em silêncio? A seguir, no texto propriamente dito, e separado pelo traço incisivamente grafado,

\footnotetext{
56 "It cannot be reduced to a merely external visual effect. When physical movement is slowed down to such an extent that the time of its development itself seems to be enlarged as through a magnifying glass, the body itself is inevitably exposed in its concreteness. It is being zoomed in on as through the lens of an observer and is simultaneously 'cut out' of the time-space continuum as an art object. At the same time, the motor apparatus is alienated: every action (walking, standing, getting up and sitting down) remains recognizable but is changed, as never seen."

57 Padrões gráficos projetados sobre a cena. Podem resultar de aplicações de acessórios adicionados aos instrumentos do tipo elipsoidal, ou programados nos chamados instrumentos de luz, "inteligentes" [moving light].
} 
vê-se um desdobramento de imagens que mixam a descrição figurativa de um lugar, com indícios de fantasia: ${ }^{8}$

Uma consciência consolidada reside num salão de banquete escurecido perto do teto de uma mente cujo chão se move como dez mil baratas quando um facho de luz penetra enquanto todos os pensamentos se unem num instante de harmonia corpo não mais repelente enquanto as baratas contêm uma verdade que ninguém nunca pronuncia [...]..$^{59}$ (KANE, 2001, p. 205, tradução nossa)

O iluminador encontrará nesse fragmento muitas questões, possibilidades e provocações. A pessoa que o construiu esteve mergulhada em um modo visual de pensar; os aspectos poéticos da construção literária podem se confundir (mixar) com as imagens latentes no texto; difícil determinar, e talvez não seja importante, onde está o acento ou relevância: na elaboração poética ou nas imagens. Há um salão de banquete escurecido, o que já representa uma indicação prenhe de provocações visuais. O salão, no entanto, traz uma particularidade: ele se localiza nas proximidades do teto de uma mente, cujo piso lembra o movimento de 10 mil baratas. Por que baratas? O sujeito-narrador que descreve o ambiente terá medo de baratas? Quem gosta de baratas e por quê? De todo modo, em seguida o ambiente escurecido é invadido por um facho de luz que liga pensamento, harmonia, corpo, baratas e "verdade". Ainda que escurecido o salão, já era possível ver o movimento das baratas e identificar o próprio salão. A luz, no entanto, rasga a escuridão (ou penumbra), no momento em que os pensamentos são interligados na harmonia. Pragas, trevas, luz e revelação; soa bíblico, místico e até mítico.

E as indagações se avolumam. Se num espetáculo provocado pelo texto de Kane for efetuada a tentativa de fisicalizar essa mente particular na qual se instalaria o movimento de baratas respondendo à provocação originada pelo diálogo que antecede a mencionada descrição, o grau de fantasia estabelecido por uma imagem de tal natureza pode levar o espectador a incorporar plausibilidade em qualquer ação (incluindo palavras, diálogos) que ali seja apresentada ou representada, pois o traço de união será a fantasia, que atuará como linha mestra de unidade

58 Como na psicologia, de acordo com o Dicionário Houaiss: "atividade representativa com certo grau de criação, cujos conteúdos são determinados por ideias súbitas e por lembranças modificadas ou enfraquecidas de objetos, acontecimentos e situações, inclusive sua significação emocional."

59 "a consolidated consciousness resides in a darkened banqueting hall near the ceiling of a mind whose floor shifts as ten thousand cockroaches when a shaft of light enters as all thoughts unite in an instant of accord body no longer expellent as the cockroaches comprise a truth which no one ever utters [...]." 
no discurso, tornando-se uma espécie de orientação para o jogo proposto pelo espetáculo, ou pela cena. Daí, tudo aquilo que ocorrer será validado pela liberdade do fantástico e de elaboração. Ou seja, em um lugar assim, tudo pode acontecer. No entanto, um diretor pode também compreender no texto em si (fragmentado), o contraste entre a situação e o julgamento, o que poderá lhe provocar tratamento diferenciado que assinale cada um dos "momentos-fragmento", configurando estados da pessoa apresentada e/ou representada.

Tanto esses momentos-fragmento quanto os estados da pessoa podem ser ligados aos estados de imagem mencionados por Lehmann (2006, p. 68, tradução nossa) quando ele relaciona o teatro com a elaboração de imagens numa pintura cujo processo de pintar é invisível para o observador: "O teatro aqui mostrava 'menos uma sucessão, um desenvolvimento de uma história [e] mais um envolvimento de estados internos e externos"'.60 Às 4 h48 a depressão visita. (KANE, 2001) Nessa mesma hora, entretanto, a sanidade aparece. (KANE, 2001) É possível estabelecer um contraste entre os momentos (estados) nos quais o portador da depressão incorpora maneiras diferentes de pensar sobre as coisas e sobre si mesmo e aqueles nos quais a mesma pessoa se comporta, como no instante da segunda ocorrência das 4 h48, sob as regras da "sanidade".

Afinal, há um momento no qual se lê: "Estou vendo coisas | Estou ouvindo coisas | Eu não sei quem sou [...]". ${ }^{61}$ (KANE, 2001, p. 225, tradução nossa) Aqui a autora pode estar apontando para imagens inscritas ao longo do texto. E há muitas, além daquelas já mencionadas, que invocam o teto de uma mente: "Eu me afogarei na ansiedade [disforia, ou enfermidade, em grego] | na fria e negra lagoa de mim mesma | o fosso da minha mente imaterial [...]".62 (KANE, 2001, p. 213, tradução nossa) Ou seja, para compreender o que se pode ler e vislumbrar naquilo que está inserido em "estou vendo coisas", vale começar com uma leitura que sublinhe essas imagens mentais, e enfrentar o desafio de incorporar, como exemplo, essa lagoa negra e fria, alojada no fosso de uma mente destituída de matéria.

Ainda, e não menos importante, devem-se observar as dezenas de referências específicas à luz presentes no texto, como já foi dito na referência à primeira rubrica, estendendo a outros termos, como escuridão, visão, olho, vista, noite, dia, claridade e hora. Quando se considera particularmente o substantivo luz, certos

\footnotetext{
60 "The theatre here showed "less a succession, a development of a story, more an involvement of inner and outer states."

61 "I'm seeing things | I'm hearing things | I don't know who I am."

62 "I will drown in dysphoria | in the cold black pond of myself | the pit of my immaterial mind [...]."
} 
períodos chamam a atenção: "Lembre-se da luz e acredite na luz" (KANE, 2001, p. 206, tradução nossa); "Alçapão é aberto | Luz crua". 64 (KANE, 2001, p. 225, tradução nossa) Tais invocações da luz estabelecem ligações com fé e verdade, mas também, com encarceramento e violência, acentuando situações que se repetem durante todo o texto. Vale também ressaltar as muitas referências à Bíblia, das quais cito as que se seguem, para indicar uma trilha que pode aproximar o leitor das imagens que moveram a autora: "[...] Isso deve passar [...]". ${ }^{5}$ (KANE, 2001, p. 228, tradução nossa) Há outro exemplo, evocando também trevas, escuridão: "[...] vejam a luz do desespero | o brilho da angústia | e sereis lançados às trevas [...]". ${ }^{66}$ (KANE, 2001, p. 228, tradução nossa)

Há outros momentos de grande provocação visual para um iluminador que leve em consideração 4 h4 8 psycosis, de Sarah Kane (2001, p. 228, tradução nossa): "Eu tive visões de Deus". ${ }^{67}$ Deus, cuja invocação se repete por sete vezes, número também presente nas menções a testes aos quais são submetidos pacientes com enfermidades mentais, para observar níveis de concentração e memória.

Como se não bastasse, caberia sublinhar o modo visual da construção do texto, a disposição das palavras como interferências visuais na página em si, como se vê no exemplo abaixo, mantida a organização visual do texto impresso, para aproximar o leitor dessa compreensão.

Hatch opens

Stark light

A table two chairs and no windows

Here I am

and there is my body

dancing on glass

(KANE, 2001, p. 230)

63 "Remember the light and believe the light."

64 "Hatch opens | Stark light."

65 "[...] it shall come to pass [...], que se refere a Zacarias 14:6: "And it shall come to pass in that day, that the light shall not be clear, nor dark" [E isso acontecerá naquele dia, no qual a luz não será clara, nem escura].

66 "[...] behold the light of despair | the glare of anguish | and ye shall be driven to darkness [...]", que aparece no Antigo Testamento, Isaías 8:22: "And they shall look unto the earth; and behold trouble and darkness, dimness of anguish; and they shall be driven to darkness." [E olharão para a terra, e verão angústia e escuridão, sombras da aflição, e serão lançados às trevas].

67 "I saw visions of God." 
A tradução [nossa] pode aparecer assim:

\author{
Alçapão é aberto \\ Luz crua \\ Uma mesa duas cadeiras e nenhuma janela \\ Aqui estou eu \\ e aqui está meu corpo \\ dançando sobre vidro
}

Dada tal situação (ou acontecimentos que norteiam a obra), as características desse fragmento como texto elaborado para expressar e/ou comunicar a psicose misturam-se à elaboração visual desse mesmo contexto: o "alçapão" (uma porta?) leva a um ambiente duramente exposto pela crueza da iluminação. Isoladas, mesa e cadeiras; isolados aqueles que as ocuparão, já que o mundo exterior é deixado de fora, pois não há janelas. Para o narrador que tem voz nesse instante, a vida incorpora a sensação de um corpo disposto (que dança - note-se o intervalo, espaço vazio ou silêncio expresso graficamente no texto) em uma superfície que pode ser fria, escorregadia, cortante, finamente perigosa, e assim por diante. Insegurança, desespero, incerteza, solidão, dor e angústia reunidos em um pequeno fragmento, um momento breve, mas prenhe de visualidade.

Essa breve abordagem refere-se exclusivamente ao texto e dá uma pequena mostra da sua capacidade provocativa. Na criação de um espetáculo, essa categoria de observações - estendida para a totalidade do texto - teria papel importante na elaboração do ponto de vista de um designer, cujo confronto com aquele do diretor poderia resultar em contribuição para um projeto de luz. Pode-se observar, portanto, a possibilidade de estabelecimento, tanto dos ambientes nos quais as situações dialógicas acontecem, quanto daqueles nos quais os diversos fragmentos se passam. Afinal, Kane perpassou o texto com diversas instâncias de luz, abrindo muitas possibilidades para a abordagem de presenças da visualidade. A realização de espetáculos que apliquem o seu texto, na totalidade ou em quaisquer fragmentos, dá aos artistas envolvidos a chance de incorporação dessa presença.

Observa-se, por conseguinte, que desde as considerações críticas de HansThies Lehmann, passando pelo trabalho de um diretor que ele menciona como um expoente do seu teatro pós-dramático, Robert (Bob) Wilson, e finalizando com o texto de uma autora que há pouco gerou um burburinho como extrema novidade, Sarah Kane, cuja obra foi referendada pelo pensamento teatral de Lehmann, a interação entre cena e visualidade confirmou-se intensa. 


\section{BERTOLT BRECHT E A LUZ DO TEATRO CIENTÍFICO}

Se o teatro pós-dramático de Lehmann incorporava uma espécie de requalificação visual da palavra falada, em Bertolt Brecht o drama perdeu sua hegemonia para a qualidade narrativa do que ele compreendia como "teatro épico", operando também uma nova compreensão da palavra no teatro. Brecht confrontou a teoria apresentada por Goethe e Schiller, no que se refere à separação entre a poesia épica e a dramática. A proposição do jovem dramaturgo e diretor repercutiu amplamente no teatro brasileiro, na segunda metade do século XX.

O que Brecht denominou teatro da era científica incluía uma atitude crítica na qual o espetáculo contava uma história incorporando a forte tendência de acentuar a presença do palco, dos seus aparatos, mostrando alternadamente ator e personagem em cena, levando o espectador a tomar ciência de que ocupava uma posição na plateia de um teatro, configurando um conjunto de iniciativas que desconstruíam o caráter ilusionista do realismo. Posicionado "do lado de fora da cena", o espectador tornava-se capaz de chegar às suas próprias conclusões acerca daquilo que seria apresentado na cena, através da observação crítica. Martin Esslin (1980) aponta uma analogia entre o combate ao realismo no teatro e a reação dos pintores impressionistas à representação figurativa presente na chamada pintura acadêmica da época. Assim como nas telas o palco parecia ter alcançado seus limites, na tentativa de reproduzir a realidade, tornando-se inevitável a busca de outros caminhos.

Essa busca se evidenciou na obra de Bertolt Brecht, da qual dois aspectos estão aqui destacados: em primeiro lugar, o seu Pequeno organon para o teatro (Kleines organon für das theater), escrito em 1948, no qual ele apresentou o pensamento que sustentava o seu teatro épico ou científico, capaz de instruir e entreter; em seguida, será abordado seu poema A iluminação (Die beleuchtung), raramente mencionado no Brasil. A tradução do trabalho de Martin Esslin, Brecht: dos males o menor (Brecht: a choice of evils: a critical study of the man, his work and his opinions) traz parte do poema, sem grande repercussão entre nós.

Outros aspectos importantes das reflexões apresentadas em O pequeno organon para o teatro foram exaustivamente discutidos. Acentue-se a compreensão de Brecht, quando ele se refere ao teatro como a apresentação de relações entre seres humanos e, também, entre seres humanos e deuses. Aí se confirmava, portanto, a necessidade de um lugar onde esses acontecimentos deviam ocorrer, cabendo observar no texto teórico traços para a orientação do tratamento cênico desse lugar, ou lugares. Além disso, ele acreditava que o novo teatro deveria se 
afastar dos pressupostos do Naturalismo, voltando-se para "[...] representações cientificamente exatas [...]”. ${ }^{68}$ (BRECHT apud WILLET, 1977, p. 179, tradução nossa) Desse modo, o teatro precisava mostrar a realidade com precisão científica, o que determinou a inclusão do seu teatro épico ou científico na presente investigação. Curiosamente, pode-se até dizer que o Naturalismo de Zola incorpora certa curiosidade científica.

Em Brecht, contudo, a natureza política do novo teatro configurava uma resposta crítica ao drama: "Quanto tempo mais nossas almas manterão os nossos corpos 'genuínos' sob a capa da escuridão, para mergulhar nessas figuras oníricas no palco, para tomar parte nos crescendos e nos climaxes que a vida 'normal' nos nega?". 69 (BRECHT apud WILLET, 1977, p. 184, grifo e tradução nossos) Já se pode observar aqui o forte apelo visual da sua compreensão do teatro, anunciando a presença de tal apelo no seu combate ao "mergulho onírico". Em sua opinião, o caminho para a nova cena impunha uma nova maneira de apresentar a realidade:

Onde está o próprio homem, o homem inconfundível, vivo, não totalmente idêntico àqueles que a ele se assemelham? É claro que a sua imagem no palco deve trazê-lo à luz, e isso vai acontecer se essa contradição particular for recriada pela imagem. A imagem que dá a definição histórica irá reter algo do esboço irregular que indica traços de outros movimentos e recursos em torno da figura totalmente efetivada. ${ }^{70}$ (BRECHT apud WILLET, 1977, p. 191, tradução nossa)

Tais reflexões comprovam sua exigência de uma maneira particular de mostrar seu espetáculo épico, ou científico, que exigia uma nova imagem, indicando parcerias contundentes com a luz para determinar uma visualidade muito peculiar: "Essas imagens certamente exigem um modo de representar que vai deixar o intelecto do espectador livre e altamente móvel". ${ }^{71}$ (BRECHT apud WILLET, 1977, p. 191, tradução nossa) O ator, então, devia ser treinado para representar de um modo que permitisse a criação de imagens especialmente tratadas para alcançar um resultado específico: estimular no espectador a compreensão, provocando opiniões sobre os conflitos apresentados.

\footnotetext{
68 "[...] scientifically exact representations."

69 "How much longer are our souls, leaving our 'mere' bodies under cover of the darkness, to plunge into those dreamlike figures up on the stage, there to take part in the crescendos and climaxes which 'normal' life denies us?" 70 "Where is the man himself, the living, unmistakeable man, who is not quite identical with those identified with him? It is clear that his stage image must bring him to light, and this will come about if this particular contradiction is recreated in the image. The image that gives historical definition will retain something of the rough sketching which indicates traces of other movements and features all around the fully-worked-out figure."

71 "Such images certainly demand a way of acting which will leave the spectator's intellect free and highly mobile."
} 
Trabalhando em soluções para um tratamento visual particular, Brecht propôs uma maneira de tratar a cena que gerasse um novo "efeito": "[...] a produção dessas imagens, é baseada no 'efeito de estranhamento' [V-effect (Verfremdungseffekt)]. Uma representação que causa estranhamento é aquela que nos permite reconhecer o seu objeto, mas, ao mesmo tempo, o faz parecer estranho [causa estranheza]". ${ }^{72}$ (BRECHT apud WILLET, 1977, p. 192, tradução nossa) Essa representação exigia do ator uma performance que interagisse com os outros aspectos visuais. Sua presença em cena devia se efetivar através de escolhas precisas das atitudes, determinando uma fisicalização especial que compreendia o ator como uma imagem

O campo das atitudes adotadas pelas personagens em relação às outras é o que chamamos o âmbito do gesto. Atitude física, tom de voz e expressão facial são todos determinados por um gesto social: as personagens estão amaldiçoando, lisonjeando, instruindo as outras, e assim por diante. As atitudes que uma pessoa adota em relação a outras, incluem até mesmo aquelas atitudes que parecem bastante privadas, como as expressões da dor física de uma doença, ou da fé religiosa. Essas expressões de um gesto são geralmente muito complicadas e contraditórias, de modo que não podem ser expressas com uma única palavra e o ator deve compreender que dando à sua imagem a ênfase necessária, ele não perde nada, ao contrário, enfatiza o inteiro complexo. ${ }^{73}$ (BRECHT apud WILLET, 1977, p. 199, tradução nossa)

Brecht acreditava que tal complexo está ligado a um acontecimento a ser contado: “[...] a 'história', [Geschichte] é o coração da performance teatral. Pois é o que acontece entre pessoas que fornece todo o material que ela pode discutir, criticar, alterar". (BRECHT apud WILLET, 1977, p. 200, grifo e tradução nossos) Quando usou o termo Geschichte, ele não se referia ao gênero literário que prioriza a narração. Em uma peça didática de Brecht, uma "história" [Geschichte], pode ser uma cena curta, um evento, por exemplo, um acidente de tráfego que pode ser contado por várias testemunhas, sob vários ângulos. No teatro didático de Brecht, o que interessava

72 '[...] producing such images, is based on the 'alienation effect' (A-effect). A representation that alienates is one which allows us to recognize its subject, but at the same time makes it seem unfamiliar."

73 "The realm of attitudes adopted by the characters towards one another is what we call the realm of gest. Physical attitude, tone of voice and facial expression are all determined by a social gest: the characters are cursing, flattering, instructing one another, and so on. The attitudes which people adopt towards one another include even those attitudes which would appear to be quite private, such as the utterances of physical pain in an illness, or of religious faith. These expressions of a gest are usually highly complicated and contradictory, so that they cannot be rendered by any single word and the actor must take care that in giving his image the necessary emphasis he does not lose anything, but emphasizes the entire complex." 
era como os envolvidos no acidente deveriam ter agido para evitá-lo. Ele fazia um uso estratégico, teatral, da "história", para sustentar suas convicções políticas. Nesse processo, atores e espectadores desempenhavam o mesmo papel de aprendizes (lernendem), pessoas que estão compreendendo a história e aprendendo.

Para contar efetivamente uma "história", tratada nos pressupostos do efeito de "estranhamento", o gesto ganha espaço e qualidade particular, e começa a ser definido no corpo de cada ator, expandindo-se para os demais, gerando movimento, o que determinava ritmos e andamentos, interagindo com melodias, harmonias e contrastes para elaborar um tema visual:

O agrupamento das personagens no palco e os movimentos dos grupos devem ser tais, que a beleza necessária é alcançada, sobretudo, pela elegância com que o transporte de materiais que compõem o gesto é organizado e exposto à compreensão do público. ${ }^{74}$ (BRECHT apud WILLET, 1977, p. 200-201, tradução nossa)

Cada ator, ou grupo de atores, precisava ser compreendido como um sintoma de visualidade. Portanto, oferecendo o traço que fazia interagir todos os aspectos do espetáculo épico, proposto por Brecht, a história era contada visualmente:

A 'história' é definida, desenvolve-se é e mostrada pelo teatro como um todo, pelos atores, cenógrafos, aderecistas, figurinistas, compositores e coreógrafos. Eles unem suas várias artes para a operação conjunta sem, naturalmente, sacrificar sua independência no processo. ${ }^{75}$ (BRECHT apud WILLET, 1977, p. 200, tradução nossa)

A presença viva de personagens em cena para "contar" uma história exigia um comportamento específico, não somente do ator, mas de todo o complexo do espetáculo, que devia incorporar uma proposição estética particular:

[...] o cenógrafo recebe uma considerável liberdade, pois ao construir seus cenários, ele não tem mais que criar a ilusão de uma sala ou uma localidade. É suficiente dar indicações, ainda que elas devam fazer declarações de maior interesse histórico ou social, do que a coisa real faz. No Teatro Judeu, em Moscou,

\footnotetext{
74 "The grouping of the characters on the stage and the movements of the groups must be such that the necessary beauty is attained above all by the elegance with which the material conveying that gest is set out and laid bare to the understanding of the audience."

75 "The 'story' is set out, brought forward and shown by the theatre as a whole, by actors, stage designers, mask-makers, costumiers, composers and choreographers. They unite their various arts for the joint operation, without of course sacrificing their independence in the process."
} 
no [espetáculo] Rei Lear, uma estrutura que lembrava um tabernáculo medieval, causou o estranhamento; Neher pôs Galileu na frente de projeções de mapas, documentos e obras de arte renascentistas; para Haitang Erwacht, ${ }^{76}$ no Teatro Piscator, Heartfield ${ }^{77}$ utilizou um fundo de bandeiras reversíveis [uma espécie de porta-estandarte com face dupla] com inscrições, para marcar as mudanças na situação política da qual as pessoas no palco, às vezes, não tinham conhecimento. ${ }^{78}$ (BRECHT apud WILLET, 1977, p. 203, grifo e tradução nossos)

Brecht cita duas importantes figuras do teatro alemão daquele período: John Heartfield [pseudônimo de Helmut Herzfeld (1891-1968), artista plástico que nos anos de 1920 se notabilizou pelas suas montagens fotográficas, usadas nos seus cenários], e Caspar Neher (1987-1962), que trabalhou em estreita parceria com Brecht. Uma das mais recentes menções a essa parceria foi registrada no trabalho de Pamela Howard, publicado na sua primeira edição em 2001. Esclarecendo que o termo scenography deriva da expressão grega sceno-grafika, cuja tradução remeteria para o desenho (ou a grafia) do espaço da cena, sublinhando a sua profunda relação com os atores, já que eles representam seus elementos visuais primevos. Ela argumenta que os atores integram a scenography e a decisão de separar os cenários dos figurinos é, nesse sentido, uma contradição. A autora menciona a relação entre Caspar Neher e Bertholt Brecht, para apontar as raízes da scenography, no século XX, chamando a atenção para o trabalho coletivo e para a ideia de colaboração.

Howard (2009) afirma que Neher contribuiu tanto no que se refere ao contexto literário, quanto artístico, de modo geral. Nas montagens de $A$ ópera dos três vinténs e Ascenção e queda da cidade de Mahagonny ela vê em Neher o precursor daquilo

76 Ou Tai Yang Erwacht, como aparece no livro de John Willet, The theatre of Erwin Piscator: half a century of politics in the theatre, 1978, p. 105.

77 John Heartfield (1891-1968), cujo nome de batismo era Helmut Herzfeld, nasceu em Berlim. Especula-se que ele mudou seu nome em 1917, como protesto contra o exarcebado nacionalismo alemão da sua época, usando o pseudônimo John Heartfield até a sua morte; ilustrador, conhecedor das artes gráficas e da fotografia, considerado um precursor do design gráfico, passou pelo dadaísmo e trabalhou em arranjos cenográficos para espetáculos de Erwin Piscator (1893-1966).

78 " [...] the stage designer gets considerable freedom as soon as he no longer has to give the illusion of a room or a locality when he is building his sets. It is enough for him to give hints, though these must make statements of greater historical or social interest than does the real setting. At the Jewish Theatre in Moscow King Lear was alienated by a structure that recalled a medieval tabernacle; Neher† set Galileo in front of projections of maps, documents and Renaissance works of art; for Haitang erwacht at the Piscator-Theater Heartfield used a back ground of reversible flags bearing inscriptions, to mark changes in the political situation of which the persons on the stage were sometimes unaware." 
que hoje se entende como scenographer. Segundo a autora, ele desenvolvia grande intimidade com o texto e usava os atores, no espaço, para construir imagens com pessoas. Com um estilo graficamente simples e econômico, ele fazia continuamente uma variedade de pequenos desenhos, arranjos para a marcação, que Brecht usava como elementos da construção visual, em todo o espetáculo. Assim, Neher orientava espacialmente o autor/diretor e os atores, evidenciando o alto grau da sua contribuição para o teatro de Brecht. (HOWARD, 2009)

Na sua tese de doutoramento Caspar Neher e Bertholt Brecht: uma scenographic contribuition ${ }^{79}$ para o teatro épico (Caspar Neher and Bertholt Brecht: a scenographic contribuition to epic theater/1983), Ewald Hackler (1983) analisa o design e as montagens de três peças do início da carreira de Brecht - Na selva das cidades (Im dickicht, 1923), Homem é homem (Mann ist mann) (1926), e Ascenção e queda da cidade de Mahagonny (Mahagonny, 1927) - descrevendo a elaboração do texto, assim como a história das montagens, na primeira parte. Na segunda, ele aborda as soluções formais para os cenários, demonstrando sua tese através, inclusive, de desenhos de Neher, assim como de fotografias. No Abstract, Hackler (1983, grifo e tradução nossos) pondera:

Os projetos de Neher para as primeiras peças de Brecht mostram a evidência de uma experimentação teatral única. Seus 'arranjos cênicos' dissolvem as fronteiras entre as atribuições do diretor e do designer e, fazendo isso, ele demostra que a influência de Neher estendeu-se para além da esfera do meramente 'visual'. ${ }^{80}$

As ilustrações referentes à montagem de Sr. Puntilla e seu criado Matt (Her Puntilla und sein knecht Matti, 1949), incluídas por Ewald Hackler no capítulo que conclui sua tese, representam importante documentação da parceria e da cumplicidade alcançada por Neher e Brecht. Diferentemente da prática da época, Neher acompanhava quase todos os ensaios para os espetáculos os quais fazia os cenários e não somente aqueles dirigidos pelo seu amigo Brecht. Para fazer os desenhos, Neher interagia com os agrupamentos dos atores elaborados por Brecht. Ou seja: num certo sentido, ele inverteu a ordem conhecida, na qual os cenários eram concebidos antecipadamente e entravam no processo como algo imutável. O processo aplicado por Neher foi largamente praticado no teatro alemão, à exceção da ópera e do balé. Um depoimento de Ewald Hackler, que trabalhou como assistente de Neher

79 Difícil traduzir: o trabalho de Neher é diferente das atribuições regulares de um "cenógrafo", no Brasil.

80 "Neher's designs for the early Brecht's plays give evidence of a unique theatrical experiment. His 'arrangment sketches' blur the conventional boundaries between the tasks of director and designer, and in doing so demonstrate the degree to which Neher's influence extended far beyond the sphere of the merely visual." 
na montagem de A morte de Gregori Rasputin, de Nikolas Nabokov, em 1959, dá conta que Neher, enfermo e frágil, não deixou de acompanhar os ensaios, desenhando por horas a fio.

Essa parceria apresentou um novo modo de construir a cena, apontando uma contribuição que se estendia para além daquilo que se caracteriza na abordagem aqui desenvolvida como mera visibilidade do design e abria um processo de coautoria, evidenciando uma visualidade particular. Egon Monk, um dos assistentes de Brecht, comenta:

$\mathrm{Na}$ mesa do diretor encontravam-se os desenhos [de Neher] sempre à mão. Em cima, o desenho da cena que está sendo ensaiada. Quase todos os arranjos [cênicos] das montagens no Berliner Ensemble referem-se diretamente aos desenhos de Neher. ${ }^{81}$ (MONK apud HACKLER, 1983, p. 254, tradução nossa)

O processo compartilhado por Caspar Neher e Bertolt Brecht revela um curioso fato visual: os cenários projetados por Neher pareciam "vazios e incompletos" sem os atores, sem a ação cênica. Essa é uma constatação fundamental para a compreensão da indissociabilidade entre o espaço que ele criava e a cena. Aliás, sem os seus arranjos de marcação, aquela cena não teria se desenvolvido. (HOWARD, 2009) Isso talvez permita ponderar que, para se efetivar de modo consistente na sua condição de obra artística, o espetáculo teatral dispensa uma intervenção "meramente" visível. Ou seja, quando a cenografia, o figurino, os adereços - a scenography - e a luz, quando cada um deles dá a efetiva contribuição artística para um espetáculo, o meramente visível desaparece. Desse modo, o caminho trilhado por Neher, ao introduzir sua contribuição para o teatro de Brecht, pode ser caracterizado como um processo muito diferente daquele que acentua a mera visibilidade.

Se considerarmos as exigências visuais do teatro de Brecht, talvez a luz pudesse ser aplicada de modo diverso daquele que aparece, especificamente, no Pequeno organon para o teatro, referindo -se a transições:

[...] os atores não devem 'mergulhar' [cair dentro] da canção, mas devem marcar claramente, separando-a do resto do texto; e isso é mais bem demonstrado por alguns métodos teatrais, como a mudança de luz ou inserção de um título. ${ }^{82}$ (BRECHT, 1977, p. 203, tradução nossa)

81 "On the director's desk [Neher's drawings] lay, always near at hand, on top the drawing of the scene in progress. Almost all arrangements of the Berliner Ensemble productions go straight back to Neher's sketches."

82 "the actors ought not to 'drop into' song, but should clearly mark it off from the rest of the text; and this is best reinforced by a few theatrical methods such as changing the lighting or inserting a title. 
Bertolt Brecht, no seu modo poético e com grande compreensão da questão, deu-se ao trabalho de escrever um poema para esclarecê-la. O poema representa um pequeno trecho da sua obra do qual muitos comentadores se mantiveram distantes, mesmo quando Brecht parecia representar uma das principais e definitivas saídas para as vanguardas do século XX.

É importante mencionar Esslin mais uma vez, quando ele comenta a opinião de Brecht sobre a ilusão de realidade, que deveria ser abolida para dar lugar à clareza, à lucidez e à racionalidade, em lugar da emoção desmedida que originava o descontrole, e dele se alimentava. Esslin (1980, p. 125) pondera: "Os inúmeros e variados dispositivos através dos quais a ilusão de realidade deve ser dissipada precisam ostentar a marca do trabalho honesto, a perfeição que vem do uso despretensioso e sem disfarce dos materiais [instrumentos]". ${ }^{33}$ Esslin (1980) cita, ainda, parte do poema A iluminação (Die beleuchtung), no qual Brecht adverte e faz apelos ao iluminador dos seus espetáculos:

Dê-nos luz sobre o palco, Iluminador! Como podemos nós, Autores de peças e atores, apresentar na penumbra Nossos retratos do mundo? A sombra do crepúsculo Faz adormecer. Mas nós necessitamos do espectador Desperto, alerta. Deixe que eles Sonhem no claro!... ${ }^{84}$

(BRECHT apud ESSLIN, 1980, p. 125, tradução nossa)

Como infere Esslin, o palco deve ser completamente banhado de luz. Pode-se fazer uma analogia com um projeto de luz para um evento de moda ou para uma exposição de animais, como exemplo, nos quais as texturas, as formas e as cores originalmente planejadas, devem ser cuidadosamente preservadas. A continuação do poema até sugere procedimentos apropriados à visualidade do teatro épico:

O pouco da noite

Que precisarmos, agora e depois, nossas lâmpadas e luas

Podem indicar. E nós, com a nossa apresentação,

\footnotetext{
83 "The numerous and varied devices by which the illusion of reality was to be dispelled must bear the hallmark of honest craftsmanship, the perfection which comes from the unpretensions use of undisguised materials."

84 "Give us light on the stage, lighting engineer! How can we, | Playwrights and actors, present our images of the world | In semi-darkness? Nebulous twilight | Lulls to sleep. | But we need the spetators' | Wakefullness, even watchfulness. Let them dream | In blazing clarity! ..." Texto original: "Gib uns doch Lig auf die Bühne, Beleuchter! Wie | Können wir | Stückeschreiber und Schauspieller bei Halbdunkel | Unsre Abbilder der Welt vorführen? Die schummrige | Dämmerung | Schläfert ein. Wir aber brauchnen der Zuschauer | Wachheit, ja, Wachsamkeit. Laßsie | In der Helle träumen!"
} 
Também podemos mostrar os diferentes momentos do dia.

o Elisabetano deixou versos

Sobre uma charneca à noite, na qual nenhuma luz vai chegar.

Nem mesmo a charneca abraçará. Portanto, ilumine

O trabalho que fizemos

Para que o espectador possa enxergar

O camponês indignado

Sentar-se sobre o solo de Tavastland

Como se ela fosse sua própria terra. ${ }^{85}$

(BRECHT, 1967, p. 795, tradução nossa)

Partindo das demandas apresentadas pelo poema e, se nos referirmos à exigência de abolir os "disfarces" para mostrar a mecânica teatral desnudada é até possível traçar especulações para a teoria da luz no teatro científico [épico]. Esslin menciona ainda a desaprovação de Brecht para o uso de efeitos de luz com o objetivo de criar atmosfera e "clima", presumindo uma indicação presente no teatro de Shakespeare quando um disco que representava a lua, por vezes acompanhado de lamparinas na cena, indicava o estado de "noite".

Ficava, portanto, dispensada a redução da intensidade da luz no palco, a mudança de cor, textura ou ângulo. Mesmo por que, quando trabalhava no Globo, Shakespeare não poderia exigir tais interferências, sob a luz do sol. No teatro de Brecht, alojado numa edificação coberta e fechada, as decisões apontavam outra abordagem, ou seja: a deliberada intenção de mostrar, de expor e confirmar a presença do espectador no teatro, assistindo a um evento artificialmente planejado e executado. O palco deveria ser plenamente iluminado, com os instrumentos à mostra: "Ninguém espera que os instrumentos [spotlights/refletores] dispostos sobre um ringue de box estejam escondidos". ${ }^{86}$ (BRECHT apud ESSLIN, 1980, p. 126) Do mesmo modo, Brecht não encontrava razão para que eles fossem camuflados no teatro. E, também, assistir a um dos combates incluía o desejo de "ver

85 "The little bit | Of night that's wanted now and then | Our lamps and moons can indicate. | And we with our acting too can keep | The times of day apart. | The Elizabethan wrote us | Verses on a heath at evening | Which no lights will ever reach | Nor even the heath itself embrace. | Therefore flood full on | What we have made with work | That the watcher may see | The indignant peasant | Sit down upon the soil of Tavastland | As though it were her own." Disponível em: 〈http://www.theatrecrafts.com/lx_brecht.shtml〉. Acesso em: 11 abr. 2011.

"Das bißchen Nacht | Ab und zu gewünscht, kann mit Monden oder Lampen | Augedeutet werden, auch unser Spiel | Kann die Tageszeiten erkennbar machen | Dann, wenn es nötig ist. Über die abendliche Heide | Schrieb uns der Elisabethaner Verse | Die Klein Beleuchter erreicht, noch | Die Heide selber! Also beleuchter | Was wir erarbeitet, daß die Zuschauer | Sehen können, wie beleidigte Bäurin | Sich auf den tavastländischen Boden setzt |Als wär's der ihrige!"

86 "Nobody would expect the spotlights over a box ring to be hidden." 
claramente" os antagonistas e ser capaz de avaliar objetivamente a situação que determinaria os papéis de vencedor e derrotado. A estética da luz aplicada a uma contenda da "nobre arte" (o box) parecia indicada para que fossem mostrados os golpes desferidos pelo teatro de Brecht.

Um aspecto em particular dessa questão pode ser sublinhado: como Brecht avaliaria as possibilidades de lâmpadas, instrumentos e filtros, hoje disponíveis, considerando sua predileção pelo teatro de Shakespeare, realizado sob a luz do sol? Ainda que aspectos de natureza geográfico-climática interfiram diretamente na ação do sol, de acordo com cada região do planeta, quando se pensa numa temperatura de cor média para a luz do sol, algo em torno $5.400 \mathrm{~K}$, o resultado é uma luz azul muito brilhante e reduzida saturação, que nos leva a ver "branco". O senso comum leva o olho humano a ver "branco" onde há um azul tão sutil que exige atenção particular para ser efetivamente percebido.

Na verdade, o mencionado azul comporta-se como um "branco de referência" (o mais próximo da luz branca que se poderia alcançar), em comparação com as limitações das lâmpadas incandescentes disponíveis no século passado, que não produziam mais que uma luz amarelada, em muito distante da temperatura de cor da luz do sol que alcança a terra, depois que já se elevou na atmosfera e antes de começar a se por.

O que se produzia no teatro, então, era uma luz com temperatura de cor muito aquém do branco de referência que se vê na iluminação natural durante grande parte do dia. Por um lado, banindo as cores que criavam os "climas" realistas e emocionais do teatro da sua época e iluminando completamente o palco ele se afastava da visualidade apresentada pelo teatro realista; por outro, a cor produzida pelos instrumentos (refletores), vinculados às lâmpadas e sistemas de controle disponíveis àquela época, banhando o seu palco com uma luz amarelada, influenciada pelos vermelhos e teatralmente romântica, o aproximava do teatro que ele combatia. Talvez valesse a pena introduzir no seu teatro uma luz fria, desde a família dos cianos e subindo na temperatura de cor, situando-se na categoria ou qualidade do branco (de referência) para expor a cena de modo científico, perscrutador.

É preciso levar em conta que com os instrumentos que Brecht conheceu seria difícil imaginar essa luz "branca", no palco. Mesmo a luz cirúrgica da época redundaria amarelada quando se considera a alta temperatura de cor que algumas lâmpadas oferecem hoje, aliada aos filtros (gelatinas) disponíveis. O que Brecht queria era uma luz intensa, sem a influência de dimmer e/ou dos filtros coloridos de alta saturação, como até hoje se usa corriqueiramente, e até sem qualquer critério artístico. 
Qual seria a reação de Brecht, sentado hoje numa plateia, diante de uma luz efetivamente expositiva, criada pela aplicação de filtros indicados para alcançar uma temperatura de cor que afaste os amarelos alaranjados da luz incandescente e sem a redução da intensidade que abranda a imagem? Brecht poderia sentir-se contemplado se, hoje em dia, ele trabalhasse com um theatre lighting designer que aplicasse em suas montagens do teatro científico uma investigação competente de IRC (índice de reprodução de cor) que resultasse na aplicação de lâmpadas capazes de desconstruir a visualidade romântica das antigas lâmpadas incandescentes. Portanto, intervenções que pudessem modificar as características visuais de cada elemento do espetáculo somente seriam feitas depois de discussões que as referendassem.

Vale ainda mencionar um importante aspecto da convenção visual proposta por Brecht, relacionado ao uso da cortina:

[...] e faça | minha cortina, com metade da altura, não ponha um lacre no palco! | Recostado na cadeira, deixe que o espectador | Esteja ciente dos vívidos preparativos, feitos para ele | Engenhosamente; ele vê uma lua recortada de uma folha de alumínio | Flutuar para baixo, ou um telhado | transportado para dentro do palco. ${ }^{87}$ (BRECHT apud ESSLIN, 1980, p. 126, tradução nossa)

A cortina de meia altura, na verdade, tinha dimensões menores do que a boca de cena, tanto no sentido horizontal quanto vertical, para permitir que o espectador enxergasse parcialmente o que acontecia no palco, mesmo quando ela estava fechada. Era possível perceber o trânsito dos técnicos, pois parte do piso do palco permanecia visível; também se podia enxergar elementos do cenário por cima da cortina, já que ela não fechava completamente a dimensão vertical da boca de cena.

Brecht deixou escapar aí outra nuança da sua compreensão da natureza teatral, da natureza artística do seu objeto: "não mostre muito, | mas dê a ele alguma coisa | E deixe-o perceber que vocês não são magos, | Amigos, mas trabalhadores [...]". ${ }^{88}$ (BRECHT apud ESSLIN, 1980, p. 126, tradução nossa) Ele indicou uma qualidade provocativa numa mistura que anunciava o que está por vir na cena, despertando atenção do espectador, mostrando a "máquina cênica" em funcionamento. A visualidade como índice norteador.

87 "[...] and make | my curtain half high, don't seal off the stage! | Leaning back in his chair, let the spectator | Be aware of busy preparations, made for him | Cunningly; he see a tinfoil moon | Float down, or a tiled roof | Being carried in."

88 "do not show him too much, | But show him something! And let him notice | that you are not wizards, | Friends, but workers [...]." 


\section{A DANÇA DA SAIA OU O CORPO COMO MOVIMENTO EXPRESSIVO}

Se o gesto e o movimento no teatro de Brecht deviam buscar um específico grau de racionalidade vinculada a propósitos científicos de acordo com os quais o estranhamento se daria também na abordagem visual do corpo do ator, observa-se, no trabalho de Loie Fuller [Marie Louise Fuller (1862-1928)], um interesse diferenciado pelo tom expressivo do corpo em movimento. Ela fez interagir sua intuição de artista com instrumentos produzidos pelo progresso científico do seu tempo para criar abstrações visuais radicais através do movimento, subvertendo o contexto teatral que acentuava a representação realista de personagens.

Diante de argumentação que vincule exclusivamente sua proposição cênica ao trabalho de uma dançarina e/ou coreógrafa pode-se questionar a imposição de fronteiras ou limites entre teatro e dança. Ainda que suas inovações possam ter sugerido interferências muito relevantes nas relações entre a luz e a cena, inscrevendo mesmo seu interesse na face científica da questão, é necessário refletir sobre a repercussão da sua abordagem espetacular do corpo em movimento. Desse modo, pode-se observar as contribuições de Loie Fuller para a pesquisa estética vislumbrando-se na sua investigação mais do que um exclusivo fascínio por inovações técnicas. Ficava indicada uma conjuntura que compreendia a atriz - e/ ou a dançarina - como figura, objeto ou, corpo em movimento, o que apontava para o reconhecimento da natureza cênica do corpo em si.

É então possível reconhecer também outra relevância das iniciativas de Fuller: nas suas danças o palco pode ganhar o status de lugar por excelência da ação, destituindo quaisquer intenções da representação ou figuração de qualquer outro ambiente, como resumiu Arnold Aronson (1991, p. 4) (historiador, professor da Columbia University), tratando do design moderno no teatro: "Antes de qualquer coisa, o palco não era ilusionista, ele era identificado como um palco ou um espaço para o trabalho do ator, não outro lugar qualquer, como uma sala, uma floresta, etc." ${ }^{89}$ Os movimentos estabeleciam autonomia artística para a dançarina na sua condição de corpo-espaço totalizado e totalizador da cena. A performance podia constituir-se cruamente de um corpo em movimento, no instante mesmo da sua ocorrência, elegendo o corpo do ator como espaço e objeto primevo daquela práxis cênica, um corpo que se bastava como objeto expressivo e cuja manifestação cênica exigia outros dois parceiros: a luz e o público.

89 "First of all, the stage was not illusionistic - it was identified as a stage or a space for acting, not as some other place, such as a room, a forest, etc." 
É importante observar, contudo: se por um lado, o performer ganhava o status de corpo autônomo, impondo sua presença como resultado de uma "trinomia" que fisicalizava em cena uma simultaneidade mágica efetivada em corpo/meio/ imagem cujo movimento o apresentava como uma multiplicidade formal, por outro, a individualidade do ator era diluída para favorecer a elaboração de formas abstratas em movimento. Ou, como tentou resumir Roubine (1982b, p. 22): “[...] se a luz tende a tornar-se protagonista do espetáculo, por sua vez a dançarina tende a dissolver-se, a não ser mais do que uma soma de formas e volumes desprovidos de materialidade".

Ainda que se possa questionar a compreensão de "materialidade" delineada por Roubine (1982b) - uma vez que as formas e os volumes configuram objetivamente a natureza material da imagem cênica - é possível dizer que o trabalho de Loie Fuller determinava, sim, a dissolução da personagem, dissolução que seria mais tarde reclamada por iniciativas que desejariam afastar o drama do contexto teatral. De modo geral, um espetáculo projeta imagens relacionadas com uma interpretação particular da vida, de acordo com a abordagem estético-poética do artista que o concebe; O contato com o trabalho de Loie Fuller pode, por conseguinte, indicar espaços para uma investigação particular da cena como imagem diferenciada daquela imagem bidimensional produzida por aparelhos, presente em abordagens que estudam a iconologia, a pintura, a fotografia e até o medium eletrônico-digital contemporâneo, desde Erwin Panofski (1892-1968, crítico e historiador da arte alemã, um dos principais representantes dos estudos acadêmicos em iconografia) até Vilém Flusser (1920-1991, filósofo e autor, nascido em Praga e naturalizado brasileiro), mencionados aqui como exemplos.

La Loie oferecia o próprio corpo como meio para a fisicalização de múltiplas imagens em movimento, elaboradas de modo fluido na cena. A presente abordagem procura ocupar um espaço de discussão diferente daquele que estuda a imagem como um produto de aparelhos, de meios externos, localizados - vale a tautologia, fora do corpo, ou como uma entidade abstrata, teórica. Ao invés disso, a abordagem em curso aproxima-se também da compreensão das imagens como "representações internas" geradas em uma unidade corpo-mente, seja o ator ou o fruidor, organicamente relacionadas à imagem fisicalizada na cena, aquilo que é percebido visualmente em um acontecimento teatral.

Loie Fuller iniciou sua carreira no teatro desde a infância, declamando poemas já aos quatro anos. Desde o final da década de 1870, ela apareceu em vários espetáculos, com pequenos papéis, até mesmo produzindo, escrevendo e viajando com um circo. Em 1884, deixou o teatro para, segundo declarou, estudar música. No ano seguinte, Fuller participou como cantora na montagem de Fausto, no Teatro de 
Ópera Hooley e também no Festival de Música, ambos em Chicago. Voltando a trabalhar como atriz em 1886, fez alguns papéis masculinos - o que era comum, na época. Trabalhando no vaudeville, em 1887, Fuller interpretou Marguerite Gauthier, quase acidentalmente, onde usou sua experiência em tournées como ela relata:

Provei isso repetidamente aceitando papéis inesperados dos quais eu não sabia uma palavra um dia antes da estreia. Isso aconteceu, por exemplo, quando interpretei Marguerite Gauthier, em A dama das camélias, com apenas quatro horas para aprender o texto..$^{90}$ (FULLER, 1913, p. 23, tradução nossa)

Em 1889, casou-se com William Hays e mesmo que nunca tenham efetivamente vivido como um casal ele parecia muito dedicado, a ponto de acompanhá-la numa viagem a Londres, onde assumiu a posição de esposo, além de arcar com todas as despesas. Sem grande sucesso, Fuller retornou a Nova York em 1890, engajando-se em dois espetáculos: a comédia musical Viagem à Chinatown (Trip to Chinatown), de Charles Hoyt, e Dr. Quack (Quack, M.D.). Segundo seu próprio relato, durante os ensaios de Dr. Quack, o autor decidiu incluir uma nova cena na qual o Dr. Quack hipnotizava uma viúva; o hipnotismo estava em voga na cidade de Nova York. Ela comenta a solução para a cena, no espetáculo propriamente dito:

Para dar à cena seu efeito completo, ele precisava uma música muito doce e iluminação indeterminada. Nós pedimos ao eletricista do teatro para colocar lâmpadas verdes na ribalta e ao regente para executar uma air ${ }^{91}$ suave. $^{92}$ (FULLER, 1913, p. 25 , tradução nossa)

É importante registrar a escolha do verde, como uma família cromática distante do espectro da luz natural, estabelecendo uma qualidade visualmente "estranha". Para encaminhar a solução do problema, faltava, entre outros detalhes, o figurino. Sem dinheiro para comprar um novo vestido, Fuller decidiu buscar uma solução entre as suas próprias roupas. Por mero acaso, encontrou no fundo de um dos

\footnotetext{
90 "I have proved it repeatedly by unexpectedly taking parts of which I did not know a word the day before the first performance. It was thus, for instance, when I played the part of Marguerite Gauthier in La Dame aux Camélias with only four hours to learn the lines."

91 Uma melodia ou canção, ligada aos registros tenor ou soprano. Pode remeter também a um solo sem acompanhamento. O termo "air" [ária] pode se referir também a uma dança de origem renascentista, que entra como forma musical do Barroco, nas sequências de danças, ou música instrumental que reúne um ciclo de danças. Aparecem, como exemplo, na obra de Johan Sebastian Bach (1685-1750), suítes francesas, suítes inglesas. A melodia da Ária em G (sol ou quarta corda) é um exemplo notabilizado.

92 "To give the scene its full effect he needed very sweet music and indeterminate illumination. We asked the electrician of the theatre to put green lamps along the footlights and the orchestra leader to play a subdued air."
} 
seus baús uma pequena caixa, de não mais que 20 centímetros de largura, dentro da qual havia uma fina, comprida e rodada saia branca, de seda, presente de um oficial do exército britânico que se encontrava na Índia. Ela decidiu fazer a cena, usando essa que chamou de saia hindu, transformando-a numa espécie de túnica ou manto, uma vez que era muito comprida. (Cf. Figura 105)

Apesar disso, com quase um metro além do tamanho de uma saia que lhe coubesse de modo justo, o manto criava dificuldades para o deslocamento no palco. Para flutuar misteriosamente no palco, hipnotizada sob a melancólica atmosfera da música e o verde pálido da ribalta, ela abriu os braços sugerindo a presença de um "espírito alado", seguindo o médico que se deslocava cada vez mais rapidamente no palco. Fuller relata as respostas da plateia: "É uma borboleta!"; “É uma orquídea!” Seguidas de forte aplauso. Sua descrição do final da cena registra a reação do público:

Por fim, petrificada, em estado de êxtase, deixei-me cair a seus pés, completamente envolta em uma nuvem de tecido leve. O público pedia bis, e pedia novamente, tão alto e tantas vezes que tivemos que voltar vinte vezes, ou mais..$^{93}$ (FULLER, 1913, p. 31-32, grifo e tradução nossos)

Entretanto, depois de um mês e meio de temporada, a peça estreou nos subúrbios, recebendo ataques dos críticos, e não logrou espaço nos teatros de Nova York, ainda que a "atuação" de Fuller na cena do hipnotismo - como ela denominou - tenha gerado o entusiasmo de um dos críticos da cidade, e também repercutido de modo positivo na imprensa. Finalizada a temporada, e sem recursos financeiros para assumir um espetáculo exclusivamente com o seu número, ela decidiu fazer alguns reparos necessários no manto depois do repetido uso nos espetáculos. Ao concluir, ela vestiu a indumentária sobre a camisola de dormir, para relembrar os movimentos. O acaso mais uma vez mostrou um surpreendente resultado; filtrado pela cortina, o sol lançou sobre o tecido uma luz âmbar, criando translucidez e reflexos dourados nas dobras cintilantes da seda, revelando vagamente seu próprio corpo. Sob o efeito dessa visão, ela experimentou movimentos e revelou mais tarde que ficou convencida de haver elaborado ou descoberto algo novo (Figura 112).

Vale dizer que tal natureza de movimento ou coreografia já tinha alguma popularidade em Londres e que Kate Vaughan, nome artístico de Catherine

93 "At last, transfixed in a state of ecstasy, I let myself drop at his feet, completely enveloped in a cloud of the light material. The audience encored the scene, and then encored it again - so loudly and so often that we had to come back twenty times, or more." 
Candelin (1853-1903), já havia se apresentado em 1873 como dançarina-da-saia, no Balé das fúrias [Ballet of the furies], segundo afirma Clare de Morinni (2010). ${ }^{94}$ Ela interpretava o Espírito das Trevas, envolta em uma longa saia preta, repleta de ornamentos dourados e palidamente iluminada de frente, como se estivesse ao luar. Logo depois desse espetáculo, no Anfiteatro de Holborn (1873), Vaughan apresentou outras versões dessa dança, usando leves saias de gaze, no Gaiety Theatre, em Londres. Coreografias ou performances com a mesma tendência tornaram-se conhecidas e imitadas.

O que Loie Fuller (1913) buscava, no entanto, diferenciava-se através do seu vigoroso interesse pelo movimento e pela sua confiança na contribuição da luz. Depois de pesquisar relações entre a extensão de tecido, os movimentos, as consequentes formas que integravam todo o seu corpo e, contando com as observações de duas amigas, ela resumiu: "Finalmente cheguei a um ponto onde cada movimento do corpo se expressava nas dobras da seda, com uma ação de cores, que podiam ser matemática e sistematicamente calculadas". ${ }^{95}$ (FULLER, 1913, p. 31-32, tradução nossa) Sua atenção para a possibilidade de calcular e planejar indicava o caráter investigativo do trabalho de uma performer que se empenhava em desenvolver um método nas suas pesquisas para a cena.

Na mencionada primeira fase, Fuller (1913) chegou a 12 "movimentos característicos" - como ela denominou - identificados por números e pela cor a ser aplicada em cada um deles. A dança n. ${ }^{\circ}$, com luz azul; a n. ${ }^{\circ} 2$, luz vermelha; a n. ${ }^{\circ}$, amarela. Tocada pela cor, pelo poder expressivo da luz nas relações entre cor e forma, ela imergia na pesquisa: "Para a iluminação das minhas danças, eu pretendia usar um refletor com vidro colorido na frente da lente. Eu queria a última dança em total escuridão, com um único raio de luz amarela cruzando o palco". ${ }^{66}$ (FULLER, 1913, p. 34-35, tradução nossa) Nessa declaração ela fez mais um registro da contundência da luz na proposição da cena, desde os seus primeiros passos, quando um espetáculo que será montado ainda se constitui de imagens mentais elaboradas por um artista que concebe e/ou planeja a cena.

O contato com agentes e administradores (produtores) de teatros, contudo, não deu o resultado que Fuller desejava. Todos se negavam a aceitá-la como dança-

\footnotetext{
94 O artigo de Morinni aparece no título organizado por Paul Magriel (1906-199o, colecionador de arte, curador dos arquivos de dança do Museu de arte Moderna - NYC) depois de ser originalmente publicado no periódico Dance Index, em março de 1942, e é considerado um dos mais importantes relatos biográficos sobre Loie Fuller. 95 "Finally I reached a point where each movement of the body was expressed in the folds of silk, in a play of colours in the draperies that could be mathematically and systematically calculated."

96 "For illumination of my dances I intended to have a lantern with coloured glass in front of the lens. I wanted to dance the last one in total darkness with a single ray of yellow light crossing the stage."
} 
rina e somente com a intervenção de um amigo comum ela conseguiu acesso a um produtor que aceitou a ideia de assistir uma das suas danças. Não havia um camarim disponível, muito menos um piano para acompanhá-la e, como iluminação, somente um bico de gás. Pondo a "saia" sobre o próprio vestido com o qual havia chegado ao teatro, ela começou sua apresentação, lentamente, na penumbra. O produtor aproximou-se cada vez mais, e subiu ao palco; segundo ela, com olhos brilhando. Fuller (1913, p. 38, tradução nossa) continuou dançando, distanciando-se para a escuridão, e retornando para o alcance do facho da luz de gás. Sua descrição do último trecho é muito peculiar: "Finalmente, eu levantei uma parte do manto sobre meus ombros, fiz uma espécie de nuvem que me envolveu completamente e então caí, uma massa flutuante de seda macia, aos pés do produtor". ${ }^{97}$ Com brilho nos olhos, o homem reagiu dizendo que chamaria a apresentação de $A$ dança da serpentina (The serpentine dance).

Antevendo o sucesso - e os lucros - ele ofereceu um contrato de cinquenta dólares por semana apressando-se em escolher uma música para acompanhá-la, Au loin du bal, ${ }^{98}$ que se lhe tornaria familiar, a partir de então. Ela aceitou o pequeno salário pedindo que, em contrapartida, seu nome fosse divulgado, numa tentativa de retomar o contato com o público e afirmar sua nova empreitada. Juntou-se, então, a uma companhia desse mesmo produtor, que partiria em tournée. Um mês e meio depois, já no Brooklyn, sua dança alcançara grande sucesso e, mesmo com o sucesso repetido em Nova York, com a reação muito favorável da crítica, seu nome ainda não aparecia nos anúncios e letreiros que eram largamente distribuídos. Ao reclamar, descobriu: temendo que outro agente lhe tirasse a cliente, o homem havia deliberadamente evitado que a autoria das danças fosse conhecida.

Sem conseguir convencê-lo a incluir seu nome na divulgação que se espalhava pela cidade, ela procurou outro teatro. No dia seguinte, comparecendo para já assinar um contrato, foi informada que sua dança continuava sendo anunciada pelo antigo produtor, com outra dançarina em seu lugar. Por essa razão foi obrigada a aceitar condições contratuais pouco favoráveis, estreando e mantendo grande sucesso durante toda a temporada no Madison Square Theatre, enquanto o teatro que a havia substituído logo retirou rapidamente o número de cartaz. Não se tratava de substituir uma dançarina, mas de levar ao público um espetáculo que promovia uma interação diferenciada entre a luz e a cena, através de um conjunto expressivo de movimentos, formas e cores.

97 "Finally I lifted a part of my robe over my shoulders, made a kind of cloud which enveloped me completely and then fell, a wavering mass of fluffy silk, at the manager's feet."

98 Ou, Loin du bal, de Ernest Gillet (1856-1940), compositor francês, ativo no pós-romantismo. 
O olhar atento às manifestações da luz ficou registrado nas suas memórias, aparecendo de modo peculiar quando ela relatou sua primeira visita à Catedral de Notre-Dame, em Paris, e comentou o incidente que resultou em sua retirada do interior da igreja: fascinada com a luz do sol que entrava pelos enormes vitrais góticos ela usou um lenço branco para experimentar os efeitos da luz colorida, assim como fazia no teatro, com sua saia especial. Um dos responsáveis pelo respeito e disciplina, no interior do templo, levou-a pelo braço até colocá-la do lado de fora. A observação da luz gerou também sua crítica à iluminação de museus, para os quais ela indicava o planejamento da luz, acentuando-a como um recurso pouco estudado. Criticando os processos convencionais de formação em dança, que definiu como movimentos de braços e pernas, Fuller (1913, p. 68, tradução nossa) indica a necessidade de um desafio dos limites expressivos do corpo humano e simplifica a sua busca: "Luz, cor, movimento e música". ${ }^{99}$

Desde sua primeira passagem pela França, já desligada do marido e tendo passado por Berlim e Hamburgo ela registrou a frustração de não haver sido aprovada para o Opéra, em Paris. De todo modo, desconsiderando a fama de lugar pouco indicado para uma atriz respeitável, ela apresentou-se ao Folies Bergère, encontrando ali uma dançarina que fazia performances parecidas com suas danças, à qual os comentadores se referem como imitadora. Apesar disso, Loie Fuller alcançou grande sucesso nessa casa de espetáculos, mudando a reputação da mesma, até levando aos seus espetáculos senhoras e crianças em horários especialmente planejados. Continuando sua pesquisa ela buscava novos efeitos, tornando particularmente conhecida a coreografia Dança do fogo (Fire dance), como se pode ler no depoimento de Morinni (1913, p. 210, grifo do autor):

[...] 'Fire dance', foi particularmente popular, por causa dos efeitos de fogo e fumaça, que ela produzia dançando sobre um painel de vidro, iluminado por baixo. Essa inovação, uso pioneiro de luz indireta, era um efeito 'maior que o Bayreuth', e foi inspiração direta para a litogravura de Toulouse Lautrec [Figura 113]. ${ }^{100}$

Sua presença no ambiente artístico de Paris rendeu-lhe notoriedade fazendo com que outros artistas, além de Toulouse-Lautrec, se voltassem para sua figura. Jules Chéret (1836-1932) fez o cartaz das suas apresentações no Folies Bergère; ela tornou-se tema de uma pintura de Mantelet (Albert Mantelet, 1858-?); Rodin

99 "Light, colour, motion and music."

100 "'Fire dance', was particularly popular, because of the effects de flame and smoke produced by dancing in a pane of glass lighted from beneath. This innovation, a pioneer realization of indirect light, was an effect 'greater than Bayreuth', and was the direct inspiration for the Toulouse Lautrec lithograph." 
(François-Auguste-René Rodin, 1840-1917) elogiaria os efeitos de luz que ela criou; Alexandre Dumas insistiu que ela escrevesse suas memórias; e Mallarmé (1897, p. 181) a transformou em La Loie: “[...] essa transição de sonoridades do tecido (ou, melhor, uma gaze que remete à música!) é, apenas, a magia que La Loie Fuller realiza por instinto, com exagero, elevações, saia ou asa, instituindo um lugar". ${ }^{101}$

A caracterização do "lugar" nas performances de Loie Fuller pode ser relevante quando se compreende sua pesquisa como uma nova maneira de tratar o locus cênico, tornando-o abstrato, "lugar-nenhum" e palco em si, no qual se fisicalizava um novo corpo "desfigurado" em seda, ainda que, sob a intensidade dos movimentos da performer seu corpo até poderia responder aos desejos do público de ver representações figurativas no palco. O espectador integrava a totalização da elaboração artística, inclusive, com exclamações: "Uma orquídea! Uma borboleta!". A expectativa de "ver" algo familiar na cena aparece até na dúvida poética de Mallarmé: trata-se de uma saia ou são asas? Loie Fuller, portanto, indica a força da qual o ator deve impregnar seu trabalho se ele busca provocar o público, fazendo-o assumir o papel de membro do coletivo que fisicaliza a cena. Nem sempre um título rebuscado, acompanhado de longo subtítulo, alcançará tal objetivo.

Depois dessa primeira fase em Paris, Fuller começou a apresentar espetáculos nos quais era acompanhada por um grupo de jovens dançarinas, enquanto expandia seus conhecimentos da luz teatral. Permanecendo algum tempo com apenas um instrumento (um refletor) de cada lado da cena, ambos com a mesma cor, ela começou a fazer mudanças, ampliando o número de instrumentos, mas mantendo uma cor de cada vez. Devido a um acidente relatado por Clare de Morinni, que parece cercado por um tom de anedota, Fuller mudou radicalmente o resultado visual das suas danças. Um eletricista bêbado (vários técnicos trabalhavam no espetáculo, atendendo a deixas que ela indicava por gestos, como sinais para cada mudança) usou várias cores simultaneamente, deixando-a furiosa. Após perceber a reação positiva da plateia e demonstrando perspicácia, ela incorporou a mixagem de cores, cujo resultado renderia um comentário no jornal Sketch, de Londres:

A orgia de cor era tão maravilhosa que deixava muda qualquer objeção. A luz vinha de todos os lados. La Loie dançou em cima do vidro, do qual o vívido esplendor da luz refletia, enquanto das coxias, do palco e da orquestra, maravilhosos fluxos luminosos pareciam fluir em sua direção. Com o ritmo da música, as cores mudaram, e onde o branco antes governara, havia uma

101 “[...] cette transition de sonorités aux tissus (y a-t-il, mieux, à une gaze ressemblant que la Musique!) est, uniquement, le sortilège qu'opère la Loie Fuller, par instinct, avec l'exagération, les retraits, de jupe ou d'aile, instituant un lieu." 
visão caleidoscópica. Movimentos de violeta, laranja, púrpura e cor de malva [algo entre o magenta e o violeta] se sucediam rapidamente até que um rico e profundo vermelho dominou a dançarina, e ela se tornou, por um breve momento, uma rosa viva, com o coração palpitante e folhas que voavam. Em segui$\mathrm{da}$, os tons do arco-íris vieram de todos os lados, e caindo sobre as cortinas em movimento constante. Cada dobra de tecido tinha sua tonalidade e esquema de cor, intensificados pela escuridão envolvente, até que o olho mal podia suportar. Então, quando a tensão estava se tornando quase insuportável, as cores desapareceram, viu-se um flash branco de brilho espantoso e La Loie desapareceu sob a diáfana indumentária. ${ }^{102}$ (SKETCH apud MORINNI, 2010, p. 211, tradução nossa)

Loie Fuller empenhou-se cada vez mais nessa pesquisa, na qual aplicava a maior parte do dinheiro que recebia, mantendo uma equipe experimental de seis eletricistas e fazendo diversos experimentos que incluíam, segundo Morinni, "sais fluorescentes", derivados do mineral pechblenda (do qual se extrai o urânio em forma de um sal amarelo). Antoine Henri Becquerel (1852-1908) descobriu que essa pedra emitia uma forte luz, capaz de atravessar objetos opacos. Da pesquisa com a pechblenda, o casal Marie Curie (1867-1934) e Pierre Curie (1859-1906) desenvolveram pesquisas com o radium. Loie Fuller teria se aproximado do casal, intrigada com a notícia de que o radium podia prover uma luz mágica e pálida. Ela apresentou-se na casa da família onde tomou conhecimento das dificuldades práticas da aplicação do radium na cena. Funcionando ou não, ficou registrada a postura de uma artista atenta às diversas possibilidades da abrangência de aplicação dos diversos materiais no seu trabalho.

O depoimento do historiador e romancista Jules Claretie (1840-1913), publicado no jornal Temps, em 5 de novembro de 1907, pode corroborar tais elaborações:

Na noite passada [...] eu tive, por assim dizer, uma visão do teatro do futuro, [...] algo da natureza de um teatro feminista. [...] As mulheres estão, cada vez mais, ocupando o lugar dos ho-

\footnotetext{
102 "The orgie of color was so wonderful as to leave objection mute. Light came from every side. La Loie danced upon glass, from which the vivid splendor of the headlights was reflected, while from the the wings, stage and orchestra, wonderful luminous streams seemed to flow toward her. With the rhythm of the music the colors changed, and where white ruled before, there was a kaleidoscopic vision. Violet, orange, purple and mauve movements succeeded in rapid sucession until a rich deep red dominated the dancer, and she became, for one brief moment, a living rose, with palpitating heart and flying leaves. Then the hues of the rainbow came from all sides and ranged themselves upon the ever moving draperies. Every fold had its tint and scheme of color intensified by the sorrounding darkness until the eye could scarcely bear to look. Just as the strain was becoming almost intolerable, the colors desappeared, there was a white flash of appaling brilhancy and la Loie faded under diaphanous drapery."
} 
mens. [...] Loie Fuller tem feito muitos estudos em um laboratório especial, de todos os efeitos da luz que transforma o palco, [...]. É certo que novas possibilidades estão se desenvolvendo na arte teatral e que a Srta. Loie Fuller tem dado uma importante contribuição. ${ }^{103}$ (CLARETIE apud FULLER, 1913, p. 282-285, tradução nossa)

Quem ainda hoje, depois dessa descrição, mergulha, impensadamente em efeitos de cores, fumaça e movimentos pode, portanto, reconsiderar: realizar tal categoria de efeito, como novidade ou saída técnica para a luz na cena, é repetir algo antigo; mesmo se for empregada a tecnologia mais atual. Assim foi no tempo do primeiro color changer (variador de cor), do uso redutor do elipsoidal como "maquininha" de efeito, do intellabeam e depois tecnobeam (exemplos da tecnologia de instrumentos de iluminação cênica com gabinete fixo e moving mirror - ou espelho com movimento automatizado), do moving head (instrumento automatizado, com gabinete e espelho móveis) com lâmpadas incandescentes, do PAR (Parabolic aluminized reflector) que aplica a tecnologia do led, ou qualquer inovação tecnológica que se venha a aplicar. ${ }^{104} \mathrm{O}$ uso da fumaça combinada com filtros coloridos, com padrões gráficos e movimento pode sugerir muita "criatividade" e agradar o senso comum. Mas é antigo. Sua eficiência foi confirmada antes da consolidação da eletricidade, por Marie Louise Fuller, há mais de um século.

Levando em consideração apenas o depoimento de Claretie talvez ainda seja possível especular acerca de outras contribuições deixadas por ela, como o controle do tempo-ritmo de um efeito ou movimento. Pode-se também argumentar que ela teria definido intuitivamente tal procedimento; de todo modo, cabe registrar seu exaustivo trabalho de pesquisa, que, provavelmente, incluía investigações de processos químicos para produzir efeitos no tecido da sua indumentária. Suas danças tornavam o palco, como já foi dito, um lugar cênico híbrido e/ ou indefinido, e a artista em um corpo-espaço abstrato, expresso em cor, forma, textura e movimento. Para tanto, a luz que incidia sobre a cena devia ser operada com extrema precisão, exigindo um processo de comunicação entre aquela que elaborava e aqueles que controlavam os instrumentos, como ela definiu:

103 "The other evening [...] I had, as it were, a vision of a theatre of the future, [...] something of the nature of a feministic theatre. [...] Women are more and more taking men's places. [...] Loie Fuller has made studies in a special laboratory of all the effects of light that transform the stage, [...] It is certain that necapacities are developing in theatrical art, and that Miss Loie Fuller will have been responsible for an important contribution."

104 Acessórios considerados a última novidade, em seu tempo. 0 mais importante apelo de cada um deles é definir a luz projetada na cena e/ou fazer mudanças automaticamente, para criar efeitos ilusionistas. 
Um eletricista qualificado tem que chegar à frente para cortar o piso corretamente e arranjar os fios. Depois disso, eu posso trabalhar. Às vezes eu uso dez lâmpadas, por vezes, dezesseis, vinte, já usei trinta e quatro, e isso requer um eletricista qualificado, para operar cada uma delas. ${ }^{105}$ (FULLER apud MORINNI, 2010 p. 211, tradução nossa)

Aqui se pode registrar como o treinamento dos técnicos já era indispensável, assim como sua relevância para a cena. Em outro trecho do seu livro de memórias, ela menciona a estreia no Folies Bergère, tocando em pontos importantes dessa relação:

[...] o ensaio geral só terminou às quatro horas da manhã, e eu ainda não tinha conseguido completar meu programa, que compreendia cinco danças: 1 , a serpentina; 2 , a violeta; 3 , a borboleta; 4, uma dança que o público mais tarde chamou de 'dança branca'. Para concluir, eu pretendia dançar com iluminação de baixo, a luz vindo através de um quadrado de vidro sobre o qual me encontrava, o que seria o clímax das minhas danças. Após o [ensaio do] quarto número, meus eletricistas, que estavam esgotados, me deixaram lá, sem a menor cerimônia. ${ }^{106}$ (FULLER, 1913, p. 57, tradução nossa)

Como se pode constatar, ela também pode haver cometido erros, pois a efetiva contribuição da luz para um espetáculo exige disciplina para ser concebida, planejada e executada. Nem sempre é possível fazer a "mágica", num passe de mágica; exaurir uma equipe pode produzir resultados negativos no espetáculo. Afinal, como já foi mencionado, erros similares se repetem até hoje.

Mesmo considerando aparentemente rudimentar o trabalho de Loie Fuller no que se refere aos aspectos coreográficos ou gestuais, Roubine (1982b) acentua positivamente o caráter expressivo do qual eram impregnadas suas performances à medida que ela se afastava da representação figurativa. E Roubine (1982b, p. 21) relacionou suas inovações às possibilidades da luz elétrica: "[...] a iluminação elétrica pode, por si só, modelar, modular, esculpir um espaço vazio, dar-lhe vida [...]". Levando

105 "A skilled electrician has to go ahead to cut the floor properly and to lay the wires. When this is done I can go to work. Sometimes I use ten lamps, sometimes sixteen, again twenty, and I have used as may as thrity four and it requires a skilled electrician to run each of them."

106 "Eight days later the general rehearsal occurred, which ended only at four o'clock in the morning, and still I had been unable to complete my programme, comprising five dances: 1 , the serpentine; 2 , the violet; 3 , the butterfly; 4 , a dance the public later called the 'white dance'. As a finale I intended to dance with illumination from beneath, the light coming through a square of glass over which I hovered, and this was to be the climax of my dances. After the fourth number my electricians, who were exhausted, left me there unceremoniously." 
em conta os avanços implantados pela produção de luz artificial, com a aplicação da eletricidade, ele afirmou que Fuller assumiu o papel de principal instrumento de estruturação e animação do espaço cênico. Mencionando vários espetáculos, sem qualquer ligação aparente, ele reconheceu: "[...] a luz torna-se elemento preponderante da cenografia”. (ROUBINE, 1982b, p. 21)

Talvez fosse possível dizer que Loie Fuller contribuiu para uma assertiva que vem sendo aqui proferida: quando se reconhece a cena como uma expressão de visualidade, a luz se torna um elemento "preponderante" da práxis cênica. Essa preponderância é relativizada na presente abordagem para acentuar a importância da luz naquilo que Roubine (2003) chama de imagem cênica, considerando suas inúmeras referências à cena como uma imagem, o que caracteriza o ator, seu corpo, como parte da imagem cênica e, ele mesmo, como uma imagem Além disso, ele identificou ecos do pioneirismo de Fuller no teatro simbolista, assim como na teoria de Antonin Artaud (1896-1948) - segundo o próprio Roubine, de discutível precisão técnica, mas poderosamente sugestiva do uso da imaginação criadora na aplicação da luz no teatro.

A última apresentação de Loie Fuller ocorreu em Londres, no ano de 1927, e incluía o resultado de experimentações influenciadas pelo cinema, usando silhuetas e sombras. Ela denominou seu último trabalho de Balé Sombra (Shadow Ballet).

\section{ADOLPHE APPIA: A CENA IMERSA NA SOMBRA}

O interesse pela sombra aparece também nas investigações do já mencionado Adolphe Appia (1862-1928 - arquiteto e teórico suíço, estudioso do espaço teatral), nas quais se origina o trinômio ator-música-cena, incorporando uma compreensão inovadora da "verdade" na cena, ao vislumbrar novas funções para a luz, exigindo uma diferente relação entre o corpo do ator e o dispositivo cenográfico.

Appia introduziu o primeiro esboço moderno de uma teoria acerca das relações entre a luz e a práxis cênica, já no fim do século XIX e, ainda assim, os caminhos indicados pelos seus estudos foram apenas parcialmente abordados, em parte porque a luz permanece numa espécie de região nebulosa do conhecimento teatral. Algumas ponderações podem ser encaminhadas em direção a uma exegese do relativo desinteresse pela trilha teórica deixada por Appia. Seu próprio texto traz pistas para a compreensão de tal comportamento.

Em primeiro lugar, ao dispor o ser humano no centro da discussão, ele já elabora a provocação para movimentos teórico-práticos que tratam da corporificação do performer, como foi possível observar no decorrer do século XX e na 
atualidade. Seu reconhecimento do ator como corpo primordial da cena estabeleceu provocações. Desde Antonin Artaud (1896-1948), Jacques Copeau (1879-1949), passando por Jacques Lecoq (1921-1999) e Jerzi Grotowski (1933-1999), até Eugenio Barba, como exemplos, mesmo que a luz tivesse sempre papel decisivo na construção da cena, é compreensível que as ações, as reações e as relações humanas encontrassem destaque no pódio discursivo, tanto na teoria quanto na prática. No entanto, desde a acentuação do corpo como espaço no qual repercutem as emoções até a proposta de hegemonia da expressão física "autônoma" na práxis cênica, a luz permaneceu como elo entre a cena e o observador, corroborando a excelência da compreensão teatral de Adolphe Appia, que promove a consistente interação expressiva entre corpo e luz.

Em segundo lugar, sua investigação relacionava a luz para a cena de modo muito particular com a música. Expandir a compreensão do papel da luz na práxis cênica depois de Appia, por conseguinte, requer mais do que inferências meramente intuitivas no que se refere às relações entre a música, as artes visuais e a luz.

De todo modo, outras particularidades podem ser destacadas para que se compreenda o caráter parcial de determinadas abordagens. Já na década de 1930, Stanley McCandless (1897-1967) advertiu:

O design, ${ }^{107}$ ou mais especificamente, o planejamento e a execução da luz para uma montagem são frequentemente cobertos por um véu de mistério que se deve, sem dúvida, à falta de conhecimento, tanto dos limites quanto das potencialidades do problema. Esse mistério resulta, primeiro, da falta de filosofia fundamental de uma precedência na utilização da luz, como uma atividade do design, segundo, do primitivo equipamento empregado e, em terceiro lugar, da ausência de um plano simples, bem definido, que pode ser aplicado nas soluções de problemas da luz. ${ }^{108}$ (MCCANDLESS, 1984, p. 9-10, grifo e tradução nossos)

\footnotetext{
107 Uma tradução do termo design pode ser problemática principalmente devido ao uso indiscriminado do termo no Brasil, indicando a urgência da discussão dos processos que decorrem ou estão incluídos nas funções de um designer, especificamente de um designer trabalhando no teatro e mais, no design para a luz de espetáculos. No Brasil, essa discussão parece soar cada vez mais estranha e deslocada. Os processos de conceber e projetar a luz para a cena, incluindo planejamento e sistematização, parecem transitar no nível da idiossincrasia. Se cada um pode "fazer luz" usando seu jeito particular, sistematizar parece absurdo.

108 "The design, or more specifically, the planning and execution of the lighting for a production is often surrounded by a veil of mistery which is due, undoubtedly, to lack of knowledge of both the limits and the potentialities of the problem. This mistery arises first from the fundamental lack of philosophy of precedent in the use of light as a design medium, second, from the primitive equipment employed, and third, from the absence of a simple, well defined plan which may be applied to the solutions of lighting problems."
} 
McCandless (1984) apontava relevantes aspectos da discussão que, afortunadamente, deram lugar a estudos posteriores e efetiva repercussão no teatro norte-americano. Ainda que se depreenda de seu trabalho a busca por uma resposta aos limites financeiros que resultaram da grande depressão, na terceira década do século XX, nos Estados Unidos da América, ele incorpora às suas reflexões a possibilidade da sistematização dos processos de conceber e planejar a luz para a cena. Os temas abordados por McCandless parecerão carecer de aprofundamento até hoje, se aquilo que ele chamou sabiamente "um método" para a luz no teatro for transformado, em "fórmula", "receita" ou "cartilha" aplicada superficialmente. Ele mencionou ainda um "véu de mistério", causado pela aplicação dos, então recentes, conhecimentos da eletricidade, além da possibilidade de abordagem da luz como elaboração estética no espetáculo.

Outra face dessa mesma questão se apresenta de modo diferenciado nos nossos tempos de democratização da informação: hoje, pode-se "baixar" na rede mundial de computadores cartilhas e manuais que orientam a operação de acessórios, instrumentos e sistemas de controle da luz para a cena, dissipando - parcialmente - o mistério e instruindo virtualmente muitos iluminadores. Infelizmente, tal nível de instrução é insuficiente para a educação de um designer.

Observando os estudos de Appia, registra-se que as questões estéticas representam parte importante do trabalho de um iluminador. Do campo das artes visuais, liderados pela noção de contraste, variados temas, como forma, textura, cor, massa, volume, equilíbrio, design-composição, projeto, luz e sombra, dentre outros, apresentam-se como problemas a serem estudados. Acentuando as especificidades de cada um dos temas, faz-se necessário um enorme empenho investigativo.

Por outro lado, a objetiva integração da música ao contexto da luz para a cena incorporou a noção de tempo, que se pode fazer acompanhar de ritmo, melodia, harmonia, timbre (cor tonal), integrando andamento, movimento, tema, textura musical, atmosfera. Uma intricada rede de grande relevância para o compositor, uma vez que cada um desses aspectos contribui para a qualidade sonora percebida pelo apreciador. O seu estudo particular, ligado ao conhecimento da história da música, pode ser imprescindível para o músico com interesse investigativo no seu próprio campo de trabalho, determinando grande profundidade técnica.

De todo modo, resta ao iluminador o alívio de não ser um músico com tal interesse, o que o desobriga do imenso volume de estudos que isso exigiria. No entanto, tais observações podem alertar que, ignorando a música, ou a natureza 
musical do espetáculo, a interação da música com a luz, ele desconsidera possibilidades de expressão e controle que podem contribuir para o seu trabalho.

E ainda, ao tratar as relações entre a luz, a sombra, o ser humano e o seu ambiente, Appia abriu um grande leque de possibilidades teóricas, em diversas áreas do conhecimento. Tratar de luz e sombra inclui lidar com a química, a física, a mecânica, assim como envolve a história, a filosofia e as artes visuais. Appia abordava a excelência da expressão visual na práxis cênica com especial atenção para as relações entre a cenografia e a luz. Isso gerou um primeiro princípio plástico-crítico através do qual ele tratou duramente a pintura usada para sugerir tridimensionalidade na cena, uma vez que, em sua opinião, essa técnica gerava um conflito ou negava a efetiva tridimensionalidade do corpo do ator, assim como do espaço cênico, resultando numa incongruência visual, espacial. Vale destacar um importante princípio norteador de suas observações:

Hoje, o ressurgimento do corpo como um meio de expressão essencial para a nossa cultura estética, é um conceito que se apossa de muitas mentes, anima a imaginação, e dá origem a diversos experimentos, não de igual valor, sem dúvida, mas todos voltados para a mesma reforma. ${ }^{109}$ (APPIA, 1962, p. 4, tradução nossa)

Estudando o ator como referência para a compreensão visual do teatro, ele elaborou uma teoria que via no palco um lugar expressivo da tridimensionalidade, o que indicava tratamentos da cena muito diferentes daqueles que se observava no seu tempo. A apreensão da totalidade e da grandeza da sua obra sugere que o leitor esteja capacitado, disposto ou, quando menos, seja flexível o suficiente para pensar a cena como uma ocorrência visual. Recomenda-se até ao interessado nas ideias de Appia a efetiva experiência na produção visual e, melhor, determinado grau de educação visual fundamentada na experimentação. Haverá maiores chances de afinidade com suas ideias se o leitor evitar o encarceramento dos textos na rigidez de molduras teóricas que se revelam incapazes de pensar visualmente. Na eventual ausência de tais habilidades e competências e/ ou na presença de preconceito ou desentendimento da cena como manifestação artística visual a leitura pode resultar superficial ou equivocada. Jean-Jacques Roubine (1998, p. 132-133) esboça um comentário que tangencia o problema:

109 "Today, the resurgence of the body as an expressive medium essential to our aesthetic culture is a concept which possesses many minds, animates the imagination, and gives rise to diverse experiments doubtless not all of equal value, but all directed toward the same reform." 
Se encenadores tais como Copeau ou Gémier saudaram Appia como um dos teóricos mais importantes do teatro moderno, e se Craig o tinha na mais alta estima, não se pode dizer que a sua notoriedade tenha ultrapassado os círculos especializados dos profissionais e historiadores.

Com efeito, um historiador envolvido com a práxis cênica e habilitado a construir uma reputação positiva jamais negligenciará, deixando Adolphe Appia fora do contexto teatral, dada a contundência do seu pensamento. Mas é compreensível que a face das suas ideias cuja compreensão implica em familiaridade com estudos visuais deixe de receber a devida atenção da teoria teatral. Afinal, a visualidade (e, principalmente, a aplicação da luz na cena) representa terreno praticamente não visitado pela vertente teórica do teatro. Além disso, as opiniões de Jacques Copeau (1879-1949) e Firman Tonerre Gémier (1865-1933) são importantes principalmente para registrar a repercussão positiva da teoria appiana, entre os diretores franceses. A obra de Appia, no entanto, fala por si mesma e deveria garantir amplo espaço de estudo. Pode-se observar nos comentários do próprio Roubine (1982b, p. 134) a categoria do reconhecimento das suas proposições: "[...] um dos primeiros a tomar consciência dos extraordinários recursos que a iluminação elétrica põe a disposição do encenador". Nesse depoimento fica, ao menos, caracterizada a possibilidade de incorporação de uma teoria especificamente voltada para questões visuais da cena, envolvendo conceitos importantes:

Essa teoria cenográfica que repousa essencialmente em princípios arquitetônicos (estruturação das três dimensões do espaço cênico, modulação das formas e dos volumes, cheios e vazios, exploração dos potenciais da verticalidade e da horizontalidade, jogando com os planos oblíquos, ou contra eles...) levou Appia a diminuir, talvez até a sacrificar a parte da cor na imagem cênica. (ROUBINE, 1982b, p. 137-138)

Nesse comentário de Roubine, por conseguinte, encontram-se relevantes elementos para discussões da obra de Appia: além da inclusão de uma teoria cenográfica, podem ser considerados indícios para uma teoria da interação da luz com a cena, incluindo o sacrifício da cor e a investigação da "imagem cênica". A teoria teatral poderia alcançar maior relevância, reparando-se a grave lacuna no que se refere à especificidade da luz na cena como um campo de problematizações. Afinal, ainda que seja possível identificar papéis determinantes da luz em diversificados e importantes documentos da história do teatro, como tem sido sublinhado ao longo do presente trabalho, Appia introduziu um tratamento teórico 
particular, indicando o estudo do pensamento visual como estratégia para a resolução de problemas teatrais. E mesmo que seu trabalho acentue em grande parte críticas à cena wagneriana, ${ }^{110}$ ele deixou espaços para a observação da sua obra como teoria abrangente. Mesmo registrando que alguns leitores considerariam sua crítica pretensiosa levando-se em conta a reputação de Wagner, ele afirma: "Se não fui dissuadido diante dessas considerações foi apenas porque não conheço nenhuma maneira de comunicar tais convicções, que me parecem de considerável significado para a arte do teatro. ${ }^{111}$ (APPIA, 1962, p. 7, tradução nossa)

O breve comentário de Jean-Jacques Roubine acerca da cor traz um exemplo da amplitude radical das ideias de Appia. O que ele propôs não foi o sacrificío da cor na imagem cênica e, sim, o reconhecimento do seu elevado potencial expressivo quando ela é incorporada aos elementos cenográficos através da luz. Em lugar da informação cromática fixada nas pinturas que pretendiam sugerir tridimensionalidade, Appia acentuou uma enorme fluidez visual derivada da interação entre a luz e a cena em decorrência da aplicação sistematizada da cor, o que possibilitaria a elaboração de uma tridimensionalidade cênica integral e orgânica. Essa é uma sensível demonstração da sua abordagem da cena como um pensamento visual.

Um relato de Richard C. Beacham (1994) (autor, professor da Universidade de Warwick e professor visitante da Universidade de Yale) revela como o próprio Appia, já na adolescência, começou a desenvolver as preocupações visuais que mais tarde fundamentariam suas convicções sobre o teatro:

[...] Appia construiu, com um colega da escola, um pequeno teatro de papelão, mas ele discordava do uso que o colega fazia de recortes para o cenário. Ele os achava sem sentido e insistia em usar objetos reais no palco. A disputa foi fundamental e irreconciliável: culminou com a solene e deliberada destruição do teatro de brinquedo e todo o incidente funcionou como uma precursora miniatura da futura relação de Appia com o teatro real. ${ }^{112}$ (BEACHAM, 1994, p. 8, tradução nossa)

\footnotetext{
110 Muito influenciado pela obra e pela teoria de Richard Wagner (1813-1883), tanto no que se refere às composições do artista alemão, quanto à sua teoria, desenvolveu sua própria compreensão da parceria entre os diversos aspectos que compunham uma obra teatral.

111 "If I have not been dissuaded by these considerations, it is only because I know of no other way to communicate those beliefs which seem to me to have considerable significance for the art of the theatre."

112 "[...] Appia and a schoolmate.designed a small cardboard stage but fell out over the friend's use of conventional painted cut-outs for the scenery. Appia found these meaningless and insisted on placing real objects on stage. The dispute was fundamental and irreconcilable: it ended with the solemn and deliberate destruction of the original toy theatre, the whole incident a precursor in miniature of Appia's later relationship to the real theatre."
} 
Beacham (1994) afirma que ele sempre demonstrou interesse por atividades teatrais, mas a família calvinista o mantinha distante do teatro, restando-lhe inquirir os amigos que tinham permissão para assistir espetáculos, sobre que se via por lá. A permissão para envolver-se com a arte ficou limitada ao estudo da música, no Conservatório de Leipzig, sob a orientação do renomado maestro Hugo von Senger (1835-1892). Em 1878 Appia foi autorizado pelos pais a visitar a Opera local, onde assistiu Fausto, de Gounod, o que reforçou seu desagravo aos cenários de telões pintados, assim como ao arranjo espacial que decorria dessa técnica, como ele registrou: "Eu estava consciente de que os cenários eram frágeis e de que o piso do palco era chapado". ${ }^{113}$ (APPIA apud BEACHAM, 1994, p. 8, tradução nossa) Continuando os estudos da música, ele esteve em Paris, entre 1884 e 1886, seguindo depois para Dresden, onde permaneceu entre 1886 e 1890 . Nesses períodos, Appia desenvolvia seu pensamento sobre a cena, influenciado pelas ideias da cooperação entre as artes, derivada da obra teórica de Wagner, notadamente pelo conceito traduzido como "obra de arte total" que pode ser lido "obra de arte integral" (Gesamtkunstwerk).

É importante dizer que, se a obra musical e a teoria de Wagner deixavam profunda impressão positiva em Appia desde que assistiu Parsifal em 1882, apontada pela crítica como avançado estágio nos espetáculos wagnerianos, ele se sentiu decepcionado pelo uso tradicional do espaço cênico. A desaprovação de montagens com essa tendência é perpassada por uma nova maneira de conceber as funções da luz. Um dos mais importantes aspectos da sua abordagem já é exposto no início do seu discurso, assentando as bases da sua teoria:

Toda obra de arte deve conter uma relação harmoniosa entre sentimento e forma, um equilíbrio perfeito entre a ideia que o artista deseja expressar e os meios que ele usa. Se um dos meios nos parece claramente desnecessário para a expressão da ideia, ou se a ideia do artista - o objeto de sua expressão - nos é comunicada apenas imperfeitamente através dos meios que ele emprega, nosso prazer estético é enfraquecido, se não destruído. ${ }^{114}$ (APPIA, 1962, p. 10, tradução nossa)

Como se pode observar, Appia acreditava numa obra de arte norteada pelo conceito de unidade, questionada no decorrer do século XX, e confrontada pelas

113 "I was conscious of the flimsiness of the settings and the flatness of the stage floor."

114 "In every work of art there must be a harmonious relationship between felling and form, a perfect balance between the idea which the artist wishes to express and the means he uses to express it. If one of the means seems to us clearly unnecessary to the expression of the idea, or if the artist's idea - the object of his expression - is only imperfectly communicated to us by the means he employs, our aesthetic pleasure is weakened, if not destroyed." 
rupturas que defendem a fragmentação, a descontinuidade e a justaposição praticadas em iniciativas não realistas, para as quais a unidade buscada por ele pode soar ultrapassada, até idealista e/ou romântica. Apesar disso, sua obra ganhou repercussão entre especialistas e lhe garantiu reputação de inovador, precisamente devido à sua crítica às práticas do século XIX que, em sua opinião, incluíam primeiro a acentuação do ilusionismo pictórico e depois a representação detalhista da realidade, uma vez que ambas podem redundar em falsos espaços cênicos.

A despeito do grande respeito pela obra musical e teórica de Wagner, ele criticava o espetáculo produzido pelo compositor, considerando-o aquém do pensamento teórico e da harmoniosa conexão dos elementos do seu wort-tondrama. Sobre a expressão alemã, Beacham (1994, p. 38, grifo e tradução nossos) comenta:

O termo foi cunhado por seu amigo Houston Stewart Chamberlain: Ver Volbach, Adolphe Appia, p.35-6 e Bablet-Hahn (ed.), Oeuvres Complètes, vol. I, p. 444, nota 7. Na primeira página de A montagem do drama wagneriano [La mise en scène du drame wagnérien], Appia acentua que usa a expressão alemã WORTTONDRAMA - um drama, portanto, em que o poeta utiliza tanto a palavra, quanto a música. Esse tipo de drama é de alguma forma, uma síntese do Wort-drama, o 'drama em palavras', a peça propriamente dita, e o Ton-drama, o único e verdadeiro 'drama musical', no qual o poeta usa a música apenas, como Beethoven em Coriolan, na Sinfonia $n^{\circ} .3$ Heroica, entre outras obras. Assim como Berlioz em sua Symphonie Fantastique e Liszt nos Poemas Sinfônicos. Nunca será demais repetir quantas vezes Wagner se opôs fortemente à aplicação da expressão 'drama musical' para se referir ao seu trabalho para o palco. Como não temos em francês um equivalente para WORT-TONDRAMA, vou usar a expressão 'drama wagneriano' [drame wagnérien] ou 'drama do músico-poeta' [drame du poète-musicien], mas gostaria que o leitor tivesse em mente que, por 'drama wagneriano', não me refiro apenas à obra de Richard Wagner, mas, em geral, à nova forma de drama criado por ele. ${ }^{115}$

115 "The term was coined by his friend Houston Stewart Chamberlain: see Volbach, Adolphe Appia, p.35-36, e Bablet-Hahn (Ed.), Oeuvres complètes, Vol. I, p. 444, nota 7. On the first page of La mise en scène du drame wagnérien, Appia notes that he uses 'the German term WORT-TONDRAMA' - a drama, thus, in which the poet uses word and music alike. This kind of drama is in some way a synthesis of the Wort-drama, the 'drama in words', the play proper, and the Ton-drama, the only true 'music drama', in which the poet uses only music, as Beethoven in Coriolan, The Heroic Symphony, etc. Berlioz in his Symphonie Fantastique. Liszt in it's Symphonic Poems. One cannot repeat often enough that Wagner strongly objected to having this term of 'music drama' applied to his stage-work. As the French do not have an equivalent for WORT-TONDRAMA, I shall use the term 'Wagnerian drama' [drame wagnérien] or 'drama of the poetmusician' [drame du poète-musicien], but I would like the reader to keep in mind that 
O próprio Appia (1962, p. 28-29, tradução nossa) resume: "Os elementos constitutivos do drama poético-musical pertencem a dois grupos distintos: as palavras e os sons, transmitidos pela voz dos atores e pela orquestra, e os elementos visuais da montagem". ${ }^{116}$ Appia acentua seu interesse pela música, justificando-o na convicção de uma forte afinidade entre ela e a luz.

Ele pondera, citando Houston Stewart Chamberlain: "Apolo era, não apenas Deus da música, mas também da luz". ${ }^{17}$ (CHAMBERLAIN apud APPIA, 1962, p. 72, tradução nossa) Appia compreendia que luz e música compartilham grande flexibilidade, permitindo amplitude expressiva desde o mais sutil até um extraordinário e grandioso momento. Parte do seu empenho crítico para aproximar-se do novo "drama do músico-poeta", questionando as montagens tradicionais e, em particular, as montagens da obra de Wagner, pode ser observado em A música e o espetáculo (La musique et la mise en scène). ${ }^{118}$ Escrito entre 1892 e 1897, e publicado dois anos depois, numa tradução alemã (Die musik und die inscenierung), assinada pela princesa Elza de Cantacuzène, é hoje um livro raro como exemplar impresso. A cópia usada no presente trabalho pode ser encontrada na rede mundial de computadores.

Ele escreveu outros dois textos, A montagem do drama wagneriano (La mise en scène du drame wagnerien), em 1891 e A obra de arte viva (L'oeuvre d'art vivant), publicado em 1921, nos quais se pode confirmar sua presença como primeiro grande teórico moderno a concentrar esforços na investigação de presenças da luz na cena. Aqui serão citados, prioritariamente, trechos de A música e o espetáculo; não somente o original, mas também a tradução inglesa, de Robert W. Corrigan e Mary Douglas Dirks (1962), na qual eles usaram tanto o original francês - disponível na Schweizer Theatersammlung, Landesbibliothek, em Berna, Suíça - quanto a versão alemã. Essa edição inglesa de 1962 traz um prefácio original escrito pelo próprio Appia, em 1918.

A escolha de A música e o espetáculo é sintomática para o método aqui aplicado, pois identifica um momento ou fragmento da sua obra que sublinha as interações entre a luz e a cena, no caso, apresentando uma interação particular com a música. Como já foi dito acima, a obra de Wagner estabelece relações com outros composi-

\footnotetext{
by 'Wagnerian drama' I do not only refer to the work of Richard Wagner, but, more generally, to the new form of drama created by him. Trans. Peter Loefer. Staging Wagnerian Drama, p. 89."

116 "The constituent elements of word-tone drama fall into two distinct groups: the words and tones as they are transmitted by the actors'voices and the instruments of the orchestra, and the visual elements of the production." 117 "Apollo was not only the god of song, but also of light."

118 Para aqueles leitores interessados numa abordagem da sua obra, em língua portuguesa, Cibele Forjaz traçou um panorama que incorpora competência de pesquisadora e paixão de quem pensa visualmente a cena, na sua dissertação de mestrado, mencionada na introdução deste trabalho.
} 
tores, como os citados Ludwig von Beethoven (1770-1827), Hector Berlioz (1803-1869) e Franz Liszt (1811-1866). Se for tomado como exemplo o Coriolano, ${ }^{119}$ [Coriolan] de Beethoven, pode-se levar em conta outras obras de referência como Coriolano, de Shakespeare e até o Coriolano que aparece na obra de Plutarco (ca. 46-12o d.C.), Vidas de nobres gregos e romanos.

Pode-se dizer que Beethoven "conta a história" - escrita por Shakespeare, provocado por Plutarco - de um general romano que luta contra o infortúnio causado pela inconsequência do seu próprio orgulho. Dessa assertiva deriva um questionamento, acentuando-se que Beethoven teria permitido a invasão da estrutura da sonata ao privilegiar o interesse em contar a história. Para o apreciador, ao contrário disso, pode impressionar a singularidade da obra, capaz de narrar com paixão permeada de precisão e controle a história de Coriolano. Os dois aspectos podem, por si só, justificar uma profunda relação cênica entre a música e a luz.

Um estudioso da música ou, em particular da obra de Beethoven, poderá estabelecer análises comparativas - com acuidade técnica não disponível a simples apreciadores - que podem incluir outras obras, principalmente do mesmo compositor. Para o iluminador torna-se necessária a aproximação com a estética, com a forma, com a poética de Beethoven para promover subsídios, fundamentação, ouvindo, não somente a abertura em questão, mas outras peças, por exemplo, Fidelio,' considerando que essa é a única ópera escrita pelo compositor.

Pode-se compreender o fascínio de Appia pela música quando são observados o controle e a precisão, caros para sua abordagem visual, constatando-se a relevância dessas variáveis na contribuição da luz para o teatro. Diante de um projeto para Coriolano, a Abertura pode ser esclarecedora para o iluminador, observada a consistência dos temas musicais que elaboram a saga do general romano, as súplicas da sua mãe que - como Appia acentuou - não são narradas com palavras, mas expressas nas frases sonoras através da elaboração de atmosferas, no contraste entre o cortante dos violinos e a suavidade e maciez arredondada dos sopros, mais em congruência com os violoncelos. A importante relação entre a música e a cena, presente na compreensão de Appia, sugere elos entre o modo como a luz pode contribuir para as atmosferas de uma montagem, promovendo parcerias e trocas esteticamente produtivas.

119 Opus 62 em dó menor, para duas flautas, dois oboés, dois clarinetes, dois fagotes, duas trompas, dois trompetes, tímpanos e cordas, escrita em 1807 e incluída como introdução a uma apresentação da peça Coriolan, de Heinrich Joseph von Collin (1771-1811), dramaturgo vienense com o qual Beethoven pretendia trabalhar, tendo-o como libretista, escrevendo anualmente uma ópera, no Teatro Imperial de Viena. A parceria não aconteceu, pois Beethoven não conseguiu fechar o contrato, mas nos rendeu sua Abertura para Coriolano. 
De acordo com Arnold Aronson (1991, p. 3, tradução nossa), Appia investiu na sugestão, na simplicidade, na abstração e na grandeza, propondo um dispositivo cênico tridimensional, escultural, capaz de unificar o ator e a cena como espaço teatral: "O resultado é uma imagem visual em concordância com o pensamento do autor". ${ }^{20}$ A plasticidade explícita das suas proposições, portanto, mantém a presença da dramaturgia - poético-musical - como um aspecto provocador do espetáculo, afirmando o valor da visualidade e, consequentemente, do binômio luz-sombra. Ainda assim, pode-se observar que o presumível poder do dramaturgo se relativiza:

Segue-se, portanto, que o drama (tal como produzido no palco), não somente é a mais complexa de todas as artes, mas também a única na qual um dos elementos básicos [a montagem/o espetáculo] não pode ser considerado um meio de expressão controlado pelo dramaturgo, uma condição que diminui de modo agudo a integridade do drama, como uma forma de arte, relegando-o a um status inferior. ${ }^{121}$ (APPIA, 1962, p. 11, grifo e tradução nossos)

O texto enfrentava, então, uma crise imposta pela incompletude inerente à sua própria natureza, enraizada na sua condição de estágio pré-cênico, de momento transitório a caminho do palco. Appia compreendia a cena como duas partes interligadas: o elemento animado - o ator, a forma viva do corpo humano - e os elementos inanimados (mesmo que postos em movimento), que ele reduz a três, para a sistematização da sua teoria: a luz, a organização espacial do dispositivo cenográfico - la plantation - e a pintura, os telões. Ele procurou demonstrar, então, a incongruência da pintura, dos telões cenográficos que, como objetos bidimensionais concebidos para criar ilusão de volume geravam sérios conflitos com a efetiva tridimensionalidade do corpo do ator. Era indispensável, portanto, investir em um novo arranjo espacial da cena cujos elementos inanimados já fossem construídos como corpos tridimensionais.

Appia (1962, p. 22, tradução nossa) ponderou: "[o cenário pintado] é incapaz de revelar qualquer realidade viva e expressiva por si mesmo e perde o poder de significação à medida que todo o resto da cenografia desempenha uma função ativa na

120 "The result is a visual image at one with the playwright's thoughts."

121 "It follows therefore that the drama (as produced on stage) is not only the most complex of all arts, but also the only one of which one of the basic elements may not be judged as a medium of expression in the dramatist's control, a condition acutely diminishing the integrity of drama as an art form and relegating it to an inferior status." 
cena". ${ }^{122}$ Reconhecendo que o cenário figurativo pintado ocupava de forma predominante o teatro do seu tempo, desde o início da apresentação da sua teoria ele destacou a luz como o mais expressivo entre os elementos inanimados da cena. No entanto, projetá-la sobre cenários pintados significava promover a mera função de iluminar, para tornar visível, criando "falsas realidades". Isso destruiria a harmonia orgânica exigida para a integridade da arte teatral, que depende da presença do ator, sem a qual os demais aspectos da montagem permaneceriam alienados do drama (compreendido, nesse caso, como expressão artística de conflitos humanos). O corpo vivo do ator exige funções ativas da luz.

Ficava indicado o caminho para a produção de um dispositivo cenográfico vivamente integrado ao espetáculo e cujo objetivo se afastasse da ilusão promovida por elementos pictóricos bidimensionais: "[...] é apenas através do poder da luz que o cenário pode tornar-se verdadeiramente expressivo, e isso deve ser considerado na sua construção". ${ }^{23}$ (APPIA, 1962, p. 64, tradução nossa) Como já foi dito, o dramaturgo produz sua obra com o olhar na cena; além de discutir a autonomia do autor, Appia elaborou indicações teóricas de uma cena integralmente concebida e construída sob os pressupostos da sua relação com a luz. A verdadeira expressão de uma montagem somente seria alcançada quando efetivada essa relação. Ele justifica, então, espaço para a discussão da luz, ao descartar o meio termo entre o que denomina "realização plástica positiva" (o dispositivo cenográfico tridimensional, não necessariamente figurativo) e os telões pintados. (APPIA, 1962, 1986) Appia (1962, p. 46, tradução nossa) ratifica, portanto, a função ativa da luz na nova cena:

[...] o que, senão a luz, dá essa magnífica unidade ao espetáculo que contemplamos cada dia, permitindo-nos viver através dos nossos olhos. | Sem essa unidade, distinguiríamos apenas vagamente o significado das coisas e nunca sua expressividade, pois, para que as coisas sejam expressivas, elas devem ter forma, e forma sem luz comunica apenas o sentido do tato. ${ }^{124}$

\footnotetext{
122 "[the scene painting] is incapable of revealing any living and expressive reality by itself, and it loses its power of signification to the extent that the rest of the setting plays an active part in the scene."

123 Da tradução inglesa: "[...] it is only through the power of the lighting that the setting can become truly expressive, and this fact must be taken into account in its construction".

124 "[...] what is it if not light that gives that wonderful unity to the spectacle we contemplate each day, allowing us to live through our eyes? / Lacking this unity, we should be able to distinguish only dimly the meaning of things, and never their expressiveness; for in order that things be expressive, they must have form, and form without light communicates only to our sense of touch."
} 
Em uma nota de rodapé, ele chamou a atenção do leitor: "Quando me refiro à luz, é evidente, quero dizer a atividade da luz, não apenas "visibilidade". ${ }^{25}$ (APPIA, 1962, p. 46, tradução nossa) Sucinta ponderação que congrega toda a sua teoria e que poderia repercutir positivamente em projetos de luz para a cena, até hoje. Essa "atividade" da luz estaria ligada às chamadas funções ativas que ela pode desempenhar no espetáculo. Ou seja, não bastaria projetar luz colorida, gráfica, recortada, em movimento mecânico constante, pois ainda assim o espectador poderá ter apenas o resultado de banalização da alta tecnologia, sem que isso repercuta numa práxis cênica com força visual expressiva. Aliás, mesmo os envolvidos nas diversificadas iniciativas, cujos fundamentos se encontram na desconstrução da unidade, poderiam "ouvir" Appia. Afinal, sem familiaridade estética com a luz eles podem até gerar, acidentalmente, unidade. Mesmo que isso seja pouco provável, caso ocorresse a função ativa da luz, estaria transformada numa armadilha, pois negaria ou trairia a intenção de desconstruir a unidade.

Ainda que sua preocupação com a luz se manifeste em toda a primeira parte do seu livro, voltada para a montagem propriamente dita, Appia (1962, p. 72, tradução nossa) reservou um espaço específico para aspectos da luz, e depois para a pintura, onde as funções da cor ganham grande destaque. Reafirmando as relações entre a luz e a música, ele acentua: “[...] ambas, [a luz e música] são dotadas de incomparável flexibilidade que as permite percorrer consecutivamente todos os graus de expressão, do mais simples ato de presença até o mais intenso transbordar de emoções". ${ }^{226}$ Importa relacionar tal flexibilidade expressiva com a intenção do autor de propor alguma sistematização para a aplicação da luz, acentuando os benefícios do estudo das possíveis relações entre o ator, o arranjo espacial (la plantation) e o texto (poético-musical).

Partindo dessa relação dinâmica, Appia sugeriu princípios que definiram sua abordagem da luz teatral. Destaco observações que incorporam provável sistematização, como a noção da "quase simultaneidade" inerente à composição do arranjo cênico e da luz, dando pistas da interação dinâmica entre os dois aspectos, um dependendo do outro. Além disso, é importante registrar a compreensão de Appia do arranjo espacial - ou dispositivo cenográfico - que deveria apresentar respostas particulares a cada espetáculo, descartando os cenários que se repetiam, ficando evidenciada sua indicação de uma intervenção flexível da luz, que a tornasse capaz de interagir especificamente com cada acontecimento e cada cena.

125 "By light, of course, I mean the activity of light, not simply 'visibility'."

126 "Both elements have an extraordinary flexibility which permits them to run through all modes of expression consecutively, from a simple statement of existence to the most intense overflow of emotion." 
Isso quer dizer que o posicionamento fixo dos instrumentos - denominados refletores - pode determinar limitações para que a luz intervenha de acordo com as exigências de cada momento. Em tais observações, reside uma importante crítica aos sistemas mais comumente encontrados nos teatros do seu tempo, nos quais ele apontava a ausência de mobilidade e de precisão.

Appia analisava os mencionados sistemas usando como critério a relação entre as características técnicas de cada instrumento, sua posição no palco e a função que ele esperava dos mesmos, apresentando os quatro modos de sistemas de iluminação geralmente usados: uma vara horizontal atrás e acima da boca de cena para iluminar os telões pintados, complementada por luzes dispostas nas coxias e no piso do palco, com o mesmo objetivo; a ribalta, que ele chamou de "monstruosidade", para iluminar os atores e também os cenários, projetando uma luz frontal, de baixo para cima; dispositivos móveis que permitiam acesso e manipulação para fachos de luz precisos, ou diversificadas projeções; e a luz por transparência, geralmente produzida por instrumentos colocados atrás dos telões pintados, para interagir com elementos cenográficos transparentes (ou translúcidos).

Em sua opinião, os espetáculos mostravam como a interação técnica dos aparatos poderia ser complicada e até impraticável, se fosse negligenciada a precisão, resultando em contradição que destrói a potencialidade da harmonia. Ele elaborou uma problematização: "Como conciliar, de fato, uma luz destinada a iluminar os telões verticais, que não ilumine outros elementos [cenográficos] dispostos entre a fonte de luz e os mencionados telões e painéis verticais?". ${ }^{127}$ (APPIA, 1962, p. 95, tradução nossa)

Sua crítica concentrava-se na imprecisão, tanto no que se refere às limitações de cada instrumento quanto ao seu uso simultâneo, que produziam resultados contraditórios, como no caso da ribalta, responsável pela exposição indiscriminada de tudo que estivesse ao seu alcance. A postura de Appia indicava certa sistematização que procurasse estabelecer ligações entre a técnica e as funções expressivas da luz, das quais ele apontava duas principais: a luz poderia ser "difusa", ou seja, aquela que preencheria o ambiente; ou a "ativa", que produziria focos específicos. Tais funções baseavam-se na observação da luz do sol, considerando os mais variados resultados da sua interação cotidiana com o ambiente. Tratava-se de uma convenção muito radical, se for levado em conta que a luz passiva e a luz ativa, observadas à luz do sol, em momentos e locais diferenciados, podem ser

127 “Comment concilier, en effet, une lumiére destinee à eclairer les toiles verticales et qui n'en frappe pas moins les objets placés entre elles, avec une lumiere destinée à ces objets et qui n'en frappe pas moins les toiles verticales?" 
aplicadas simultaneamente na cena, do modo como o artista considerar indicado para a construção visual do seu espetáculo.

Appia até considerava que os instrumentos disponíveis em posições fixas nos teatros, poderiam operar na produção da luz difusa, mas apontava a necessidade de estudos do seu posicionamento, uma vez que a nova práxis cênica por ele proposta descartava a disposição sucessiva de pinturas verticais paralelas, para as quais as posições fixas dos instrumentos de luz foram concebidas. Para a luz ativa ele demandou pesquisas que investigassem maior eficiência técnica dos instrumentos, incluindo sua mobilidade e manuseio, para permitir flexibilidade no atendimento das novas proposições dos dispositivos cenográficos concebidos a partir de então, diretamente relacionados às particularidades de cada espetáculo, mudando radicalmente a geografia da cena, a partir da introdução do verdadeiro [real] tridimensional. ${ }^{128}$ (Figuras 114 e 115)

Tal flexibilidade deveria também alcançar as relações técnicas entre a luz difusa - através da qual se estabeleceria "visibilidade" e a luz ativa, que - ainda segundo Appia - deveria expressar a noite, a lua, uma tocha, e até o "sobrenatural". A inclusão do sobrenatural abria enormes espaços para a aplicação da luz ativa, indicando saídas para a limitação imposta pela proposição figurativa - ou realista. Além disso, preocupado com o controle da intensidade da luz, ele indicou o uso de telas-filtro que apresentassem variados graus de transparência, com o objetivo de evitar a exposição excessiva de elementos cenográficos, ou mesmo de atores que se aproximassem dos instrumentos destinados à luz difusa.

A estratégia era criar diversificadas variações visuais no espetáculo, contando com a mobilidade e com a possibilidade de adaptações dos instrumentos aplicados à luz ativa, além de alguma organização prévia do sistema elétrico do teatro, incluindo o aparato da iluminação. Isso indicava esboços do pensamento que originaria, na década de trinta do século XX, o theatre lighting design, em busca da efetiva expressão visual da cena, uma vez que o arranjo espacial e a luz deveriam atuar em constante interação, criando uma espécie de atuação "invisível” da luz.

Appia também parte de uma compreensão muito inovadora do ator, emprestando-lhe um papel até então não mencionado, para fundamentar suas convicções acerca do espetáculo:

[...] o ator é uma massa sólida que não pode ser iluminada por uma imitação da luz; para ter luz no palco um ou outro deve ser eliminado [o ator ou a pintura de telões, que ele considera

128 Cf. Figuras 139 e 140, para comparação entre a proposta de Appia e o cenário da montagem do Bayreuth. 
imitação da luz]. Se dispensamos o ator, o drama é eliminado, [...]. Portanto, a pintura deve ser sacrificada. ${ }^{129}$ (APPIA, 1962, p. 75, tradução nossa)

Em primeiro lugar, reduzida a "massa sólida", uma diva sentir-se-ia ofendida. Nessa constatação, entretanto, Appia estava defendendo o ator na sua condição de corpo que afastava as convenções da pintura, da bidimensionalidade:

O arranjo cenográfico tem [...] apenas uma maneira de se transportar para a cena: através do Ator. Sem ele [o ator], o drama não existe, e, sem a sua influência sobre outros fatores representativos, o espetáculo permanece estranho ao drama. É ele quem traduz o Arranjo Espacial, a Iluminação e a Pintura, em uma linguagem que o drama possa compreender e na qual o texto poético-musical confie. Ele é o intérprete da música diante de um quadro inanimado. ${ }^{130}$ (APPIA, 1986, p. 76, tradução nossa)

O conceito de organismo unificado, no qual Appia baseou sua ideia de espetáculo, dispensava, portanto, a pintura figurativa, uma vez que a luz nela imitada estabeleceria sérios conflitos visuais com a luz ativa, viva, definidora da cena. O próprio pintor (cenógrafo) deveria incorporar certas limitações para vincular seu trabalho ao palco, pois a luz viva da cena destruiria, como diz Appia, os princípios que regulavam o uso da cor na pintura para o teatro. O arranjo cromático, assim como as formas da pintura figurativa, ambos perdem seu sentido e valor expressivo, pois não permitem a interação com os elementos "vivos" da cena: não somente o ator, mas também os elementos (tridimensionais) inanimados. Isso indicava a criação de novos princípios, que afastassem a imposição de um caráter "quimérico" para a luz, fazendo-a renunciar à representação figurativa. Appia considerava que a diferença entre as convenções que regiam a pintura e a cena levariam a primeira a submeter-se à expressão tridimensional da outra, já manifestada no seu elemento vivo principal, o ator.

Dessa relação derivaram questões que merecem observação. O pintor de cenários, afirmava Appia, deveria abrir mão da presença do ser humano, uma vez que

129 " [...] the actor is a solid mass, which cannot be lighted by imitation light; in order to have light on the stage, one or the other must be sacrificed. If we dispense with the actor, the drama is effaced, [...]. Therefore, the painting must be sacrificed."

130 “La partition n'a, [...], qu'une voie pour se transporter sur la scene: c'est l'Acteur. Sans lui le drame n'existe pas, et sans son influence sur les autres facteurs representatifs la mise en scene reste etrangere au drame. C'est lui qui traduit pour la Plantation, l'Eclairage et la Peinture, en un langage qu'ils puissent comprendre, ce que le texte poetique-musical lui a confie. Il est l'interprete de la musique aupres du tableau inanime. 
na pintura ele seria reduzido a uma representação fictícia - como o próprio Appia qualifica - enquanto que na cena o ator se apresentaria vivo e na condição de corpo principal. O artista que fazia uma obra pictórica para o teatro estava pronto para refrear suas próprias visões, atendendo aos caminhos apontados pelo dramaturgo. E o poeta-músico trazia suas visões para a cena através da própria música, que detinha posição hierárquica superior, promovendo controle do poeta sobre todos os outros elementos do espetáculo, incluindo a pintura.

Fora da cena um pintor impregnava de visões, de imagens pessoais, seus suportes, enquadrando-os à "imobilidade" que Appia via na pintura. O pintor-cenógrafo, entretanto, perdia tal poder, uma vez que deveria se render aos pressupostos encaminhados pela dramaturgia. O novo espetáculo, por conseguinte, impunha à pintura a exclusão da representação pictórica do ser humano, evitando assim conflitos com a imagem viva do ator, em movimento na cena. E, no caso específico do wort-tondrama, o drama poético-musical, a música teria enorme contribuição naquilo que seria visto na cena, provocando atmosferas. Para Appia (1962), a mobilidade mecânica da pintura de cenários era uma incongruência, uma vez que atacava e subtraía um dos maiores poderes do pintor, ou seja: o direito de observar seus objetos ou temas, selecioná-los e fixá-los na bidimensionalidade imóvel de um suporte que, assim como os instrumentos e materiais, refletem prioritariamente suas escolhas e decisões.

Isso sugere uma nova postura, assumida por Appia (1962, p. 100, tradução nossa):

Desse modo, torna-se necessário estudar mais detalhadamente a interação da iluminação, no que se refere à cor, para saber se a pintura, no sentido comum da palavra, mantém um papel distinto no novo espetáculo, fora do conceito geral de imagem cênica [quadro]. ${ }^{131}$

Mais que listar regras, ele indicou investigações, reflexões norteadas pela aplicação da luz, que apontem caminhos para o uso da cor na montagem do drama poético-musical. Na opinião de Appia, portanto, a cor que representava a luz na pintura figurativa, tornou-se desnecessária; ao contrário disso, a luz incorporaria à cor usada na cena as características vivas que a imobilidade da pintura lhe subtraíra. Além disso, ele ponderou que a luz pode incorporar cor ao espetáculo, não somente através de acessórios, como filtros de vidro colorido, mas, também,

131 “Il devient donc necessaire d'étudier plus en detail le jeu de l'eclairage au point de vue de la couleur pour savoir si la peinture, au sens ordinaire du mot, conserve un role distinct de la nouvelle mise en scène, en dehors de la conception generale du tableau scenique." 
das características particulares de cada instrumento ou fonte (temperatura de cor). O que Appia (1962, p. 97, tradução nossa) procurava esclarecer pode ser observado num pequeno fragmento do seu texto: “[...] a cor já não depende de telas verticais para exteriorizar-se, [...] ela está tão estreitamente ligada à luz, que é difícil separar uma da outra”. ${ }^{132}$ A relação intrínseca entre luz e cor pode, até hoje, servir de alerta para o iluminador.

Appia (1962, p. 32, tradução nossa) discordava do teatro do seu tempo também no que se referia às relações entre a luz e os objetos da cena: "[...] para cada um dos objetos é designada uma cor e, finalmente, a luz é usada para torná-los mais ou menos visíveis." ${ }^{33}$ E quando a ilusão buscada pela cena incluía diferentes momentos do dia, procurando expressar esses momentos com mudanças convencionais de cor e intensidade na luz, o resultado não satisfazia, uma vez que a luz "viva" não interagia com a luz pintada no cenário, produzindo falso tratamento cromático. Tal constatação estava ligada à ilusão cênica ideal defendida por Appia (1962, p. 32 , tradução nossa): "A ilusão criada por uma obra de arte não se destina a nos iludir acerca da natureza das emoções ou objetos, em sua relação com a realidade, e sim, para nos levar tão completamente a visão do artista, de modo que ela pareça ser a nossa própria". ${ }^{134}$

Ele apontava o crescente gosto pelo sensacional - aparatoso - como responsável pelos investimentos na pintura figurativa e nos artifícios decorativos, desconsiderando-se as funções ativas da luz, que era usada somente para - mais ou menos - iluminar. Appia aplicou também a expressão "suprema ilusão", na qual ator e cenário abrem mão de características figurativo-representativas, buscando uma presença em comum na cena. Se o ator perde em liberdade, quando interage com elementos musicais - como a duração - que ganham considerável importância estética, operando como aspectos responsáveis pela transformação do corpo humano vivo, em movimento, em corpo artístico, o cenário responde apresentando-se como lugar para, com a luz, elaborar as atmosferas nas quais o corpo vivo se manifestará. Um telão pintado torna-se, portanto, obsoleto.

O cenário ganhava nova abordagem para se tornar o "terreno" do ator, como explica Appia (1962, p. 64, tradução nossa):

\footnotetext{
132 "[...] la couleur, pour s'exterioriser et ne plus dependre des toiles verticales, [...]."

133 Da tradução inglesa: "[...] each of these objects is given a suitable color, and finally, light is used only to make them more or less visible".

134 "The illusion created by a work of art is not to delude us regarding the nature of emotions or objects in their relationship to reality, but rather to draw us so completely into the artist's vision that it seems to be our own."
} 
O terreno do ator no drama poético-musical é determinado, acima de todas as outras considerações, pela sua presença. Entenda-se que terreno não se refere apenas àquela parte do palco tocada pelos pés do ator, mas tudo na composição do cenário, relativo à forma material da personagem e às suas ações. ${ }^{135}$

Isso sugeria caminhos para decisões visuais que promoveriam harmonia na cena, exigindo alto grau de planejamento dos elementos cenográficos, inclusive da cor que, interagindo com a luz, expressaria as atmosferas indicadas, ou resultantes da ação. Uma vez que o terreno estaria desatrelado da ilusão figurativa, ele poderia ser concebido e construído com o objetivo de revelar profundas instâncias visuais evocadas pela ação das personagens. (APPIA, 1992) O afastamento da ilusão cromática aponta a nova função da luz:

Privada pela luz viva da sua própria vida no palco, a cor [pintada] perde os benefícios derivados da imobilidade na pintura. Se a cor deve funcionar como um elemento valioso na montagem, ela deve estar subordinada à luz. Pois, quando a luz deixa de ser fictícia, ela destrói a importância relativa de combinações de cores [da pintura de cenários]. A mobilidade característica de qualquer imagem da cena requer, portanto, que a iluminação assuma a maioria das funções anteriormente oferecidas pela cor, ao pintor. [...] As cores estáticas da pintura deixam de representar a luz, mas a luz retira da cor tudo aquilo que se opõe à sua mobilidade. ${ }^{136}$ (APPIA, 1962, p. 81, tradução nossa)

Appia (1962) propõe uma práxis cênica na qual a cor ganha nova posição e a luz nova função. A última deve ser concebida e planejada para, interagindo com os elementos do dispositivo cenográfico, revelar novas cores a cada cena, de acordo com as atmosferas criadas pela música. Além da capacidade de transmitir, de criar cor, Appia via, na cena, possibilidades técnico-estéticas da luz citadas em dois parágrafos que, pela sua importância, impõem menção integral:

135 "The terrain of the actor in the word-tone drama is determined above all other considerations by the actor's presence. Here it is to be understood that by terrain I mean not merely that portion of the stage trod by the actor's feet, but everything in the composition of the setting relating to the material form of the character and his actions." 136 "Color, deprived of its own life on the stage by living light, loses the benefits it once derived from immobility. If color is to perform as a valuable element in production, it must be subordinate to light. For when light ceases to be fictive in character, it destroys the relative importance of color combinations. The mobility characteristic of any stage picture requires, therefore, that the lighting assume a good many of the functions which color alone once gave to the painter. [...] It is no longer static colors which represent light, but light which takes from color all that opposes its mobility." 
A luz pode também projetar imagens que vão desde a gradação de tons mais delicados até os mais definidos efeitos. Um obturador [qualquer acessório para bloquear a luz], colocado diante da fonte de luz, pode dirigir um facho para uma parte do palco, deixando as outras áreas na escuridão. Começando com esse efeito simples, temos uma série de possibilidades, cujo escopo é limitado apenas pelas variedades, formas e combinações de transparências. A luz, que já ganha mobilidade pela presença dos atores, em cuja atividade ela toma parte, torna-se ainda mais móvel, se a fonte de luz pode ser movimentada, se as imagens projetadas são colocadas em movimento diante de uma fonte de luz estável, ou se a lente colocada na frente da fonte de luz pode, de alguma maneira, vibrar. Essas cores, formas e movimentos, combinadas entre si e com a imagem palco, oferecem inúmeras possibilidades; elas constituem a paleta do autor do drama poético-musical. ${ }^{137}$ (APPIA, 1962, p. 82, tradução nossa)

Ele compreendia a práxis cênica como uma manifestação artística que, já no drama, se impõe como uma assertiva visual:

Tanto a luz viva quanto a difusa requerem um objeto no qual sejam projetadas. A luz não muda a forma desses objetos, mas, ao contrário, serve para revelar sua presença e, portanto, torná-los expressivos. Com a adição de cor, a iluminação agora começa a modificar o esquema cromático do próprio objeto; além disso, uma fonte de luz equipada para projetar uma combinação de cores, ou uma imagem ou design, tem o poder de criar um ambiente no palco, e até mesmo de criar objetos através da projeção. Para tornarem-se visíveis as imagens projetadas devem atingir um objeto, o que vale tanto para a luz ordinária [sem cor] quanto para a colorida. Mas, ao contrário dos raios de luz simples, imagens projetadas afetam fortemente a natureza essencial desses objetos (para o espectador). Outrossim, esses objetos, por causa das suas várias formas e dimensões, respondem ativamente, modificando a imagem projetada. Portanto, se a inte-

\footnotetext{
137 "Light can also project images ranging from the most delicate gradation of hues to the sharpest effects. A shutter, placed over the source of light, can direct a beam to one part of the stage, leaving the other areas in darkness. Starting with this simple effect, we have a host of possibilities whose scope is limited only by the varieties, shapes, and combinations of transparencies used. The lighting, already made mobile by the presence of the actors, in whose activity it takes part, becomes even more so, if the light source can be moved about, if the projected images are placed in motion before a stable light source, or if the lens in front of the light source is vibrated in some manner. These colors, forms, and motions, variously combined with each other, and, in turn, with the stage picture, offer innumerable possibilities; they constitute the palette of the word-tone poet."
} 
ração entre a luz colorida e um cenário pintado é simplesmente uma questão de dimensões cromáticas, o problema da projeção está, além disso, associado às formas. Em ambos os casos, estamos preocupados com a cor dos objetos, independentemente dos efeitos de luz. Essa independência é, naturalmente, relativamente pequena, quando consideramos a soma total dos elementos que compõem a imagem cênica. ${ }^{138}$ (APPIA, 1962, p. 82, tradução nossa)

Confirma-se que, dispensando a pintura de telões, o teatro se concentraria numa nova categoria de arranjo espacial na qual a ilusão figurativa perdia seu papel dominante na qualidade plástica da cena. Tornava-se necessário procurar outros critérios através de meios plásticos para mensurar o grau de realidade do qual a cena deveria ser impregnada, já que o drama poético-musical apresentava proporções que não podiam ser encontradas no cotidiano, nos objetos com os quais o espectador estava familiarizado. O corpo do ator afirmava-se como parâmetro para a ligação com a realidade. Um corpo que desenvolveu grande capacidade vocal e domínio expressivo do movimento, através daquilo que Appia chama de treinamento em ginástica, ganhando em flexibilidade, no seu sentido mais amplo. Para serem levados à cena, os detalhes visuais da experiência cotidiana submeter-se-iam a uma seleção que até os poderia omitir inteiramente, de acordo com a representação visual de cada espetáculo. Alcançando a excelência da combinação entre luz e movimento, os elementos cênicos poderiam ser esteticamente concebidos em forma, cor e textura.

O interesse pelo realismo (figurativo) da cena dava lugar à expressão visual do drama poético-musical como espaço "verdadeiro". Até mesmo o ator podia ter sua própria dimensão/proporção reconsiderada para acentuar a expressão dos elementos inanimados, exigida por uma montagem. Afinal, quebravam-se os compromissos com qualquer imitação de realidade. Os novos princípios cêni-

138 "Both the living and the diffused light require an object on which to focus. The lighting does not change the form of these objects, but rather serves to make their presence felt, and hence to make them expressive. With the addition of color, the lighting now begins to modify the object's own chromatic scheme; moreover, a light source equipped to project a combination of colors, or an image or design, has the power to create an environment on stage, and even to create objects by means of projection. In order to be visible, projected images must strike an object as is the case for both ordinary and colored light. But, unlike simple light rays, projected images strongly affect the essential nature of these objects (for the spectator). Moreover, these objects, because of their various shapes and dimensions, respond by actively modifying the projected image. Therefore, if the interplay of colored light and painted scenery is simply a matter of chromatic dimensions, the problem of projection is in addition associated with forms. In both cases, we are concerned with the color of objects independent of the effects of lighting. This independence is, of course, relatively small when we consider the sum total of the elements making up the stage picture; yet its existence cannot be ignored any more than that of any other element of production." 
cos baseavam-se numa composição construída para cada cenário dado, no qual superfícies "poliformais" seriam distribuídas na cena. O que antes era pintura de telões, transformar-se-ia em "cor no espaço". A cor assume, portanto, o papel de simplificador "harmonizante": "A cor dos objetos, que constitui o estrito papel da pintura no nosso novo conceito de montagem, é importante para a forma do ator, em geral, e, particularmente, para a forma do seu figurino". ${ }^{139}$ (APPIA, 1962, p. 86, tradução nossa)

Ficava determinada a importância do modo como o ator seria iluminado, descartando-se o tratamento decorativo dos cenários que negariam sua presença viva, tornando-o apenas visível, a despeito dos inúmeros efeitos (meramente decorativos, que as novas combinações da luz possam oferecer). O tratamento visual do ator devia levar em consideração o figurino que transformaria seu corpo numa unidade visual particular, em cada espetáculo, cena ou momento. Nas palavras de Appia (1962, p. 89, grifo e tradução nossos): "[...] o figurino deve ser considerado, também, do ponto de vista da cor e do design". ${ }^{140}$ Essa relação entre cor e design indicava a relevância do projeto visual de cada montagem, que deveria interagir com os elementos vivos do espetáculo, a luz e o ator.

A compreensão de Appia (1962, p. 81, tradução nossa) é projetada firmemente, quando ele estabelece: "O autor do drama poético-musical pinta sua imagem com luz". ${ }^{141}$ A cena, portanto, seria imagem tridimensional pintada com luz, já presente no texto dramático e, no caso particular, desde a música. Essa é a primeira referência explícita à cena como uma imagem - ou sucessão de imagens - pintada(s) com luz. Tal princípio ainda carece de discussão no ambiente teatral brasileiro.

Qualquer relação de tais pressupostos com a cena que se efetivou ao longo das décadas que se sucederam, não será mera coincidência. Muito ao contrário, Appia comprovou que as revoluções propostas por sucessivas vanguardas teatrais, e até "antiteatrais", derivam da qualidade visual do espetáculo.

\section{Tristão e Isolda: entre Appia e Wagner}

Serão aqui consideradas relações estabelecidas por Appia com possíveis montagens da obra de Richard Wagner, concentrando as observações nas proposições referentes à ópera Tristão e Isolda (Tristan und Isolde) de Richard Wagner (música e libreto

\footnotetext{
139 "The color of objects, which constitutes the restricted role of painting in our new concept of production, is important for the form of the actor in general, and particularly for his costume."

140 "the costume must also be considered from the point of view of color and design."

141 "The word-tone poet paints his picture with light."
} 
escritos entre 1857-1859), levada ao público pela primeira vez em 1865 sob a condução do maestro Hans Guido Freiherr von Bülow (1830-1894). O libreto, escrito em alemão, apresenta uma livre versão do romance considerado obra-prima medieval germânica, Tristan, de Gottfried von Strassburg (?-1210) que se baseou, por sua vez, em uma lenda de origem celta que narra a história de dois jovens nobres Tristão e Isolda.

Esta abordagem específica da obra de Wagner leva em conta sua representatividade na história da música e da cena, o que recomenda alguma atenção para seu trabalho prático-teórico. Tal produção artístico-intelectual oferece pontos de interesse para a pesquisa nas artes cênicas incluindo obras que apresentam seus pressupostos para a nova arte da cena, de grande relevância para os estudiosos do teatro, se for considerada a influência da tragédia grega nas suas convicções em direção àquilo que ele chamou de Obra de arte do futuro, (Das kunstwerk der zukunft, 1849). Outros textos, como os longos ensaios Arte e revolução (Die kunst und die revolution), publicados no mesmo ano, além de Ópera e drama (Oper und drama, 1851), mostram a tentativa de sistematizar uma teoria que revelava ligações com o pensamento do filósofo alemão Arthur Schopenhauer (1788-1860).

Buscando novas rotas, Wagner vislumbrava uma obra de arte que incorporaria as qualidades de Shakespeare e Beethoven, resultando numa profunda força emocional, com a música assumindo grande papel descritivo - até criticado em Beethoven - e desempenhando funções semelhantes ao coro trágico grego. Sua elaboração do leitmotiv ${ }^{142}$ de relevante contribuição na estrutura narrativo-emocional da sua música pode exercer função qualificada na educação de designers, diretores e coreógrafos. Cabe citar, também, sua desaprovação da arte teatral do seu tempo que, em sua opinião, havia se transformado em mero entretenimento.

Não se pode ignorar críticas que consideram inconsistentes tanto os seus textos teóricos quanto os políticos, além da controvérsia que dá conta de uma influência de Wagner na trajetória de Adolf Hitler, acirrada pelas notas autobiográficas de Gottfried Wagner, bisneto do compositor, Wer nicht mit dem wolf heult, obra da qual não foi identificada tradução em português e que, em inglês, aparece como He who does not howl with the wolf (Aquele que não uiva com o lobo), publicada em 1997.

O trabalho em curso acentua a relação estabelecida por Appia com o drama poético-musical de Wagner e, particularmente, com sua ópera Tristão e Isolda. Dividido em três atos, o libreto da obra inicia com eventos que ocorrem durante uma viagem de Tristão, que segue da Irlanda para a Cornuália, na Inglaterra.

142 Um pequeno tema, numa peça musical, que apresenta conexões com um objeto, coisa ou personagem. 
Seguindo ordens do rei Marke, seu tio, ele transporta em seu navio a jovem Isolda, noiva prometida ao rei. Num diálogo entre Isolda e sua confidente Brangânia (Brangäne), toma-se conhecimento que a jovem já conhecia Tristão antes dessa viagem: depois da morte do seu noivo Morold numa recente batalha, ela encontrou um desconhecido mortalmente atingido na mesma contenda, e usou seus poderes de cura, ou antigos conhecimentos farmacêuticos, para recuperá-lo.

Durante o restabelecimento do enfermo ela descobre que, na verdade, o homem é o assassino do seu noivo e decide matá-lo. Despertando, ao invés de dar atenção à espada ou à mão que lhe ameaça a vida, Tristão fita diretamente os olhos de Isolda. Diante dessa atitude ela decide libertá-lo exigindo que ele jamais retorne à Irlanda. Apesar disso, fiel ao rei ele volta, obedecendo ordens de levá-la à Cornuália. Sentindo-se ultrajada, Isolda decide vingar-se e solicita a presença de Tristão à sua tenda com o pretexto de celebrar uma espécie de ritual de perdão compartilhando uma bebida. Na verdade, ela instrui a criada para que essa lhes sirva um veneno, ou poção da morte. Relutante, Tristão comparece ao encontro e, mesmo temendo morrer, bebe a poção, acompanhado pela "noiva" do rei. A reviravolta nas pretensões de Isolda ocorre quando, depois de ingerir a bebida, os dois se revelam profundamente apaixonados: Brangânia, a criada confidente, confessa que trocou o conteúdo do vaso por uma poção do amor. O primeiro ato é concluído com o final da viagem e a subida a bordo do rei Marke, da Cornuália.

Além de introduzir a narrativa, esse momento apresentava um traço valioso para a argumentação em curso: ameaçado de morte, um homem ganha a liberdade através da simples ação de olhar nos olhos do seu iminente algoz. O mito abre portas para as convicções cênicas de Appia. Ele considerou que a cabine-tenda poderia representar uma espécie de cárcere, mas provê certo conforto a Isolda: com as cortinas fechadas e a cabeça embaixo de almofadas ela se afasta da luz do dia cujo brilho acentua sua dor através da visão que expõe e confirma a traição de Tristão. A voz do marinheiro, que abre o ato, impõe a realidade para a qual ela não encontra outra saída senão enfrentar a luz. Registrando a presença de Tristão e diante da impossibilidade de escapar, ela se nega a mergulhar na passividade. Retornando à tenda, sob a proteção (visual) das cortinas que deixam lá fora a realidade iluminada e exposta pela luz, ela prepara a vingança. Appia (1962, p. 206, tradução nossa) apresenta uma interpretação visual da ação:

As cortinas da tenda de Isolda, por conseguinte, separam simbolicamente, no sentido mais pleno do termo, o aspecto visual do mundo exterior da expressão da vida interior. O conflito que constitui a ação dramática é então realizado diretamente dian- 
te dos nossos olhos em uma forma plástica justificada pela expressão dramática, e completa, desde as necessidades básicas do lugar até as demandas mais sutis do som. ${ }^{143}$

Exemplificando a natureza do pensamento visual presente na cena, Appia deixou pistas para a incorporação de excelência a uma montagem de Tristão e Isolda através da elaboração do contraste entre os dois ambientes. No interior da tenda da heroína encontra-se a expressão da face interior do conflito e as cortinas atuam como pálpebras que se abrem para revelar a realidade externa. Na elaboração das imagens cênicas, o iluminador pode avaliar a provocação dessa contundente imagem-metáfora.

Appia (1962) considerava que a luz no interior da tenda deveria ser difusa e uniforme. A intensidade seria reduzida a ponto de fornecer iluminação suficiente para que fosse visto o rosto do ator e estabelecer contrastes com o exterior brilhantemente iluminado. Appia indicou uma sugestão de tempo (hora) através dos ângulos e cores da luz, desde o início do ato, quando ela deveria cair perpendicularmente sobre o ambiente, inclusive sobre a tenda, sem alcançar diretamente o seu interior. Adiante, quando a ação se passa ao cair da tarde, Appia (1962, p. 206, tradução nossa) propôs: "[...] a luz no exterior é menos brilhante, mas os raios são mais inclinados; eles cobrem a parte 'baixa' do palco, como um grande e brilhante tecido dourado". 144

Se o primeiro ato poderia ser intitulado "a poção do amor" (ou da morte), a ação principal do segundo está no momento em que Tristão é mortalmente ferido. Esse segundo ato começa com o som de uma caçada ao longe. Acompanhado dos seus súditos, o rei Marke afasta-se do castelo para um entretenimento na noite de verão. Na companhia de Brangânia, defronte do jardim no qual apenas uma tocha ilumina o ambiente Isolda aguarda o momento propício quando o som das cornetas ao longe anunciará o afastamento seguro dos homens, permitindo-lhe enviar ao seu amado um sinal para o almejado encontro. Na espreita, ele espera que Isolda apague a tocha. A primeira cena encerra-se quando os dois se aproximam do lugar combinado, protegidos pela noite e pela escuridão.

\footnotetext{
143 "The curtains of Isolde's tent thus symbolically separate in the fullest meaning of the term the visual aspect of the outer world from the expression of inner life. The conflict which constitutes the dramatic action is then directly realized before our eyes in a plastic form justified by the dramatic expression, and complete, from the bare necessities of place to the most subtle demands of sound."

144 "[...] light is less bright (it is late afternoon), but the rays are more slanted; it covers the floor of the downstage area as with a large bright golden cloth."
} 
A cena seguinte mostra o repúdio de ambos ao dia que traz a luz capaz de expor seus desejos. As trevas da noite são tratadas como "doce escuridão" que abriga os amantes. Isolda anuncia que o dia traz a morte. Pulsa no encontro dos enamorados a ameaça do nascer do sol, que tem o poder de expor seu inevitável amor proibido. Apesar dos avisos de Brangânia, eles não conseguem se separar e concluem a cena num abraço arrebatador. A última parte do segundo ato inicia-se com o retorno do rei com seu séquito, guiados por Melot - um dos cavaleiros da corte - também apaixonado por Isolda. Tristão desafia Melot que ergue sua arma ao tempo em que o herói se desfaz da sua própria espada e recebe um duro golpe que lhe será fatal.

A interpretação de Appia (1962) demonstra como a luz pode se constituir na linha mestra da obra. Ele descreve o início de segundo ato que gostaria de ver:

A aparência do palco, quando a cortina se abre: uma tocha grande e brilhante no centro da imagem. O espaço bastante limitado do palco é iluminado por uma luz difusa, suficiente para fazer as personagens claramente distintas, sem privar totalmente a tocha de seu brilho, um tanto ofuscante [...]. ${ }^{145}$ (APPIA, 1962, p. 200, tradução nossa)

Antes, ele já havia ponderado que, ao entrar em cena Isolda vê apenas a tocha, registra a ausência de Tristão, e toma uma decisiva atitude para a ação dramática: "Extinguindo a luz da tocha Isolda remove os obstáculos, [...]". ${ }^{146}$ (APPIA, 1962, p. 199, tradução nossa) Ainda que a visão da realidade material para os amantes, assim como para nós espectadores, permanecerá muito limitada até que a luz do dia invada ameaçadoramente o ambiente, o que deve ser visto em cena, segundo Appia, é apenas a presença de ambos, assim fisicalizada:

Aparece para nós, assim como para eles, aquilo que arde nos seus corações, superior às suas formas visíveis, e a existência fictícia da música nos transporta, cada vez mais profundamente, para o interior do misterioso mundo no qual sua união se consumará para sempre. ${ }^{147}$ (APPIA, 1962, p. 200, tradução nossa)

O ambiente da cena está envolvido numa densa penumbra que os transforma em espectros, diluindo visualmente as formas da arquitetura e da natureza,

\footnotetext{
145 "The appearance of the stage when the curtain opens: a large bright torch in the center of the picture. The rather limited space of the stage is illuminated by a diffuse light, just enough to make the characters clearly distinguishable without entirely depriving the torch of its somewhat blinding brightness, nor above all, destroying the shadows projected by this brightness."

146 "By extinguishing the torch Isolde removes the obstacle, [...]."

147 "What burns in their hearts appears to us, as to them, superior to their visible forms, and the fictitious existence of the music carries us deeper and deeper into the mysterious world where their union is consummated forever."
} 
confundindo o olhar do espectador que, somente aos poucos, se adapta à atmosfera. Ainda assim, a apreensão visual das personagens deve ser sempre vaga, um tanto indefinida. Anunciando a chegada do rei o dia brilha, como o próprio Appia diz, sem cor. Aqui parece que ele está dispensando qualquer sugestão cromática do nascer do sol e indicando um tratamento frio para a luz, sem a aplicação de matizes comuns a esse momento numa abordagem realista. O sol entra como uma afiada arma branca que corta a densa penumbra abrindo espaços para revelar as personagens e o ambiente, de modo claro e direto. Para Tristão, desafortunadamente, o retorno à claridade abre as portas do infortúnio, ao final do segundo ato.

$\mathrm{O}$ ato seguinte e conclusivo encaminha como desfecho as mortes de Tristão e Isolda. O honrado cavaleiro do primeiro ato e dedicado amante do segundo é agora somente um homem mortalmente ferido. Ele foi levado inconsciente pelo seu escudeiro Kurvenal para o castelo abandonado dos seus ancestrais. No jardim diante do castelo, Tristão aparece adormecido num sofá colocado à sombra de uma limeira, observado por Kurvenal. O escudeiro mandou chamar Isolda assegurando que somente sua presença fará Tristão sobreviver. Eles esperam uma canção alegre que será tocada por um pastor para anunciar a chegada de Isolda.

Tristão desperta e desejando na música o anúncio jubiloso pensa, ao invés disso, ouvir a mesma canção tocada, no passado, quando the foi revelada a morte dos seus pais. Exausto, delira. Ouve-se a flauta do pastor que traz a boa notícia. Kurvenal apressa-se para encontrar Isolda. Agitado, Tristão retira os curativos das suas feridas. Na chegada de Isolda ele morre proferindo o nome da amada. Appia observa essa precipitação de breves acontecimentos através da relação com a luz. Ele comenta as atitudes de Tristão: "[...] ele pensa somente na sensação de luz, que causa distúrbio e dor, e na sensação de escuridão que lhe escapa, mas que ele gostaria de recuperar"148 (APPIA, 1962, p. 203, tradução nossa)

Na opinião de Appia, a luz do sol, no início do terceiro ato, tem a mesma função da tocha usada no início do ato anterior, que afasta os amantes. O sentido da visão ganha qualidade simbólica na alucinação de Tristão, que "vê" em sua imaginação ou delírio (sem a necessidade da luz física do sol que afastaria qualquer alívio, ampliando o sabor amargo da sua aflição) o navio que traz a amada. A melodia tocada pelo pastor projeta revelações. Tristão, no entanto, desfalece, mergulhando na segurança do sono ou, da escuridão "noturna".

A mágica visão da amada tornar-se-á realidade sob a luz física do sol. Para Tristão, no entanto, ela deve apagar-se transformando a escuridão em abrigo.

148 "he can think only of a sensation of light that disturbs and pains him and of a sensation of darkness escaping him but which he would like to retrieve." 
Diante de Isolda, portanto, ele morre em seus braços. Appia (1962, p. 204, tradução nossa) descreve o momento:

A bela claridade da luz do dia - que se tornou a sua ilusão suprema - lentamente desaparece no horizonte marinho lançando um último halo tingido de sangue em torno dos amantes que se reencontram. | Assim, o papel desempenhado pela luz é claramente prescrito para o ato. Como a luz é apenas uma fonte do sofrimento de Tristão ela não deve cair diretamente sobre ele. Mas, assim que ele realmente a associa a visões de felicidade, ela o alcança e ilumina seu rosto. ${ }^{149}$

Aqui se pode observar um procedimento ou um método que caracterizaria as funções da visualidade na práxis cênica. A abordagem do iluminador, mesmo organicamente ligada aos pressupostos da dramaturgia e da direção, apresenta contribuição particular, pois apenas a luz pode representar tal papel. Os contrastes evidenciados nas cores, texturas, formas, intensidades, a composição de cada imagem cênica, enfim, determinaria a presença da luz no espetáculo que, efêmera, desempenharia funções exclusivas.

Aqui se encontra um dos mais importantes aspectos das relações entre a luz e a cena. Comprometida esteticamente, ela dispensaria sua própria acentuação indiscriminada e promoveria a construção das imagens cênicas, de um modo que somente o olhar particularmente educado seria capaz de observá-la tecnicamente e avaliar sua contribuição.

Appia faz proposições para a cena que podem exemplificar suas expectativas de elaboração das imagens:

Na página $215,{ }^{150}$ tornando-se cada vez mais dourada, a luz começa a tocar os pés de Tristão, na página 218 chega até a cintura; na página 221, ela toca o seu rosto; na página 223, Tristão está totalmente iluminado; na página 225, o facho se estende a seus arredores. ${ }^{151}$ (APPIA, 1962, p. 205, tradução nossa)

\footnotetext{
149 "The beautiful clarity of daylight - which became their supreme illusion - slowly sinks below the sea's horizon throwing a last bloodtinged halo around the reunited lovers. | So the part played by lighting is clearly prescribed for the act. As long as light is only a source of Tristan's suffering, it must not fall on him directly. But as soon as he really sees it and associates it with blissful visions, it comes and illuminates his face."

150 Essa numeração de páginas refere-se à partitura vocal, preparada por Hans von Buelow, e publicada por Breitkopf \& Haertel, em Leipzig, e também em Nova lorque.

151 “On page 215, the light, turning increasingly more golden, begins to touch Tristan's feet; on page 218 it reaches up to his waist; on page 221 it touches his face; on page 223 Tristan is fully lighted; on page 225 , the beam extends to his surroundings."
} 
O que poderia ser um pôr do sol fixado numa composição pintada, torna-se um movimento que constitui uma assertiva visual em profunda cumplicidade com a ação cênica, com o tempo inscrito pela música, inundando o espaço cênico da atmosfera romântica da qual estaria impregnado o espetáculo. No tratamento em questão pode-se observar porque a abordagem de Appia se rebelava contra a pintura de telões cujo congelamento da luz lhe parecia desconectado da qualidade viva da cena. Ele já diagnosticara essa impropriedade: "Os arranjos de cores, bem como as formas que expressam a sua qualidade e variações de luz e sombra, não só perdem a sua expressividade na presença dos elementos vivos, mas também o seu significado". ${ }^{152}$ (APPIA, 1962, p. 78, tradução nossa)

\section{Sombras reveladoras}

Ainda que as combinações de forma, cor e movimento mencionadas por Appia tenham influenciado enormemente a prática da iluminação teatral que lhe sucedeu, ele incluiu nessa última assertiva outro aspecto da cena a respeito do qual não se observa grande interesse da prática da iluminação para o palco, tampouco da teoria que trata da cena. Quando ele diz "variações de luz e sombra", se for considerada a importância da sombra na sua obra, ficam sugeridas pesquisas específicas acerca do tema.

Mesmo que seu trabalho trate de relações entre o arranjo espacial e a luz ele faz menções à sombra que podem intrigar o leitor. Numa primeira instância, referindo-se à potencialidade da luz para envolver a cena em atmosferas, ele faz sua primeira inserção objetiva da sombra no universo da cena: “[...] [se] o espectador deve apreender a existência real de uma janela, um edifício, um pórtico, uma rocha, o limite de uma floresta, o mastro de um navio etc., a luz pode apresentar esses objetos através do uso da sombra”. ${ }^{153}$ (APPIA, 1962, p. 67, tradução nossa) Appia não estava discutindo o chamado "teatro de sombras", mas indicando a imperativa necessidade da sombra para a fisicalização do corpo em cena, da imagem cênica. Essa operação técnica, que ganha qualidade estética no corpo de um espetáculo, origina-se na observação da luz natural, como ele expõe:

152 "The color arrangements, as well as the forms they express through their quality and variations of light and shade, lose not only their expressiveness in the presence of the living elements, but also their meaning."

153 " [...] the spectator must apprehend the actual existence of a window, a building or portico, a rock, the edge of a forest, ship's mast, etc., the lighting can present these objects by means of shadows." 
A luz do dia inunda toda a atmosfera, mas, mesmo assim, estamos sempre conscientes da direção de onde ela vem. Mas a direção da luz só pode ser detectada através da sombra - é a qualidade das sombras que exprime a qualidade da luz. As sombras são formadas pela mesma luz que ilumina a atmosfera. Esse enorme efeito não pode ser obtido artificialmente. O brilho de uma fogueira acesa em uma área escura nunca irá produzir luz suficiente para criar o que chamamos de claro-escuro, isto é, a sombra mais ou menos distinta que se projeta sobre uma área já iluminada. No palco, essa tarefa deve ser dividida de modo que parte do equipamento de iluminação seja aplicada para a iluminação geral, enquanto o restante cria as sombras por meio de fachos exatamente dirigidos. ${ }^{154}$ (APPIA, 1962, p. 74, tradução nossa)

Na condiçao de responsável pela criação das imagens cênicas, o iluminador pode avaliar a indicação de Appia quando ele considera a observação sistemática da luz - incluindo a luz natural - como procedimento relevante para o seu traba1ho. Leve-se em conta que Appia estava tratando de um teatro no qual a ilusão realista devia ser banida e, ainda assim, ele considerava que o processo investigativo da luz deve ser abrangente. Suas breves observações acerca da sombra deixaram pistas da importância do mencionado processo para a cena ou, antes, para a apreensão humana do mundo:

[...] não há objeto plástico de nenhum tipo, animado ou não, que possa dispensar a sombra. Se não há sombra, não há luz; pois luz não é simples 'visibilidade' [...] apenas a plateia está interessada em 'visibilidade' - a luz distingue-se da visibilidade pela virtude do seu poder de ser expressiva. ${ }^{155}$ (APPIA, 1962, p. 75, tradução nossa)

Em primeiro lugar, até mesmo uma apreensão primária humana do mundo visível depende da presença da sombra, desde aquela produzida pela luz natural até as diversas possibilidades de sombras decorrentes das fontes artificiais de luz.

\footnotetext{
154 "Daylight floods the whole atmosphere, but nevertheless we are always aware of the direction from which it comes. But the direction of light can only be sensed by means of shadow - it is the quality of the shadows which expresses the quality of light. Shadows are formed by the same light which illuminates the atmosphere. This tremendous effect cannot be obtained artificially. The brightness of a lighted fire in a dark area will never produce sufficient light to create what we call chiaroscuro, i.e., the more or less distinct shadow cast on an already lighted area. On stage this task must therefore be divided, so that part of the lighting equipment will be used for general illumination, while the rest will cast shadows by means of exactly focused beams."

155 " [...] there is no plastic object of any kind, animate or otherwise, which can dispense with shadow. If there is no shade, there is no light; for light is not simple 'visibility' [...] only the audience is concerned with 'visibility' - light is distinguished from visibility by virtue of its power to be expressive."
} 
No desejo de substituir o sol, com o intuito de ampliar ou prolongar sua relação de visibilidade com a vida até para ampliar seu tempo produtivo, o ser humano inventou a luz artificial e gerou um novo mundo de sombras. Na obra de arte em geral - na práxis cênica, em particular - essas sombras emprestam poder expressivo à luz, promovendo a diferença entre visibilidade e aquilo que denominei visualidade, alcançada pela inclusão estética da sombra, em um projeto de luz. Isso exige do iluminador familiaridade com os instrumentos e acessórios, para determinar a distância entre a fonte de luz e o objeto a ser revelado expressivamente, os ângulos, as formas e texturas com as quais se pode definir a qualidade da sombra.

É provável que o conhecimento da geometria aliado à familiaridade com os materiais oferecidos pelo dramaturgo e suas ramificações possa contribuir, tanto nos cálculos necessários para as definições técnicas, quanto na qualificação estética do trabalho do iluminador. No teatro proposto por Appia, melhor que "iluminador" talvez a denominação indicada fosse "sombreador", se o artista compreende a expressividade visual, a qualidade estética da sua contribuição, como um processo que desconstrói as fronteiras da visibilidade e instala a visualidade através da criação de sombras. Sombras que alcançam um estágio diferente daquele fixado na pintura de telões, pois, de acordo com Appia (1962, p. 75, tradução nossa), as sombras pintadas corrompem a cena com falsas imagens: “[...] o cenário pintado pode tornar-se expressivo somente na ausência do ator, pois a imitação de luz pintada no telão corresponde, igualmente, às falsas sombras pintadas". ${ }^{156}$ Ele procurou, ainda, esboçar um método para a aproximação técnica da sua proposição estética.

Evitar as sombras causa interferência na energia da luz viva; [...] por meio da luz difusa atingimos a 'visibilidade' no palco; as sombras serão neutralizadas e prontas para a luz viva. Com a exceção de alguns casos bastante raros nos quais uma das duas formas de luz deve operar de modo independente, não é preciso dizer que temos de começar com 'visibilidade'. A intensidade da luz difusa, em seguida, será modificada pela luz viva. ${ }^{157}$ (APPIA, 1962, p. 77, tradução nossa)

156 "the painted setting can become expressive only in the absence of the actor, because the imitation light painted on the canvas corresponds to the equally false painted shadows."

157 "To avoid the shadows would interfere with the power of living light; [...] by means of the diffused light, we achieve 'visibility' on the stage; the shadows will be neutralized and ready now for the living light. With the exception of some rather rare instances in which one of the two light forms must operate independently, it goes without saying that we must begin with 'visibility.' The intensity of the diffused light will then be modified by the living light." 
Appia parecia dizer que essa pintura com luz proposta para o drama poético-musical, exigia a elaboração de uma base ou suporte, aplicando a luz difusa para eliminar sombras desnecessárias à expressividade do espetáculo, para depois serem elaboradas as sombras exigidas em cada cena ou momento. No sentido positivo do termo, trata-se de criar sombras artificialmente planejadas pelo "sombreador" (já que a tarefa do "iluminador" ficou concluída no estabelecimento da luz difusa, de preenchimento, generalizante, e até colorida). Ele justificou: “[...] que modo de existência poderíamos imaginar para a luz, além da oposição de intensidades ocasionadas pelas sombras - e como é possível imaginar sombras, senão em termos dos objetos que as originam?". ${ }^{15}$ (APPIA, 1962, p. 77, tradução nossa)

Fica evidenciada uma profunda relação com a organização dos elementos visuais da cena, incluindo o ator, tratado como um aspecto visual. Por outro lado, as implicações emocionais, humanas e sociais da personagem exigem um tratamento visual particularizado, de acordo com suas funções em cada espetáculo. Portanto, para observar o ator como corpo e elemento visual da cena, exige-se do "sombreador" familiaridade - para não usar o termo domínio - com as diversificadas instâncias técnico-estéticas que permeiam, circundam e perpassam a cena. Sua função inclui, segundo Appia (1962, p. 78, tradução nossa): “[...] promover os meios para a projeção das sombras, permitindo, assim, que a luz viva trabalhe”. ${ }^{159}$

Ele propôs exemplos práticos que podem corroborar sua compreensão das sombras como elementos essenciais da cena. Já no primeiro ato de Tristão e Isolda, no qual a luz do sol deve expor a realidade, agredindo Isolda que dela decide se afastar, pode-se observar:

A iluminação dessa área será bastante uniforme, sem qualquer sombra. [...] permitindo que os planos característicos das faces sejam claramente vistos. Pelo contrário, a área ao ar livre será brilhantemente iluminada e sua realidade enfatizada através de uma variedade de sombras lançadas sobre a tenda. ${ }^{160}$ (APPIA, 1962, p. 207, tradução nossa)

Pode-se dizer que o papel da sombra na elaboração da imagem cênica estava aí delineado. Mesmo quando Appia chamou a atenção para a necessidade da

\footnotetext{
158 "But, what mode of existence could we imagine for light except the opposing intensities occasioned by shadows - and how is it possible to imagine shadows but in terms of the objects causing them?"

159 Da tradução inglesa: "[...] furnishing the means of casting shadows, thus enabling the living light to function." 160 "The illumination of this area will be quite uniform, with no shadow whatever. [...] will permit the characteristic planes of the faces to be distinctly seen. By contrast, the outdoor area will be brightly lighted and its reality emphasized through a variety of shadows thrown against the tent."
} 
eliminação das sombras no interior da tenda de Isolda, o que, por um lado, pode sugerir argumentos para aqueles que pretendam questionar o valor das sombras, por outro, a observação atenta pode fazer cair por terra certas contestações. Appia tentou explicitar que nesse momento as sombras projetadas pelos corpos devem ser evitadas, uma vez que não há nenhuma fonte de luz no interior da tenda e precisamente porque essa condição é imprescindível para a elaboração do pensamento visual, que suporta e exprime a relação de Isolda com a realidade exposta pela luz, pelo conhecimento que lhe sublinha a morte do noivo, seu infortúnio. Ou seja, a realidade é construída visualmente nas sombras duramente projetadas pela luz natural que incide sobre o exterior da tenda:

Brangânia ergue um canto da parede lateral para olhar para o mar, o espectador vê apenas uma parte ínfima do horizonte, percebendo o exterior somente através da luz brilhante que roça os pés da cantora, sem penetrar o suficiente para lançar uma sombra pesada sobre o chão da tenda. ${ }^{161}$ (APPIA, 1962, p. 207, tradução nossa)

A narrativa encaminhada durante todo o espetáculo vislumbrado por Appia (1962, p. 207, tradução nossa) inscreve-se visualmente:

Quando as cortinas da tenda são abertas pela primeira vez (páginas 13-14), a luz de fora, caindo quase em linha reta, não passa além do limiar da tenda. Na página 80, quando elas se abrem de novo, a luz exterior é menos brilhante (estamos no final da tarde), mas os raios estão mais inclinados; eles cobrem o piso da parte frontal da cena, como um grande e brilhante tecido dourado. As sombras das personagens caem em direção ao público. Tudo o que se vê são dois grupos de pessoas: aqueles que serão recebidos, e aqueles que os observam de frente, aguardando o rei. ${ }^{162}$

Deve-se atentar para a relevância de tais construções visuais, assim como para o decisivo papel das sombras no teatro de Appia (1962, p. 207, tradução nossa):

161 "Brangaene lifts a corner of the side wall to look at the sea, the spectator sees merely an infinitely small part of the horizon, perceiving the outdoors only through the bright light that grazes the singer's feet without penetrating enough to throw a heavy shadow on the tent floor."

162 "When the tent curtains part for the first time (page 13-14), the light from outside, falling almost straight down, does not pass beyond the threshold of the tent. On page 80 when they open again, the outside light is less bright (it is late afternoon), but the rays are more slanted; it covers the floor of the downstage area as with a large bright golden cloth. The shadows of the characters fall toward the audience. All that is seen is two groups of people: those who are to be received, and those who face them waiting for the king." 
Aquelas [personagens], no primeiro grupo (em especial, Tristão e Isolda) atingido por um raio oblíquo, que vem do fundo do palco, são vistas pelo público como silhuetas sombreadas, o segundo grupo não está colocado diretamente entre a luz [o instrumento, o 'refletor'] e o espectador sendo, então, muito mais brilhantemente iluminado e totalmente visível. ${ }^{163}$

A mencionada abordagem estende-se ao segundo ato, aparecendo desde a primeira imagem que denota nas proposições da cena um alto nível de atenção, não apenas para a luz, mas também para a sombra.

O espaço bastante limitado do palco é iluminado por uma luz difusa, suficiente para fazer as personagens claramente distintas, sem privar totalmente a tocha de seu brilho um tanto ofuscante, nem, acima de tudo, destruir as sombras projetadas por esse brilho. ${ }^{164}$ (APPIA, 1962, p. 200, tradução nossa)

Sem a pretensão de criar uma obra de arte isolada a cada imagem elaborada, ele acentuava a necessidade de tratá-la como um novo componente do discurso visual do espetáculo em questão. Levando-se em conta a harmonia buscada por Appia, a sucessão de imagens deveria constituir-se de elementos que estabeleceriam a unidade visual que construiria a totalidade da obra, indicando rigor na elaboração de cada movimento da luz, consequentemente, de cada imagem em movimento. Se ele acreditava que toda imagem necessita da sombra para se tornar presente a excelência do espetáculo dependia da precisão de cada sombra.

A sombra, portanto, que pode remeter a um simples buraco escuro, o preto, ausência, repetição negativa e vazia, tem aqui papel decisivo e muito diferente da sombra em Platão, que sugere ignorância e limitação, como na parábola da caverna, e mais próxima daquela sombra que aparece na obra de Caio Plínio, o Velho (23-79). Tratando da criação da escultura, ele constata:

Butades, um oleiro de Sicyon, inventou em Corinto a arte da modelagem de retratos na terra, que ele usou no seu comércio. Ele fez a descoberta através da sua filha, que, profundamente apaixonada por um jovem que estava prestes a partir para uma longa viagem, traçou o perfil do seu rosto, projetado sobre uma

163 "Those in the first group (in particular Tristan and Isolde), hit by a slanted ray from upstage, are seen by the audience as shadowed silhouettes; the second group is not placed directly between the spotlight and the spectator, and consequently is much more brightly lighted and fully visible."

164 "The rather limited space of the stage is illuminated by a diffuse light, just enough to make the characters clearly distinguishable without entirely depriving the torch of its somewhat blinding brightness, nor above all, destroying the shadows projected by this brightness." 
parede pela luz de uma lamparina. Ao ver isso, o pai da jovem preencheu o contorno, através de compressão de argila na superfície, e assim fez o rosto em relevo, que foi então endurecido pelo fogo, juntamente com outros artigos de cerâmica. ${ }^{165}$ (PLINY, 1867, p. 283, tradução nossa)

A sombra aqui recebe abordagem positiva, quando registra e preserva a forma da pessoa amada, criando uma presença que desconstrói a ausência iminente.

Na descrição de Appia, imprescindível para a compreensão expressa na presente abordagem, quando a cortina se abre, os artistas compartilham imagens com o espectador. Parece claro, ainda que nem sempre conscientemente assumido: seja a abertura da cortina ou outro instrumento de corte realidade-ficção efetivado no começo de um espetáculo, uma imagem é oferecida ao público. E se uma cortina neutra for mantida fechada e o espetáculo começar com estímulos sonoros, o espectador responderá com seu imaginário, elaborando associações, criando suas próprias imagens mentais. A simplicidade da imagem proposta por Appia determina certas exigências em Tristão e Isolda: o espaço da cena deve ser iluminado por uma luz difusa, sugerindo que a iluminação está sendo provida por uma tocha posicionada em um ponto específico da imagem cênica. Essa iluminação revela claramente as personagens, mas deve evidenciar o valor físico do brilho da tocha como fonte principal de luz.

E, finalmente, devem ser reveladas as sombras originadas pelas relações entre a tocha e os corpos que se oferecem como obstáculos. Essa operação exige conhecimento técnico para fazer interagir intensidade, contraste, cor, ângulo, textura e movimento, aproximando-se daquilo que a prática da luz para a cena no século XX denominou, nos EUA, luz "motivada". ${ }^{66}$ Vale chamar a atenção para a instabilidade da luz de uma tocha, que impregnaria a cena com uma qualidade muito particular de luz e sombra em movimento.

Parece óbvio que hoje em dia, além da tocha propriamente dita e dos instrumentos aplicados para a luz difusa, outros tantos podem ser usados para criar sombras, como se elas fossem efetivamente criadas por essa tocha. De todo modo, tal conceito de imagem se diferencia da compreensão atual da imagem gravada, editada, mani-

165 "Butades, a potter of Sicyon, was the first who invented, at Corinth, the art of modeling portraits in the earth which he used in his trade. It was through his daughter that he made the discovery; who, being deeply in love with a young man about to depart on a long journey, traced the profile of his face, as thrown upon the wall by the light of the lamp. Upon seeing this, her father filled in the outline, by compressing clay upon the surface, and so made a face in relief, which he then hardened by fire along with other articles of pottery."

166 Uma luz que parece originar-se numa fonte específica, como uma lâmpada, o sol, uma fogueira, entre outros. (BOULANGER; LOUNSBURY, 1992, p. 102) 
pulada eletronicamente e reproduzida. Appia tratou da imagem cênica, efêmera, elaborada imediata e sucessivamente diante do espectador, com precisão e maestria que promoveria interação e construiria as visões da obra em questão.

No decorrer do segundo ato de Tristão e Isolda, os heróis parecem mixados ao ambiente quando permanecem mergulhados na penumbra, numa visualidade que atua diretamente na qualidade da ação dramática ao camuflar os amantes.

Após descrever o ambiente do terceiro ato, Appia (1962, p. 204, tradução nossa) traça recomendações finais: "Apenas aquilo que é estritamente necessário para proteger as coxias e para motivar as sombras que preenchem o pátio deve ser adicionado a essa construção simples." ${ }^{167}$ Mais uma vez observa-se que a sombra se configurava como um aspecto essencial da sua abordagem espetacular. Isso pode incluir a extensão, a cor e a textura de cada sombra projetada na cena:

Durante as páginas 233-236, o palco atinge o máximo de luz, relativamente baixa, pois a parte da parede que limita a visão do céu, ao fundo do palco, lança uma profunda sombra sobre grande parte do pátio, principalmente sobre a porta, e áreas mais próximas. ${ }^{168}$ (APPIA, 1962, p. 205, tradução nossa)

Uma elaboração visual dessa natureza, que inclui uma sombra de tamanha extensão, pode lembrar outro aspecto decisivo da criação das imagens cênicas, ou seja, o preenchimento das sombras. Um evento que ocorre na natureza ou, na realidade objetiva, e que deve ser elaborado artificialmente na cena, estabelece um alto grau de dificuldade técnica, uma vez que, em certos espetáculos, certas cenas ou certos "momentos-imagem", as sombras não podem ser projetadas de modo simplório como um buraco negro inevitável ou acidental na cena. Ao contrário, pode haver a necessidade de inserir na sombra um grau de visibilidade ou realidade, somente alcançado com a aplicação de critérios técnico-estéticos muito específicos, por vezes relacionados a um raciocínio gráfico, visual, geométrico, físico, cujo resultado (ou forma) só raramente será encontrado no cotidiano fora do teatro.

Em algumas ocasiões, quando um espetáculo muda de teatro, numa excursão ou nova temporada, torna-se difícil para um ou outro envolvido no processo, compreender que determinada casa de espetáculos - algumas delas nem sequer qualificadas para receber a simples denominação de teatro - não apresenta condi-

167 "Only what is strictly needed to mask the flies and to motivate the shadows which fill the courtyard should be added to this simple construction."

168 During pages $233-236$, the stage attains the maximum of light which is relatively low, for the section of wall restricting the view of the sky upstage throws a deep shadow over a large part of the courtyard, especially over the door and its approaches". 
ção técnica para assegurar a criação das sombras que o espetáculo em questão exige. Parece difícil aceitar que a simples posição de uma vara de luz tenha participação efetiva na elaboração da visualidade de um espetáculo; e que a visualidade tenha tal importância; e que as sombras mereçam "tamanha" atenção. O que pensaria Appia em uma situação de tal natureza?

O exemplo a seguir, que ainda se refere ao terceiro ato de Tristão e Isolda, revela como um iluminador pode aplicar variações de sombra de modo muito especificamente relacionado a cada evento:

Começando na página 236, a iluminação assume os tons do pôr do sol, em seguida, rapidamente diminui sua intensidade durante as páginas 238-242, até que, nas páginas 245-248, a ação turbulenta ocorre em relativa escuridão e o público não pode distinguir seus detalhes, enquanto as áreas da frente do palco são atingidas diretamente por uma luz que se torna cada vez mais vermelha... ${ }^{169}$ (APPIA, 1962, p. 205, tradução nossa)

A recomendação final de Appia pode servir como alerta para o estudo da sombra, assim como de sua aplicação na práxis cênica:

Os praticáveis na base da parede servem bem para a luta (páginas 138-149). Kurvenal, quando ferido, caminha para a luz e cai perto de Tristão. Nenhum dos homens de Mark ou Kurvenal deixa a área escura. - O máximo cuidado deve ser tomado na aplicação das sombras criadas pelos personagens na última cena. Isso significa que Mark e Brangânia, de costas para os instrumentos [refletores], tornam-se silhuetas escuras que não projetam qualquer sombra sobre as personagens centrais. Kurvenal caiu na sombra projetada por Tristão. Começando na página 254, a luz continua a desvanecer-se, mergulhando o ambiente em um crepúsculo cada vez mais profundo. A cortina fecha-se em uma imagem calma e uniformemente iluminada, na qual o olho pode distinguir apenas o último toque do sol minguante, que vai suavemente colorir o vestido branco de Isolda. ${ }^{170}$ (APPIA, 1962, p. 205, tradução nossa)

169 "Starting with page 236 , the lighting takes on the hues of sunset, then rapidly decreases its intensity during pages 238-242 until, on pages $245-248$, the turbulent action occurs in relative darkness and the audience cannot distinguish its details, while the downstage areas are hit directly by a light which grows redder and redder..."

170 "The platforms at the foot of the wall serve well for the fighting (pages 138-149). Kurvenal, when wounded, steps into the light and falls down close to Tristan. None of or Kurvenal's men leaves the dark area. - The greatest care must be taken in handling the shadows created by the characters in the last scene. This means that Mark and Brangaene, their backs turned toward the spotlight, must become dark silhouettes without throwing any shadow on the two principals. - Kurvenal has fallen into the shadow cast by Tristan. Beginning with page 254 , the light 
Provocado pelas referências do libreto de Wagner aos conflitos entre noite e dia, Appia efetivamente pensava que se deve dispensar cuidado particular às sombras. Ele acreditava que, no espetáculo de Wagner, a interação entre luz e sombra poderia funcionar como uma espécie de leitmotiv visual: uma vez estabelecido, poderia ser desenvolvido, irradiando-se e impregnando o espetáculo.

Em face disso, o ato de projetar luzes sobre a cena, por mais coloridas, tecnologicamente atraentes, pulsantes, ainda pareceria pouco, sem a atenção devida à qualidade dos volumes da geografia da cena que somente se efetivam através da elaboração precisa das sombras. Vale reiterar que tais ponderações sugerem justificativa para a investigação da sombra e sua contribuição para a cena, o que indica pesquisas específicas, considerando-se os importantes estudos acerca da sombra, já disponíveis. Portanto, a estrita "visibilidade" que apenas ilumine, mesmo maquilada de cor, grafismo, brilho e efeitos especiais, pode se revelar parcial e incompleta na práxis cênica se não incorporar o valor visual da sombra.

Há uma sutileza, incluída na tradução alemã da obra de Appia, que destaca - influenciada pela Teogonia ${ }^{171}$ - a diferença entre Erebus, ou sombra profunda, filho de Caos, deus da escuridão e Nix [Nv́\}], sua irmã gêmea, a bela e sombria personificação da noite que traz o dia. Em Nix, a noite incorpora uma atitude positiva, construtiva, pois representa uma espécie de mensageira que anuncia o dia.

Portanto, para concluir essas observações acerca da obra de Appia cabe reafirmar que sua abordagem da luz como agente ativo da cena inclui a sombra, na sua condição de aspecto definidor da presença e da extensão de um corpo em um ambiente e, portanto, como aspecto estético-poético do seu teatro.

Como provocação, restam algumas perguntas: por que, apesar do seu avançadíssimo idearium, Wagner não levou em conta o projeto visual de Appia e se manteve ligado à cenografia de telões neorrealistas-românticos da empresa dos irmãos Brückner, já citados, em conjunto com os aparatos usados na iluminação teatral de sua época? Como explicar tal contradição, que põe frente à frente,

\footnotetext{
continues to fade, plunging the setting into an ever deeper twilight. The curtain closes on a quiet and uniformly lighted picture in which the eye can distinguish only the last touch of the waning sun which faintly colors Isolde's white dress."

171 Poema de Hesíodo sobre o nascimento dos deuses. Segundo Marilena Chauí (2000, p. 19): A palavra gonia tem sua origem etmológica em duas palavras gregas: do verbo gennao (engendrar, gerar, fazer nascer e crescer) e do substantivo genos (nascimento, gênese, descendência, gênero, espécie). Gonia, portanto, quer dizer: geração, nascimento, a partir da concepção sexual e do parto. Cosmos, como já vimos, quer dizer mundo ordenado e organizado. Assim, a cosmogonia é a narrativa sobre o nascimento e a organização do mundo, a partir de forças geradoras (pai e mãe) divinas. Teogonia é uma palavra composta de gonia e theós, que, em grego, significa as coisas divinas, os seres divinos, os deuses. A teogonia é, portanto, a narrativa da origem dos deuses, a partir de seus pais e antepassados.
} 
o Wagner inovador e revolucionário do drama poético-musical (Wort-tondrama) e da arquitetura teatral, e o conservador sustentado pelos aspectos visuais de um espetáculo que se apoiava visualmente nos mencionados telões pintados? Ainda que não se conheçam respostas para tais indagações há, pelo menos, espaço para apresentá-las.

Como se pode constatar, há questões estreitamente ligadas ao discurso visual que nem sempre estão diretamente ligadas à abordagem do diretor (nem mesmo àquelas do "encenador" brasileiro), mas que precisam contar com o iluminador para reconhecê-las e encaminhá-las como problematização visual para a cena. 


\title{
A LUZ NA GÊNESE DO ESPETÁCULO
}

\begin{abstract}
A luz ingressa na arte teatral em um momento que antecede à montagem propriamente dita. Melhor, a luz acompanha a cena desde os seus primeiros passos. Ela contribui para sua gestação e desenvolvimento. Como decorrência dessas assertivas pode-se também inferir que a presença da luz na história da arte teatral antecede as construções renascentistas de teatros cobertos ou as edificações fechadas da práxis cênica eclesiástica. Desde as mais remotas manifestações espetaculares a luz produziu contribuição indissociável.

Este livro intenta indicar caminhos para a investigação de traços da luz no espetáculo, em iniciativas históricas. Estudando processos mais recentes, já no século XX, é possível encontrar volume considerável de literatura técnica - em língua estrangeira, principalmente em inglês - acerca da luz na cena. Tal literatura inclui o trabalho de vários designers, cujos projetos estão disponíveis para consulta, documentando seus processos.
\end{abstract}


Considerando, no entanto, a possibilidade de identificar traços da contribuição da luz para a cena em processos ainda anteriores, é possivel estabelecer aproximação com o trabalho de vários teóricos e artistas, observando diversificadas rotas que levam à cena. Constata-se, então, que, desde uma iniciativa atual e considerada inovadora, até aquelas que acompanham tradições, é possível sublinhar a incorporação da luz já na ideia primeira que alimenta textos, roteiros, ou outros estágios iniciais de um acontecimento teatral. Mesmo que os autores o façam de modo intuitivo, quase como um aspecto organicamente intrínseco à natureza espetacular, a interação da luz com a cena é primeva (no sentido de crueza). Ou seja, mantido às escuras, um espetáculo parecerá uma exceção ou um novo modo de acontecimento "artístico". O que nada terá de errado, mas representará ou provocará um estudo diferenciado daquele que aqui encaminhado.

Tal observação determinou o ordenamento deste livro, cuja estratégia foi construir um corpo argumentativo em parceria com o trabalho de artistas e/ou teóricos importantes para a práxis cênica que, em obras e poéticas diversificadas, incorporaram a luz no seu modo de elaborar e refletir sobre a cena. Os autores e teóricos aqui estudados reconheceram (mesmo intuitivamente) a contribuição artística da luz para a natureza da cena e, diante da reputação dessas personalidades ficam abertos espaços para o estudo aprofundado do contexto. Isso pode sugerir que, não somente os interessados na luz de modo particular, mas o estudioso e artista, em geral, investiguem as relações entre a luz e espetáculo.

Um espetáculo é uma manifestação visual cuja observação e problematização deve incluir o contexto das relações entre visibilidade e visualidade. É possível considerar que a compreensão abrangente da arte teatral exige investigação frequente e aprofundada da visualidade, na sua condição de instância fundamental da práxis cênica.

Certas questões podem contribuir para que sejam investigadas possíveis funções da luz: criticar a visualidade de um espetáculo exige do candidato a crítico efetiva familiaridade com as implicações estéticas da aplicação da luz na cena. A aplicação da luz com a função de determinar a aparência imediata de uma cena ou espetáculo, usando efeitos que se repetem como uma fórmula de sucesso, pretendendo apenas "maravilhar" o espectador, acompanhando "tendências" que fazem ver no teatro a mesma luz que está em centros de compra (shopping malls), em eventos corporativos, em shows musicais, resulta na banalização de tecnologia.

Nesse sentido, cabe ao iluminador incorporar aspectos da sua relação com o outro e com o mundo e elaborar uma expressão visual particular que inclua seus pontos de vista acerca daquilo que ele ou ela pretende discutir através da imagem 
cênica. Quando se considera que a luz define a sucessão dessas imagens cênicas, incorporando qualidade expressiva, crítica, poética e plástica ao espetáculo, pode-se dizer que o trabalho do iluminador exige a acuidade de um artista com formação abrangente.

Se na cena não há uma pintura executada por um só indivíduo, mas imagens elaboradas por um grupo de artistas, poder-se-ia dizer, então, que a formação de um diretor, assim como de todo artista envolvido com essas questões, deveria incorporar o estudo das artes visuais. Deveria ser acentuada a efetiva experimentação visual na formação de um diretor de modo a capacitá-lo para discussões com o iluminador acerca de cada imagem criada.

Entre a tarefa do iluminador e o trabalho de um pintor há, por conseguinte, uma grande diferença: enquanto o pintor toma todas as decisões estético-poéticas da sua obra, fisicalizando num suporte dado aquilo que pretende dirigir ao observador, na cena, o objeto visual é criado como resultado de um conjunto de esforços dos diversos artistas envolvidos. E mesmo que não haja acordo estético entre eles, o resultado das suas interferências estará, simultaneamente, em contato com o público.

Sendo verdadeira tal premissa, a educação do iluminador deveria incluir uma profunda imersão no estudo teórico-prático da visualidade, corrigindo o equívoco da instrução formal que se afasta progressivamente de tais caminhos à medida que o educando se aproxima de determinada instrução especializada, desconsiderando as funções do pensamento visual como instrumento de elaboração da linguagem, na articulação do raciocínio, assim como de outras estratégias pedagógicas.

Para o iluminador tais aspectos da educação são particularmente importantes, pois contribuirão nas inúmeras decisões que ele precisa tomar durante a elaboração da visualidade de um espetáculo. Ele deve ser capaz de identificar a diferença entre tornar um pensamento visível e a atitude de impregnar a obra teatral de um discurso visual esteticamente articulado.

Isso pode solicitar mais do que uma relação intuitiva com as questões visuais, ou mesmo questionar a expectativa de que cada iluminador (assim como cenógrafo, maquiador, figurinista ou diretor) seja um gênio das artes visuais capaz de dominar o contexto, sem a precedência ou o apoio de estudos específicos e continuados.

Se as experimentações com as questões visuais vão sendo progressivamente cerceadas desde a instrução fundamental e a efetiva experimentação visual perde espaço para os estudos teóricos e as práticas específicas de cada profissão, tal impo- 
sição hegemônica pode gerar prejuízos para a educação de um artista. A situação agrava-se quando é identificada em cursos superiores que pretendem "formar" artistas que trabalharão no teatro, cursos nos quais a expressão visual é deixada sob a tutela dos estudos teóricos e/ou ao acaso da intuição e da genialidade. Na ausência ou combinação de tais "ingredientes" (a teoria, a intuição e a genialidade), certos espetáculos contam com os possíveis bons resultados acidentais ou com a visibilidade superficial que agrada ao público, assim como àquela crítica sem familiaridade com a questão. Cabe lembrar que o tratamento da visualidade da cena pode envolver habilidades e competências particulares, cujo trato acadêmico (teoria e práxis) já está presente em diversos programas de estudo ao redor do mundo. Além disso, cada nova revolução que irrompe no acontecimento espetacular provoca e fundamenta discussões dos elos entre essa práxis artística e a visualidade.

O artista comprometido com a elaboração visual do espetáculo pode aplicar estratégias capazes de provocar o espectador através da criação de um discurso poético-visual particular para cada obra, questionando o modelo que define a relação visual público/cena como uma atitude meramente contemplativa ou passiva. A apreensão visual do mundo - e do espetáculo, em particular - deixa de ser algo que é "dado" a um observador, passando a constituir-se como conjunto de imagens em cuja criação o observador-espectador toma parte ativa. Mesmo que se o disponha num assento da plateia.

Ao artista que se envolve com o acontecimento espetacular cabe corrigir os equívocos da educação formal-tradicional ainda atrelada aos resquícios de velhas classificações. A atitude de separar as artes "liberais" das artes "mecânicas", dispondo, de um lado, a qualidade livre da aritmética, da geometria, da astronomia e da música, todas regidas pela matemática, incluindo no âmbito de excelência a gramática, a dialética e a retórica, como artes da linguagem e, do outro, a pintura e a escultura (artes visuais), como "habilidades" relegadas ao contexto da percepção e longe da razão, deixaram certos resquícios em ambientes ditos "letrados". Inclusive aqueles ligados à cena. Arnheim (1997, p. 2) lembra que, na República, Platão recomendava a música para a educação dos heróis, uma vez que ela introduziria o homem na ordem harmônica e matemática do cosmos, e recomendava cautela com as "artes" (visuais, plásticas), já que elas, particularmente a pintura, eram responsáveis por laços entre o ser humano e imagens ilusórias, simulacros do real.

No espetáculo, entretanto, mesmo o mais revolucionário entre os "encenadores" brasileiros elabora imagens espetaculares, assim como, o mais revolucionário entre os performers - na sua condição de corpo integrado a esse acontecimento 
- funciona como uma imagem ou promove uma sucessão de imagens. Imagens ligadas a um organismo constituído de imagens cênicas fiscalizadas, em movimento (ou o espetáculo). Como se ainda fosse necessário dizer, inexoravelmente comprometidas com a visualidade e, portanto, com a luz.

É possível encontrar inúmeras menções - entre profissionais brasileiros - à expressão anglo-americana (theatre) lighting design (projeto de iluminação para o teatro), o que sugere a necessidade de investigações acerca da natureza do projeto ao qual esse processo se refere. (TUDELLA, 2012) A justificativa para tanto já se encontra na própria expressão, quando ela inclui o termo design, aqui mencionado, uma vez que o mesmo é originário de outra cultura e está ligado a instâncias de concepção e planejamento, passos decisivos na elaboração de um projeto de qualquer natureza.

Uma vez que cada projeto responde a variáveis particulares de cada área da atuação humana a investigação que o trabalho em curso provoca está ligada aos aspectos de natureza estética da atuação do designer em questão, relacionados às características técnicas e aos objetivos de um projeto de luz para espetáculos. No que se refere à vertente estética é imprescindível um estudo da visualidade da cena que inclua pesquisas acerca do papel da sombra na constituição da cena e da natureza da imagem cênica.

A efetiva elaboração deste livro apresentou algumas dificuldades e facilidades que merecem destaque. Em primeiro lugar, foi fácil descobrir que um enorme número de autores e artistas produziu obras que poderiam ser incorporadas à argumentação elaborada no presente texto. Por outro lado, isso criou a relativa dificuldade de seleção daquelas obras que apareceram na versão final do trabalho.

Tal escolha resultou na exclusão de nomes e obras que parecem preciosos objetos de pesquisa, como a parceria entre Philippe-Jacques (ou Philip James) de Loutherbourg (1740-1812) e David Garrick (1717-1779), dado o compromisso visual que impregnou esse pensamento teatral. Ficou também de fora a ópera Fidélio (1805), de Ludwig van Beethoven (1770-1827), cuja abordagem do iluminismo é um grande exemplo da capacidade de um artista de discutir, questionar e/ou interpretar seu próprio tempo em cena; a ária de Florestan, quando ele percebe a presença de Leonore, é um estimulante desafio para o iluminador, em um espetáculo. Antonin Artaud deixou registro de significativo interesse na visualidade da cena que merece citação, mesmo que não tenha despertado a atenção da teoria teatral brasileira, como no prefácio de Teatro da crueldade. Para destacar mais um exemplo de ausência neste trabalho, menciono Johann Wolfgang von Goethe (17491832) e destaco Fausto (1775-1808), sublinhando sua alusão à noite das Walpurgas, 
referência à antiga divindade de origem teutônica que indica densas e primitivas relações entre o ser humano, o fogo e vida. Sem mencionar os mitos de Narciso e Prometeu.

E, por fim, até os momentos que antecederam a redação deste livro não foi possível registrar um estudo brasileiro que tenha aplicado a abordagem de relações entre a cena e a visualidade aqui encontrada. Quiça ela possa encaminhar alguma provocação para o desbravamento de rotas nos estudos do acontecimento espetacular que levem em conta a origem do termo espetáculo em spectare, do latim, indicando olhar para, ver, assistir. De todo modo, cabe às pessoas interessadas no tema compreenderem que certas desconfianças no que se refere ao estudo da imagem cênica aqui empreendido podem derivar, em certo grau, da ausência de familiaridade que pode gerar insegurança, resistência e temor. Quando a atenção se volta para a práxis espetacular elaborada por um artista ou um grupo de artistas com o intuito de propor um evento estético-poético a ser compartilhado com o outro - já chamado de espectador, mencionado como fruidor no desejo de ampliar a qualidade do compartilhamento da cena -, extensas relações com a percepção visual permanecem pulsantes, vivas. 


\section{REFERÊNCIAS}

ACCUM, F. A practical treatise on gas-light. Londres: R. Ackermaxn, 1815. Disponível em: 〈http://archive.org/details/practicaltreatisooaccuuoft $>$. Acesso em: 10 ago. 2008.

ADKINS, L.; ADKINS, R. A. Handbook to life in ancient Rome. New York: Facts on File, 2004.

AgostinHo. Confissões. Tradução de J. Oliveira Santos e Ambrósio de Pina. São Paulo: Abril Cultural, 1980a. (Os Pensadores, v. 6).

AGOSTINHO. De magistro. Tradução de Ângelo Ricci. São Paulo: Abril Cultural, 1980b. (Coleção Os Pensadores, v. 6).

AGOSTINHO. The city of god. Tradução de Marcus Dods. Buffalo: Christian Literature Publishing Co., 1887. v. 2. Disponível em: <http://www.newadvent. org/fathers/1201.htm>. Acesso em: 25 set. 2008.

ALIGHIERI, D. Commedia. Milano: Mondatori, 1966.

ALIGHIERI, D. A divina comédia. Tradução de José Pedro Xavier Pinheiro. São Paulo: Ebooks Brasil, 2003.

ALIGHIERI, D. Commedia. Tradução de Henry W. Longfellow. New York:

Columbia University Press, 1997. Disponível em: <http://dante.ilt.columbia. edu/comedy/>. Acesso em: 25 jan. 2010.

ALTON, J. Painting with light. California: University of California Press, 1995.

ANTOINE, A. Le Théâtre Libre. Paris: Le Théâtre Libre, 1890.

ANTOINE, A. Mês souvenirs sur le Théâtre-Libre. Paris: Arthème Fayard, 1921.

APPIA, A. A obra de arte viva. Tradução de Redondo Júnior. Lisboa: Editora Arcádia, [1921]. 
APPIA, A. Music and the art of the theatre. Translated by Robert W. Corrigan and Mary Douglas Dirks. Miami: University of Miami Press, 1962.

APPIA, A. Actor, space, light. London: John Calder, 1982a.

APPIA, A. Music and the art of the theatre. Translated by Robert W. Corrigan and Mary Douglas Dirks. Miami: University or Miami Press, 1962.

APPIA, A. Staging wagnerian drama. Translation by Peter Loeffler. Basel: Birkhauser Verlag, 1982b.

APPIA, A. Oeuvres completes: tome II. Paris: L'Age d'Homme, 1986.

ARAÚJO, J. S. O. de. A cena ensina: uma proposta pedagógica para formação de professores de teatro. 2005. 177 f. Tese (Doutorado em Educação) - Centro de Ciências Sociais Aplicadas, Universidade Federal do Rio Grande do Norte, Natal, 2005.

ARISTÓTELES. Poética. Tradução de Eudoro de Souza. Lisboa: Guimarães, 1951.

ARISTOTLE. Poetics. Translation by Gerald Frank Else. Ann Arbor: The University of Michigan Press, 1983.

ARNAUD, C. Les théories dramatiques au XVIIe siécle: etude sur la vie et les ouevres de l'abbé d'Aubignac. Paris: Alphonse Picard, 1888.

ARNHEIM, R. Arte e percepção visual: uma psicologia da percepção criadora. 8. ed. Tradução de Ivonne Terezinha de Faria. São Paulo: Pioneira, 1994.

ARNHEIM, R. Visual thinking. Los Angeles: University of California Press, 1997. ARONSON, A. Postmodern design. Theatre journal, Baltimore, v. 43, p. 1-13, 1991. AROUET, F.-M. Dissertations on ancient and modern tragedy. In: DAVIS, L.; REYMERS, C. (Ed.). Critical essays on dramatic poetry. Glasgow: Robert Urie, 1761. p. 132-16o.

AROUET, F.-M. Oeuvres complètes: tome deuxième. Paris: Furne LibrairieEditeur, 1835 .

ARTAUD, A. O teatro e seu duplo. São Paulo: Max Limonad, 1984.

ARTICULAR. In: DICIONÁRIO eletrônico Houaiss da língua portuguesa. Rio de Janeiro: Objetiva, 2007. 1 CD-ROM.

ASSOCIATION OF BRITISH THEATRE TECHNICIANS. Theatre planning. London: Architectural Press, 1974.

AUMONT, J. A imagem. 9. ed. Tradução de Estela dos Santos Abreu e Cláudio César Santoro. São Paulo: Papipus, 2004.

AZEVEDO, W. O que é design. São Paulo: Brasiliense, 2001. 
BALDACCHINO. In: THE OXFORD Dictionary of Art. $3^{\text {rd }}$. Oxford: Oxford University Press, 2004.

BAROQUE! From St Peter's to St Paul's. Direção: Waldemar Januszczac. [S.1.], ZCZ Films para a BBCFour, 2009. (59 min.). Documentário.

BARTHES, R. Aula. 11. ed. Tradução de Leyla Perrone-Moisés. São Paulo: Cultrix, 2004.

BAUDRILLARD, J. L'echange impossible. Paris: Galilée, 1999.

BAVCAR, E. A imagem: vestígio desconhecido da luz. In: NOVAES, A. (Org.). Muito além do espetáculo. São Paulo: Senac, 2005. p. 144-157.

BEACHAM, R. C. Adolphe Appia: texts on theatre. London: Routledge, 1993.

BEACHAM, R. C. Adolphe Appia: artist and visionary of the modern theatre. Philadelphia: Harwood Academic Academic Publishers, 1994.

BEAUMARCHAIS, P.-A. C.de. Le mariage de Figaro. Paris: Libr. Larousse, 1934.

BECKETT, S. Fotfalls. In: BECKETT, S. Collected shorter plays: Samuel Beckett. New York City: Grove Press, 1984a. p. 237-243

BECKETT, S. Play. In: BECKETT, S. Collected shorter plays: Samuel Beckett. New York City: Grove Press, 1984b. p. 145-160.

BELASCO, D. The theatre through its stage door. New York: Benjamim Blom, 1919.

BELASCO, D. Foreword. In: HARTMANN, L. Theatre lighting: a manual of the stage switchboard. New York: DBS Publications, 1970. p. V.

BELTING, H. The end of the history of art? Translated by Christopher S. Wood. Chicago: University of Chicago Press, 1987.

BELTING, H. O fim da história da arte: uma revisão dez anos depois. Tradução de Rodnei Nascimento. São Paulo: Cosac Naify, 2006.

BELTING, H. Beyond iconoclasm. N. J. Paik. The Zen Gaze and the escape from representation. In: LATOUR, B.; WEIBL, P. W. (Ed.). Iconoclash: beyond the image wars in science, religion and art. Cambridge: Mit Press, 2002. p. 390-391.

BELTING, H. Pour une anthropologie des images. Paris: Gallimard, 2004.

BELTING, H. Image, medium, body: a new approach to iconology. Critical inquiry, Chicago, v. 31, n. 2, p. 302-319, 2005.

BELTING, H. Toward an antropology of the image. Disponível em: <http://kunstwissenschaften.hfgkarlsruhe.de/docs/Toward\%20an\%20 Anthropology.pdf $>$. Acesso em: 20 jun. 2009. 
BENEVIDES, P. D. Desenho de luz: um estudo sobre o uso da iluminação no palco. 2011. 134 f. Dissertação (Mestrado em Artes Cênicas) - Escola de Teatro, Universidade Federal da Bahia, Salvador, 2011.

BENTLEY, G. E. Shakespeare and the Blackfriars Theatre, Shakespare's Survey. Cambrige: Cambridge University Press, 1948.

BERBEL, N. A. N. Metodologia da problematização: uma alternativa metodológica apropriada para o ensino superior. Semina: Ciências Sociais e Humanas, Londrina, v. 16, n. 2, p. 9-19, out. 1995. Edição Especial.

BERGMAN, G. M. Lighting in the theatre. Stockholm: Almqvist \& Wiksel International, 1977.

BERTHOLD, M. História mundial do teatro. Tradução de Maria Paula V. Zurawski, J. Guinsburg, Sérgio Coelho e Clóvis Garcia. São Paulo: Perspectiva, 2001.

BÍBLIA. Português. Bíblia de estudo de Genebra. São Paulo: Cultura Cristã e Sociedade Bíblica do Brasil, 1999.

BLEEKER, M. A. The locus of looking: dissecting visuality in the theatre. 2002. 259 f. Dissertation (Phylosophy Doctor in Humanities) - Faculty of Humanities, Amsterdam School for Cultural Analysis (ASCA), Universiteit van Amsterdam, Amsterdam, 2002. Disponível em: <http://dare.uva.nl/ record/107762>. Acesso em: 10 jan. 2009.

BOAL, A. Hamlet e o filho do padeiro: memórias imaginadas. Rio de Janeiro: Record, 2000.

BOILEAU-DESPRÉAUX, N. Art poétique. Paris: L. Hachette, 1838.

BOILEAU-DESPRÉAUX, N. Reflexion critiques sur quelques passages du Rheteur Longin. In: BOILEAU-DESPRÉAUX, N. Ouevres complètes. Paris: Firmin Didot Librairies, 1851. p. 348-378.

BONFITTO, M. A cinética do invisível. Sala Preta, São Paulo, ano 1, n. 2 , p. $82-88,2002$.

BOULANGER, N. C.; LOUNSBURY, W. C. Theatre lighting from a to z. Seattle. London: University of Washington Press, 1992.

BRECHT, B. Gesammelt werk. In: Gedichte: Tomo 2. Frankfurt am Main: Edition Surkamp, 1967. v. 9.

BRECHT, B. Die beleuchtung. In: BRECHT, B. Schriften zum theater 5: 1937-1951. Frankfurt am Main: Suhrkamp, 1963.

BRECHT, B. The lighting. Theatre Crafts International. [200-]. Disponível em: 〈http://www.theatrecrafts.com/lx_brecht.shtml〉. Acesso em: 11 abr. 2011.

BROCKETT, O. G. History of the theatre. Boston: Allyn and Bacon, 1995. 
BRYSON, B. Shakespeare: the illustrated edition. London: Harper Press, 2009.

BUCKHAM, P. W. The theatre of the greeks, or the history, literature, and criticismo of the grecian drama: with an original treatise on

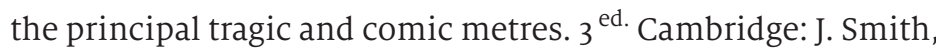
1830. Disponível em: <https://play.google.com/books/reader?id fAAAAMAAJ\&printsec $=$ frontcover\&output $=$ reader \&authuser $=0 \& \mathrm{hl}=\mathrm{pt}$ BR\&pg=GBS.PP1>. Acesso em: 12 jan. 2011.

BURIAN, Y. The scenography of Josef Svoboda. Connecticut: Wesleyan University Press, 1971.

BURLINGAME, E. L. Art, life, and theories of Richard Wagner. New York: Henry Holt and Company, 1875.

CALVINO, Í. Seis propostas para o próximo milênio: lições americanas. 2. ed. Tradução de Ivo Barroso. São Paulo: Companhia das Letras. 1998.

CALVINO, Í. Porque ler os clássicos. Tradução de Nilson Moulin. São Paulo: Companhia das Letras, 2009.

CAMARGO, R. A. Luz e cena: processos de comunicação co-evolutivos. 2006. 181 f. Tese (Doutorado em Comunicação e Semiótica) - Pontifícia Universidade Católica, São Paulo, 2006.

CAMARGO, R. A. Função estética da luz. São Paulo: Perspectiva, 2012.

CAMARGO, R. A. Conceitos de iluminação cênica. Rio de Janeiro: Música e Tecnologia, 2012.

CARLSON, M. Teorias do teatro: estudo histórico-crítico, dos gregos à atualidade. São Paulo: Unesp, 1997.

CARTER, P. Backstage handbook. New York: Broadway Press, 1988.

CARVALHO, J. de. (Coord.). Oficina de iluminação cênica. Rio de Janeiro: IBAC, 1983.

CARVALHO, W. A. de. Santa Maria del fiori, Florença: a maçonaria operativa e a descoberta da América. [200-]. Disponível em: <http://www.freemasonsfreemasonry.com/13carvalho.html $>$. Acesso em: 17 ago. 2009.

CARVER, G.; WHITE, C. Computer visualization for the theatre: 3D modelling for designers. Burlington: Focal Press, 2003.

CASATI, R. A descoberta da sombra: de Platão a Galileu: a história de um enigma que fascina a humanidade. Tradução de Eduardo Brandão. São Paulo: Companhia das Letras, 2001.

CASTLE of perseverance, anônimo medieval. From Stage to Page. [200-].

Disponível em: <http://www.umm.maine.edu/faculty/necastro/drama/index. asp >. Acesso em: 21 out. 2003. 
CHAMBERS, E. K. The elizabethan stage. Oxford: Clarendon Press, 1923.

CHARLTON, H. B. Castelvetro's theory of poetry. Manchester: University Press, 1913.

CHAUÍ, M. Convite à filosofia. São Paulo: Ática, 2000.

CHILVERS, I. (Ed.). The Oxford dictionary of art. $3^{\text {nd }}$. Oxford: Oxford University Press, 2004.

CLURMAN, H. On directing. New York: Collier Books, 1974.

CORNEILLE, P. Andromède. In: Marty-Laveaux, Charles. (Ed.). Les grands ecrivains de la france: oeuvres de Pierre Corneille. Paris: Librairie de L. Hachette et Cie., 1862. Tome V. p. 243-402. (Les grands ecrivains de la France: Oeuvres de Pierre Corneille).

COSTA, R. F. A Oficina de iluminação e a construção do espetáculo: uma proposta pedagógica. 2009. 89 f. Trabalho de Conclusão de Curso (Graduação) - Centro de Ciências Humanas, Letras e Artes, Universidade Federal do Rio Grande do Norte, Natal, 2009.

(THE) COUNCIL of trent: the canons and decrees of the sacred and ecumenical council of trent. Ed. and trans. J. Waterworth. London: Dolman, 1848. Disponível em <http://history.hanover.edu/texts/trent/trentall.html $>$. Acesso em: 26 jun. 2011.

CURRENT, R. N.; CURRENT, M. E. Loie Fuller: goddess of light. Massachusetts: Northeastern University Press, 1997.

D’AUBIGNAC, A. La pratique du theatre. Amsterdam: Jean Frederic Bernard, 1715. Disponível em: <http://www.archive.org/details/lapratiquedutho1aubi . Acesso em: 16 maio 2008.

DE LA GORCE, J. Une scénographie de Servandoni conservée pour les spectacles de l'opéra à Paris: le décor de la ville de Thèbes du triomphe de l'harmonie (1737). Journal for eighteenth-century studies, London, v. 32, n. 4, p. 577-590, 2009. Disponível em: <http://onlinelibrary.wiley.com/doi/10.1111/ j.1754-0208.2009.00228.x/pdf >. Acesso em: 15 abr. 2009.

DENIS, R. C. Uma introdução à história do design. São Paulo: Edgar Blücher, 2000.

DESIGN. In: ADVANCED Oxford learner's dictionary Cd-rom. Oxford: Oxford University Press, 2010.

DICIONÁRIO Houaiss eletrônico da língua portuguesa. Rio de Janeiro:

Objetiva, 2009. 1 CD-ROM.

DIDEROT, D. Essais sur la peinture. Paris: Buisson, 1796. 
DIDEROT, D. Ouevres de théâtre de M. Diderot, avec un discours sur la poésie dramatique: tome premier. Paris: Duchesne et Delalain, 1771.

DIDEROT, D. Ouevres de Denis Diderot. Théâtre. Paris: J. L. J. Brière, 1821.

DIDEROT, D. Ouevres complètes de Diderot: revues sur les éditions originales. Paris: Garnier Frères, 1875. 20 v.

DIDEROT, D. Correspondance: recuille, etablie e annotée par Georges Both. Paris: Editions de Minuit, 1956. v. 2

DINIZ, I. N. Profissão: lighting designer. $L+D$, [S.1.], n. 4, p. 52-57, jul./ago. 2005.

DOLLAR, C. Stage managers do make coffee: a handbook for stage managers. 200o. Disponível em: <http://www.geocities.com/Broadway/Stage/2203/ SMhandbook.html\# Job\%2oDescription >. Acesso em: 25 ago. 2003.

DONDIS, A. D. Sintaxe da linguagem visual. 2. ed. São Paulo: Martins Fontes, 1997.

DONDIS, A. D. Design, cultura material e o fetichismo dos objetos. São Paulo: Arcos, 1998. v. 1, p. 14-26.

DUBOS, J.-B. Réflexions critiques sur la poésie et la peinture. Paris: P. J. Mariette, 1733.

ENERGIA. In: DICIONÁRIO eletrônico Houaiss da língua portuguesa. Rio de Janeiro: Objetiva, 2007. 1 CD-ROM.

ÉSQUILO. Oréstia. Tradução de Mário da Gama Kury. Rio de Janeiro: Jorge Zahar Editor, 1990.

ESSIG, L. Lighting and design idea. Forth Worth: Hartcourt Brace College Publishers, 1997.

ESSIG, L. The speed of light: dialogues on lighting design and technological change. Portsmouth: Heinemann, 2002.

ESSLIN, M. Brecht, a choice of evils: a critical study of the man, his work a nd his opinions. London: Eyre Methuen, 1980.

ETHOS. In: ADVANCED Oxford learner's dictionary Cd-rom. Oxford: Oxford University Press, 2010.

EURÍPEDES. Medea. Translated by Ian Johnston. Virginia: Richer Resources Publications, 2008.

EYNAT-CONFINO, I. Beyond the mask: Gordon Craig, movement and the actor. Chicago: Southern Illinois University, 1987.

FANTASIA. In: DICIONÁRIO eletrônico Houaiss da língua portuguesa. Rio de Janeiro: Objetiva, 2007. 1 CD-ROM. 
FÉNELON, F. de S. de la M. Dialogues sur l'eloquence en general et sur celle da claire en particulier avec une lettre écrite à l'academie françoise. Paris: Veuve Etienne, 1740.

FÉRAL, J. Por uma poética da performatividade: o teatro performativo. Sala Preta, São Paulo, n. 8, p. 197-209, 2008.

FERNANDES, C. Em algum lugar do presente: performance, performance art ou prática espetacular. Repertório Teatro \& Dança, Salvador, ano 4, n. 5, p. 3, 1999.

FERNANDES, J. de M. A enunciação na encenação teatral. Estudos Semióticos, São Paulo, n. 2, p. 1-11, 2006. Disponível em: <www.fflch.usp.br/dl/semiotica/ es>. Acesso em: 7 nov. 2009.

FIGUEIREDO, L. M. de. Luz: a matéria cênica pulsante - apontamentos didáticos e estudo de caso. 2007. 160 f. Dissertação (Mestrado em Artes Cênicas) - Escola de Comunicações e Artes, Universidade de São Paulo, São Paulo, 2007.

FISCHER, B. Maestro of light: Vittorio Storaro, ASC. Writing poetry with light. [200-]. Disponível em: 〈http://www.cameraguild.com〉. Acesso em: 12 ago. 2004. FISCHER, B. D. A history of opera: milestones and metamorphoses. Miami: Opera Journeys Publishing, 2005.

FISICALISMO. In: DICIONÁRIO eletrônico Houaiss da língua portuguesa. Rio de Janeiro: Objetiva, 2007. 1 CD-ROM.

FLUSSER, V. Filosofia da caixa preta: ensaios para uma futura filosofia da fotografia: São Paulo: Hucitec, 1985.

FLUSSER, V. The shape of things: a philosophy of design. Translated by Anthony Mathews. London: Reaktion Books, 1999.

FORJAZ, C. À luz da linguagem: a iluminação cênica: de instrumento de visibilidade à 'scriptura do visível' (primeiro recorte: do fogo à revolução teatral). 2008. 232 f. Dissertação (Mestrado em Artes Cênicas) - Escola de Comunicações e Artes, Universidade de São Paulo, São Paulo, 2008.

FOSTER, H. (Ed.). Vision and visuality. Settle: Bay Press, 1988.

FRAGA, F.; MATAMORO, B. A história. In: MONTEVERDI, C. Orfeo. São Paulo: Moderna, 2011. p. 13-16. (Folha Grandes Óperas, v. 8).

FRANCASTEL, P. Imagem, visão e imaginação. Tradução de Fernando Caetano. São Paulo: Martins Fontes, 1983.

FUCHS, E. The death of character: perspectives on theater after modernism. Indiana: Indiana University Press, 1996.

FUCHS, T. Stage lighting. New York: B. Blum, 1963. 
FULLER, L. Fifteen years of a dancer's life. Londres: Herbert Jenkins Limited, 1913.

FÜSSEL, S. Gutenberg and the impact of printing. Translated by Douglas Martin. Burlington: Aldershot Publishing, 2003.

GAZONI, F. M. G. A poética de Aristóteles: tradução e comentários. 2006. 131 f. Tese (Doutorado em Filosofia) - Departamento de Filosofia da Faculdade de Filosofia, Letras e Ciências Humanas, Universidade de São Paulo, São Paulo, 2006. Disponível em: <http://www.fflch.usp.br/df/site/posgraduacao/20o6_ mes/Fernando_Gazoni_A_Poetica_de_Aristoteles.pdf $>$. Acesso em: 20 jul. 2010.

GILLETTE, J. M. Designing with light: an introduction to stage lighting. New York: McGraw-Hill, 2003.

GLEASON, J. Color part three: dominant/recessive qualities. Lighting dimensions, New York, v. 12, n. 3, p. 84-89, May/June 1988.

GLENN, B. L. The threepenny opera: designing lights with Brecht. 2002. 93 1. Thesis (Graduate) - Department of Music and Dramatic Arts, Louisiana State University, Louisiana, 2002. Disponível em: <http://etd.1su.edu/docs/ available/etd-o411102- 220101/ unrestricted/Glenn_thesis.pdf 〉. Acesso em: 18 abr. 2008.

GONTARSKI, S. E. Editing Beckett. Twentieth century literature, New York, v. 41, p. 190-207, 1995.

GRAMMONT, M. Le Vers Français. Paris: Librairie Edouard Champion, 1913.

GRAVES, R. B. The greek myths. London: Victoria Penguin Books, 1957. 2 v.

GRAVES, R. B. Lighting the shakespearean stages: 1567-1642. Carbondale: Southern Illinois University Press, 1999.

GREENBERG, R. Bach and the high baroque: part I. Virginia: The Teaching Company, 1998a.

GREENBERG, R. Bach and the high baroque: part II. Virginia: The Teaching Company, 1998b.

GREENBERG, M. Corneille, classicism, and the ruses of symmetry. Cambridge: Cambridge University Press, 1986.

GROSS, M. Light and life. New York: London: Oxford University Press, 2002.

GROUT, D. J.; WILIIAMS, H. W. A shot story of opera. New York: Columbia University Press, 2003.

GUIMARÃES, R. Dicionário da mitologia grega. São Paulo: Cultrix, 1995.

GUINSBURG, J. Leone de'Sommi: um judeu no teatro da renascença italiana. São Paulo: Perspectiva, 1989. 
GUINSBURG, J. Teoria do teatro e estética teatral. Sala preta, São Paulo, ano 1, n. 1, p. 173-179, 2002.

GUIZOT, F. Dictionnaire universel des synonymes de la langue française. 5 ème èd. Paris: Didier et $C^{\mathrm{e}}, 1861$.

GUIZOT, M. Corneille and his times. New York: Harper \& Brothers Publishers, 1852.

HACKLER, E. Caspar Neher and Bertholt Brecht: a scenographic contribuition to epic theater. 1983. 200 1. Dissertation (Doctor of philosophy in dramatic art) University of California, Berkeley, 1983.

HAGIWARA, Y. La théorie de la représentation dans la pratique du théâtre de d'Aubignac. La Societé Japanaise de Langue e Literature Françaises, 1982. Disponível em: <http://ci.nii.ac.jp/els/110001247295. pdfid=ARTooo1625629\&type=pdf\&lang=eng\&host=cinii\&order_no=\&ppv_ type=)\&lang_sw $=\& n o=1319800014 \& c p=>$. Acesso em: 3 jan. 2007.

HARTMANN, L. Theatre lighting: a manual of the stage switchboard. New York: DBS Publications, 1970.

HARTNOLL, P. (Ed.). The oxford companion to the theatre. $2^{\text {nd. }}$ London: Oxford University Press, 1957.

HAYS, D. Light on the subject. New York: Limelight Editions, 1995.

HENDERSEN, C. Theater in America. New York: Harry N. Abrams, Inc, 1986.

HESIOD. The homeric hymns and homerica. Translated by Hugh G. Evelyn-White. Cambridge: Harvard University Press; London: William Heinemann, 1914.

HEWITT, B. (Ed.). The Renaissance stage: documents of Serlio, Sabbattini and Furttenbach. Miami: University of Miami Press, 1958.

HEWITT, B. Histoire de l'academie royale des sciences, Année I78I: avec les mémoire de matematique et de physique pour la même année. Paris: L’Imprimière Royale, 1884.

HODGE, F. Play directing: analysis, communication and style. New Jersey: Prentice-Hall, 1971.

HONOUR, H.; FLEMING, J. The visual arts: $a$ history. $5^{\text {th. }}$ New Jersey: Prentice Hall, 1984.

HOWARD, P. What is scenography?. $2^{\text {nd }}$. New York: Routledege, 2009.

HUGO, V. Do grotesco ao sublime. Tradução de Celia Berrettini. São Paulo: Perspectiva, 1988.

HUGO, V. Marion de Lorme. Bruxelles: Antoine Peeters, 1831. 
HUGO, V. William Shakesperare. Paris: Librairie Internationale, 1864.

HUGO, V. William Shakesperare. Tradução de Renata Cordeiro e Paulo Schmidt. Paraná: Campanário, 2000.

IZENOUR, G. Theatre design. New York: McGraw-Hill, 1977.

JACQUEMONT, C. V. La luminotechnie dans le theatre de Samuel Beckett: dramaturgie et metaphysique. 1980. 286 1. Thesis (Doctor of Philosophy) - Rice University, Houston, 1980.

JAEGER, W. Paidéia: a formação do homem grego. Tradução de Arthur M. Pereira. São Paulo: Martins Fontes, 1995.

JAY, M. Scopic regimes of modernity. In: FOSTER, H. (Ed.). Vision and visuality. Seattle: Bay Press, 1988. p. 3-23.

JONES, R. E. The dramatic imagination: reflections and speculations on the art of the theatre. New York: Theatre Arts Books, 1984.

JOURNAL OF BECKETT STUDIES. Edinburg: Edinburg University Press, 1978. v. 3. JÜRS-MUNBY, K. Introduction. In: LEHMANN, H.-T. Postdramatic theatre. New York: Routledge, 2006. p. 1-15.

KANE, S. Complete plays. London: Methuen, 2001.

KASTNER, L. E.; ATKINS, H. G. Short history of french literature. New York: Henry Holt and Company, 1907.

KATINSKY, J. R. Preliminares a um estudo futuro de Vitrúvio. In: OLIÃO, M. V. Da arquitetura. Tradução de Marco Aurélio Lagonegro. São Paulo: Hucitec, 1999. p. 9-47.

KELLER, M. Light fantastic. Munich: Prestel Verlag, 1999.

KERNODLE, G. R. General introduction: the renaissance stage. In: HEWITT, B. (Ed.). The renaissance stage: documents of Serlio, Sabbattini and Furttenbach. Miami: University of Miami Press, 1958a. p. 1-17.

KERNODLE, G. R. Joseph Furttenbach the elder. In: HEWITT, B. (Ed.). The renaissance stage: documents of Serlio, Sabbattini and Furttenbach. Miami: University of Miami Press, 1958b. p. 178-251.

KIMBLE, D. R. B. Italian opera. Cambridge: Cambridge University Press, 1995.

KNAUSS, P. Aproximações disciplinares: história, arte, imagem. Anos 90, Porto Alegre, v. 15, n. 28, p. 151-168, dez. 2008.

KNOWLSON, J. Damned to fame: the life of Samuel Beckett. London:

Bloomsbury Publishing, 1996. 
KNOWLSON, J.; Pilling, J. Frescoes of the skull: the later prose and drama of Samuel Beckett. London: John Calder, 1979.

KRANZFELDER, I. Edward Hopper I882-I967: visions of reality. Colonia: Taschen, 1995 .

LAMY, B. De l'art de parler. Paris: André Pralard, 1679.

LANCASTER, H. C. (Ed.). Le Mémoire de Mahelot, Laurent et d'autres décorateurs de L'hôtel de Bourgogne et de la Comédie-Française au XVII siècle. Paris: Honoré Champion, 1920.

LANZI, L. La storia pittorica della italia inferiore o sia delle scuole fiorentina a senese romana napolitana. Firenze: Stamperia di Ant. Gius. Panani, 1972.

LAVOISIER, A. Mémoire sur la manière d'éclairer les salles de spectacle Academies de Sciences. In: HEWITT, B. Histoire de l'academie royale des sciences. Année I78I: avec les mémoire de matematique et de physique pour la même année. Paris: L’Imprimière Royale, 1781. p. 409-420.

LAWLEY, P. Samuel Beckett's relations. Journal of Beckett studies, Florida, v. 6, n. 2, p. 1-61, 1996. Disponível em: <http://www.academia.edu/218619/Samuel_ Becketts_Relations $>$. Acesso em: 23 fev. 2012.

LAWLEY, P. Beckett's dramatic counterpoint: a reading of 'Play'. Journal of Beckett studies, Florida, n. 9, p. 1-13. 1983, Disponível em: <http://www. academia.edu/193181/Becketts_Dramatic_Counterpoint_A_Reading_of_PLAY $\rangle$. Acesso em: 23 fev. 2012.

LEÃO, E. C. Filosofia grega: uma introdução. Teresópolis: Daimon, 2010.

LEHMANN, H. -T. Postdramatic theatre. Translated by Karen Jurs-Munby. London: Routledge, 2006.

LOCUS. In: ADVANCED Oxford learner's dictionary Cd-rom. Oxford: Oxford University Press, 2010.

LYOTARD, J. F. A condição pós-moderna. Tradução de Carlo Irineu Costa.

São Paulo: José Olympio, 1979.

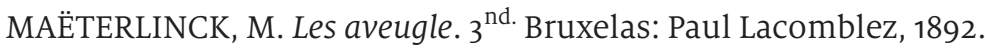

MAIRET, J. La silvanire ou la morte-vive. Paris: François Targa. 1631.

MALLARMÉ, S. Divagations. Paris: Bibliotèque Charpentier, 1897

MANNONI, L. A grande arte da luz e da sombra. Tradução de Assef Kfouri. São Paulo: Unesp, 2003.

MARTY-LAVEAUX, C. J. (Org.). Les grands ecrivains de la France: oeuvres de Pierre Corneille. Andromèd. Paris: Librairie de L. Hachette et Cie., 1862. Tome V. 
MCCANDLESS, S. A method of lighting the stage. $4^{\text {th. }}$ New York: Theatre Arts Books, 1984.

MCDOWELL, J. H. Nicola Sabbattini. In: HEWITT, B. (Ed.). The Renaissance stage: documents of Serlio, Sabbattini and Furttenbach. Miami: University of Miami Press, 1958. p. 37-177.

MÉZIÈRES, N. L. de. Le genie d'architecture, ou l'analogie de cet art avec nos sensations. Paris: Benoit Morin, 1780.

MERRIAM WEBSTER. The new Merriam: vebster dictionary. Massachusetts, 1989.

MITCHELL, W. J. T. Iconology: image, text, ideology. Chicago: The University of Chicago Press, 1986.

MITCHELL, W. J. T. Interdisciplinarity and visual culture. Art bulletin, California, v. 77, n. 4, p. 540-544, 1995.

MITCHELL, W. J. T. Showing seeing: a critique of visual culture. Journal of visual culture, London, v. 1, p. 165-181, Aug. 2002.

MONTEVERDI, C. Orfeo. São Paulo: Moderna, 2011. (Coleção Folha Grandes Óperas, v. 8).

MORINNI, C. de. Loie Fuller: the fairy of light. In: MAGRIEL, P. (Ed.). Chronicles of american dance: from the shakers to Martha Graham. New York: Da Cappo Press, 2010. p. 203-220.

MOURA, E. P. de. 50 anos: luz, câmera e ação. São Paulo: Senac, 1999.

MÚSICA. In: DICIONÁRIO eletrônico Houaiss da língua portuguesa. Rio de Janeiro: Objetiva, 2009. 1 CD-ROM.

NAGLER, A. M. A source book in theatrical history: sources of theatrical history. New York: Dover Publications, 1952.

NAGLER, A. M. Shakespeare's stage. New Haven: Yale University Press, 1964. NICOLL, A. The development of the theatre: a study of theatrical form from the beginnings to the presente day. London: George C. Harrap, 1927.

NICOLL, A. Sebastiano Serlio. In: HEWITT, B. (Ed.). The renaissance stage: documents of Serlio, Sabbattini and Furttenbach. Miami: University of Miami Press, 1958. p 18-36.

NIETZSCHE, F. O livro do filósofo. 6. ed. Tradução de Rubens Eduardo Ferreira Frias. São Paulo: Centauro, 2005.

NIXON, M. Samuel Beckett's german diaries. London: Continuum International, 2011. 
(THE) NOBEL prize in literature 1911: Maurice Maeterlinck: Biographical. Nobelprize.org. [200-]. Disponível em:<http://www.nobelprize.org/nobel_ prizes/literature/ laureates/ 1911/index.html.> Acesso em 13 dez. 2011.

(THE) NOBEL prize in Literature 1911. Nobelprize.org. 2014. Disponivel em: $\langle$ http://www.nobelprize.org/nobel_prizes/literature/laureates/1911/>. Acesso em: 9 dez. 2012.

NÖSSEST, F. Mythology: greek and roman. Translated by Angus W. Hall. London: Kerby and Endean, 1885.

NOVAES, A. (Org.). Muito além do espetáculo. São Paulo: Senac, 2005.

NOVERRE, M. Lettres sur la dance et sur les ballets. Lyon: Aimé Delaroche, 1760.

OGDEN, D. H. The staging of drama in the medieval church. New Jersey:

Associated University Press, 2002.

OPPENHEIM, L. The painted word: Samuel Beckett's dialogue with Art. Ann Arbor: University of Michigan Press, 2000.

O'TOOLE, J. L. Andrea Pozzo: the joining of truth and Illusion. 1999. $131 \mathrm{f}$. Thesis (Master of Architecture) - School of Architecture, McGill University, Montréal, 1999.

OVÍDIO. Metamorfoses. Tradução de Manuel Maria Barbosa de Bocage. São Paulo: Martin Claret, 2006.

(THE) OXFORD Dictionary of Art. $3^{\text {rd. }}$ Oxford: Oxford University Press, 2004.

PARTITURA. In: DICIONÁRIO eletrônico Houaiss da língua portuguesa. Rio de Janeiro: Objetiva, 2009. 1 CD-ROM.

PAGLIANO, A. Il disegno dello sapazio scenico. Milão: Hoepi, 2002.

PALIMPSESTO. In: DICIONÁRIO Houaiss eletrônico da língua portuguesa. Rio de Janeiro: Objetiva, 2009. 1 CD-ROM.

PALMER, R. H. The lighting art: the aesthetics of stage lighting design. $2^{\text {nd. }}$ New Jersey: Prentice Hall, 1998.

PARKER, O. W.; SMITH, H. K. Scene design and stage lighting. $3^{\text {rd. }}$ New York: Holt, Rinehart and Winston, 1974.

PATERSON, M. The stagecraft of the revels office during the reign of Elizabeth: studies in the elizabethan theatre. Ed. Charles T. Prouty. Cambridge: Shoe String Press, 1961.

PATRICK, G. T. W. (Comp.). The fragments of the work of Heraclitus de Ephesus: on nature. Baltimore: N. Murray, 1889. 
PATTE, P. Essai sur l'architecture théâtral ou de l'ordonnance la plus avantageuse à une salle de spectacles, relativement aux principes de l'optique \& de l'acoustique. Paris: Moutard. 1782.

PAVIS, P. A análise dos espetáculos. São Paulo: Perspectiva. 2005.

PAVIS, P. Dicionário de teatro. São Paulo: Perspectiva, 2003.

PELLETIER, L. Architecture in words: theatre, language and the sensuous space of architecture. London: Routledge, 2006.

PENNELL, J.; PENNELL, E. R. Pictorial successes of Mr. Irving's Faust.

The century, New York, v. 35, n. 2, p. 309-311, dez. 1887.

PEREZ, V. Desenho de iluminação de palco: pesquisa, criação e execução de projetos. 2007. 154 f. Dissertação (Mestrado em Multimeios) - Instituto de Artes Universidade Estadual de Campinas, Campinas, 2007.

PEREZ, V. Luz e arte: um paralelo entre as ideias de grandes mestres da pintura e o design de iluminação. São Paulo: De Maio, 2012.

PILBROW, R. Stage lighting design: the art, the craft, the life. New York: Design Press, 2002.

PIXERÉCOURT, R. C. G. de. Theatre choisi: tome Premier. Nancy: L'Auter, 1841.

PLATÃO. Diálogos III: a república. Tradução de Leonel Vallandro. 26. ed. Rio de Janeiro: Ediouro, 2001.

PLATO. Ion. Translated by Benjamin Jowett, [S.1., s.n.], 2008. Disponível em: 〈www.gutenberg.org〉. Acesso em: 3 jan. 2010.

PLINY. The natural history. Translated by John Bostock e H. T. Ryley. London: Henry G. Bohn, 1867. v. VI.

POLIÃO, M. V. Da arquitetura. Tradução de Marco Aurélio Lagonegro. São Paulo: Hucitec, 1999.

POLLIO, M. V. The ten books of architecure. Translation by Morris Hicky Morgan. Cambridge: Harvard University Press, 1914. 2 v.

POLLIO, M. V. The architecture. Translation by Joseph Gwilt. London: Priestley and Weale, 1826. Disponível em: <http://www.ukans.edu/history/index/europe/ ancient_rome/E/Roman/Texts/Vitruvius/1.html\#5.1〉. Acesso em: 5 maio 2004.

POMPIGNAN, J.-J. L. Le triomphe de l'harmonie. Paris: Jean-Baptiste; Christophe Ballard, 1737.

PORTUGAL, D. B.; ROCHA, R. M. Como caçar e ser caçado por imagens: entrevista com W. J. T. Mitchell. E-compós, Brasília; DF, v. 12, n. 1, p. 1-16, jan./ abr. 2009. Disponível em: <http://www.compos.org.br/seer/index.php/ ecompos/article/viewPDFInterstitial/376/327>. Acesso em: 27 jun. 2009. 
POWELL, J. Music and scenic portrayal of gods, men, and monsters in Cornéille's Andromède. [200-]. Disponível em: <http://www.personal.utulsa.edu/ johnpowell/Andromede/>. Acesso em: 17 out 2011.

QUADRATURA. In: THE OXFORD Dictionary of Art. $3^{\text {rd. }}$ Oxford: Oxford University Press, 2004.

QUINCY, A. C. Q. de. Histoire de la vie et des ouvrages des plus célèbres architectes du XI $I^{\mathrm{e}}$ siècle jusqu'a la fin du XVIII ${ }^{\mathrm{e}}$. Paris: Jules Renouard, 1830.

QUINTILIAN. The instruction of the orator. Translation by J. Patssal. London: B. Law; J. Wilkie, 1774. v. 2.

RACINE, J. Athalie. New York: Henry Holt \& Company, 1892.

RACINE, J. Iphigénie. Paris: Claude Barbin, 1675.

RÉGLÉ, RÉGULIÈR. In: Dictionnaire universel des synonymes de la langue française. 5 ème. èd. Paris: Didier et $C^{\mathrm{e}}, 1861$.

RÉGULIER, IÈRE. In: DICTIONNAIRE de 1'Academie Française. 6. ed. Paris: Institut de France, 1835.

REID, F. The stage lighting handbook. New York: Theatre Arts Books, 1976.

RICHARDS, W. The manufacture and distribution of coal gas. Londres: E \& F. N. Spon. 1877.

RIGON, F. Das teatro olimpico in Vicenza. Milão: Electa, 2004.

ROSE, R. Drafting scenery for theater, film and television. Virginia: Betterway Publications, 1990.

ROSENAU, H. (Ed.). Boullée \& visionary architecture. London: Academy Editions, 1976.

ROSENTHAL, J.; WERTENBAKER, L. The magic of light. Boston: Little, Brown and Company, 1972.

ROSTAND, E. Oeuvres complètes illustrées: biografia e análise de Émile Fasquelle. Paris: Pierre Laffitte, c. 1910/1911.

ROUBINE, J.-J. A arte do ator. Rio de Janeiro: Jorge Zahar, 1982a.

ROUBINE, J.-J. A linguagem da encenação teatral. Rio de Janeiro: Jorge Zahar, $1982 \mathrm{~b}$.

ROUBINE, J.-J. Introdução às grandes teorias do teatro. Tradução de André Telles. Rio de Janeiro: Jorge Zahar, 2003.

SALUSTRI, F. A. An extremely short history of design. 2001. Disponível em: $\langle$ http://deed.ryerson.ca/ fil/T/gen/historyo.html $\rangle$. Acesso em: 2 ago. 2003. 
SARAIVA, H. Curso básico de iluminação teatral. São Paulo: Livraria Cena Brasileira, [1985?].

SARAIVA, H. Iluminação teatral: história, estética e técnica. 1989. $300 f$. Dissertação (Mestrado em Artes) - Escola de Comunicações e Artes, Universidade de São Paulo, São Paulo, 1989.

SARAIVA, H. Interações físicas e psíquicas geradas pelas cores na iluminação teatral. 1999. 122 f. Tese (Doutorado em Artes) - Escola de Comunicações e Artes, Universidade de São Paulo, São Paulo, 1999.

SCHMIDGALL. G. Shakespeare and the courtly aesthetic. Berkeley: University of California Press, 1981.

SCHOENBERG, A. Theory of harmony. Translation by Roy E. Carter. London: Faber and Faber, 1978.

SELDON, S.; SELLMAN, H. D. Stage scenery and lighting. New York: AppletonCentury Crofts, 1936.

SERRAT, B. S. B. V. M. Iluminação cênica como elemento modificador dos espetáculos: seus efeitos sobre a cena. 2006. 93 f. Dissertação (Mestrado em Ciências em Arquitetura) - Faculdade de Arquitetura e Urbanismo, Universidade Federal do Rio de Janeiro, Rio de Janeiro, 2006.

SHAKESPEARE, W. A tempestade. Tradução de Bárbara Heliodora. Rio de Janeiro: Lacerda Editores, 1999.

SHAKESPEARE, W. Hamlet. Tradução de Anna Amélia Carneiro de Mendonça. Rio de Janeiro: Nova Fronteira, 1995.

SHAKESPEARE, W. Hamlet (First Folio Edition, I623). Virginia, [2008a].

Disponível em: <http://etext.virginia.edu/toc/modeng/public/ShaHamF. html $>$. Acesso em: 3 jan. 2010.

SHAKESPEARE, W. King Lear (First Folio Edition, I623). Virginia, [2003]. Disponível em: <http://etext.virginia.edu/toc/modeng/public/ShaKLF.html〉. Acesso em: 5 jan. 2010.

SHAKESPEARE, W. Rei Lear. Tradução de Bárbara Heliodora. Rio de Janeiro: Lacerda Editores, 1998.

SHAKESPEARE, W. Sonho de uma noite de verão. Tradução de Carlos Alberto Nunes. Rio de Janeiro: Ediouro, 1995.

SHAKESPEARE, W. The tempest (First Folio Edition, I623). Virginia, [2008b]. Disponível em: 〈http://etext.virginia.edu/toc/modeng/public/ShaTemF.html〉. Acesso em: 29 dez. 2009.

SHAKESPEARE, W. The first part of Henry the VI (First Folio Edition, 1623). In: MR. WILLIAM Shakespeares Comedies, histories \& tragedies, 
published according to the true originall copies. London: William Jaggard, Edward Blount, L. Smithweeke, and W. Aspley, 1623. Disponível em: <http://internetshakespeare.uvic.ca/Library/facsimile/book/Bran_ F1/461/?zoom=1200 $>$. Acesso em: 25 fev. 2010.

SHARP, T. A dissertation on the pageants or dramatic mysteries ancienlty performed at Coventry, [S.1.: s.n.], 1825.

SIRLIN, E. La luz en el teatro: manual de iluminación. $2^{\text {a }}$ ed. Buenos Aires: Instituto Nacional de Teatro, [2006].

SMITH, I. Shakespeare's globe playhouse: a modern reconstruction in text and scale drawings. New York: Charles Scribner's Sons, 1956.

SMITH, W. (Ed.). Dictionary of greek and roman biography and mithology. Boston: Little, Brown and Company, 1866. Disponível em: <http://www.ancientlibrary. com/smith-bio/1744.html $>$. Acesso em: 14 ago. 2012.

SOUTHERN, R. The medieval theatre in the round. London: Faber and Faber Limited, 1957.

SOUZA, T. C. C. Discurso e imagem: perspectivas de análise do não verbal. Ciberlegenda, Niterói, n. 1, 1998. Disponível em: <http://www.uff.br/mestcii/ tania1.htm>. Acesso em: 28 ago. 2003.

SPINELLI, M. Filósofos pré-socráticos:primeiros mestres da filosofia e da ciência grega. 2 ed. Porto Alegre: Edipucrs, 2003.

STOKER, B. Personal reminiscence of Henry Irving. Londres: William Heinemann. 1907.

STORM. In: OXFORD advanced learner's dictionary. Oxford: Oxford University Press, 2010. 1 CD-ROM.

STREADER, T.; WILLIAMS, J. A. Create your own stage lighting. New Jersey: Prentice-Hall, Inc., 1985.

STRIGGIO, A. Libreto de Orfeo. In: MONTEVERDI, C. Orfeo. São Paulo, 2011. p. 23-43. (Folha Grandes Óperas, v. 18).

STRINDBERG, A. Contess Julie. Translation by Edith and Warner Oland, [S.1.: s.n.], 2009. Ebook. Disponível em: <http://www.gutenberg.org/ files/8499/8499-h/8499-h.htm>. Acesso em: 6 abr. 2011.

STRINDBERG, A. Senhorita Júlia. Tradução de Knut Bernstrom e Mario da Silva. Rio de Janeiro: Civilização Brasileira, 1970.

SURGERS, A. Escenografias del teatro occidental. Traducción de Magdalena Arnoux. Buenos Aires: Ediciones Artes del Sur, 2005a.

SURGERS, A. Scenographies du théâtre ocidental. Paris: Arman Collin, 2005b. 
SWIFT, N. The shield of Achilles: Iliad 18.478-608. Aoid.org. 2005. Disponível em: 〈http://www.aoidoi.org/poets/homer/il/shield.pdf 〉. Acesso em: 19 nov. 2011.

SZONDI, P. Tableau and coup de théâtre: on the social psychology of diderot's bourgeois tragedy. New Literary History, Baltimore, v. 11, n. 2, p. 323-343, 1980.

SZONDI, P. Theory of the modern drama. Boundary 2, North Carolina, v. 11, n. 3, p. 191-230, 1983.

TCHÉKHOV, A. P. Os males do tabaco e outras peças em um ato. São Paulo: Ateliê, 2001.

TERTULLIANO, C. De spectaculis. In: TERTULLIAN. Apologetic and practical treatise. Oxford: Parker, 1842. v. 1, p. 187-219. (Library of fathers of the Holy Catholic Church, v. 10).

THE AMERICAN THEATRE PLANNING BOARD. Theatre check list: a guide to the planning and construction of proscenium and open stage theatres Connecticut: Wesleyan University Press, 1969.

THORNTON, P. Authentic decor: the domestic interior I62O-I92O. New York: Viking Penguin Inc., 1984.

TORMANN, J. Caderno de iluminação: arte e ciência. 2. ed. Rio de Janeiro: Música e Tecnologia, 2008.

TÖRNQUIST, E.; STEENE, B. Strindberg on drama and theatre: a source book. Amsterdam: Amsterdam University Press, 2007.

TRÍPTICO. In: DICIONÁRIO eletronico Houaiss da língua portuguesa. Rio de Janeiro: Objetiva, 2009. 1 CD-ROM.

THORNTON, W. Our town. New York: Harper Collins Publishers, 2003.

TUDELLA, E. A. da S. Conceitos para a luz. 2009. Disponível em: <https://www. listas.unicamp.br/pipermail/dicasdeiluminacaol/20080421/000181.html〉. Acesso em: 22 set. 2009.

TUDELLA, E. A. da S. Design, cena e luz: anotações. Revista A[l]berto, São Paulo, n. 3, p 11-24, 2012,

VASARI, G. The lives of the artists. Translated by Julia Conaway Bondanella and Peter Bondanella. Oxford: University Press, 1998.

VASARI. G. Le vite dei più eccelenti pittori, scultori e architetti. 2. ed. Roma: Grande Tascabili Economici, 1993.

VASARI, G. The lives of the painters, sculptors and architects. Translation by A. B. Hinds, New York: E. P. Dutton \& Co., 1927.

VENDRAMINI, J. E. O teatro de origem não-dramatúrgica. Sala Preta, São Paulo, ano 1, n. 1, p. 81-86, 2002. 
VITRUVIUS. De architectura libri decem. [200-]. Biblioteca Augustana. Disponível em: <http://www.fhaugsburg.de/ harsch/Chronologia/Lsanteo1/ Vitruvius/vit_aroo.html $>$. Acesso em: 18 mar. 2003.

VOSSLER, K. Jean Racine. Translated by Isabel McHugh and Florence McHugh. New York: Frederick Ungar, 1972.

WARFEL, W. B. The new handbook of stage lighting graphics. New York: Drama Book Publishers, 1990.

WATSON, L. Lighting design handbook. New York: McGraw-Hill, 1990.

WEBB, R. Ekphrasis, imagination and persuation in ancient rhetorical theory and practice. Farnham: Ashgate, 2009.

WEINBERG, B. Critical prefaces of french renaissance. Illinois: Northwestern University Press, 1950.

WICKHAM, G. Early english stages. London: Routledge \& Kegan Paul, 1980.

WILD, L. An approach to stage lighting. 2003. Disponível em: <http://lupus. northern.edu:9o/wild/th241/ldapp.htm >. Acesso em: 8 ago. 2003.

WILD, L. Jean Rosenthal I9I2-I969. 2000. Disponível em: <http://www. northern.edu/wild/jr.htm\#articles $>$. Acesso em: 27 out. 2003.

WILLET, J. (Ed.). Brecht on theatre: the development of an aesthetic. New York: Hill and Wang, 1977.

WILLIAMS, B. A history of light and lighting. 1999. Disponível em: <http://www.mts.net/ william5/history/hol.htm〉. Acesso em: 28 fev. 2003

WILLIAMS, B. World Lighting Links. 2011. Disponível em:

〈http://billwilliams.ca/resources/links.htm〉. Acesso em 12 dez.2011.

WILLIAMS, T. The glass menagerie. $30^{\text {th. }}$ New York: New Directions Books, 1970.

WORVILL, R. From prose peinture to dramatic tableau Diderot, Fénelon and the emergence of the pictorial aesthetic in France. Studies in eighteenth century culture, Maryland, v. 39, p. 151-170, 201

YOUNG, H. D.; FREEDMAN, R. A. Física IV: ótica e física moderna. 10. ed. São Paulo: Pearson, 2004.

ZANKER, G. Enargeia in the ancient criticism of poetry. Rheinisches Museum, Bonn, n. 124, p. 297-311,1981.

ZOLA, É. Le roman expérimental. 5 ème èd. Paris: G. Charpentier, 1881.

ZOLA, É. Le naturalisme au théàtre: les théories et les exemples. Paris: Bibliotèque Charpentier, 1921. 
CADERNO DE IMAGENS 


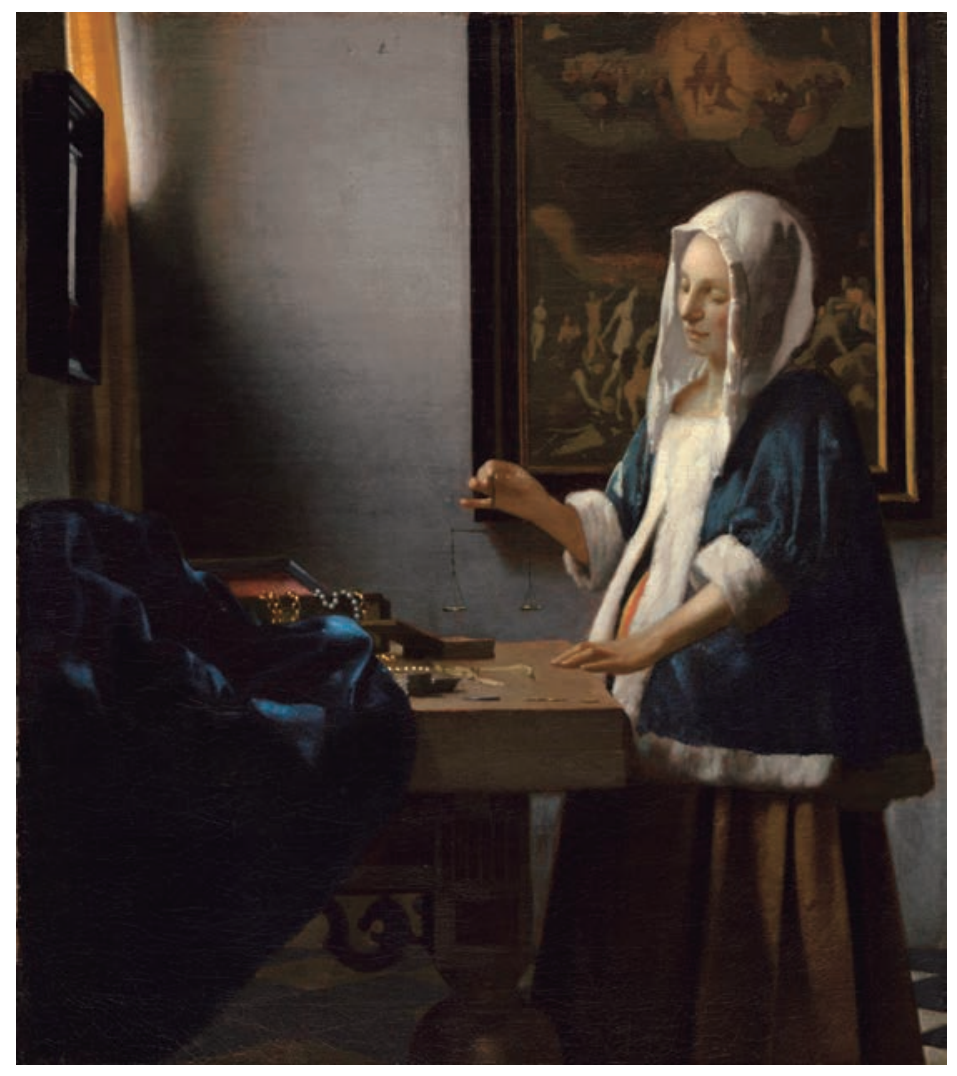

FIGURA 1 - Mulher

segurando uma balança

[Vrouw met Weegschaal] 1662-1663.

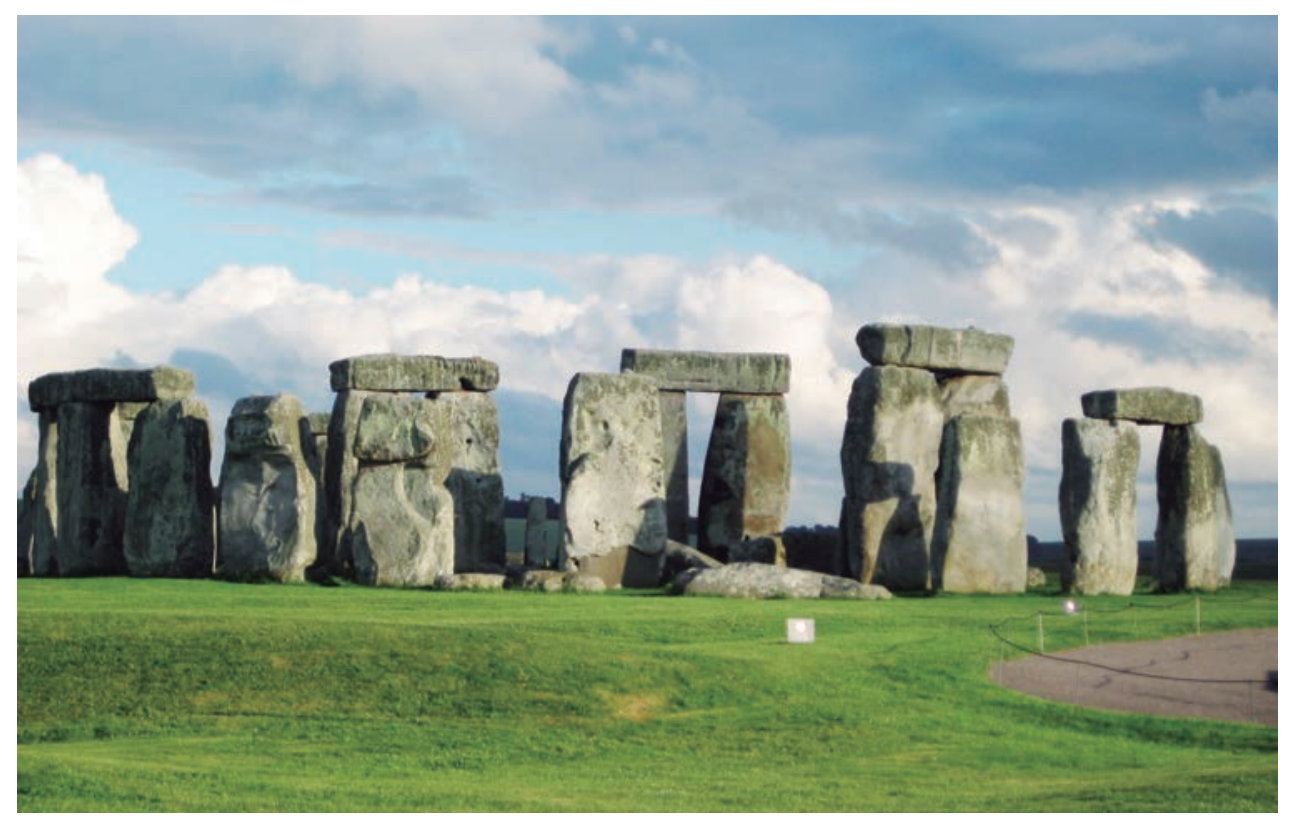

FIGURA 2 - Stonehenge. Salisbury/Inglaterra. 


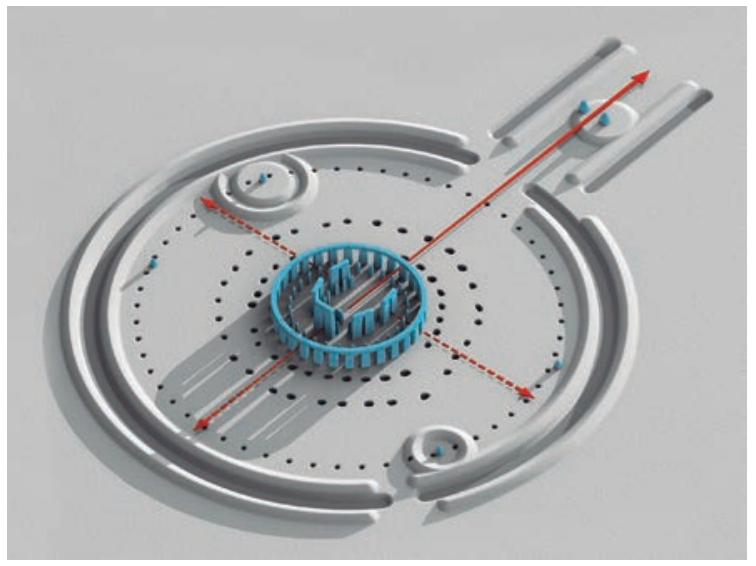

FIGURA 3 - Stonehenge. Ilustração de prováveis funções astronômicas.

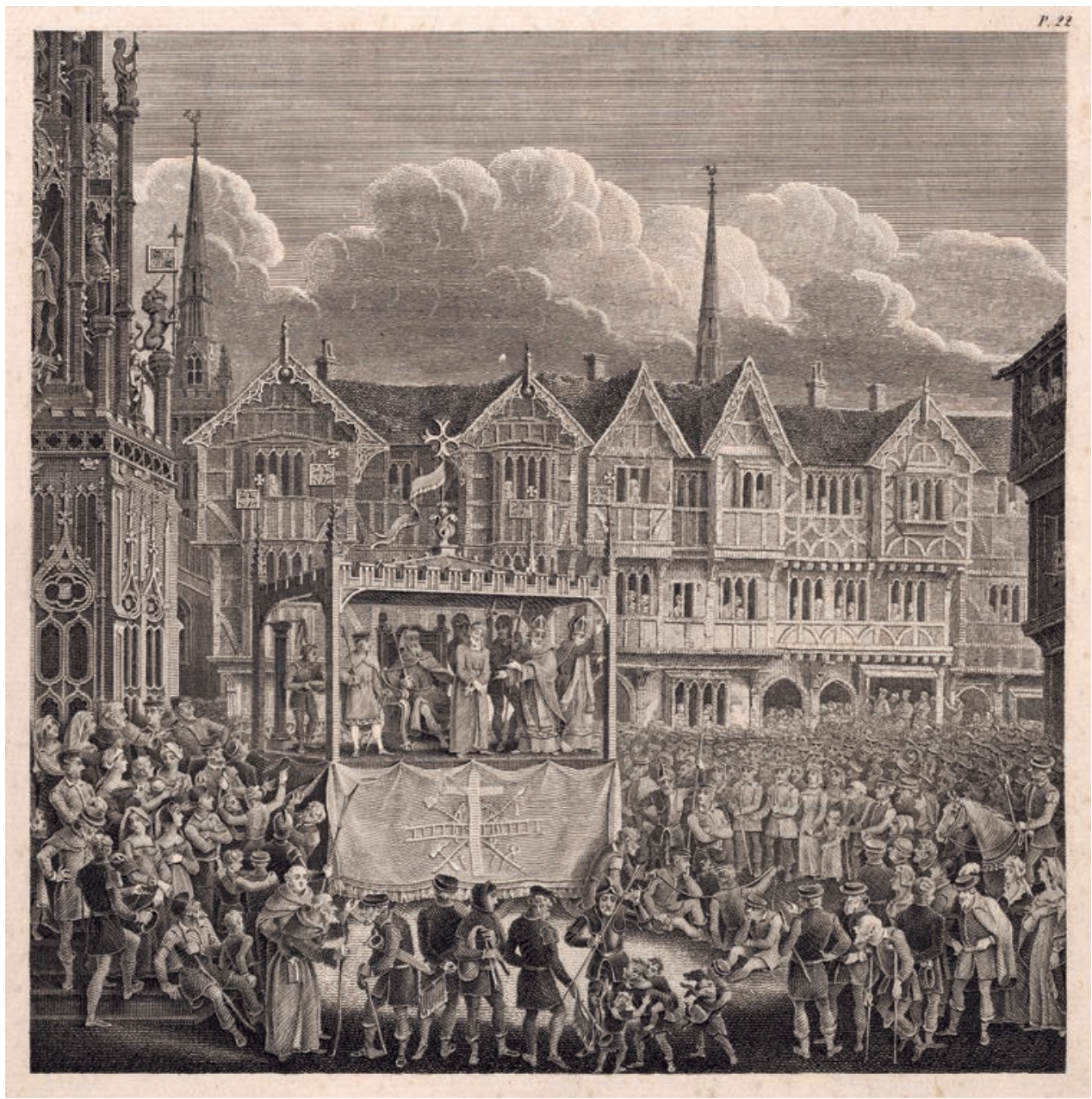

FIGURA 4 - Pageant. Thomas Sharp. 
152

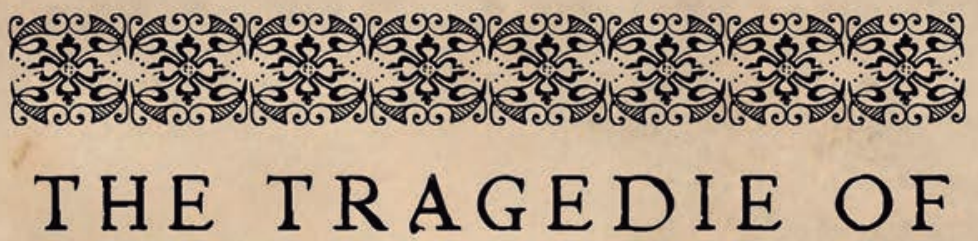
HAMLET, Prince of Denmarke.

\section{AEtus Primus. Scona Prima.}

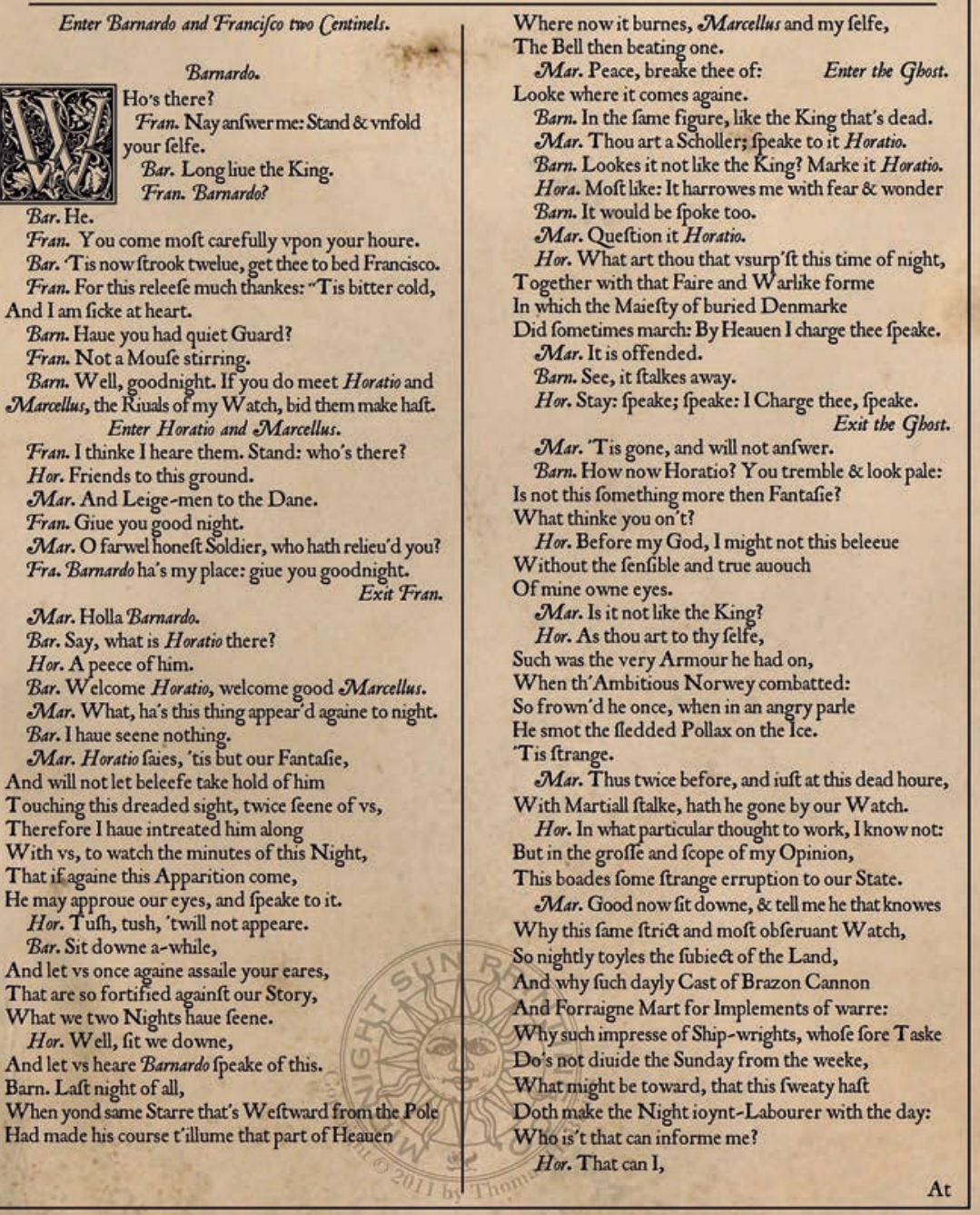



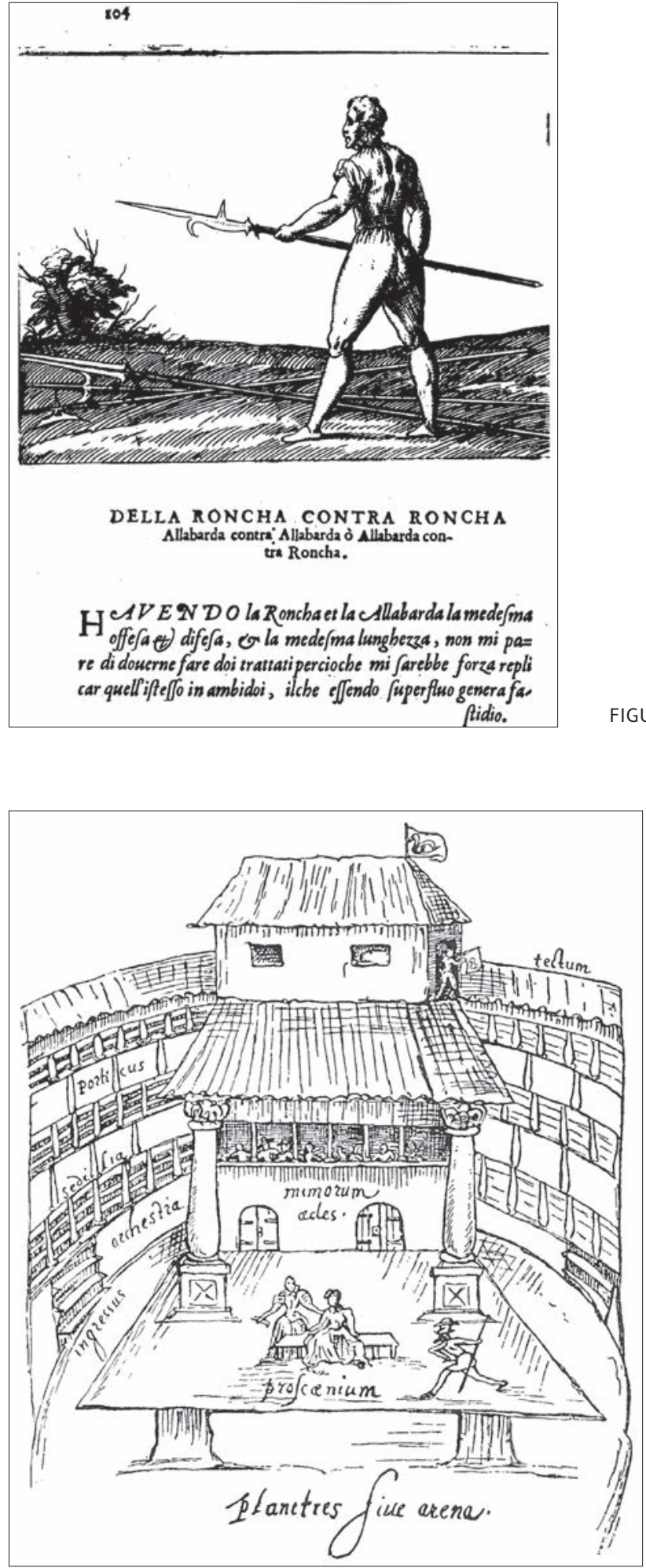

FIGURA 6 - Partisan ou alabarda.
FIGURA 7 - Cópia do desenho de Johannes de Witt, 1596. 


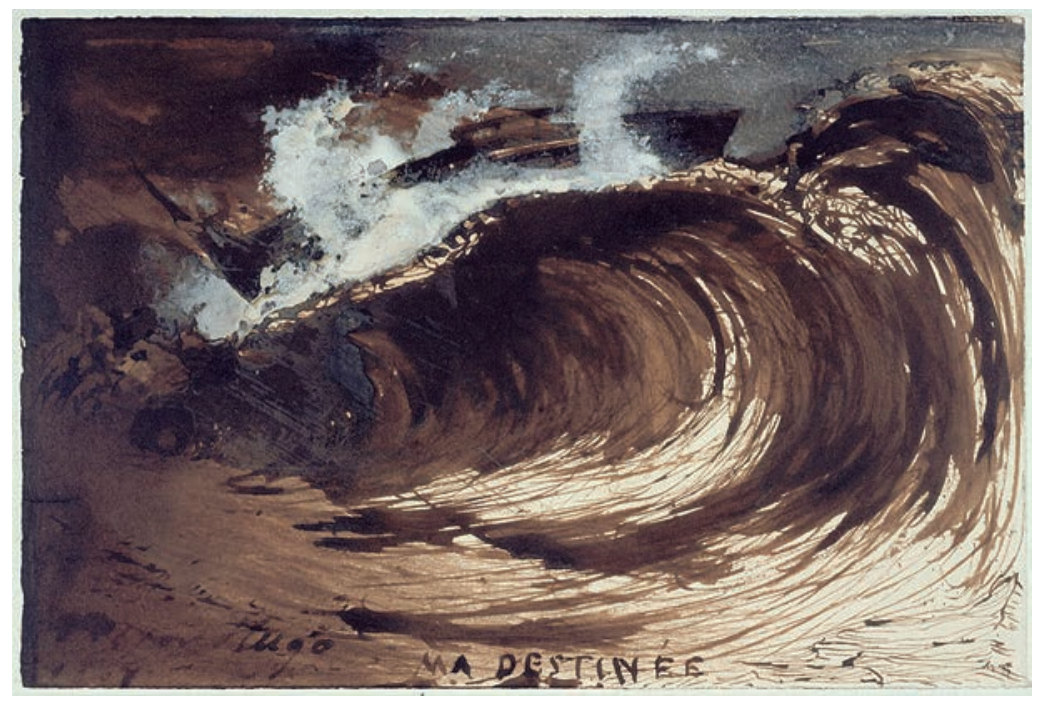

FIGURA 8 - Ma Destinée, Pena e gouache aguada.

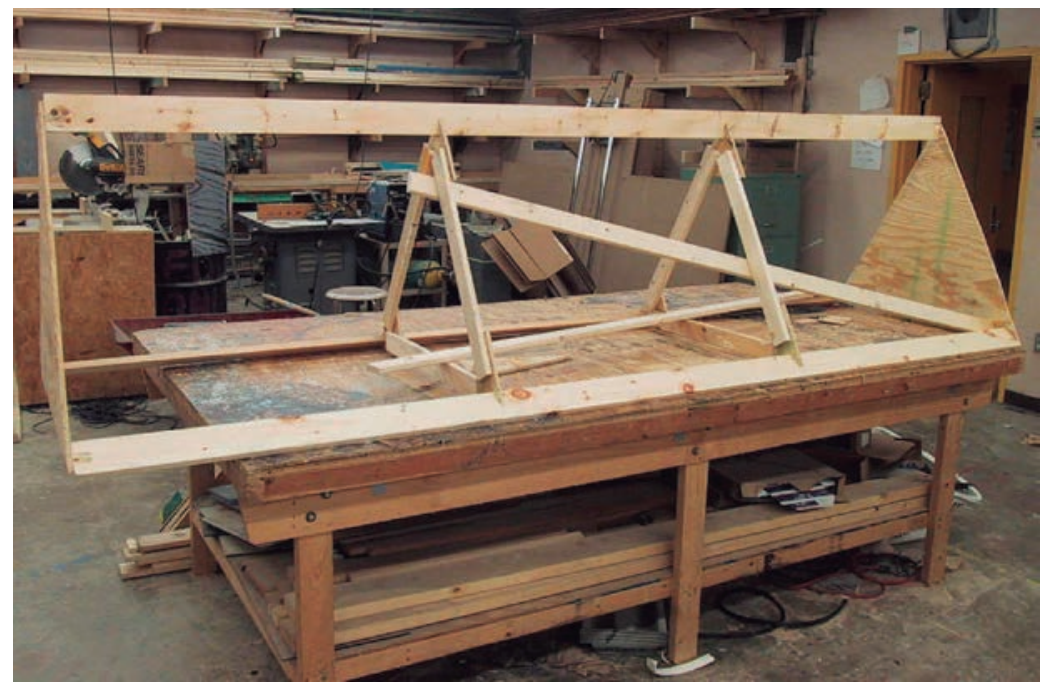

FIGURA 9 - Estrutura de Periaktos para acabamento em tecido. 


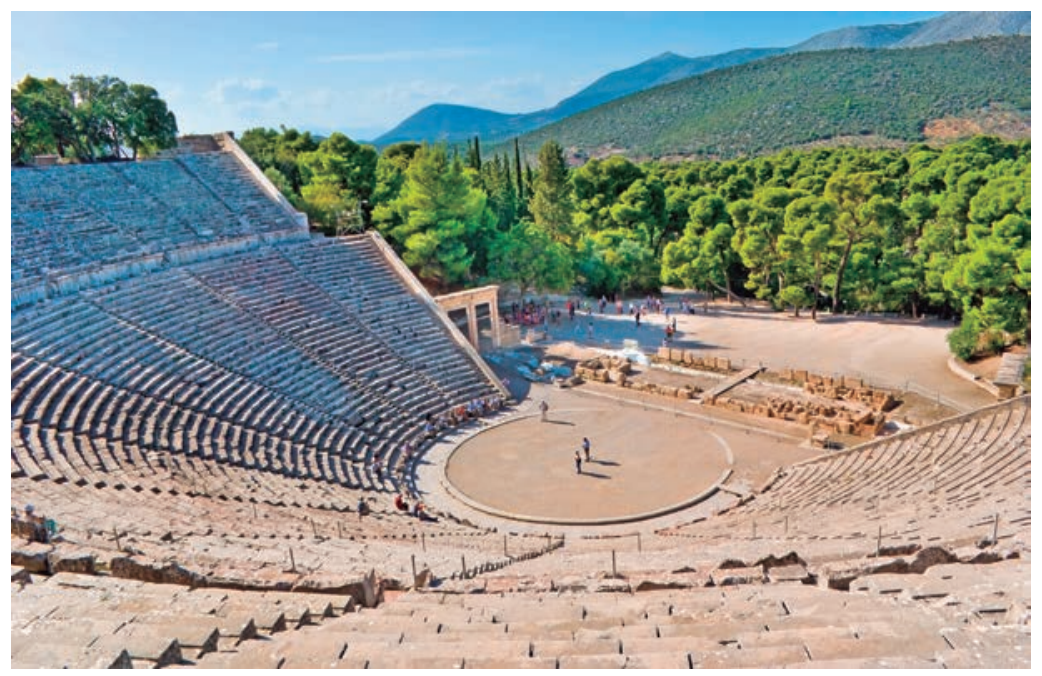

FIGURA 10 - Teatro Epidaurus. Grécia (300-340 a. C.).

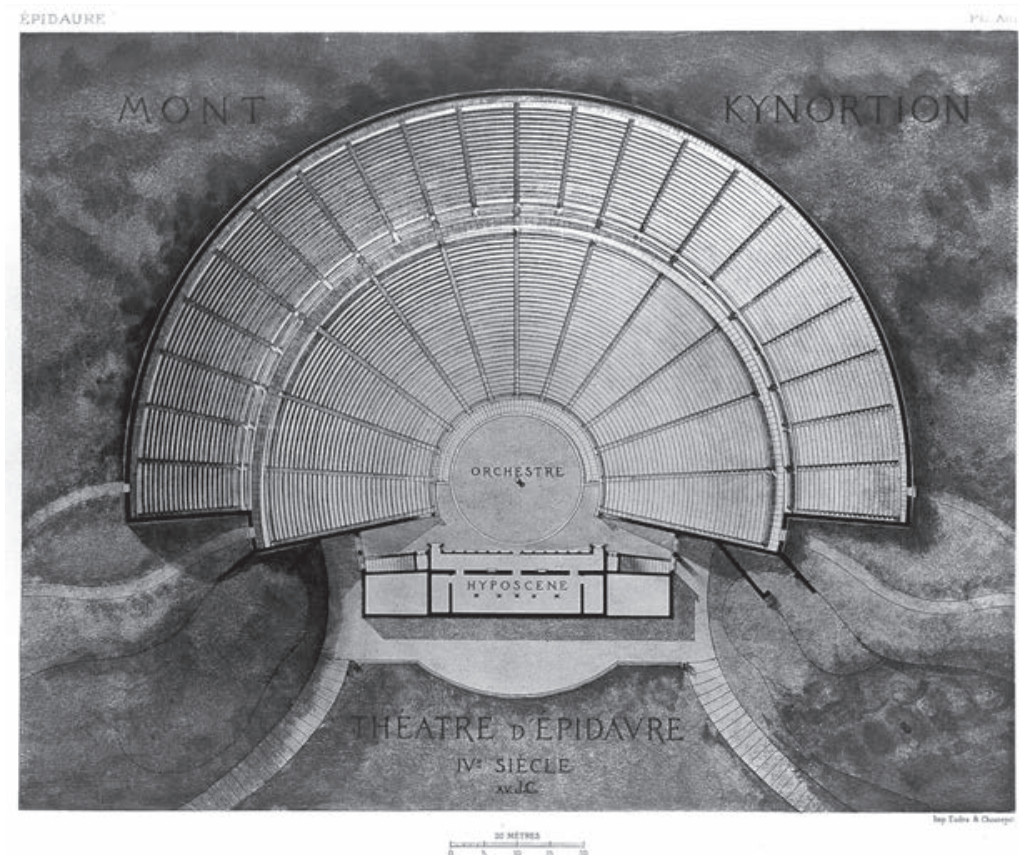

FIGURA 11 - Teatro de Epidaurus/ Planta Baixa. 


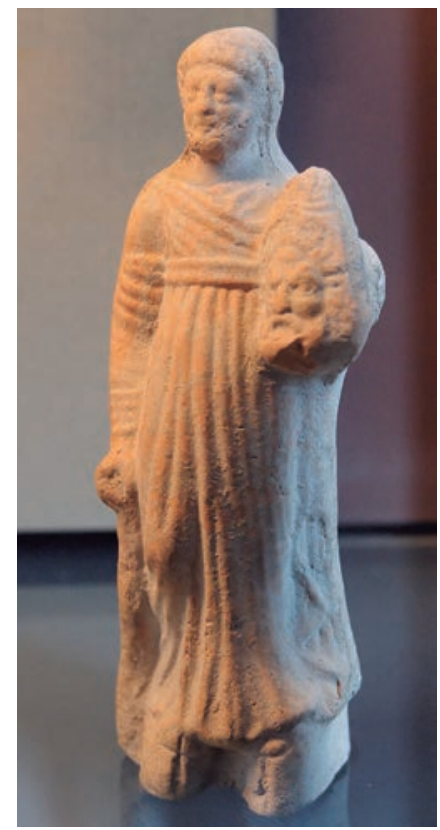

FIGURA 12 - Ator usando coturno e máscara.

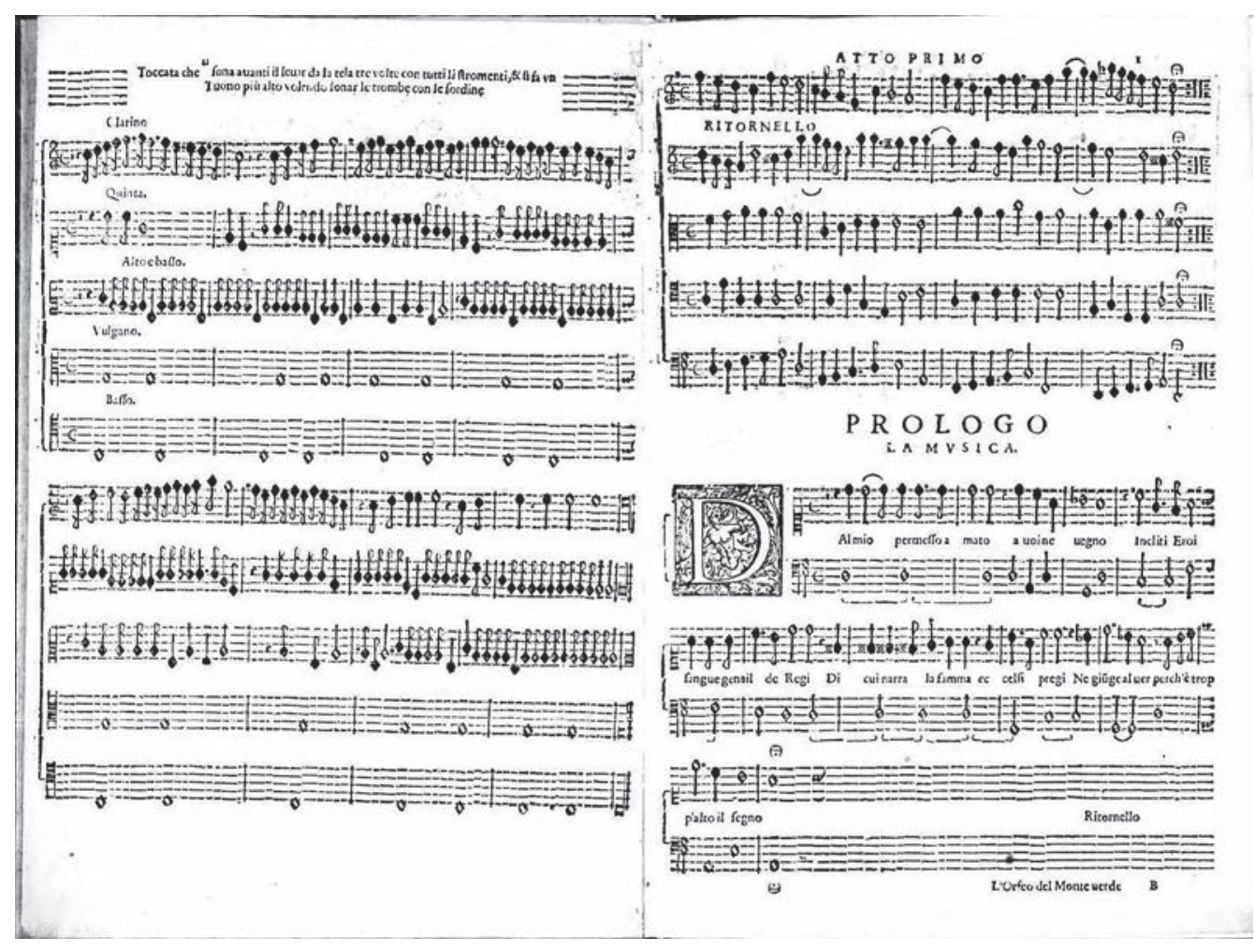

FIGURA 13 - Orfeo. Ritornello [Prólogo]. 


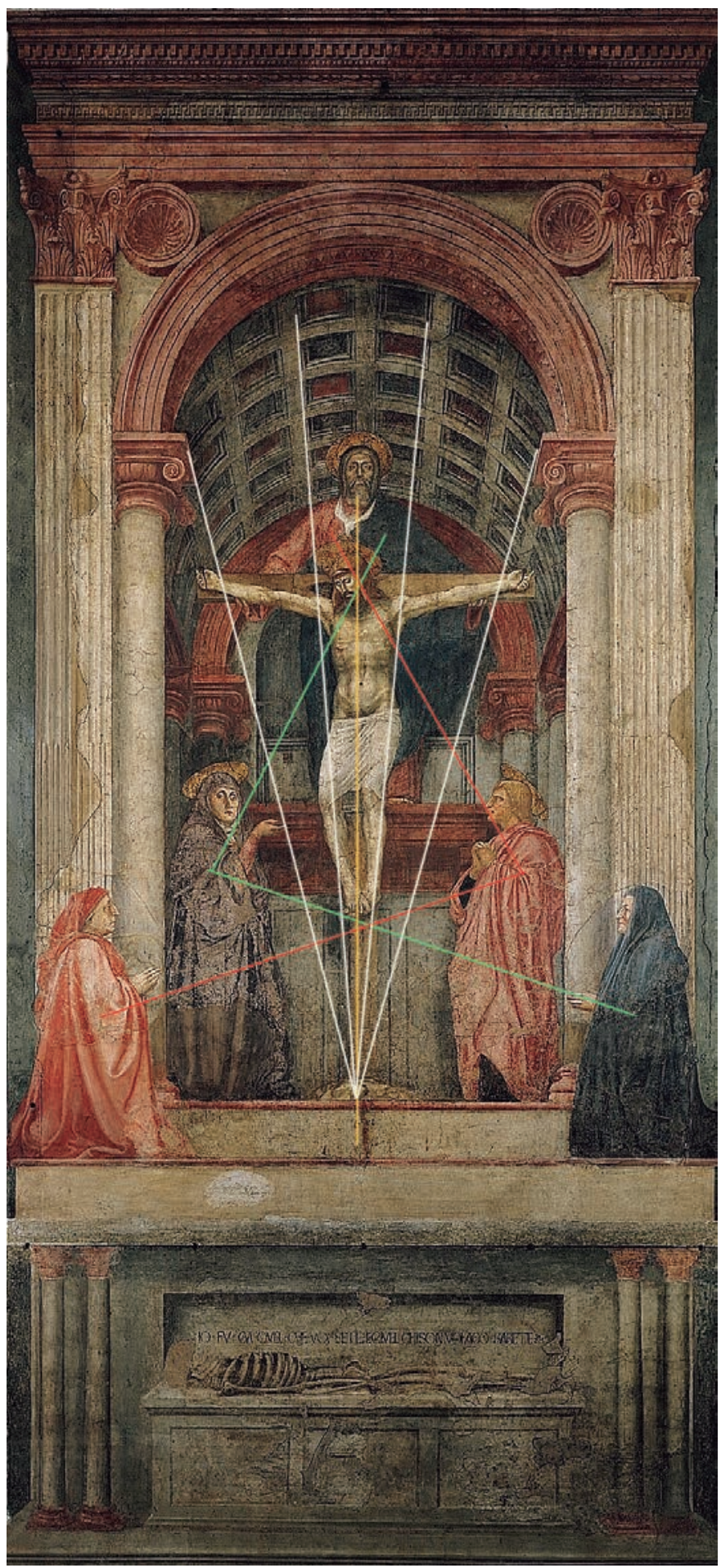

FIGURA 14 - Masaccio. A Trindade. 1425/1428. 


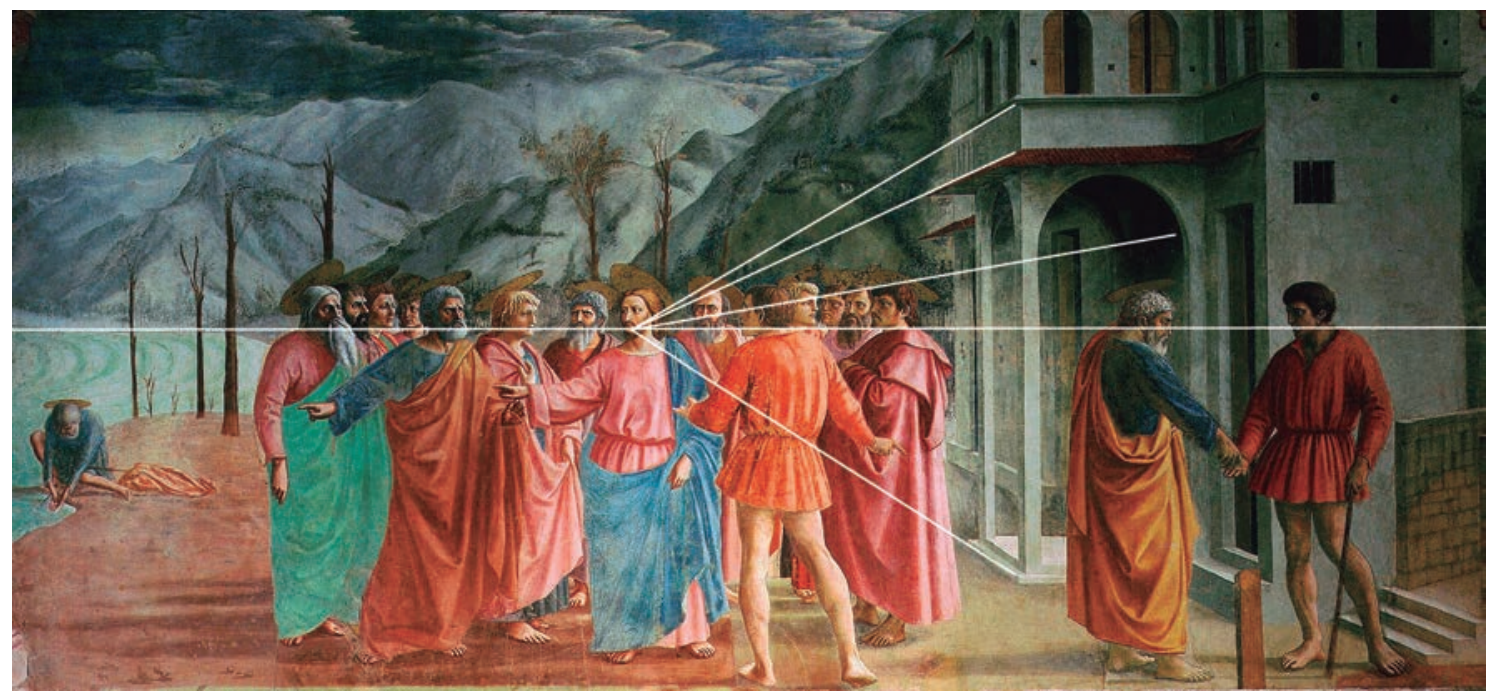

FIGURA 15 - Masaccio. O Pagamento do tributo. $1425 / 1426$.

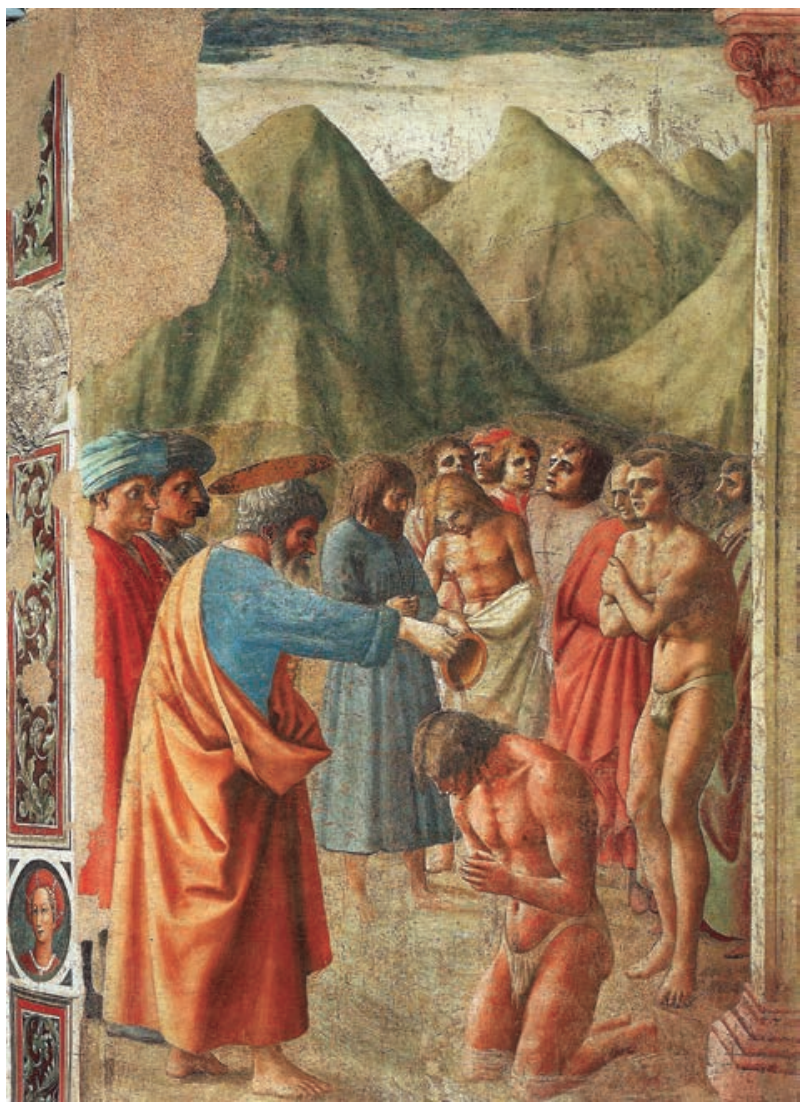

FIGURA 16 - Masaccio. O Batismo dos neófitos, 1426-1427. 

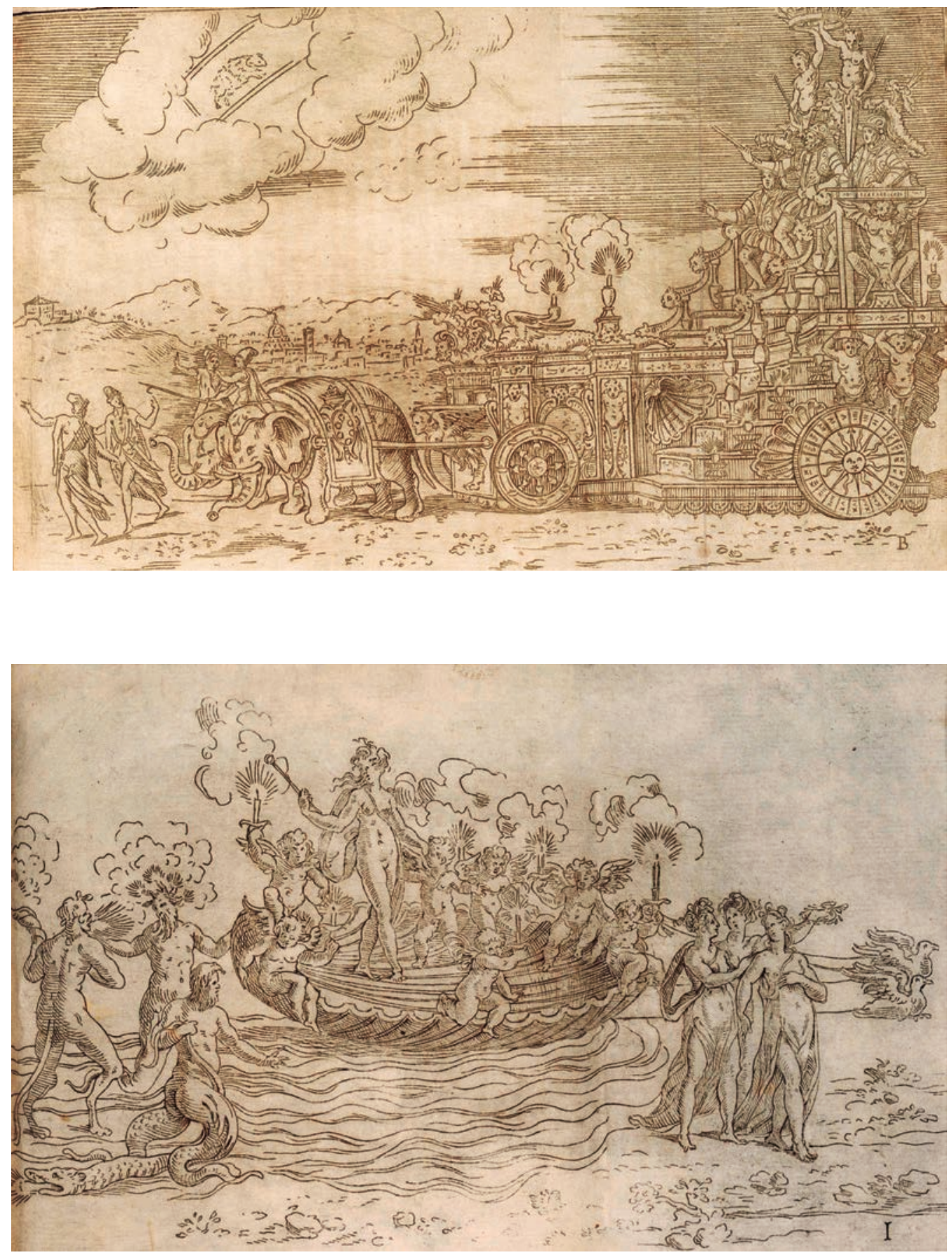

FIGURAS 17 e 18 - Gualterotti. Celebração do casamento de Francesco Medici e Bianca Capello, 1579. 

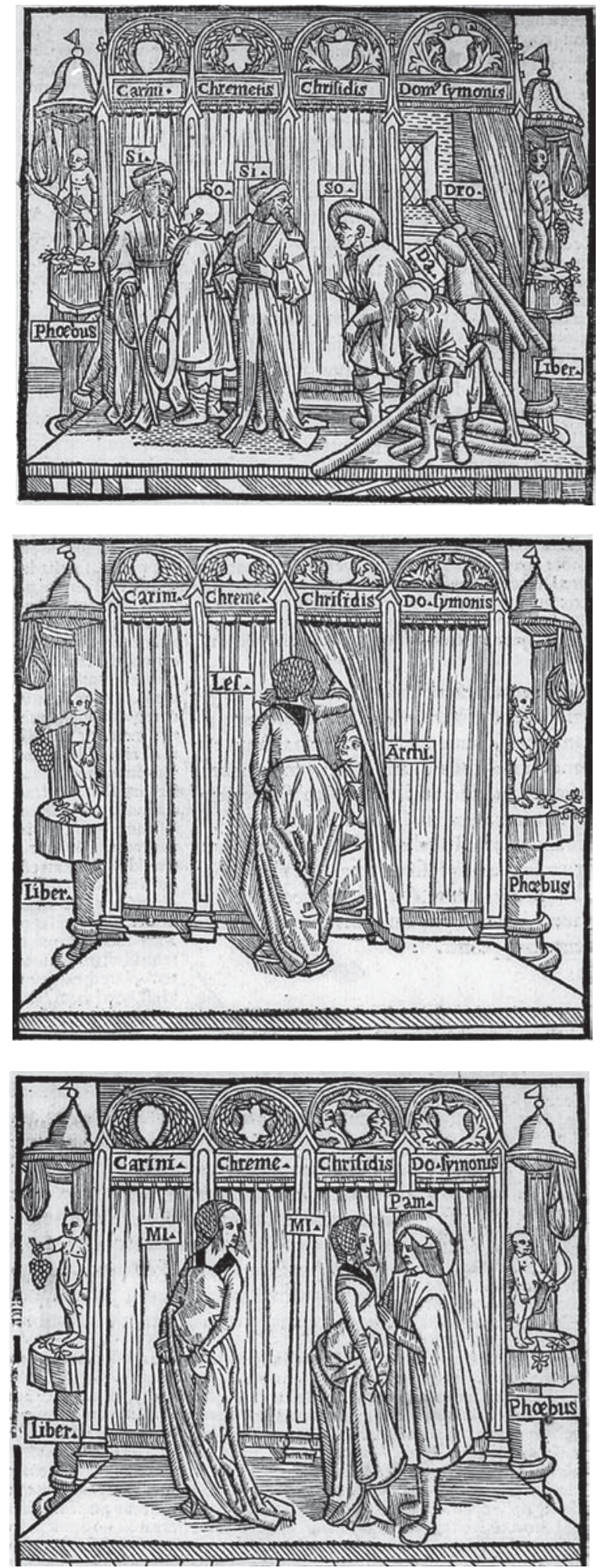


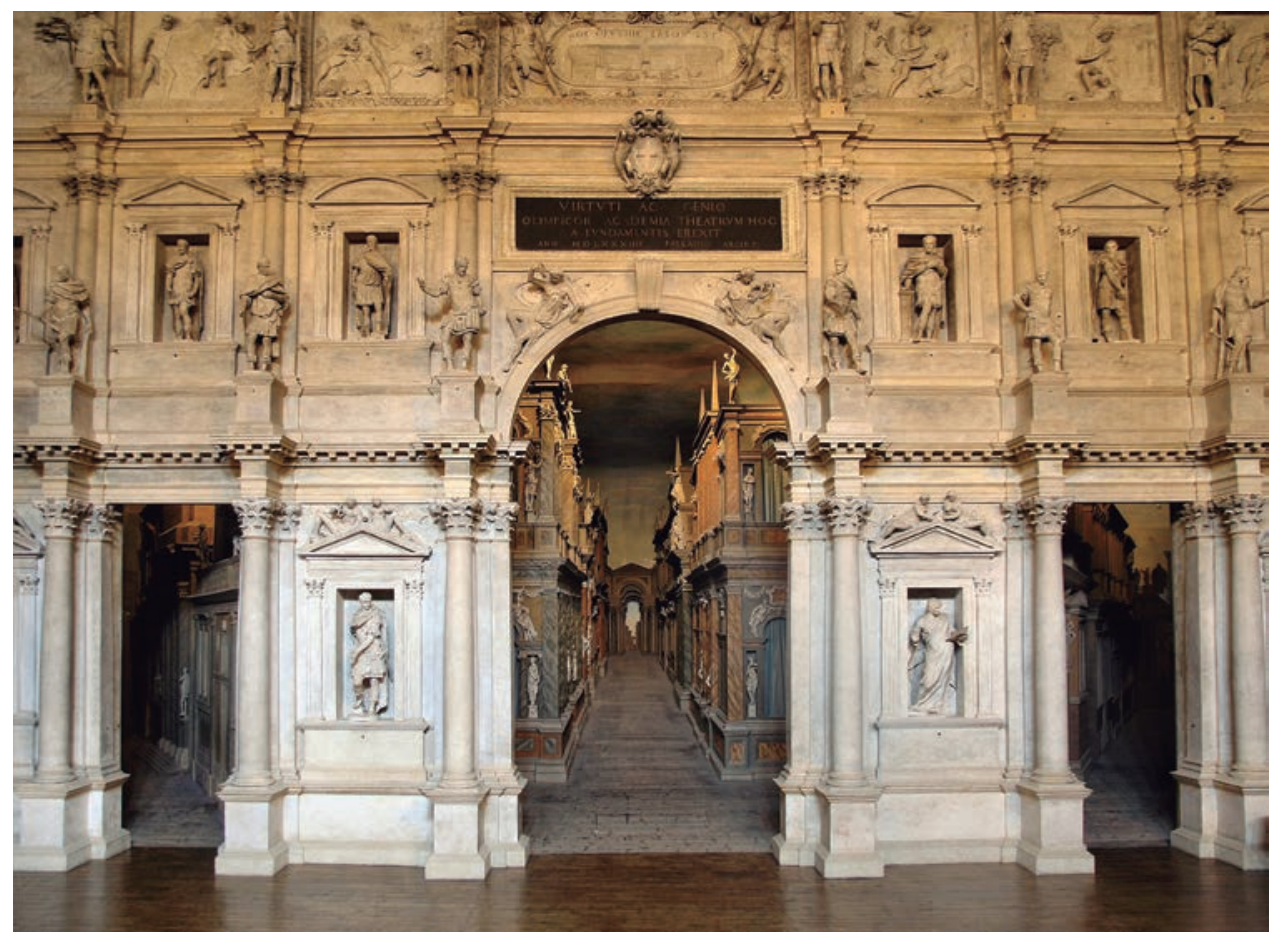

FIGURA 22 - Teatro Olímpico,

Vicenza. Vista Frontal do Palco.

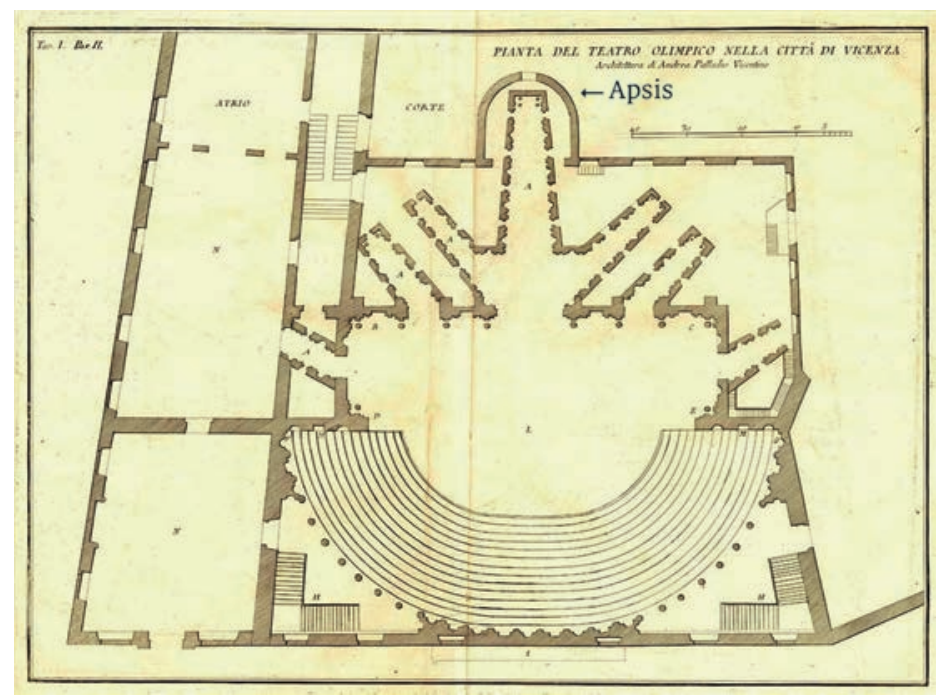

FIGURA 23 - Teatro Olímpico.

1580/1585. Planta-Baixa, projetado por Palladio. 


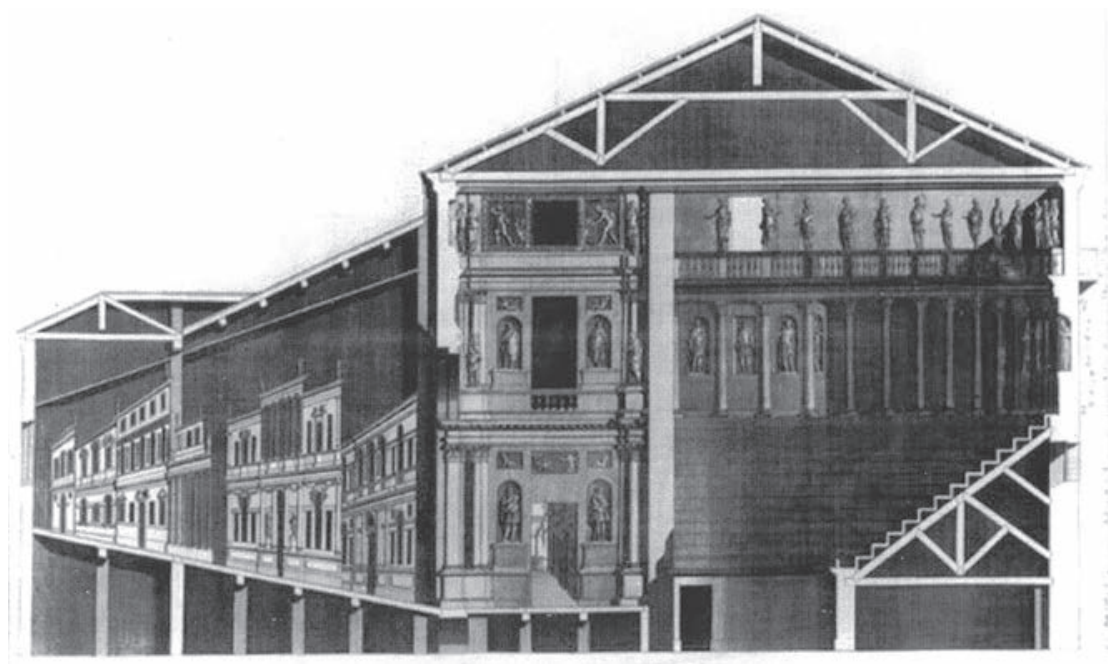

FIGURA 24 - Teatro Olímpico. Corte;

desenho de Ottavio Bertotti Scamozzi, 1776.

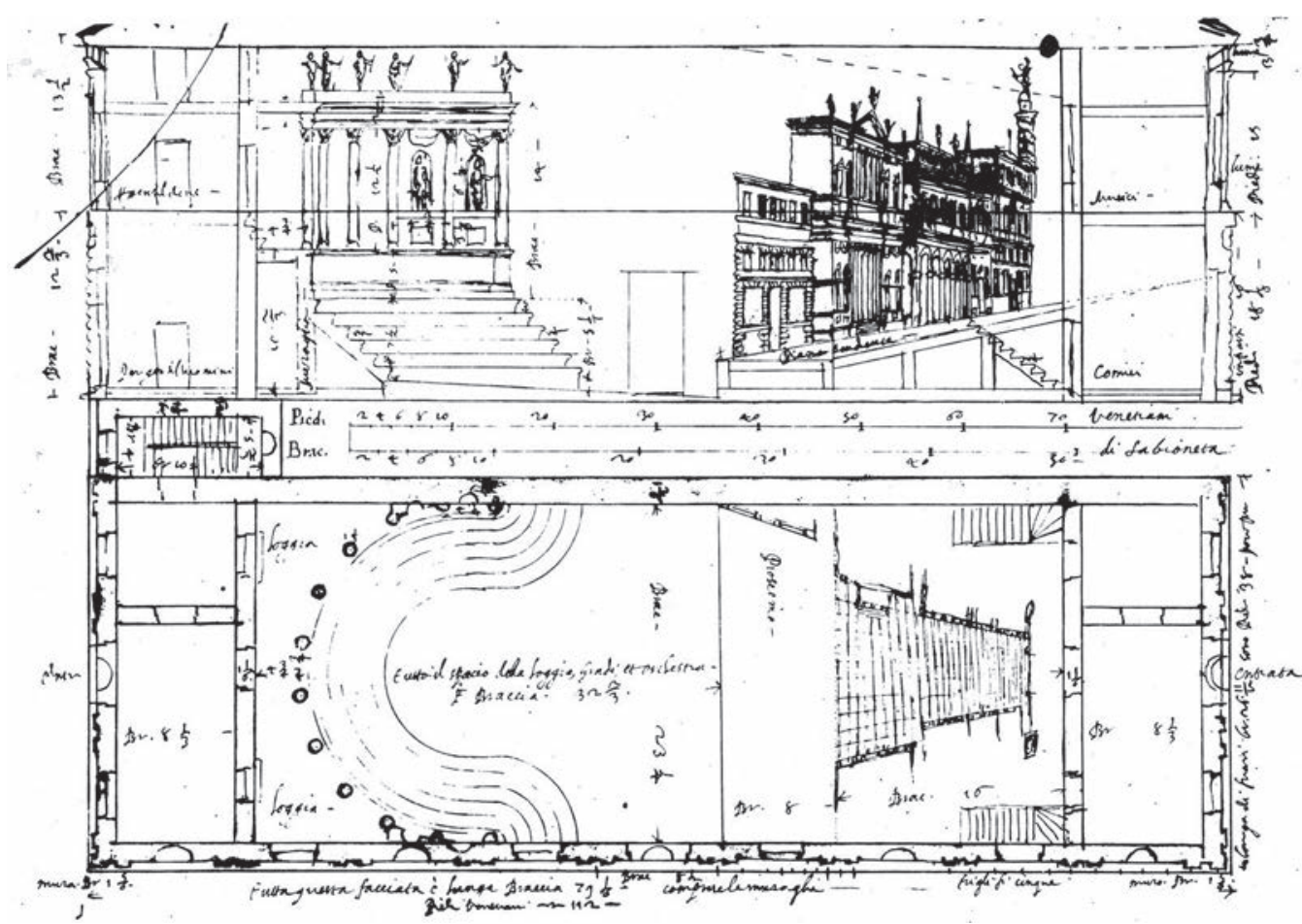

FIGURA 25 - Teatro all'Antica, em Sabionetta, 1588 a 1590 [desenhos técnicos]. 


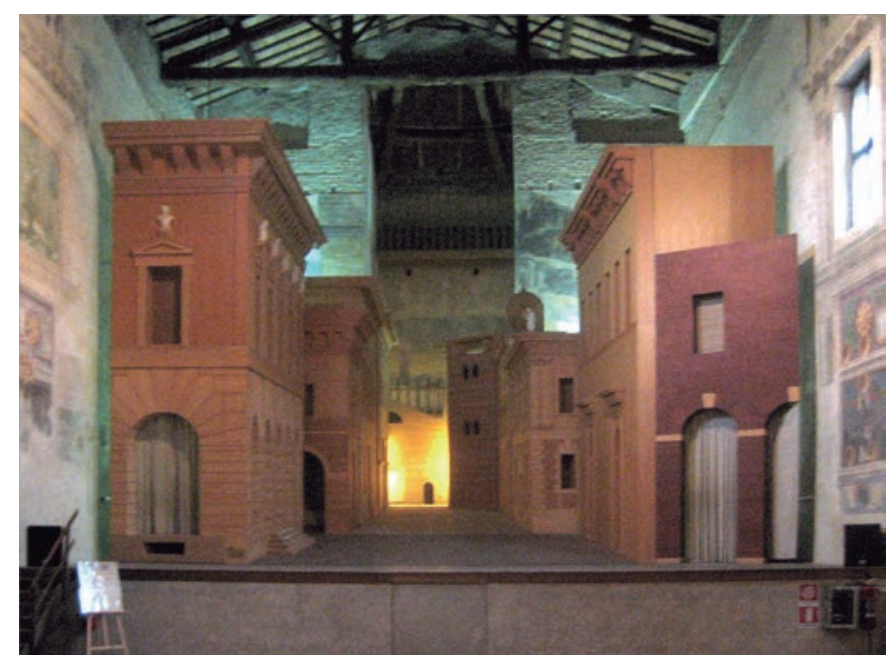

FIGURA 26 - Vista frontal do palco desse mesmo teatro.

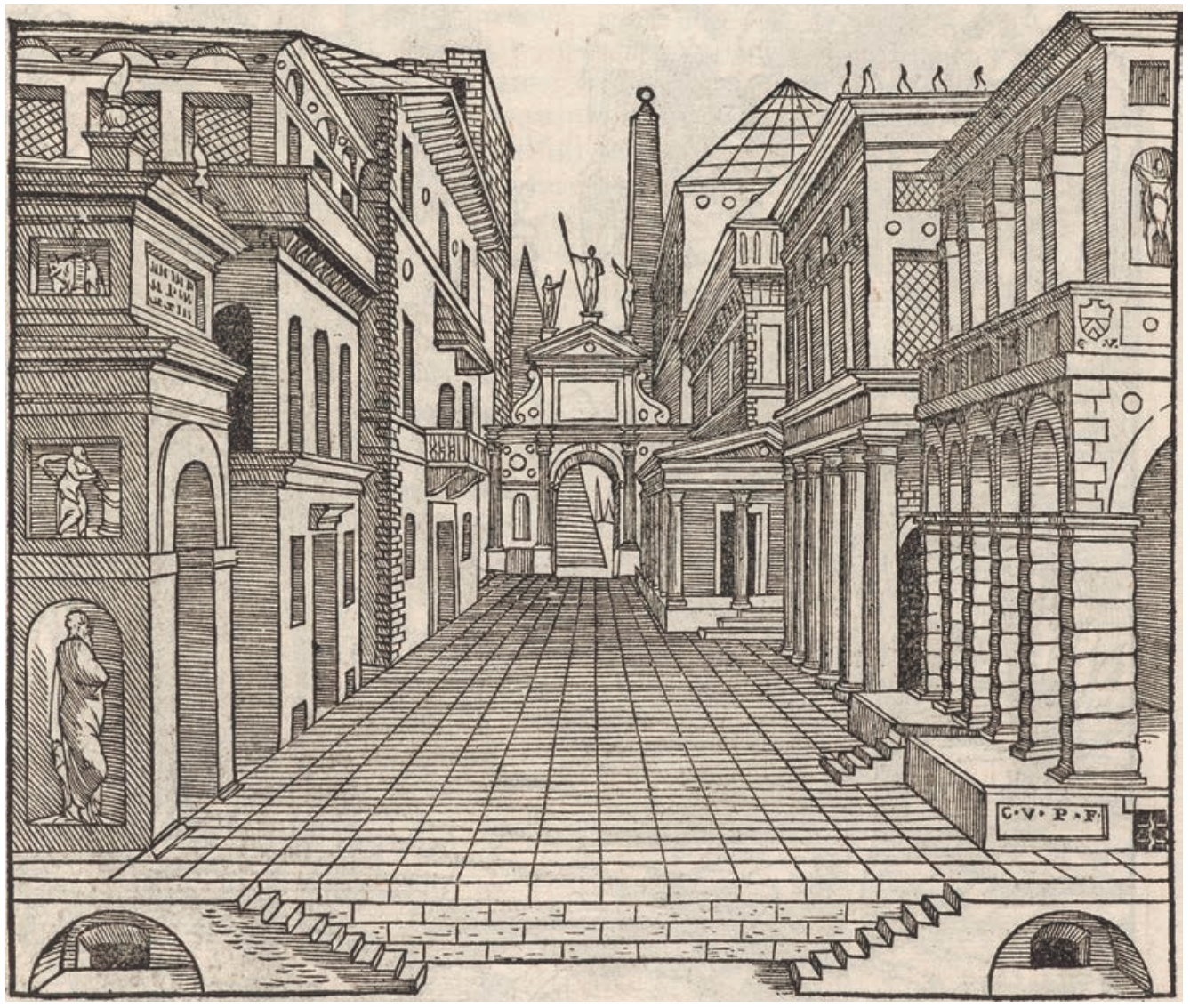

FIGURA 27 - Serlio. Cenários para a Tragédia, a Comédia, e a Sátira Tutte l'Opere d'Architettura et Prospetiva. 

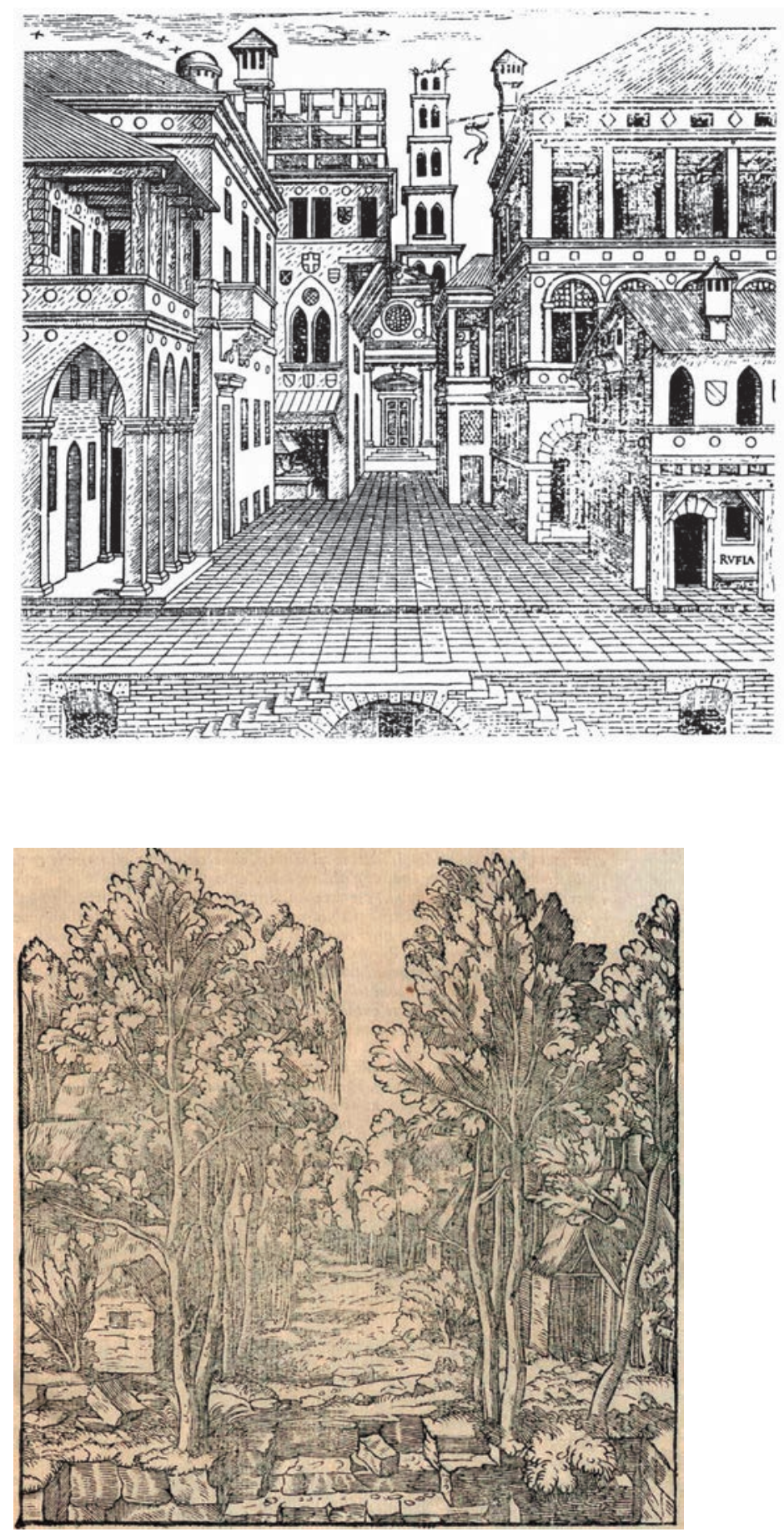

FIGURAS 28 e 29 - Serlio. Cenários para a Tragédia, a Comédia, e a Sátira Tutte l'Opere d'Architettura et Prospetiva. 


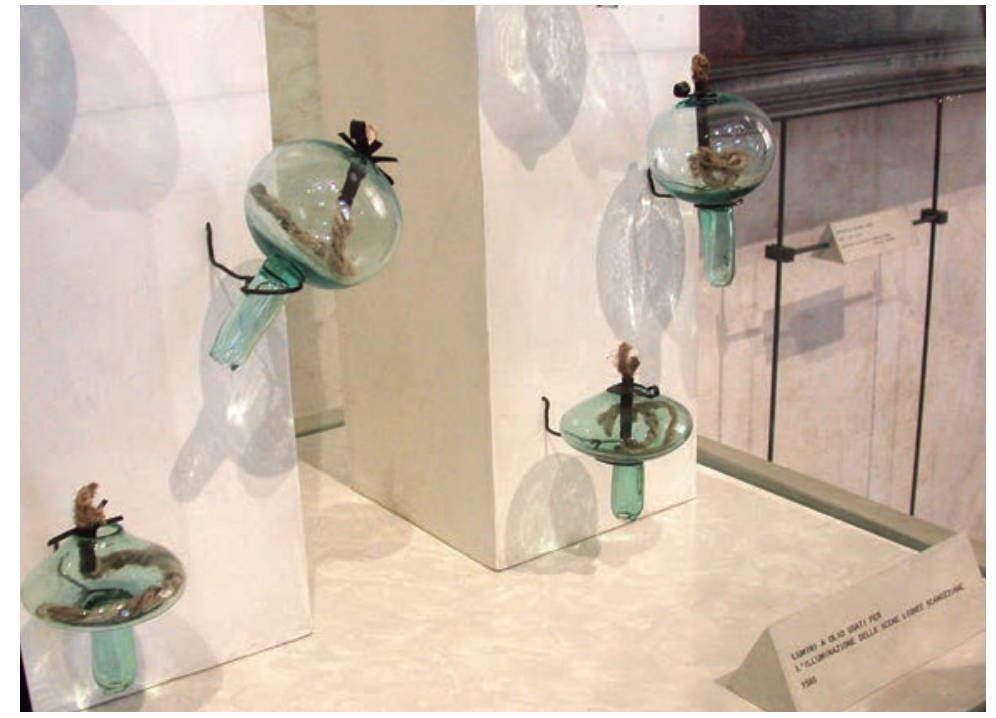

FIGURA 30 - Bozze.

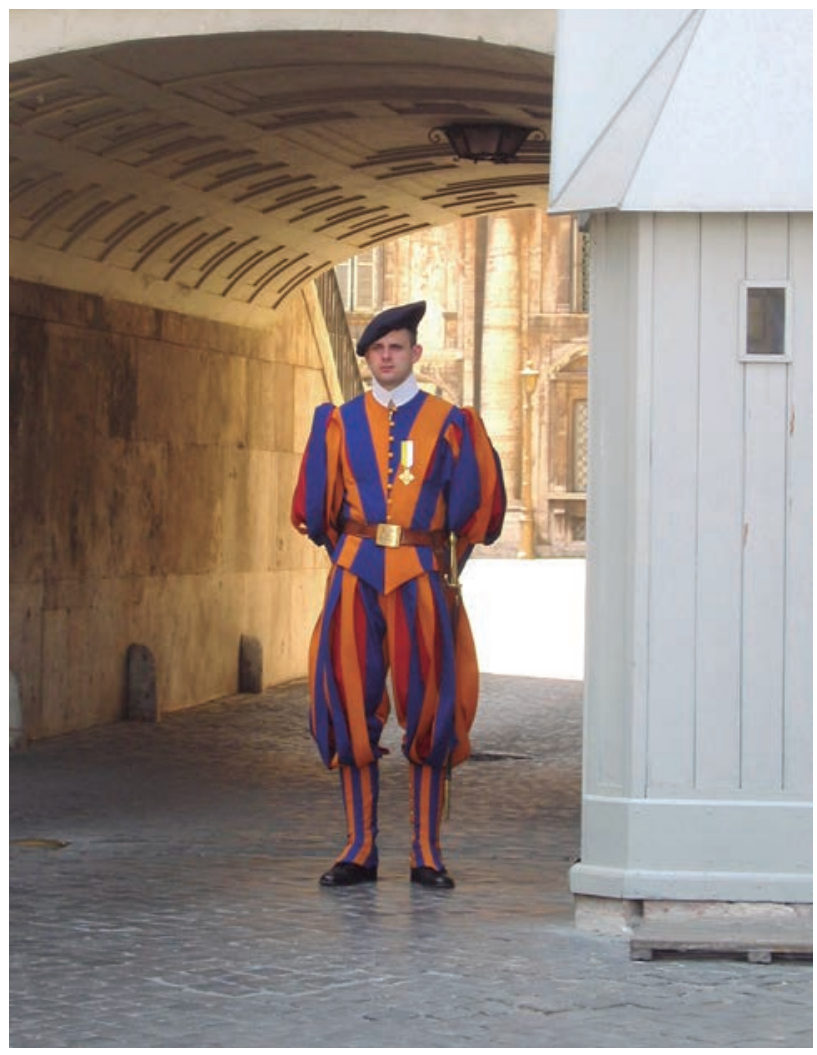

FIGURA 31 - Guarda Suíça do Vaticano - Design de Leonardo da Vinci. 


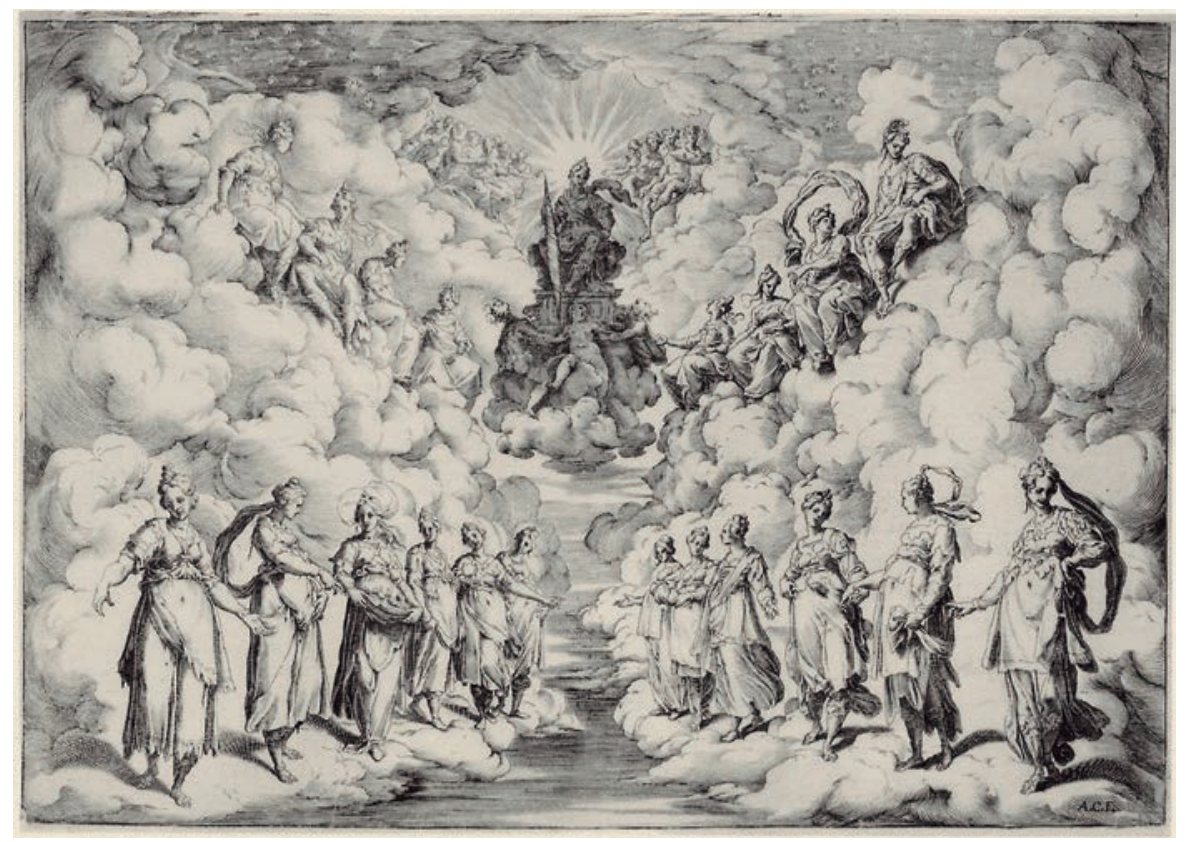

FIGURA 32 - Bernardo Buontalenti - Primeiro intermezzo para A Peregrina: A Harmonia das Esferas, 1589.

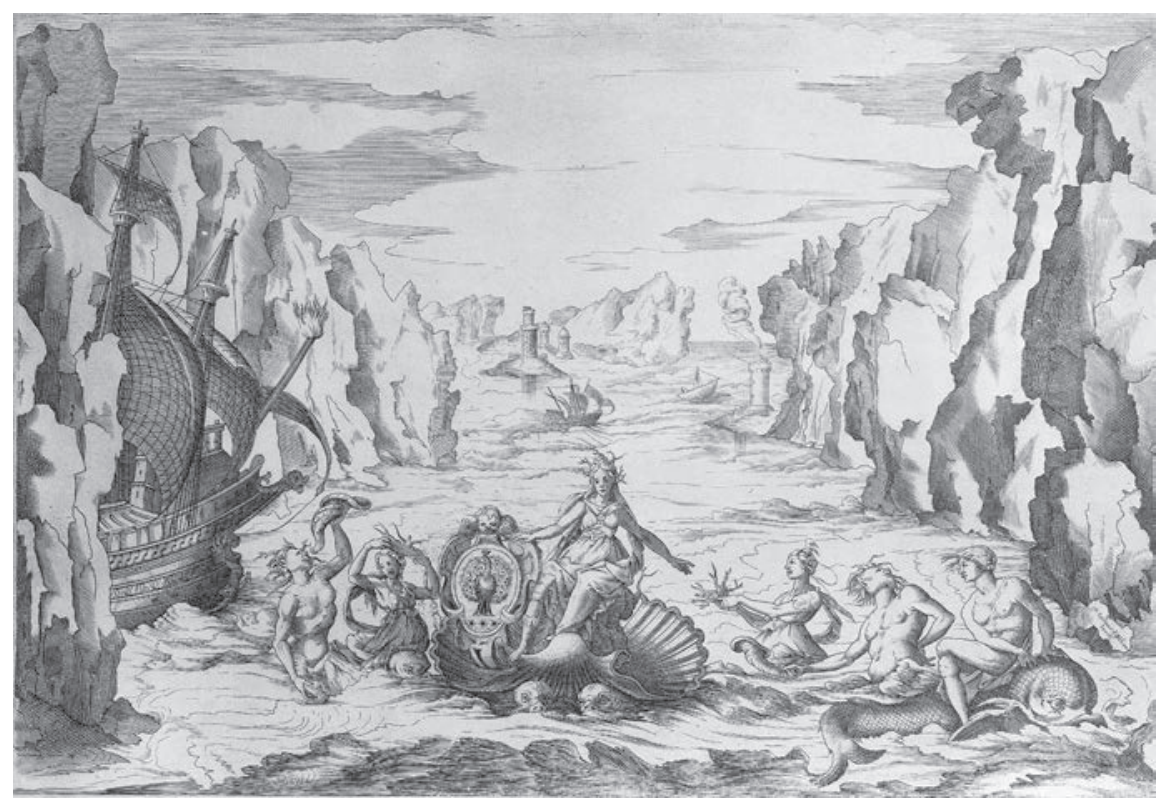

FIGURA 33 - Bernardo Buontalenti. Cenário para o casamento do Arqueduque Ferdinando de' Medici e Christine of Lorraine, Florence, 1589. 


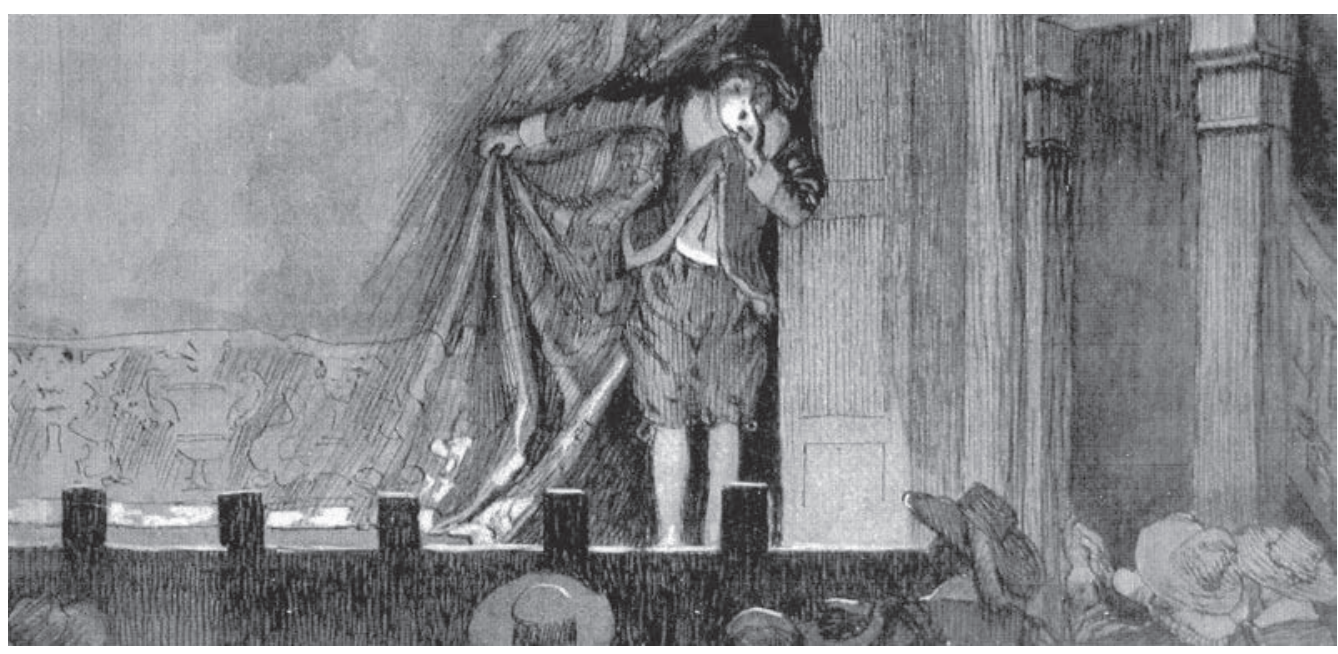

FIGURA 34 - Imagem da Ribalta.

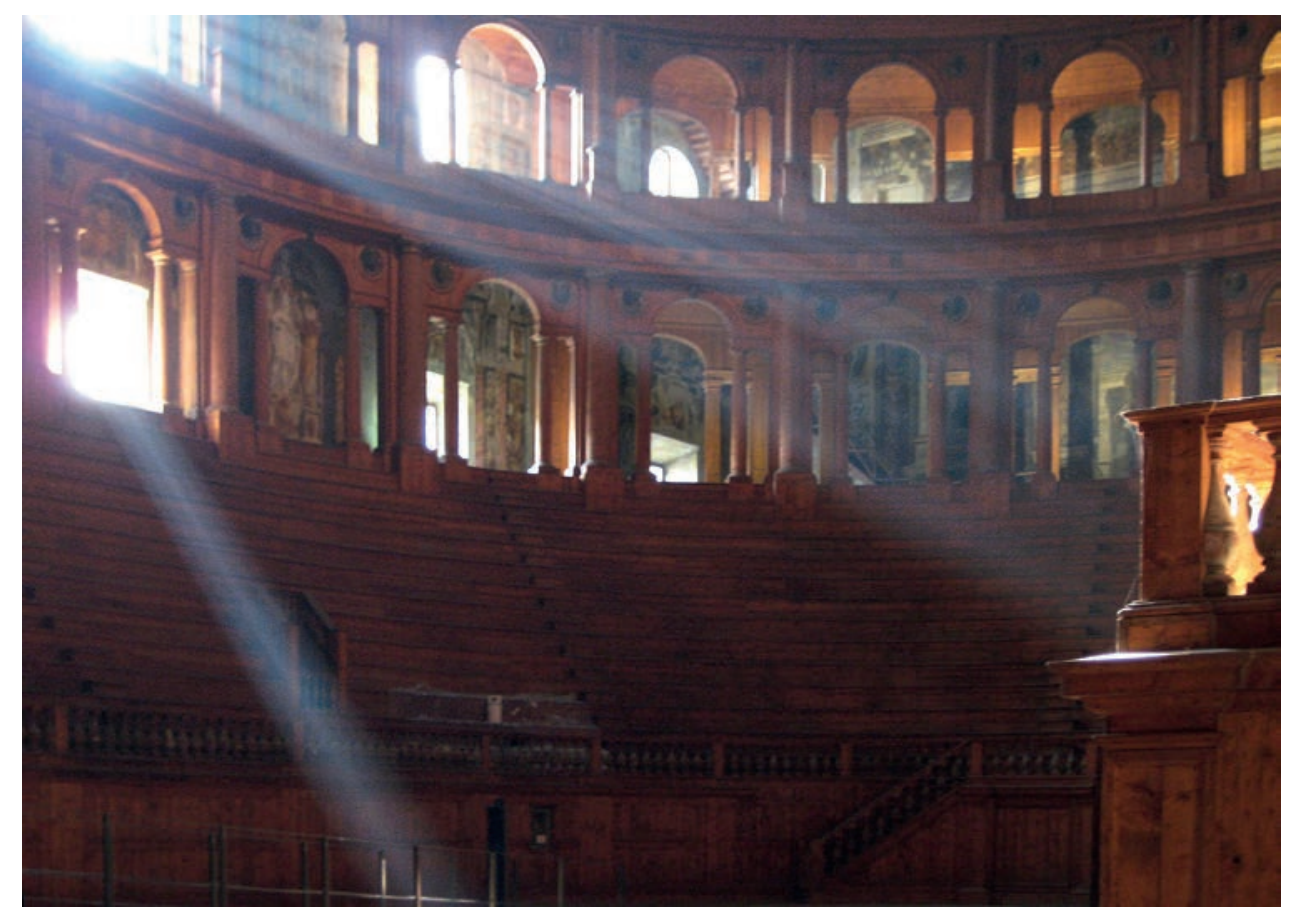

FIGURA 35 - Teatro Farnese. Vista da plateia. 


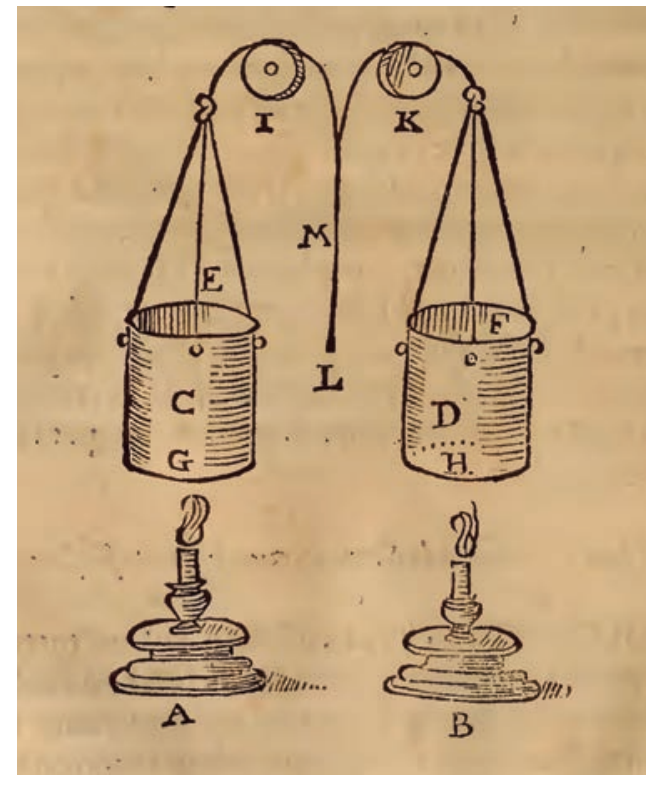

FIGURA 36 - Cópia do desenho que ilustra a obra original, Sistema de Dimmers, de acordo com Sabbattini (1638).

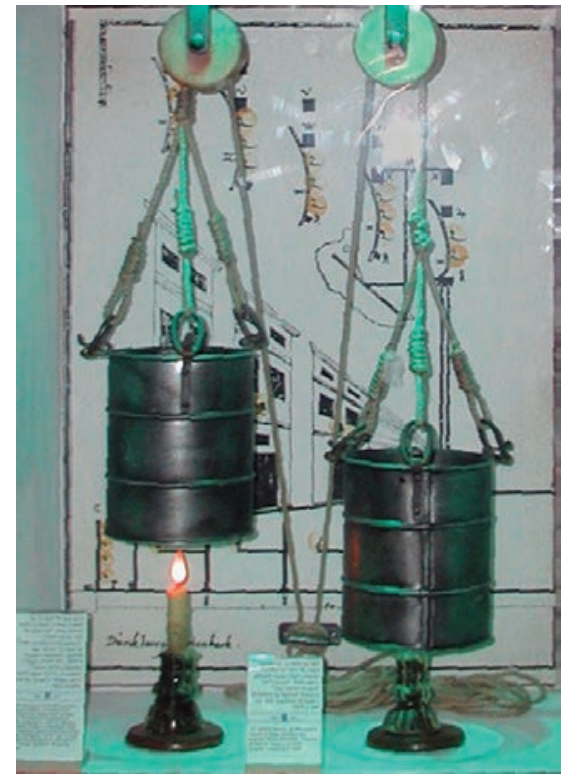

FIGURA 37 - Reconstrução em exibição no Stage Light Museum em Hod Hasharon, Israel.

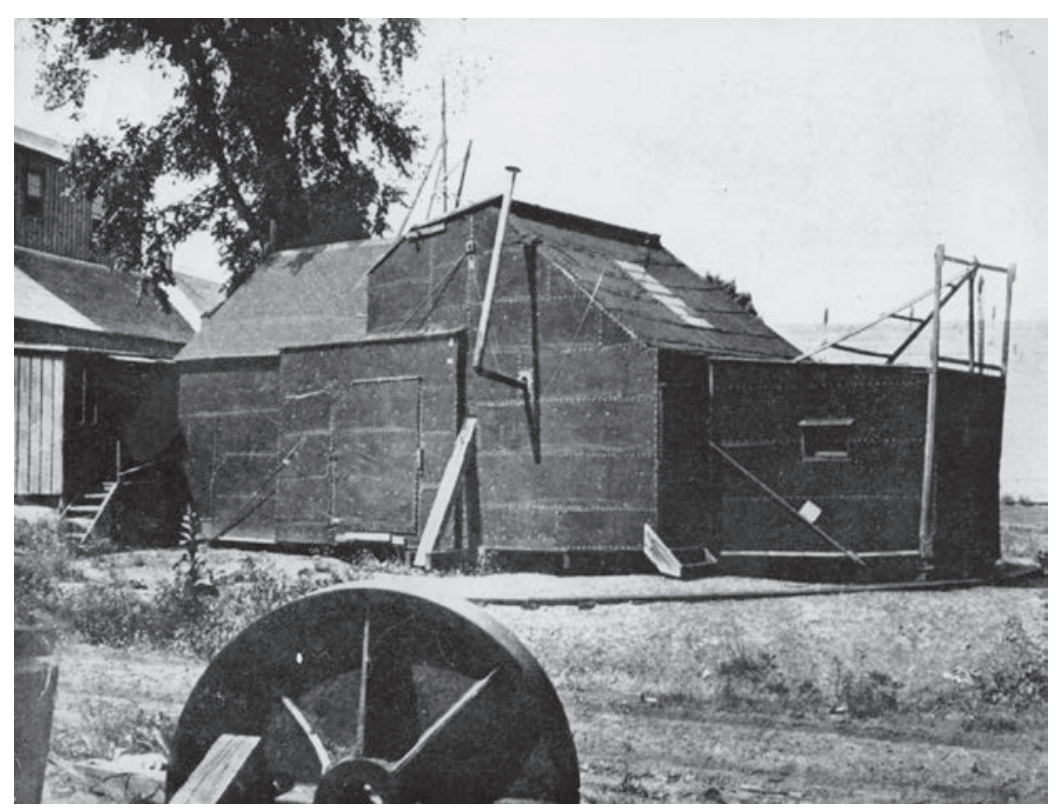

FIGURA 38 - Black-Maria/1893. Acima, o veículo policial que originou o nome. 


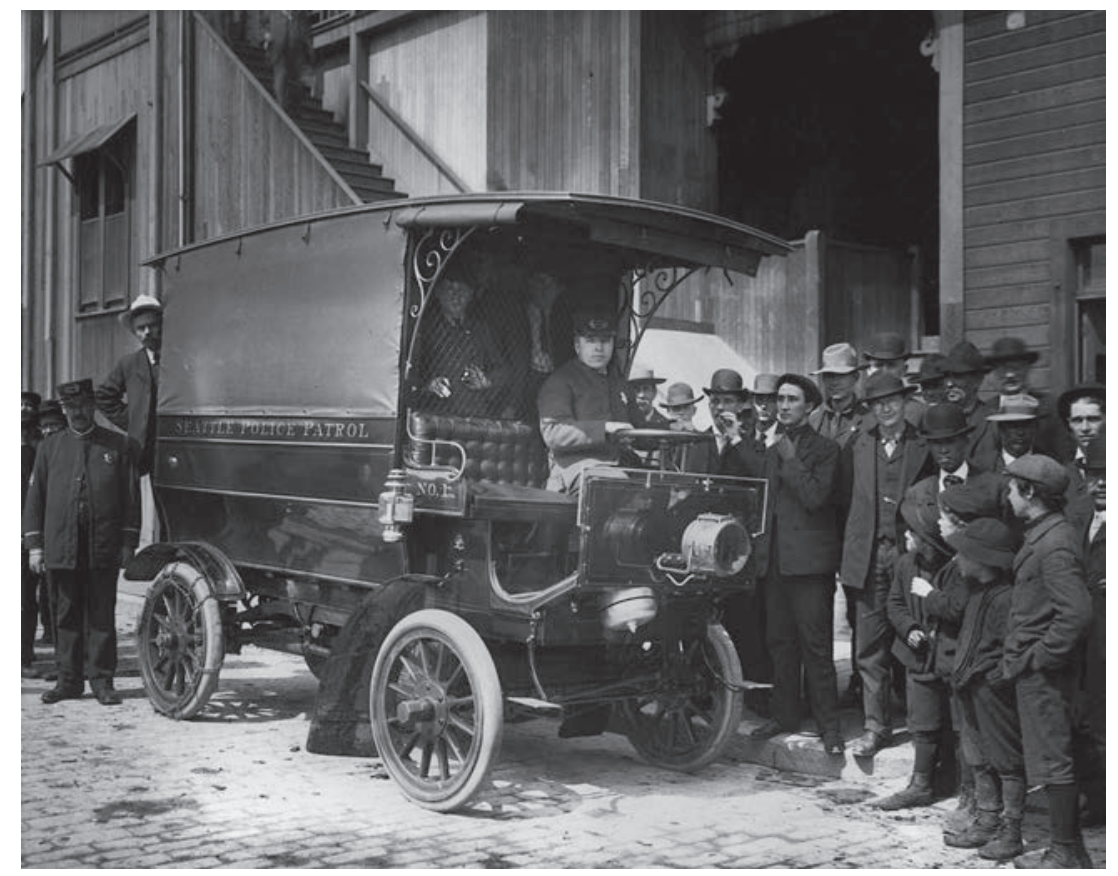

FIGURA 39 - O estúdio Photographic Building.

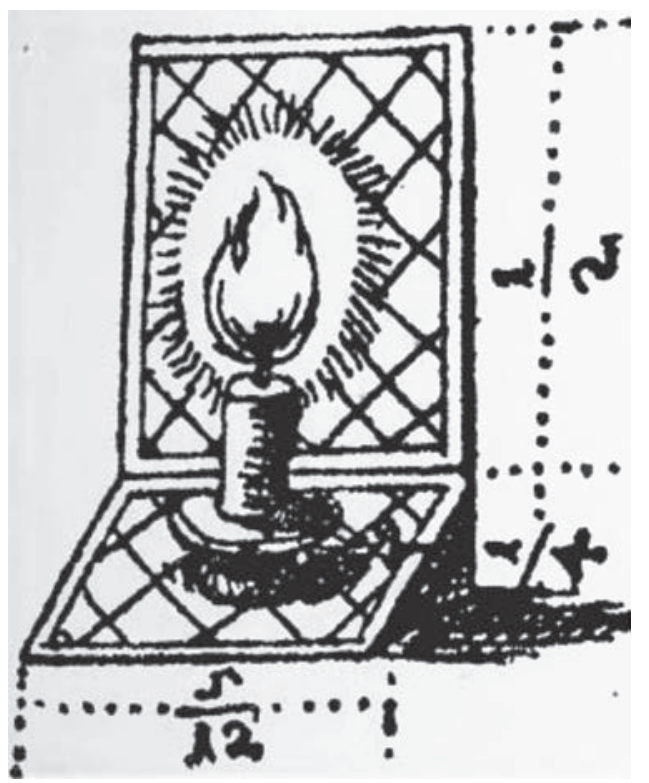

FIGURA 40 - Instrumento com refletor de “mica”, projetado por Furttenbach (1663). 


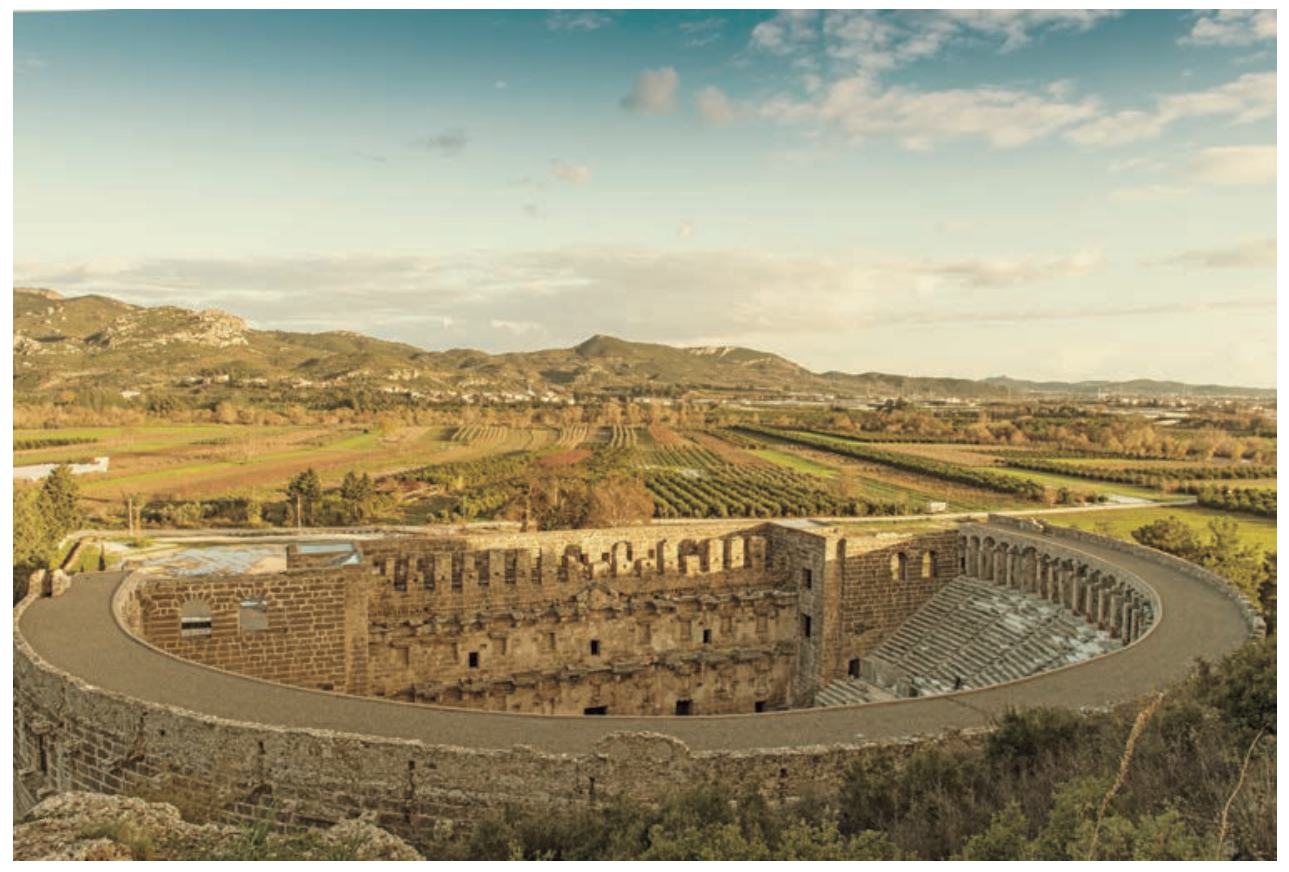

FIGURA 41 - Teatro de Aspendos/Turquia (161-180 d. C.).

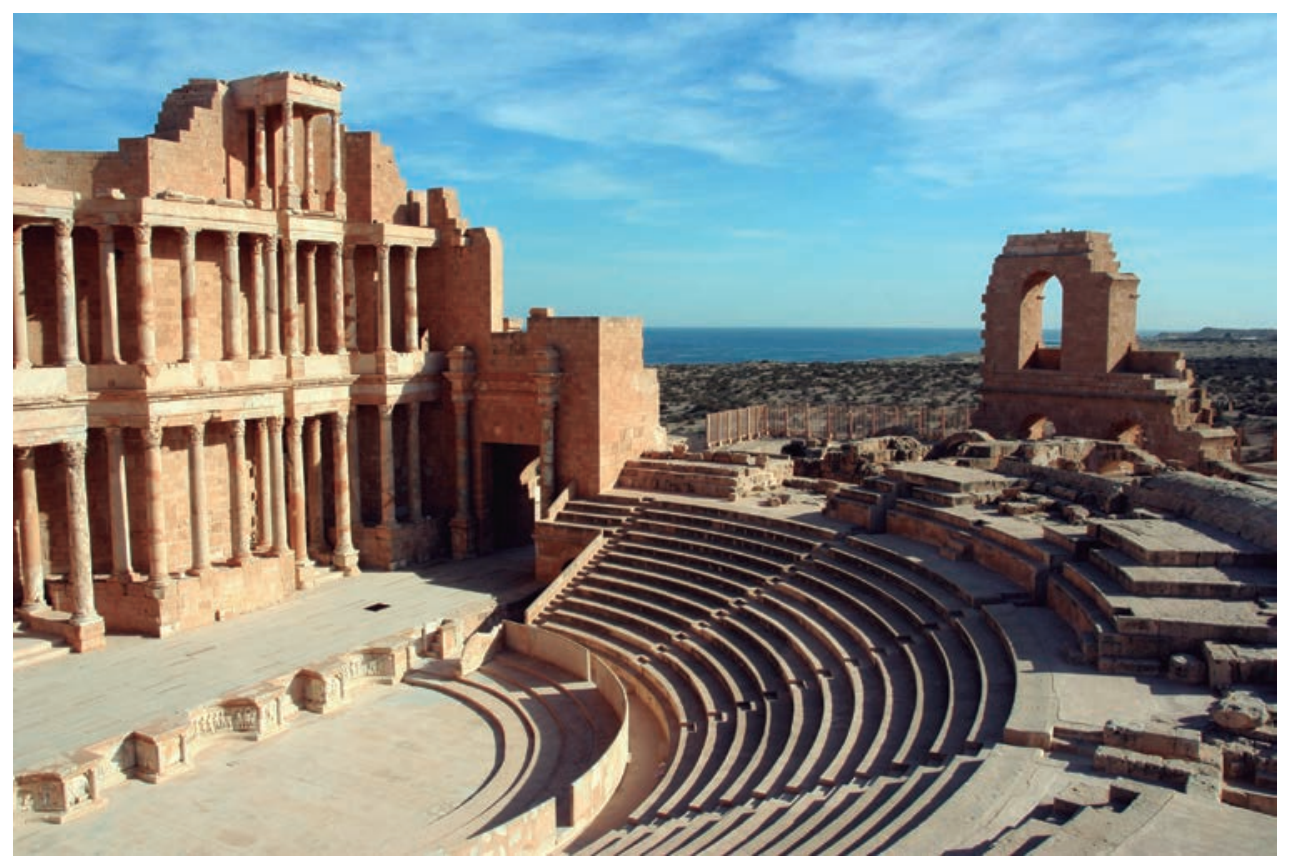

FIGURA 42 - Teatro Romano em Sabratha/Líbia 175-20o d. C. 


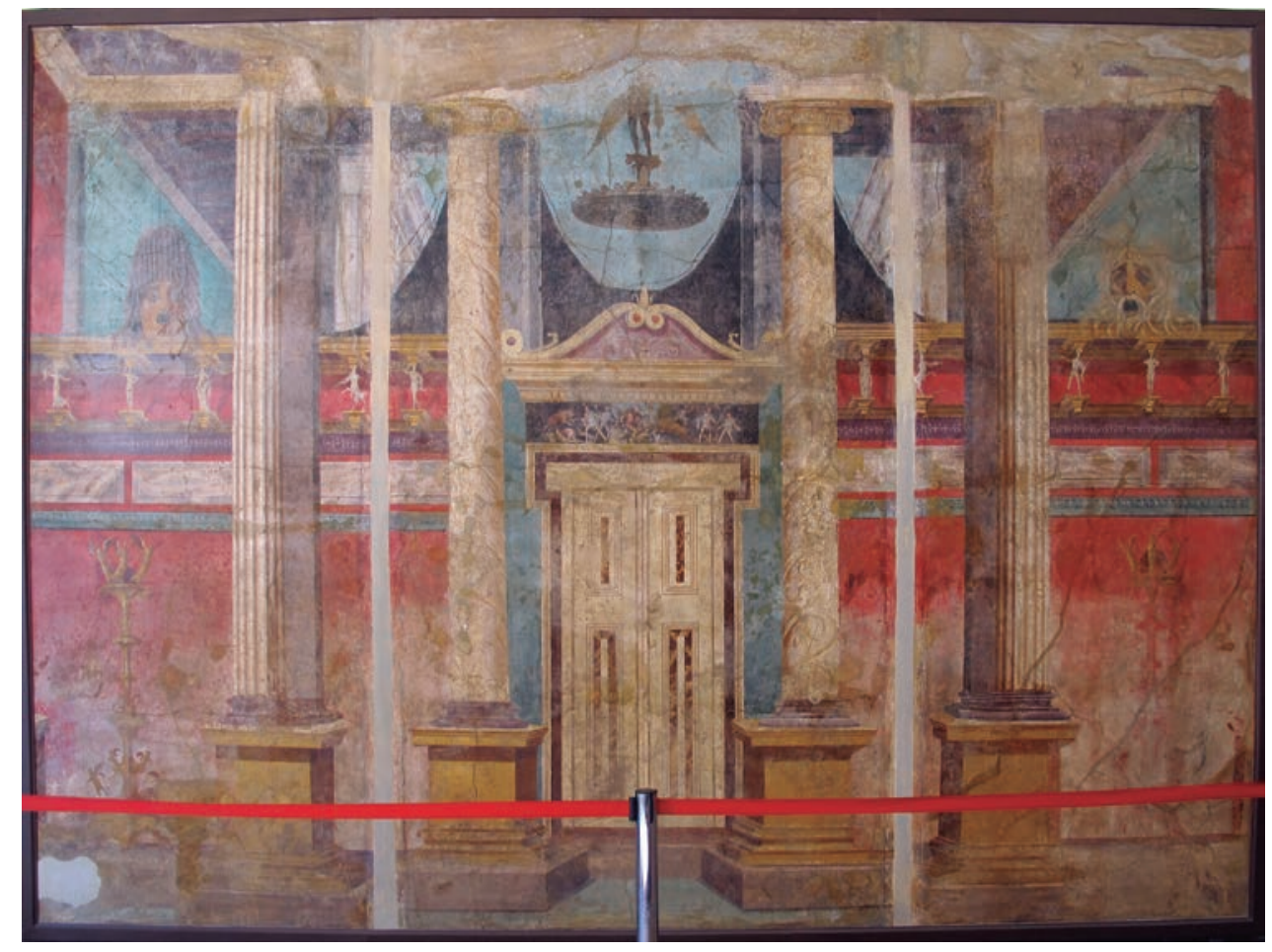

FIGURA 43 - Afresco de Boscoreale - Vila de

Publius Fannius Sinistor Itália (ca. Século I a. C.).

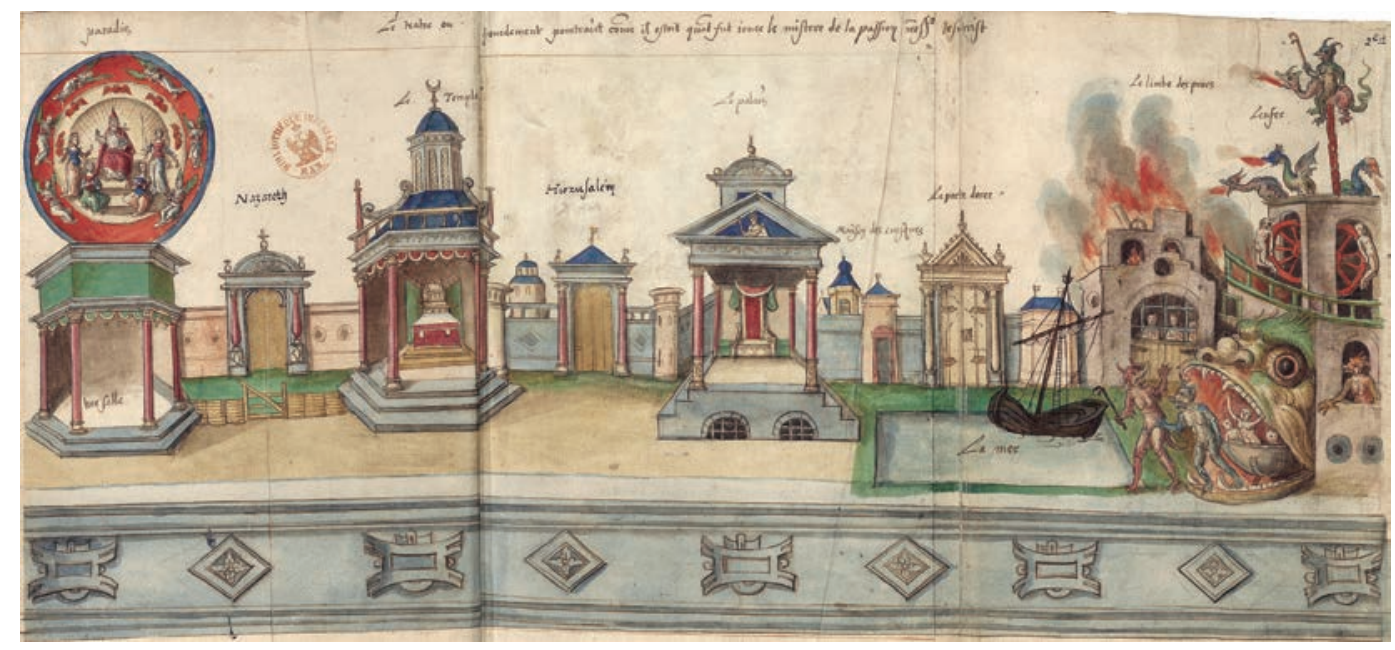

FIGURA 44 - Paixão de Valenciennes/Bélgica (1547). 

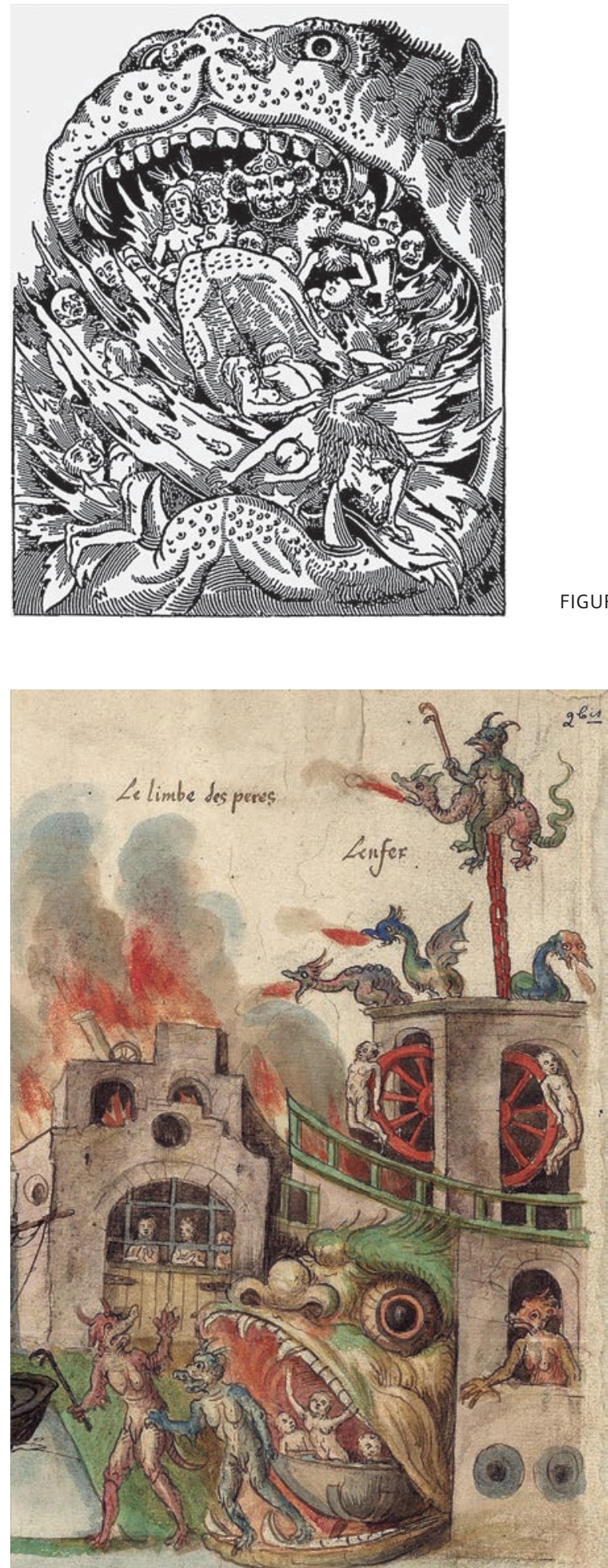

FIGURA 45 - Boca do Inferno.

FIGURA 46 - Detalhe da Paixão

de Valenciennes/Bélgica (1547). 

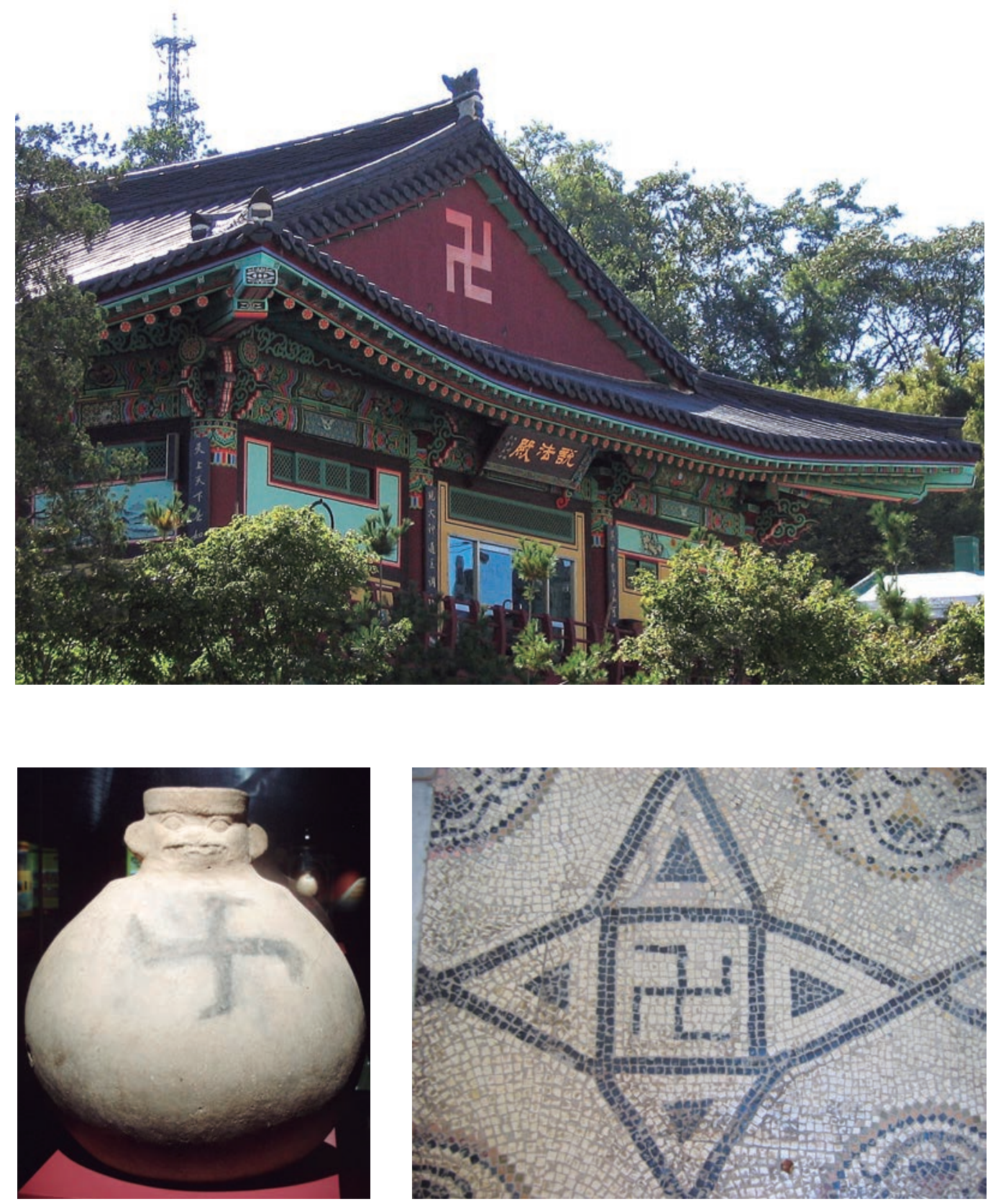

FIGURA 47 A, B e C - Exemplos da

Cruz ou Roda do Sol em diversificadas culturas e épocas. 


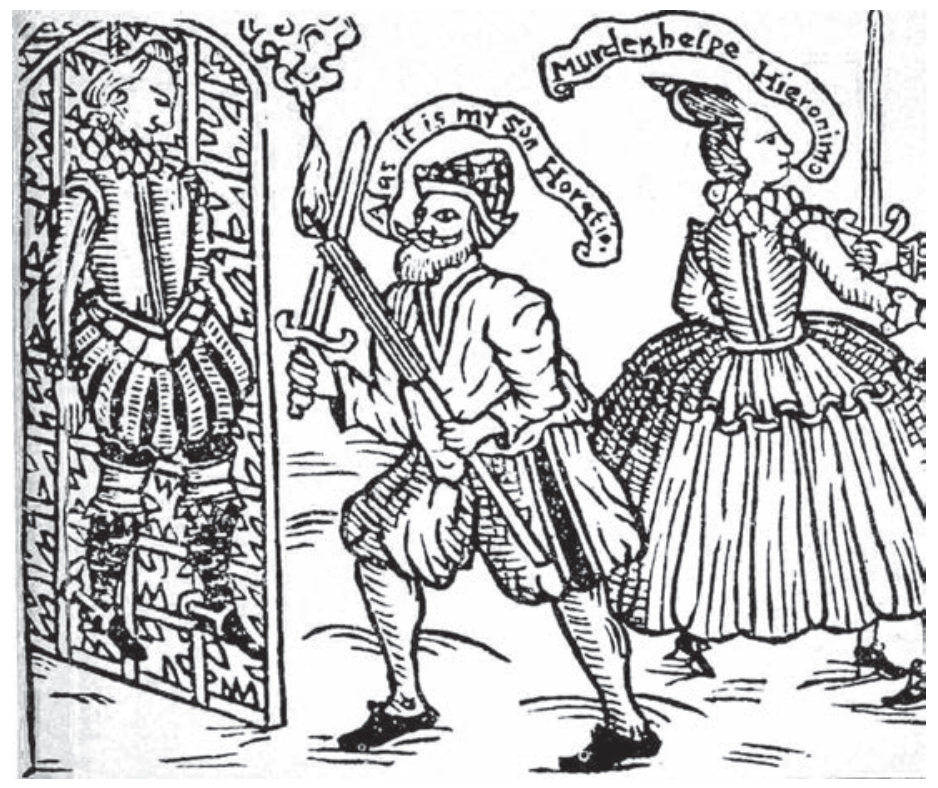

FIGURA 48 - Ilustração

de uma cena noturna

apresentada à luz do dia.

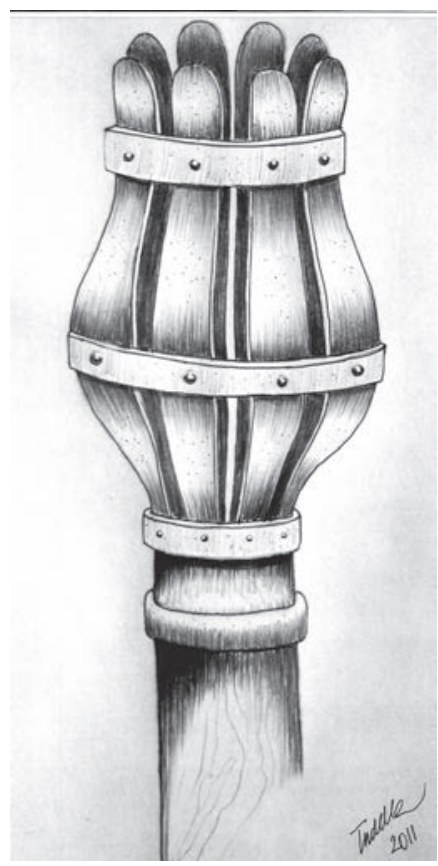

FIGURA 49 - Falot.

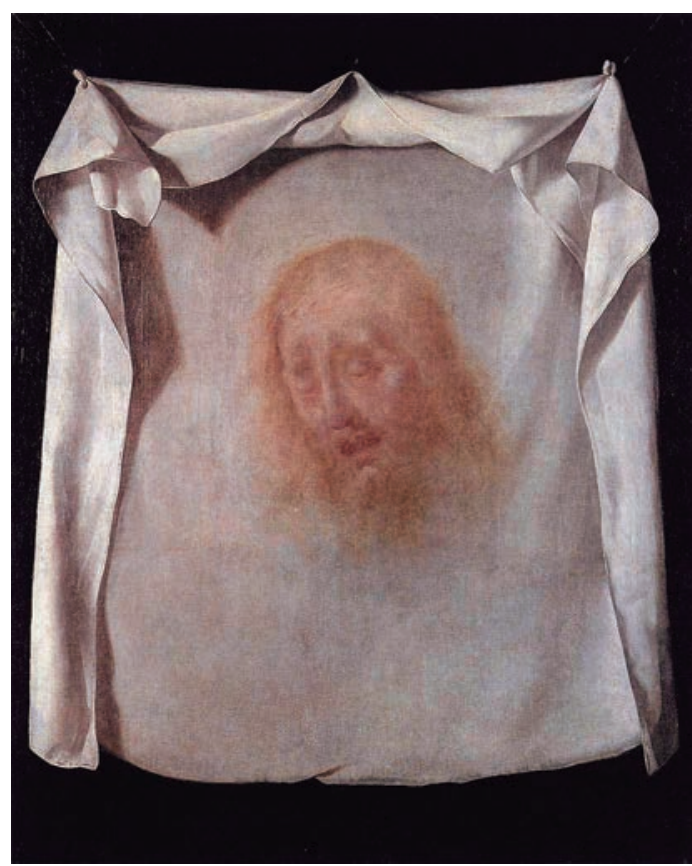

FIGURA 50 - Zurbarán. O Véu de Santa Verônica, c. 1631. 


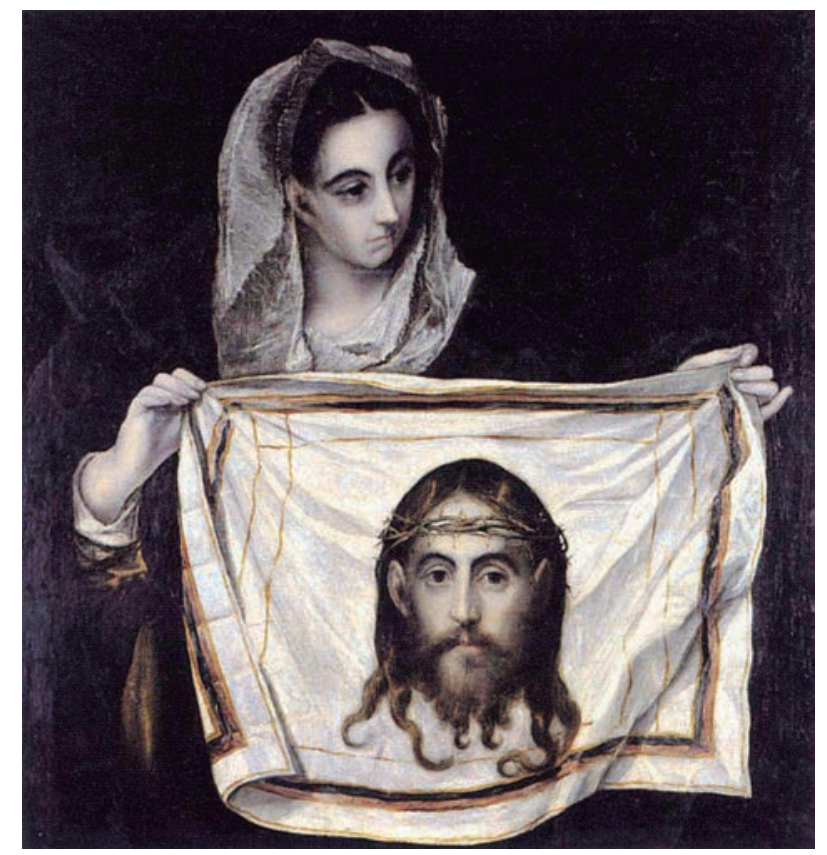

FIGURA 51 - El Greco. A Verônica,

ca. 1580.

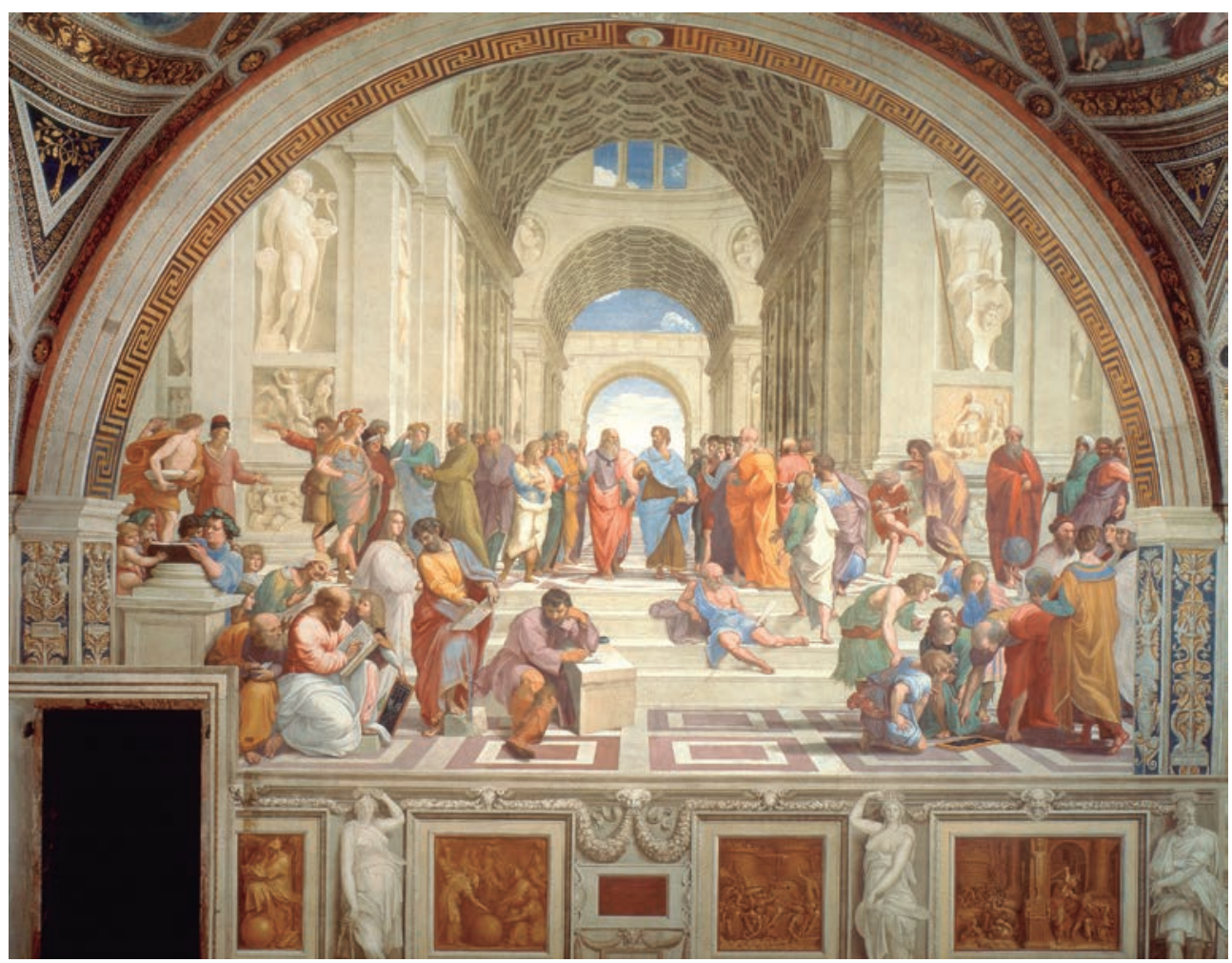

FIGURA 52 - Rafael. A Escola de Atenas. Afresco (1516-1518). Vaticano. 


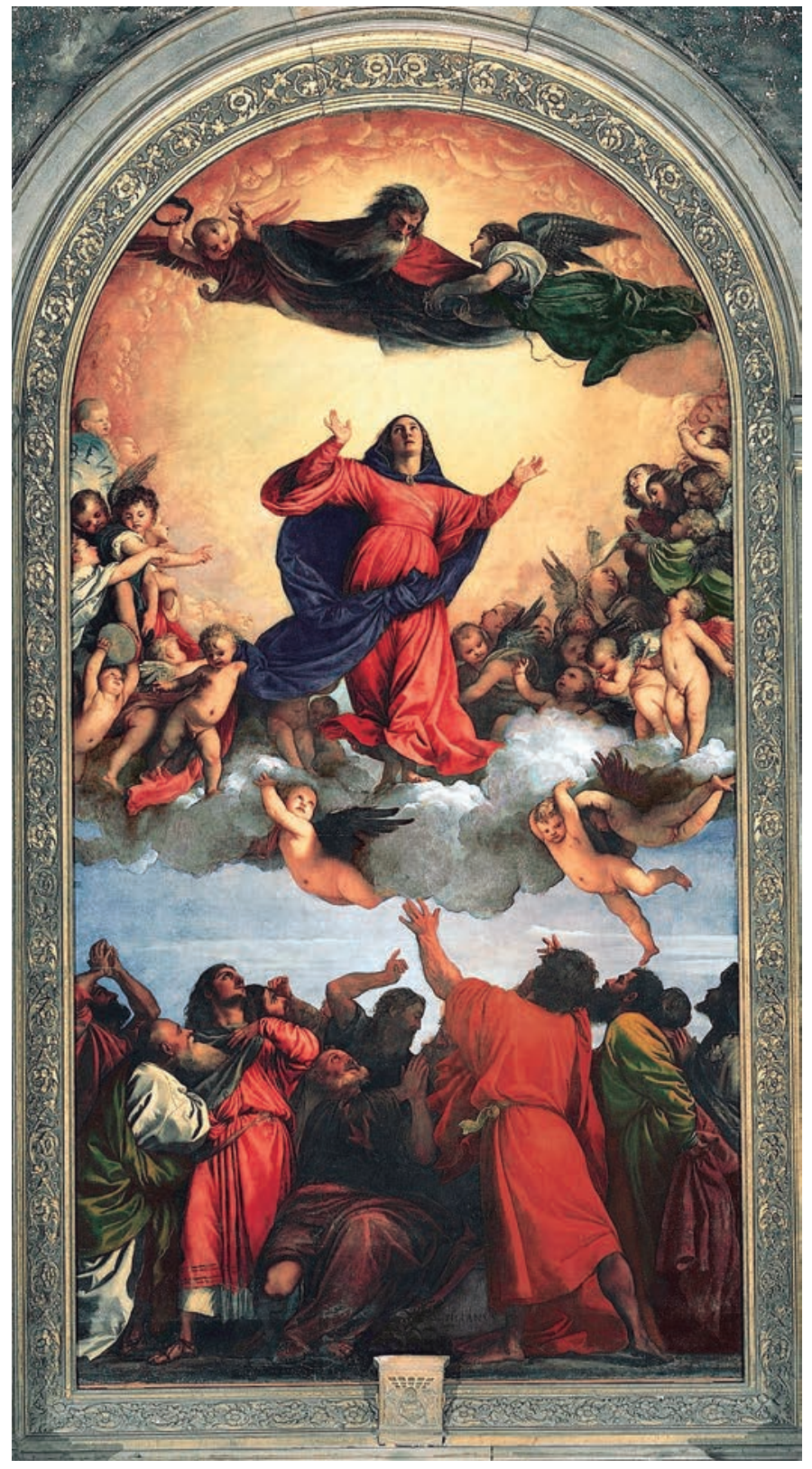

FIGURA 53 - Titian. A Assunção da Virgem.

Basílica de Santa Maria Gloriosa dei Frari, Veneza. 


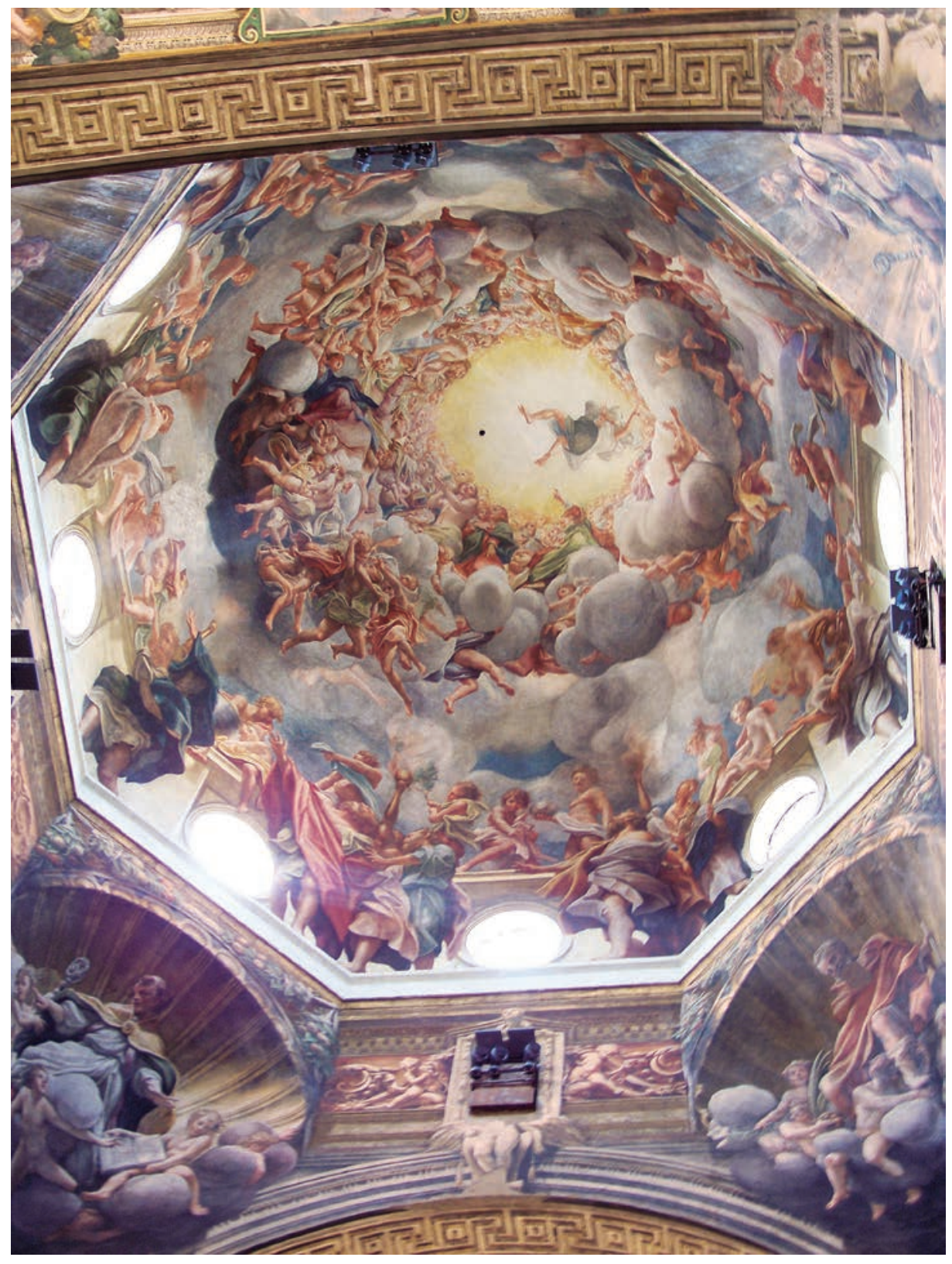

FIGURA 54 - Correggio. A Assunção

da Virgem Maria. Catedral de Parma. 


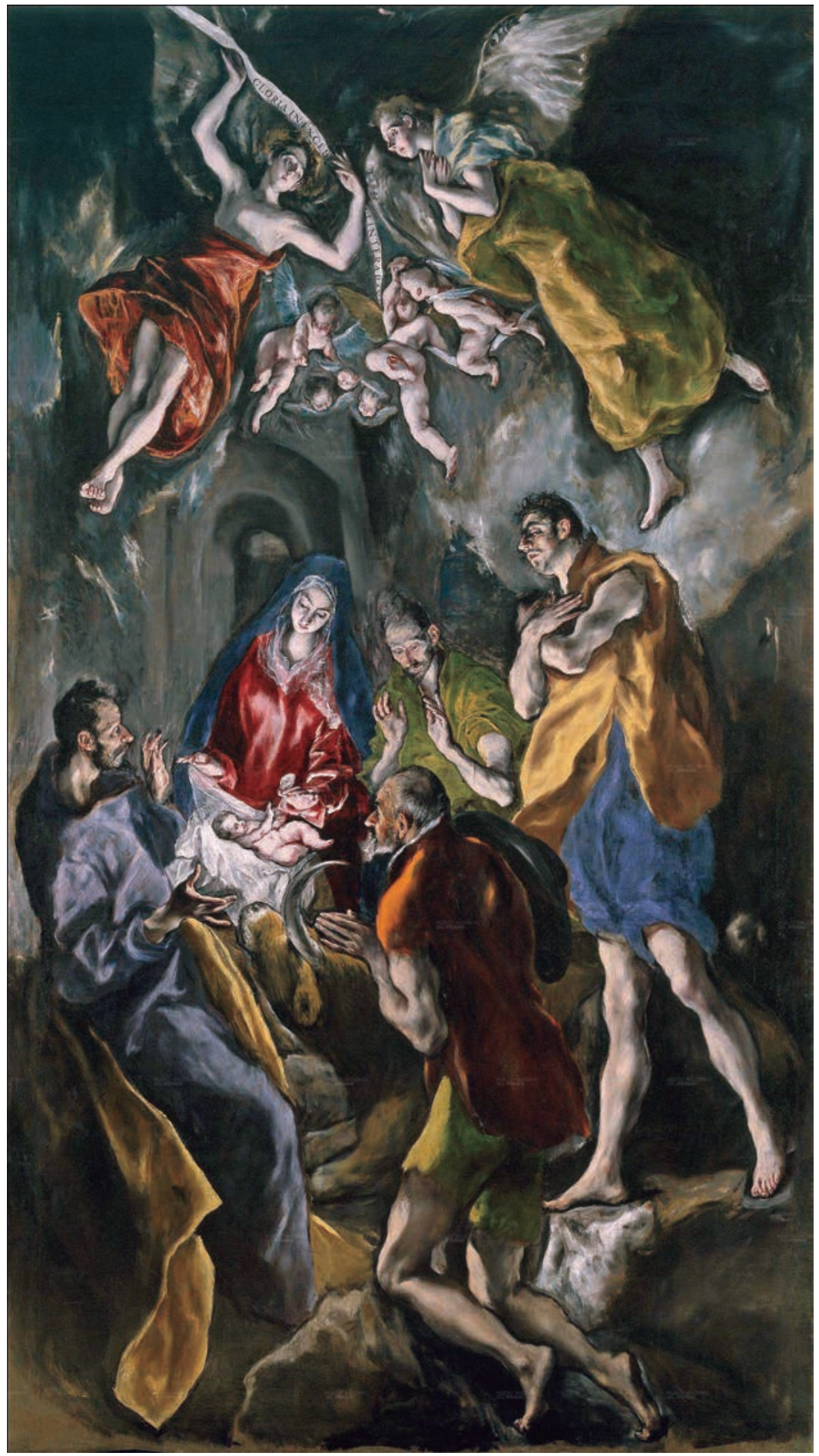

FIGURA 55 - El Greco. Adoração dos Pastores (1612-1614). Museu do Prado, Madri. 

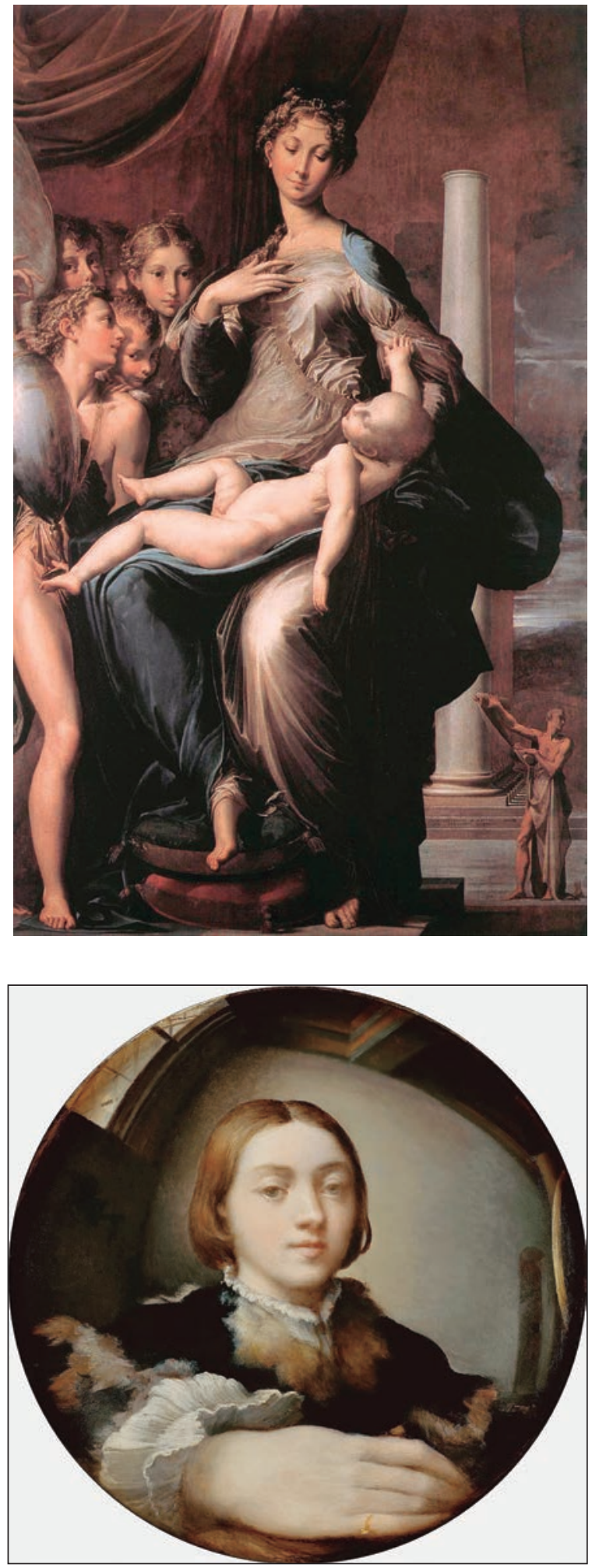

FIGURA 56 - Parmigianino. Madona com longo pescoço. (1534-1540).

FIGURA 57 - Parmigianino. Autorretrato em um espelho convexo (1524). 


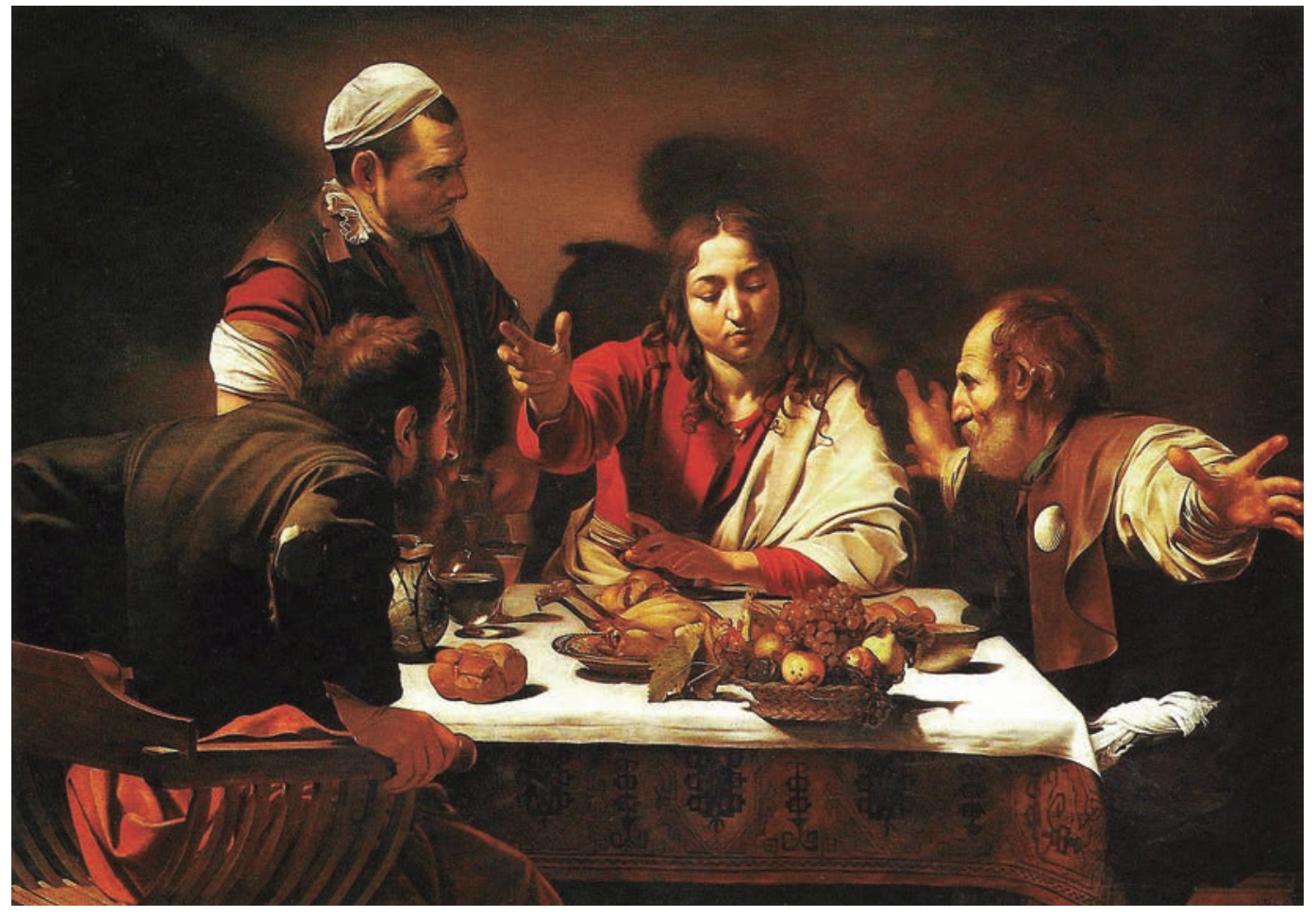

FIGURA 58 - Caravaggio.

Ceia em Emaús (1601).

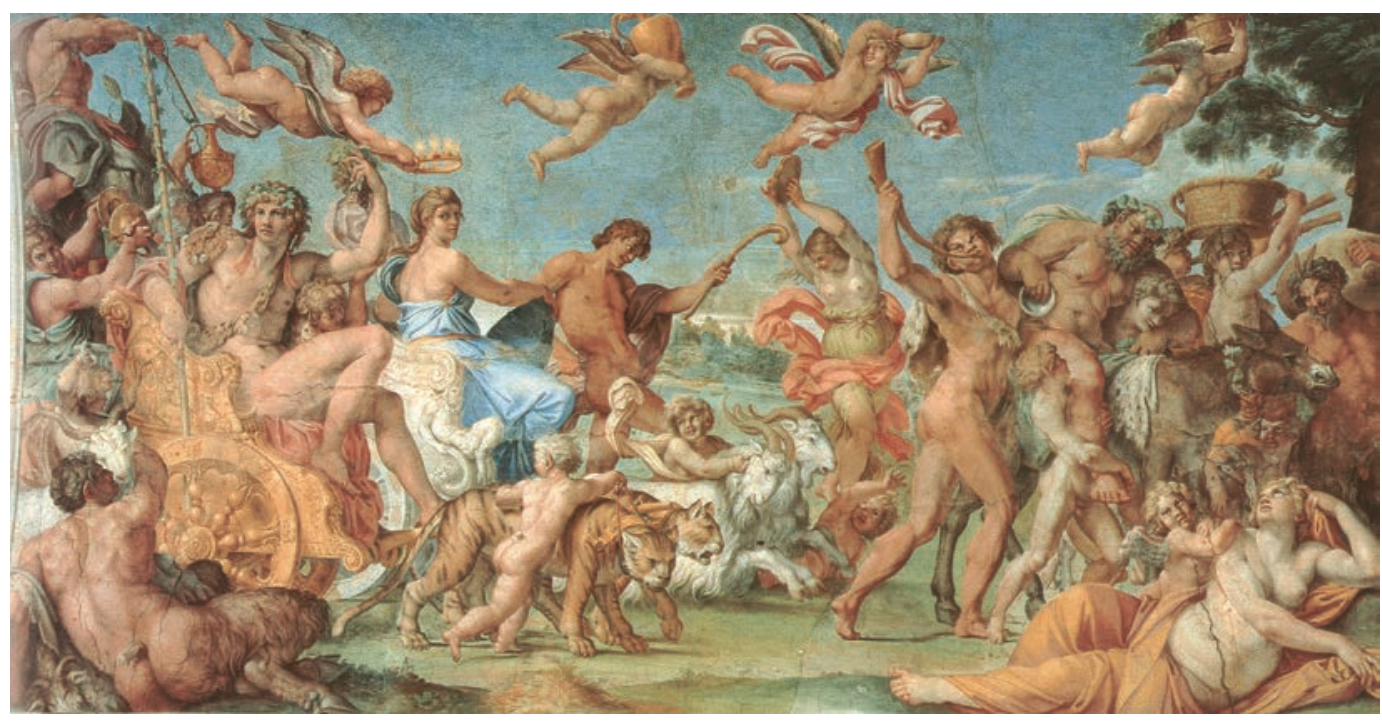

FIGURA 59 - Caracci. O Triunfo de Baco e Ariadne (1597-1600). 


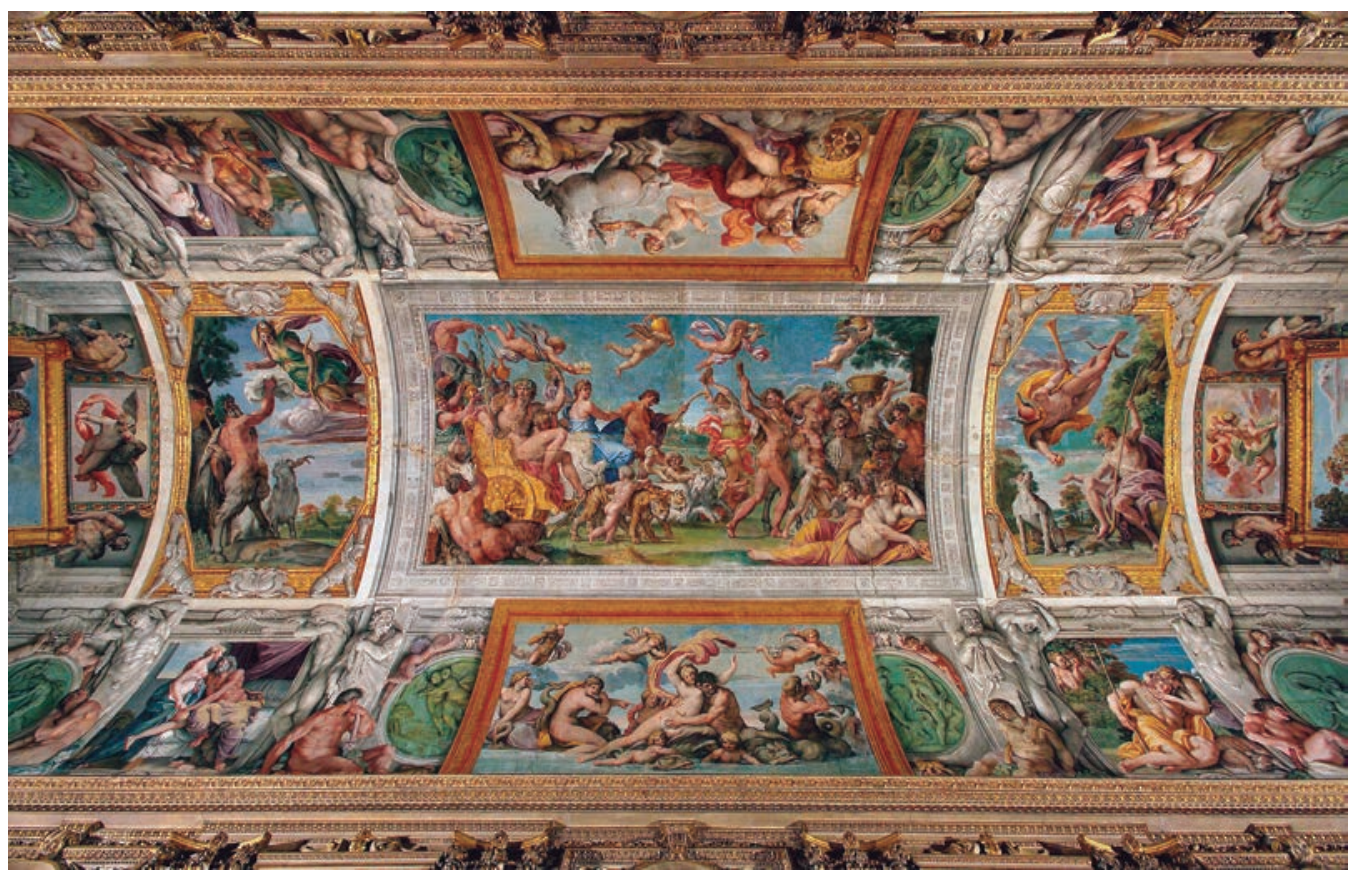

FIGURA 60 - Galeria Farnese. Afrescos de Caracci.

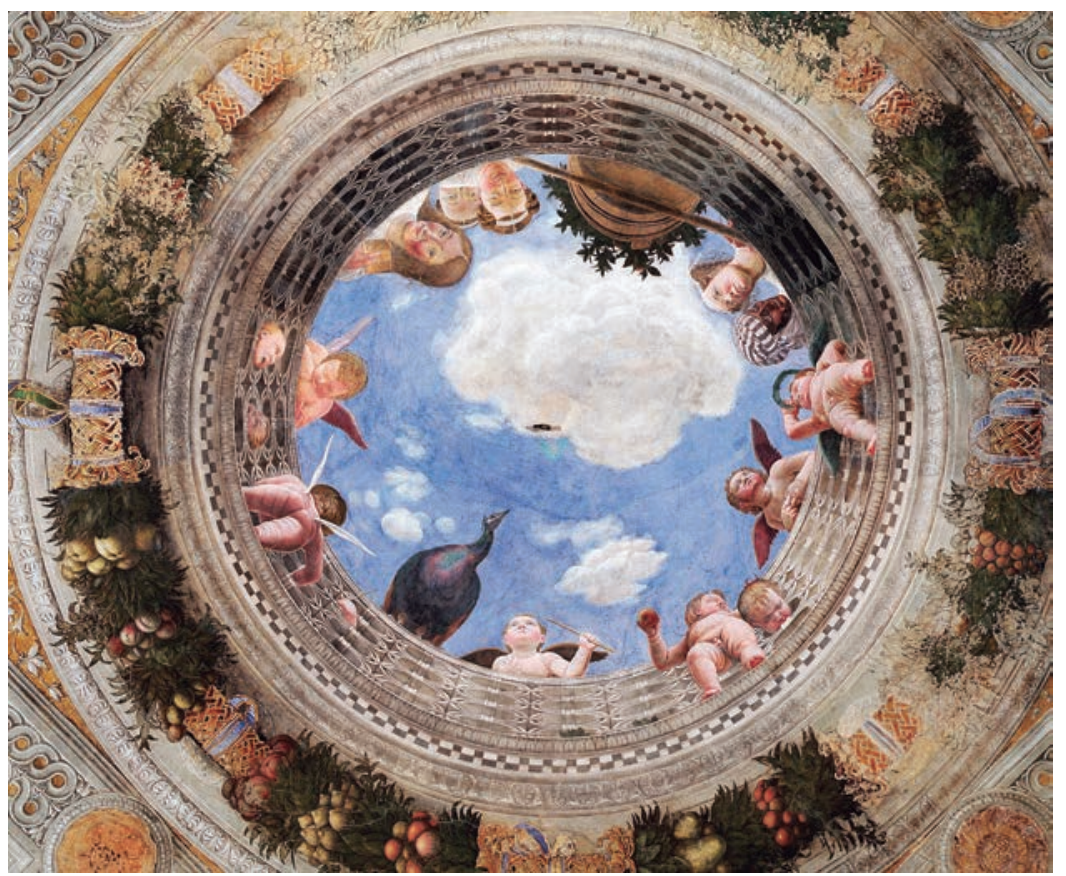

FIGURA 61 - Mantegna. Sotto-in-su nos aposentos do casal do Palácio Ducal de Mântua (1473). 


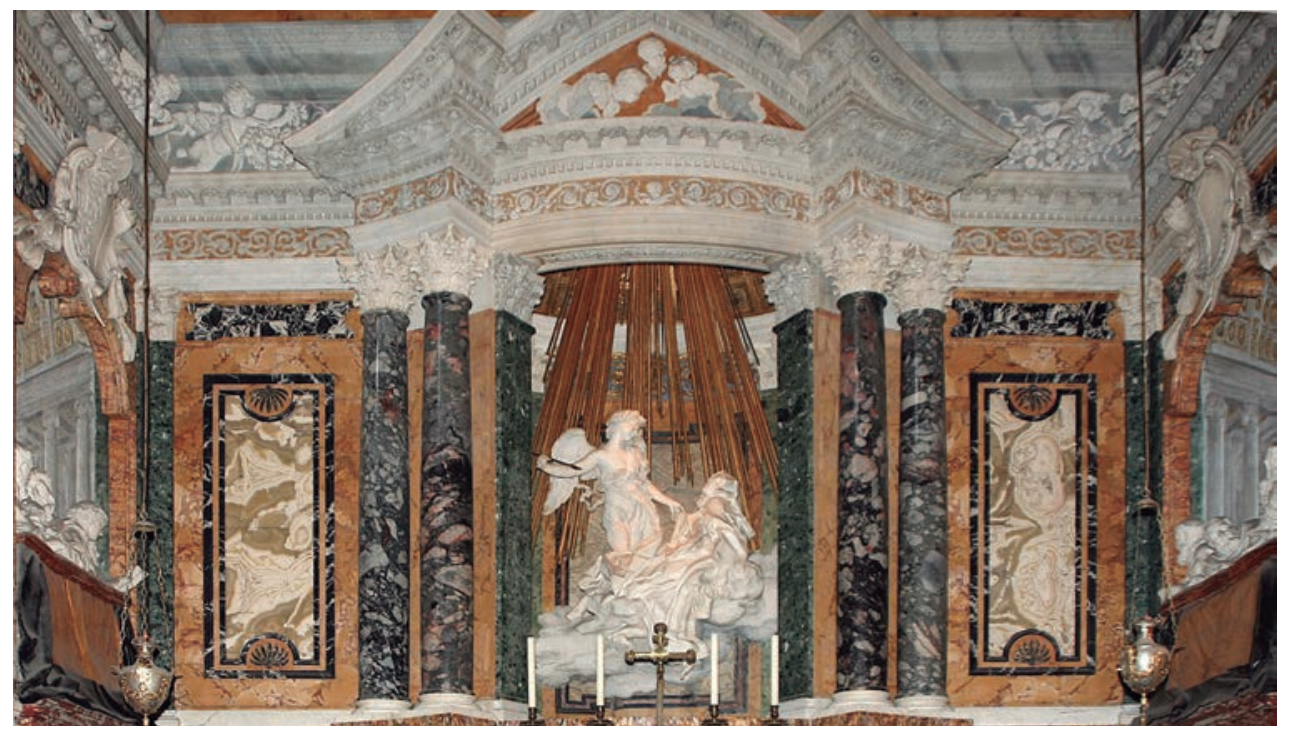

FIGURA 62 - Bernini. O Êxtase de Santa Teresa. (1647-1652).

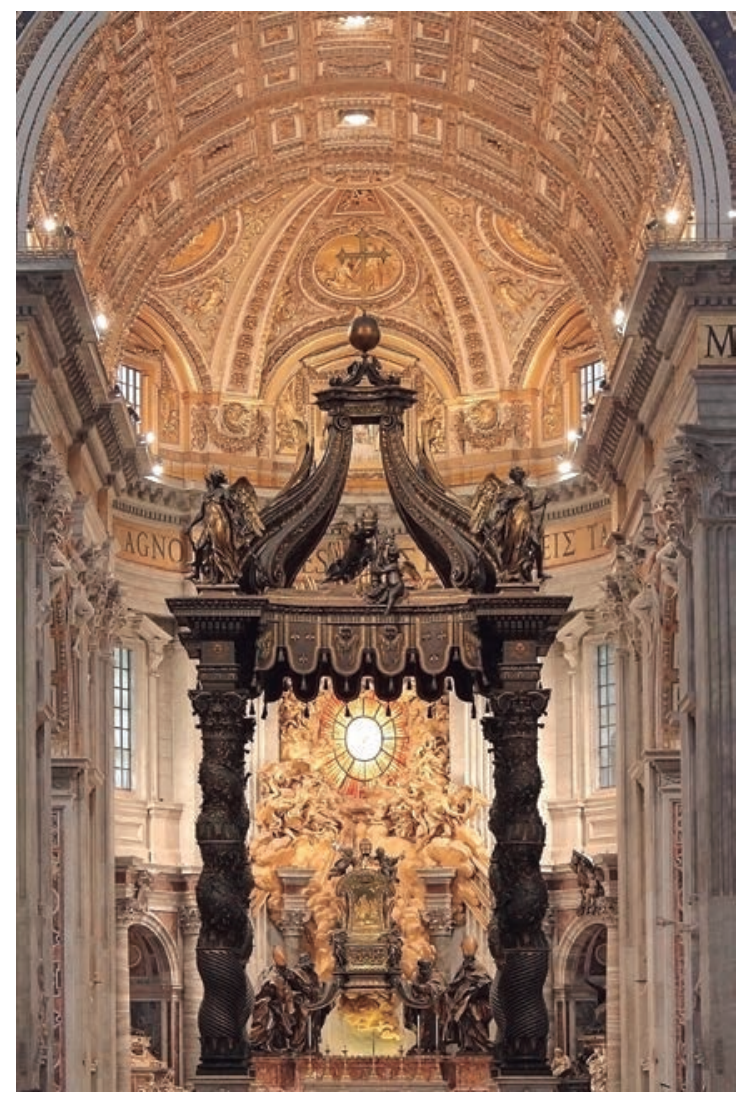

FIGURA 63 - Bernini. Baldacchino na Catedral de São Pedro - Roma, (1624-1633). 


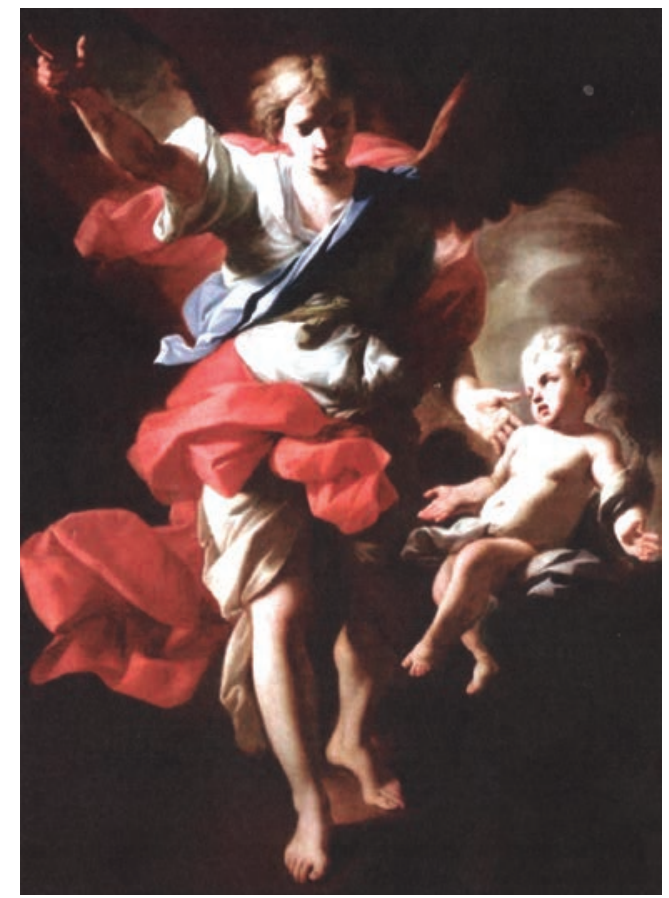

FIGURA 64 - Pozzo. O Anjo da Guarda (c. 1685).

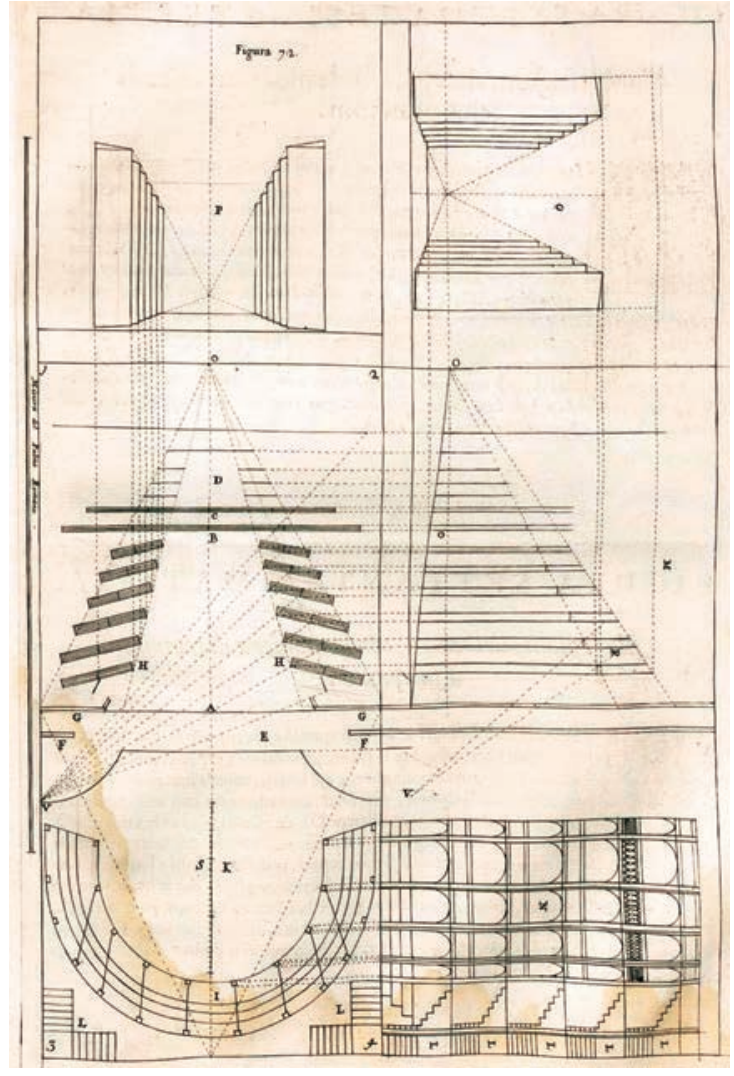

FIGURA 65 - Andrea Pozzo. Projeto para

Teatro [plateia no padrão de cavea (c. 1692)]. Perspectiva pictorum et architectorum. 


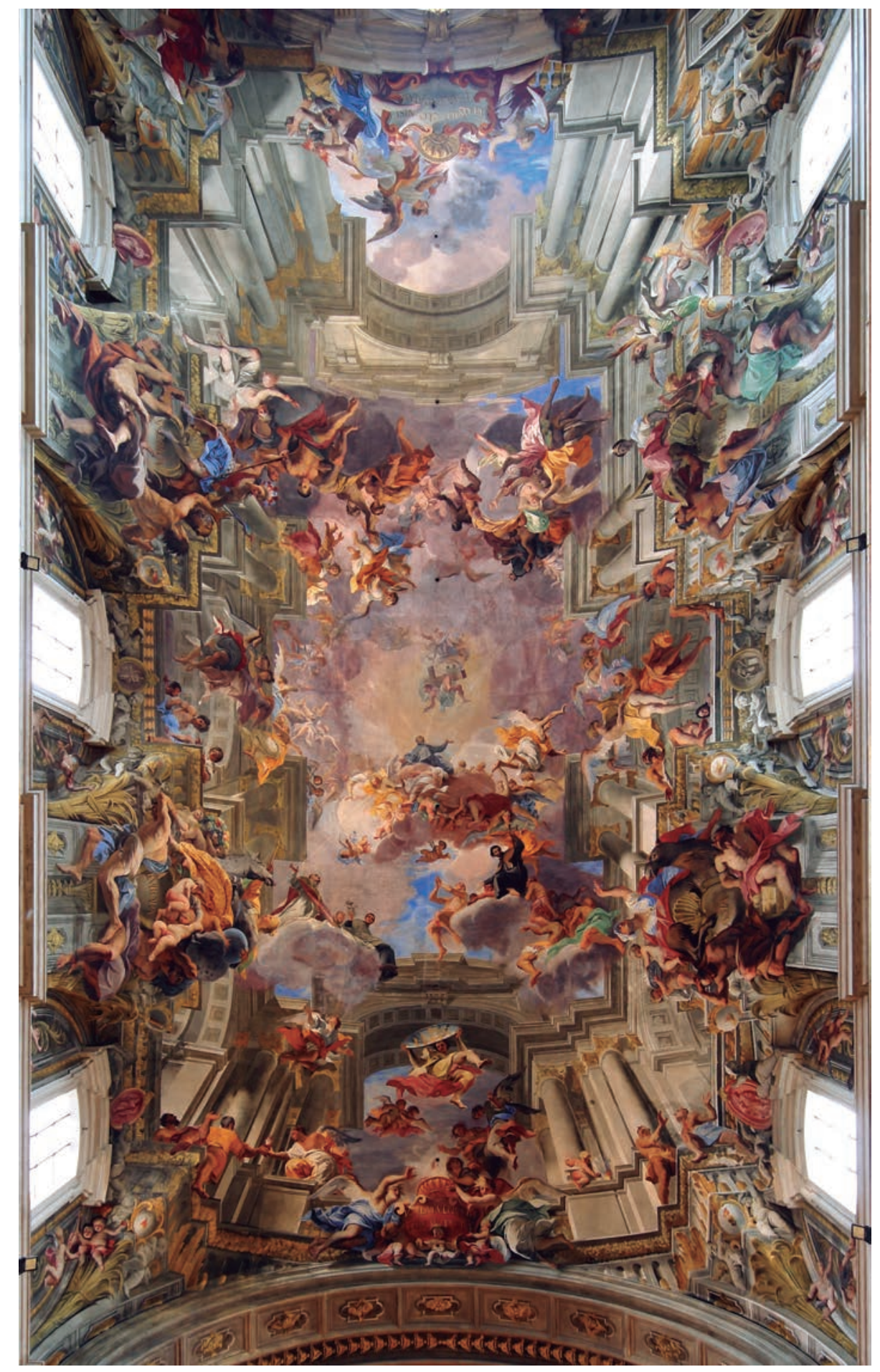

FIGURA 66 - Andrea Pozzo. Apoteose de Santo Inácio (c. 1694). 


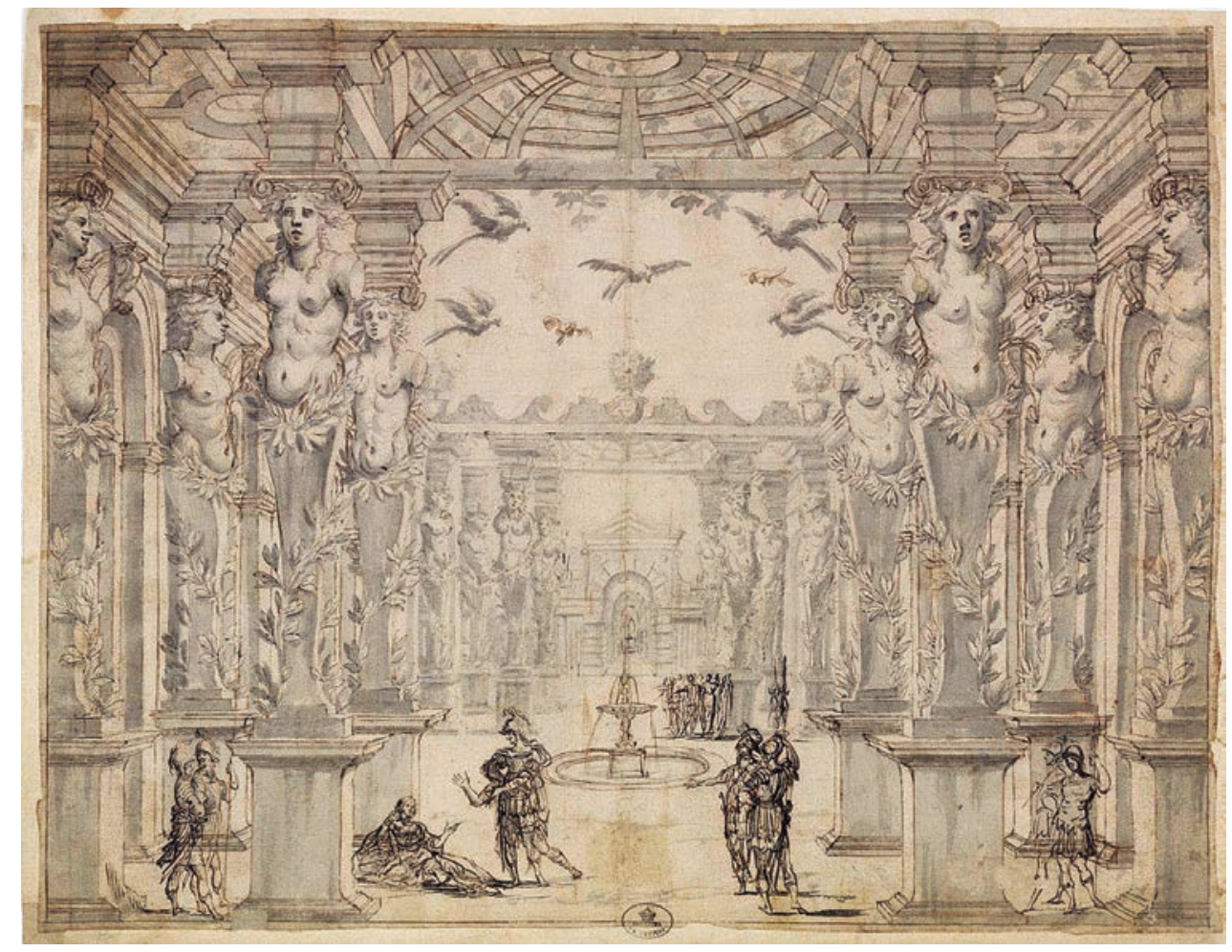

FIGURA 67 - Giacomo Torelli. La finta pazza (1645).

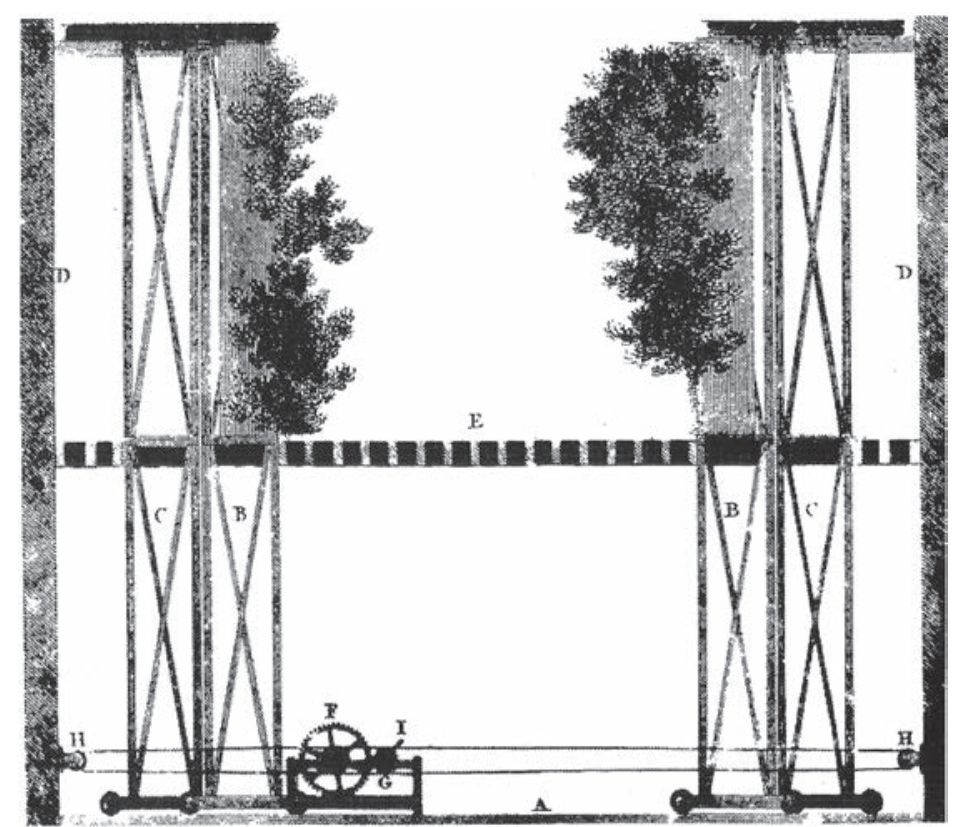

FIGURA 68 - Torelli. Sistema para mudanças de cenário. 


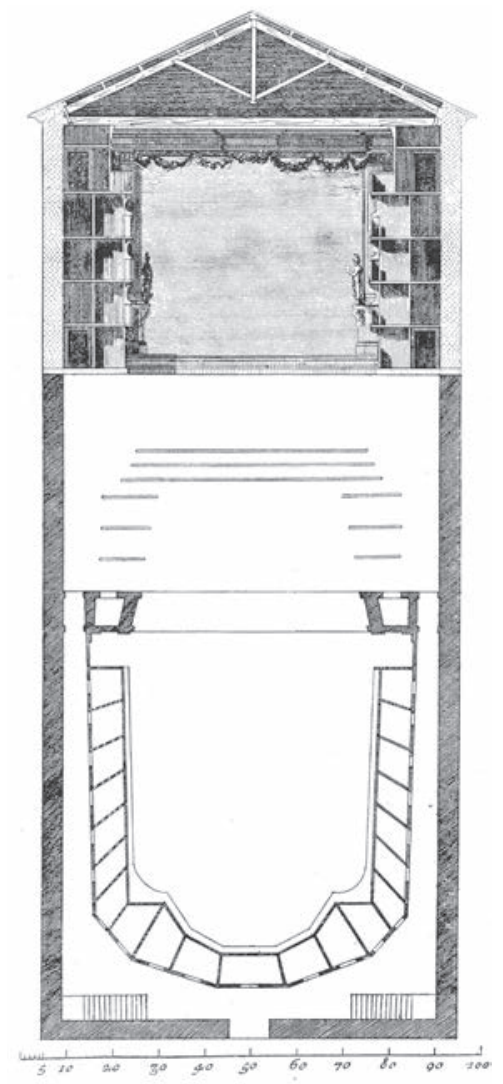

FIGURA 69 - Giacomo Torelli.

Teatro dela Fortuna, em Fano.

Planta Baixa e Corte.

FIGURA 70 - Ferdinando

Bibiena. Cenário para Didio

Giuliano, de Sabadini, (1697).

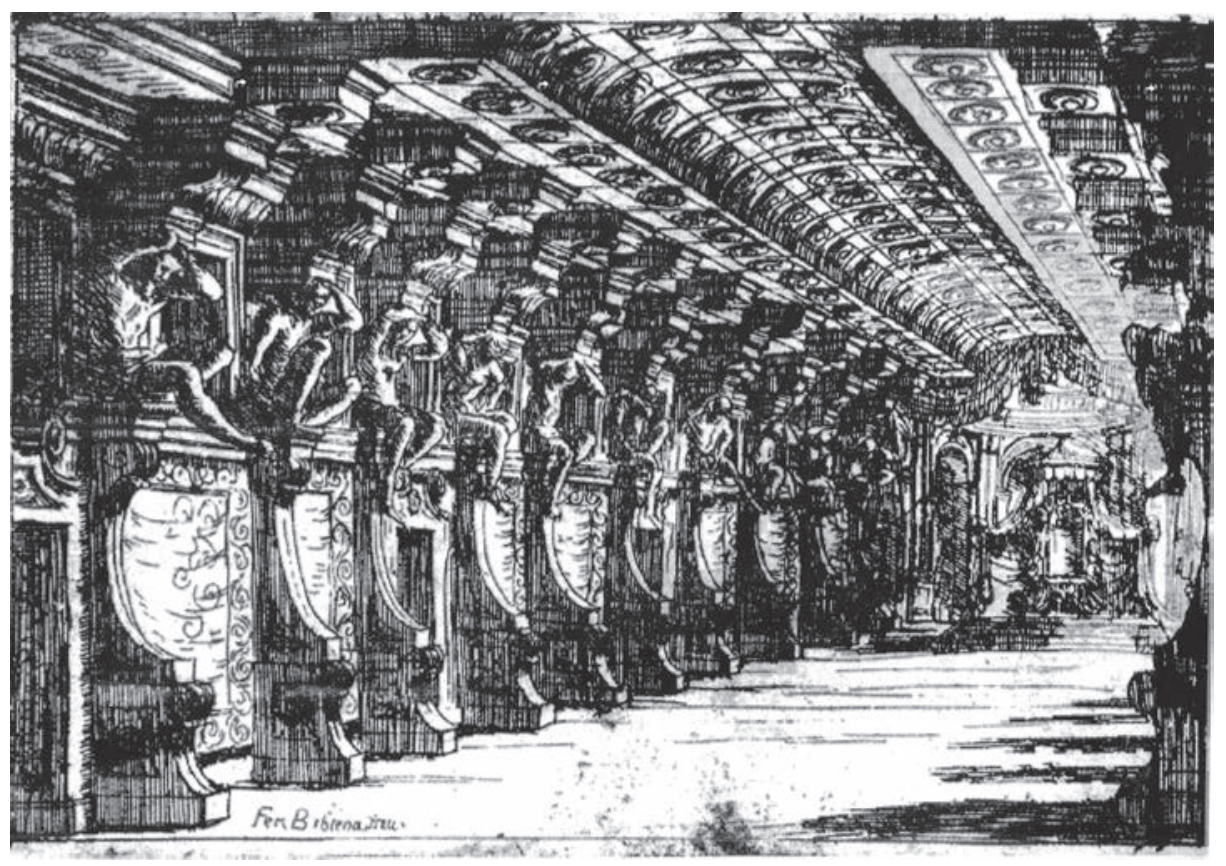




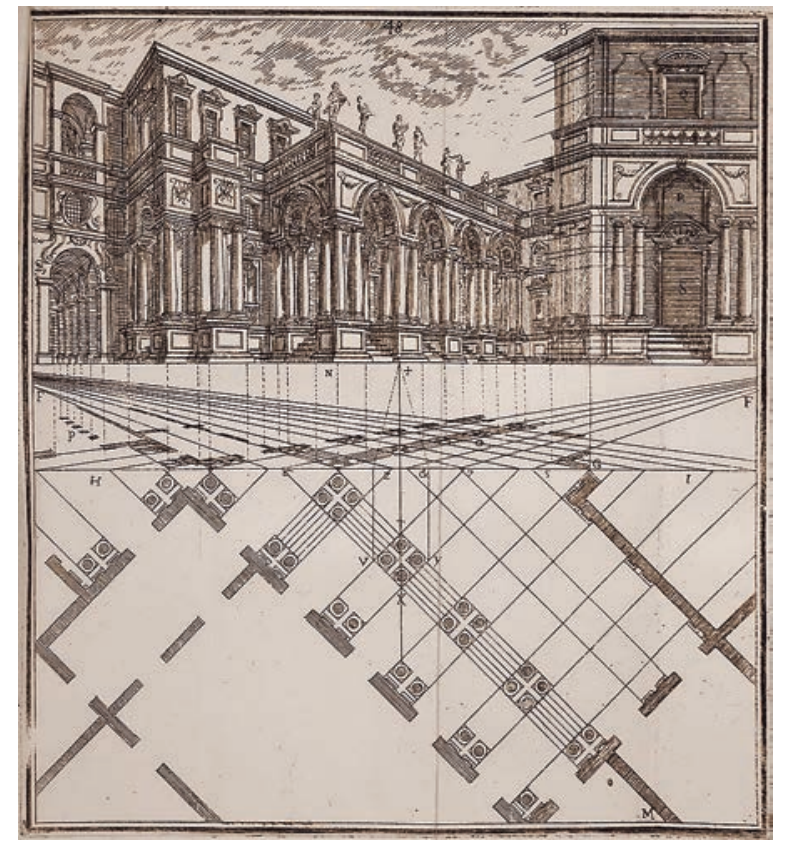

FIGURA 71 - Ferdinando Bibiena. Scena per angolo [Planta e perspectiva frontal].

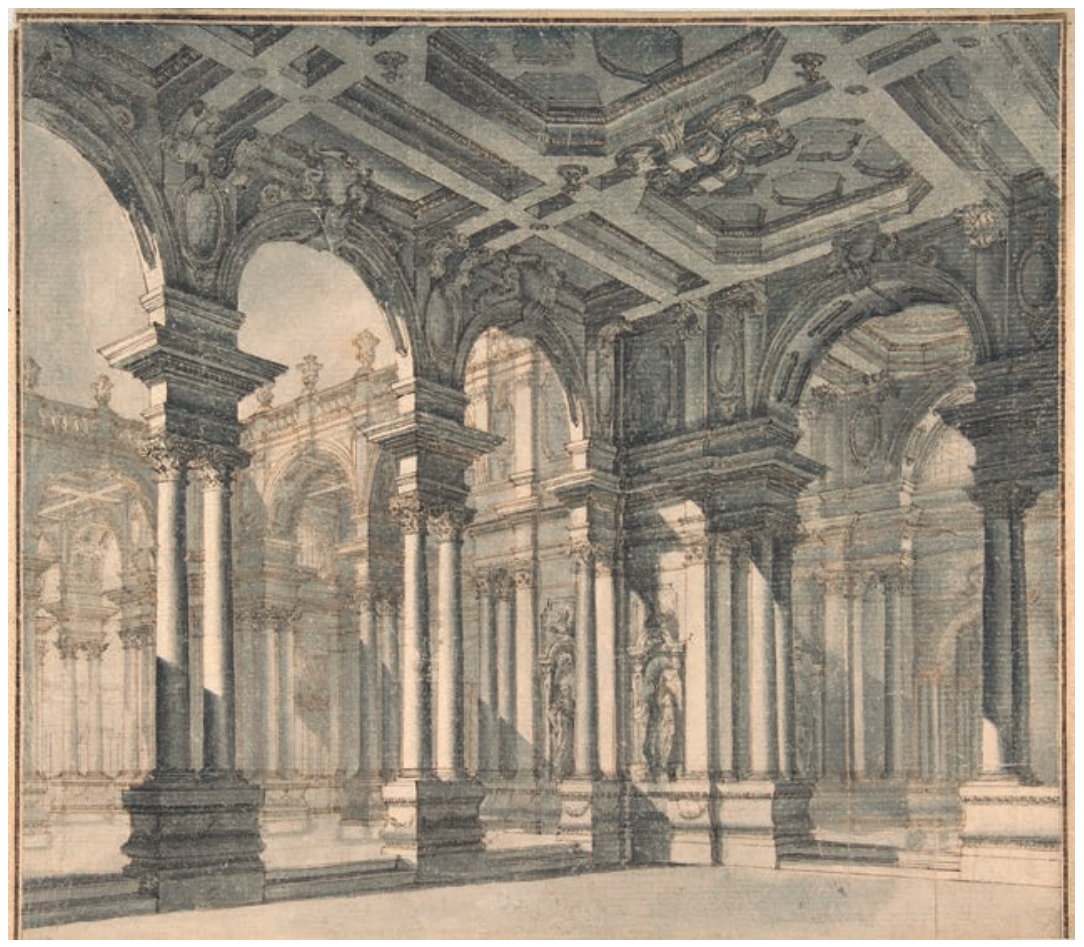

FIGURA 72 - Giuseppe Bibiena. Projeto para um cenário com um monumental pátio com arcada. 


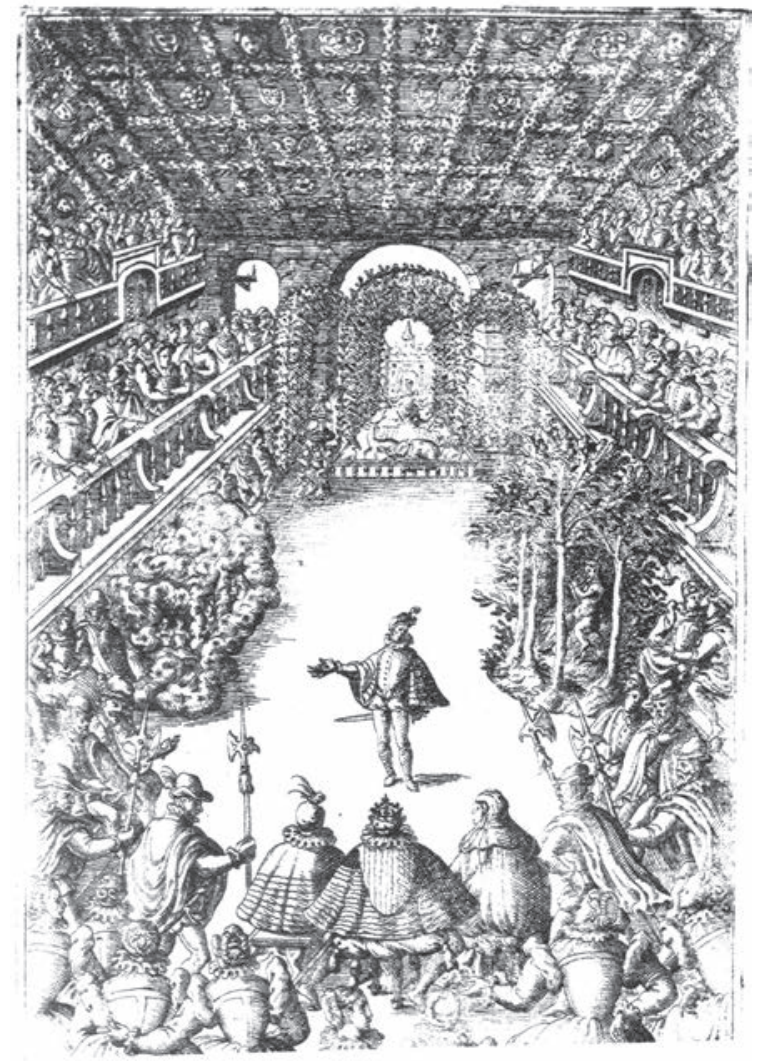

FIGURA 73 - Apresentação de um Balé para Henrique III e sua corte na Galeria do Louvre.

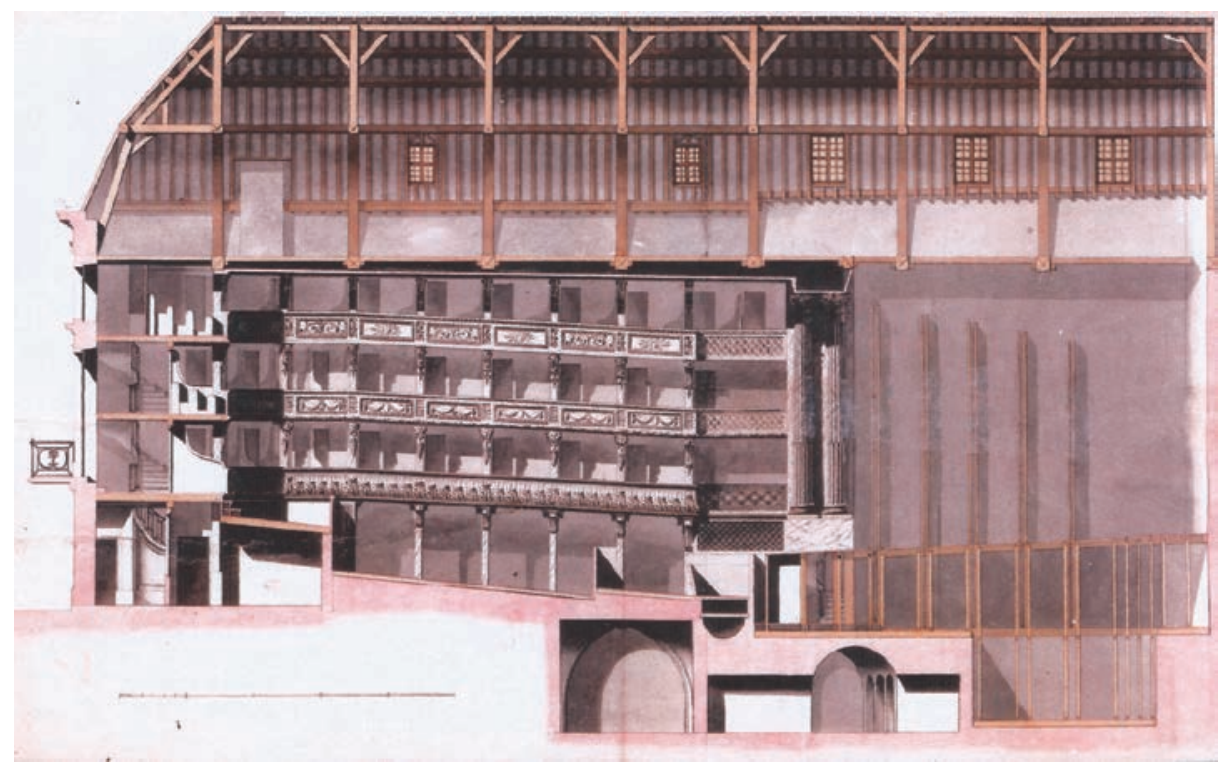

FIGURA 74 - Hôtel de Bourgogne. Corte longitudinal - plateia e palco. 


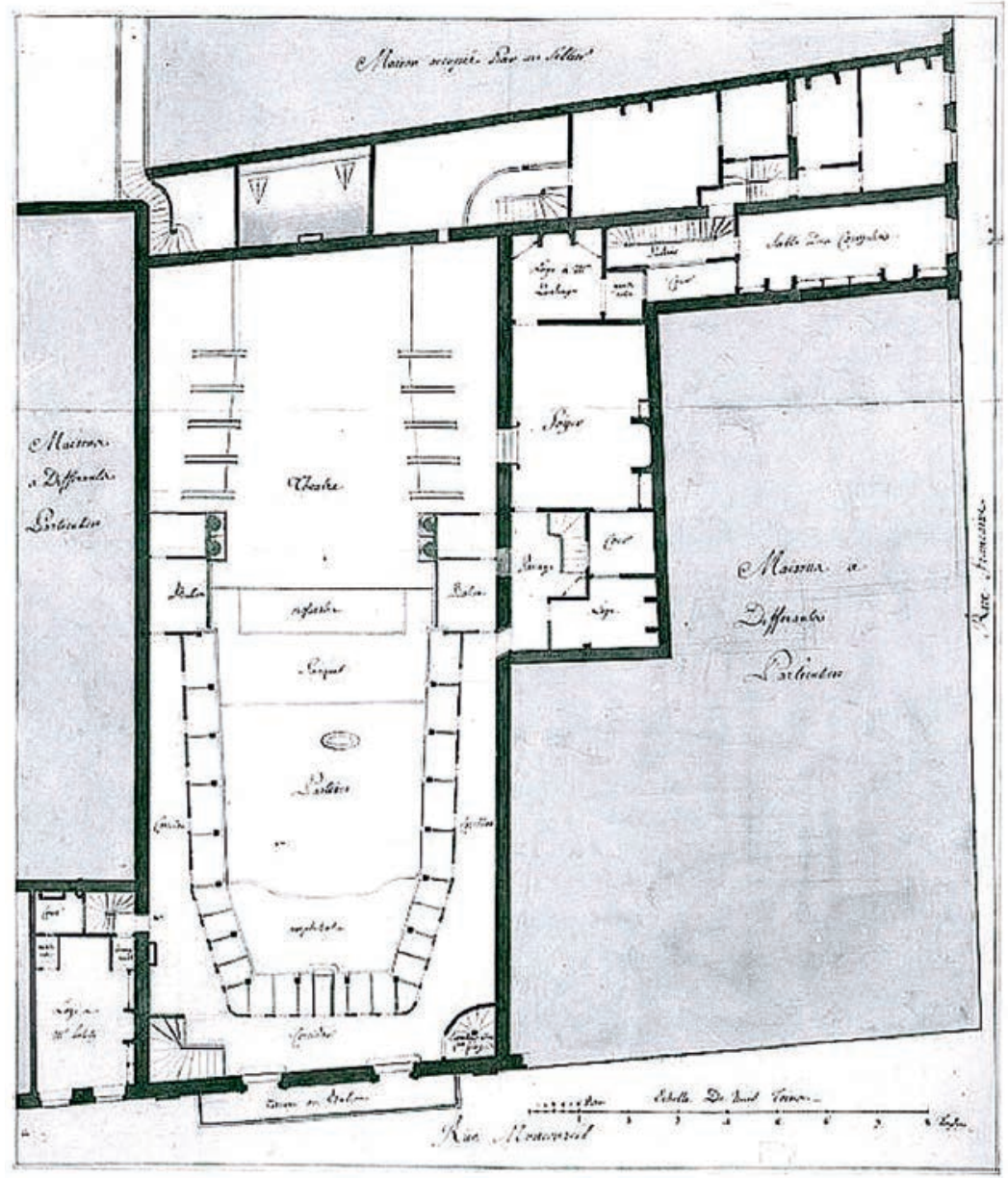

FIGURA 75 - Hôtel de Bourgogne. Planta-Baixa $(68 \mathrm{~cm} \times 58.1 \mathrm{~cm})$.

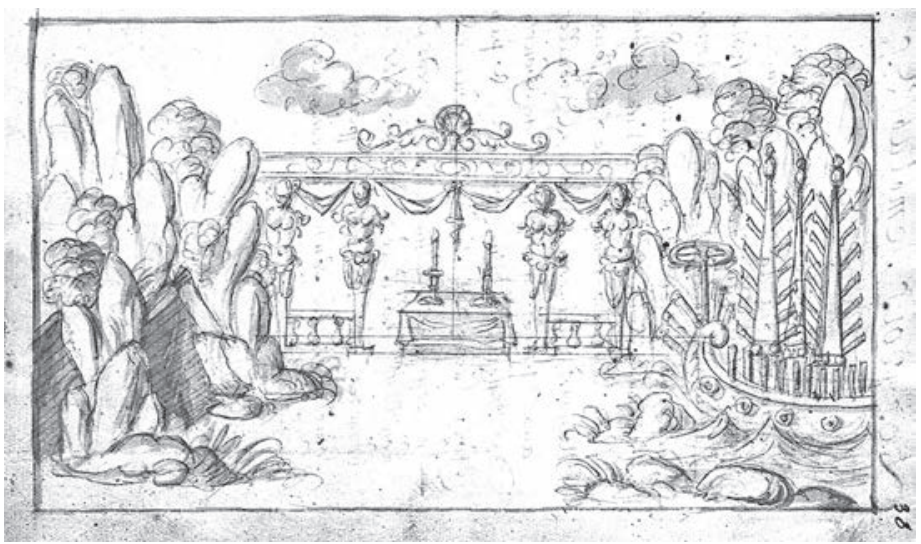

FIGURA 76 - Du Ryer,

L'Argénis. Hôtel de Bourgogne. 


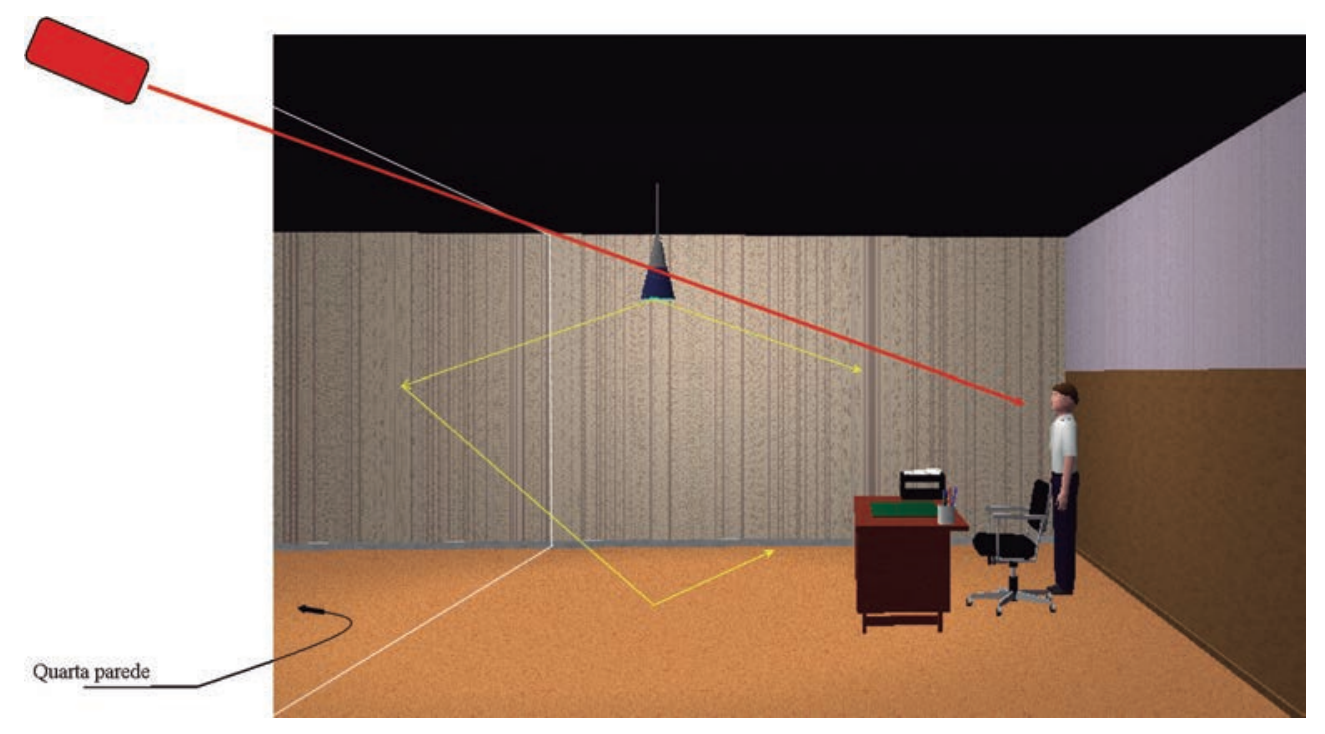

FIGURA 77 - Realismo e Luz.

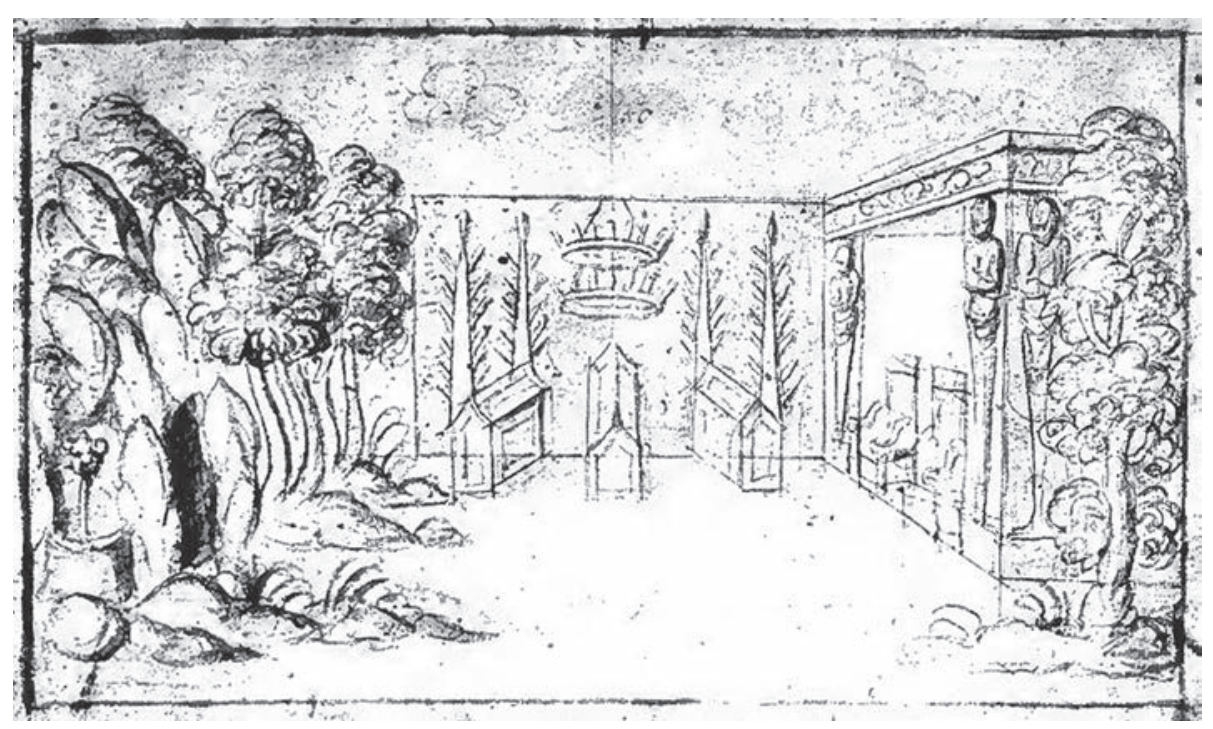

FIGURA 78 - Rotrou. L'Hypocondriaque ou le Mort Amoureux [O Hipocondríaco] de Jean Rotrou Hôtel de Bourgogne. 


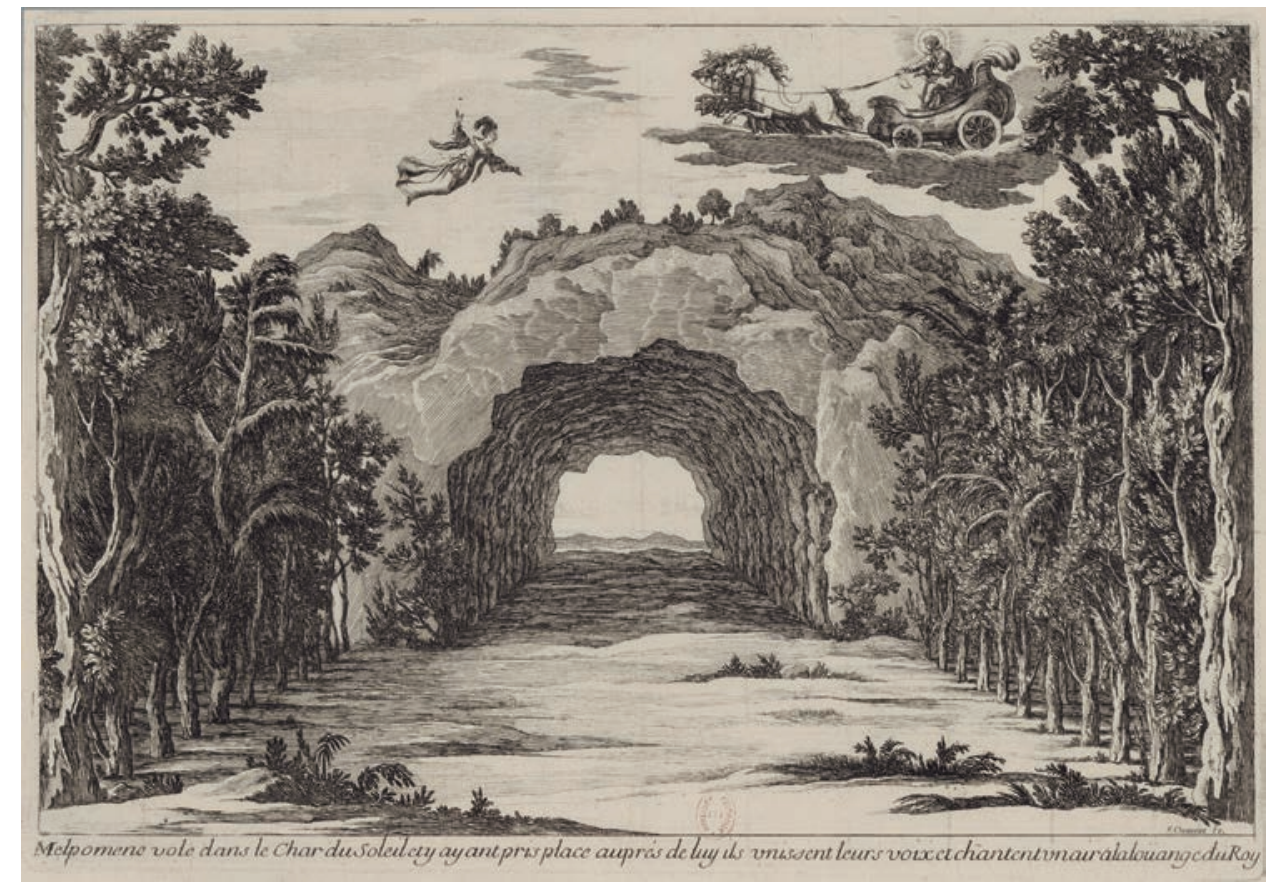

FIGURA 79 - Corneille. Andrômeda, 1651. Prólogo. Cenário de Torelli. Gravura sobre cobre de François Chauveau.

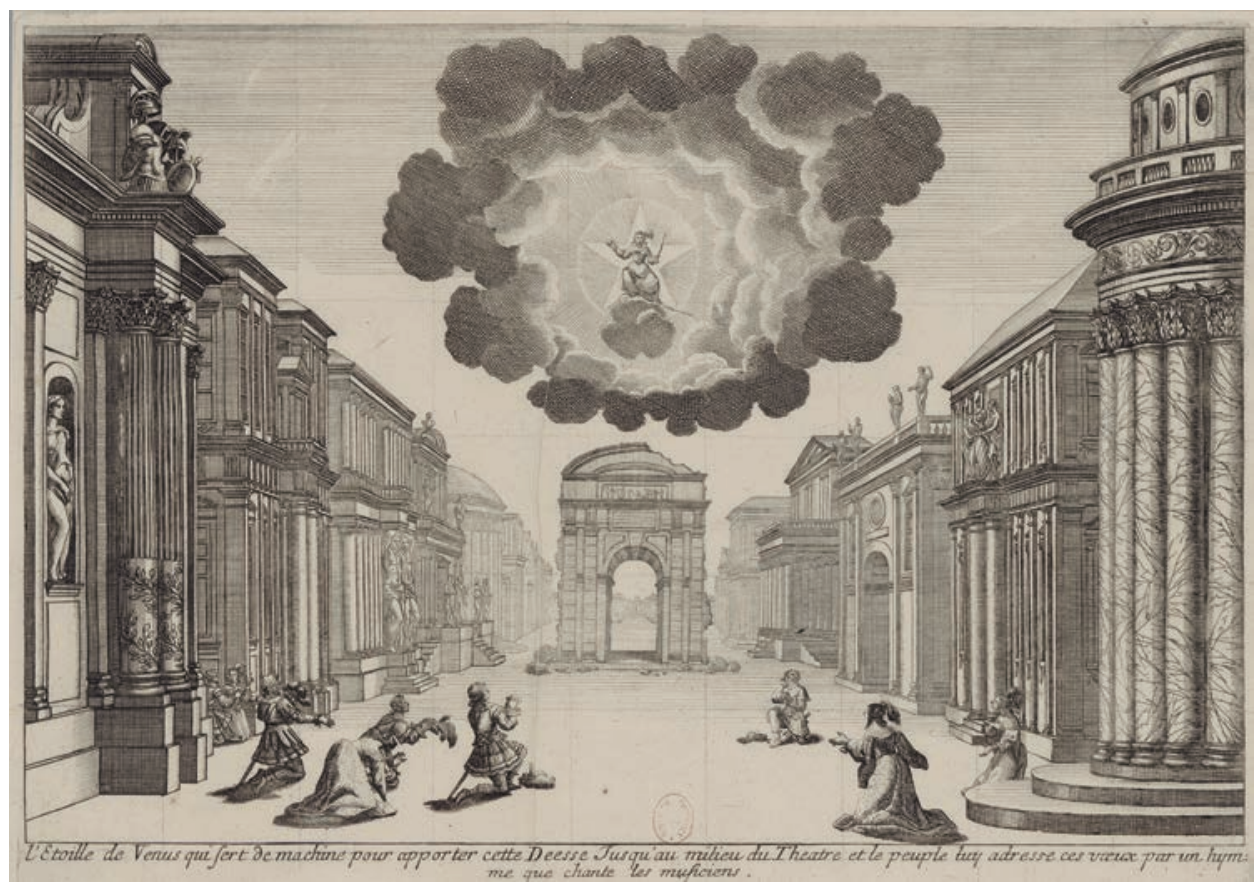

FIGURA 80 - Corneille. Andrômeda, 1651, Ato 1. Cenário de Torelli. Gravura sobre cobre de François Chauveau. 


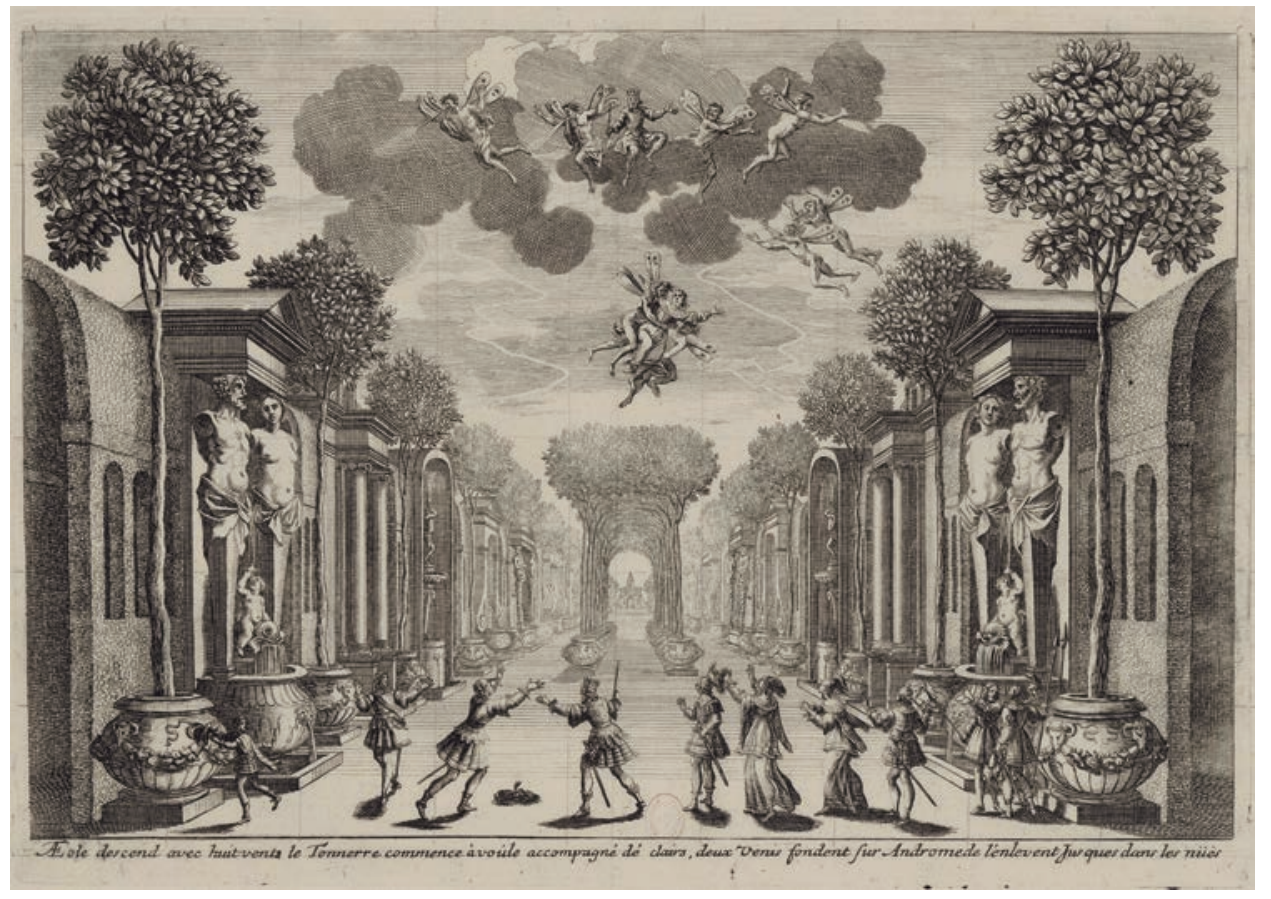

FIGURA 81 - Corneille. Andrômeda, 1651, Ato 2. Cenário de Torelli.

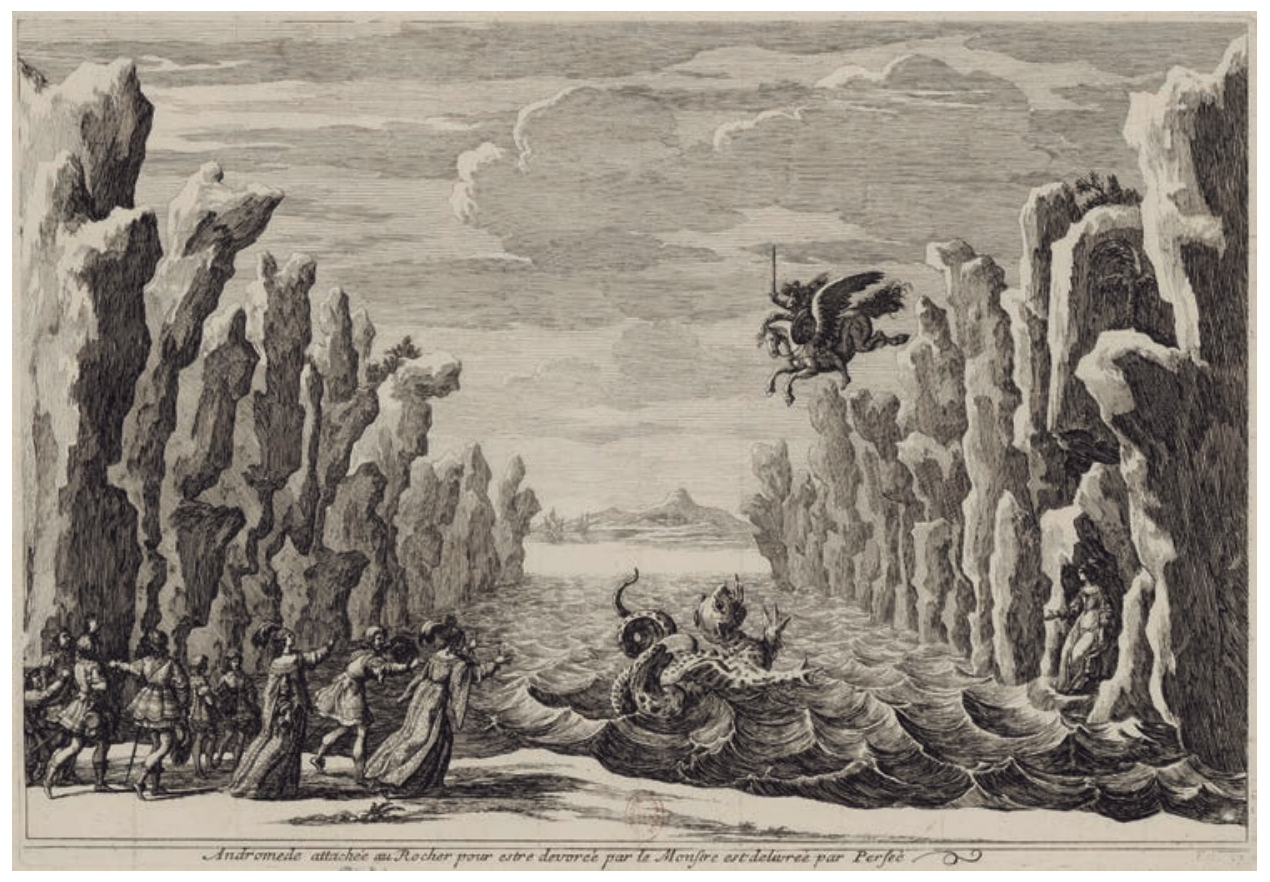

FIGURA 82 - Corneille. Andrômeda, 1651, Ato 3. Cenário de Torelli. Gravura sobre cobre de François Chauveau. 


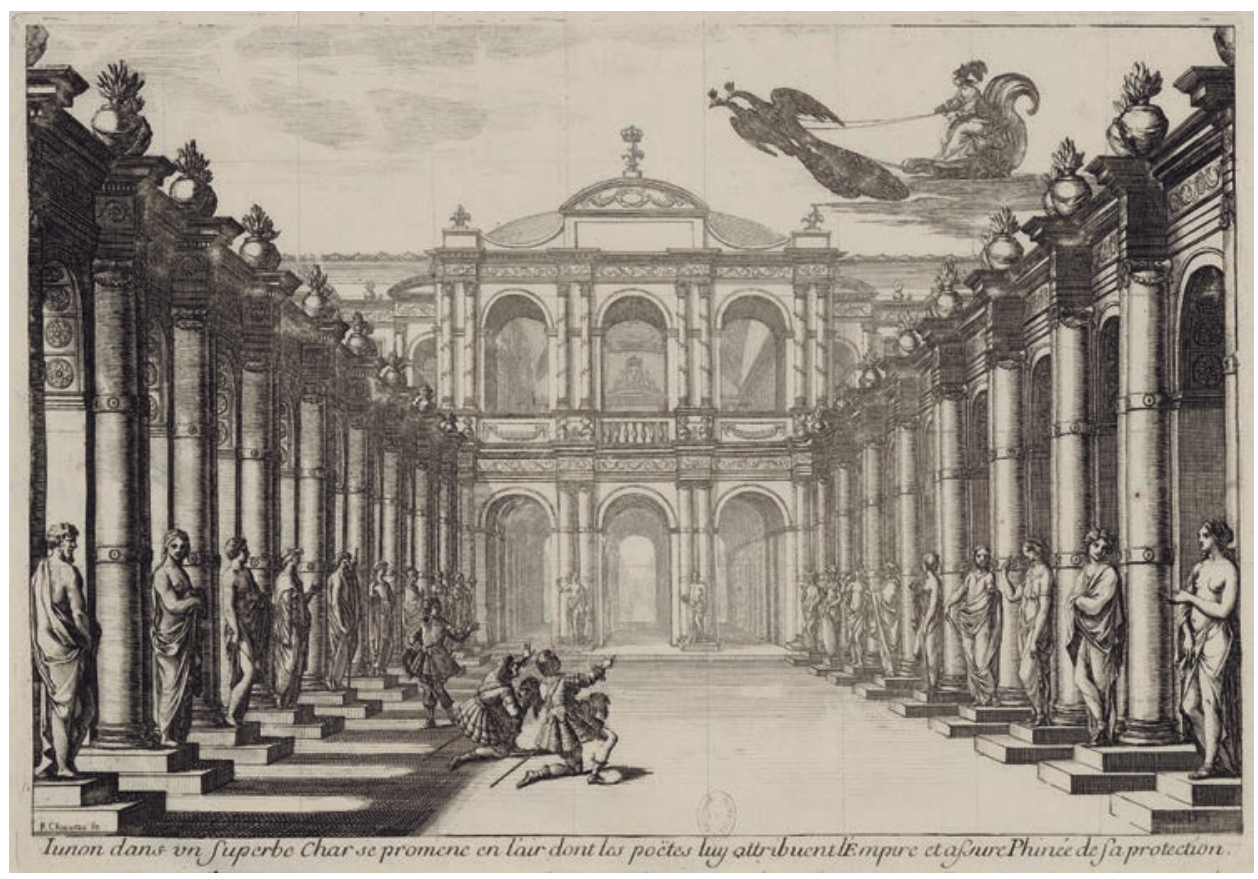

FIGURA 83 - Corneille. Andrômeda, 1651, Ato 4. Cenário de Torelli.

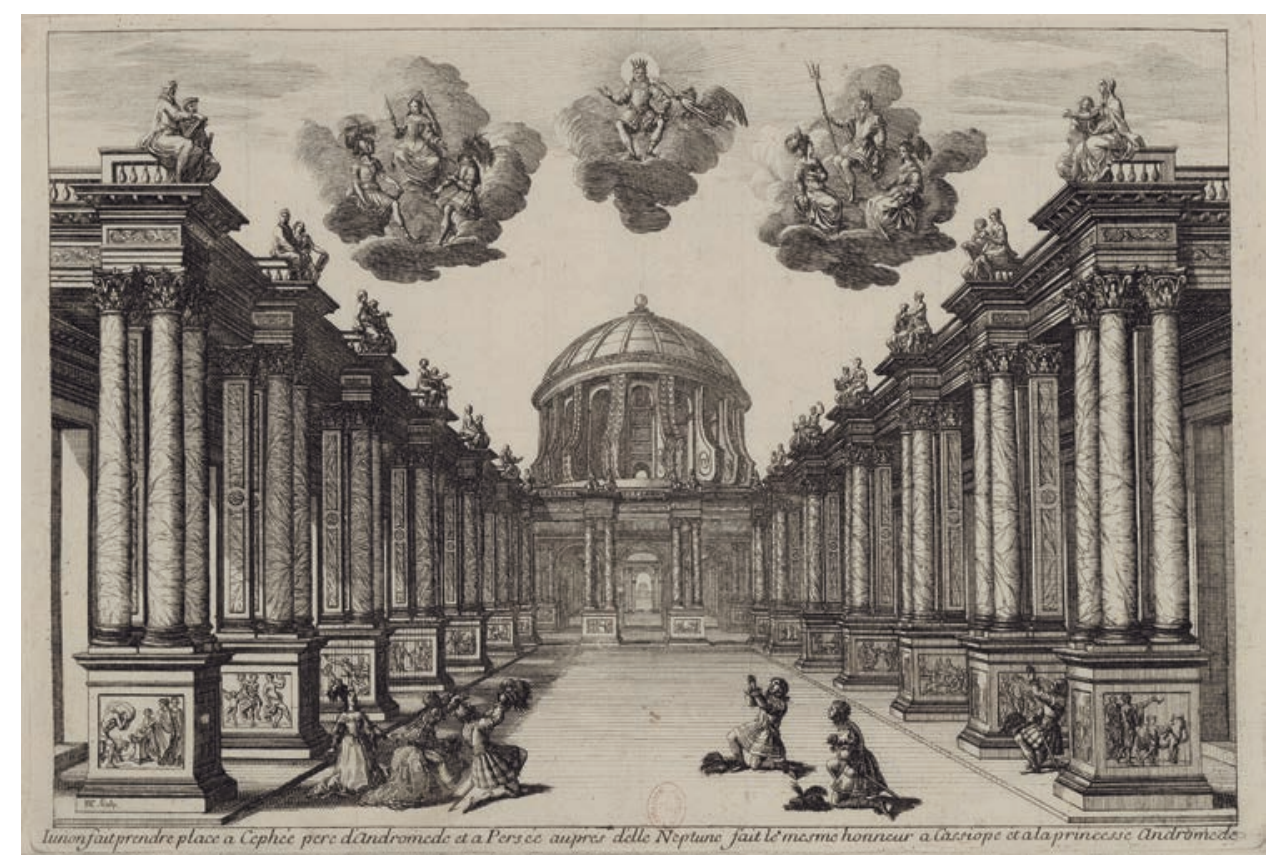

FIGURA 84 - Corneille. Andrômeda, 1651, Ato 5. Cenário de Torelli. 


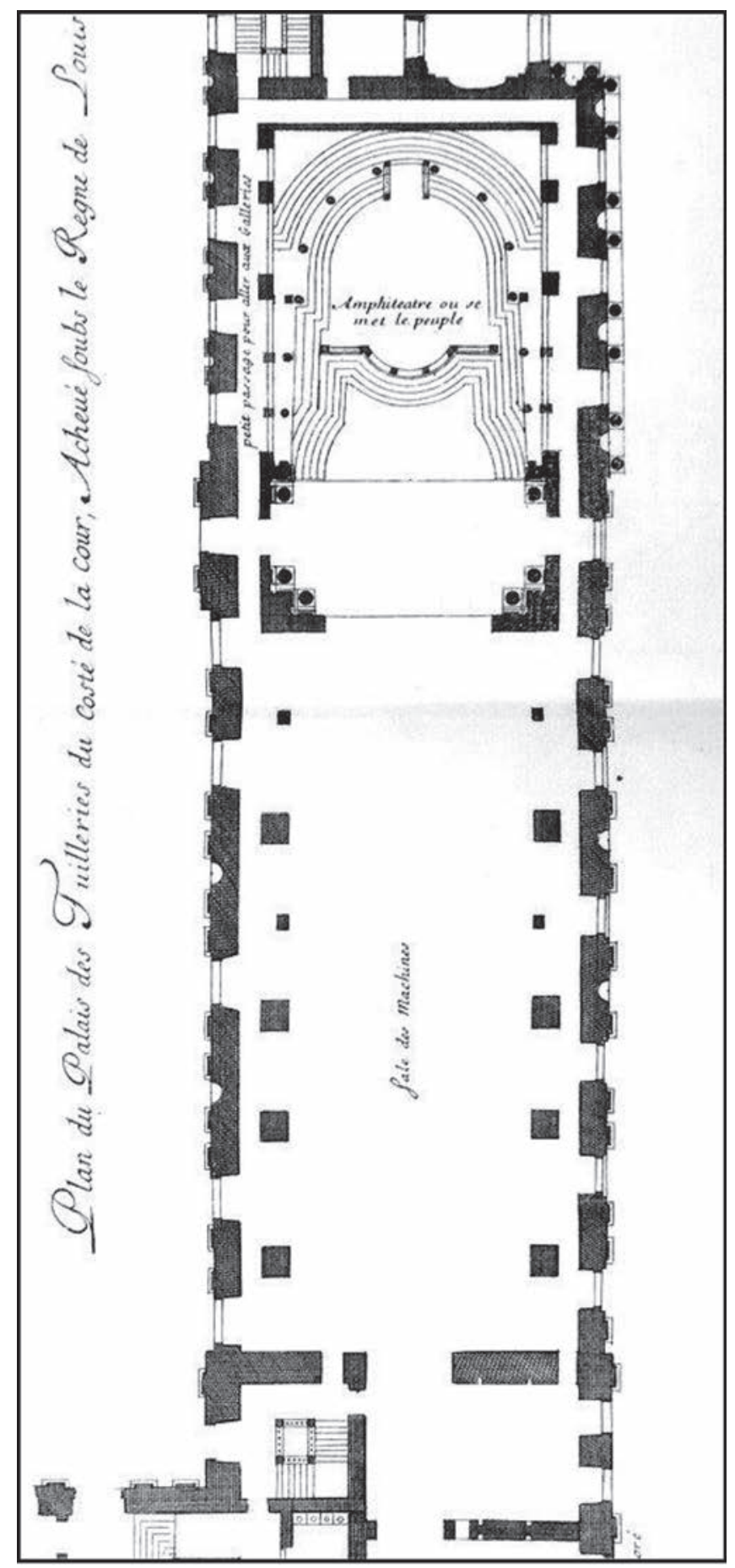

FIGURA 85 - Salle des Machines. Tulleries Planta Baixa. 


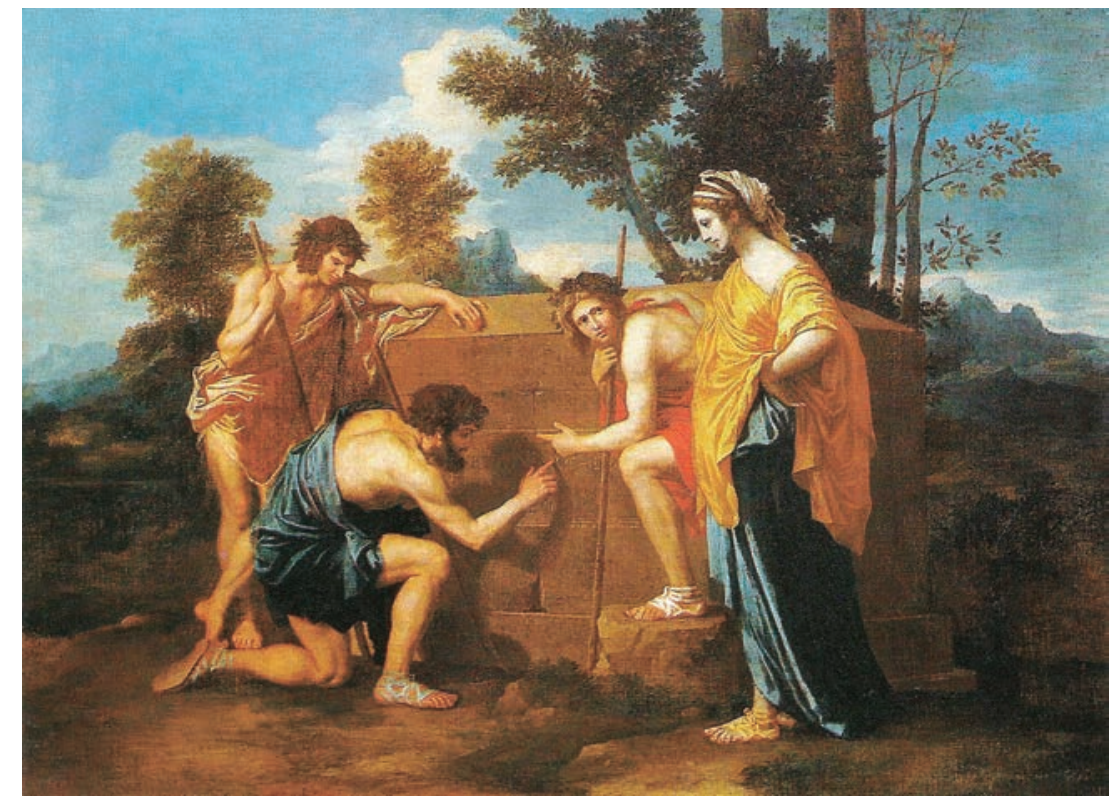

FIGURA 86 - Poussin. Pastores de Arcádia [Et in Arcadia Ego ou Les Bergers d'Arcadie] - 1637/39.

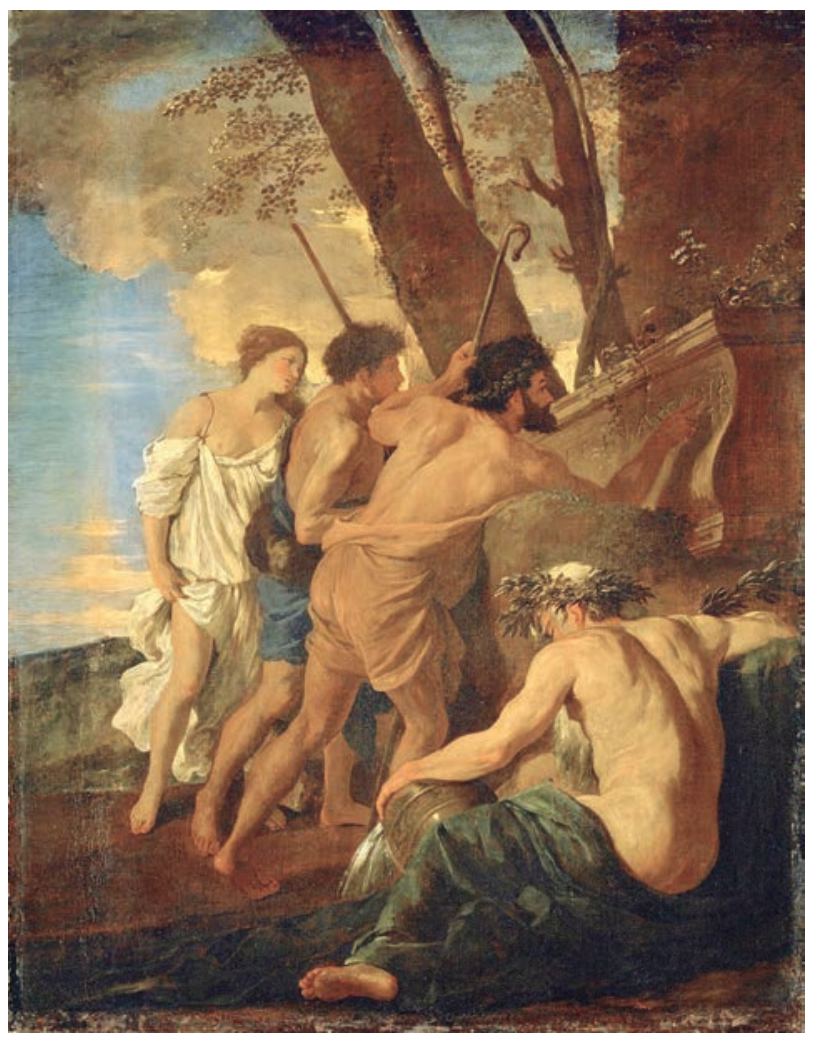

FIGURA 87 - Poussin. Pastores de Arcádia - 1627/30. 


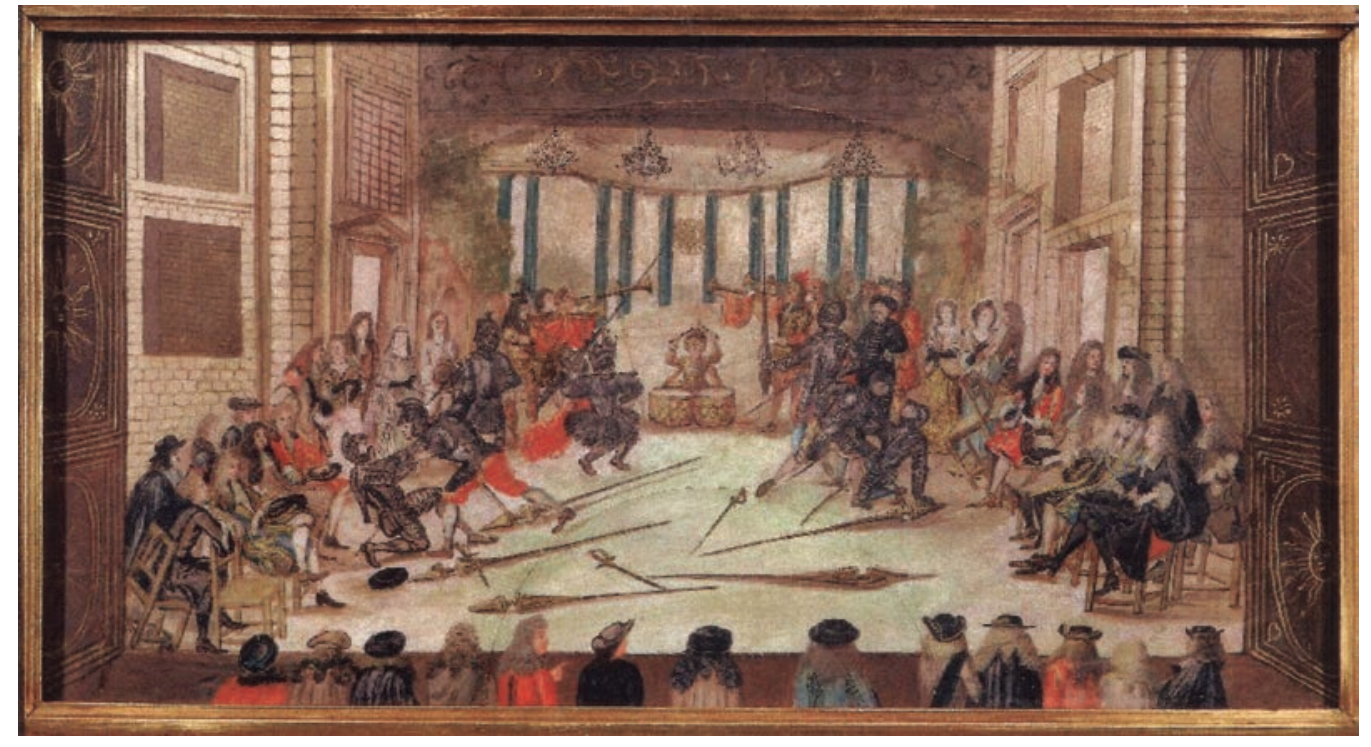

FIGURA 88 - Anônimo do século XVII. Comédie Française. Espetáculo com o público sobre o palco.

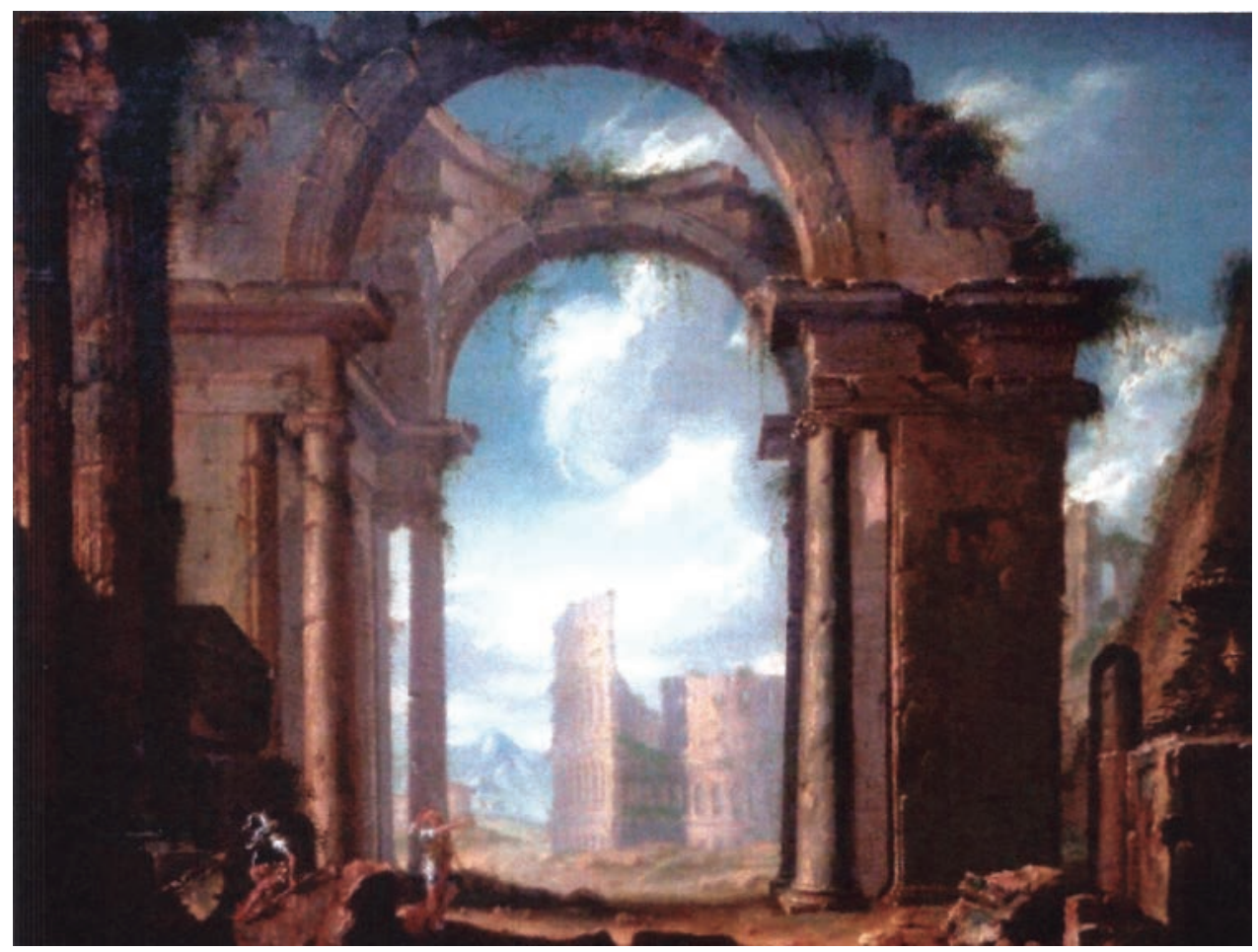

FIGURA 89 - Servadoni. Capriccio Romano com o Coliseu e a Piramide de Cestius, c. 1731. 


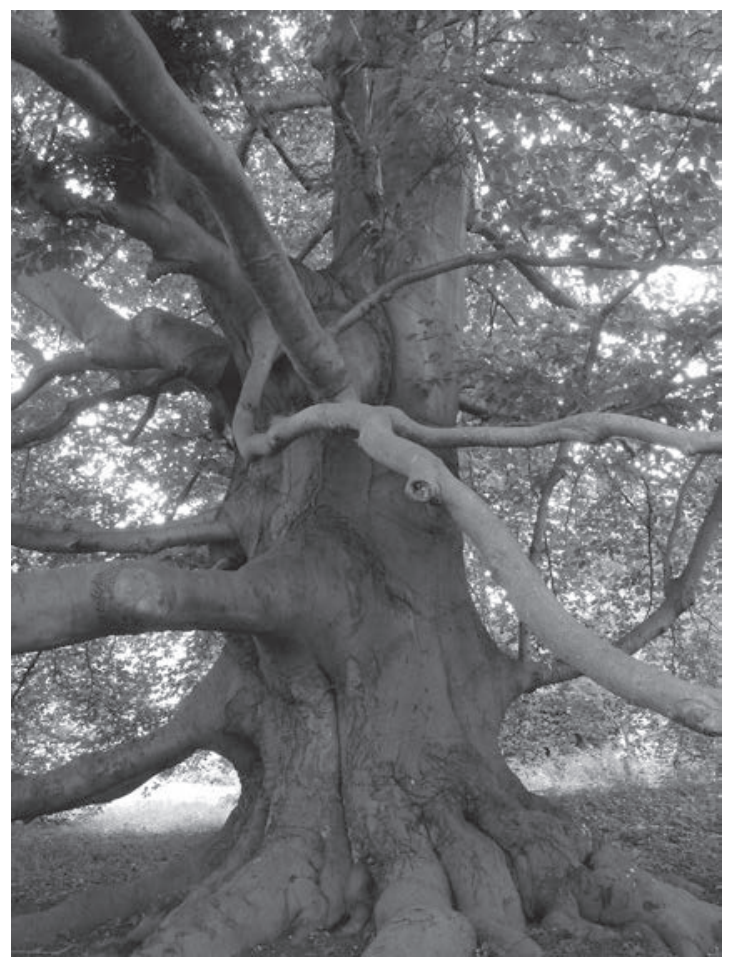

FIGURA 90 - Fagus Sylvatica ou Faia.

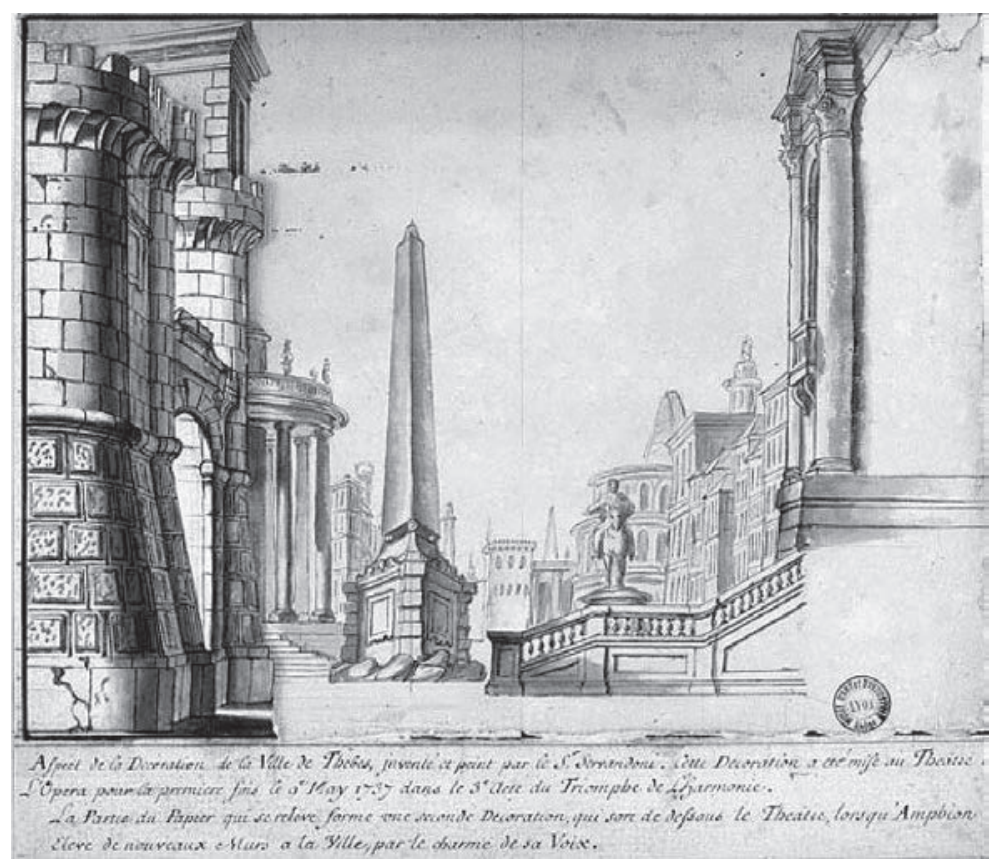

FIGURA 91 - Servandoni. A cidade de Tebas. Cenário para a terceira entrada em $O$ triunfo da harmonia. 


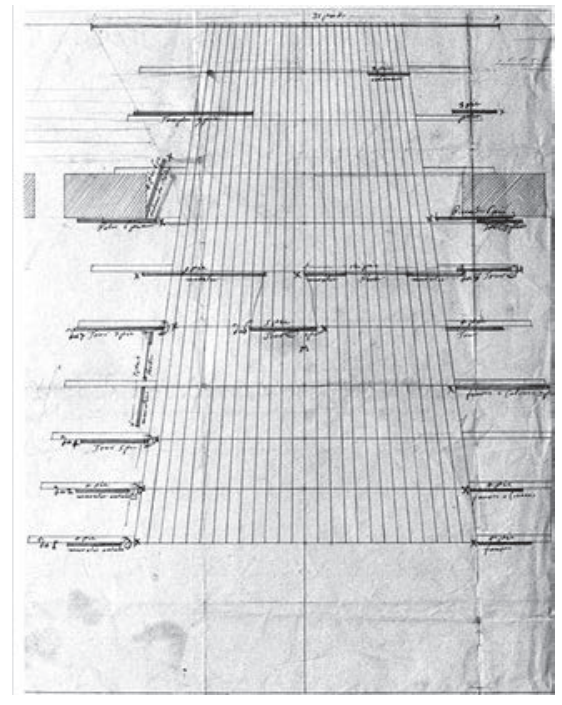

FIGURA 92 - Servandoni. A Cidade de Tebas. Provável planta-baixa para a terceira entrada.

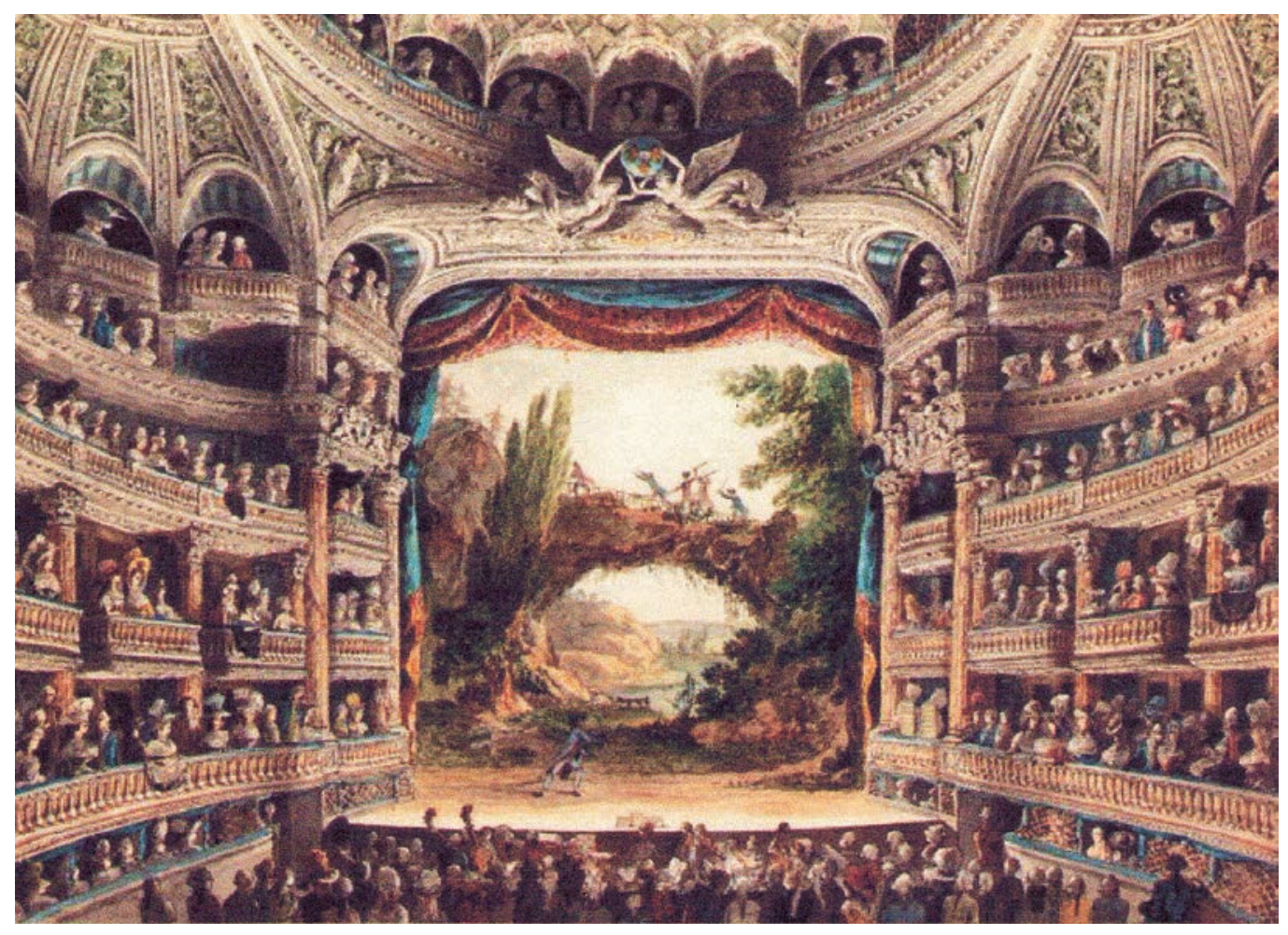

FIGURA 93 - Comédie Française, interior. 


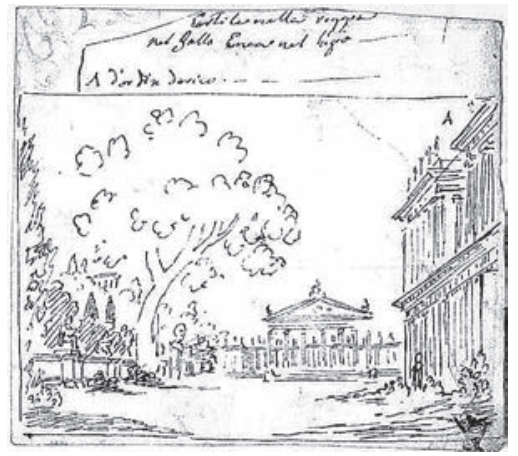

FIGURA 94 - Fabrizio Galliari (1709 - 1790).

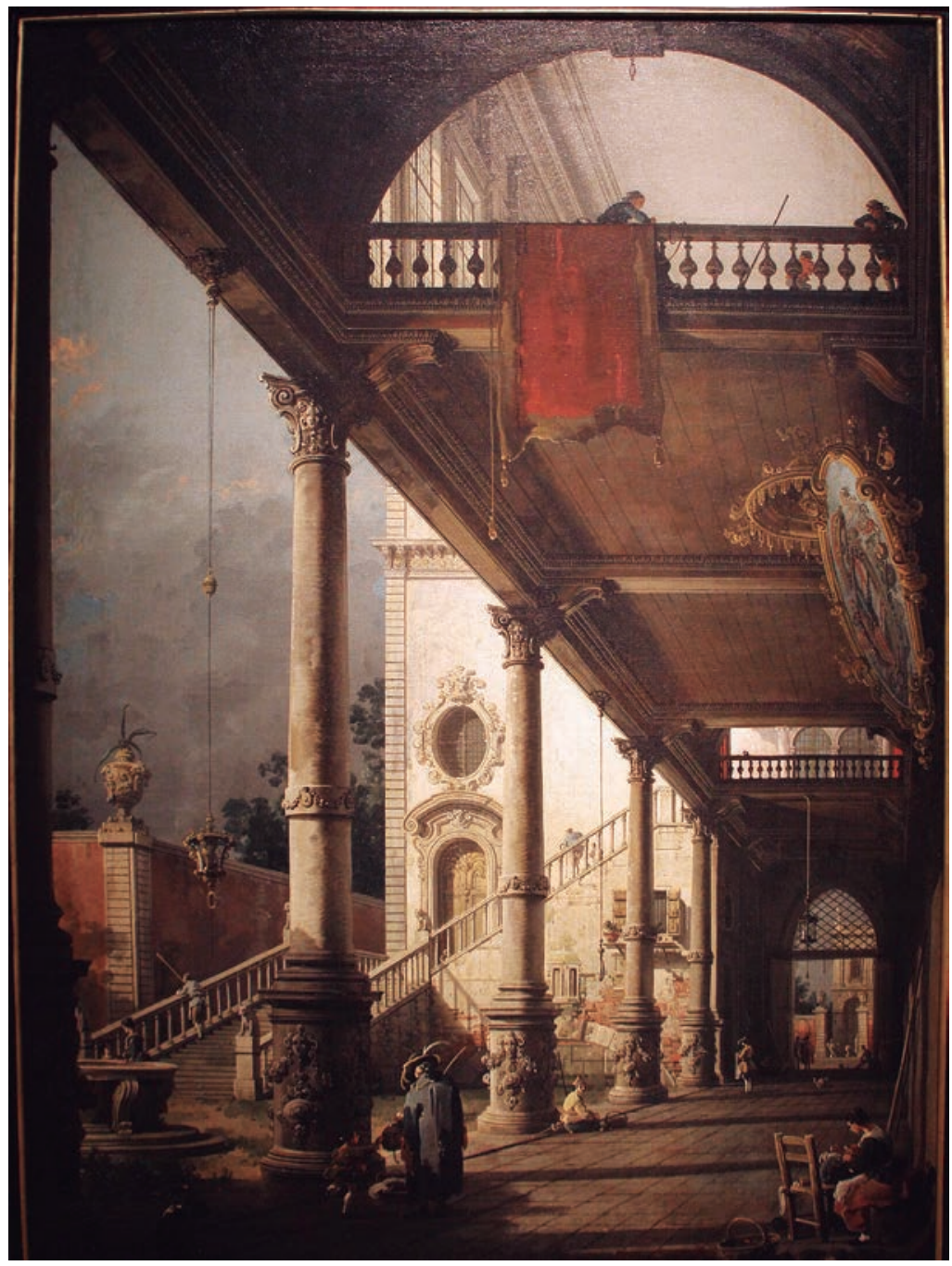

FIGURA 95 - Canaletto. Perspectiva $(93 \times 131$ cm). 


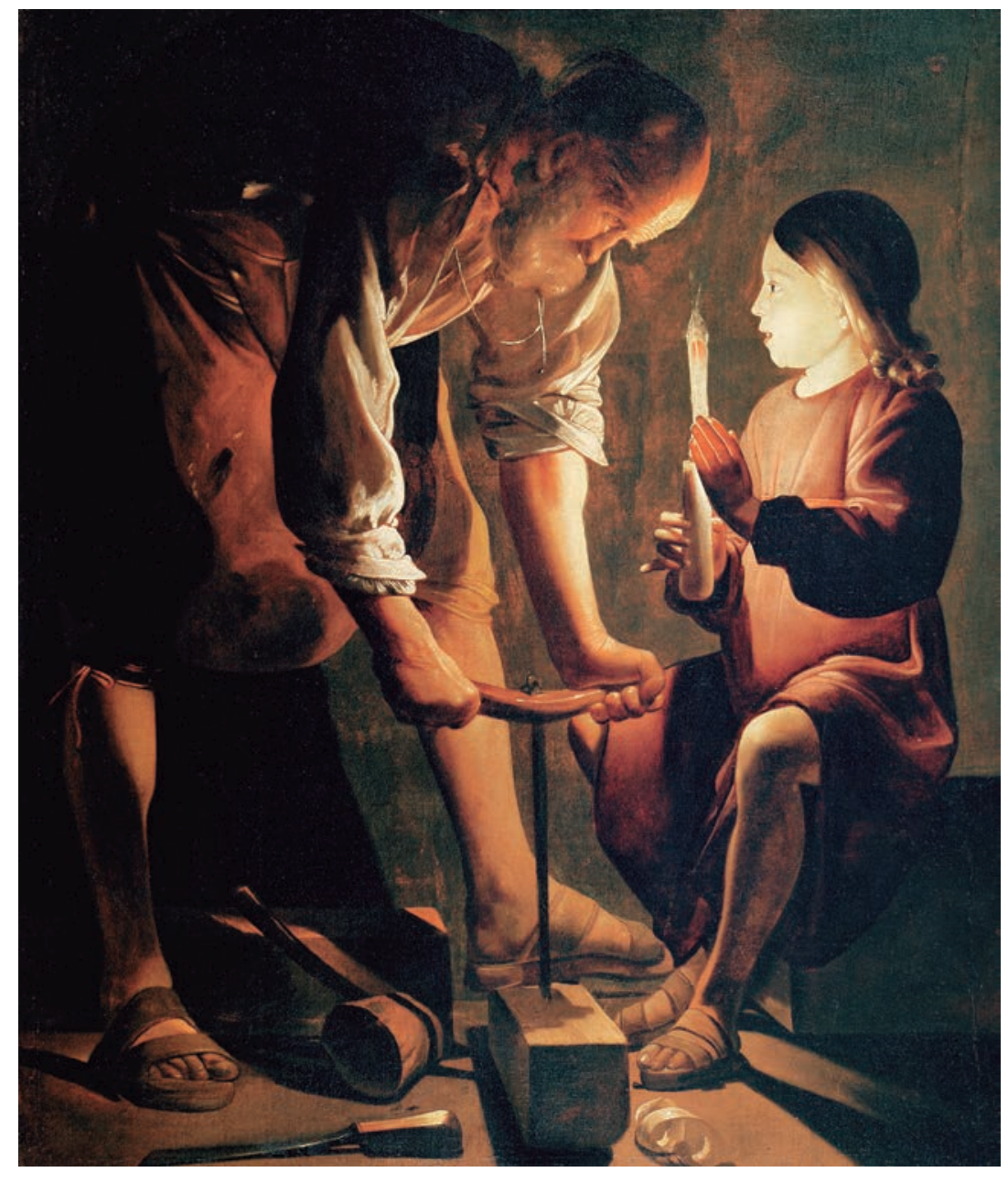

FIGURA 96 - Georges de la Tour. A Aparição do Anjo a São José. 


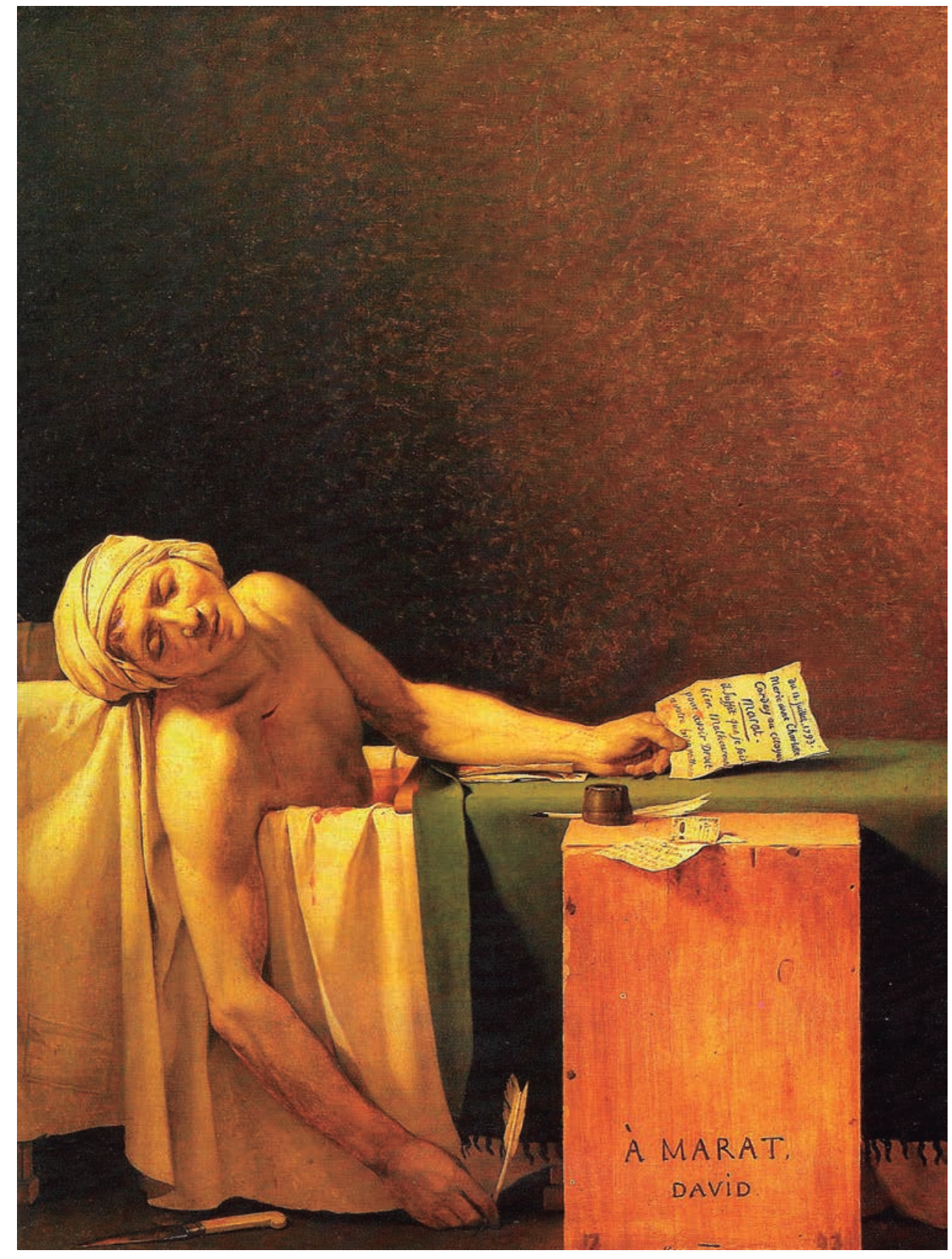

FIGURA 97 - Jacques-Louis David. A Morte de Marat, 1793. 


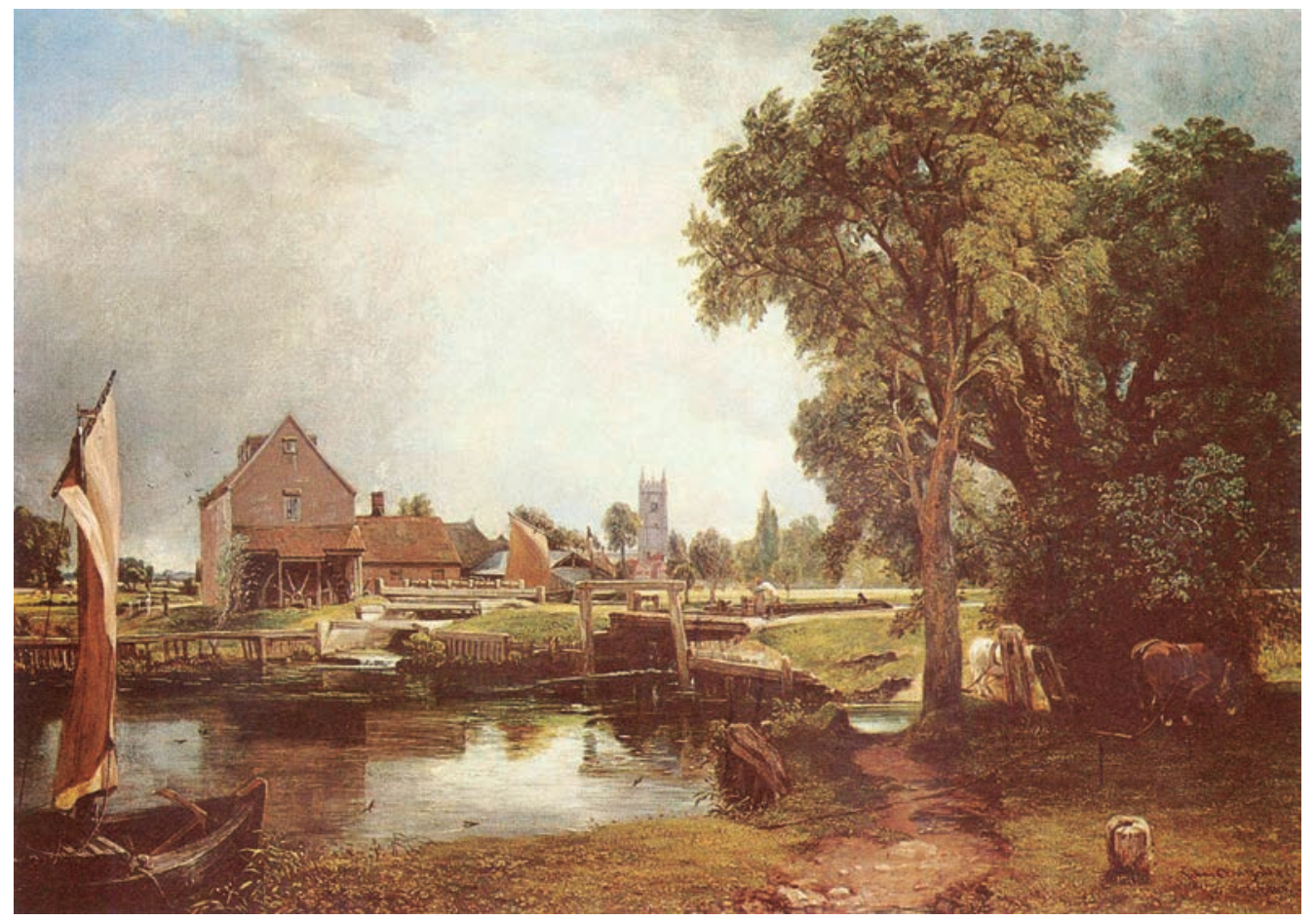

FIGURA 98 - John Constable. Dedham Lock and Mill, C. 1618.

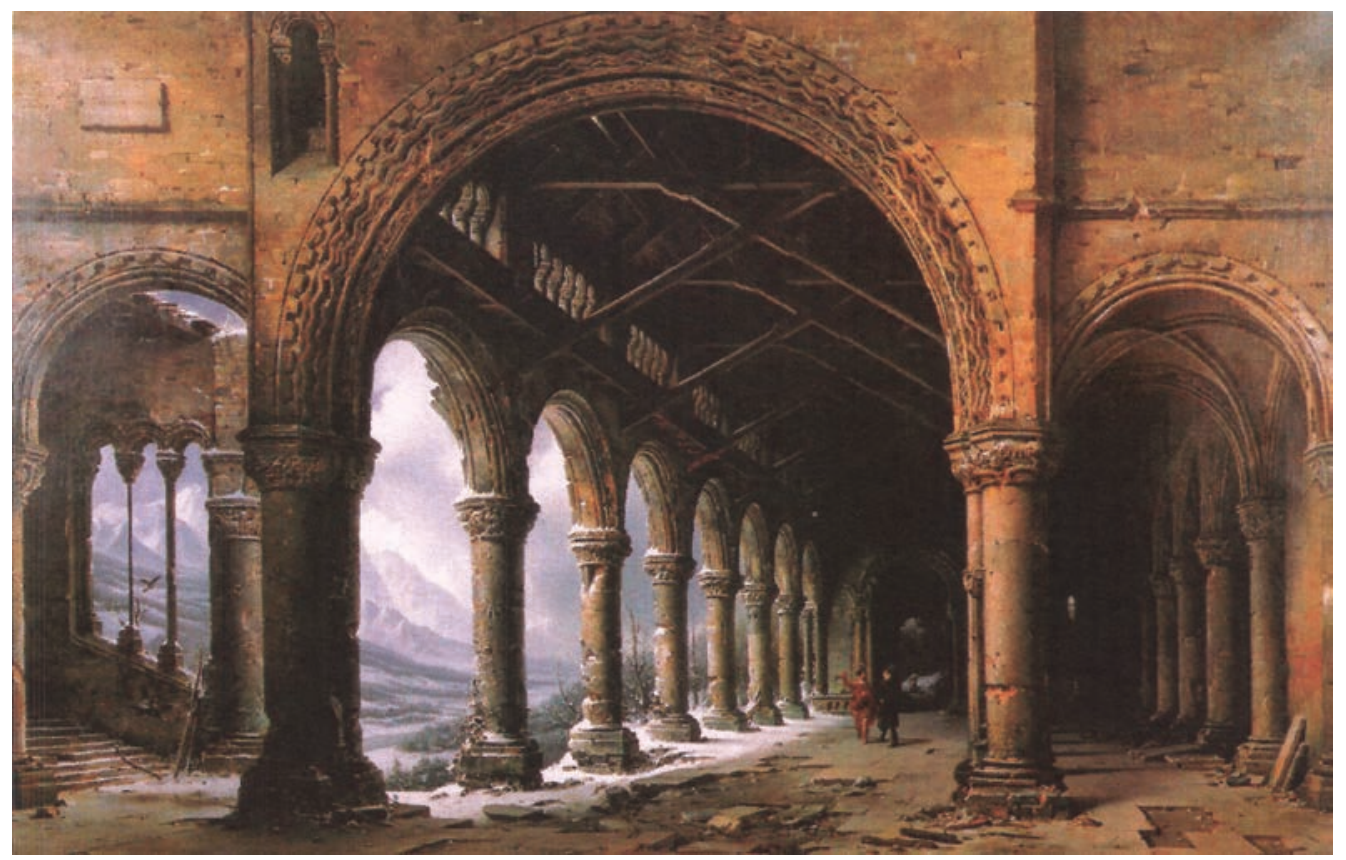

FIGURA 99 - Daguerre. O Efeito de Neblina e Neve visto através de uma Ruína de Colunata Gótica, 1826. 


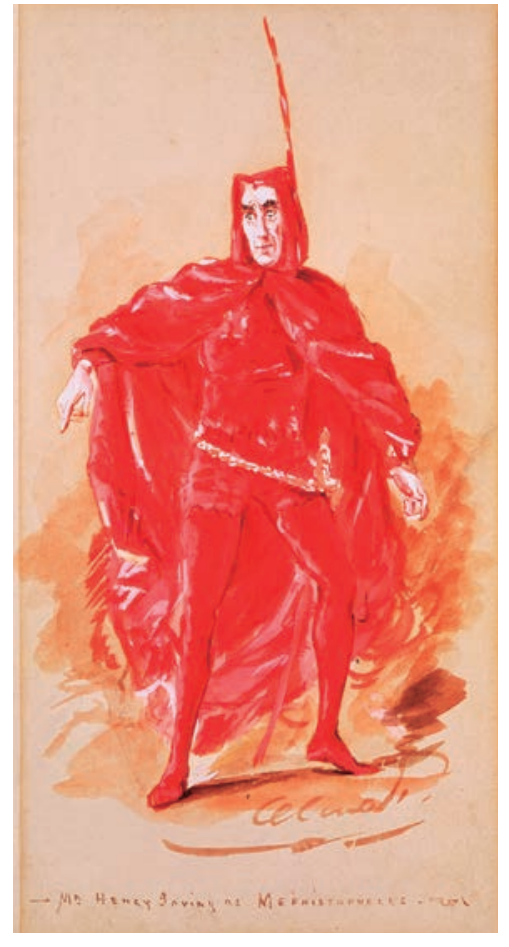

FIGURA 100 - Henry Irving como Mefistófeles (Becken) em Fausto, de Goethe.

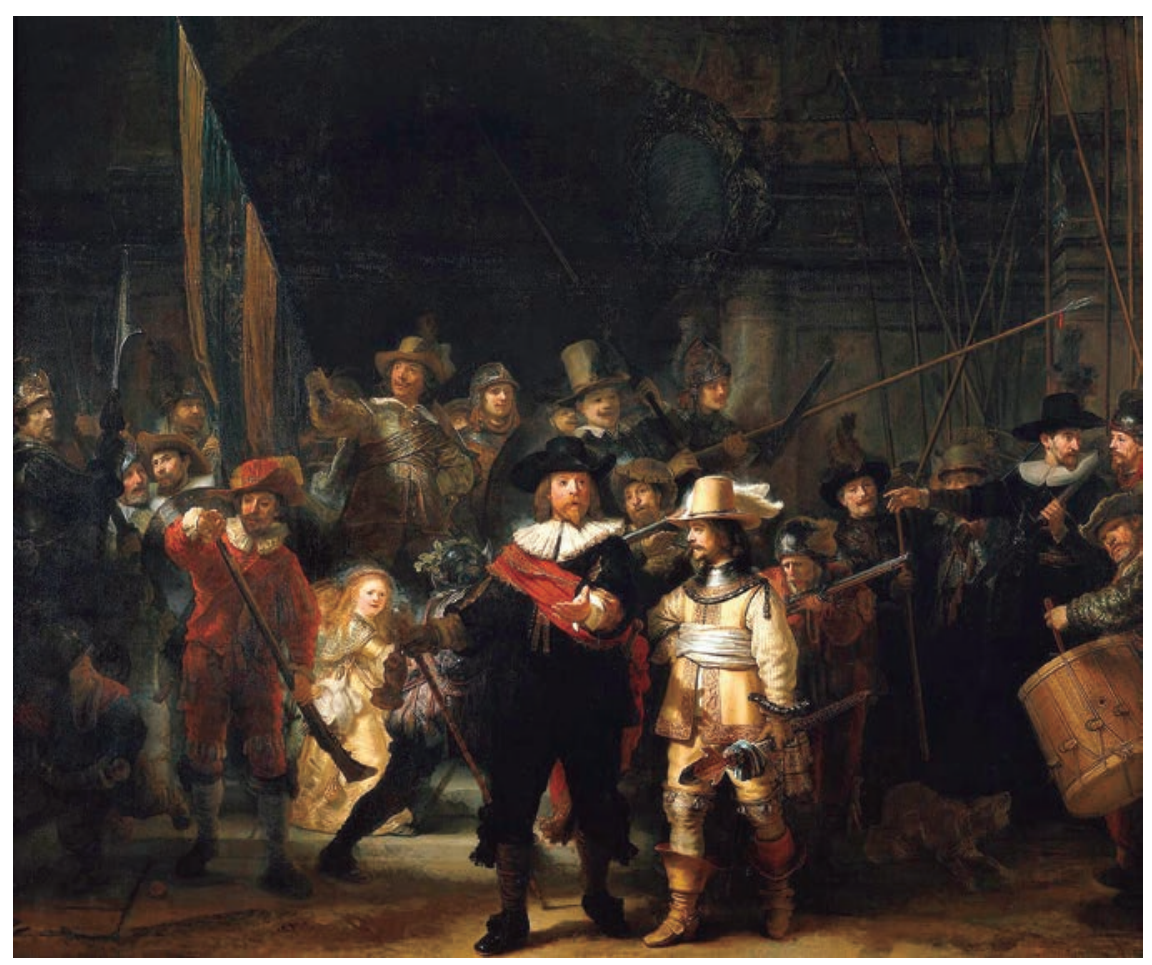

FIGURA 101 - Rembrandt. A Ronda Noturna, 1640/1642. 


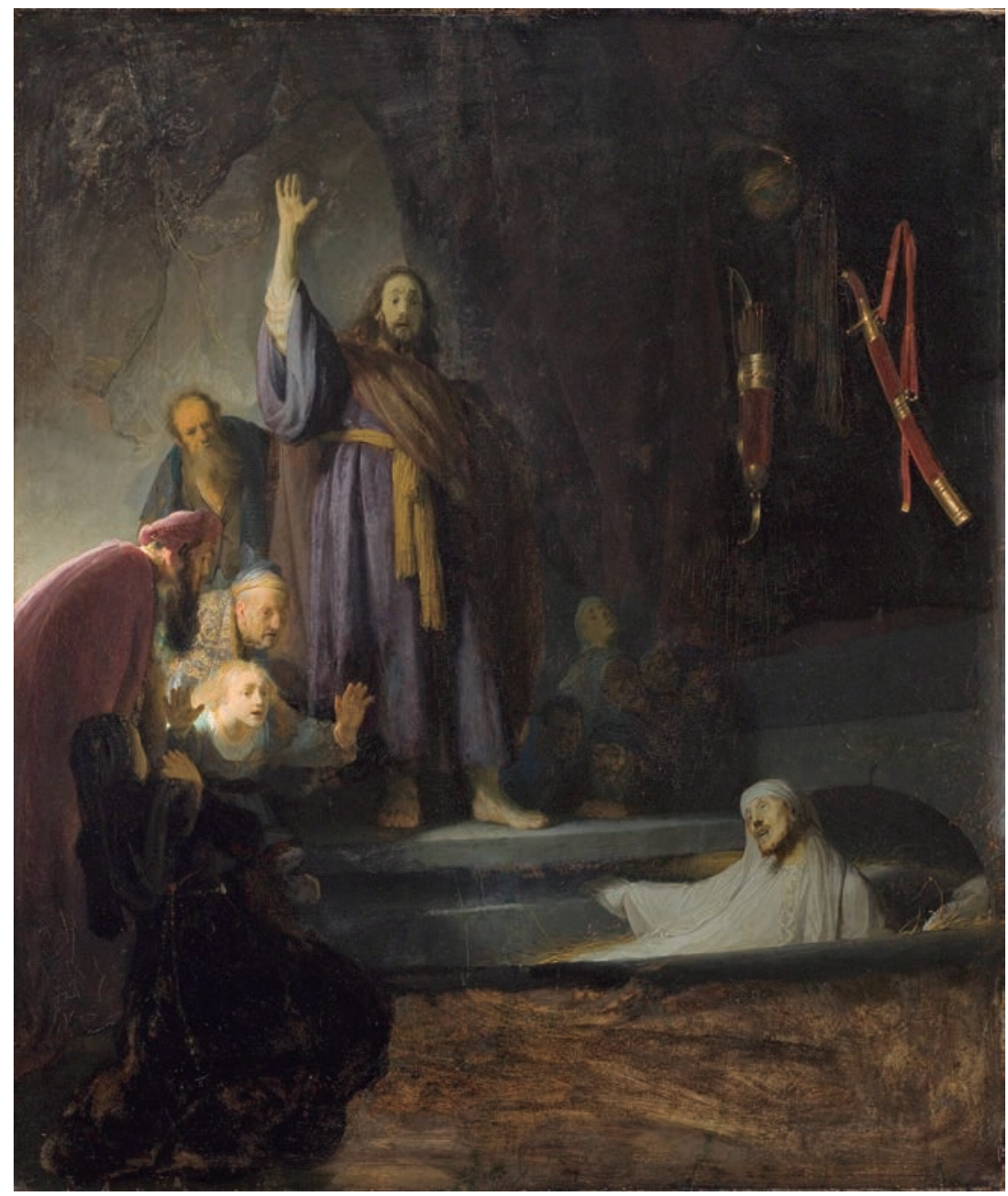

FIGURA 102 - Rembrandt.

A Ressureição de Lázaro, C. 1630,

$359 \times 438 \mathrm{~cm}$, óleo sobre painel.

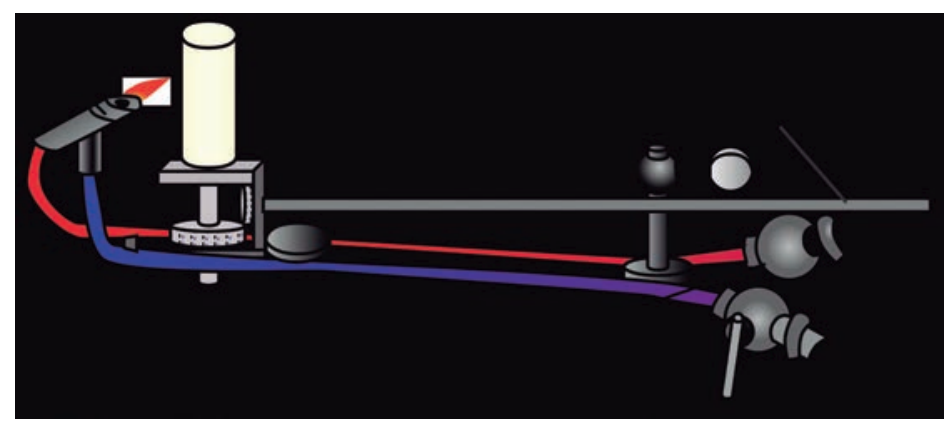

FIGURA 103 - Limelight. 

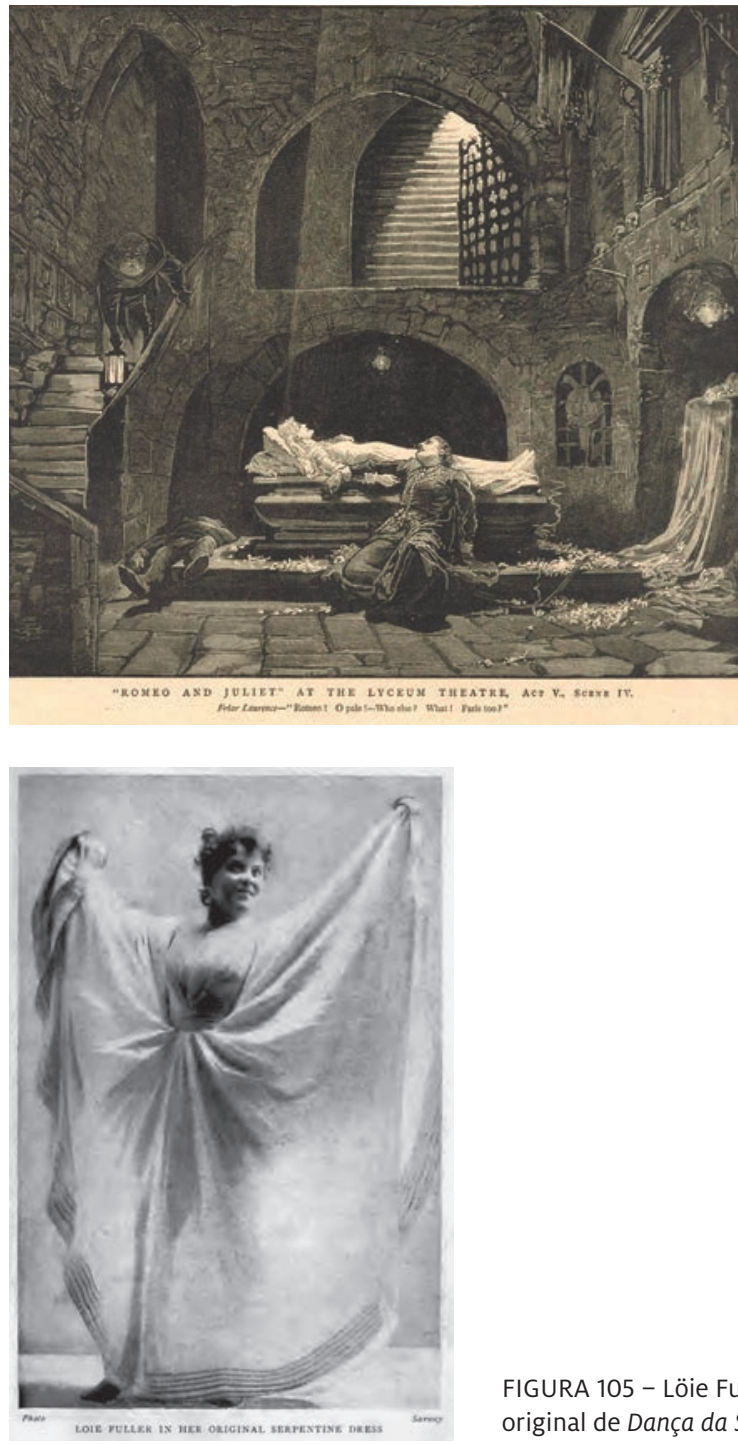

FIGURA 104 - Henry Irving como Romeo em Romeu e Julieta, de Shakespeare. Londres, Lyceum Theatre, 1882.
FIGURA 105 - Löie Fuller. O vestido original de Dança da Serpentina.

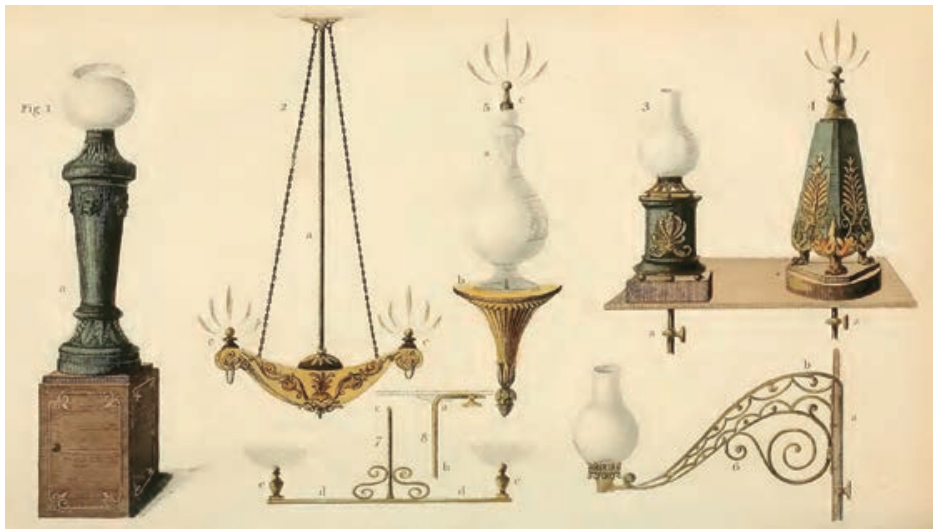

FIGURA 106 -

Lâmpadas a gás. 


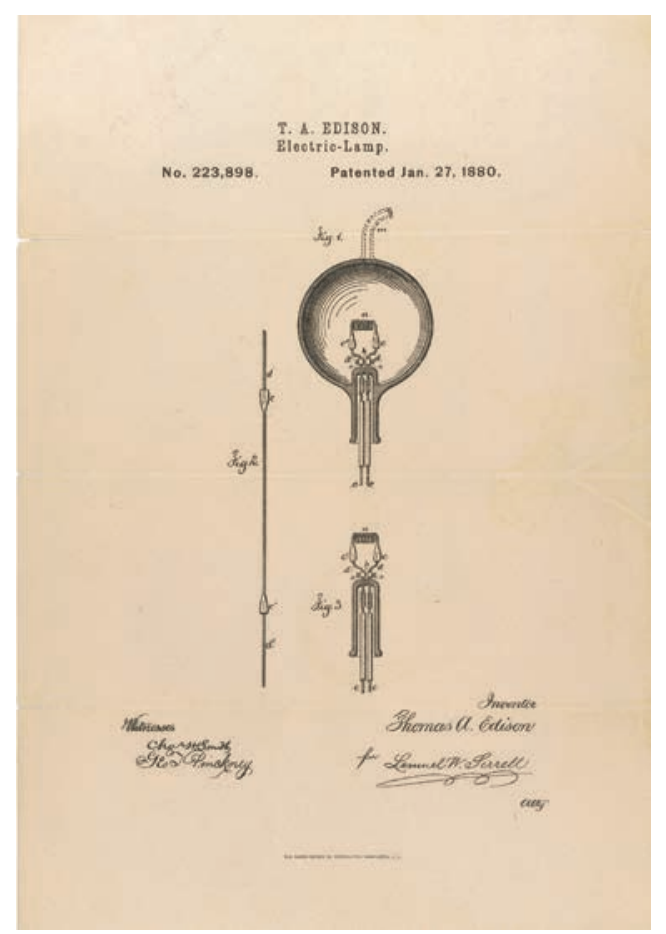

FIGURA 107 - Lâmpada elétrica patenteada por Thomas A. Edison, 27 de janeiro de 1880.

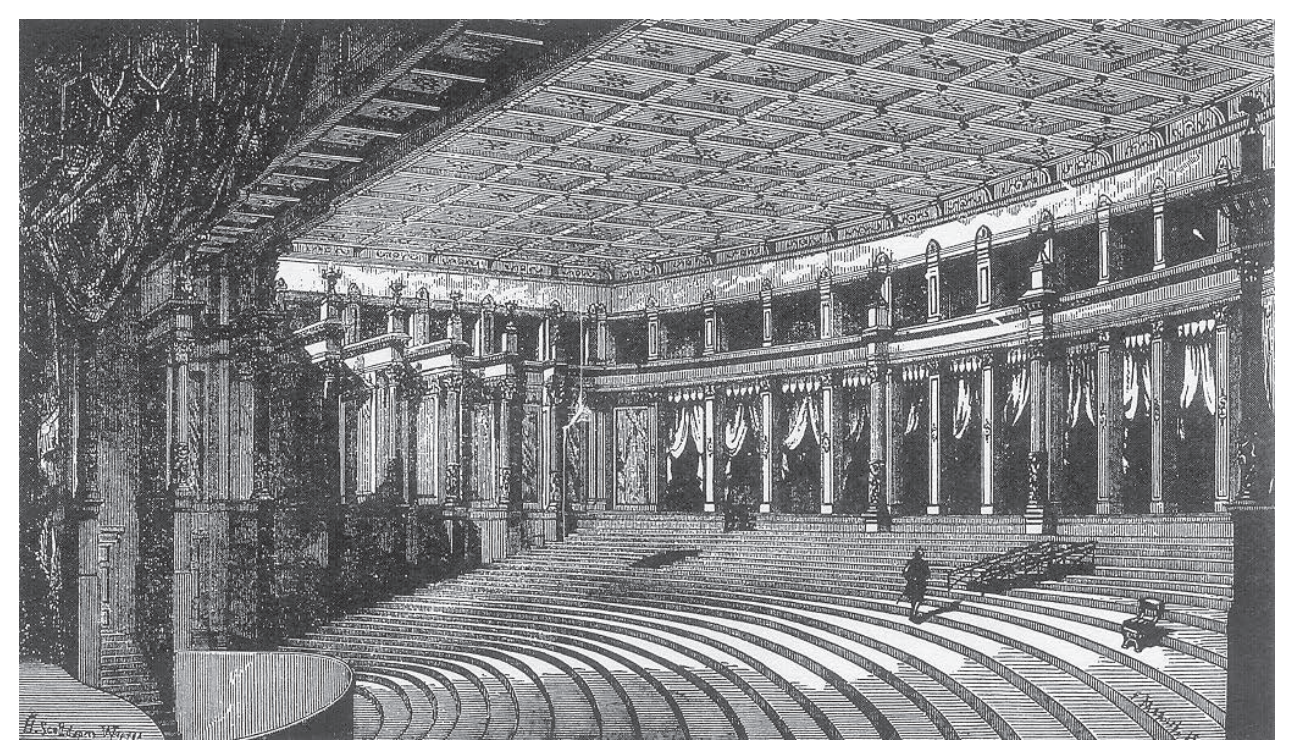

FIGURA 108 - Bayreuth. Vista parcial da plateia e do Palco. Foto: Joerg Schulze. 


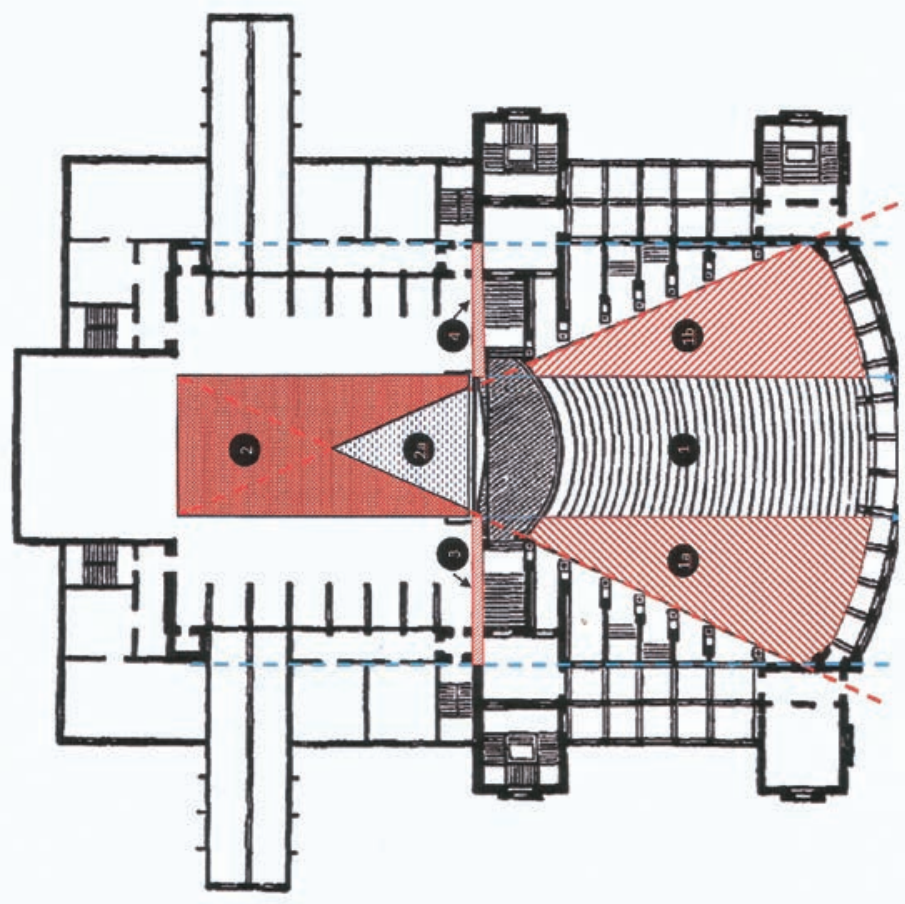

FIGURA 109 - Bayreuth/Planta-baixa 1.

(Editada para as observações do texto).

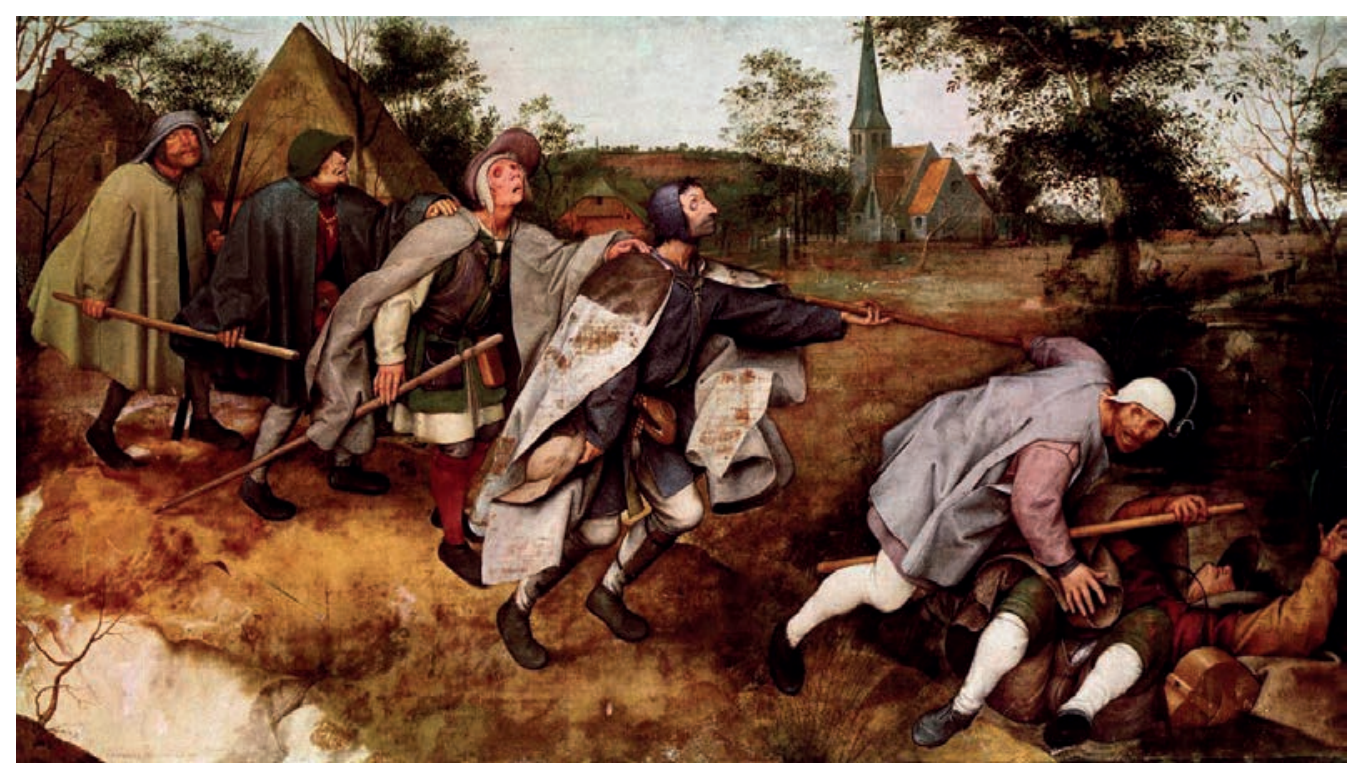

FIGURA 110 - Pieter Breughel. A Queda dos Cegos. 1568. 


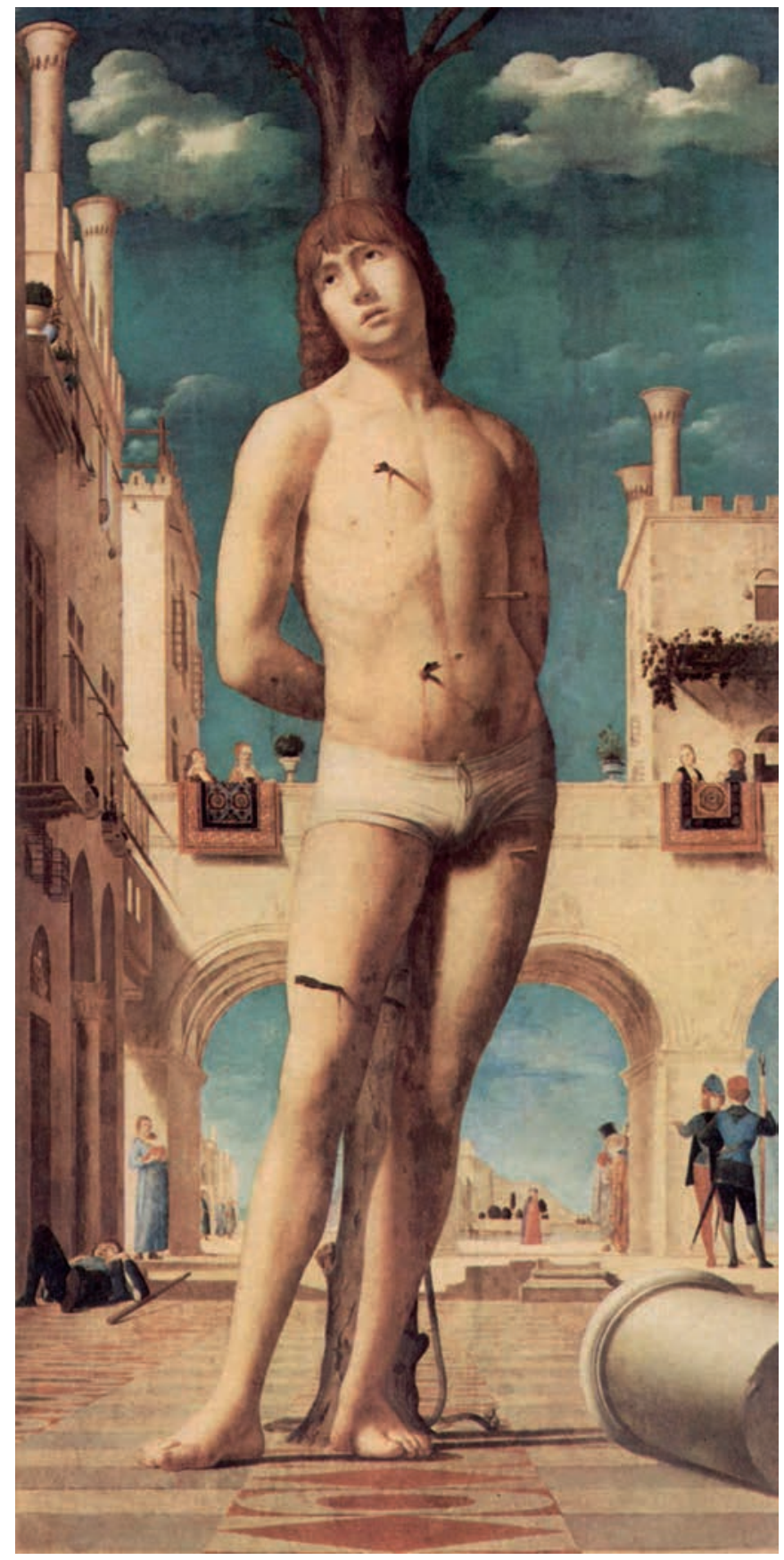

FIGURA 111 - Antonello da Messina

(1430-1479). São Sebastião, 1476-1477. 


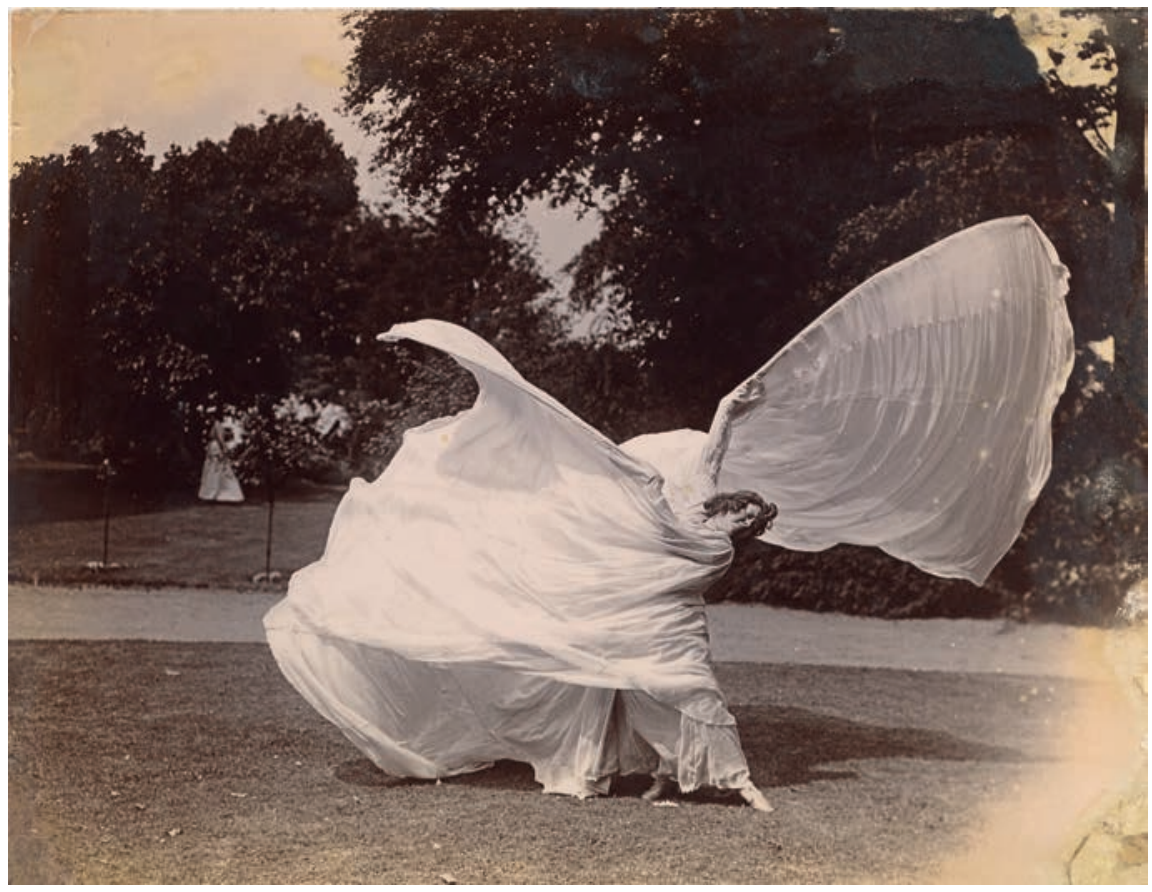

FIGURA 112 - Loie Fuller. Dançando ao ar livre.

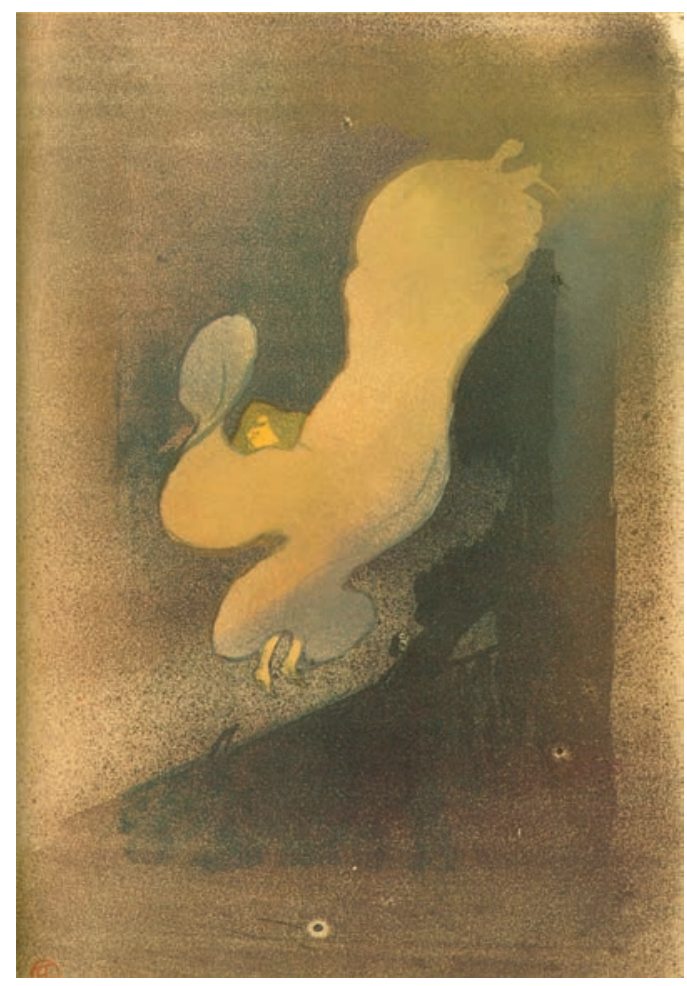

FIGURA 113 - Henri de Toulouse-Lautrec, Miss Loie Fuller, 1893. 


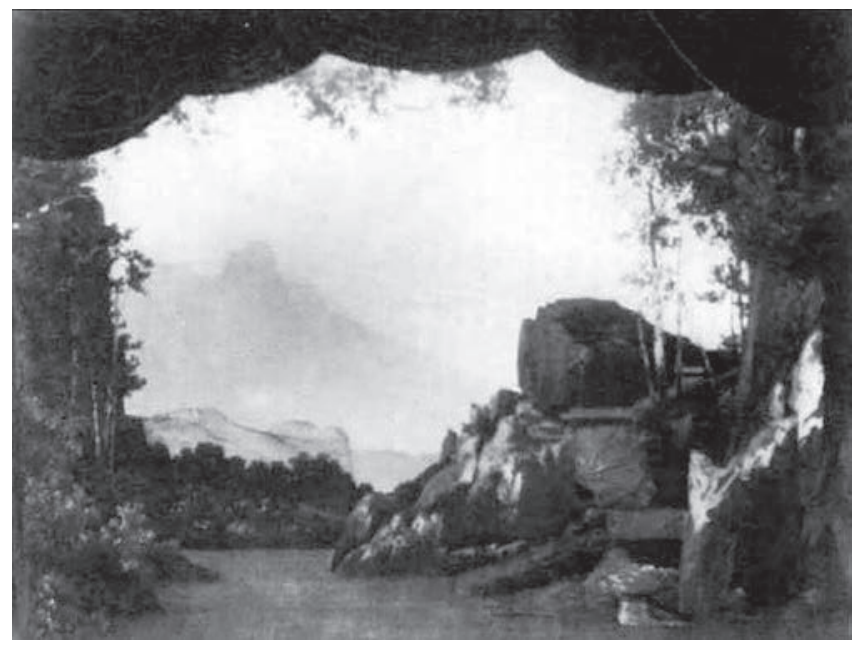

FIGURA 114 - Wagner. Bayreuth.

Cenário para a paisagem de

valhalla. 1896.

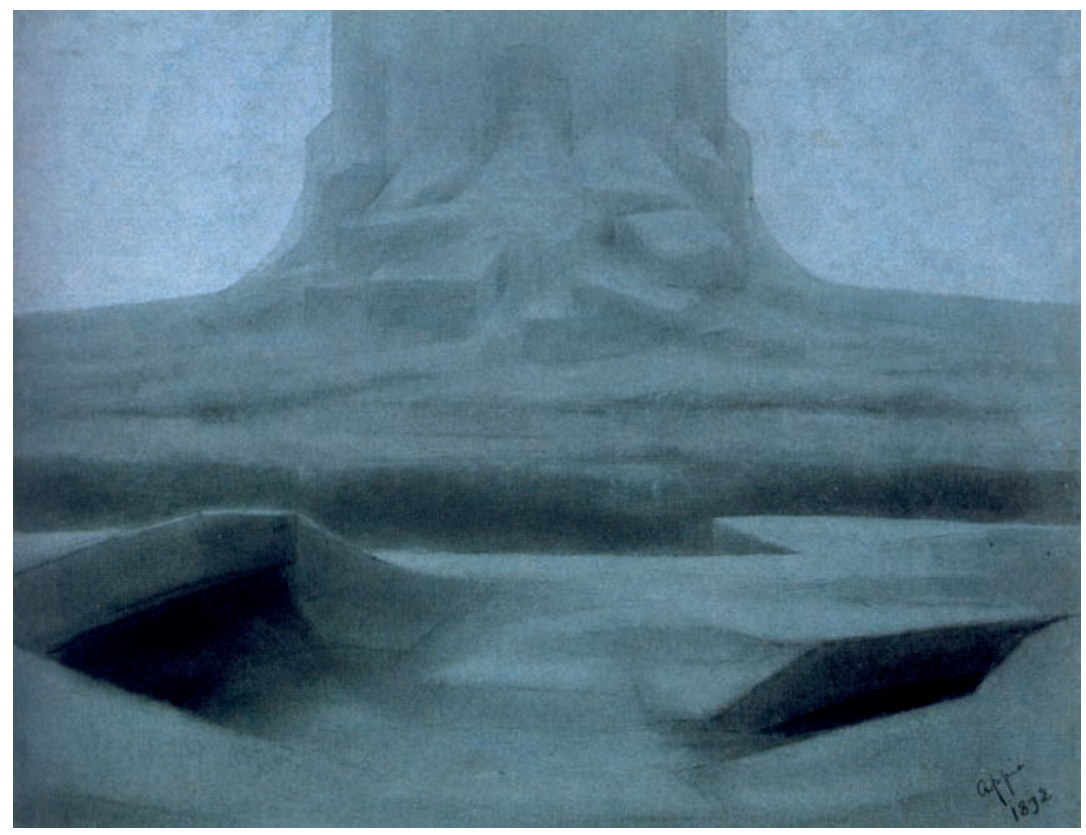

FIGURA 115 - Appia. Cenário para a paisagem de Valhalla. 1892. 


\section{CRÉDITOS DAS IMAGENS}

FIGURA 1 - Mulher segurando uma balança [Vrouw met Weegschaal] 1662-1663. Johannes Vermeer. Woman Holding a Balanc. Disponível em: <http://www. vermeer-foundation.org/Woman-Holding-a-Balance-1662-63.html > .

FIGURA 2 - Stonehenge. Salisbury/Inglaterra. Disponível em: 〈http://www.knowth.com/wallpaper/stonehenge-snow_1024.jpg〉.

FIGURA 3 - Stonehenge. Ilustração de prováveis funções astronômicas. Disponível em: <http://viagemreinounido.wordpress.com/2011/o8/12/ alem-de-stonehenge/.

FIGURA 4 - Pageant. Thomas Sharp. A dissertation on the pageants or dramatic mysteries ancienlty performed at Coventry, 1825 .

FIGURA 5 - Hamlet. Primeiro folio. Isaac Iaggard and Ed. Blount, 1623. Disponível em: <http://sceti.library.upenn.edu/sceti/printedbooksNew /index. cfm?textID=hamlet_f1\&PagePosition $=1\rangle$.

FIGURA 6 - Partisan ou alabarda. Disponível em: <http://www.thearma.org/ Manuals/NewManuals/DiGrassi/o3001110.jpg .

FIGURA 7 - Cópia do desenho de Johannes de Witt, 1596. Disponível em: <http://www.gutenberg.org/files/22397/22397-h/22397-h.htm〉.

FIGURA 8 - Ma Destinée, Pena e gouache aguada. Maison de Hugo, Paris,1857.

FIGURA 9 - Estrutura de Periaktos para acabamento em tecido. Disponível em: 〈http://www.hstech.org/howto/carpentr/flats/periaktoioo7.jpg〉.

FIGURA 10 - Teatro Epidaurus. Grécia (300-340 a. C.). Disponível em: <http:// www.whitman.edu/theatre/theatretour/epidaurus/images/large\%2oimages/ epidaurus.cover.jpg>.

FIGURA 11 - Teatro de Epidaurus/Planta Baixa. Disponível em: <http://www. whitman.edu/theatre>.

FIGURA 12 - Ator usando coturno e máscara. Disponível em: <http:// ancienthistory.about.com/b/2009/12/03/thursdays-term-to-learn-cothurnus $\rangle$. FIGURA 13 - Orfeo. Ritornello [Prólogo]. Donald J. Grout e Hermine Weigel Williams, A short history of opera, 2003.

FIGURA 14 - Masaccio. A Trindade. 1425/1428. Disponível em: <http:// catholicteenapologetics.files.wordpress.com/2012/05/masaccio_trinity.jpg.

FIGURA 15 - Masaccio. O Pagamento do tributo. 1425/1426. Disponível em: 〈http://www.italica.rai.it/argomenti/storia_arte/masaccio/galleria/4.htm〉. 
FIGURA 16 - Masaccio. O Batismo dos neófitos, 1426-1427. Disponível em: 〈http://www.italica.rai.it/argomenti/storia_arte/masaccio/galleria/4.htm〉.

FIGURAS 17 e 18 - Gualterotti. Celebração do casamento de Francesco Medici e Bianca Capello, 1579. Livro impresso pela Stamperia dé Giunti com gravuras de Accursio Bardi e Bastiano Marsili.

FIGURAS 19, 20 e 21 - Três cenas da peça Andria, de Terêncio. Disponível em: Publicação da obra de Terêncio, em Lyon, 1493, reproduzida por Nicoll, 1927.

FIGURA 22 - Teatro Olímpico, Vicenza. Vista Frontal do Palco. Disponível em: 〈http://upload.wikimedia.org/wikipedia/commons/thum〉.

FIGURA 23 - Teatro Olímpico. 1580/1585. Planta-Baixa, projetado por Palladio. Disponível em: <http://commondatastorage.googleapis.com/static.panoramio. com/photos/original/16120725.jpg $>$.

FIGURA 24 - Teatro Olímpico. Corte; desenho de Ottavio Bertotti Scamozzi, 1776. Disponível em: <http://www.ancientdigger.com/2010/o8/mondayground-up-famous-teatro-olimpico.html $>$.

FIGURA 25 - Teatro all'Antica, em Sabionetta, 1588 a 1590 [desenhos técnicos]. FIGURA 26 - Vista frontal do palco desse mesmo teatro. Disponível em: <http://www.agen-zia.it/andiamo-a-teatri/\#!prettyPhoto[slides]/11/〉.

FIGURAS 27, 28 e 29 - Serlio. Cenários para a Tragédia, a Comédia, e a Sátira. Tutte l'Opere d'Architettura et Prospetiva di Sebastiano Serlio, Veneza, Giacomo de Franceschi, 1619.

FIGURA 30 - Bozze. Disponível em: <http://lordarbus.com/THEA148/2_ Lighting_Sound_History.pdf $>$.

FIGURA 31 - Guarda Suíça do Vaticano - Design de Leonardo da Vinci. Autor Anônimo.

FIGURA 32 - Bernardo Buontalenti - Primeiro intermezzo para A Peregrina: A Harmonia das Esferas, 1589. Gravura de Agostino Carracci (1557-1602). Toronto Reference Library, Special Collections, Theatre Engravings Collection. Disponível em: <http://ve.torontopubliclibrary.ca/operaatelier/sources_ harmony.htm $>$.

FIGURA 33 - Bernardo Buontalenti. Cenário para o casamento do Arqueduque Ferdinando de' Medici e Christine of Lorraine, Florence, 1589. Gravura de Cherubino Alberti [Zaccaria Mattia]1553-1615). Disponível em: $<$ http://metmuseum.org/collections/searchthecollections/90007428?img= o\# fullscreen $>$.

FIGURA 34 - Imagem da Ribalta. Rostand (1910-1911). 
FIGURA 35 - Teatro Farnese. Vista da plateia. Disponível em: <http://www. internetculturale.it/genera.jsp?id=792>.

FIGURA 36 - Cópia do desenho que ilustra a obra original, Sistema de Dimmers, de acordo com Sabbattini (1638).

FIGURA 37 - Reconstrução em exibição no Stage Light Museum em Hod Hasharon, Israel. Stage Lighting the $C D-R O M$, editado por Ben Tzion Munitz.

FIGURA 38 - Black-Maria/1893. Acima, o veículo policial que originou o nome.

FIGURA 39 - O estúdio Photographic Building. Disponível em: <http:blackmery. wordpress.com/.

FIGURA 40 - Instrumento com refletor de "mica", projetado por Furttenbach (1663). Stage Lighting the CR-ROM, Editado por Ben Tzion Munitz.

FIGURA 41 -Teatro de Aspendos/Turquia (161-18o d. C.). Disponível em: <http:// www.whitman.edu/theatre/theatretour/aspendos/introduction /aspendso. intro1.htm>.

FIGURA 42 - Teatro Romano em Sabratha/Líbia 175-200 d. C. Disponível em: 〈http://www.suite101.com/content/the-theatre-of-sabratha-libya-a153511〉.

FIGURA 43 - Afresco de Boscoreale - Vila de Publius Fannius Sinistor Itália (ca. Século I a. C.). Museu Arqueológico Nacional, Nápoles Itália.

FIGURA 44 - Paixão de Valenciennes/Bélgica (1547). Biblioteca Nacional da França, Paris.

FIGURA 45 - Boca do Inferno. Robert Huntington Fletcher, A History of English Literature.

FIGURA 46 - Detalhe da Paixão de Valenciennes/Bélgica (1547). Biblioteca Nacional da França, Paris.

FIGURA 47 A, B e C - Exemplos da Cruz ou Roda do Sol em diversificadas culturas e épocas. Disponível em: <http://www.pfps.com.br/comunidade/ threads/a-hist\%C3\%B3ria-da-su\%C3\%A1stica.24622>.

FIGURA 48 - Ilustração de uma cena noturna apresentada à luz do dia. The Spanish Tragedy, de Thomas Kid (1663).

FIGURA 49 - Falot. Elaborada pelo autor.

FIGURA 50 - Zurbarán. O Véu de Santa Verônica, c. 1631. Disponível em: <http://elogedelart.canalblog.com/archives/2009/o7/o4/14295315.html.

FIGURA 51 - El Greco. A Verônica, ca. 1580. Museo de Santa Cruz, Toledo. Disponível em: 〈http://elogedelart.canalblog.com/tag/E1\%20Greco >. 
FIGURA 52 - Rafael. A Escola de Atenas. Afresco (1516-1518). Vaticano.

Disponível em: <http://upload.wikimedia.org/wikipedia/commons/9/94/

Sanzio_01.jpg >.

FIGURA 53 - Titian. A Assunção da Virgem. Basílica de Santa Maria Gloriosa dei Frari, Veneza. Disponível em: <http://upload.wikimedia.org/wikipedia/ commons/9/9e/Tizian_041.jpg .

FIGURA 54 - Correggio. A Assunção da Virgem Maria. Catedral de Parma. Disponível em: <http://upload.wikimedia.org/wikipedia/commons/a/a5/ Cupola_Duomo_Parma_Correggio.jpg $\rangle$.

FIGURA 55 - El Greco. Adoração dos Pastores (1612-1614). Museu do Prado, Madri. Disponível em: <http://ibiblio.org/wm/paint/auth/greco/

FIGURA 56 - Parmigianino. Madona com longo pescoço. (1534-1540). Galleria degli Uffizi, Florença. Disponível em: <http://pt.wikipedia.org/wiki/Ficheiro: Parmigianino_oo3b.jpg >.

FIGURA 57 - Parmigianino. Autorretrato em um espelho convexo (1524).

Kunsthistorisches Museum, Viena. Disponível em: <http://pt.wikipedia.org/ wiki/Ficheiro:Parmigianino_Selfportrait.jpg >.

FIGURA 58 - Caravaggio. Ceia em Emaús (1601). Galeria Nacional, Londres. Disponível em: <http://en.wikipedia.org/wiki/File:16023_Caravaggio, Supper_ at_Emmaus_National_Gallery,_London.jpg $>$.

FIGURA 59 - Caracci. O Triunfo de Baco e Ariadne (1597-1600). Disponível em: <http://en.wikipedia.org/wiki/File:The_Triumph〉.

FIGURA 60 - Galeria Farnese. Afrescos de Caracci. Palácio Farnese, Roma. Disponível em: <http://upload.wikimedia.org/wikipedia/en/8/8o/Galleria_ Farnese_-_Annibale_Carracci___Palazzo_Farnese\%2C_Rome.jpg $>$.

FIGURA 61 - Mantegna. Sotto-in-su nos aposentos do casal do Palácio Ducal de Mântua (1473). Disponível em: <http://en.wikipedia.org/wiki/File:Andrea_ Mantegna_064.jpg>.

FIGURA 62 - Bernini. O Êxtase de Santa Teresa. (1647-1652). Santa Maria della Vittoria, Roma. Disponível em: <http://en.wikipedia.org/wiki/File:Santa_ Maria_della_Vittoria_-_4.jpg $>$.

FIGURA 63 - Bernini. Baldacchino na Catedral de São Pedro - Roma, (1624-1633). Disponível em: <http://saintpetersbasilica.org/Altars/PapalAltar/ Baldacchino-fw.jpg>.

FIGURA 64 - Pozzo. O Anjo da Guarda (c. 1685). <http://pt.wikipedia.org/wiki/ Ficheiro: Guardian-Angel-1685-94-Andrea-Pozzo.jpg >

FIGURA 65 - Andrea Pozzo. Projeto para Teatro [plateia no padrão de cavea (c. 1692)]. Perspectiva pictorum et architectorum, Figura 72. 
FIGURA 66 - Andrea Pozzo. Apoteose de Santo Inácio (c. 1694). Disponível em: 〈http://pt.wikipedia.org/wiki/Ficheiro:Andrea_Pozzo__Apoteose_de_Santo_ Inacio.jpg .

FIGURA 67 - Giacomo Torelli. La finta pazza (1645). Disponível em: 〈http://www. culture.gouv.fr/Wave/image/archim/MP/FRDAFA No8_NUMHo01897_2.jpg〉.

FIGURA 68 - Torelli. Sistema para mudanças de cenário. Oscar G. Brockett, History of the theatre, 1995, p. 133.

FIGURA 69 - Giacomo Torelli. Teatro dela Fortuna, em Fano. Planta Baixa e Corte. Hammitszch_1906_p. 9o. Disponível em: <http://upload.wikimedia.org/ wikipedia/commons/o/of/Teatro_di_Fano\%2C_transverse_section_and_floor_ plan_by_Torelli_-_Hammitszch_1906_p9o.jpg .

FIGURA 70 - Ferdinando Bibiena. Cenário para Didio Giuliano, de Sabadini, (1697). Museu Cívico Bibliográfico Musical de Bolonha. Histoire de l'opéra italien. Tome 5, L’opéra spectacle. Lorenzo Bianconi,Giorgio Pestell. Figura 16.

FIGURA 71 - Ferdinando Bibiena. Scena per angolo [Planta e perspectiva frontal]. L' Architectura Civile... Ilustração 22 [entre p 136 e 137] (1711).

FIGURA 72 - Giuseppe Bibiena. Projeto para um cenário com um monumental pátio com arcada. Disponível em: <http://www.metmuseum.org/Collections/ search-thecollections/0051486? $\mathrm{rpp}=20 \& \mathrm{pg}=1 \& \mathrm{ft}={ }^{*} \&$ who $=$ Giuseppe $+\mathrm{Galli}+\mathrm{Bibi}$ ena\&pos=14\#fullscreen $>$.

FIGURA 73 - Apresentação de um Balé para Henrique III e sua corte na Galeria do Louvre. Folio, Marriet Patison, Paris, 1582.

FIGURA 74 - Hôtel de Bourgogne. Corte longitudinal - plateia e palco. Arquivos Nacionais, Paris, Mapas e plantas, N III, 1142.2.

FIGURA 75 - Hôtel de Bourgogne. Planta-Baixa $(68 \mathrm{~cm}$ x $58.1 \mathrm{~cm})$. Paris, Arquivos Nacionais, Mapas e plantas, N III, 1142.28.

FIGURA 76 - Du Ryer, L’Argénis. Hôtel de Bourgogne. Fonte: MAHELOT, p. 69.

FIGURA 77 - Realismo e Luz. Elaborado pelo autor.

FIGURA 78 - Rotrou. L'Hypocondriaque ou le Mort Amoureux

[O Hipocondríaco] de Jean Rotrou - Hôtel de Bourgogne. Henry Carrington

Lancaster, Le Mémoire de Mahelot, Laurent et d'autres décorateurs de L'hôtel de Bourgogne et de la Comédie-Française au XVIIe siècle, 1920.

FIGURA 79 - Corneille. Andrômeda, 1651. Prólogo. Cenário de Torelli. Gravura sobre cobre de François Chauveau.

FIGURA 80 - Corneille. Andrômeda, 1651, Ato 1. Cenário de Torelli. Gravura sobre cobre de François Chauveau. Biblioteca Nacional da França, Réserve, RES-YF-3864; 4-BL-3522; RES 4-3523. 
FIGURA 81 - Corneille. Andrômeda, 1651, Ato 2. Cenário de Torelli.

FIGURA 82 - Corneille. Andrômeda, 1651, Ato 3. Cenário de Torelli. Gravura sobre cobre de François Chauveau.

FIGURA 83 - Corneille. Andrômeda, 1651, Ato 4. Cenário de Torelli.

FIGURA 84 - Corneille. Andrômeda, 1651, Ato 5. Cenário de Torelli. Biblioteca Nacional da França, Paris, Réserve, RES-YF-3864; 4-BL-3522; RES 4-3523.

FIGURA 85 - Salle des Machines. Tulleries - Planta Baixa. Disponível em: 〈http://www.unav.es/ha/oo7-TEAT/primeros-paris.htm〉.

FIGURA 86 - Poussin. Pastores de Arcádia [Et in Arcadia Ego ou Les Bergers d'Arcadie] - 1637/39. Disponível em: <http://en.wikipedia.org/wiki/ Et_in_Arcadia_ego.

FIGURA 87 - Poussin. Pastores de Arcádia - 1627/30. Wikipédia. Disponível em: $<$ http://en.wikipedia.org/wiki/File:Poussin1627.jpg.

FIGURA 88 - Anônimo do século XVII. Comédie Française. Espetáculo com o público sobre o palco. Collections Comédie-Française. P. Lorette. In: A. Sanjuan (dir), La Comédie-Française s'expose au Petit Palais, Paris-Musées, 2011, cat. 20, repr. p. 46-47. Disponível em: <http://www.comedie-francaise.fr/lagrange-loupe.php?img=BM-P0301>.

FIGURA 89 - Servadoni. Capriccio Romano com o Coliseu e a Piramide de Cestius, c. 1731. Disponível em: <http://www.thearttribune.com/A-Capriccioby-Servandoni-enters.html .

FIGURA 90 - Fagus Sylvatica ou Faia. Disponível em: <http://upload. wikimedia.org/wikipedia/commons/d/df/Fagus_sylvatica_f_purpurea_3.JPG $\rangle$. FIGURA 91 - Servandoni. A cidade de Tebas. Cenário para a terceira entrada em O triunfo da harmonia. (1737). De la Gorce, Une scénographie de Servandoni conservée pour les spectacles de l'opéra à Paris: le décor de la ville de Thèbes du triomphe de l'harmonie (I737), 2009, p. 578.

FIGURA 92 - Servandoni. A Cidade de Tebas. Provável planta-baixa para a terceira entrada em O Triunfo da Harmonia. (1737). Museu Nacional Suécia, Estocolmo. Jérôme De La Gorce, Une scénographie de Servandoni conservée pour les spectacles de l'opéra à Paris: le décor de la ville de Thèbes du triomphe de l'harmonie (I737), 2009, p. 585.

FIGURA 93 - Comédie Française, interior. A. Meunier: Paris, Interior da Comédie-Française de acordo com o projeto de Victor Louis, 179o. Disponível em: 〈http://es.wikipedia.org/wiki/Archivo:Paris_Comedie-Francaise.jpg .

FIGURA 94 - Fabrizio Galliari (1709 - 1790). Disponível em: <http://www. liveauctioneers.com/item/6750151>. 
FIGURA 95 - Canaletto. Perspectiva $(93$ x $131 \mathrm{~cm}$ ). Galleria Dell'Accademia, Florence, Italy. Disponível em: <http:/www.backtoclassics.com/gallery/ canaletto/perspective/>.

FIGURA 96 - Georges de la Tour. A Aparição do Anjo a São José. Museu de Belas Artes, Nantes. Disponível em: <http://en.wikipedia.org/wiki/File:Georges_de_ La_Tour_022.jpg >.

FIGURA 97 - Jacques-Louis David. A Morte de Marat, 1793. Museu Real das Belas Artes Bruxelas. Disponível em: <http: //www.fine-arts-museum.be/site/ asp/Oeuvre_details.asp?ID=48>.

FIGURA 98 - John Constable. Dedham Lock and Mill, c. 1618 Coleção particular. Disponível em: 〈http://www.wga.hu/support/viewer/z.html〉.

FIGURA 99 - Daguerre. O Efeito de Neblina e Neve visto através de uma Ruína de Colunata Gótica, 1826. Ralph Hyde. Panoramania: the art and entertainment of the "all-embracing" view. 1988, p. 168. Disponível em: <http://www.rc.umd. edu/praxis/gothic/thomas/thomas.html>.

FIGURA 100 - Henry Irving como Mefistófeles (Becken) em Fausto, de Goethe. Disponível em: 〈http://www.theirvingsociety.org.uk/>.

FIGURA 101 - Rembrandt. A Ronda Noturna, 1640/1642. Amsterdã.

Rijksmuseum. Disponível em: https://www.rijksmuseum.nl/en/my/ collections/22543--henk/mijn-eerste-verzameling/objecten\#/SK-C-5,O>.

FIGURA 102 - Rembrandt. A Ressureição de Lázaro, c. 1630, 359X438cm, óleo sobre painel. Los Angeles, Museum of Art da Cidade. Disponível em: <http:// www.wga.hu/preview/r/rembrand/11biblic/ognewtes.jpg>.

FIGURA 103 - Limelight. Disponível em: <http://www.iatse635.org/635_pages/ extras/blowth.html>.

FIGURA 104 - Henry Irving como Romeo em Romeu e Julieta, de Shakespeare. Londres, Lyceum Theatre, 1882. Disponível em: <http://www. societefrancaiseshakespeare.org/document.php?id=1060 >.

FIGURA 105 - Löie Fuller. O vestido original de Dança da Serpentina. Clare de Morinni, Loie Fuller: the fairy of light, 2010, p. 207.

FIGURA 106 - Lâmpadas a gás. Fredrick Accum, A practical treatise on gas-light,1815. Louis Hartmann, Theatre lighting: a manual of the stage switchboard, 1970.

FIGURA 107 - Lâmpada elétrica patenteada por Thomas A. Edison, 27 de janeiro de 1880. Disponível em: Patent and Trademark Office Image, Record Group 241. 〈http://en.wikipedia.org/wiki/File:Electric_lamp_patent.jpg〉. 
FIGURA 108 - Bayreuth. Vista parcial da plateia e do Palco. Foto: Joerg Schulze. Disponível em: <http://3.bp.blogspot.com/rMaOS_co1_Q/T_cyzYKDoPI/AAAA AAAAF_k/4ck-48JvAmo/s160o/Bayreuther_Festspiele_Foto_Joerg_Schulze.jpg > FIGURA 109 - Bayreuth/Planta-baixa 1. (Editada para as observações do texto) FIGURA 110 - Pieter Breughel. A Queda dos Cegos. 1568. Disponível em: <http://commons.wikimedia.org/wiki/Category: The_Blind_Leading_the_Blind_by_Pieter_Bruegel_the_Elder $>$.

FIGURA 111 - Antonello da Messina (1430-1479). São Sebastião, 1476-1477. Disponível em: <http://en.wikipedia.org/wiki/File:Antonello_da_Messina_o18. jpg Gemäldegalerie Alte Meister, Dresden>.

FIGURA 112 - Loie Fuller. Dançando ao ar livre. Samuel Joshua Beckett (1870-1940). Disponível em: <http://www.metmuseum.org/collections/ search-the-collections/190041580 $>$.

FIGURA 113 - Henri de Toulouse-Lautrec. Miss Loie Fuller, 1893. Disponível em: <http://www.britishmuseum.org/explore/highlights/highlight_image. aspx?image $=$ ps233874.jpg\&retpage $=21532>$.

FIGURA 114 - Wagner. Bayreuth. Cenário para a paisagem de Valhalla. 1896. Disponível em: <http://pt.scribd.com/doc/45108773/ Appia-Theatrical-Experiences $>$.

FIGURA 115 - Appia. Cenário para a paisagem de Valhalla. 1892. Disponível em: 〈http://pt.scribd.com/doc/45108773/Appia-Theatrical-Experience〉. 


\title{
COLOFÃO
}

\author{
Formato $\quad 19,5 \times 27 \mathrm{~cm}$ \\ Tipografia Milo OT/ Milo Serif OT \\ Papel Off set $75 \mathrm{~g} / \mathrm{m}^{2}$ (miolo) \\ Triplex $350 \mathrm{~g} / \mathrm{m}^{2}$ (capa) \\ Impressão e EGBA \\ Acabamento \\ Tiragem 500 exemplares
}

